UNIVERSIDADE DE SÃO PAULO

ESCOLA DE COMUNICAÇÕES E ARTES

MARLI BATISTA ÁVILA

\title{
A OBRA PEDAGÓGICA DE HEITOR VILLA-LOBOS - UMA LEITURA ATUAL DE SUA CONTRIBUIÇÃO PARA A EDUCAÇÃO MUSICAL NO BRASIL
}

Tese apresentada ao Programa de PósGraduação em Artes, Área de concentração Musicologia, Linha de pesquisa Técnicas Composicionais e Questões Interpretativas, da Escola de Comunicações e Artes da Universidade de São Paulo, como exigência parcial para a obtenção do título de Doutor em Artes, sob a orientação do Prof. Dr. Marco Antônio da Silva Ramos

São Paulo 
BANCA EXAMINADORA 
Aos que percorrem os caminhos da educação semeando a música. 
Agradecimentos

Ao Autor e Compositor da Vida

A Villa-Lobos e Z. Kodály, que dedicaram parte de sua música à criança À minha amada família, base de apoio e sustentação deste trabalho Ao Prof. Dr. Marco Antônio da Silva Ramos, por orientar com sabedoria e competência Aos Professores Doutores Gil Jardim, Rogério Costa, Clóvis Garcia e Paulo de Tarso pelas contribuiç̧̃es e incentivo Aos amigos e colegas co-participantes 


\section{RESUMO}

Este trabalho discute a obra pedagógica musical de H.Villa-Lobos contida nos cinco volumes editados para uso no Canto Orfeônico (Guia Prático, Solfejos - volumes 1 e 2 e Canto Orfeônico - volumes 1 e 2) sob o ponto de vista da pedagogia musical; não é focado, em primeiro plano, nas questões ideológicas do Canto Orfeônico, nem pretende recomendar a aplicação dessa política educacional nos dias atuais. A proposta principal é apresentar uma análise do material selecionado, arranjado, composto e editado por Villa-Lobos para o Canto Orfeônico, para uma possível utilização no processo de ensino musical, face à importância do compositor e desse segmento de sua obra. A partir da análise pedagógica, são apresentadas sugestões de cunho didático relacionadas à metodologia de ensino musical relacionada com a priorização da atividade. Considerando o objetivo principal deste trabalho, que é sugerir uma organização didática para a utilização das canções e solfejos contidos nos cinco volumes analisados, são estabelecidos os critérios adotados, bem como os instrumentos utilizados para tanto. São abordados os precedentes do movimento do Canto Orfeônico e as personagens que influenciaram Villa-Lobos na preparação de sua obra pedagógica. Os textos que serviram de base para o trabalho foram os cinco volumes da edição Vitale e os quatro volumes do Guia Prático pela editora ABM - Academia Brasileira de Música (FUNARTE-ABM, último trimestre de 2009). O primeiro capítulo refere-se ao contexto da criação da obra pedagógica de Villa-Lobos e o segundo capítulo apresenta as análises das peças contidas nos cinco volumes em questão.

Palavras-chave: Educação Musical. Canto Orfeônico. Pedagogia Musical. Didática. Solfejo. 


\begin{abstract}
This paper discusses the musical pedagogical work of H.Villa-Lobos contained in the five volumes edited for use in Canto Orfeônico ("Guia Prático, Solfejos" - volumes 1 e 2 and "Canto Orfeônico" - volumes 1 and 2) of the musical pedagogy point of view; it is not focused, in first plan, the ideological questions of Canto Orfeônico, nor intends to recommend the implementation of educational policy in the current days. The main purpose is to present an analysis of the selected, arranged, composed material and edited by Villa-Lobos for Canto Orfeônico, for a possible use in the process of musical education, given the importance of the composer and this segment of his work..From this pedagogical analysis, suggestions are presented related to the didactic methodology of music education related to the prioritization of activity. Considering the main objective of this work, which is to suggest a didactic organization for the use of the songs and solfeges contained in the five analyzed volumes, the adopted criterias are established, as well as the instruments used for both . The precedents of the movement of the Canto Orfeônico who had influenced Villa-Lobos in the preparation of his pedagogical work and also the characters are registered. The texts that served as the basis for this work were the five-volume edition of Vitale and four volumes of the Practical Guide by ABM - Brazilian Academy of Music (FUNARTE-ABM, the last semester of 2009). The first chapter refers to setting up the educational work of Villa-Lobos and the second chapter presents the analysis of the parts contained in five volumes in question.
\end{abstract}

Key words: Musical Education - Choral Music (Canto Orfeônico) - Musical Pedagogy Didactic - Solfege 


\section{GLOSSÁRIO}

1) Nomeação dos sons:

a) Notação literal para os sons absolutos: $\boldsymbol{A} \boldsymbol{B} \boldsymbol{C} \boldsymbol{D} \boldsymbol{E} \boldsymbol{F} \boldsymbol{G}$, considerando a escala 3 como a região central, 1 e 2 para as regiões graves e 4 para a aguda.

b) Notação silábica para os sons relativos: dó ré mi fá sol lá ti (DÓ RÉ MI FÁ SOL LÁ SI), ou simplesmente $\boldsymbol{d} \boldsymbol{r} \boldsymbol{m} \boldsymbol{f} \boldsymbol{s} \boldsymbol{l} \boldsymbol{t}$ para os sons médios; $\boldsymbol{d}$ ' $\boldsymbol{r}$ ' $\boldsymbol{m}$ ' $\boldsymbol{f}$ ' $\boldsymbol{s}$ ' $\boldsymbol{l}$ ' $\boldsymbol{t}$ ' para a oitava superior e $\boldsymbol{d}, \boldsymbol{r}, \boldsymbol{m}, \boldsymbol{f}, \boldsymbol{s}, \boldsymbol{l}, \boldsymbol{t}$, para a oitava inferior. Notas com sustenidos: $\boldsymbol{d \#}$

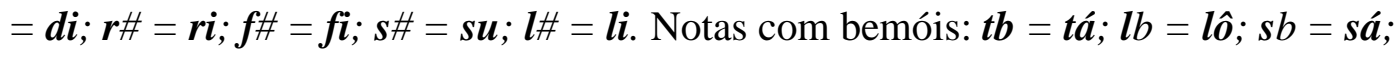
$\boldsymbol{m b}=\boldsymbol{m a} ; \boldsymbol{r} b=r a ́$.

2) Sistemas de geração de quintas para a organização das escalas e modos:

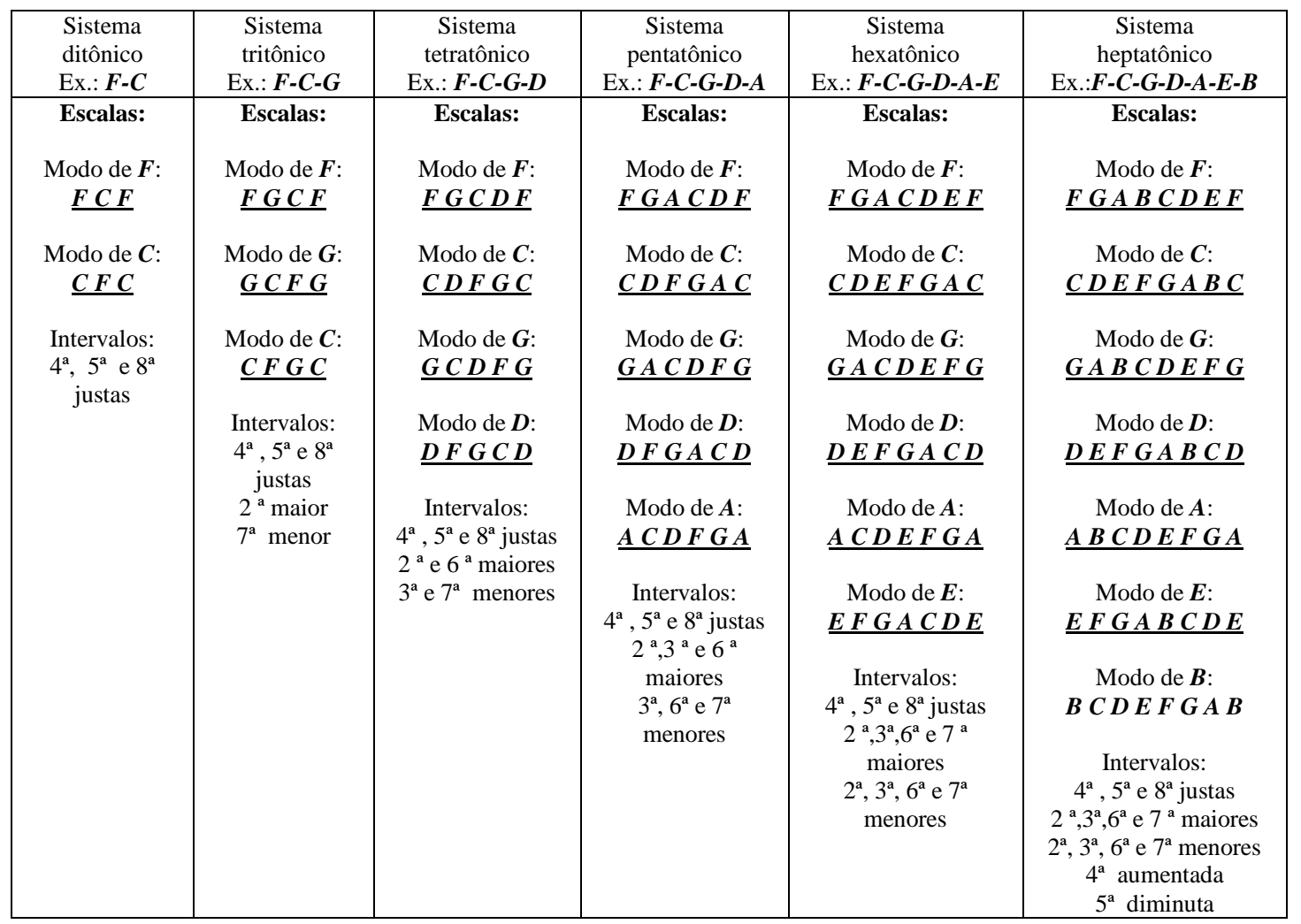

3) Solfa - linha melódica entoada em qualquer altura com os nomes das notas segundo suas funções representadas pelos graus da escala - ex. Dó $=$ primeiro grau, Ré $=$ segundo grau e assim por diante. A solfa baseia-se sobre: a escala móvel de Dó maior (modo jônio): $\boldsymbol{d} \boldsymbol{r} \boldsymbol{m} \boldsymbol{f} \boldsymbol{s} \boldsymbol{l} \boldsymbol{t} \boldsymbol{d}^{\prime}$, modo lídio ( $\left.\boldsymbol{d} \boldsymbol{r} \boldsymbol{m} \boldsymbol{f i} \boldsymbol{s} \boldsymbol{t} \boldsymbol{d}^{\prime}\right)$ e mixolídio ( $\boldsymbol{d} \boldsymbol{r} \boldsymbol{f} \boldsymbol{s} \boldsymbol{t} \boldsymbol{a}$ $\left.\boldsymbol{d}^{\prime}\right)$, ou Lá menor (modo eólio): $\boldsymbol{l}, \boldsymbol{t}, \boldsymbol{d} \boldsymbol{r} \boldsymbol{m} \boldsymbol{f} \boldsymbol{s}$, modo dórico $(\boldsymbol{l}, \boldsymbol{t}, \boldsymbol{d} \boldsymbol{r} \boldsymbol{m} \boldsymbol{f i} \boldsymbol{s} \boldsymbol{l}$ ) e frígio $(l, t a, d r m f s l)$.

4) Manossolfa - sinais manuais relativos às notas das escalas segundo suas funções. 
5) Intervalos: M / m / J / A / D - respectivamente Maior, menor, Justo, Aumentado e Diminuto.

6) Escalas (dois a sete sons ordenados por altura ascendentemente em âmbito de oitava) - Ditônica, Tritônica, Tetratônica, Pentatônica, Hexatônica e Heptatônica. Escala ou modo defectivo: incompleto, mas identificado.

7) Tricorde, tetracorde, pentacorde, hexacorde e heptacorde: sequências por graus conjuntos de 3, 4, 5, 6 ou 7 notas ordenadas por altura, extraídas das escalas.

8) Funções harmônicas: relacionadas aos sete graus da escala tonal, maior ou menor. Siglas: T / D / S / Tr / Sr / Dr / (D) / DD - respectivamente: Tônica, Dominante, Subdominante, Tônica relativa, Subdominante relativa, Dominante relativa, Dominante secundária e Dominante da Dominante no modo maior.

9) Palavras rítmicas: palavras que correspondem a figuras ou células rítmicas empregadas como recurso didático no aprendizado da leitura rítmica.

\begin{tabular}{|c|c|c|c|c|c|c|}
\hline ta & titi & tiritiri & tiri-ti & ti-tiri & titi-ri & tiíri \\
\hline d & & $\widehat{00}$ & है & $\sqrt{0}$ & 0. & $\sqrt{.5}$ \\
\hline
\end{tabular}

\begin{tabular}{|c|c|c|c|c|c|c|}
\hline titií & tititi & tititi & ta $1-t i$ & ta-a & ta-a-a & ta-a-a-a \\
\hline $\bar{\sigma}$ & 3 & & d. & $\delta$ & $d$. & o \\
\hline
\end{tabular}

10) Ostinato - trecho ou célula de caráter harmônico, rítmico e/ou melódico que se repete de modo significativo.

11) Quodlibet - combinações de melodias diferentes normalmente conhecidas em separado.

12) Siglas:

- GP-VTL: Guia Prático - edição VITALE.

- GP-ABM: Guia Prático - edição da Academia Brasileira de Música

- CO1 e CO2: Canto Orfeônico - volumes 1 e 2

- S1 e S2: Solfejos - volumes 1 e 2

- m.d. e m.e. - mão direita e mão esquerda - na execução pianística.

- B.C. : boca chiusa - canto com a boca fechada 


\section{SUMÁRIO}

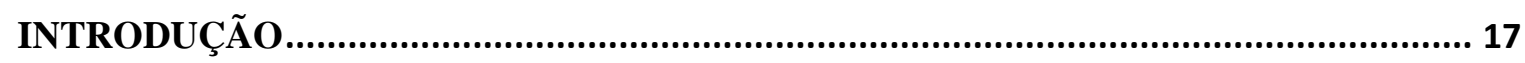

1 CANTO ORFEÔNICO E EDUCAÇÃO MUSICAL .................................................... 21

1.1 O Canto Orfeônico como fator de civismo e disciplina coletiva ............................. 21

1.1.2 O Canto Orfeônico e a formação da consciência musical brasileira .................. 25

1.2 Educação Musical e conceitos pedagógicos de Villa-Lobos ................................. 26

1.2.2 Villa-Lobos e a prática do ativismo educacional musical................................. 28

1.3 Aproveitamento da obra de Villa-Lobos para o Canto Orfeônico na Educação Musical 30

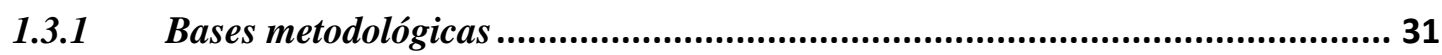

2 PROPOSTA DE REORDENAMENTO PEDAGÓGICO........................................... 36

2.1 Análises de melodias e canções a uma voz ................................................................. 36

2.1.1 Melodias e canç̃̃es sem semitons ............................................................................. 36

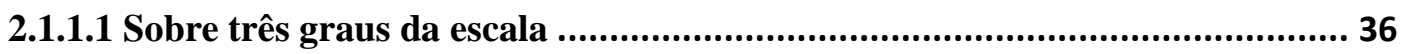

2.1. 1.2 Sobre quatro graus da escala ................................................................. 39

2.1.1.3 Sobre cinco graus da escala ....................................................................... 44

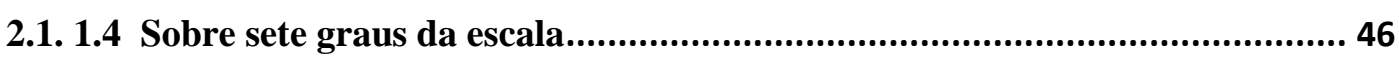

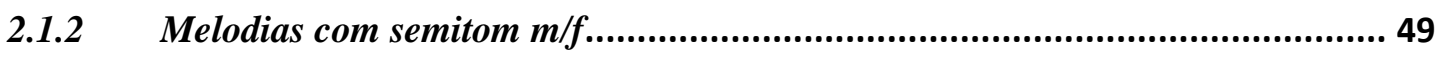

2.1.2.1 Sobre quatro graus da escala...................................................................... 49

2.1.2.2 Sobre cinco graus da escala .......................................................................... 51

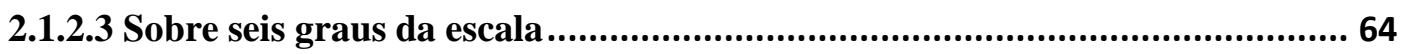

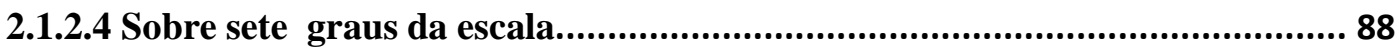

2.1.3 Melodias e canções com semitom $t$-d .........................................................107

2.1.3.1 Sobre quatro graus da escala....................................................................107

2.1.3.2 Sobre cinco graus da escala .......................................................................108

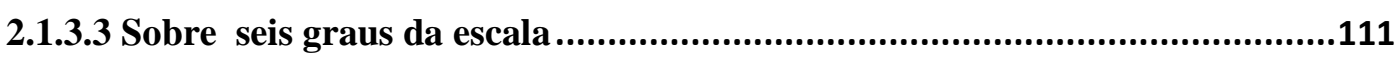

2.1.3.4 Sobre sete graus da escala ......................................................................119

2.1.4 Melodias com semitons $m-f$ e $t$-d ........................................................................124

2.1.4.1 Sobre seis graus da escala ...........................................................................124

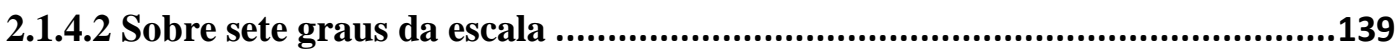

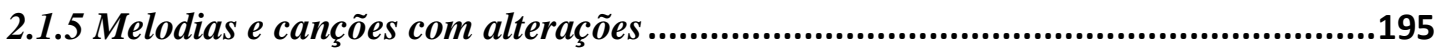

2.1.5.1 Sobre cinco graus da escala e alterações ....................................................195

2.1.5.2 Sobre seis graus da escala e alterações....................................................197 
2.1.5.3 Sobre sete sons da escala e alterações ...........................................................198

2.2 Melodias e canções a duas ou mais vozes .........................................................230

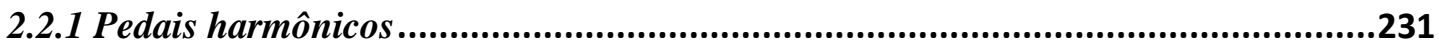

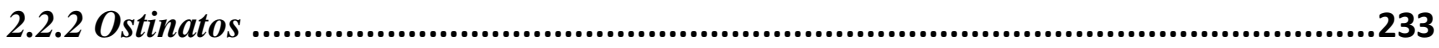

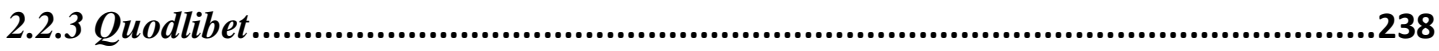

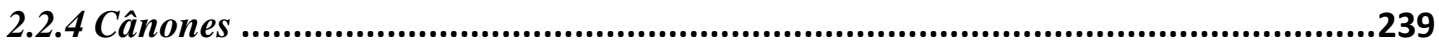

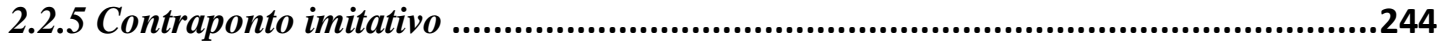

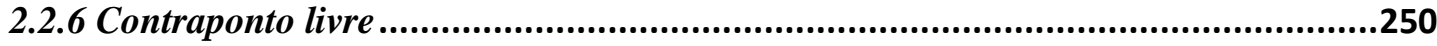

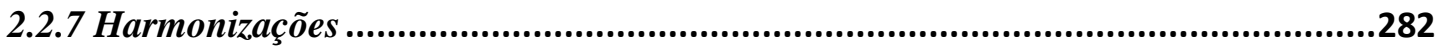

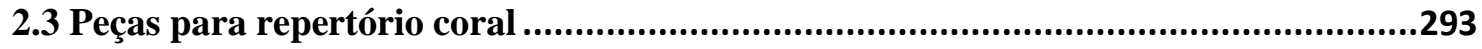

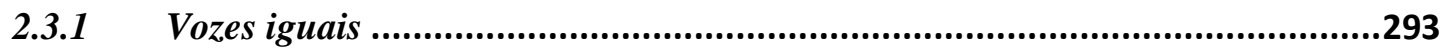

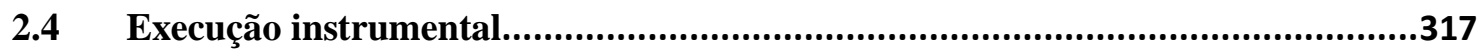

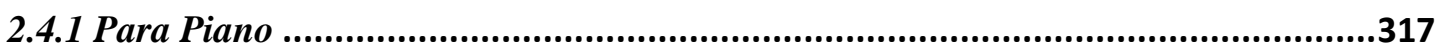

2.4.2 Para canto e piano, conjunto instrumental ou piano solo (Peças já analisadas nos

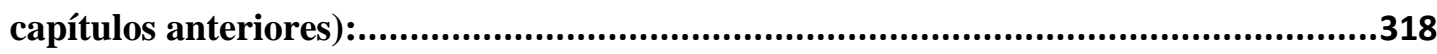

2.4.3 Peças para percussão, cordas ou sopro (instrumentos em geral - solos ou conjuntos) 318

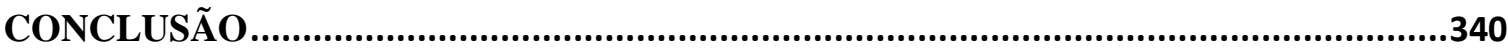

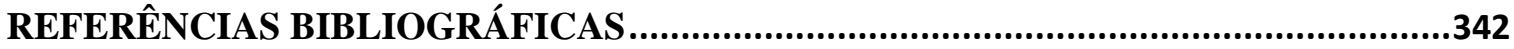

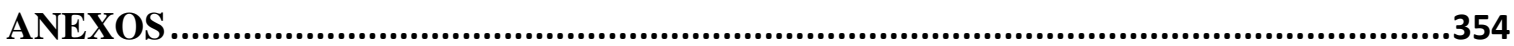

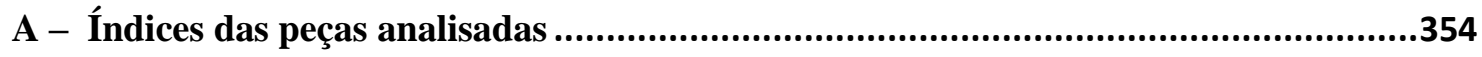

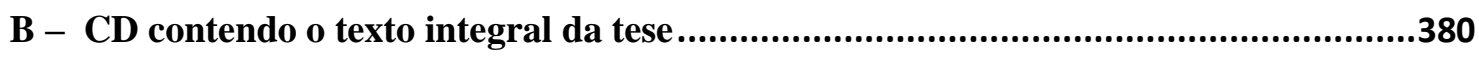

C - CD contendo arquivos com os volumes da edição Vitale dos cinco volumes analisados; arquivos de peças por ordem de apresentação no capítulo dois.......................................381 


\section{INTRODUÇÃO}

Este trabalho tem como objetivo principal discutir a obra pedagógica musical de H.Villa-Lobos contida nos cinco volumes editados para uso no Canto Orfeônico (Guia Prático, Solfejos - volumes 1 e 2 e Canto Orfeônico - volumes 1 e 2) enquanto conteúdo de significado pedagógico e artístico para a educação musical.

Não é propósito de nossas análises, a não ser para contextualização das questões em foco, fazer críticas aos objetivos ideológicos do Canto Orfeônico, nem tampouco recomendar a aplicação dessa política educacional nos dias atuais.

O que se propõe aqui é analisar o material selecionado, arranjado, composto e editado por Villa-Lobos para o Canto Orfeônico, e verificar sua possível utilização no processo de Educação Musical nos dias de hoje.

Villa-Lobos não menciona nominalmente pedagogos europeus com quem eventualmente teve contato direto, exceto Kestenberg, porém tudo indica, pelas suas próprias declarações, que sua observação sobre aspectos da música na escola tenha se baseado nas práticas orfeônicas das escolas francesas e alemãs.

Mesmo considerando que suas observações sobre processos de ensino musical em andamento tanto na Europa como no Brasil foram fundamentais para a implantação do Canto Orfeônico, há princípios e conceitos pedagógicos que são próprios de Villa-Lobos, os quais são aqui abordados. Tais princípios, sejam aqueles que sofreram influência européia ${ }^{1}$ como os que foram construídos a partir de sua própria experiência de formação musical ${ }^{2}$, ajudam a compreender os critérios de Villa-Lobos e, ao mesmo tempo, constam dos parâmetros que orientaram a presente reordenação das peças contidas nos volumes abordados.

Os cinco volumes em questão, considerados conjuntamente, são analisados sob o ponto de vista musical, pedagógico e didático. Nesta linha, são também apresentadas

\footnotetext{
1 Contato com Leo Kestenberg (1882-1962) em visitas a escolas européias. Kestenberg, músico checo, desenvolveu sua carreira pedagógica na Alemanha a partir de 1920, tendo interrompido suas atividades de chefia no sistema educacional alemão em 1931, quando a Nacional Socialista assumiu o poder e Kestenberg retira-se do país por ser de origem judia, voltando para Praga onde passara sua juventude. Foi o primeiro presidente honorário da ISME (Sociedade Internacional de Educação Musical), e é considerado um dos grandes pedagogos do século XX - em sua homenagem foi fundada a International Leo Kestenberg Society, em junho de 2009, em Berlim, Alemanha, sob a presidência do Prof. Dr. Wilfried Gruhn. (HTTP//WWW.leokestenberg.com).

${ }^{2}$ Aprendizado inicial com Raul Villa-Lobos e contato com músicos populares, de acordo com vários biógrafos de Villa-Lobos.
} 
sugestões de atividades didático-pedagógicas extraídas de cada peça, objetivando o eventual uso do material para ensino da leitura e escrita da música. São sugestões atreladas ao procedimento ativista, ou seja, definível pelo conjunto ordenado conforme segue: o aluno canta por imitação, vivencia a peça escolhida explorando o movimento corporal, a ludicidade, a memória, a improvisação e a criatividade, utilizando ou não instrumentos; memoriza a solfa da melodia; analisa a forma, a linha melódica e rítmica; associa pequenos trechos selecionados ao registro gráfico correspondente, e assim vai acumulando dados para o desenvolvimento da leitura e interpretação de novas peças (CHOKSY, 1981).

As sugestões de Villa-Lobos correspondentes à metodologia descrita acima se encontram esparsas em suas declarações e também registradas nas normas que regiam o Canto Orfeônico, bem como nas edições dos volumes aqui abordados.

Considerando o objetivo principal deste trabalho, que é sugerir uma organização didática para a utilização das canções e solfejos contidos nos cinco volumes analisados, é necessário estabelecer os critérios adotados para tanto.

Quanto à parte melódica, vamos nos valer dos conceitos de Carl Orff ${ }^{3}$ e Zoltán Kodály ${ }^{4}$, que partem da apresentação de melodias sobre escalas ditônicas, tritônicas, tetratônicas, pentatônicas, pela ordem, as quais não contêm semitons, para depois chegar à hexatônica - contendo um semitom e heptatônica - contendo dois semitons (ORFF; KEETMAN, 1964).

A justificativa para se adotar tal ordenação baseia-se na conclusão dos pedagogos citados de que a percepção de intervalos melódicos e harmônicos, bem como a emissão vocal, acontece de forma natural quando se parte da maior para a menor extensão dos mesmos. Esse procedimento possibilita a que os intervalos estruturais de todos os modos - quintas, quartas e oitavas, e posteriormente das tríades perfeitas maiores e menores sejam solidificados na memória auditiva e no ato da emissão vocal, promovendo assim uma afinação mais segura e precisa quando da inclusão dos semitons (SÖNYI, 1996).

Dessa forma, as melodias mais indicadas para o início do processo de aquisição dos sons da escala diatônica deveriam partir de escalas que não contêm semitons, ou seja, a partir dos sistemas ditônico ao pentatônico. Segundo o mesmo raciocínio, podem também ser selecionadas melodias hexa ou heptatônicas defectivas, que não contenham semitons (KODÁLY, 2003).

\footnotetext{
${ }^{3}$ Carl Orff, compositor e pedagogo alemão (1895-1982).

${ }^{4}$ Zoltán Kodály, compositor e pedagogo húngaro (1882-1967).
} 
Os critérios adotados para a seleção e ordenação das melodias e das canções resultaram em se partir da menor para a maior complexidade de execução e da possibilidade de apresentação de atividades didáticas visando ao aprendizado da leitura e da escrita musicais.

Os textos que serviram de base para o trabalho foram, inicialmente, os volumes, da editora Vitale, únicos até então, até o lançamento da edição dos quatro volumes do Guia Prático pela editora $\mathrm{ABM}^{5}$ - Academia Brasileira de Música (FUNARTE-ABM, último trimestre de 2009), os quais passaram a ser incorporados como fonte de pesquisa.

As análises das peças basearam-se no estudo feito sobre cada uma delas com base no referencial para “Análise de Obras Corais”, desenvolvido por pelo Prof. Dr. Marco Antônio da Silva Ramos, assim como seu capítulo “A pergunta Certa” (ambos em RAMOS, 1997 e 2003).

No caso das análises harmônicas, o instrumento utilizado é a harmonia funcional, por facilitar a visão do campo harmônico.

A discussão sob o ponto de vista pedagógico é feita a partir de uma revisão de literatura em âmbito interdisciplinar, nas áreas da história da educação e da musicologia, e com base em pressupostos extraídos de pensadores da educação em geral e musical.

Inicialmente, no primeiro capítulo, são consideradas as diferenças entre a proposta do Canto Orfeônico e o processo de Educação Musical, e as concepções pedagógicas de VillaLobos válidas para os dois enfoques.

No segundo capítulo, são apresentadas análises de melodias e canções reordenadas segundo a proposta contida neste trabalho:

- a uma voz - peças selecionadas e sugeridas para a aquisição do bom desempenho vocal, individual e coletivo, de leitura e da escrita musical e da interatividade como proposta de criação e improvisação.

- a duas ou mais vozes, com objetivos de aprendizagem vocal coletiva e de formação de repertório coral.

\footnotetext{
${ }^{5}$ Trata-se de uma edição que apresenta importantes revisões, correções, ampliação de dados históricos e uma pesquisa apurada sobre origem, classificação, ordenação e autoria das peças, tanto da música como das letras.
} 
- repertório coral (peças não selecionadas no capítulo anterior), disponível para grupos vocais infanto-juvenis de experiência mediana e avançada, ou de adultos.

- demais peças não selecionadas nos capítulos anteriores, todas passíveis de execução vocal, porém com indicação para a execução instrumental, com o intuito viabilizar de forma mais generalizada a sua prática.

A análise sob o ponto de vista da pedagogia musical da obra de Villa-Lobos contida nos volumes ora analisados pode constituir-se em referencial de estudo ou de eventual utilização em programas de ensino da música, seja por meio da voz ou de instrumentos. 


\section{CANTO ORFEÔNICO E EDUCAÇÃO MUSICAL}

\subsection{O Canto Orfeônico como fator de civismo e disciplina coletiva}

O Canto Orfeônico não consiste, em princípio, em um sistema de educação musical, sendo necessário, para a compreensão desta tese, discernir as diferenças entre o próprio, um movimento pontual dentro da história da educação em determinadas culturas, e os sistemas de ensino musical nas escolas, definidos por princípios, instrumentos e metodologias específicas.

O canto coletivo, denominado orfeônico em homenagem a Orfeu, personagem da mitologia grega antiga, sempre teve como objetivo a difusão de ideologias e ideais de cunho nacionalista, para reforço do sentimento de nacionalidade. Este tema, inclusive o Canto Orfeônico no Brasil, tem sido exaustivamente explorado e devidamente pesquisado por muitos autores, entre os quais cito CONTIER (1985); LISBOA (2005); UNGLAUB (2006); GALINARI (2007); AMATO (2008), entre outros, que abordaram seus aspectos políticos e ideológicos. Embora não seja esse o foco deste trabalho, faremos, sobre esses temas, um levantamento de dados para compor o raciocínio e o fio condutor das idéias aqui discutidas.

Mesmo tendo se iniciado no século XIX, foi na primeira metade do século XX que os movimentos nacionalistas chegaram ao seu auge, em todo o mundo, e a música foi então um veículo ideológico importante, especialmente quando utilizado nas escolas. Da França, onde se iniciou o Canto Orfeônico ${ }^{6}$ como o conhecemos, propagou-se o movimento por vários países europeus, e foi a partir de suas viagens pela Europa que Villa-Lobos se inspirou para desenvolver o Canto Orfeônico no Brasil “... de volta de uma viagem ao Velho Mundo, onde estivemos em contato com os grandes meios musicais e onde tivemos a oportunidade de estudar as organizações orfeônicas de vários países..." (VILLA-LOBOS, 1991, p.9) ${ }^{7}$.

Assim como essa modalidade de prática vocal cumpriu sua função em momentos políticos variados nos países onde foi utilizado, no Brasil foi apoiado no governo Vargas:

O movimento de 1930 traçava novas diretrizes políticas e culturais, apontando ao Brasil rumos decisivos, de acordo com o seu processo lógico de evolução histórica.

\footnotetext{
${ }^{6}$ Guillaume-Louis Willelm (Bocquillon), músico francês (1781-1842), criou em seu país os Orpheonistes, que eram sociedades populares de canto que se espalhou pela França, Bélgica e Espanha. Influenciado por essa iniciativa, John Pyke Hullah (1812-1884), músico e educador inglês, levou o mesmo conceito para a Inglaterra. (WWW.insecula.com)

${ }^{7}$ Por concentrar praticamente todas as declarações de Villa-Lobos a respeito de seus conceitos sobre o Canto Orfeônico e o ensino musical, o volume 13 de Presença de Villa-Lobos - Educação Musical (1991) será constantemente citado.
} 
Cheios de fé na força poderosa da música, sentimos que era chegado o momento de realizar uma alta e nobre missão educadora dentro da nossa Pátria. [...] Era preciso por toda a nossa energia a serviço da Pátria e da coletividade, utilizando a música como um meio de formação e de renovação moral, cívica e artística de um povo. [...] crentes de que o canto orfeônico é uma fonte de energia cívica vitaliza Dora e um poderoso fator educacional. Com o auxílio das forças coordenadoras do Governo, essa campanha lançou raízes profundas... (IBIDEM, p. 10)

O canto orfeônico já era praticado em alguns estados brasileiros, especialmente em São Paulo ${ }^{8}$, desde o final do século XIX (GOMES JARDIM, 2003 e GILIOLI, 2003). Porém, mesmo contando com a colaboração de alguns professores que atuavam nesse período anterior, Villa-Lobos apresenta-se como único autor da proposta vencedora entre outras apresentadas na época, bem como das inovações metodológicas nela contida. Da mesma obra:

Era necessário, antes de tudo, uma base inicial, uma etapa dificultosa de experiência e pesquisas - pois a aplicação de métodos estrangeiros seria de uma perfeita inadequação, assim como também os métodos nacionais existentes, cuja ineficiência era uma coisa comprovada. [...] E como esse ensino, absolutamente novo, não podia repousar em programas anteriormente elaborados, que não cogitavam dessa nova finalidade da música socializada, organizamos um programa atendendo a todas as suas necessidades de ordem técnica, constando... dos pontos que não figuravam, até então, em nenhuma obra didática de canto coral ou canto orfeônico.

Não se tratava de uma proposta de ensino musical para a escola brasileira, mas de um movimento em prol da aquisição de uma consciência cívica através do canto coletivo. $\mathrm{O}$ próprio Villa-Lobos ressalta a diferença entre o Canto Orfeônico e a Educação Musical:

E não confundir o seu objetivo (do Canto Orfeônico) cívico-educacional com outras exibições de ordem puramente estética, que não visam senão o prazer imediato da arte desinteressada. Essas outras manifestações exclusivamente artísticas devem haurir os seus conhecimentos nas escolas e conservatórios de música, onde lhes são fornecidos os elementos técnicos e culturais de que carecem (IBIDEM, p.11)

O processo educacional do Canto Orfeônico incluiu, de certa forma, o ensino da música na escola, mas para servir aos seus objetivos primeiros: “... o ensino e a prática do canto orfeônico nas escolas impõem-se como uma solução lógica, não só à formação de uma

\footnotetext{
${ }^{8}$ Desde o Barão de Macahubas, nas escolas do período imperial, até Gomes de Araújo, João Gomes Júnior, C. A. Gomes Cardim, João Baptista Julião, Fabiano Lozano, Lázaro Lozano e Honorato Faustino, a atividade orfeônica foi desenvolvida segundo os padrões estrangeiros, com as devidas adaptações dos pedagogos mencionados para as escolas paulistas, especialmente, e de outros estados.
} 
consciência musical, mas também como um fator de civismo e disciplina social coletiva". (IBIDEM, p.11)

Tratava-se de: “Aproveitar o sortilégio da música como um fator de cultura e de civismo e integrá-la na própria vida e na consciência nacional...” (IBIDEM)

Villa-Lobos chega a comparar o trabalho de catequese feito pelos primeiros jesuítas no período colonial com a sua nova empreitada no século XX:

Quase se pode afirmar, assim, que os padres Anchieta e Nóbrega lançaram os fundamentos do canto orfeônico no Brasil. E com essa admirável intuição de catequistas foram, até certo ponto, os precursores do aproveitamento da música como fator de disciplina coletiva. [...] E não será também, noutra esfera de cultura, uma obra de legítima catequese, essa que empreendemos atualmente no Brasil, quatro séculos mais tarde, lançando as bases do canto orfeônico nas escolas brasileiras e procurando, por meio dessa catálise musical e desse renascimento do canto coletivo despertar as energias raciais e fortalecer o sentimento do civismo? Tudo leva a crer que sim. (IBIDEM, p.14)

É preciso admitir que o movimento mundial do canto orfeônico existiu, foi explorado e cumpriu o seu papel em um momento histórico - paralelo ao ensino da música, porém com suas características e especificidades determinadas pelas políticas dos países que o utilizaram.

No Brasil, alcançou seus objetivos com as gerações que participaram dos programas escolares nos quais foi inserido, independente do juízo de valor que se faça desses resultados.

Constam da Portaria que regulava o Canto Orfeônico nos estados brasileiros finalidades e conteúdos que revelam as intenções de seu mentor (os grifos são nossos):

Finalidades (para as escolas secundárias, que equivalem a partir da quinta série do sistema atual:

a) Estimular o hábito de perfeito convívio coletivo, aperfeiçoando o senso de apuração do bom gosto.

b) Desenvolver os fatores essenciais da sensibilidade musical, baseados no ritmo, no som e na palavra.

c) Proporcionar a educação do caráter em relação à vida social por intermédio da música viva.

d) Incutir o sentimento cívico, de disciplina, o senso de solidariedade e de responsabilidade no ambiente escolar.

e) Despertar o amor pela música e o interesse pelas realizações artísticas.

f) Promover a confraternização entre os escolares.

Tendo finalidade pedagógica educar e disciplinar, não se presta à função de caráter festivo, mas apenas como elemento de colaboração nos programas de solenidades cívicas, artísticas e religiosas. 
Aulas previstas para grupos de 45 alunos. Frequência obrigatória. Além das aulas, práticas coletivas para grupos heterogêneos de idade e para grupos de séries iguaissempre programadas para horários extra-aula.

Avaliação: notas obtidas por exercícios orais e práticos, coletivos e individuais, evitando-se problemas de natureza puramente teóricos. Nessas provas deverá ser verificado o aproveitamento em afinação, ritmo, dicção, atitude e disciplina de conjunto.

Atendimento especial a alunos com defasagem de aquisição de conteúdos, com aulas extraordinárias. Esses alunos aprenderão por audição os hinos oficiais e canções patrióticas, caso os elementos técnicos musicais não lhes sejam suficientes.

\section{Programas e conteúdos:}

a) Elementos gráficos

b) Elementos rítmicos

c) Elementos melódicos

d) Elementos harmônicos

e) Prática orfeônica

f) História e Apreciação Musical

História e Apreciação Musical: orfeão; música e músicos no Brasil; audições comentadas; discernimento de gêneros musicais; música ameríndia, africana, portuguesa, espanhola e outras que influíram na música brasileira; alguns instrumentos indígenas; palestras sobre audições e concertos; conhecimentos dos instrumentos de banda e orquestra, orquestra antiga, clássica e moderna; origem e evolução da música; folclore nacional - sua utilidade ligada à música e à história das artes; (discernimento das tonalidades maiores e menores).

Nota-se que há também uma preocupação de Villa-Lobos com a formação cultural e musical reconhecível em meio ao seu plano de Canto Orfeônico.

Digno de nota é também o caráter inclusivo do Canto Orfeônico, como na programação para "escolas de cegos":

Para o pré-primário (Jardim da Infância): recreação rítmica (com brinquedos, pequenos instrumentos de percussão e caixinhas de papelão para despertar o instinto da "unidade de movimento marcial"); historietas e palestras sobre os sons da natureza do Brasil (canto de pássaros, dos grilos, sapos e outros animais, efeitos de vento nos bambuais, etc., em confronto com a voz humana); ensaios pedagógicos e declamação rítmica de canções fáceis, exercícios de respiração (aspirar o perfume de uma flor, apagar a vela, etc.); fazer rodas aplicando canções do programa oficial (A barquinha, Uma duas angolinhas... Carneirinho, Carneirão, etc.); audições de discos ou rádio, de músicas selecionadas, de acordo com a mentalidade da classe, observando cuidadosamente, em cada aluno, os efeitos causados pelos vários gêneros 
das músicas aplicadas e anotando-se os resultados fisiológicos e psicológicos na "ficha de terapêtica escolar".

Para as demais séries: Igual ao anterior, diferençando apenas na aplicação do sistema Braille para conhecimento das figuras dispostas na pauta comum. Noções gerais da musicografia Braille; conhecimento, pelo tato, dos instrumentos musicais.

A visão abrangente de Villa-Lobos previu também o desenvolvimento da tecnologia musical da época, levando-o a pensar no Curso de Formação de Músico-Artífice, que preparava profissionais para as áreas especializadas em serviços de cópia, gravação e impressão de música em todas as suas modalidades, não só para as casas editoras de música como para o ensino do Canto Orfeônico. (IBIDEM, 1991, p.76)

\subsubsection{O Canto Orfê̂nico e a formação da consciência musical brasileira}

Para atingir os objetivos da aquisição de sentimentos nacionalistas e cívicos, era preciso determinar-se o que seria o "nacional", especialmente quais as características da "música brasileira".

Os textos das canções aludiam à exuberante natureza e grandeza territorial do país, à nobreza do povo, aos heróis de sua história e outros tantos temas que apontavam para a necessidade de se amar o Brasil.

Tratava-se de preparar a mentalidade infantil para reformar, aos poucos, a mentalidade coletiva das gerações futuras. [...] Os caracteres psicológicos da nossa raça e os seus processos de evolução histórica indicavam claramente o caminho a seguir: só a implantação do ensino musical na escola renovada, por intermédio do canto coletivo, seria capaz de iniciar a formação de uma consciência musical brasileira. Efetivamente, o canto orfeônico é uma síntese de fatores educacionais os mais complexos. (IBIDEM, pp.7-8)

Com relação à formação musical, propriamente dita, os objetivos eram de médio e longo prazo:

Ora, para preencher a sua verdadeira função de música socializadora, era necessário, em primeiro lugar, que a música nacional tomasse conhecimento de si mesma pela formação de uma consciência musical brasileira e pela apreensão total do conjunto de fenômenos históricos, sociais e psicológicos, capazes de determinar os seus caracteres éticos, as suas tendências naturais e o seu ambiente próprio. (IBIDEM, p.7)

A música folclórica sempre foi utilizada como instrumento de memória das tradições dos povos. Villa-Lobos, tanto quanto Carl Orff na Alemanha, Zoltán Kodály na Hungria e outros compositores e pedagogos em todo o mundo, priorizou o repertório popular com bastante ênfase. Sobre isso, disse: "Ora, não é possível considerar a música como uma coisa 
à parte e um fator estranho à coletividade, uma vez que ela é um fenômeno vivo da criação de um povo. [...] A música é a própria voz da nacionalidade...” (IBIDEM, p. 7)

Nesse mesmo sentido, para Villa-Lobos, J. S. Bach foi o maior expoente do cenário musical de todos os tempos, pois considerava sua música, inspirada na música da sua cultura, “a mais sagrada dádiva do mundo artístico”. Completa seu pensamento sobre o elo entre a obra do compositor alemão e a música de seu povo, como um exemplo a ser seguido:

Além do mais, a maior substância técnica e psicológica da inspiração de sua monumental obra está baseada no canto livre da terra, através das expressões espontâneas dos homens simples e inconvencionais. [...] Pelo que devemos compreender, amar e cultivar a música que vem e vive, direta ou indiretamente da nossa terra e universalizá-la com fé e consciência. (IBIDEM, p.31)

Considerando o folclore "um amigo inseparável da infância” nas páginas seguintes da mesma obra, Villa-Lobos declarou:

Hoje não é mais possível fazer abstração do material fornecido pelo folclore musical para as questões educacionais da infância. [...] pela compreensão racional e quase intuitiva das melodias e dos ritmos fornecidos pelo próprio folclore nacional, o que facilmente se compreende, pela analogia que existe entre a mentalidade ingênua, espontânea e primária do povo e a mentalidade infantil, igualmente ingênua e primitiva.

O Guia Prático vem confirmar seu conceito acerca da música folclórica como conteúdo pedagógico:

O folclore é hoje considerado uma disciplina fundamental para a educação da infância e para a cultura de um povo. Porque nenhuma outra arte exerce sobre as camadas populares uma influência tão poderosa quanto a música - como também nenhuma outra arte extrai do povo maior soma de elementos de que necessita como matéria prima. (IBIDEM)

\subsection{Educação Musical e conceitos pedagógicos de Villa-Lobos}

Considerando-se que no Canto Orfeônico estava embutido um programa de ensino de música, e já tendo sido discutido sobre em que consistia o Canto Orfeônico para Villa-Lobos, pode-se constatar, através de suas declarações (VILLA-LOBOS, 1991), como ele conceituava a Educação Musical:

- Deve-se ensinar música, desde o começo, como uma força viva, do mesmo modo que se aprende a linguagem.[...] Antes do aluno ser atrapalhado com regras, deve familiarizar-se com os sons.

- Para o apreciador comum da música basta simplesmente dotá-lo de um preparo completo nos valores básicos do som. 
- A apreciação musical - ao invés de trazer para o aluno dados extra-musicais sobre compositor e considerações técnicas ou históricas, deixá-lo apenas ouvir: "Quanto melhor não seria colocar simplesmente a música diante dele, e ensinar-lhe a conhecer e apreciar os sons! [...] Deixem a música falar por si mesma!"

- Devemos primeiro velar para que a nossa rotina pedagógica seja, antes de mais nada, baseada em uma distinção ou compreensão mais clara possível dos termos, palavras e expressões a serem usados durante todo o curso de educação musical.

- Devemos lutar para extirpar do ensino musical todos os valores falsos, insistindo principalmente na educação do ouvido e da alma e pondo resolutamente de lado todo o fútil academismo de "música-papel" puramente intelectual.

- Devemos procurar educar os nossos artistas e compositores de modo a que acabem apreciando devidamente o seu dever de servidores da humanidade.

Seus princípios:

- A música, eu a considero, em princípio, como um indispensável alimento da alma humana. Por conseguinte, um elemento e fator imprescindível à educação do caráter da juventude.

- A todo povo assiste o direito de ter, sentir e apreciar a sua arte, oriunda da expressão popular mas, nunca o de julgá-la definitiva, em relação ao universo. Só é arte definitiva dos sons aquela que se faz compreender numa expressão universal, embora possuidora de característicos específicos.

- ... os elementos essenciais à verdadeira formação musical: - a iniciação segura no ritmo, a educação auditiva, a sensação perfeita dos acordes. E, mais tarde, o tirocínio da leitura, a compreensão e a familiaridade com as idéias melódicas e com os textos expressos pelos autores diversos e, por último, as sensações de ordem propriamente estética: - a faculdade de emoção ante a beleza melódica ou ante a capacidade dinamogênica do ritmo.

- A cultura da música universal, em todos os seus aspectos - histórico, técnico ou estético - é absolutamente necessária a uma sólida formação artística. Mas para que esse ensino seja proveitoso e venha completar, e não perturbar a evolução natural em que se deve processar a educação da criança, é preciso que seja ministrado simultaneamente com os conhecimentos da música nacional.

- Quanto ao repertório: A melodia e o texto devem ser de ótima qualidade artística e moral, para servir à sua finalidade educativa.

Nos cinco volumes que basearam este trabalho, Villa-Lobos faz constar observações e algumas recomendações relativas aos seus conceitos e objetivos (os grifos são nossos):

Guia Prático: O primeiro volume contém 137 canções infantis populares, cantadas pelas crianças brasileiras. Tem como objetivo orientar os jovens compositores regionais, podendo ser destinado a ramos diversos de atividade escolar. Mas, acima de tudo, reflete a 
fisionomia sonora do Brasil, através das mais puras e sugestivas canções infantis do seu rico patrimônio folclórico.

Sobre o índice e quadro sinótico do primeiro volume do Guia Prático, é dividido em colunas com os seguintes dizeres: Ordem numérica, Títulos, Melodia, Onde e por quem foi recolhido, Autores, Execução, Ambiente, Gêneros, Finalidades, Andamentos, Caráter, Origem e afinidades étnicas da melodia, Ordem cronológica, Indicação e Observações. ${ }^{9}$

Solfejos 1: Para cursos dos Conservatórios que formam professores especializados $e$ os mais fáceis para os alunos do ensino primário, ginasial, industrial, comercial e normal. Embora na aplicação do seu conteúdo seja exigido o mais perfeito conhecimento das regras da melodia clássica, estes solfejos obedecem a uma relativa liberdade de desenho melódico para, não só melhor orientar os alunos na compreensão das melodias populares e irregulares como para habituá-los a se preocuparem conscientemente com os elementos das manifestações populares, nativas e cultivadas que se encontram na atmosfera musical do nosso país, e assim sentirem a razão psicológica da música nacional.

Solfejos 2 - de grau mais adiantado, constitui-se de cinco partes: Vocalismo, Ditados, Imitações, Cânones e Fugas. Com exceção destas últimas e de alguns cânones, destinados aos professores, toda a matéria está ao alcance de classes de alunos mais desenvolvidos.

Canto Orfeônico 1 - (marchas e canções de vários estilos, para a educação consciente da unidade de movimento), é todo destinado a esse fim. Afora essa feição didática, contém vários números de interesse artístico, além do caráter cívico de que estão impregnados alguns deles.

Canto Orfeônico 2: (marchas, canções, cantos cívicos, marciais, folclóricos e artísticos para a formação consciente da apreciação do bom gosto na música brasileira) possui as mesmas características didáticas e artísticas do primeiro volume, apenas a maior parte de suas músicas está em grau de dificuldade técnica e estética mais adiantada.

\subsubsection{Villa-Lobos e a prática do ativismo educacional musical}

São considerados métodos ativos aqueles desenvolvidos por pedagogos no início do século XX, inspirados por pensadores a partir do século XVIII. Caracterizaram-se pelo ensino musical a partir da prática, da vivência vocal, corporal e/ou instrumental, com encaminhamento posterior de análise e síntese para a construção de conceitos teóricos a respeito.

\footnotetext{
${ }^{9}$ A esse respeito citamos a versão GP-AMB, que corrobora com ampla pesquisa que enriquece os dados constantes em GP-VTL, com novas informações e algumas correções.
} 
$\mathrm{Na}$ atualidade, dentro das múltiplas visões sobre a metodologia do ensino musical, sejam quais forem os conteúdos, o conceito da atividade é fundamental como ponto de partida para o processo de aprendizagem.

Villa-Lobos expressa-se (VILLA-LOBOS, 1991) de forma a se enquadrar dentro dessa mesma linha:

- Para tornar-se acessível à mentalidade infantil, a música deverá interessá-la, em primeiro lugar, pelo ritmo e, em seguida, pelo caráter de simplicidade e pelo aspecto socializador da melodia.

- As melodias adequadas a essa função socializadora são precisamente aquelas com as quais a criança já se havia familiarizado espontaneamente, isto é, os brinquedos ritmados, as marchas, as cantigas de ninar ou as canções de roda.

- A prática dessas melodias criará o estímulo e fomentará o interesse da criança, facilitando de uma maneira sensível a aquisição de noções técnicas decorrentes e necessárias ao canto coral, tais como: o senso rítmico, a educação auditiva e os demais elementos imprescindiveis ao conhecimento da teoria geral.

A prática orfeônica deveria ser, conforme idealizada por Villa-Lobos, organizada por ordem de complexidade e conteúdos pertinentes segundo as faixas etárias, e por imitação inicialmente, com posterior aquisição da teoria na medida da necessidade.

Quanto à prática orfeônica, são previstos: manossolfa simples, a uma até quatro vozes; canções de diversos estilos, hinos e marchas, especialmente de autores brasileiros; efeitos de timbres diversos; exercícios de entoação de notas cromáticas, longas, sustentadas de um pianíssimo a um fortíssimo e vice-versa; entoação da escala harmonizada por meio de processos teóricos e práticos; canto até a quatro vozes. (Solfejo 2, pp. VI e VII)

A utilização: da manossolfa ${ }^{10}$, instrumento facilitador da memória das relações intervalares (utilizado tanto para os sons fixos como relativos no Canto Orfeônico); da califasia, que consistia na boa dicção do texto; da califonia, ou boa entoação das alturas melódicas; da calirritmia, a boa execução rítmica; da declamação rítmica, que era a leitura rítmica da melodia por meio do próprio texto, constituíam em recursos de vivência prática que precediam os conceitos teóricos. Podem ser ainda lembrados os exercícios de regência, composição, execuções solísticas realizados pelos alunos e ainda os efeitos orfeônicos.

Quanto aos conteúdos previstos na Portaria que regia o ensino do Canto Orfeônico, há uma observação de Villa-Lobos: "As unidades didáticas: elementos gráficos, rítmicos,

\footnotetext{
${ }^{10}$ A manossolfa tem origem na "Mão Guidoneana", um conjunto de gestos e convenções para leitura dos sons relativos, atrelada ao sistema hexacordal de Guido D’Arezzo.
} 
melódicos, harmônicos, deverão ser aplicadas de preferência após o exercício dos solfejos adotados".

Vale ressaltar que os pedagogos ativistas europeus apresentaram suas propostas em educação musical em época posterior ao ano de início da proposta de Villa-Lobos no Brasil (1931). Por outro lado, ele teve contato com Leo Kestenberg ${ }^{11}$ (IBIDEM, pp. 55,56), cujos pensamentos sobre educação musical influenciaram tanto Villa-Lobos, em sua visita à Alemanha, na década de 20, quanto Kodály em período posterior, o que justifica a aproximação do trabalho de ambos. Porém, é preciso notar que Kodály iniciou seu sistema de ensino musical nas escolas húngaras em 1950, portanto, até por uma questão cronológica, parece pouco adequado citá-lo como fonte de inspiração para o canto orfeônico de VillaLobos.

\subsection{Aproveitamento da obra de Villa-Lobos para o Canto Orfeônico na Educação Musical}

Sobre a obra de Villa-Lobos aqui analisada:

- O Guia Prático apresenta 137 peças, sendo que $36^{12}$ delas se repetem, sem textos, em S1, e três em CO2. Trata-se de uma série de canções populares, ambientadas, arranjadas ou harmonizadas por Villa-Lobos.

- O volume 1 dos Solfejos totaliza 163 peças, sendo 36 populares, extraídas do Guia Prático, conforme informação acima, 3 solfejos repetidos e 124 compostos por Villa-Lobos.

- Solfejo 2 é dividido em seções: 8 ditados; 27 vocalismos (um deles aparece repetido em S1); 7 imitações; 20 cânones (um deles se repete) e 4 fugas, totalizando 66 peças: 48 composições de Villa-Lobos, 13 de outros compositores e 3 temas populares.

- Canto Orfeônico 2: contém 45 peças, totalizando 17 composições de Villa-Lobos, 11 de outros compositores, 14 populares e 3 peças repetidas no Guia Prático, sendo uma constante também em S1.

\footnotetext{
11 Villa-Lobos e Sá Pereira estiveram em contato direto com Kestenberg em 1936 em Praga. (VILLALOBOS,1991)

${ }^{12}$ Em GP-ABM consta o número de 35 (Separata, PP. 20 e 21)
} 
As composições musicais de Villa-Lobos somam 212 nos cinco volumes, sendo 41 compostas por outros músicos e 157 são temas populares. O total de peças seria em número de 452 , sendo que, menos as 44 repetidas nos volumes, totalizam 408 músicas.

Os arranjos das peças apresentam também as modalidades de harmonização e de 'ambientação', que se refere à qualificação de “arranjos que não se limitam a uma harmonização direta do tema, mas que procuram inseri-lo em um contexto musical específico, senão típico. [...] podendo descrever ou caracterizar: o transplante "cultural” em relação ao contexto da origem da melodia; um estilo; um caráter nacional”. (GP-ABM, Separata, pp. 26-27).

A obra vocal pedagógica de Villa-Lobos pode ser aproveitada em sua totalidade no ensino musical em qualquer instância, se forem consideradas suas múltiplas possibilidades de utilização:

- todas as peças são indicadas para o desenvolvimento do solfejo.

- os textos podem ser eliminados e substituídos por sílabas que componham planos timbrísticos especiais.

- a prática vocal pode ser substituída pela prática instrumental.

- as execuções deverão ser realizadas por ordem de interesse e capacidade do grupo vocal ou instrumental segundo faixas etárias adequadas.

- o repertório artístico para coral pode ser selecionado desde entre as canções a uma voz, a capella ou com acompanhamento instrumental, como entre as demais - a duas e mais vozes, de acordo com as competências e objetivos dos grupos e preferência de seus regentes.

\subsubsection{Bases metodológicas}

Este trabalho parte do princípio de que a prática vocal é fundamental em educação musical, pelo seu caráter democrático, ou seja, de acesso a todo indivíduo, pelas possibilidades de expressão artística e de comunicação via texto, pelas características de socialização e por facilitar o desenvolvimento dos aparelhos fonador e auditivo, entre outras vantagens. 
A prática pedagógica calcada nesse conceito tem demonstrado como resultado uma apurada qualidade de afinação vocal, como tem ocorrido, por exemplo, ao longo de mais de cinco décadas, especialmente na Hungria, onde Kodály implementou oficialmente seu sistema de educação musical a partir de 1951 (SZÖNYI, 1996).

Entre os instrumentos utilizados para o ensino da música vocal, selecionamos o solfejo relativo $^{13}$, que tem origem, tanto quanto a manossolfa, no sistema hexacordal de Guido D’Arezzo. Quanto às palavras rítmicas, utilizaremos as mesmas empregadas no sistema Kodály: ta, titi e tiritiri e demais combinações. (Idem, 1973).

Em São Paulo, na década de 60, a professora Lucy Ivancko ${ }^{14}$ propôs o método TônicaDó, sugerindo a nomenclatura $\mathrm{Da} M e \mathrm{Ni}$ Po $\mathrm{Tu} L \mathrm{La}$ Be para os sons relativos, as palavras rítmicas de Galin-Chevé: Ta, Tate, Tafatefe e suas combinações, e a manossolfa de origem inglesa $^{15}$ (IVANCKO $^{16}, 1968$, pp.5, 7 e 10). No Canto Orfeônico, utilizavam-se essas mesmas palavras rítmicas, a manossolfa de origem alemã, porém o solfejo absoluto era o mais utilizado, inclusive por preferência de Villa-Lobos, como se pode comprovar na canção "Havia um Pastorzinho" (n 91 em GP - VTL/ n 125 em GP/ABM). Por outro lado, outros professores utilizavam o solfejo relativo, inclusive a citada Professora. Lucy Ivancko, docente do curso de Canto Orfeônico no Instituto Musical São Paulo, na década de 1960.

A orientação de Carl Orff (ORFF; KEETMAN, 1964) e Zoltán Kodály (SZÖNYI, 1996) quanto à metodologia da apresentação dos sons parte, minimamente da escala pentatônica de Dó (relativamente) - formada pelas notas dó ré mi sol lá (podendo ainda partir de escalas ditônicas, tritônicas ou tetratônicas). O caminho para a inserção da nota fá será feito associando-se primeiramente o fá ao dó e ré (formando intervalos de quarta justa e terça menor), depois ao sol e ao lá (formando intervalos de segunda maior e terça maior), e finalmente ao $\boldsymbol{m i}$, partindo de sol fá mi para mi fá sol (chegando-se ao intervalo de segunda menor). O mesmo procedimento deve ser repetido quando da inserção da nota $s i$ - que se

\footnotetext{
${ }^{13} \mathrm{O}$ método atual de solfejo relativo tem precedentes na Inglaterra, Estados Unidos e Escócia a partir do século XVIII, com o método Lancashire (Fa-Sol-La). Jean-Jacques Rousseau (1712-1778) instituiu a leitura relativa dos sons por meio de números, e do ritmo por palavras rítmicas, procedimentos aperfeiçoados por Galin, Paris e Chevé no início do século XIX. John Spencer Curwen (1816-1880) implementou a leitura relativa na Inglaterra, com grande êxito, adaptada por Agnes Hundoegger (1858-1927) com o nome Tônica

DO, para utilização na Alemanha e Polônia. (STOKES ENCYCLOPEDIA OF MUSIC AND MUSICIANS, vol. 2) - in HTTP://books.google.com . Acesso em 14/10/2009.

${ }^{14} \mathrm{O}$ método Tônica-Dó foi trazido a São Paulo pela ex-diretora do Seminário Pedagógico da Academia de Música de Berlim, Frieda Löebenstein, posteriormente D. Paula Löebenstein O. S. B., de quem Lucy Ivancko foi aluna.

${ }^{15}$ Manossolfa inglês: desenvolvida por Sarah Ann Glover (1785-1867), aperfeiçoada por John Spencer Curwen e adaptada na Hungria para o Método Kodály. (SANDOR, 1981)

${ }^{16}$ Lucy Ivancko, inspetora regional do Conselho estadual de Música da Secretaria de Cultura, Esportes e Turismo do Estado de São Paulo (1968)
} 
associará inicialmente a ré' e ré (terça menor e sexta maior), depois ao sol e lá (intervalos de segundas maiores e terça maior), ao $\boldsymbol{m i}$ e $\boldsymbol{m i}$ ' (quarta e quinta justas), e finalmente ao dó ' formando o novo semitom, pela ordem: ré' dó' si e si dó' ré', considerando-se que a linha melódica descendente precede à ascendente em grau de facilidade de percepção e emissão vocal. Para a eventual prática do solfejo relativo, os semitons naturais obtidos nessa sequência de apresentação são sempre nomeados mi-fá e si-dó. Há maior possibilidade de precisão na afinação dos semitons quando sua emissão for obtida pelo processo descrito acima.

Com base nesses pressupostos, passo a descrever a ordenação dos critérios adotados para a seleção das melodias que será apresentada em seguida.

Do ponto de vista pedagógico:

- Ludicidade

- Filtragem de complexidades rítmicas e melódicas - para fins de percepção, leitura e escrita

- Coerência entre objetivos e resultados

- Ordenação de conteúdos inseridos no programa estabelecido

- Metodologias pertinentes segundo os grupos discentes (faixa etária, especificidades de cursos, regiões, grupos sociais e outras)

- Seleção do repertório segundo os objetivos propostos

Do ponto de vista melódico: quantidade de sons; extensão da tessitura; agrupamentos por células; escalas dos sistemas a partir do ditônico ao heptatônico; escalas modais; escalas tonais maiores; escalas tonais menores; notas alteradas (número crescente de alterações); claves originais; melodias em cânone; modulações.

Do ponto de vista rítmico: quantidade de figuras empregadas; extensão da peça número de compassos; agrupamento por células; som / silêncio; tético / anacrúsico; subdivisão binária; compasso binário, quaternário, ternário, quinário; subdivisão ternária; subdivisão do pulso a partir de 2 a 4 (ou 6) figuras; figuras pontuadas; síncopas; quiálteras.

Quanto a estilos, os infantis, compondo as canções de ninar, canções de roda, brincadeiras ritmadas e romances. Outros seriam canções folclóricas, populares, didáticas, cívicas, religiosas ou de origem erudita.

As concepções de cunho pedagógico e didático que nortearam as análises são de caráter universal e presentes na prática de métodos ativos:

A aprendizagem das canções, em princípio, deve ser lúdica, motivada pelo interesse musical em si mesmo, pelo texto e, sendo o caso, pela brincadeira. Deve acontecer por aquisição da memória auditiva / visual / (tátil / sinestésica - associativa) e da percepção cinestésica (do movimento) cumprindo a função estética de arte e lazer musical. 
Do ponto de vista didático, torna-se natural o aproveitamento do repertório adquirido para o processo de musicalização, em suas múltiplas dimensões - desde o desenvolvimento rítmico e dos demais elementos musicais por meio da vivência, até o processo de escrita e leitura de códigos musicais.

Transcendendo a vivência das canções, a aquisição da leitura e da escrita da música deve considerar os diferentes tipos de códigos musicais, respeitando habilidades e capacidades segundo as diversas faixas etárias, tanto quanto as possibilidades de codificação da música ao longo da história, incluindo a música popular e a música da atualidade.

$\mathrm{Na}$ abordagem do repertório proposto por Villa-Lobos, quase que totalmente voltado para a música brasileira e para a idade escolar relativa ao ensino básico, vamos nos ater às propostas de aproveitamento desse repertório voltadas para o ensino do código nele contido, como ponto de partida, deixando em aberto os caminhos para eventuais complementação e ampliação de outros conhecimentos.

Procura-se também observar as principais características das canções para as diferentes faixas etárias:

- Crianças até cinco anos - canções em uníssono com tessitura de pequena extensão; de preferência, acompanhadas de gestos e ações lúdicas; que contenham elementos facilitadores para a preparação de codificação e decodificação do ritmo e da melodia, e do exercício da memória; apreciação musical a partir de seleção de peças compatíveis com a capacidade de atenção e concentração segundo a idade dos alunos.

- Desde cinco a nove anos - gradativo aumento da tessitura e da complexidade rítmica, melódica, harmônica e polifônica; codificação e decodificação de elementos básicos rítmico-sonoros; apreciação musical.

- A partir de nove anos - desde que se constate capacidade de abstração, inserção de conhecimentos teóricos básicos, estritamente ligados à prática musical e necessários para solidificar a aquisição da codificação e decodificação da música; dados históricos complementares; apreciação musical.

Ações pedagógicas paralelas ao aprendizado de canções:

- Improvisação vocal e instrumental com base em pesquisa sonora abrangente, com inclusão de timbres de qualquer fonte sonora e alturas independentes de escalas e modos convencionais.

- Codificação e decodificação livres, a partir da escrita espontânea ao desenvolvimento de qualquer tipo de registro rítmico-sonoro. 
- Criação de peças - coletiva ou individualmente - com base em pesquisas e improvisações.

O que daí retiramos é o que se segue, ordenando as canções em torno de parâmetros explicitados nos subtítulos: melodias a uma voz, a duas ou mais vozes, repertório coral e execução instrumental. 


\section{PROPOSTA DE REORDENAMENTO PEDAGÓGICO}

\subsection{Análises de melodias e canções a uma voz}

Selecionamos inicialmente melodias a uma voz, seguindo os seguintes critérios, por ordem: menor número de sons da escala utilizada; menor extensão vocal; ausência de semitons; presença de semitons $M i / F a ́$; presença de semitons Si/Dó; presença de semitons Mi/Fá e Si/Dó; presença de notas alteradas; ritmo de subdivisão binária; ritmo de subdivisão ternária.

Foram utilizados os seguintes critérios analíticos: sistema de geração de quintas que originou a escala; escala e modo utilizado - completo ou defectivo; intervalos melódicos; tonalidade ou modalidade; tessitura; extensão; forma; gênero - segundo a classificação de Villa-Lobos; compassos - fórmula e quantidade; solfa - para eventual utilização no aprendizado do solfejo (relativo ou absoluto); créditos referentes à autoria de letra e música, ao arranjo e à ambientação; indicações de andamento e de intensidade; indicação do autor das possibilidades de execução: a capella, canto e piano, conjunto instrumental ou piano solo; eventuais problemas detectados nas edições consultadas; considerações sobre o texto, particularidades técnicas e aspectos lúdico-didáticos.

São também apresentadas sugestões ${ }^{17}$ de atividades didático-pedagógicas extraídas de cada peça, objetivando o eventual uso do material para ensino da leitura e escrita da música: seleção de células rítmicas para registro gráfico; seleção de células melódicas para registro gráfico; possível ostinato rítmico; possível ostinato melódico; outras eventuais possibilidades de inserção de atividades didáticas.

\subsubsection{Melodias e canções sem semitons}

\subsubsection{Sobre três graus da escala}

1) BAM-BA-LA-LÃO (Senhor Capitão) - a capella

\footnotetext{
${ }^{17}$ Sugestões de atividades didático-pedagógicas com base em diversos métodos constatados como eficientes em muitos sistemas de educação musical, bem como na prática pedagógica da autora.
} 


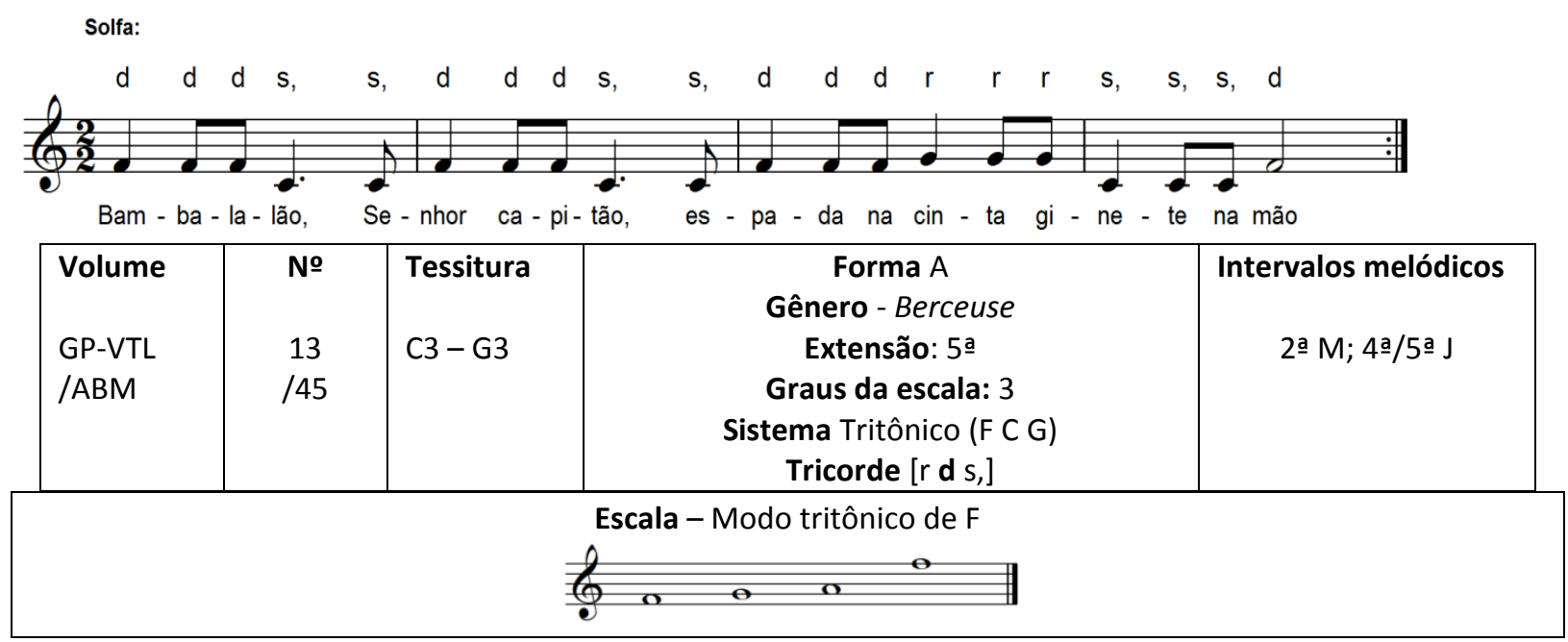

Sugestões de atividades didático-pedagógicas:

Células rítmicas para registro gráfico:

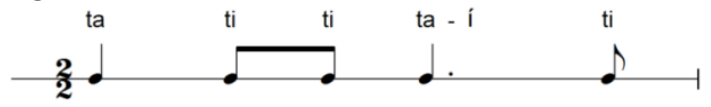

Células melódicas para registro gráfico:

$d d d s, \quad s, \quad s, d \quad d d d r \quad r \quad r \quad s$,

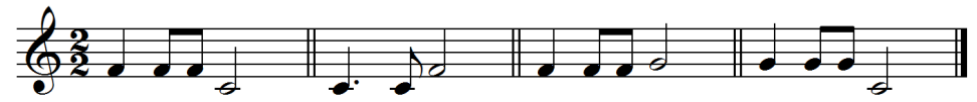

Possível ostinato rítmico:

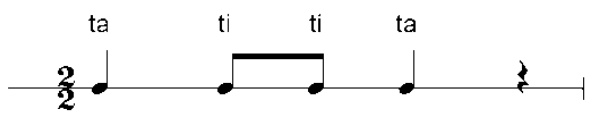

Possível ostinato melódico:

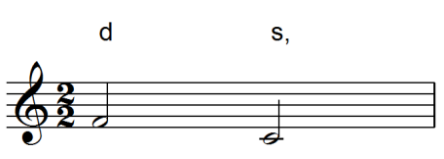

Análise complementar em $2.2-n^{\circ} 18$.

Canção com quatro compassos binários, com a indicação de andamento: Allegro gracioso (M.M. 76= d); indicações de dinâmica: $\boldsymbol{m f}$

Tema popular de brincadeira infantil com alusão à figura do militar, presente em muitas brincadeiras e canções infantis.

Texto - Bam-ba-la-lão é uma expressão rítmica que lembra a batida do tambor. Variantes: João Balalão, Tão-talalão.

Ritmo - O movimento da brincadeira coincide com os pulsos do compasso binário. A frase, com início tético, reforça o senso da marcha. O compasso e a subdivisão binária constituem elementos fundamentais para a aquisição do ritmo. $\mathrm{O}$ andamento favorece a possibilidade de se explorar movimentos corporais que remetem ao brincar, como por exemplo: passos largos, movimentos de braços, cabeças e pernas a partir do pulso.

Melodia - com saltos descendentes de quarta e quinta e ascendentes de quarta e segunda. Quanto à harmonia, a melodia sugere as funções básicas T D T. Os intervalos entoados, quartas e quintas justas, e segunda maior, são claramente perceptíveis e de fácil reprodução vocal. A altura e a tessitura são apropriadas para crianças de qualquer idade. 
Ludicidade - $\mathrm{O}$ brinquedo corresponde a um brinco e tem sua melodia cantada por um adulto, que coloca a criança sentada sobre seus joelhos, segurando-a pelos braços. A criança é balançada para frente e para trás no pulso da música. Esses movimentos possibilitam o desenvolvimento do senso de pulso a partir da vivência corporal, o meio eficaz segundo Dalcroze $^{18}$ (JAQUES-DALCROZE, 1965). O texto possibilita o contato com a rima, que se alia ao ritmo, podendo ser explorado de maneira que torne a brincadeira ainda mais divertida, além de introduzir novos elementos musicais: substituir as sílabas com rima por outras rimas, por pausa ou outros sons.

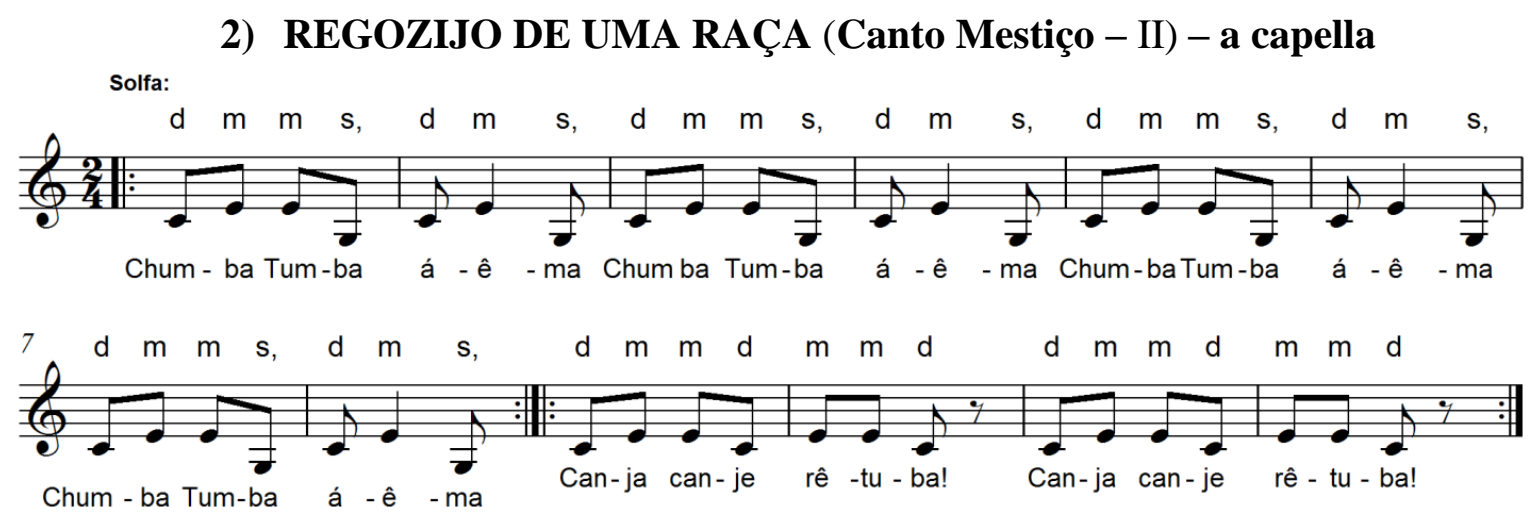

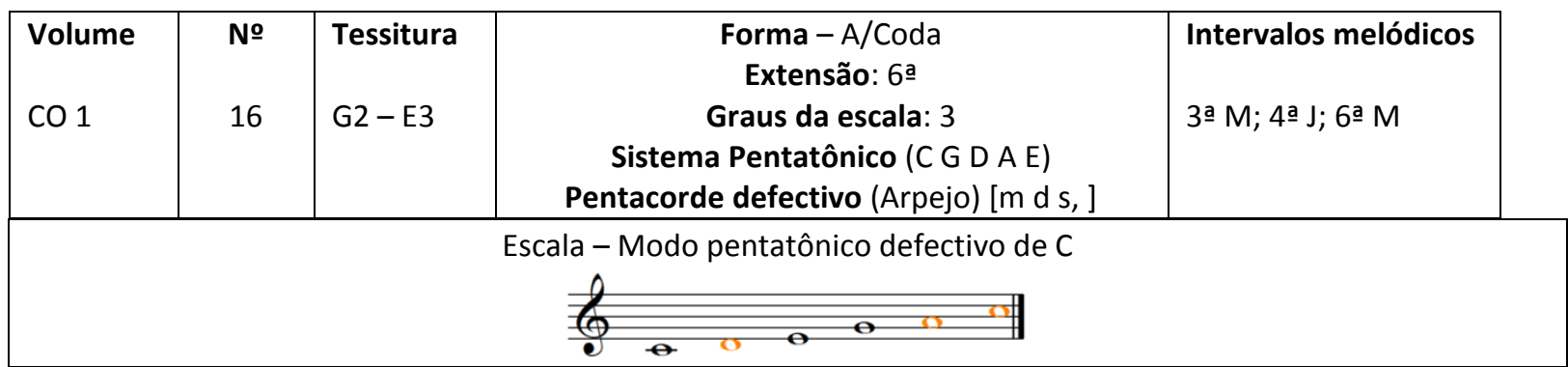

Sugestões de atividades didático-pedagógicas:

Células rítmicas para registro gráfico:

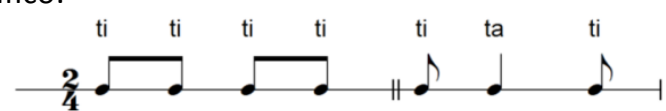

Células melódicas para registro gráfico:

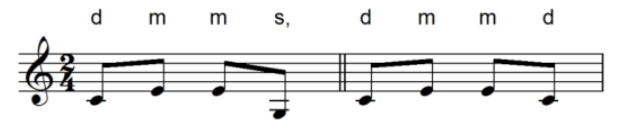

Possivel ostinato rítmico:

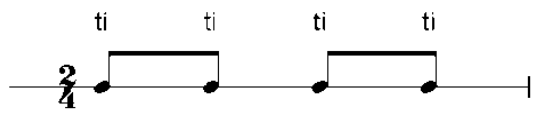

Possivel ostinato melódico: Segunda Parte

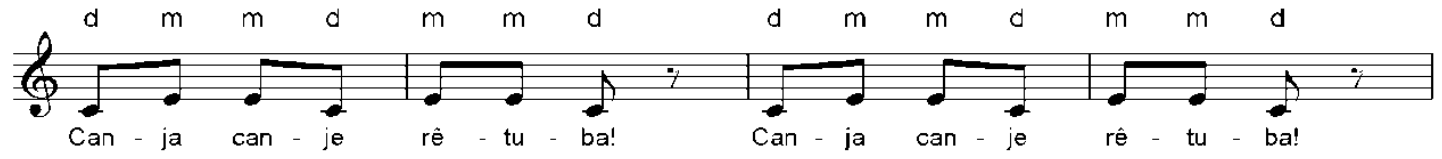

Outras possibilidades: Pedal de T ou D; cânone - segunda voz iniciando no segundo pulso da canção; contracanto improvisado sobre escala pentatônica de C.

\footnotetext{
${ }^{18}$ Émile Jaques-Dalcroze, compositor e pedagogo suíço (1865-1950).
} 
Canção de 12 compassos binários, com a indicação de andamento: Marcial; indicações de dinâmica: $\boldsymbol{m f} ; \boldsymbol{f}$

Tema africano sem indicação de procedência.

Texto em idioma africano - não consta a tradução.

Ritmo - interesse rítmico: síncopa métrica (abrange o compasso).

Melodia - Melodia baseada no arpejo do acorde maior de $\boldsymbol{C}$ na segunda inversão. Por estar em registro grave, pode ser transposta para outras tonalidades, segundo a faixa etária do grupo.

Ludicidade - a presença de ostinatos, o caráter repetitivo do texto, a intensidade forte e as acentuações nas síncopas, podem sugerir uma dança de origem africana.

\subsection{2 Sobre quatro graus da escala}

\section{3) NO JARDIM CELESTIAL - acompanhamento instrumental}

(Canto com piano, conjunto instrumental ou piano solo) Amb. por H. Villa-Lobos
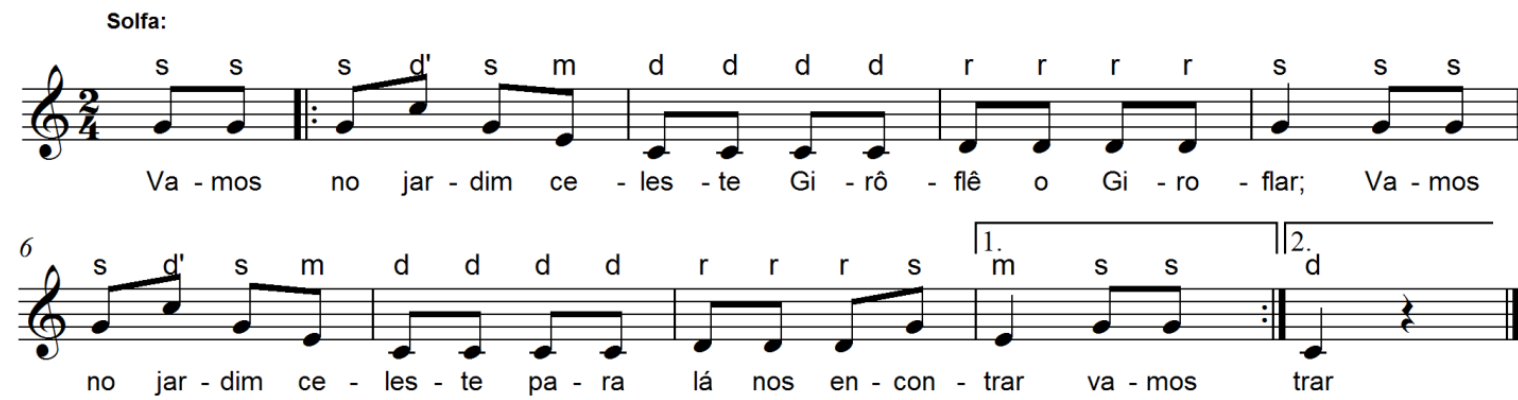

\begin{tabular}{|c|c|c|c|c|}
\hline $\begin{array}{l}\text { Volume } \\
\text { GP- VTL/ } \\
\text { ABM }\end{array}$ & $\begin{array}{l}\text { № } \\
65 \\
\text { /122 }\end{array}$ & $\begin{array}{l}\text { Tessitura } \\
\text { C3 - C4 }\end{array}$ & $\begin{array}{c}\text { Forma - A estrófica; } \\
\text { Gênero: Dança Canção } \\
\text { Extensão: 8a } \\
\text { Graus da escala: } 4 \\
\text { Sistema Pentatônico (C G D A E) } \\
\text { Pentacorde defectivo [d's m r d] }\end{array}$ & $\begin{array}{l}\text { Intervalos } \\
\text { melódicos } \\
\text { 2a } \mathrm{M} ; 3 \text { a } \mathrm{M} / \mathrm{m} ; 4 \mathrm{a} \\
\mathrm{J}\end{array}$ \\
\hline & & & $\begin{array}{l}\text { Modo pentatônico defectivo de C } \\
\mathbf{O}\end{array}$ & \\
\hline
\end{tabular}

Sugestões de atividades didático-pedagógicas:

Célula rítmica para registro gráfico:

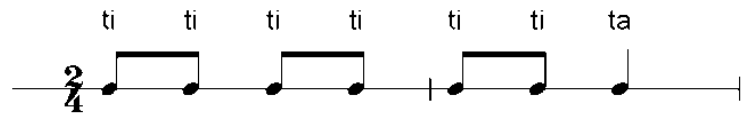

Célula melódica para registro gráfico:

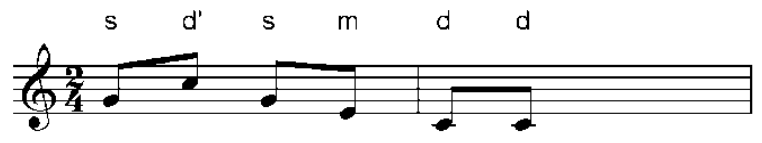


Possivel ostinato rítmico:

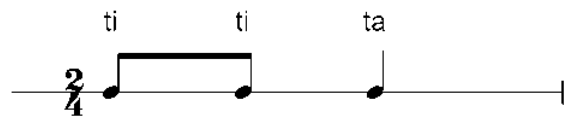

Possivel ostinato melódico:

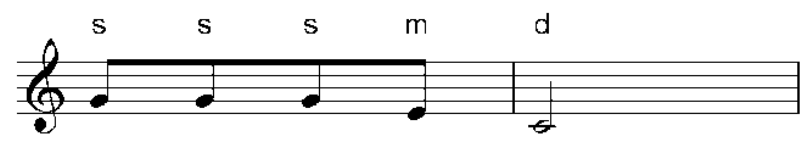

Outras possibilidades: pedal em G.

Análise complementar em $2.2-n^{\circ} 76$.

Canção com 10 compassos binários, com a indicação de andamento: Allegro $(132=\mathrm{J})$; indicações de dinâmica: $\boldsymbol{f f}$; $\boldsymbol{m f}$; $\boldsymbol{d i m} . ; \boldsymbol{f}$

Tema popular, folclórico infantil, de brincadeira de roda cujo desenvolvimento baseia-se no texto.

Texto - descrição de brincadeira de roda de origem francesa - "giroflée" (goiveiro, planta e flor) - sobre um passeio ao jardim celeste e colher flores para coroar Nossa Senhora.

Ritmo - a movimentação da brincadeira coincide com os pulsos do compasso binário.

Melodia - baseia-se no arpejo de tônica em modo maior. A linha melódica sugere as funções básicas T D T. Os intervalos e a tessitura são adequados para crianças a partir de seis anos de idade. Preferimos conservar a melodia segundo GP/VTL no sétimo compasso (DD $\boldsymbol{D} \boldsymbol{G})$, diferentemente de GP/ABM (DD DD), por ser a versão mais encontrada entre variantes.

Ludicidade - brincadeira cantada com jogo cênico, que se relaciona com o texto: uma fileira crianças com as de mãos dadas, e, em frente à fileira uma criança sozinha. Inicia-se o diálogo com o movimento para frente da fileira, no pulso da música até o final da primeira frase. Também no pulso, a criança sozinha responde o diálogo, completando sua frase. Nesse movimento alternado entre avanço e recuo, desenvolve-se a compreensão de pulso e frase, bem como se possibilita o exercício de se cantar em coro e solo.

Complementação do texto ${ }^{19}$ :

Refrão: Vamos no jardim celeste / Giroflê, o giroflar; Vamos no jardim celeste / para lá nos encontrar.

- O que foram lá fazer? / Giroflê, o giroflar; O que foram lá fazer? / para lá nos encontrar.

- Colher muitas violetas / Giroflê, o giroflar; Colher muitas violetas / e também nos encontrar

- Pra que servem as violetas / Giroflê, o giroflar; Pra que servem as violetas / para lá nos encontrar.

- Pra coroar Nossa Senhora / Giroflê, o giroflar; Pra coroar Nossa Senhora / para lá nos encontrar.

- Se encontrasse com a rainha / Giroflê, o giroflar; Se encontrasse com a rainha / para lá nos encontrar.

- Eu daria os cumprimentos / Giroflê, o giroflar; Eu daria os cumprimentos / para lá nos encontrar.

- Se encontrasse com o demônio / Giroflê, o giroflar; Se encontrasse com o demônio / para lá nos encontrar.

- Mostraria minhas cruzes / Giroflê, o giroflar; Mostraria minhas cruzes / para lá nos encontrar.

\footnotetext{
${ }^{19} \mathrm{GP} / \mathrm{ABM}$ - 3ํㅡㄹ Caderno, pp. 65,67. Fonte: Alexina Magalhães Pinto: Os nossos brinquedos.
} 


\section{4) BELA PASTORA - acompanhamento instrumental}

(Canto com piano, conjunto instrumental ou piano solo)

Amb. por H. Villa-Lobos Solfa:
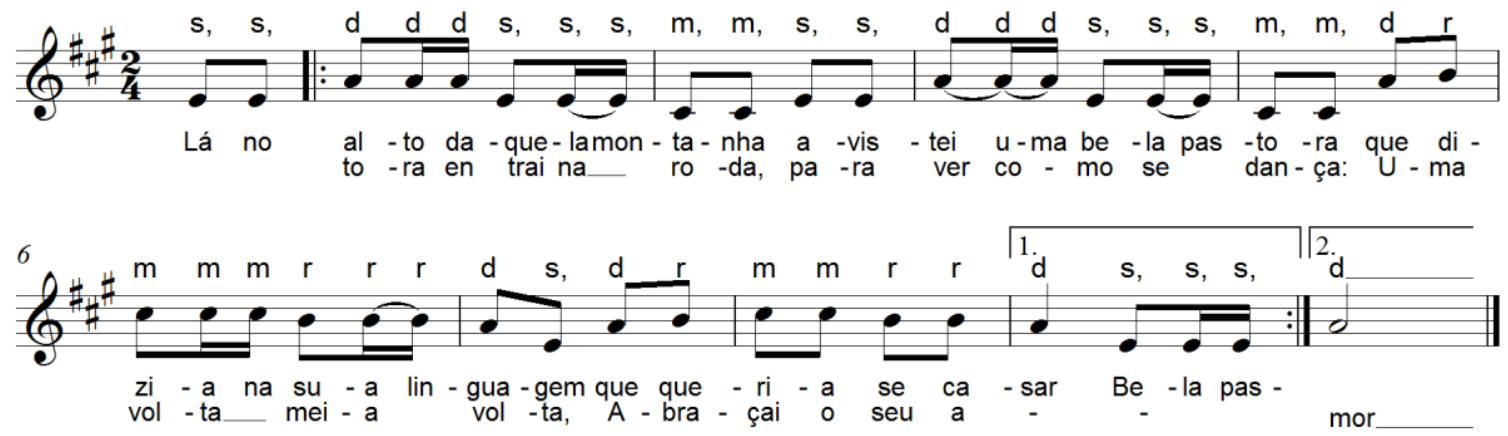

\begin{tabular}{|c|c|c|c|c|}
\hline $\begin{array}{l}\text { Volume } \\
\text { GP- VTL } \\
\text { /ABM }\end{array}$ & $\begin{array}{l}\text { № } \\
15 \\
\text { /124 }\end{array}$ & $\begin{array}{l}\text { Tessitura } \\
\text { C\#3-C\#4 }\end{array}$ & $\begin{array}{c}\text { Forma - A estrófica } \\
\text { Gênero: Canção marcial } \\
\text { Extensão: 8ạ } \\
\text { Graus da escala: } 4 \\
\text { Sistema pentatônico (A E B F\# C\#) } \\
\text { Pentacorde defectivo [l s m r d] }\end{array}$ & $\begin{array}{c}\text { Intervalos } \\
\text { melódicos } \\
\text { 2a } \mathrm{M} ; 3 \stackrel{\mathrm{a}}{\mathrm{m} ; 4 \mathrm{a}} \mathrm{J} ; 6^{\mathrm{a}} \\
\mathrm{m}\end{array}$ \\
\hline & & & $\begin{array}{l}\text { - Modo pentatônico defectivo de A } \\
\bar{\sigma} \sigma \bar{\sigma} \quad \boldsymbol{\theta}\end{array}$ & \\
\hline
\end{tabular}

Sugestões de atividades didático-pedagógicas:

Células rítmicas para registro gráfico:

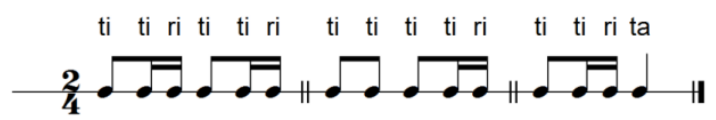

Células melódicas para registro gráfico:

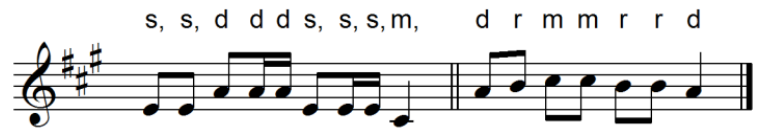

Possivel ostinato rítmico:

Possivel ostinato melódico:
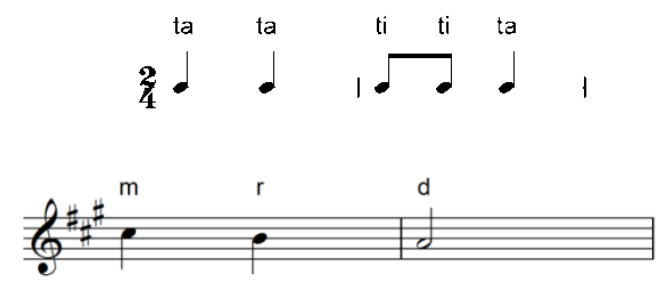

Outras possibilidades: pedal na T; cânone com a segunda voz entrando no segundo pulso da melodia.

Análise complementar no capítulo $3 n^{\circ} 53$.

Canção com 10 compassos binários, com a indicação de andamento: Quasi allegretto (104 $=\downarrow$ ); indicações de dinâmica: $\boldsymbol{m f} ; \boldsymbol{f f}$

Tema popular, folclórico infantil, de brincadeira de roda.

Texto - cantiga que descreve o desenvolvimento de uma brincadeira de roda de escolha.

Ritmo - anacrúsico, subdivisão binária; os movimentos da brincadeira coincidem com os pulsos do compasso binário. As colcheias seguidas de duas semicolcheias sugerem movimentos saltitantes, possibilitando através do corpo a compreensão dessa figura rítmica. 
A melodia apoia-se no arpejo do acorde da T na primeira inversão.

Ludicidade - Esta roda de escolha possibilita desempenho solístico da criança que vai ao centro, com improvisação na primeira parte e coreografia estipulada pelo texto na segunda parte. Uma criança vai ao centro da roda, dança e escolha a próxima que tomará o seu lugar.

\section{5) CANTOS DE ÇAIRÉ (2) - a capella}

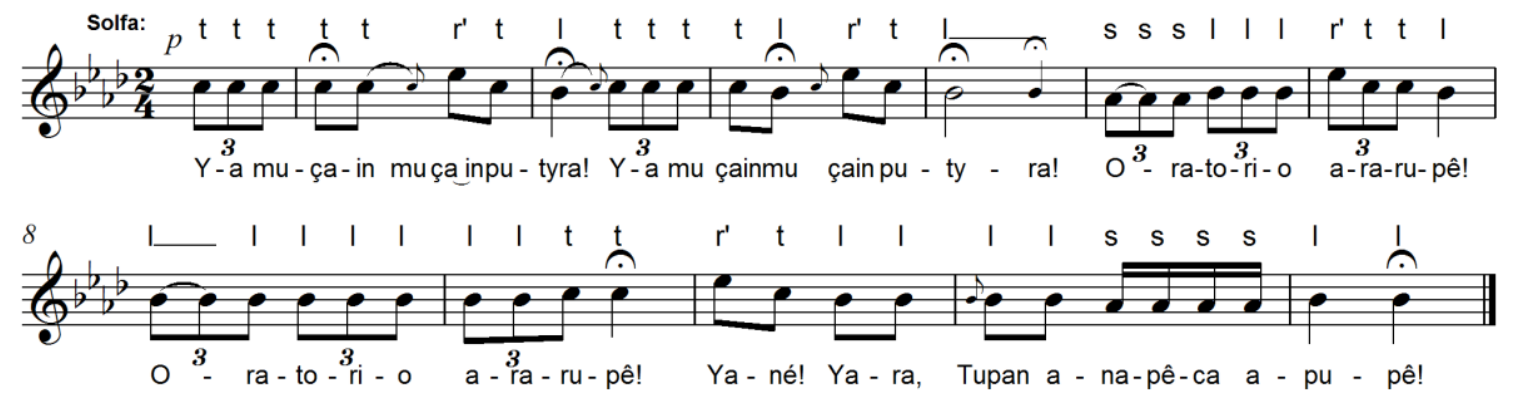

\begin{tabular}{|c|c|c|c|c|}
\hline $\begin{array}{l}\text { Volume } \\
\text { CO } 2\end{array}$ & $\begin{array}{l}\text { № } \\
19\end{array}$ & $\begin{array}{l}\text { Tessitura } \\
\text { Bb3 - Eb4 }\end{array}$ & $\begin{array}{c}\text { Forma - A } \\
\text { Extensão: 4ạ } \\
\text { Graus da escala: } 4 \\
\text { Sistema Heptatônico (Db Ab Eb Bb F C) } \\
\text { Pentacorde defectivo ( } \mathrm{r} \text { (tls) }\end{array}$ & $\begin{array}{l}\text { Intervalos } \\
\text { melódicos } \\
\text { 2a M; } 3 \text { a m; } \\
4 \text { a J }\end{array}$ \\
\hline & & & 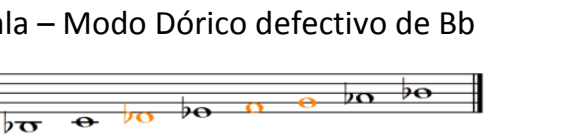 & \\
\hline
\end{tabular}

Sugestões de atividades didático-pedagógicas:

Células rítmicas para registro gráfico:

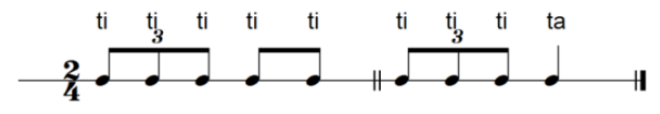

Células melódicas para registro gráfico:

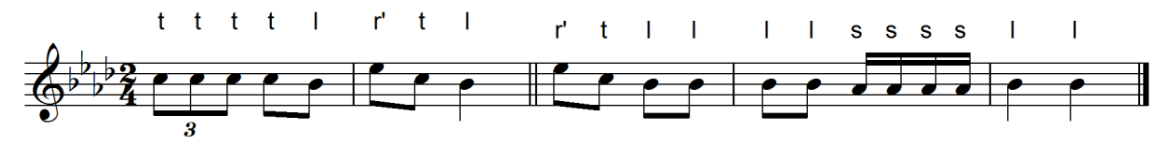

Análise complementar em $2.2-n^{\circ} 171$.

Canção com 12 compassos binários, com a indicação de andamento: Andantino; indicação de dinâmica: $\boldsymbol{p}$

Tema folclórico amazônico ambientado por H.Villa-Lobos.

Texto - nos compassos 2, 3, 4, 5 e 11 aparecem apojaturas longas para acomodação do texto, em possível língua indígena (incluindo a palavra portuguesa "oratório"), não constando a tradução.

Ritmo - o interesse rítmico está na polirritmia horizontal determinada pelas tercinas entre as figuras de subdivisão binária.

Melodia em modo dórico defectivo, com notas rebatidas e desenvolvimento melódico por graus conjuntos e pequenos saltos. 
Ludicidade - há indicação de $\boldsymbol{D}$.C. ad libitum, o que pode sugerir uma dança, cuja coreografia seria um desafio para a criatividade do grupo. O texto também é um desafio lúdico.

6) UM CANTO QUE SAIU DAS SENZALAS - a capella
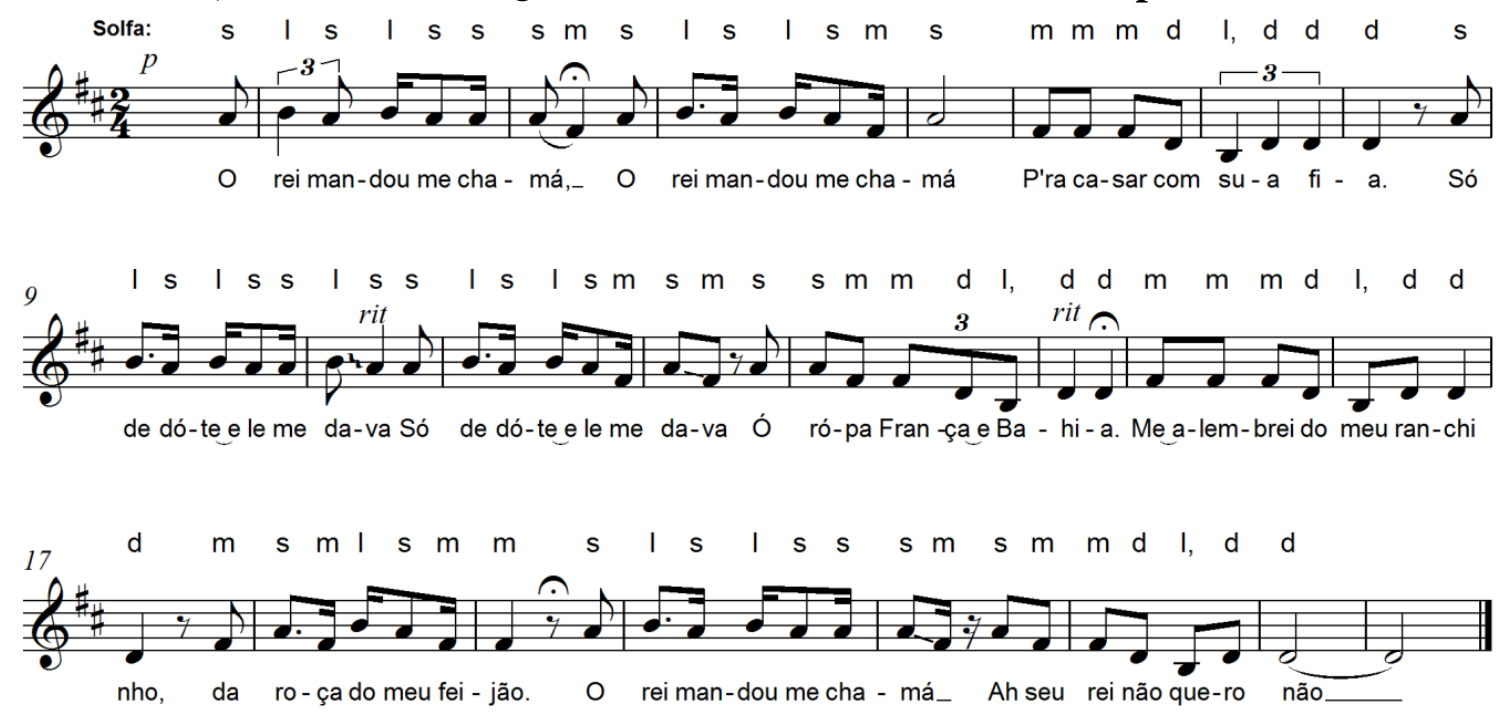

\begin{tabular}{|c|c|c|c|c|}
\hline $\begin{array}{l}\text { Volume } \\
\mathrm{CO} 2\end{array}$ & $\begin{array}{l}\text { № } \\
23\end{array}$ & $\begin{array}{l}\text { Tessitura } \\
\text { B3-B4 }\end{array}$ & $\begin{array}{c}\text { Forma - A } \\
\text { Extensão: } 8^{a} \\
\text { Graus da escala: } 4 \\
\text { Sistema Heptatônico (G D A E B F\# C\#) } \\
\text { Heptacorde defectivo (sfmrdtl) }\end{array}$ & 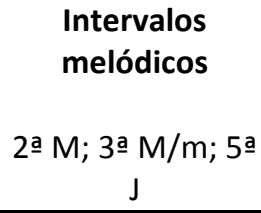 \\
\hline & & & 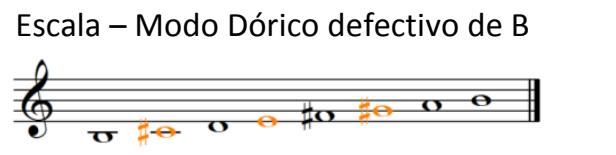 & \\
\hline
\end{tabular}

Sugestões de atividades didático-pedagógicas:

Células rítmicas para registro gráfico:

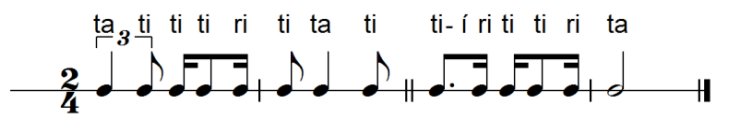

Células melódicas para registro gráfico:

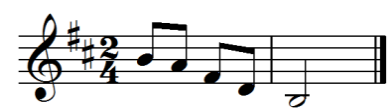

Análise complementar em $2.2-n^{\circ} 3$.

Canção com 24 compassos binários. Anônimo, recolhido por Sodré Vianna e ambientado por H.Villa-Lobos, com a indicação: Moderato.

Tema - motivo dos pretos do recôncavo baiano, ambientado por H.Villa-Lobos.

Texto - linguajar do negro escravo.

Ritmo - o interesse rítmico está na polirritmia horizontal determinada pelas tercinas de pulso e de metro, das síncopas e indicações de variação do andamento, como cedendo, ritmando e fermatas suspensivas. 
Melodia sobre o acorde de $\boldsymbol{B} \mathrm{m}^{7}$. As frases são assimétricas: A (aab); A' (aab); A" (b a); A (a b)

Ludicidade - a canção propicia a pesquisa sobre épocas históricas do Brasil colonial e apresentação de expressões artísticas múltiplas. $\mathrm{O}$ texto, no contexto dessa pesquisa, é um desafio lúdico.

\subsubsection{Sobre cinco graus da escala}

7) A ROSEIRA (1 ${ }^{\mathrm{a}}$ versão $)$ - a capella

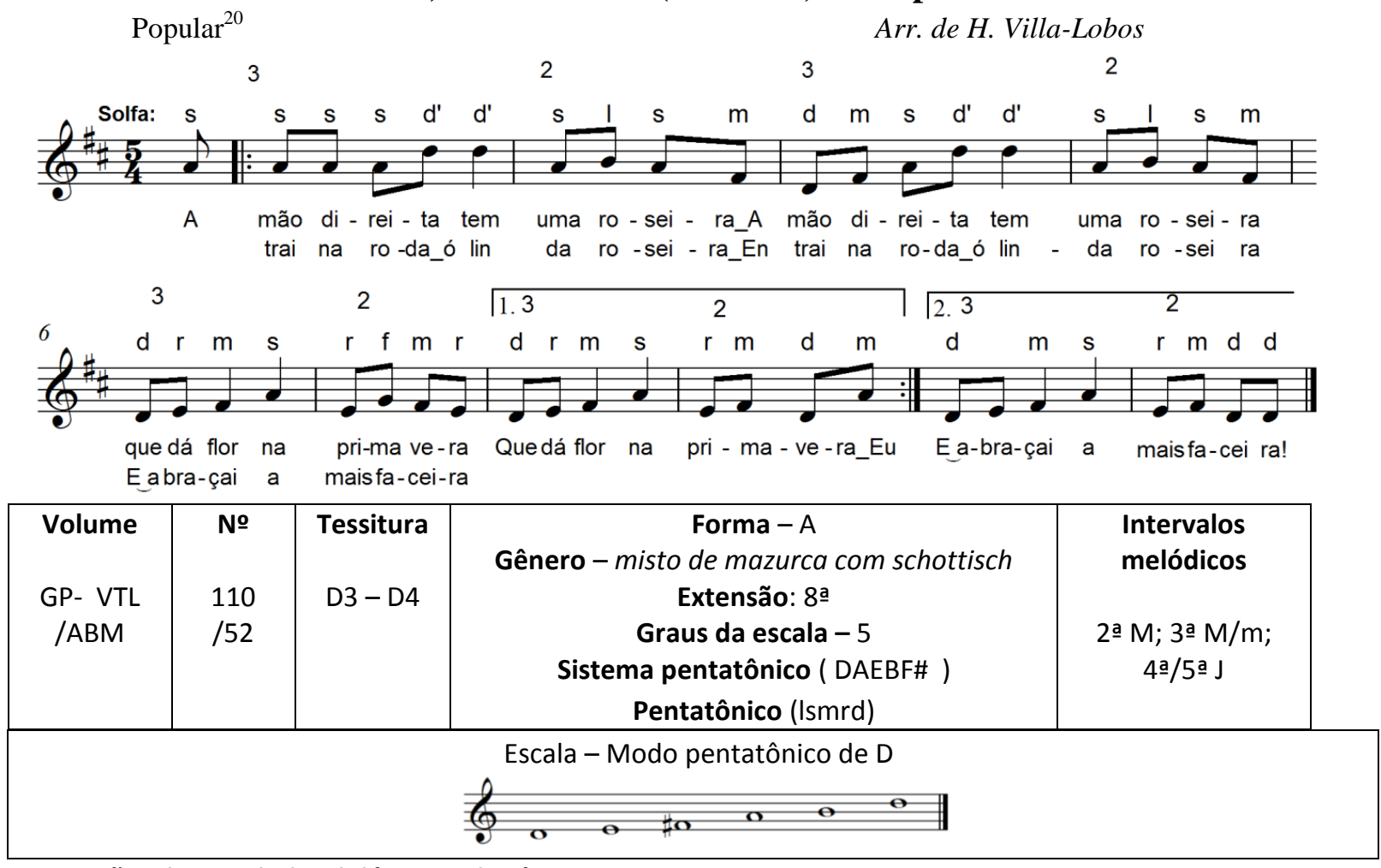

Sugestões de atividades didático-pedagógicas:

Célula rítmica para registro gráfico:

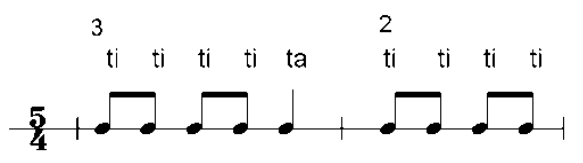

Células melódicas para registro gráfico:

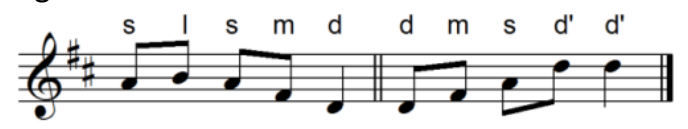

Possível ostinato rítmico:

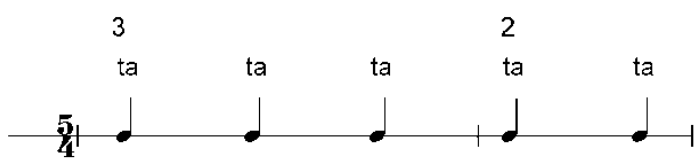

Possivel ostinato melódico:

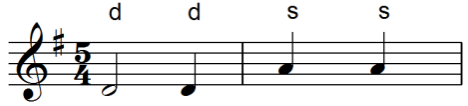

${ }^{20}$ GP/ABM - $1^{\circ}$ Caderno, p.92 : Fonte - SEMA. 
Análise complementar em $2.2-n^{\circ} 7$.

Canção com 11 compassos quinários, com a indicação de andamento: Andantino quasi Allegretto $(\mathbf{1 7 6}=$ 」 ); sem indicações de dinâmica.

Tema popular, folclórico infantil, de brincadeira de roda de escolha cujo desenvolvimento baseia-se no texto.

Texto - descrição de brincadeira de roda em que a roseira é personagem principal, destacada ao centro da roda. De origem francesa - A ma main droite.

Ritmo - o interesse rítmico está nos compassos alternados - ternário e binário (como indicado na versão GP/ABM, que corrige a confusão causada pelo excesso de fórmulas de compasso em GP/VTL).

Melodia - desenho melódico sobre arpejo de $\mathrm{T}^{6}$ em âmbito de oitava, seguido de finalização descendente de $\mathrm{D}$ para $\mathrm{T}$.

Ludicidade - o texto define a movimentação: uma criança ao centro que escolherá outra para substituí-la, através de um abraço.

\section{8) A ROSEIRA ( $2^{\mathrm{a}}$ versão) - acompanhamento instrumental}

$(\text { Piano solo })^{21}$
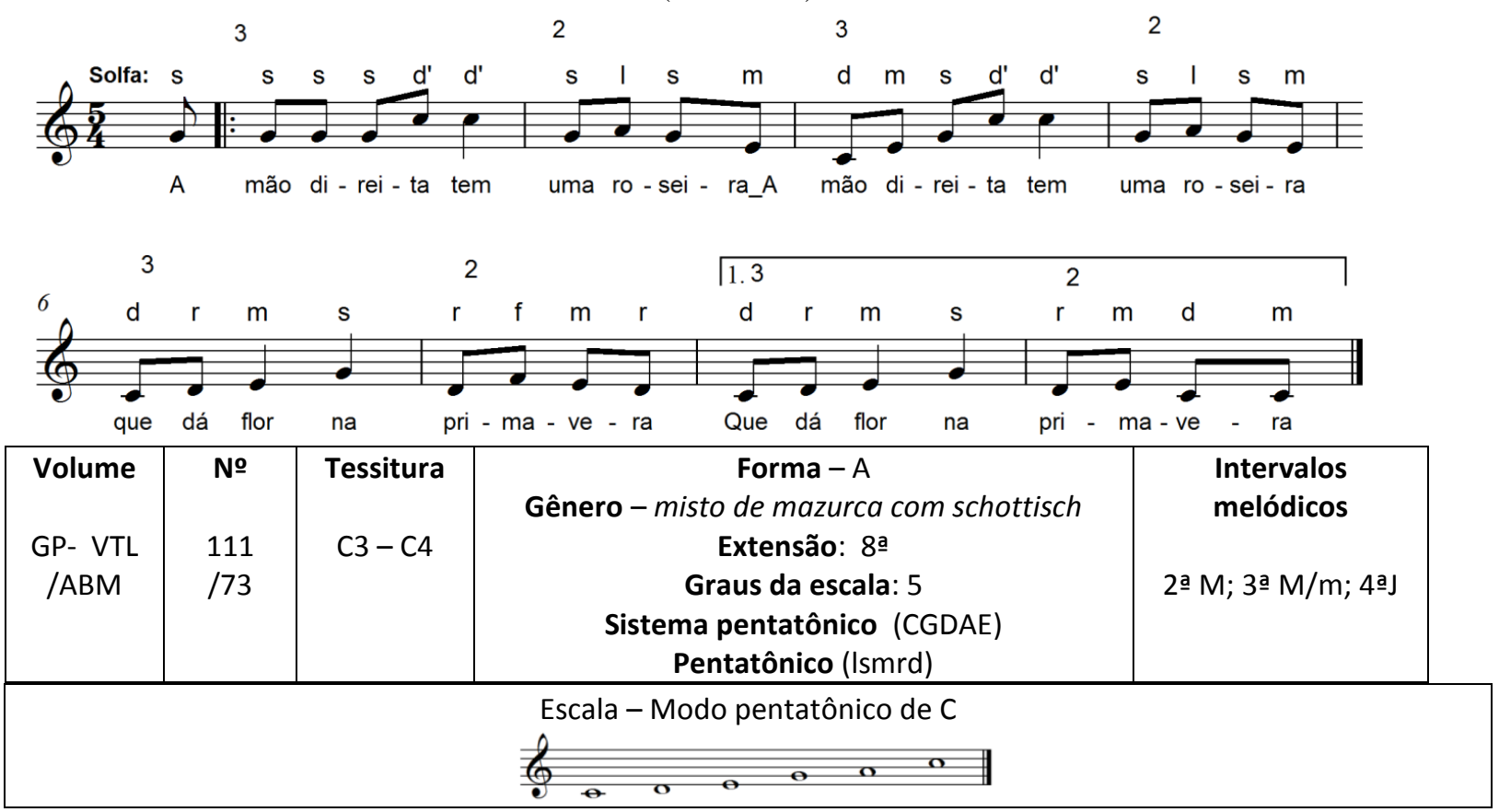

Sugestões de atividades didático-pedagógicas:

Célula para registro gráfico:

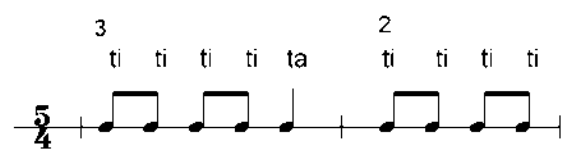

Células melódicas para registro gráfico:

${ }^{21}$ GP/ABM - $2^{\circ}$ Caderno, p.120: nota informativa de que em outras edições a indicação "Para quinteto de sopros" está equivocada. 


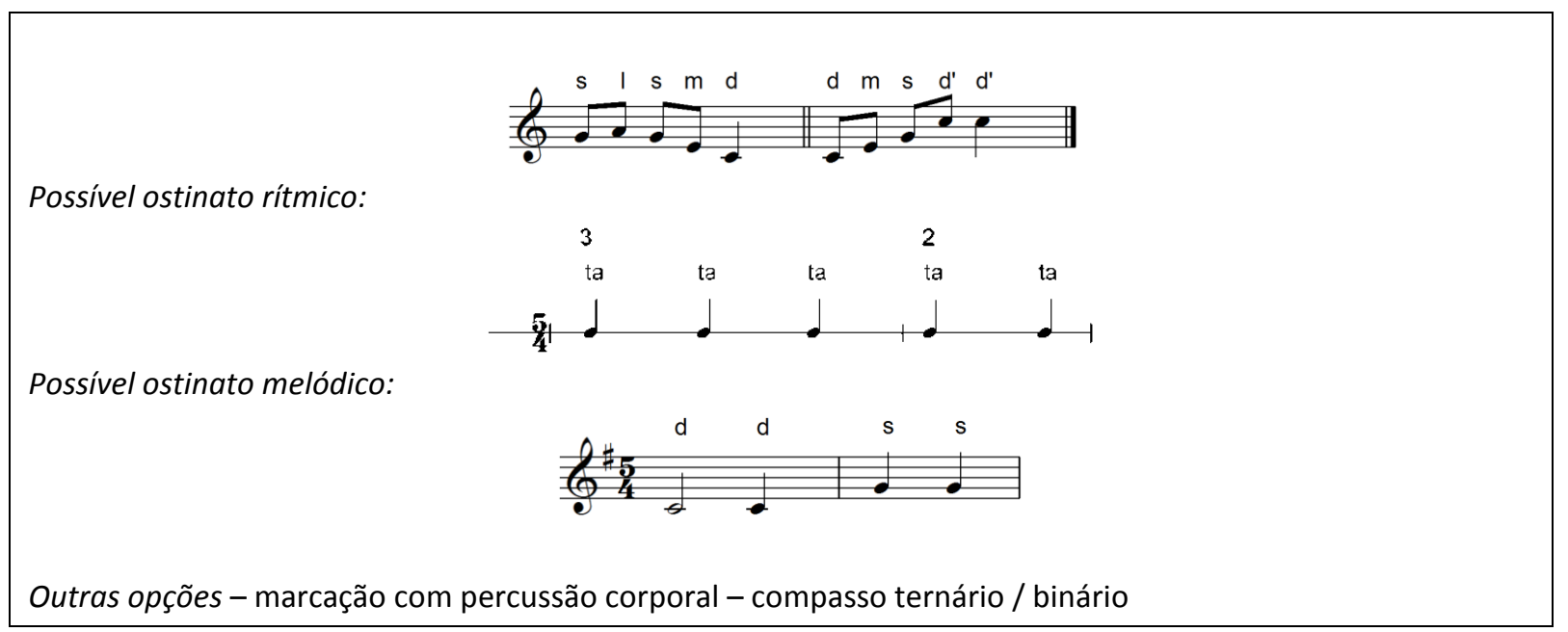

Canção com 9 compassos quinários, com a indicação de andamento: Allegro non Troppo $(\mathbf{1 7 6}=ل$ ل); indicações de dinâmica: $f ; s f z ; p$; dim. poco a poco; $m f$; acentos _

Ritmo - o interesse rítmico está no compasso quinário, com indicação de alternância entre ternário e binário.

Acompanhamento instrumental (piano) - introdução e coda sobre pedal sobre o quinto grau na mão direita, com a linha do baixo sendo idêntica à utilizada no acompanhamento da melodia, dobrada na mão direita.

\subsection{4 Sobre sete graus da escala}

\section{9) JOÃO CAMBUETE - acompanhamento instrumental}

(Canto com piano, conjunto instrumental) Amb. por H. Villa-Lobos

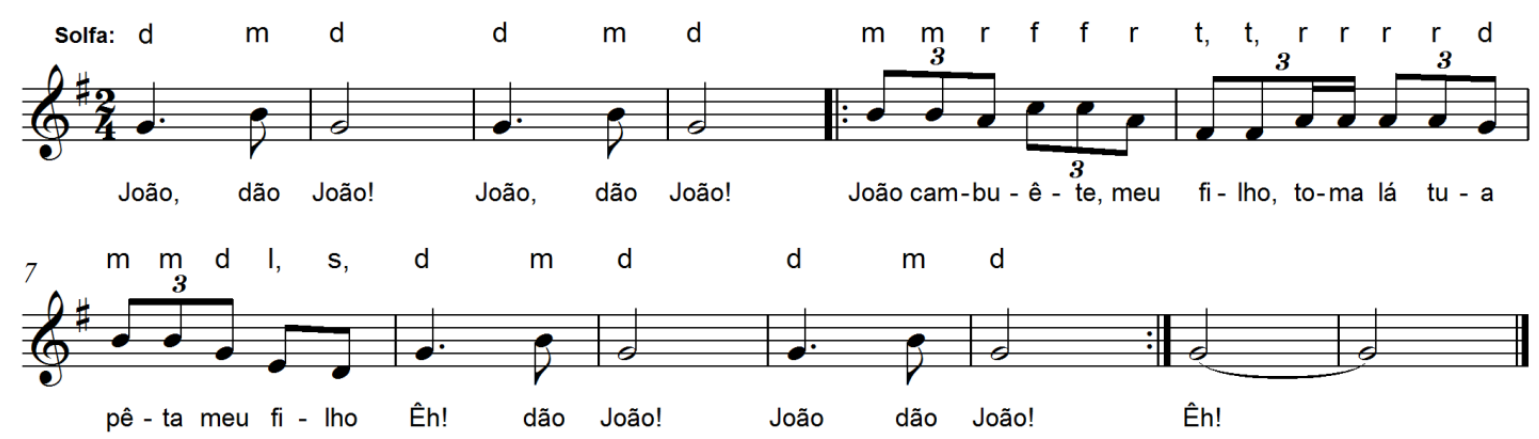

\begin{tabular}{|c|c|c|c|c|}
\hline $\begin{array}{l}\text { Volume } \\
\text { GP- VTL } \\
\text { /ABM }\end{array}$ & $\begin{array}{c}\text { No } \\
66 \\
/ 110\end{array}$ & $\begin{array}{l}\text { Tessitura } \\
\text { D3-C4 }\end{array}$ & $\begin{array}{c}\text { Forma - Introdução A Coda } \\
\text { Gênero: Acalanto } \\
\text { Extensão: 7ạ } \\
\text { Graus da escala: } 7 \\
\text { Sistema heptatônico (C G D A E B F\#) } \\
\text { Heptacorde ( } \mathrm{m} r \mathrm{~d} \mathrm{t} \mathrm{l}, \mathrm{s}, \text { ) }\end{array}$ & $\begin{array}{c}\begin{array}{c}\text { Intervalos } \\
\text { melódicos }\end{array} \\
\text { 2a } \mathrm{M} ; 3 \text { a } \mathrm{M} / \mathrm{m} ; 4 \text { a J }\end{array}$ \\
\hline \multicolumn{5}{|c|}{ Escala - Modo de G maior } \\
\hline
\end{tabular}


Célula rítmica para registro gráfico:

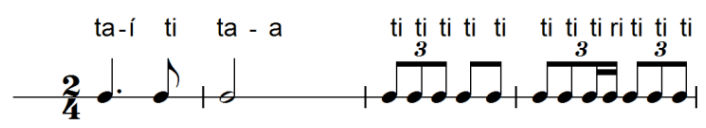

Células melódicas para registro gráfico:

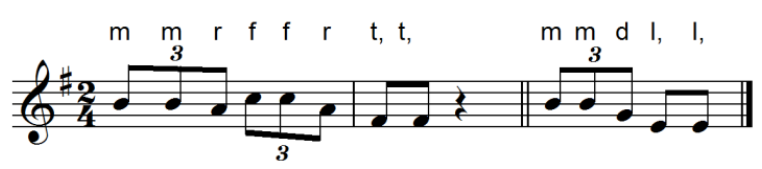

Possivel ostinato rítmico:

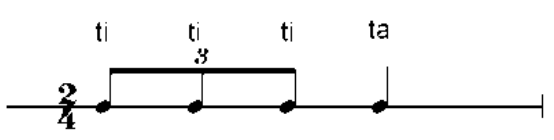

Possivel ostinato melódico:

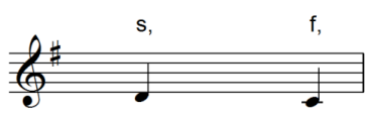

Outras opções: acompanhamento com instrumentos de teclas em substituição ao piano.

Canção com 13 compassos binários, com a indicação de andamento: Acalanto (M.M. 54= ل ); indicação de dinâmica: $\boldsymbol{m f}$

Tema popular, folclórico infantil, de canção de ninar - acalanto.

Texto - descreve o canto da mãe que embala o filho João, dando-lhe a chupeta para adormecer. Os acentos nas sílabas Dão; $\hat{E} h$ ! Dão podem ter intenção timbrística (sino), tanto quanto sugerir o movimento de balanço.

Ritmo - o interesse rítmico está nas tercinas e na polirritmia decorrente.

Melodia - o ostinato inicial e final com salto de terça maior a partir do primeiro grau envolve a melodia central desenvolvida sobre terças e graus conjuntos, com finalização descendente, voltando ao ostinato na coda com salto de quarta ascendente.

Acompanhamento instrumental (piano) - ao pedal grave de T na mão esquerda, em apojatura com os acordes que dobram a melodia cantada, contrapõe-se um ostinato na mão direita, na região aguda - apojaturas sobre quinto e primeiro graus em contratempos, em polirritmia com as tercinas da linha melódica. Na coda, de dois compassos, as apojaturas da mão direita sobre os mesmos graus seguem em tercinas.

Ludicidade - a canção de ninar torna-se um dos primeiros estímulos à aquisição dos elementos primários da música pela criança. Voz e movimento são componentes de grande importância na formação dos bebês e possibilitam um diálogo afetivo e musical entre o adulto e a criança. 


\section{0) CONSTÂACIA - acompanhamento instrumental}

(Canto com piano, conjunto instrumental ou piano solo)

Harm. por H. Villa-Lobos

\section{$\%$}
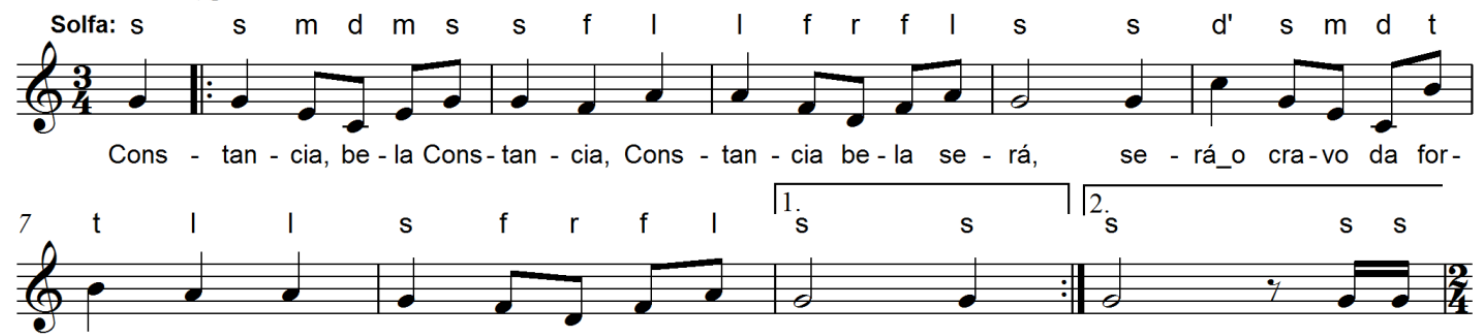

tu - na, A vol - ta que_o mun - do dá. Cons - dá Do - lin!

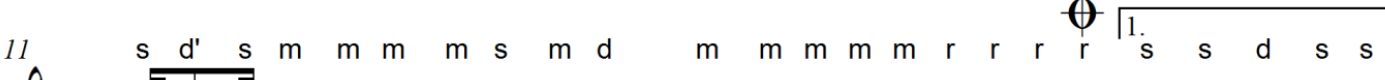

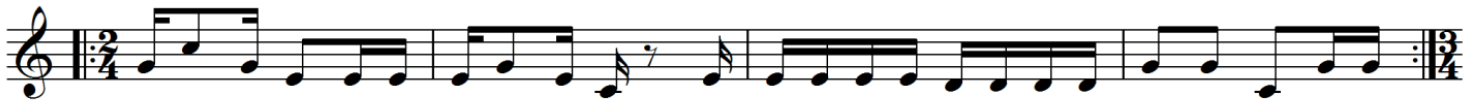

lin! do - lê! lê! Do-lin! lin! Do - lá! lá! To - can-do na vi - o-la Pa-ra se dan-çar! Do lin!

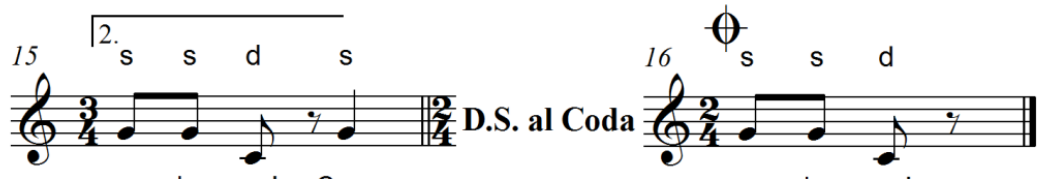

se dan-çar! Cons se dan - çar!

\begin{tabular}{|c|c|c|c|c|}
\hline $\begin{array}{l}\text { Volume } \\
\text { GP- VTL } \\
\text { /ABM }\end{array}$ & $\begin{array}{l}\text { № } \\
41 \\
/ 95\end{array}$ & $\begin{array}{l}\text { Tessitura } \\
\text { C3-C4 }\end{array}$ & $\begin{array}{c}\text { Forma - A / B } \\
\text { Gênero: Canção } \\
\text { Extensão: } 8 \text { ạ } \\
\text { Graus da escala: } 7 \\
\text { Sistema heptatônico (F C G D A E B) } \\
\text { Heptacorde (d' t I s f m r d) }\end{array}$ & $\begin{array}{l}\text { Intervalos melódicos } \\
\begin{array}{c}\text { 2a M; 3a } \mathrm{M} / \mathrm{m} ; 4 \text { a } / 5 \text { a } \\
\mathrm{J} ; 7 \text { a } \mathrm{M}\end{array}\end{array}$ \\
\hline & & & 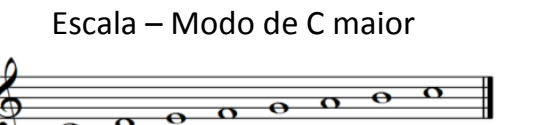 & \\
\hline
\end{tabular}

Sugestões de atividades didático-pedagógicas:

Célula rítmica para registro gráfico:

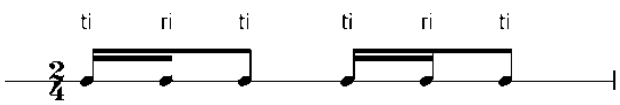

Células melódicas para registro gráfico:

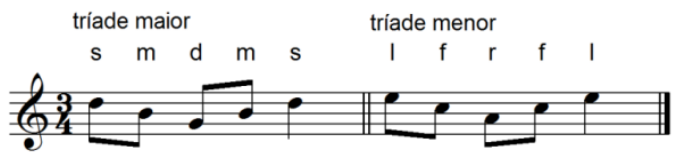

Possivel ostinato rítmico:

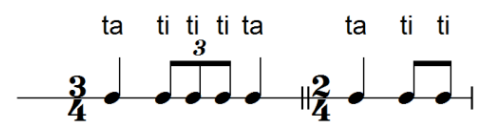

Canção com 16 compassos ternários e 8 compassos binários, com a indicação de andamento: Andantino (104= ل ); indicação de dinâmica: $f \boldsymbol{f}$

Tema popular, folclórico infantil, de brincadeira de roda cujo desenvolvimento baseia-se no texto.

Texto - Constância é a personagem homenageada nos versos. Na segunda parte do texto, as sílabas do-lin-do-lêflá, têm a intenção timbrística de imitação da viola. 
Ritmo - o interesse rítmico está na troca de compassos nas partes e nas síncopas de pulsação nos compassos binários da segunda parte.

Melodia - baseada nos arpejos em sequências de tríades maiores e menores; na segunda parte privilegia notas rebatidas. Destaque-se a apojatura com salto de sétima maior ascendente, raro em melodias infantis.

Acompanhamento instrumental (piano) - a mão direita dobra a melodia, com acompanhamento de ritmo de valsa na mão esquerda sobre acordes das funções primárias. Idem na parte $\mathrm{B}$, com ritmo sincopado acompanhando a melodia, com acordes de $\mathrm{T}$ e $\mathrm{D}$. Coda com um compasso, com acorde de T no contratempo métrico.

Ludicidade - brincadeira de roda de escolha, em que a roda canta a primeira parte e a criança do centro responde o diálogo em solo, escolhendo outra criança que a substituirá no centro, o que traz a possibilidade de experimentarem o cantar em coro e solo.

Complementação do texto ${ }^{22}$ :

- Constância, bela Constância / Constância bela será,/ Será o cravo da fortuna / a volta que o mundo dá.

- Entrei num jardim de flores, / não sei qual escolherei,/ Escolho a mais formosa / aquela que abraçarei.

- Refrão: Dolin! Lin! Dolê! Lê! / Dolin! Lin! Dolá! Lá! / Tocando na viola para se dançar!

\subsubsection{Melodias com semitom $\mathrm{m} / \mathrm{f}$}

\subsubsection{Sobre quatro graus da escala}

\section{1) REGOZIJO DE UMA RAÇA (Canto Africano I ) - a capella}
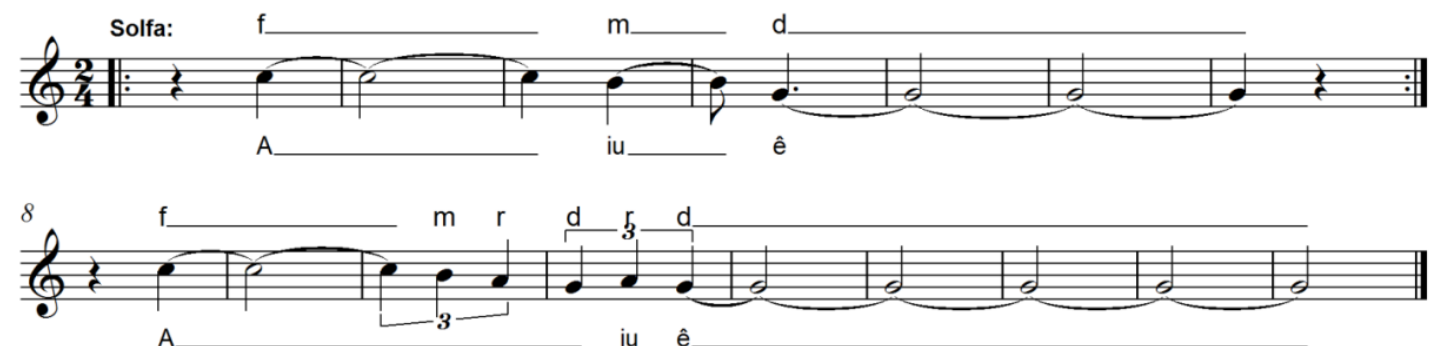

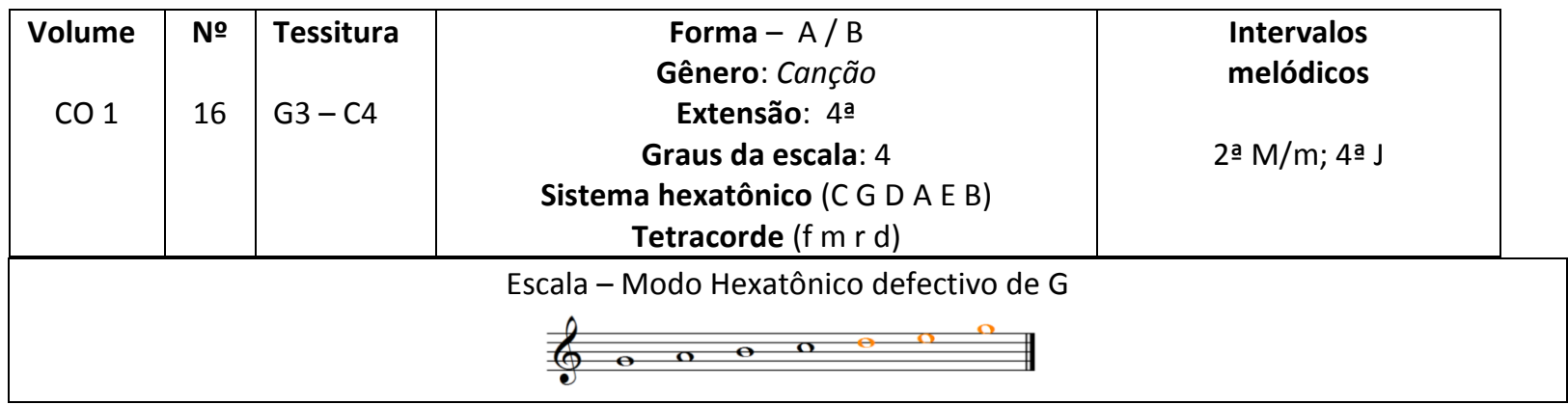

${ }^{22}$ GP/ABM - 2ํㅡㄹ Caderno, p. 112 - Fonte: SEMA 
Sugestões de atividades didático-pedagógicas:

Célula rítmica para registro gráfico:

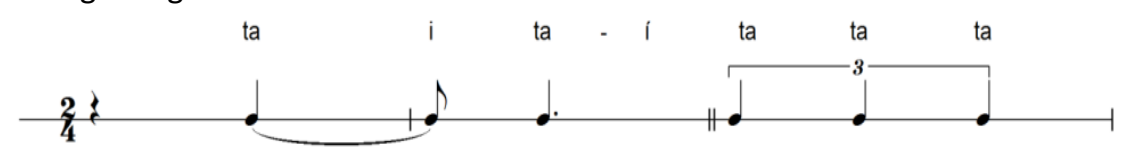

Células melódicas para registro gráfico:

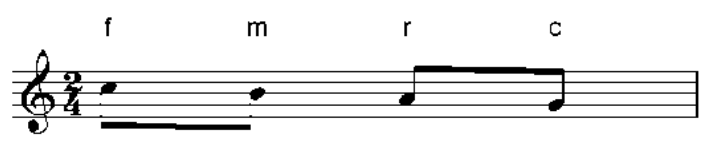

Possivel ostinato rítmico:

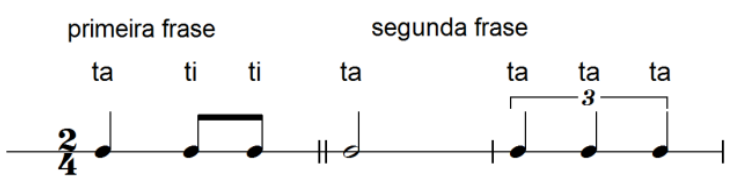

Outras opções: pedal na dominante

Canção com 16 compassos binários, com a indicação de andamento: Marcial; sem indicações de dinâmica.

Tema africano sem indicação de procedência.

Texto em idioma africano - não consta tradução.

Ritmo - o interesse rítmico está nas tercinas métricas, e na polirritmia horizontal decorrente. A primeira parte segue uma abordagem rítmica binária e a segunda parte, quando for o caso de não se querer tratar a polirritmia, pode ter uma abordagem rítmica de divisão ternária.

Melodia - baseada em tetracorde descendente, destacando sons longos, que têm importância timbrística.

Ludicidade - o idioma africano pode sugerir tanto uma coreografia como um acompanhamento percussivo.

\section{2) CANTOS DE ÇAIRÉ № 1 - a capella}

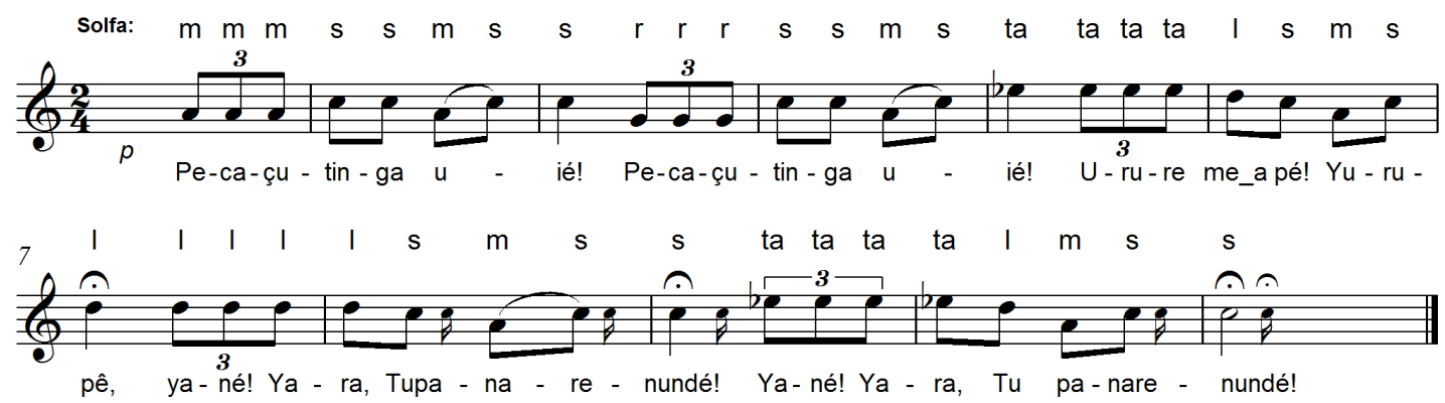

\begin{tabular}{|l|l|l|c|c|}
\hline Volume & № & Tessitura & $\begin{array}{c}\text { Forma - A } \\
\text { Extensão: 5a } \\
\text { Graus da escala: } 4\end{array}$ & $\begin{array}{c}\text { Intervalos } \\
\text { Melódicos }\end{array}$ \\
\hline
\end{tabular}




\begin{tabular}{|c|c|c|c|c|}
\hline CO2 & 18 & G3-Eb4 & $\begin{array}{c}\text { Sistema Heptatônico (Eb Bb F C G D A) } \\
\text { Heptacorde ( } \mathrm{m} \mathrm{r} \mathrm{d} \mathrm{t} \mathrm{I} \mathrm{s)} \mathrm{ou} \mathrm{(ta} \mathrm{I} \mathrm{s} \mathrm{f} \mathrm{m} \mathrm{r} \mathrm{d)}\end{array}$ & $\begin{array}{c}\text { 2a M/m; 3a } \mathrm{m} \\
\text { 4a J }\end{array}$ \\
\hline \multicolumn{4}{|c|}{ Escala - Modo mixolídio defectivo de F } \\
\hline
\end{tabular}

Sugestões de atividades didático-pedagógicas:

Célula rítmica para registro gráfico:

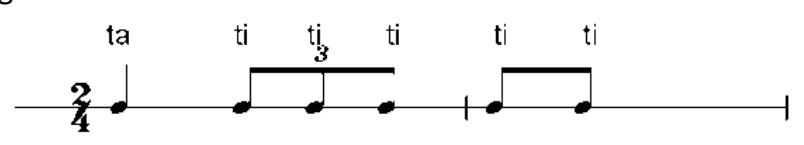

Células melódicas para registro gráfico:

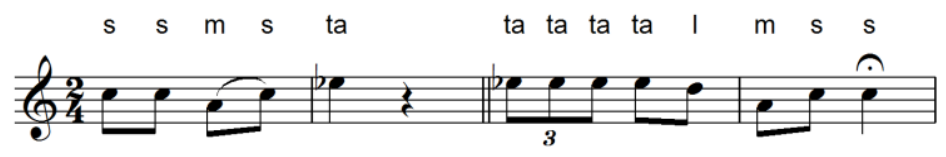

Possivel ostinato rítmico:

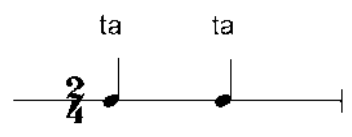

Possivel ostinato melódico:

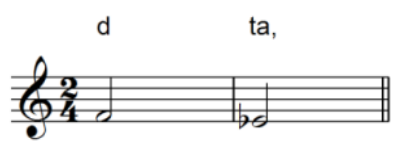

Análise complementar em $2.2-n^{\circ} 9$.

Canção com 11 compassos binários, com a indicação de andamento: Lento; indicações de dinâmica: $\boldsymbol{p}$; acentos >.

Tema popular, folclórico amazônico, ambientado por H.Villa-Lobos. Nos compassos 8 a 11 aparecem apojaturas longas para acomodação do texto.

Texto - em língua indígena, sem indicação da procedência ou tradução.

Ritmo - o interesse rítmico está na polirritmia horizontal determinada pelas tercinas. $\mathrm{O}$ andamento lento sugere certa liberdade rítmica, quase um recitativo. Há suspensões por fermata nos compassos 7, 9 e 11 .

Melodia em modo mixolídio, com apenas quatro graus, em quatro frases expressas por notas rebatidas e pequenos saltos.

Ludicidade - a indicação de $\boldsymbol{D}$.C. ad libitum pode sugerir uma coreografia.

\subsubsection{Sobre cinco graus da escala}


13) O RICO E O POBRE- acompanhamento instrumental

(Canto com piano, conjunto instrumental ou piano solo) Amb. por H. Villa-Lobos

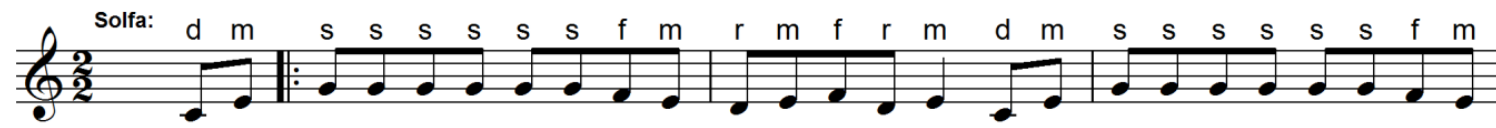

Eu sou ri-co ri-co ri-co de mar - ré mar-ré mar-ré Eu sou po-bre po-bre po-bre de mar-

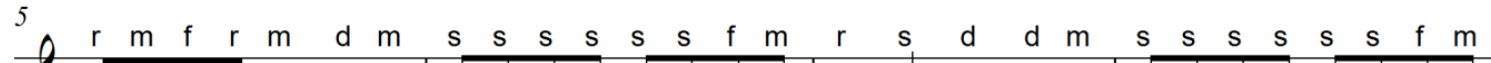
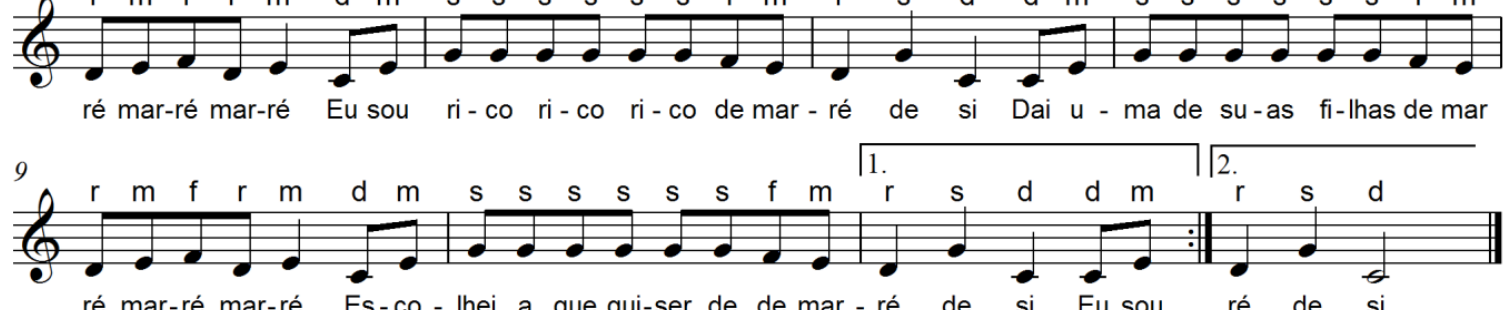

ré mar-ré mar-ré Es-co - Ihei a que qui-ser de de mar - ré de si Eu sou ré de si

\begin{tabular}{|c|c|c|c|c|}
\hline $\begin{array}{l}\text { Volume } \\
\text { GP- VTL } \\
\text { /ABM }\end{array}$ & $\begin{array}{c}\text { No } \\
98 \\
\text { /104 }\end{array}$ & $\begin{array}{c}\text { Tessitura } \\
\text { C3-G3 }\end{array}$ & $\begin{array}{c}\text { Forma - A } \\
\text { Gênero: Cantiga } \\
\text { Extensão: } 5 \underline{a} \\
\text { Graus da escala: } 5 \\
\text { Sistema hexatônico (F C G D A E) } \\
\text { Pentacorde (s f m r d) }\end{array}$ & $\begin{array}{c}\text { Intervalos } \\
\text { Melódicos } \\
2 \text { ạ } \mathrm{M} / \mathrm{m} ; 3^{a} \underline{\mathrm{a}} \mathrm{M} / \mathrm{m} ; 4^{\mathrm{a}} \stackrel{\mathrm{a}}{\mathrm{a}} \mathrm{a} \mathrm{J}\end{array}$ \\
\hline \multicolumn{5}{|c|}{ 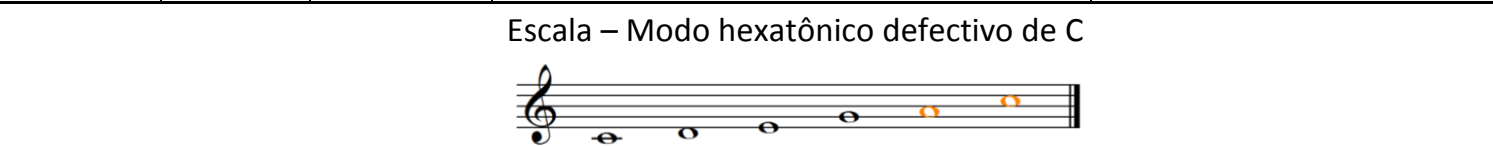 } \\
\hline
\end{tabular}

Sugestões de atividades didático-pedagógicas:

Célula rítmica para registro gráfico:

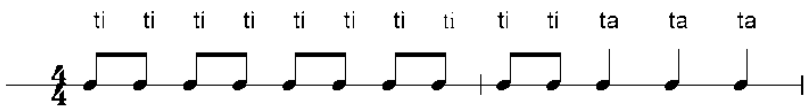

Célula melódica para registro gráfico:

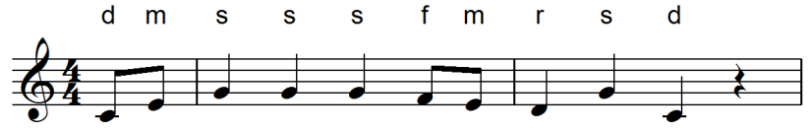

Possivel ostinato rítmico:

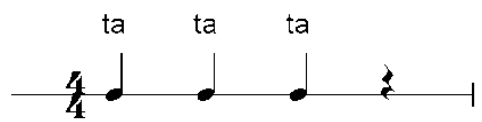

Possivel ostinato melódico:

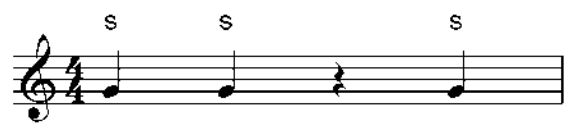

Canção com 12 compassos binários, com a indicação de andamento: Allegro (M.M. $160=$ ل); indicações de dinâmica: $\boldsymbol{f}$; $\boldsymbol{s f f z} ; \boldsymbol{f f}$; acentos >

Tema popular, folclórico infantil, de brincadeira cantada, cujo desenvolvimento baseia-se no texto.

Texto - descrição de brincadeira cantada em que o rico pede a mão da moça pobre, o que lhe é concedido facilmente. Possivelmente de origem francesa - corruptelas de 'Marier (Casar) / d'ici (daqui)'. As repetições de palavras têm intenção timbrística, de reforço e lúdica.

Ritmo - baseado na divisão binária dos pulsos, acompanhando as acentuações tônicas das palavras. 
Melodia - desenhos sobre arpejo ascendente da tríade da $\mathrm{T}$ e notas rebatidas na $\mathrm{D}$, com finalização nos saltos de quarta ascendente e quinta descendente para a T. Preferimos grafar a melodia oitava abaixo da grafia encontrada em GP/ABM, para situar a tessitura mais adequadamente para vozes infantis.

Acompanhamento instrumental (piano) - a mão direita dobra a melodia em oitavas na região aguda, enquanto que a mão esquerda, sobre pedal na $\mathrm{T}$ em região grave, estabelece um contraponto com tríades descendentes por três oitavas em graus conjuntos, repetindo, da mesma forma, agora por duas oitavas, e terminando com a cadência $\mathrm{D}^{11^{+}} /{ }^{9-} / \mathrm{T}$.

Ludicidade - brinquedo cantado no qual as crianças ficam dispostas em uma fileira e em frente a essa uma criança sozinha, representando os pobres e o rico respectivamente. Inicia-se o diálogo a partir do texto, com o recuo para frente da criança que está sozinha e a fileira responde, recuando para trás. A solista escolhe seu par, que passará a ficar ao seu lado. Assim se segue a brincadeira até que todas as crianças sejam escolhidas, isto é, todas as crianças passem para o outro lado, restando apenas uma. Toda essa movimentação obedece ao pulso da música e às frases do diálogo, possibilitando o exercício de se cantar em solo coro, o qual aumenta de um lado seus integrantes, enquanto do outro eles diminuem gradativamente.

\section{4) SOLFEJO 144 - a capella}
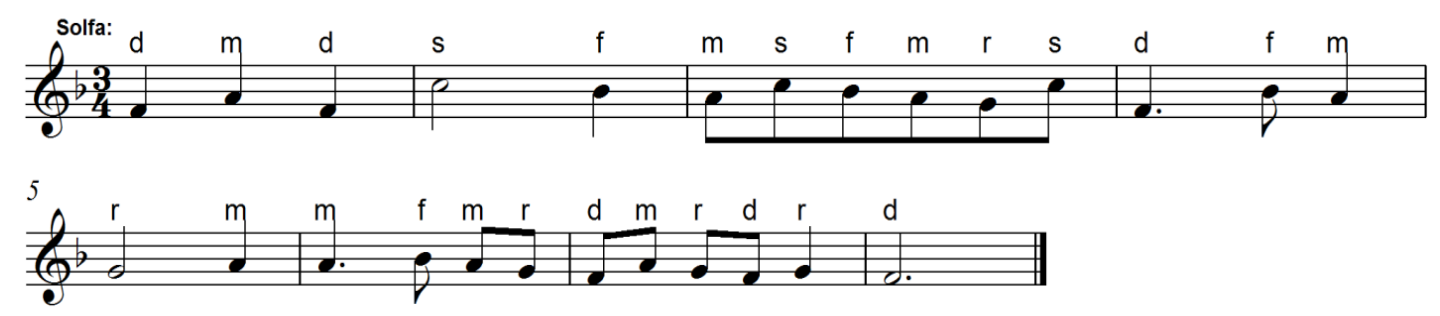

\begin{tabular}{|c|c|c|c|c|}
\hline Volume & $\begin{array}{l}\text { № } \\
144\end{array}$ & $\begin{array}{l}\text { Tessitura } \\
\text { F3-C4 }\end{array}$ & $\begin{array}{c}\text { Forma - A } \\
\text { Extensão: } 5 \underline{a} \\
\text { Graus da escala: } 5 \\
\text { Sistema hexatônico (Bb F C G D A) } \\
\text { Pentacorde (s f m r d) }\end{array}$ & $\begin{array}{c}\text { Intervalos } \\
\text { Melódicos } \\
\text { 2a } \mathrm{M} / \mathrm{m} ; 3 \text { ạ } \mathrm{M} / \mathrm{m} ; 4 \text { ạ } / 5 \text { a } \mathrm{J}\end{array}$ \\
\hline & & & 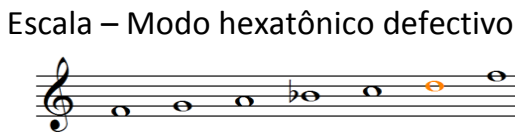 & \\
\hline
\end{tabular}

\section{Sugestões de atividades didático-pedagógicas:}

Células rítmicas para registro gráfico:

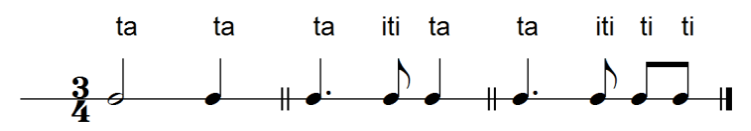

Células melódicas para registro gráfico:

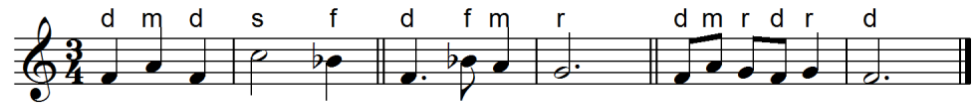

Possivel ostinato rítmico:

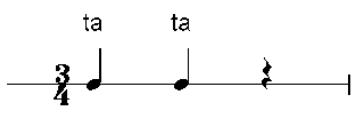

Possível ostinato melódico: 


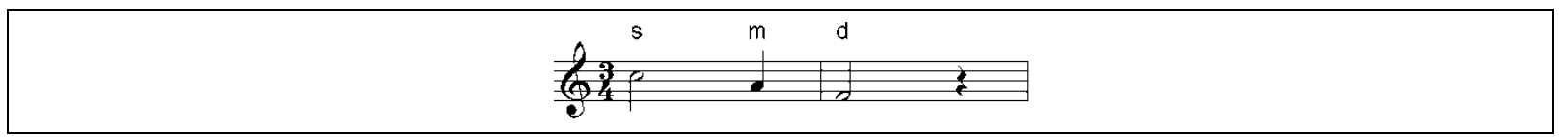

Análise complementar em $2.2-n^{\circ} 97$.

Tema de Villa-Lobos à semelhança de dança de procedência européia, com 8 compassos ternários, com a indicação de andamento: Tempo de Mazurka; sem indicações de dinâmica.

Ritmo - o interesse rítmico está no compasso ternário e nas notas pontuadas.

Melodia no pentacorde da T, iniciada por arpejo quebrado da tríade de T, seguido de desenhos por graus conjuntos e intervalos de terças e quartas, com terminação na T.

Ludicidade - apesar de se tratar de um solfejo, sendo em tempo de mazurca, pode-se acrescentar ao canto uma coreografia, podendo a mesma integrar movimentos que representem as alturas das notas, as figuras rítmicas, ou o pulso, permitindo perceber-se e internalizar corporalmente a melodia ternária.

15) VAMOS, MARUCA- acompanhamento instrumental

(Canto com piano, ou conjunto instrumental ou piano solo)

Arr. de H. Villa-Lobos

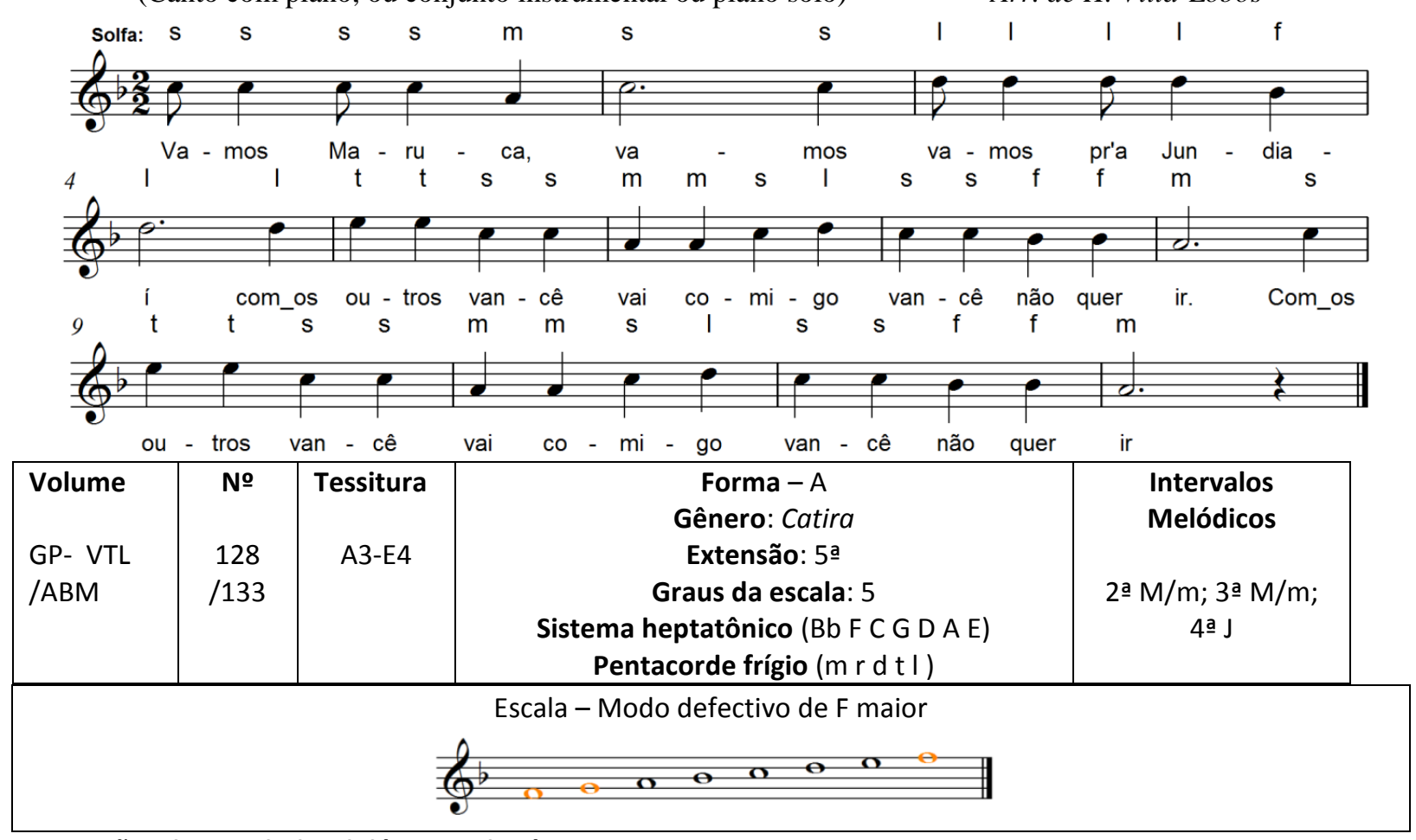

Sugestões de atividades didático-pedagógicas:

Célula rítmica para registro gráfico:

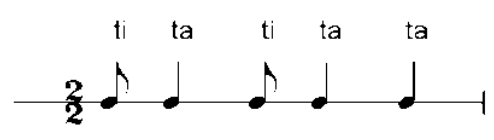


Células melódicas para registro gráfico:

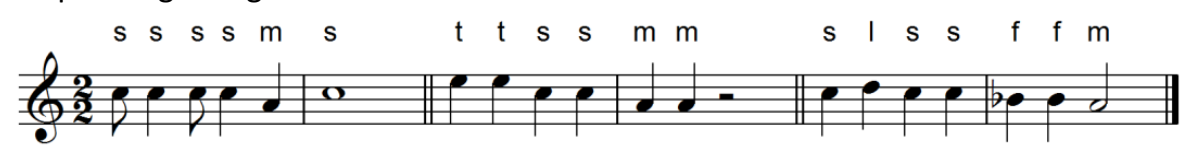

Possivel ostinato rítmico:

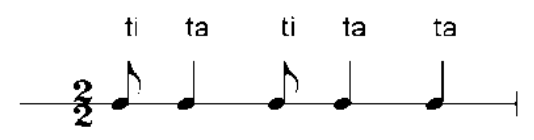

Análise complementar em $2.2-n^{\circ} 164$.

Canção com 12 compassos binários, com a indicação de andamento: Poco Moderato (M.M. $\mathbf{8 4}=d$ ); indicações de dinâmica: $\boldsymbol{m f}$; $\boldsymbol{a c e n t o s}>$

Tema popular, folclórico infantil, de brincadeira cantada, cujo desenvolvimento baseia-se no texto.

Texto - descrição de brincadeira de roda, em que a personagem, Maruca, é convidada a participar da coreografia. Linguagem própria da região interiorana no sudeste do país.

Ritmo - o interesse rítmico está nas síncopas seguidas de notas longas.

Melodia - baseada em intervalos de terças, a melodia inicia-se nas terças superiores das tríades de $\mathrm{T}$ e $\mathrm{S}$, em sequência, seguidas das terças descendentes da $\mathrm{D}$ e $\mathrm{T}$, com final convergindo para a terça da $\mathrm{T}$.

Ludicidade - o texto sugere que, na coreografia, quem representa a Maruca deva oferecer, inicialmente, certa resistência para entrar na roda. Como não foram encontrados registros sobre o desenvolvimento da brincadeira, a criatividade pode levar a várias soluções, entre elas a inclusão de batida das palmas e pés, características de seu gênero musical que é a Catira.

\section{6) MANDA O TIRO, TIRO, LÁ - acompanhamento instrumental}

(Canto com piano, conjunto instrumental ou piano solo) Arr. de H. Villa-Lobos

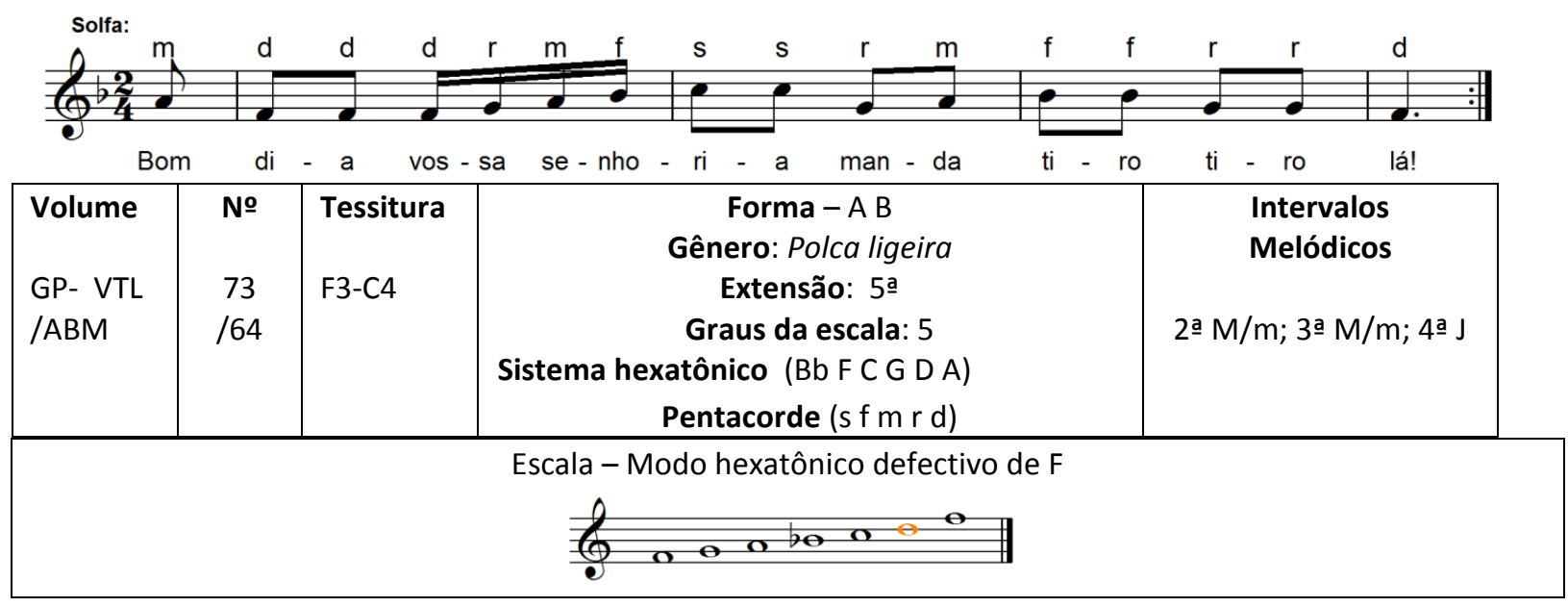

Sugestões de atividades didático-pedagógicas: 
Célula rítmica para registro gráfico:

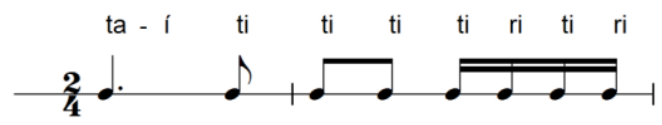

Célula melódica para registro gráfico:

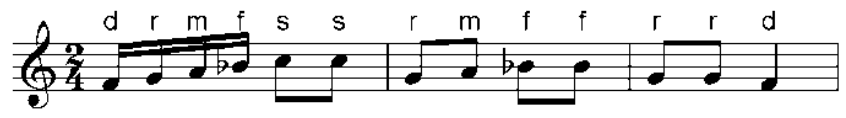

Possível ostinato rítmico:

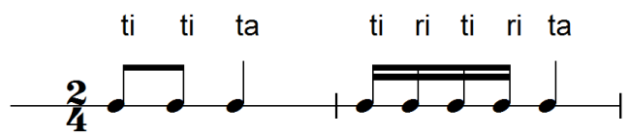

Possível ostinato melódico:

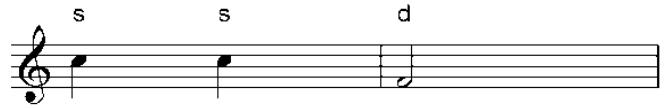

Canção com 5 compassos binários, com a indicação de andamento: Vivace $(\mathbf{1 3 8}=\mathrm{d})$; indicações de dinâmica: $\boldsymbol{f} ; \boldsymbol{m f}$; acentos > _

Tema popular, folclórico infantil, de brincadeira cantada, cujo desenvolvimento baseia-se no texto.

Texto - descrição de brincadeira cantada com resquícios de tratamento formal cortesão. Em GP/VTL consta a expressão "mando tiro, tiro lá", que resulta da elisão de "manda o tiro tiro lá", encontrado em outras versões. Na versão GP/ABM, aparece "manda tiro, tiro, lá". Nossa sugestão é que se mantenha o artigo, ficando: "manda o tiro, tiro lá".

Ritmo - o interesse rítmico está nos grupos de semicolcheias em contraste com os de colcheias.

Melodia - iniciada no pentacorde da T, segue-se por desenhos em graus conjuntos e resolução descendente em terças quebradas na $\mathrm{D}$ com resolução na $\mathrm{T}$. A segunda parte, que deve ser dançada, pode ou não ser cantada com a sílaba 'lá'. Havendo acompanhamento, a dança é mais bem desenvolvida sem o canto. Caso contrário, a linha melódica da parte B consiste em uma dupla sequência descendente de desenhos sobre o tetracorde $\boldsymbol{l} \boldsymbol{s} \boldsymbol{f} \boldsymbol{m}$.

Acompanhamento instrumental (piano) - introdução e coda com três apojaturas triplas: $\mathrm{T}^{9 / 8} / 6^{6-5} /{ }^{4 / 3} \mathrm{em}$ três oitavas em sequência ascendente. Na parte $\mathrm{A}$, a mão direita dobra a melodia cantada e a esquerda faz um ostinato rítmico com duas colcheias nos primeiros pulsos dos compassos, contemplando uma pequena linha cromática na sequência dos acordes. $\mathrm{Na}$ parte B, muda apenas o acompanhamento da mão esquerda que, sobre uma linha descendente do tetracorde $\boldsymbol{f} \boldsymbol{m} \boldsymbol{r} \boldsymbol{d}$ intercala um pedal de $\mathrm{T}$ na segunda metade de cada pulso.

Ludicidade - A brincadeira consiste em movimentação de avanço e recuo de duas alas, frente a frente, com diálogos segundo o texto.

Complemento do texto ${ }^{23}$ :

Refrão: Bom dia vossa Senhoria, Manda (o) tiro, tiro lá.

- Que é que você quer? Manda (o) tiro, tiro lá.

- Quero uma de vossas filhas. Manda (o) tiro, tiro lá.

- E qual delas a senhora quer? Manda (o) tiro, tiro lá.

- Quero a F... Manda (o) tiro, tiro lá.

${ }^{23}$ ABM - Segundo Caderno, p.70 - Fonte: J. Gomes Junior \& J. Batista Julião - Ciranda Cirandinha. 
- Que ofício dá pra ela? Manda (o) tiro, tiro lá.

- Dou ofício de florista. Manda (o) tiro, tiro lá.

- Ela disse que sim. Manda (o) tiro, tiro lá.

- Vamos fazer a festa juntos. Manda (o) tiro, tiro lá.

\section{7) VAMOS ATRÁS DA SERRA, OH CALUNGA - acompanhamento instrumental \\ (Canto com piano, conjunto instrumental ou piano solo) \\ Amb. por H. Villa-Lobos}
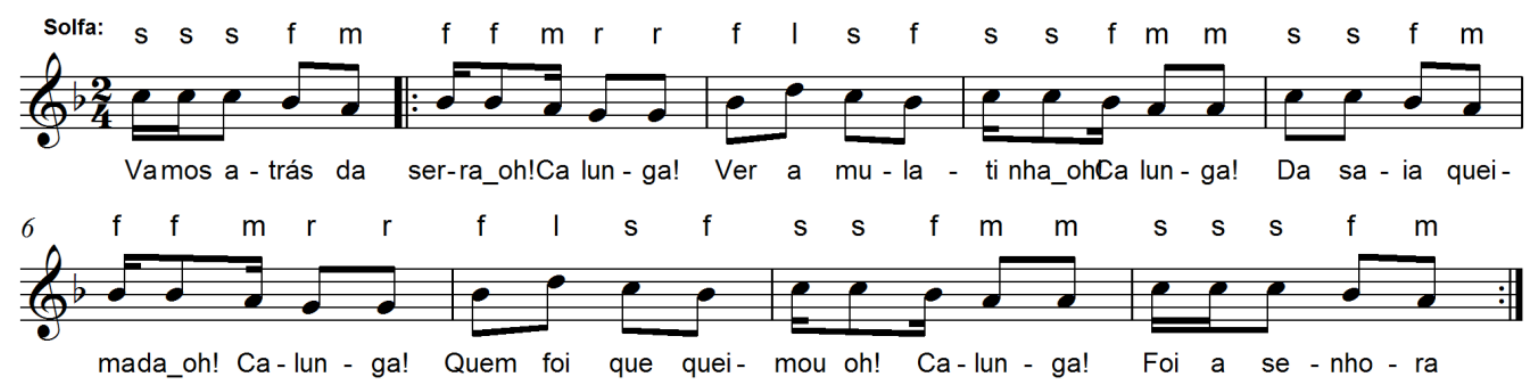

\begin{tabular}{|c|c|c|c|c|}
\hline $\begin{array}{l}\text { Volume } \\
\text { GP- VTL } \\
\text { /ABM }\end{array}$ & $\begin{array}{c}\text { No } \\
126 \\
/ 134\end{array}$ & $\begin{array}{l}\text { Tessitura } \\
\text { G3-D4 }\end{array}$ & $\begin{array}{c}\text { Forma - A } \\
\text { Gênero: Um pouco coco de embolada } \\
\text { Extensão: } 5 \text { ạ } \\
\text { Graus da escala: } 5 \\
\text { Sistema hexatônico (Bb F C G D A) } \\
\text { Pentacorde (I s f m r) }\end{array}$ & $\begin{array}{c}\text { Intervalos } \\
\text { Melódicos } \\
\text { 2a } \mathrm{M} / \mathrm{m} ; 3 \text { a } \mathrm{M} / \mathrm{m}\end{array}$ \\
\hline \multicolumn{5}{|c|}{ 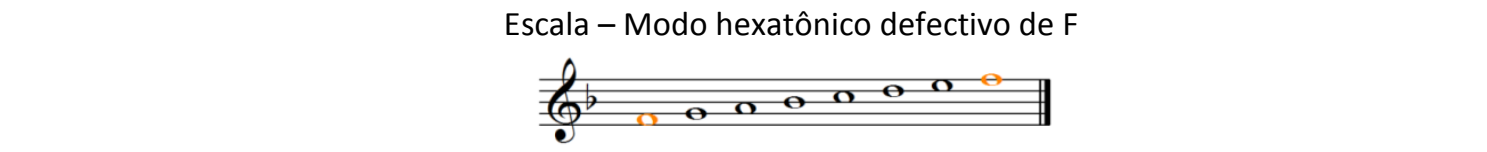 } \\
\hline
\end{tabular}

\section{Sugestões de atividades didático-pedagógicas:}

Células rítmicas para registro gráfico:

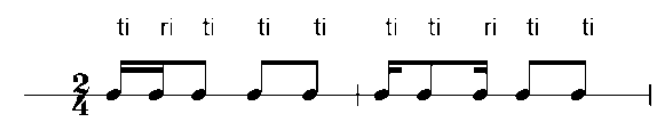

Células melódicas para registro gráfico:

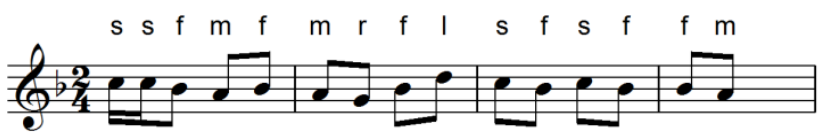

Possível ostinato rítmico:

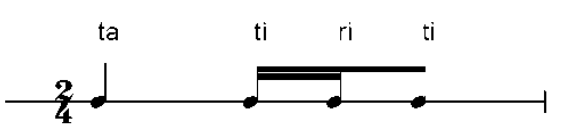

Possivel ostinato melódico:

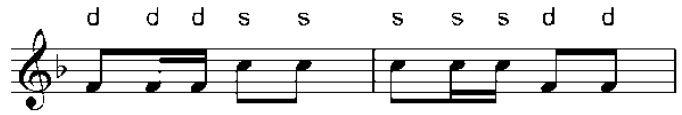

Análise complementar em 2.2 - $n^{\circ} 162$.

Canção com16 compassos binários, com a indicação de andamento: Poco Animato $(108=$ ل ); indicações de dinâmica: $\boldsymbol{p}$; $\boldsymbol{m f}$; poco rall. ; rit.

Tema popular, folclórico infantil, de brincadeira de roda cujo desenvolvimento baseia-se no texto.

Texto - Descrição de canto acumulativo, normalmente utilizado como canção de ninar. Presença de ostinato com a palavra Calunga - de origem banta, que significa "Pequeno". 
Ritmo - o interesse rítmico está nas síncopas e ostinatos.

Melodia sobre terças cheias descendentes com sequências e ostinatos, sugerindo harmonização sobre T D T.

Ludicidade - embora sendo um brinco, pode-se utilizar a canção para brincadeira de roda uma criança é escolhida para dançar ou interpretar o texto com mímica no centro da roda e escolher a próxima solista.

Complementação do texto ${ }^{24}$ :

1. Vamos atrás da serra, ó Calunga! / ver a mulatinha, ó Calunga! Da saia queimada, ó Calunga! / quem foi que queimou, ó Calunga!

2. Foi a senhora dela, ó Calunga! / diz por causa de quê, ó Calunga! Pelo peixe frito, ó Calunga! / que o gato comeu, ó Calunga!

3. Que dê o gato, o gato, ó Calunga! / fugiu para o mato, ó Calunga! Que dê o mato, ó Calunga! / o fogo o queimou, ó Calunga!

4. Que dê o fogo, o fogo, ó Calunga! / a água já o apagou, ó Calunga! Ó que dê a água, ó Calunga! / o frade a bebeu, ó Calunga!

5. Que dê o frade, o frade, ó Calunga! / está dizendo missa, ó Calunga! Que dê essa missa, ó Calunga! / está no seu altar, ó Calunga!

\section{8) PASSE, PASSE, GAVIÃo (Lá na ponte de Vinhaça) - acompanhamento instrumental}
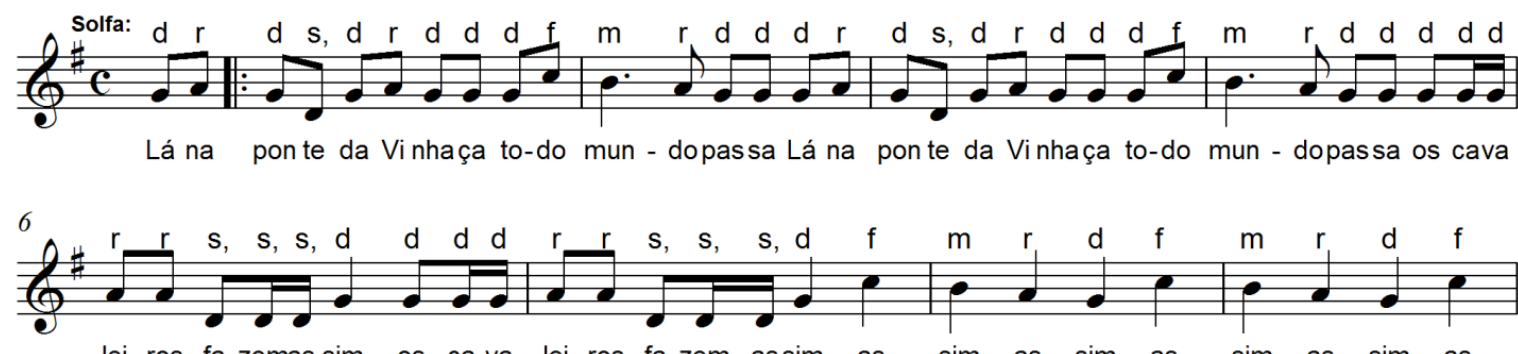

lei-ros fa-zemas sim, os ca va - lei-ros fa-zem assim as - sim, as - sim, as - sim, as sim, as -

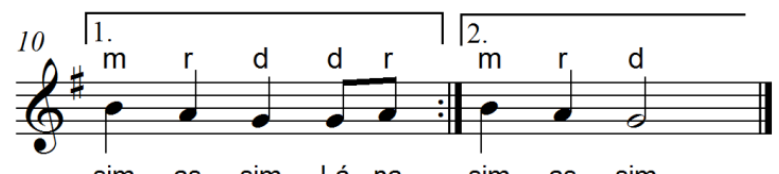

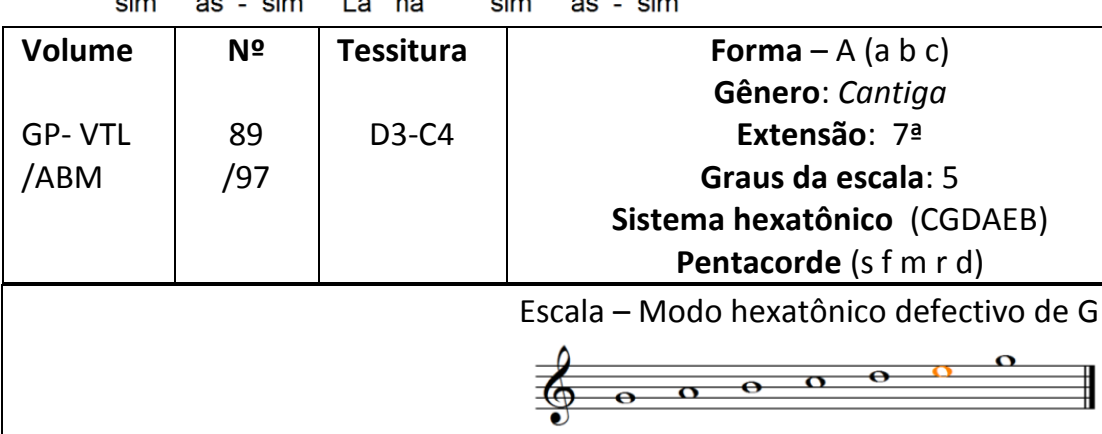

Sugestões de atividades didático-pedagógicas:

Células rítmicas para registro gráfico:

$$
\begin{aligned}
& \text { ta-í ti ti ti ti ti ri ti ti ti ti ri ta }
\end{aligned}
$$

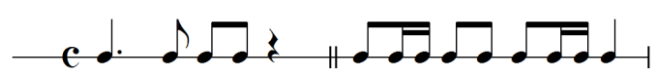

${ }^{24}$ GP/ABM - 2º Caderno, p. 112 - Fonte: SEMA 
Células melódicas para registro gráfico:

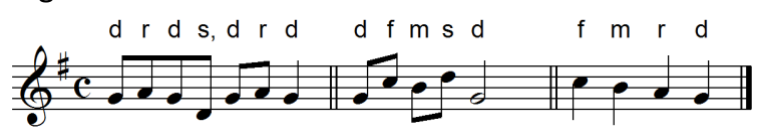

Possivel ostinato rítmico:

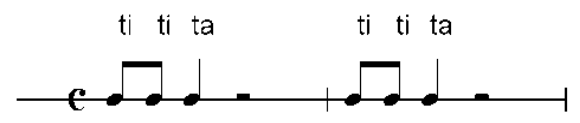

Canção com 11 compassos quaternários, com a indicação de andamento: Allegretto; indicações de dinâmica: $\boldsymbol{f}$; >.

Tema popular, folclórico infantil, de brincadeira cantada, cujo desenvolvimento baseia-se no texto.

Texto - descrição de brincadeira cantada, em que as profissões são apresentadas por meio de mímica. Texto originário de canção francesa - Sur le pont d'Avignon.

Ritmo - o interesse rítmico está no contraste entre notas rebatidas com colcheias/semicolcheias e as semínimas que as seguem.

Melodia iniciada por célula do sistema tritônico de G, seguida de tetracorde descendente, com variação rítmica dos mesmos elementos na segunda frase. Há recorrência na finalização na $T$ em todas as semifrases.

Acompanhamento instrumental (piano) - a introdução apresenta o motivo em movimento contrário do grave e agudo para o registro médio em movimento mais rápido que o indicado para a parte A. A melodia é dobrada em uníssono em sua totalidade, com acordes nos finais dos motivos. Na frase " $c$ ” o baixo faz contraponto com oitavas em movimento contrário par estabelecer as cadências finais

Ludicidade - A movimentação segue o pulso da música, podendo variar o andamento. É também uma roda de movimento na qual as crianças em roda cantam e imitam a movimentação sugerida pelas diferentes profissões.

\section{9) AINDA NÃO COMPREI- a capella}

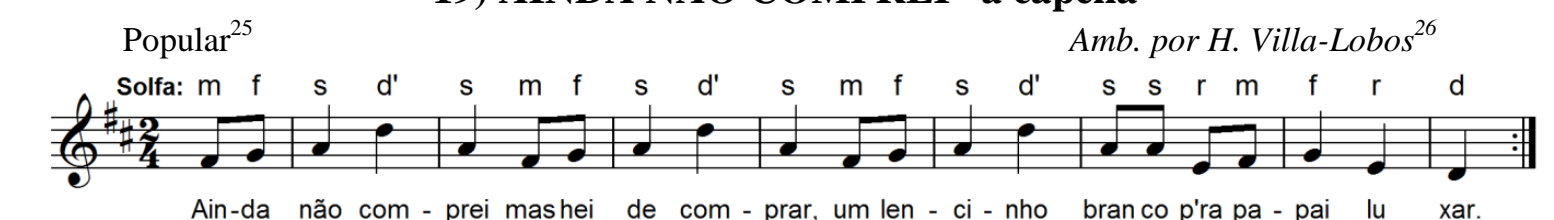

\begin{tabular}{|c|c|c|c|c|}
\hline $\begin{array}{l}\text { Volume } \\
\text { GP- VTL } \\
\text { /ABM }\end{array}$ & $\begin{array}{c}\text { No } \\
\\
4 \\
/ 51\end{array}$ & $\begin{array}{c}\text { Tessitura } \\
\text { D3-D4 }\end{array}$ & $\begin{array}{c}\text { Forma - A } \\
\text { Gênero - Polca } \\
\text { Extensão: } 8^{\underline{a}} \\
\text { Graus da escala: } 5 \\
\text { Sistema hexatônico (GDAEBF\#) } \\
\text { Pentacorde (sfmrd) }\end{array}$ & 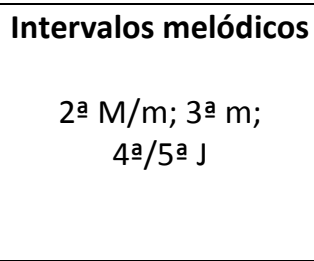 \\
\hline \multicolumn{5}{|c|}{$\begin{array}{l}\text { Escala - Modo hexatônico defectivo de D } \\
\end{array}$} \\
\hline
\end{tabular}

Sugestões de atividades didático-pedagógicas:

Célula rítmica para registro gráfico:

${ }^{25}$ GP/ABM - $1^{\circ}$ Caderno, p.92 : Fonte - G. \& J.

${ }^{26}$ Ibidem: correção - ambientado ao invés de arranjado. 


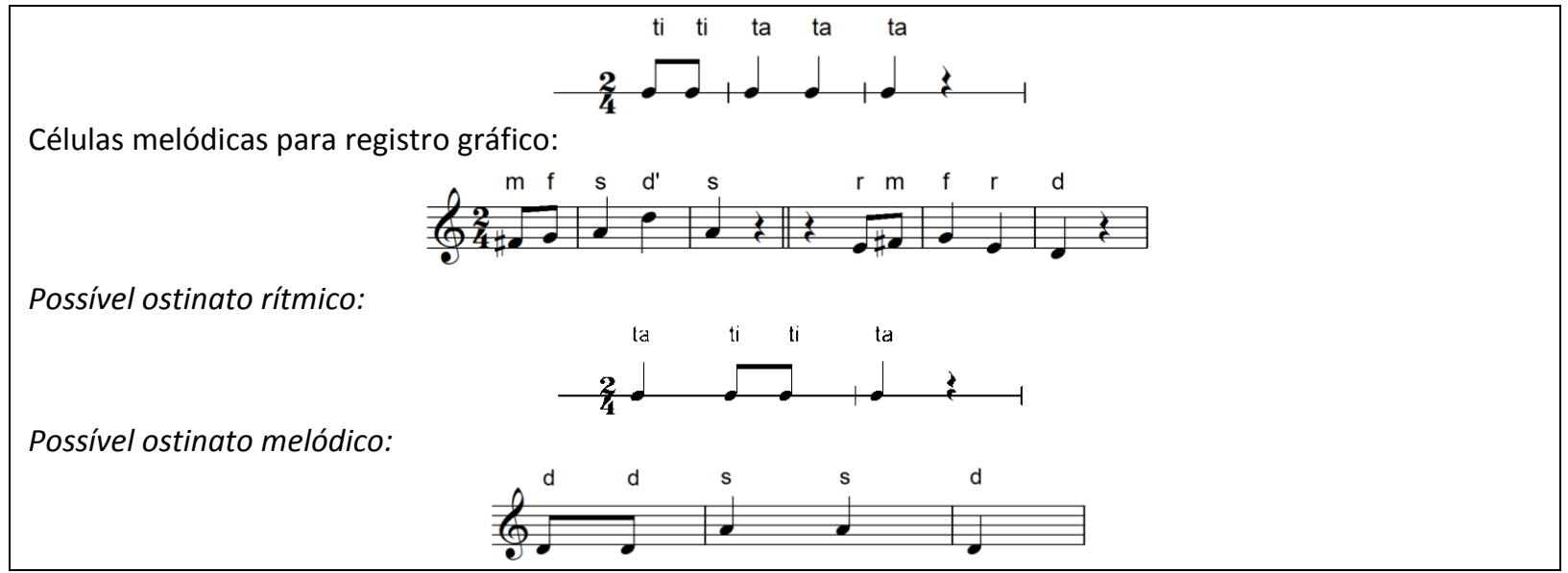

Análise complementar em $2.2-n^{\circ} 5$.

Canção com 9 compassos binários, com a indicação de andamento: Allegretto $(138=$ ل ); indicações de dinâmica: $<$; > pp

Tema popular, folclórico infantil, de brincadeira de roda, cujo desenvolvimento baseia-se no texto.

Texto - Trata-se de menção ao uso/costume antigo de os homens elegantes usarem lenços brancos no bolso superior do paletó.

Ritmo - anacrúsico, básico, sobre metro, pulso e subdivisão binária.

Melodia - inicia-se sobre arpejo da $\mathrm{T}$ na primeira inversão, com uma nota de passagem. Desenho repetido por três vezes, com resolução descendente da $\mathrm{D}$ para a $\mathrm{T}$.

Ludicidade - coreografia simples com formação de roda, com possível representação cênica de afetividade de filho para pai.

\section{0) ENTREI NA RODA- a capella}

Arr. de H. Villa-Lobos
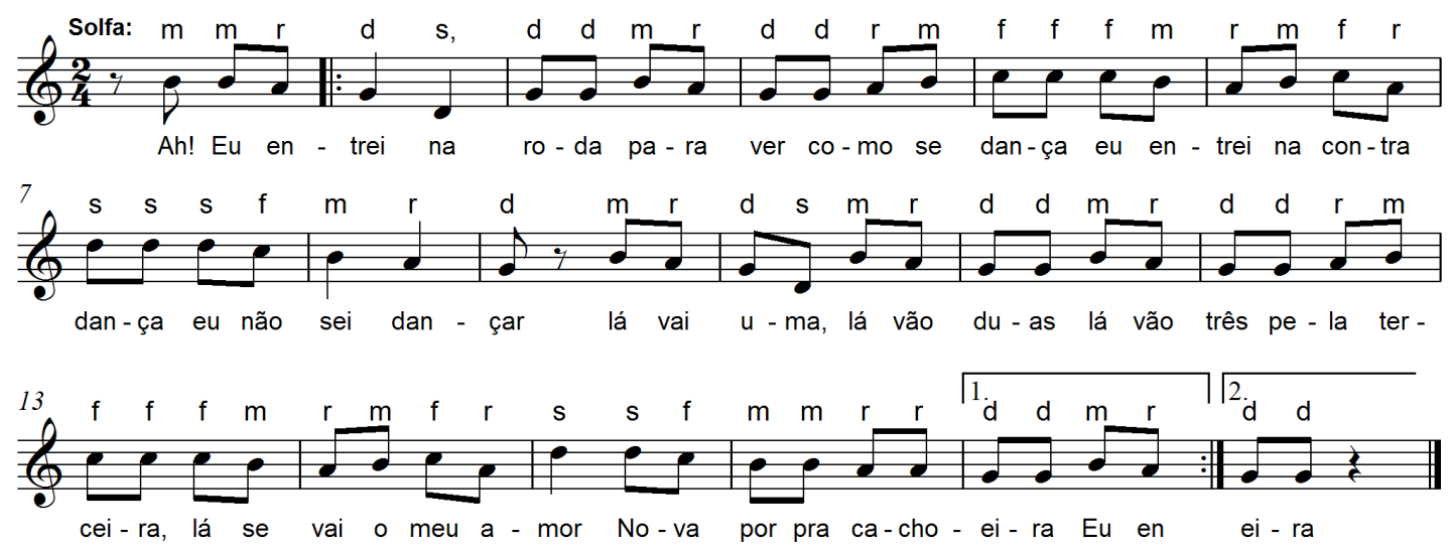

\begin{tabular}{|c|c|c|c|c|}
\hline Volume & № & Tessitura & Forma $-\mathrm{A}$ & Intervalos melódicos \\
\hline GP- VTL & $\begin{array}{r}49 \\
118\end{array}$ & D3 - D4 & $\begin{array}{c}\text { Gênero - Galope canção } \\
\text { Extensão: } 8 \text { a } \\
\text { Graus da escala } 5\end{array}$ & 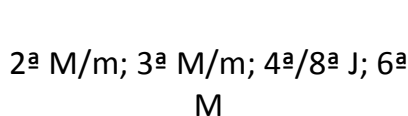 \\
\hline /ABM & /43 & & $\begin{array}{c}\text { Sistema hexatônico (C G D A E B) } \\
\text { Pentacorde (sfmrd) }\end{array}$ & \\
\hline
\end{tabular}




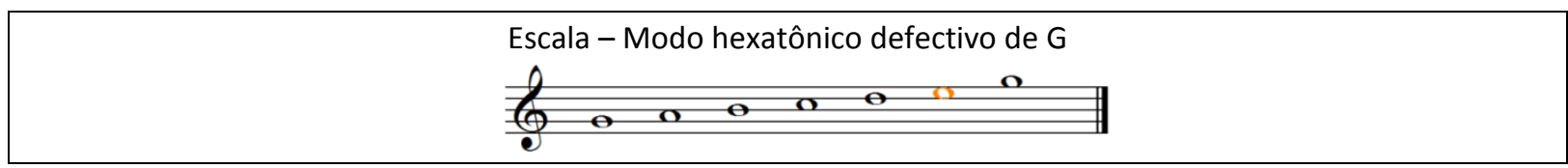

Sugestões de atividades didático-pedagógicas:

Célula rítmica para registro gráfico:

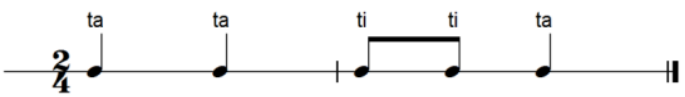

Células melódicas para registro gráfico:

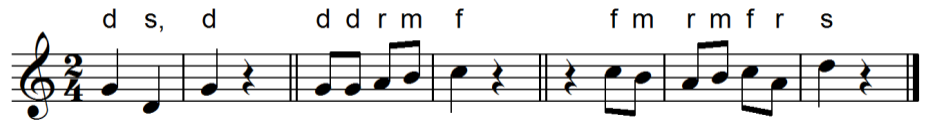

Possivel ostinato rítmico:

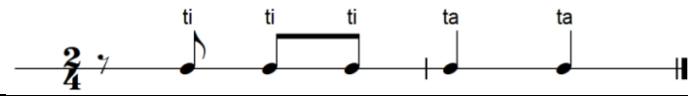

Análise complementar em $2.2-n^{\circ} 40$.

Canção com 18 compassos binários, com a indicação de andamento: Vivace $(\mathbf{1 5 6}=\mathrm{J})$; indicações de dinâmica: $\boldsymbol{m f} ; \boldsymbol{f}$

Tema popular, folclórico infantil, de brincadeira de roda, cujo desenvolvimento baseia-se no texto.

Texto - descrição de coreografia de brincadeira de roda, com alusão à navegação de barco a vapor.

Ritmo - binário, de subdivisão binária, marchinha popular.

Melodia desenvolvida sobre o acorde T na segunda inversão, encaminhando-se para a S, D e resolução na $\mathrm{T}$ por pentacorde descendente.

Ludicidade - brinquedo de roda com movimentação em ritmo de marchinha popular, muito comum em bailes da época, inclusive no Carnaval.

\section{1) NA MÃO DIREITA - a capella}

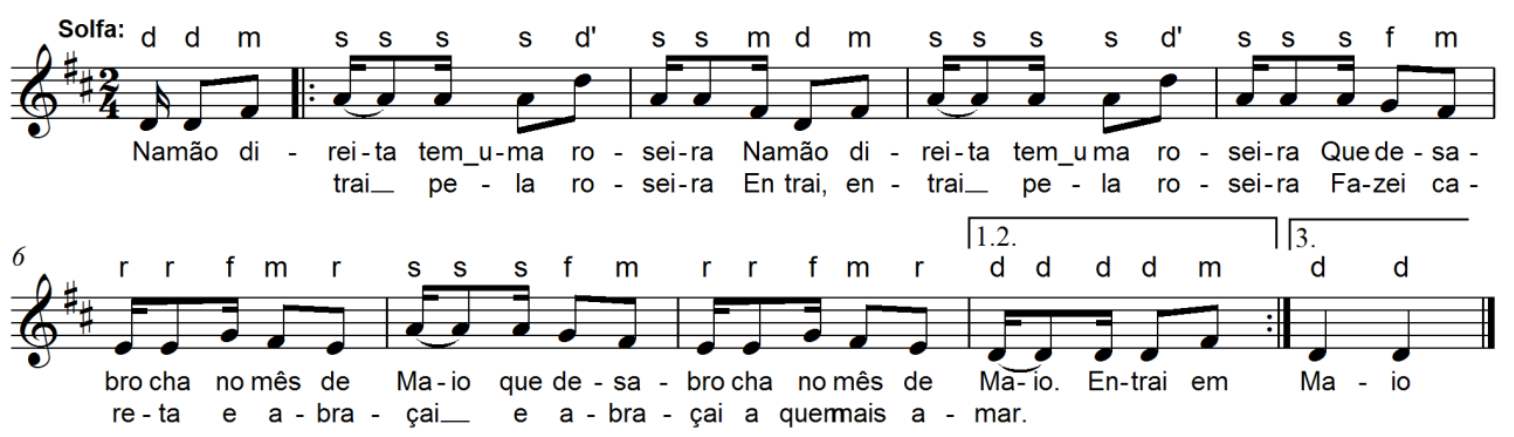

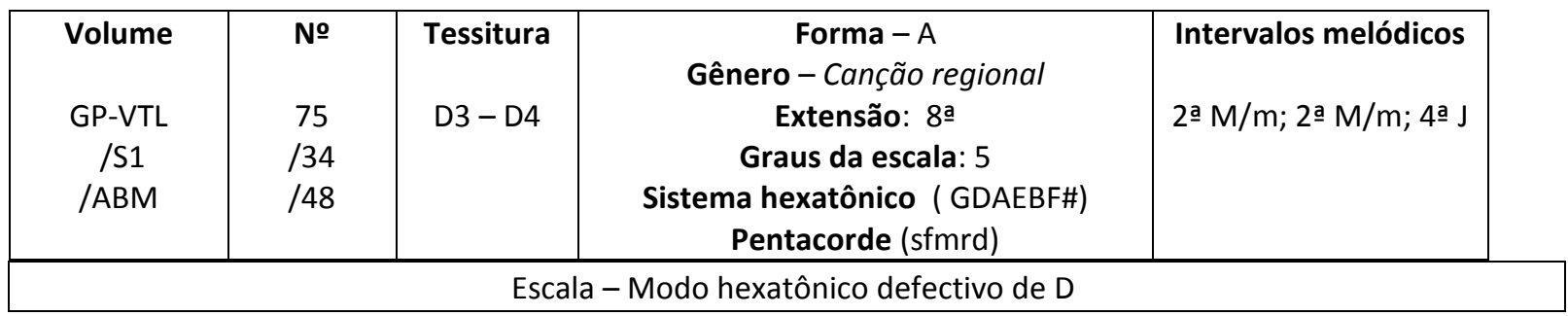


की

Sugestões de atividades didático-pedagógicas:

Células rítmicas para registro gráfico:

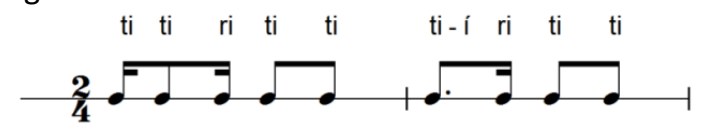

Células melódicas para registro gráfico:

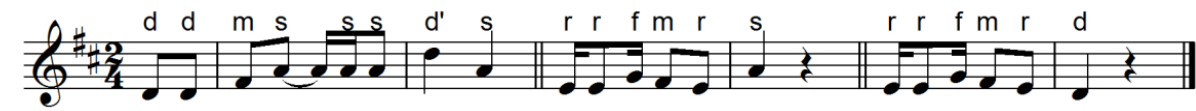

Possivel ostinato rítmico:

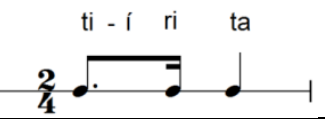

Análise complementar em $2.2-n^{\circ} 158$.

Canção de 10 compassos binários, com a indicação de andamento: Allegretto (M.M. 112 $=\downarrow$ ). Sem indicações de dinâmica.

Tema popular, folclórico infantil, de brincadeira de roda cujo desenvolvimento baseia-se no texto.

Texto - descrição de brincadeira de roda em que a roseira é personagem principal, destacada ao centro da roda. De origem francesa - A ma main droite, apontando para a primavera européia no mês de maio. Foram editadas duas estrofes, com indicação de execução de uma terceira, cujo texto não se encontra, sendo, provavelmente, a repetição da primeira, como sugere GP/ABM.

Ritmo - o interesse rítmico está no ostinato de ritmo sincopado, abrasileiramento do ritmo original da canção francesa em compasso quinário.

Melodia - construção sobre os arpejos ascendente e descendente de T. Resolução com desenho descendente de D para T.

Ludicidade - roda de escolha onde, a partir do texto, uma criança no centro da roda escolhe outra que a substituirá.

22) NA CORDA DA VIOLA - acompanhamento instrumental

(Canto com piano, conjunto instrumental ou piano solo) Amb. por H. Villa-Lobos

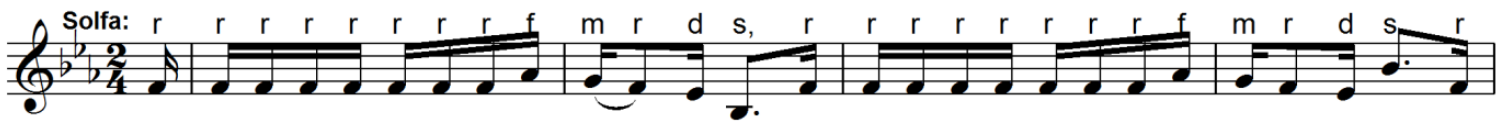

$\mathrm{Na}$ cor-da da vi-o-la todo_o mun_ dobate; Na cor-da da vi-o-la todo_o mun_ dobate; Na

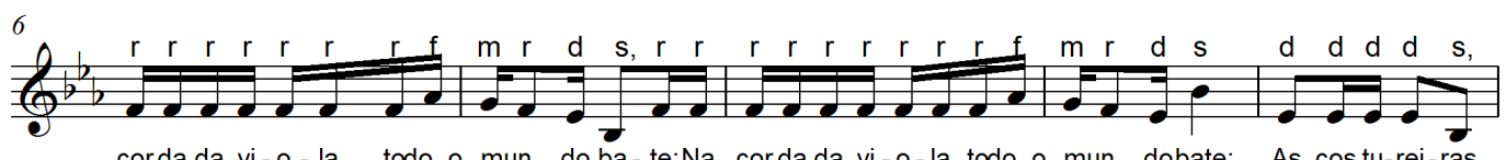

corda da vi-o-la todo_o mun do ba-te;Na corda da vi-o-la todo_o mun dobate; As costu-rei-ras

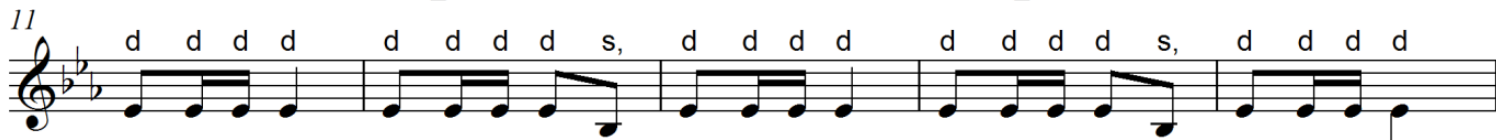

fa-zem as-sim Os car pin-tei-ros fa-zem as-sim Os mar-ce-nei-ros fa-zem as-sim

\begin{tabular}{|c|c|c|c|c|}
\hline Volume & № & Tessitura & $\begin{array}{c}\text { Forma - A (ab) } \\
\text { Gênero - Coco canção } \\
\text { Extensão: 8a }\end{array}$ & $\begin{array}{c}\text { Intervalos } \\
\text { melódicos }\end{array}$ \\
\hline
\end{tabular}




\begin{tabular}{|c|c|c|c|c|}
\hline /ABM & /87 & $\begin{array}{c}\text { Graus da escala: } 5 \\
\text { Sistema hexatônico (Ab Eb Bb F C G ) } \\
\text { Pentacorde (sfmrd) }\end{array}$ & $\begin{array}{c}2 \mathrm{a} \mathrm{M} / \mathrm{m} ; 3^{\mathrm{a}} \mathrm{m} \\
4 \mathrm{a} / 5 \mathrm{a} / 8^{\mathrm{a}} \mathrm{J}\end{array}$ \\
\hline \multicolumn{4}{|c|}{\begin{tabular}{c} 
Escala - Modo hexatônico defectivo de Eb maior \\
\hline
\end{tabular}} \\
\hline
\end{tabular}

Sugestões de atividades didático-pedagógicas:

Células rítmicas para registro gráfico:

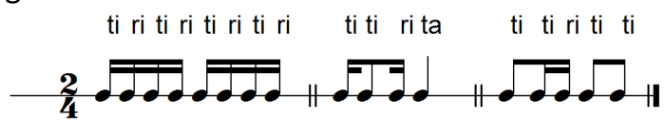

Células melódicas para registro gráfico:

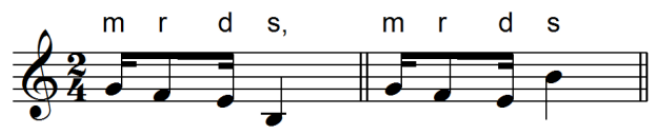

Possivel ostinato rítmico:

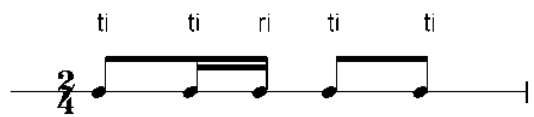

Possível ostinato melódico:

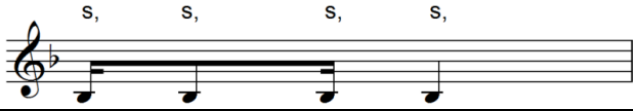

Canção com 15 compassos binários, com a indicação de andamento: Poco Animato $(112=ل$ ل); indicações de dinâmica: $\boldsymbol{m f}$; acentos $>$.

Tema popular, similar a Passe, passe, gavião, Lá na ponde de Vinhaça, originárias da canção francesa Sur le pont d'Avignon, brincadeira cantada, cujo desenvolvimento baseia-se no texto.

Texto - exaltação ao trabalho, comparado à corda da viola (comum ao povo brasileiro, em geral) e ao seu toque, contínuo e repetitivo, descrevendo a ação de costureiras, carpinteiros, marceneiros e outros.

Ritmo - todas as palavras 'bate' deveriam ter sua correspondência com figuras dobradas. A peça desenvolve-se ritmicamente como um moto quase contínuo.

Melodia - caracteriza-se pelas notas rebatidas, ora resolvidas ao final das frases na D por salto descendente, ora por salto ascendente; o segundo tipo de frase é de notas rebatidas na $\mathrm{T}$, com saltos de quarta - descendente e ascendente - para a T. O ostinato rítmico-melódico sugere igualdade de importância para todas as profissões.

Acompanhamento instrumental (piano) - rondó $\mathrm{ABACA}$ - parte A: sobre pedal na $\mathrm{D}$, a mão esquerda apresenta o tetracorde descendente $\boldsymbol{d}$ ' $\boldsymbol{t} \boldsymbol{l} \boldsymbol{s}$ na primeira frase (quatro vezes), completando a escala descendente com o tetracorde $\boldsymbol{f} \boldsymbol{m} \boldsymbol{r} \boldsymbol{d}$. Segue, por linha cromática descendente terminando na tônica menor; parte B: tema exposto em seis compassos na tonalidade menor com finalização na $\mathrm{D}$ para repetição de $\mathrm{A}$; terceira parte $(\mathrm{C})$ - desenvolvida em 23 compassos, sobre pedal da $\mathrm{T}$, com acompanhamento em ostinatos rítmicos e harmônicos $\left(\mathrm{T}^{6}\right.$ e $\left.\mathrm{D}^{9}\right)$ na mão direita, a mão esquerda apresenta o tema variado em divisão ou subdivisão ternária, com polirritmos de três contra dois, com uma pequena ponte de quatro compassos para reinício da parte A; coda: em quatro compassos sobre acorde e arpejos sobre a T em fortíssimo. 
Ludicidade - As crianças em roda cantam e imitam o tocar a viola e as movimentações sugeridas pelas diferentes profissões.

\subsubsection{Sobre seis graus da escala}

23) VAMOS, CRIANÇAS - a capella

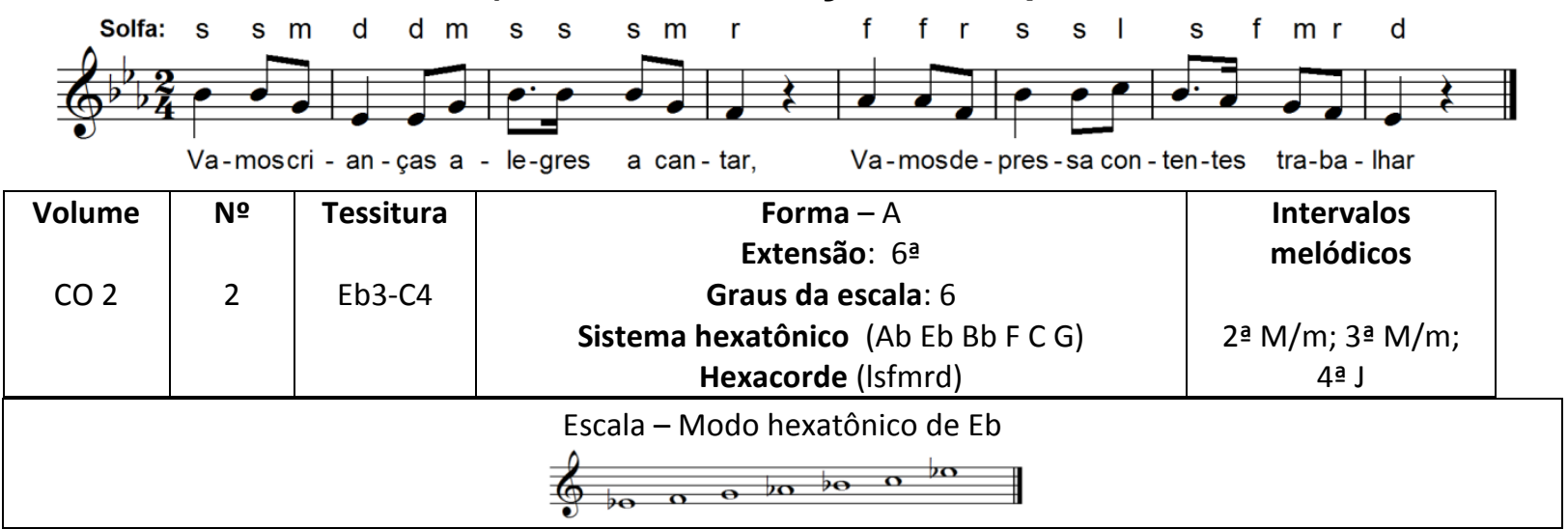

Sugestões de atividades didático-pedagógicas:

Células rítmicas para registro gráfico:

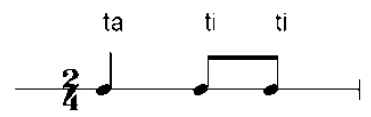

Células melódicas para registro gráfico:

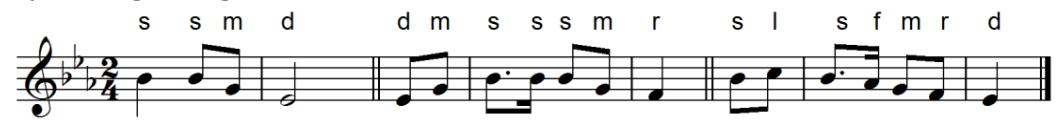

Possivel ostinato rítmico:

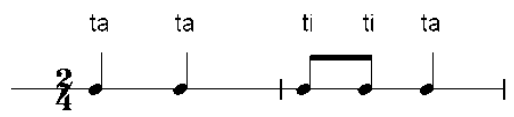

Possível pedal harmônico:

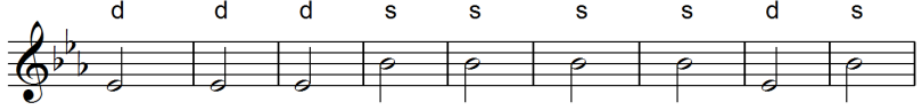

Análise complementar em $2.2-n^{\circ} 52$.

Canção com 8 compassos binários, com a indicação de andamento: Tempo de Marcha; indicações de dinâmica: $\boldsymbol{f} ; \boldsymbol{m} \boldsymbol{f} ; \boldsymbol{p p}$.

Tema popular, folclórico infantil, com arranjo de H.Villa-Lobos, 1932 - Rio de Janeiro.

Texto inspirado na canção Marcha Soldado, tem a intenção de enaltecer o trabalho, associado à alegria agregada ao ato de trabalhar. Há sugestão em rodapé em GP/VTL para se aplicar outros textos à melodia.

Ritmo - de marcha, binário, tético.

Melodia - inicia-se no arpejo descendente/ascendente da tríade da $\mathrm{T}$ com final na $\mathrm{D}$ seguida de linha descendente por grau conjunto para a $\mathrm{T}$. 
Ludicidade - os participantes devem marchar em fila indiana ou em outras formações, e poderão ser incluídos andamentos diferentes, tornando a brincadeira mais divertida.

\section{4) UMA, DUAS ANGOLINHAS - a capella}
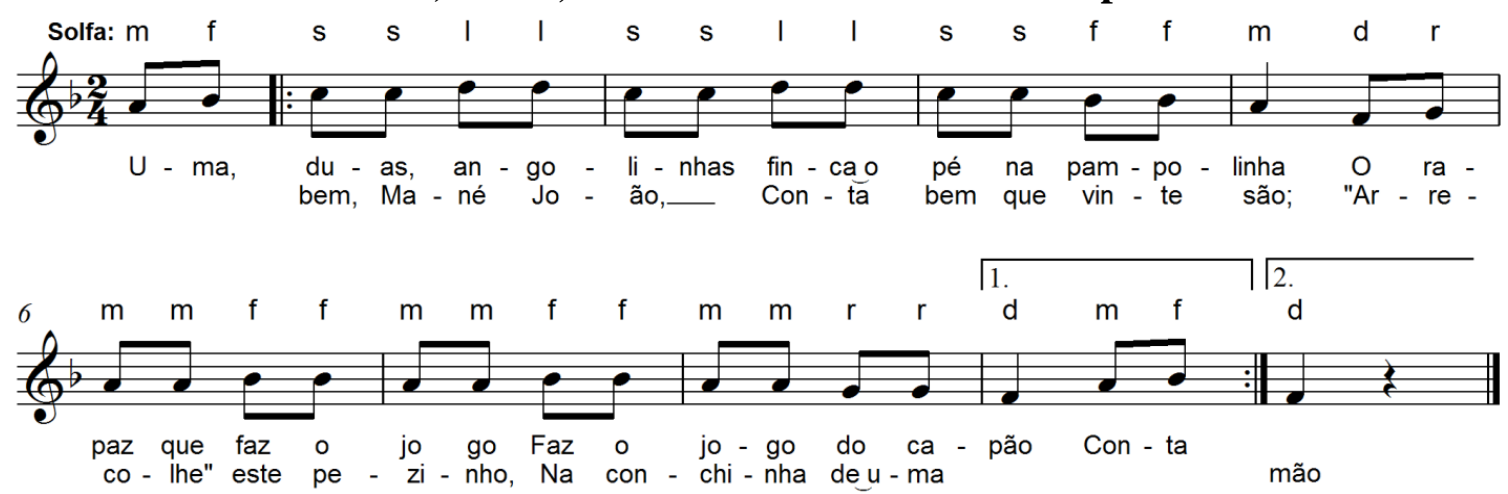

\begin{tabular}{|c|c|c|c|c|}
\hline $\begin{array}{c}\text { Volume } \\
\text { GP-VTL } \\
\text { /ABM }\end{array}$ & $\begin{array}{l}\text { № } \\
124 \\
/ 47\end{array}$ & $\begin{array}{c}\text { Tessitura } \\
\text { F3-D4 }\end{array}$ & $\begin{array}{c}\text { Forma - A } \\
\text { Gênero - Cantiga } \\
\text { Extensão: 6a } \\
\text { Graus da escala: } 6 \\
\text { Sistema hexatônico (Bb F C G A) } \\
\text { Hexacorde (I s f m r d) }\end{array}$ & Intervalos melódicos \\
\hline \multicolumn{5}{|c|}{ Escala - Modo hexatônico de F } \\
\hline
\end{tabular}

Sugestões de atividades didático-pedagógicas:

Célula rítmica para registro gráfico:

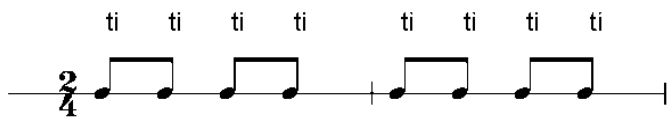

Células melódicas para registro gráfico:

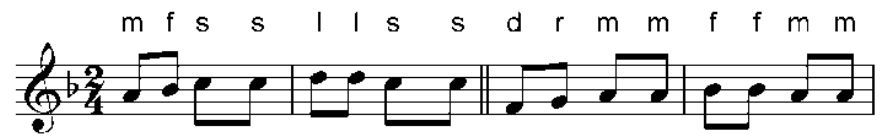

Possivel ostinato rítmico:

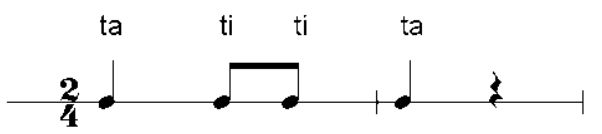

Outras possibilidades: cânone a duas vozes, com entrada da segunda voz no segundo pulso do quinto compasso

Análise complementar $2.2-n^{\circ} 160$.

Canção com 10 compassos binários, com a indicação de andamento: Andantino (104= ل ); indicação de dinâmica: $\boldsymbol{p}$

Tema popular de brincadeira cantada, cujo desenvolvimento baseia-se no texto.

Texto - Traz como tema o jogo das argolinhas de origem portuguesa ${ }^{27}$. É uma roda de verso composta por um refrão e uma quadrinha, que a cada vez que se repete o refrão é substituída

${ }^{27}$ GP/ABM $1{ }^{\circ}$ Caderno, p. 92. 
por outra, na maioria das vezes cantada por uma pessoa diferente. Faz parte da brincadeira uma quadrinha declamada, como a que segue registrada em GP/ABM:

Pé de pilão / Carne seca com feijão / Milho debulhado / Arroz com camarão

Segue outra quadrinha informada por Lucilene Ferreira da Silva, pesquisadora do repertório lúdico infantil:

Eu queria ser agora / Um cavalinho de vento / Para ir à galopada / Onde está teu pensamento.

Ritmo - anacrúsico, binário, acompanha o texto em subdivisão binária.

Melodia - inicia-se com graus conjuntos e notas rebatidas de tetracorde ascendente/descendente, com repetição do desenho, por sequência, terça abaixo, com terminação na T.

Ludicidade - Nessa roda de verso cada pessoa canta uma quadrinha obedecendo à mesma melodia do refrão. Ao encaixar a quadrinha no ritmo do refrão podem ocorrer variações rítmicas e deslocamento das sílabas tônicas. São utilizadas quadrinhas da tradição oral ou as mesmas podem ser improvisadas pelos participantes.

25) CAPELINHA DE MELÃO - a capella
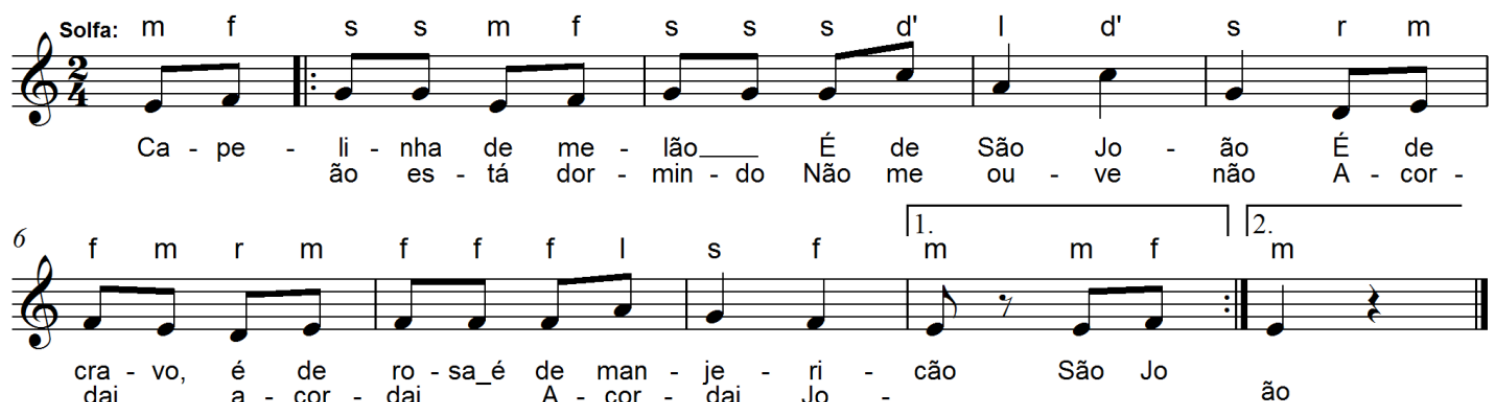

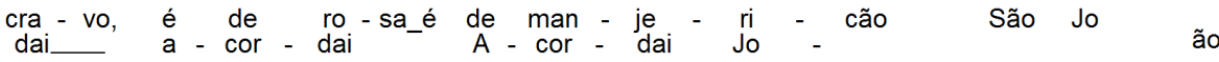

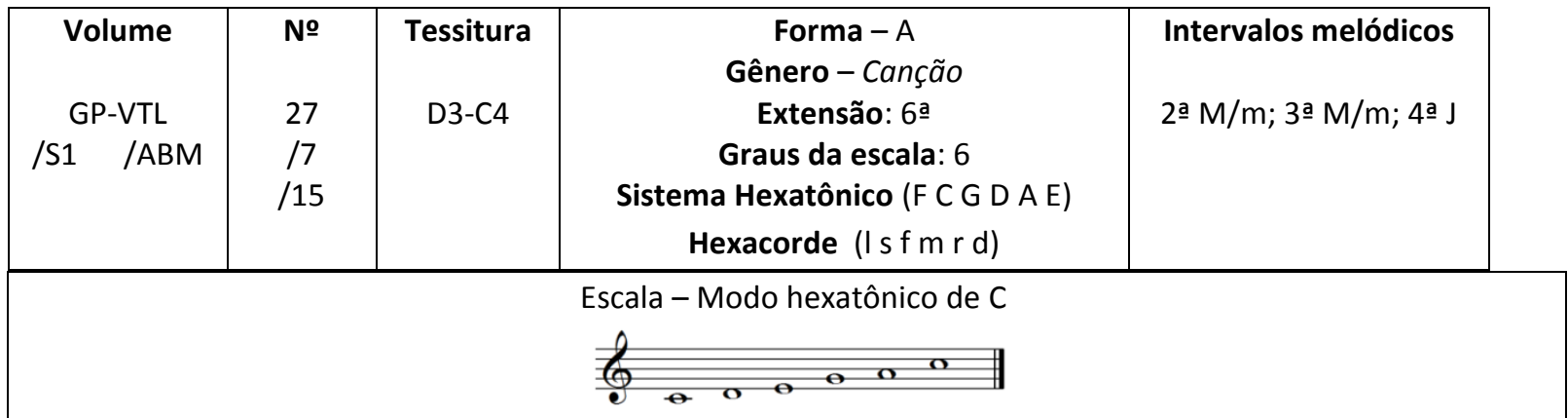

Sugestões de atividades didático-pedagógicas:

Células rítmicas para registro gráfico:

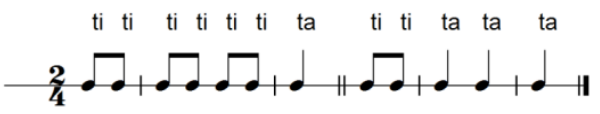

Células melódicas para registro gráfico:

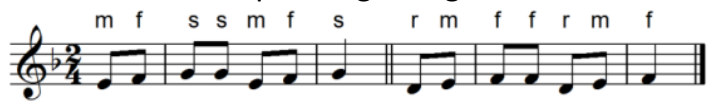

Possível ostinato rítmico:

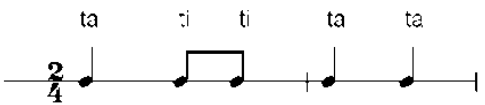

Análise complementar em $2.2-n^{\circ} 56$. 
Canção com 10 compassos binários, com a indicação de andamento: Andantino (92= ل ); sem indicações de dinâmica.

Tema popular, folclórico, sobre folguedos em comemoração aos santos católicos do mês de junho. Fala sobre um mito relacionado a São João, de que na sua noite ele dorme e se despertar o mundo acordará em chamas.

Texto - descrição de brinquedo tradicional em época de festas juninas.

Ritmo - anacrúsico, binário, acompanha o texto em subdivisão binária.

Melodia - desenho iniciado em terça menor cheia ascendente seguida de saltos ascendentes e descendentes de terça e quartas. Segunda frase - o desenho é repetido segunda abaixo, em seqüência, com terminação na terça da $\mathrm{T}$.

Ludicidade - brincadeira de roda que na qual as crianças caminham no andamento da música, podendo utilizar a mímica para interpretar o texto.

\section{6) CÂNONE 13 - a capella}
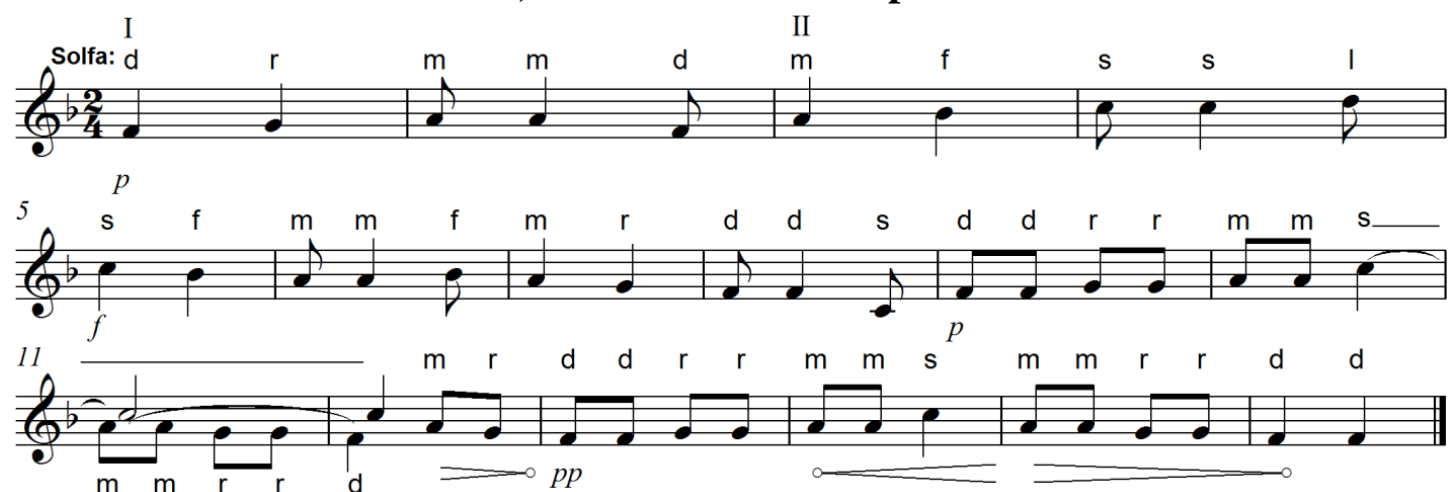

\begin{tabular}{|c|c|c|c|c|}
\hline $\begin{array}{c}\text { Volume } \\
\text { S2 }\end{array}$ & $\begin{array}{c}\text { № } \\
\text { 13/p.22 }\end{array}$ & $\begin{array}{c}\text { Tessitura } \\
\text { F3-D4 }\end{array}$ & $\begin{array}{c}\text { Forma - A (ab) } \\
\text { Extensão: } 6 \underline{a} \\
\text { Graus da escala: } 6 \\
\text { Sistema Hexatônico (Bb F C G D A) } \\
\text { Hexacorde (I s f m r d) }\end{array}$ & $\begin{array}{l}\text { Intervalos melódicos } \\
\text { 2a } \mathrm{M} / \mathrm{m} ; 3 \text { a } \mathrm{M} / \mathrm{m} ; 4 \text { a J }\end{array}$ \\
\hline \multicolumn{5}{|c|}{ Escala - Modo Hexatônico de F } \\
\hline
\end{tabular}

\section{Sugestões de atividades didático-pedagógicas:}

Células rítmicas para registro gráfico:

Células melódicas para registro gráfico:
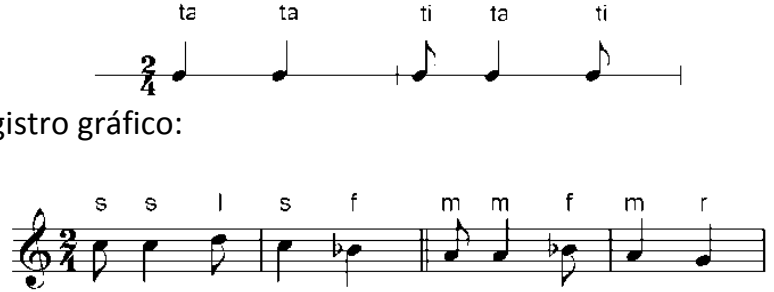

Possível ostinato rítmico:

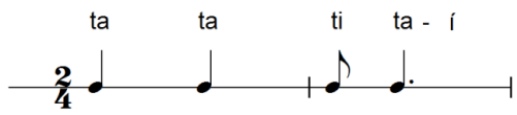


Possivel ostinato melódico:

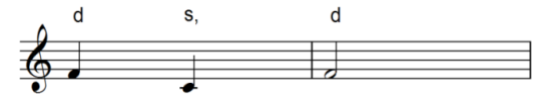

Outras possibilidades: Cânone a duas vozes

Tema de Villa-Lobos com 16 compassos binários, sem indicação de andamento; com indicações de dinâmica: $\boldsymbol{p} ; \boldsymbol{f} ;>$; $<$; p p

Ritmo - o interesse rítmico está sincopas métricas.

Melodia em pequenos desenhos em âmbito e terças e quartas, com presença de notas opcionais, ou divisi, com terminação na T. Cânone exato.

Ludicidade - apesar de se tratar de um solfejo, a prática do cânone é sempre um desafio lúdico. Outro desafio seria a criação de um texto para a melodia.

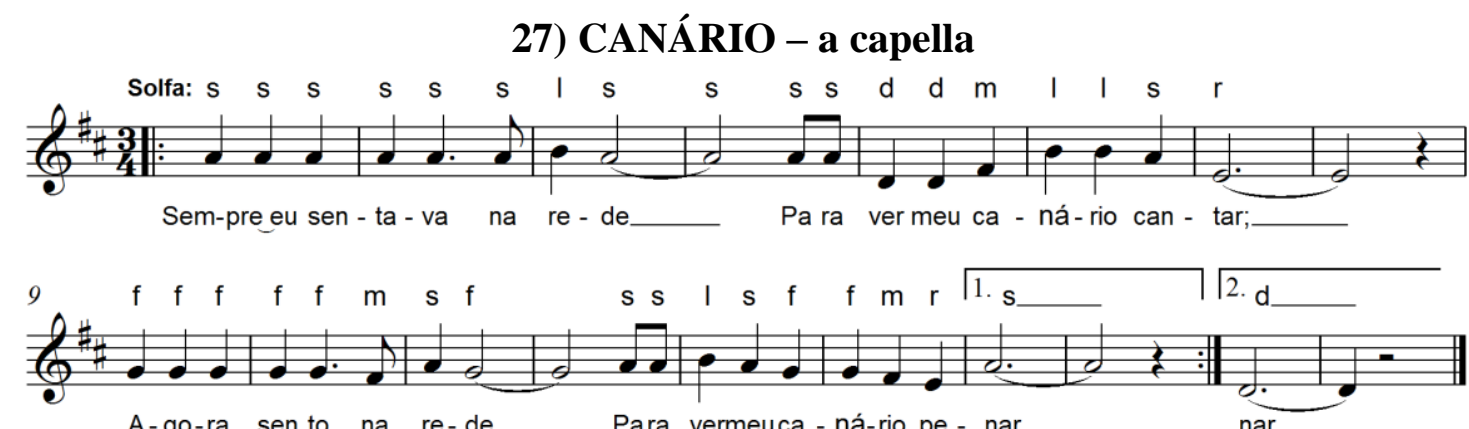

A-go-ra sen to na re-de___ Para vermeuca - ná-rio pe - nar__

\begin{tabular}{|c|c|c|c|c|}
\hline $\begin{array}{c}\text { Volume } \\
\text { GP-VTL } \\
\text { /S1 /ABM }\end{array}$ & $\begin{array}{l}\text { No } \\
21 \\
/ 26 \\
/ 28\end{array}$ & $\begin{array}{l}\text { Tessitura } \\
\text { D3-B3 }\end{array}$ & $\begin{array}{c}\text { Forma - A } \\
\text { Gênero - Valsa } \\
\text { Extensão: 6ㅁ } \\
\text { Graus da escala: } 6 \\
\text { Sistema hexatônico (GDAEBF\#) } \\
\text { Hexacorde (Isfmrd) }\end{array}$ & $\begin{array}{c}\text { Intervalos } \\
\text { melódicos } \\
\text { 2a } \mathrm{M} / \mathrm{m} ; 3 \text { a } \mathrm{M} / \mathrm{m} ; \\
4 \text { a } / 5 \text { a } \mathrm{J}\end{array}$ \\
\hline & & & $\begin{array}{l}\text { - Modo hexatônico de D } \\
\mathbf{\theta} \# \mathbf{0} \quad \mathbf{0} \quad \mathbf{\theta}\end{array}$ & \\
\hline
\end{tabular}

Sugestões de atividades didático-pedagógicas:

Células rítmicas para registro gráfico:

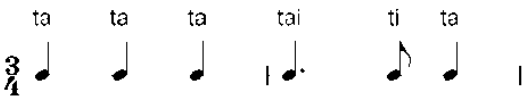

Células melódicas para registro gráfico:

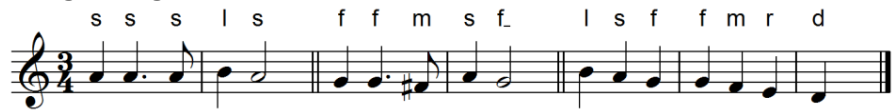

Possivel ostinato rítmico:

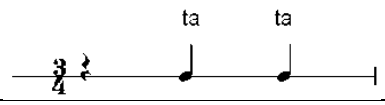

Canção com 18 compassos ternários, com a indicação de andamento: Animato (M.M. $76=\downarrow$ ); indicações de dinâmica: acentos >

Tema popular, folclórico, sobre pássaro canoro.

Texto - descrição (quase romance) de história sobre tema de pássaros.

Ritmo - Valsa. O compasso ternário pode levar à sensação do balanço na rede. 
Melodia com extensão de uma sexta, com frases com terminação na dominante e na tônica. A primeira frase inicia-se no quinto grau e termina quarta abaixo, na $\mathrm{D}$; a segunda frase inicia-se no quarto grau e termina quarta abaixo, na T. Preferimos manter a repetição das estrofes, como na edição GP/VTL, ao contrário da edição GP/ABM, que apresenta a finalização da frase na $\mathrm{T}$ apenas no final da terceira estrofe.

Ludicidade - Essa cantiga traz características dos romances de origem portuguesa que trazem temas tristes. Esses romances são representados pelas crianças de maneira teatral.

Complementação do texto:

- Sempre eu sentava na rede / para ver meu canário cantar / Agora sento na rede / para ver meu canário penar.

- Meu canário está doente / Doença de inflamação / Mandei chamar o doutor / para fazer a operação.

- Na primeira lancetada / o canarinho tremeu / Na segunda lancetada / bateu as asas e morreu.

\section{8) HIGIENE - a capella}
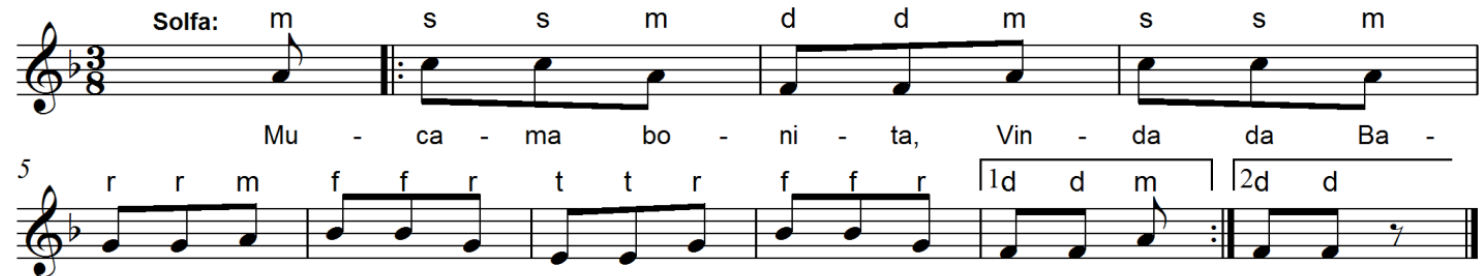

hi - a, To -maes-te me - ni - no, La - vai na ba - ci - a! Mu

ci - a

\begin{tabular}{|c|c|c|c|c|}
\hline $\begin{array}{c}\text { Volume } \\
\text { GP-VTL } \\
\text { /S1 /ABM }\end{array}$ & $\begin{array}{l}\text { № } \\
64 \\
/ 3 \\
/ 19\end{array}$ & $\begin{array}{l}\text { Tessitura } \\
\text { E3-C4 }\end{array}$ & $\begin{array}{c}\text { Forma - A } \\
\text { Gênero - Canção } \\
\text { Extensão: 6a } \\
\text { Graus da escala: } 6 \\
\text { Sistema Heptatônico (Bb F C G D A E) } \\
\text { Pentacorde + t (sfmrd t) }\end{array}$ & $\begin{array}{c}\text { Intervalos } \\
\text { melódicos } \\
\text { 2a } \mathrm{M} / \mathrm{m} ; 3 \text { a } \\
\mathrm{M} / \mathrm{m}\end{array}$ \\
\hline & & & $\begin{array}{l}\text { Escala - F maior defectiva } \\
0 \text { e } 0 \text { be } 0\end{array}$ & \\
\hline
\end{tabular}

Sugestões de atividades didático-pedagógicas:

Células rítmicas para registro gráfico:

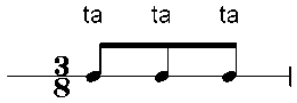

Células melódicas para registro gráfico:

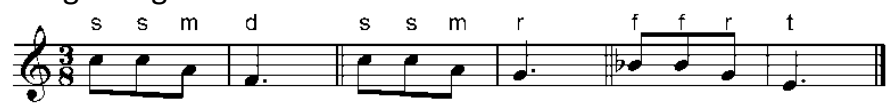

Possivel ostinato rítmico:

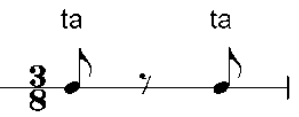

Análise complementar em $2.2-n^{\circ} 54$.

Canção com 10 compassos ternários, com a indicação de andamento: Acalanto (M.M. $\boldsymbol{S}=$ 152); sem indicações de dinâmica.

Tema popular, folclórico infantil, sobre atividades da mucama, ou mucamba (serva amásia do senhor, no idioma africano) - escrava que servia na casa dos senhores, algumas vezes ama de leite.

Texto - acalanto, canção de ninar, que descreve o trabalho da mucama baiana. 
Ritmo - o interesse rítmico está no compasso ternário.

Melodia - consta de duas frases em sequência de segunda abaixo, com curvas ascendentes e descendentes sobre tríades de $\mathrm{T}$ e $\mathrm{D}$, com terminação na $\mathrm{T}$.

Ludicidade - o compasso ternário sugere movimentos de embalar a criança para fazê-la dormir.

Complemento do texto ${ }^{28}$ :

- Mucama bonita / vinda da Bahia / Toma este menino / lavai na bacia.

- Bacia de prata / lavada com sabão / toma este menino / vesti-lhe o roupão.

- Roupão de veludo / touquinha de filó / camisa de renda / lhe deu a vovó.

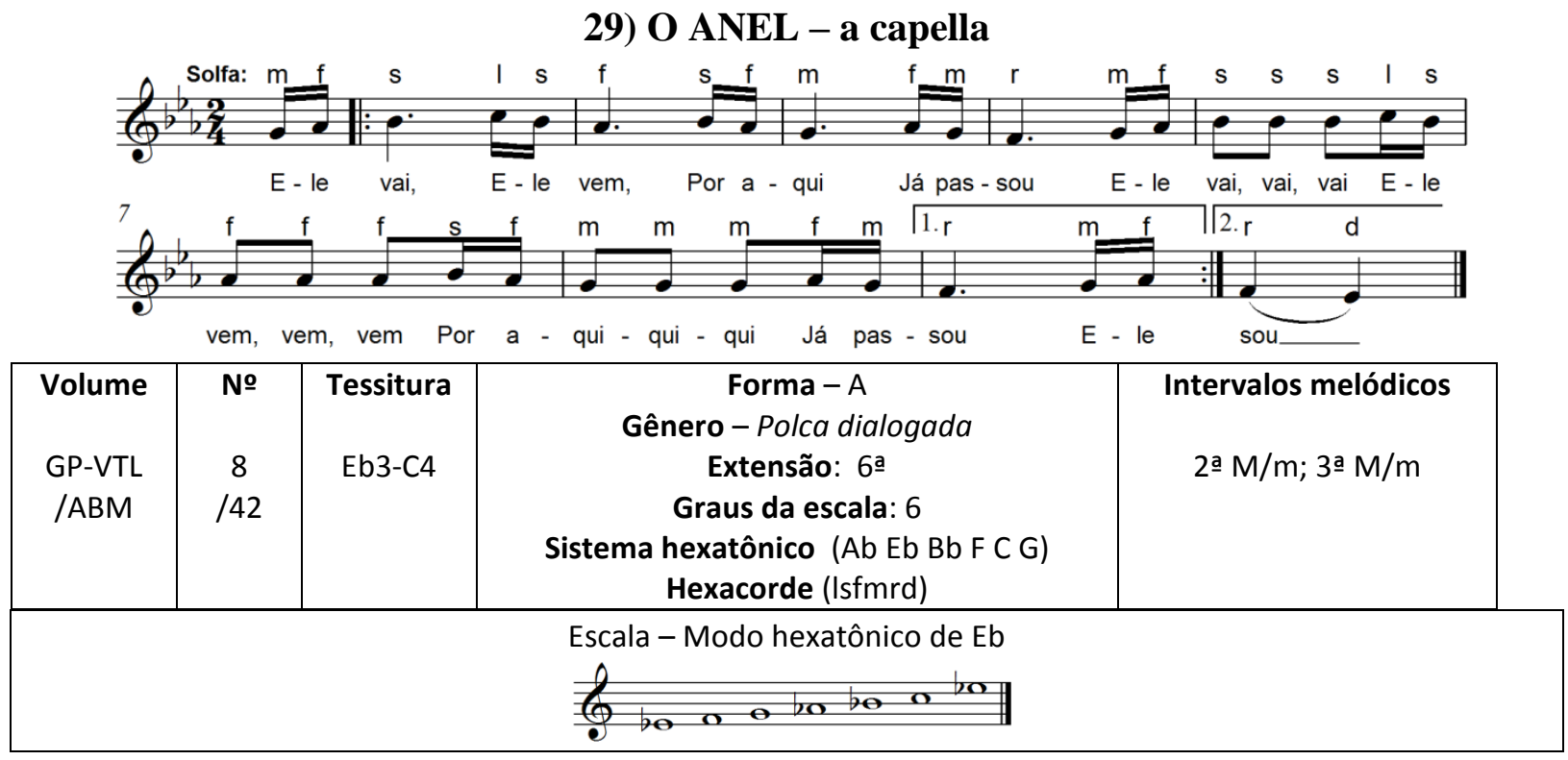

Sugestões de atividades didático-pedagógicas:

Células rítmicas para registro gráfico:

Células melódicas para registro gráfico:
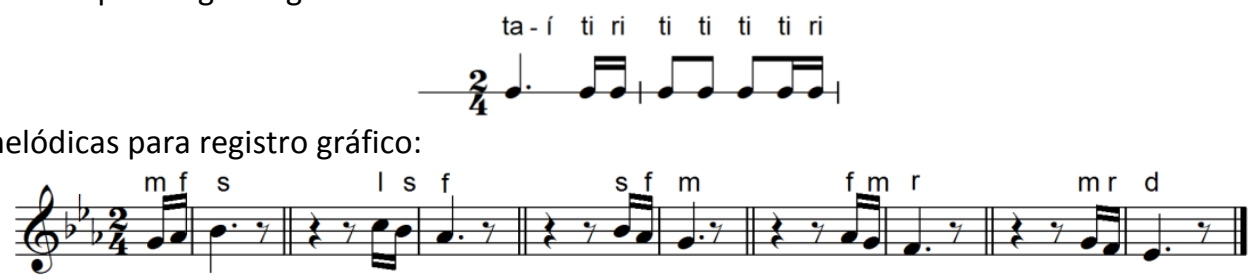

Possivel ostinato rítmico:

Possivel ostinato melódico:
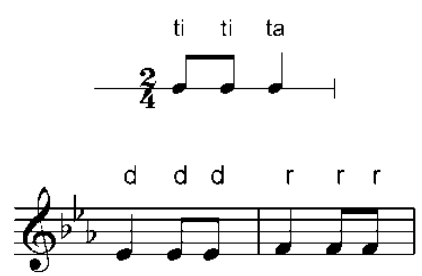

Análise complementar EM 2.2 - $n^{\circ} 31$.

Canção com 10 compassos binários, com a indicação de andamento: Allegretto (M.M. $\boldsymbol{8 8}=$ ل ); indicações de dinâmica: $\boldsymbol{M F}$

${ }^{28}$ GP/ABM - 1ํㅡㄹ Caderno, p. 85 - Fonte: Mário de Andrade, Ensaios sobre a Música Brasileira. 
Tema popular, folclore infantil.

Texto - descrição da brincadeira de Passa-anel. Na segunda frase aparecem repetições de palavras e sílabas nas notas rebatidas.

Ritmo - as notas pontuadas na primeira frase aparecem repicadas na segunda frase.

Melodia - pentacorde descendente da $\mathrm{T}$ intercalado por apojaturas duplas. Sequências descendentes por graus conjuntos.

Ludicidade - uma criança passa as mãos fechadas em concha, entre as mãos de outras crianças sentadas em roda, fingindo colocar um anel, que é deixado em uma das mãos escolhida por ela. Depois de passar por todas as crianças, são elas escolhidas para adivinharem com quem está o anel. A criança que acerta será a próxima a passá-lo.

\section{0) BRINQUEDO (Olhe aquela menina) - acompanhamento instrumental}

(Canto com piano, conjunto instrumental ou piano solo) Amb. por H. Villa-Lobos

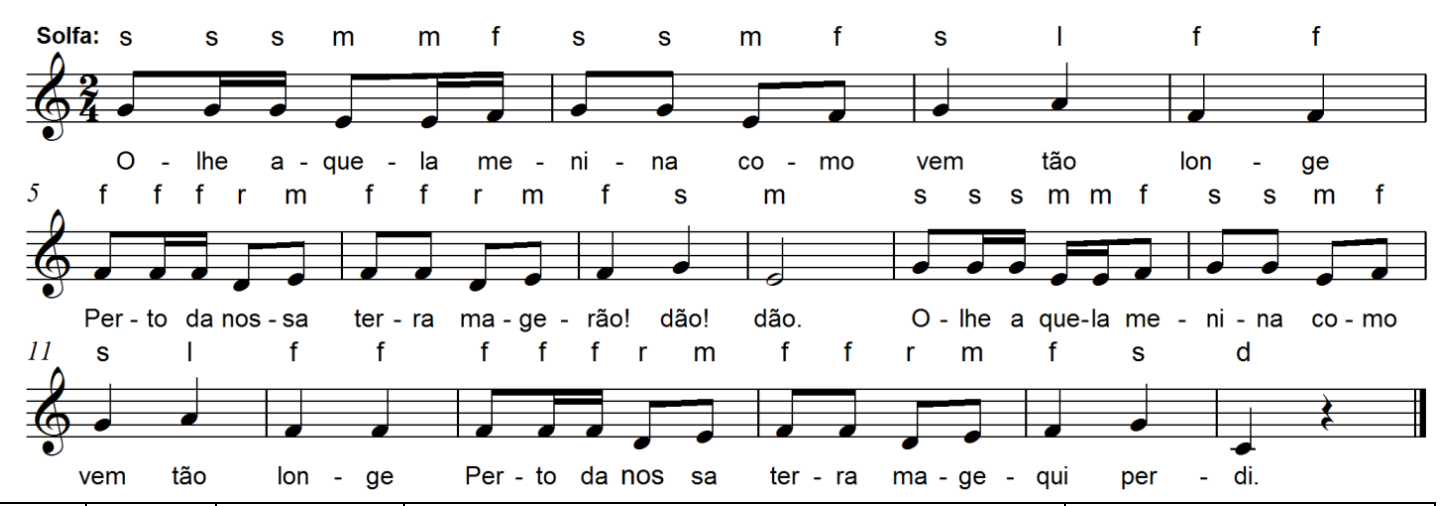

\begin{tabular}{|c|c|c|c|c|}
\hline $\begin{array}{c}\text { Volume } \\
\text { GP-VTL } \\
\text { /ABM }\end{array}$ & $\begin{array}{r}\text { № } \\
\\
17 \\
/ 89\end{array}$ & $\begin{array}{l}\text { Tessitura } \\
\text { C3-C4 }\end{array}$ & $\begin{array}{c}\text { Forma - A } \\
\text { Gênero - Dança } \\
\text { Extensão: 6ạ } \\
\text { Graus da escala: } 6 \\
\text { Sistema hexatônico (F C G D A E) } \\
\text { Hexacorde (I s f m r d) }\end{array}$ & $\begin{array}{l}\text { Intervalos melódicos } \\
\text { 2aㅡ } \mathrm{M} / \mathrm{m} ; 3 \text { a } \mathrm{M} / \mathrm{m} \text {; 5a J }\end{array}$ \\
\hline \multicolumn{5}{|c|}{ 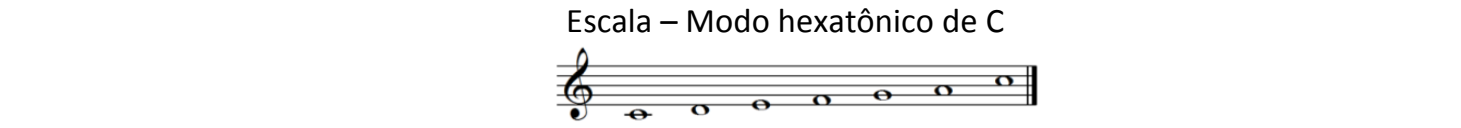 } \\
\hline
\end{tabular}

Sugestões de atividades didático-pedagógicas:

Células rítmicas para registro gráfico:

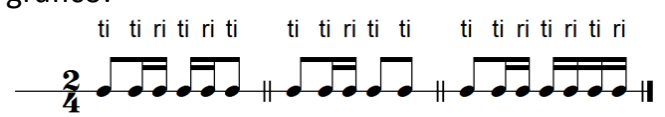

Células melódicas para registro gráfico:

Possível ostinato rítmico:
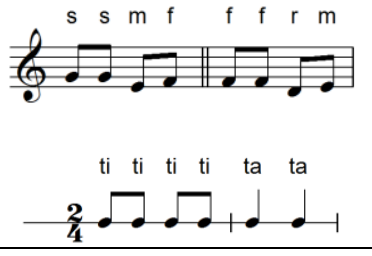

Canção com 16 compassos binários, com indicações de andamento: Allegro $(\mathbf{1 6 0}=\mathrm{d}) /$ Più mosso. GP/ABM apresenta a solução para as indicações confusas em GP/VTL para a localização da expressão più mosso e as repetições. 
Tema popular, folclórico infantil, de brincadeira de roda de escolha, cujo desenvolvimento baseia-se no texto.

Texto - faz parte de uma série de estrofes, variadas segundo a região de origem, que conta a história de uma menina que perdeu uma agulha e vai procurá-la em lugar distante. A palavra "tão" é reforçada em seu sentido pela nota aguda. Termos aproximados para mangerão: manjerona (erva cheirosa de origem européia; povo extinto que habitava a Amazônia); possível corruptela de manjericão - erva cheirosa brasileira. Segundo Veríssimo de Melo ${ }^{29}$ em Natal usa-se o termo "mangicão". "Magequi" - variação para constituição de rima.

Ritmo - simétrico, com repetição da semifrase por quatro vezes.

Melodia - consta de duas frases iguais, com desenhos sobre terças cheias e saltos, com finalizações na $\mathrm{D}$ e na $\mathrm{T}$.

Acompanhamento instrumental (piano) - com dois compassos de introdução (arpejo da T em oitavas com nota de passagem), três de Codeta e um de Coda (idem à codeta, com ritmo dobrado). A linha da mão esquerda do piano descreve um 'passeio' - contraponto em movimento contínuo em oitavas com stacatto por graus conjuntos e arpejos de T e D. Como variação timbrística, há uma recomendação para se dobrar as oitavas da mão direita na repetição D.C. A mão direita, também em oitavas simples ou com acordes, dobra a melodia do canto, com acentos constantes em todas as notas. Indicações de dinâmica na parte instrumental: $f$;ff; fff; Acentos $>v$

Ludicidade - brinquedo no qual as crianças ficam dispostas em uma fileira, e em frente uma criança sozinha. Inicia-se o diálogo a partir do texto com o recuo para frente da o grupo de crianças na frase: - Olha aquela menina como vem tão longe, tão longe. O recuo para traz na frase: Perto de nossa terra mangerão dão! Dão! A criança sozinha responde também recuando para frente e para trás. Ao fim do diálogo escolhe uma criança que a substituirá. Toda essa movimentação obedece ao pulso da música e às frases do diálogo, possibilitando o exercício de se cantar em coro e solo.

Complemento do texto ${ }^{30}$ :

- Olha aquela menina / como vem tão longe / perto da nossa terra / mangerão! dão! dão!

- Eu vou indo por aqui / por aqui assim / à procura de uma agulha / que eu aqui perdi.

- Ó menina, ó menina / vá dizer a seu pai / que uma agulha que se perde / não se acha mais.

\section{1) CAI, CAI BALÃO (Vem cá, Bitu) - a capella}

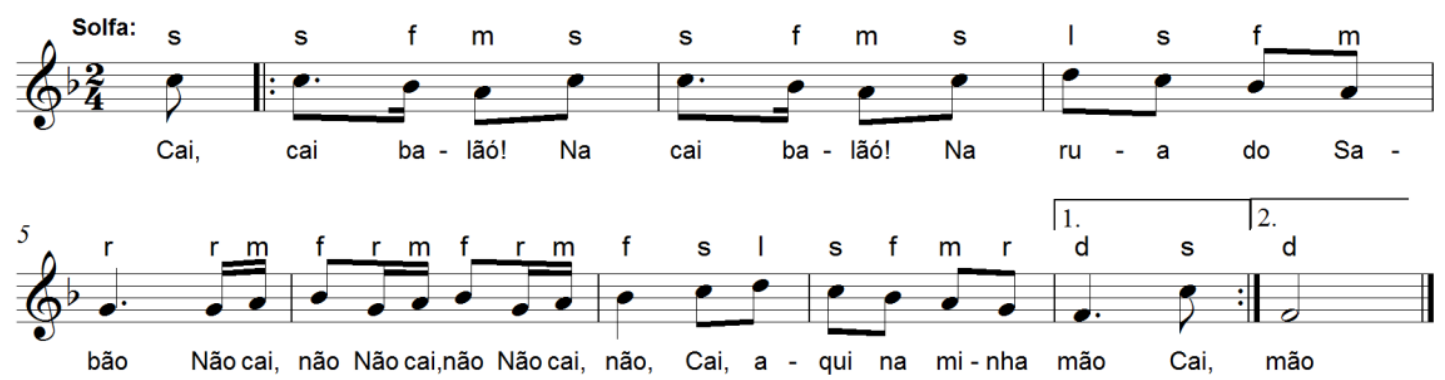

\footnotetext{
${ }^{29}$ MELO, Veríssimo. Folclore Infantil. Belo Horizonte: Itatiaia, 1979.

${ }^{30}$ GP/ABM - Segundo Caderno, p. 111 - Fonte: João Gomes Júnior \& João Baptista Julião - Ciranda, Cirandinha.
} 


\begin{tabular}{|c|c|c|c|c|}
\hline $\begin{array}{l}\text { Volume } \\
\text { GP- VTL } \\
\text { /S1 } \\
\text { /ABM }\end{array}$ & $\begin{array}{l}\text { № } \\
19 \\
\text { /9 } \\
\text { /13 }\end{array}$ & $\begin{array}{c}\text { Tessitura } \\
\text { F3-D4 }\end{array}$ & $\begin{array}{c}\text { Forma - A } \\
\text { Gênero - Polca canção } \\
\text { Extensão: 6ạ } \\
\text { Graus da escala: } 6 \\
\text { Sistema hexatônico (Bb F C G D A) } \\
\text { Hexacorde (I s f m r d) }\end{array}$ & $\begin{array}{c}\begin{array}{c}\text { Intervalos } \\
\text { melódicos }\end{array} \\
\text { 2a } \mathrm{M} / \mathrm{m} ; 3^{a} \mathrm{~m} ; 5 \text { a }\end{array}$ \\
\hline \multicolumn{5}{|c|}{ Escala - Modo hexatônico de F } \\
\hline & & & $\begin{array}{lllllll}\theta & 0 & b & 0 & 0 & \theta\end{array}$ & \\
\hline
\end{tabular}

Sugestões de atividades didático-pedagógicas:

Células rítmicas para registro gráfico:

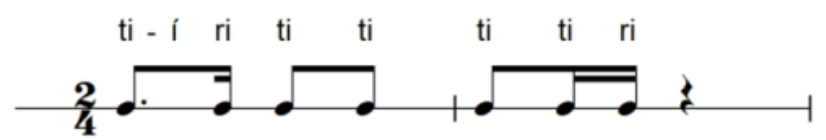

Células melódicas para registro gráfico:

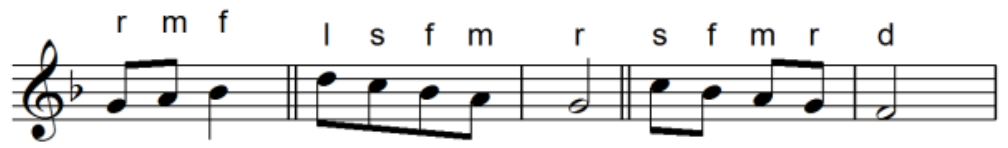

Possivel ostinato rítmico:

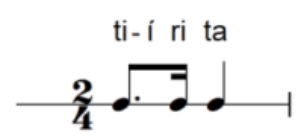

Possível ostinato melódico:

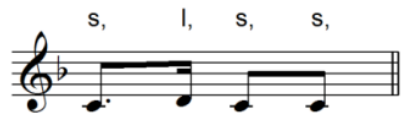

Análise complementar em $2.2-n^{\circ} 64$.

Canção com 10 compassos binários, com a indicação de andamento: Allegretto (M.M. 92= ل ); sem indicações de dinâmica.

Tema popular, folclórico infantil, de folguedo junino.

Texto - alusivo à caça ao balão em festas juninas. As repetições de palavras têm intenção timbrística.

Ritmo - o interesse rítmico está nas células com figuras pontuadas e suas variantes com semicolcheias.

Melodia - inicia-se por dois motivos iguais em linhas descendentes por grau conjunto em âmbito de terça menor, seguidos de pentacorde menor descendente; a resposta consta de três motivos iguais em linhas ascendentes por grau conjunto em âmbito de terça menor, seguidos de hexacorde descendente com finalização na $\mathrm{T}$.

Ludicidade - Brincadeira de roda na qual as crianças fazem gestos relacionados ao texto. 
32) VITU - acompanhamento instrumental

(Canto com piano, conjunto instrumental ou piano solo) Amb. por H. Villa-Lobos
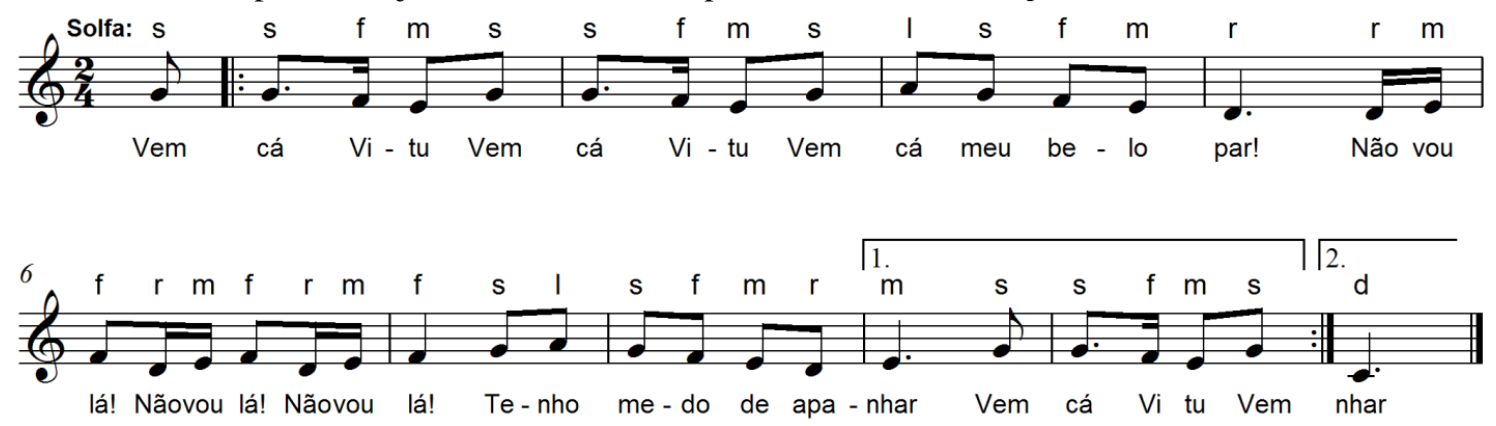

\begin{tabular}{|c|c|c|c|c|}
\hline $\begin{array}{l}\text { Volume } \\
\text { GP-VTL } \\
\text { /ABM }\end{array}$ & $\begin{array}{c}\text { № } \\
133 \\
\text { /119 }\end{array}$ & $\begin{array}{l}\text { Tessitura } \\
\text { C3-A3 }\end{array}$ & $\begin{array}{c}\text { Forma - A } \\
\text { Gênero - um pouco batuque } \\
\text { Extensão: } 6 \underline{a} \\
\text { Graus da escala: } 6 \\
\text { Sistema hexatônico (F C G D A E) } \\
\text { Hexacorde (I } \mathrm{s} \mathrm{m} \mathrm{r} \mathrm{d} \text { ) }\end{array}$ & $\begin{array}{l}\text { Intervalos } \\
\text { melódicos } \\
\text { 2a } \mathrm{Mm} ; 3^{\mathrm{a}} \mathrm{m}\end{array}$ \\
\hline & & & 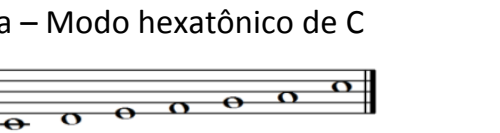 & \\
\hline
\end{tabular}

Sugestões de atividades didático-pedagógicas:

Células rítmicas para registro gráfico:

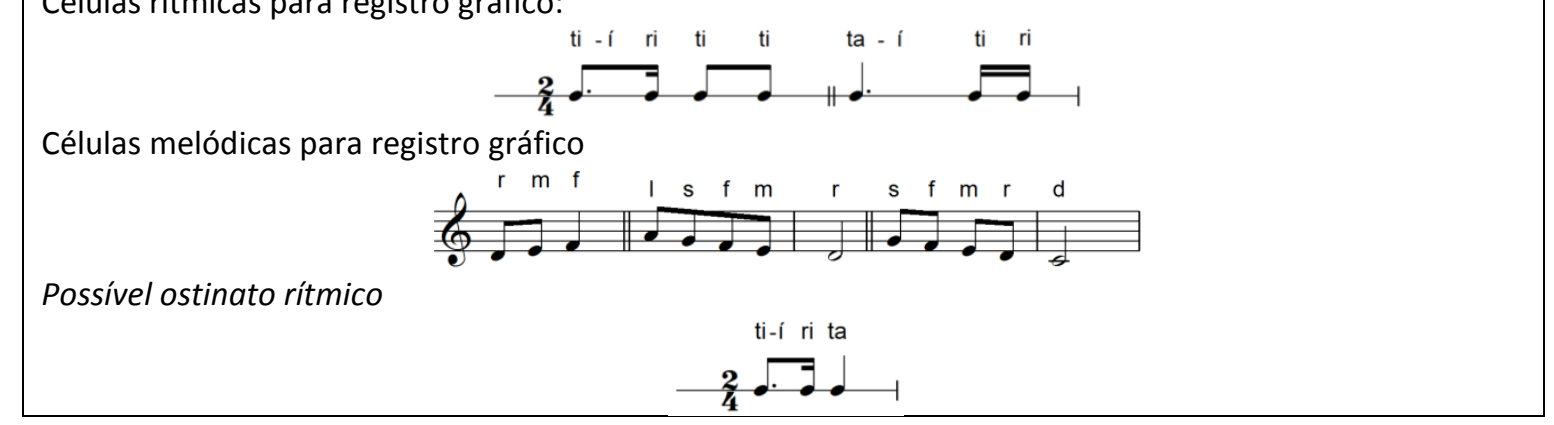

Análise complementar em $2.2-n^{\circ} 87$.

Canção com 11 compassos binários, com a indicação de andamento: Andantino (M.M. $88=\downarrow$ )/ morrendo poco a poco; indicações de dinâmica: $\boldsymbol{m f}$

Tema popular de brincadeira cantada cujo desenvolvimento baseia-se no texto.

Texto - Descrição de brincadeira de roda. Variante - Bitu.

Ritmo - o interesse rítmico está nas células com figuras pontuadas e suas variantes com semicolcheias.

Melodia - inicia-se por dois motivos iguais em linhas descendentes por grau conjunto em âmbito de terça menor, seguidos de pentacorde menor descendente; a resposta consta de três motivos iguais em linhas ascendentes por grau conjunto em âmbito de terça menor, seguidos de hexacorde descendente com finalização na T.

Ludicidade - brincadeira de roda, em que Vitu, ou Bitu, é a criança escolhida para entrar na roda e ganhar uma palmada. 


\section{3) VIUVINHA DA BANDA D'ALÉM - a capella}
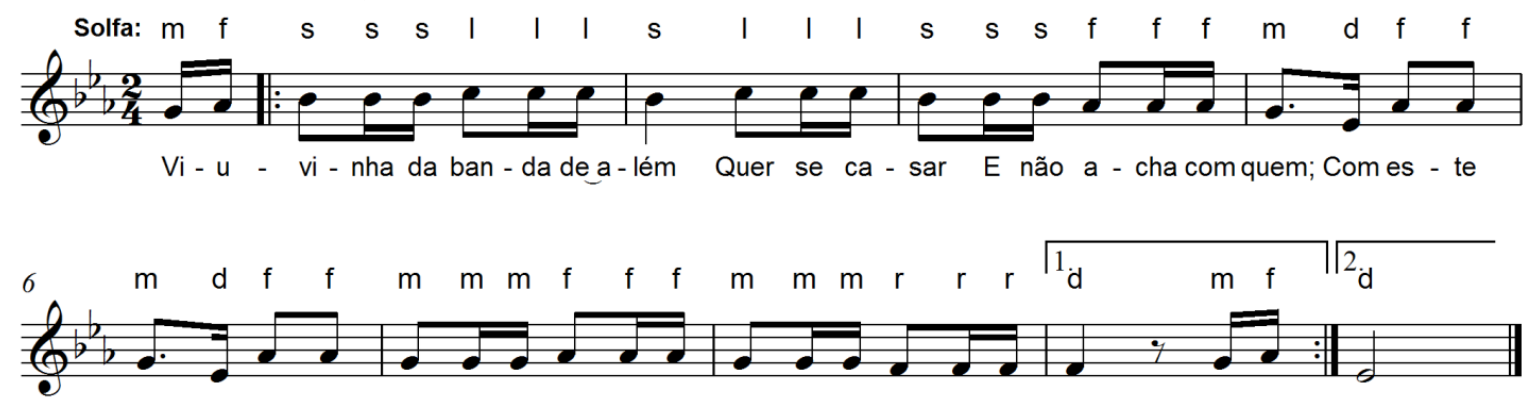

sim, Comes - te não, Ha de ser com a - que - le do meu co-ra - ção.

Vi - u - ção

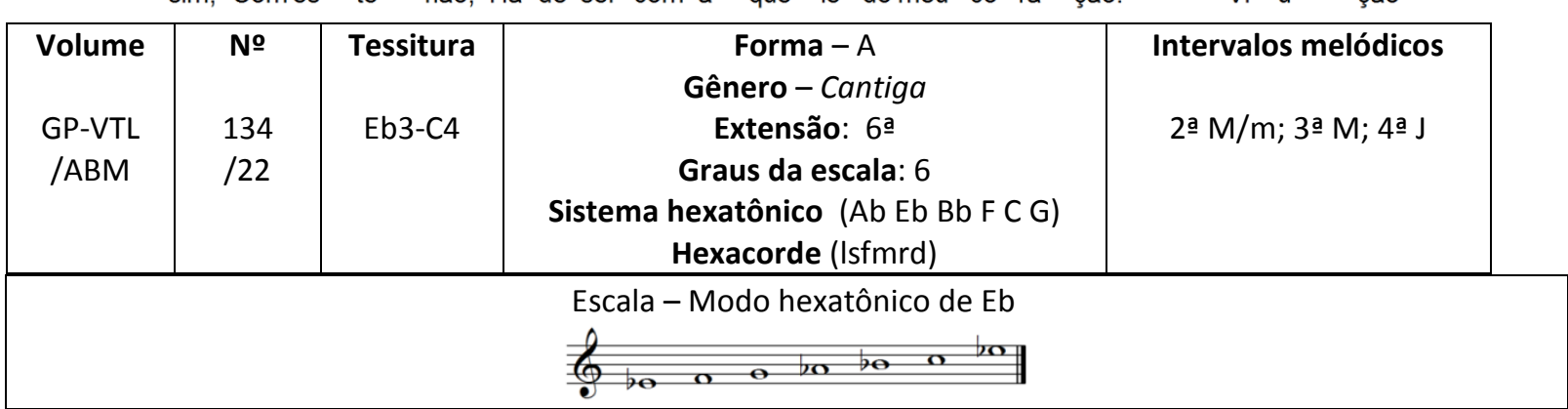

Sugestões de atividades didático-pedagógicas:

Células rítmicas para registro gráfico:

Células melódicas para registro gráfico:
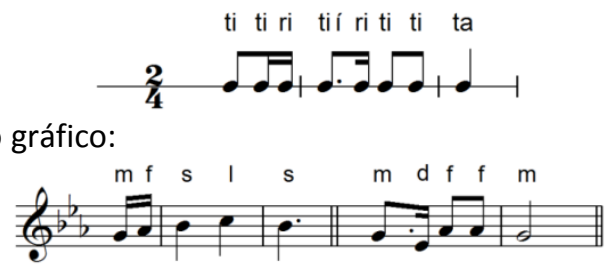

Possivel ostinato rítmico:

Possivel ostinato melódico:
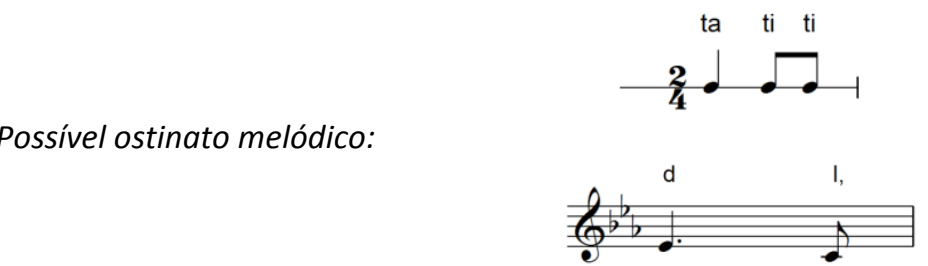

Análise complementar em $2.2-n^{\circ} 68$.

Canção com 10 compassos binários, com a indicação de andamento: Allegretto (M.M. $\mathbf{9 2 =} \downarrow$ ) ); sem indicações de dinâmica.

Tema popular de brincadeira cantada cujo desenvolvimento baseia-se no texto.

Texto - descrição de brincadeira de roda, sobre tema social do casamento da viúva.

Ritmo - binário, anacrúsico, de subdivisão binária. $\mathrm{O}$ interesse rítmico está na repetição da célula de colcheia/duas semicolcheias.

Melodia - frase com desenho ascendente na terça cheia superior da tríade de $\mathrm{T}$, com bordaduras com o sexto grau, e tetracorde descendente. Segunda frase semelhante, com abordagem do quarto grau e tetracorde descendente para $\mathrm{T}$.

Ludicidade - Roda de escolha com uma criança no meio, na qual se estabelece um diálogo a partir do texto entre os integrantes da roda e a criança do centro, que escolherá outra para substituí-la. 


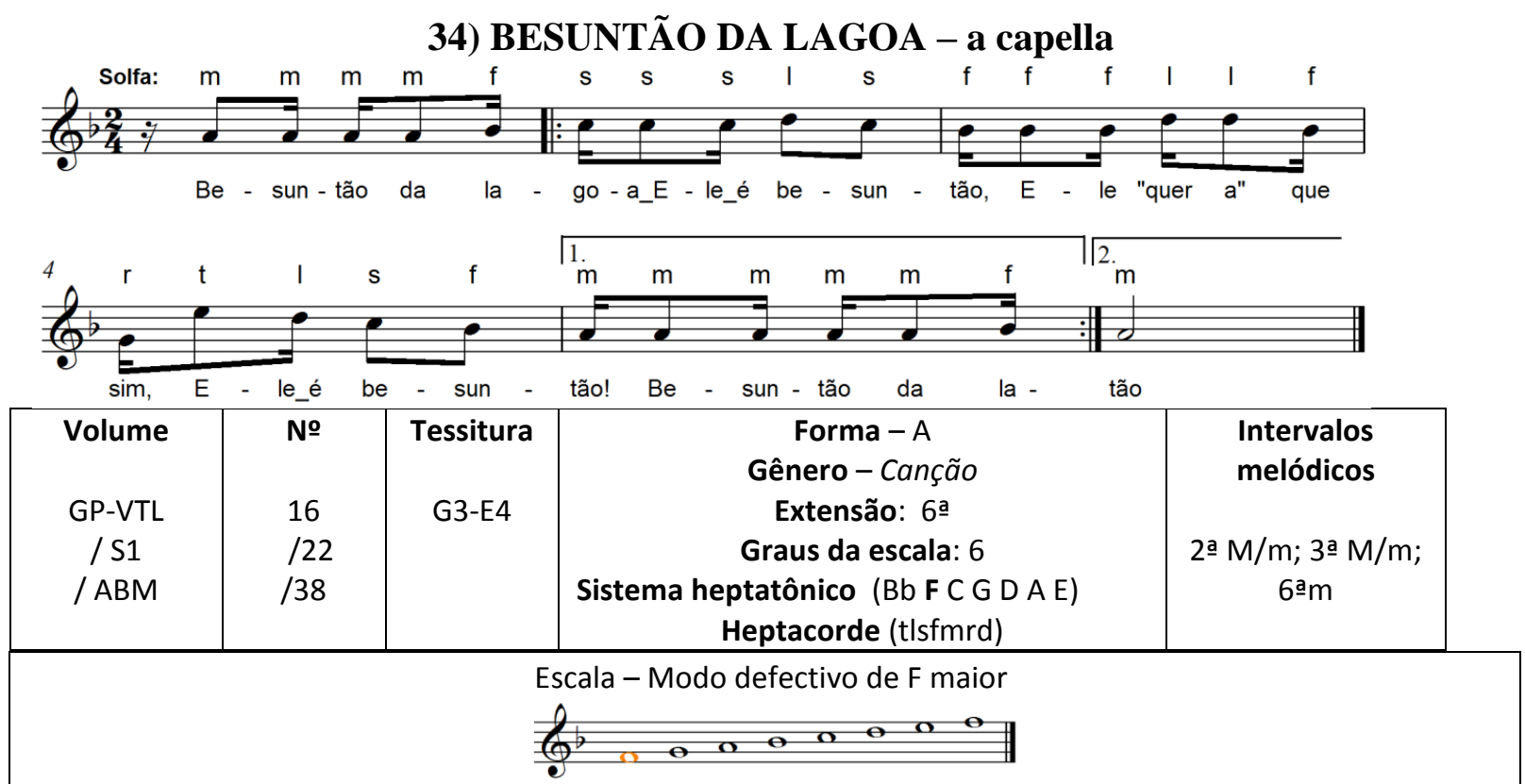

Sugestões de atividades didático-pedagógicas:

Células rítmicas para registro gráfico:

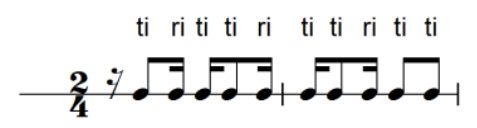

Células melódicas para registro gráfico:

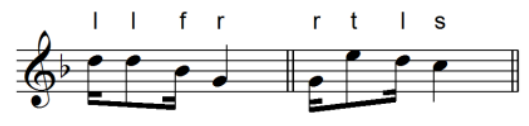

Possivel ostinato rítmico:

ti ri ti ti

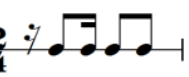

Análise complementar em $2.2-n^{\circ} 70$.

Canção com 6 compassos binários, com a indicação de andamento: Allegretto $($ M.M. $84=$ ل $)$ ); indicações de dinâmica: $\boldsymbol{m f}$; acentos >

Tema popular, folclórico, de brincadeira cantada cujo desenvolvimento baseia-se no texto.

Texto - Besuntão, personagem de reisado "Zé do Vale"31.

Ritmo - o interesse rítmico está síncopas.

Melodia - pequena curva inicial com final na $\mathrm{D}$, linha descendente a seguir, com final na $\mathrm{T}$.

Ludicidade - Roda de escolha com uma criança no centro, que escolherá outra para substituíla.

Complemento do texto:

- Besuntão da lagoa / ele é besuntão / ele "quer a" que sim, / ele é besuntão

- Besuntão da lagoa / ele é besuntão / ele "quer a" que não, / ele é besuntão

${ }^{31}$ GP/ABM - $1^{\circ}$ Caderno, p.90, apud Mello Moraes. Texto - Fonte: SEMA. 
35) SENHORA DONA SANCHA ( $2^{\mathrm{a}}$ versão $)$ - a capella
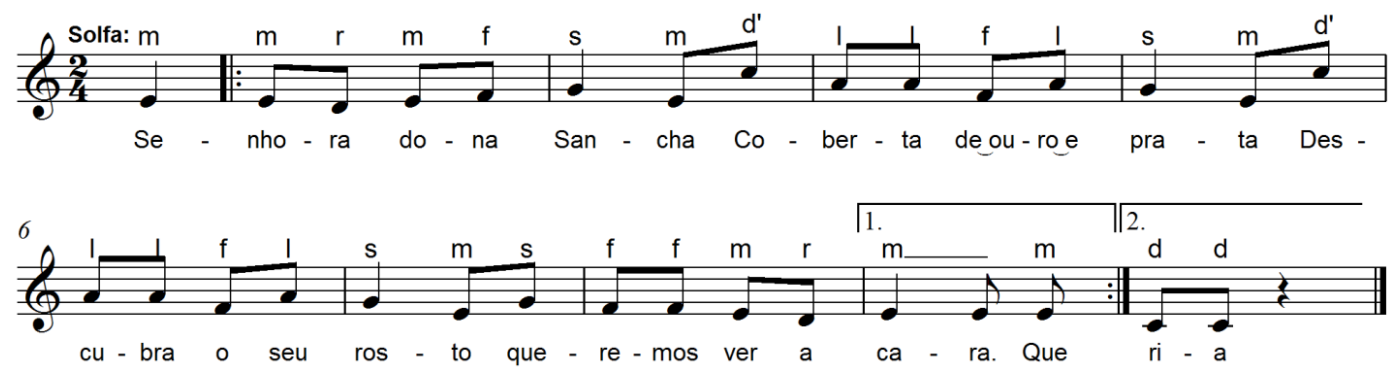

\begin{tabular}{|c|c|c|c|c|}
\hline $\begin{array}{l}\text { Volume } \\
\text { GP-VTL } \\
\text { / S1 / } \\
\text { ABM }\end{array}$ & $\begin{array}{c}\text { № } \\
115 \\
/ 1 \\
/ 1\end{array}$ & $\begin{array}{l}\text { Tessitura } \\
\text { C3-C4 }\end{array}$ & $\begin{array}{c}\text { Forma - A } \\
\text { Gênero - Cantiga } \\
\text { Extensão: } 8 \underline{a} \\
\text { Graus da escala: } 6 \\
\text { Sistema hexatônico (F C G D A E) } \\
\text { Hexacorde (Isfmrd) }\end{array}$ & $\begin{array}{c}2 \text { a } M / m ; 3 \mathrm{M} / \mathrm{m} ; \\
6 \stackrel{\mathrm{a}}{\mathrm{m}}\end{array}$ \\
\hline
\end{tabular}

Sugestões de atividades didático-pedagógicas:

Células rítmicas para registro gráfico:

Células melódicas para registro gráfico:
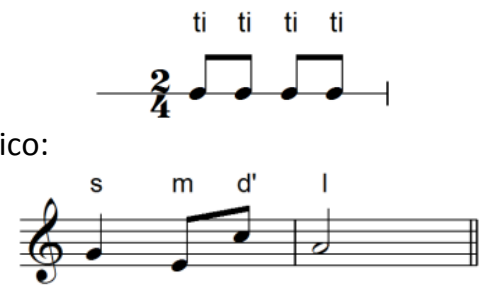

Possivel ostinato rítmico

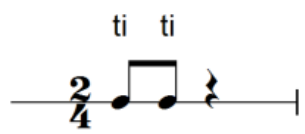

Possivel ostinato melódico

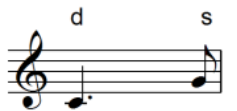

Canção com 10 compassos binários, com a indicação de andamento: Allegretto (M.M. $112=」$ ); sem indicações de dinâmica.

Tema popular, folclórico infantil, de brincadeira cantada.

Texto - descrição de brincadeira de roda, com personagens ligadas a figuras do cristianismo.

Ritmo - binário, anacrúsico, com subdivisão binária seguindo o texto.

Melodia - iniciada com desenho em torno da terça menor da tríade de T seguido de salto ascendente de sexta; segue desenho descendente sobre arpejo da tríade de $\mathrm{S}$, voltando às notas iniciais (duas vezes), finalizando com pentacorde descendente de $\mathrm{D}$ para $\mathrm{T}$.

Ludicidade - Brincadeira de roda, também denominada cobra cega, na qual se estabelece o diálogo a partir do texto entre os integrantes da roda e uma criança com os olhos vendados ao centro. Ao final da cantiga as crianças se abaixam e tentam fugir da Dona Sancha, que com os olhos vendados tentará pegar uma delas. Aquela que for pega substituirá a Dona Sancha no centro. 
Complemento do texto ${ }^{32}$ :

Senhora Dona Sancha / coberta de ouro e prata / descubra o seu rosto / queremos ver a cara.

- Que anjos são estes / que andam me guiando / de noite e de dia / Padre-nosso, Ave-Maria.

- Somos filhas de Dom Rei / e netas de Dom Conde / que manda que se esconda / debaixo de uma pedra.

36) VAMOS, COMPANHEIROS - a capella
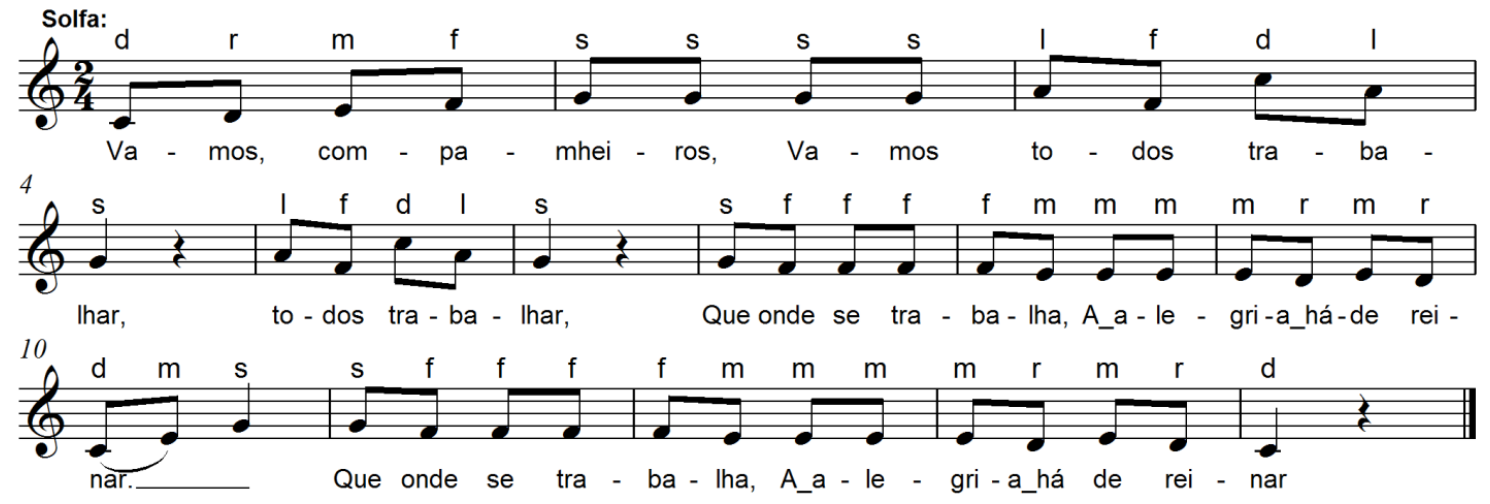

\begin{tabular}{|c|c|c|c|c|}
\hline $\begin{array}{l}\text { Volume } \\
\text { CO } 1\end{array}$ & $\begin{array}{l}\text { No } \\
3\end{array}$ & $\begin{array}{c}\text { Tessitura } \\
\text { C5-C4 } \\
\text { A2 - C4 }\end{array}$ & $\begin{array}{c}\text { Forma - A } \\
\text { Extensão: } 8 \underline{a} \\
\text { Graus da escala: } 6 \\
\text { Sistema hexatônico (F C G D A E) } \\
\text { Hexacorde (Isfmrd) }\end{array}$ & 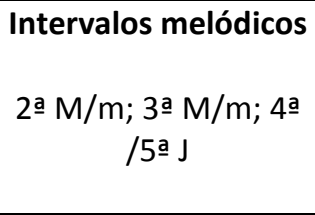 \\
\hline & & & $\begin{array}{l}\text { Escala - Modo hexatônico de C } \\
6 \begin{array}{lllllll}0 & 0 & 0 & 0 & 0\end{array}\end{array}$ & \\
\hline
\end{tabular}

Sugestões de atividades didático-pedagógicas:

Células rítmicas para registro gráfico:

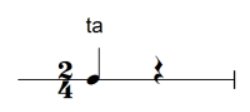

Células melódicas para registro gráfico:

Possivel ostinato rítmico:
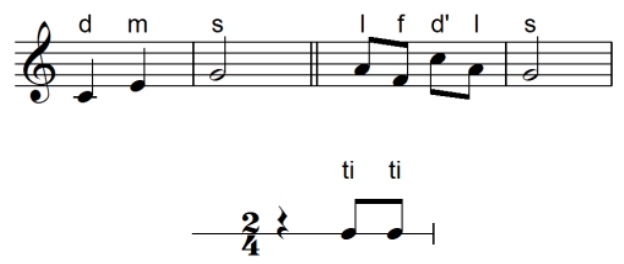

Possivel ostinato melódico:

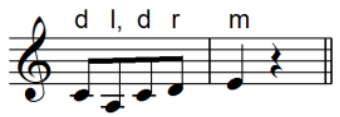

Análise complementar em $2.2-n^{\circ} 38$.

Canção com 14 compassos binários, com a indicação de andamento: Marcha (Moderato); indicações de dinâmica: $\boldsymbol{f}$; $\boldsymbol{m} \boldsymbol{f}$; $\boldsymbol{p p}$; Acentos >

Tema - canção escolar (do livro Alvorada de Fabiano Lozano), com arranjo de H. VillaLobos, 1935 - Rio de Janeiro.

${ }^{32}$ GP/ABM - Primeiro Caderno, p. 71 - Fonte: (G.M.) - João Gomes Júnior \& João Baptista Julião - Ciranda, Cirandinha. 
Texto - infantil, de métrica variada, associando trabalho à alegria e valorizando o trabalho em grupo.

Ritmo - binário, tético, com subdivisão binária seguindo o texto.

Melodia - pentacorde ascendente com notas rebatidas no quinto grau, terças arpejadas na tríade de $\mathrm{S}$ e volta descendente em direção à $\mathrm{T}$ com notas rebatidas e bordaduras.

Ludicidade - o texto possibilita a criação de movimentos ou jogos.

\section{7) OS POMBINHOS - a capella}
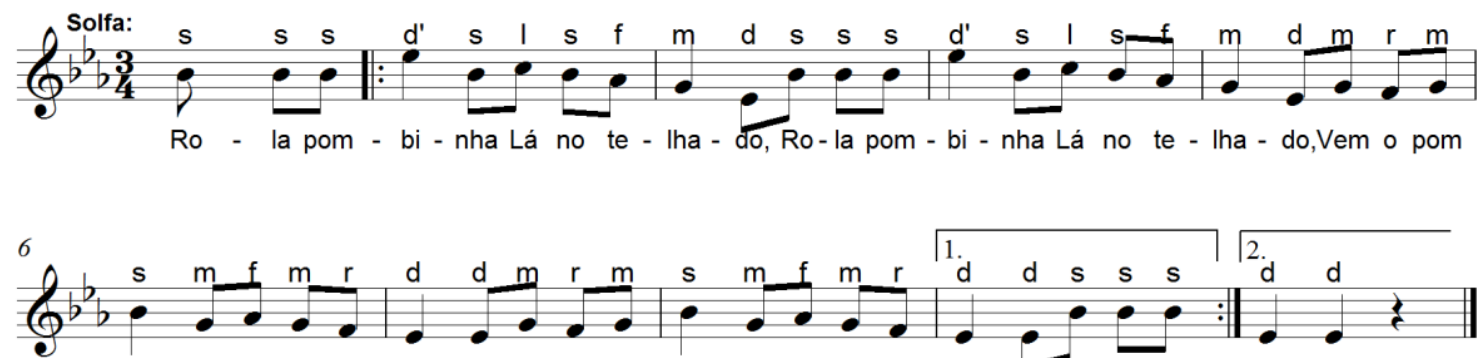

bi - nhoPõe-se de la - do.Vem o pom - bi - nhoPõe-se de la - đo. Ro-la pom la - do

\begin{tabular}{|c|c|c|c|c|}
\hline $\begin{array}{l}\text { Volume } \\
\text { GP-VTL } \\
\text { /S1 } \\
\text { /ABM }\end{array}$ & $\begin{array}{l}\text { № } \\
101 \\
/ 15 \\
/ 8\end{array}$ & $\begin{array}{l}\text { Tessitura } \\
\text { Eb-Eb' }\end{array}$ & $\begin{array}{c}\text { Forma - A } \\
\text { Gênero - Minueto } \\
\text { Extensão: } 8 \text { ạ } \\
\text { Graus da escala: } 6 \\
\text { Sistema Hexatônico (Ab Eb Bb F C G) } \\
\text { Hexacorde (I s f m r d) }\end{array}$ & $\begin{array}{c}\text { Intervalos } \\
\text { melódicos } \\
\text { 2a } \mathrm{M} / \mathrm{m} ; 3 \text { a } \mathrm{M} / \mathrm{m} \text {; } \\
4 \text { a } / 5 \text { J }\end{array}$ \\
\hline & & & 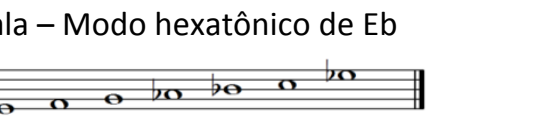 & \\
\hline
\end{tabular}

Sugestões de atividades didático-pedagógicas:

Células rítmicas para registro gráfico:

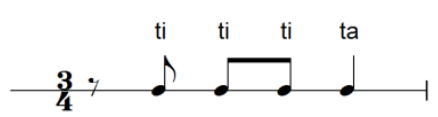

Células melódicas para registro gráfico:

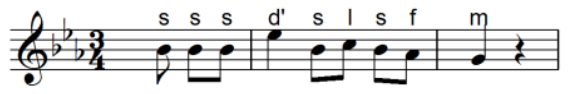

Possivel ostinato rítmico:

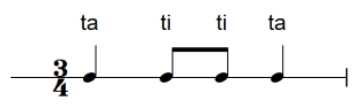

Possivel ostinato melódico:

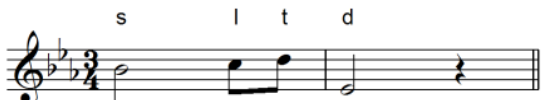

Análise complementar em $2.2-n^{\circ} 12$.

Canção com 10 compassos ternários, com a indicação de andamento: Andantino quasi Allegretto (Minueto) $\mathbf{1 3 8}=$ ل ); indicações de dinâmica: $\boldsymbol{m} \boldsymbol{f}$

Tema popular, folclórico, de brincadeira de roda, cujo desenvolvimento baseia-se no texto.

Texto - GP/ABM indica como correção "Rola a pombinha" ao invés de "Rola pombinha" como consta em GP/VTL, embora esteja correta, pois se trata da ave rola-pomba, ou pomba- 
rola. Na segunda versão da mesma canção (número 102) consta em GP/VTL "Rola a pombinha", como variante.

Ritmo - ternário, tempo de minueto.

Melodia - primeira frase com desenho repetido sobre arpejo de T, com bordaduras e notas de passagem, com finalização descendente; segunda frase da mesma forma sobre a tríade da $\mathrm{T}$.

Ludicidade - brincadeira de roda que segue o texto em seu desenvolvimento.

\section{8) OS POMBINHOS ( $2^{\mathrm{a}}$ versão $)$ - acompanhamento instrumental}

(Canto com piano, conjunto instrumental ou piano solo) Amb. por H. Villa-Lobos
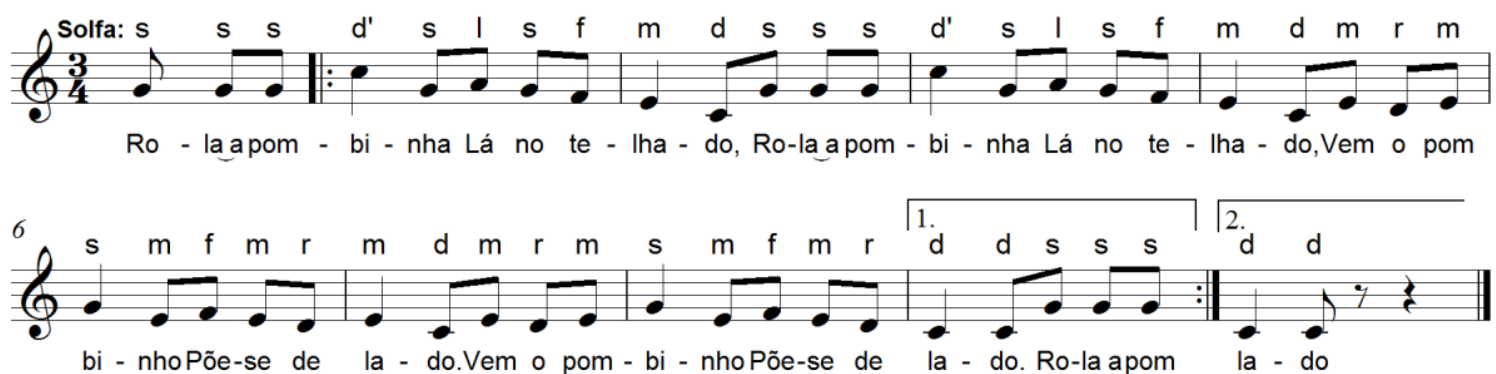

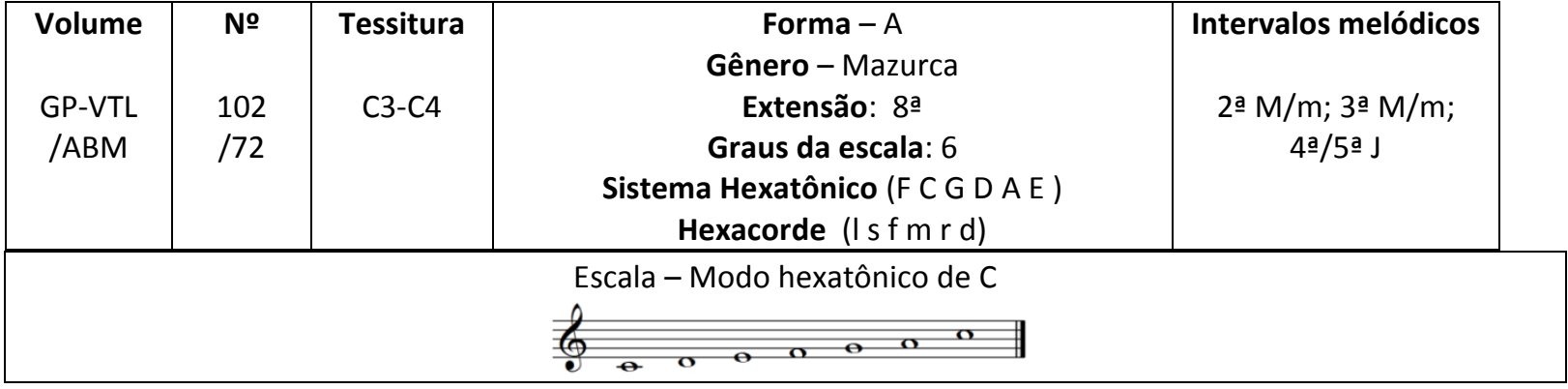

Sugestões de atividades didático-pedagógicas:

Células rítmicas para registro gráfico:

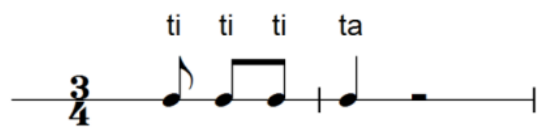

Células melódicas para registro gráfico:

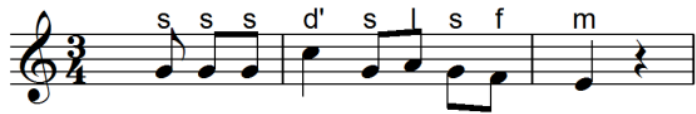

Possível ostinato rítmico:

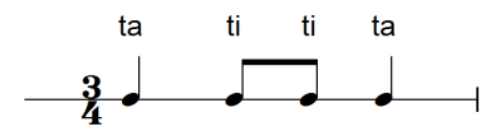

Possível ostinato melódico:

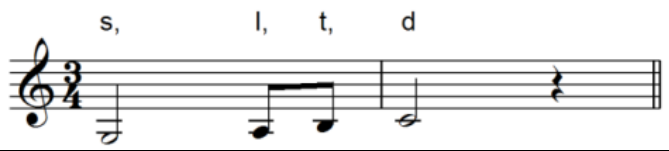

Canção com 14 compassos ternários, com a indicação de andamento: Tempo de Mazurka $(\boldsymbol{M} . \boldsymbol{M} . \mathbf{1 6 0}=ل$ ل $)$; indicações de dinâmica: $\boldsymbol{f} ; \boldsymbol{p p}$. Em GP/ABM, a indicação de andamento consta como Allegretto.

Tema popular, folclórico, de brincadeira de roda, cujo desenvolvimento baseia-se no texto. 
Texto - relativo ao companheirismo das pombas-rolas. Descrição de brincadeira de roda que sugere a coreografia da brincadeira.

Ritmo - ternário, com sugestão do arranjador, Villa-Lobos, de tempo de mazurca. Sugerimos a adequação da prosódia como grafamos no oitavo compasso (primeira casa do ritornello), diferente das edições GP/VTL e GP/ABM.

Melodia - primeira frase com desenho repetido sobre arpejo de T, com bordaduras e notas de passagem, com finalização descendente; segunda frase da mesma forma sobre a tríade da $\mathrm{T}$.

Acompanhamento instrumental (piano) - a introdução, após seis compassos, inicia, por dois compassos, o ostinato na mão esquerda, que estará presente em todo o acompanhamento da melodia: pedal na $\mathrm{T}$ e uma linha cromática em âmbito de terça menor a partir do quinto grau. A mão direita dobra a melodia. A coda repete os seis primeiros compassos da introdução.

Ludicidade - Brincadeira de roda com gestos sugeridos a partir do texto.

\section{9) LÁ NA PONTE DA VINHAÇA (Passa, passa gavião) - a capella}
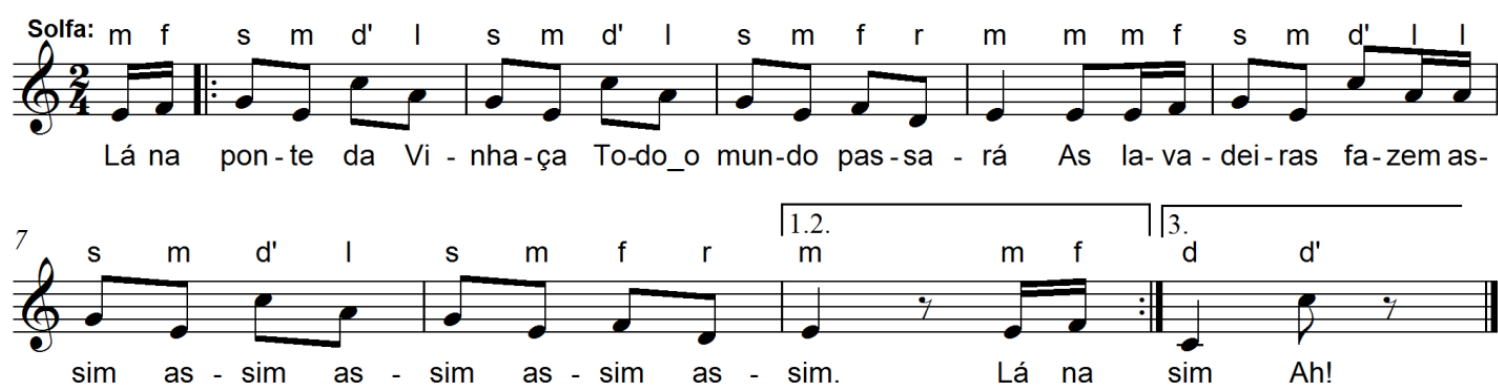

\begin{tabular}{|c|c|c|c|c|}
\hline $\begin{array}{c}\text { Volume } \\
\text { GP-VTL } \\
\text { /S1 } \\
\text { /ABM }\end{array}$ & $\begin{array}{c}\text { No } \\
\\
104 \\
/ 2 \\
/ 14\end{array}$ & $\begin{array}{l}\text { Tessitura } \\
\text { C3-C4 }\end{array}$ & $\begin{array}{c}\text { Forma - A } \\
\text { Gênero - Cantiga } \\
\text { Extensão: } 8 \text { ạ } \\
\text { Graus da escala: } 6 \\
\text { Sistema Hexatônico (F C G D A E) } \\
\text { Hexacorde (I s f m r d) }\end{array}$ & 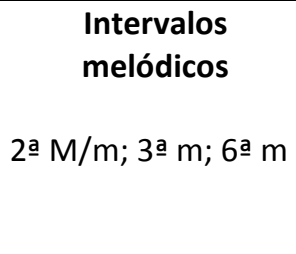 \\
\hline & & & 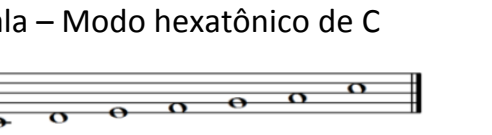 & \\
\hline
\end{tabular}

Sugestões de atividades didático-pedagógicas:

Células rítmicas para registro gráfico:

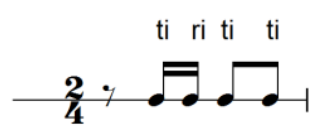

Células melódicas para registro gráfico:

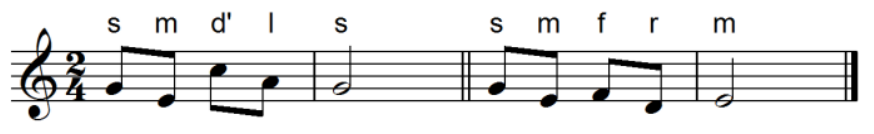

Possível ostinato rítmico:

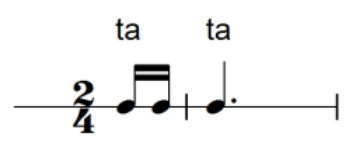


Possível ostinato melódico:

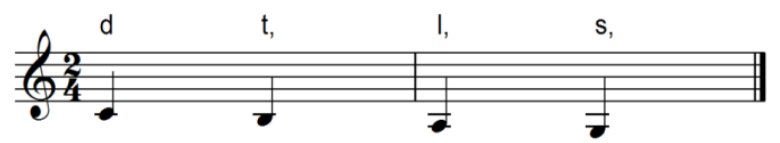

Análise complementar em $2.2-n^{o} 11$.

Canção com 10 compassos binários, com a indicação de andamento: Allegretto (M.M. $138=$ 」); indicações de dinâmica: <

Tema popular, folclórico infantil, de origem francesa (Sur le pont d'Avignon), brincadeira cantada cujo desenvolvimento baseia-se no texto.

Texto - descrição de brincadeira cantada que sugere a coreografia da brincadeira. A edição GP/ABM apresenta a complementação da prosódia da segunda e terceira estrofes, ausentes em GP/VTL. Sugerimos, no entanto, as figuras colcheia e duas semicolcheias para o texto fazem as-(sim) do quinto compasso, como grafamos aqui, em virtude da impossibilidade de se fazer elisão entre consoante e vogal. Apresentamos acima a grafia segundo a forma de repetição mais praticada.

Ritmo - binário, anacrúsico, seguindo a prosódia.

Melodia - desenho que, iniciado em terça cheia ascendente, baseia-se em terças descendentes, com saltos de sexta e terças quebradas, em linha descendente para a $\mathrm{T}$.

Ludicidade - brincadeira de roda em que as profissões são representadas por meio de mímica.

Complementação do texto:

Lá na ponte da Vinhaça todo mundo passará / As lavadeiras fazem assim, / assim, assim, assim, assim Lá na ponte da Vinhaça todo mundo passará / As costureiras fazem assim, / assim, assim, assim, assim Lá na ponte da Vinhaça todo mundo passará / As floristas fazem assim, / assim, assim, assim, assim

\section{0) NO FUNDO DO MEU QUINTAL - acompanhamento instrumental}
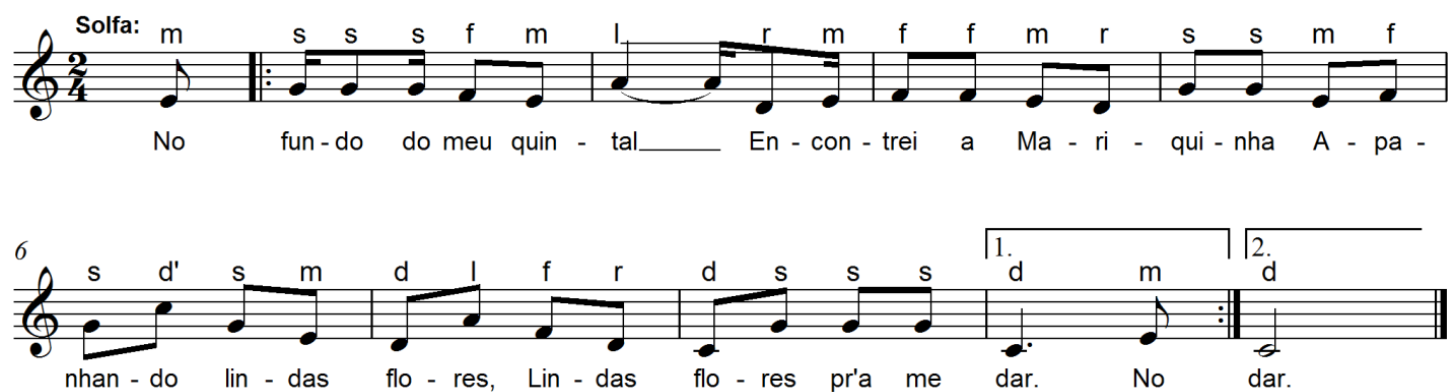

\begin{tabular}{|c|c|c|c|c|}
\hline Volume & № & Tessitura & Forma $-\mathrm{A}$ & Intervalos melódicos \\
\hline GP-VTL & 57 & C3-C4 & $\begin{array}{c}\text { Gênero - Samba canção } \\
\text { Extensão: } 8 \mathfrak{a}\end{array}$ & 2a $\mathrm{M} / \mathrm{m} ; 3$ a $\mathrm{M} / \mathrm{m}$; \\
\hline /ABM & /85 & & $\begin{array}{c}\text { Graus da escala: } 6 \\
\text { Sistema hexatônico (F C G D A E) } \\
\text { Hexacorde (I s f m r d) }\end{array}$ & $4 \underline{a} / 5$ J \\
\hline
\end{tabular}




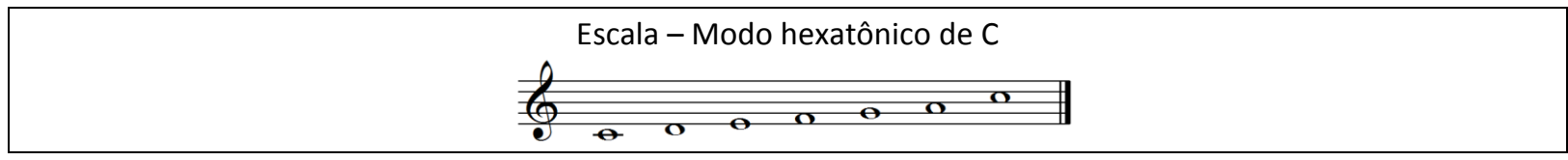

Sugestões de atividades didático-pedagógicas:

Célula rítmica para registro gráfico:

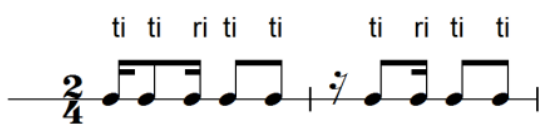

Células melódicas para registro gráfico:

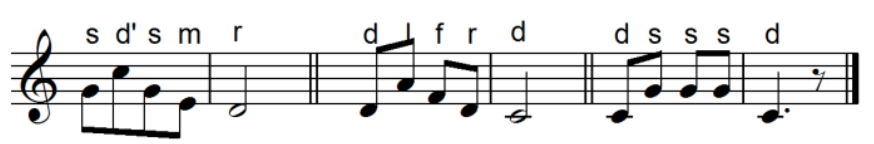

Possivel ostinato rítmico:

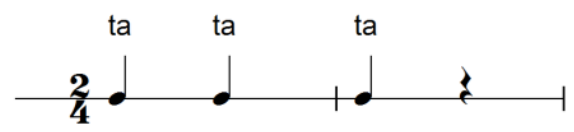

Canção com 10 compassos binários, com a indicação de andamento: Poco Moderato (M.M. $100=\downarrow) /$ rall.; indicações de dinâmica: $p ; s f z$

Tema de popular, folclórico, de brincadeira cantada cujo desenvolvimento baseia-se no texto.

Texto - sobre triângulo amoroso. Preferimos o texto constante em GP/VTL na segunda estrofe: deixe disso, deixe disso, em concordância verbal com: olhe lá, ao invés de deixa disso, deixe disso como consta em GP/ABM.

Ritmo - binário, anacrúsico, subdivisão binária. O interesse rítmico está nas síncopas de pulsação.

Melodia - pequenas curvas sobre terças menores com finalização na $\mathrm{S}$ e $\mathrm{T}$ seguidas por arpejos descendentes de $\mathrm{T}$ e $\mathrm{Sr}$, com finalização por salto descendente de quinto para primeiro grau.

Acompanhamento instrumental (piano) - introdução com quatro compassos em ostinatos rítmico-harmônicos sobre T com bordaduras 3-4/8-9. A mão direita dobra a melodia e a mão esquerda faz ostinatos rítmicos com harmonia contendo cromatismos junto ao primeiro motivo melódico, sobre as funções harmônicas primárias. A coda repete a introdução e se estende por mais dois compassos.

Ludicidade - Brincadeira de roda com gestos sugeridos a partir do texto.

Complementação do texto:

No fundo do meu quintal / encontrei a Mariquinha / apanhando lindas flores / lindas flores pra me dar. Lindas flores pro casamento / Mariquinha vai se casar / Mariquinha deixe disso / deixe disso, olhe lá. 


\section{1) BOAS FESTAS (Canção de cordialidade) - a capella}

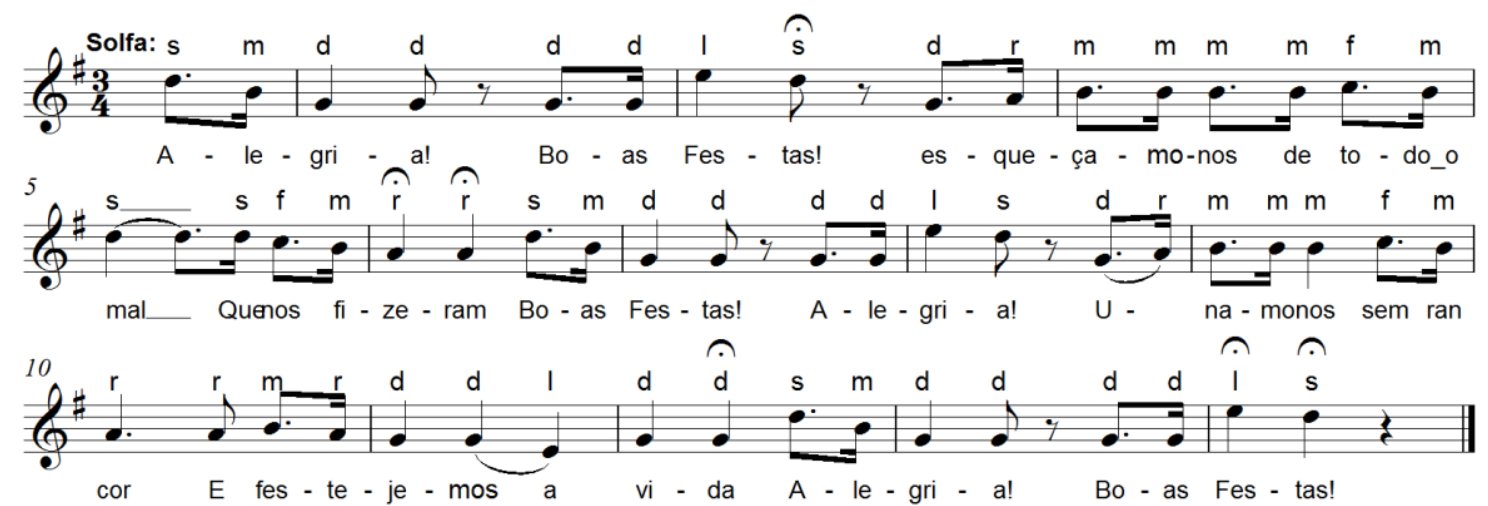

\begin{tabular}{|c|c|c|c|c|}
\hline $\begin{array}{l}\text { Volume } \\
\text { CO } 2\end{array}$ & № & $\begin{array}{l}\text { Tessitura } \\
\text { E3-E4 }\end{array}$ & $\begin{array}{c}\text { Forma - A } \\
\text { Extensão: } 8^{a} \\
\text { Graus da escala: } 6 \\
\text { Sistema hexatônico (C G D A E B) } \\
\text { Hexacorde (I } s \mathrm{f} \mathrm{m} \mathrm{r} \mathrm{d)}\end{array}$ & $\begin{array}{c}\text { Intervalos } \\
\text { melódicos } \\
\text { 2a } \mathrm{M} / \mathrm{m} ; \text { 3a } \mathrm{M} / \mathrm{m} ; 5 \underline{a} \\
\mathrm{~J} ; \text { 6ㅁM }\end{array}$ \\
\hline & & & 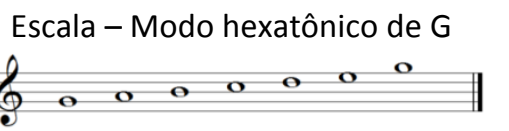 & \\
\hline
\end{tabular}

Sugestões de atividades didático-pedagógicas:

Células rítmicas para registro gráfico:

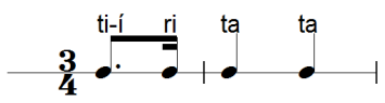

Células melódicas para registro gráfico:

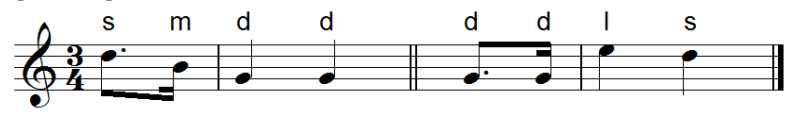

Possivel ostinato rítmico:

Análise complementar em $2.2-n^{\circ} 169$.

Canção com 15 compassos ternários, com a indicação de andamento: Andante (com alegria); indicações de dinâmica: $\boldsymbol{f}$; acento >

Tema natalino datado de 1945 - Rio de Janeiro.

Texto - de Manuel Bandeira: "Canção de cordialidade" - uma conclamação à paz, com duas frases imperativas entre três saudações, a segunda com texto invertido e cadência harmônica diferente das demais. As repetições das saudações (três) reforçam a mensagem do texto. Sete frases assimétricas, com 7, 9, 4,7, 7,7 e 7 sílabas.

Ritmo - papel importante para as fermatas, responsáveis pelos cortes entre saudações e as frases. Esses cortes chamam a atenção para o conteúdo que se segue. Os ritmos pontuados remetem à alegria indicada no texto.

Melodia - música e harmonização de H.Villa-Lobos. A três saudações de 'boas festas', arpejos descendentes da tríade da $\mathrm{T}$, seguidos de salto ascendente e apojatura de sexta - quinta, contrastam com as frases que se seguem em graus conjuntos - a primeira finalizando na $\mathrm{D}$ e a segunda na $\mathrm{T}$. 
Ludicidade - o tema natalino tem seu aspecto religioso permeado pelas simbologias dessa festa comemorada e cantada nacionalmente.

\section{2) A AGULHA - a capella}

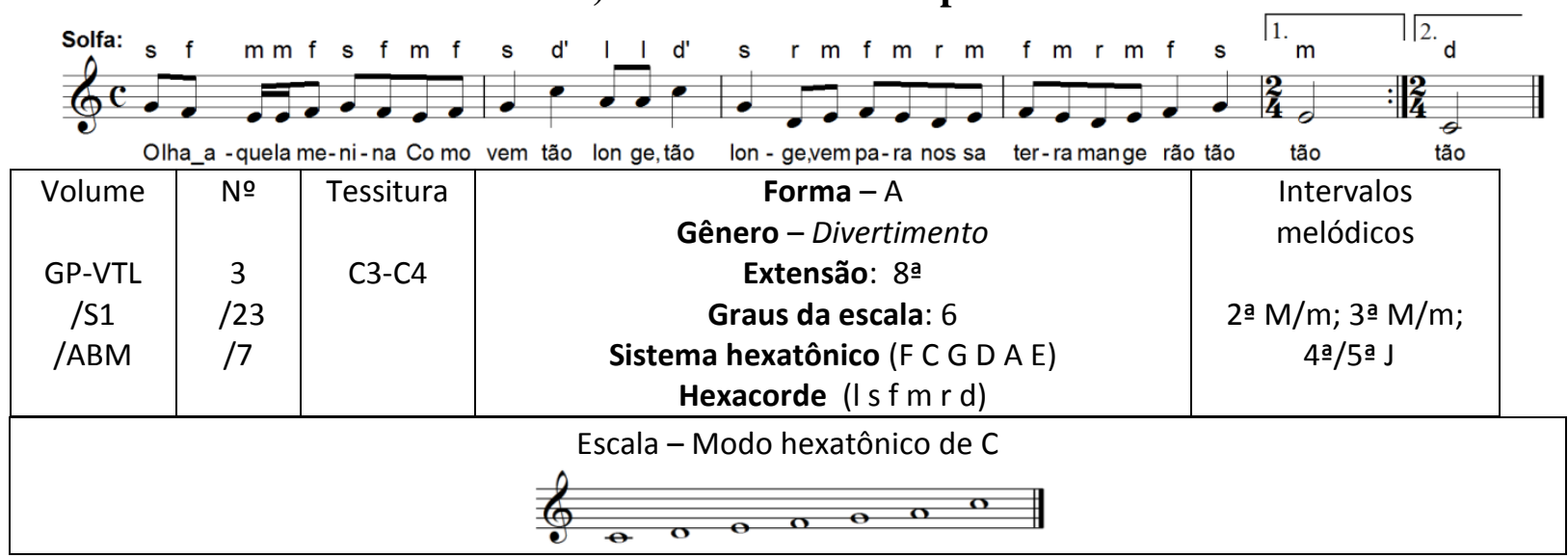

Sugestões de atividades didático-pedagógicas:

Células rítmicas para registro gráfico:

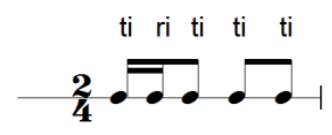

Células melódicas para registro gráfico:

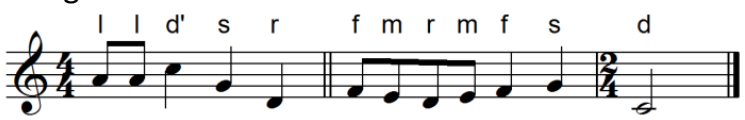

Possivel ostinato rítmico:

Possivel ostinato melódico:
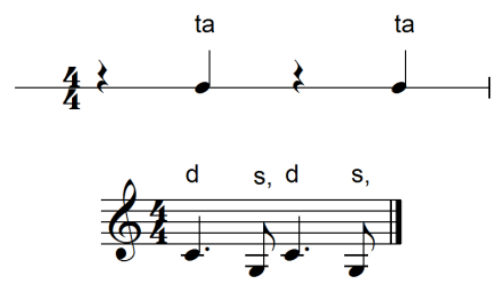

Análise complementar em $2.2-n^{\circ} 58$.

Canção com 6 compassos quaternários e 2 binários, com a indicação de andamento: Allegro $(\mathbf{1 6 0}=ل$ ل ); sem indicações de dinâmica.

Tema popular, folclórico infantil, de brincadeira cantada cujo desenvolvimento baseia-se no texto.

Texto - idem ao $\mathrm{n}^{\mathrm{o}} 30$.

Ritmo - O compasso binário é mais adequado para essa melodia, resultando em 18 compassos. Resultaria melhor prosódia se a célula com semicolcheias do segundo pulso do primeiro compasso fosse: $\bullet$, pela fluência da palavra menina.

Melodia - pequenas curvas em torno de terças menores cheias, seguidas de saltos ascendentes e descendentes de quartas, ou terças e quintas, alternando as finalizações na $\mathrm{D}$ e $\mathrm{T}$.

Ludicidade - variação da canção número 17 do Guia Prático - BRINQUEDO (Olhe aquela menina), analisada no item 30 . O desenvolvimento consta da ação de duas alas de crianças, 
uma defronte a outra, que promovem um diálogo - movimento de avanço e recuo quando o grupo canta.

43) SOLFEJO 5 (Cânone) - a capella

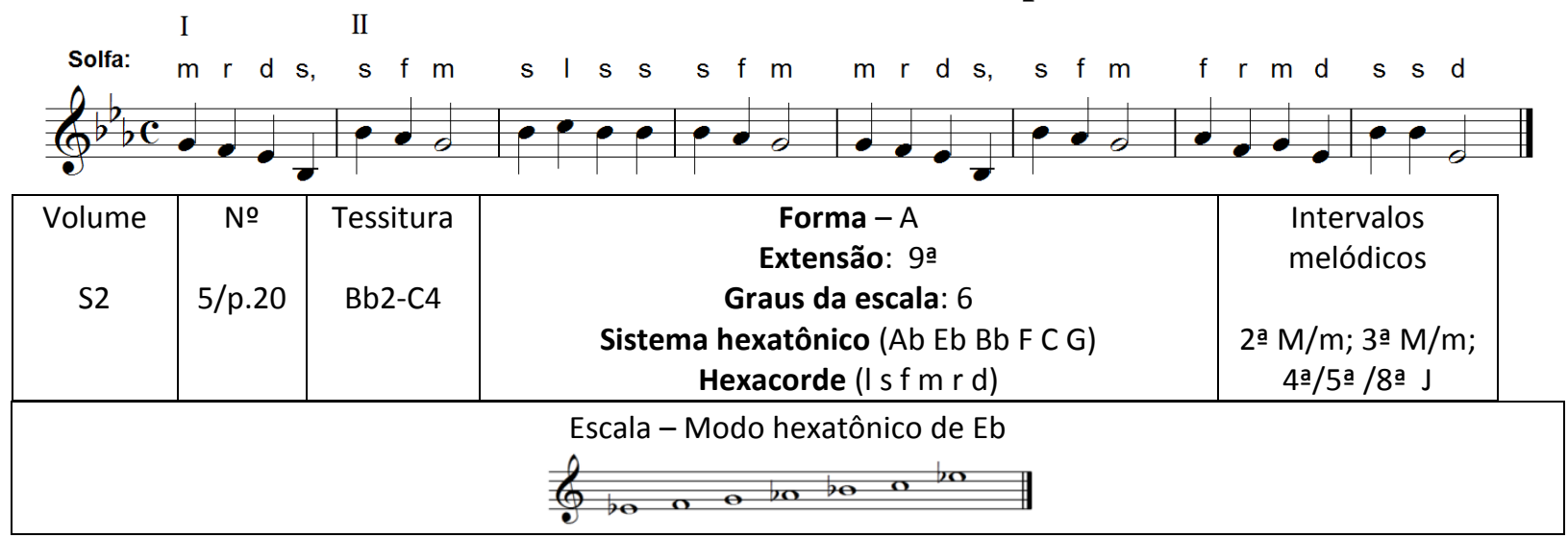

Sugestões de atividades didático-pedagógicas:

Células rítmicas para registro gráfico:

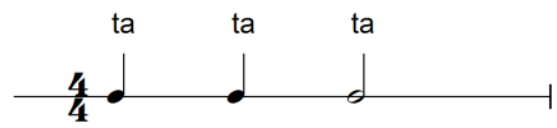

Células melódicas para registro gráfico:

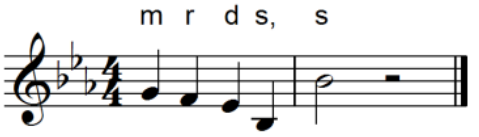

Possivel ostinato rítmico:

Possivel ostinato melódico:
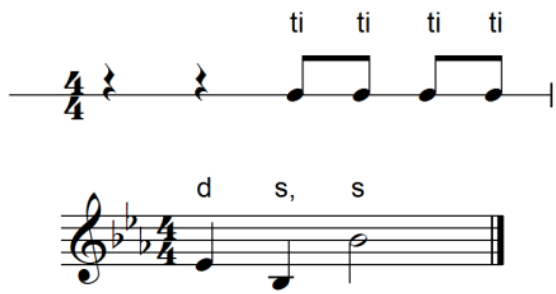

Outras possibilidades: acompanhamento com instrumentos de teclas em substituição ao piano

Tema de Villa-Lobos com 7 compassos quaternários, com a indicação de andamento:

Marcial; sem indicações de dinâmica.

Ritmo - cânone exato em compasso quaternário, tético, com figuras sem subdivisão de pulsos.

Melodia - desenvolvida no pentacorde da T, caracterizando-se por desenhos descendentes. Cânone exato a duas vozes. O interesse didático está nos saltos de quartas, quintas e oitavas justas.

Ludicidade - apesar de se tratar de um solfejo, a prática do cânone é um desafio lúdico, tanto quanto pode sugerir movimentação de dois grupos com movimentos iguais, porém defasados, com caráter Marcial. 


\section{4) COMPANHEIROS, COMPANHEIROS}

(Cânone $\mathbf{n}^{0}$ 2) - a capella

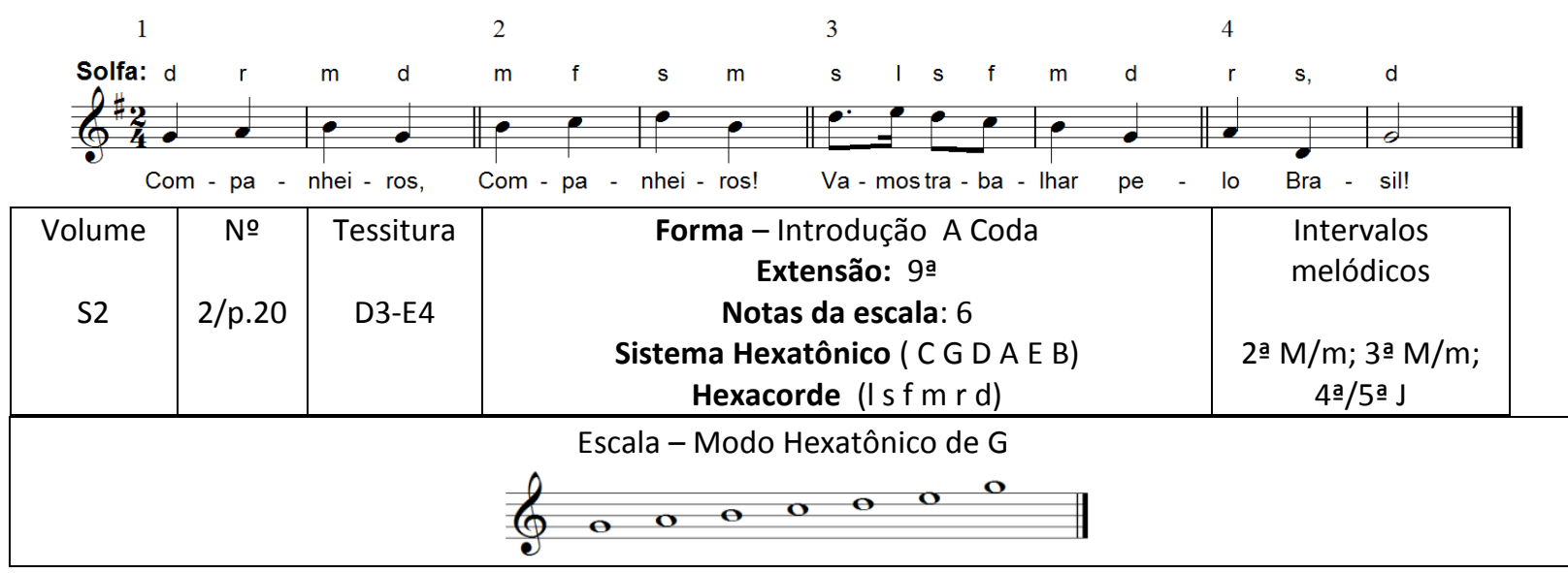

Sugestões de atividades didático-pedagógicas:

Células rítmicas para registro gráfico:

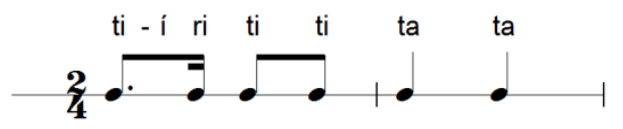

Células melódicas para registro gráfico:

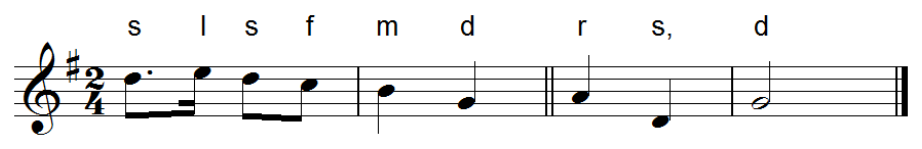

Possível ostinato rítmico:

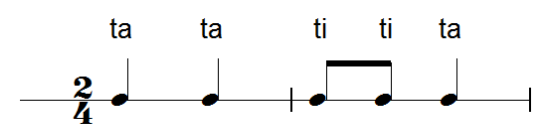

Outras possibilidades: cânone a duas, três ou quatro vozes.

Tema popular francês com 8 compassos binários, sem indicação de andamento ou de dinâmica.

Texto - adaptação de texto em português para a melodia francesa. Trata-se de uma conclamação (lúdica) ao trabalho pelo Brasil.

Ritmo - binário, tético, com subdivisão binária. Interesse rítmico: contrastar a execução simultânea do quinto e sexto compassos com terceiro e quarto, ou primeiro e segundo. $\mathrm{O}$ compasso quaternário seria mais adequado.

Melodia no hexacorde da T, iniciando, a cada dois compassos, pelas notas da tríade de $\mathrm{T}$, ascendentemente, com terminação em salto do quinto para o primeiro grau. Cânone exato extraído de "Frère Jacques" - sem a repetição dos motivos.

Ludicidade - o texto sugere várias possibilidades de improvisação gestual. Sendo cantado em cânone a quatro vozes, podem ser criadas várias maneiras de movimentação de quatro grupos. 


\subsubsection{Sobre sete graus da escala}

\section{5) ESPANHA - acompanhamento instrumental}

(Canto com Piano, ou conjunto instrumental ou Piano solo)

Amb. por H.Villa-Lobos

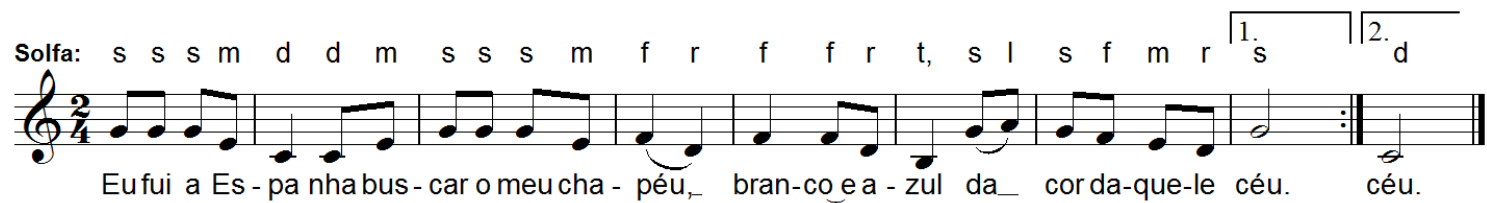

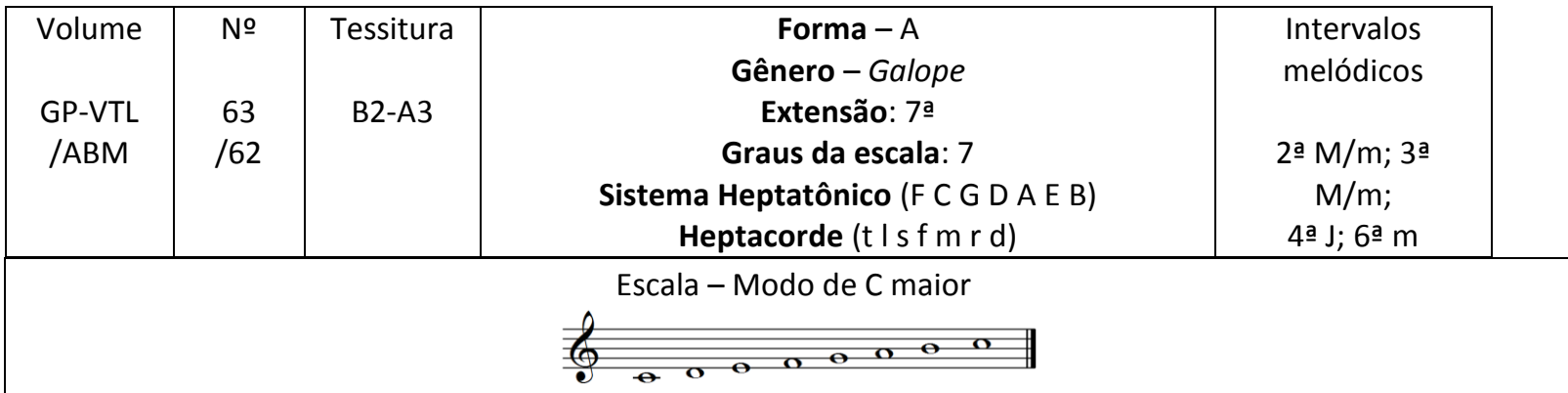

Sugestões de atividades didático-pedagógicas:

Células rítmicas para registro gráfico:

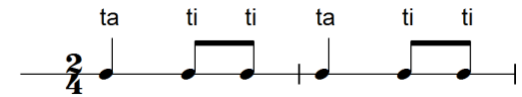

Células melódicas para registro gráfico:

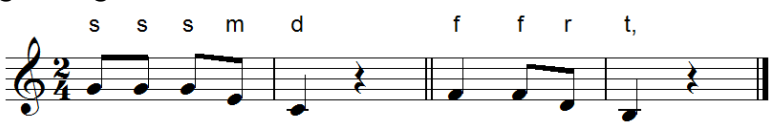

Possível ostinato rítmico:

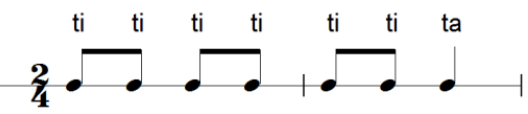

Canção com 9 compassos binários, com a indicação de andamento: Vivace $(160=\downarrow$ ل); indicações de dinâmica: $f \boldsymbol{f} ; \boldsymbol{f}$; acentos >

Tema popular, folclórico infantil, de brincadeira cantada cujo desenvolvimento baseia-se no texto.

Texto - quadrinhas entre muitas outras cantadas com essa mesma melodia, fala de alguém que buscou na Espanha um chapéu branco e azul, da cor do céu; a segunda estrofe trata da alegria das férias e de comer goiabada, uma das poucas delícias da época; a terceira descreve os movimentos de brincadeira de pegar. Há problemas com a prosódia no quarto compasso da primeira e da terceira estrofes - deveria constar uma ligadura entre as duas semínimas, para não se separar os ditongos "éu" e "ei".

Ritmo - binário, de subdivisão binária, próprio para a marcha.

Melodia - curvas ascendentes e descendentes sobre tríades de T e D, com terminação em hexacorde descendente na T. Preferimos grafar a melodia oitava abaixo da grafia encontrada na edição GP/ABM, para situar a tessitura mais adequadamente para vozes infantis.

Acompanhamento instrumental (com Introdução, Codeta e Coda) - harmonização ao piano, com a mão direita dobrando a melodia, sobre acordes das funções primárias, com 
cromatismos e variações timbrísticas. Compassos 12-14 na mão esquerda - bordadura (ornamental) e passagem expressiva; 41-42 - apojatura tripla cromática descendente.

Ludicidade - por analogia à canção Marcha Soldado, a movimentação pode ser a evolução de marcha por filas indianas, duplas, ou com outras formações.

Complemento do texto:

Eu fui à Espanha / buscar o meu chapéu / branco e azul / da cor daquele céu.

Vivam nossas férias / colégios acabados / vamos para casa / comer a goiabada.

Foge, foge, foge / que eu já te avistei / foge, foge, foge / que eu já te apanhei.

46) PASSARÁS, NÃO PASSARÁS - acompanhamento instrumental

(Canto com Piano, ou conjunto instrumental ou Piano solo)

Arr. de H.Villa-Lobos

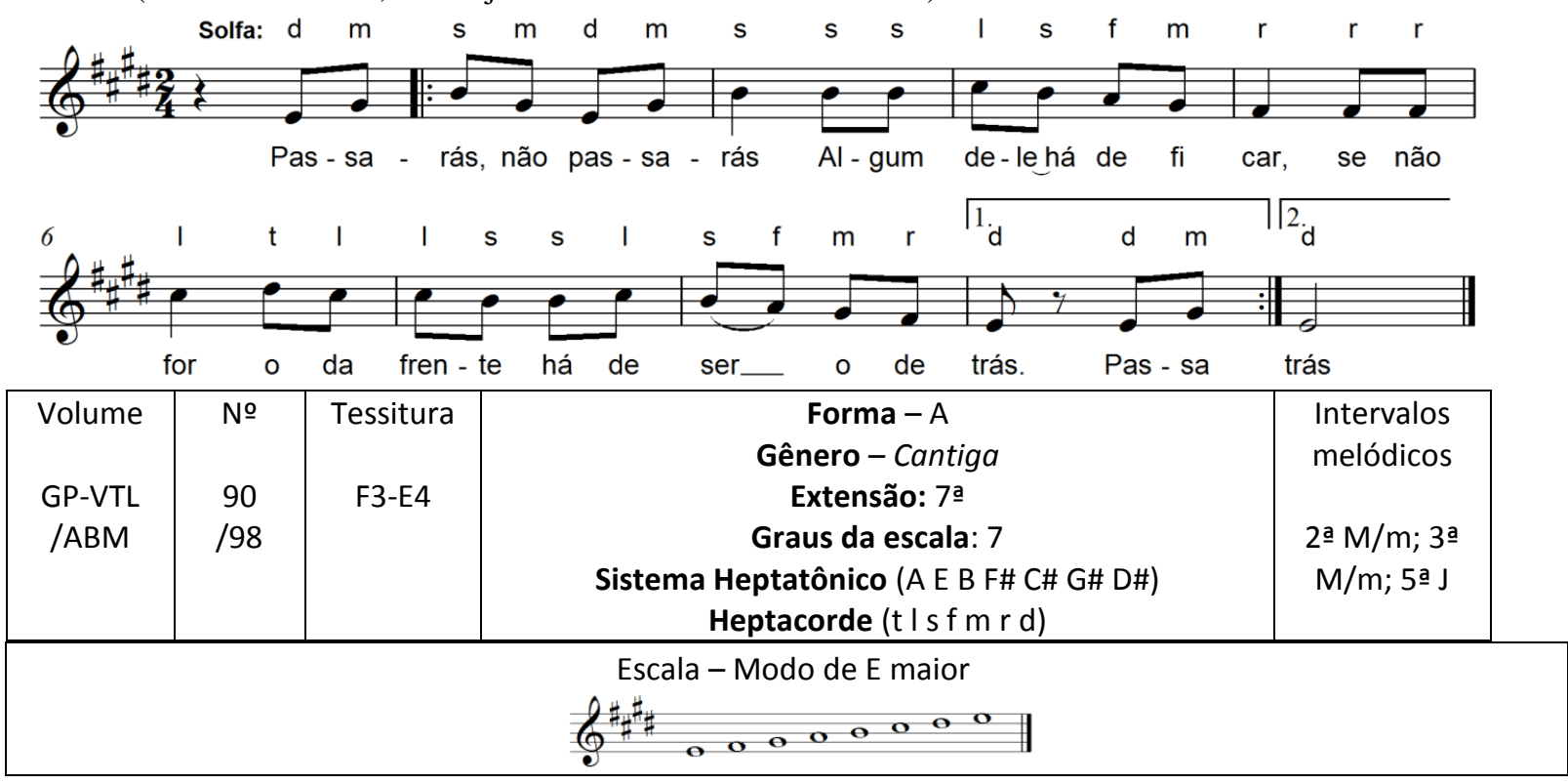

Sugestões de atividades didático-pedagógicas:

Células rítmicas para registro gráfico:

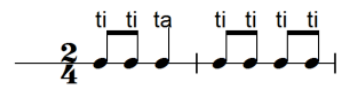

Células melódicas para registro gráfico:

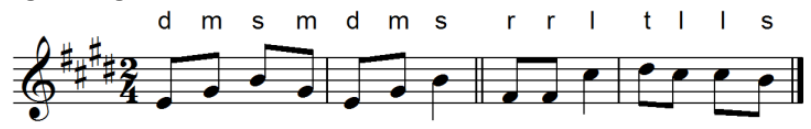

Possivel ostinato rítmico:

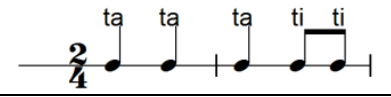

Canção com 10 compassos binários, com a indicação de andamento: Vivace (152= ل); Vivo; Andantino; indicações de dinâmica no acompanhamento instrumental: $f ; f f f ; \boldsymbol{m f} ;<$

Tema popular, folclórico infantil, de brincadeira cantada cujo desenvolvimento baseia-se no texto.

Texto - Descrição da brincadeira, uma variante de Passe, passe, gavião.

Ritmo - binário, de subdivisão binária, apropriado para a movimentação de marcha existente no desenvolvimento da brincadeira. 
Melodia - desenho inicial sobre arpejo da $\mathrm{T}$ com terminação descendente na $\mathrm{D}$; salto ascendente de quinta e desenho com final descendente por hexacorde para a $\mathrm{T}$

Acompanhamento instrumental (com Introdução, Codeta e Coda) - harmonia ao piano, sobre T e D na introdução e Coda. Melodia dobrada inicialmente em oitava, depois em terças e sextas paralelas. Ostinatos na introdução e coda.

Ludicidade - a coreografia é semelhante à do $\mathrm{n}^{0} 18$.

\section{7) ROSA AMARELA ( $1^{\text {a }}$ versão $)$ - acompanhamento instrumental}

(Canto com Piano, ou conjunto instrumental ou Piano solo)

Amb. por H.Villa-Lobos
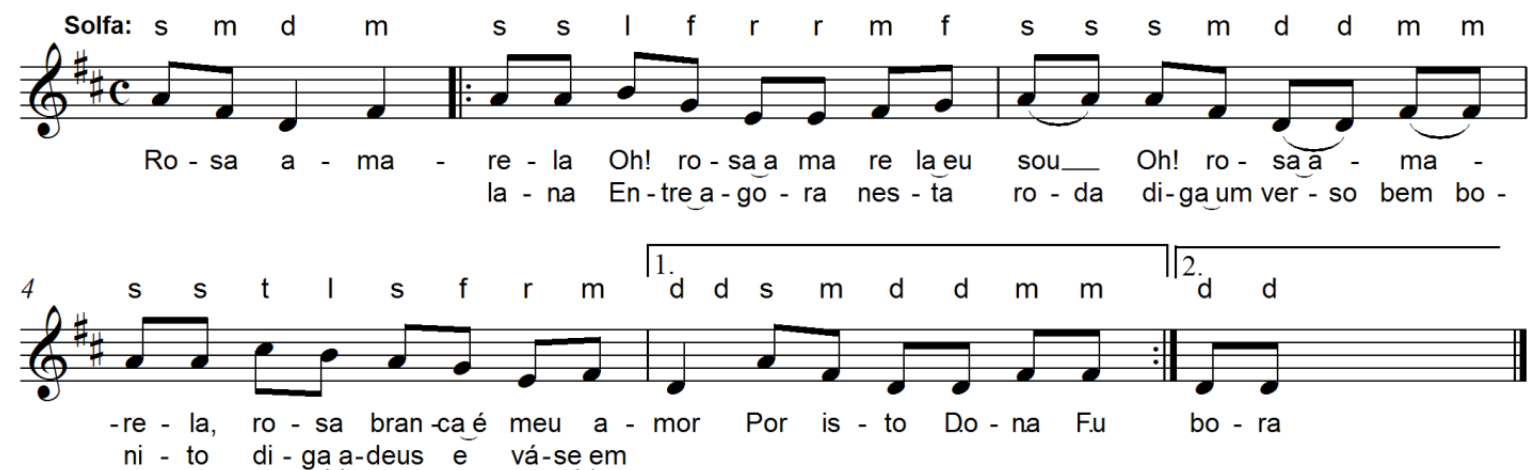

\begin{tabular}{|c|c|c|c|c|}
\hline $\begin{array}{l}\text { Volume } \\
\text { GP-VTL } \\
\text { /ABM }\end{array}$ & $\begin{array}{l}\text { № } \\
108 \\
/ 92\end{array}$ & $\begin{array}{l}\text { Tessitura } \\
\text { D3-C\#4 }\end{array}$ & $\begin{array}{c}\text { Forma - A } \\
\text { Gênero - Dança canção } \\
\text { Extensão: 7ạ } \\
\text { Graus da escala: } 7 \\
\text { Sistema Heptatônico (G D A E B F\# C\#) } \\
\text { Heptacorde (t I s f m r d) }\end{array}$ & $\begin{array}{c}\text { Intervalos } \\
\text { melódicos } \\
\text { 2a } \mathrm{M} / \mathrm{m} ; 3 \text { a } \mathrm{M} / \mathrm{m} \text {; } \\
5 \text { a j }\end{array}$ \\
\hline & & & $6^{\text {Escala - Modo de D maior }}$ & \\
\hline
\end{tabular}

Sugestões de atividades didático-pedagógicas:

Células rítmicas para registro gráfico:

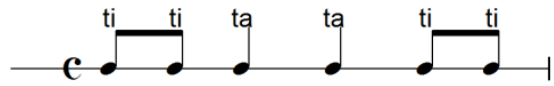

Células melódicas para registro gráfico:

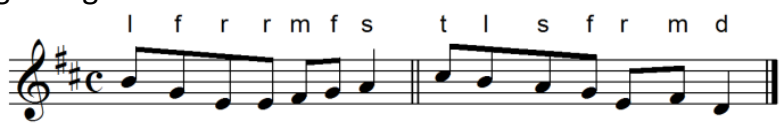

Possivel ostinato rítmico:

Possível ostinato melódico:
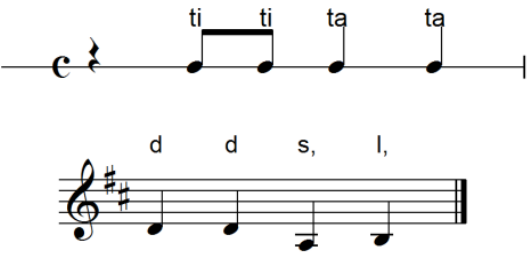

Canção com 16 compassos quaternários, com indicações de andamento: Allegretto $(120=ل$ ) $)$;

Allargando; indicações de dinâmica: $\boldsymbol{p}$

Tema popular, folclórico infantil, de brincadeira de roda cujo desenvolvimento baseia-se no texto.

Texto - descrição da brincadeira. GP/ABM corrige o problema com a prosódia no compasso 11 , porém restou a ligadura inadequada na primeira palavra do texto. 
Ritmo - o compasso binário seria mais adequado para a marchinha em questão.

Melodia - desenhos em seqüências sobre tríades arpejadas descendentemente, seguidos de linha descendente para a $\mathrm{T}$.

Acompanhamento instrumental (piano) - a introdução desenvolve, na mão direita, a primeira célula motívica da melodia em sextas sobre ostinato na mão esquerda; o acompanhamento segue com o mesmo ostinato e dobramento da melodia na mão direita. A codeta repete a introdução e a coda tem dois compassos sobre o acorde de T.

Ludicidade - uma criança, a rosa amarela, deve dizer uma quadrinha e escolher a rosa branca, que será a próxima solista.

Complementação do texto:

Rosa amarela / ó rosa amarela eu sou / ó rosa amarela / rosa branca é meu amor.

Por isso Dona Fulana / entre agora nesta roda / diga um verso bem bonito / diga adeus e vá se embora.

\section{8) CONSTANTE - acompanhamento instrumental}

(Canto com Piano, ou conjunto instrumental ou Piano solo) Arr. de H.Villa-Lobos
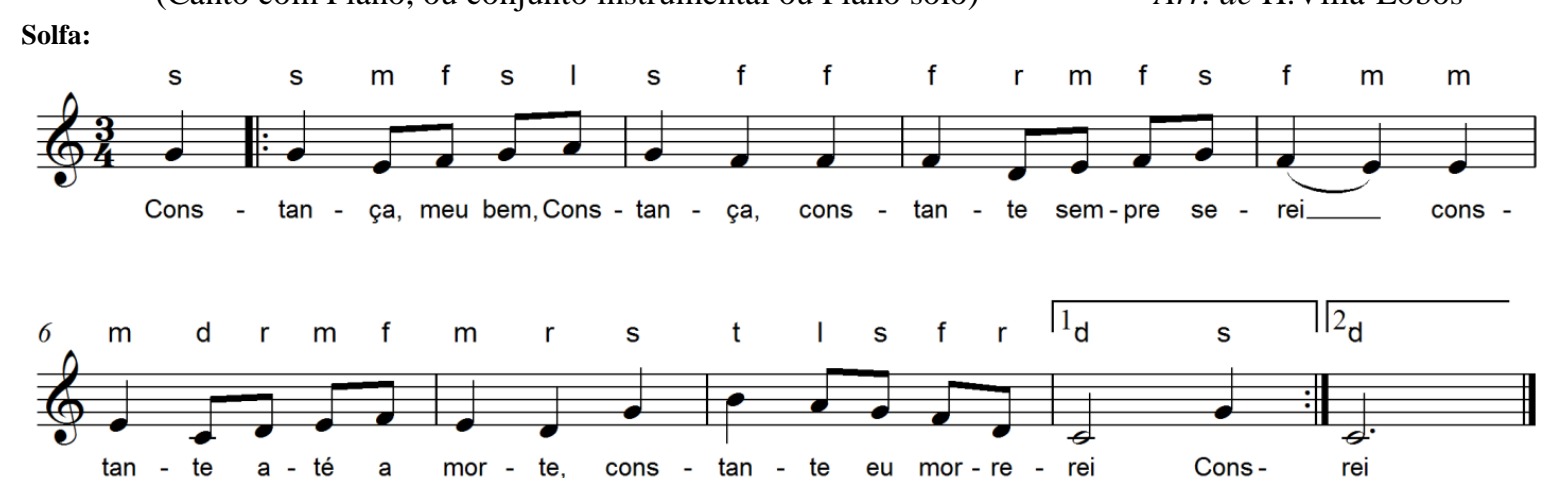

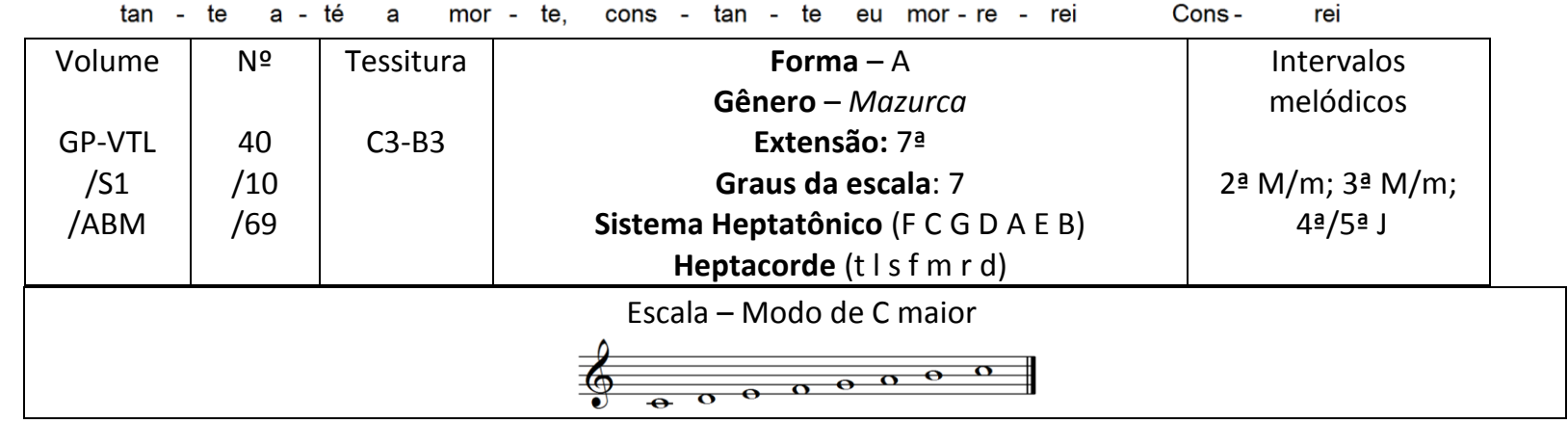

Sugestões de atividades didático-pedagógicas:

Células rítmicas para registro gráfico:

Células melódicas para registro gráfico:
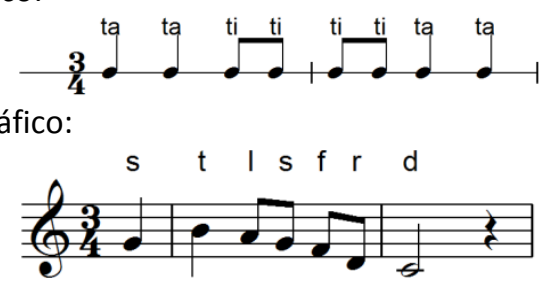

Possível ostinato rítmico:

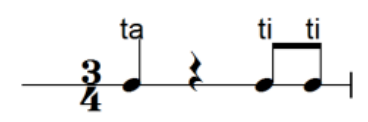


Possivel ostinato melódico:

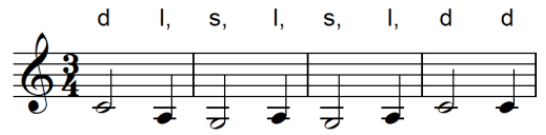

Canção com 10 compassos ternários, com a indicação de andamento: Andantino quasi Allegretto (M.M. 132= 」); indicações de dinâmica: $f ; \boldsymbol{p} ; \boldsymbol{a c e n t o s}>$

Tema popular, folclórico infantil, de brincadeira cantada cujo desenvolvimento baseia-se no texto.

Texto - trata-se de um jogo de palavras entre o nome da amada, Constância, e a promessa de se praticar constância, de ser constante até a morte. Quanto à prosódia da palavra uma, no décimo segundo compasso, deveriam constar duas colcheias.

Ritmo - sequiências das células rítmicas contidas na primeira semifrase, por quatro vezes. $\mathrm{O}$ interesse está no compasso ternário.

Melodia - pequenas curvas em âmbito da terça menor e terminação em apojatura descendente repetem-se em sequiência descendente por três vezes, por grau conjunto, seguidas por linha descendente para a T. Em GP/ABM, a última nota do oitavo compasso deveria ser $\boldsymbol{D}$ e não $\boldsymbol{B}$; no nono e décimo sétimo compassos, na mão esquerda, o primeiro acorde deveria ser $\boldsymbol{G} \boldsymbol{C} \boldsymbol{E}$ e não $\boldsymbol{G B E}$.

Acompanhamento instrumental (piano) - pequena introdução (dois compassos) no acorde de T. A mão esquerda faz um contraponto em terças, com cromatismos ornamentais, enquanto a mão direita dobra a melodia. A coda é ornamentada com arpejo sobre a subdominante menor com sexta e nona, terminando com o desenho inicial com apojatura 9-8 na T.

Ludicidade - brincadeira de roda, simples, com possibilidades de criação de movimentos ou mímica.

Complemento do texto ${ }^{33}$ :

Constança, meu bem, Constança / constante sempre serei / Constante até a morte / constante eu morrerei.

No jardim das belas flores / uma delas escolherei / Escolha, meu bem, escolha / e essa abraçarei.

49) FUI PASSAR NA PONTE (Na Bahia tem) - a capella

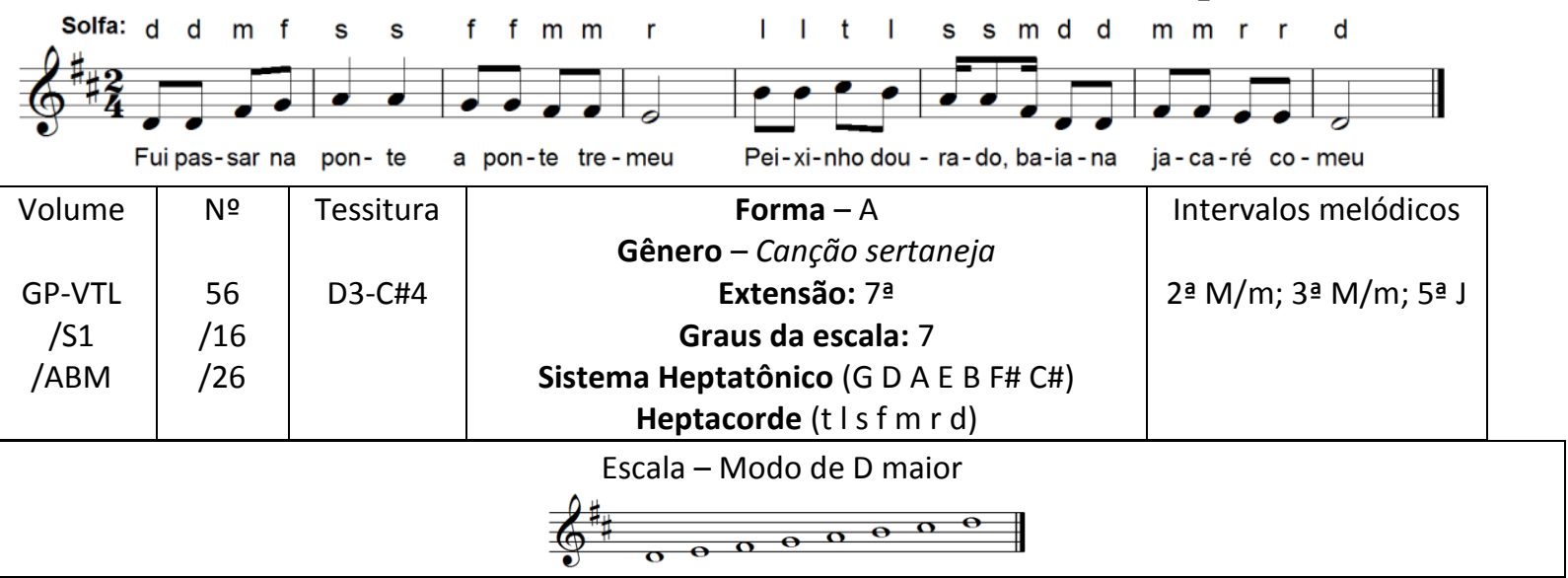

Sugestões de atividades didático-pedagógicas:

${ }^{33}$ GP/ABM - Fonte: J. Gomes Júnior \& J. Baptista Julião, Ciranda, Cirandinha. 
Células rítmicas para registro gráfico:

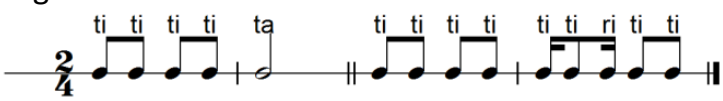

Células melódicas para registro gráfico:

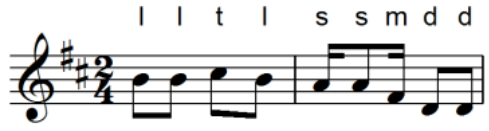

Possivel ostinato rítmico:

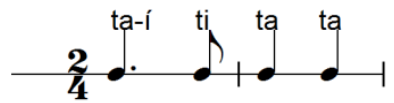

Possivel ostinato melódico:

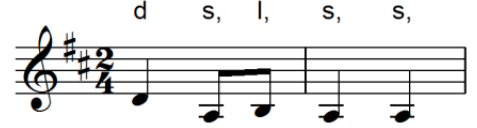

Análise complementar em $2.2-n^{\circ} 72$.

Canção com 8 compassos binários, com a indicação: Andante (M.M. $84=$ ل ); sem indicações de dinâmica.

Tema popular, folclórico infantil, de brincadeira cantada cujo desenvolvimento baseia-se no texto.

Texto - quadrinha popular.

Ritmo - binário, de subdivisão binária, com interesse didático na sincopa.

Melodia - curva inicial passando pela tríade da $\mathrm{T}$ com linha descendente por grau conjunto para a D; nova curva com arpejo descendente da $\mathrm{T}$ e linha descendente por grau conjunto para a T. O primeiro compasso é variante de ' $\boldsymbol{d} \boldsymbol{d} \mathbf{m} \boldsymbol{m}$ ' - da melodia de $\mathrm{Na}$ Bahia tem (GP/VTL $\mathbf{n}^{\circ}$ 12 e GP/ABM n $\left.{ }^{\circ} 137\right)$.

Ludicidade - brincadeira de roda, simples, com possibilidades de criação de movimentos ou mímica.

Complemento do texto ${ }^{34}$ :

Fui passar na ponte / a ponte tremeu / peixinho dourado, baiana / jacaré comeu.

$\mathrm{Eu}$ andei, andei / eu andei no mar / procurando agulha, baiana, / só achei dedal.

\section{0) NA BAHIA TEM - acompanhamento instrumental}

(Canto com Piano, ou conjunto instrumental)

Arr. de H.Villa-Lobos

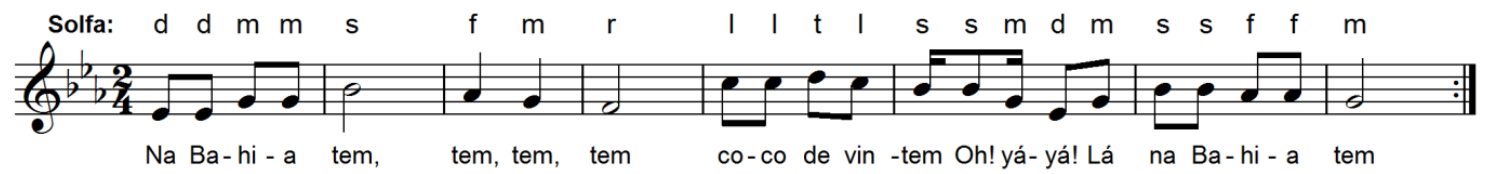

\begin{tabular}{|c|c|c|c|c|}
\hline Volume & № & Tessitura & $\begin{array}{c}\text { Forma - A } \\
\text { Gênero - Samba do norte }\end{array}$ & $\begin{array}{l}\text { Intervalos } \\
\text { melódicos }\end{array}$ \\
\hline GP-VTL & 12 & Eb3-D4 & Extensão: 7ạ & \\
\hline /ABM & $/ 137$ & & $\begin{array}{c}\text { Graus da escala: } 7 \\
\text { Sistema Heptatônico (Ab Eb Bb F C G D) } \\
\text { Heptacorde ( } \mathrm{t} \mid \mathrm{s} \text { f m r d) }\end{array}$ & $\begin{array}{l}\text { 2a } \mathrm{M} / \mathrm{m} ; 3 \text { a } \\
\mathrm{M} / \mathrm{m} ; 5^{\mathrm{a}} \mathrm{J}\end{array}$ \\
\hline
\end{tabular}

\footnotetext{
${ }^{34}$ GP/ABM - Fonte: J. Gomes Júnior \& J. Baptista Julião, Ciranda, Cirandinha.
} 


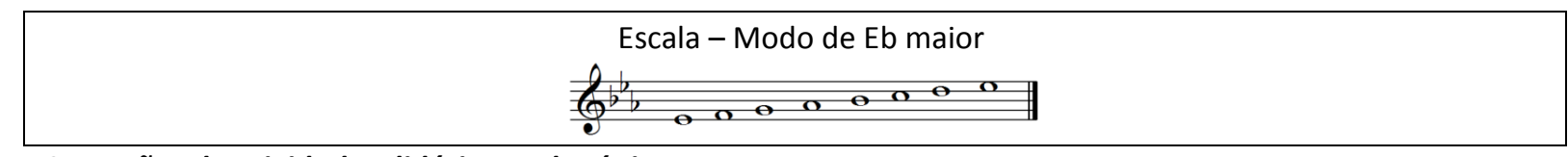

\section{Sugestões de atividades didático-pedagógicas:}

Células rítmicas para registro gráfico:

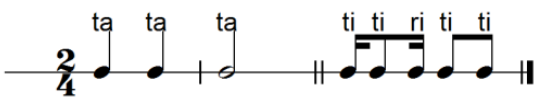

Células melódicas para registro gráfico:

$\mathrm{d} \mathrm{d} \mathrm{m} \mathrm{m} s \quad$ I $\mathrm{t}$ l $s \mathrm{~s} m \mathrm{~d}$

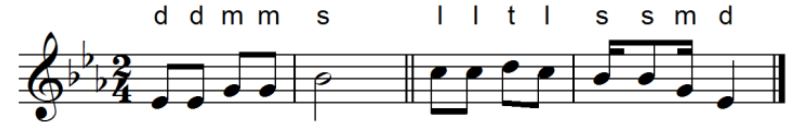

Possivel ostinato rítmico:

Possivel ostinato melódico:
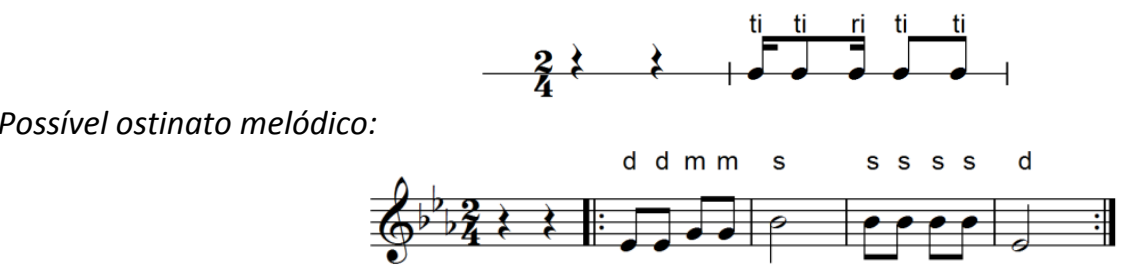

Análise complementar em 2.2 - $n^{\circ} 163$.

Canção com 8 compassos binários, com a indicação de andamento: Moderato $(88=\downarrow$ ل); indicações de dinâmica: $\boldsymbol{f f}$; $\boldsymbol{m} \boldsymbol{f}$; acentos >

Tema popular, folclórico, possivelmente um canto de trabalho.

Texto - quadrinha popular, cuja repetição: Tem, tem, tem pode associar-se com o som do quebra-coco.

Ritmo - binário, de subdivisão binária, com interesse didático na síncopa.

Melodia - curva inicial passando pela tríade da $\mathrm{T}$ com linha descendente por grau conjunto para a $\mathrm{D}$; nova curva com arpejo descendente da $\mathrm{T}$ e linha descendente com variante terminação na terça da $\mathrm{T}$.

Ludicidade - brincadeira de roda, com dança, com possibilidades de criação de movimentos ou mímica.

51) A GATINHA PARDA ( $1^{\text {a }}$ versão $)$ - a capella
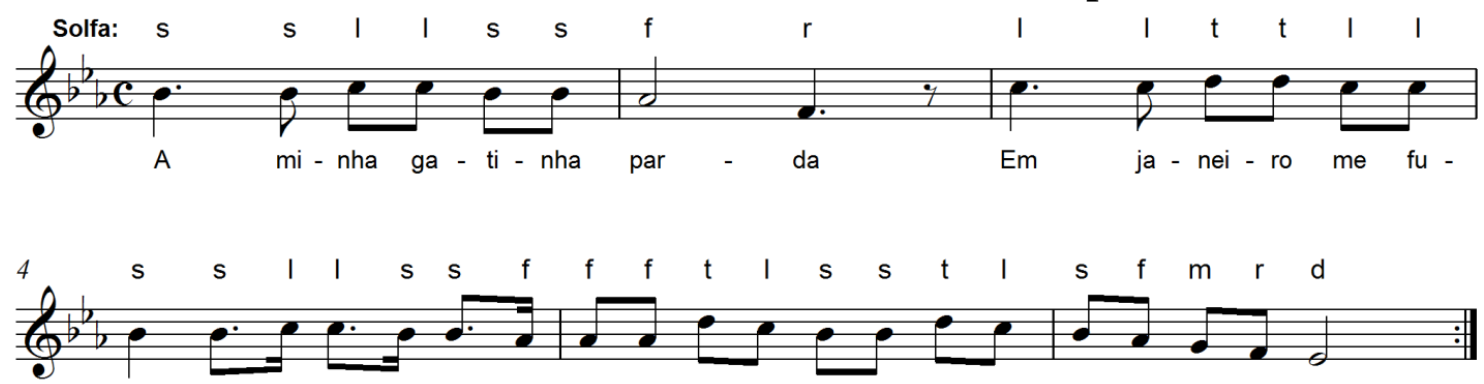

giu Quem a-chou mi-nha ga - ti - nha, vo - cê sa-be? vo - cê sa - be? vo - cê viu?

\begin{tabular}{|c|c|c|c|c|}
\hline Volume & № & Tessitura & $\begin{array}{c}\text { Forma - A } \\
\text { Gênero - Polca canção }\end{array}$ & $\begin{array}{l}\text { Intervalos } \\
\text { melódicos }\end{array}$ \\
\hline
\end{tabular}




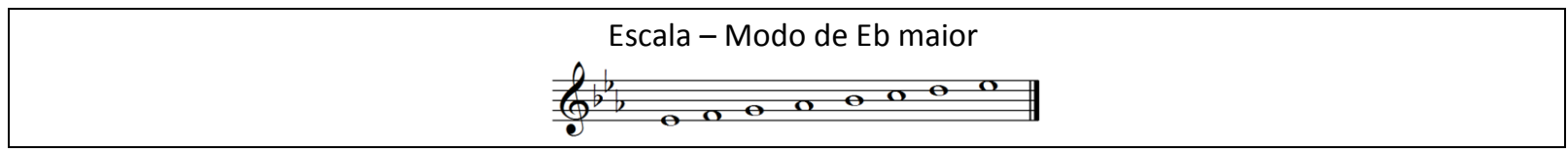

Sugestões de atividades didático-pedagógicas:

Células rítmicas para registro gráfico:

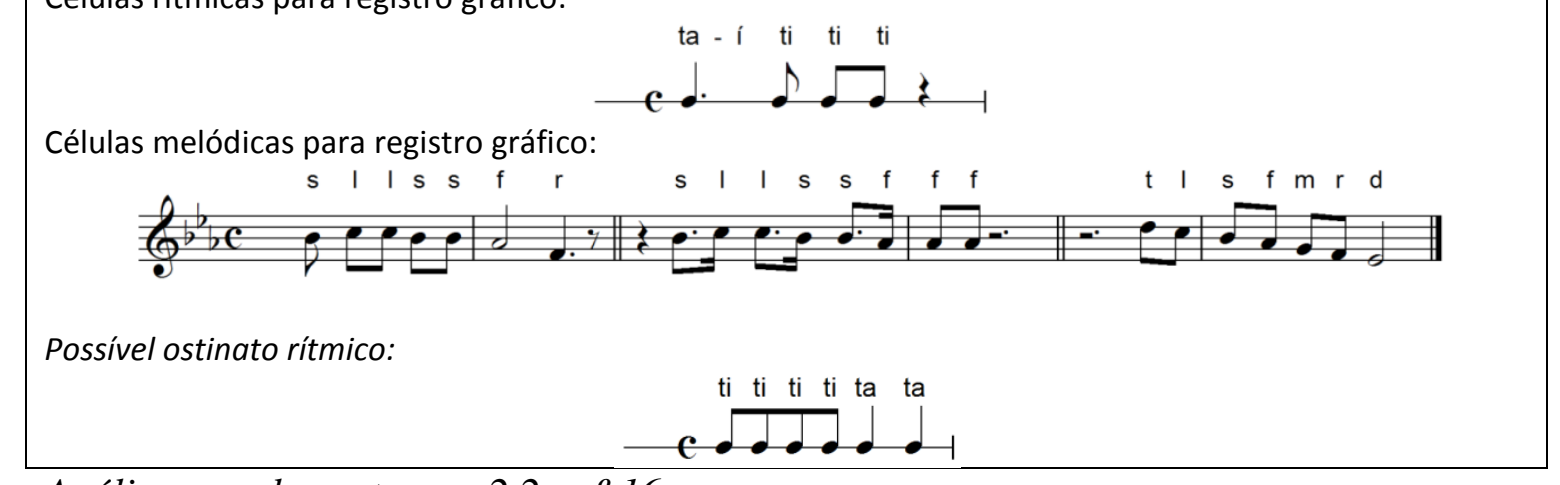

Análise complementar em $2.2-n^{\circ} 16$.

Canção com 7 compassos quaternários, com a indicação de andamento: Tempo de marcha (Moderato) $112=ل$ ); indicações de dinâmica: $\boldsymbol{m f}$

Tema popular, folclórico infantil, de brincadeira cantada cujo desenvolvimento baseia-se no texto.

Texto - descreve a brincadeira sobre localizar algo ou alguém escondido.

Ritmo - o interesse didático está notas longas, pontuadas ou não.

Melodia - O primeiro desenho, repetido em sequência segunda acima, aparece compactado em seguida. Segue a finalização em linha descendente escalar para a T.

Ludicidade - a brincadeira privilegia o humorismo contido no texto e a movimentação pode ser rica e variada, com inserção de esconde-esconde.

\section{2) MENINAS, Ó MENINAS - acompanhamento instrumental}

(Canto com Piano, ou conjunto instrumental ou Piano solo)

Amb. por H.Villa-Lobos
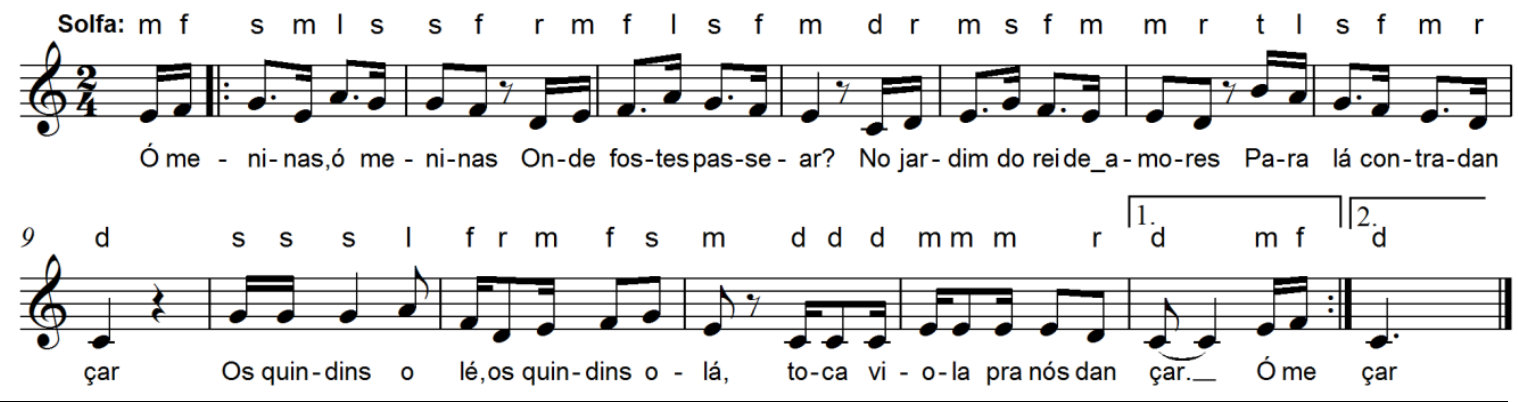

\begin{tabular}{|c|c|c|c|c|}
\hline $\begin{array}{l}\text { Volume } \\
\text { GP-VTL } \\
\text { /ABM }\end{array}$ & $\begin{array}{l}\text { № } \\
79 \\
193\end{array}$ & $\begin{array}{l}\text { Tessitura } \\
\text { C3-B3 }\end{array}$ & $\begin{array}{c}\text { Forma - A } \\
\text { Gênero - Polca canção } \\
\text { Extensão: 7ạ } \\
\text { Graus da escala: } 7 \\
\text { Sistema Heptatônico (F C G D A E B) } \\
\text { Heptacorde (t I s f m r d) }\end{array}$ & 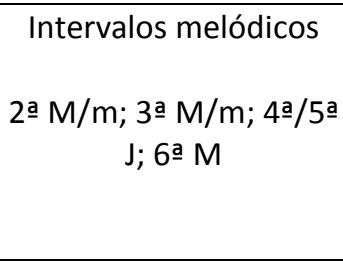 \\
\hline \multicolumn{5}{|c|}{$\overbrace{0}^{\text {Escala - Modo de C maior }}$} \\
\hline
\end{tabular}


Sugestões de atividades didático-pedagógicas:

Células rítmicas para registro gráfico:

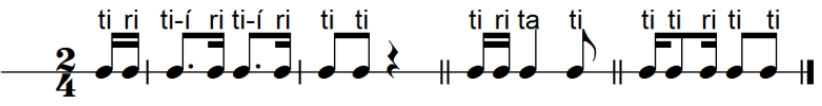

Células melódicas para registro gráfico:

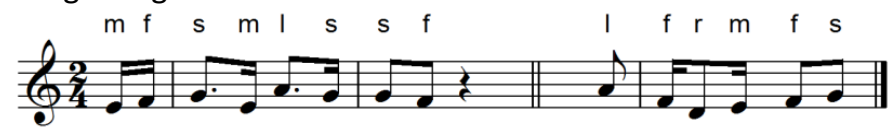

Possivel ostinato rítmico:

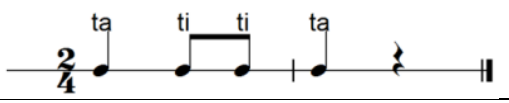

Canção com 15 compassos binários, com a indicação: Andantino (M.M. 96= ل ); allegro; indicações de dinâmica: $\boldsymbol{m f}$

Tema popular, folclórico infantil, de brincadeira cantada cujo desenvolvimento baseia-se no texto.

Texto - Descrição de brincadeira de roda em que um diálogo introduz uma dança.

Ritmo - considerando-se que em brincadeiras de roda a movimentação para o lado esquerdo ou direito é invertida ao final das frases, em função da quadratura dos textos, o nono e décimo compassos deveriam ser modificados ritmicamente:

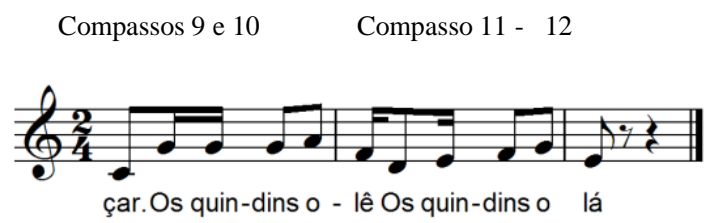

- totalizando, assim, 12 compassos para a frase (8 para $\boldsymbol{a}$ mais 4 para $\boldsymbol{b}$ ). Interesse didático formação de motivos rítmicos por contratempos.

Melodia - sequência descendente por grau conjunto de três desenhos iniciados por terças cheias ascendentes, seguidos de linha escalar descendente com terminação na T. Segunda frase - três motivos similares com terminação na $\mathrm{T}$.

Acompanhamento instrumental - pequena introdução rítmica, em uníssono, ao piano; melodia acompanhada por ostinatos rítmicos e Coda com indicação de Allegro sobre arpejo de T com fermata na última nota que precede o acorde final.

Ludicidade - após diálogo entre os participantes da roda e algumas meninas que estão no centro da mesma, estas escolhem seus pares para a dança que se segue.

\section{3) GARIBALDI FOI À MISSA - acompanhamento instrumental}

(Canto com Piano, ou conjunto instrumental ou Piano solo) Amb. por H.Villa-Lobos Solfa: $d m s s s m d d d m s s f m f r r m f f f r$ t, $s$ l $s f m r m d d m$

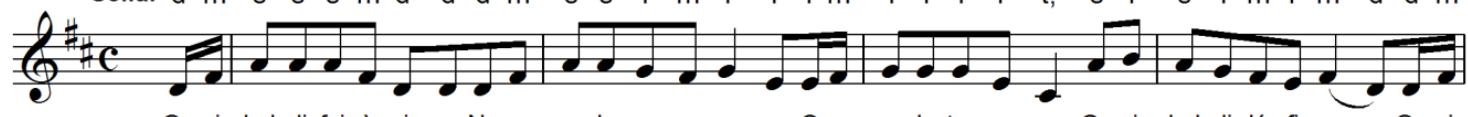

Ga-ri - bal-di foi à mis-sa No ca - va-lo sem es-po-ras O ca - va-lo tro-pe-çou Ga ri - bal-di lá fi cou_ Ga-ri

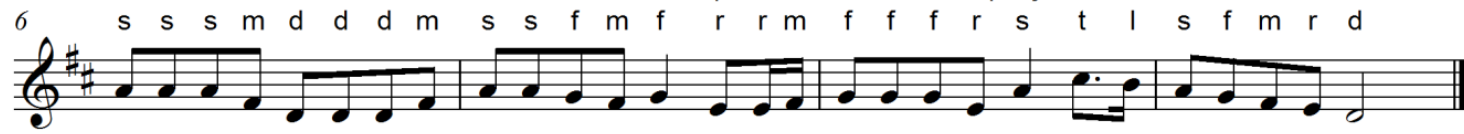

bal-di foi à mis-sa no ca - va-lo semes-po - ras O ca-va-lo tro-pe-çou Ga-ri-bal-di lá fi-cou! 


\begin{tabular}{|c|c|c|c|c|}
\hline $\begin{array}{l}\text { Volume } \\
\text { GP-VTL } \\
\text { /ABM }\end{array}$ & $\begin{array}{c}\text { № } \\
58 \\
\text { /102 }\end{array}$ & $\begin{array}{l}\text { Tessitura } \\
\text { B2-B3 }\end{array}$ & $\begin{array}{c}\text { Forma - A } \\
\text { Gênero - Canção } \\
\text { Extensão: } 8 \text { ã } \\
\text { Graus da escala: } 7 \\
\text { Sistema Heptatônico (G D A E B F\# C\#) } \\
\text { Heptacorde ( } \mathrm{I} \text { I f f m r d) }\end{array}$ & $\begin{array}{c}\text { Intervalos } \\
\text { melódicos } \\
\text { 2a } \mathrm{M} / \mathrm{m} ; 3 \text { a } \mathrm{M} / \mathrm{m} \text {; } \\
\text { 6ㅁ } \mathrm{m}\end{array}$ \\
\hline \multicolumn{5}{|c|}{ Escala - Modo de D maior } \\
\hline
\end{tabular}

Sugestões de atividades didático-pedagógicas:

Células rítmicas para registro gráfico:

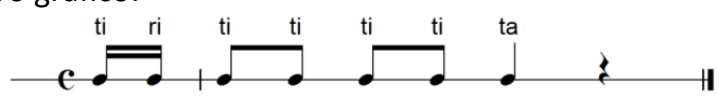

Células melódicas para registro gráfico:

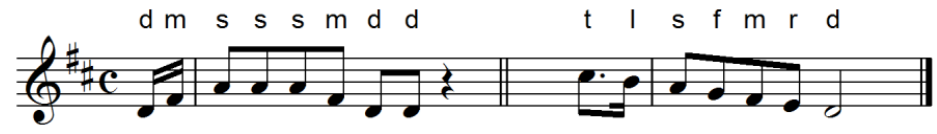

Possivel ostinato rítmico:

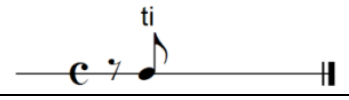

Canção com 9 compassos quaternários, com a indicação de andamento: Animato $(\mathbf{1 4 4}=\mathrm{d}$ ); indicações de dinâmica: $\boldsymbol{m f} ; \boldsymbol{f}$; acentos $>$.

Tema popular, folclórico infantil, de brincadeira cantada cujo desenvolvimento baseia-se no texto.

Texto parcial de uma série de quadrinhas sobre Garibaldi, herói na história da região sul do Brasil. Nesta versão, embora o cavalo tropece, Garibaldi permanece firme, como herói que é diferentemente de outras versões em que ele vai ao chão.

Ritmo - o interesse está no motivo rítmico inicial com anacruse formada por semicolcheias seguidas de colcheias. $\mathrm{O}$ compasso binário seria mais adequado.

Melodia sobre arpejo de T e D, com resoluções na $\mathrm{D}$ e $\mathrm{T}$ por linha escalar descendente desde o sétimo grau.

Acompanhamento instrumental - pequena introdução propondo o ostinato que pretende imitar o trote do cavalo, desenvolvimento da melodia na mão esquerda com mesmo ostinato na mão direita. Segue-se uma codeta, ou mesmo uma parte B instrumental, sobre arpejos de $\boldsymbol{B}^{7-}$, $\boldsymbol{G}^{7+\prime 9} ; \boldsymbol{E} \mathrm{m}^{11}$ e $\boldsymbol{A}^{13}$ para motivos melódicos em torno da $\mathrm{T}$ e $\mathrm{Tr}$, com terminação em motivo sobre a $\mathrm{T}$ e ritornello. A Coda tem variação rítmica com tercinas.

No compasso 16, há problemas no primeiro pulso, tanto em GP/VTL (ilustração a) como em GP/ABM (ilustração b): na primeira, há duas semicolcheias a mais no valor da pulsação; GP/ABM considera o primeiro pulso como uma quiáltera de nove fusas, porém a primeira

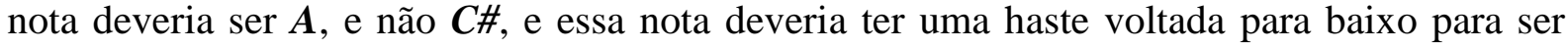
ligada às duas mínimas seguintes que também seriam notas $\boldsymbol{A}$. Preferimos a concepção rítmica mais próxima do original, corrigindo da seguinte forma: eliminando o ponto da primeira nota, uma colcheia, acrescentando haste de semínima voltada para baixo, seguindo-se uma semicolcheia e duas tercinas em semifusas (ilustração c). 
a) em GP/VTL

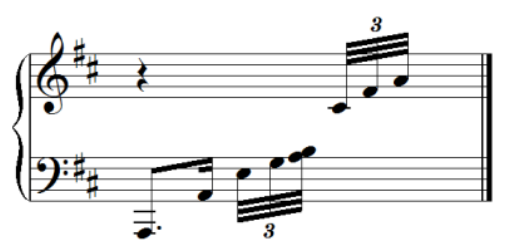

b) em GP/ABM

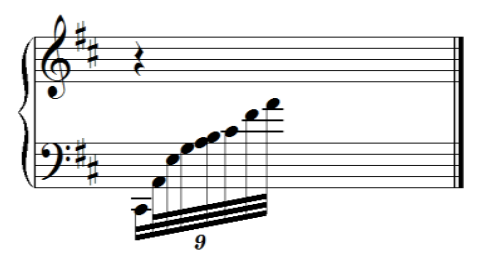

c) sugestão de correção

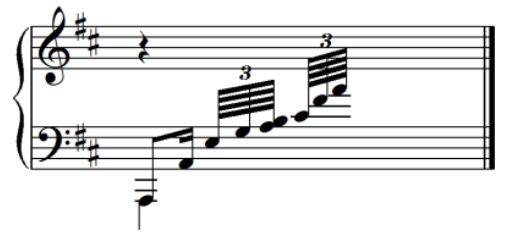

Ludicidade - a brincadeira privilegia o humorismo contido no texto e a movimentação pode ser rica e variada.

\section{4) SOLFEJO 49 - a capella}
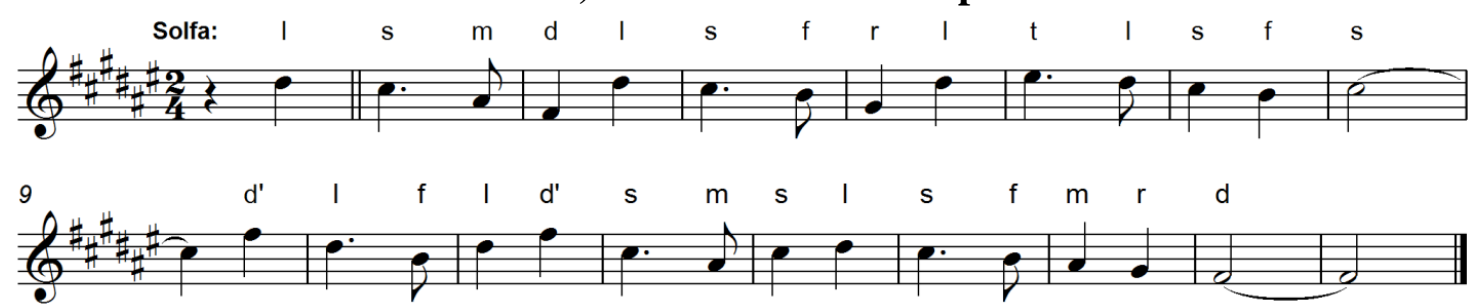

\begin{tabular}{|c|c|c|c|c|}
\hline $\begin{array}{l}\text { Volume } \\
\text { S1 }\end{array}$ & № & $\begin{array}{l}\text { Tessitura } \\
\text { F\#3-F\#4 }\end{array}$ & $\begin{array}{c}\text { Forma - A } \\
\text { Gênero - Canção } \\
\text { Extensão: 8ạ } \\
\text { Graus da escala: } 7 \\
\text { Sistema Heptatônico (B F\# C\# G\# D\# A\# E\#) } \\
\text { Heptacorde (t I s f m r d) }\end{array}$ & $\begin{array}{c}\text { Intervalos } \\
\text { melódicos } \\
\text { 2a } \mathrm{M} / \mathrm{m} ; 3 \text { a } \mathrm{M} / \mathrm{m} \text {; } \\
\text { 4므 } / 5 \text { a j; 6a } \mathrm{M}\end{array}$ \\
\hline & & & $\begin{array}{c}\text { Escala - Modo de F\# maior } \\
0\end{array}$ & \\
\hline
\end{tabular}

\section{Sugestões de atividades didático-pedagógicas:}

Células rítmicas para registro gráfico:

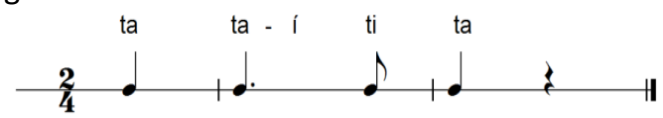

Células melódicas para registro gráfico:

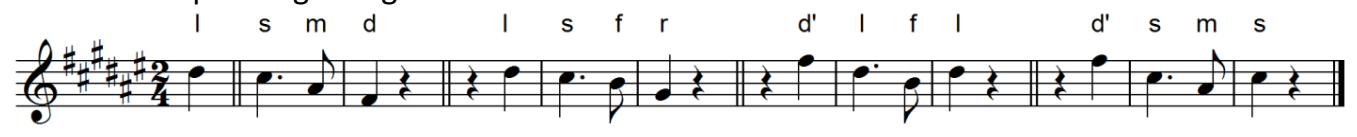

Possivel ostinato rítmico:

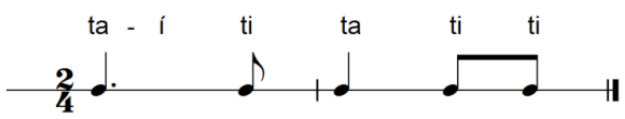

Possivel ostinato melódico:

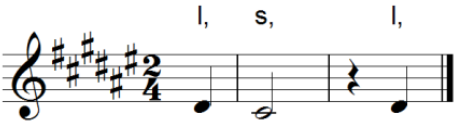

Tema de Villa-Lobos, de inspiração popular, com 17 compassos binários, com a indicação: Allegretto; sem indicações de dinâmica. 
Ritmo - o interesse rítmico está notas pontuadas.

Melodia - desenhos descendentes alcançados por saltos ascendentes com final descendente por hexacorde.

Ludicidade - apesar de se tratar de um solfejo, a configuração rítmica em ostinato pode sugerir uma coreografia.

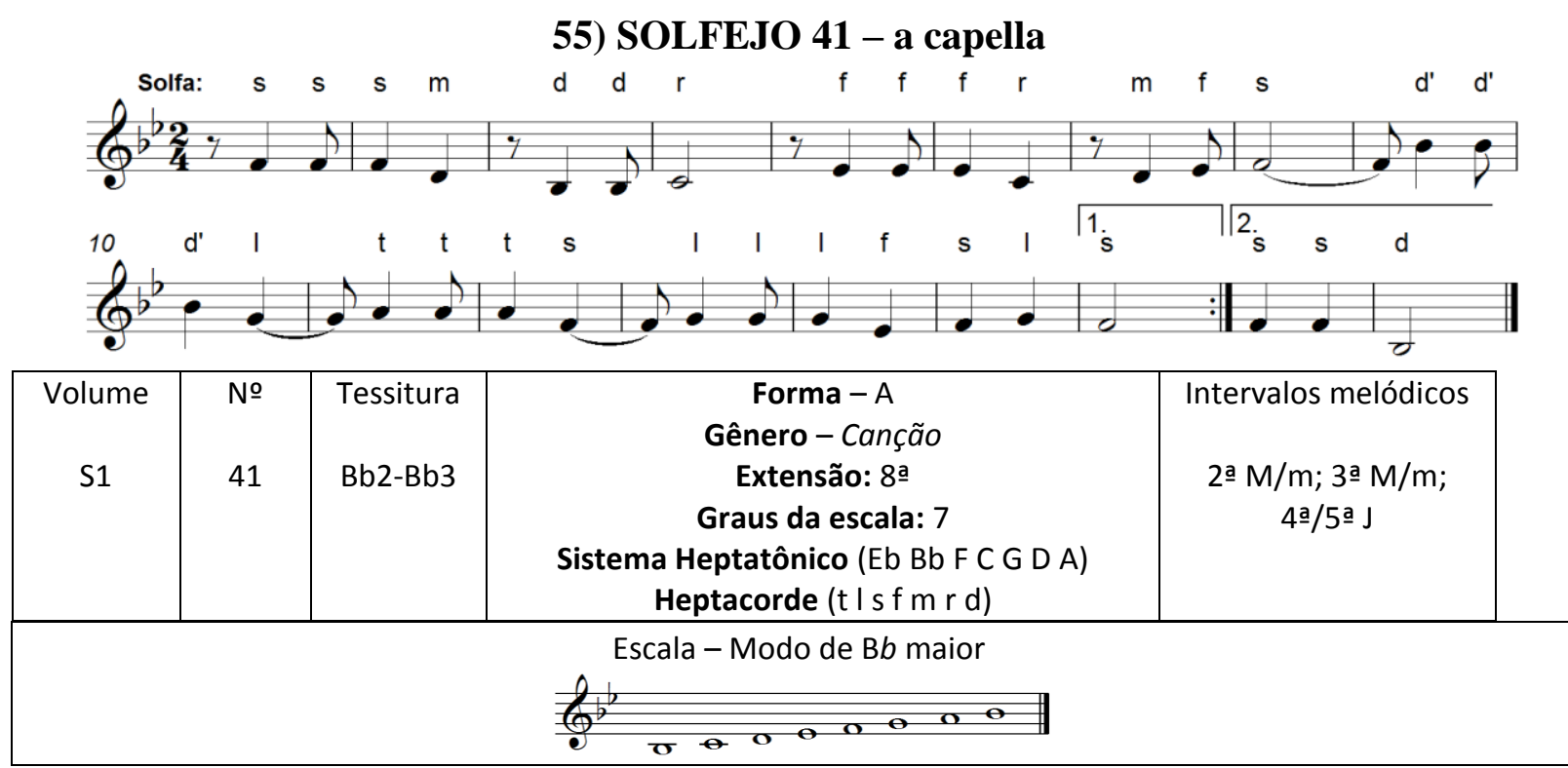

Sugestões de atividades didático-pedagógicas:

Células rítmicas para registro gráfico:

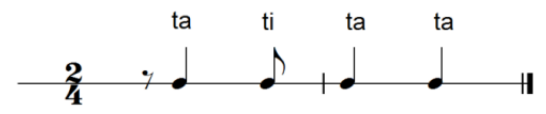

Células melódicas para registro gráfico:

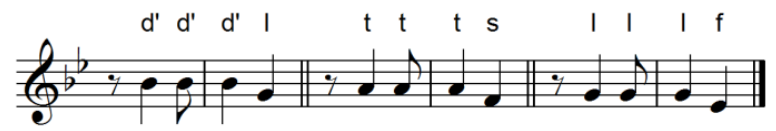

Possivel ostinato rítmico:

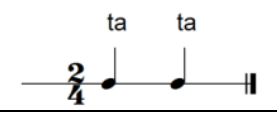

Tema de Villa-Lobos, de inspiração popular, com 18 compassos binários, sem indicações de andamento ou de dinâmica.

Ritmo - o interesse rítmico está nas síncopas com contratempo ou ligaduras.

Melodia - desenho sincopado sobre terça menor descendente, inicialmente intercalado por motivos ascendentes e, na segunda frase (sobre terças menores e maiores), repetido em sequências descendentes por grau conjunto com finalização na $D$ na primeira vez e na $T$ na repetição.

Ludicidade - apesar de se tratar de um solfejo, a configuração rítmica em ostinato pode sugerir uma coreografia - um cânone de série de movimentos, por exemplo. 
56) PAI FRANCISCO (1 ${ }^{\mathrm{a}}$ versão $)$ - acompanhamento instrumental

(Canto com Piano, ou conjunto instrumental)

Arr. de H.Villa-Lobos
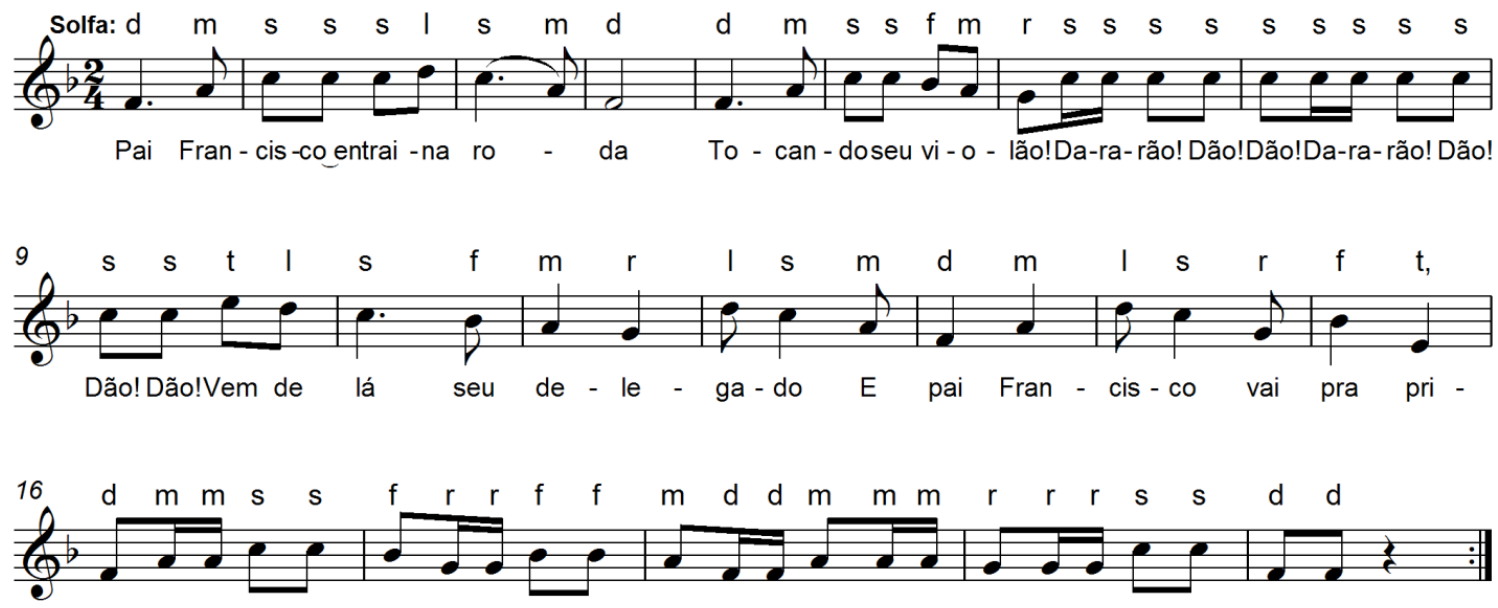

são Co-mo e - le vai to-do re-que - bra-do pa-re ce umbo - ne - co de-sen-gon - ça - do

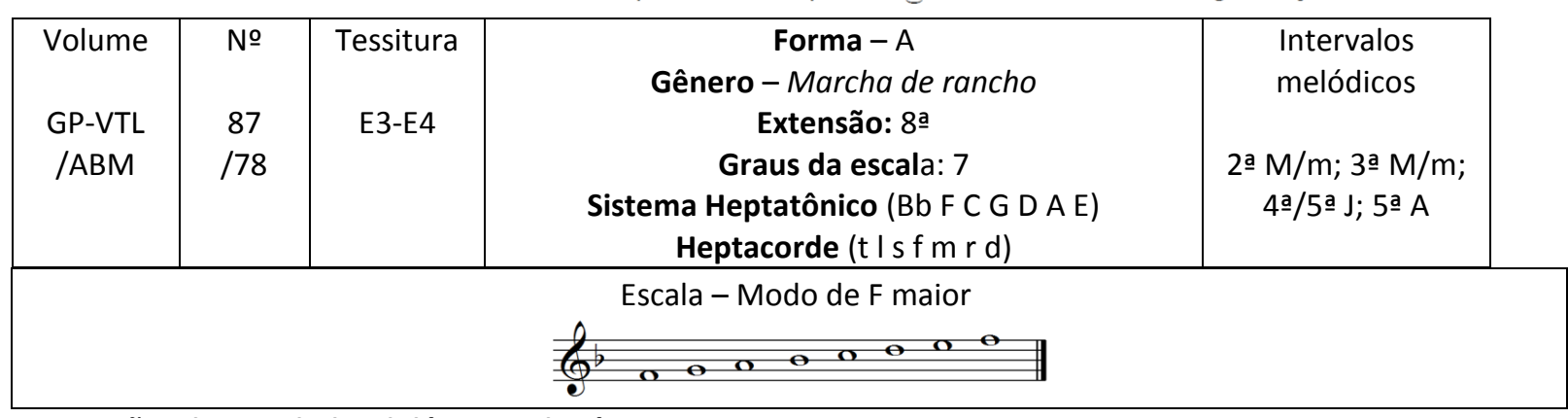

Sugestões de atividades didático-pedagógicas:

Células rítmicas para registro gráfico:

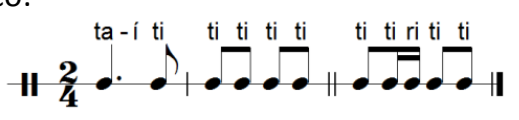

Células melódicas para registro gráfico:

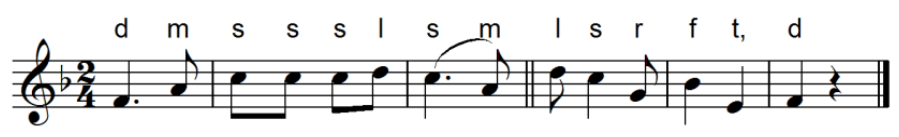

Possivel ostinato rítmico:

Possivel ostinato melódico:
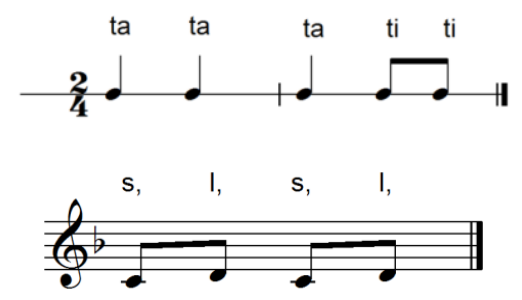

Canção com 20 compassos binários, com a indicação: Tempo de Marcha de Rancho $(\mathbf{1 2 0}=$ ل ); Poco più Mosso; indicações de dinâmica: $p$; acentos >

Tema popular, folclórico, de brincadeira cantada cujo desenvolvimento baseia-se no texto. Segundo GP/ABM ${ }^{35}$, o personagem Pai Francisco pode estar associado ao personagem Matheus, do Bumba-meu-boi, ou ao palhaço Veludo (SP e MG - final do século XIX), ou ainda a Pai João do "Lundu do escravo". 
Texto - variante de Padre Francisco, Pai Francisco é um violeiro desengonçado que é preso pelo delegado. Dararão Dão Dão - imitação do ritmo articulado (rasqueado) ao violão.

Ritmo - binário, de subdivisão binária, o interesse rítmico está nas células com semicolcheias e semínimas pontuadas.

Melodia - inicia-se no arpejo da tríade de $\mathrm{T}$ ascendente e descendente, com a frase terminando na $\mathrm{D}$ com notas rebatidas; segue um desenho descendente em pequenas curvas para a T. Na segunda parte, desenho em terças repetidas em sequência descendente por graus conjuntos com final na $\mathrm{T}$ por salto descendente. GP/ABM corrige adequadamente o ritornello dos compassos 17 a 21 de GP/VTL. Omite, no entanto, no décimo terceiro compasso as notas $\boldsymbol{B}$ e $\boldsymbol{C}$ na linha do baixo, na mão esquerda.

Acompanhamento instrumental - harmonia e contraponto ao piano, sobre funções primárias, apoiando a melodia. Na segunda parte, o acompanhamento se inicia com o baixo de Alberti.

Ludicidade - brincadeira de roda em que Pai Francisco entra na roda, é preso e sai dançando com o delegado, o qual, na repetição, entra na roda como Pai Francisco, e assim por diante.

57) PAI FRANCISCO (2 $2^{\text {a }}$ versão $)$ - acompanhamento instrumental (Canto com Piano, ou conjunto instrumental)

Arr. de H.Villa-Lobos

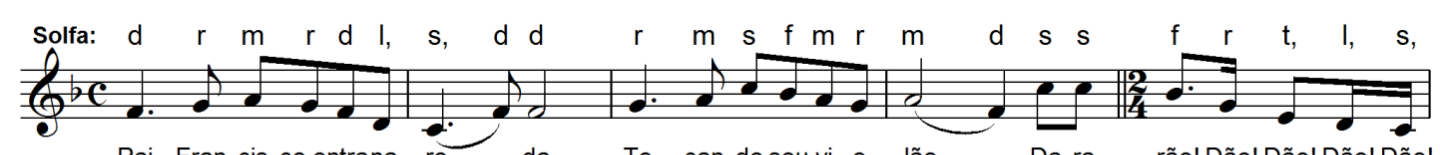

Pai Fran-cis-co_entrana ro_- da To - can-do seu vi-o - lão__ Da-ra - rão! Dão! Dão! Dão! Dão!
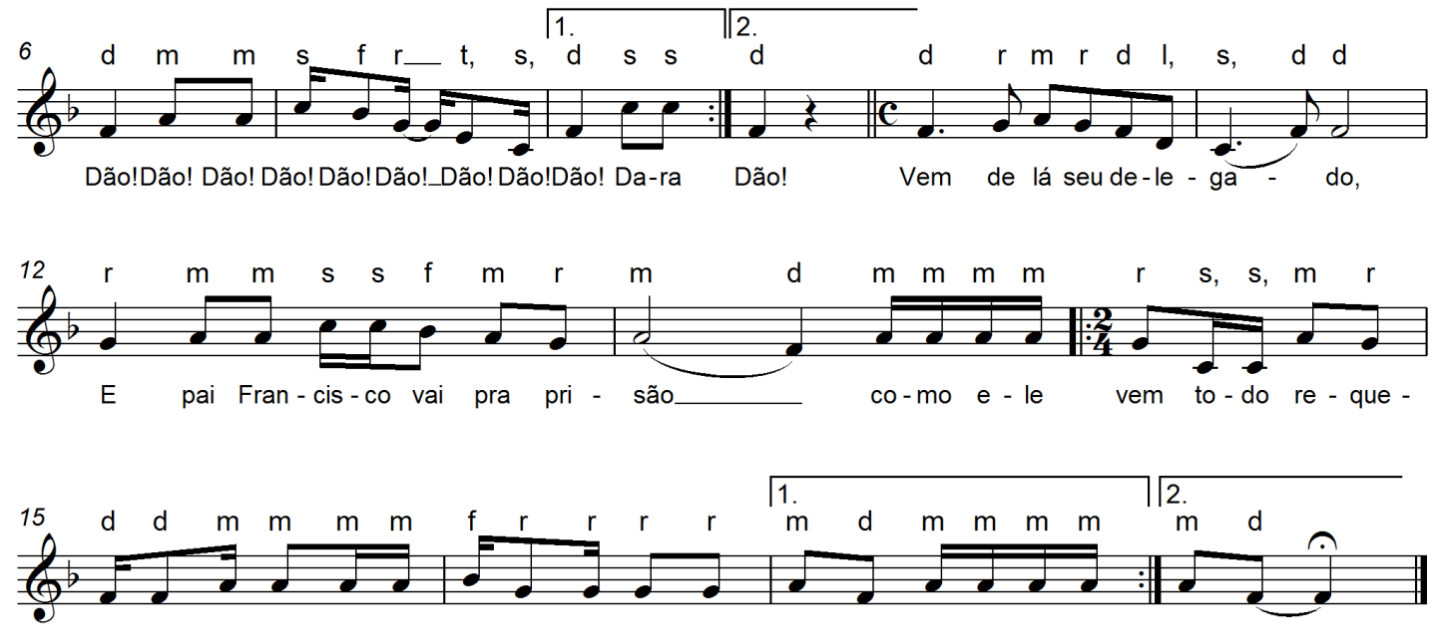

bra-do, pa-re -ce umbo - ne-co de-sen-gon - ça - do co-mo e - le ça - do__

\begin{tabular}{|c|c|c|c|c|}
\hline $\begin{array}{c}\text { Volume } \\
\text { GP-VTL } \\
\text { /ABM }\end{array}$ & $\begin{array}{c}\text { № } \\
88 \\
/ 79\end{array}$ & $\begin{array}{l}\text { Tessitura } \\
\text { C3-C4 }\end{array}$ & $\begin{array}{c}\text { Forma - ABA'B' } \\
\text { Gênero - Marcha de rancho } \\
\text { Extensão: } 8^{\text {a }} \\
\text { Graus da escala: } 7 \\
\text { Sistema Heptatônico (Bb F C G D A E) } \\
\text { Heptacorde (t I s f m r d) }\end{array}$ & $\begin{array}{l}\text { Intervalos melódicos } \\
\text { 2a } \mathrm{M} / \mathrm{m} ; 3 \text { a } \mathrm{M} / \mathrm{m} ; \\
\text { 4a/5a J; 6 } \mathrm{M}\end{array}$ \\
\hline \multicolumn{5}{|c|}{ Escala - Modo de F maior } \\
\hline
\end{tabular}


Sugestões de atividades didático-pedagógicas:

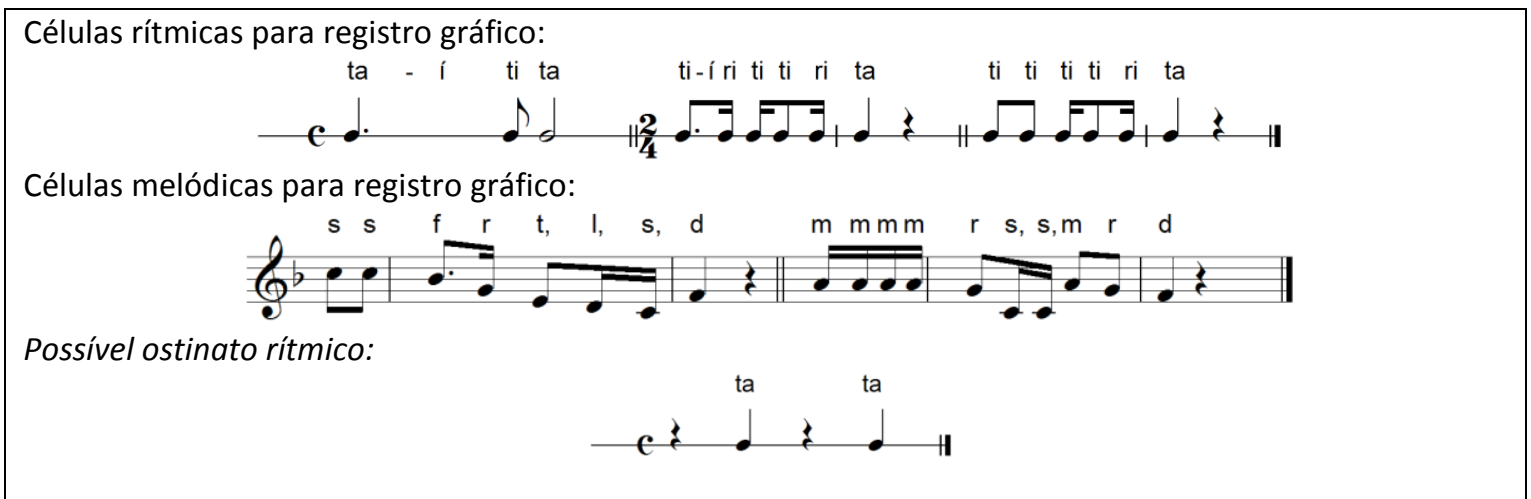

Canção com 18 compassos alternando quatro quaternários e oito binários, com a indicação: Tempo de Marcha de Rancho $(120=$ ل); Poco più Mosso; indicações de dinâmica: $p$; acentos >

Ritmo - quaternário, de subdivisão binária, o interesse rítmico está nas síncopas com ligadura.

Melodia - inicia-se no arpejo da tríade de $\mathrm{T}$ ascendente e descendente, com a frase terminando na $\mathrm{D}$ com notas rebatidas; segue um desenho descendente em pequenas curvas para a T. Na segunda parte, desenhos sobre arpejo descendente da D7 seguidos de finalização na $\mathrm{T}$ por saltos. Parece-me equivocado o acréscimo da sílaba Dão em GP/ABM nos compassos 12 e 36, que, além de não constarem em GP/VTL, está na nota $\boldsymbol{F} 4$, em salto de oitava ascendente, não muito confortável para a voz infantil.

Acompanhamento instrumental - na parte A, ostinatos sobre tetracordes descendentes, na mão esquerda, parte deles em oitavas, com variação cromática, e na parte $\mathrm{B}$, harmonia sobre acordes de $\mathrm{D}$ e $\mathrm{T}$.

\section{8) A MARÉ ENCHEU - acompanhamento instrumental}

(Canto com Piano, ou conjunto instrumental ou Piano solo)

Amb. por H.Villa-Lobos
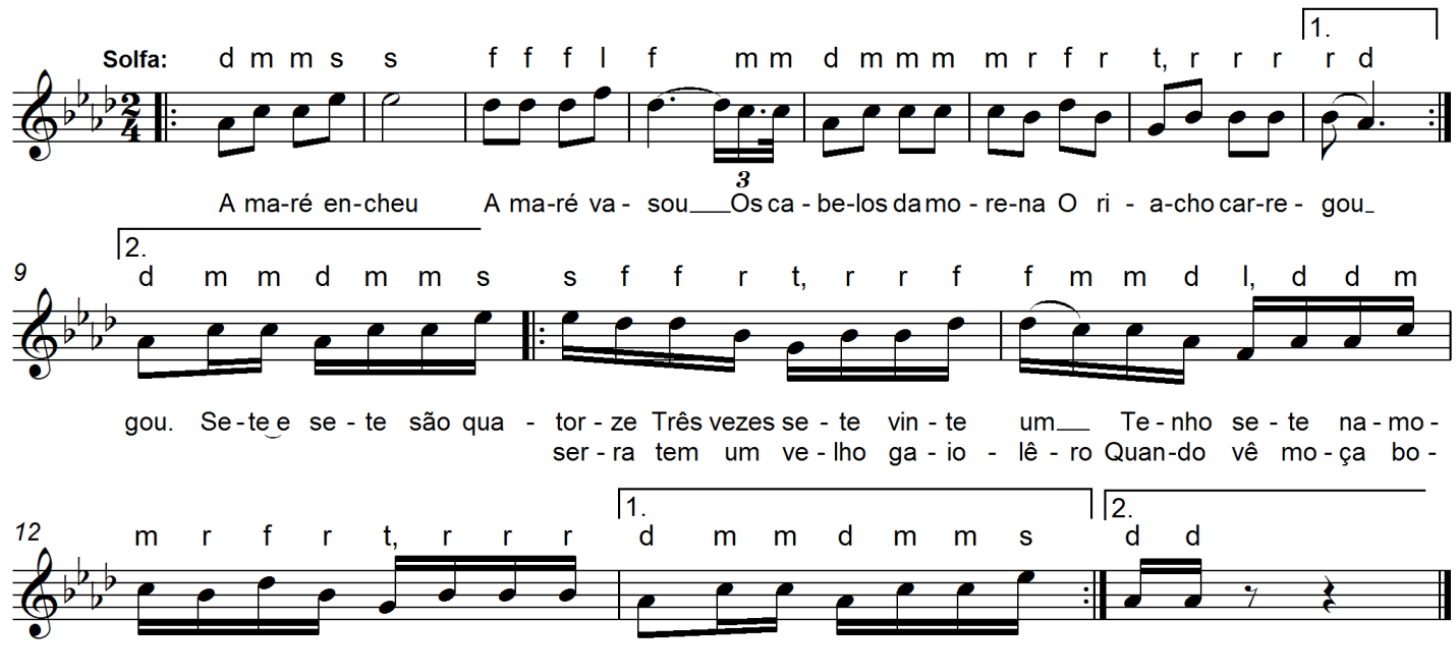

ra-dos não me ca - so com ne-nhum Em ci-ma da-que - la tê - ro ni - ta Faz ga - io - la sem pon -

\begin{tabular}{|c|c|c|c|c|}
\hline Volume & № & Tessitura & $\begin{array}{c}\text { Forma - } \mathrm{ABA}^{\prime} \mathrm{B}^{\prime} \\
\text { Gênero - do lundu ao samba sertanejo }\end{array}$ & Intervalos melódicos \\
\hline $\begin{array}{l}\text { GP-VTL } \\
\text { /S1 } \\
\text { /ABM }\end{array}$ & $\begin{array}{l}76,76 a \\
/ 36 \\
/ 83\end{array}$ & F3-F4 & $\begin{array}{c}\text { Extensão: 8a } \\
\text { Graus da escala: } 7 \\
\text { Sistema Heptatônico (D } b \text { A } b \text { E } b \text { B } b \text { F C G) } \\
\text { Heptacorde ( } \mid \text { I s f m r d) }\end{array}$ & 2a $\mathrm{M} / \mathrm{m} ; 3$ a $\mathrm{M} / \mathrm{m}$ \\
\hline
\end{tabular}




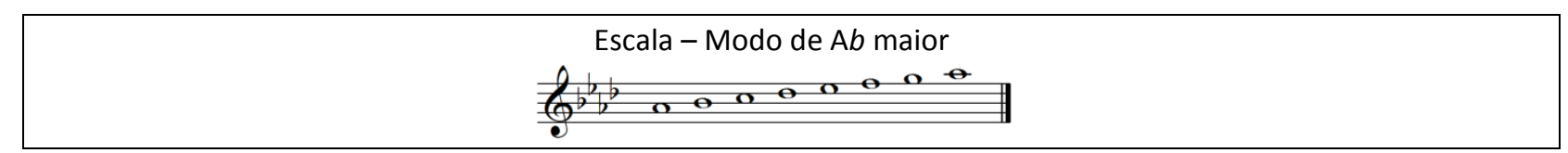

Sugestões de atividades didático-pedagógicas:

Células rítmicas para registro gráfico:

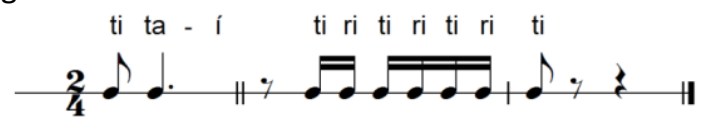

Células melódicas para registro gráfico:

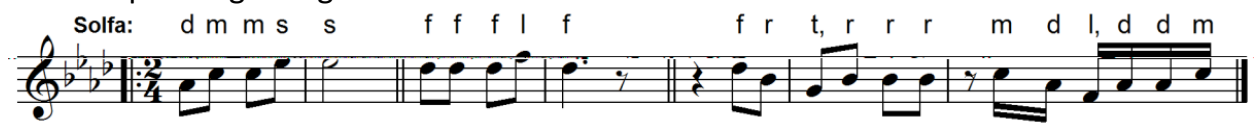

Possivel ostinato rítmico:

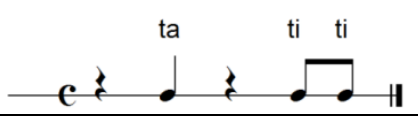

Canção com 14 compassos binários, com a indicação de andamento: Poco Moderato ${ }^{36}$ (69= ل ); rall. A tempo ; poco rall.; indicações de dinâmica: $m f$; $<$; $; f$

Tema popular folclórico nordestino.

Texto - embolada (popular da Paraíba). Quadrinha inicial sobre tema da maré cheia e baixa, com comentário sobre o cabelo da morena, símbolo da mulher brasileira no cancioneiro popular. Na segunda parte, novas quadrinhas, cujas variantes são comumente encontradas em emboladas. No compasso 27, a separação de sílabas na palavra gaiola deveria ser gai - o - la, respeitando o ditongo ai, e não ga - io - la, como consta em GP/VTL e GP/ABM. O texto em $\mathrm{GP}^{\mathrm{ABBM}}{ }^{37}$ difere de GP/VTL nas frases: Tenho sete namorados não me caso com nenhum (GP/VTL: Tenho sete namorados faço caso só de um) e Quando vê moça bonita (GP/VTL: Quando vê moça solteira).

Ritmo - o interesse maior está no contraste provocado pelo andamento dobrado na segunda parte. No compasso 8 aparece uma tercina de difícil execução, dentro do contexto, podendo ser simplificada por síncopa de (semicolcheia), colcheia e semicolcheia, o que já acontece na prática.

Acompanhamento instrumental (piano) - introdução em modo menor, iniciando com desenho em curva ascendente/descendente, com tercina métrica no primeiro compasso contrastando com semicolcheias em direção à $\mathrm{T}$. $\mathrm{O}$ acompanhamento está sobre pedal de $\mathrm{T}$ na mão esquerda, sendo que o acorde do compasso 8, dominante sem fundamental com nona menor, deveria conservar a mesma grafia nos compassos 11 e 19, por manter a mesma função e ser de visualização mais fácil. A mão direita dobra a melodia em oitavas na parte A. Na parte B a melodia apóia-se em apojaturas em pedal no quinto grau em cada compasso, enquanto a mão esquerda estabelece ostinatos rítmicos e harmônicos (em registros grave e agudo, abaixo e acima da melodia). A coda inverte a linha descendente da introdução (agora em modo maior) e finaliza com apojatura $\mathrm{D}^{4-3} \mathrm{~T}^{6}$.

Melodia - na parte A, arpejo da tríade de $\mathrm{T}$, ponto culminante pela $\mathrm{S}$ e desenho descendente com tríades descendentes de $\mathrm{T}$ e $\mathrm{D}$, terminando na $\mathrm{T}$; a parte $\mathrm{B}$ é desenvolvida sobre as tríades de $\mathrm{T}$ e $\mathrm{D}$, ascendentes e descendentes, em seqüências descendentes com finalização na $\mathrm{T}$. Em

\footnotetext{
${ }^{36}$ Em GP/ VTL constam os números 76 para a versão com acompanhamento instrumental, com essa indicação de andamento, e $76^{\mathrm{a}}$, a capella, com indicação Moderato.

${ }^{37}$ GP/ABM - Fonte: SEMA - Gazzi de Sá.
} 
GP/ABM, no compasso 2, as duas últimas notas são $\boldsymbol{F}$ e $\boldsymbol{E}$ (mão direita) e não $\boldsymbol{G}$ e $\boldsymbol{F}$; no compasso 28, a quarta semicolcheia (mão esquerda) é $\boldsymbol{F}$ e não $\boldsymbol{G}$.

Ludicidade - o interesse maior está no texto humorístico, suas possibilidades de criatividade e também na possível movimentação, sugerida pelos diferentes andamentos.

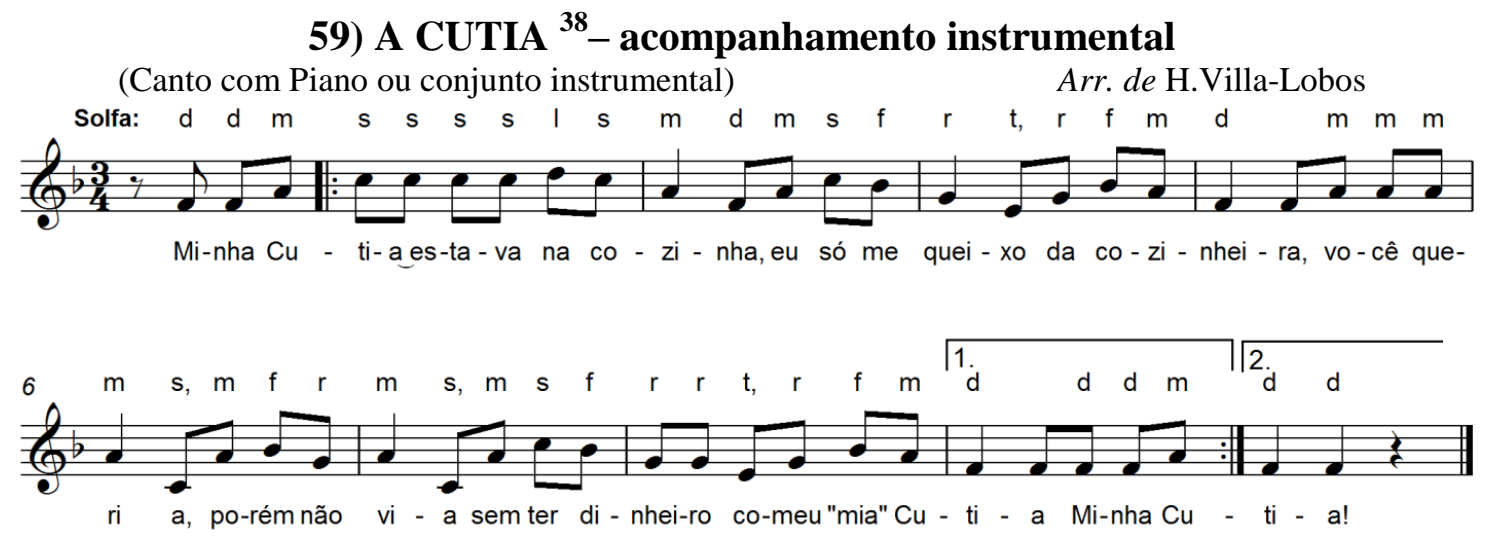

\begin{tabular}{|c|c|c|c|c|}
\hline $\begin{array}{l}\text { Volume } \\
\text { GP-VTL } \\
\text { /ABM }\end{array}$ & $\begin{array}{r}\text { № } \\
44 \\
/ 70\end{array}$ & $\begin{array}{c}\text { Tessitura } \\
\text { C3-D4 }\end{array}$ & $\begin{array}{c}\text { Forma - A } \\
\text { Gênero - Mazurca } \\
\text { Extensão: 9ạ } \\
\text { Graus da escala: } 7 \\
\text { Sistema Heptatônico (Bb F C G D A E) } \\
\text { Heptacorde (t I s f m r d) }\end{array}$ & $\begin{array}{c}\text { Intervalos } \\
\text { melódicos } \\
\text { 2a } \mathrm{M} / \mathrm{m} ; 3 \text { a } \mathrm{M} / \mathrm{m} \text {; } \\
\text { 6a } \mathrm{M}\end{array}$ \\
\hline \multicolumn{5}{|c|}{ 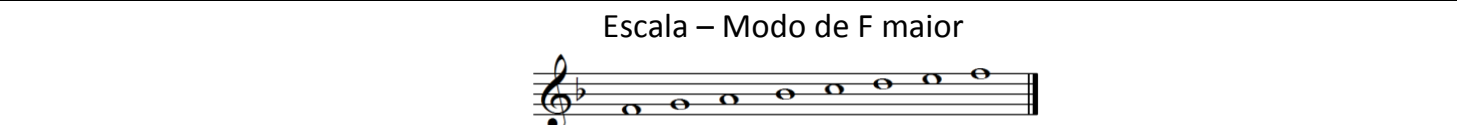 } \\
\hline
\end{tabular}

Sugestões de atividades didático-pedagógicas:

Células rítmicas para registro gráfico:

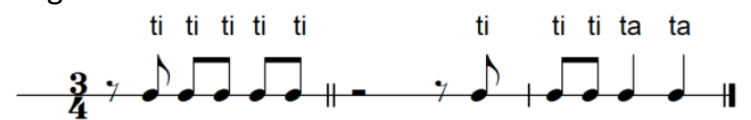

Células melódicas para registro gráfico:

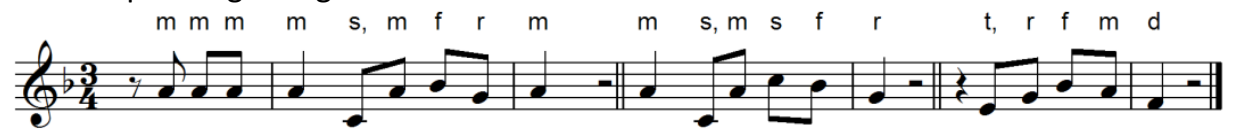

Possivel ostinato rítmico:

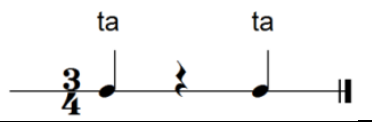

Canção com 10 compassos ternários, com a indicação de andamento: Tempo de Mazurka $(132=ل$ ); indicações de dinâmica: $f$. As ligaduras são indevidas em relação ao texto.

Tema popular, folclórico infantil, de brincadeira cantada cujo desenvolvimento baseia-se no texto.

Texto - descrição de brincadeira de roda. Conta a história de uma cutia que foi comida pela cozinheira. Ambas as edições, GP/VTL e GP/ABM trazem o título Cotia de forma equivocada, pois a grafia correta do nome do animal em questão é Cutia. Em GP/ABM, no oitavo compasso não deveria constar a ligadura na parte da voz, no nono compasso a palavra

\footnotetext{
${ }^{38}$ Segundo o dicionário Aurélio: Cotia - antiga embarcação, pequena e ligeira, do Oceano Índico; Cutia mamífero roedor, dasiproctídeo, gênero Dasyprocta, com sete espécies em território brasileiro.
} 
porém está mal acentuada e no décimo primeiro compasso a palavra "mia" deveria estar entre aspas, e não a palavra comeu com um apóstrofo.

Ritmo - o interesse rítmico está no compasso ternário, em tempo de mazurca.

Melodia - arpejo ascendente/descendente da $\mathrm{T}$ seguido de dois desenhos descendentes com base no arpejo da $\mathrm{D}$, e resolução descendente na $\mathrm{T}$; salto descendente e ascendente de sexta, pequenas curvas e finalização descendente na $\mathrm{T}$.

Acompanhamento instrumental (piano) - Introdução e Coda com variação rítmica sobre tercinas. Primeira frase com ostinato na mão esquerda privilegiando o terceiro tempo, com ornamentos de apojaturas. Na segunda frase, o acompanhamento segue o ritmo da melodia em contraponto. Em GP/ABM, no terceiro compasso, a primeira nota da mão esquerda deve ser $\boldsymbol{C}$ e não $\boldsymbol{E}$. As ligaduras das apogiaturas nesta edição corrigem adequadamente a grafia constante em GP/VTL.

Ludicidade - a brincadeira privilegia o humorismo contido no texto e a movimentação pode ser rica e variada.

\section{0) CARANGUEJO - a capella}
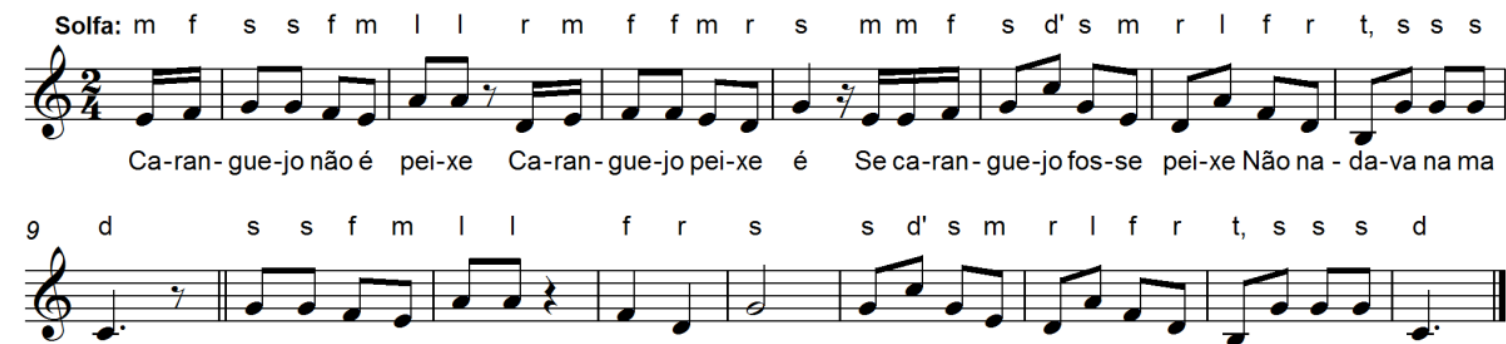

ré Pal-ma, pal-ma, pal-ma, pé, pé, pé Ro-da, ro-da, ro-da, ca-ran-gue-jo pei-xe é.

\begin{tabular}{|c|c|c|c|c|}
\hline $\begin{array}{c}\text { Volume } \\
\text { GP-VTL } \\
\text { /S1 } \\
\text { /ABM }\end{array}$ & $\begin{array}{l}\text { № } \\
30 \\
/ 10 \\
/ 16\end{array}$ & $\begin{array}{l}\text { Tessitura } \\
\text { B2-C4 }\end{array}$ & $\begin{array}{c}\text { Forma - AA' } \\
\text { Gênero - Canção } \\
\text { Extensão: 9â } \\
\text { Graus da escala: } 7 \\
\text { Sistema Heptatônico (F C G D A E B) } \\
\text { Heptacorde (t I s f m r d) }\end{array}$ & 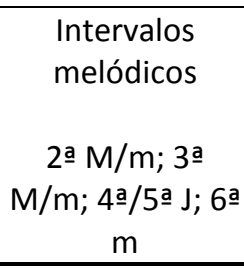 \\
\hline \multicolumn{5}{|c|}{ Escala - Modo de C maior } \\
\hline
\end{tabular}

Sugestões de atividades didático-pedagógicas:

Células rítmicas para registro gráfico:

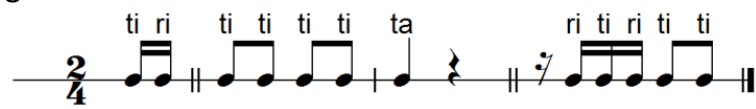

Células melódicas para registro gráfico:

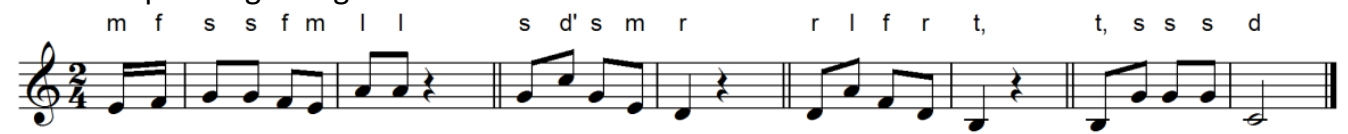

Possível ostinato rítmico:

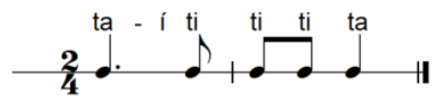

Análise complementar em $2.2-n^{\circ} 71$. 
Canção com 17 compassos binários, com a indicação de andamento: Allegretto (M.M. 132= ل ); sem indicações de dinâmica.

Tema popular, folclórico infantil, de brincadeira cantada cujo desenvolvimento baseia-se no texto.

Texto - cantiga de roda sobre a contradição entre o caranguejo não ser considerado peixe na vazante e ser considerado peixe na enchente da maré.

Ritmo - o interesse rítmico está na possibilidade de aquisição das figuras colcheias (pela da palavra palma) e semínimas (pela da palavra pé).

Melodia - parte de terças menores cheias ascendentes e descendentes, com terminação por salto ascendente (duas vezes), na terceira vez, arpejos descendentes e terminação na $\mathrm{T}$ por salto de quinta descendente.

Ludicidade - o texto descreve a movimentação da segunda parte, e a roda é simples na primeira parte.

\section{1) O CAFÉ - a capella}

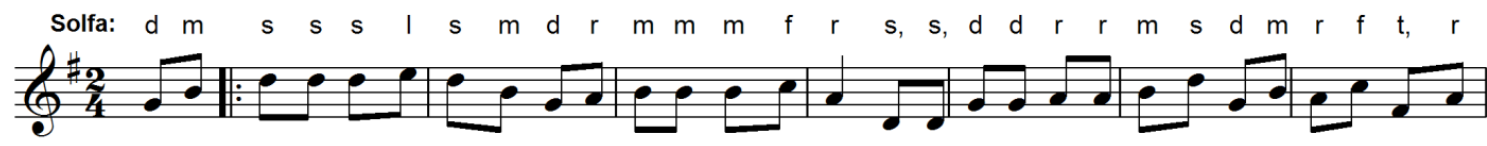

Nasen - cos-tasdas mon-ta-nhas, o ca-fé va-mos plan tar. Mas pri mei robem de-ve-mos o ter-re-no pre-pa-

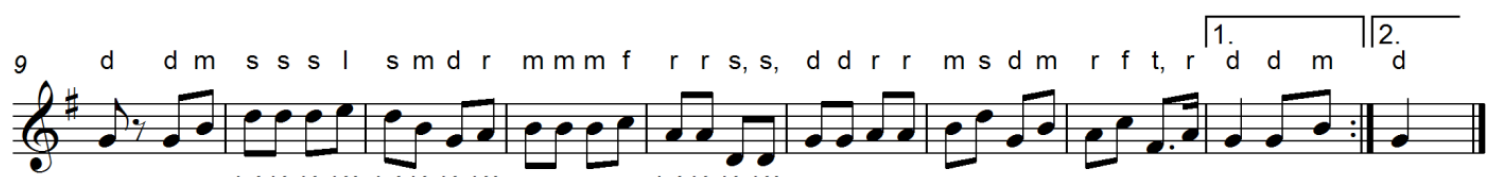

rar Lá lá! Lá lá lá lá! Lá lá lá lá! Lá lá lá lá! Lá lá lá lá! Lá lá lá lá! Lá lá lá lá! Lá lá lálá! Lá Se já es lá!

\begin{tabular}{|c|c|c|c|c|}
\hline $\begin{array}{l}\text { Volume } \\
\text { GP-VTL } \\
\text { /S1 } \\
\text { /ABM }\end{array}$ & $\begin{array}{l}\text { No } \\
20 \\
/ 8 \\
/ 10\end{array}$ & $\begin{array}{c}\text { Tessitura } \\
\text { D3-E4 }\end{array}$ & $\begin{array}{c}\text { Forma - } \mathrm{AA}^{\prime} \\
\text { Gênero - Quadrilha } \\
\text { Extensão: } 9 \underline{a} \\
\text { Graus da escala: } 7 \\
\text { Sistema Heptatônico (C G D A E B F\#) } \\
\text { Heptacorde (t I s f m r d) }\end{array}$ & 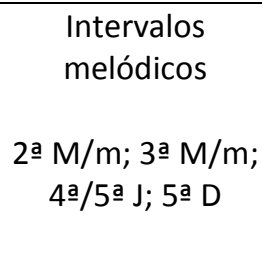 \\
\hline & & & $\begin{array}{l}\text { Escala - Modo de G maior } \\
\mathbf{0}\end{array}$ & \\
\hline
\end{tabular}

Sugestões de atividades didático-pedagógicas:

Células rítmicas para registro gráfico:

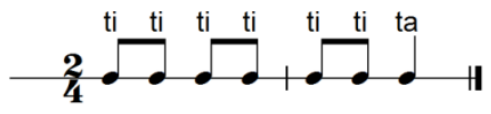

Células melódicas para registro gráfico:

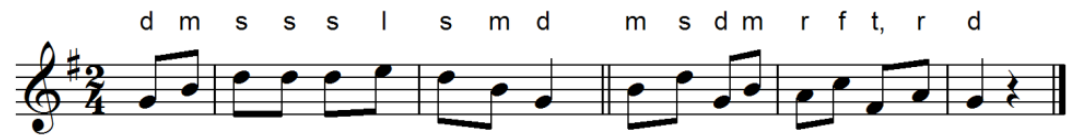

Possível ostinato rítmico:

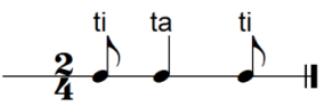


Análise complementar em 2.2 - $n^{\circ} 69$.

Canção com 18 compassos binários, com a indicação de andamento: Allegretto (M.M. 132= ل ); sem indicações de dinâmica.

Tema didático com objetivo de apreensão de conteúdo.

Texto - o texto descreve o processo de plantação e colheita do café, provavelmente escrito para uso didático. GP/ABM despreza, muito adequadamente, na partitura, as estrofes que seguem contando a história do plantio e colheita do café, pois a prosódia resulta sofrível. Segue o texto completo aqui (segundo GP/ABM, originado do opúsculo do Colégio Menezes Vieira, Cânticos infantis para o jardim das crianças, publicado em 1897), com a nossa sugestão de que as estrofes sejam declamadas. A repetição da melodia com a sílaba Lá! tem, provavelmente, o objetivo de promover um lapso de tempo para fixação do texto cantado em cada estrofe, contribuindo também para a variação timbrística da canção.

Ritmo -binário, basicamente desenvolvido na subdivisão também binária.

Melodia - primeira frase sobre arpejo ascendente e terminação na D; segunda frase com desenho ascendente e terminação na $\mathrm{T}$ por terças quebradas descendentes.

Ludicidade - descrição de história, que pode levar a várias interpretações, como, por exemplo, dança na segunda parte e declamação das demais estrofes (somente a primeira seria cantada) por solistas ou grupos de participantes. Como se trata de procedimento de época, podem ser incluídas informações históricas complementares.

Complementação do texto ${ }^{39}$ :

- Nas encostas das montanhas / o café vamos plantar / mas primeiro bem devemos / o terreno preparar.

- Se já está bem lavrado / é só o buraco abrir / nele meter os grãozinhos / e com terra os cobrir.

- Cinco anos se passaram / o cafeeiro cresceu / vieram as lindas flores / e belas cerejas deu.

- As cestinhas estão prontas / vamos o café colher / tenhamos muito cuidado / para nenhum só perder.

- As cestinhas para casa / já podemos carregar / no terreiro bem limpinho / o café fique, a secar.

- O fruto bem seco está / é preciso descascar / a máquina já e já / comecemos a tocar.

- Nossos ventiladores / suas pás já vão mover / para o belo café / toda casquinha perder.

- Depois de tanto trabalho / é mui justo repousar / juntos pelas roças / vamos um passeio dar.

\subsubsection{Melodias e canções com semitom $t$-d}

\subsubsection{Sobre quatro graus da escala}

39 GP/ABM - modifica a ordem das quadrinhas, alterando o sentido da descrição, apresentando, equivocadamente, as estrofes: primeira, quinta, segunda, sexta, terceira, sétima, quarta e oitava. Primeiro caderno, p. 72. 
62) CANTOS DE ÇAIRÉ (3) - a capella

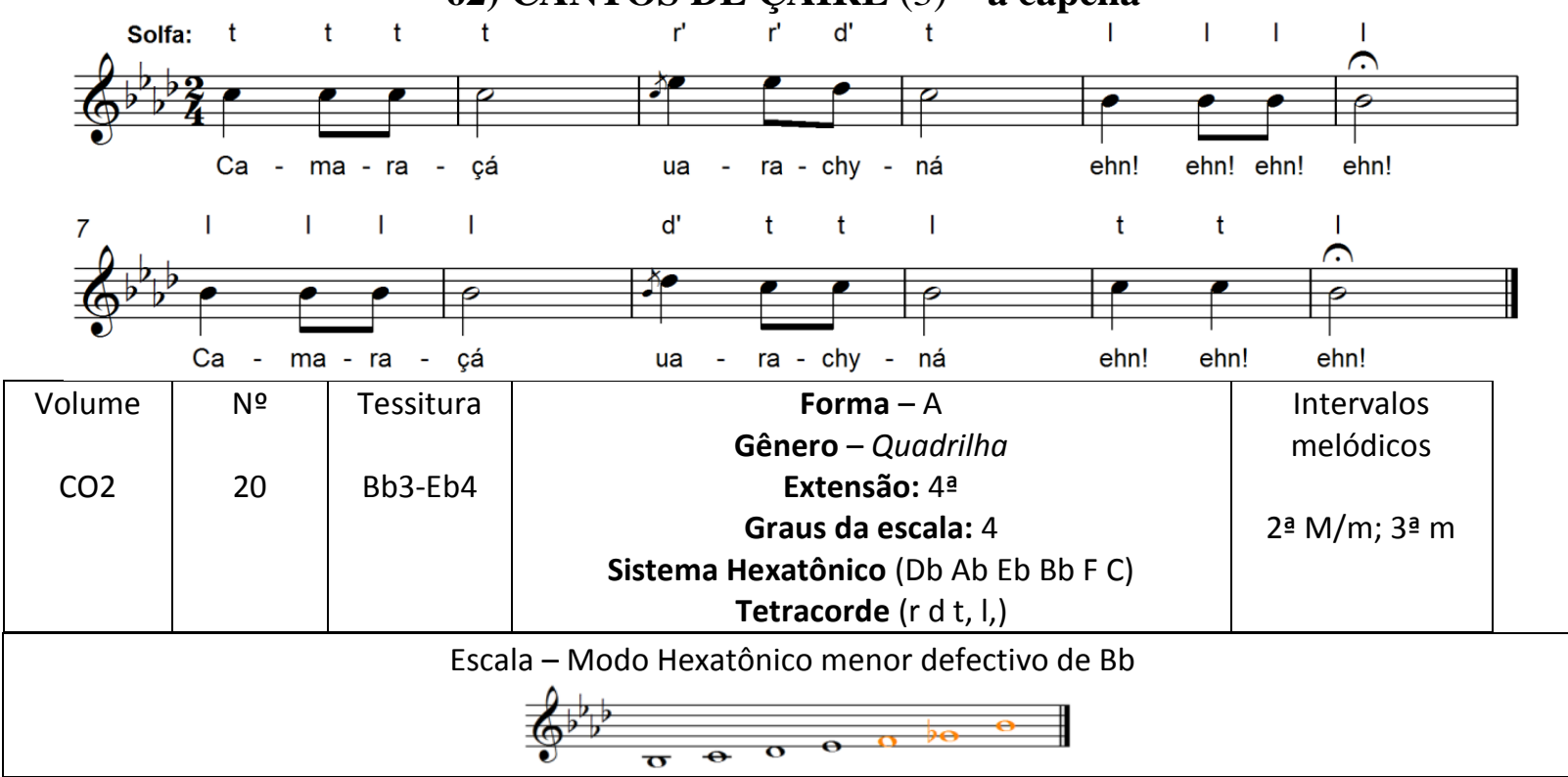

Sugestões de atividades didático-pedagógicas:

Células rítmicas para registro gráfico:

Células melódicas para registro gráfico:
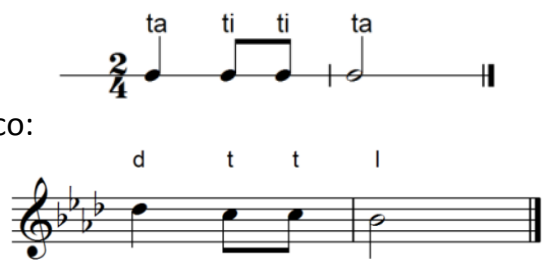

Possível ostinato rítmico:

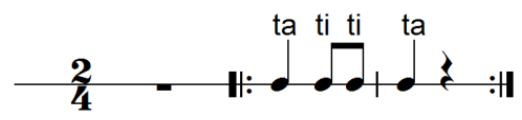

Análise complementar em $2.2-n^{\circ} 32$.

Canção com 12 compassos binários, com a indicação de andamento: Allegro Moderato; sem indicações de dinâmica.

Tema anônimo, ambientado por H.Villa-Lobos.

Texto - em língua indígena, sem indicação da procedência ou de tradução.

Ritmo - o interesse rítmico no ostinato rítmico.

Melodia - em tetracorde menor, com pergunta e resposta simétricas, ambas terminando na tônica menor.

Ludicidade - a curiosidade prevalece como motivação no caso de melodias indígenas, ocasião propícia à inserção de novos conteúdos sobre a música de povos brasileiros.

\section{$\underline{\text { 2.1.3.2 Sobre cinco graus da escala }}$}




\section{3) O PASTORZINHO - acompanhamento instrumental}

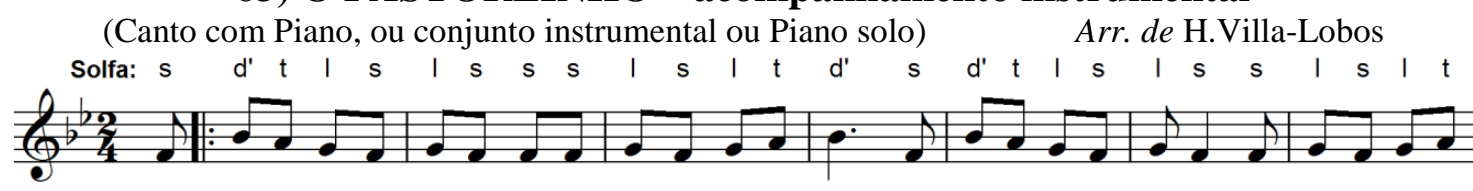

Ha - via um pas-tor - zi-nho Que an - da va a pas-to - rar, sa - iu de su-a ca-sa e pôs-se a can
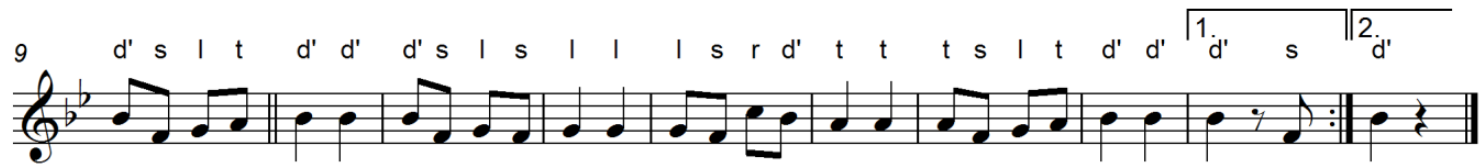

tar!FaSol Lá Si Si SiFá SolFá Sol Sol SolFá DóSi Lá Lá LáFá Sol Lá Si Si Si Che Si

\begin{tabular}{|c|c|c|c|c|}
\hline $\begin{array}{l}\text { Volume } \\
\text { GP-VTL } \\
\text { /ABM }\end{array}$ & $\begin{array}{c}\text { № } \\
91 \\
\text { /125 }\end{array}$ & $\begin{array}{l}\text { Tessitura } \\
\text { F3-C4 }\end{array}$ & $\begin{array}{c}\text { Forma - A } \\
\text { Gênero - Quadrilha } \\
\text { Extensão: 5ạ } \\
\text { Graus da escala: } 5 \\
\text { Sistema Hexatônico (Eb Bb F C G D) } \\
\text { Pentacorde ( } \mathrm{r} \text { d t I s) }\end{array}$ & 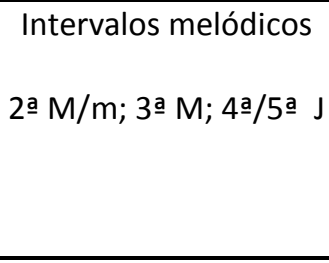 \\
\hline \multicolumn{5}{|c|}{ 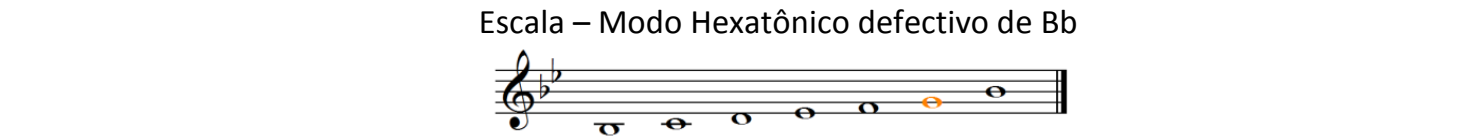 } \\
\hline
\end{tabular}

Sugestões de atividades didático-pedagógicas:

Células rítmicas para registro gráfico:

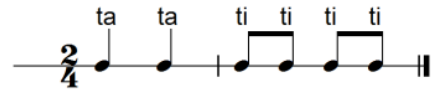

Células melódicas para registro gráfico:

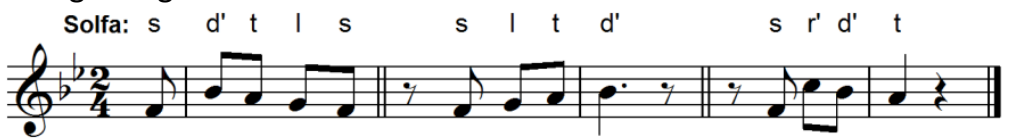

Possível ostinato rítmico: (Diferentes timbres)

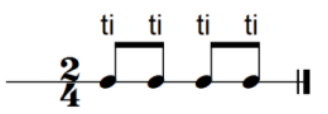

Análise complementar em $2.2-n^{\circ} 90$.

Canção com 18 compassos binários, com a indicação de andamento: Molto Animato (M.M. $\mathbf{1 4 4 =} \downarrow$ ); indicações de dinâmica: $f$; > ; $\boldsymbol{m f}$; $f \boldsymbol{f}$; acentos > _

Tema popular, folclórico infantil, de brincadeira cantada cujo desenvolvimento baseia-se no texto.

Texto - Quadrinhas que descrevem o pastorzinho cantor e sua ida a palácio e a apreciação da rainha ao seu canto. O texto mais conhecido contém as notas: Dó Ré Mi Fá Sol na segunda parte da canção. Preferimos aqui utilizar a nomenclatura relativa.

Ritmo - o interesse rítmico está no pulso e sua subdivisão.

Melodia - desenvolve-se com desenho inicial em graus conjuntos sobre tetracorde e notas rebatidas com finalização ascendente na $\mathrm{T}$. Na segunda parte, alcançando o pentacorde com salto de quinta, a terminação é ascendente na T. Utilizando-se o solfa relativo na segunda parte, a canção é muito adequada para a aquisição de intervalos e nomenclatura de sons relativos, devendo ser cantada em várias alturas com o mesmo texto (ver nota).

Ludicidade - brincadeira de roda em duas partes, com a segunda quase sempre dançada ou brincada com batidas de mãos aos pares. 
Complementação do texto ${ }^{40}$ :

- Havia um pastorzinho / que andava a pastorar / saiu de sua casa / e pôs-se a cantar!

- Refrão: Sol Lá Si Dó Dó Dó / Sol Lá Sol Lá Lá Lá / Sol Ré Dó Si Si Si / Sol Lá Si Dó Dó Dó

- Chegando ao palácio / a rainha lhe falou / contando ao pastorzinho / que seu canto lhe agradou.

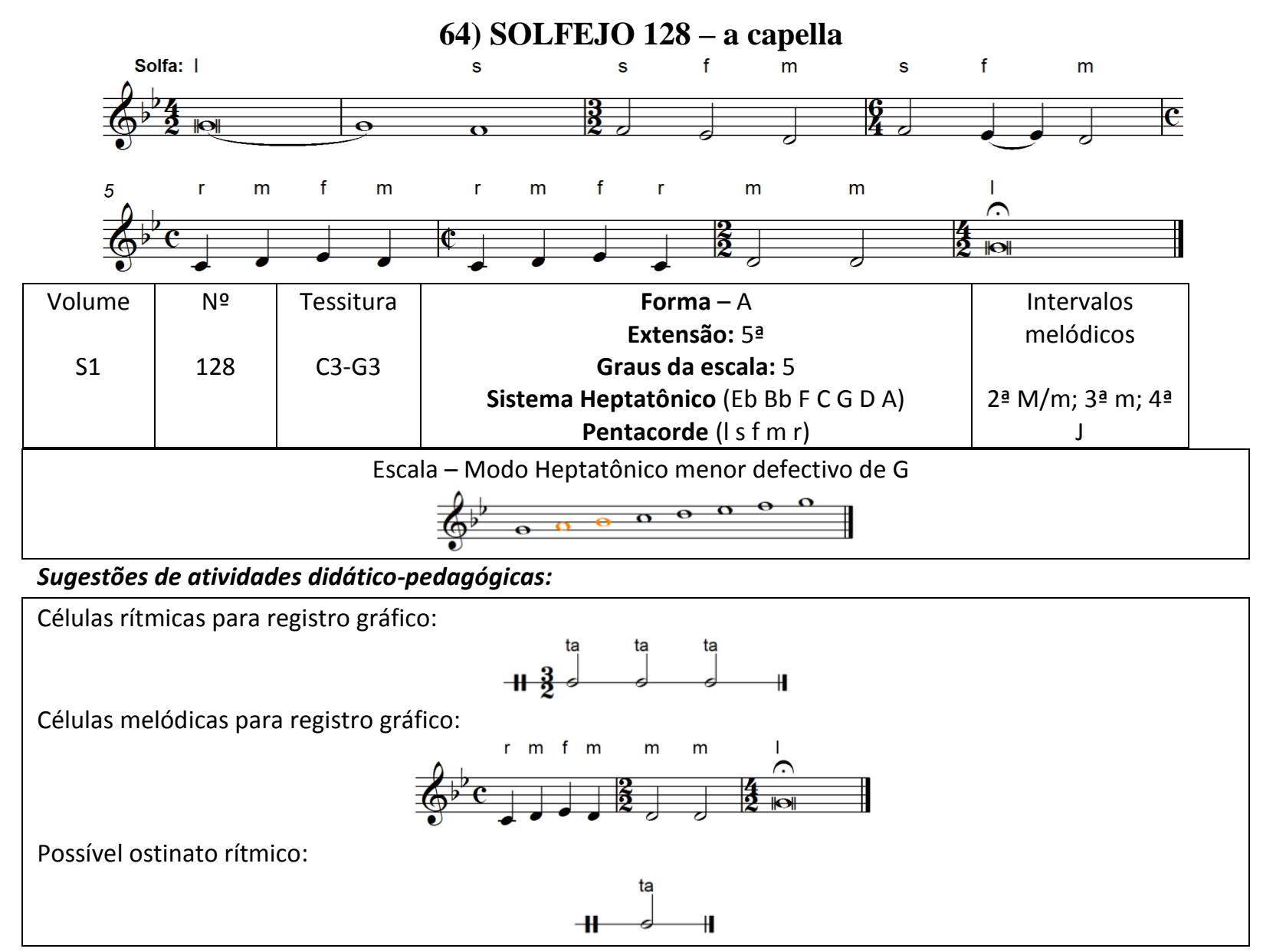

Análise complementar em $2.2-n^{\circ} 96$.

Canção com 8 compassos (primeiro, segundo e último compassos: quaternário com subdivisão binária; terceiro: ternário de subdivisão binária; quarto: binário com subdivisão ternária; quinto: quaternário com subdivisão binária; sexto e sétimos: com subdivisão binária); com a indicação: Grave; sem indicações de dinâmica.

Tema de Villa-Lobos.

Ritmo - o interesse está nos compassos diferentes com mudanças de subdivisão e de unidades de pulso.

Melodia - tetracordes descendentes e finalização por quarta ascendente para a tônica menor.

Ludicidade - está nos desafios do conteúdo teórico e na possibilidade de variações de interpretações e execuções - vocais, instrumentais ou gestuais.

\footnotetext{
${ }^{40}$ Inserindo o solfa relativo, em C maior, a canção pode ser cantada em qualquer tonalidade com as mesmas notas.
} 


\section{$\underline{\text { 2.1.3.3 Sobre seis graus da escala }}$}

\section{5) SOLFEJO n 156 - a capella}

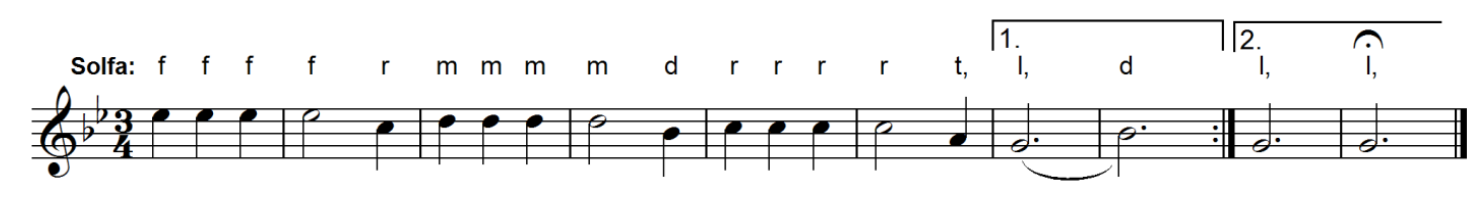

\begin{tabular}{|c|c|c|c|c|}
\hline $\begin{array}{l}\text { Volume } \\
\text { S1 }\end{array}$ & $\begin{array}{l}\text { № } \\
156\end{array}$ & $\begin{array}{l}\text { Tessitura } \\
\text { G3-Eb4 }\end{array}$ & $\begin{array}{c}\text { Forma - A } \\
\text { Gênero - Valsa Brasileira } \\
\text { Extensão: } 6 \underline{a} \\
\text { Graus da escala: } 6 \\
\text { Sistema Hexatônico (Eb Bb F C G D ) } \\
\text { Hexacorde ( } \mathrm{m} \mathrm{r} \mathrm{d} \mathrm{t} \mathrm{l} \text { ) }\end{array}$ & $\begin{array}{c}\text { Intervalos } \\
\text { melódicos } \\
\text { 2a } \mathrm{M} / \mathrm{m} ; 3 \text { a } \mathrm{M} / \mathrm{m} \text {; } \\
\text { 4a } \mathrm{J}\end{array}$ \\
\hline \multicolumn{5}{|c|}{$\begin{array}{l}\text { Escala - Modo Hexatônico de G menor } \\
\text { (a) }\end{array}$} \\
\hline
\end{tabular}

Sugestões de atividades didático-pedagógicas:

Células rítmicas para registro gráfico:

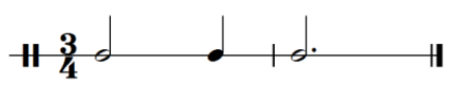

Células melódicas para registro gráfico:

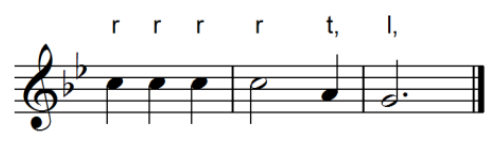

Possível ostinato rítmico:

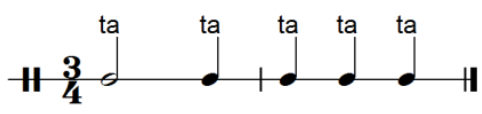

Possível ostinato melódico:

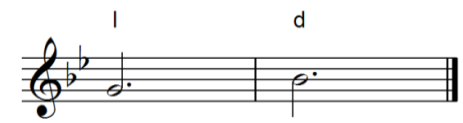

Análise complementar em 2.2 - $n^{\circ} 130$.

Tema de Villa-Lobos com inspiração popular, com 10 compassos ternários, com a indicação: Allegretto Moderato; sem indicações de dinâmica.

Ritmo - o interesse rítmico está nos ostinatos.

Melodia - desenvolve-se por linha descendente em seqüencia por graus conjuntos de desenho em terças quebradas, finalizando na tônica.

Ludicidade - caracterizada por valsa brasileira, pode sugerir uma dança propícia para a percepção do compasso ternário. 
66) ANQUINHAS - a capella
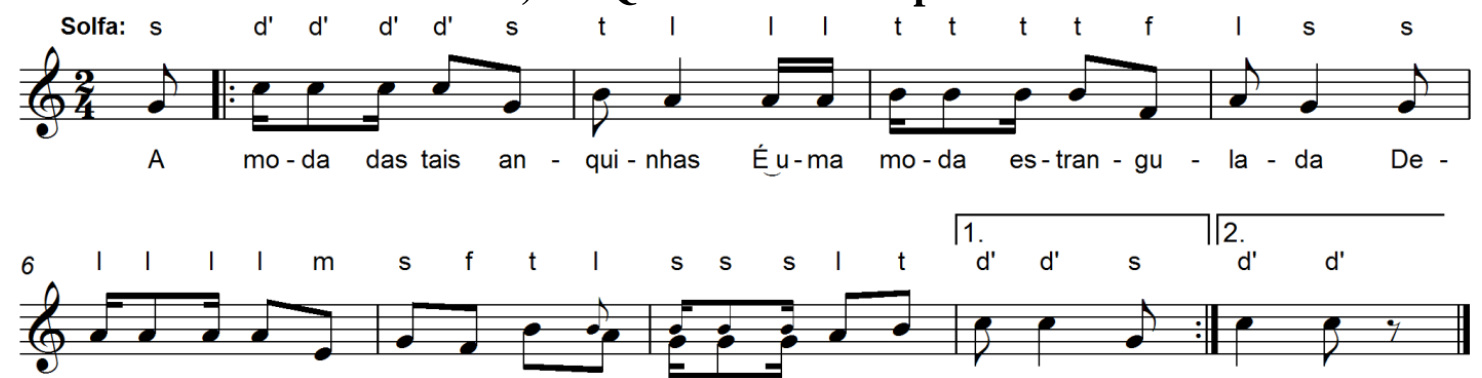

pois de jo-e-lho_em ter - ra Faz a gen-te fi-car pas - ma - da Fu__ bra - ço

\begin{tabular}{|c|c|c|c|c|}
\hline $\begin{array}{l}\text { Volume } \\
\text { GP-VTL } \\
\text { /S1 } \\
\text { /ABM }\end{array}$ & $\begin{array}{c}\text { No } \\
9 \\
9 \\
/ 24 \\
/ 30\end{array}$ & $\begin{array}{l}\text { Tessitura } \\
\text { E3-C4 }\end{array}$ & $\begin{array}{c}\text { Forma - A } \\
\text { Gênero - Habanera } \\
\text { Extensão: 6a } \\
\text { Graus da escala: } 6 \\
\text { Sistema Heptatônico (F C G D A E B) } \\
\text { Hexacorde (d t I s f m) }\end{array}$ & $\begin{array}{c}\text { Intervalos } \\
\text { melódicos } \\
\text { 2a } \mathrm{M} / \mathrm{m} ; 4 \text { a j/A }\end{array}$ \\
\hline & & & $\begin{array}{l}\text { a - Modo Defectivo de C maior } \\
\boldsymbol{\theta} \quad \boldsymbol{\theta} \mathbf{0} \\
\end{array}$ & \\
\hline
\end{tabular}

Sugestões de atividades didático-pedagógicas:

Células rítmicas para registro gráfico:

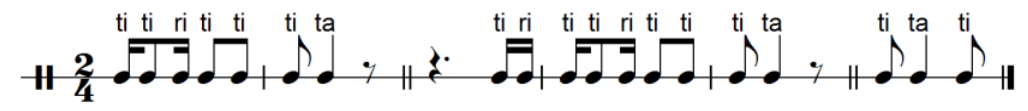

Células melódicas para registro gráfico:

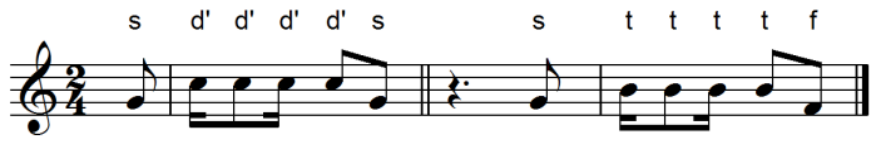

Possível ostinato rítmico:

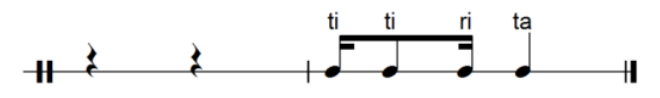

Possível ostinato melódico:

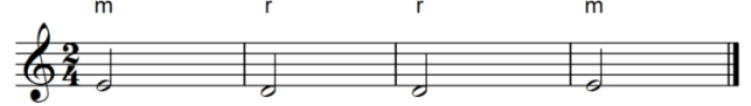

Análise complementar em $2.2-n^{\circ} 14$.

Canção com 10 compassos binários, com a indicação de andamento: Andantino $(76=$ ل ); indicações de dinâmica: $f \boldsymbol{f}$

Tema popular, folclórico infantil, de brincadeira cantada cujo desenvolvimento baseia-se no texto.

Texto - descrição de acessório feminino que servia para armar as saias nos quadris, firmemente presas à cintura ("à estrangulação").

Ritmo - de dança, caracterizada pelas síncopas seguidas de duas colcheias em compasso binário.

Melodia - abordagens por quartas ascendentes, com sequências de desenhos descendentes por graus conjuntos, com terminação em tetracorde ascendente para a T.

Ludicidade - brincadeira cantada e dançada, com representação e mímica segundo o texto. 
Complemento do texto ${ }^{41}$ :

A moda das tais anquinhas / é uma moda estrangulada / depois de joelho em terra / faz a gente ficar pasmada. Fulana, sacode a saia / Fulana abre teus braços / Fulana tem dó de mim / Fulana dá-me um abraço.

\section{7) O GATO - acompanhamento instrumental}

(Canto com Piano, ou conjunto instrumental)

Arr. de H.Villa-Lobos

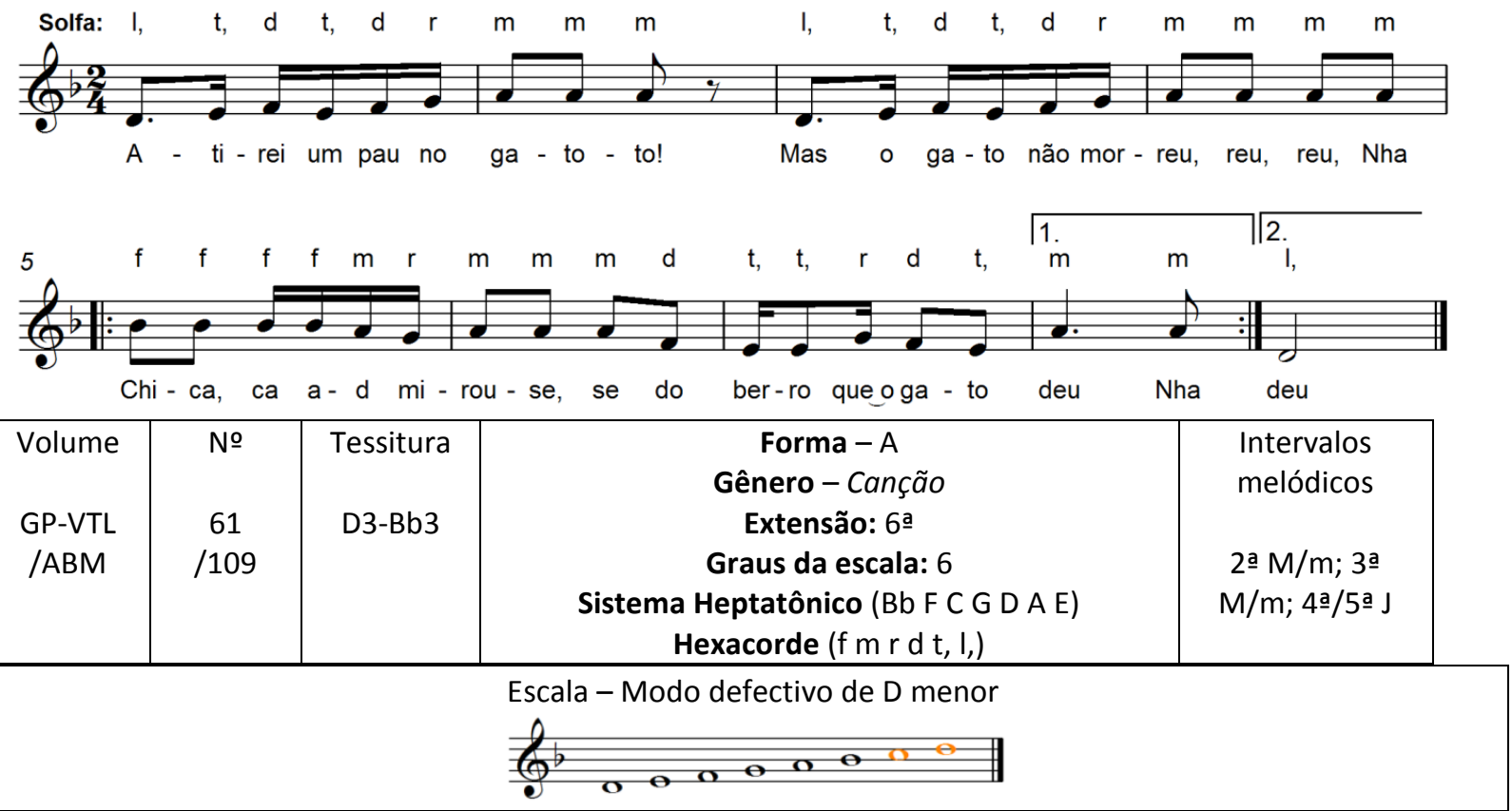

Sugestões de atividades didático-pedagógicas:

Células rítmicas para registro gráfico:

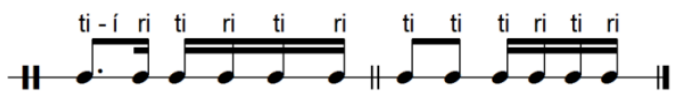

Células melódicas para registro gráfico:

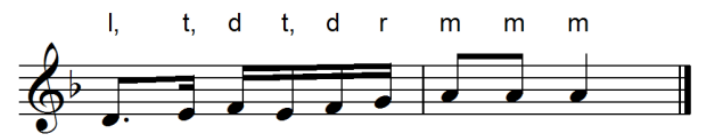

Possível ostinato rítmico:

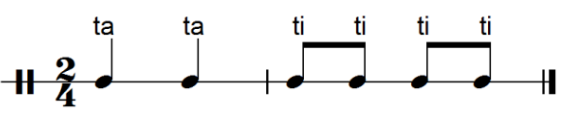

Canção popular, de 9 compassos binários, com a indicação de andamento: Andantino quasi allegretto $(\mathbf{1 0 4}=」)$ ); indicações de dinâmica: $\boldsymbol{m f} ; \boldsymbol{f f}$; acentos >

Tema popular, folclórico infantil, de brincadeira cantada cujo desenvolvimento baseia-se no texto.

Texto - O texto humorístico ${ }^{42}$ caracteriza-se pelas repetições de sílabas e da idéia fantasiosa do "berro" do gato.

\footnotetext{
${ }^{41}$ GP/ ABM Primeiro Caderno, p. 74, registra a segunda estrofe sugerida, porém ausente em GP/VTL. Fonte: G. $\& \mathrm{~J}$.

${ }^{42}$ O texto é de caráter humorístico, não cabendo "correções" como: "não atire o pau no gato" e outras, o que descaracteriza o propósito e a intenção original da letra da música.
} 
Ritmo - o interesse rítmico está na possibilidade de confrontar a célula de quatro

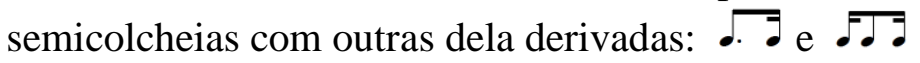

Melodia - a proposta está em linha ascendente no pentacorde menor; a resposta segue para o hexacorde, vai para a subdominante menor, e em movimento de curva convexa termina na $D$ na primeira vez, e na tônica na repetição.

Ludicidade - brincadeira propícia para estimular a criatividade, havendo muitas possibilidades de soluções lúdicas, a partir do texto humorístico.

\section{8) SAMBA LELE - acompanhamento instrumental}

(Canto com Piano, ou conjunto instrumental ou Piano solo)

Arr. de H.Villa-Lobos
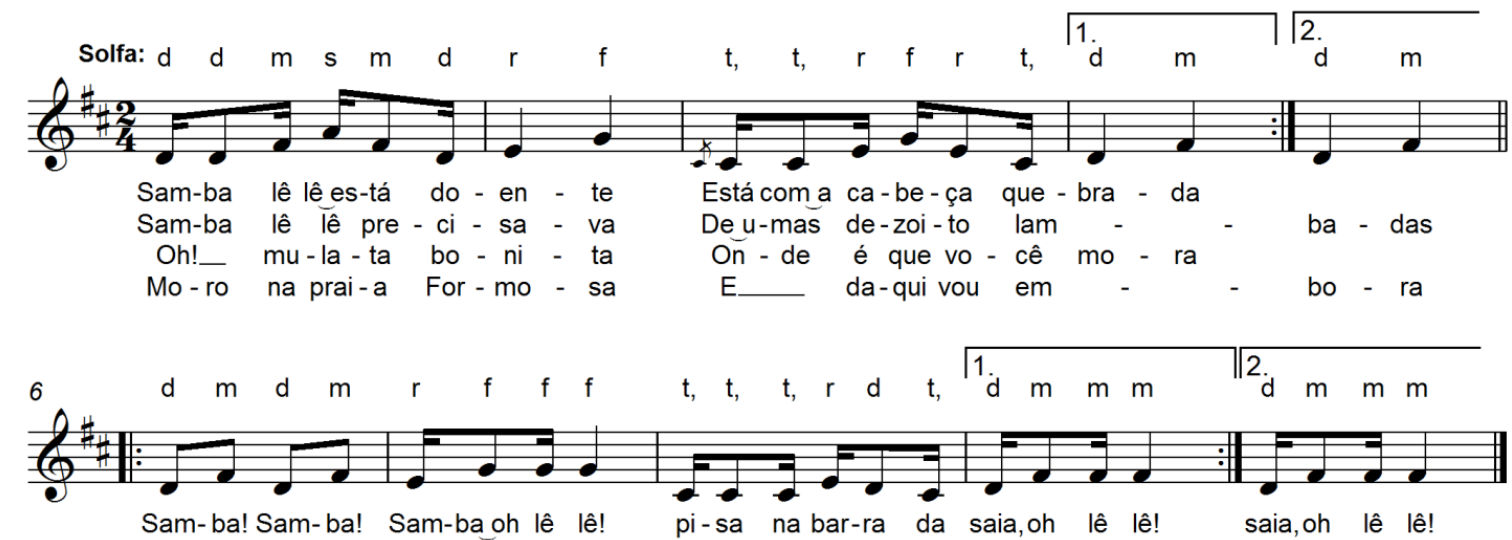

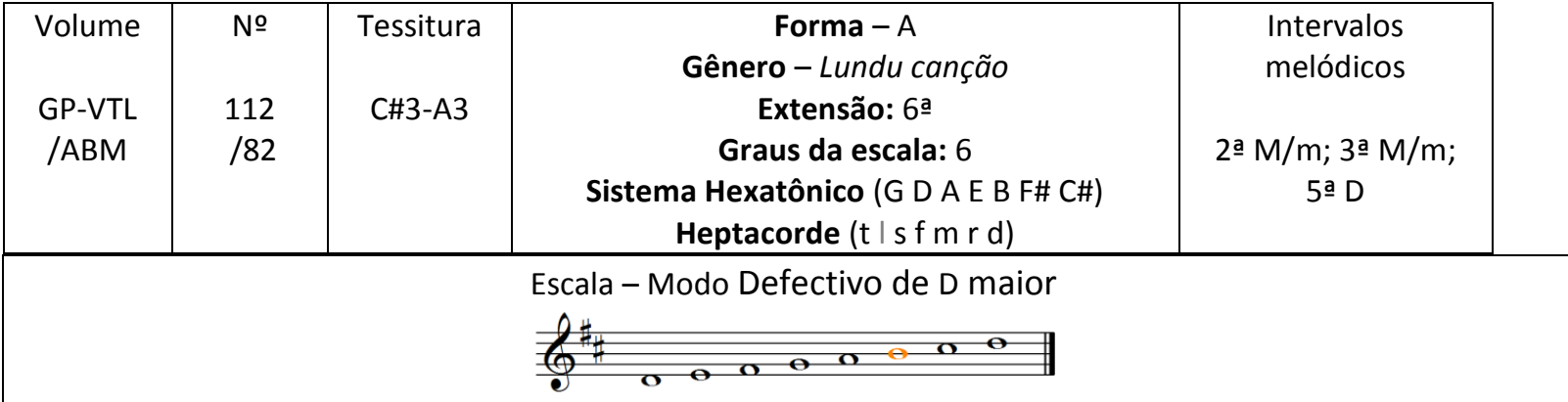

Sugestões de atividades didático-pedagógicas:

Células rítmicas para registro gráfico:

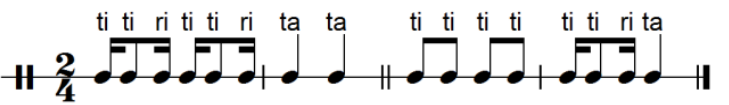

Células melódicas para registro gráfico:

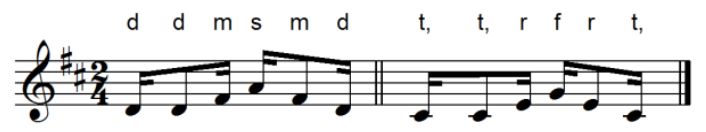

Possível ostinato rítmico:

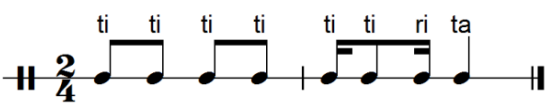

Possível ostinato melódico:

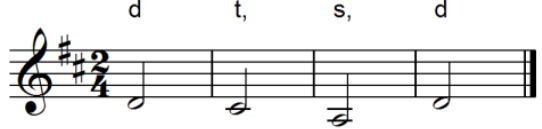


Canção com 10 compassos binários, com a indicação: Poco Lento $(69=$ ل ); indicações de dinâmica: acentos > _

Tema popular, folclórico infantil, de brincadeira cantada cujo desenvolvimento baseia-se no texto.

Texto - em forma estrófica, com refrão. Descrição de brincadeira de roda, em que Lelê é o personagem que tem a cabeça quebrada e apanha pela traquinagem feita. Na codeta aparece um recurso timbrístico - B.C. - que prepara a entrada da segunda estrofe.

Ritmo - o interesse rítmico está síncopas.

Melodia - desenvolve-se sobre as tríades de $\mathrm{T}$ e $\mathrm{D}$, em arpejos ascendentes e descendentes. A melodia da codeta repete a linha melódica da introdução. Em GP/ABM parece ser mais coerente com a versão GP/VTL que a segunda casa do ritornello seja no compasso 31, cortando-se os compassos 27 a 30. Nos compassos 4 e 30, o último acorde da mão direita deve ter as notas: $\boldsymbol{G} \boldsymbol{C} \boldsymbol{E}$ e não $\boldsymbol{A} \boldsymbol{C} \boldsymbol{E}$.

Acompanhamento instrumental (piano) - a introdução, com ostinato rítmico na mão esquerda, apresenta, na direita, uma linha melódica que sai da terça da $\mathrm{T}$, segue para a $\mathrm{D}^{5+}$, volta para a $\mathrm{T}$, passa pela tônica menor e termina na $\mathrm{T}$. A melodia é apresentada alternadamente pela mão direita e esquerda, sobre ostinatos. No refrão, há um acompanhamento harmônico, com a melodia na mão direita, sobre T D D T. A codeta repete a introdução, com indicação de B.C. para a melodia cromática que resolve na $\mathrm{T}$, partindo do terceiro grau. A coda tem dois compassos sobre o acorde de $\mathrm{T}$.

Ludicidade - brincadeira que se baseia na coreografia do lundu e dos movimentos em roda.

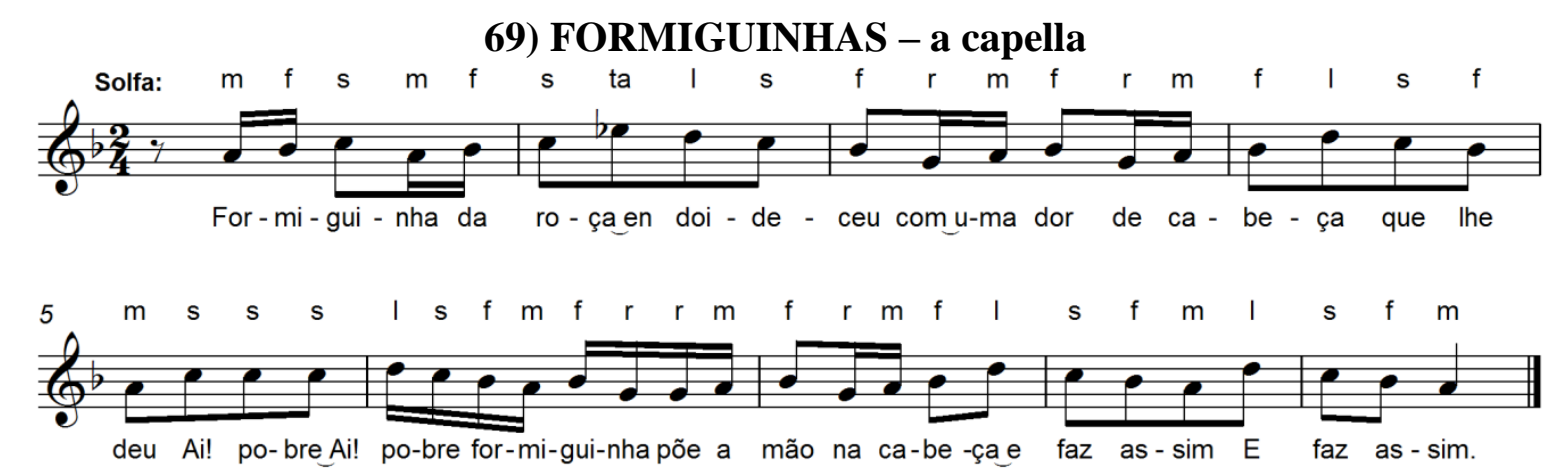

\begin{tabular}{|c|c|c|c|c|}
\hline $\begin{array}{l}\text { Volume } \\
\text { GP-VTL } \\
\text { /S1 } \\
\text { /ABM }\end{array}$ & $\begin{array}{l}\text { № } \\
52 \\
/ 33 \\
/ 17\end{array}$ & $\begin{array}{l}\text { Tessitura } \\
\text { G3-Eb4 }\end{array}$ & $\begin{array}{c}\text { Forma - A } \\
\text { Gênero - Cantiga } \\
\text { Extensão: 6a } \\
\text { Graus da escala: } 6 \\
\text { Sistema Heptatônico (Bb F C G D A E) } \\
\text { Heptacorde (ta I s f m r d) }\end{array}$ & $\begin{array}{c}\text { Intervalos } \\
\text { melódicos } \\
\text { 2a } \mathrm{M} / \mathrm{m} ; 3^{\mathrm{a}} \mathrm{m} ; 4 \text { a }\end{array}$ \\
\hline \multicolumn{5}{|c|}{ 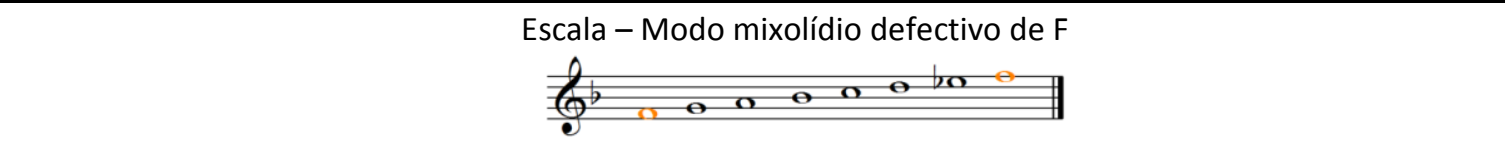 } \\
\hline \multicolumn{5}{|c|}{ Sugestões de atividades didático-pedagógicas: } \\
\hline \multicolumn{5}{|c|}{ Células rítmicas para registro gráfico: } \\
\hline
\end{tabular}


Células melódicas para registro gráfico:

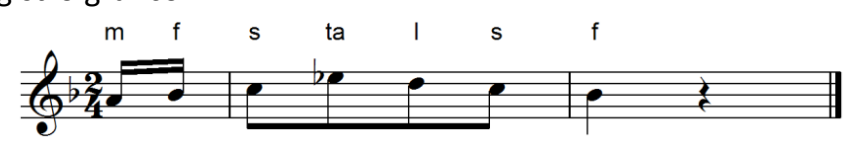

Possivel ostinato rítmico:

$$
\# 2^{\text {ta }} \cdot
$$

Análise complementar em $2.2-n^{\circ} 79$.

Canção com 19 compassos binários, com a indicação de andamento: Andantino (M.M. $84=$ ل ); sem indicações de dinâmica.

Tema popular, folclórico infantil de brincadeira cantada cearense ${ }^{43}$.

Texto - descrição de canção de roda.

Ritmo - o interesse rítmico está em sobrepor a célula de quatro semicolcheias às demais constantes da melodia.

Melodia - desenhos sobre terças preenchidas ou em saltos, ascendentes e descendentes, formando pequenas curvas com resoluções na Sr, T, D e T.

Ludicidade - o texto descreve as possíveis mímicas para as idéias descritas.

\section{0) NIGUE NINHAS - a capella}

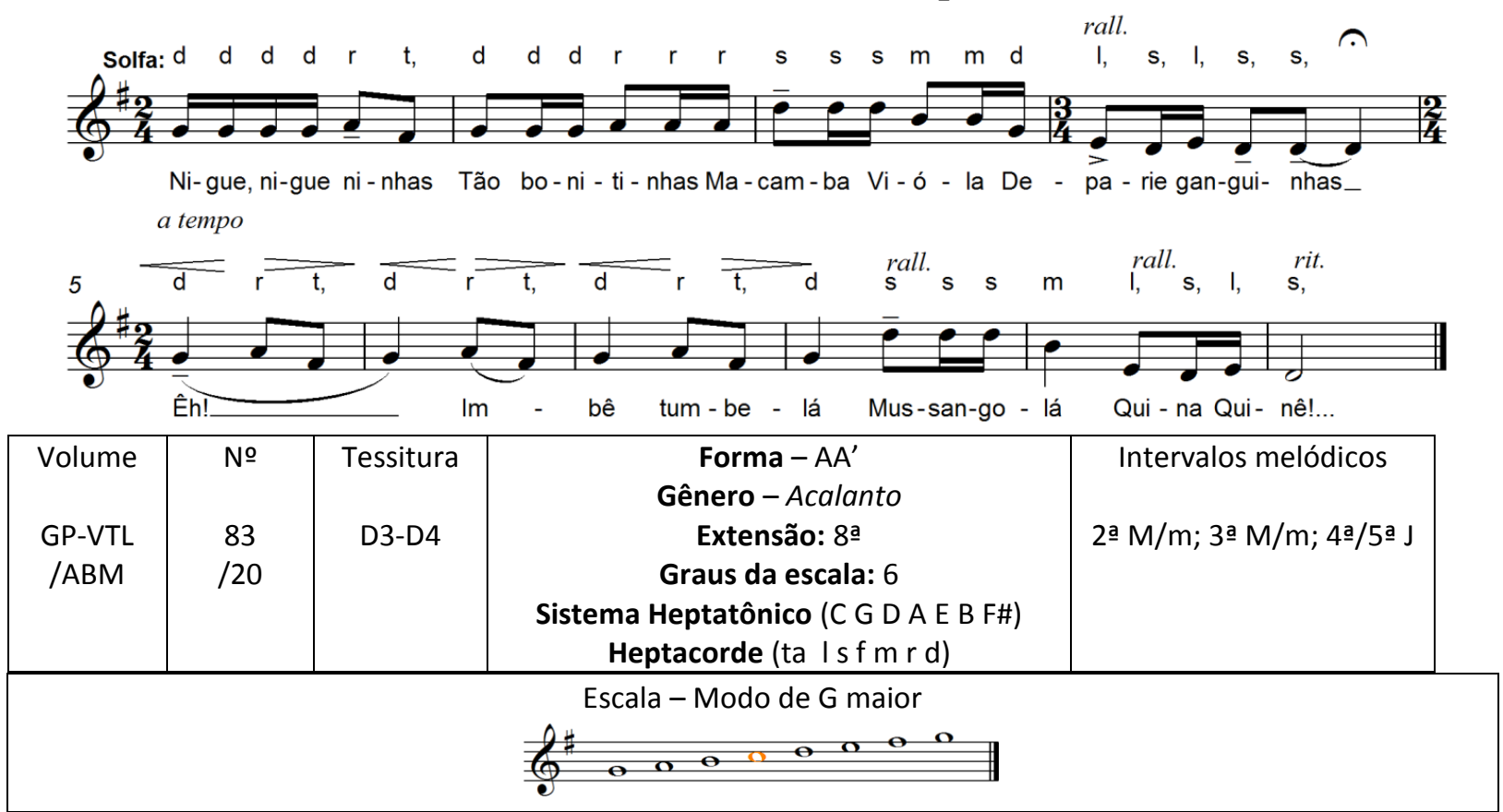

Sugestões de atividades didático-pedagógicas:

43 Notas de Villa-Lobos em GP/VTL: a) "Como cantam as crianças no Ceará. - Cantado pela professora Consuelo Pinheiro". b) "Quando tocado ao piano, toda a parte da mão esquerda deve ser executada uma oitava abaixo". 
Células rítmicas para registro gráfico:

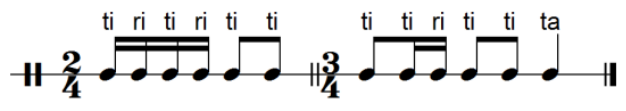

Células melódicas para registro gráfico:

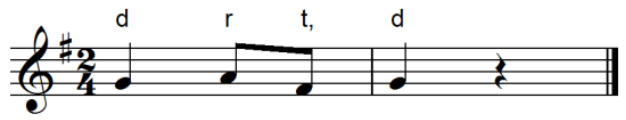

Análise complementar em $2.2-n^{\circ} 75$.

Canção com 11 compassos binários e 2 ternários, com a indicação de andamento: Acalanto (M.M. 58= ل ); Rallentando com fermata / a tempo; rall. Rall. Rit.; indicações de dinâmica: ppp ; < > ; acentos > _

Tema popular, folclórico infantil, de canção de ninar.

Texto - híbrido, com expressões em português e idioma africano. GP/ABM corrige mussangolá (mussangalá em GP/VTL), segundo texto original de Mário de Andrade (GP/ABM - $1^{\circ}$ Caderno, p. 85)

Ritmo - binário, tético, subdivisão binária, com ênfase na célula

Melodia - caracteriza-se pelas notas rebatidas, com preponderância de saltos de terças.

Ludicidade - Canção de ninar, cujo texto sem tradução possibilita a criatividade gestual segundo o tema.

\section{1) POBRE PEREGRINO - acompanhamento instrumental}
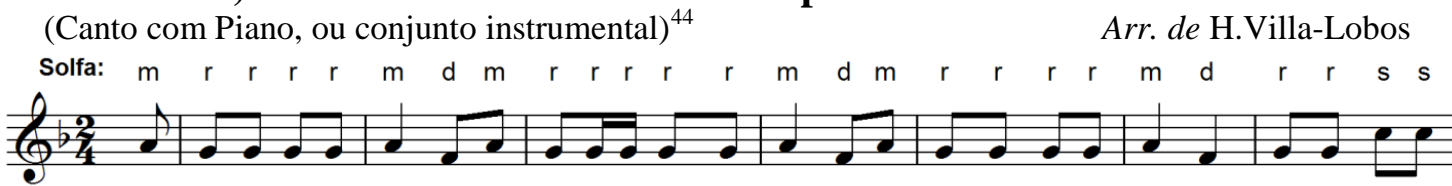

O po-bre pe-re - gri - no, que an-dade por-ta_em por - ta, pe - din-do u-ma es - mo - la Pe-lo_a-morde
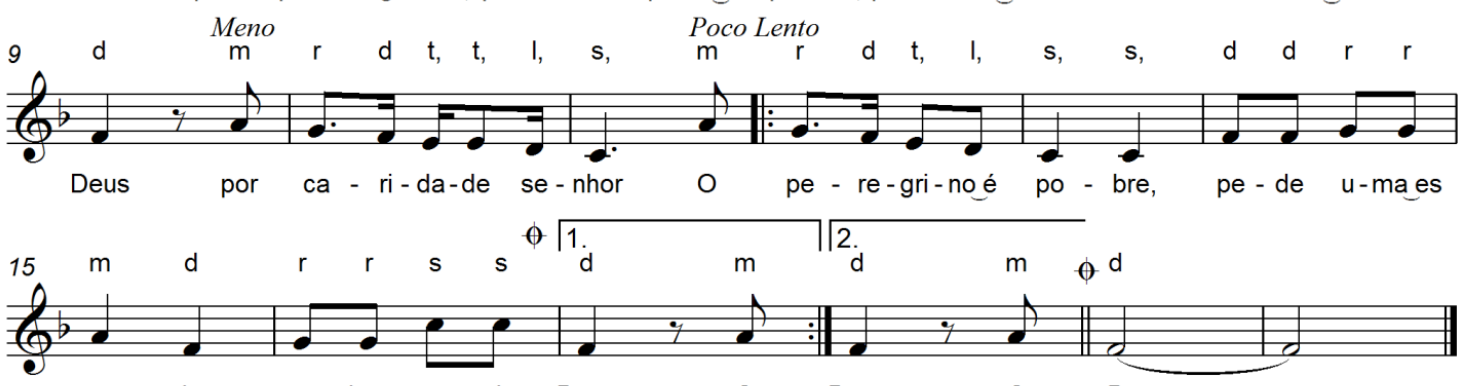

mo - la pe-loa-mor de Deus O Deus O Deus_

\begin{tabular}{|c|c|c|c|c|}
\hline & & & D.C. al Coo & \\
\hline \multirow[t]{2}{*}{ Volume } & & & Gênero - Canção & melódicos \\
\hline & 99 & C3-C4 & Extensão: 8aㅗ & \\
\hline \multirow{2}{*}{$\begin{array}{l}\text { GP-VTL } \\
\text { /ABM }\end{array}$} & /99 & & Graus da escala: 6 & 2a $\mathrm{M} / \mathrm{m} ; 3^{\mathrm{a}}$ \\
\hline & & & $\begin{array}{c}\text { Sistema Heptatônico (Bb F C G D A E) } \\
\text { Heptacorde (t I s f m r d) }\end{array}$ & $\begin{array}{c}\mathrm{M} / \mathrm{m} ; 4 \underline{\mathrm{a}} / 5^{\mathrm{a}} \mathrm{J} ; 6^{\mathrm{a}} \\
\mathrm{M}\end{array}$ \\
\hline
\end{tabular}

Escala - Modo defectivo de F maior

\footnotetext{
${ }^{44}$ Em GP/VTL não consta indicação "Piano Solo", como informa GP/ABM - 2 Caderno, p. 127.
} 


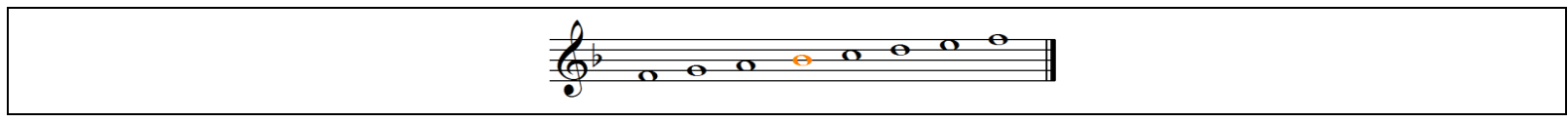

Sugestões de atividades didático-pedagógicas:

Células rítmicas para registro gráfico:

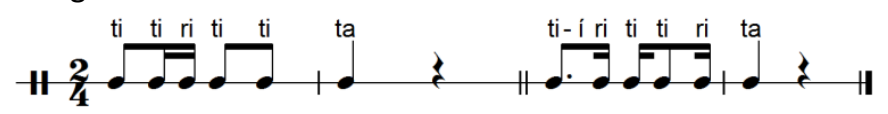

Células melódicas para registro gráfico:

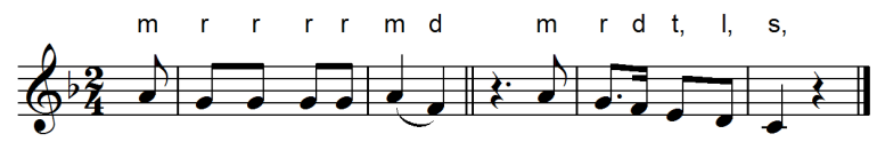

Possivel ostinato rítmico:

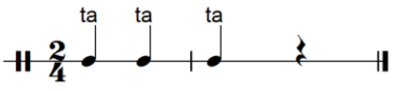

Canção com 20 compassos binários, com a indicação de andamento: Poco Animato $(\mathbf{1 3 2}=$ ل ); indicações de dinâmica: $s f z ; \boldsymbol{p}$. Em GP/ABM falta a expressão poco rall. nos compassos 8 e 16

Tema popular folclórico recolhido por Villa-Lobos, com pseudônimo de Epaminondas Villalba Filho.

Texto - Descrição de pedido de esmolas por pedintes peregrinos.

Ritmo - o interesse rítmico está nas variações de andamento.

Melodia - parte $\mathrm{A}^{45}$ : motivo em âmbito de terça maior com terminação na $\mathrm{T}$ repetido duas vezes: na primeira frase e iniciando a segunda frase, com conclusão por salto ascendente de quarta e descendente de quinta na T; uma pequena ponte em hexacorde descendente introduz a segunda parte. $A^{\prime}$ - repetição do hexacorde descendente, e repetição da segunda frase da parte A.

Acompanhamento instrumental (piano) - na primeira parte apresenta contrastes entre uníssonos e acordes que oscilam entre $\mathrm{Tr}$ e $\mathrm{T}$. Na segunda parte a mão direita dobra a melodia, acompanhada harmonicamente pela mão esquerda com pequenos cromatismos em acordes de funções primárias da tonalidade.

Ludicidade - texto propício para encenações e mímicas.

72) A DANÇA DA CARRANQUINHA - a capella

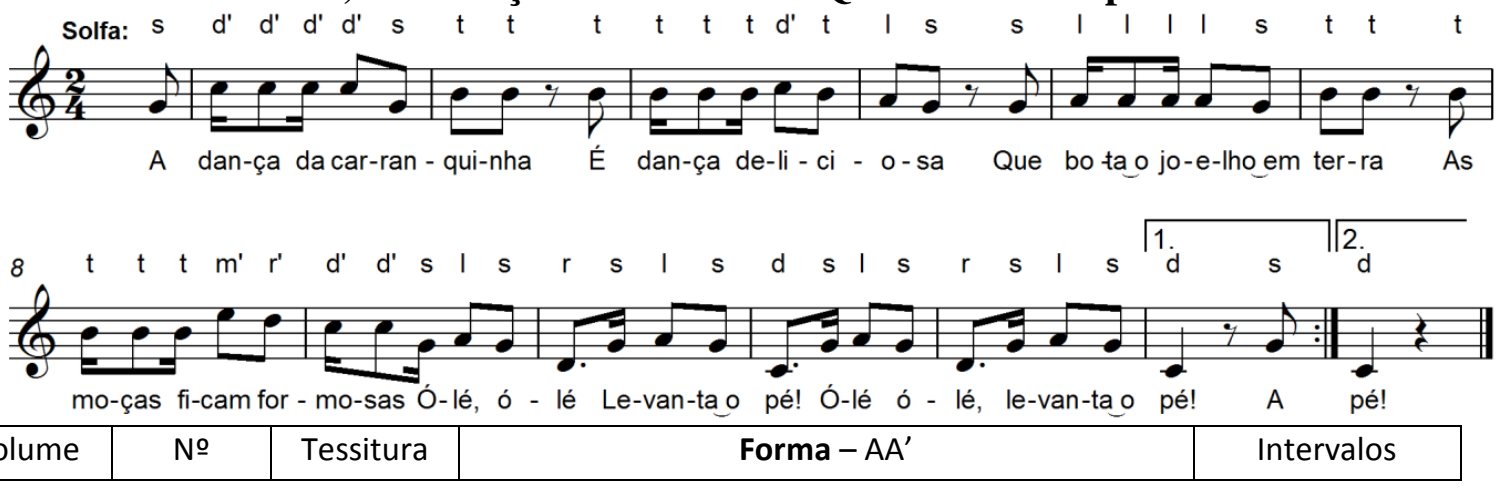

\footnotetext{
${ }^{45}$ A melodia da parte A é idêntica a uma variante da canção "Que é da Margarida”, que consta no Guia Prático com outra melodia.
} 


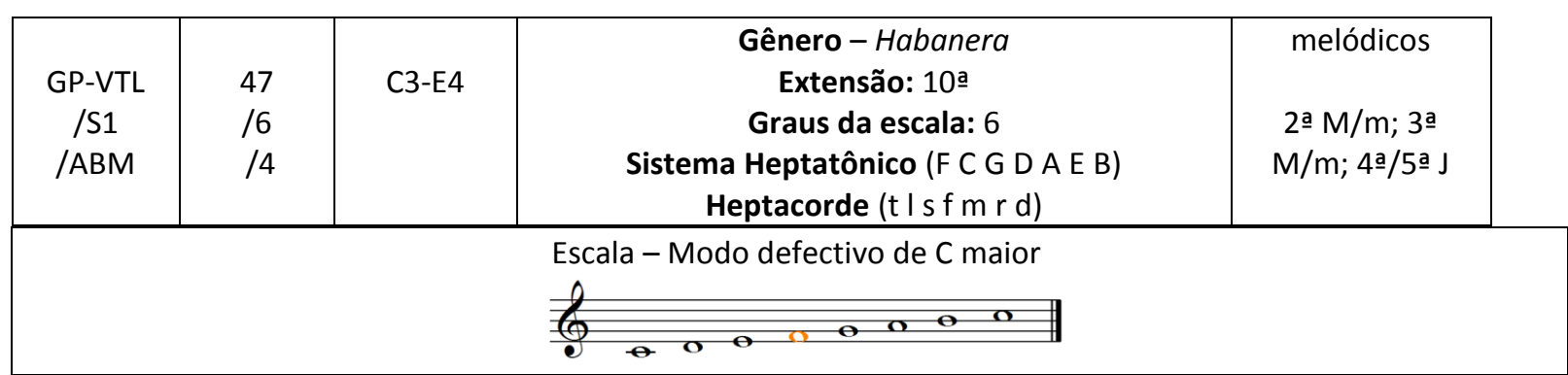

Sugestões de atividades didático-pedagógicas:

Células rítmicas para registro gráfico:

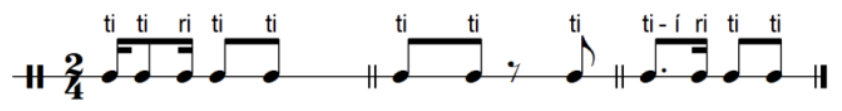

Células melódicas para registro gráfico:

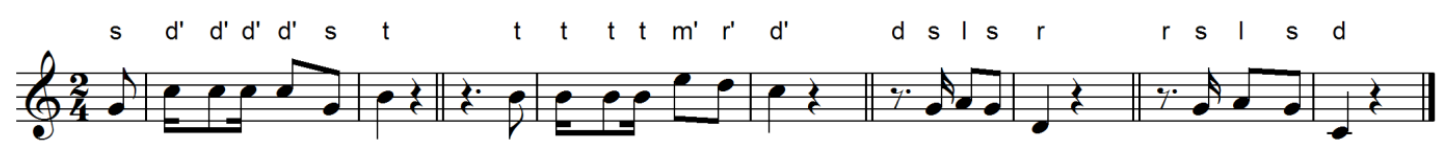

Possivel ostinato rítmico:

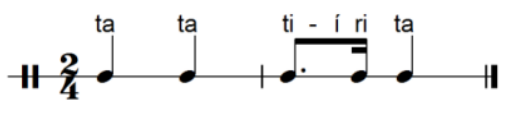

Canção com 14 compassos binários, com a indicação de andamento: Poco Andantino (M.M. $80=\downarrow$ ); sem indicações de dinâmica.

Tema popular, folclórica, de origem portuguesa.

Texto - descrição da dança da carranquinha, na qual as moças ficam formosas realizando a coreografia.

Ritmo - o interesse rítmico está na formação de contratempos nos inícios dos primeiros motivos. Segundo GP/ABM, $1^{\circ}$ Caderno, p.81, Mário de Andrade classifica o ritmo dessa canção como "caracteristicamente um lundum brasileiro, daqueles em rítmo (sic) de habanera".

Melodia - a primeira frase contém duas pequenas curvas finalizando por salto ascendente na $\mathrm{D}$ e por grau conjunto descendente na $\mathrm{T}$; a segunda frase repete o primeiro desenho, e o segundo termina com linha descendente por grau conjunto na $\mathrm{T}$; a terceira frase repete dois desenhos com bordadura superior e salto descendente - uma vez na D outra na T.

Ludicidade - o texto descreve a coreografia.

\section{$\underline{\text { 2.1.3.4 Sobre sete graus da escala }}$}



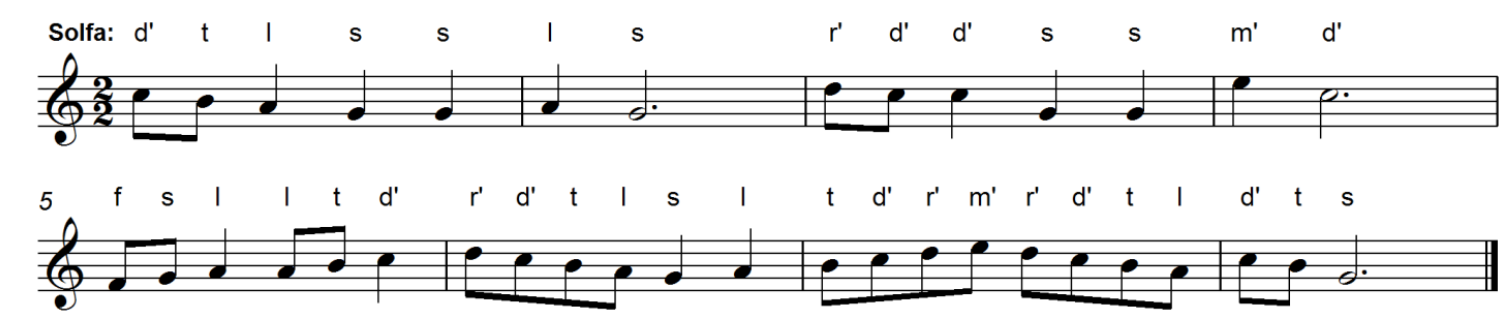

\begin{tabular}{|c|c|c|c|c|}
\hline $\begin{array}{l}\text { Volume } \\
\text { S1 }\end{array}$ & № & $\begin{array}{l}\text { Tessitura } \\
\text { F3-E4 }\end{array}$ & $\begin{array}{c}\text { Forma - A } \\
\text { Extensão: } 7 \text { a } \\
\text { Graus da escala: } 7 \\
\text { Sistema Heptatônico (F C G D A E B) } \\
\text { Heptacorde ( } \mathrm{f} \mathrm{m} r \mathrm{~d} \text { I s) }\end{array}$ & 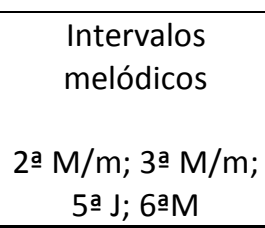 \\
\hline \multicolumn{5}{|c|}{ Escala - Modo Mixolídio em G } \\
\hline
\end{tabular}

\section{Sugestões de atividades didático-pedagógicas:}

Células rítmicas para registro gráfico:

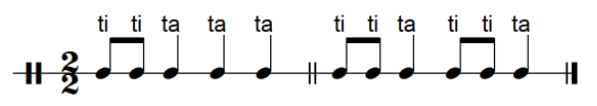

Células melódicas para registro gráfico:

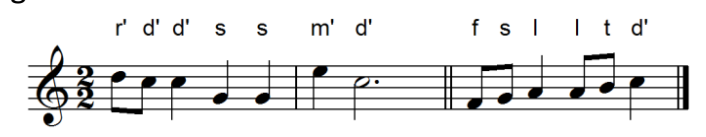

Possivel ostinato rítmico

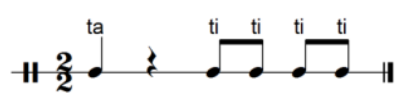

Análise complementar em $2.2-n^{\circ} 138$.

Tema de Villa-Lobos com 8 compassos binários, com a indicação de andamento: Andantino; sem indicações de dinâmica.

Ritmo - o interesse rítmico está na mínima como unidade de pulsação.

Melodia - predominância de graus conjuntos, com apenas um salto de quinta justa, um de quarta justa e um de sexta maior.

Ludicidade - apesar de se tratar de um solfejo, podem ser criados jogos a partir da sucessão dos intervalos melódicos, por exemplo.

74) SOLFEJO $n^{\circ} 38$ - a capella

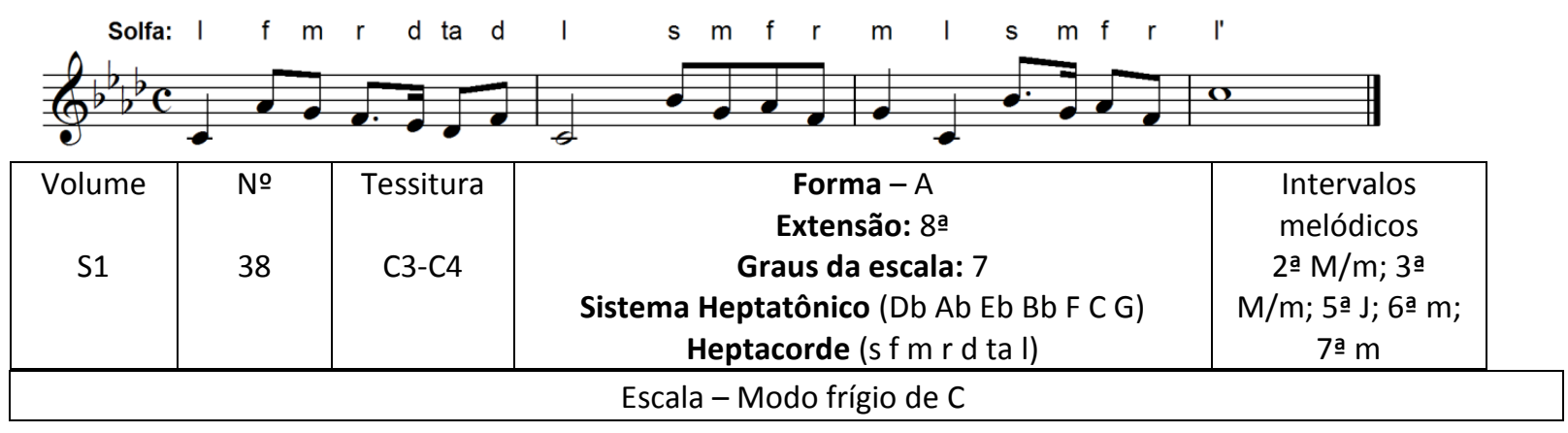




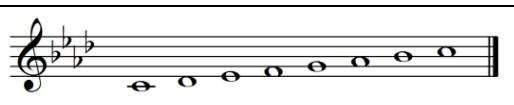

Sugestões de atividades didático-pedagógicas:

Células rítmicas para registro gráfico:

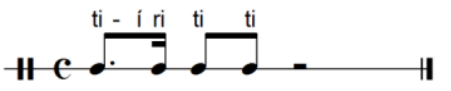

Células melódicas para registro gráfico:

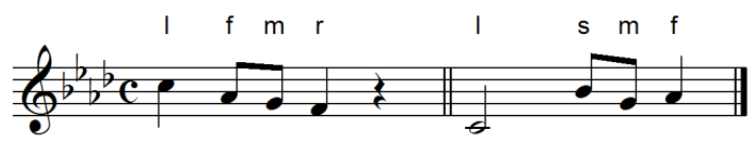

Possivel ostinato rítmico:

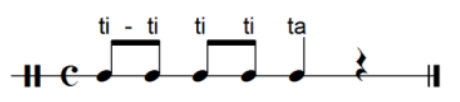

Tema de Villa-Lobos, com 4 compassos quaternários, sem indicação de andamento ou de dinâmica.

Ritmo - o interesse está nas células rítmicas seguidas de notas longas.

Melodia - em modo frígio, a pergunta se inicia por salto de sexta menor ascendente, e a resposta dupla realça terças quebradas alcançadas por saltos ascendentes de sétima menor.

Ludicidade - apesar de se tratar de um solfejo, a sonoridade do modo frígio pode proporcionar inspiração para várias soluções lúdicas.

\section{5) O CASTELO - acompanhamento instrumental}

(Canto com Piano, ou conjunto instrumental ou Piano Solo) Amb. por H.Villa-Lobos

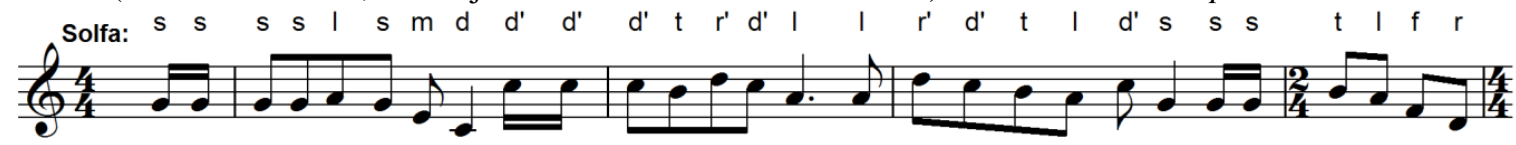

O Cas - te-lo pe-gou fo-go São Fran - cis-co deu si-nal A - cu-da a-cu-da a-cu-da A ban - dei-ra na-cio

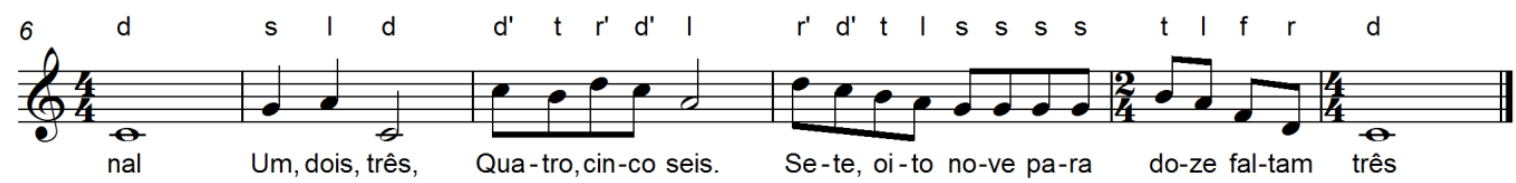

\begin{tabular}{|c|c|c|c|c|}
\hline $\begin{array}{l}\text { Volume } \\
\text { GP-VTL } \\
\text { /ABM }\end{array}$ & $\begin{array}{l}\text { № } \\
32 \\
/ 76\end{array}$ & $\begin{array}{l}\text { Tessitura } \\
\text { C3-D4 }\end{array}$ & $\begin{array}{c}\text { Forma - A } \\
\text { Gênero - Marcha } \\
\text { Extensão: 9a } \\
\text { Graus da escala: } 7 \\
\text { Sistema Heptatônico (F C G D A E B) } \\
\text { Heptacorde (t I s f m r d) }\end{array}$ & $\begin{array}{c}\text { Intervalos } \\
\text { melódicos } \\
\text { 2a } \mathrm{M} / \mathrm{m} ; 3 \text { a } \mathrm{M} / \mathrm{m} \text {; } \\
\text { 4a } / 8 \text { a j; 6a } \mathrm{M}\end{array}$ \\
\hline \multicolumn{5}{|c|}{ Escala - Modo de C maior } \\
\hline
\end{tabular}

Sugestões de atividades didático-pedagógicas:

Células rítmicas para registro gráfico:

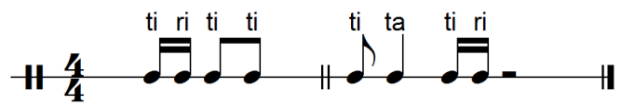

Células melódicas para registro gráfico: 


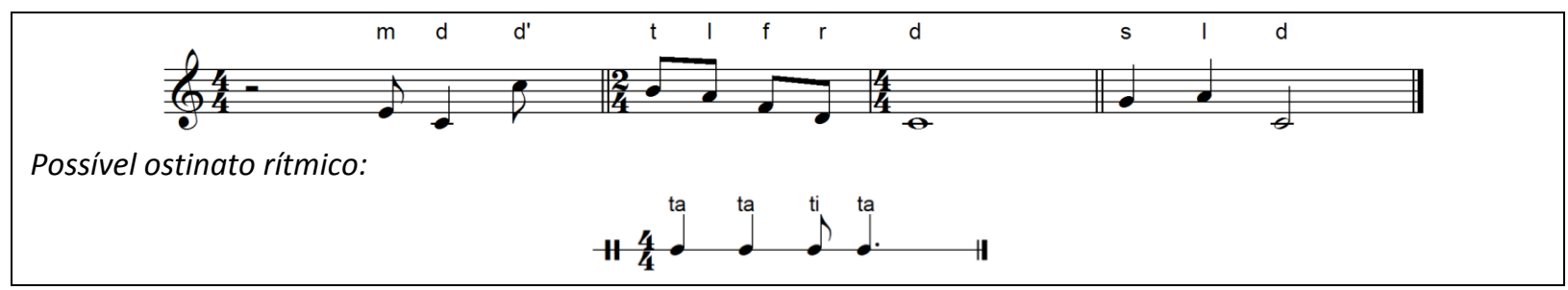

Canção com 11 compassos quaternários e 2 binários, com a indicação de andamento: Movimento de Marcha (Animado) M.M. 132= $\downarrow$; indicações de dinâmica: Acentos $>v$; cresc. ; ff ; ffff

Tema popular, folclórico infantil, de brincadeira cantada.

Texto - sobre uma história medieval de incêndio num castelo, com a participação de S. Francisco para salvar a bandeira nacional. Preferimos a prosódia segundo GP/VTL no compasso 11, pois em GP/ABM os acentos tônicos estão deslocados desnecessariamente.

Ritmo - o compasso binário é o mais adequado para essa melodia, o que evitaria a troca de fórmula de compasso.

Melodia - desenhos sobre $\mathrm{T}^{6}$ e $\mathrm{F}^{6}$ seguidos de linhas descendentes com finalização na T. Em GP/ABM na quarta pulsação, a última nota aguda do compasso 7 na mão direita é $\boldsymbol{G}$ e não $\boldsymbol{B}$.

Acompanhamento instrumental (piano) - a introdução (com 8 compassos) apresenta o ostinato em oitavas (sobre quartas descendentes) que será utilizado em toda a peça, com exceção de poucos compassos, na mão esquerda. A mão direita, inicialmente acompanhando o baixo, desenvolve uma linha descendente para finalizar a introdução, e segue dobrando a melodia. A coda repete a introdução, acrescentando mais dois compassos para resolução na $\mathrm{T}^{6}$, com serialização de níveis de dinâmica: cresc. ff ffff.

Ludicidade - cortejo: o autor acrescenta no primeiro compasso a nota: "Com imponência", o que sugere uma imponente marcha da corte - são várias as possibilidades de criação para a interpretação, a começar de um eventual figurino.

76) SAPO JURURU - a capella

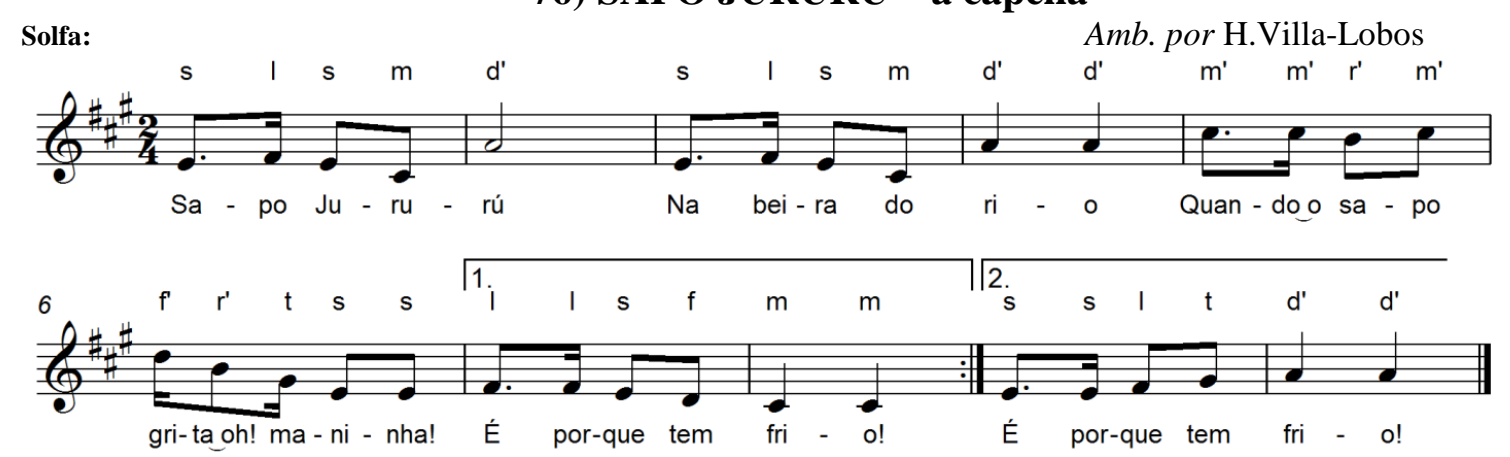

\begin{tabular}{|c|c|c|c|c|}
\hline $\begin{array}{l}\text { Volume } \\
\text { GP-VTL } \\
\text { /ABM }\end{array}$ & $\begin{array}{l}\text { № } \\
113 \\
\text { / } 41\end{array}$ & $\begin{array}{l}\text { Tessitura } \\
\text { C\#3-D4 }\end{array}$ & $\begin{array}{c}\text { Forma - A } \\
\text { Gênero - Cantiga do Norte sertaneja } \\
\text { Extensão: 9ạ } \\
\text { Graus da escala: } 7 \\
\text { Sistema Heptatônico (D A E B F\# C\# G\#) } \\
\text { Heptacorde (t I s f m r d) }\end{array}$ & $\begin{array}{c}\text { Intervalos } \\
\text { melódicos } \\
\text { 2a } \mathrm{M} / \mathrm{m} ; 3 \text { a } \\
\mathrm{M} / \mathrm{m} ; 4 \text { a j; 6a } \mathrm{m}\end{array}$ \\
\hline \multicolumn{5}{|c|}{ Escala - Modo de A maior } \\
\hline
\end{tabular}




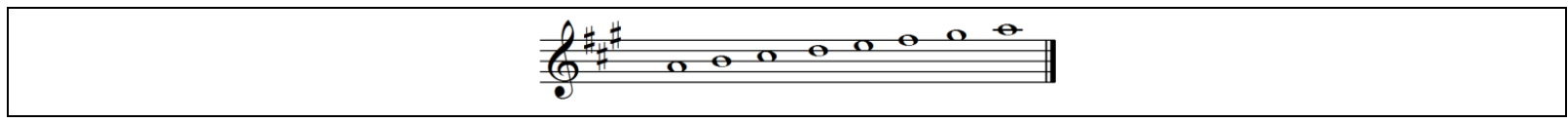

Sugestões de atividades didático-pedagógicas:

Células rítmicas para registro gráfico:

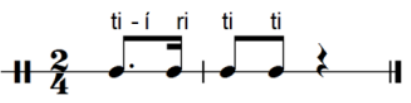

Células melódicas para registro gráfico:

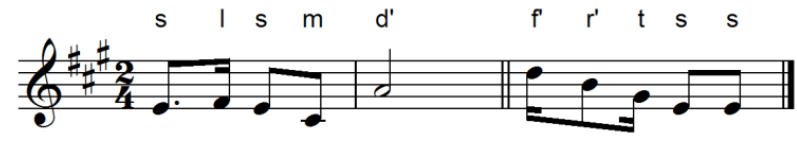

Possivel ostinato rítmico:

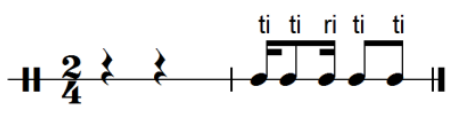

Análise complementar em $2.2-n^{\circ} 35$.

Canção com 10 compassos binários, com a indicação de andamento: Andante M.M. 72= ل ; sem indicações de dinâmica.

Tema popular, folclórico infantil, de brincadeira cantada.

Texto - Descrição de brincadeira de roda, em que o sapo Jururu (variante: Cururu) é a personagem central da brincadeira.

Ritmo - binário, de subdivisão binária, segundo a quadratura do texto.

Melodia - salto do quinto grau para o primeiro, passando por notas da tríade da $\mathrm{T}$ na primeira frase, com resposta em linha descendente com arpejo da $\mathrm{D}^{7}$ e finalização por tetracorde ascendente para a $\mathrm{T}$.

Ludicidade - brincadeira de roda que costuma tratar do romance do sapo e sua amada, próprio para a criação de rimas e de interferências na história.

77) SOLFEJO 37 - a capella
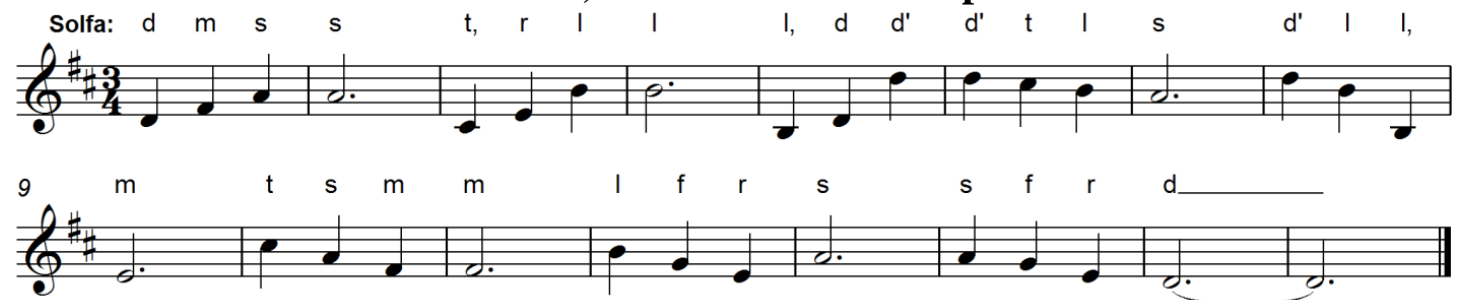

\begin{tabular}{|c|c|c|c|c|}
\hline Volume & $\begin{array}{l}\text { № } \\
37\end{array}$ & $\begin{array}{l}\text { Tessitura } \\
\text { B2-D4 }\end{array}$ & $\begin{array}{c}\text { Forma - A } \\
\text { Gênero - Marcha } \\
\text { Extensão: 10a } \\
\text { Graus da escala: } 7 \\
\text { Sistema Heptatônico (G D A E B F\# C\#) } \\
\text { Heptacorde (t I s f m r d) }\end{array}$ & $\begin{array}{l}\text { Intervalos } \\
\text { melódicos } \\
\text { 2a } \mathrm{M} / \mathrm{m} ; 3 \text { a } \\
\mathrm{M} / \mathrm{m} ; 4 \text { a } / 5 \text { a } \\
\text { /8a J; 6a } \mathrm{M} / \mathrm{m}\end{array}$ \\
\hline \multicolumn{5}{|c|}{$\begin{array}{lllllllll}0 & 0 & 0 & 0 & 0 & 0 & 0 & 0\end{array}$} \\
\hline
\end{tabular}

Sugestões de atividades didático-pedagógicas:

Células rítmicas para registro gráfico: 


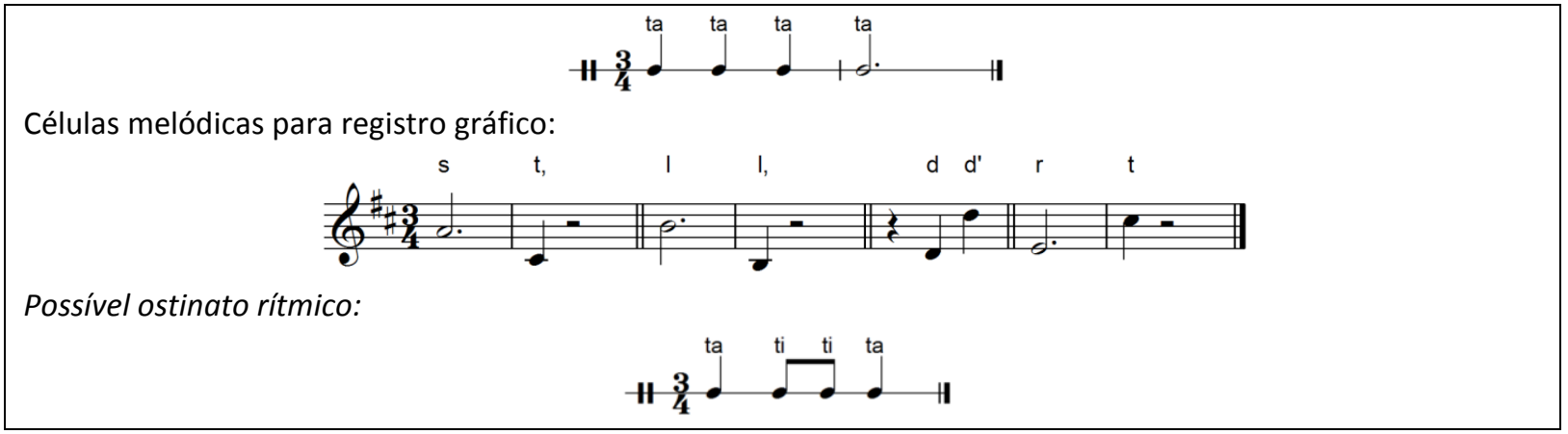

Canção com 16 compassos ternários, sem indicação de andamento ou dinâmica.

Tema de Villa-Lobos, com citação inicial de valsa de J. Strauss (Danúbio Azul).

Ritmo - o interesse rítmico está no compasso ternário.

Melodia - assimétrica, com frases de 7 e 9 compassos, caracteriza-se por arpejos ascendentes na primeira frase (T D e S) e descendentes na segunda (S, Dr, Sr e $\left.D^{7}\right)$, com terminação na T.

Ludicidade - apesar de se tratar de um solfejo, sendo em tempo de valsa, pode-se acrescentar uma coreografia.

\subsubsection{Melodias com semitons $m-f$ e $t$-d}

\subsubsection{Sobre seis graus da escala}

78) NOZANI-NÁ - A capella
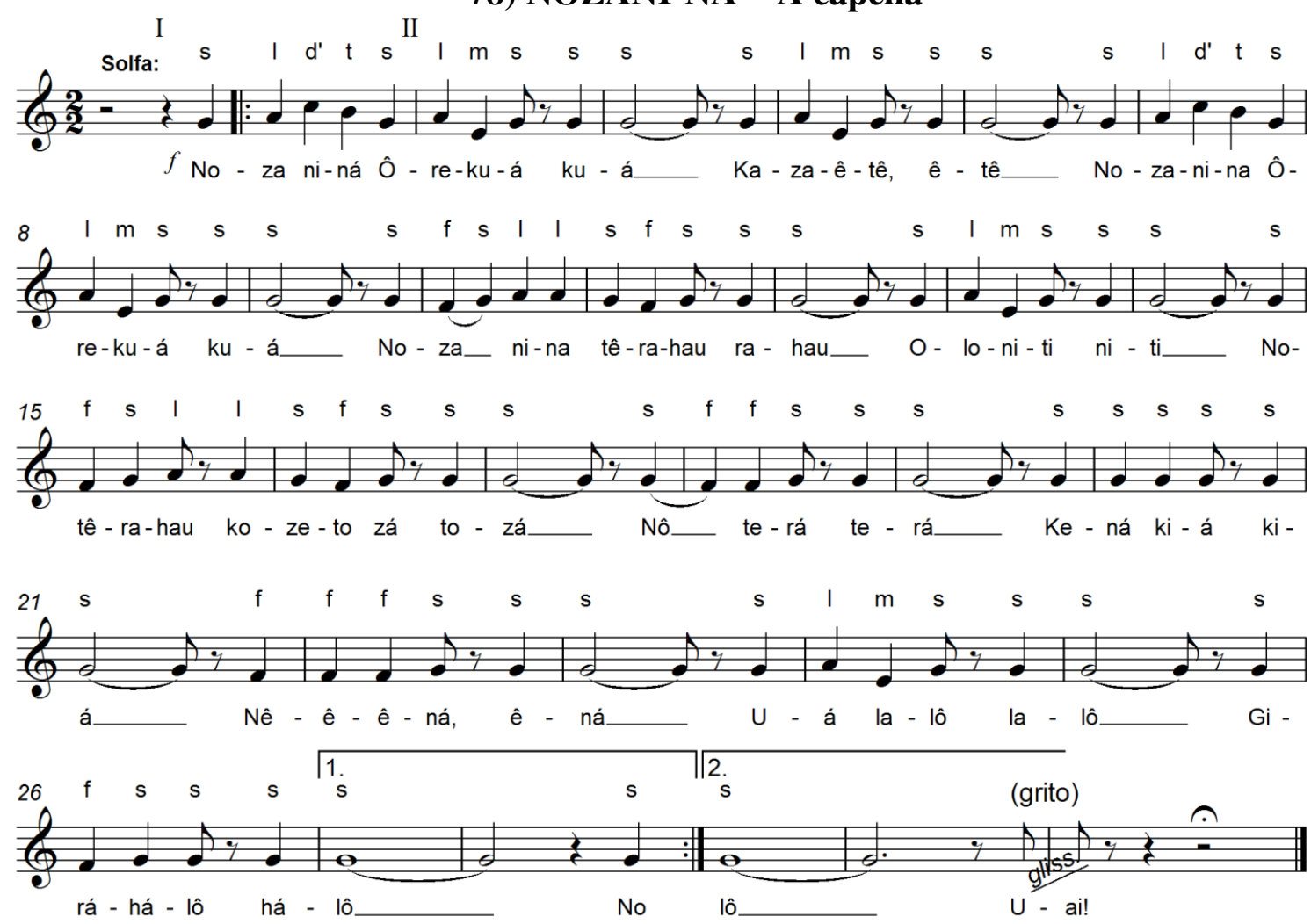

\begin{tabular}{|l|l|l|c|c|}
\hline Volume & No & Tessitura & $\begin{array}{c}\text { Forma - A } \\
\text { Extensão: 6a }\end{array}$ & Intervalos melódicos \\
\hline
\end{tabular}




\begin{tabular}{|c|c|c|c|c|}
\hline $\mathrm{CO} 1$ & 32 & E3-C4 & $\begin{array}{c}\text { Graus da escala: } 6 \\
\text { Sistema Heptatônico (F C G D A E B) } \\
\text { Heptacorde ( } \mathrm{m} r \mathrm{~d} \text { t Is) }\end{array}$ & 2a $\mathrm{M} / \mathrm{m} ; 3^{\mathrm{a}} \mathrm{M} / \mathrm{m} ; 4^{\mathrm{a}} \mathrm{J}$ \\
\hline & & & ala - Modo mixolídio defectivo de G & \\
\hline
\end{tabular}

Sugestões de atividades didático-pedagógicas:

Células rítmicas para registro gráfico:

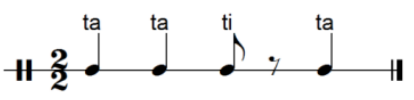

Células melódicas para registro gráfico:

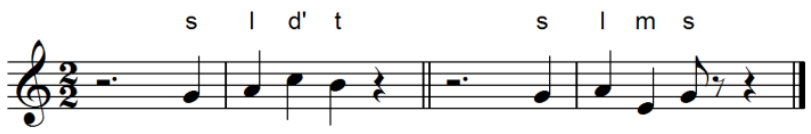

Possivel ostinato rítmico:

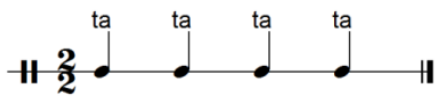

Análise complementar em $2.2-n^{\circ} 20$.

Tema dos índios Parecis, recolhido por Roquete Pinto, com 31 compassos binários, com indicação de andamento Animato e de dinâmica: $\boldsymbol{f}$

Ritmo - o interesse rítmico está nos cortes determinados por pausas de colcheias. O texto parece soar mais confortável eliminando-se a primeira pausa de mínima, com o primeiro compasso completo, com contratempo no primeiro pulso.

Melodia - em âmbito de sexta menor, a melodia se desenvolve sobre graus conjuntos, pequenos saltos de quarta e terça, bem como notas rebatidas.

Ludicidade - o texto e o caráter rítmico incisivo sugerem uma coreografia indígena. O canto em cânone também é um desafio lúdico.

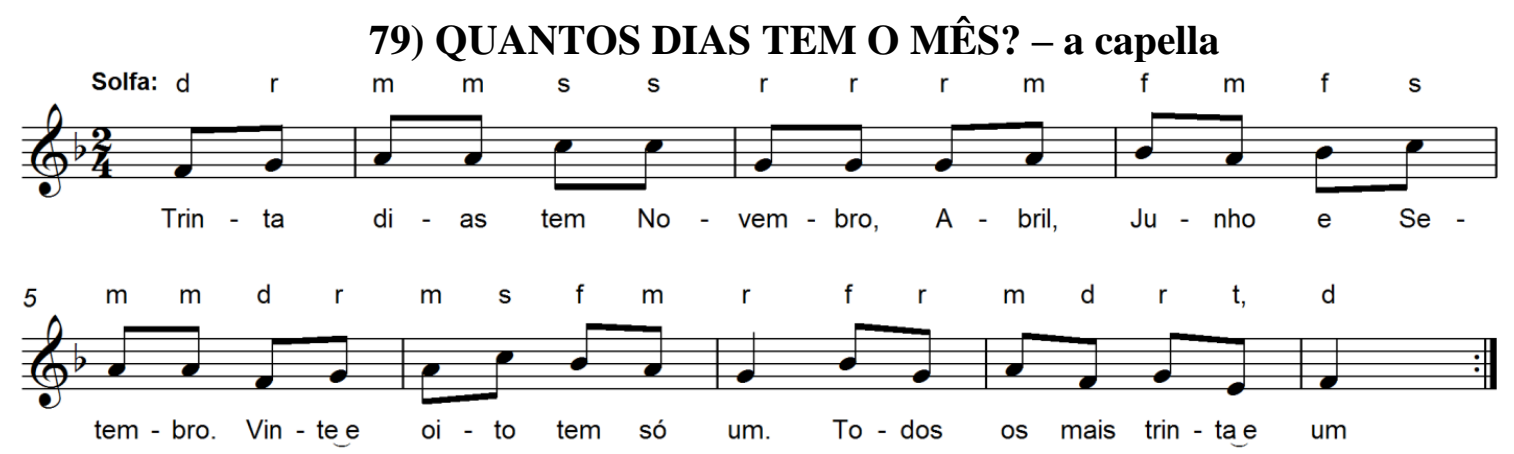

\begin{tabular}{|c|c|c|c|c|}
\hline Volume & № & Tessitura & Forma - Introdução A Coda & Intervalos melódicos \\
\hline GP-VTL & 106 & E3-C4 & Extensão: 6a & 2a $\mathrm{M} ; 3^{\text {a }} \mathrm{M} / \mathrm{m} ; 4$ a J \\
\hline /S1 & $/ 11$ & & Graus da escala: 6 & \\
\hline$/ A B M$ & /39 & & Sistema Heptatônico (Bb F C G D A E) & \\
\hline & & & Heptacorde $(\mathrm{t} \mid \mathrm{s} f \mathrm{~m} \mathrm{r} \mathrm{d})$ & \\
\hline
\end{tabular}




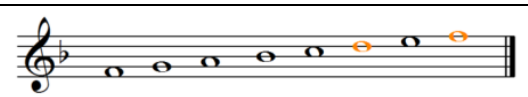

Sugestões de atividades didático-pedagógicas:

Células rítmicas para registro gráfico:

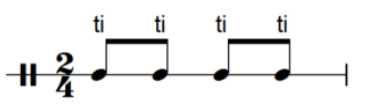

Células melódicas para registro gráfico:

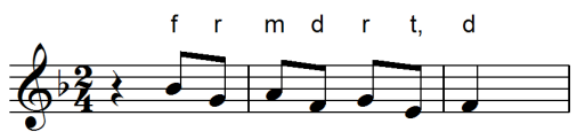

Possivel ostinato rítmico:

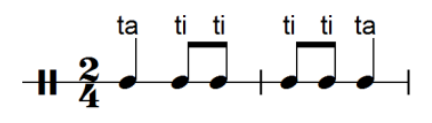

Possível ostinato melódico:

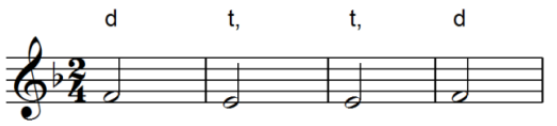

Análise complementar em $2.2-n^{\circ} 63$.

Canção popular, folclórica infantil de 9 compassos binários, com a indicação: Poco Moderato $(84=$ ل ); indicações de dinâmica: $\boldsymbol{m f}$; acentos >.

Tema popular de brincadeira cantada.

Texto - preferimos o texto como se encontra em GP/VTL, pois, GP/ABM registra dois enganos nos compassos 2 (têm, quando o correto é tem) e 4 (julho, quando o correto é junho). Ainda assim, em ambas as edições, o último verso está prejudicado, portanto, sugiro uma pequena alteração no texto para corrigir a prosódia: ao invés de "todos os mais trinta e um", "os demais têm trinta e um". Se fosse o caso de aprimorar também a construção da frase anterior, poderia se inverter o verbo (para que "fevereiro" seja o sujeito): "28 um só tem", ou substituir o verbo ('28' é o sujeito): "28 há só um”, o que seria preciosismo para um texto popular.

Ritmo - o interesse rítmico está na subdivisão do pulso e a quadratura das frases.

Melodia no pentacorde da $\mathrm{T}$, iniciada por arpejo da tríade de $\mathrm{T}$, seguido de desenhos por graus conjuntos e intervalos de terças e quartas, com terminação na $\mathrm{T}$.

Ludicidade - canção pedagógica mnemônica visando à memorização da quantidade de dias dos meses do ano. 


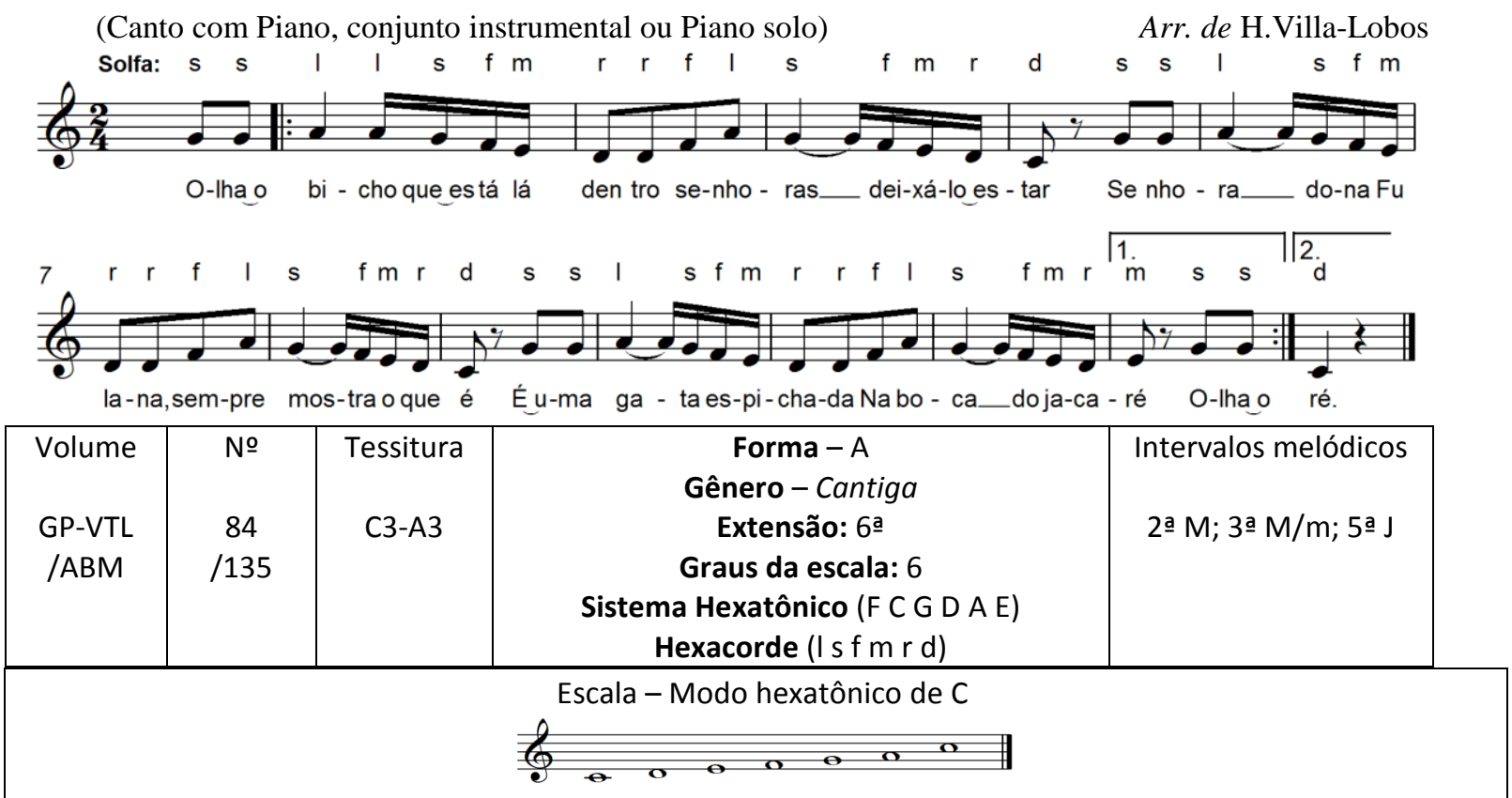

Sugestões de atividades didático-pedagógicas:

Células rítmicas para registro gráfico:

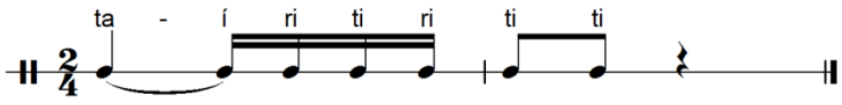

Células melódicas para registro gráfico:

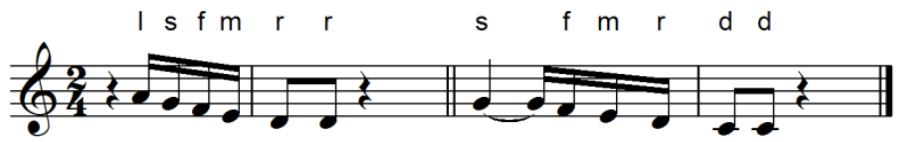

Possivel ostinato rítmico:

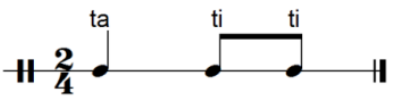

Canção popular, folclórica infantil de 12 compassos binários, com a indicação: Poco animato $(100-104=ل$ ); indicações de dinâmica: $f$; acentos $>v$

Tema popular de brincadeira cantada.

Texto - Descrição de brincadeira sobre imaginário infantil. Os acentos iniciais sobre a palavra "Olha" têm intenção interpretativa.

Ritmo - o interesse está no ritmo acelerado em movimento lento/rápido.

Melodia - três desenhos idênticos sobre dois pentacordes descendentes em seqüência por grau conjunto. Preferimos a terminação sempre na nota $\boldsymbol{C}$, por ser mais lógica para a criança pequena, para quem está destinada a melodia, embora em GP/VTL a nota final, constando na primeira casa de repetição, seja $\boldsymbol{E}$. Em GP/ABM, a nota $\boldsymbol{E}$ está no final da segunda frase e a nota $\boldsymbol{C}$ no final da terceira. Nesta mesma edição, consta como nota ${ }^{46}$, equivocadamente, que as reprises indicadas foram realizadas por extenso. Menciona também uma indicação de VillaLobos: “...” que sublinha a acentuação inesperada na sílaba fraca no primeiro tempo dos compassos, a qual não existe em GP/VTL.

${ }^{46}$ GP/ABM $3^{\circ}$ Caderno, p.70. 
Ludicidade - explorando o imaginário infantil no universo dos monstros e personagens assustadores, o ritmo lento/rápido pode sugerir a variação da velocidade de movimento. A imaginação do grupo pode ampliar o tema.

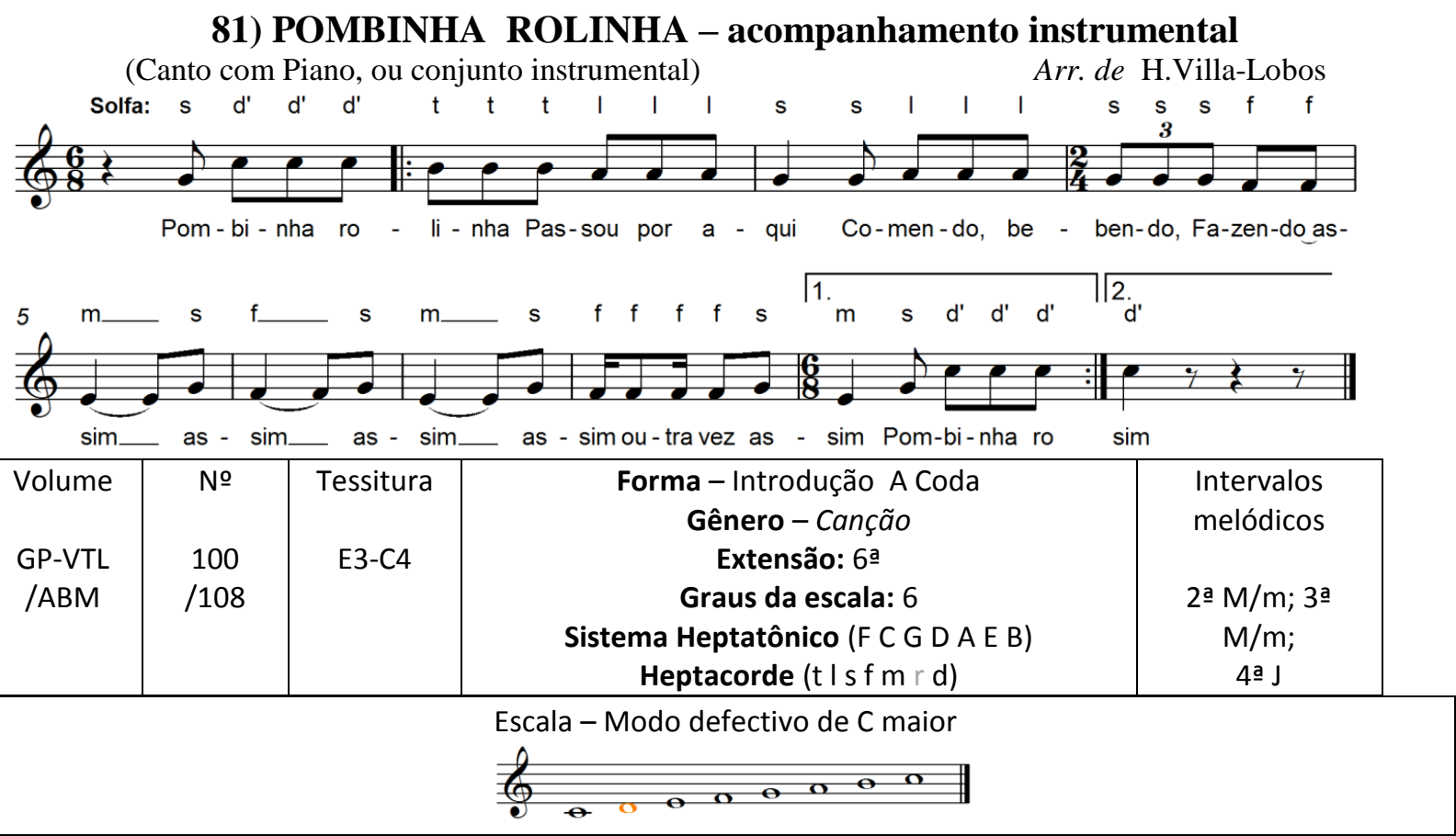

Sugestões de atividades didático-pedagógicas:

Células rítmicas para registro gráfico:

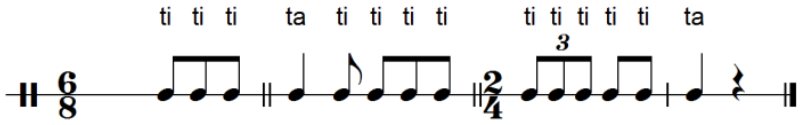

Células melódicas para registro gráfico:

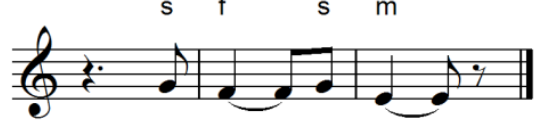

Possivel ostinato rítmico:

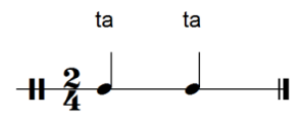

Canção com 5 compassos binários de subdivisão ternária e 5 compassos binários de subdivisão binária, com a indicação de andamento: Allegro Vivace $($ M.M. $144=」)-($ deveria ser ل.); Moderato; Vivo; indicações de dinâmica: $\boldsymbol{m f}$; acentos $>_{-}$>.

Tema popular, folclórico infantil, de brincadeira cantada cujo desenvolvimento baseia-se no texto.

Texto - descrição de brincadeira de roda que sugere o gestual lúdico.

Ritmo - a indicação metronômica deveria ser $(144=$ d.); o interesse rítmico está na alternância de subdivisão ternária e binária. Em prol da simetria presente no texto, na partitura, o compasso 6 por 8 deveria se estender até o compasso 4 , com duas quiálteras no segundo pulso, e o compasso 2 por 4 passaria a valer para o quinto até o oitavo compasso (4 compassos com subdivisão ternária e 4 com subdivisão binária). 
Melodia - em linha descendente com notas rebatidas, em âmbito de hexacorde com terminação na terça da $\mathrm{T}$; segunda parte com desenhos em torno da terça da $\mathrm{T}$.

Acompanhamento instrumental (piano) - após pequena introdução com cromatismo em linha descendente na mão esquerda, a mão direita dobra a melodia, mantendo um pedal no quinto grau alcançado por apojatura em saltos ascendentes, em registro agudo acima da linha melódica, a coda, em 3 compassos, reforça a cadência final D T.

Ludicidade - as mudanças de subdivisão ternária/binária e o conteúdo do texto possibilitam grande riqueza de movimento para a brincadeira.

\section{2) MARIQUITA MUCHACHA - acompanhamento instrumental}

(Canto com Piano, ou conjunto instrumental ou Piano solo)

Amb. por H.Villa-Lobos

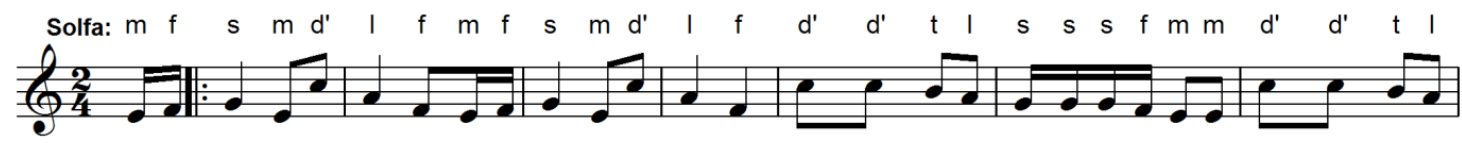

Ma-ri - qui - ta mu-cha cha!Ma-ri-qui - ta mu-cha cha! Que que es-tá fa - zen-do ma-ri-qui ta Que que es-tá fa-

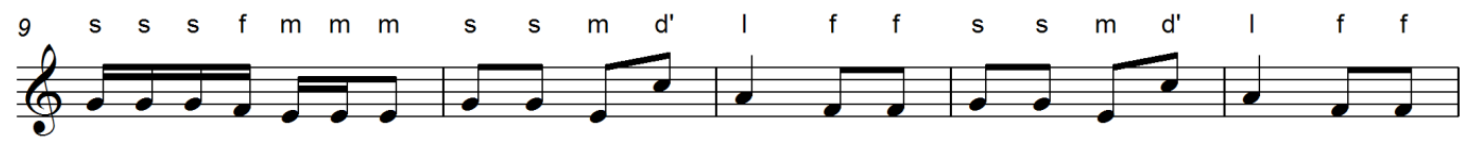

zen-do ma-ri-qui-ta Es - tou co-sen-doa sa - ia Es - tou co-sen-do a sa - ia Que

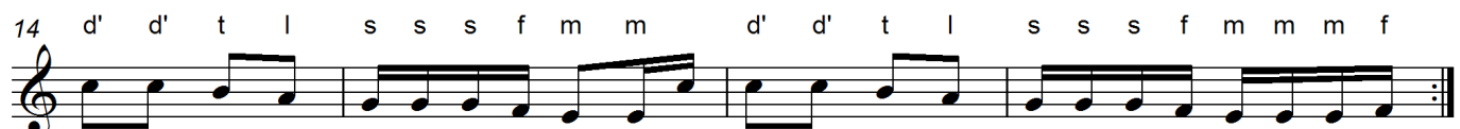

já es - tá rom - pen-do ma - ri - qui - ta Que já es - tá rom - pen-do Ma - ri - qui - ta. A ga -

\begin{tabular}{|c|c|c|c|c|}
\hline $\begin{array}{c}\text { Volume } \\
\text { GP-VTL } \\
\text { /ABM }\end{array}$ & $\begin{array}{l}\text { № } \\
78 \\
\text { /91 }\end{array}$ & $\begin{array}{l}\text { Tessitura } \\
\text { E3-C4 }\end{array}$ & $\begin{array}{c}\text { Forma - Introdução A Coda } \\
\text { Gênero - Dança canção } \\
\text { Extensão: 6a } \\
\text { Graus da escala: } 6 \\
\text { Sistema Heptatônico (F C G D A E B) } \\
\text { Heptacorde (t I s f m r d) }\end{array}$ & $\begin{array}{l}\text { Intervalos } \\
\text { melódicos } \\
\text { 2a M/m; 3ạ } \\
\mathrm{M} / \mathrm{m} ; 6 \underline{a} \mathrm{~m}\end{array}$ \\
\hline & & & $\begin{array}{l}\text { la - Modo defectivo de C maior } \\
\mathbf{0} \quad \mathbf{0}\end{array}$ & \\
\hline
\end{tabular}

Sugestões de atividades didático-pedagógicas:

Células rítmicas para registro gráfico:

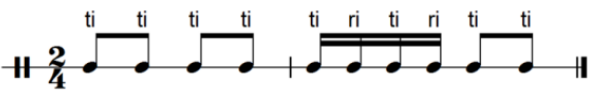

Células melódicas para registro gráfico:

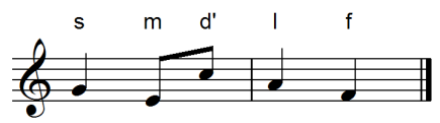

Possivel ostinato rítmico:

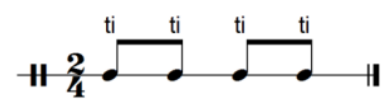

Possivel ostinato melódico:

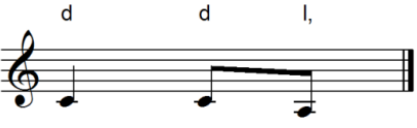


Canção com 17 compassos binários, com a indicação de andamento: Allegro non tropo $(112=$ ل ); indicações de dinâmica: $\boldsymbol{m f} ; \boldsymbol{f} ; \boldsymbol{p p}$

Tema popular, folclórico infantil, de brincadeira cantada cujo desenvolvimento baseia-se no texto.

Texto - descrição de brincadeira de roda em que Mariquita Muchacha é personagem principal. Um diálogo entre a solista e os demais participantes determina o desenvolvimento da movimentação. Em GP/ABM, no compasso 21, para as duas últimas notas, o texto é " $A$ ga" (linha... - segunda estrofe), como consta em GP/VTL, para que se complete a brincadeira com todas as estrofes.

Ritmo - o interesse rítmico está no ostinato que envolve o nome da Mariquita em todas as estrofes. Em GP/ABM, nos compassos 7 e 8, constam indicações de $s f z$ que não aparecem em GP/VTL.

Melodia Duas pequenas curvas sobre as tríades de $\mathrm{T}$ e $\mathrm{S}$, seguidas de linha descendente de hexacorde, com resolução na T. Em GP/ABM, no compasso 10 o último acorde da mão direita deve conter as notas: $\boldsymbol{C} \boldsymbol{D} \boldsymbol{F} \boldsymbol{A}$ e não $\boldsymbol{A} \boldsymbol{B} \boldsymbol{D} \boldsymbol{A}$, como consta. No compasso 27, a primeira nota da mão esquerda $(\boldsymbol{A b})$ deve ser uma mínima, como consta em GP/VTL.

Acompanhamento instrumental (piano) - a introdução apresenta um ostinato ornamentado na mão esquerda por quatro compassos (primeiro e quinto graus em linha descendente), enquanto a direita apresenta uma linha melódica em torno do quinto e terceiro graus da T. A melodia é dobrada pela mão direita, com contratempos em ostinato rítmico, acompanhada de contraponto na mão esquerda. A coda repete a introdução e acrescenta um arpejo sobre pedal da $\mathrm{T}$ em registro grave, com $\mathrm{T}^{6-} /{ }^{4+}$ finalizando na terça. Em ambas as edições, no compasso 13, no segundo pulso (mão direita), a segunda nota deve ser uma colcheia pontuada.

Ludicidade - a brincadeira de roda desenvolve-se segundo a sequência de ações contidas no texto.

Complemento do texto:

Mariquita muchacha! (bis) / quê que está fazendo, Mariquita? (bis) / Estou cosendo a saia (bis) / que já está rompendo, Mariquita (bis)

A galinha está no ninho (bis) / batendo com as asas assim, Mariquita (bis) / pra chamar os seus filhinhos (bis) / que estão chorando assim, Mariquita (bis)

Lá no alto daquela serra (bis) / estão me chamando assim, Mariquita (bis) / é uma menininha (bis) / deste tamanho assim, Mariquita (bis)

\section{3) Ó LIMÃO - acompanhamento instrumental}

(Canto com Piano, ou conjunto instrumental)

Arr. de H.Villa-Lobos
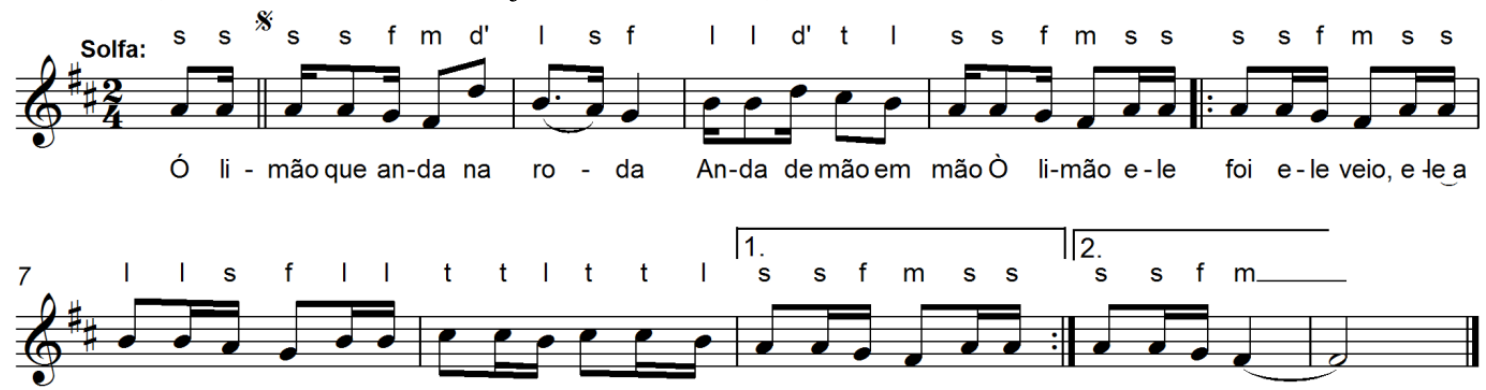

qui não che-gou, lá no meio do ca-mi nho a prin - ce - sa to-mou! E-le

ce - sa to mou 


\begin{tabular}{|c|c|c|c|c|}
\hline $\begin{array}{l}\text { Volume } \\
\text { GP-VTL } \\
\text { /ABM }\end{array}$ & $\begin{array}{l}\text { № } \\
69 \\
/ 49\end{array}$ & $\begin{array}{l}\text { Tessitura } \\
\text { F\#3-D4 }\end{array}$ & $\begin{array}{c}\text { Forma - A } \\
\text { Gênero - Canção } \\
\text { Extensão: } 6 \text { ạ } \\
\text { Graus da escala: } 6 \\
\text { Sistema Heptatônico (G D A E B F\# C\#) } \\
\text { Heptacorde (t I s f m r d) }\end{array}$ & $\begin{array}{c}\text { Intervalos } \\
\text { melódicos } \\
\text { 2a } \mathrm{M} / \mathrm{m} ; 3 \text { a } \mathrm{M} / \mathrm{m} \text {; } \\
\text { 6a } \mathrm{m}\end{array}$ \\
\hline \multicolumn{5}{|c|}{ Escala - Modo D maior } \\
\hline
\end{tabular}

Sugestões de atividades didático-pedagógicas:

Células rítmicas para registro gráfico:

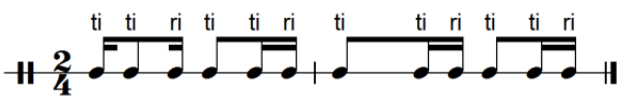

Células melódicas para registro gráfico:

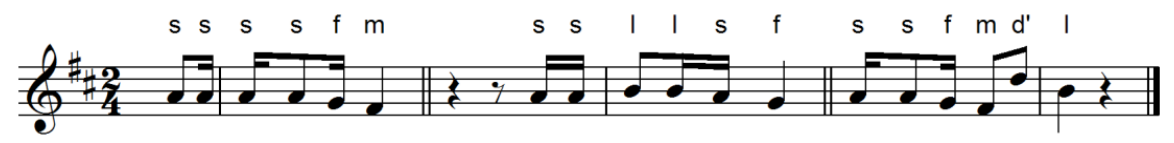

Possivel ostinato rítmico:

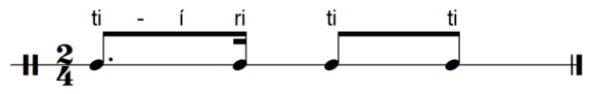

Análise complementar em 2.2 - $n^{\circ} 159$.

Canção com 13 compassos binários, com a indicação: Allegro Moderato (68=ل); sem indicações de dinâmica.

Tema popular, folclórico infantil, de brincadeira cantada cujo desenvolvimento baseia-se no texto.

Texto - descrição de brincadeira que desencadeia um jogo que disputa um limão.

Ritmo - interesse rítmico: motivo inicial em contratempo na sincopa. Para uma prosódia adequada, o compasso 8 deveria conter 4 semicolcheias no primeiro pulso.

Melodia - inicia-se em desenho com terça menor cheia descendente a partir do quinto grau da $\mathrm{T}$, seguida de salto ascendente e resolução na $\mathrm{S}$ por graus conjuntos descendentes; pequena curva com finalização na $\mathrm{T}$ por hexacorde descendente; segunda parte: pequenas curvas com terminação em desenho descendente para a $\mathrm{T}$.

Ludicidade - roda estática com um participante passando o limão até que fique na mão de alguém, que entrará na roda na sequência. Há variantes em que há uma disputa (com a intervenção da Princesa) pelo limão.

\section{4) SENHORA DONA SANCHA ( $\left(3^{\text {a }}\right.$ versão $)$ - a capella}

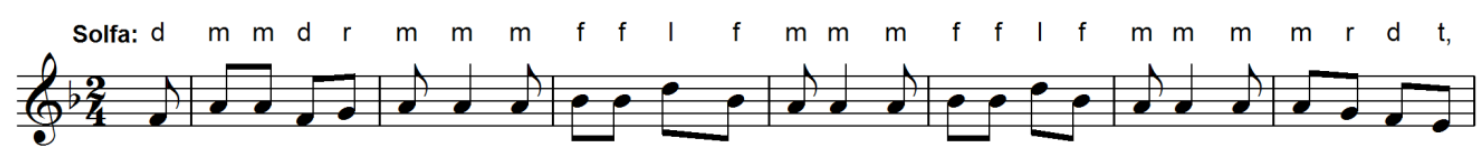

Se-nho-ra Do-na San-cha co-ber-ta de ou-roe pra-ta des-cu bra o seu ros-to que nós que-re-mos

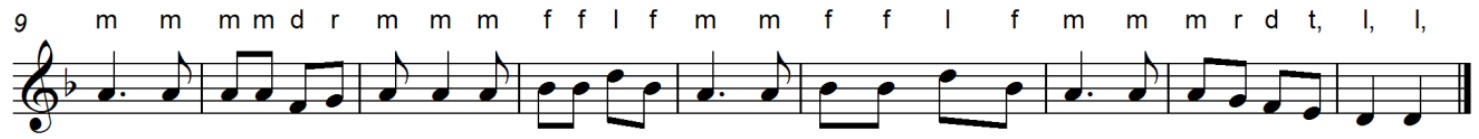

ver. Eu sou fi-lha do Con-de, eu sou fi-Iha do Rei que man-dou lhe es-con-der de - bai-xo da-pe - dri-nha 


\begin{tabular}{|c|c|c|c|c|}
\hline $\begin{array}{c}\text { Volume } \\
\text { GP-VTL } \\
\text { /S1 } \\
\text { /ABM }\end{array}$ & $\begin{array}{c}\text { № } \\
116 \\
/ 28 \\
/ 2\end{array}$ & $\begin{array}{l}\text { Tessitura } \\
\text { D3-D4 }\end{array}$ & $\begin{array}{c}\text { Forma - A } \\
\text { Gênero - Cantiga } \\
\text { Extensão: } 8^{\text {a }} \\
\text { Graus da escala: } 6 \\
\text { Sistema Heptatônico (Bb F C G D A E) } \\
\text { Heptacorde (s f m r d t I) }\end{array}$ & 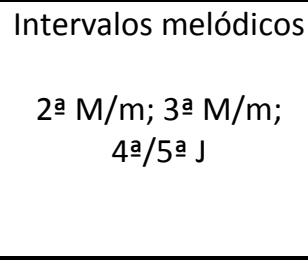 \\
\hline \multicolumn{5}{|c|}{ 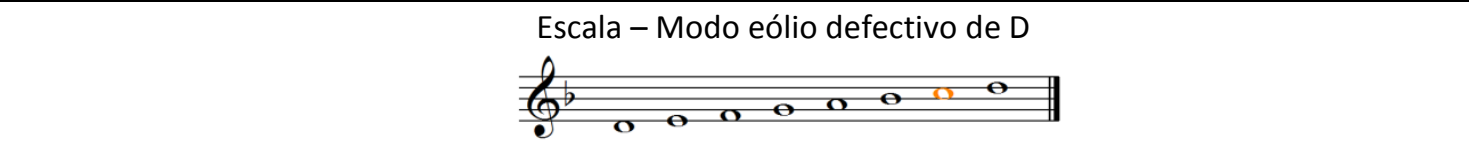 } \\
\hline
\end{tabular}

\section{Sugestões de atividades didático-pedagógicas:}

Células rítmicas para registro gráfico:

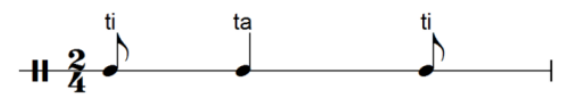

Células melódicas para registro gráfico:

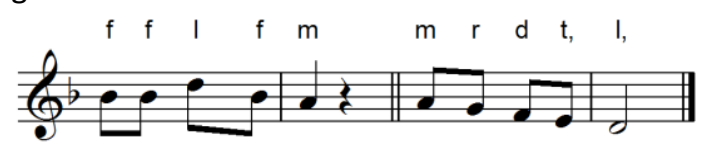

Possivel ostinato rítmico:

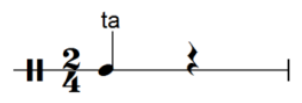

Canção com 16 compassos binários, com a indicação de andamento: Poco Allegretto (M.M. $138=」$ ); sem indicações de dinâmica.

Tema popular, folclórico infantil, de brincadeira cantada cujo desenvolvimento baseia-se no texto.

Texto - Em GP/VTL não há texto para a melodia. Em GP/ABM, a terceira frase da segunda estrofe, registrada na p. 71, não corresponde à que está na partitura, na p. 12 . No compasso 20 a grafia do texto deve ser: mandou me esconder.

Ritmo - o interesse rítmico está nas síncopas métricas - $\downarrow \cdot d$

Melodia - desenho em torno da terça menor da tríade de $\mathrm{T}$ seguido de salto de terça na $\mathrm{S}$, ascendente e descendente para $\mathrm{T}$ por grau conjunto (duas vezes), finalizando com pentacorde descendente de $\mathrm{D}$ para T. Quanto à introdução, como não há indicação para voz, tanto em GP/VTL como em GP/ABM, sendo a mesma realizada na versão para piano solo, preferimos abrir mão de seu registro e eventual realização vocal, considerando, neste capítulo, apenas a canção.

Ludicidade - brincadeira de roda, rica em possibilidades de interpretação cênica, gestual e de movimentação rítmica.

Complemento do texto ${ }^{47}$ :

Senhora Dona Sancha / coberta de ouro e prata / Descubra o seu rosto / que o queremos ver - Eu sou filha do Conde / eu sou a filha do Rei / que mandou me esconder / debaixo da pedrinha. (Declamado): Valentim, tim, tim / quem se casou, se casou, / quem não está casado / ficará só.

\footnotetext{
${ }^{47}$ Texto adotado em ABM - extraído do Folklore brésilien, edição e tradução (1993) do Professor Vicente Salles (p.49), segundo referência registrada no $1^{\circ}$ Caderno, p. 80.
} 
85) VIVA O CARNAVAL - a capella

(a duas vozes com efeitos rítmicos) Arr. de H. Villa-Lobos

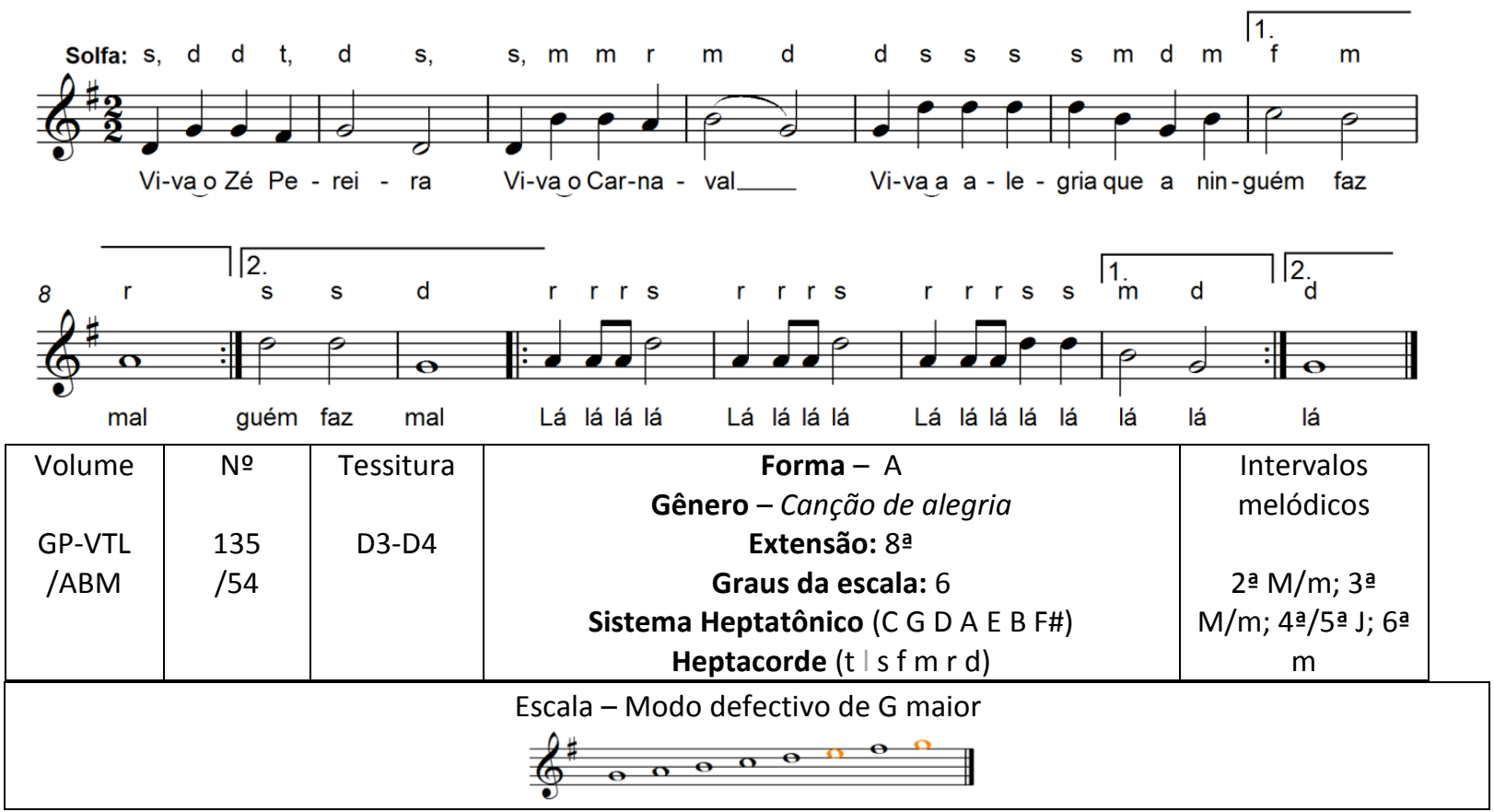

Sugestões de atividades didático-pedagógicas:

Células rítmicas para registro gráfico:

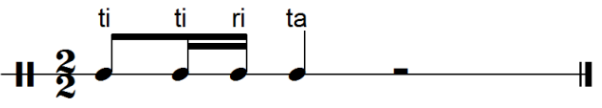

Células melódicas para registro gráfico:

$s, \quad d \quad d t, \quad d \quad s, \quad s, m \quad m \quad r \quad m \quad d$

Possivel ostinato rítmico:

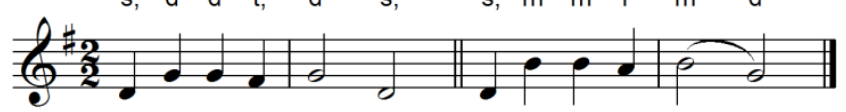

Possivel ostinato ritmico:

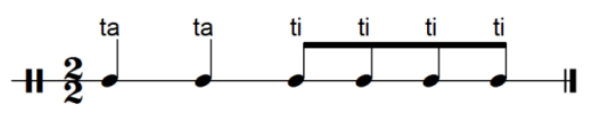

Possivel ostinato melódico:

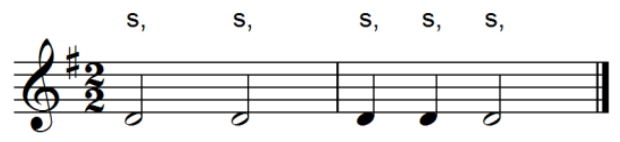

Análise complementar em $2.2-n^{\circ} 81$.

Canção com 15 compassos binários, com a indicação de andamento: Allegro Vivace (M.M. $120=d$ ); indicações de dinâmica: $\boldsymbol{f}$

Tema popular de brincadeira de Carnaval.

Texto - Saudação ao personagem carnavalesco Zé Pereira.

Ritmo - binário, subdivisão binária, marchinha carnavalesca. Em GP/ABM, falta uma pausa de mínima no último compasso do ostinato rítmico.

Melodia - segundo notas no $1^{\circ}$ Caderno, p. 93 em BM, a melodia é de Antonin-Louis Clapisson (1808-1866) - Les Pompiers de Nanterre, adaptada pelo ator Francisco Correa 
Vasquez. Consta de desenhos sobre as inversões e posição fundamental do acorde de $\mathrm{T}$ na primeira parte e na $\mathrm{D}$ na segunda, com finalização na $\mathrm{T}$.

Ludicidade - música própria para folguedos carnavalescos, pode servir a várias interpretações e brincadeiras.

\section{6) Ó CIRANDA, Ó CIRANDINHA - acompanhamento instrumental}

(Canto com piano, conjunto instrumental ou Piano solo) Amb. por H. Villa-Lobos
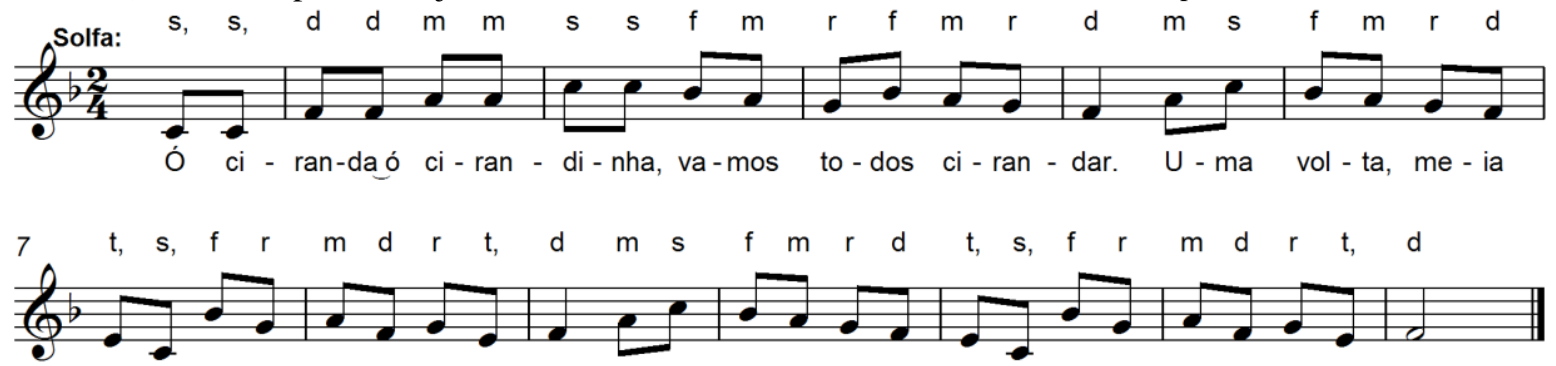

vol-ta, vol-tae me-ia va-mos dar. U-ma vol-ta, me-ia vol-ta, vol-ta e me-ia va-mos dar

\begin{tabular}{|c|c|c|c|c|}
\hline $\begin{array}{l}\text { Volume } \\
\text { GP-VTL } \\
\text { /ABM }\end{array}$ & $\begin{array}{l}\text { № } \\
35 \\
\text { /61 }\end{array}$ & $\begin{array}{l}\text { Tessitura } \\
\text { C3-C4 }\end{array}$ & $\begin{array}{c}\text { Forma - A } \\
\text { Gênero - Quadrilha } \\
\text { Extensão: } 8 \text { a } \\
\text { Graus da escala: } 6 \\
\text { Sistema Heptatônico (Bb F C G D A E) } \\
\text { Heptacorde (t } \mid \mathrm{s} f \mathrm{~m} \text { r d) }\end{array}$ & $\begin{array}{c}\text { Intervalos } \\
\text { melódicos } \\
\text { 2a } \mathrm{M} / \mathrm{m} ; 3 \text { a } \mathrm{M} / \mathrm{m} \text {; } \\
\text { 4a J; 6a m; 7ㅁm }\end{array}$ \\
\hline \multicolumn{5}{|c|}{ 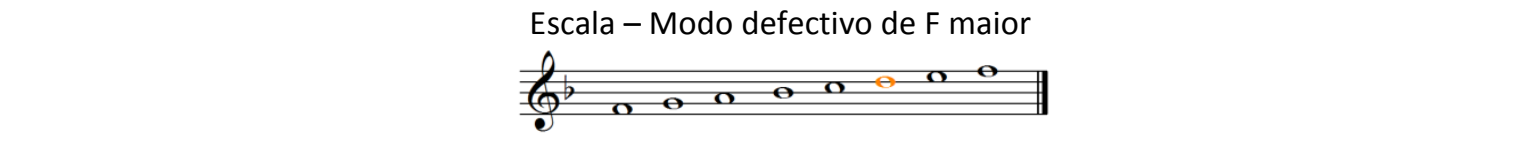 } \\
\hline
\end{tabular}

Sugestões de atividades didático-pedagógicas:

Células rítmicas para registro gráfico:

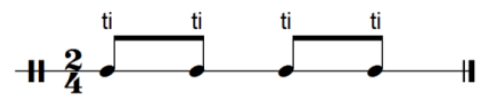

Células melódicas para registro gráfico:

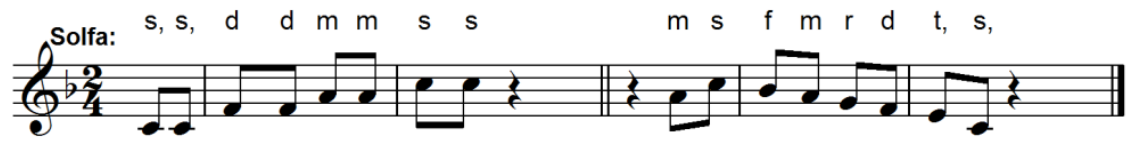

Possível ostinato rítmico:

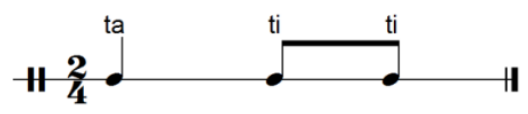

Canção popular, de 13 compassos binários, com a indicação: Andantino até Allegro (M.M. $120=」)$ ); indicações de dinâmica - em nota do autor: "repetir quatro vezes crescendo proporcionalmente". Em GP/VTL, o autor sugere, para a execução instrumental, os andamentos: Andantino, Allegretto, Allegro e Vivace para cada repetição. Em GP/ABM, aparecem, para cada uma das três estrofes, as três primeiras indicações, omitindo a indicação metronômica para o Allegro (M.M. $120=$ ل ). Na p. 116 do $2^{\circ}$ Caderno, há uma interpretação equivocada de que a indicação metronômica que acompanha a expressão Allegro devesse valer para toda a peça, o que não está determinado em GP/VTL (Andantino até Allegro (M.M. $120=\downarrow$ ).

Tema popular, folclórico infantil, de brincadeira cantada cujo desenvolvimento baseia-se no texto. 
Texto - descrição de brincadeira de roda, a ciranda, ou cirandinha, e seus movimentos de volta e volta e meia; outras quadrinhas tradicionais são mencionadas, bem como outras podem ser acrescentadas. Conforme nota, segue a quarta estrofe, por mim recolhida.

Ritmo - o interesse rítmico está na prosódia em subdivisão binária.

Melodia - consiste em três desenhos em curva sobre tríades de T e D, ascendente/descendente com terminação na $\mathrm{T}$.

Acompanhamento instrumental (piano) - acordes iniciais como que marcando os passos, seguidos de linha em colcheias, dando movimento (volta e meia volta). A harmonia gira em torno da T Tr S e D. Em nota, Villa-Lobos indica, para a execução de piano solo, que haja quatro repetições, oitavando somente a melodia na mão direita com a dinâmica crescendo e andamento acelerado proporcionalmente.

Ludicidade - brincadeira de roda em que um participante é escolhido, devendo recitar uma quadrinha e escolher o próximo solista.

Complemento do texto ${ }^{48}$ :

- Ó ciranda, ó Cirandinha, / vamos todos cirandar / uma volta, meia volta / volta e meia vamos dar.

- Ó ciranda, ó Cirandinha, / vamos todos cirandar / vamos ver a Dona Luíza / que já está para casar.

- O anel que tu me deste / era vidro se quebrou / o amor que tu me tinhas /era pouco e se acabou.

- Por isso, D. Fulana / por favor, entre na roda / diga um verso bem bonito / diga adeus e vá se embora.

\section{7) MACHADINHA - acompanhamento instrumental}

(Canto com piano, conjunto instrumental ou Piano solo) Arr. de H. Villa-Lobos

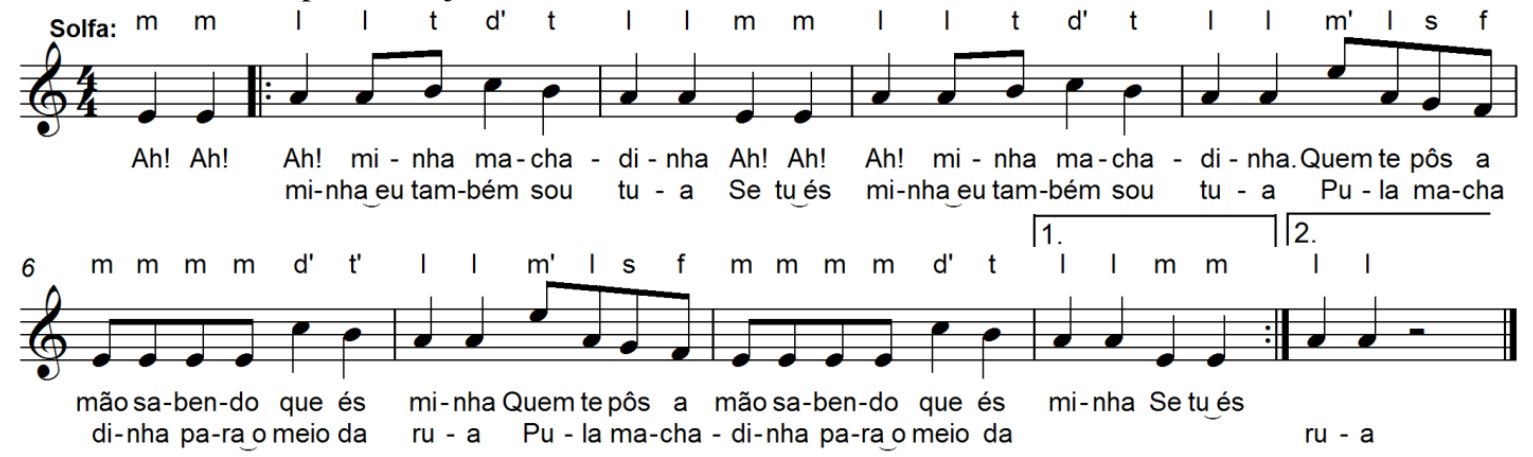

\begin{tabular}{|c|c|c|c|c|}
\hline $\begin{array}{l}\text { Volume } \\
\text { GP-VTL } \\
\text { /ABM }\end{array}$ & $\begin{array}{l}\text { № } \\
71 \\
\text { /74 }\end{array}$ & $\begin{array}{l}\text { Tessitura } \\
\text { E3-E4 }\end{array}$ & $\begin{array}{c}\text { Forma - A } \\
\text { Gênero - quase schottisch } \\
\text { Extensão: } 8 \text { a } \\
\text { Graus da escala: } 6 \\
\text { Sistema Heptatônico (F C G D A E B) } \\
\text { Heptacorde (s f m r d t l) }\end{array}$ & $\begin{array}{c}\text { Intervalos } \\
\text { melódicos } \\
\text { 2a M/m; 4a } / 5^{\mathrm{a}} \\
\mathrm{J} ; 6^{\mathrm{a}} \mathrm{m}\end{array}$ \\
\hline \multicolumn{5}{|c|}{$\begin{array}{l}\text { Escala - Modo defectivo de A menor } \\
\end{array}$} \\
\hline
\end{tabular}

Sugestões de atividades didático-pedagógicas:

Células rítmicas para registro gráfico:

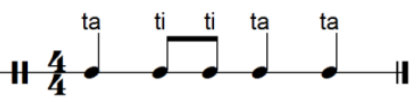

\footnotetext{
${ }^{48}$ Aproveitando a sugestão de Villa-Lobos para a execução ao piano em quatro repetições, sugiro o acréscimo da quarta estrofe, muito conhecida em São Paulo e comumente acoplada a outras brincadeiras.
} 
Células melódicas para registro gráfico:

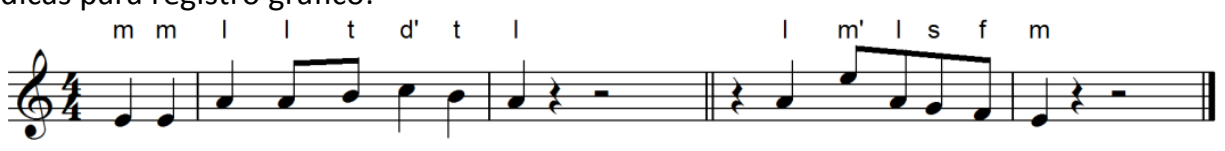

Possivel ostinato rítmico:

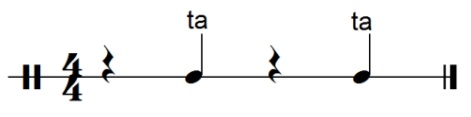

Canção com 10 compassos quaternários, com a indicação: Allegretto $(132=\downarrow$ ); indicações de dinâmica: $\boldsymbol{m f}$; < ; > acentos > sfz

Tema popular, folclórico infantil, de brincadeira cantada cujo desenvolvimento baseia-se no texto.

Texto - descrição de brincadeira de roda, sobre a relação de posse ente o dono e sua machadinha. Descreve o andamento do jogo quando convida a machadinha a pular para o meio da rua. A interjeição "Ah!" pode significar zanga ou lamento. Problema com prosódia no compasso 6: "pa-ra o meio da ru - a" - ficaria melhor "no mei - o da ru-a".

Ritmo - ênfase no pulso na primeira parte e na subdivisão na segunda.

Melodia - desenho em curva com início em salto ascendente de quarta, com linha descendente por grau conjunto para a tônica - duas vezes, a segunda vez para a subdominante; linha descendente por salto e graus conjuntos (tônica), bordadura cromática descendente, salto ascendente (D) e resolução na tônica por graus conjuntos descendentes - duas vezes.

Acompanhamento instrumental (piano) - pequena introdução com linha cromática sobre o quinto grau na mão direita, com linha descendente em terças na esquerda, com terminação na D. A melodia é dobrada pela mão direita, com acompanhamento harmônico e rítmico na mão esquerda sobre as funções primárias.

Ludicidade - brincadeira de roda com representação cênica.

\section{8) VAI ABÓBORA - acompanhamento instrumental}

(Canto com piano, conjunto instrumental ou Piano solo)

Arr. de H. Villa-Lobos
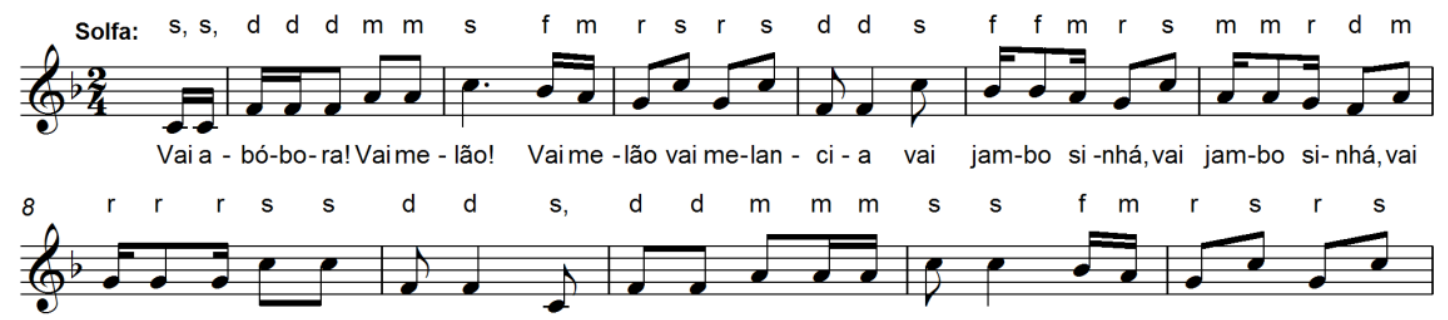

jam-bo si-nhá bem do - ce. Se - nho - ra Do - na Fu - la - na en-tre nes - ta ro - da -

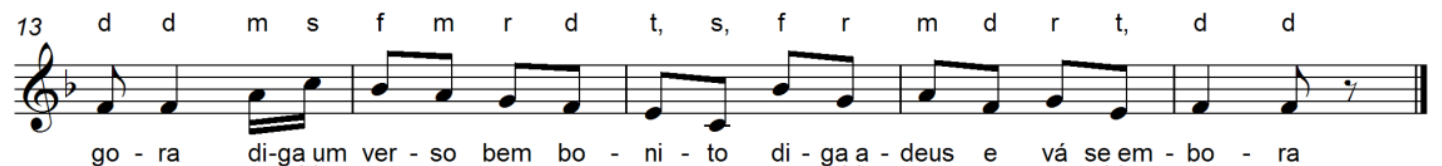

\begin{tabular}{|c|c|c|c|c|}
\hline Volume & No & Tessitura & $\begin{array}{c}\text { Forma - A } \\
\text { Gênero - Cantiga }\end{array}$ & $\begin{array}{l}\text { Intervalos } \\
\text { melódicos }\end{array}$ \\
\hline GP-VTL & 125 & C3-C4 & Extensão: 8aa & \\
\hline
\end{tabular}


Escala - Modo defectivo de F maior

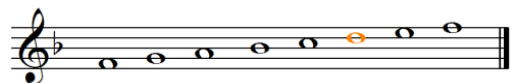

Sugestões de atividades didático-pedagógicas:

Células rítmicas para registro gráfico:

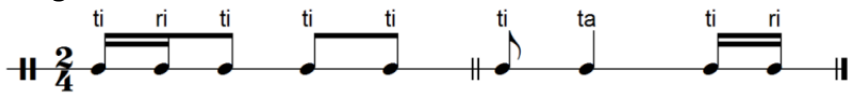

Células melódicas para registro gráfico:

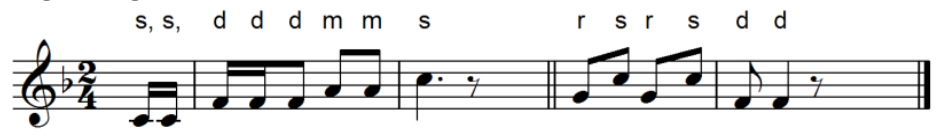

Possivel ostinato rítmico:

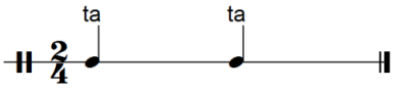

Canção com 17 compassos binários, com a indicação: Allegretto (M.M. 126= ل ); indicações de dinâmica: $f$

Tema popular, folclórico infantil, de brincadeira cantada cujo desenvolvimento baseia-se no texto.

Texto - Descrição de brincadeira de roda, baseada em pregão de vendedor de frutas e legumes. A segunda quadrinha é comum em outras cantigas de roda.

Ritmo - o interesse rítmico está sincopas e células com semicolcheias.

Melodia - inicia-se com arpejo de $\mathrm{T}$ ascendente, com volta para a o primeiro grau por saltos de quarta e quinta; linha descendente em sequência de terças cheias e salto ascendente de terça, com finalização ascendente por salto de quarta e descendente de quinta; na repetição do tema, a finalização é de hexacorde descendente, salto ascendente de sétima menor e terças quebradas até a T.

Acompanhamento instrumental (piano) - introdução com 7 compassos, com a mão esquerda desenvolvendo uma linha melódica, em contraponto com a direita que apresenta uma escala ascendente e uma linha descendente em segundas quebradas, que será repetida e desenvolvida em movimento contínuo pela mão esquerda na parte $\mathrm{A}$, em que a melodia é dobrada pela mão direita.

Ludicidade - originário de pregão, canto de trabalho, o tema pode ser explorado de muitas maneiras.

89) MANQUINHA - acompanhamento instrumental

(Canto com piano, conjunto instrumental ou Piano solo) Amb. por H. Villa-Lobos
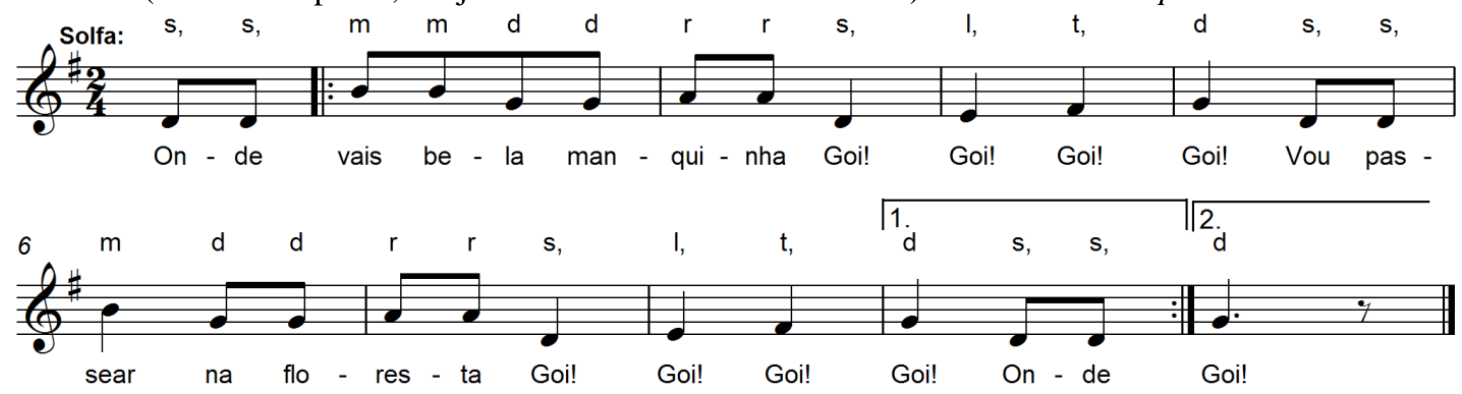


\begin{tabular}{|c|c|c|c|c|}
\hline $\begin{array}{l}\text { Volume } \\
\text { GP-VTL } \\
\text { /ABM }\end{array}$ & $\begin{array}{l}\text { № } \\
74 \\
\text { /111 }\end{array}$ & $\begin{array}{l}\text { Tessitura } \\
\text { D3 - B3 }\end{array}$ & $\begin{array}{c}\text { Forma - A } \\
\text { Gênero - Canção regional } \\
\text { Extensão: 8a } \\
\text { Graus da escala: } 6 \\
\text { Sistema Heptatônico (C G D A E B F\#) } \\
\text { Heptacorde (t I s f m r d) }\end{array}$ & $\begin{array}{l}\text { Intervalos } \\
\text { melódicos } \\
\text { 2a } \mathrm{M} / \mathrm{m} ; 3 \text { a } \\
\mathrm{M} / \mathrm{m} ; 4 \text { a } / 5 \text { a j; } \\
\text { 6a } \mathrm{M}\end{array}$ \\
\hline
\end{tabular}

Sugestões de atividades didático-pedagógicas:

Células rítmicas para registro gráfico:

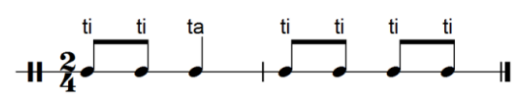

Células melódicas para registro gráfico:

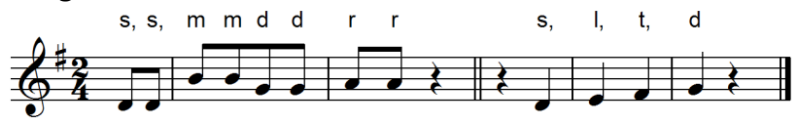

Possível ostinato rítmico:

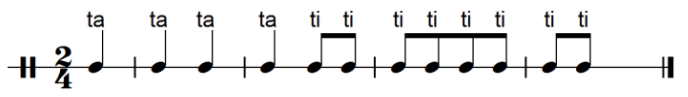

Possivel ostinato melódico:

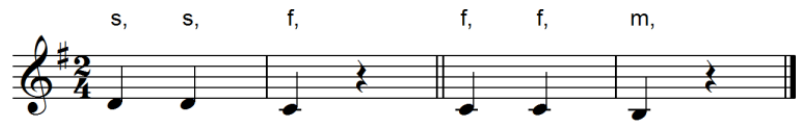

Canção com 10 compassos binários, com a indicação de andamento: Andante Moderato $(\mathbf{6 3}=\rfloor)$; poco rall. ; rall. ; dim. Poco a poco; indicações de dinâmica: $\boldsymbol{m f} ; \boldsymbol{f} ; \boldsymbol{p p}$. Em GP/ABM, a indicação de andamento consta como Andante moderato, sendo que em GP/VTL está Acalanto Moderato. No compasso 6 há indicação: $\left(2{ }^{\text {a }}\right.$ vez pp), ausente em GP/VTL e não justificada entre as notas da p. 130, a qual está com numeração equivocada (110 ao invés de 111). Nos compassos 37 e 40 falta a expressão rall.

Tema popular, folclórico infantil, de brincadeira cantada cujo desenvolvimento baseia-se no texto.

Texto - Descrição por diálogo de brincadeira de roda sobre um passeio da bela manquinha pela floresta. Note-se o sentido de inclusão expresso pelo adjetivo: "bela" - dirigido a uma deficiente física.

Ritmo - o interesse rítmico está nos ostinatos que permeiam perguntas e respostas.

Melodia - para efeito de aproveitamento didático, optamos por utilizar a melodia da primeira parte para ser utilizada em todas as estrofes, como é mais encontrada na prática lúdica infantil $^{49}$. Sobre arpejo da $\mathrm{T}$, com salto inicial ascendente e linha descendente por terças quebradas, segue tetracorde ascendente para a T (duas vezes). Em GP/ABM, no compasso 30, na mão esquerda, a segunda nota deve ser precedida por um bequadro; no compasso 35, na mão esquerda, a segunda semínima deve ser precedida de bequadro. No compasso 41, na parte da voz, a última nota, segundo GP/VTL, deve ser oitava abaixo.

\footnotetext{
${ }^{49}$ Villa-Lobos propõe uma variação da melodia na segunda estrofe como parte deste arranjo.
} 
Acompanhamento instrumental (piano) - introdução com 4 compassos sobre ostinato em pedal de T/D. A melodia é dobrada pela mão direita, acompanhada por harmonização em T S D DD T, com apojaturas cromáticas em linhas duplas em sextas e variações rítmicas; na parte central (não utilizada aqui), breve incursão na Tr com variações melódicas, em plano mais agudo, terça acima e terça abaixo do desenho inicial, dão contraste à harmonização.

Ludicidade - Brincadeira de roda dialogada, com solista e desenvolvimento atrelado ao texto.

Complementação do texto:

- Onde vais, bela manquinha? / Goi! Goi! Goi! Goi! / Vou passear na floresta / Goi! Goi! Goi! Goi!

- Que fazes na floresta? / Goi! Goi! Goi! Goi! / Apanhar as lindas flores / Goi! Goi! Goi! Goi!

- Para quem são essas flores? / Goi! Goi! Goi! Goi! / Para enfeitar nossas cabeças / Goi! Goi! Goi! Goi!

\subsubsection{Sobre sete graus da escala}

90) SENHORA DONA SANCHA - acompanhamento instrumental

(Canto com piano, conjunto instrumental ou Piano solo)

Arr. de H. Villa-Lobos
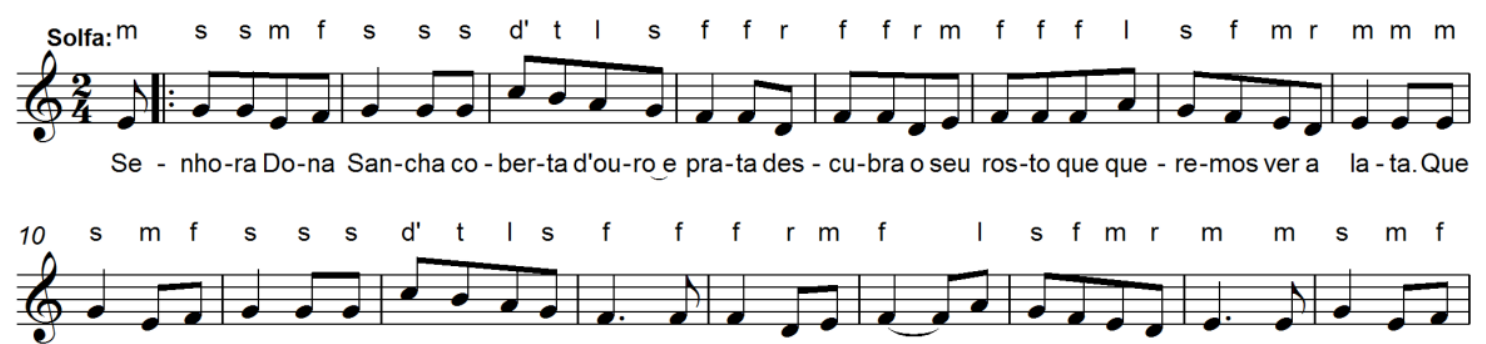

an-jossão es-sesque an-dampor a - qui, de dia e de noi - te__ Á ro - da de mim? São fi-lhos de

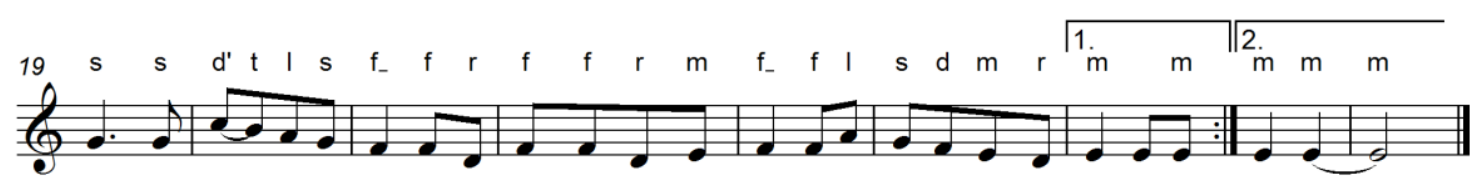

Rei E ne - tos de con-de,que man-dam que se es-con-da de-bai-xo de u-ma pe-draSe pe-dra__

\begin{tabular}{|c|c|c|c|c|}
\hline $\begin{array}{l}\text { Volume } \\
\text { GP-VTL } \\
\text { /ABM }\end{array}$ & $\begin{array}{l}\text { № } \\
114 \\
/ 75\end{array}$ & $\begin{array}{l}\text { Tessitura } \\
\text { D3-C4 }\end{array}$ & $\begin{array}{c}\text { Forma - A } \\
\text { Gênero - Marcha } \\
\text { Extensão: 7ạ } \\
\text { Graus da escala: } 7 \\
\text { Sistema Heptatônico (F C G D A E B) } \\
\text { Heptacorde (t I s f m r d) }\end{array}$ & $\begin{array}{l}\text { Intervalos } \\
\text { melódicos } \\
\text { 2a M/m; 3ạ } \\
\mathrm{M} / \mathrm{m} ; 4 \text { a J }\end{array}$ \\
\hline \multicolumn{5}{|c|}{ 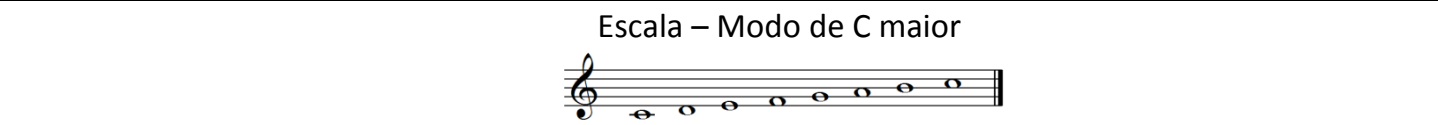 } \\
\hline
\end{tabular}

Sugestões de atividades didático-pedagógicas:

Células rítmicas para registro gráfico:

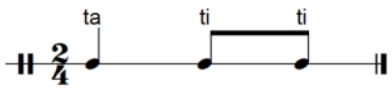

Células melódicas para registro gráfico:

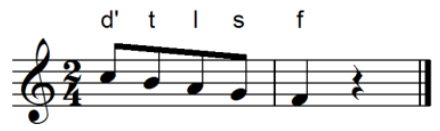


Possivel ostinato rítmico:

$$
\text { H? } 2: \text { ta }
$$

Canção popular, de 25 compassos binários, com a indicação de andamento: Allegro $(160=$ ل ); indicações de dinâmica: $\boldsymbol{f} ; \boldsymbol{m} \boldsymbol{f}$

Tema popular, folclórico infantil, de brincadeira cantada cujo desenvolvimento baseia-se no texto.

Texto - descrição de brincadeira de roda, em que a senhora D. Sancha tem seu rosto coberto e deve se revelar ao grupo e transmitir ordens de anjos para o desenvolvimento do jogo.

Ritmo - o interesse rítmico está nos motivos anacrúsicos. Em GP/ABM, as semínimas pontuadas nos compassos 8, 12, 18, 24, 26 e 28, deveriam ser semínimas seguidas de colcheia, já que a intenção é que a mão direita dobre a voz cantada.

Melodia - desenho sobre a terça menor ascendente em curva seguido de salto ascendente de quarta e pentacorde descendente para a D; idem, segunda abaixo terminando em $\mathrm{T}$.

Ludicidade - brincadeira de roda em que a solista, D. Sancha, tem seu rosto coberto e desvendado, dialogando com a roda sobre outros personagens, os anjos, e revelando as ordens de ações que compõem o desenrolar do jogo. A troca dos personagens pode acontecer ou não.

\section{1) DE FLOR EM FLOR-acompanhamento instrumental}

(Canto com piano, conjunto instrumental ou Piano solo)

Amb. por H. Villa-Lobos

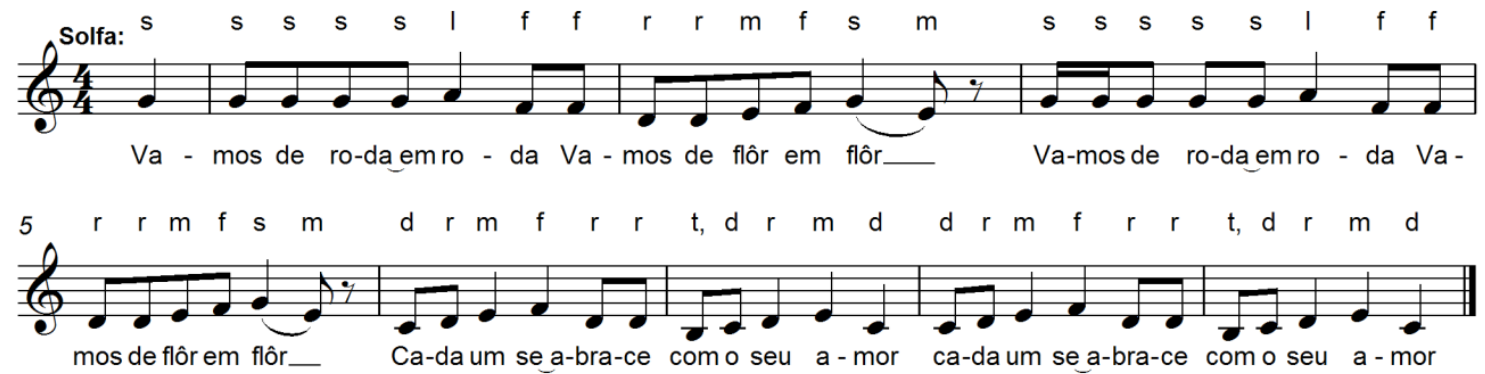

Sugestões de atividades didático-pedagógicas:

Células rítmicas para registro gráfico:

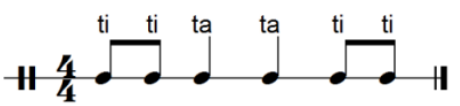

Células melódicas para registro gráfico:

\begin{tabular}{|c|c|}
\hline $\begin{array}{c}\text { Forma - A } \\
\text { Gênero - Polca canção } \\
\text { Extensão: 7ạ }\end{array}$ & $\begin{array}{l}\text { Intervalos } \\
\text { melódicos }\end{array}$ \\
\hline $\begin{array}{l}\text { Graus da escala: } 7 \\
\text { Heptatônico (F C G D }\end{array}$ & 2 a $M / m ; 3$ a \\
\hline
\end{tabular}

Heptacorde ( $\mathrm{I}$ s f $\mathrm{m} \mathrm{r}$ d)

Escala - Modo de C maior
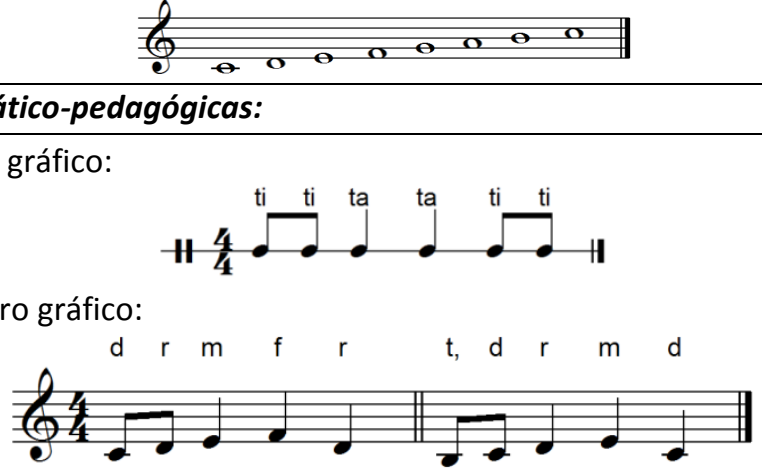
Possivel ostinato rítmico:

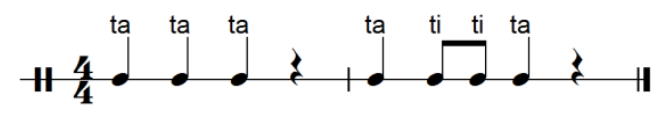

Possivel ostinato melódico:

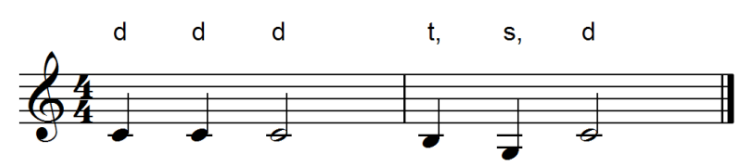

Análise complementar em 2.2 - $n^{\circ} 166$.

Canção popular, de 9 compassos quaternários, com a indicação: Allegro (M.M. 132=ل ); indicações de dinâmica: $f ; \boldsymbol{m f} ;<; s f z ;>$; acentos $>$; fff

Tema popular, folclórico infantil, de brincadeira cantada cujo desenvolvimento baseia-se no texto.

Texto - Descrição da brincadeira em que as crianças são flores em formação de rodas, em que todos se abraçam.

Ritmo - O compasso não é confortável para a movimentação da roda: o compasso binário é mais adequado. Após o final da primeira frase, a segunda deveria ser anacrúsica: uma solução possível seria alterar o ritmo do compasso 5 para:

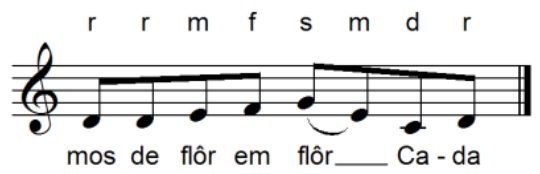

Melodia - notas rebatidas no quinto grau são seguidas pela tríade de $\mathrm{Sr}$ em arpejo descendente, tetracorde ascendente e resolução na T. Segunda parte com pequenas curvas em torno da $\mathrm{T}$ e da $\mathrm{D}$, com terminação por terça descendente para a $\mathrm{T}$.

Ludicidade - brincadeira com uma ou mais rodas, em que pares são formados a cada vez que a música se repete.

92) SOLFEJO no 57 - a capella

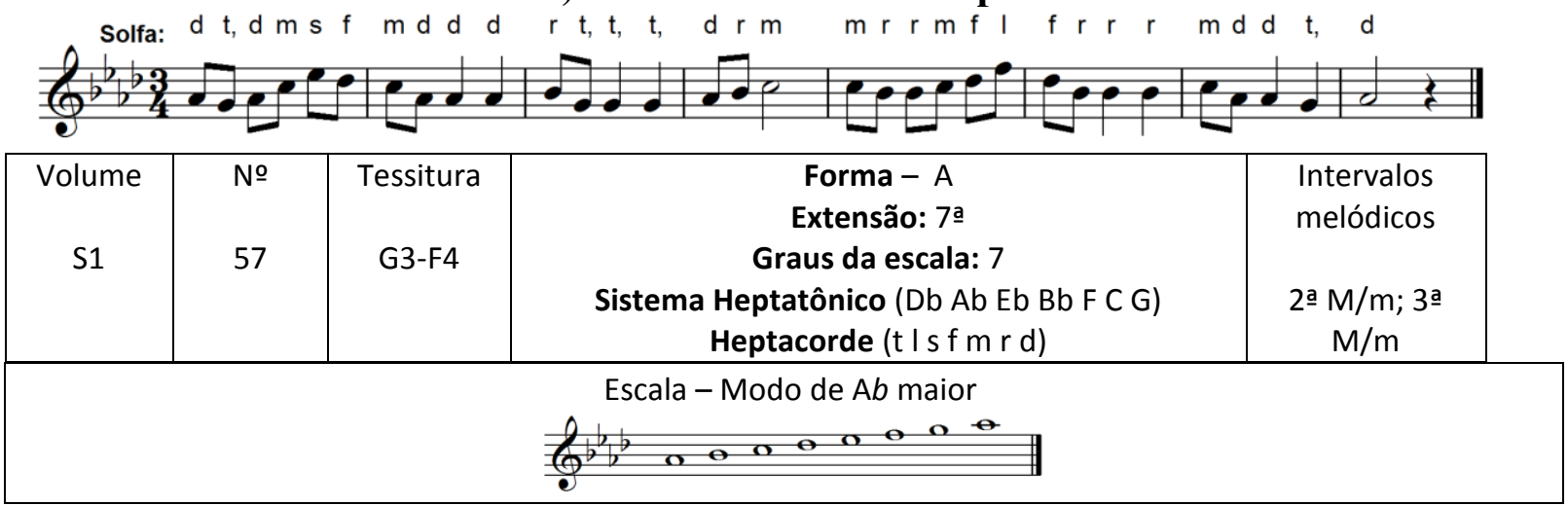

Sugestões de atividades didático-pedagógicas:

Células rítmicas para registro gráfico:

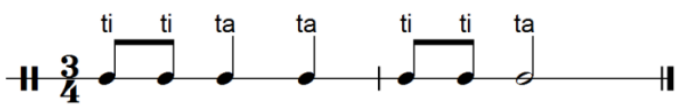


Células melódicas para registro gráfico:

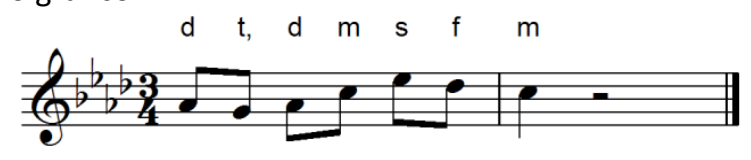

Possivel ostinato rítmico:

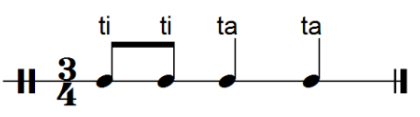

Tema de Villa-Lobos em tempo de mazurca com 8 compassos ternários, com a indicação de andamento: Movimento de Mazurka; sem indicações de dinâmica.

Ritmo - o interesse rítmico está no compasso ternário e no movimento de dança.

Melodia - pequenas curvas a partir da $\mathrm{T}$ e $\mathrm{Sr}$ com finalização em sequências de terças descendentes e notas rebatidas, com final na $\mathrm{T}$.

Ludicidade - apesar de se tratar de um solfejo, sendo em tempo de Mazurka, pode-se acrescentar uma coreografia.

\section{3) OFERTA DA CRIANÇA À LUA - a capella}

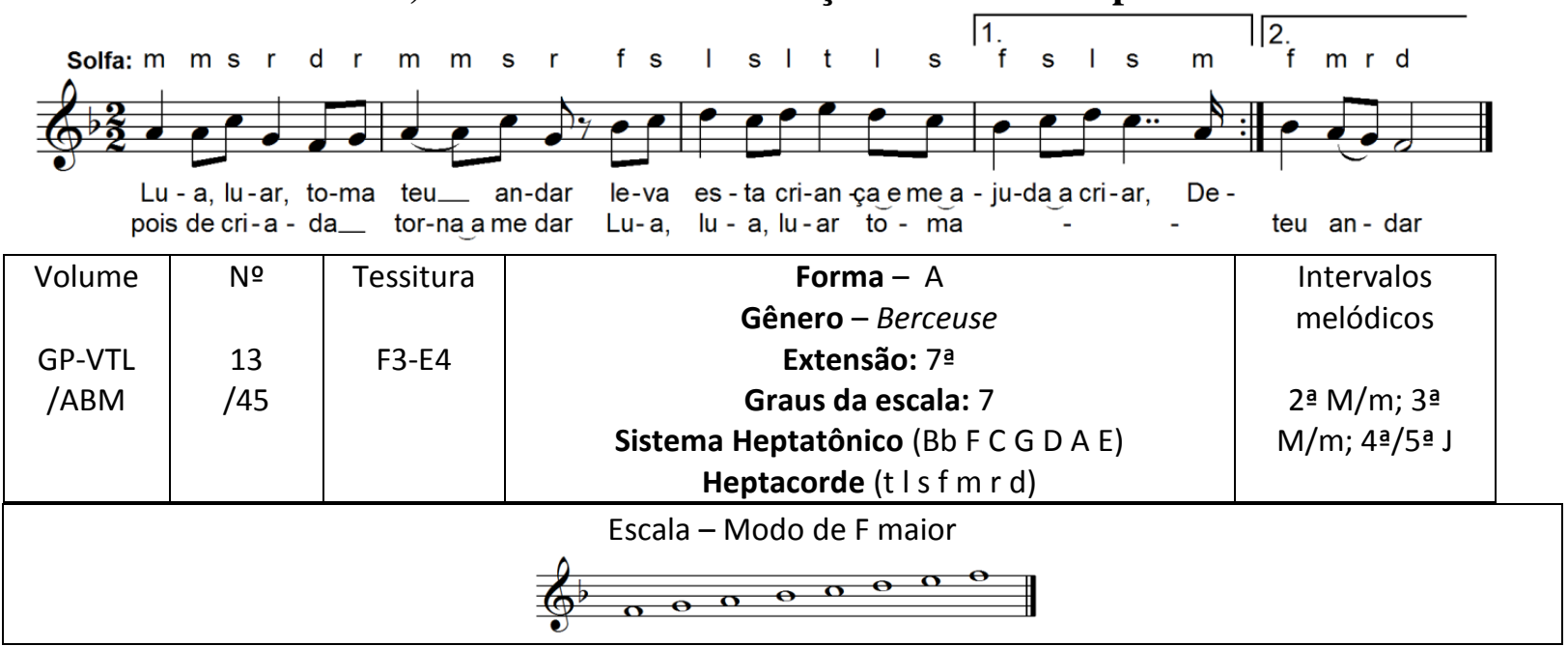

\section{Sugestões de atividades didático-pedagógicas:}

Células rítmicas para registro gráfico:

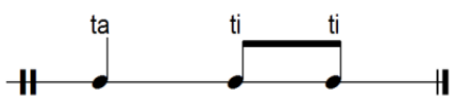

Células melódicas para registro gráfico:

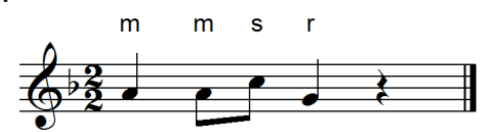

Possivel ostinato rítmico:

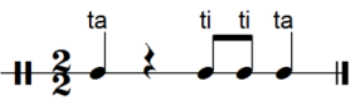

Análise complementar em $2.2-n^{\circ} 13$.

Canção com 5 compassos binários, com a indicação de andamento: Allegro gracioso (M.M. $\mathbf{7 6}=d$ ) indicações de dinâmica: $\boldsymbol{m f}$ 
Tema de Villa-Lobos.

Texto - oferenda da criança à lua, pedido de ajuda para a sua criação. A prosódia não é adequada na palavra "teu”, com separação do ditongo. Deveria haver uma ligadura da semínima para a colcheia.

Ritmo - o interesse está no ostinato rítmico.

Melodia - saltos de terças menores e quartas justas em direção à $\mathrm{D}$, com curva por graus conjuntos na $\mathrm{S}$ e $\mathrm{D}$, finalizando descendentemente na $\mathrm{T}$.

Ludicidade - sendo uma canção de ninar, as possibilidades de representação cênica ou simplesmente do canto são desafios lúdicos.

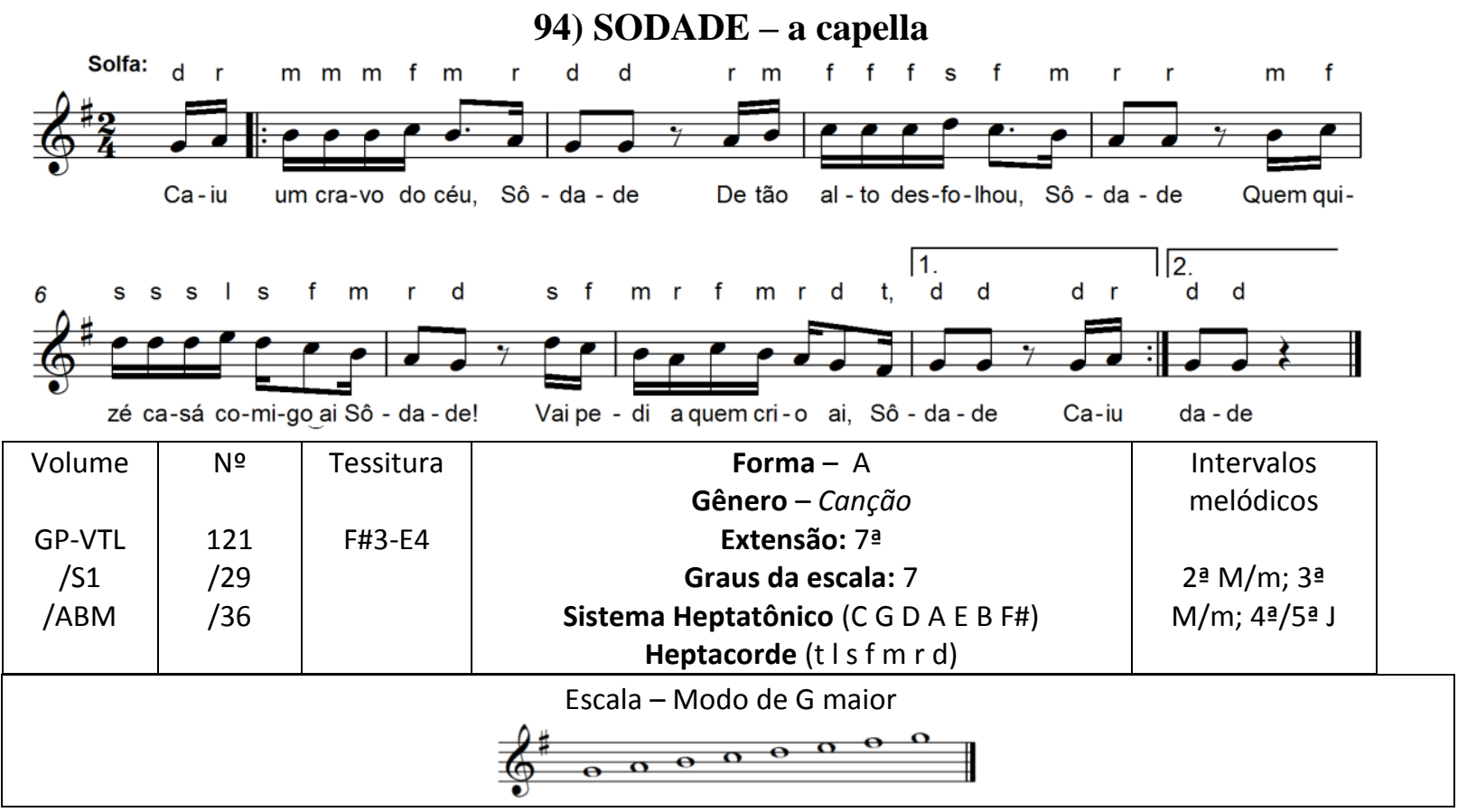

Sugestões de atividades didático-pedagógicas:

Células rítmicas para registro gráfico:

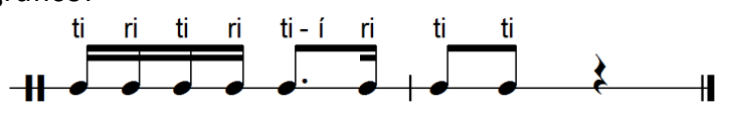

Células melódicas para registro gráfico:

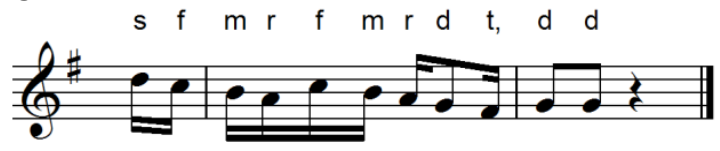

Possivel ostinato rítmico:

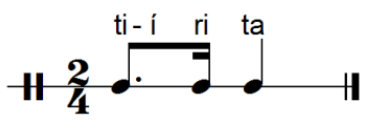

Análise complementar em $2.2-n^{\circ} 4$.

Canção popular, de 10 compassos quaternários, com a indicação: Andantino (84= ل ); sem indicações de dinâmica.

Tema popular, folclórico, de brincadeira cantada. 
Texto - quadrinha com interpolação da palavra 'sodade' entre os versos, sem significado lógico, buscando a rima. A grafia sugere a interpretação do texto com sotaque característico do caboclo brasileiro.

Ritmo - o interesse está nos ritmos pontuados e síncopas.

Melodia - partindo da tônica, o quinto grau é alcançado ascendentemente e a conclusão se dá por desenho descendente também na T, alcançada pela sensível.

Ludicidade - brincadeira de roda simples, com interesse na criação de quadrinhas com a inclusão do ostinato.

Complemento do texto ${ }^{50}$ :

- Caiu um cravo do céu, Sôdade! / de tão alto desfolhou / Sôdade! /quem quizé casá cumigo, Ai! Sôdade! / vá pedi a quem me criô, Ai! Sôdade!

- Quem quizé moço bunito, Sôdade! / arme um laço na parede, Sôdade! / Inda onti apanhei um, Ai! Sôdade! / num laço de fita verde, Ai! Sôdade!

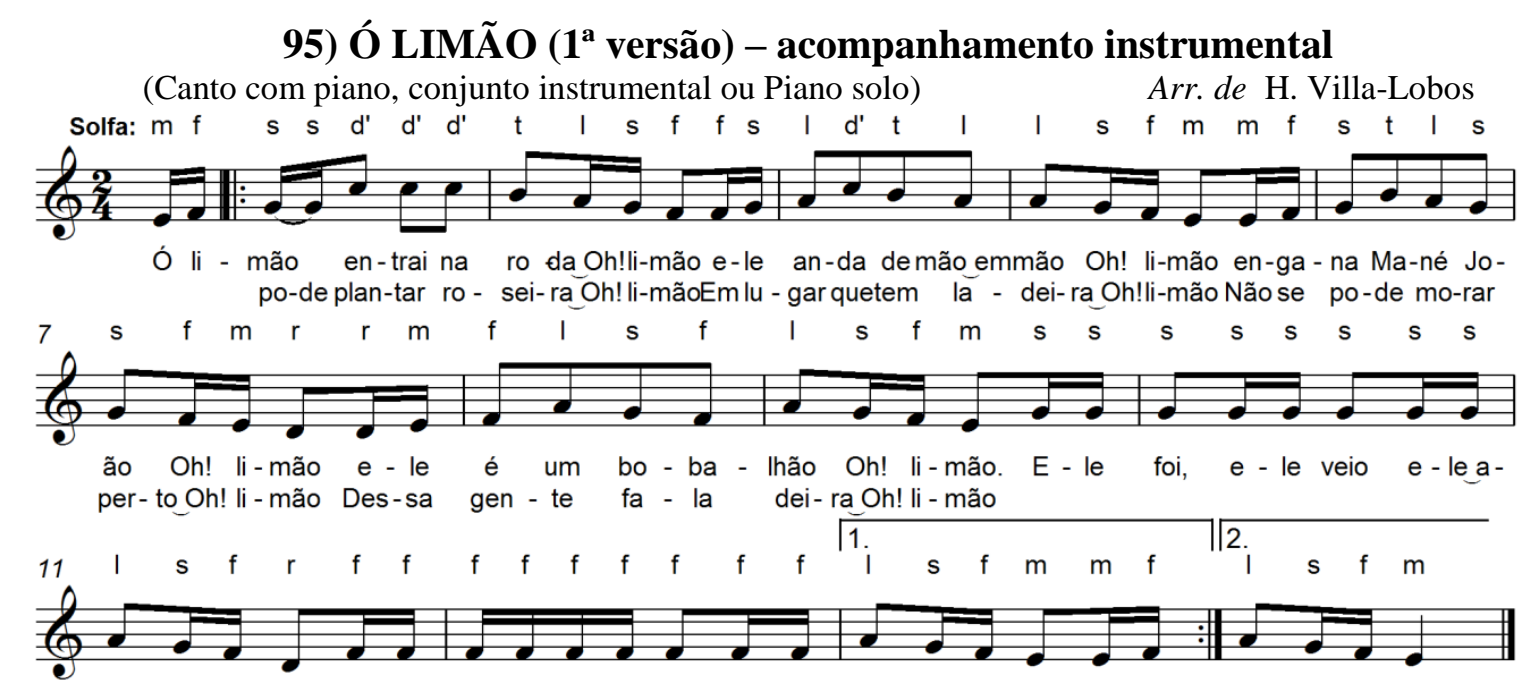

qui não che-gou, lá no me-io do ca-mi -nho a prin - ce - sa to-mou. Não se ce - sa to-mou

\begin{tabular}{|c|c|c|c|c|}
\hline $\begin{array}{l}\text { Volume } \\
\text { GP-VTL } \\
\text { /ABM }\end{array}$ & $\begin{array}{l}\text { № } \\
68 \\
/ 88\end{array}$ & $\begin{array}{l}\text { Tessitura } \\
\text { D3-C4 }\end{array}$ & $\begin{array}{c}\text { Forma - A } \\
\text { Gênero - quase batucada } \\
\text { Extensão: 7ạ } \\
\text { Graus da escala: } 7 \\
\text { Sistema Heptatônico (F C G D A E B) } \\
\text { Heptacorde ( } \mathrm{t} \text { / s f m r d) }\end{array}$ & $\begin{array}{c}\text { Intervalos } \\
\text { melódicos } \\
\text { 2a } \mathrm{M} / \mathrm{m} ; 3 \text { a } \mathrm{M} / \mathrm{m} ; \\
4 \text { a } / 5 \mathrm{a} \mathrm{J}\end{array}$ \\
\hline \multicolumn{5}{|c|}{ Escala - Modo de C maior } \\
\hline
\end{tabular}

Sugestões de atividades didático-pedagógicas:

Células rítmicas para registro gráfico:

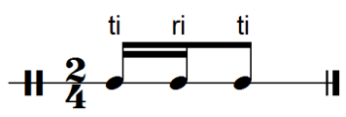

Células melódicas para registro gráfico:

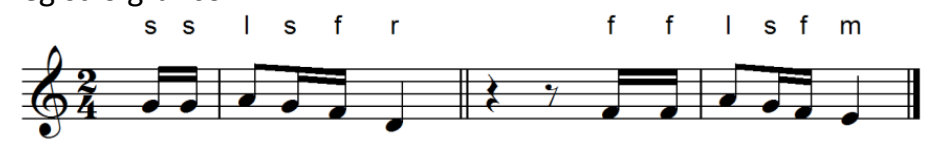

${ }^{50}$ Segunda estrofe registrada por Mário de Andrade, Ensaio sobre a Música Brasileira. 
Possivel ostinato rítmico:

$$
\mathbf{1 1} \frac{\mathbf{2}}{\mathbf{4}} \cdot \mathbf{t a}
$$

Canção com 14 compassos binários, com a indicação de andamento: Allegretto Vivace $(\mathbf{1 4 4}=$ ل ); indicações de dinâmica: $s f z$; acentos > ;ff

Tema popular, folclórico infantil, de brincadeira cantada cujo desenvolvimento baseia-se no texto.

Texto - descrição de brincadeira com uso de limão, com frases humorísticas ao gosto da época.

Ritmo - o interesse rítmico está nas notas rebatidas e na formação de motivo rítmico por contratempo.

Melodia - terça menor cheia ascendente seguida de salto ascendente e linha descendente por graus conjuntos - desenho semelhante repetido em sequências em alturas diferentes, com resoluções na D; T; D; T. Segunda parte com notas rebatidas com resolução descendente para $\mathrm{D}$ e na repetição para a $\mathrm{T}$.

Acompanhamento instrumental (piano) - a introdução inicia-se com a primeira célula do primeiro motivo por oitava, a mão direita sustenta o quinto grau como pedal, enquanto a mão esquerda apresenta o ostinato rítmico que será utilizado em seguida; a melodia é dobrada pela mão direta, às vezes compondo a harmonia com outras notas, enquanto o baixo apresenta o ostinato utilizado na introdução. Na segunda parte o acompanhamento é mais rarefeito, com sforzattos no primeiro pulso e no contratempo do segundo. A coda utiliza uma célula extraída do ostinato, repetindo-a por sequência de grau conjunto descendente até a finalização na $\mathrm{T}$. Em GP/ABM, falta uma ligadura nas duas primeiras notas da mão direita no compasso 7 e uma nota $\boldsymbol{D}$ no primeiro acorde na mão direita nos compassos 18 e 30 .

Ludicidade - brincadeira de roda, com o limão como acessório, podendo haver interferência de personagens como o Limão, a Princesa, ou outros.

\section{6) A CANOA VIROU - a capella}

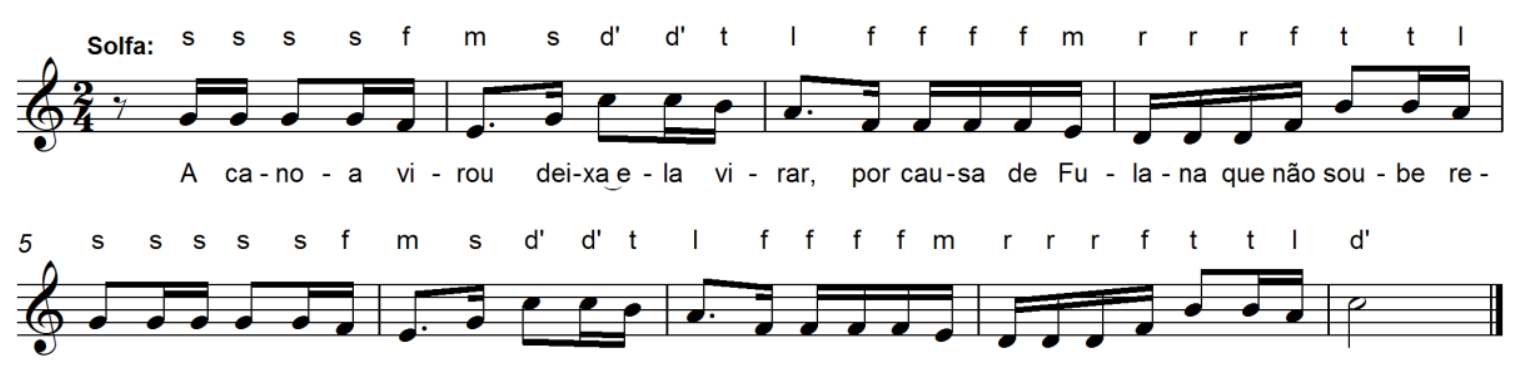

mar. A ca-no - a vi - rou. Dei-xa - - la vi - rar, porcau-sa de Fu - la-na que não sou-be re - mar

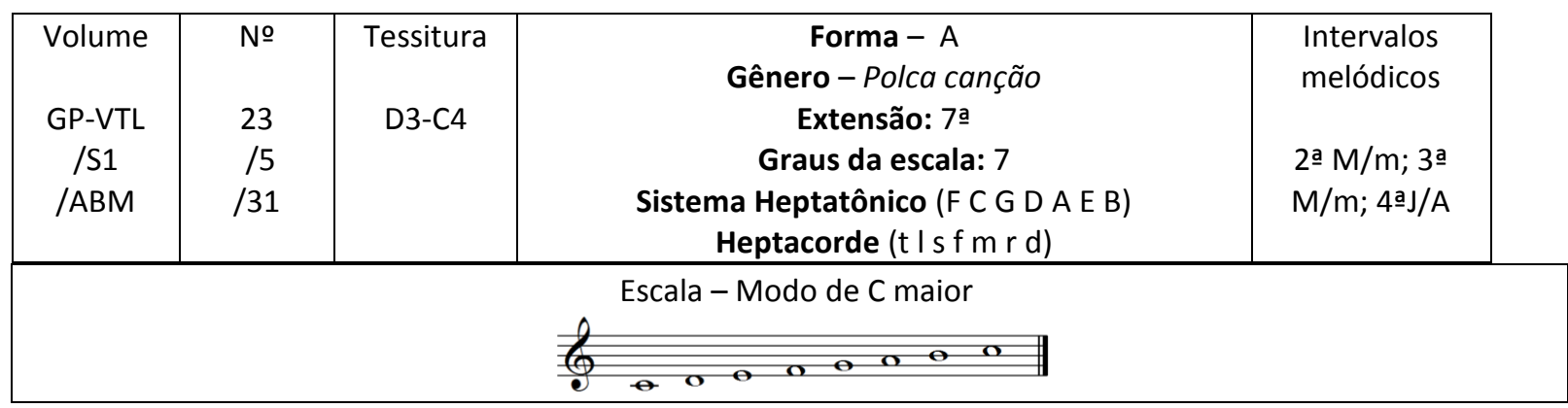


Sugestões de atividades didático-pedagógicas:

Células rítmicas para registro gráfico:

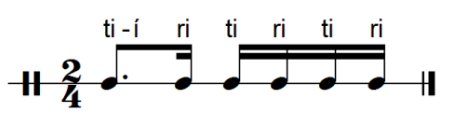

Células melódicas para registro gráfico:

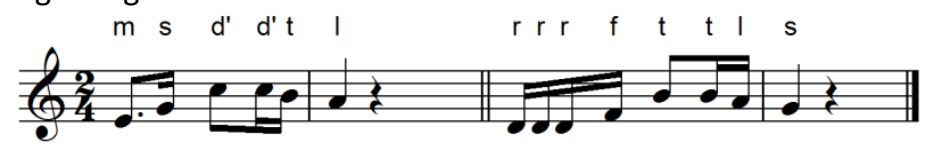

Possivel ostinato rítmico:

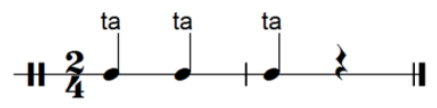

Análise complementar em 2.2 - $n^{\circ} 55$.

Canção com 9 compassos binários, com a indicação de andamento: Allegretto $(72=$ d); indicações de dinâmica: $\boldsymbol{m f}$

Tema popular, folclórico infantil, de brincadeira cantada cujo desenvolvimento baseia-se no texto.

Texto - descrição da brincadeira de roda caracterizada pela personalização dos participantes, citados nominalmente.

Ritmo - o interesse está no repouso a cada compasso, que pode estar associado ao eventual movimento do remo.

Melodia - pequenos desenhos descendentes em torno de terças menores e maiores, com as conclusões na $\mathrm{S} / \mathrm{D} / \mathrm{T}$. Primeiro motivo chega à $\mathrm{S}$ e a frase conclui na $\mathrm{T}$ - a segunda frase repete a primeira.

Ludicidade - brincadeira de roda, em que cada criança tem seu nome citado, quando troca sua posição para o lado externo da roda, até que todas assim estejam para então recomeçarem o processo para 'desvirar' a roda (uma a uma, as crianças voltam para a posição inicial).

\section{7) Ó PIÃO - acompanhamento instrumental}

(Canto com piano, conjunto instrumental ou Piano solo) Amb. por H. Villa-Lobos
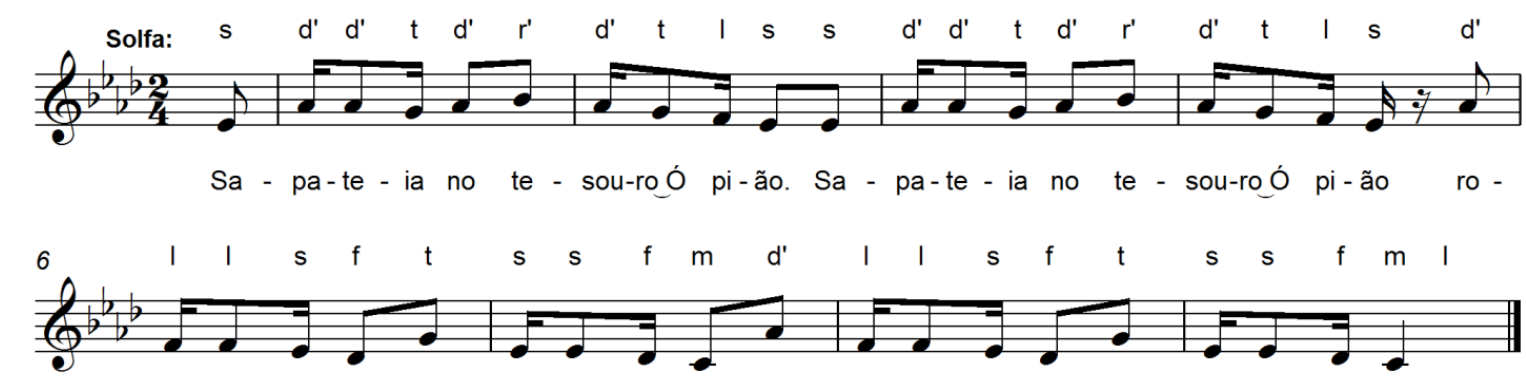

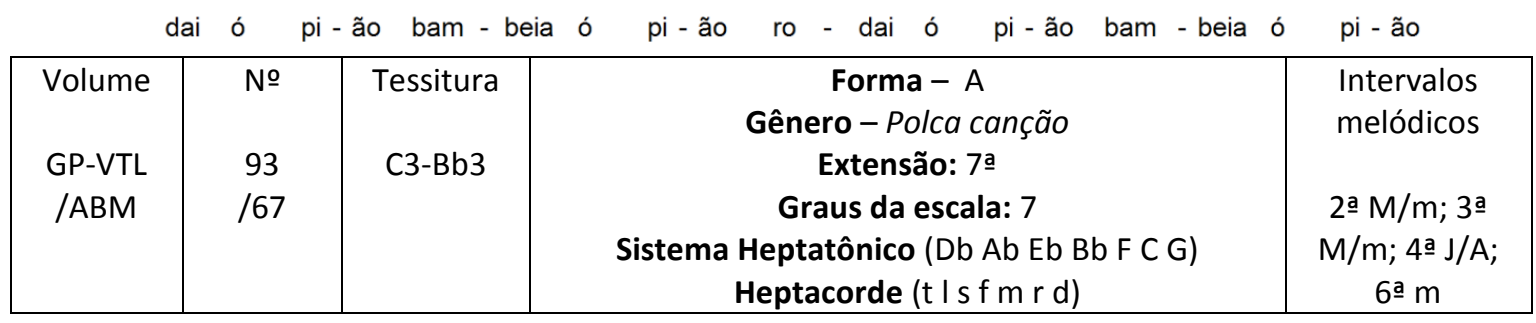




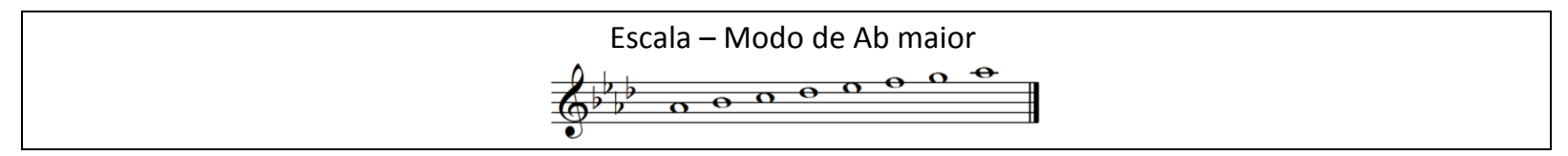

Sugestões de atividades didático-pedagógicas:

Células rítmicas para registro gráfico:

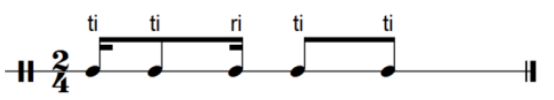

Células melódicas para registro gráfico:

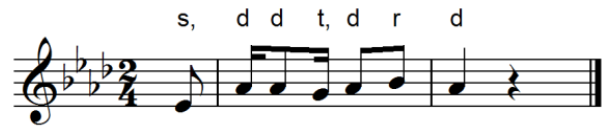

Possivel ostinato rítmico:

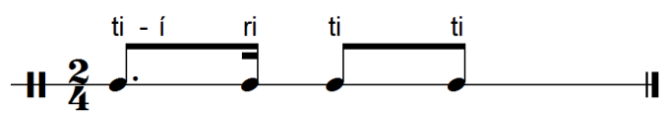

Canção com 9 compassos binários, com a indicação de andamento: Movimento de Marcha $(\mathbf{1 0 4}=ل)^{51}$; Poco rall. ; Rápido; indicações de dinâmica: $\boldsymbol{m f}$; acentos >.

Tema popular, folclórico infantil, de brincadeira cantada cujo desenvolvimento baseia-se no texto.

Texto - Descrição de brincadeira de roda, em que a variação mais frequente é a substituição de "tesouro" por "tijolo". Segue, abaixo, complementação do texto, por mim recolhida, para dar mais sentido à brincadeira, como atividade voltada a estratégias didáticas paralelas já mencionadas.

Ritmo - o interesse rítmico está nos ostinatos com

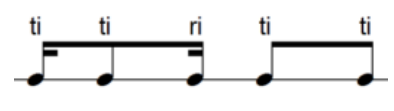

Melodia - iniciada por saltos anacrúsicos de quarta ascendente, a resposta segue por terças anacrúsicas descendentes, com terminação na terça da T. Neste capítulo desprezamos a codeta vocal, pelos motivos já explicados anteriormente. GP/ABM, na repetição (compasso 13), corrige a última nota (em GP/VTL $\boldsymbol{F}$ ) para $\boldsymbol{E}$ b, conservando, todavia, $\boldsymbol{F}$ no compasso 21, início da codeta, adequadamente, para conservar a linha descendente sempre iniciada por terça. Em GP/VTL, a solução seria antecipar em meio tempo as barras de repetição.

Acompanhamento instrumental - a introdução apresenta o tema da codeta vocal na mão direita, resolvendo em $\mathrm{D}^{6} \mathrm{~T}$, sobre linha descendente em oitavas na mão esquerda, e finalização em uníssono com notas rebatidas no quinto grau. Tanto em GP/VTL como em GP/ABM, o compasso 4 contém 4 pulsos, sendo binário. Segue uma solução viável:

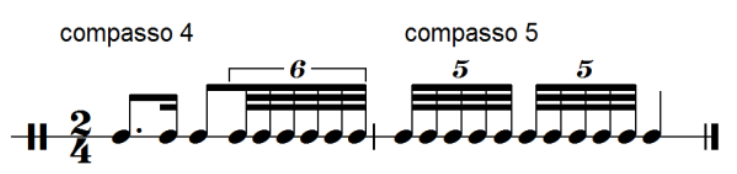

No compasso 5, em ABM, o primeiro acorde deveria ser de $\boldsymbol{A b}$ maior e não $\boldsymbol{C}$ menor como consta. A melodia é dobrada na mão direita, em acordes para determinar a harmonização, enquanto a mão esquerda faz contraponto em oitavas. Em GP/ABM, no compasso 13, na mão esquerda, as duas últimas notas devem ser $\boldsymbol{D} \boldsymbol{C}$ e não $\boldsymbol{F} \boldsymbol{E}$ como consta. A coda apresenta novos elementos sobre pedal de $\mathrm{T}$ - iniciada por ponte escalar, desenvolve-se por duas vezes, uma linha melódica quebrada descendente em torno dos graus: 6 e 8,5 e 8,4 e 8, e 3; a

\footnotetext{
${ }^{51}$ Em GP/ABM, a indicação é Movimento de marcha (lento).
} 
cadência final, iniciada por linha descendente, terminando em acorde cromático em $\boldsymbol{E}$ maior, segue descendente para o retorno à $\mathrm{D}$ e $\mathrm{T}$.

Ludicidade - brincadeira de roda, com ou sem o brinquedo pião como acessório, que inclui o sapateado na coreografia.

Complemento do texto:

- Sapateia no tesouro, ó pião, (Bis) / Rodai ó pião, Bambeia ó pião (Bis)

- Sapateia no tijolo, ó pião, (Bis) / Rodai ó pião, Bambeia ó pião (Bis)

- E faz uma cortesia, ó pião, (Bis) / Rodai ó pião, Bambeia ó pião (Bis)

- E passa o pião a outro, ó pião, (Bis) / Rodai ó pião, Bambeia ó pião (Bis)

98) O BASTÃO (MIA GATO) - acompanhamento instrumental

(Canto com piano, conjunto instrumental ou Piano solo) Amb. por H. Villa-Lobos

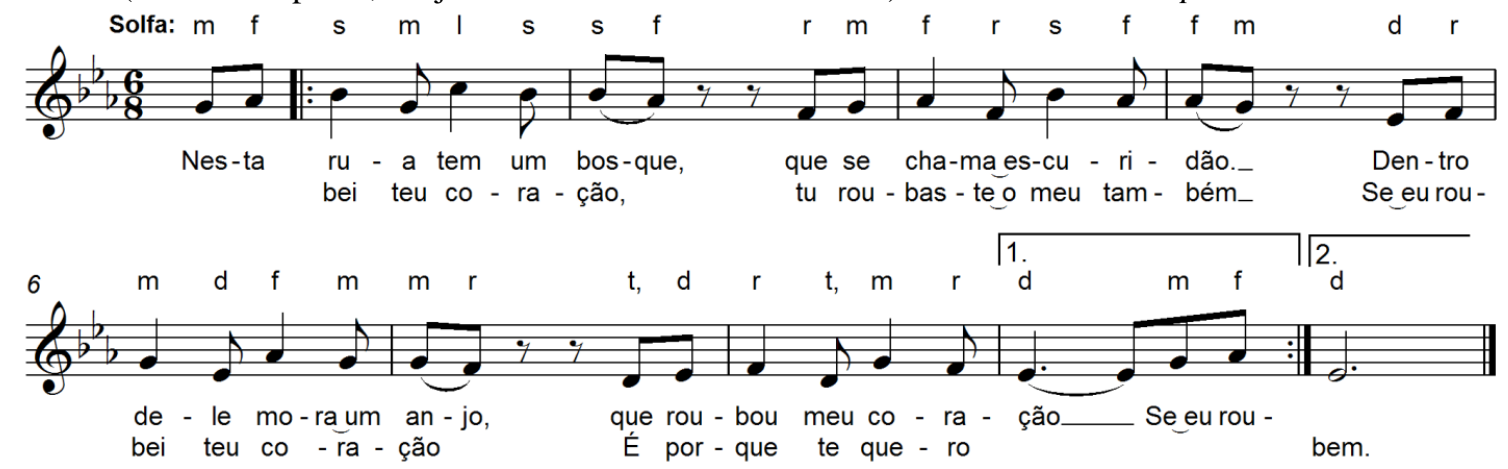

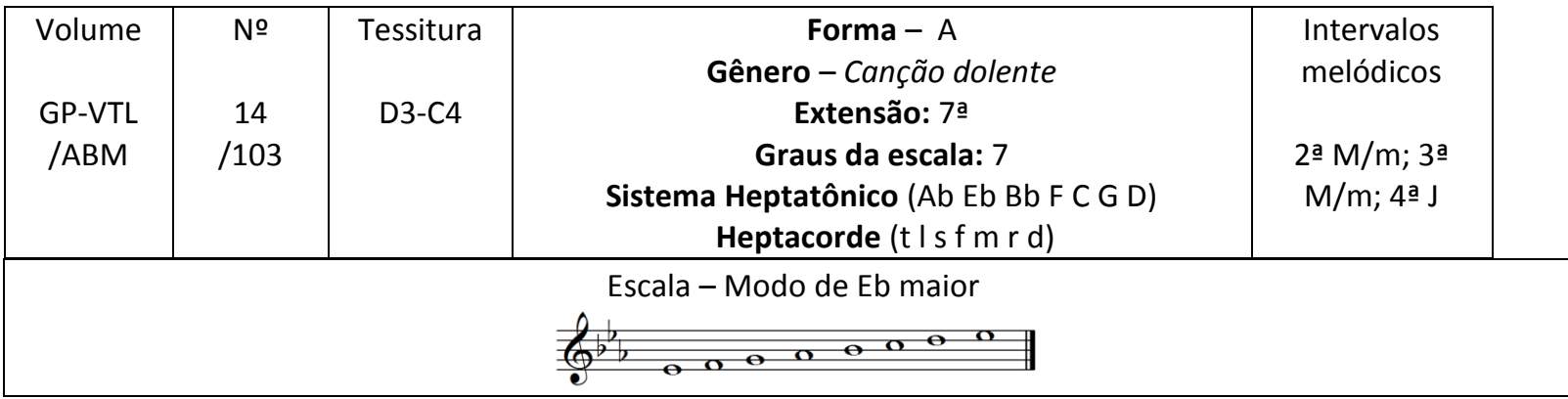

\section{Sugestões de atividades didático-pedagógicas:}

Células rítmicas para registro gráfico:

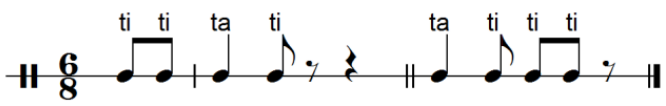

Células melódicas para registro gráfico:

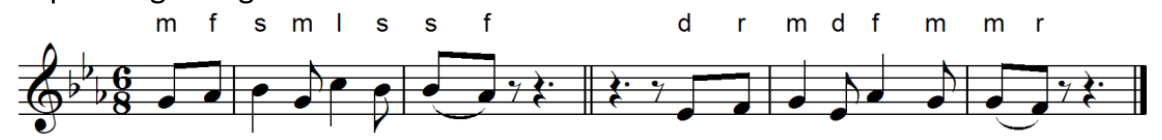

Possível ostinato rítmico:

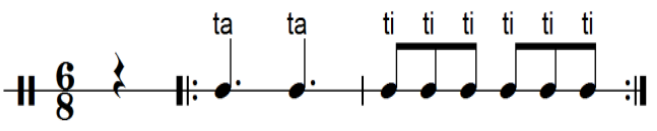

Canção com 10compassos binários, com subdivisão ternária, com a indicação de andamento: Andante quasi andantino (M.M. 54=ل) - (deveria ser ل J.); poco rall.; indicações de dinâmica: $f$; $\boldsymbol{m f}$; $\boldsymbol{p p}$; acentos >

Tema popular, folclórico infantil, de brincadeira cantada cujo desenvolvimento baseia-se no texto. 
Texto - quadrinhas de romance, encontradiças em diferentes melodias. "Mia gato", português arcaico. O clima romântico é criado pelos cromatismos e pedal no acompanhamento instrumental.

Ritmo - o interesse rítmico está na subdivisão ternária.

Melodia - pequenas curvas em sequências descendentes por grau conjunto do quinto grau alcançado por terça cheia ascendente para o primeiro.

Acompanhamento instrumental (piano) - presença de pedal de $\mathrm{T}$ em toda a peça. A introdução apresenta duplo pedal, de primeiro grau na mão esquerda e de quinto grau na mão direita, tendo na região média cromatismo entre tríades em linhas curvas côncavas. A mão direita dobra a melodia, que tem o mesmo acompanhamento adotado na introdução. A coda repete os mesmos elementos, terminando ascendente na T. GP/ABM acrescenta adequadamente oitavas nas duas notas últimas notas, porém seria útil indicar as notas inferiores para execução da mão esquerda. Da mesma forma, para facilitar a leitura pianística, essa mesma indicação deveria constar no segundo pulso do compasso 21 e na primeira nota do compasso 22 .

Ludicidade - brinquedo de roda com diálogo e escolha de solistas. É possível cantar em cânone essa canção, com entrada da segunda voz no compasso 5.

99) SOLFEJO 142 - a capella

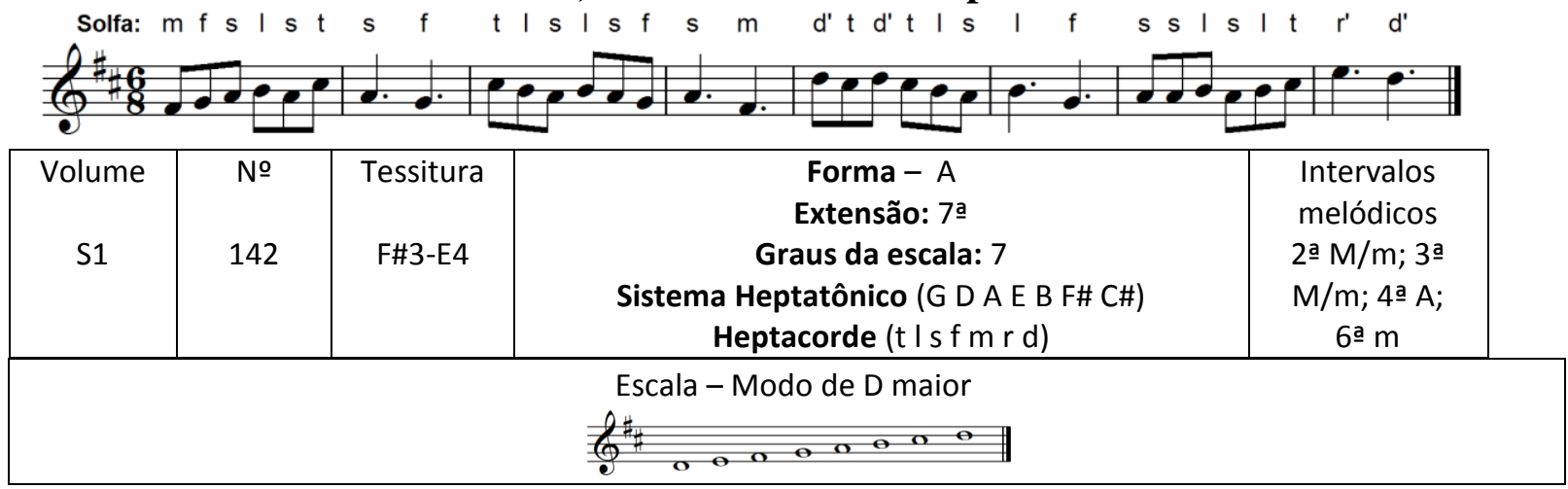

Sugestões de atividades didático-pedagógicas:

Células rítmicas para registro gráfico:

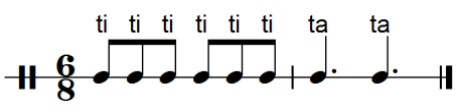

Células melódicas para registro gráfico:

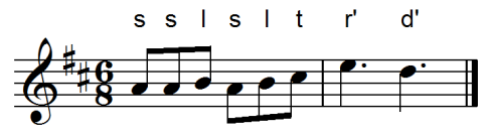

Possivel ostinato rítmico:

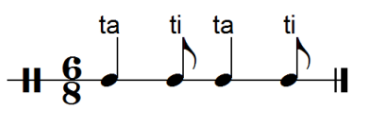

Canção com 8 compassos binários, com subdivisão ternária, com a indicação: Andantino, sem indicações de dinâmica.

Tema de Villa-Lobos.

Ritmo - o interesse rítmico está na subdivisão ternária. 
Melodia - desenhos em pequenas curvas sobre pentacordes com terminações $\mathrm{D}^{7}$ (apojatura); T; S; T (apojatura).

Ludicidade - apesar de se tratar de um solfejo, pode-se introduzir leitura acompanhada de movimentação, com ou sem acessórios (bolas, lenços, fitas, etc.).

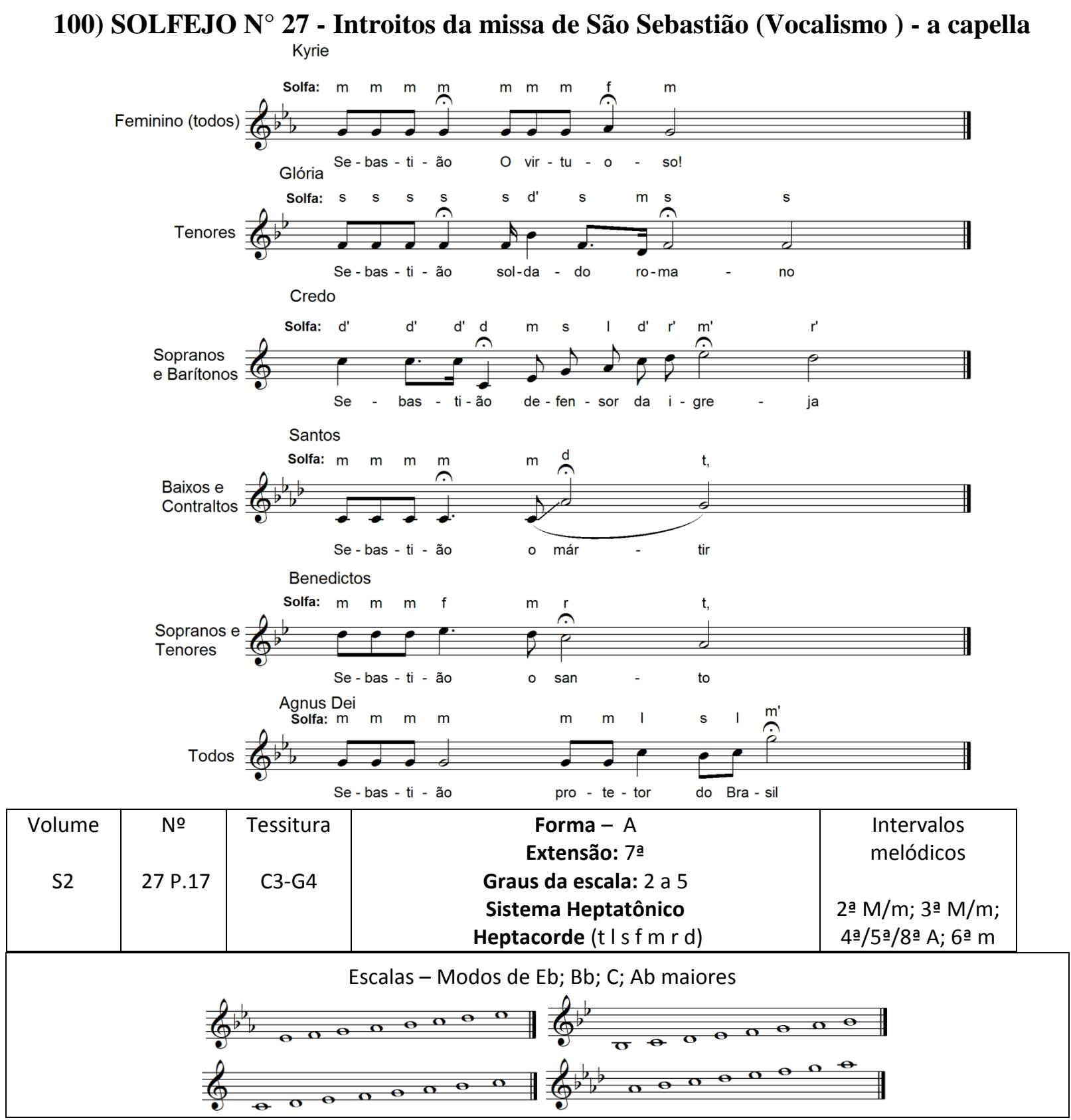

Pequenas frases de recitativos em ritmo livre, sem indicação de compassos, de andamento ou de dinâmica.

Tema de Villa-Lobos, trechos da missa de São Sebastião: Kirye, Glória, Credo, Sanctus (Santos, como consta), Benedictus (Benedictos, como consta) e Agnus Dei.

Ritmo - o interesse está no ritmo livre, atrelado aos acentos tônicos das palavras.

Melodia - desenhos usuais em recitativos - de pequenos intervalos a grandes saltos. 
Ludicidade - apesar de se tratar de uma ilustração de uma forma vocal religiosa, atividades paralelas de pesquisa histórica, em torno do autor, da obra ou do personagem, pode se transformar em atividade lúdica.

\section{1) FICARÁS SOZINHA (Fui no Itororó) - a capella}

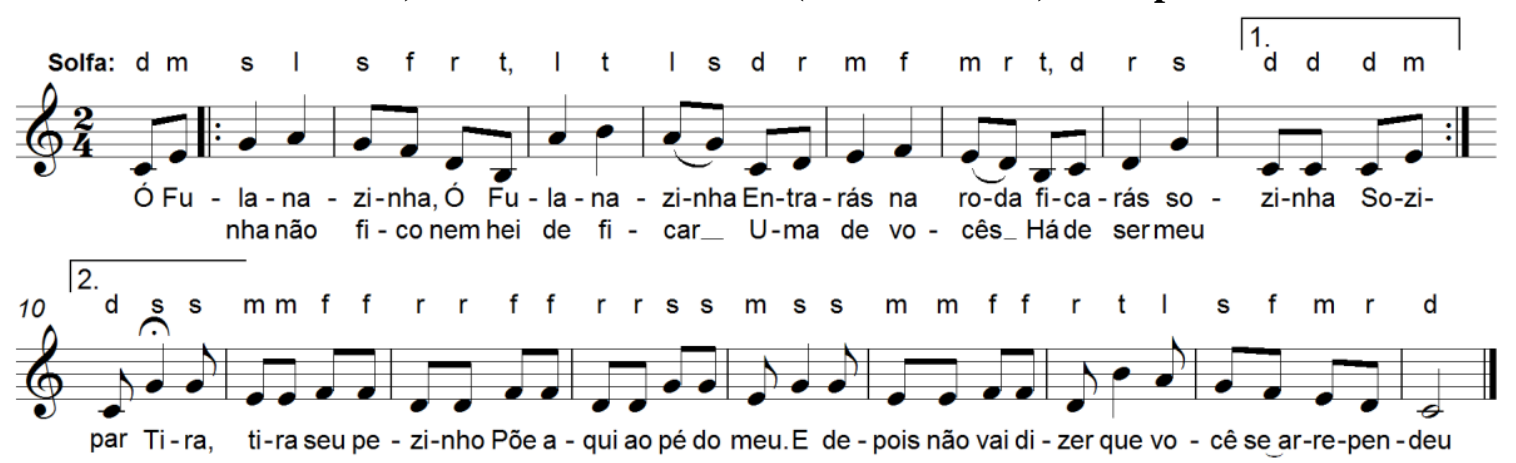

\begin{tabular}{|c|c|c|c|c|}
\hline $\begin{array}{l}\text { Volume } \\
\text { GP-VTL } \\
\text { /S1 } \\
\text { /ABM }\end{array}$ & $\begin{array}{l}\text { № } \\
51 \\
/ 4 \\
/ 3\end{array}$ & $\begin{array}{c}\text { Tessitura } \\
\text { B2-B3 }\end{array}$ & $\begin{array}{c}\text { Forma - A } \\
\text { Gênero - Cantiga } \\
\text { Extensão: } 8 \underline{a} \\
\text { Graus da escala: } 7 \\
\text { Sistema Heptatônico (F C G D A E B) } \\
\text { Heptacorde (t I s f m r d) }\end{array}$ & $\begin{array}{l}\text { Intervalos } \\
\text { melódicos } \\
\text { 2a M/m; 3ạ } \\
\text { M/m; 4å /5a J }\end{array}$ \\
\hline & & & $\overbrace{0}^{\text {Escala - Modo de C maior }}$ & \\
\hline
\end{tabular}

Sugestões de atividades didático-pedagógicas:

Células rítmicas para registro gráfico:

Células melódicas para registro gráfico:
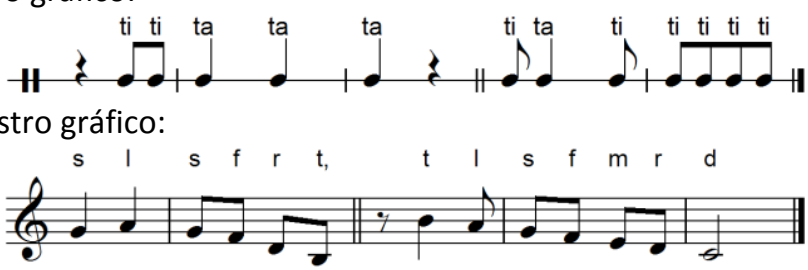

Possivel ostinato rítmico:

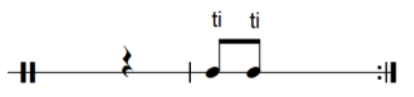

Canção com 18 compassos binários, com a indicação: Allegretto (M.M. $152=$ d); sem indicações de dinâmica.

Tema popular, folclórico infantil, de brincadeira cantada cujo desenvolvimento baseia-se no texto.

Texto - descrição de brincadeira de roda, que muitas vezes aparece acoplada a outras brincadeiras.

Ritmo - o interesse rítmico está nas sincopas métricas. Em GP/VTL, no compasso 9, constam 3 pulsações, sendo o compasso binário. ABM corrige o problema, mas conserva a prosódia das sílabas "zi-nha” em apenas uma semínima - o correto seriam duas colcheias.

Melodia - sobre arpejo ascendente da $\mathrm{T}$ e descendente da $\mathrm{D}^{7}$ e linha descendente alcançada por salto e pequenas curvas para a $\mathrm{T}$; segunda parte - terças quebradas descendentes finalizando com linha escalar descendente para a $\mathrm{T}$. 
Ludicidade - brincadeira de roda que aparece como complemento de outras, mais notadamente em Fui no Itororó.

\section{2) A COBRA E A ROLINHA - a capella}

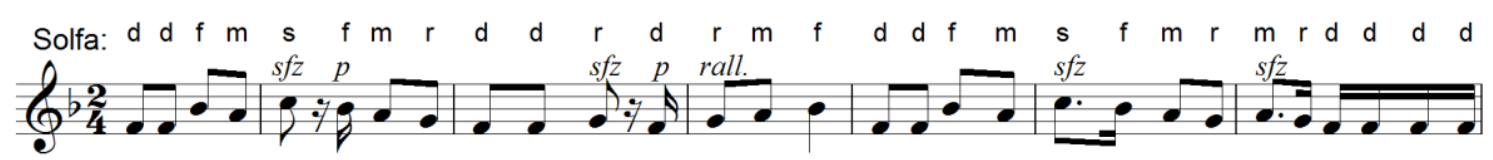

A ro-li-nha fez seuni-nho, pa-ra os seus o-vos cho-car. Veio a co-bra e co-me-oso-vos, a ro-li-nha põe-se
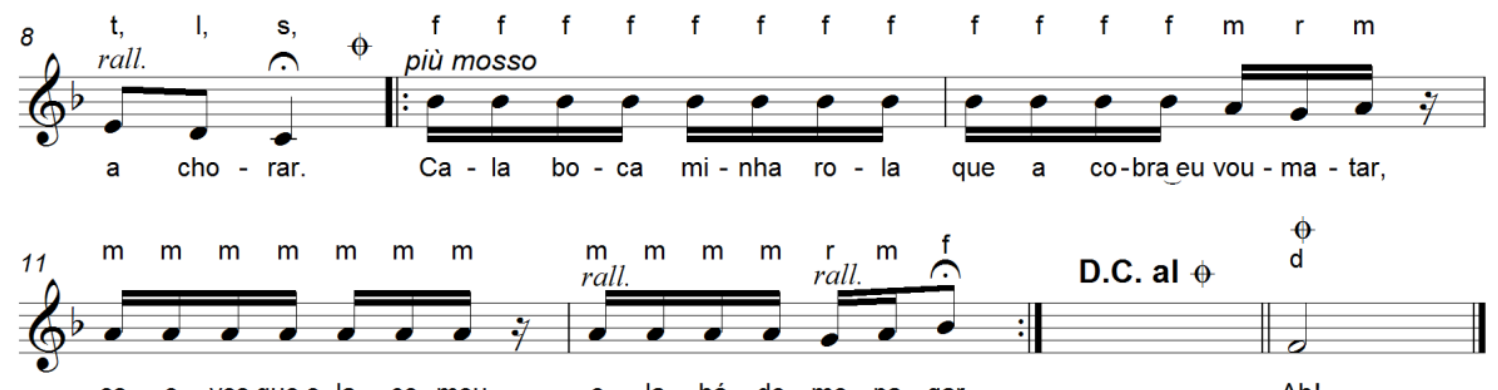

os o-vosque e-la co-meu e - la há de me pa-gar

Ah!

\begin{tabular}{|c|c|c|c|c|}
\hline $\begin{array}{c}\text { Volume } \\
\text { GP-VTL } \\
\text { /ABM }\end{array}$ & $\begin{array}{l}\text { № } \\
36 \\
/ 27\end{array}$ & $\begin{array}{l}\text { Tessitura } \\
\text { C3-C4 }\end{array}$ & $\begin{array}{c}\text { Forma - ABA } \\
\text { Gênero - Sertanejo } \\
\text { Extensão: } \text { 8a }^{\text {Graus da escala: } 7} \\
\text { Grau } \\
\text { Sistema Heptatônico (B } b \text { F C G D A E) } \\
\text { Heptacorde (t I s f m r d) }\end{array}$ & 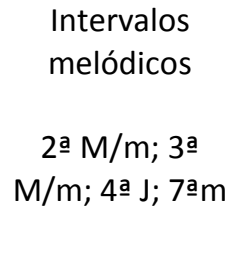 \\
\hline & & & 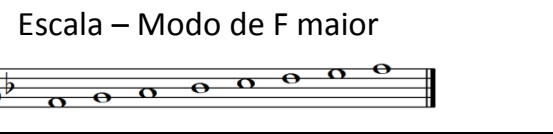 & \\
\hline
\end{tabular}

Sugestões de atividades didático-pedagógicas:

Células rítmicas para registro gráfico:

$$
+2 \cdot \% \cdot D \cdot \text {. }
$$

Células melódicas para registro gráfico:

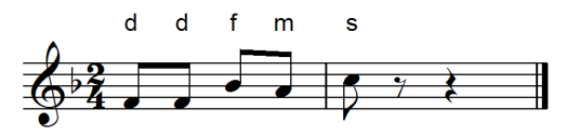

Análise complementar em 2.2 - $n^{\circ} 93$.

Canção com 13 compassos binários, com a indicação: Andante (M.M. 63= ل ); Più Mosso ; rall. fermatas; indicações de dinâmica: $s f z ; p$

Tema popular, folclórico infantil, de brincadeira cantada cujo desenvolvimento baseia-se no texto.

Texto - Quadrinhas dramáticas sobre a rolinha que teve seus ovos comidos pela cobra. As células rítmicas com pausas dos compassos 2 e 4, com $s f z$, e acento (>), seguidas de $\boldsymbol{p}$, podem sugerir soluços, assim como a sílaba: $A h$ !, no último compasso, pode significar um lamento.

Ritmo - o interesse rítmico está na variação de andamentos. Preferimos a prosódia segundo GP/VTL, nos compassos 7, 8 e 10. GP/ABM conserva uma ligadura desnecessária da segunda para a terceira nota, e faz elisão da última nota do compasso 7 para a primeira do compasso 8, porém não recua o artigo "a" para o compasso 7. No compasso 10 a elisão na primeira nota forçará um acento na segunda sílaba da palavra "cobra" (co-brá). 
Melodia - Pequena curva no pentacorde da tonalidade com terminação ascendente; idem com terminação descendente. A segunda parte, em andamento mais rápido apresenta notas rebatidas com terminação segunda abaixo na primeira frase e na repetição por sequência por grau conjunto descendente, terminando segunda acima, na $\mathrm{D}$, para o retorno à parte $\mathrm{A}$.

Ludicidade - brincadeira de roda com possibilidades cênicas.

103) A GATINHA PARDA ( $2^{\mathrm{a}}$ versão $)$ - a capella

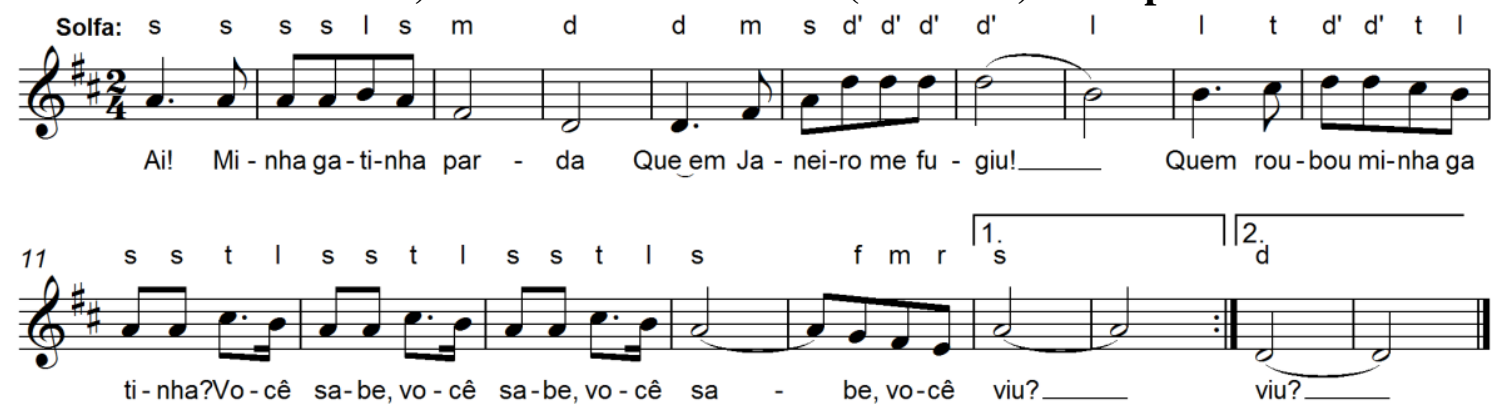

\begin{tabular}{|c|c|c|c|c|}
\hline $\begin{array}{l}\text { Volume } \\
\text { GP-VTL } \\
\text { /ABM }\end{array}$ & $\begin{array}{l}\text { № } \\
60 \\
\text { /33 }\end{array}$ & $\begin{array}{l}\text { Tessitura } \\
\text { D3-D4 }\end{array}$ & $\begin{array}{c}\text { Forma - A } \\
\text { Gênero - Marcha canção } \\
\text { Extensão: } 8 \text { ạ } \\
\text { Graus da escala: } 7 \\
\text { Sistema Heptatônico (G D A E B F\# C\#) } \\
\text { Heptacorde (t I s f m r d) }\end{array}$ & $\begin{array}{l}\text { Intervalos } \\
\text { melódicos } \\
\text { 2a } \mathrm{M} / \mathrm{m} \text {; 3aㅡ } \\
\mathrm{M} / \mathrm{m} ; 4 \text { a } / 5 \text { a } \mathrm{J}\end{array}$ \\
\hline \multicolumn{5}{|c|}{$\begin{array}{l}\text { Escala - Modo de D maior } \\
\mathbf{0}\end{array}$} \\
\hline
\end{tabular}

Sugestões de atividades didático-pedagógicas:

Células rítmicas para registro gráfico:

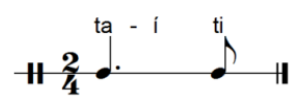

Células melódicas para registro gráfico:

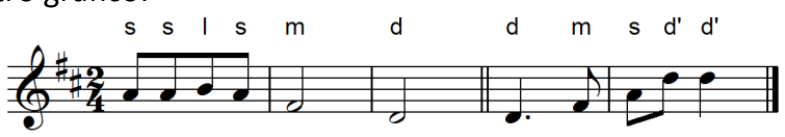

Possível ostinato rítmico:

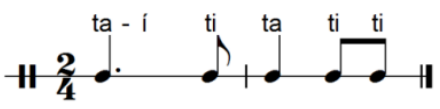

Análise complementar em $2.2-n^{\circ} 15$.

Canção com 17 compassos binários, com a indicação de andamento: Allegretto em Marcha $(\mathbf{1 4 4}=$ ل ); indicações de dinâmica: $\boldsymbol{m f}$

Tema popular, folclórico infantil, de brincadeira cantada cujo desenvolvimento baseia-se no texto.

Texto - Descrição de brincadeira de roda. Em GP/ABM consta um complemento de texto, que, no entanto, não apresenta prosódia confortável. Nos compassos 11-12, na primeira voz, tanto GP/VTL como GP/ABM indicam a separação do ditongo [i-u], quando o correto seria constar a sílaba "giu!" no compasso 11 com sinal de prolongação da mesma para o compasso 12. 
Ritmo - o interesse rítmico está nas notas longas.

Melodia - linha descendente sobre arpejo de $\mathrm{T}^{6}$, arpejo ascendente de $\mathrm{T}$ com terminação na S; desenho descendente com terminação por linha escalar descendente para a T.

Ludicidade - brincadeira de roda com escolha de solistas.

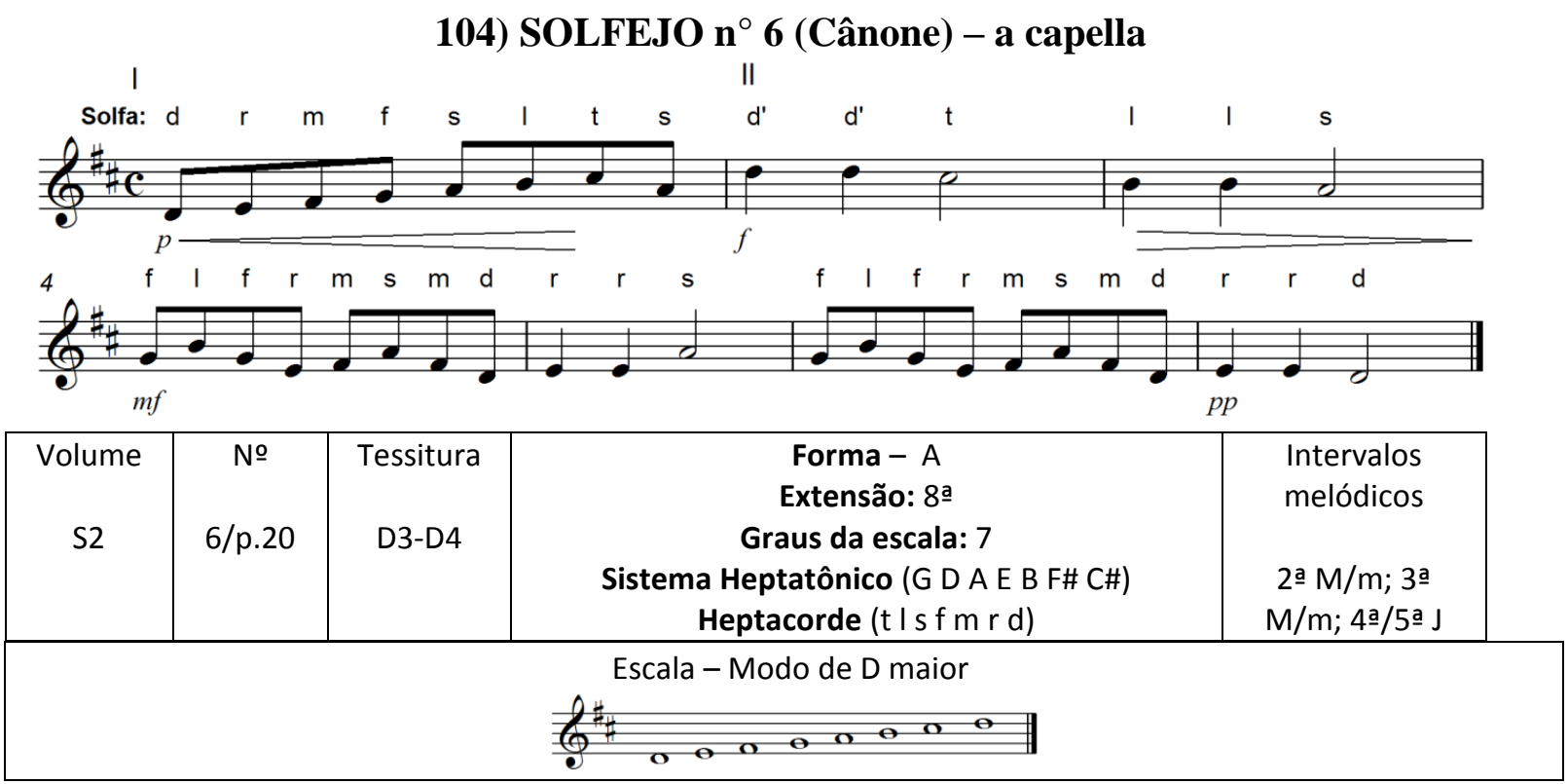

Sugestões de atividades didático-pedagógicas:

Células rítmicas para registro gráfico:

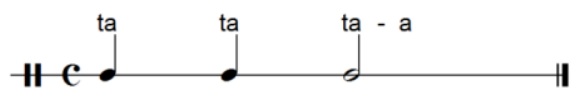

Células melódicas para registro gráfico:

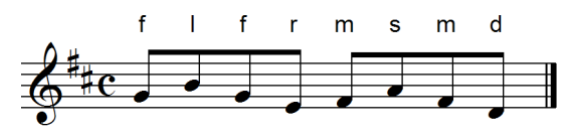

Possível ostinato rítmico:

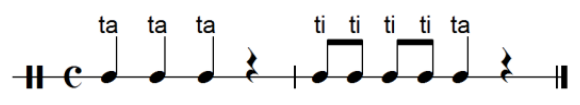

Tema de Villa-Lobos com 7 compassos quaternários, sem indicação de andamento; indicações de dinâmica: $\boldsymbol{p} ;<; f:>; \boldsymbol{m} \boldsymbol{f} ; \boldsymbol{p p}$

Ritmo - o interesse rítmico está nas unidades de pulso, metro e subdivisão.

Melodia - linha escalar ascendente seguida de tetracorde descendente da T para a D; motivos sobre arpejos sequenciais descendentes de $\mathrm{Sr}$ e $\mathrm{T}$ seguidos de finalização ascendente na $\mathrm{D}$, e, em sua repetição, descendente na $T$.

Ludicidade - apesar de se tratar de um solfejo, sendo cânone exato, pode-se explorar sua execução com atenção à serialização de níveis de dinâmica. 
105 - SOLFEJO n ${ }^{\circ} 62$ - a capella

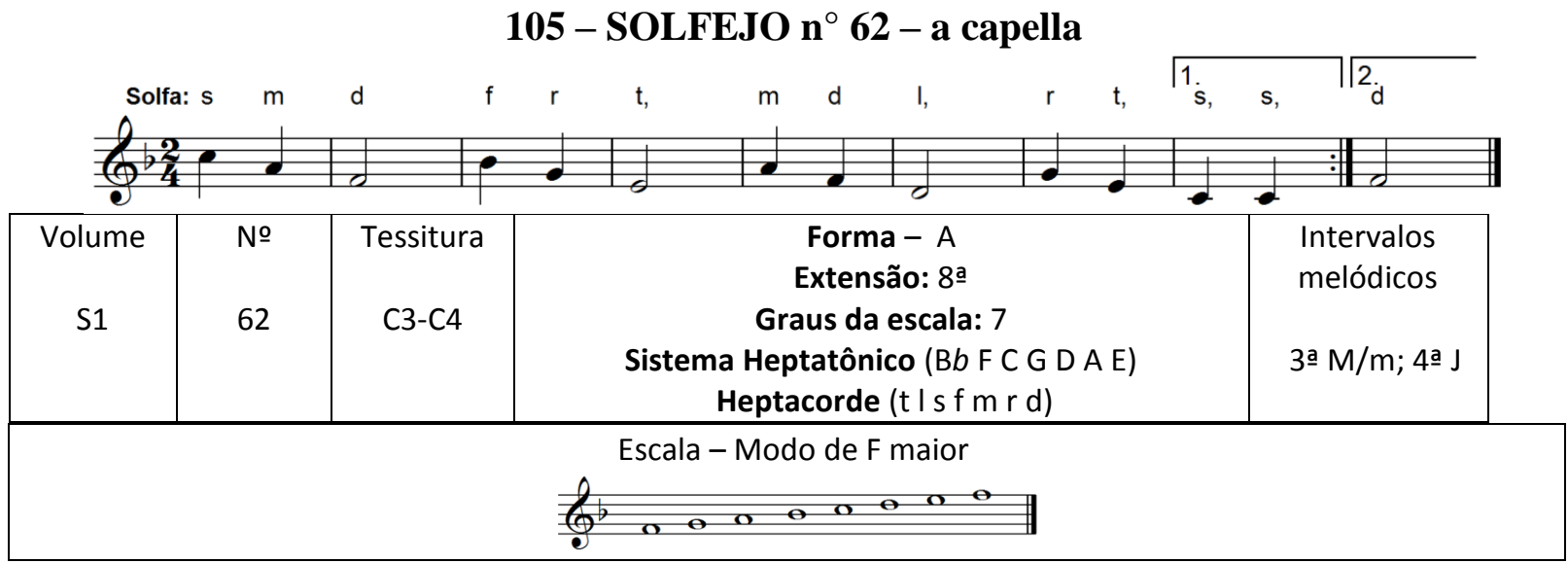

Sugestões de atividades didático-pedagógicas:

Células rítmicas para registro gráfico:

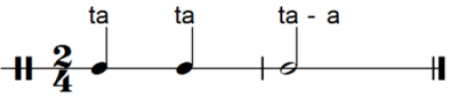

Células melódicas para registro gráfico:

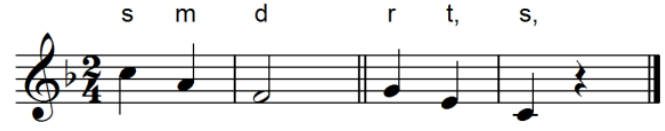

Possivel ostinato rítmico:

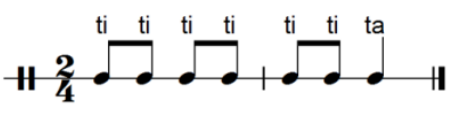

Tema de Villa-Lobos com 9 compassos binários, com indicação de andamento: Poco Moderato; sem indicações de dinâmica.

Ritmo - o interesse rítmico está nas unidades de pulso e metro.

Melodia - linha descendente de tríades arpejadas, em sequência por graus conjuntos: $T, \mathrm{D}^{7}$ sem fundamental, Tr, D. Na repetição, resolução na T.

Ludicidade - apesar de se tratar de um solfejo, pode-se propor um jogo dividindo-se os participantes em grupos de três, cada qual sustentando uma nota da tríade com entradas defasadas, segundo o ritmo proposto (ex.: compasso 1):

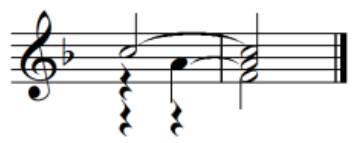

O exercício pode ter muitas variantes, invertendo-se a ordem das notas das tríades, o ritmo, trocando-se as entradas dos grupos e outras. 

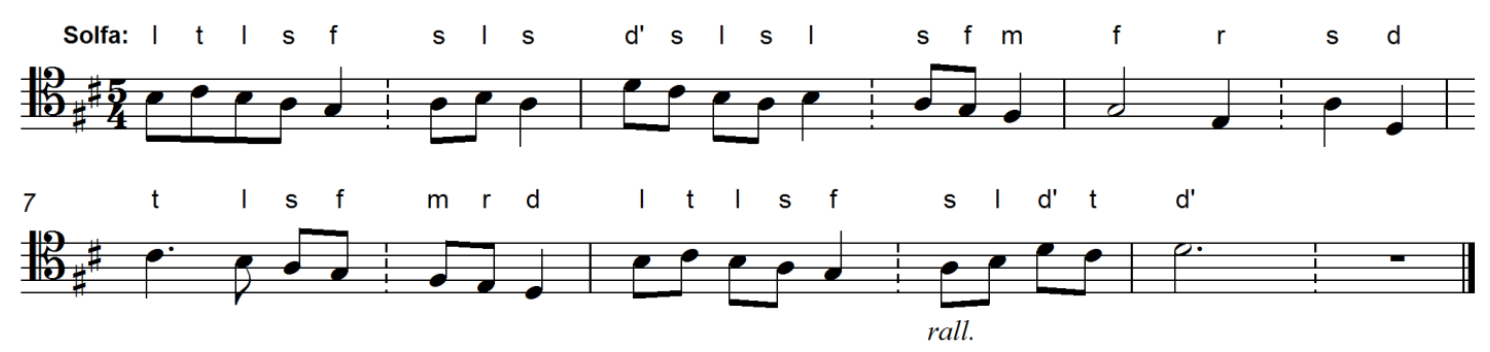

\begin{tabular}{|c|c|c|c|c|}
\hline $\begin{array}{c}\text { Volume } \\
\text { S2 }\end{array}$ & $\begin{array}{c}\text { № } \\
\text { 5/p.2 }\end{array}$ & $\begin{array}{c}\text { Tessitura } \\
\text { D2-D3 }\end{array}$ & $\begin{array}{c}\text { Forma - A } \\
\text { Extensão: 8a } \\
\text { Graus da escala: } 7 \\
\text { Sistema Heptatônico (G D A E B F\# C\#) } \\
\text { Heptacorde (t I s f m r d) }\end{array}$ & 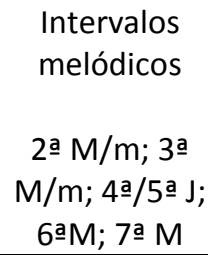 \\
\hline \multicolumn{5}{|c|}{ 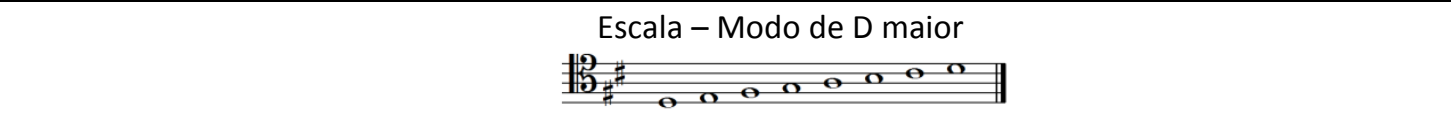 } \\
\hline
\end{tabular}

Sugestões de atividades didático-pedagógicas:

Células rítmicas para registro gráfico:

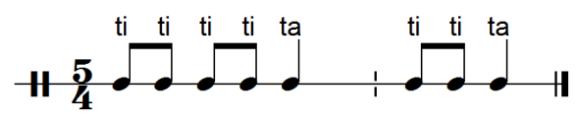

Células melódicas para registro gráfico:

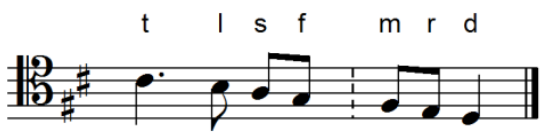

Possivel ostinato rítmico:

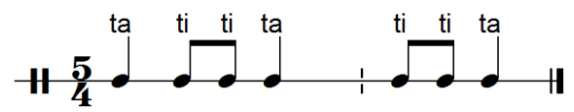

Tema de Villa-Lobos para tenor ou voz masculina com 6 compassos quinários, com indicação de andamento: Moderato; rall.; sem indicações de dinâmica.

Ritmo - o interesse rítmico está no compasso quinário.

Melodia - primeira frase, em plano de altura mais agudo, termina na $\mathrm{T}$ em plano grave; segunda frase, iniciada por linha escalar descendente para a $\mathrm{T}$, apresenta desenhos na região mais aguda, terminando acima, na $\mathrm{T}$.

Ludicidade - apesar de se tratar de um solfejo, o desafio lúdico é a leitura na clave de $\boldsymbol{C}$, na quarta linha, que pode ser relativa e absoluta. Outra sugestão seria a leitura com o compasso quinário em $2+3$.

\section{7 - A FREIRA - acompanhamento instrumental}

(Canto com piano ou conjunto instrumental)

Arr. de H. Villa-Lobos
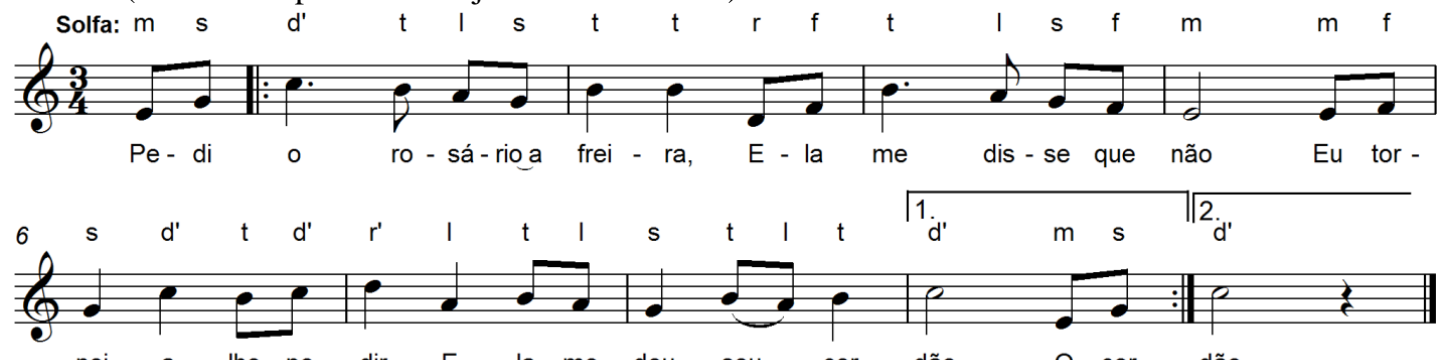

nei a lhe pe - dir, E - la me deu seu_ cor - dão $O$ cor - dão

\begin{tabular}{|c|c|c|c|c|c|}
\hline Volume & № & Tessitura & Forma - A & Intervalos \\
\hline
\end{tabular}




\begin{tabular}{|c|c|c|c|c|}
\hline $\begin{array}{l}\text { GP-VTL } \\
\text { /ABM }\end{array}$ & $\begin{array}{l}53 \\
/ 71\end{array}$ & E3-D4 & $\begin{array}{c}\text { Extensão: 7ạ } \\
\text { Graus da escala: } 7 \\
\text { Sistema Heptatônico (F C G D A E B) } \\
\text { Heptacorde ( } \mathrm{t} \text { I s f m r d) }\end{array}$ & 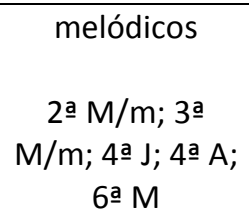 \\
\hline \multicolumn{5}{|c|}{$\begin{array}{l}\text { Escala - Modo de C maior } \\
\begin{array}{l}\mathbf{O} \\
\mathbf{O}\end{array}\end{array}$} \\
\hline
\end{tabular}

Sugestões de atividades didático-pedagógicas:

Células rítmicas para registro gráfico:

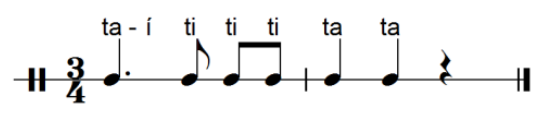

Células melódicas para registro gráfico:

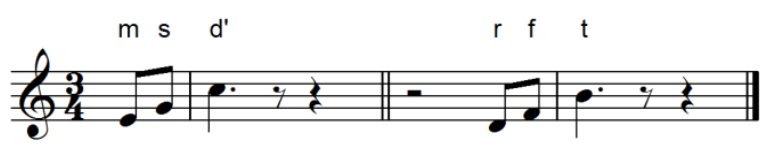

Possível ostinato rítmico:

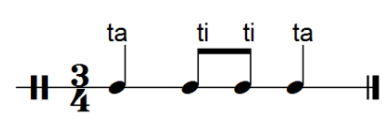

Canção com 10 compassos ternários, com indicação de andamento: Allegretto $(152=\rfloor)-$ Tempo de Mazurka; indicações de dinâmica: $\boldsymbol{f}$

Tema popular, folclórico infantil, de brincadeira cantada.

Texto - de motivação religiosa católica, em torno da personagem freira e de seu cordão. Em GP/VTL não consta a segunda estrofe sugerida na primeira casa do ritornello. GP/ABM resolve eliminando a possibilidade da segunda estrofe, solução com a qual concordamos, registrando-a, porém, na p. 101 do Segundo Caderno.

Ritmo - o interesse rítmico no compasso ternário e ritmos pontuados.

Melodia - Melodia iniciada sobre arpejos ascendentes da $\mathrm{T}$ e da $\mathrm{D}$, com finalização em desenho ascendente na $\mathrm{T}$.

Acompanhamento instrumental (piano) - introdução iniciada com arpejo descendente por terças, apresenta notas longas e acentuadas do arpejo descendente da tríade da $\mathrm{T}$, seguida por graus conjuntos até o terceiro grau, nota inicial da melodia. As funções harmônicas são: $\operatorname{Tr}^{7} /$ $\mathrm{T}^{6} / \mathrm{Sr}^{7} / \mathrm{s}^{6} / \mathrm{T}$. A mão direita dobra a melodia, enquanto na mão esquerda a harmonia desenvolve-se em torno das funções primárias, com um pedal no primeiro grau nos quatro primeiros compassos. A coda repete a introdução, acrescida de um compasso para o acorde final de $\mathrm{T}$.

Ludicidade - brincadeira de roda, encenada segundo a descrição do texto, podendo inserir acessórios ou não. 
108) SOLFEJO 60 - a capella
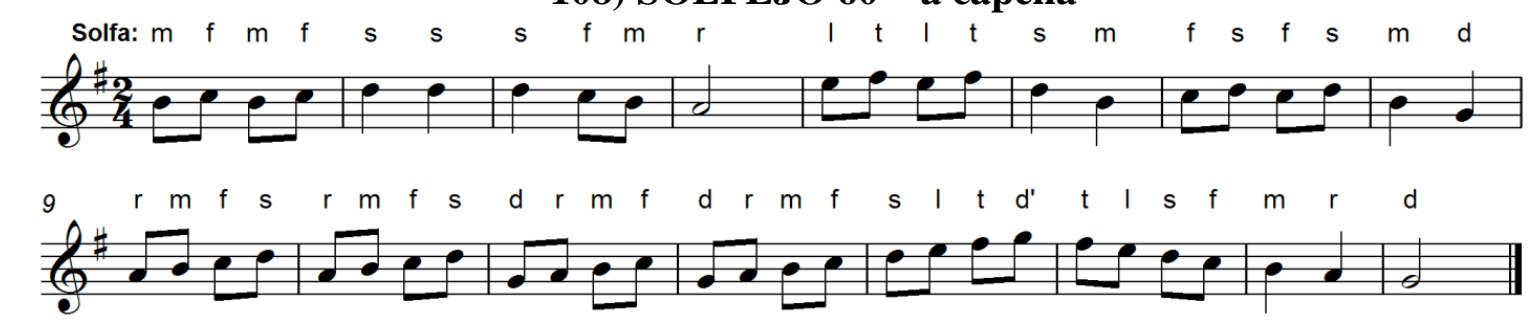

\begin{tabular}{|c|c|c|c|c|}
\hline $\begin{array}{l}\text { Volume } \\
\text { S1 }\end{array}$ & № & $\begin{array}{l}\text { Tessitura } \\
\text { G3-G4 }\end{array}$ & $\begin{array}{c}\text { Forma - A } \\
\text { Extensão: } 8 \text { ạ } \\
\text { Graus da escala: } 7 \\
\text { Sistema Heptatônico (C G D A E B F\#) } \\
\text { Heptacorde (t I s f m r d) }\end{array}$ & $\begin{array}{l}\text { Intervalos } \\
\text { melódicos } \\
\text { 2a } \mathrm{M} / \mathrm{m} ; 3 \text { a } \\
\mathrm{M} / \mathrm{m} ; 4 \text { a } / 5 \text { a J }\end{array}$ \\
\hline & & & 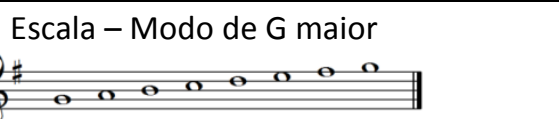 & \\
\hline
\end{tabular}

Sugestões de atividades didático-pedagógicas:

Células rítmicas para registro gráfico:

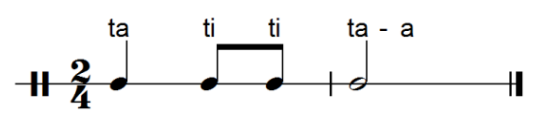

Células melódicas para registro gráfico:

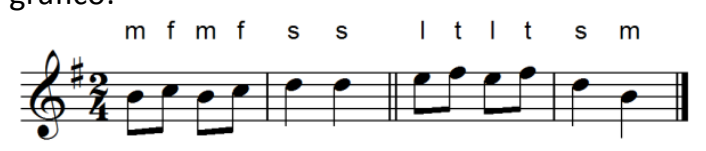

Possivel ostinato rítmico:

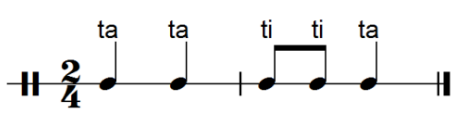

Tema de Villa-Lobos com 16 compassos binários, com a indicação: Moderato; sem indicações de dinâmica.

Ritmo - o interesse rítmico está nas unidades de pulso, metro e subdivisão.

Melodia - desenhos com apojaturas duplas em tetracorde ascendente e descendente; complemento da frase com sequência de apojaturas terminadas em arpejos de tríades descendentes. Segunda frase com tetracordes iguais ascendentes repetidos em sequência por grau conjunto descendente, com finalização em escala maior completa ascendente e descendente.

Ludicidade - apesar de se tratar de um solfejo, sendo baseado na exposição parcial e total da escala maior diatônica, podem ser acrescentados jogos, como o da escala viva, por exemplo, em que cada criança representa um grau da escala.

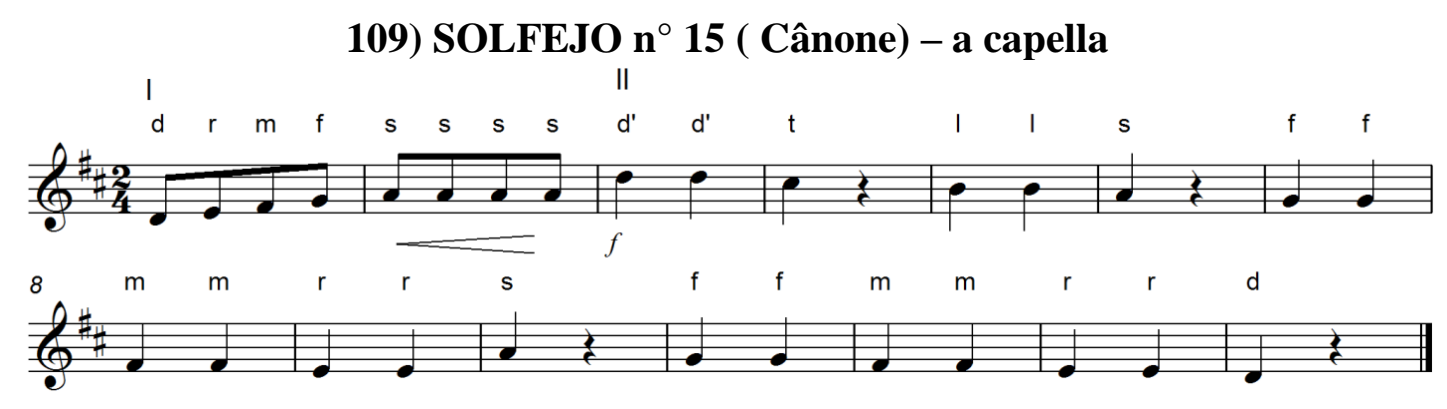




\begin{tabular}{|c|c|c|c|c|}
\hline $\begin{array}{c}\text { Volume } \\
\text { S2 }\end{array}$ & $\begin{array}{c}\text { № } \\
15 / \text { p. } 22\end{array}$ & $\begin{array}{l}\text { Tessitura } \\
\text { D3-D4 }\end{array}$ & $\begin{array}{c}\text { Forma - A } \\
\text { Extensão: } 8 \text { ạ } \\
\text { Graus da escala: } 7 \\
\text { Sistema Heptatônico (G D A E B F\# C\#) } \\
\text { Heptacorde (t I s f m r d) }\end{array}$ & $\begin{array}{l}\text { Intervalos } \\
\text { melódicos } \\
\text { 2a M/m; 4a J }\end{array}$ \\
\hline \multicolumn{5}{|c|}{$\begin{array}{l}\text { Escala - Modo de D maior } \\
\end{array}$} \\
\hline
\end{tabular}

Sugestões de atividades didático-pedagógicas:

Células rítmicas para registro gráfico:

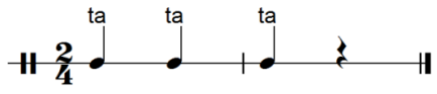

Células melódicas para registro gráfico:

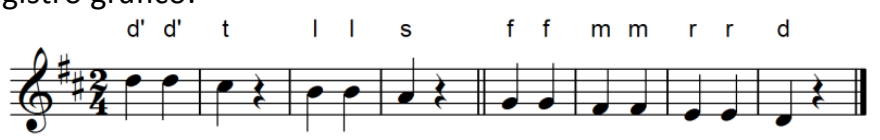

Possível ostinato rítmico:

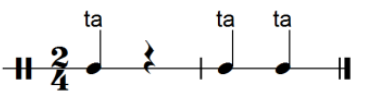

Tema de Villa-Lobos com 14 compassos binários, sem indicação de andamento; indicações de dinâmica: $<; f$

Ritmo - o interesse rítmico está nas unidades de pulso, metro e subdivisão.

Melodia - linha escalar em pentacorde ascendente seguido de desenhos descendentes por graus conjuntos com finalização na $\mathrm{T}$.

Ludicidade - apesar de se tratar de um solfejo, sendo cânone exato, pode-se explorar sua execução com atenção aos movimentos: contrário e direto.

\section{0) LARANJEIRA PEQUENINA - acompanhamento instrumental}

(Canto com piano, conjunto instrumental ou Piano solo) Amb. por H. Villa-Lobos
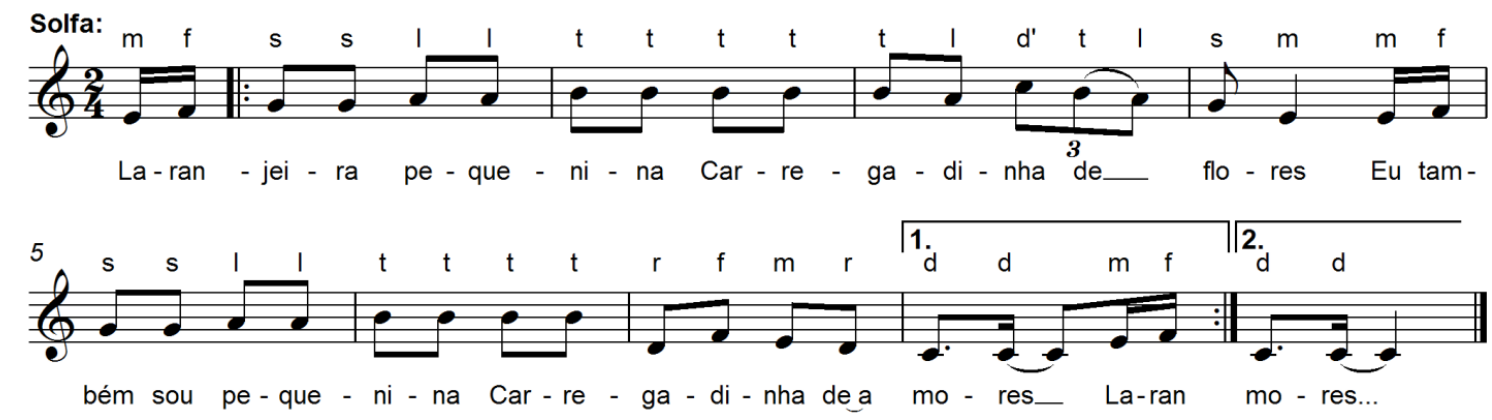

\begin{tabular}{|c|c|c|c|c|}
\hline Volume & No & Tessitura & Forma - A & Intervalos \\
melódicos \\
/ABM
\end{tabular}


Células rítmicas para registro gráfico:

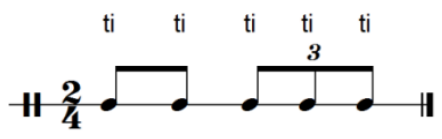

Células melódicas para registro gráfico:

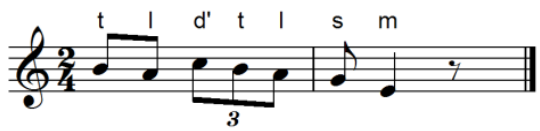

Possivel ostinato rítmico:

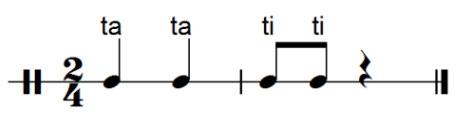

Canção com 10 compassos binários, com a indicação: Allegretto quasi Allegro (116= $=\mathrm{d}$ ); poco rall.; Lento; indicações de dinâmica: $p$; < ; $s f z$; > ; acentos > _

Tema popular, folclórico infantil, de brincadeira cantada.

Texto - descrição de brincadeira de roda, com associações de idéias.

Ritmo - o interesse rítmico está nas semicolcheias em anacruse, nos inícios de frases e na tercina

Melodia -desenho ascendente por graus conjuntos (D) e descendente por saltos e graus conjuntos $(\mathrm{T})$ - duas vezes.

Acompanhamento instrumental (piano) - introdução com pedal em trêmulo em oitavas sobre o quinto grau na mão direita, sobre acorde de T (também em pedal) na mão esquerda. A melodia é dobrada pela mão direita, em acordes ou pequenas linhas em contraponto (alternando com a mão esquerda, que conserva o pedal em trêmulo em oitavas. A coda tem indicação de andamento Lento e apresenta uma apojatura harmônica cromática na $\boldsymbol{D}^{13}$ resolvendo na $\mathrm{T}$ (com bordadura dupla).

Ludicidade - brincadeira de roda que possibilita uso de acessórios (cartas ou bilhetes, por exemplo).

Complemento do texto ${ }^{52}$

Laranjeira pequenina / carregadinha de flores / eu também sou pequenina / carregadinha de amores.

Eu plantei o roxo na água / o azul na bandeirinha / quem quiser casar comigo / mande carta e mais cartinha.

\section{1) SINH’ ANINHA - acompanhamento instrumental}

(Canto com piano, conjunto instrumental)

Arr. de H. Villa-Lobos
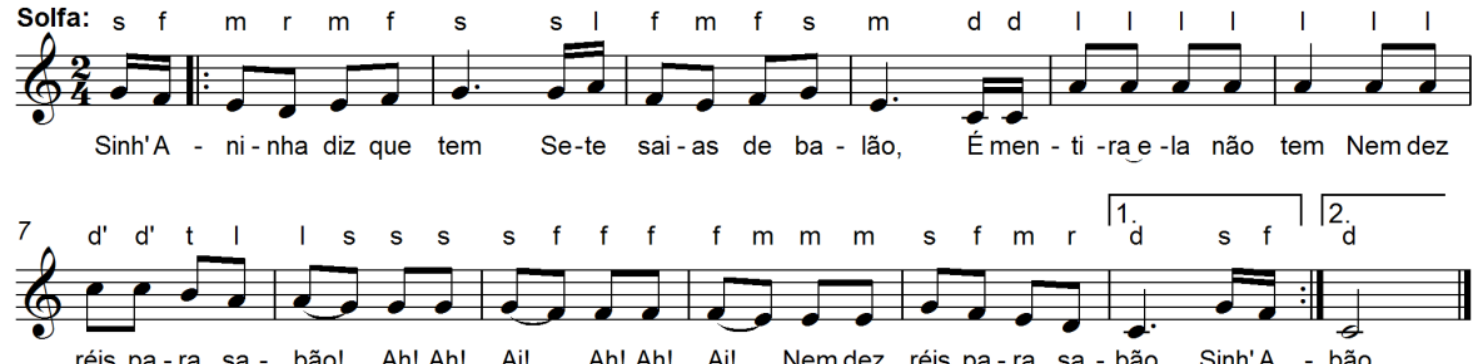

réis pa - ra sa - bão!_ Ah! Ah! Ai!_ Ah! Ah! Ai!_ Nem dez réis pa - ra sa - bão Sinh'A - bão.

\begin{tabular}{|l|l|l|l|l|}
\hline Volume & № & Tessitura & Forma - A & Intervalos \\
\hline
\end{tabular}

${ }^{52}$ GP/ABM - $2^{\circ}$ Caderno, p. 114. 


\begin{tabular}{|c|c|c|c|c|}
\hline $\begin{array}{c}\text { GP-VTL } \\
\text { /ABM }\end{array}$ & $\begin{array}{l}120 \\
/ 107\end{array}$ & C3-C4 & $\begin{array}{c}\text { Gênero - um pouco canção sertaneja } \\
\text { Extensão: } 8 \text { a } \\
\text { Graus da escala: } 7 \\
\text { Sistema Heptatônico (F C G D A E B) } \\
\text { Heptacorde (t I s f m r d) }\end{array}$ & $\begin{array}{c}\text { melódicos } \\
\text { 2a } \mathrm{M} / \mathrm{m} ; 3^{a} \\
\mathrm{M} / \mathrm{m} ; 5^{a} \mathrm{~J} ; 6^{a} \mathrm{M}\end{array}$ \\
\hline \multicolumn{5}{|c|}{ Escala - Modo de C maior } \\
\hline
\end{tabular}

Sugestões de atividades didático-pedagógicas:

Células rítmicas para registro gráfico:

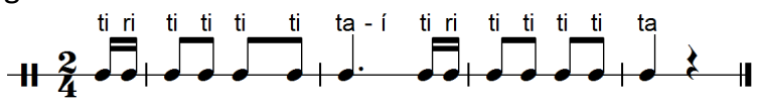

Células melódicas para registro gráfico:

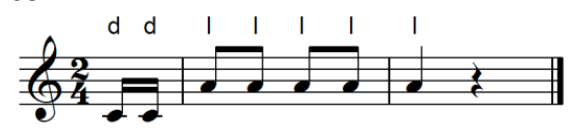

Possivel ostinato rítmico:

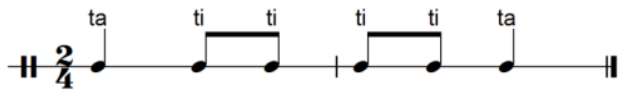

Canção com 14 compassos binários, com a indicação de andamento: Andantino (M.M. 104= ل ); indicações de dinâmica: Acentos >

Tema popular, folclórico infantil, de brincadeira cantada cujo desenvolvimento baseia-se no texto.

Texto - descrição de brincadeira de roda, com a variante "A barata diz que tem" às vezes acoplada, tem tom humorístico, sendo a interjeição " $A h$ !'” usada para interpretar gargalhadas.

Ritmo - o interesse rítmico está nas semicolcheias em anacruse no início dos motivos.

Melodia - desenho em torno do quinto grau com pequenas curvas em sequência por grau conjunto terminando no terceiro grau da T; salto de sexta ascendente $(\mathrm{S})$, com notas rebatidas finalizando em apojaturas, e linha descendente para a $\mathrm{T}$.

Acompanhamento instrumental (piano) - a melodia é dobrada pela mão direita, nos 3 primeiros compassos com harmonia na mão esquerda, os 3 seguintes em acordes, com contraponto na mão esquerda sobre linha descendente em oitavas; os 3 compassos seguintes ainda em acordes com pedal de $\mathrm{D}$ na mão esquerda, e os próximos 3 compassos com a harmonia distribuída entre as duas mãos, com a cadência $\mathrm{T} \mathrm{T}^{7} \mathrm{~S} \mathrm{D} \mathrm{T}$.

Ludicidade - brincadeira de roda muito própria para encenações.

Complemento do texto ${ }^{53}$ :

- Sinh'Aninha diz que tem / sete saias de balão / é mentira ela não tem / nem dez réis para sabão! / Ah! Ah! Ah! / - Ah! Ah! Ah! / nem dez réis para sabão!

- As mocinhas de agora / só o que querem é casar / botam a panela no fogo / mas não sabem temperar! / Ah! Ah! $\mathrm{Ah}$ ! / Ah! Ah! Ah! / mas não sabem temperar!

\section{2) OS ESCRAVOS DE JÓ - a capella}

${ }^{53}$ GP/ABM - $2^{\circ}$ Caderno, p. 113. 


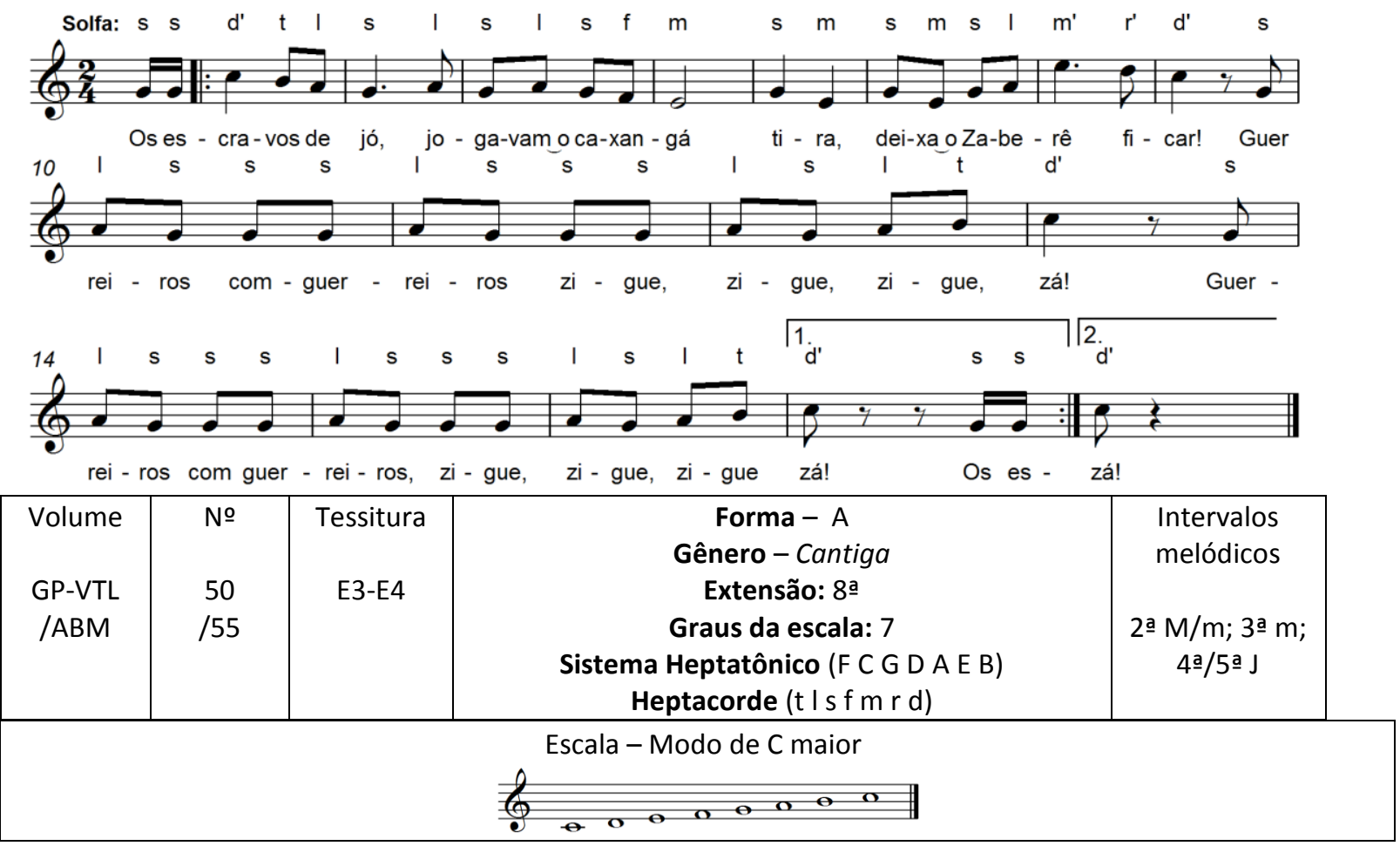

Sugestões de atividades didático-pedagógicas:

Células rítmicas para registro gráfico:

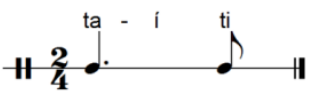

Células melódicas para registro gráfico:

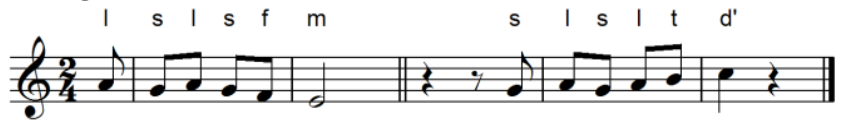

Possivel ostinato rítmico:

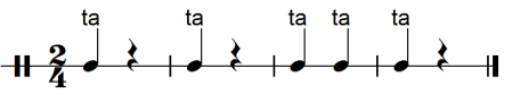

Possivel ostinato melódico:

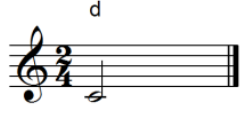

Análise complementar em $2.2-n^{\circ} 80$.

Canção com 18 compassos binários, com a indicação de andamento: Allegro (M.M. $120=\downarrow)^{54}$; indicações de dinâmica: $\boldsymbol{m f}$

Tema popular, folclórico infantil, de brincadeira cantada cujo desenvolvimento baseia-se no texto.

Texto - descrição da brincadeira cantada, o jogo do caxangá (siripuã - tipo de caranguejo). Zamberê, Zambelê ou Zabelê (jaó - ave notívaga).

Ritmo - o interesse rítmico está na leitura simultânea da linha sobreposta à melodia.

${ }^{54}$ GP/VTL, p. 69. Sugestão de Villa-Lobos: "Repete-se 4 vezes apressando pouco a pouco até Allegro vivo" 
Melodia - primeira frase: curvas ascendentes e descendentes com terminação descendente por grau conjunto para a terça da $\mathrm{T}$; idem sobre arpejo da $\mathrm{T}$ e finalização descendente na $\mathrm{T}$; segunda frase com desenhos de notas rebatidas e movimento em segundas, com terminação ascendente em graus conjuntos para a T. É muito comum a troca da nota $\boldsymbol{A}$ por $\boldsymbol{C}$ no compasso 8, por completar o arpejo da $\mathrm{T}$.

Ludicidade - o jogo do caxangá, um tipo de siri azul, é comumente brincado com um objeto que é passado lateralmente entre os participantes, para a esquerda e direita, à semelhança da locomoção do animal. Como sugerido pelo autor, a cada repetição deve-se apressar o andamento.

\section{3) CANDEEIRO - a capella}

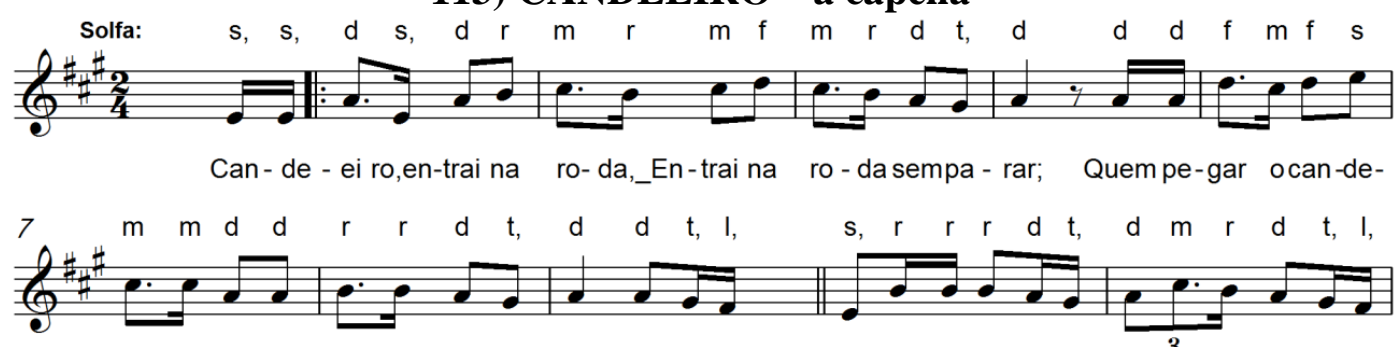

ei - ro Can-de - ei -ro_há de fi - car. Có-có-ró - có Can-de-ei - ro Si - nhá,Eu não sou cas ti

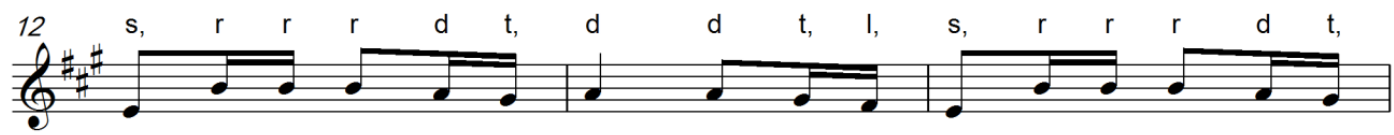

çal Can - de - ei - ro Si - nhá Có - có - ró - có Can - de - ei - ro Si -

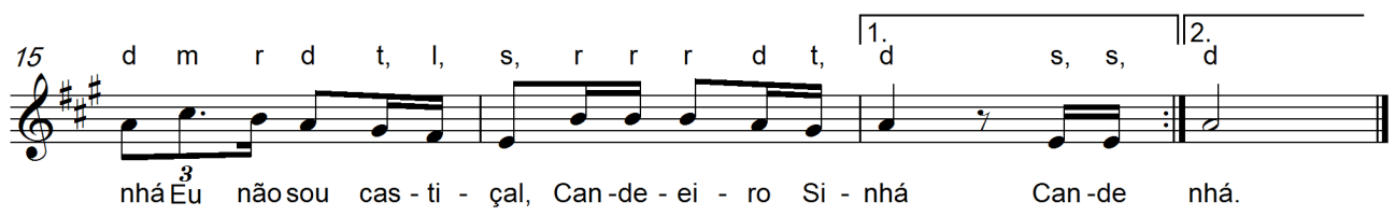

\begin{tabular}{|c|c|c|c|c|}
\hline $\begin{array}{l}\text { Volume } \\
\text { GP-VTL } \\
\text { /S1 } \\
\text { /ABM }\end{array}$ & $\begin{array}{l}\text { № } \\
22 \\
/ 27 \\
/ 21\end{array}$ & $\begin{array}{c}\text { Tessitura } \\
\text { E3-E4 }\end{array}$ & $\begin{array}{c}\text { Forma - A } \\
\text { Gênero - Cantiga } \\
\text { Extensão: } 8 \text { a } \\
\text { Graus da escala: } 7 \\
\text { Sistema Heptatônico (D A E B F\# C\# G\#) } \\
\text { Heptacorde (t I s f m r d) }\end{array}$ & 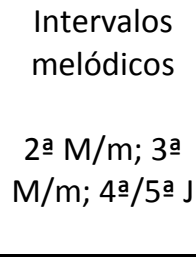 \\
\hline & & & 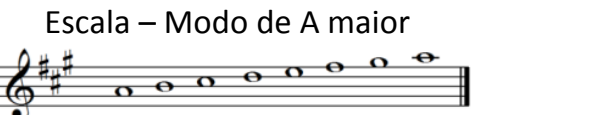 & \\
\hline
\end{tabular}

\section{Sugestões de atividades didático-pedagógicas:}

Células rítmicas para registro gráfico:

Células melódicas para registro gráfico:
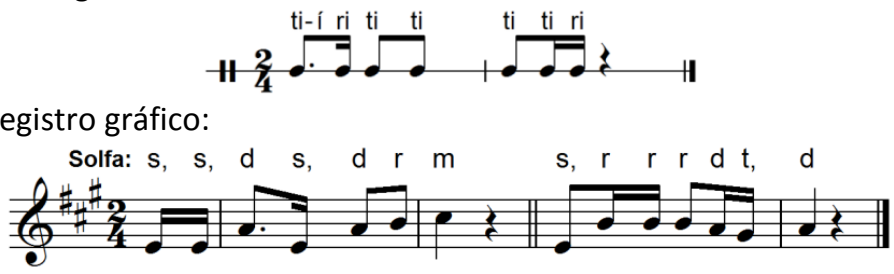

Possivel ostinato rítmico:

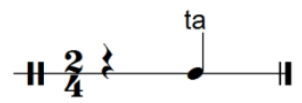

Análise complementar em $2.2-n^{\circ} 67$. 
Canção com 19 compassos binários, com a indicação de andamento: Andantino (M.M. $88=$ ل ); Più Mosso; rall, rit. ; fermata; indicações de dinâmica: $f ; \boldsymbol{m f}$; < ; >

Tema popular, folclórico infantil, de brincadeira cantada cujo desenvolvimento baseia-se no texto.

Texto - descrição da brincadeira de roda com palavras quase em desuso: castiçal, candeeiro, com imperativo na segunda pessoa do plural.

Ritmo - o interesse rítmico está nos andamentos diferentes e nas diferenças de configuração entre as duas partes. Nos compassos 12 e 16, as tercinas seriam bem substituídas por sincopa:

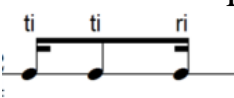

- resultado que normalmente se obtém na prática infantil dessa melodia.

Melodia - primeira frase inicia-se sobre o arpejo da T; segunda - passando pela S, volta para a $\mathrm{T}$; segunda parte - D/T alternadas por frases com pequenas curvas, notas rebatidas e linhas descendentes.

Ludicidade - brincadeira de roda incluindo outra brincadeira, o pega-pega na segunda parte, più mosso, para a determinação do próximo "candeeiro".

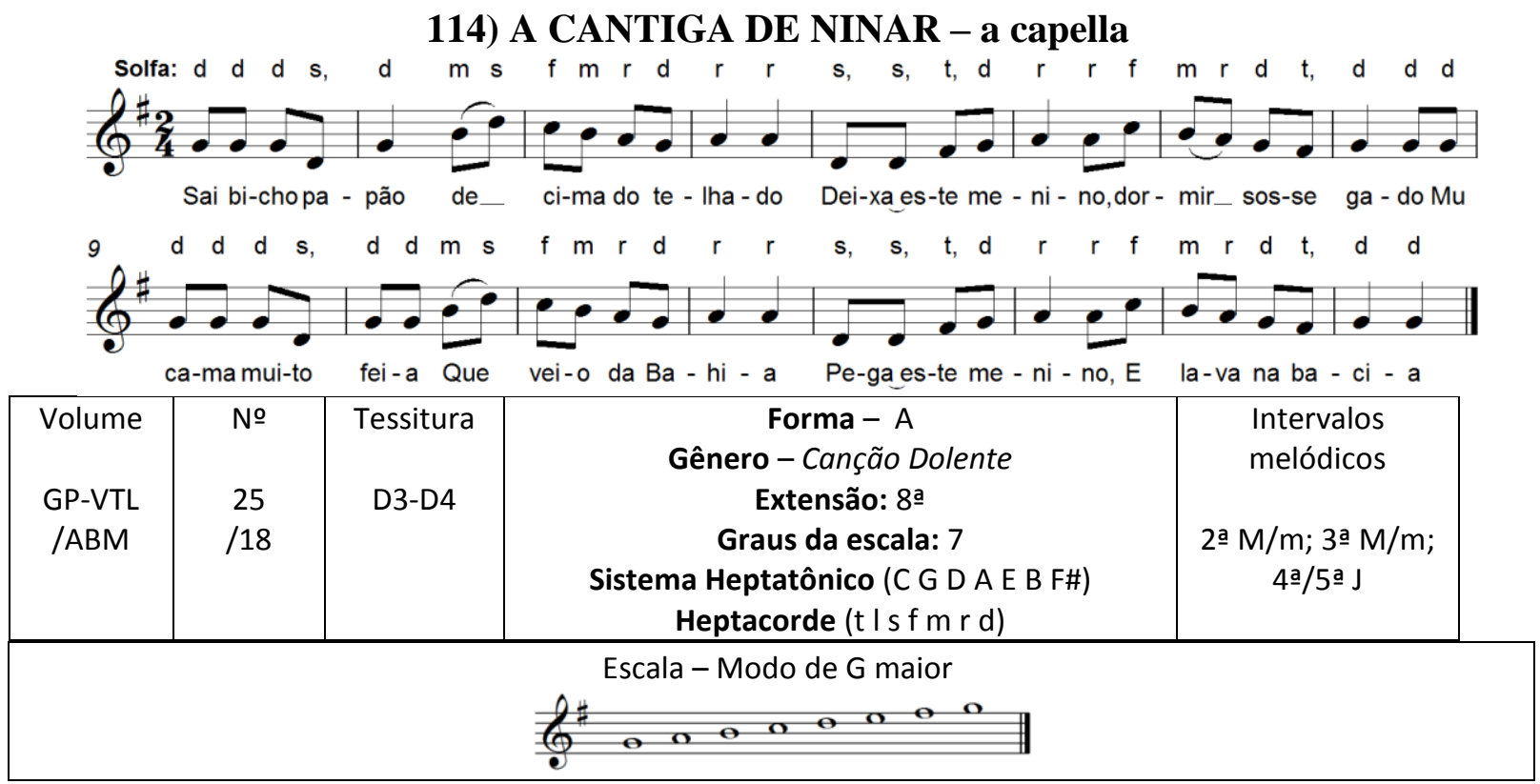

\section{Sugestões de atividades didático-pedagógicas:}

Células rítmicas para registro gráfico:

Células melódicas para registro gráfico:
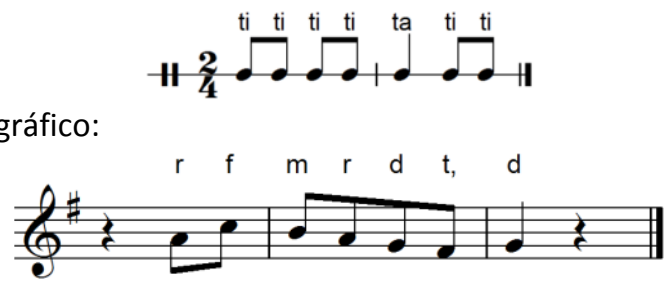

Possivel ostinato rítmico:

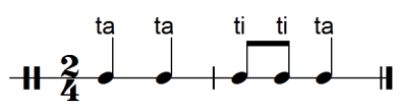

Análise complementar em $2.2-n^{\circ} 66$. 
Canção com 16 compassos binários, com a indicação de andamento: Andantino (M.M. $116=$ ل ); sem indicações de dinâmica.

Tema popular, folclórico infantil, de canção de ninar.

Texto - quadrinha relacionada ao tema "mucama" - nesta canção, em VTL, o texto está com a prosódia totalmente comprometida. Em GP/ABM, aparece a inserção da primeira estrofe, inexistente em GP/VTL, e a segunda estrofe é apresentada de forma correta quanto à prosódia. No entanto, no compasso 8 são indevidas as ligaduras e o parênteses.

Ritmo - o interesse rítmico está no pulso e subdivisão binária.

Melodia - primeira frase inicia-se sobre o arpejo da $\mathrm{T}$ com resolução na $\mathrm{D}$; a segunda sobre arpejo de $\mathrm{D}^{7}$ com nota de passagem, com resolução na $\mathrm{T}$.

Ludicidade - canções de ninar são apropriadas para brinquedos de casinha, com bonecas, e outras.

Complementação do texto ${ }^{55}$ :

Sai bicho papão / de cima do telhado / deixa este menino / dormir sossegado. Mucama muito feia, / que veio da Bahia / pega este menino / e lava na bacia. $\mathrm{Na}$ bacia de ouro / lavado com sabão / pega este menino / e vista o seu roupão. Roupão de seda / toucado de filó / pega este menino / e leva pra vovó.

\section{5) PIROLITO (FIORITO) - acompanhamento instrumental}

(Canto com piano, conjunto instrumental)

Arr. de H. Villa-Lobos
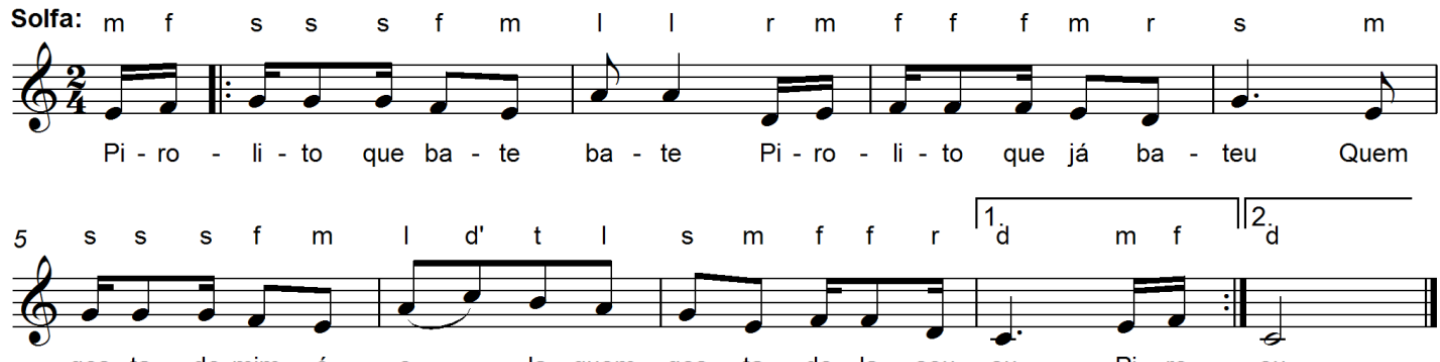

gos - ta de mim é e - la quem gos - ta de - la sou eu. Pi - ro - eu.

\begin{tabular}{|c|c|c|c|c|}
\hline $\begin{array}{l}\text { Volume } \\
\text { GP-VTL } \\
\text { /ABM }\end{array}$ & $\begin{array}{l}\text { № } \\
95 \\
/ 84\end{array}$ & $\begin{array}{l}\text { Tessitura } \\
\text { C3-C4 }\end{array}$ & $\begin{array}{c}\text { Forma - A } \\
\text { Gênero - Samba canção do Norte } \\
\text { Extensão: } 8^{a} \\
\text { Graus da escala: } 7 \\
\text { Sistema Heptatônico (F C G D A E B) } \\
\text { Heptacorde (t I s f m r d) }\end{array}$ & 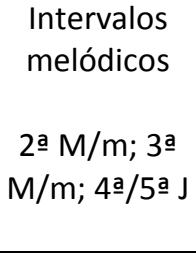 \\
\hline \multicolumn{5}{|c|}{ Escala - Modo de C maior } \\
\hline
\end{tabular}

Sugestões de atividades didático-pedagógicas:

Células rítmicas para registro gráfico:

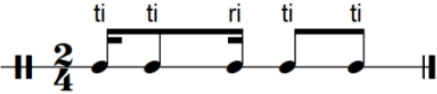

\footnotetext{
${ }^{55}$ GP/ABM, Primeiro Caderno, p. 73
} 
Células melódicas para registro gráfico:

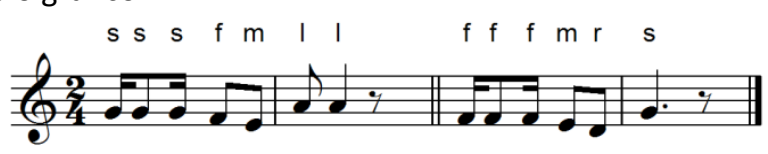

Possivel ostinato rítmico:

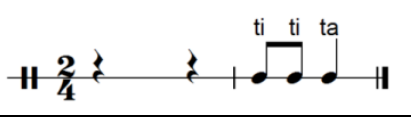

Canção popular, de 10 compassos binários, com a indicação de andamento: Allegretto (M.M. 96= ل ); indicações de dinâmica: $\boldsymbol{p}$; $<$; > ; pp ; sfz; acentos >

Tema popular, folclórico infantil, de brincadeira cantada cujo desenvolvimento baseia-se no texto.

Texto - descrição de brincadeira de mãos, cantada. (Pirolito, segundo o dicionário Aurélio: certo estribilho popular. Pirulito: cone de mel escuro e solidificado preso na extremidade de um palito. Fiorito - de "fioritura": nota ou grupo de notas de ornamento acrescidas às notas essenciais de uma melodia).

Ritmo - interesse rítmico está nas sincopas. Nas duas edições, GP/VTL e GP/ABM, há um rall. no compasso 5, sem que haja posteriormente a expressão a tempo.

Melodia - sequências de motivo em torno de terça menor cheia ascendente / descendente, segunda frase em ritmo sincopado sobre graus conjuntos e pequenos saltos, finalizando em linha escalar heptatônica descendente para a T.

Ludicidade - brincadeira de mãos, também cantada em roda com adição da segunda estrofe.

Complementação do texto:

- Pirolito que bate, bate / pirolito que já bateu / quem gosta de mim é ela,/ quem gosta dela sou eu.

- Pirolito que bate, bate / pirolito que já bateu / a menina que eu amava,/ coitadinha já morreu.

116) VESTIDINHO BRANCO - acompanhamento instrumental

(Canto com piano, conjunto instrumental ou Piano solo)

Amb. por H. Villa-Lobos
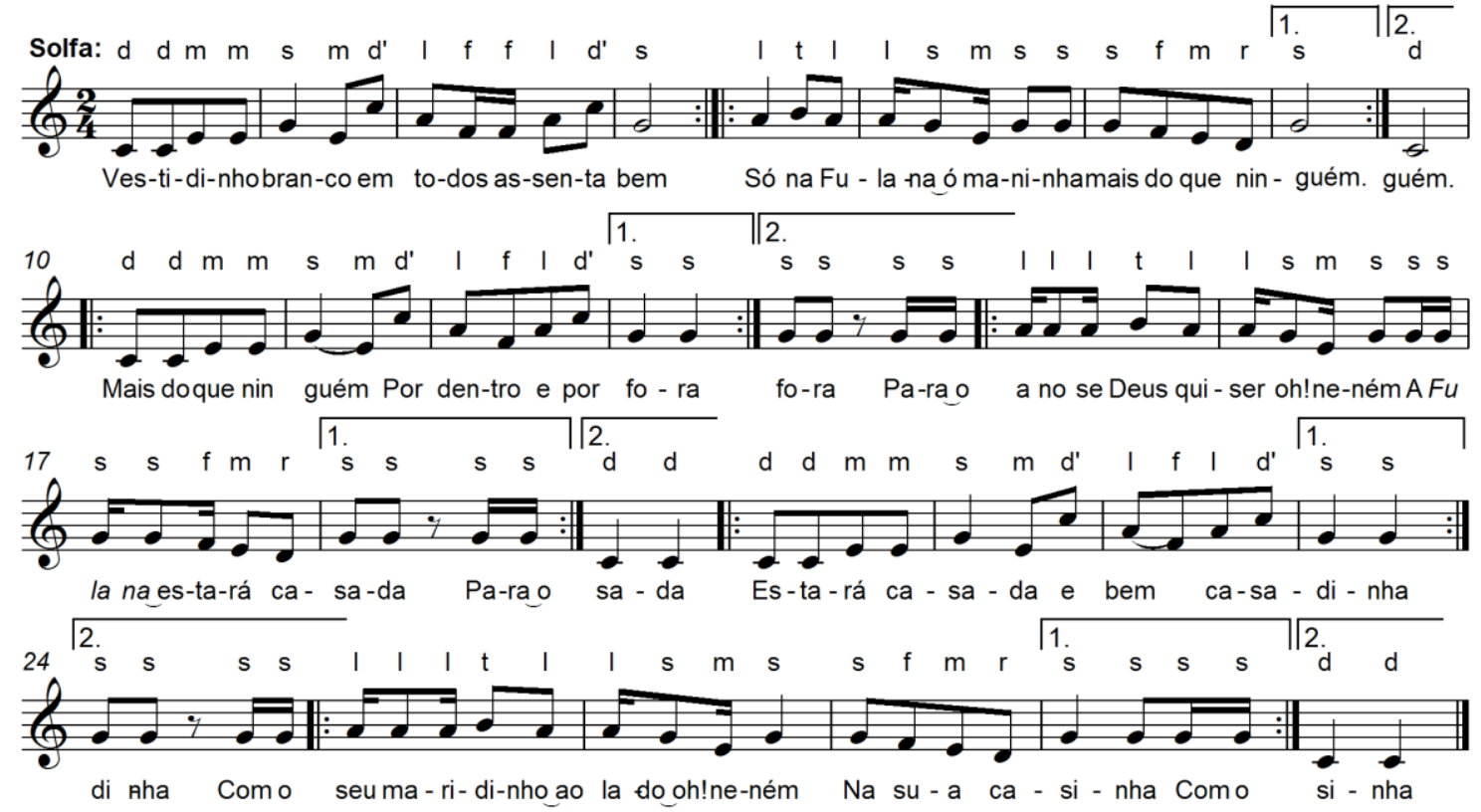


\begin{tabular}{|c|c|c|c|c|}
\hline $\begin{array}{l}\text { Volume } \\
\text { GP-VTL } \\
\text { /ABM }\end{array}$ & $\begin{array}{l}\text { № } \\
131 \\
\text { /112 }\end{array}$ & $\begin{array}{l}\text { Tessitura } \\
\text { C3-C4 }\end{array}$ & $\begin{array}{c}\text { Forma - A } \\
\text { Gênero - Cantiga } \\
\text { Extensão: } 8 \underline{a} \\
\text { Graus da escala: } 7 \\
\text { Sistema Heptatônico (F C G D A E B) } \\
\text { Heptacorde (t I s f m r d) }\end{array}$ & $\begin{array}{c}\text { Intervalos } \\
\text { melódicos } \\
\text { 2a } \mathrm{M} / \mathrm{m} ; 3^{\mathrm{a}} \\
\mathrm{M} / \mathrm{m} ; 4 \text { a j; 6a } \mathrm{m}\end{array}$ \\
\hline \multicolumn{5}{|c|}{ 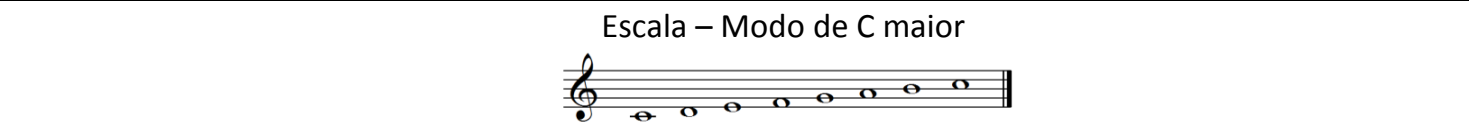 } \\
\hline
\end{tabular}

\section{Sugestões de atividades didático-pedagógicas:}

Células rítmicas para registro gráfico:

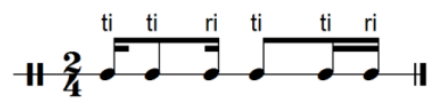

Células melódicas para registro gráfico:

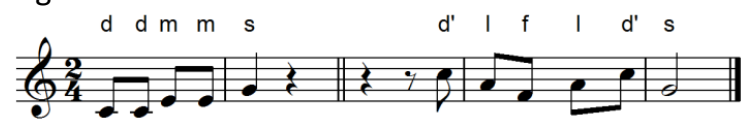

Possível ostinato rítmico:

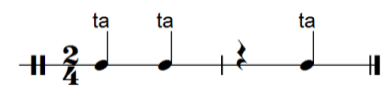

Canção com 29 compassos binários, com a indicação de andamento: Allegretto (M.M. 144= ل ); indicações de dinâmica: $f \boldsymbol{f}$

Tema popular, folclórico infantil, de brincadeira cantada cujo desenvolvimento baseia-se no texto.

Texto - descrição de brincadeira de roda sobre o vestidinho branco e o casamento da personagem. Notar a simbologia da cor branca em "por dentro e por fora". A forma das estrofes: o primeiro verso é sempre o último da estrofe anterior. Problema com a prosódia no terceiro compasso - corrigimos o ritmo em GP/VTL que continha quatro colcheias, pois não é possível a elisão em "dos as-".

Ritmo - o interesse rítmico está síncopas. Tanto em GP/VTL como em GP/ABM, no compasso 3 a prosódia é sofrível (corrigido acima); no compasso 10, também corrigido, continha uma semínima no segundo pulso.

Melodia - arpejo ascendente de $\mathrm{T}$, descendente e ascendente de $\mathrm{S}$ com final em salto descendente de quarta $(\mathrm{T})$; linha descendente por graus conjuntos para $\mathrm{T}$.

Acompanhamento instrumental (piano) - harmonia sobre funções primárias, alternando movimento contrário, terças e oitavas paralelas e com a melodia dobrada na mão direita.

Ludicidade - brincadeira de roda envolvendo personagens de um casamento.

117) CARNEIRINHO, CARNEIRÃO - acompanhamento instrumental

(Canto com piano, conjunto instrumental ou Piano solo)

Arr. de H. Villa-Lobos

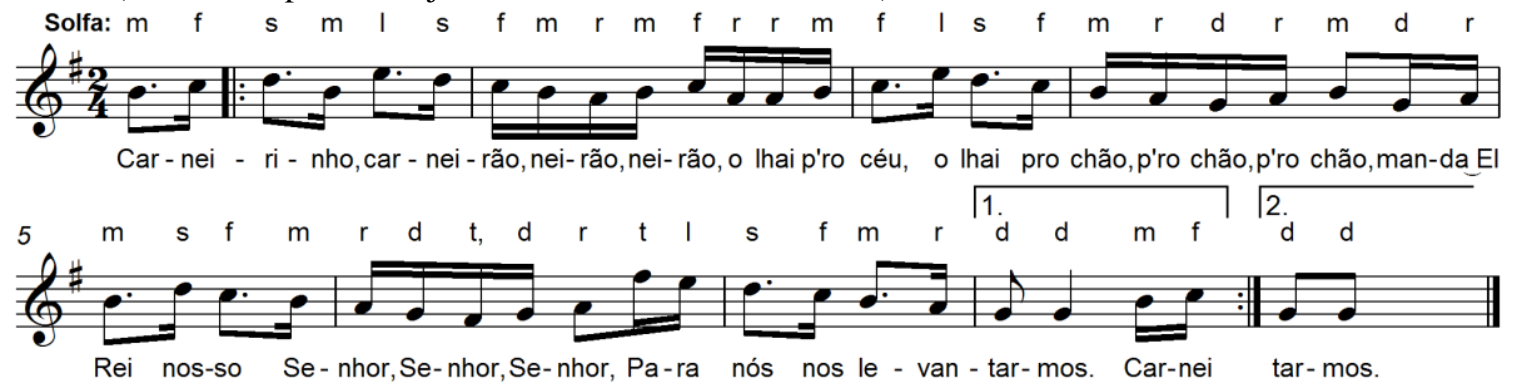




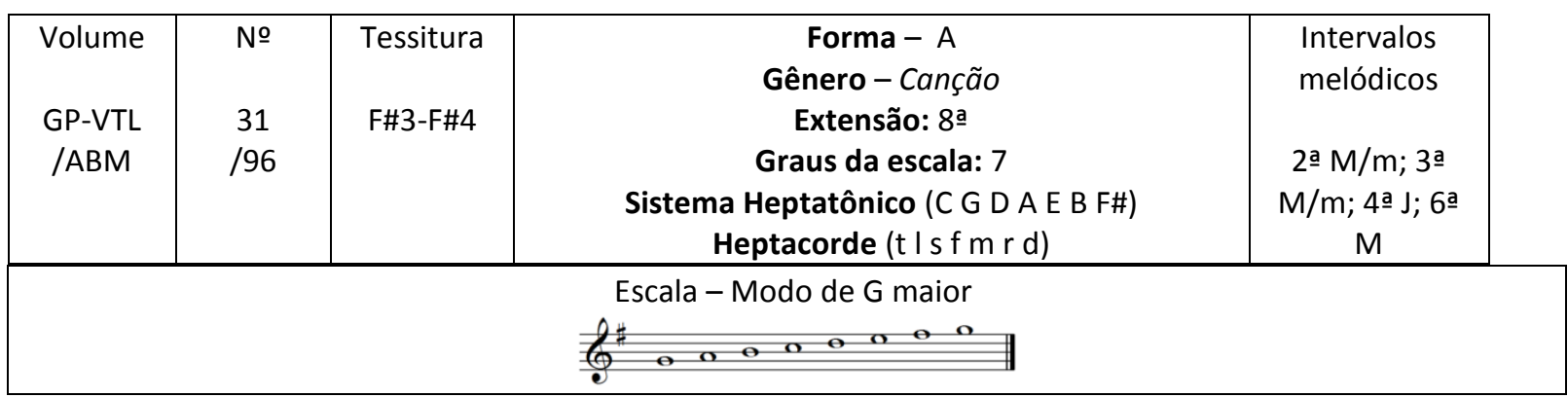

Sugestões de atividades didático-pedagógicas:

Células rítmicas para registro gráfico:

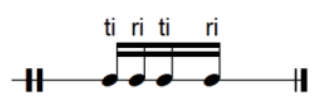

Células melódicas para registro gráfico:

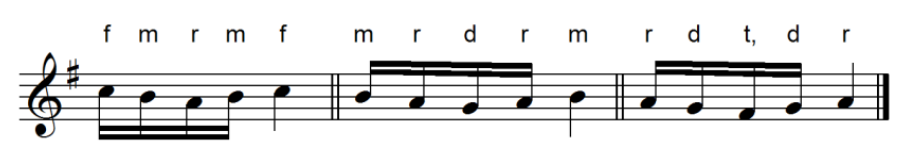

Possivel ostinato rítmico:

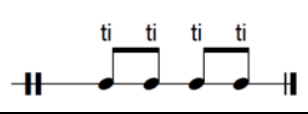

Canção com 10 compassos binários, com a indicação: Allegro non tropo (M.M. $88=ل$ ل); indicações de dinâmica: $f f ; f ; \boldsymbol{m f} ; \boldsymbol{p}$; acentos > ; dim. poco a poco

Tema popular, folclórico infantil, de brincadeira cantada cujo desenvolvimento baseia-se no texto.

Texto - contém certa ironia, associando a passividade do carneiro à obediência devida ao rei. Descreve a brincadeira de roda, ditando os tipos de movimentação.

Ritmo - o interesse rítmico nas células com semicolcheias. Trata-se de uma melodia própria para andamento mais lento - as figuras deveriam ter seus valores dobrados.

Melodia - sequência descendente por grau conjunto de três desenhos iniciados por terças cheias ascendentes seguidos de pequenas curvas por saltos e graus conjuntos. A tonalidade é muito aguda para a voz infantil, devendo ser abaixada em um tom para crianças menores, para quem o tema é mais interessante.

Acompanhamento instrumental (piano) - introdução e coda com quatro compassos sobre pedal no acorde de T, com seriação de dinâmica, em diminuendo. A melodia é dobrada pela mão direita, sobre pedal da T e linha cromática intermediária. A proposta do autor de utilizar pedal harmônico e uma linha cromática intermediária descendente altera a harmonia tradicional sugerida pela melodia, porém traz um interesse timbrístico novo.

Ludicidade - brincadeira de roda cuja movimentação é ditada pelo texto.

Complementação do texto ${ }^{56}$ :

Carneirinho, carneirão, (neirão, neirão) / Olhai pro céu, olhai pro chão, pro chão, pro chão / Manda El Rei Nosso Senhor, Senhor, Senhor, / Pra nós nos levantarmos / sentarmos / ajoelharmos / deitarmos / levantarmos.

${ }^{56}$ ABM - $2^{\circ}$ Caderno, p. 112 
118) SOLFEJO $n^{\circ} 11$ (Cânone circular) - a capella

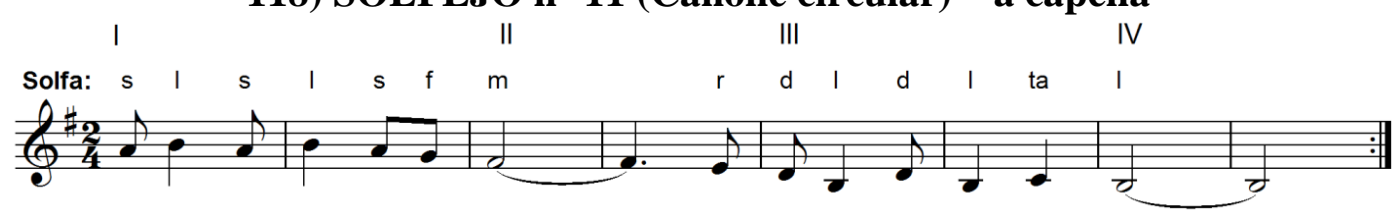

\begin{tabular}{|c|c|c|c|c|}
\hline $\begin{array}{c}\text { Volume } \\
\text { S2 }\end{array}$ & $\begin{array}{c}\text { № } \\
11 / \text { p. } 22\end{array}$ & $\begin{array}{c}\text { Tessitura } \\
\text { B2-B3 }\end{array}$ & $\begin{array}{c}\text { Forma - A } \\
\text { Extensão: 8a } \\
\text { Graus da escala: } 7 \\
\text { Sistema Heptatônico (C G D A E B F\#) } \\
\text { Heptacorde (s f m r d t l) }\end{array}$ & $\begin{array}{l}\text { Intervalos } \\
\text { melódicos } \\
\text { 2a } \mathrm{M} / \mathrm{m} ; 3 \text { a } \mathrm{m}\end{array}$ \\
\hline & & & 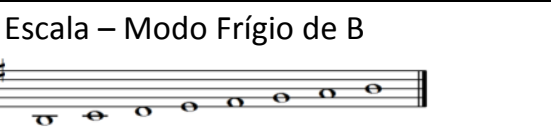 & \\
\hline
\end{tabular}

Sugestões de atividades didático-pedagógicas:

Células rítmicas para registro gráfico:

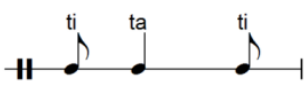

Células melódicas para registro gráfico:

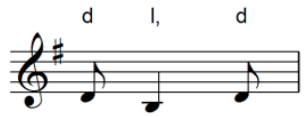

Possivel ostinato rítmico:

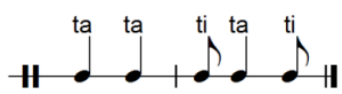

Outras possibilidades: cânone a duas, três ou 4 vozes.

Tema de Villa-Lobos com 8 compassos binários, com a indicação: Marcial; sem indicações de dinâmica.

Ritmo - o interesse rítmico está síncopas.

Melodia - descendente, sobre um acorde de $\mathrm{Bm}^{7}$. Cânone exato, cujo reinício ocorre com salto de sétima menor ascendente.

Ludicidade - apesar de se tratar de um solfejo, a possibilidade de execução do cânone é desafio lúdico.

\section{9) SOLFEJO no 39 - a capella}
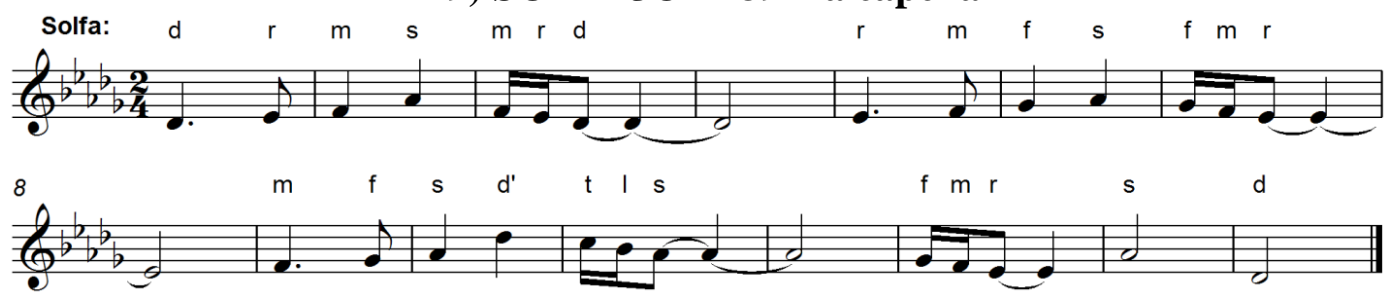

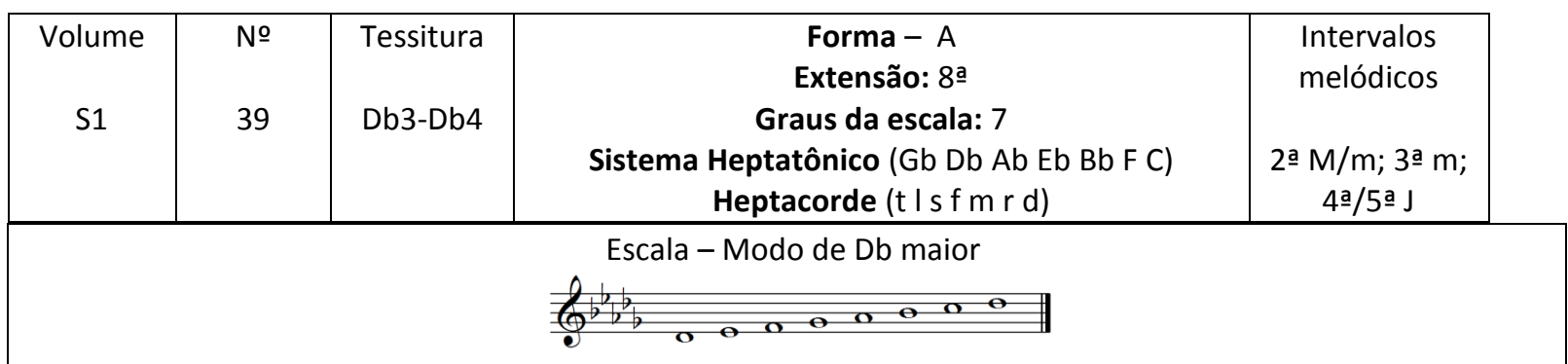


Sugestões de atividades didático-pedagógicas:

Células rítmicas para registro gráfico:

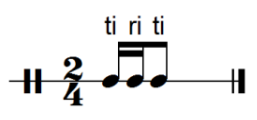

Células melódicas para registro gráfico:

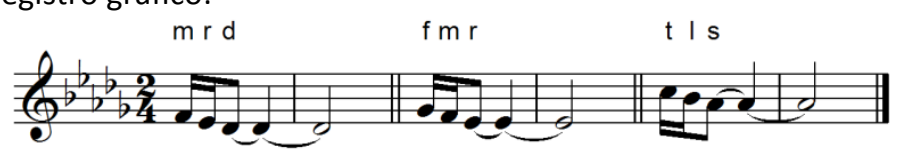

Possivel ostinato rítmico:

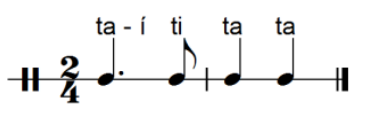

Outras possibilidades: pedal:

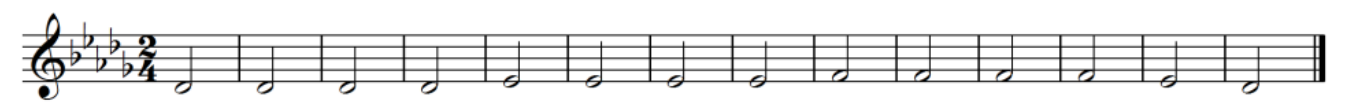

Canção com 15 compassos binários, sem indicação de andamento ou de dinâmica.

Tema de Villa-Lobos.

Ritmo - o interesse rítmico está notas longas após semicolcheias. Frases assimétricas com 8 e 7 compassos.

Melodia - sequência de linhas pentacordais incompletas ascendentes/descendentes a partir do primeiro, segundo e terceiro graus, com terminação na $\mathrm{T}$ por salto descendente de quinta.

Ludicidade - apesar de se tratar de um solfejo, atividades rítmicas corporais, por exemplo, podem se transformar em desafios lúdicos.

\section{0) HEI DE NAMORAR - a capella}

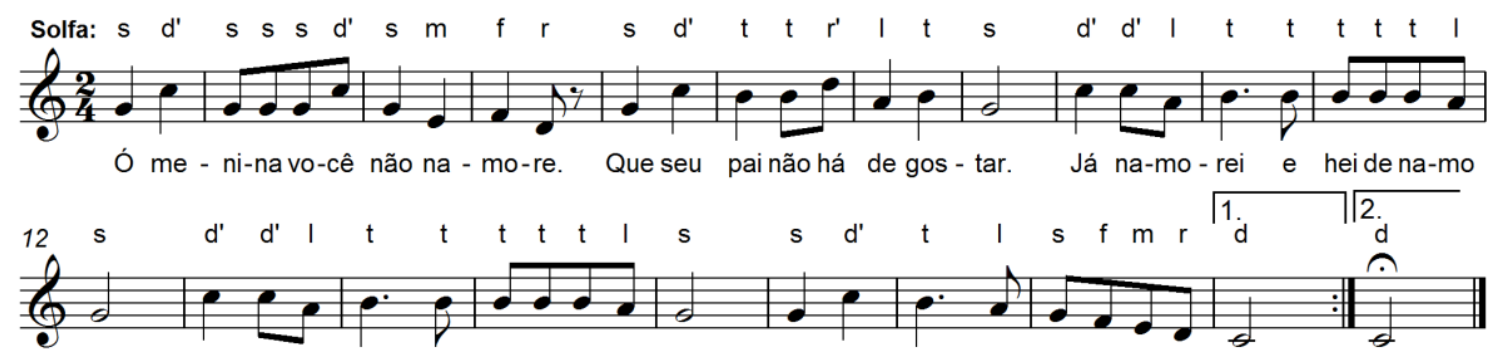

rar. Já na-mo - rei e hei de na-mo - rar. Sou sol - tei - ra, que-ro me ca - sar!

\begin{tabular}{|c|c|c|c|c|}
\hline $\begin{array}{l}\text { Volume } \\
\text { GP-VTL } \\
\text { /ABM }\end{array}$ & $\begin{array}{l}\text { № } \\
62 \\
\text { /56 }\end{array}$ & $\begin{array}{l}\text { Tessitura } \\
\text { C3-D4 }\end{array}$ & $\begin{array}{c}\text { Forma - A } \\
\text { Gênero - Canção } \\
\text { Extensão: } 9 \underline{a} \\
\text { Graus da escala: } 7 \\
\text { Sistema Heptatônico (F C G D A E B) } \\
\text { Heptacorde (t I s f m r d) }\end{array}$ & 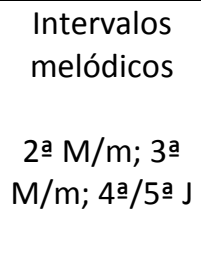 \\
\hline \multicolumn{5}{|c|}{ Escala - Modo de C maior } \\
\hline
\end{tabular}

Sugestões de atividades didático-pedagógicas:

Células rítmicas para registro gráfico:

Células melódicas para registro gráfico:

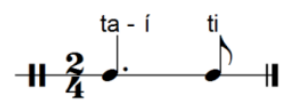




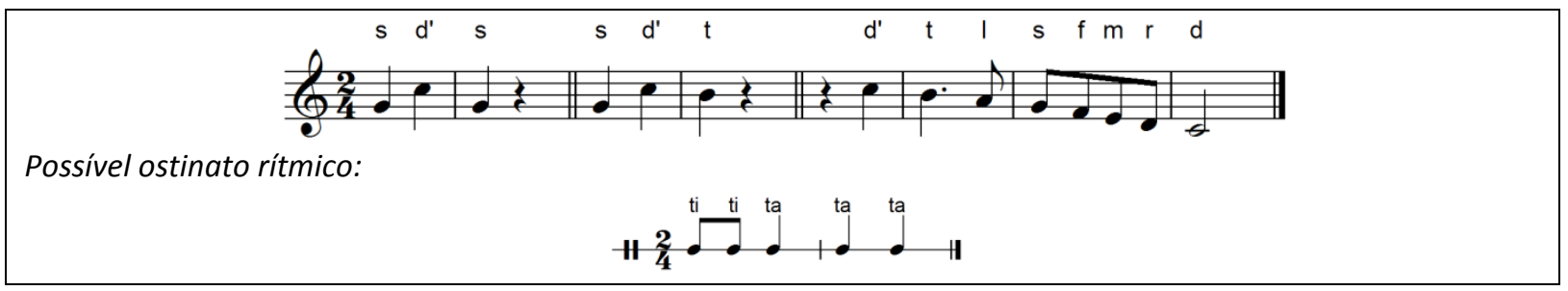

Análise complementar em $2.2-n^{\circ} 173$.

Canção popular, folclórica infantil de 21 compassos binários, com a indicação de andamento: Andantino quasi allegretto $(\mathbf{1 0 8}=\mathrm{J})$; indicações de dinâmica: $<$; >; Acentos > _

Tema popular de brincadeira cantada cujo desenvolvimento baseia-se no texto.

Texto - quadrinha com diálogo, sobre tema em contexto social de época.

Ritmo - o interesse rítmico está nas notas pontuadas.

Melodia - curva inicial sobre arpejo da $\mathrm{T}$ com finalização descendente na $\mathrm{D}$; curva com final descendente na $\mathrm{D}$; desenhos descendentes finalizando por duas vezes no quinto grau, seguidos de escala completa descendente para a $\mathrm{T}$.

Ludicidade - brincadeira de roda, com possibilidades de encenação.

\section{1) CARAMBOLA - acompanhamento instrumental}

(Canto com Piano, acompanhamento instrumental ou Piano solo) Arr. de H. Villa-Lobos
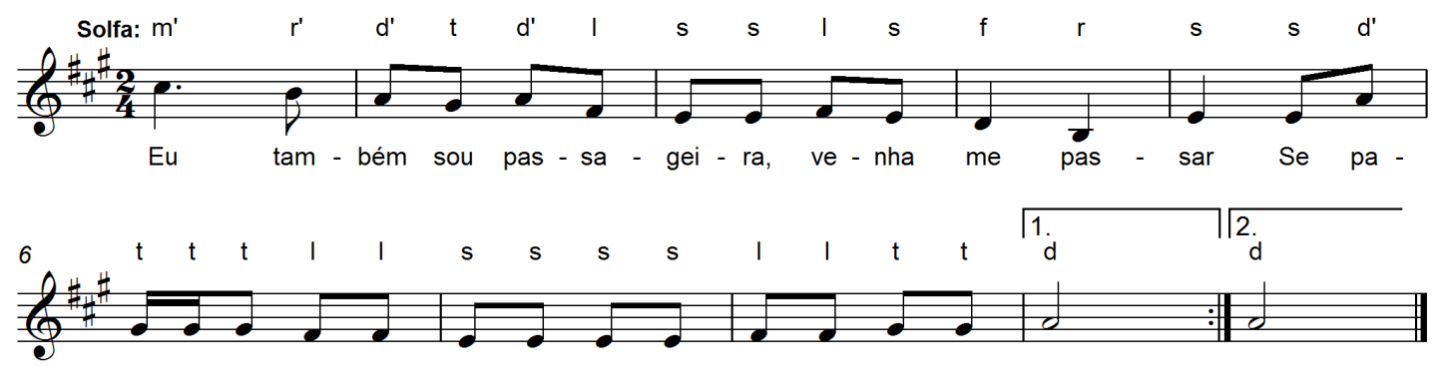

pai e ma-mãe sou - bes-sem Ca - ram - bo - la vi - rá já. já.

\begin{tabular}{|c|c|c|c|c|}
\hline $\begin{array}{l}\text { Volume } \\
\text { GP-VTL } \\
\text { /ABM }\end{array}$ & $\begin{array}{l}\text { № } \\
28 \\
/ 65\end{array}$ & $\begin{array}{l}\text { Tessitura } \\
\text { B2-C\#4 }\end{array}$ & $\begin{array}{c}\text { Forma - A } \\
\text { Gênero - Polca } \\
\text { Extensão: 9ạ } \\
\text { Graus da escala: } 7 \\
\text { Sistema Heptatônico (D A E B F\# C\# G\#) } \\
\text { Heptacorde ( } \mathrm{t} \mid \mathrm{s} \text { f m r d) }\end{array}$ & $\begin{array}{l}\text { Intervalos } \\
\text { melódicos } \\
\text { 2a } \mathrm{M} / \mathrm{m} ; 3 \text { 3a } \\
\mathrm{M} / \mathrm{m} ; 4 \text { J }\end{array}$ \\
\hline \multicolumn{5}{|c|}{$\begin{array}{l}\text { Escala - Modo de A maior } \\
0\end{array}$} \\
\hline
\end{tabular}

Sugestões de atividades didático-pedagógicas:

Células rítmicas para registro gráfico:

Células melódicas para registro gráfico:
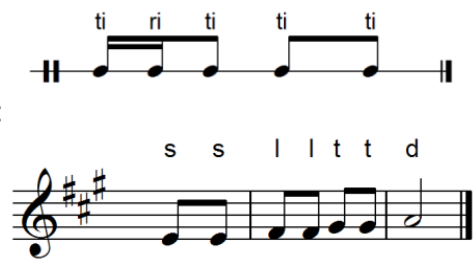

Possível ostinato rítmico: 


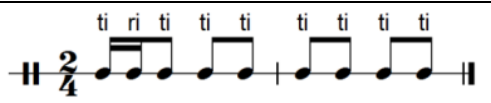

Canção popular, folclórica infantil de 10 compassos binários, com a indicação de andamento: Allegretto $(132=ل$ ل); indicações de dinâmica: $\boldsymbol{m f}$; $s f z$; acentos > ; stacatto

Tema popular de brincadeira cantada cujo desenvolvimento baseia-se no texto.

Texto - quadrinha com referência a meio de transporte.

Ritmo - o interesse rítmico está nas notas pontuadas.

Melodia - primeira frase em desenho descendente e segunda frase com terminação ascendente em tetracorde, com terminação na $\mathrm{T}$.

Execução instrumental (piano) - introdução (dois compassos) sobre pedal no primeiro grau, com célula rítmica em bordadura cromática inferior utilizada em ostinato parcial, caracterizando um ritmo padrão utilizado no acompanhamento. A mão direita dobra a melodia e juntamente com a mão esquerda explicita os acordes sobre as funções tonais básicas, com acréscimo da DD nos compassos 8, 9 e 11 e seus correspondentes na repetição. A coda (2 compassos), repete por três vezes a célula padrão acoplada ao primeiro grau em sequência de oitavas ascendentes nas duas mãos.

Ludicidade - brincadeira de roda, com possibilidades de encenação, criando situações em meios de transporte como um barco, ônibus ou outros.

\section{2) FUI NO ITORORÓ (1ª versão) - acompanhamento instrumental}

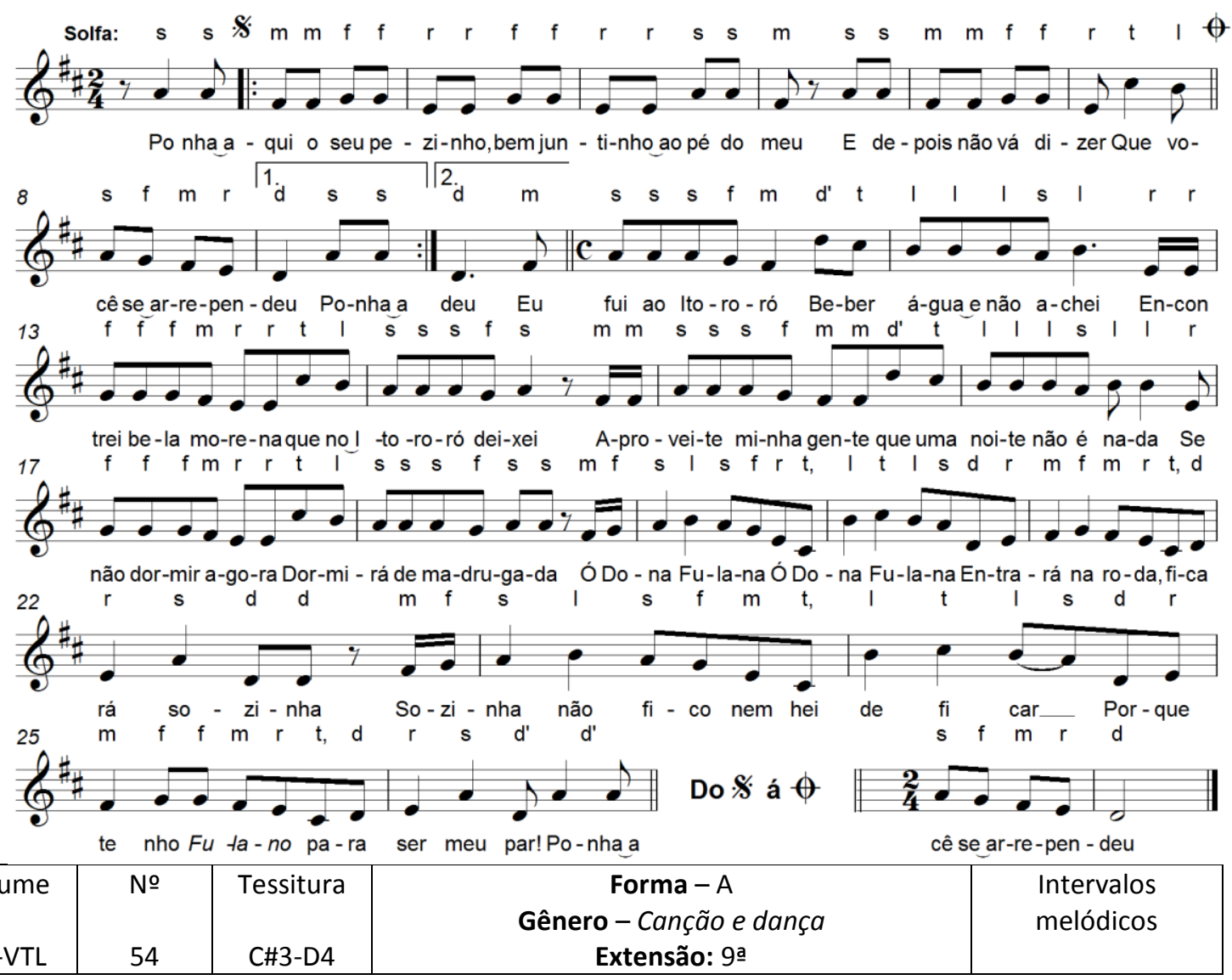




\begin{tabular}{|c|c|c|c|}
\hline /ABM & $/ 129$ & $\begin{array}{c}\text { Graus da escala: } 7 \\
\text { Sistema Heptatônico (G D A E B F\# C\#) } \\
\text { Heptacorde (t I s f m r d) }\end{array}$ & $\begin{array}{c}2 \text { a } M / m ; 3 \text { a } M / m ; \\
4 a / 5 \text { a J }\end{array}$ \\
\hline \multicolumn{4}{|c|}{ Escala - Modo de D maior } \\
\hline
\end{tabular}

Sugestões de atividades didático-pedagógicas:

Células rítmicas para registro gráfico:

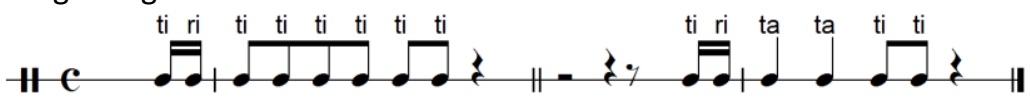

Células melódicas para registro gráfico:

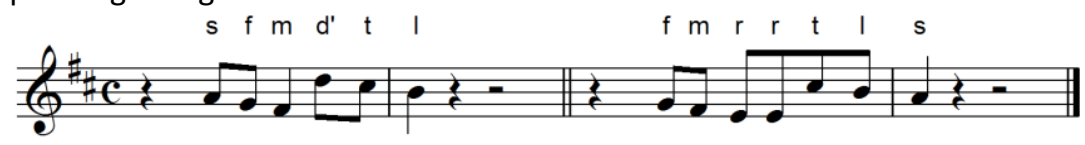

Possivel ostinato rítmico:

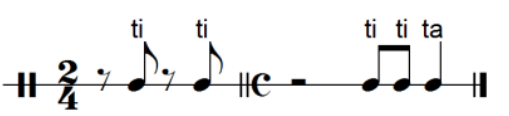

Análise complementar em 2.2 - $n^{\circ} 86$.

Trata-se da mesma melodia analisada a seguir, porém em outra tonalidade e com alguma variação melódica.

Canção com 20 compassos quaternários, com a indicação de andamento: Vivo $(\mathbf{1 6 0}=$ ل ); Andantino; indicações de dinâmica: $\boldsymbol{f} ; \boldsymbol{p}$

\section{3) FUI NO ITORORÓ ( $2^{\mathrm{a}}$ versão) - a capella}

(Canto com piano, conjunto instrumental ou Piano solo) Arr. de H. Villa-Lobos

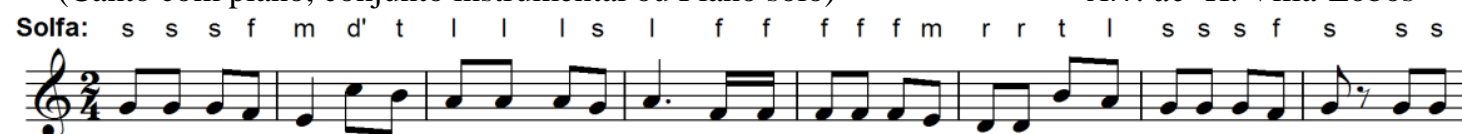

Fui nol-to-ro -ró Be-ber á -gua e não a - chei En-con - treibe-la mo - re-na que nol - to-ro-ró dei - xei. A pro

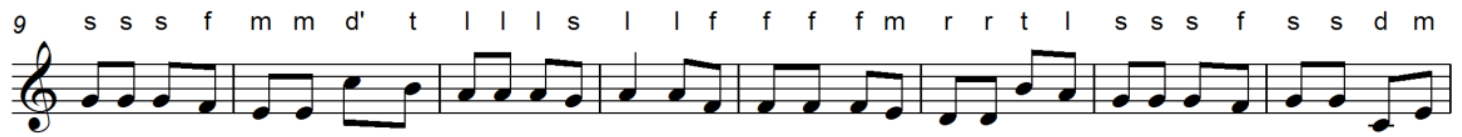

vei te mi-nha gen-te que u-ma noi tenão é na-da,se não dor-mir a - go-ra,dor-mi - rá dema-dru ga-da. Oh!Do

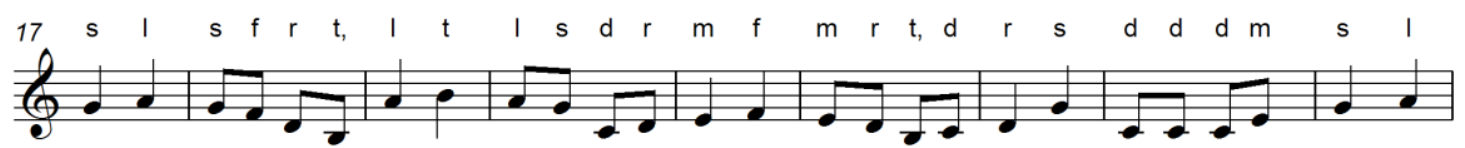

na Ma - ri-a Oh!Ma - ri - a - zi-nha,en-tra - rá na ro-da_efi-ca - rá so - zi-nha.So-zi - nha eu não

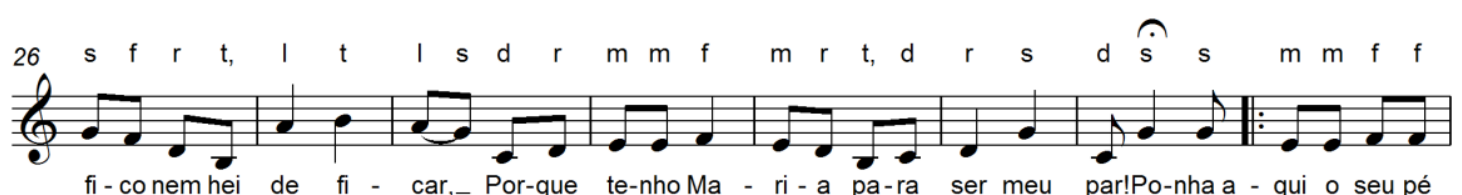

D.C. al fim

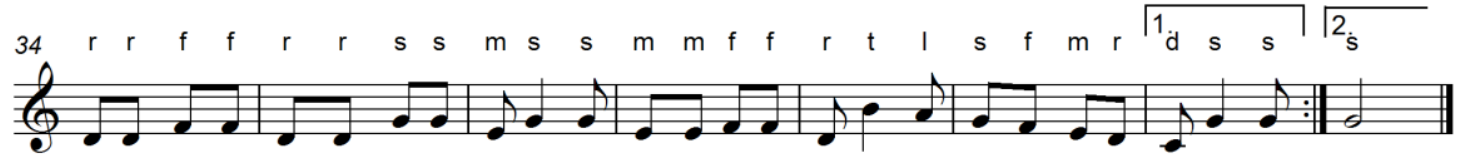

zi nho bem jun - ti-nho ao pé do meuE de - pois nãová di - zer que vo - cêse ar-repen-deuPo-nha deu!

\begin{tabular}{|c|c|c|c|c|}
\hline Volume & № & Tessitura & $\begin{array}{c}\text { Forma - A } \\
\text { Gênero - Canção e dança } \\
\text { Extensão: 9ạ }\end{array}$ & $\begin{array}{c}\text { Intervalos } \\
\text { melódicos }\end{array}$ \\
\hline
\end{tabular}




\begin{tabular}{|c|c|c|c|}
\hline /ABM & $/ 90$ & $\begin{array}{c}\text { Graus da escala: } 7 \\
\text { Sistema Heptatônico (F C G D A E B) } \\
\text { Heptacorde ( } \mathrm{t} \text { | s f m r d) }\end{array}$ & 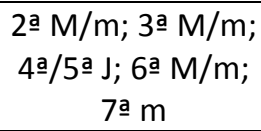 \\
\hline \multicolumn{4}{|c|}{$\begin{array}{l}\text { Escala - Modo de C maior } \\
\\
\end{array}$} \\
\hline
\end{tabular}

Sugestões de atividades didático-pedagógicas:

Células rítmicas para registro gráfico:

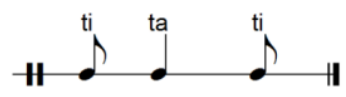

Células melódicas para registro gráfico:

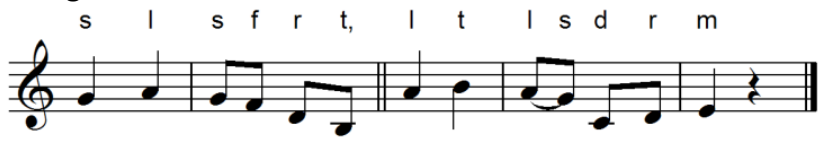

Possível ostinato rítmico:

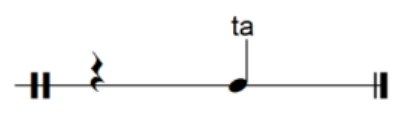

Canção com 42 compassos binários, com a indicação de andamento: Allegretto $(132=\downarrow d)$;

Più Mosso / Vivace; indicações de dinâmica: $\boldsymbol{f} ; \boldsymbol{f f}$

Temas populares, do folclore infantil, de brincadeiras cantadas, neste caso três melodias que se apresentam em conjunto, na forma $\mathrm{ABC}$.

Texto - Itororó (Tororó - Salvador, BH), fonte de água. Quadrinhas sobre os prazeres da dança.

Ritmo - o interesse rítmico está no compasso binário, pulso e sua subdivisão, como guias para a dança.

Melodia - a parte A apresenta desenhos em torno de terças cheias sobre T, S e D; parte B pequenas curvas sobre arpejos ascendentes com finalizações em arpejos descendentes para a $\mathrm{T}$; parte $\mathrm{C}$ - terças quebradas seguidas com notas rebatidas de linha escalar descendente para a T.

Ludicidade - brincadeira de roda com três partes, com a participação de solista e danças em pares.

\section{4) CARNEIRINHO DE ALGODÃO - a capella}
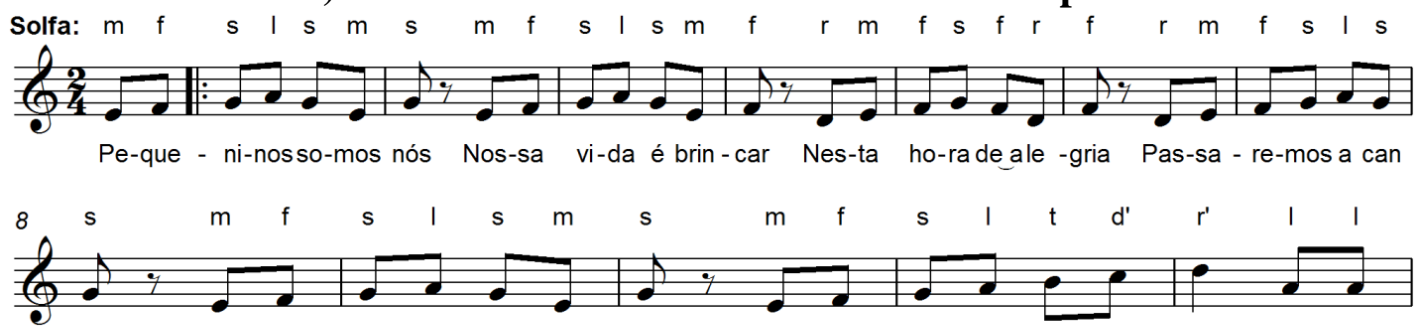

tar Car - nei - ri - nho, Car - nei - rão Ca - be - ci - nha de al - go - dão E - ra as -

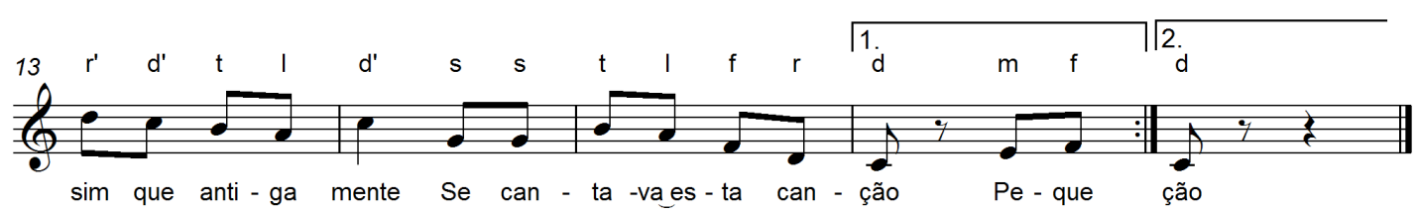

\begin{tabular}{|l|l|l|c|c} 
Volume & No & Tessitura & $\begin{array}{c}\text { Forma - A } \\
\text { Extensão: 9ạ }\end{array}$ & $\begin{array}{r}\text { Intervalos } \\
\text { melódicos }\end{array}$ \\
\hline
\end{tabular}




\begin{tabular}{|c|c|c|c|c|}
\hline $\mathrm{CO} 1$ & 4 & C3-D4 & $\begin{array}{c}\text { Graus da escala: } 7 \\
\text { Sistema Heptatônico (F C G D A E B) } \\
\text { Heptacorde (t I s f m r d) }\end{array}$ & $\begin{array}{c}2^{\text {a }} \mathrm{M} / \mathrm{m} ; 3^{\text {a }} \\
\mathrm{M} / \mathrm{m} ; 4^{\mathrm{a}} \mathrm{J}\end{array}$ \\
\hline \multicolumn{5}{|c|}{ Escala - Modo de C maior } \\
\hline
\end{tabular}

Sugestões de atividades didático-pedagógicas:

Células rítmicas para registro gráfico:

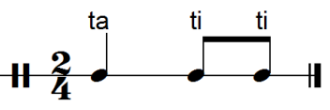

Células melódicas para registro gráfico:

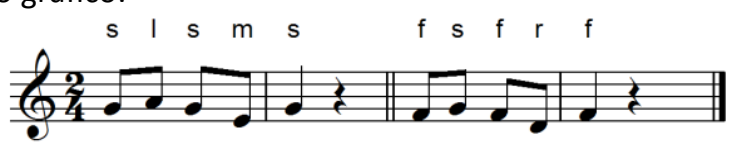

Possível ostinato rítmico:

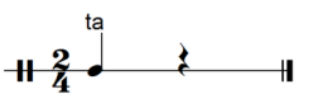

Análise complementar em $2.2-n^{\circ} 10$.

Canção com 33 compassos binários, com a indicação: Allegretto (Marcial); sem indicações de dinâmica.

Tema de Villa-Lobos - para o jardim de infância, com letra de Sylvio Salema e música de H. Villa-Lobos - Rio de Janeiro, 1934.

Texto - infantil, em redondilha maior, sobre a atividade de brincar e cantar, e no qual as crianças descrevem seu próprio universo, "nossa vida é brincar", com citação da canção folclórica Carneirinho, carneirão. Em GP/VTL, nos compassos 7e 15, a prosódia, no primeiro pulso, comporta duas colcheias. Consta equivocada a expressão: al Fim (italiano e português) - melhor seria: ao Fim. O compasso 13 apresenta equivocadamente um ponto de aumento na primeira nota.

Ritmo - o interesse rítmico está no pulso e subdivisão.

Melodia - desenho em pequena curva a partir do terceiro grau, repetido quatro vezes na primeira parte (1-8); quinta repetição da curva seguida de linha ascendente por grau conjunto e dois desenhos descendentes em direção à tônica.

Ludicidade - a canção pode ser acompanhada de mímica e outros movimentos.

\section{5) O CRAVO BRIGOU COM A ROSA - a capella}

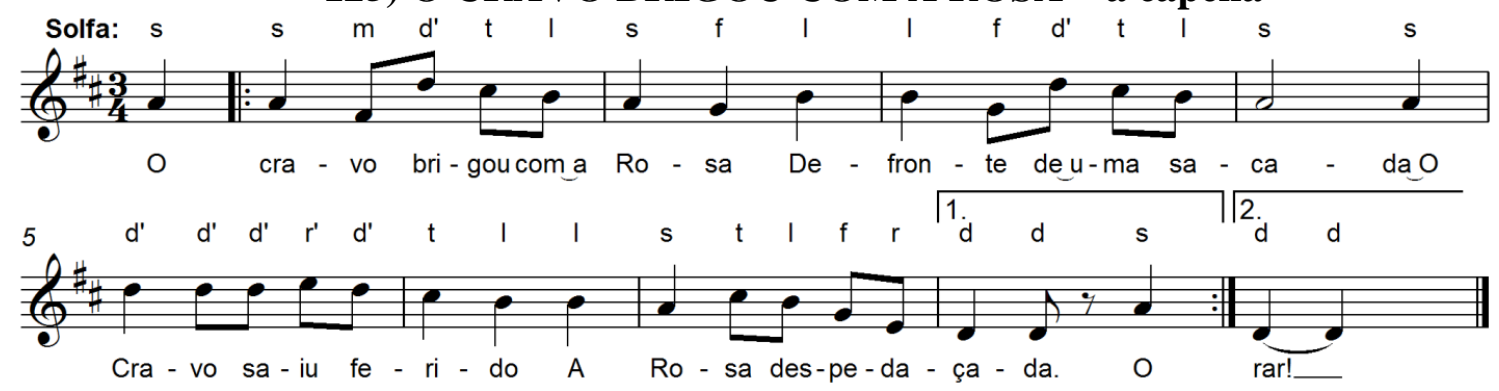

\begin{tabular}{|c|c|c|c|c|}
\hline Volume & № & Tessitura & $\begin{array}{c}\text { Forma - A } \\
\text { Gênero-Mazurca canção } \\
\text { Extensão: 9ạ }\end{array}$ & $\begin{array}{c}\text { Intervalos } \\
\text { melódicos }\end{array}$ \\
\hline
\end{tabular}




\begin{tabular}{|c|c|c|c|}
\hline $\begin{array}{l}/ \mathrm{S} 1 \\
/ \mathrm{ABM}\end{array}$ & $\begin{array}{l}/ 21 \\
/ 12\end{array}$ & $\begin{array}{c}\text { Graus da escala: } 7 \\
\text { Sistema Heptatônico (G D A E B F\# C\#) } \\
\text { Heptacorde ( } \mathrm{t} \text { / s f m r d) }\end{array}$ & $\begin{array}{c}\text { 2a } \mathrm{M} / \mathrm{m} ; 3^{\mathrm{a}} \mathrm{M} / \mathrm{m} ; \\
\text { 4a/5a J; 6a } \mathrm{m}\end{array}$ \\
\hline \multicolumn{4}{|c|}{ Escala - Modo de D maior } \\
\hline
\end{tabular}

Sugestões de atividades didático-pedagógicas:

Células rítmicas para registro gráfico:

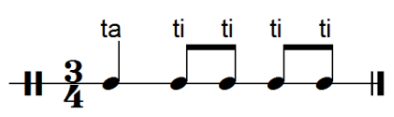

Células melódicas para registro gráfico:

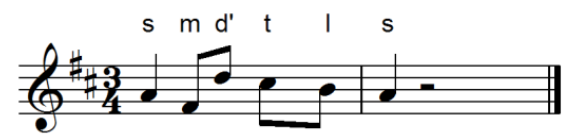

Possivel ostinato rítmico:

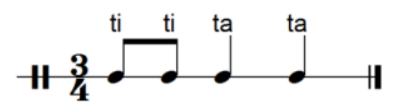

Análise complementar em $2.2-n^{\circ} 60$.

Canção com 10 compassos ternários, com a indicação de andamento: Andantino (M.M. $126=ل$ ); indicações de dinâmica: $f f$

Tema popular, folclórico infantil, de brincadeira cantada cujo desenvolvimento baseia-se no texto.

Texto - Descrição de brincadeira de roda, sobre a briga entre o cravo e a rosa, que feridos, arcam com as consequências. Para facilitar a respiração, o compasso 4 deveria conter três semínimas.

Ritmo - o interesse rítmico está no compasso ternário.

Melodia - duas pequenas curvas sobre acordes de $\mathrm{T}$, resolvendo na $\mathrm{D}$ e de $\mathrm{S}$ indo para $\mathrm{T}$, seguidas de desenho descendente, alcançado por salto ascendente, por graus conjuntos e arpejo da $\mathrm{D}^{9}$ para a $\mathrm{T}$.

Ludicidade - brincadeira de roda, entre as mais conhecidas em todas as regiões do país, própria para mímicas e representações cênicas.

Complementação do texto:

O cravo brigou com a Rosa / defronte de uma sacada / o Cravo saiu ferido, / a Rosa despedaçada.

O cravo ficou doente /A Rosa foi visitar, / o Cravo teve um desmaio, / a Rosa pôs-se a chorar.

\section{6) O CRAVO (1 ${ }^{\mathrm{a}}$ versão $)$ - acompanhamento instrumental}
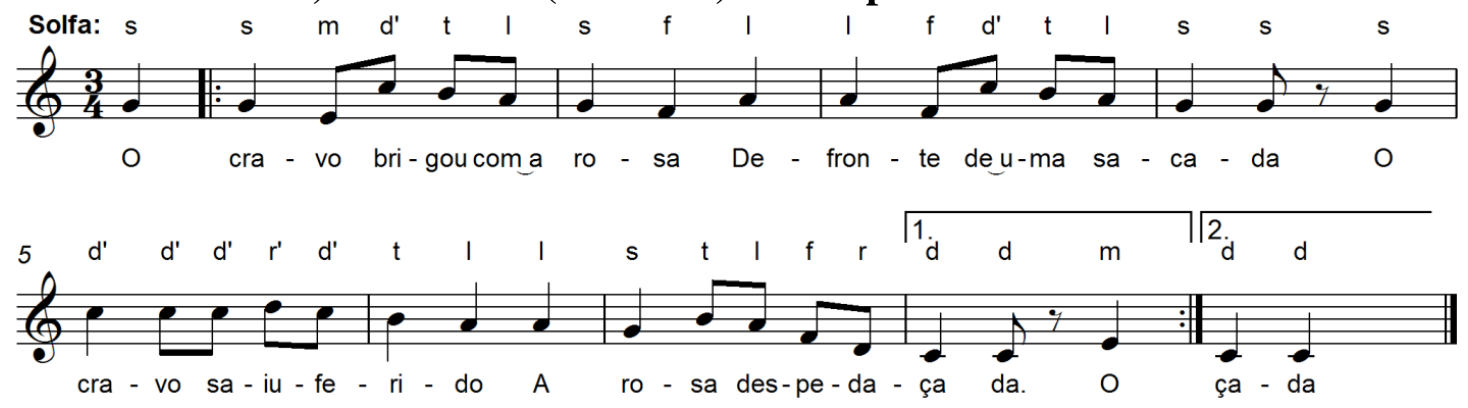


\begin{tabular}{|c|c|c|c|c|}
\hline $\begin{array}{l}\text { Volume } \\
\text { GP-VTL } \\
\text { /ABM }\end{array}$ & $\begin{array}{c}\text { № } \\
45 \\
/ 118\end{array}$ & $\begin{array}{c}\text { Tessitura } \\
\text { C3-D4 }\end{array}$ & $\begin{array}{c}\text { Forma - A } \\
\text { Gênero - Mazurca } \\
\text { Extensão: 9ạ } \\
\text { Graus da escala: } 7 \\
\text { Sistema Heptatônico (F C G D A E B) } \\
\text { Heptacorde ( } \mathrm{t} \text { | s f m r d) }\end{array}$ & $\begin{array}{l}\text { Intervalos } \\
\text { melódicos } \\
\text { 2a } \mathrm{M} / \mathrm{m} ; 3 \underline{a} \\
\mathrm{M} / \mathrm{m} ; 4 \stackrel{a}{\mathrm{a}} / 5 \text { a j; 6aa } \\
\mathrm{m}\end{array}$ \\
\hline \multicolumn{5}{|c|}{ Escala - Modo de C maior } \\
\hline
\end{tabular}

Sugestões de atividades didático-pedagógicas:

Células rítmicas para registro gráfico:

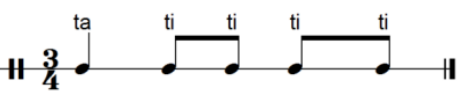

Células melódicas para registro gráfico

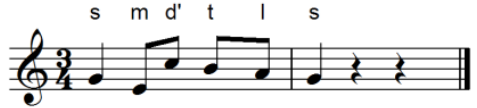

Possivel ostinato rítmico:

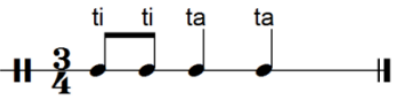

Análise complementar em $2.2-n^{\circ} 85$.

Trata-se da mesma melodia analisada acima, porém em outra tonalidade.

Canção com 10 compassos ternários, com a indicação: Allegretto $(\mathbf{1 4 4 =}$ ل); indicações de dinâmica: $f f$

\section{7) Có, Có, Có - acompanhamento instrumental}

(Canto com piano, conjunto instrumental ou Piano solo)

Amb. por H. Villa-Lobos
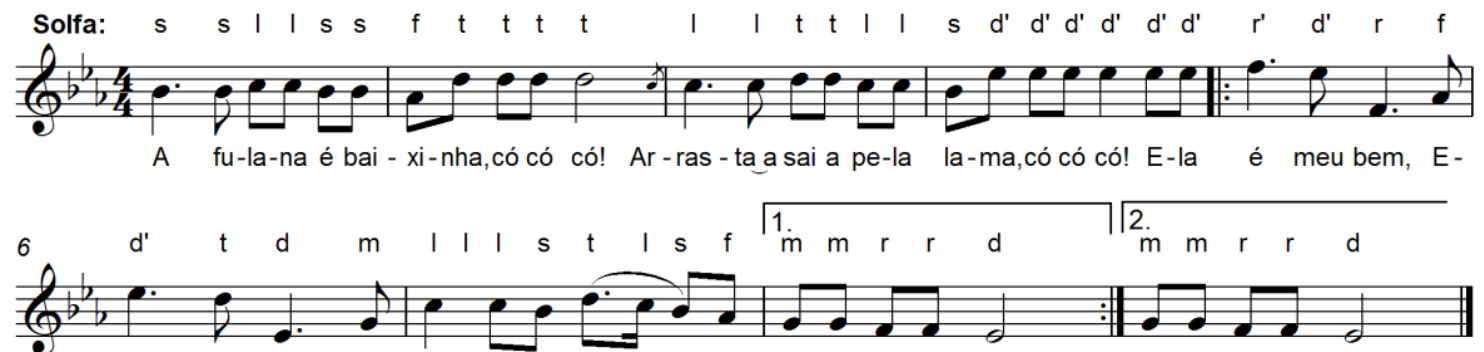
la é meu bem, Se e__la mor - rer
Eu fi - co sem nin-guém.
fi - co sem nin-guém

\begin{tabular}{|c|c|c|c|c|}
\hline $\begin{array}{l}\text { Volume } \\
\text { GP-VTL } \\
\text { /ABM }\end{array}$ & $\begin{array}{l}\text { № } \\
37 \\
/ 132\end{array}$ & $\begin{array}{l}\text { Tessitura } \\
\text { Eb3-F4 }\end{array}$ & $\begin{array}{c}\text { Forma - A } \\
\text { Gênero - Mazurca canção } \\
\text { Extensão: 9ạ } \\
\text { Graus da escala: } 7 \\
\text { Sistema Heptatônico (Ab Eb Bb F C G D) } \\
\text { Heptacorde (t I s f m r d) }\end{array}$ & 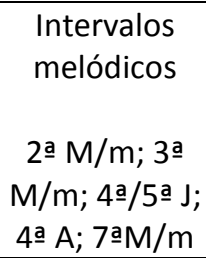 \\
\hline & & & 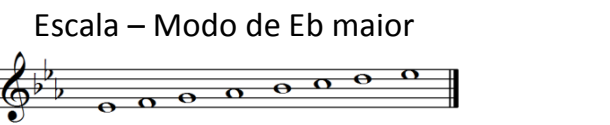 & \\
\hline
\end{tabular}

Sugestões de atividades didático-pedagógicas:

Células rítmicas para registro gráfico:

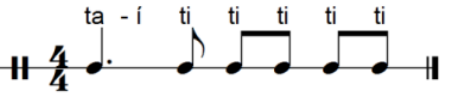


Células melódicas para registro gráfico:

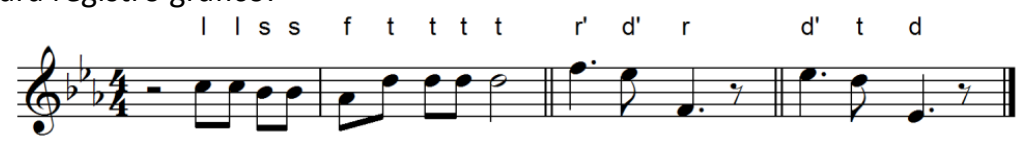

Possivel ostinato rítmico:

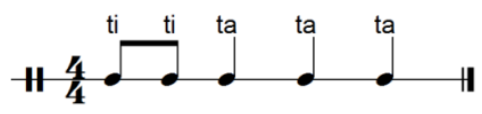

Análise complementar em $2.2-n^{\circ} 168$.

Canção com 9 compassos quaternários, com a indicação e andamento: Movimento de Marcha de Rancho (M.M. 132= ل ل $)^{57}$; indicações de dinâmica: $f ; m f ; s f z ; p ;\langle;>$; Acentos $>$; fff

Tema popular, folclórico infantil, de brincadeira cantada cujo desenvolvimento baseia-se no texto.

Texto - descrição de brincadeira cantada que menciona cada criança como sendo baixinha como uma galinha, porém importante por ser o bem de alguém. O ponto culminante está na afirmação "é meu bem".

Ritmo - o interesse rítmico está nas notas pontuadas.

Melodia - pequena linha descendente seguida de salto de quarta aumentada ascendente para a sensível da D; idem por quarta justa para a T; linha descendente após ponto culminante com salto de sétima menor para a $\mathrm{D}$, idem com sétima maior para a $\mathrm{T}$, desenho ascendente com terminação de hexacorde descendente para a T. Em se tratando da utilização da melodia para brincadeira, a tonalidade deve ser abaixada.

Ludicidade - brincadeira de roda com possibilidades de mímica e representação cênica.

128) BA, BE, BI, BO, BU - acompanhamento instrumental (Para Piano)

Amb. por H. Villa-Lobos

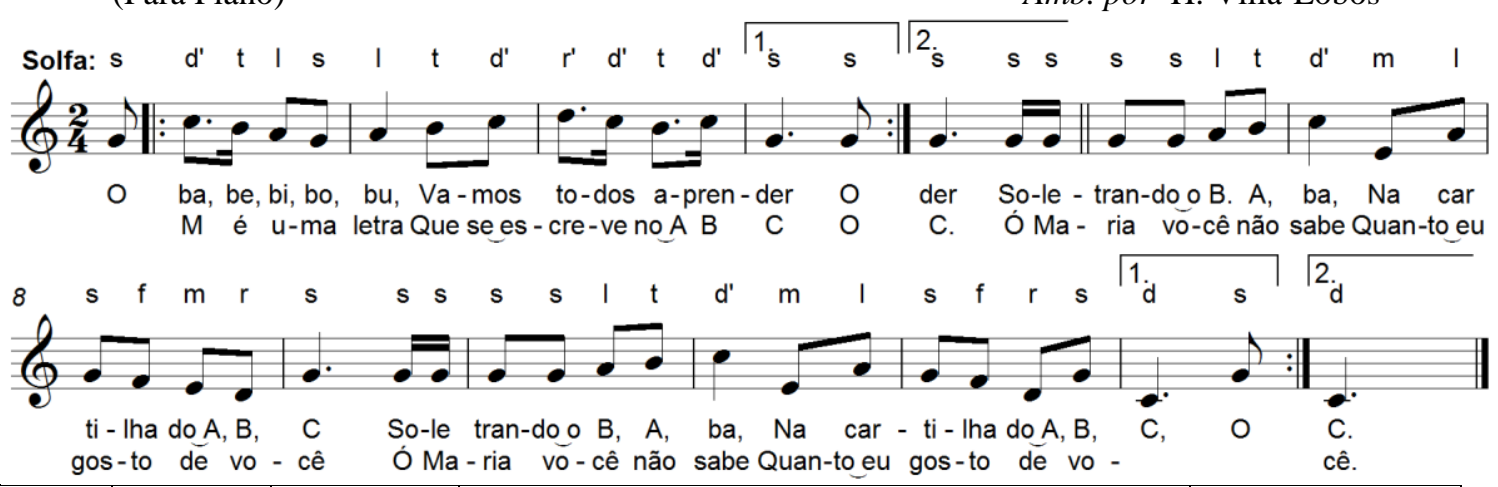

\begin{tabular}{|c|c|c|c|c|}
\hline $\begin{array}{l}\text { Volume } \\
\text { GP-VTL } \\
\text { /ABM }\end{array}$ & $\begin{array}{l}\text { № } \\
11 \\
\text { /66 }\end{array}$ & $\begin{array}{l}\text { Tessitura } \\
\text { C3-D4 }\end{array}$ & $\begin{array}{c}\text { Forma - A } \\
\text { Gênero - Polca } \\
\text { Extensão: 9ạ } \\
\text { Graus da escala: } 7 \\
\text { Sistema Heptatônico (F C G D A E B) } \\
\text { Heptacorde ( } \mathrm{t} \text { | s f m r d) }\end{array}$ & $\begin{array}{c}\text { Intervalos } \\
\text { melódicos } \\
\text { 2a } \mathrm{M} / \mathrm{m} ; 3^{\underline{a}} \\
\mathrm{M} / \mathrm{m} ; 4 \text { ㅁ J; 6ㅁ } \mathrm{m}\end{array}$ \\
\hline \multicolumn{5}{|c|}{ 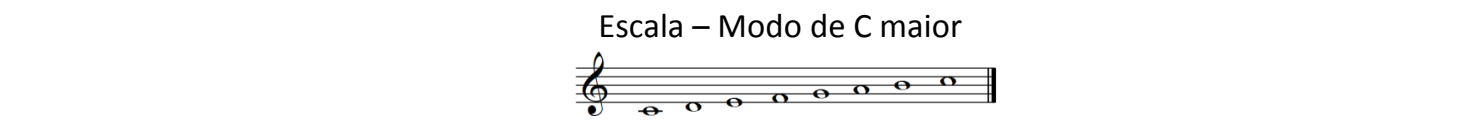 } \\
\hline
\end{tabular}

${ }^{57}$ GP/ABM - Movimento de marcha 
Sugestões de atividades didático-pedagógicas:

Células rítmicas para registro gráfico:

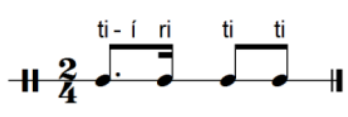

Células melódicas para registro gráfico:

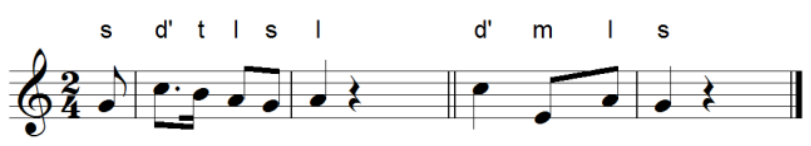

Possivel ostinato rítmico:

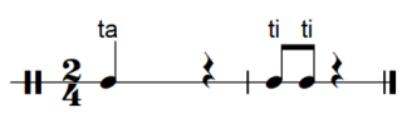

Canção com 15 compassos binários, com a indicação de andamento: Animato (132= ل ); sem indicações de dinâmica.

Tema popular, folclórico, de brincadeira cantada cujo desenvolvimento baseia-se no texto.

Texto - menciona a cartilha de alfabetização utilizada na época, que inspirou muitas quadrinhas apoiadas nas letras do abecedário da língua portuguesa, constituindo uma categoria específica de canções.

Ritmo - o interesse rítmico está nas recorrências de motivos. Em GP/VTL, a prosódia exige modificações, especialmente para a segunda parte.

Melodia - parte A - linhas descendente/ascendente com terminação descendente por salto na T (duas vezes); B linhas ascendente/descendente com terminação na T.

Acompanhamento instrumental (piano) - a introdução, no acorde de $\mathrm{D}^{7}$, em dois compassos em ritmo sincopado, antecipa o ostinato rítmico que prevalecerá em toda a peça, enquanto a melodia é dobrada pela mão direita e esquerda com duas oitavas de distância, resultando em solução timbrística original. A coda, com 5 compassos, repete o ritmo da introdução, em acorde de T em bordadura dupla 3-2 / 5-4. Em GP/VTL, a grafia do acompanhamento, no segundo pulso do compasso 13 , indicando $\boldsymbol{F} / \boldsymbol{G}$ colcheias para execução da mão direita na clave de $\boldsymbol{G}$, enquanto que em GP/ABM consta na clave de $\boldsymbol{F}$ - deveria haver uma indicação de que essas duas notas devem ser executadas pela mão direita.

Ludicidade - brincadeira cantada de roda ou não, é desafiante para a criação de outras quadras que explorem as letras do alfabeto. 
129) FELIZ NATAL - a capella

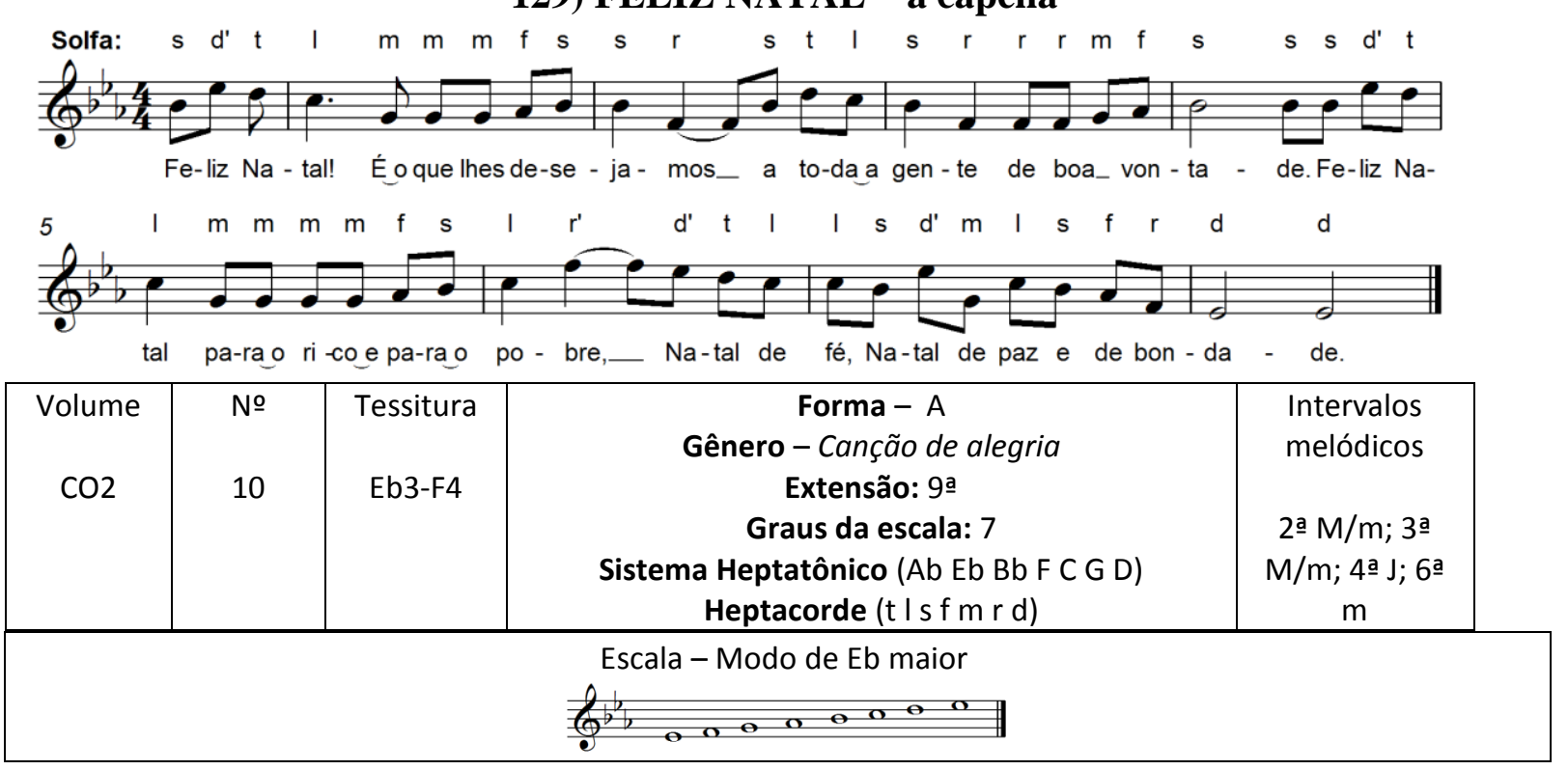

Sugestões de atividades didático-pedagógicas:

Células rítmicas para registro gráfico:

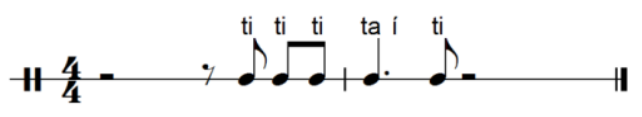

Células melódicas para registro gráfico:

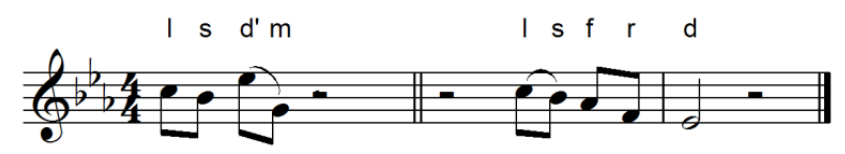

Possível ostinato rítmico:

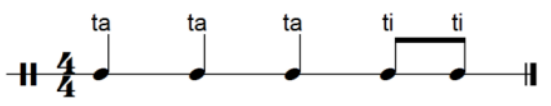

Análise complementar em $2.2-n^{\circ} 65$.

Canção com 9 compassos quaternários, com a indicação: Andantino; sem indicações de dinâmica.

Tema - canção de cordialidade, com letra de Manuel Bandeira e música e harmonização de H.Villa-Lobos, datada de 1945 - Rio de Janeiro.

Texto - quatro frases, sendo os primeiros versos decassilábicos; o terceiro eneassilábico e o último dodecassilábico. É uma saudação natalina dirigida a todos (verso1 a verso 3) e com votos para um bom futuro (verso 4)

Ritmo - o interesse rítmico está nos motivos anacrúsicos.

Melodia - caracteriza-se pela recorrência de saltos de quarta (em número de 9 em 8 compassos). Terminação na $\mathrm{T}$ por linha arpejada de $\mathrm{D}^{7}$ descendente iniciada por apojatura.

Ludicidade - canção própria para homenagens e ambientes festivos. 


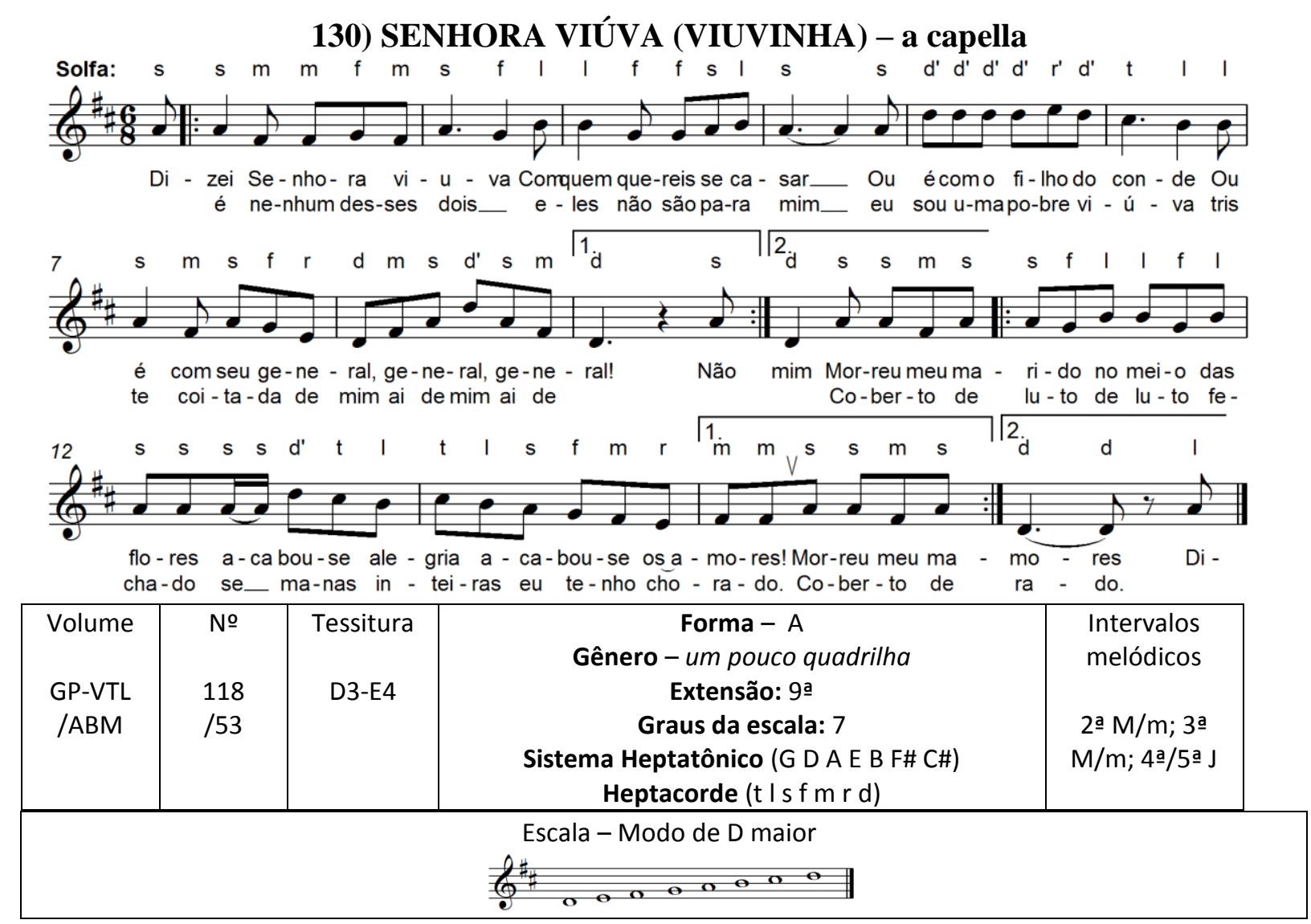

Sugestões de atividades didático-pedagógicas:

Células rítmicas para registro gráfico:

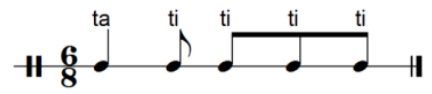

Células melódicas para registro gráfico:

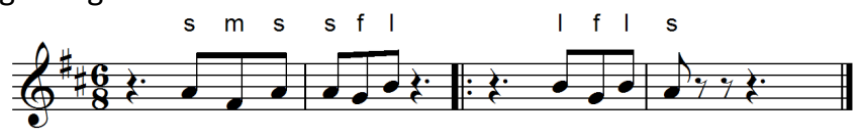

Possivel ostinato rítmico:

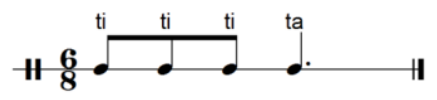

Análise complementar em 2.2 - $n^{\circ} 83$.

Canção com 16 compassos binários com subdivisão ternária, com a indicação de andamento:

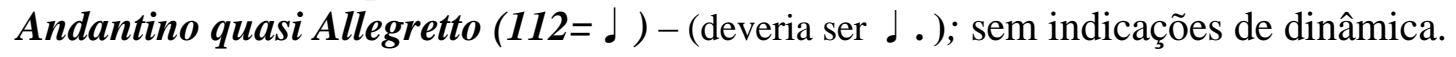

Tema popular, folclórico infantil, de brincadeira cantada cujo desenvolvimento baseia-se no texto.

Texto - descrição de brincadeira de roda, em que a senhora D. Viúva deve escolher o próximo marido entre o filho do rei ou senhor general, ambos rejeitados por ela. GP/ABM corrige a prosódia inserindo a segunda estrofe, bem como a concordância do pronome pessoal em "quereis se casar" para "quereis vos casar". Havendo essa interferência nesse caso, os demais erros deveriam ser corrigidos: "acabou-se os amores”, por exemplo.

Ritmo - o interesse rítmico está na subdivisão ternária. 
Melodia - a partir de terça menor da tríade da $\mathrm{T}$, o desenho se repete na $\mathrm{S}$, segunda acima. Nova repetição na $\mathrm{T}$ iniciado por salto ascendente de quarta, finalizando na $\mathrm{D}$, com conclusão em arpejos descendente, ascendente e descendente de T. No mesmo plano de altura inicial um novo desenho em pequenas curvas em terças, com conclusão por linha descendente e graus conjuntos para a $\mathrm{T}$.

Ludicidade - brincadeira de roda em diálogo, com solista e outros personagens.

131) A CANTIGA DE RODA - a capella
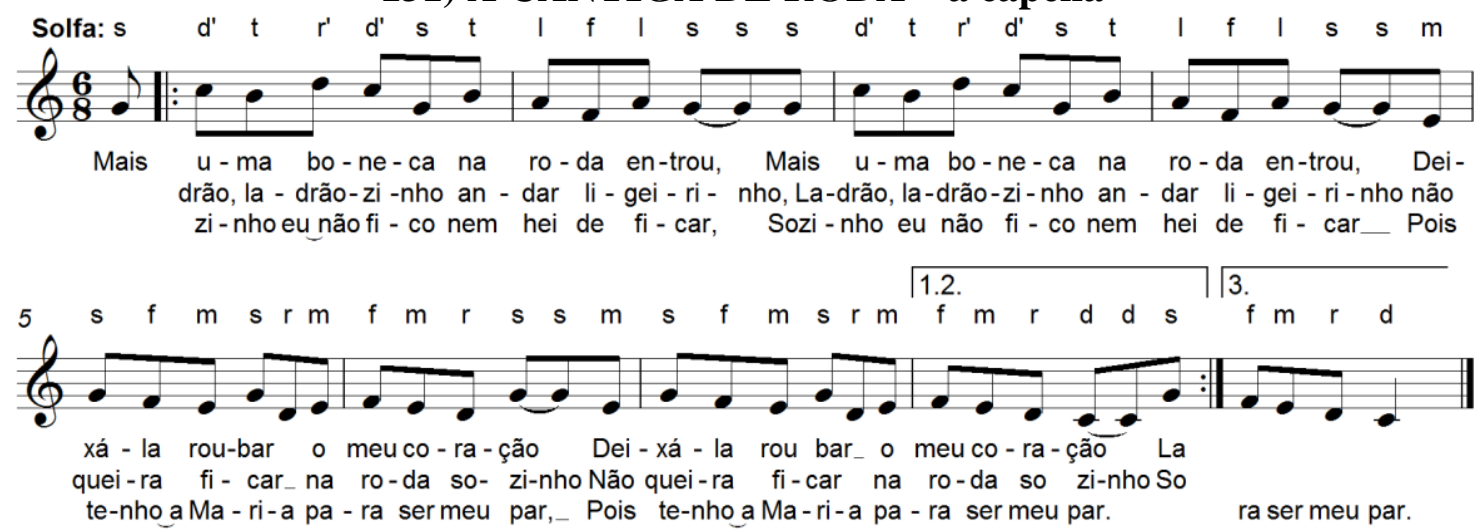

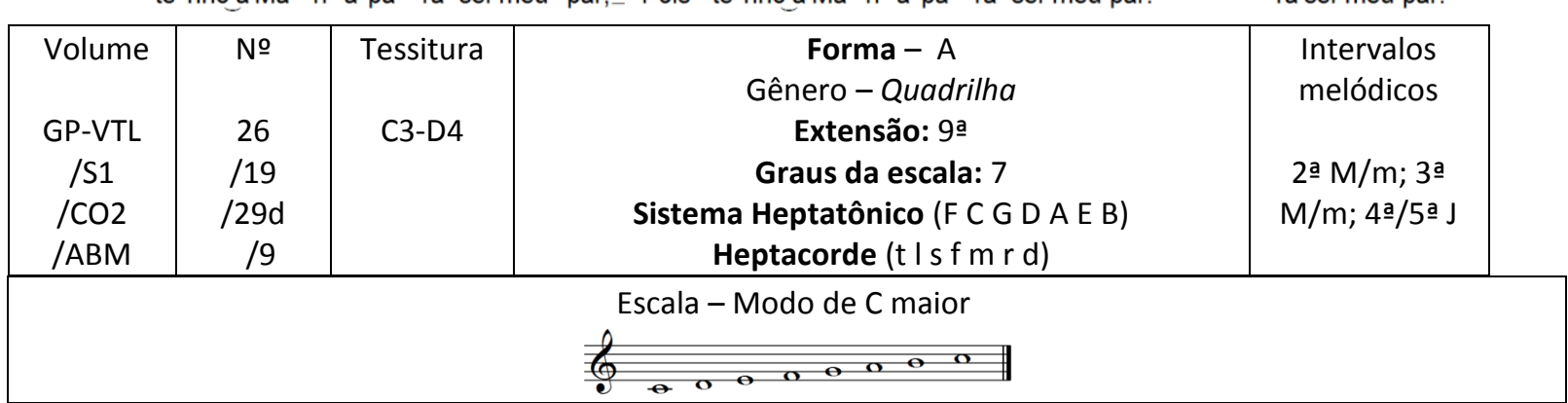

Sugestões de atividades didático-pedagógicas:

Células rítmicas para registro gráfico:

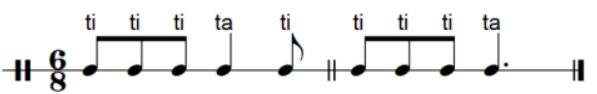

Células melódicas para registro gráfico:

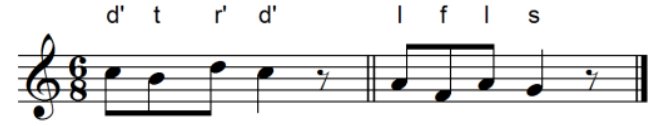

Possivel ostinato rítmico:

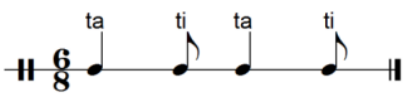

Canção com 10 compassos binários com subdivisão ternária, com a indicação: Allegretto (M.M. 72= §); sem indicações de dinâmica.

Tema popular, folclórico infantil, de brincadeira cantada cujo desenvolvimento baseia-se no texto.

Texto - Descrição de brincadeira de roda, em que a boneca é também o ladrão, portanto na terceira estrofe o sujeito poderia estar no feminino. Sugiro o texto: "Pois tenho a Maria" ao invés de "Porque tenho a Maria" para corrigir a prosódia. 
Ritmo - o interesse rítmico está na subdivisão ternária. No entanto, a melodia caracteriza-se como uma valsinha, e o compasso 6 por 8 não é adequado, pois a velocidade de $72=\delta$ é tão lenta que descaracteriza o compasso binário. Deveria ser 3 por 4 , ou a indicação metronômica deveria ser para a semínima pontuada. Mesmo assim, respeitando o compasso 6 por 8, o anacruse deveria se estender por mais três colcheias, por questão de finalizações dos impulsos métricos.

Melodia - pequenas curvas em linha descendente, por terças quebradas ou alcançadas por quartas, em pentacorde de $\boldsymbol{G}$, finalizando na T; idem em pentacorde de $\boldsymbol{C}$ com terças cheias.

Ludicidade - brincadeira de roda com personagens solistas.

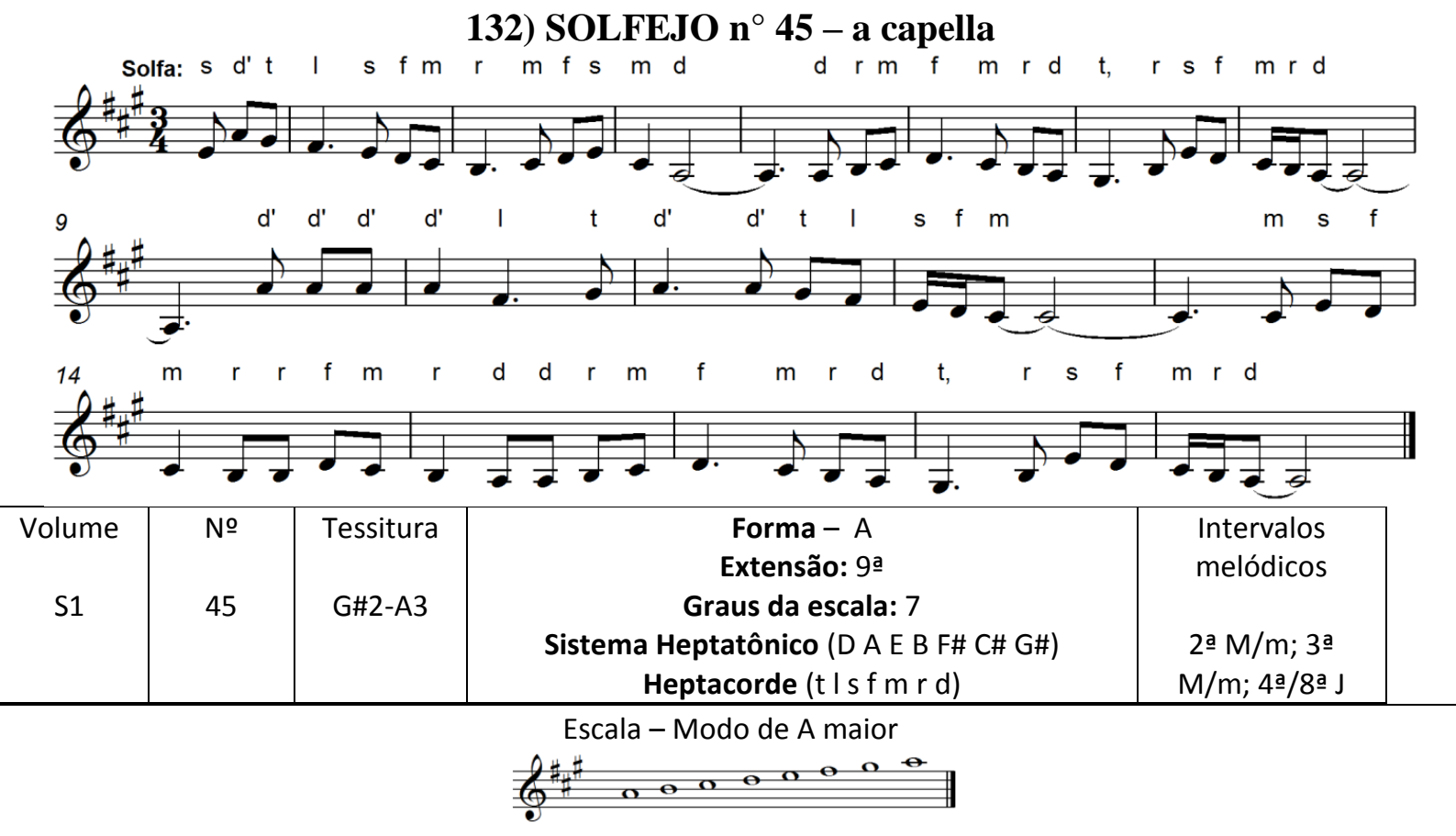

Sugestões de atividades didático-pedagógicas:

Células rítmicas para registro gráfico:

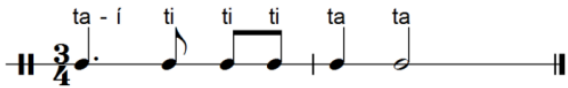

Células melódicas para registro gráfico:

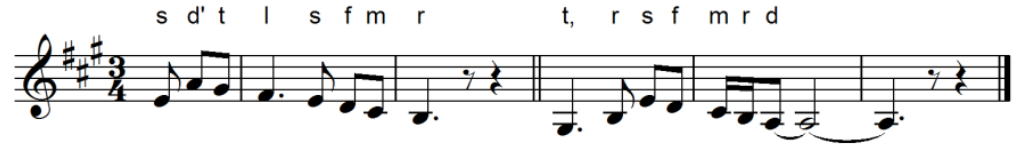

Possível ostinato rítmico:

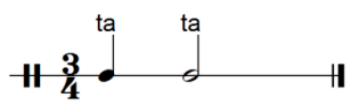

Tema de Villa-Lobos com 18 compassos ternários, com a indicação: Andantino; sem indicações de dinâmica.

Ritmo - o interesse rítmico está no compasso ternário, nas figuras pontuadas e nas apojaturas de terças cheias descendentes em semicolcheias. 
Melodia - pequenas curvas por graus conjuntos e pequenos intervalos, com finalizações em apojaturas descendentes de terças cheias. Início em plano mais agudo, com o final na $\mathrm{T}$, oitava abaixo.

Ludicidade - solfejo com características de valsa, que pode ser dançado durante sua execução.

\section{3) FELIZ ANIVERSÁRIO - a capella}

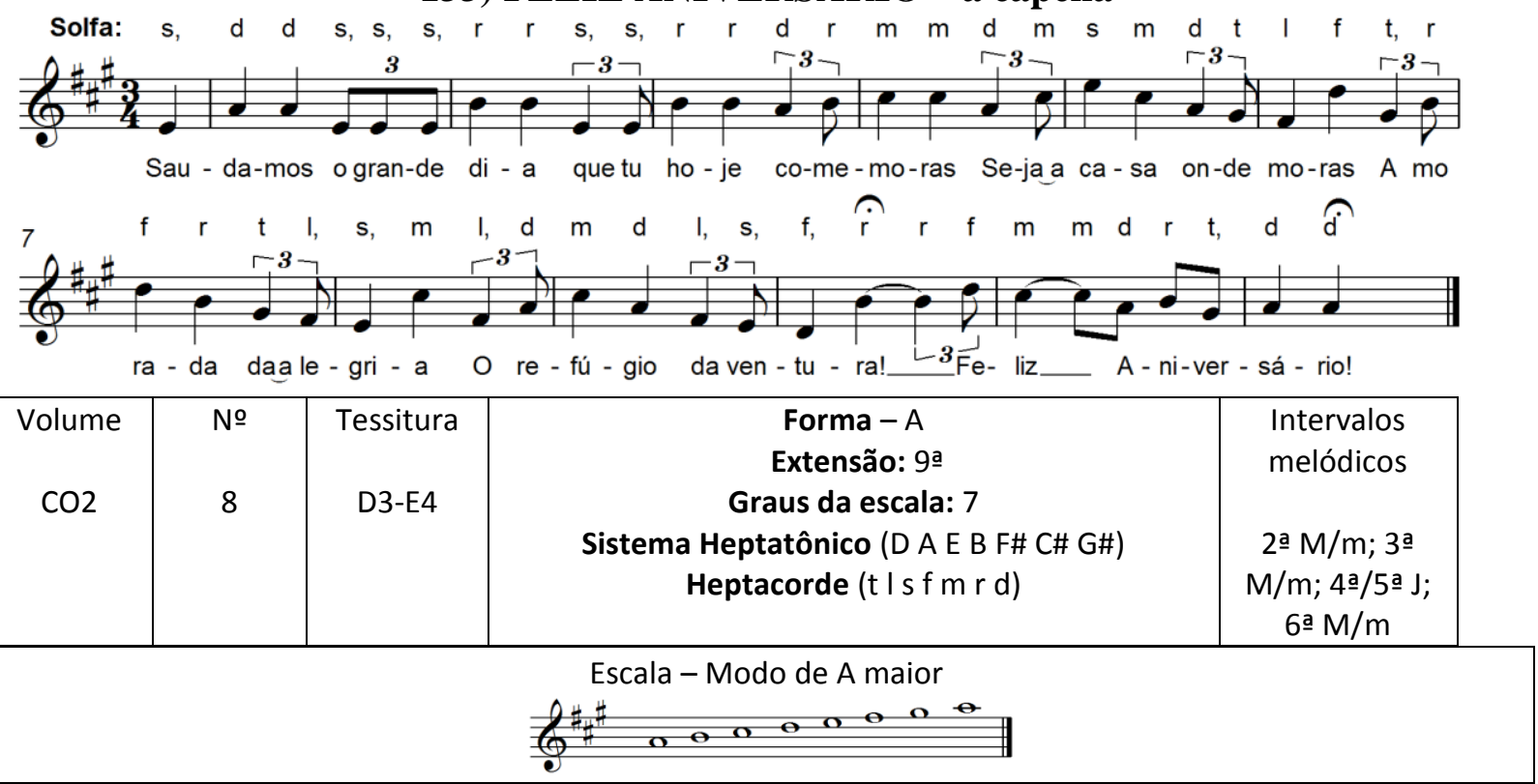

Sugestões de atividades didático-pedagógicas:

Células rítmicas para registro gráfico:

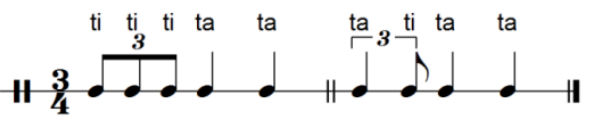

Células melódicas para registro gráfico:

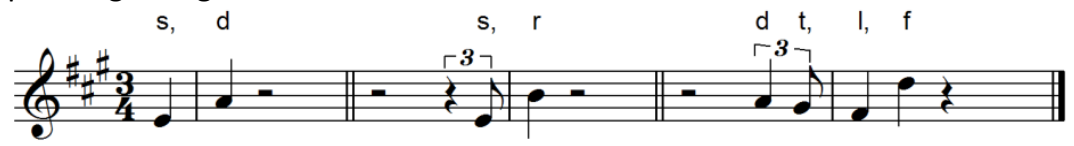

Possivel ostinato rítmico:

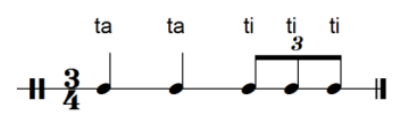

Análise complementar em 2.2 - $n^{\circ} 130$.

Canção com 13 compassos ternários, com a indicação: Pouco vagaroso e enérgico; allarg. ; sem indicações de dinâmica.

Tema - canção de cordialidade, com letra de Manuel Bandeira e música e harmonização de H.Villa-Lobos, datada de 1945 - Rio de Janeiro.

Texto - cinco versos de sete sílabas e o sexto de seis sílabas. Nos quatro primeiros versos, o primeiro rima com o quarto, o segundo com o terceiro e encerra com os dois últimos não rimados. Uma saudação pelo dia especial (versos 1 e 2) e a expressão do desejo de um futuro de felicidade (do 3 ao 6). Texto bem construído com prosódia perfeitamente adequada à música. 
Ritmo - o interesse rítmico está na subdivisão ternária de toda a peça, em contraste com os dois últimos compassos em subdivisão binária.

Melodia - caracteriza-se pela sequência de saltos de quarta, quinta e sexta, e de tríades arpejadas. Terminação na $\mathrm{T}$ por terças quebradas descendentes.

Ludicidade - canção própria para homenagens e ambientes festivos.

\section{4) SOLFEJO no 65 - a capella}
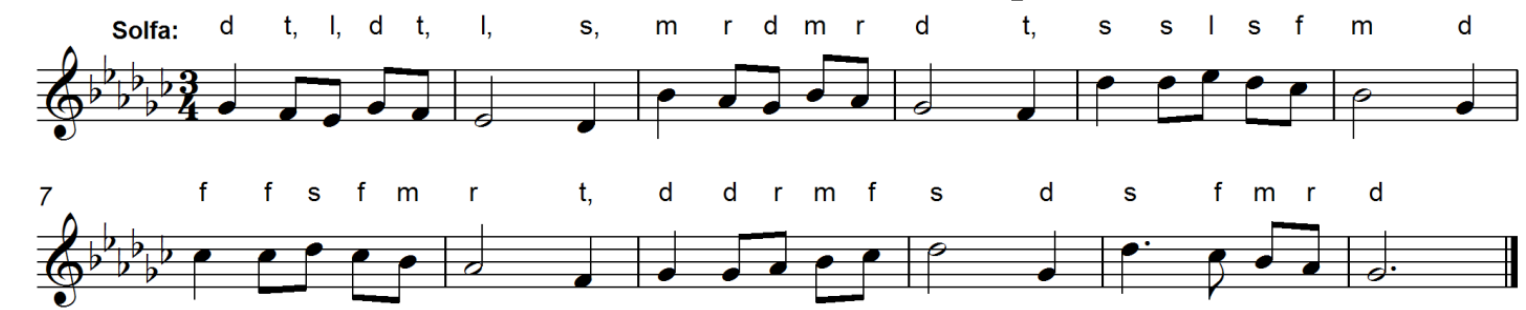

\begin{tabular}{|c|c|c|c|c|}
\hline $\begin{array}{l}\text { Volume } \\
\text { S1 }\end{array}$ & $\begin{array}{l}\text { № } \\
65\end{array}$ & $\begin{array}{l}\text { Tessitura } \\
\text { Db3-Eb4 }\end{array}$ & $\begin{array}{c}\text { Forma - A } \\
\text { Extensão: } 9 \underline{a} \\
\text { Graus da escala: } 7 \\
\text { Sistema Heptatônico (Cb Gb Db Ab Eb Bb F) } \\
\text { Heptacorde (t I s f m r d) }\end{array}$ & $\begin{array}{l}\text { Intervalos } \\
\text { melódicos } \\
\text { 2a } \mathrm{M} / \mathrm{m} ; 3 \text { a } \\
\mathrm{M} / \mathrm{m} ; 4 \text { a } / 5 \text { a j; } \\
\text { 6a } \mathrm{M} / \mathrm{m}\end{array}$ \\
\hline & & & 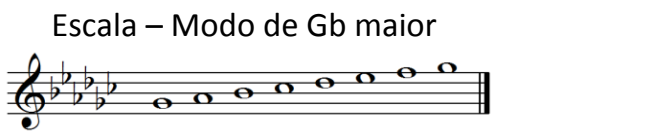 & \\
\hline
\end{tabular}

Sugestões de atividades didático-pedagógicas:

Células rítmicas para registro gráfico:

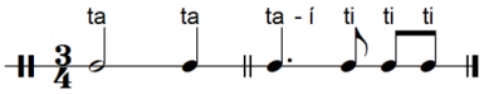

Células melódicas para registro gráfico:

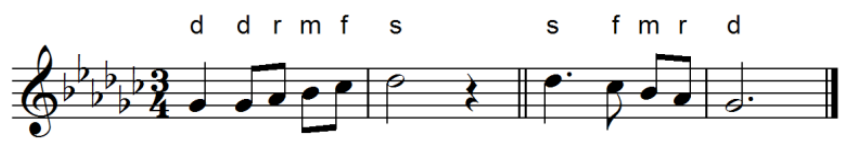

Possivel ostinato rítmico:

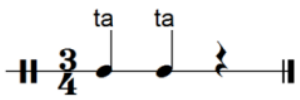

Possivel ostinato melódico:

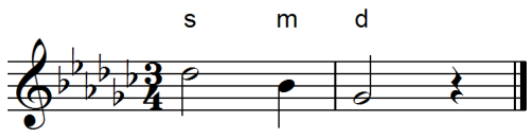

Tema de Villa-Lobos com 12 compassos ternários, com a indicação de andamento: Movimento de Mazurca; sem indicações de dinâmica.

Ritmo - o interesse rítmico está no compasso ternário e no movimento de mazurca.

Melodia - desenhos em âmbito de $4^{\mathrm{a}}$ quartas e $5^{\mathrm{a}}$ quintas com apojaturas, iniciadas nas notas da tríade da T na primeira frase, na segunda, respectivamente $4^{\circ}, 1^{\circ}$ e $5^{\circ}$ graus, em sequências ascendentes por $3^{\mathrm{a}}$, com linha descendente / ascendente / descendente por pentacordes em direção à $T$. 
Ludicidade - apesar de se tratar de um solfejo, sendo em tempo de mazurca, pode-se acrescentar uma coreografia.

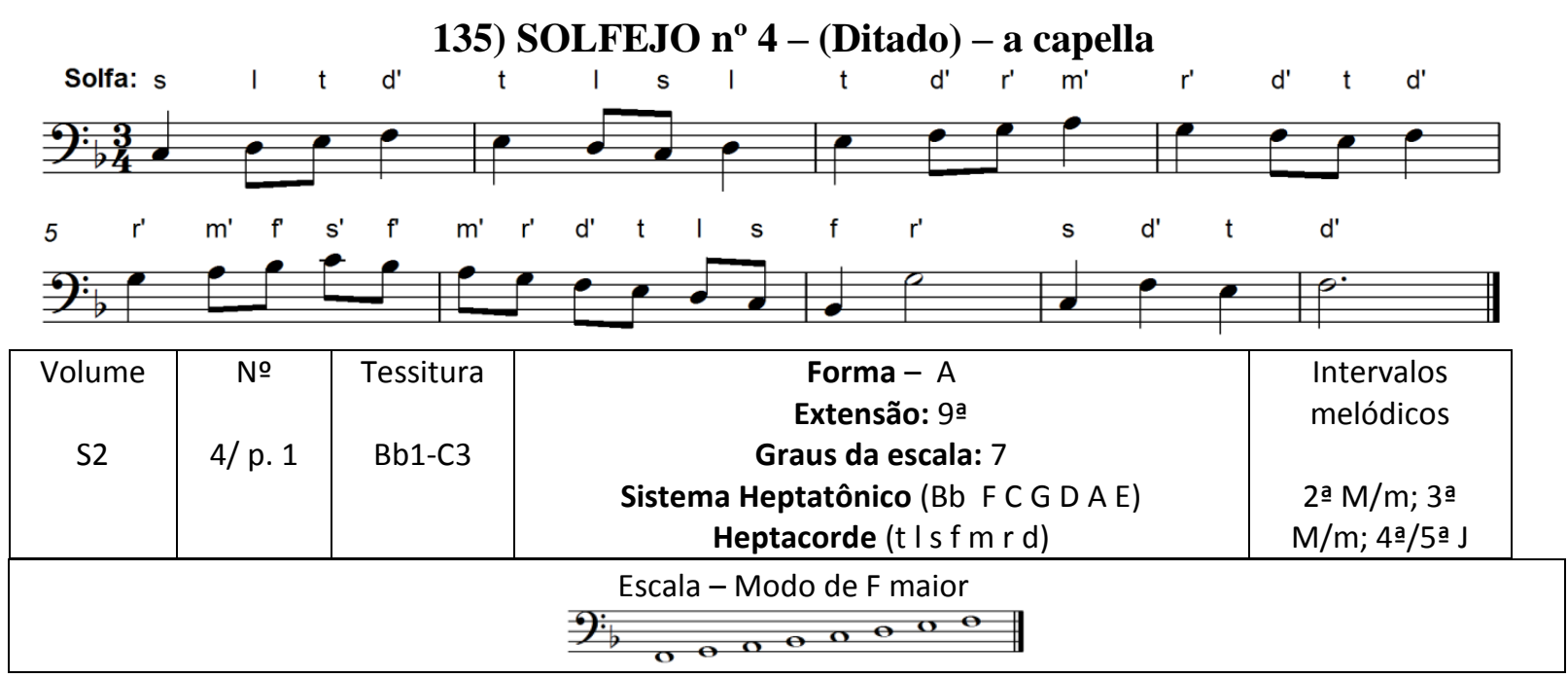

Sugestões de atividades didático-pedagógicas:

Células rítmicas para registro gráfico:

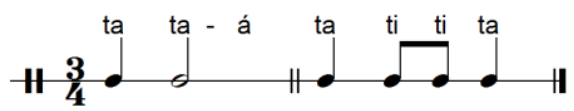

Células melódicas para registro gráfico:

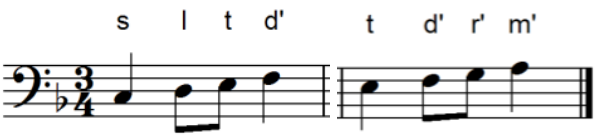

Possivel ostinato rítmico: ta i ti titi

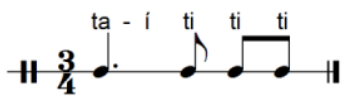

Tema de Villa-Lobos com 9 compassos ternários, com a indicação de andamento: Allegro; sem indicações de dinâmica.

Ritmo - o interesse rítmico está na primeira célula rítmica, que se repete nos quatro primeiros compassos.

Melodia - iniciada por linha em curva sobre tetracorde a partir do $1^{\circ}$ grau, repetido a partir do $3^{\circ}$ e $5^{\circ}$ graus da $\mathrm{D}$, seguida de linha escalar descendente para a $\mathrm{S}$ e finalização $\mathrm{D} \mathrm{T}$. Registro grave para voz masculina em clave de $\mathrm{F}$.

Ludicidade - apesar de se tratar de um solfejo, os desafios lúdicos estão na leitura em clave de F e possíveis jogos de re-ordenação dos tetracordes.

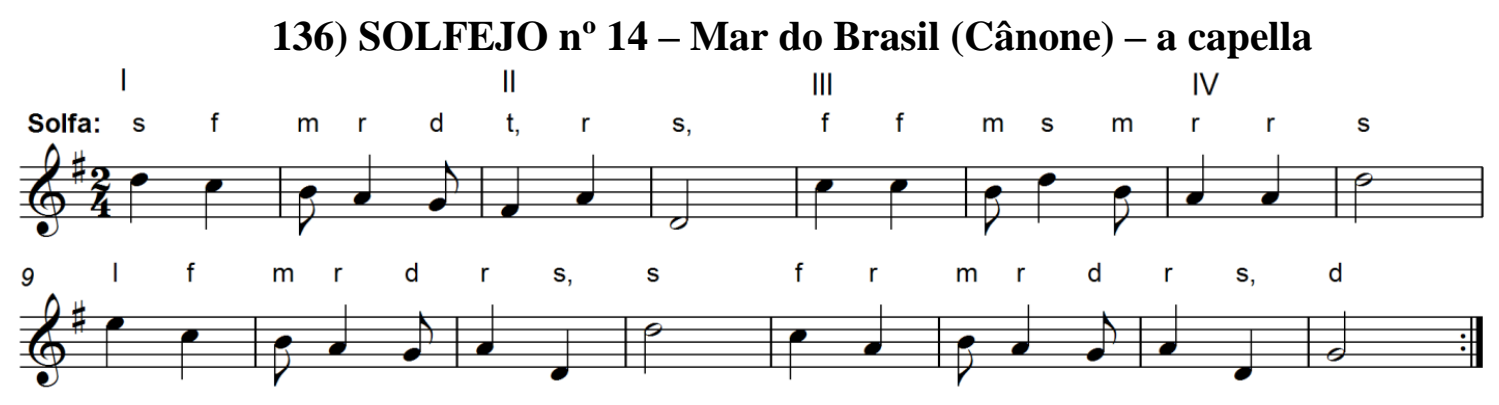




\begin{tabular}{|c|c|c|c|c|}
\hline Volume & No & Tessitura & $\begin{array}{c}\text { Forma - A } \\
\text { Extensão: 9a } \\
\text { S2 }\end{array}$ & Graus da escala: 7 \\
\end{tabular}

\section{Sugestões de atividades didático-pedagógicas:}

Células rítmicas para registro gráfico:

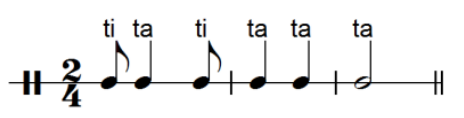

Células melódicas para registro gráfico:

Possivel ostinato rítmico:
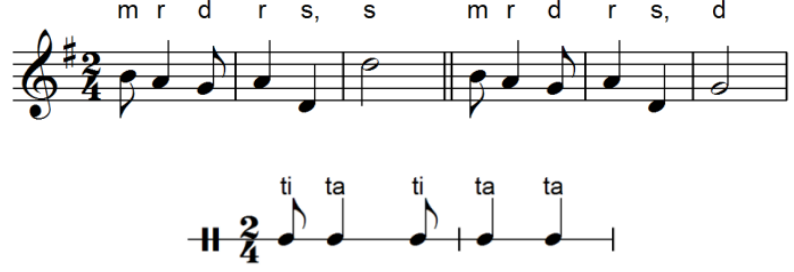

Outras possibilidades: cânone a uma, duas, três ou quatro vozes

Tema de Villa-Lobos de inspiração popular, com 16 compassos binários, com a indicação de andamento: Marcial; sem indicações de dinâmica.

Ritmo - o interesse rítmico está nas síncopas métricas e na forma de cânone exato.

Melodia - o primeiro motivo, em linha descendente é variado quatro vezes, com conclusões do motivo seguinte três vezes no $5^{\circ}$ grau e na quarta vez no $1^{\circ}$ grau.

Ludicidade - apesar de se tratar de um solfejo, sendo em forma de cânone, sua realização constitui em desafio lúdico.

\section{7) SOLFEJO no 63 - a capella}
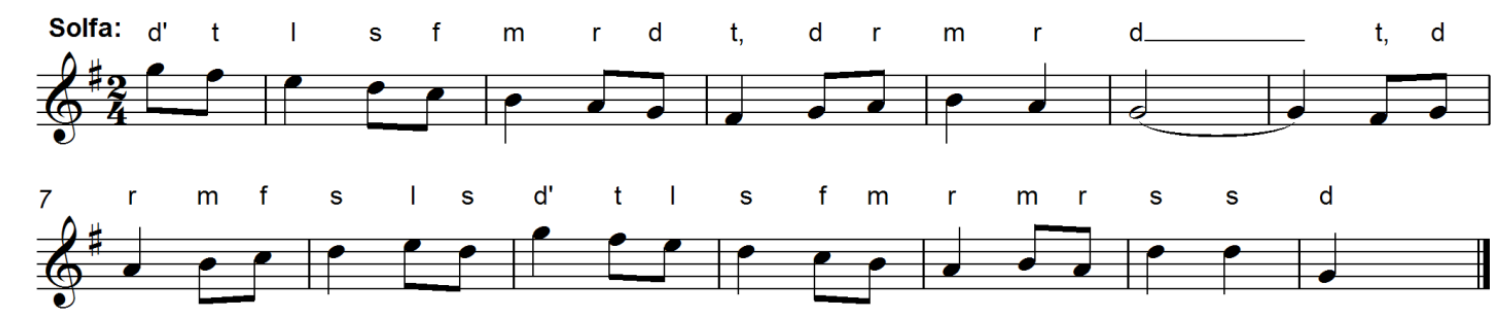

\begin{tabular}{|c|c|c|c|c|}
\hline $\begin{array}{c}\text { Volume } \\
\text { S1 }\end{array}$ & $\begin{array}{l}\text { № } \\
63\end{array}$ & $\begin{array}{l}\text { Tessitura } \\
\text { F\#3-G4 }\end{array}$ & $\begin{array}{c}\text { Forma - A } \\
\text { Extensão: 9a } \\
\text { Graus da escala: } 7 \\
\text { Sistema Heptatônico (C G D A E B F\#) } \\
\text { Heptacorde (t I s f m r d) }\end{array}$ & $\begin{array}{l}\text { Intervalos } \\
\text { melódicos } \\
\text { 2- } \mathrm{M} / \mathrm{m} ; 4 \underline{a} / 5 \underline{a}\end{array}$ \\
\hline \multicolumn{5}{|c|}{$\begin{array}{l}\text { Escala - Modo de G maior } \\
\end{array}$} \\
\hline
\end{tabular}

Sugestões de atividades didático-pedagógicas:

Células rítmicas para registro gráfico:

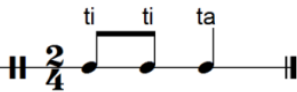


Células melódicas para registro gráfico:

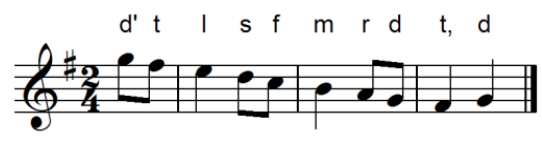

Possivel ostinato rítmico:

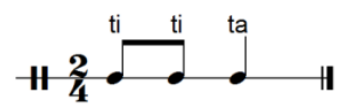

Tema de Villa-Lobos com 14 compassos binários, com a indicação de andamento: Allegretto; sem indicações de dinâmica.

Ritmo - o interesse rítmico está no pulso e subdivisão.

Melodia - em região aguda, linha escalar descendente até a sensível e terminação na T com $3^{\mathrm{a}}$ cheia ascendente e descendente; desenho escalar incompleto ascendente e descendente para a $\mathrm{T}$, com terminação com salto descendente de $5^{\mathrm{a}}$.

Ludicidade - apesar de se tratar de um solfejo, propostas como transposição de tonalidade para outras alturas, ou transformação para outros modos, podem ser desafios lúdicos.

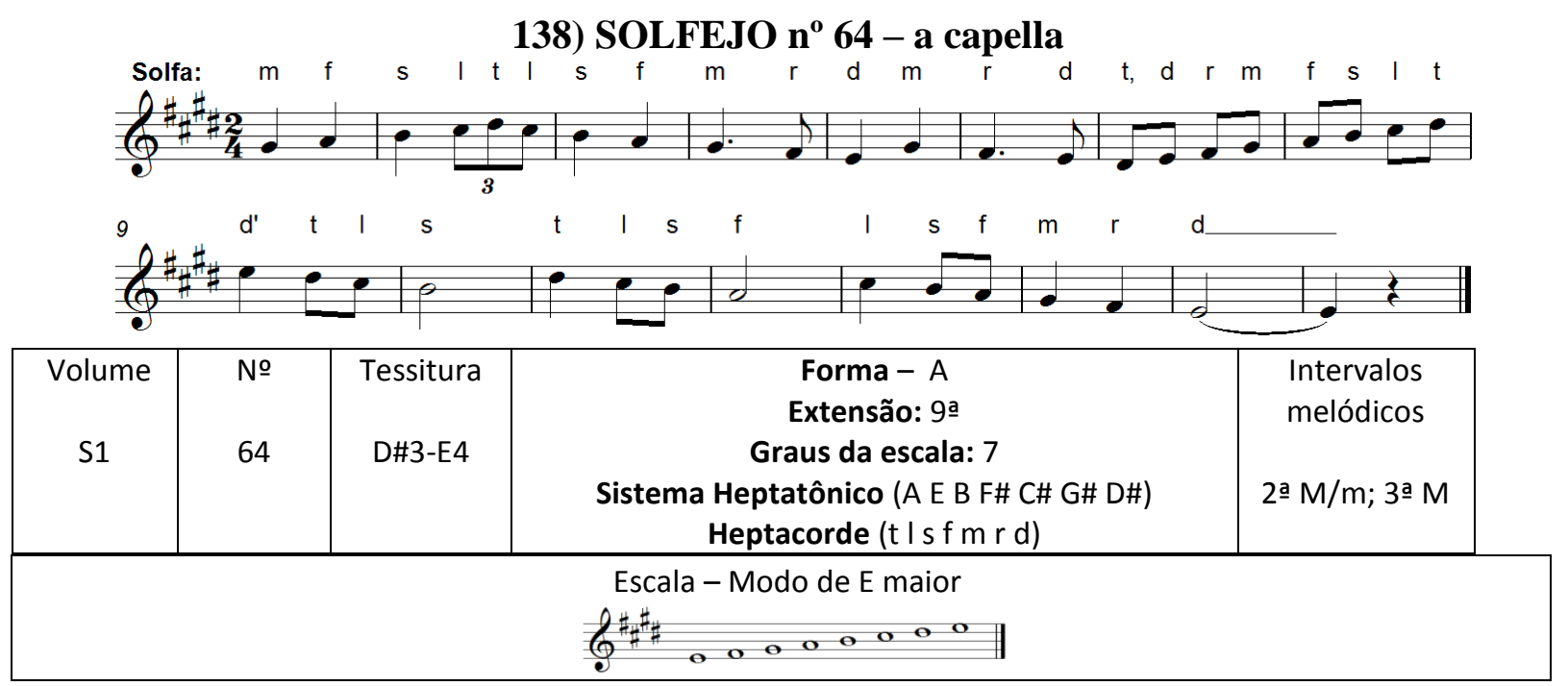

Sugestões de atividades didático-pedagógicas:

Células rítmicas para registro gráfico:

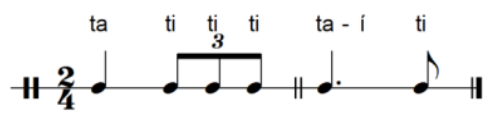

Células melódicas para registro gráfico:

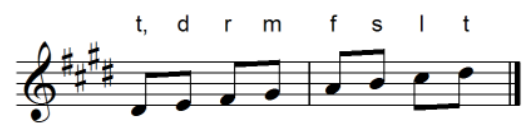

Possível ostinato rítmico:

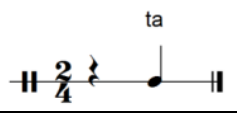

Tema de Villa-Lobos com 16 compassos binários, com a indicação de andamento: Andante; sem indicações de dinâmica.

Ritmo - o interesse rítmico está na tercina. 
Melodia - curva inicial por linha escalar ascendente/descendente até a $\mathrm{T}$, seguida de nova linha escalar ascendente completa, finalizando em desenho descendente por tetracordes em sequência por grau conjunto com terminação em hexacorde na $\mathrm{T}$.

Ludicidade - apesar de se tratar de um solfejo, a inversão da melodia por espelho, por exemplo, pode ser um desafio lúdico.

139) ROSA AMARELA ( $2^{\mathrm{a}}$ versão) - acompanhamento instrumental

(Canto com piano ou conjunto instrumental)

Arr. de H.Villa-Lobos
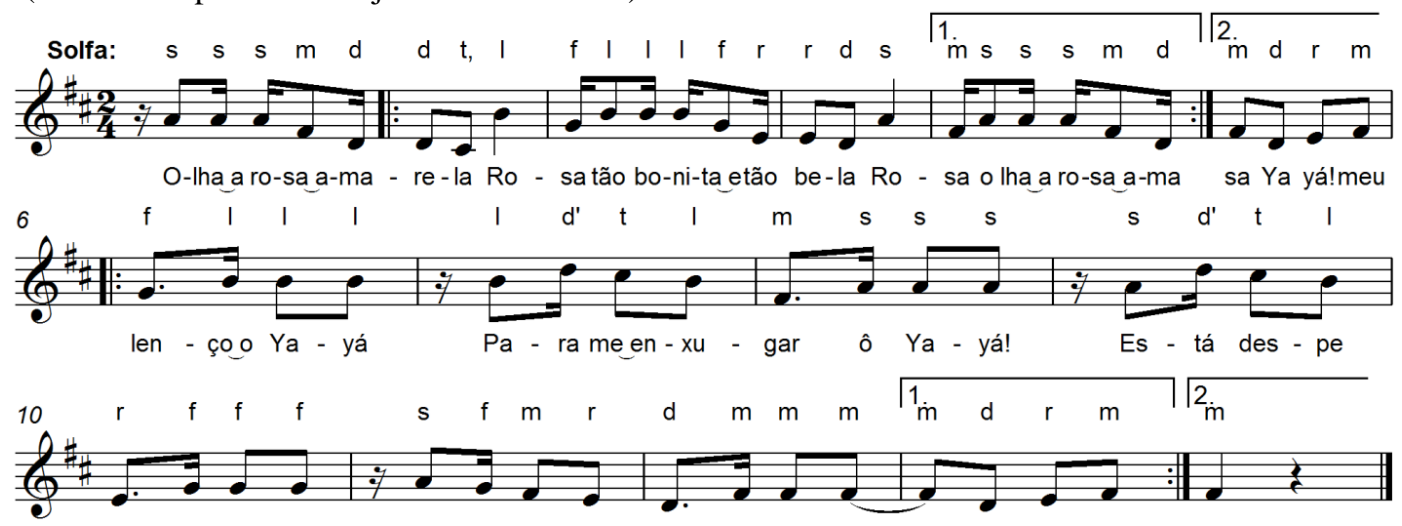

di - då Ya - yá Já me faz cho - rar o Ya - yá__ Ya - yá meu á

\begin{tabular}{|c|c|c|c|c|}
\hline $\begin{array}{l}\text { Volume } \\
\text { GP-VTL } \\
\text { /ABM }\end{array}$ & $\begin{array}{l}\text { № } \\
109 \\
\text { /120 }\end{array}$ & $\begin{array}{l}\text { Tessitura } \\
\text { C\#3-D4 }\end{array}$ & $\begin{array}{c}\text { Forma - A } \\
\text { Gênero - Coco canção } \\
\text { Extensão: 9ạ } \\
\text { Graus da escala: } 7 \\
\text { Sistema Heptatônico (G D A E B F\# C\#) } \\
\text { Heptacorde ( } \mathrm{t} \text { | s f m r d) }\end{array}$ & $\begin{array}{c}\text { Intervalos } \\
\text { melódicos } \\
\text { 2a } \mathrm{M} / \mathrm{m} ; 3 \text { a } \mathrm{M} / \mathrm{m} \text {; } \\
\text { 7a } \mathrm{m}\end{array}$ \\
\hline & & & 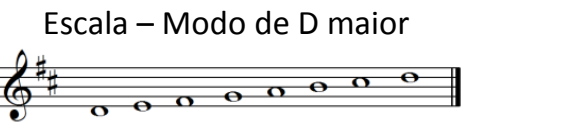 & \\
\hline
\end{tabular}

Sugestões de atividades didático-pedagógicas:

Células rítmicas para registro gráfico:

Células melódicas para registro gráfico:
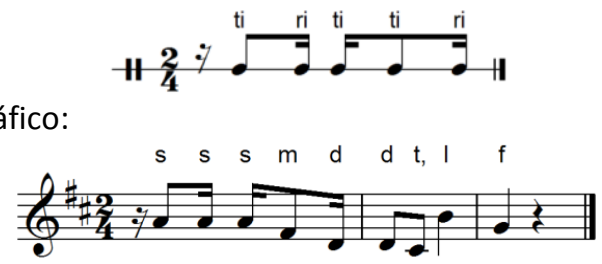

Possivel ostinato rítmico:

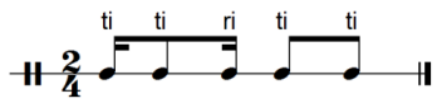

Canção com 15 compassos binários, com a indicação de andamento: Poco Moderato (M.M. $120=$ ل ); rall.; indicações de dinâmica: $p$; $\langle$; > ; sfz; acentos $>$

Tema popular, folclórico infantil, de brincadeira cantada cujo desenvolvimento baseia-se no texto.

Texto - Descrição de brincadeira de roda, em que a rosa amarela é a personagem principal e Yayá a segunda personagem.

Ritmo - o interesse rítmico está nas síncopas iniciadas com pausa.

Melodia - linha descendente por arpejo da tríade de T, salto ascendente e resolução por salto descendente (DT); na segunda frase, desenho ascendente por grau conjunto e salto, seguido de 
sequência descendente por grau conjunto (duas vezes) e conclusão na $\mathrm{T}$ por pentacorde descendente.

Ludicidade - brincadeira de roda em que a Rosa Amarela fica no meio da roda, chama Yayá (que será a próxima Rosa Amarela) para emprestar-lhe o lenço e despede-se, entregando-o a outra criança, que será a próxima Yayá.

140) SOLFEJO $n^{\circ} 56$ - a capella

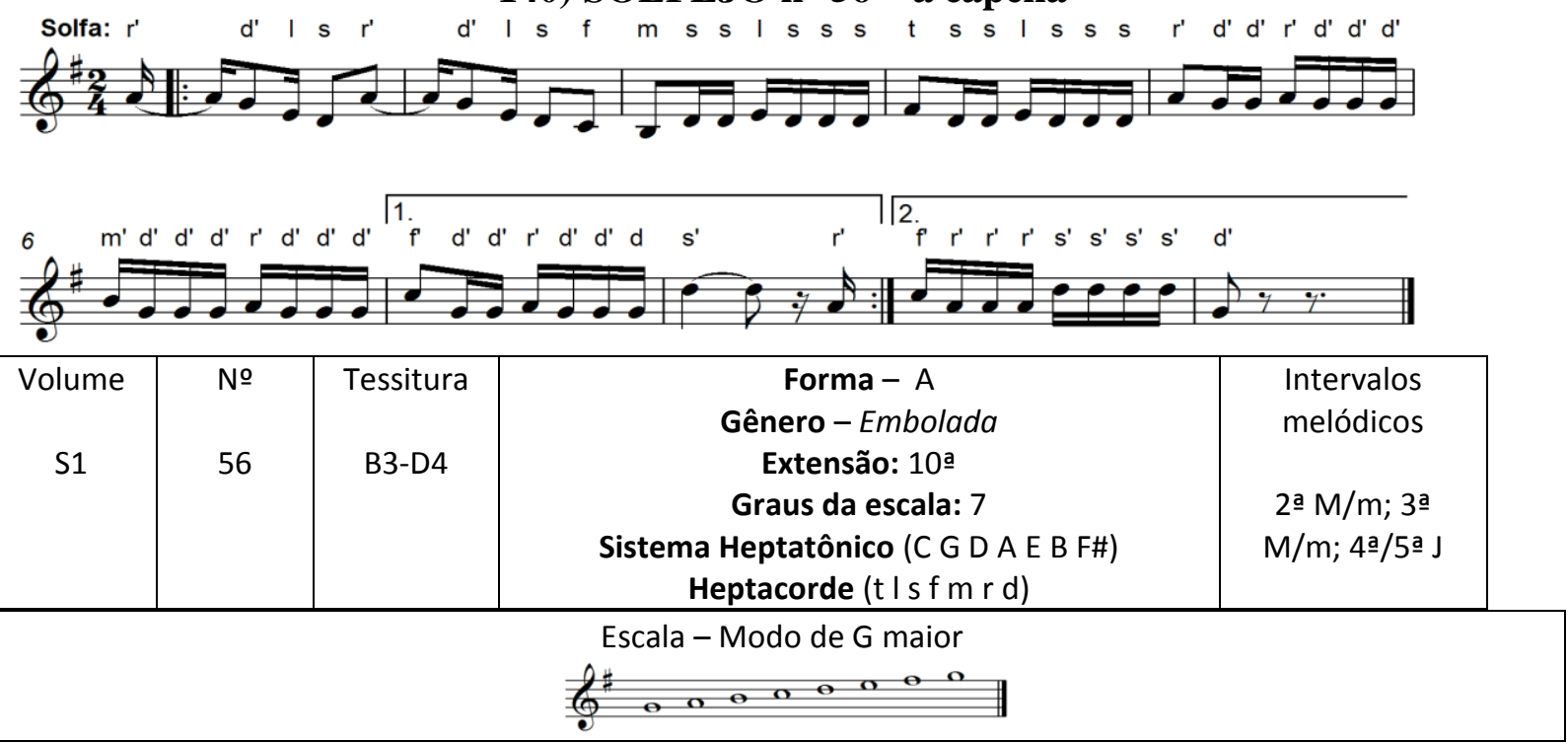

Sugestões de atividades didático-pedagógicas:

Células rítmicas para registro gráfico:

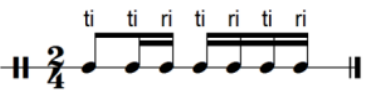

Células melódicas para registro gráfico:

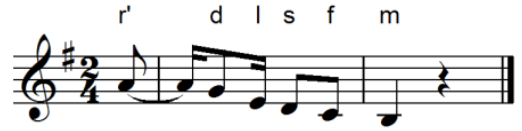

Possível ostinato rítmico:

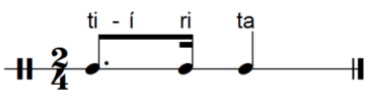

Tema de Villa-Lobos com 11 compassos binários, com a indicação de andamento: Moderato (Embolada); sem indicações de dinâmica.

Ritmo - o interesse rítmico está nas síncopas com notas ligadas.

Melodia - após dois desenhos descendentes em ritmo sincopado, o restante da peça é desenvolvido em notas rebatidas, característica do gênero embolada.

Ludicidade - o solfejo é próprio para a criação de textos para uma embolada, que, por suas características humorísticas, é sempre lúdica.

141) SOLFEJO $n^{\circ} 42$ - a capella

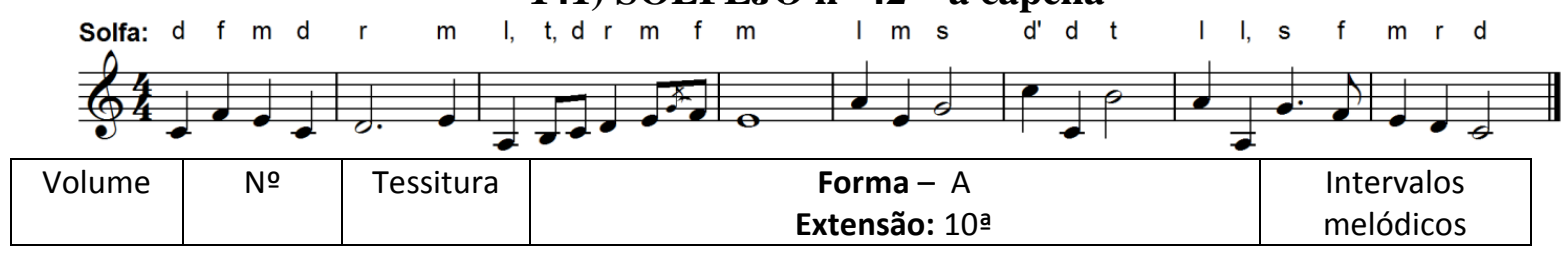




\begin{tabular}{|c|c|c|c|c|}
\hline S1 & 42 & A2-C4 & $\begin{array}{c}\text { Graus da escala: 7 } \\
\text { Sistema Meptatônico (F C G D A E B) } \\
\text { Heptacorde (t I s f m r d) }\end{array}$ & $\begin{array}{c}\text { M/m; 4a } / 5 \text { a } / 8 \text { a } \\
\text { J;7a M/m }\end{array}$ \\
\hline & \begin{tabular}{c} 
Escala - Modo de C maior \\
\hline
\end{tabular} \\
\hline
\end{tabular}

Sugestões de atividades didático-pedagógicas:

Células rítmicas para registro gráfico:

H 4

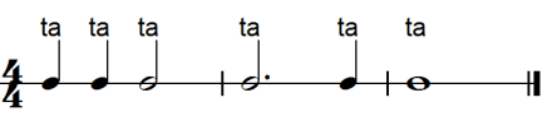

Células melódicas para registro gráfico:

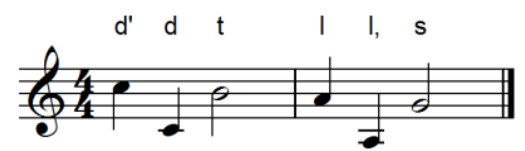

Possível ostinato rítmico: ta ta ta - a

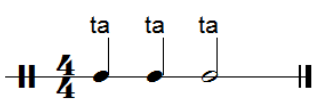

Tema de Villa-Lobos com 8 compassos quaternários, sem indicação de andamento ou dinâmica.

Ritmo - o interesse rítmico está nas notas longas.

Melodia - na primeira frase a configuração baseia-se em graus conjuntos e saltos até a quinta, com linha escalar ascendente de hexacorde. A segunda frase apresenta saltos de sétima maior e menor, com terminação em linha escalar do $5^{\circ}$ grau para a $\mathrm{T}$.

Ludicidade - o solfejo é próprio para a aquisição de intervalos de sétima, para o que devem ser criados jogos de fixação das relações intervalares, tanto para a percepção como para a entoação - por exemplo, associar trechos de canções conhecidas que contenham esses intervalos, utilizar instrumentos para realizar ostinatos baseados nos mesmos, e outras possibilidades.

\section{2) A POMBINHA VOOU - acompanhamento instrumental}

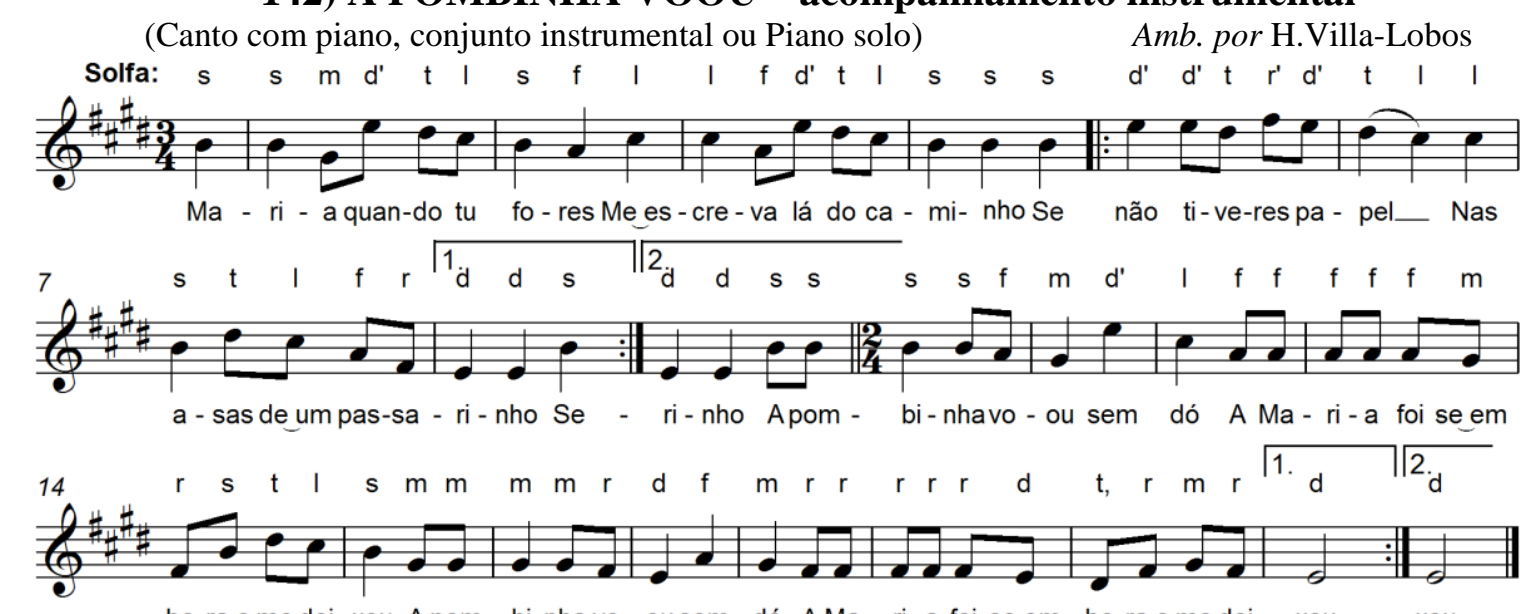

bo-ra e me dei-xou A pom bi-nhavo-ousem dó AMa - ri-a foi-se em - bo ra e me dei - xou

xou

\begin{tabular}{|c|c|c|c|c|}
\hline Volume & № & Tessitura & $\begin{array}{c}\text { Forma - A } \\
\text { Gênero - Canção }\end{array}$ & $\begin{array}{l}\text { Intervalos } \\
\text { melódicos }\end{array}$ \\
\hline GP-VTL & 103 & D\#3-F\#4 & Extensão: 10ạ & \\
\hline /ABM & /101 & & $\begin{array}{c}\text { Graus da escala: } 7 \\
\text { Sistema Heptatônico (A E B F\# C\# G\# D\#) }\end{array}$ & 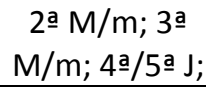 \\
\hline
\end{tabular}




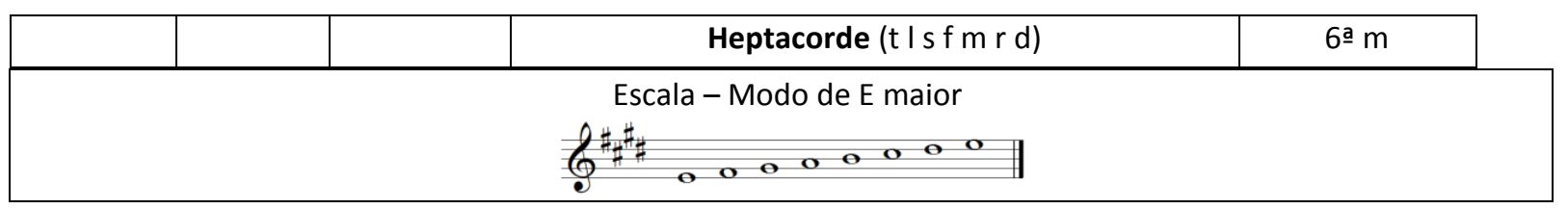

Sugestões de atividades didático-pedagógicas:

Células rítmicas para registro gráfico:

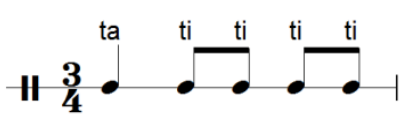

Células melódicas para registro gráfico:

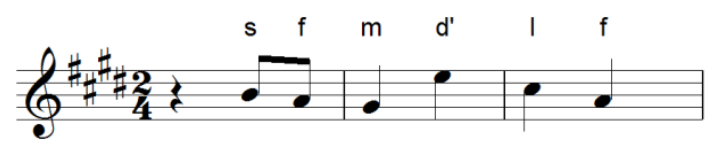

Possivel ostinato rítmico:

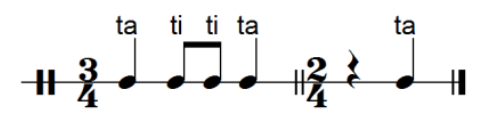

Canção com 10 compassos ternários e 12 binários, com a indicação de andamento: Andante $(96=$ 」) ); rall.; indicações de dinâmica: pp ; murmurando ;ff

Tema popular, folclórico infantil, de brincadeira cantada cujo desenvolvimento baseia-se no texto.

Texto - quadrinhas com temática sobre carta ao namorado, encontradas com muitas variantes nas diversas regiões do país.

Ritmo - o interesse rítmico está na mudança de compasso ternário para binário.

Melodia - primeira parte - desenhos sobre arpejos de T (com terminação na S) e de D (com terminação descendente na T); segunda parte - idem, com sequência em terça abaixo entre as duas frases.

Acompanhamento instrumental (piano) - introdução sobre um acorde de $\mathrm{T}^{5}{ }^{6}$. Melodia dobrada pela mão direita, com acompanhamento harmônico distribuído para as duas mãos. Coda sobre acorde de $\mathrm{T}$ no registro agudo.

Ludicidade - além da brincadeira de roda simples, valorizando mais o canto que os movimentos, outras propostas lúdicas podem ser feitas, como, por exemplo: cantar em cânone o refrão, superpondo as terças paralelas, ou, transformar o refrão em compasso ternário, dobrando o primeiro pulso em dois pulsos, e cantar como segunda voz da primeira parte.

Complemento do texto ${ }^{58}$ :

Maria, quando tu fores,/ me escreva lá do caminho;/ se não tiveres papel,/ nas asas de um passarinho.

Refrão: A pombinha voou sem dó! A Maria foi-se embora e me deixou.

Nas asas de um passarinho/ eu não posso escrever / as asas são de penas / com penas não escreverei.

Da boca faz um tinteiro / da língua pena dourada / dos dentes letra miúda / dos olhos carta fechada!

\footnotetext{
${ }^{58}$ GP/ABM - Mário de Andrade, Ensaio sobre a Música Brasileira.
} 
143) A CAXIAS (Cânone) - a capella

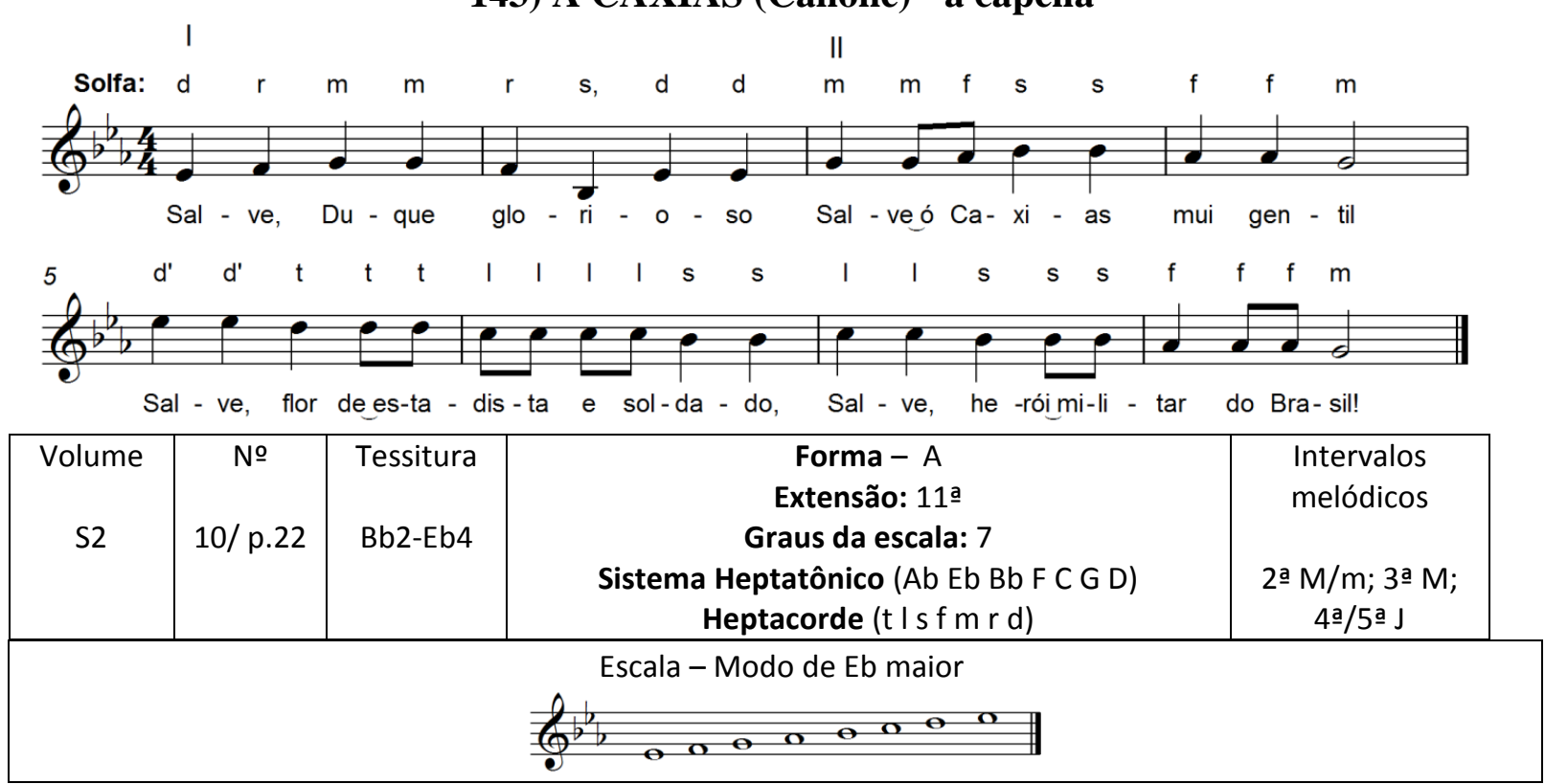

Sugestões de atividades didático-pedagógicas:

Células rítmicas para registro gráfico:

Células melódicas para registro gráfico:
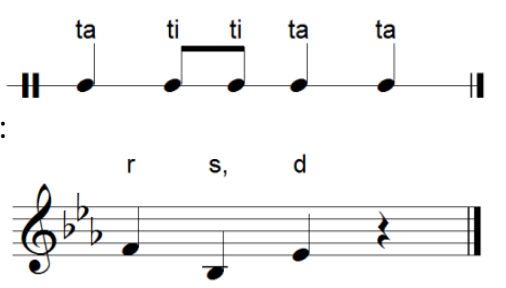

Possivel ostinato rítmico:

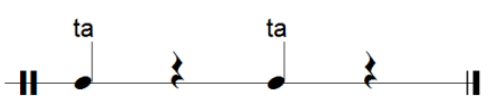

Outras possibilidades: cânone a duas vozes

Canção com 8 compassos quaternários, sem indicação de andamento ou de dinâmica.

Tema - música de H.Villa-Lobos sobre letra de D. Aquino Corrêa.

Texto - homenagem ao Duque de Caxias. Em que pese a necessidade de se perpetuar feitos e heróis da história do Brasil, os termos "gentil" e "flor" não se aplicam, atualmente, ao personagem em questão. Sugerimos a substituição de "mui gentil" por "varonil" e "flor de estadista e soldado" por "grande estadista e soldado".

Ritmo - o interesse rítmico está no compasso quaternário tético, com subdivisão binária, e a configuração de cânone exato.

Melodia - primeira frase com desenhos ascendentes por terças cheias e saltos, seguida de linha escalar descendente por tetracordes para a terça da $\mathrm{T}$.

Ludicidade - apesar de se tratar de um solfejo, sendo em forma de cânone, podem ser sugeridas atividades com movimentos corporais associados às entradas das vozes, podendo-se abrir mão do texto.

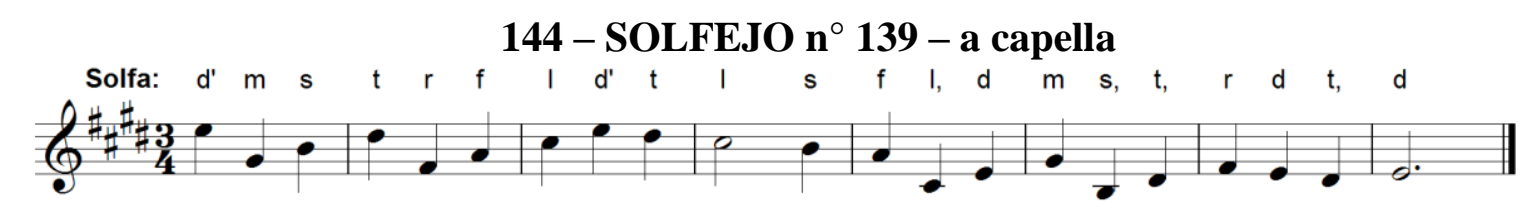




\begin{tabular}{|c|c|c|c|c|}
\hline $\begin{array}{l}\text { Volume } \\
\text { S1 }\end{array}$ & $\begin{array}{l}\text { № } \\
139\end{array}$ & $\begin{array}{l}\text { Tessitura } \\
\text { B2-E4 }\end{array}$ & $\begin{array}{c}\text { Forma - A } \\
\text { Extensão: 11ạ } \\
\text { Graus da escala: } 7 \\
\text { Sistema Heptatônico (A E B F\# C\# G\# D\#) } \\
\text { Heptacorde (t I s f m r d) }\end{array}$ & 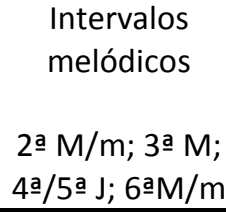 \\
\hline & & & 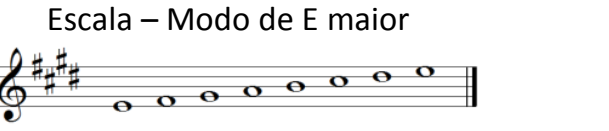 & \\
\hline
\end{tabular}

Sugestões de atividades didático-pedagógicas:

Células rítmicas para registro gráfico:

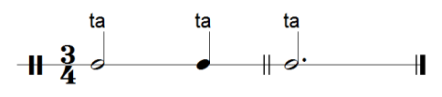

Células melódicas para registro gráfico:

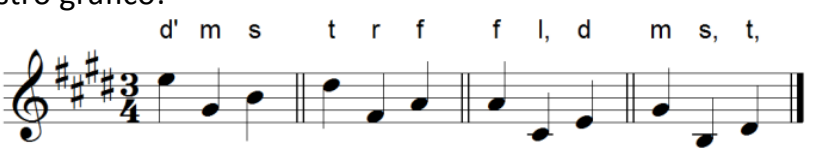

Possível ostinato rítmico:

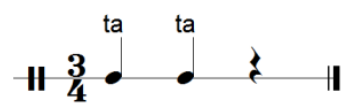

Tema de Villa-Lobos com 8 compassos ternários, com indicação de andamento Allegretto, sem indicação ou dinâmica.

Ritmo - o interesse rítmico está nas notas longas e no compasso ternário.

Melodia - Melodia baseada em arpejos de tríades invertidas em sequência descendente por grau conjunto, na primeira frase em plano agudo (tetracorde descendente do oitavo ao quinto grau) e na segunda frase com terminação na $T$ oitava abaixo (tetracorde descendente do quarto ao primeiro grau) por grupetto.

Ludicidade - o solfejo é próprio para a aquisição do conceito de tríades e suas inversões, e podem ser criados jogos como, por exemplo, 4 grupos diferentes podem entoar cada tríade de diversas maneiras - invertidas, diretas, arpejadas, harmônicas, bem como se podem trocar as tríades dos grupos, e outras propostas.

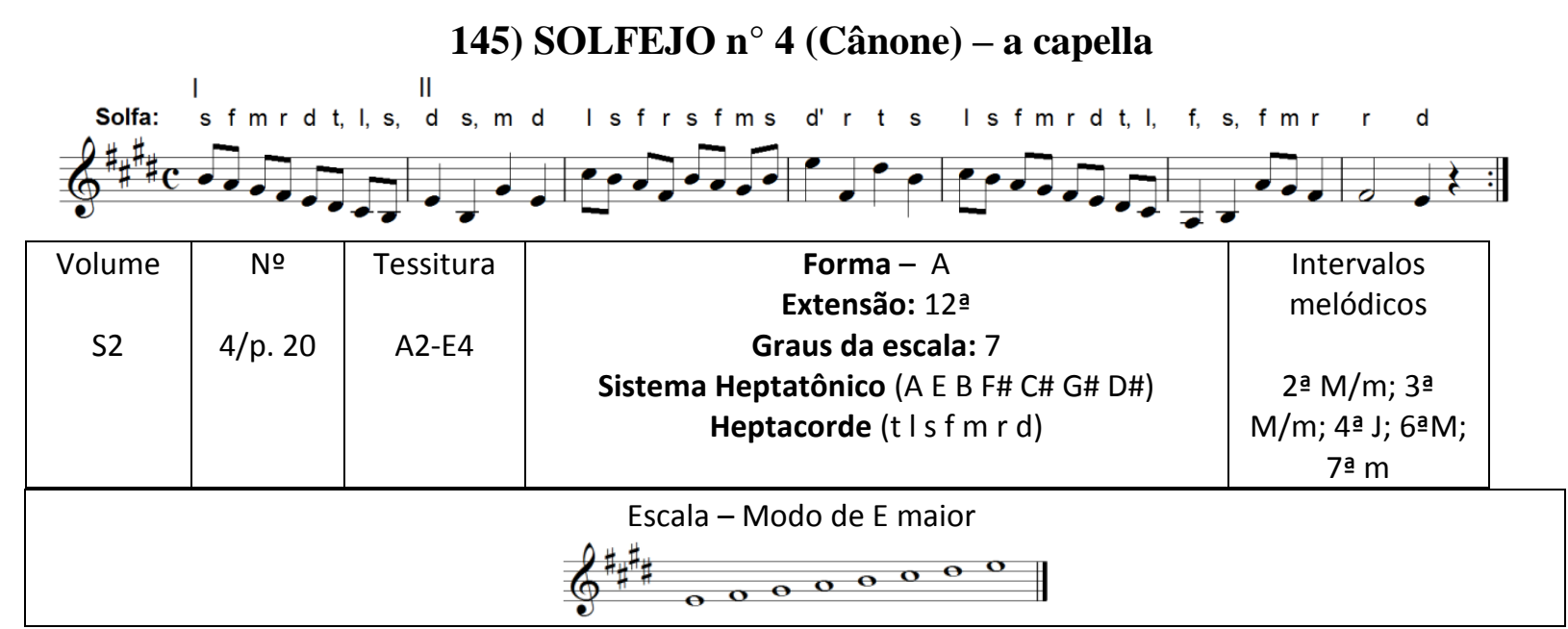

Sugestões de atividades didático-pedagógicas:

Células rítmicas para registro gráfico: 
Células melódicas para registro gráfico:

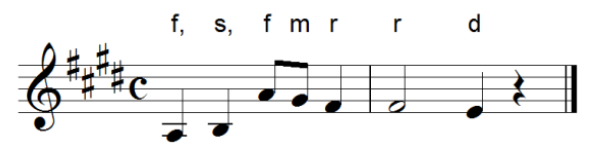

Possivel ostinato rítmico: ta íti ta íti

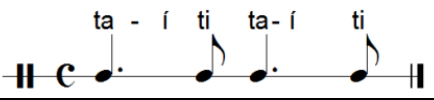

Tema de Villa-Lobos com 7 compassos quaternários, com a indicação de andamento: Allegro; sem indicações de dinâmica.

Ritmo - o interesse rítmico está no pulso e subdivisão.

Melodia - iniciada por linha descendente escalar seguida de saltos ascendentes e pequenas curvas em âmbito de quinta, saltos descendentes e ascendentes de sétima e sextas seguidos de nova linha escalar descendente para a $\mathrm{S}$ e finalização $\mathrm{D} / \mathrm{T}$ com salto ascendente de sétima e finalização por grau conjunto descendente por apojatura.

Ludicidade - apesar de se tratar de um solfejo, sendo em forma de cânone, sua realização é um desafio lúdico.

\subsubsection{Melodias e canções com alterações}

\subsubsection{Sobre cinco graus da escala e alteracões}

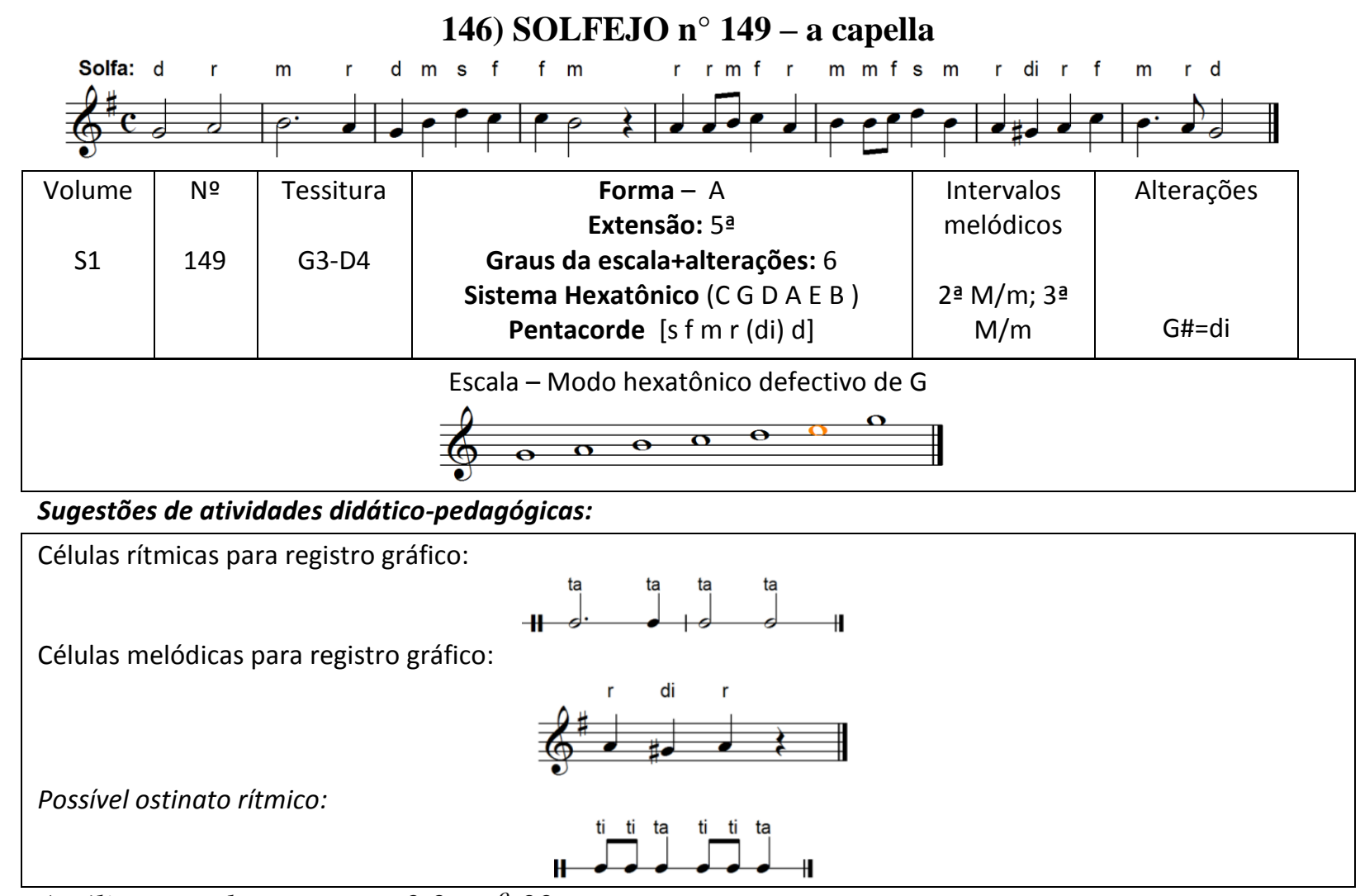

Análise complementar em $2.2-n^{\circ} 99$. 
Tema de Villa-Lobos com 8 compassos quaternários, com a indicação de andamento: Allegretto; sem indicações de dinâmica.

Ritmo - o interesse rítmico está no pulso e subdivisão.

Melodia - em pentacorde da T, com terminações na $\mathrm{T}$ em ambas as frases, com alteração em bordadura inferior no compasso 7 . Cromatismo ornamental.

Ludicidade - apesar de se tratar de um solfejo, a proposta de leitura rítmica a duas vozes, acoplando-se as frases, ou a leitura retrogradada, podem ser desafios lúdicos.

\section{7) SOLFEJO ${ }^{\circ} 7$ (Ditado) - a capella}

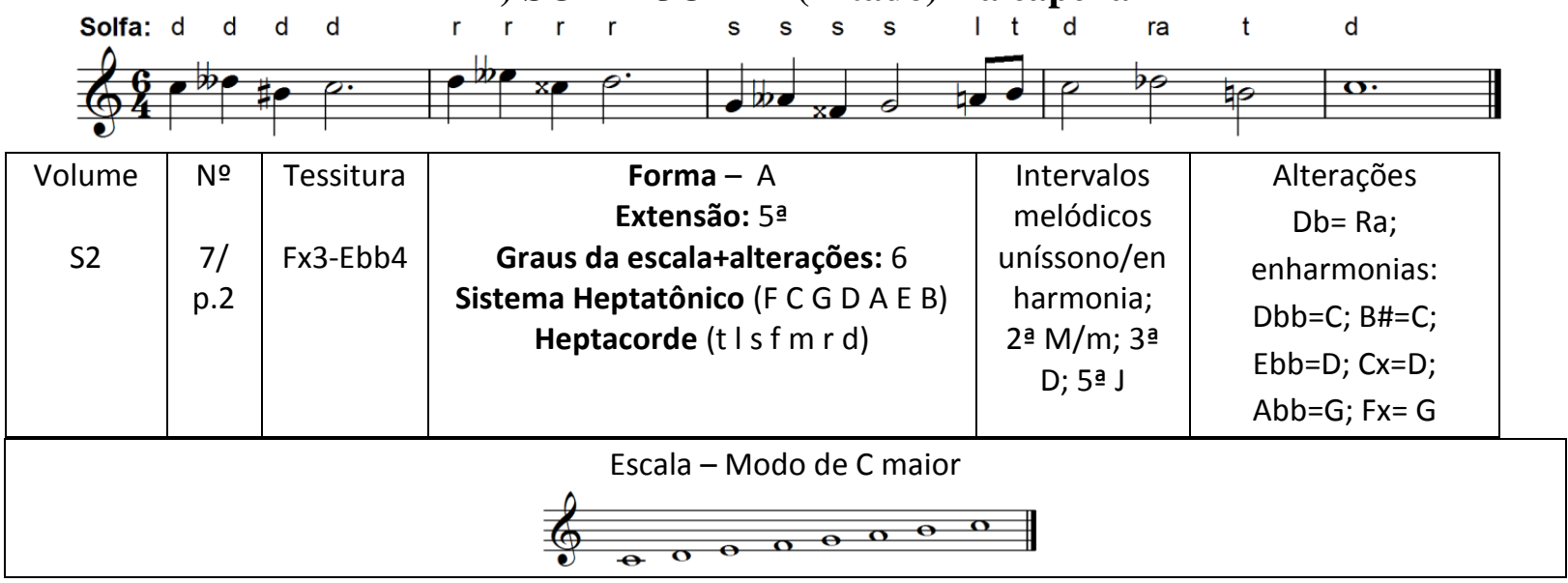

Sugestões de atividades didático-pedagógicas:

Células rítmicas para registro gráfico:

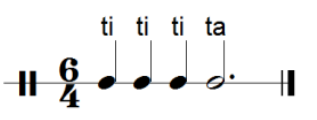

Células melódicas para registro gráfico:

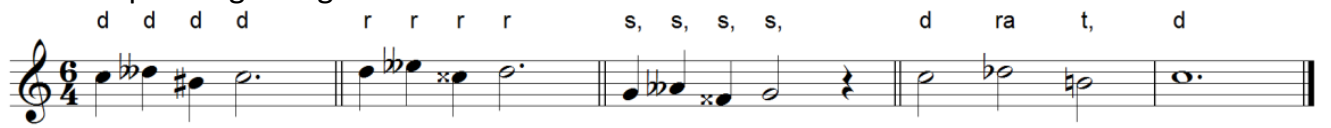

Possivel ostinato rítmico:

Possível ostinato melódico:
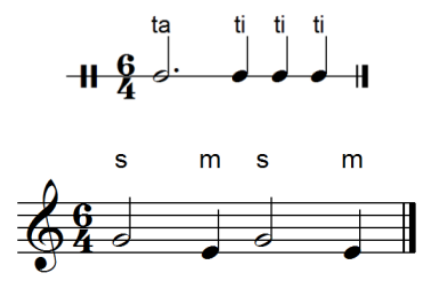

Tema de Villa-Lobos com 5 compassos binários com subdivisão ternária, com a indicação de andamento: Allegro; sem indicações de dinâmica.

Ritmo - o interesse rítmico está no compasso de subdivisão ternária e na polirritmia do penúltimo compasso.

Melodia - seqüência ascendente por grau conjunto e descendente por quinta abaixo de desenho com enharmonias com final cromático em torno da T.

Ludicidade - apesar de se tratar de um solfejo, sua leitura é um desafio lúdico pela enharmonia proposta. 


\subsubsection{Sobre seis graus da escala e alteracões}

148) VAMOS, MANINHA ( $2^{\mathrm{a}}$ versão $)$ - a capella

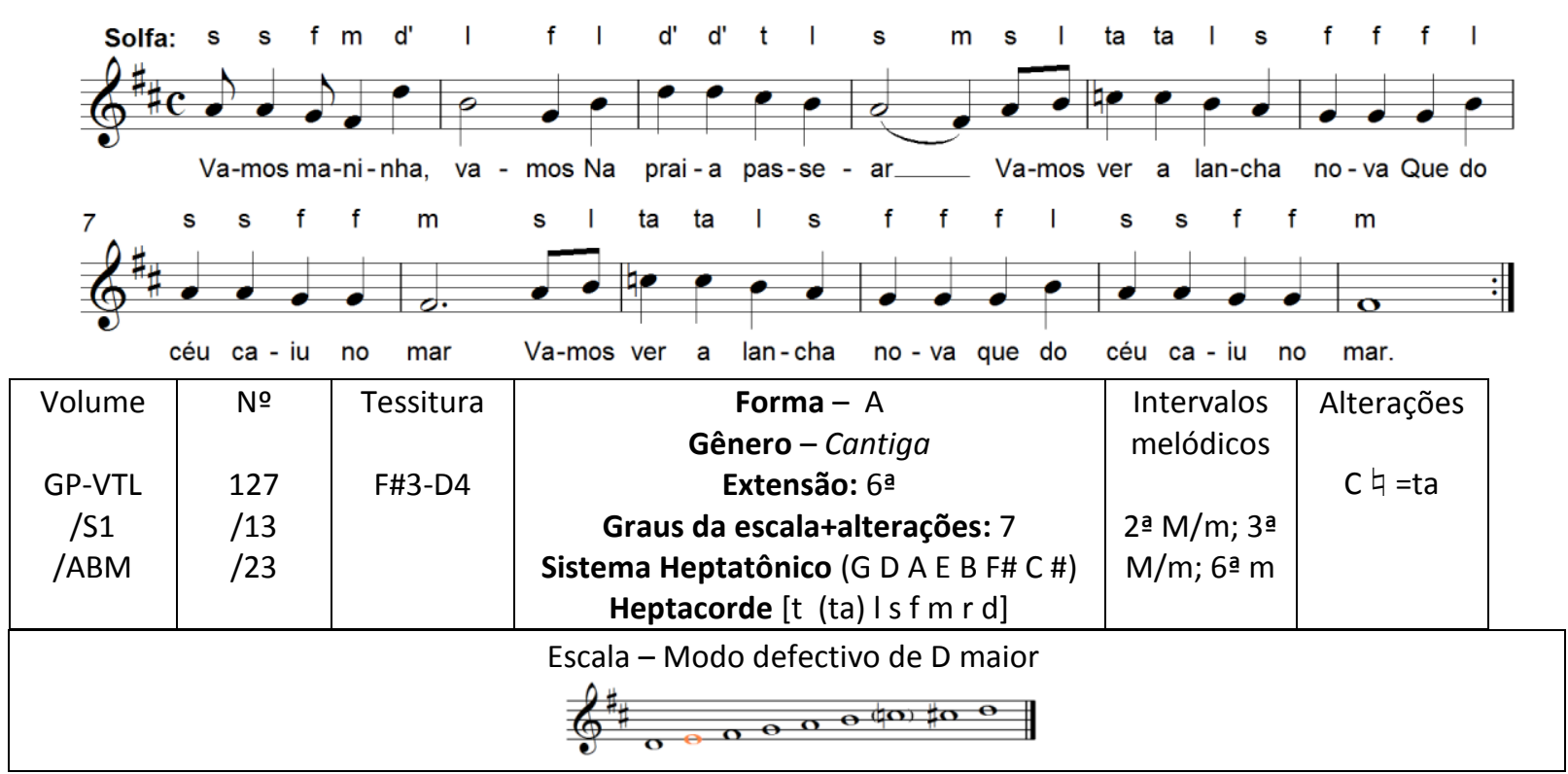

\section{Sugestões de atividades didático-pedagógicas:}

Células rítmicas para registro gráfico:

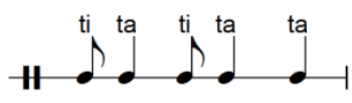

Células melódicas para registro gráfico:

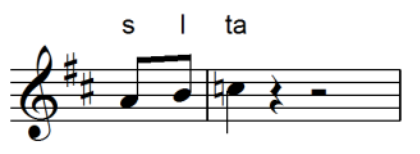

Possível ostinato rítmico:

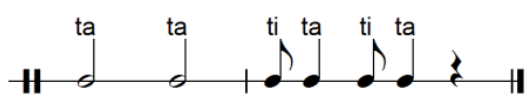

Análise complementar em $2.2-n^{\circ} 73$.

Canção com 12 compassos quaternários, com a indicação de andamento: Andantino quasi Andante (104= ل ); indicações de dinâmica: $p$; $\boldsymbol{m f}$

Tema popular, folclórico infantil, de brincadeira cantada cujo desenvolvimento baseia-se no texto.

Texto - Descrição de brincadeira de roda, com versos sobre a lancha, canoinha ou barca nova, provenientes de cheganças de mouros e de marujos, segundo Mário de Andrade ${ }^{59}$. Trata-se de uma alusão ao formato da lua nova no céu, comparado ao de uma barca no mar, ou ainda o reflexo da lua nas águas do mar.

Ritmo - o interesse rítmico está na sincopa e nas notas longas.

${ }^{59}$ Apud ABM, $1^{\circ}$ Caderno, p. 86. 
Melodia - melodia em âmbito de hexacorde, com linhas descendentes por grau conjunto, saltos ascendentes e finalizações descendentes na S, T, D e T Ao contrário de GP/ABM, preferimos a versão GP/VTL (mesmo com versão diferente em Solfejo 1, n ${ }^{\circ} 13$ ), em relação ao compasso 11, com as notas $\boldsymbol{G} \boldsymbol{G}$ nas duas primeiras semínimas, por ser mais coerente didaticamente, compondo uma simples repetição de frase, procedimento comum em melodias folclóricas.

Ludicidade - brincadeira de roda, simples, com ênfase no texto, com possibilidades de variação dos movimentos em círculo para outras formações.

\subsubsection{Sobre sete sons da escala e alteracões}

\section{9) MÊS DE JUNHO - a capella}

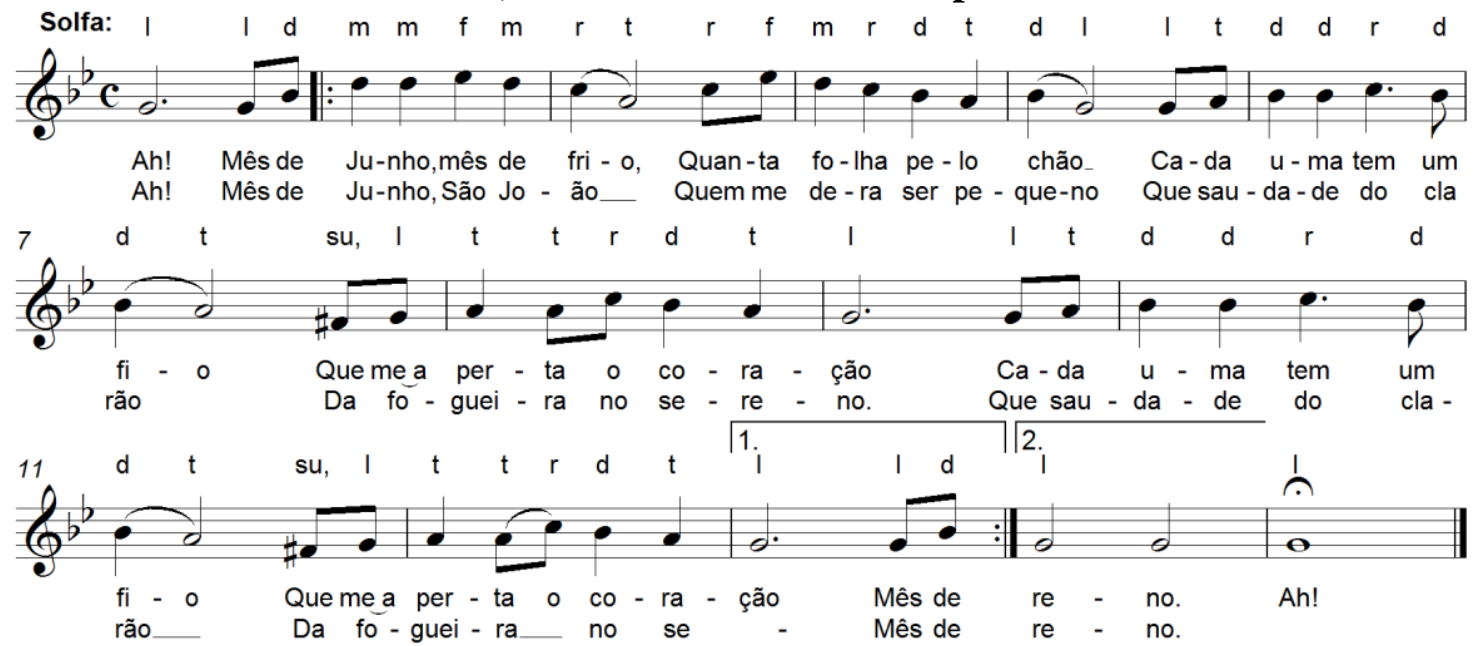

\begin{tabular}{|c|c|c|c|c|c|}
\hline $\begin{array}{l}\text { volume } \\
\text { CO2 } \\
\text { GP/VTL } \\
\text { ABM }\end{array}$ & $\begin{array}{l}\text { № } \\
15 \\
/ 96 \\
/ 46\end{array}$ & $\begin{array}{l}\text { Tessitura } \\
\text { F\#3-Eb4 }\end{array}$ & $\begin{array}{c}\text { Forma - A } \\
\text { Extensão: 7ạ } \\
\text { Graus da escala+alterações: } 7 \\
\text { Sistema Heptatônico (Eb Bb F C G D A) } \\
\text { Heptacorde }[(\mathrm{su}) \mathrm{f} \mathrm{m} \mathrm{r} \mathrm{d} \mathrm{t} \mathrm{l]}\end{array}$ & $\begin{array}{l}\text { Intervalos } \\
\text { melódicos } \\
\text { 2aㅗ } \mathrm{M} / \mathrm{m}^{3} 3^{\mathfrak{a}} \\
\mathrm{M} / \mathrm{m}\end{array}$ & $\begin{array}{l}\text { Alterações } \\
\text { F\#=su }\end{array}$ \\
\hline & & & 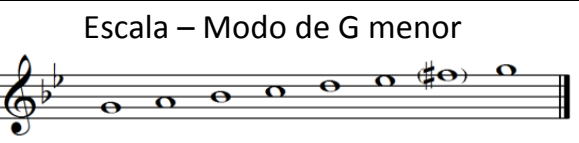 & & \\
\hline
\end{tabular}

Sugestões de atividades didático-pedagógicas:

Células rítmicas para registro gráfico:

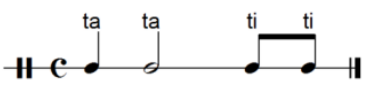

Células melódicas para registro gráfico:

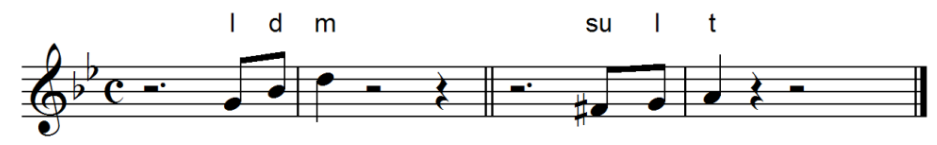

Possível ostinato rítmico:

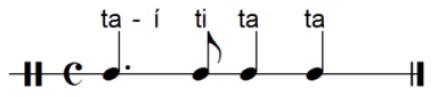


Análise complementar em $2.2-n^{\circ} 177$.

Canção com 14 compassos quaternários, com a indicação de andamento: Andante; sem indicações de dinâmica.

Tema - texto de Thomé Brandão sobre tema popular, com arranjo de H.Villa-Lobos.

Texto nostálgico que evoca a infância em noite de São João. Seis versos de sete sílabas.

Ritmo - o interesse está na simetria da métrica do texto e sua linha rítmica.

Melodia - similar à melodia Pobre Cega ( ${ }^{\circ} 96$ do GP/VTL). A primeira frase inicia-se com arpejo da tríade menor ascendente formando pequena curva que desce para a $\mathrm{T}$, assim como todas as outras frases.

Ludicidade - canção que evoca a época junina, possibilitando outras interferências de caráter lúdico. Quanto à estrutura, um desafio seria cantar a canção em tom maior.

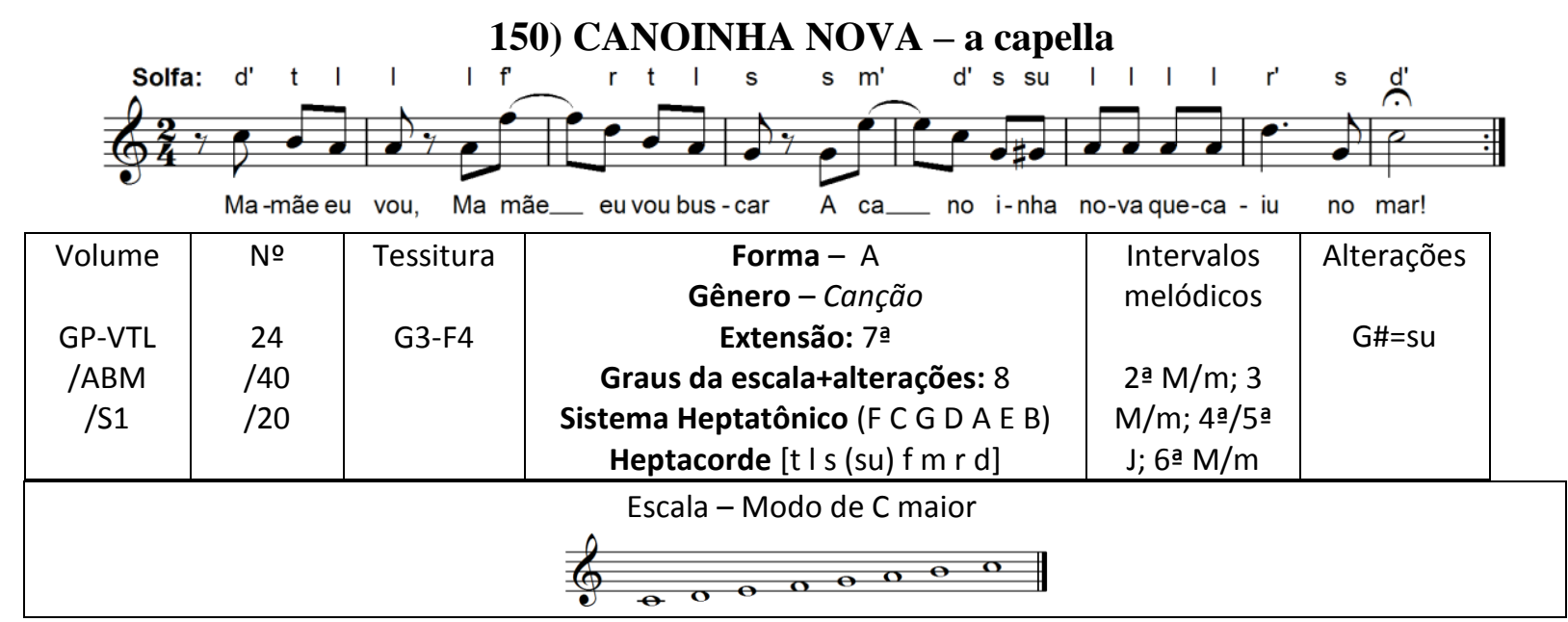

Sugestões de atividades didático-pedagógicas:

Células rítmicas para registro gráfico:

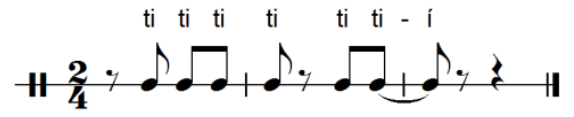

Células melódicas para registro gráfico:

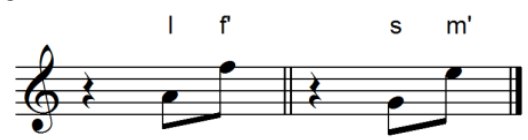

Possivel ostinato rítmico:

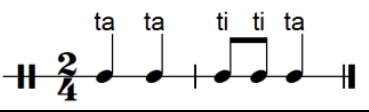

Análise complementar em 2.2 - $n^{\circ} 91$.

Canção com 8 compassos binários, com a indicação de andamento: Allegretto (M.M. $96=$ ل ); indicações de dinâmica: Acentos > ; _

Tema popular, folclórico infantil, de brincadeira cantada cujo desenvolvimento baseia-se no texto.

Texto - fragmento de texto entre muitos que abordam a canoinha, barca ou lancha nova. Som onomatopaico, Schêa! - refere-se à imitação da água sob o impulso do remo. 
Ritmo - o interesse rítmico está nos motivos anacrúsicos e nas síncopas. Os acentos reforçam as síncopas.

Melodia - grande tetracorde descendente formado pelas notas agudas acentuadas alcançadas por saltos de sexta (duas vezes) e quartas (duas vezes). Primeira semifrase vai para a $S$; a segunda volta para a $\mathrm{T}$, a terceira vai para a $\mathrm{Tr}$ e a última chega à $\mathrm{D}$ que resolve na $\mathrm{T}$. $\mathrm{O}$ movimento descendente da melodia atende à idéia de queda (cair no mar).

Ludicidade - brincadeira de roda cujo ritmo favorece a variação coreográfica.

Complemento do texto ${ }^{60}$ :

Mamãe eu vou,/ mamãe eu vou buscar / a canoinha nova / que caiu no mar!

Pus o cravo na janela / pra sinh'Aninha cheirar / sinh'Aninha de preguiça / deixou o cravo murchar.

Menina dos olhos grandes / não olhe pra mim chorando / que os seus olhos são a causa / de eu andar assim penando.

151) OLHA O PASSARINHO - acompanhamento instrumental (Para piano)

Amb. por H.Villa-Lobos

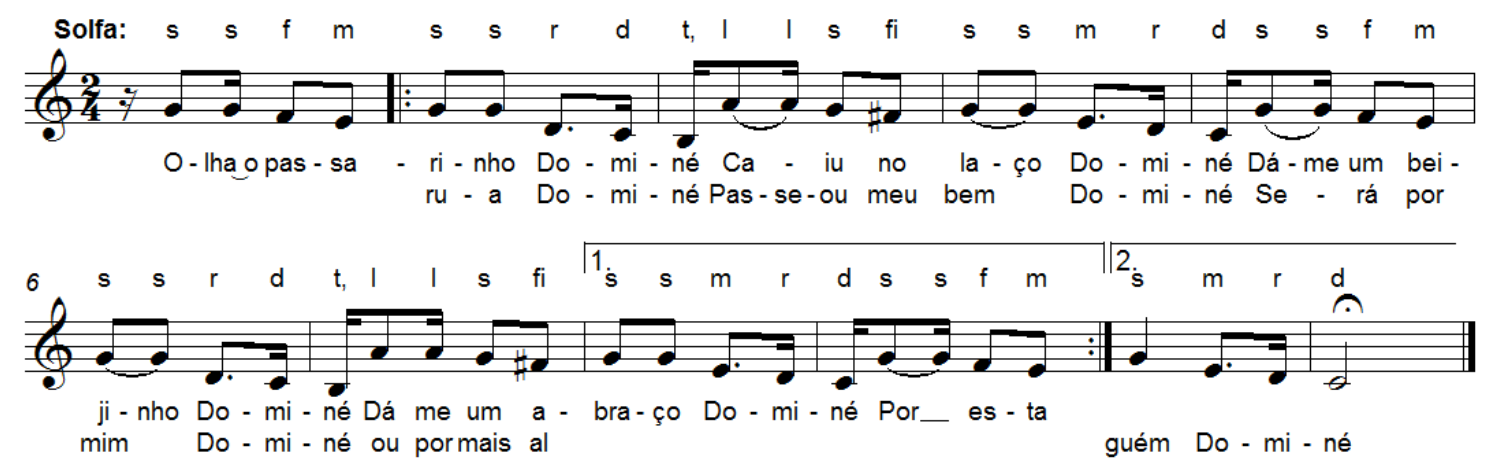

\begin{tabular}{|c|c|c|c|c|c|}
\hline $\begin{array}{l}\text { Volume } \\
\text { GP-VTL } \\
\text { /ABM }\end{array}$ & $\begin{array}{l}\text { № } \\
85 \\
194\end{array}$ & $\begin{array}{l}\text { Tessitura } \\
\text { B2-A3 }\end{array}$ & $\begin{array}{c}\text { Forma - A } \\
\text { Gênero - Dança canção } \\
\text { Extensão: 7ạ } \\
\text { Graus da escala+alterações: } 8 \\
\text { Sistema Heptatônico (F C G D A E B) } \\
\text { Heptacorde [t I s (fi) f m r d] }\end{array}$ & 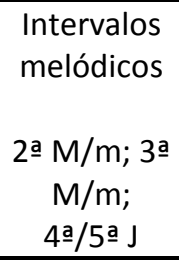 & $\begin{array}{l}\text { Alterações } \\
\qquad \mathrm{F \# =fi}\end{array}$ \\
\hline \multicolumn{6}{|c|}{$\underbrace{\text { Escala - Modo de C maior }}_{0}$} \\
\hline
\end{tabular}

Sugestões de atividades didático-pedagógicas:

Células rítmicas para registro gráfico:

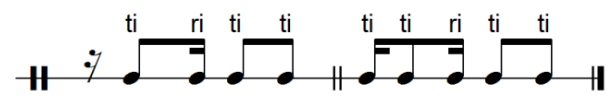

Células melódicas para registro gráfico:

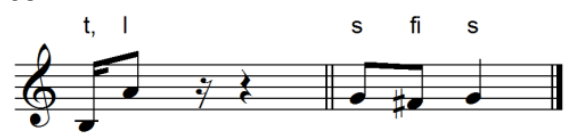

Possível ostinato rítmico:

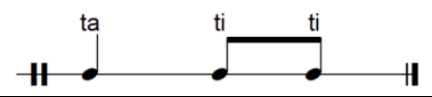

${ }^{60} \mathrm{GP} / \mathrm{ABM}-1{ }^{\circ}$ Caderno, p. 75 e 90. 
Possivel ostinato melódico:

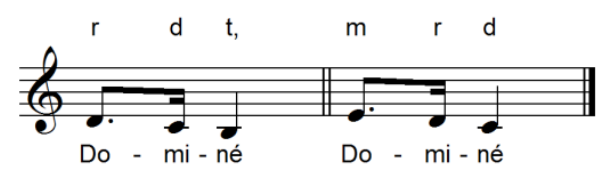

Canção com 11 compassos binários, com a indicação de andamento: Allegro non Tropo $(\mathbf{1 2 0}=\mathrm{J})$; indicações de dinâmica: $\boldsymbol{p} ; \boldsymbol{f f} ; \boldsymbol{f f f}$; acentos >

Tema popular, folclórico infantil, de brincadeira cantada cujo desenvolvimento baseia-se no texto.

Texto - Descrição de brincadeira de roda, em forma bastante usual de intercalar um texto como ostinato, deste caso, Dominé ${ }^{61}$ entre os versos das quadras.

Ritmo - o interesse rítmico está nas síncopas.

Melodia - frases com terminações em ostinato rítmico/melódico com texto Dominé (variante: Dominó), sobre linhas descendentes e terminações na D e T.

Acompanhamento instrumental (piano) - com indicação de obra para piano, apresenta a introdução com nove compassos com polirritmos, com a mão direita em linha ascendente priorizando intervalos quebrados de quarta e repouso no quinto grau, e linha escalar descendente na mão esquerda e imitação do procedimento da mão direita em seguida; após repetição dos três primeiros compassos, a melodia inicia-se na mão direita com um ostinato na esquerda conservando o procedimento inicial - arpejo ascendente e linha descendente por quartas quebradas, em relação de sextas e terças com a linha melódica. A coda tem dois compassos, em Prestissimo com finalização em oitavas da T. Em GP/ABM, no compasso 9, a última nota dever ser $\boldsymbol{E}$, e não $\boldsymbol{F}$ como consta.

Ludicidade - brincadeira de roda em que um dos elementos lúdicos é o ostinato, com possibilidades de criação de outras quadrinhas pelos participantes.

\section{2) TEREZINHA DE JESUS - a capella}

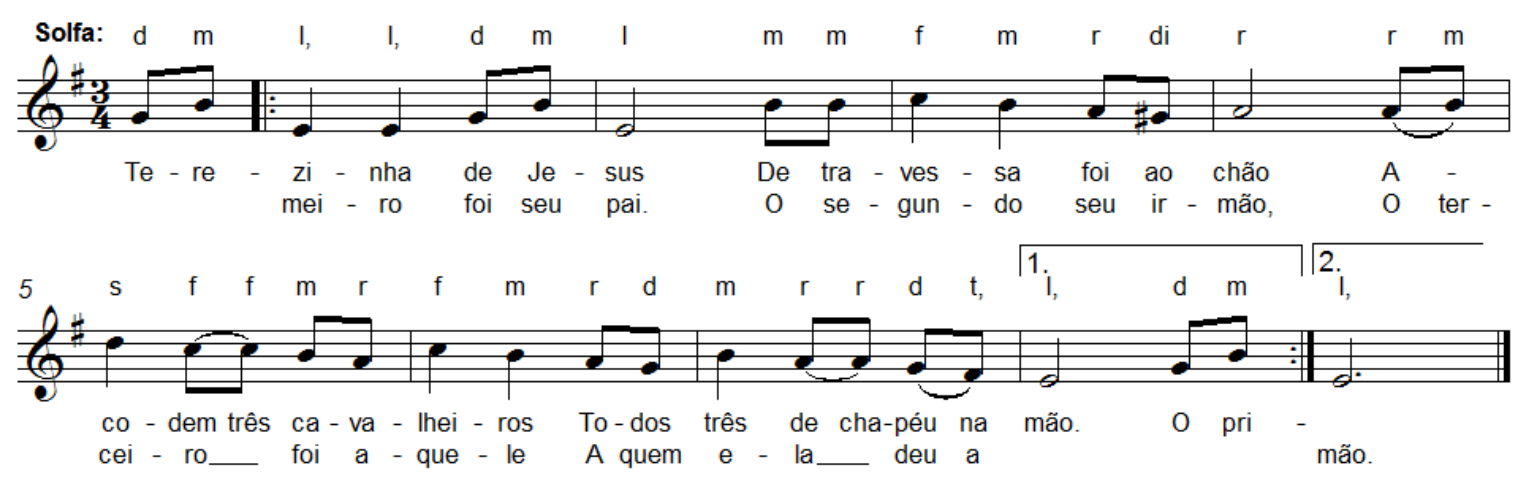

\begin{tabular}{|c|c|c|c|c|c|}
\hline Volume & № & Tessitura & $\begin{array}{c}\text { Forma - A } \\
\text { Gênero - Um pouco mazurca }\end{array}$ & $\begin{array}{l}\text { Intervalos } \\
\text { melódicos }\end{array}$ & Alterações \\
\hline GP-VTL & 123 & E3-D4 & Extensão: 7ạ & & 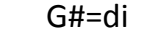 \\
\hline /S1 & $/ 12$ & & Graus da escala+alterações: 8 & 2 a $M / m ; 3 \underline{a}$ & \\
\hline
\end{tabular}

\footnotetext{
${ }^{61}$ N.A. Variante de Dominó em "Papai Ferreira”.
} 


\begin{tabular}{|c|c|c|c|}
\hline /ABM & $/ 11$ & $\begin{array}{c}\text { Sistema Heptatônico (C G D A E B F\#) } \\
\text { Heptacorde }[\mathrm{s} \mathrm{m} \mathrm{r} \mathrm{r}(\mathrm{di}) \mathrm{d} \mathrm{t} \mathrm{l}]\end{array}$ & $\mathrm{M} / \mathrm{m} ; 5^{\mathrm{a}} \mathrm{J}$ \\
\hline & & 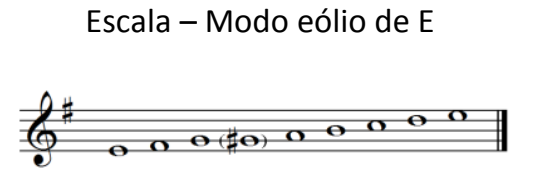 & \\
\hline
\end{tabular}

Sugestões de atividades didático-pedagógicas:

Células rítmicas para registro gráfico:

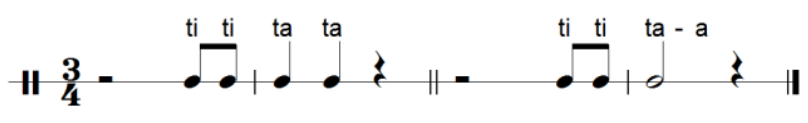

Células melódicas para registro gráfico:

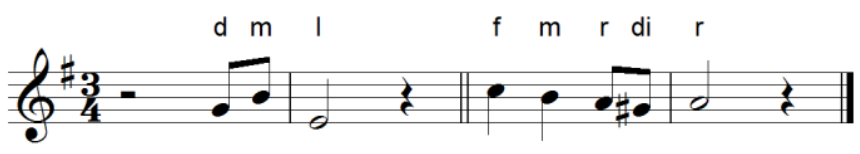

Possivel ostinato rítmico:

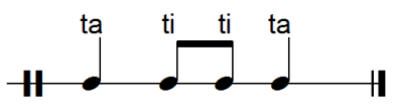

Possivel ostinato melódico:

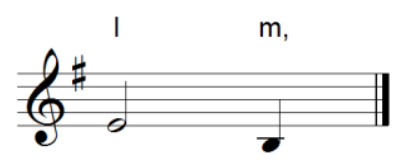

Análise complementar em $2.2-n^{\circ} 61$.

Canção com 10 compassos ternários, com a indicação de andamento: Andantino quasi Allegretto (M.M. $88=\downarrow$ ) ); sem indicações de dinâmica.

Tema popular, folclórico infantil, de brincadeira cantada cujo desenvolvimento baseia-se no texto.

Texto - Descrição de brincadeira de roda, cujos personagens, Terezinha e três cavalheiros são os protagonistas solistas.

Ritmo - o interesse rítmico está no compasso ternário e nos motivos anacrúsicos.

Melodia - desenho inicial sobre tríade da tônica, seguido de linhas descendentes de tetracordes alcançados por saltos ascendentes, em sequências, com finalização por, pentacorde com terminação na $\mathrm{T}$.

Ludicidade - brincadeira de roda com encenação da história cantada. 
153) CONDESSA - acompanhamento instrumental

(Canto com piano ou conjunto instrumental)

Arr. de H.Villa-Lobos

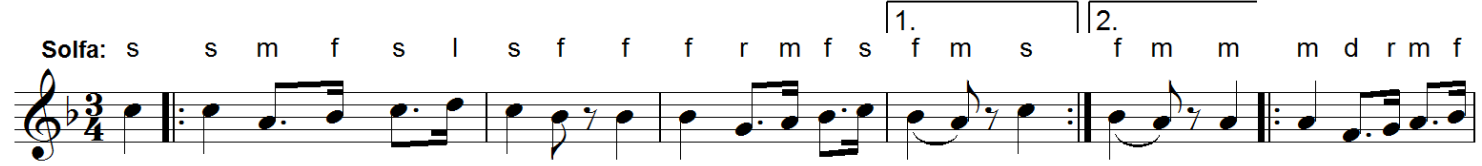

On! Con-des-sa oh!Con-des - si-nha, Oh! Con-des-sad'A ra- gão!_ Oh! gão!_ Ve - nho pe-dir u-ma
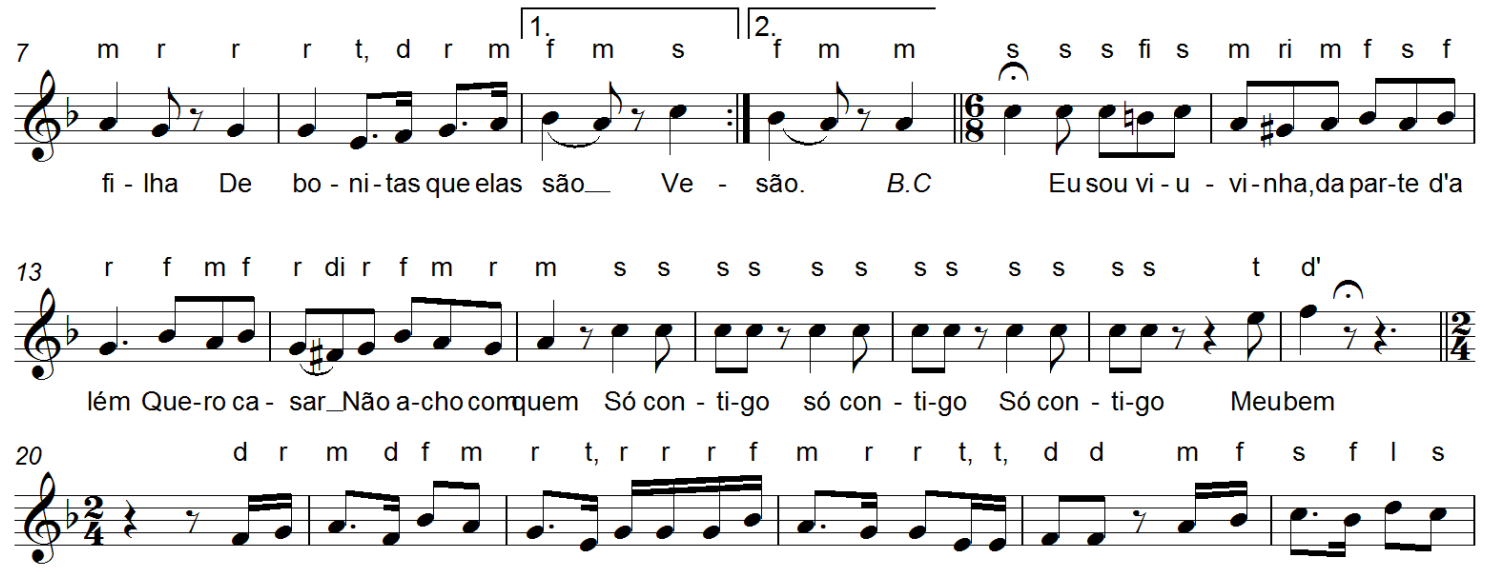

On-de mo - ra (la)Con -des-sa De-lín-gua de Fran-çąe dor delan - ce- ta? Queque-reis comla Con

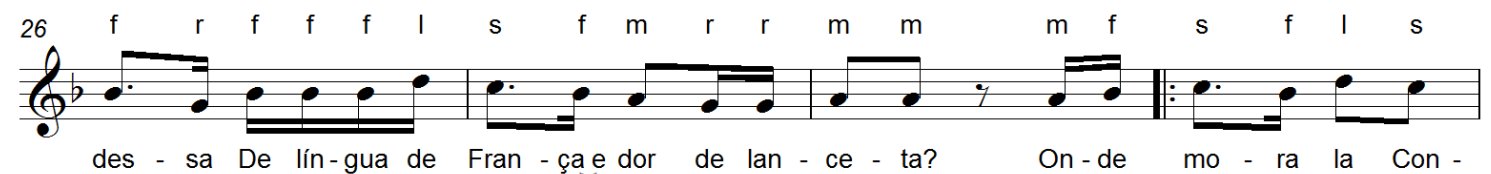

des - sa De lín-gua de Fran - ça dor de lan - ce - ta? On-de mo - ra la Con -

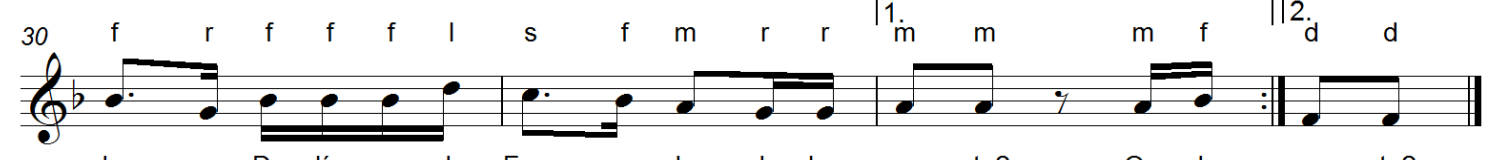

\begin{tabular}{|c|c|c|c|c|c|}
\hline des & $\mathrm{De}$ & lín - gua de & lan - ce - ta? & On - de & ce - ta? \\
\hline $\begin{array}{l}\text { Volume } \\
\text { GP-VTL } \\
\text { /ABM }\end{array}$ & $\begin{array}{c}\text { № } \\
39 \\
/ 128\end{array}$ & $\begin{array}{l}\text { Tessitura } \\
\text { E3-D4 }\end{array}$ & $\begin{array}{c}\text { Forma - ABC } \\
\text { Gênero - Canção ("variada") } \\
\text { Extensão: 7a } \\
\text { Graus da escala: } 8 \\
\text { Sistema Heptatônico (Bb F C G D A E) } \\
\text { Heptacorde [t I f f(fi) m r (ri) d (di)] }\end{array}$ & $\begin{array}{l}\text { Intervalos } \\
\text { melódicos } \\
\text { 2a } \mathrm{M} / \mathrm{m} ; 3 \text { a } \\
\mathrm{M} / \mathrm{m} ; \\
\text { 4a } / 5 \text { a J }\end{array}$ & $\begin{array}{c}\text { Alterações } \\
\text { Bh=fi; G\#=ri; } \\
\text { F\#=di }\end{array}$ \\
\hline \multicolumn{6}{|c|}{ 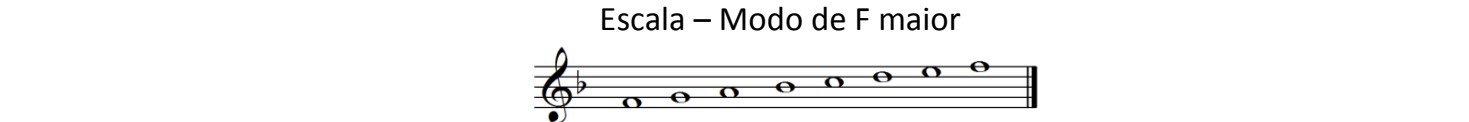 } \\
\hline
\end{tabular}

\section{Sugestões de atividades didático-pedagógicas:}

Células rítmicas para registro gráfico:

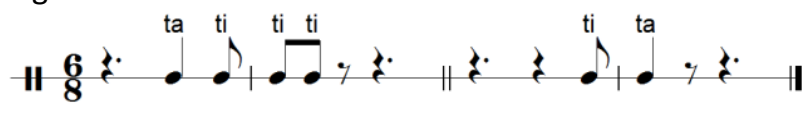

Células melódicas para registro gráfico:

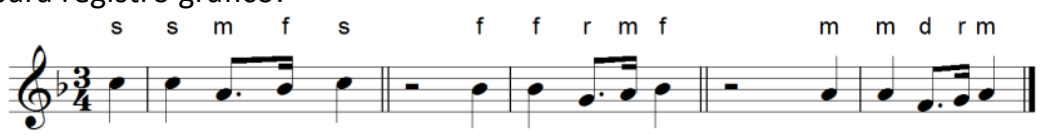

Possível ostinato rítmico:

Marcar as pulsações: a primeira com os pés e as demais com palmas

Canção com 16 compassos ternários, 9 binários com subdivisão ternária e 14 binários com subdivisão binária, com a indicação de andamento: Andante quasi Allegretto $(76=\mathrm{d})$; Allegro; Poco allegretto e muito ritmado; indicações de dinâmica: $\boldsymbol{m f} ; \boldsymbol{f f}$; acentos > ; cresc. Sfz; cresc. Sempre; fff 
Tema popular de origem portuguesa, de brincadeira cantada cujo desenvolvimento baseia-se no texto. Suíte composta de três cantigas de roda e uma dança.

Texto - o tema da Condessa é tratado por três textos que não formam contexto coerente: Condessa de Aragão, a quem alguém pede uma de suas bonitas filhas; a viuvinha, estrangeira, que escolhe com quem quer se casar; La Condessa, francesa, de dor de lanceta. Em GP/ABM, no compasso 30, a penúltima sílaba deve ser " $d e$ ", e não " $e$ ".

Ritmo - o interesse rítmico está na variedade de compassos e andamentos. Em GP/ABM, no compasso 27, falta a indicação de andamento.

Melodia - parte A: sequência descendente por grau conjunto de 4 pequenas curvas em torno de terças com terminações em apojaturas na D, T, Dr e T; parte B: terças quebradas descendentes com bordaduras inferiores, com terminação na $\mathrm{D}$ e na segunda frase, na $\mathrm{T}$; parte C: desenho em curvas em âmbito de terças com terminação descendente para a S; idem terça acima, com terminação na $\mathrm{D}$; idem com terminação na $\mathrm{T}$.

Ludicidade - brincadeira de roda que pode abranger a suíte como um todo, ou cada peça isoladamente.

\section{4) QUE LINDOS OLHOS - acompanhamento instrumental}

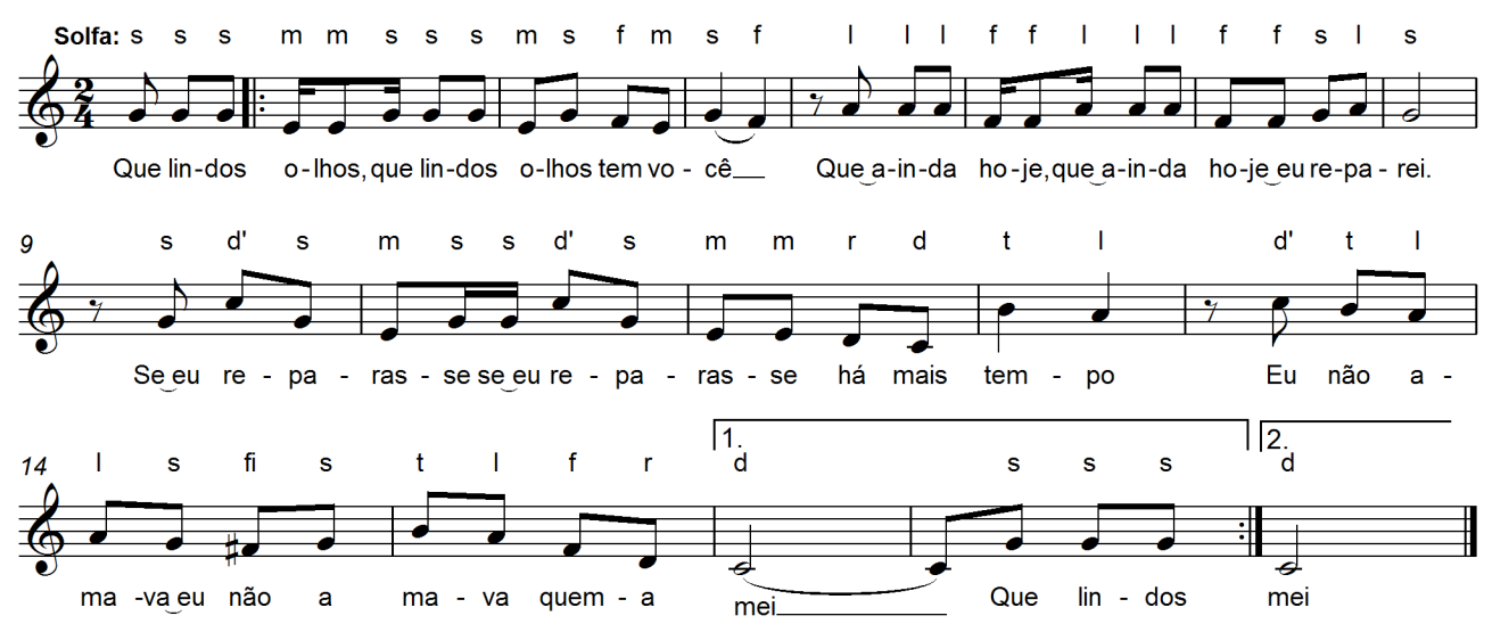

\begin{tabular}{|c|c|c|c|c|c|}
\hline $\begin{array}{l}\text { Volume } \\
\text { GP-VTL } \\
\text { /ABM }\end{array}$ & $\begin{array}{c}\text { № } \\
107 \\
\text { /121 }\end{array}$ & $\begin{array}{c}\text { Tessitura } \\
\text { C3-C4 }\end{array}$ & $\begin{array}{c}\text { Forma - A } \\
\text { Gênero - Samba canção } \\
\text { Extensão: } 8 \text { a } \\
\text { Graus da escala+alterações: } 8 \\
\text { Sistema Heptatônico (F C G D A E B) } \\
\text { Heptacorde [t I s (fi) f m r d] }\end{array}$ & $\begin{array}{l}\text { Intervalos } \\
\text { melódicos } \\
\text { 2a } \mathrm{M} / \mathrm{m} ; 3 \underline{a} \\
\mathrm{M} / \mathrm{m} ; 7 \underline{a} \\
\mathrm{M}\end{array}$ & $\begin{array}{c}\text { Alterações } \\
\qquad F \#=f i\end{array}$ \\
\hline & & & $\begin{array}{l}\text { Escala - Modo de C maior } \\
800 \text { o } 0 \text { o o a }\end{array}$ & & \\
\hline
\end{tabular}

Sugestões de atividades didático-pedagógicas:

Células rítmicas para registro gráfico:

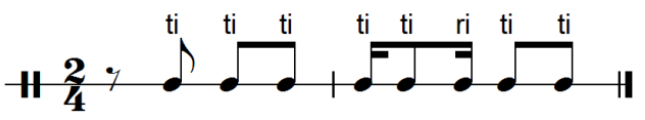


Células melódicas para registro gráfico:

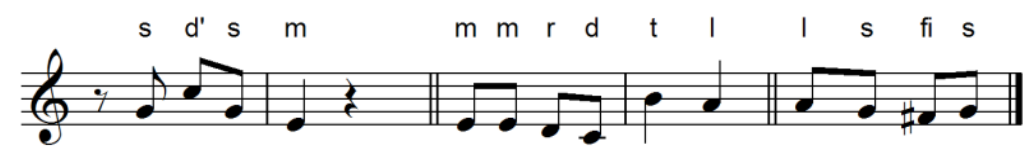

Possivel ostinato rítmico:

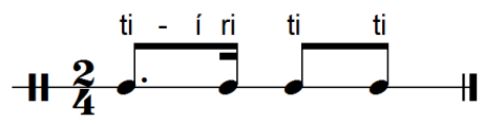

Análise complementar em $2.2-n^{\circ} 88$.

Canção com 16 compassos binários, com a indicação de andamento: Allegro Vivace $(\mathbf{1 2 0}=ل$ ل); rall. Animato; indicações de dinâmica: $f ;>;<$

Tema popular, folclórico.

Texto - com característica de repetição das primeiras palavras da frase.

Ritmo - o interesse rítmico está nas síncopas e ostinatos rítmicos.

Melodia - iniciada por terça menor descendente, na tríade de T, em âmbito de pentacorde, com finalização descendente na $\mathrm{D}$; sequência por grau conjunto ascendente, com finalização descendente na T; curvas iniciadas por salto de quarta ascendente sobre arpejo de $\mathrm{T}$, seguidas de linha descendente por grau conjunto e arpejo descendente da $\mathrm{D}$ com finalização na $\mathrm{T}$.

Ludicidade - a canção pode ser usada para várias ações lúdicas, como brincadeira de roda, canto em conjunto, grupo instrumental e outras.

155) ANDA A RODA ( $1^{\text {a }}$ versão $)$ - a capella
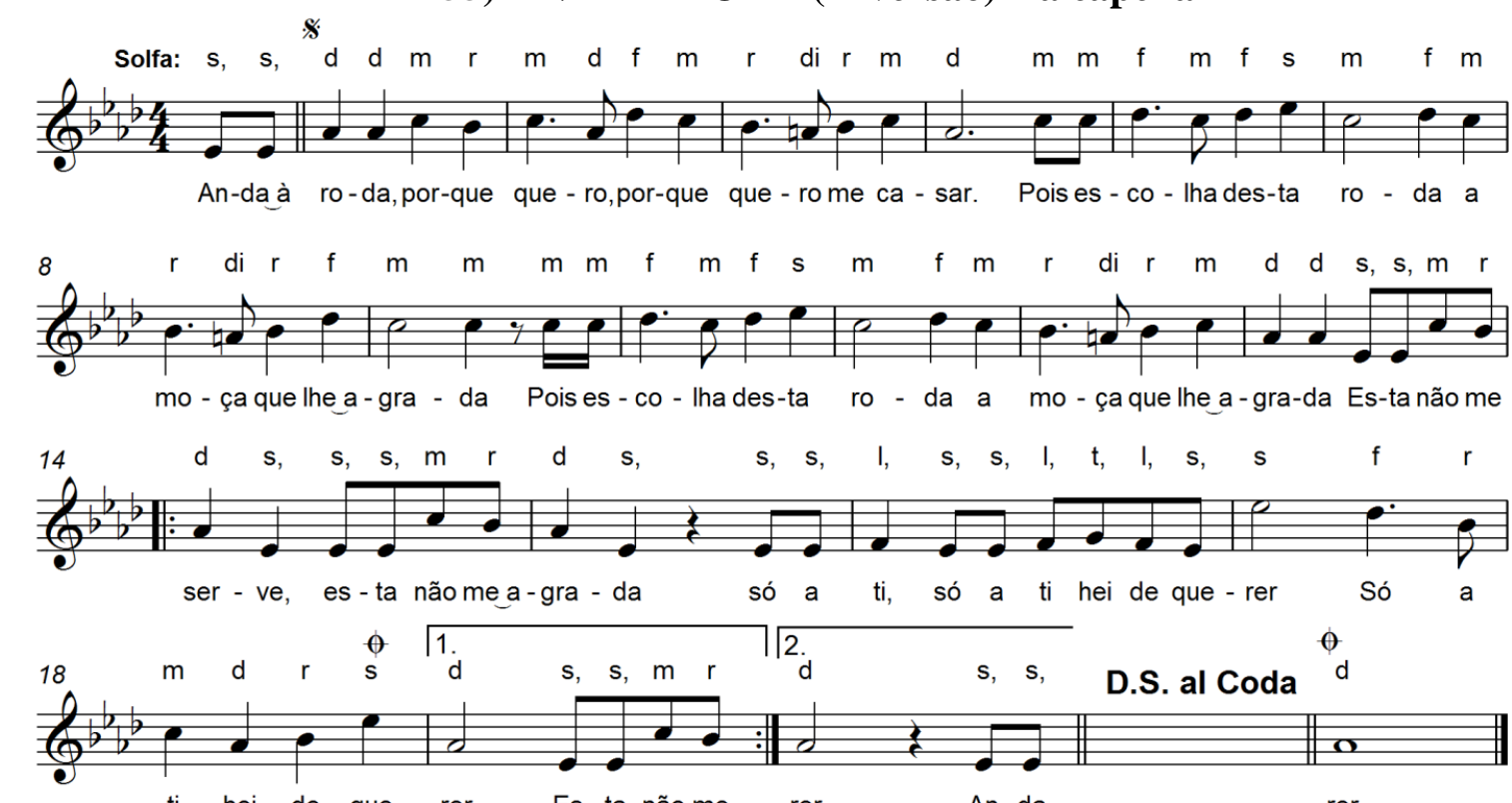

ti hei de que - rer. Es - ta nãome rer An-da rer.

\begin{tabular}{|c|c|c|c|c|c|}
\hline Volume & № & Tessitura & $\begin{array}{c}\text { Forma - A } \\
\text { Gênero-Marcha }\end{array}$ & $\begin{array}{c}\text { Intervalos } \\
\text { melódicos }\end{array}$ & $\begin{array}{c}\text { Alterações } \\
\text { melón }\end{array}$ \\
\hline
\end{tabular}




\begin{tabular}{|c|c|c|c|c|c|}
\hline $\begin{array}{l}\text { GP-VTL } \\
\text { /S1 } \\
\text { /CO2 } \\
\text { /ABM }\end{array}$ & $\begin{array}{c}5 \\
/ 31 \\
/ 29 n-5 \\
/ 5 \\
\end{array}$ & Eb3-Eb4 & $\begin{array}{c}\text { Extensão: 8a } \\
\text { Graus da escala+alterações: } 8 \\
\text { Sistema Heptatônico (Db Ab Eb Bb F C G) } \\
\text { Heptacorde }[\mathrm{t} \text { I s f m r (di) d] }\end{array}$ & $\begin{array}{c}2 \text { a } M / m ; 3 \text { a } \\
M / m ; \\
\text { 4a/5a/8 J; } \\
\text { 6a } \mathrm{M} \\
\end{array}$ & $A G=d i$ \\
\hline \multicolumn{6}{|c|}{ 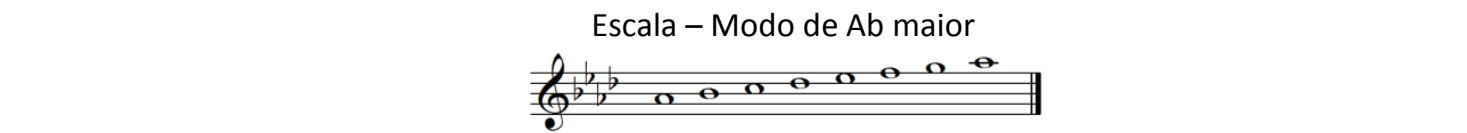 } \\
\hline
\end{tabular}

Sugestões de atividades didático-pedagógicas:

Células rítmicas para registro gráfico:

Células melódicas para registro gráfico:
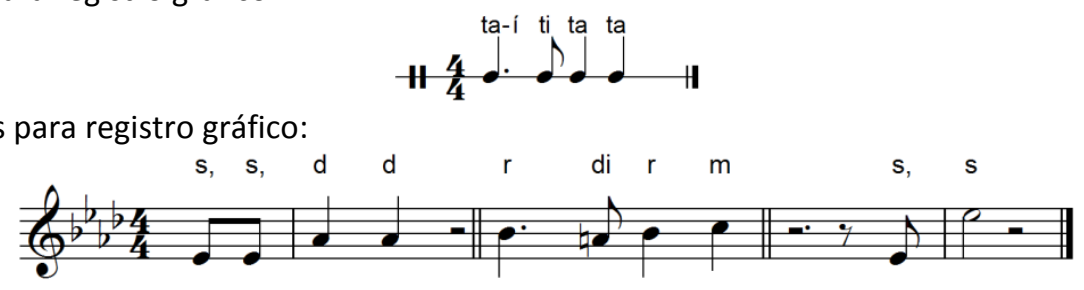

Possivel ostinato rítmico:

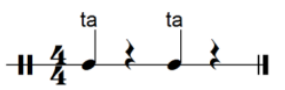

Análise complementar em $2.2-n^{\circ} 82$.

Canção com 20 compassos quaternários, com a indicação de andamento: Andantino, quasi movimento de marcha $(104=$ ل ); se indicações de dinâmica.

Tema popular, folclórico infantil, de brincadeira cantada cujo desenvolvimento baseia-se no texto.

Texto - descrição do desenvolvimento de um brinquedo de roda, em forma de diálogo.

Ritmo - o interesse rítmico está nas diferentes linhas rítmicas das partes A e B, e nos ritmos pontuados.

Melodia - desenhos alternam sobre T e D, resolvendo a primeira parte na T; na segunda após pequenas curvas, a finalização na $\mathrm{T}$ se dá por salto descendente.

Ludicidade - roda cantada em forma de diálogo, em que a criança que está no centro escolhe seu par, que, por sua vez, vai substituí-la na sequência da brincadeira.

\section{6) SOLFEJO $n^{\circ} 40$ - a capella}
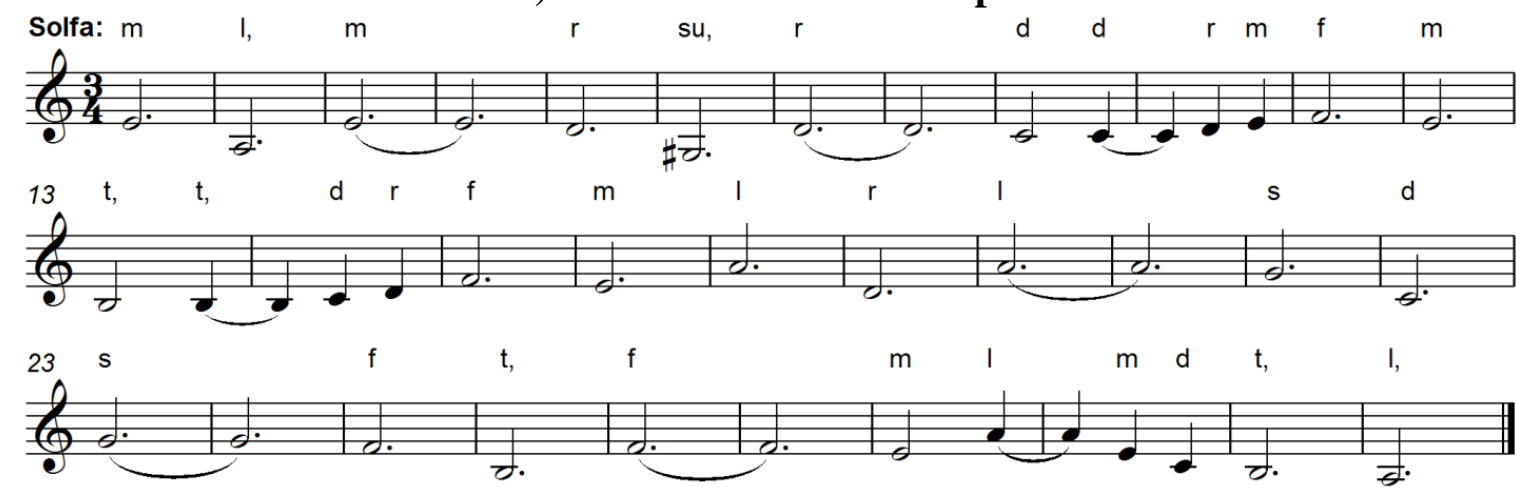

\begin{tabular}{|c|c|c|c|c|c|}
\hline Volume & $\begin{array}{l}\text { № } \\
40\end{array}$ & $\begin{array}{l}\text { Tessitura } \\
\text { G\#2-A3 }\end{array}$ & $\begin{array}{c}\text { Forma - A } \\
\text { Gênero - Samba canção } \\
\text { Extensão: } 8^{\underline{a}}\end{array}$ & $\begin{array}{l}\text { Intervalos } \\
\text { melódicos }\end{array}$ & $\begin{array}{c}\text { Alterações } \\
\text { G\#=su }\end{array}$ \\
\hline
\end{tabular}




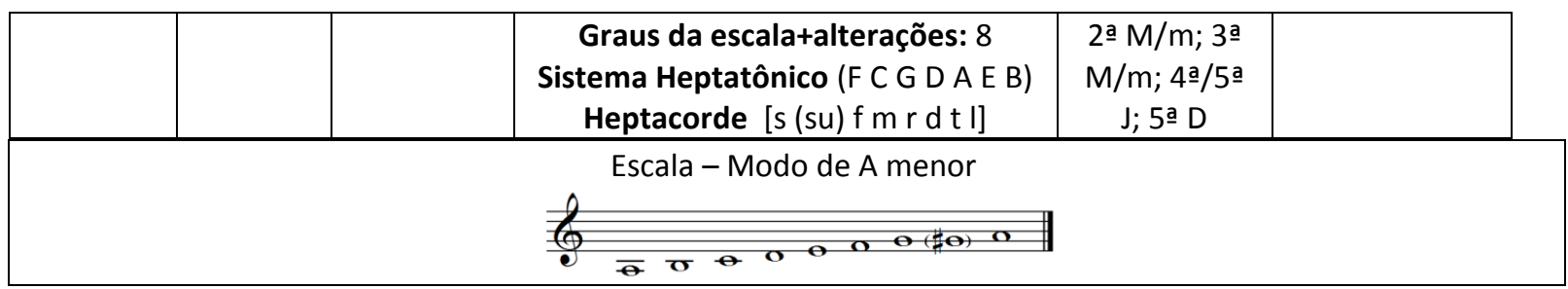

Sugestões de atividades didático-pedagógicas:

Células rítmicas para registro gráfico:

Células melódicas para registro gráfico:
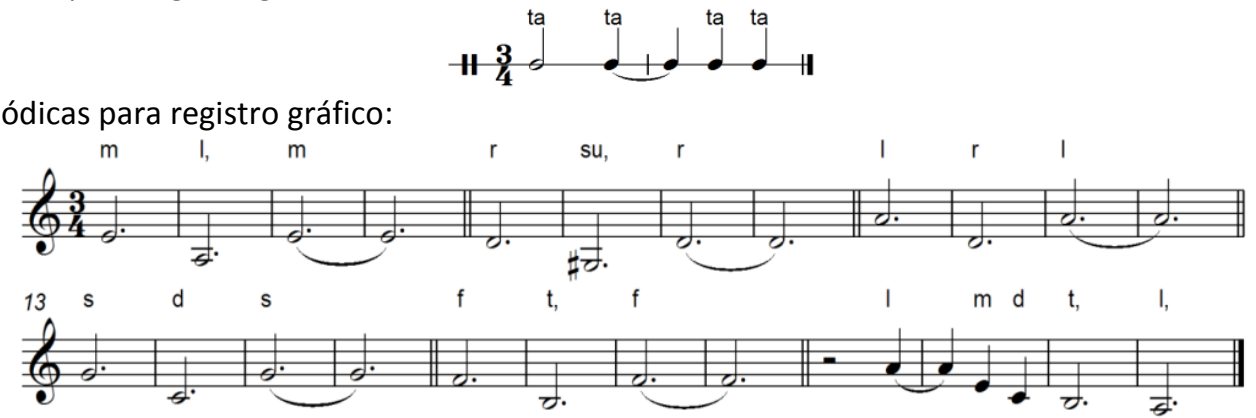

Possível ostinato rítmico:

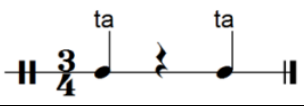

Tema de Villa-Lobos com 32 compassos ternários, sem indicações de andamento ou dinâmica.

Ritmo - o interesse rítmico está no compasso ternário. O compasso 12 por 4 seria mais adequado, conferindo maior fluência ao discurso melódico.

Melodia - sequências descendentes por grau conjunto de saltos de $5^{\mathrm{a}} \mathrm{s}$ ascendentes/descendentes/ascendentes com terminação por desenhos (em sequência ascendente por grau conjunto) ascendentes com terminação em apojaturas (a segunda na D); idem, com o desenho inicial repetido em sequência por três vezes e final descendente por arpejo de tônica com apojatura.

Ludicidade - apesar de se tratar de um solfejo, sendo em tempo de valsa, pode-se acrescentar uma coreografia.

157) MINHA TERRA TEM PALMEIRAS - a capella

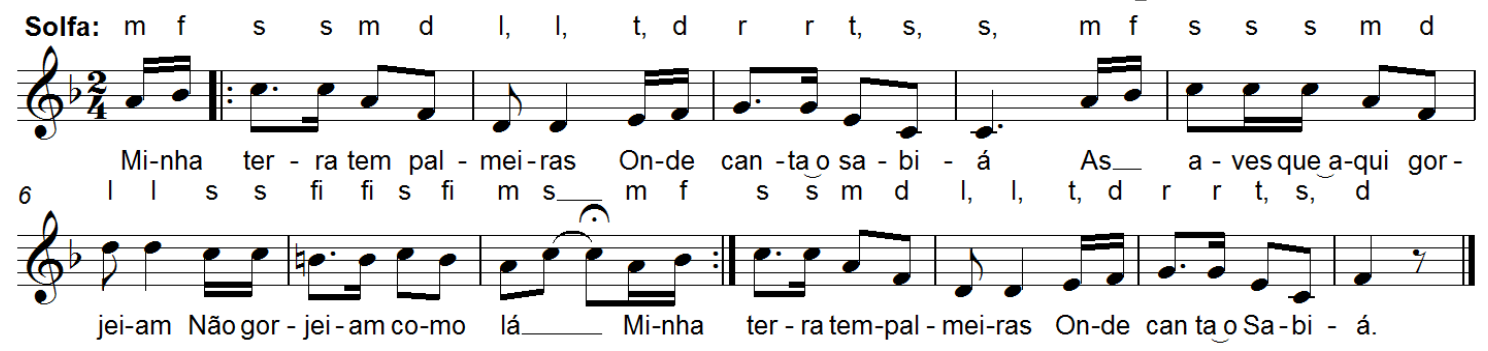

\begin{tabular}{|c|c|c|c|c|c|}
\hline $\mathrm{CO} 2$ & 5 & $\begin{array}{l}\text { Tessitura } \\
\text { C3-D4 }\end{array}$ & $\begin{array}{c}\text { Forma - A } \\
\text { Extensão: 9a } \\
\text { Graus da escala + alterações: } 8 \\
\text { Sistema Heptatônico (Bb F C G D A E) } \\
\text { Heptacorde [t I s (fi) f m r d] }\end{array}$ & $\begin{array}{l}\text { Intervalos } \\
\text { melódicos } \\
\text { 2a } \mathrm{M} / \mathrm{m} ; 3^{\text {a }} \\
\mathrm{M} / \mathrm{m} ; 4 \text { a J; } \\
\text { 6a M }\end{array}$ & $\begin{array}{c}\text { Alterações } \\
\text { B } \bigsqcup=f i\end{array}$ \\
\hline \multicolumn{6}{|c|}{ Escala - Modo de F maior (alteração ocorrente) } \\
\hline
\end{tabular}




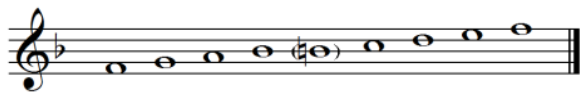

Sugestões de atividades didático-pedagógicas:

Células rítmicas para registro gráfico:

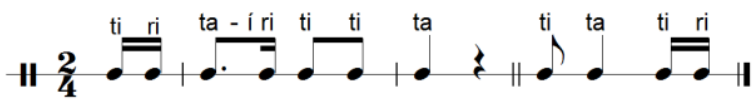

Células melódicas para registro gráfico:

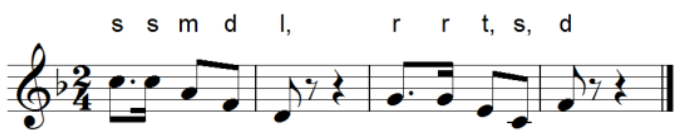

Possivel ostinato rítmico: ta titi

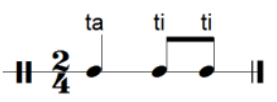

Análise complementar em $2.2-n^{\circ} 77$.

Canção com 13 compassos binários, com a indicação de andamento: Andantino; sem indicações de dinâmica.

Tema - melodia popular de autor desconhecido com arranjo de Heitor Villa-Lobos, com texto extraído da poesia Canção do exílio de Gonçalves Dias.

Texto - poesia de cinco estrofes com quadras de 7 sílabas, ou seja, uma redondilha maior, que é uma medida popular; apresenta reiterações sonoras e repetição total ou parcial dos versos, um recurso para facilitar a memorização, estando assim dentro da proposta romântica de resgatar os valores mais simples do povo. Descreve a saudade da terra do poeta longe do lar.

Ritmo - o interesse rítmico está nas síncopas, ritmos pontuados e anacruses.

Melodia - a configuração rítmica se repete em todos os versos, nas funções T S D T na primeira parte, e T S DD e Dr na segunda para o ritornello. A coda repete a primeira frase, com terminação no primeiro grau.

Ludicidade - o desafio principal é o contato com o texto literário e a memorização da poesia pode ser uma atividade lúdica.

Complemento do texto:

Minha terra tem palmeiras / onde canta o sabiá / as aves que aqui gorjeiam / não gorjeiam como lá.

Nosso céu tem mais estrelas / nossas várzeas têm mais flores / nosso bosque tem mais vida / nossa vida mais amores.

Minha terra tem primores / que tais não encontro eu cá / em cismar, sozinho, à noite / mais prazer encontrou eu lá.

Minha terra tem palmeiras / onde canta o sabiá / não permita Deus que eu morra / sem que volte para lá.

Sem que desfrute os primores / que não encontro por cá / sem que ainda aviste as palmeiras / onde canta o sabiá. 


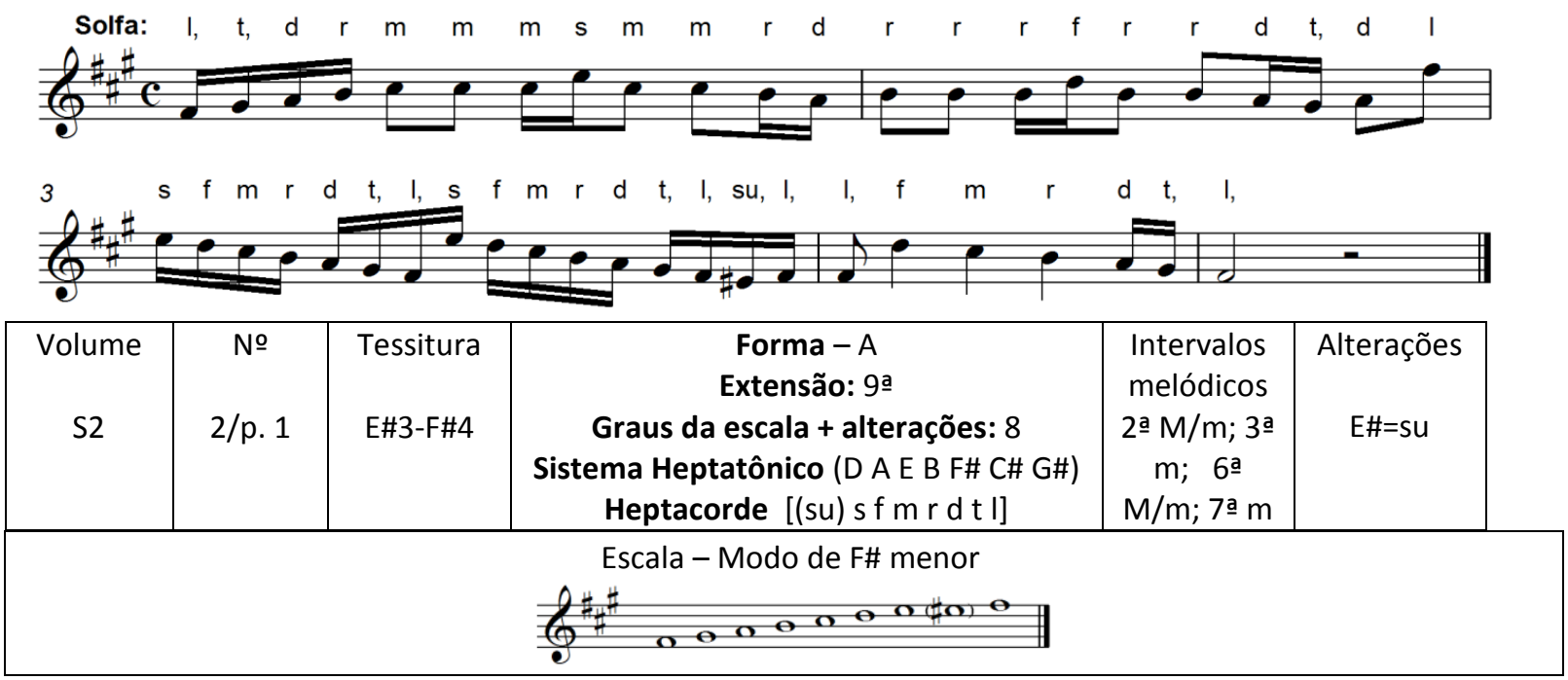

\section{Sugestões de atividades didático-pedagógicas:}

Células rítmicas para registro gráfico:

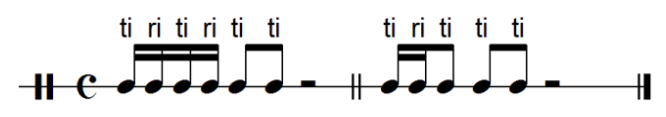

Células melódicas para registro gráfico:

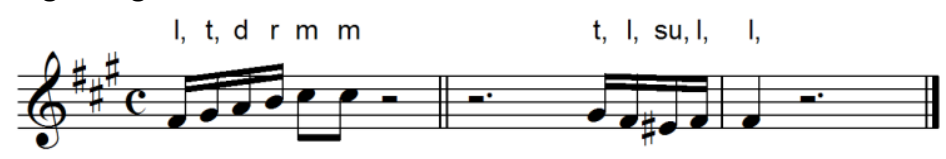

Possivel ostinato rítmico:

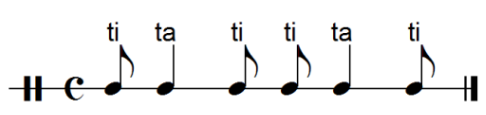

Tema de Villa-Lobos com 5 compassos quaternários, com a indicação de andamento: Poco Allegro; sem indicações de dinâmica.

Ritmo - o interesse rítmico está nas células com semicolcheias.

Melodia - pentacorde menor ascendente da tônica, seguido de desenhos em âmbito de terças, por saltos e bordaduras inferiores; a segunda frase apresenta linhas escalares descendentes, com alteração no sétimo grau, caracterizando o modo menor.

Ludicidade - uma das possibilidades lúdicas para este solfejo é um ostinato melódico para uma linha de baixo, em mínimas, por exemplo, com as funções: $l, s, f, f, m, m, m, m, l$,

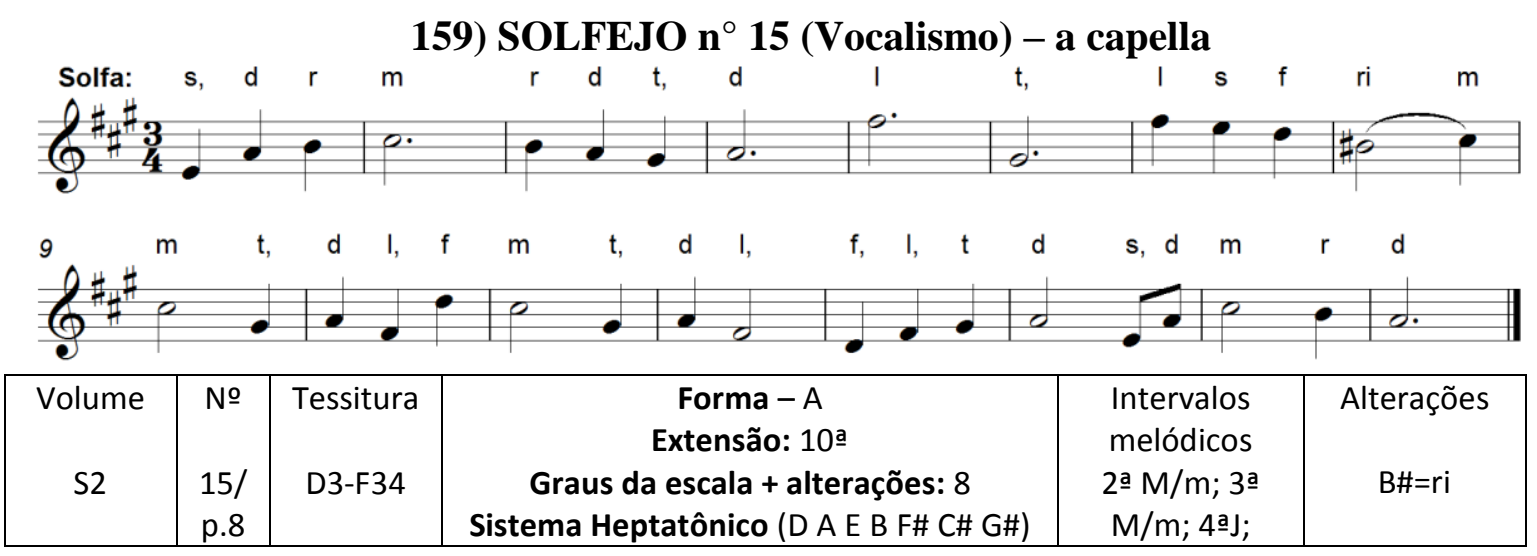




\begin{tabular}{|l|l|l|l|l|}
\hline & & Heptacorde $[\mathrm{t} \mathrm{I} \mathrm{f} \mathrm{m}$ (ri)r d] & 6a $\mathrm{M} / \mathrm{m} ; 7 \mathrm{a} \mathrm{m}$ & \\
\hline & Escala-Modo de A maior \\
&
\end{tabular}

Sugestões de atividades didático-pedagógicas:

Células rítmicas para registro gráfico:

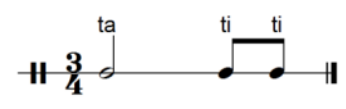

Células melódicas para registro gráfico:

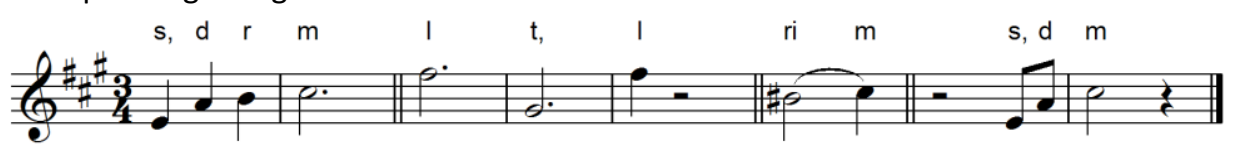

Possivel ostinato rítmico:

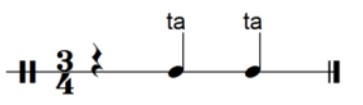

Análise complementar em $2.2-n^{o} 115$.

Tema de Villa-Lobos com 16 compassos ternários, com a indicação de andamento: Movimento de Valsa; sem indicações de dinâmica.

Ritmo - o interesse rítmico está no compasso ternário.

Melodia - no pentacorde da $\mathrm{T}$, iniciada por arpejo da tríade, seguido de desenhos por graus conjuntos e intervalos de $3^{\mathrm{a}} \mathrm{s}$ e $4^{\mathrm{a}} \mathrm{s}$, com terminação descendente na $\mathrm{T}$ por $3^{\mathrm{a}}$ cheia.

Ludicidade - apesar de se tratar de um solfejo, sendo em tempo de valsa, pode-se acrescentar uma coreografia.

\section{0) LINDAS LARANJAS - a capella}

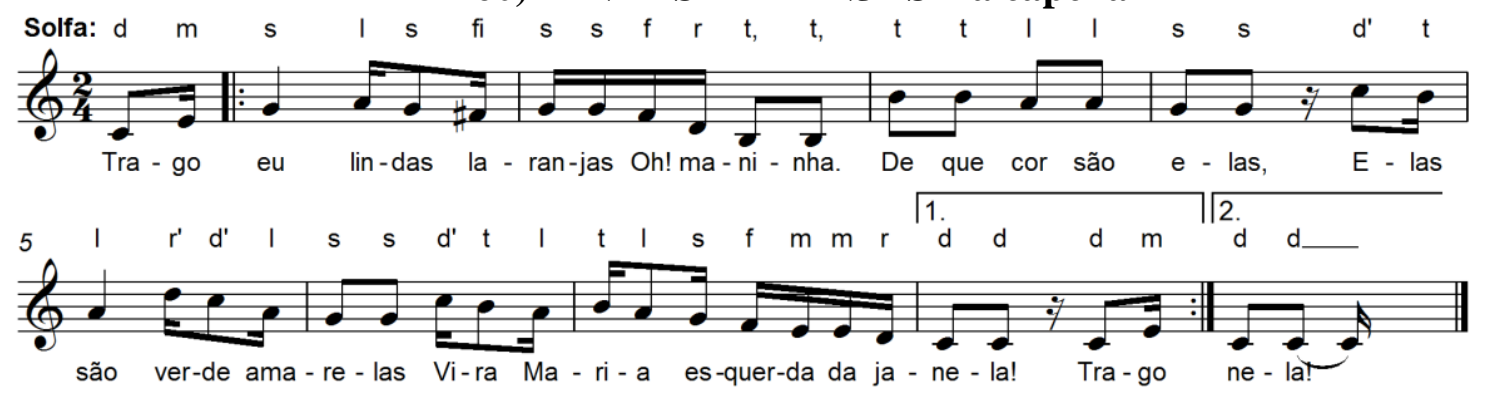

\begin{tabular}{|c|c|c|c|c|c|}
\hline $\begin{array}{l}\text { Volume } \\
\text { GP-VTL } \\
\text { /S1 } \\
\text { /ABM }\end{array}$ & $\begin{array}{l}\text { № } \\
70 \\
/ 35 \\
/ 25\end{array}$ & $\begin{array}{c}\text { Tessitura } \\
\text { B2-D4 }\end{array}$ & $\begin{array}{c}\text { Forma - A } \\
\text { Gênero - Canção regional } \\
\text { Extensão: 10ạ } \\
\text { Graus da escala + alterações: } 8 \\
\text { Sistema Heptatônico (F C G D A E B) } \\
\text { Heptacorde [t I s f (fi) m r d] }\end{array}$ & 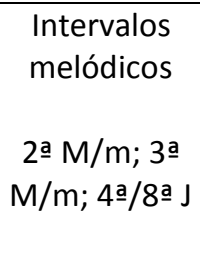 & $\begin{array}{c}\text { Alterações } \\
\text { F\#=fi }\end{array}$ \\
\hline \multicolumn{6}{|c|}{ Escala - Modo de C maior } \\
\hline
\end{tabular}

\section{Sugestões de atividades didático-pedagógicas:}

Células rítmicas para registro gráfico:

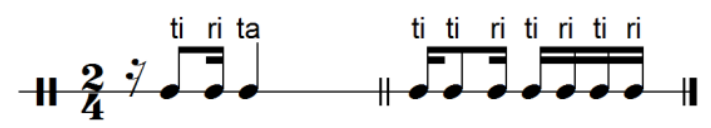

Células melódicas para registro gráfico: 


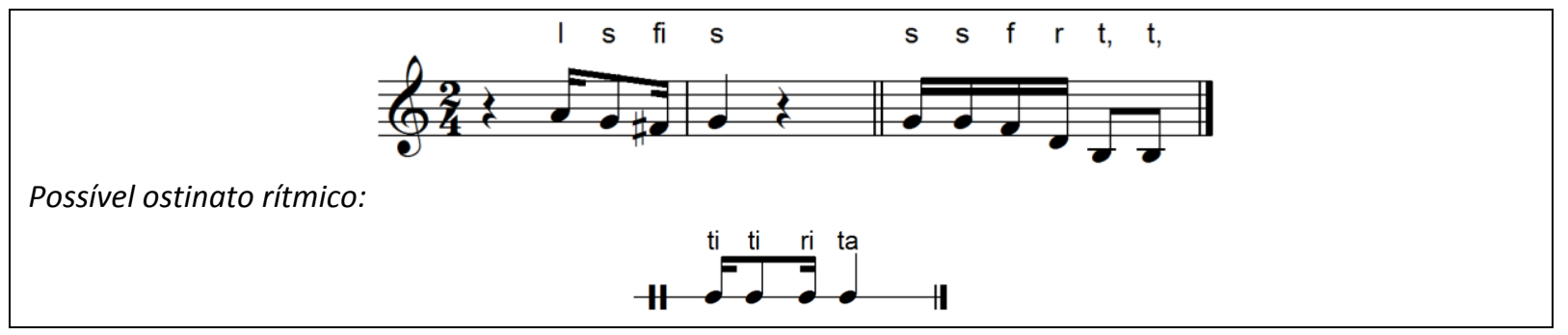

Análise complementar em $2.2-n^{\circ} 74$.

Canção com 10 compassos binários, com a indicação de andamento: Allegretto $(\mathbf{1 0 0}=\mathrm{J})$ ); sem indicações de dinâmica.

Tema popular, folclórico infantil, de brincadeira cantada cujo desenvolvimento baseia-se no texto.

Texto - descrição de brincadeira de roda com acessórios.

Ritmo - o interesse rítmico está síncopas e semicolcheias.

Melodia - início no arpejo ascendente da tríade da $\mathrm{T}$, seguido de pequena curva e arpejo descendente da tétrade da $\mathrm{D}^{7}$, com resposta iniciada oitava acima descendo para o quinto grau. A segunda frase desenvolve-se sobre pequenas curvas após salto ascendente, com finalização na $\mathrm{T}$ por heptacorde descendente.

Ludicidade - brincadeira de roda com acessórios (laranjas ou outros objetos), explorando a noção de espacialidade.

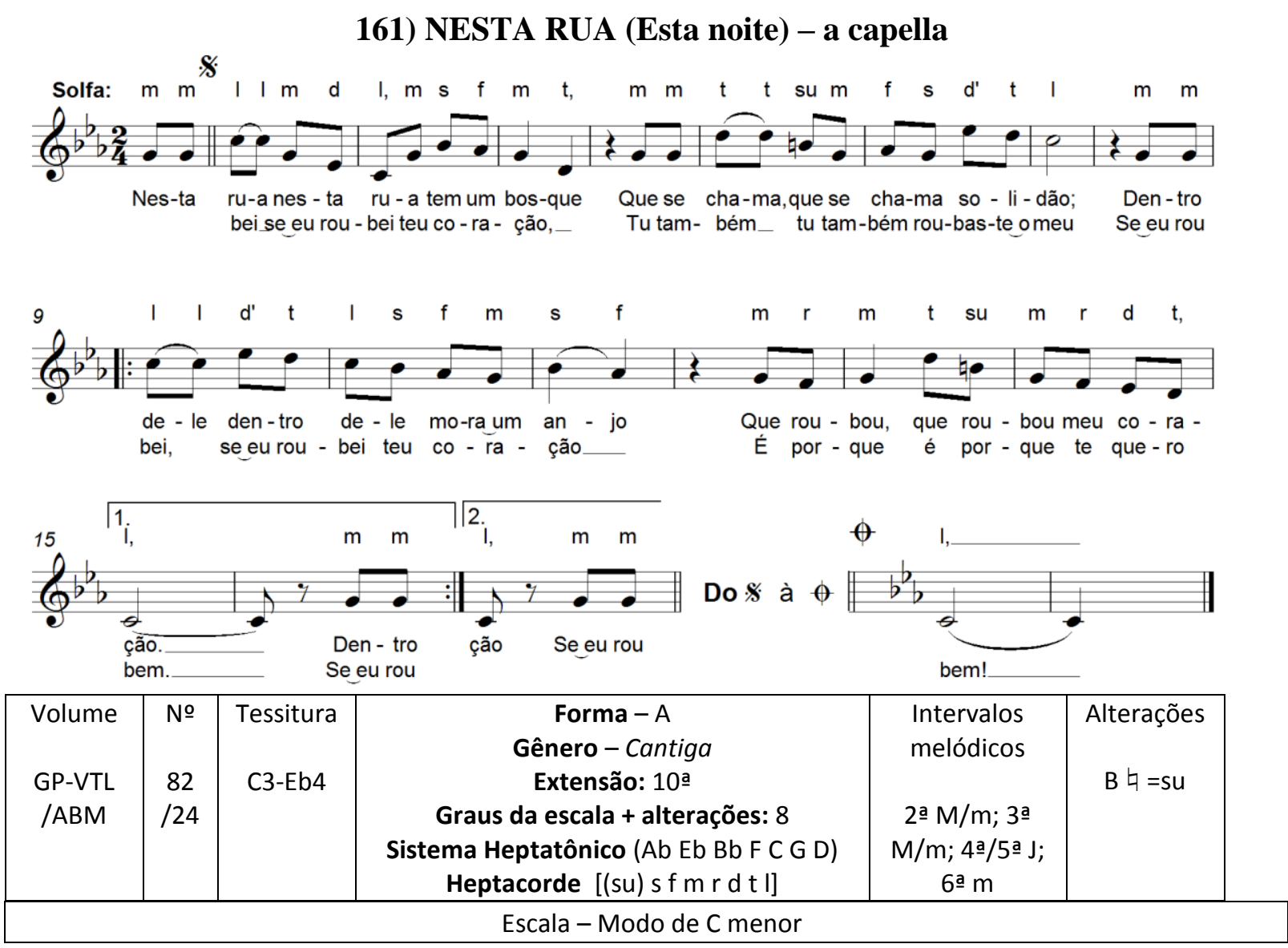




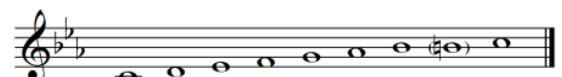

\section{Sugestões de atividades didático-pedagógicas:}

Células rítmicas para registro gráfico:

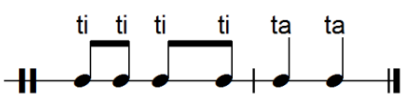

Células melódicas para registro gráfico:

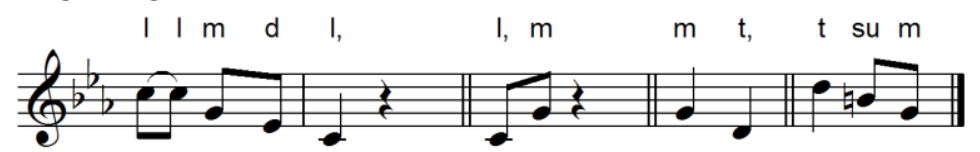

Possivel ostinato rítmico:

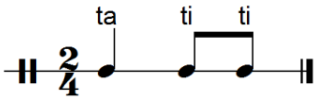

Análise complementar em $2.2-n^{\circ} 78$.

Canção com 20 compassos binários, com a indicação de andamento: Moderato $(56=\rfloor$ ); rall . a tempo; fermata; sem indicações de dinâmica.

Tema popular, folclórico infantil, de brincadeira cantada cujo desenvolvimento baseia-se no texto.

Texto - quadrinhas utilizadas em várias brincadeiras infantis, comparando a amada a um anjo.

Ritmo - o interesse rítmico está no compasso de subdivisão binária.

Melodia - baseada em arpejos das tríades de tônica e Dominante, com terminações respectivamente na $\mathrm{D}, \mathrm{t}, \mathrm{s}$, t. Em GP/ABM, falta o compasso 40, que deveria conter uma mínima.

Ludicidade - brincadeira de roda com possibilidades de encenação e criação de outras quadrinhas.

\section{2) POBRE CEGO ( $2^{\mathrm{a}}$ versão $)$ - a capella}

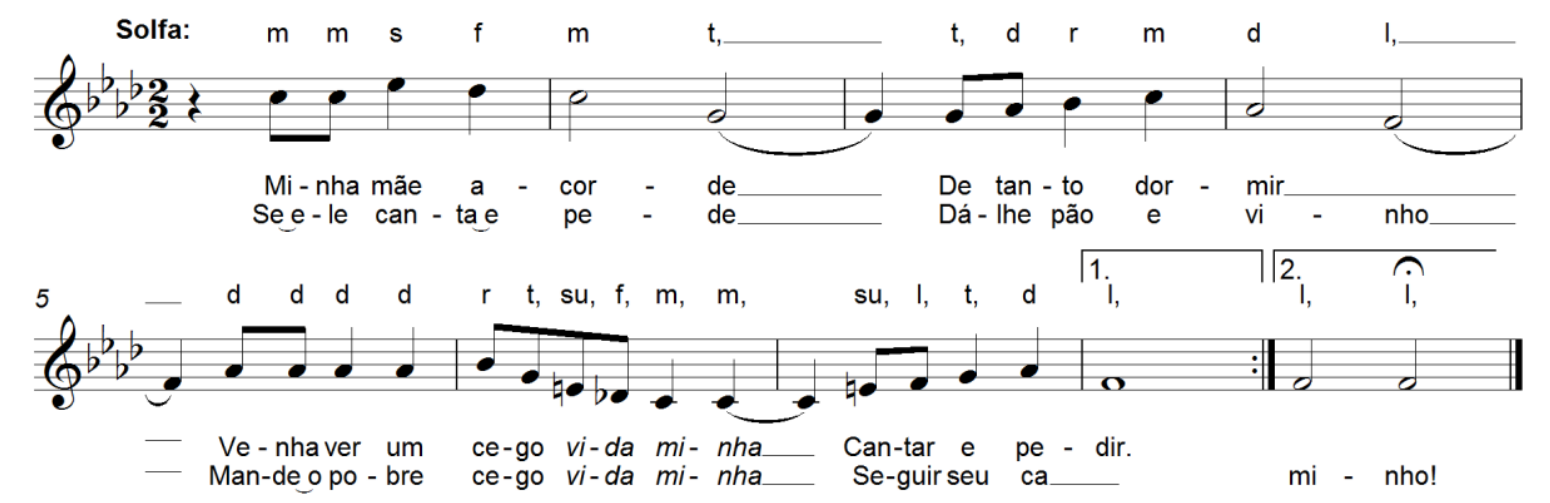

\begin{tabular}{|c|c|c|c|c|c|}
\hline Volume & № & Tessitura & $\begin{array}{c}\text { Forma - A } \\
\text { Gênero - Cantiga }\end{array}$ & $\begin{array}{l}\text { Intervalos } \\
\text { melódicos }\end{array}$ & Alterações \\
\hline GP-VTL & 97 & C3-Eb4 & Extensão: 10ạ & & $\mathrm{E}$ 曰 $=\mathrm{su}$ \\
\hline /S1 & $/ 17$ & & Graus da escala + alterações: 8 & 2a $M / m / A ;$ & \\
\hline /ABM & /44 & & $\begin{array}{c}\text { Sistema Heptatônico (Db Ab Eb Bb F C G) } \\
\text { Heptacorde [t I (su) s f m r d] }\end{array}$ & $\begin{array}{l}\text { 3a } \mathrm{M} / \mathrm{m} ; \\
\quad 4 \text { a J }\end{array}$ & \\
\hline
\end{tabular}




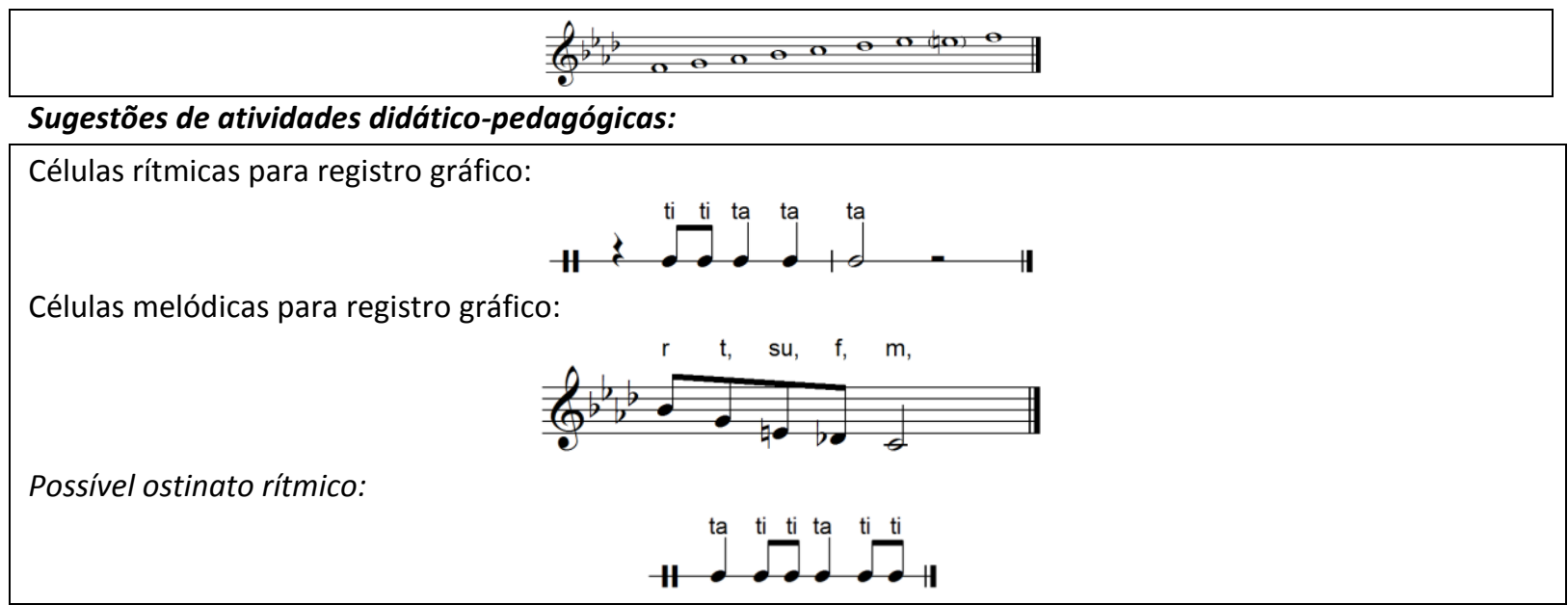

Análise complementar em $2.2-n^{\circ} 92$.

Canção com 9 compassos binários, com a indicação de andamento: Moderato (M.M. $76=d$ ); sem indicações de dinâmica.

Tema popular, folclórico, de brincadeira cantada cujo desenvolvimento baseia-se no texto. Título corrigido conforme GP/ABM ${ }^{62}$ : Pobre Cego.

Texto - Uma das versões (parcial) do romance de Aninha e o cego, com diálogo entre a filha e sua mãe a respeito do cego pedinte, com o complemento de frase "vida minha" recorrente nos terceiros versos, compondo a forma poética.

Ritmo - o interesse rítmico está no compasso com a mínima como unidade.

Melodia - duas pequenas curvas com terminação em arpejo descendente de tônica, seguidas de arpejo descendente de dominante após notas rebatidas e pequena curva finalizando descendentemente na tônica

Ludicidade - brincadeira de roda que prioriza o canto e o texto.

Complemento do texto:

Não quero teu pão, / nem também teu vinho / quero só que Aninha,/ vida minha, me ensine o caminho! Ainda mais Aninha, / mais um bocadinho, / eu sou pobre cego, vida minha, / não vejo o caminho!

\section{3) SOLFEJO $n^{\circ} 44-$ a capella}

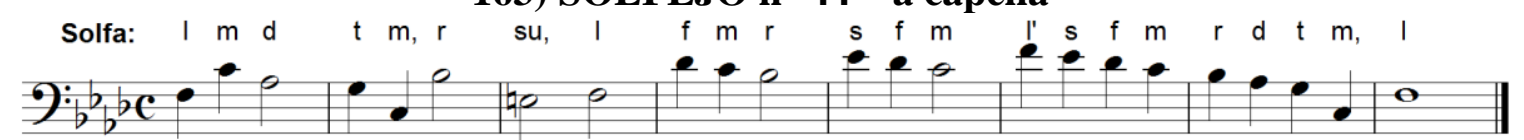

\begin{tabular}{|c|c|c|c|c|c|}
\hline $\begin{array}{c}\text { Volume } \\
\text { S1 }\end{array}$ & $\begin{array}{l}\text { № } \\
44\end{array}$ & $\begin{array}{c}\text { Tessitura } \\
\text { C2-F3 }\end{array}$ & $\begin{array}{c}\text { Forma - A } \\
\text { Extensão: } 11^{\text {a }} \\
\text { Graus da escala + alterações: } 8 \\
\text { Sistema Heptatônico (Db Ab Eb Bb F C G) } \\
\text { Heptacorde [ (su) s f m r d t l] }\end{array}$ & $\begin{array}{l}\text { Intervalos } \\
\text { melódicos } \\
\text { 2a } \mathrm{M} / \mathrm{m} / \mathrm{A} ; 3 \underline{a} \\
\mathrm{M} ; 4 \underline{\mathrm{a}} / 5 \mathrm{a} \text { J; } 5 \underline{\mathrm{a}} \\
\mathrm{D} ; 6 \underline{\mathrm{a}} \mathrm{m} ; 7 \underline{\mathrm{a}} \mathrm{m}\end{array}$ & $\begin{array}{c}\text { Alterações } \\
\text { E দ =su }\end{array}$ \\
\hline \multicolumn{6}{|c|}{ Escala - Modo de F menor } \\
\hline
\end{tabular}

Sugestões de atividades didático-pedagógicas:

${ }^{62}$ GP/ABM, Primeiro Caderno, p. 91. 
Células rítmicas para registro gráfico:

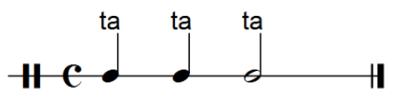

Células melódicas para registro gráfico:

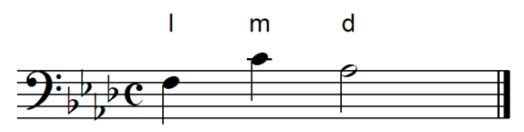

Possivel ostinato rítmico:

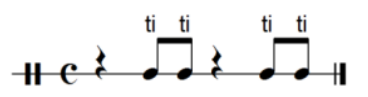

Tema de Villa-Lobos com 8 compassos quaternários sem indicações de andamento ou de dinâmica, para voz masculina.

Ritmo - o interesse rítmico está na configuração das semifrases.

Melodia - desenho inicial sobre arpejos de tônica e D e terminando da frase na subdominante; segunda frase com finalização em linha escalar descendente e terminação na tônica.

Ludicidade - um dos desafios do solfejo é a leitura na clave de F, que pode ser feita de forma relativa e absoluta.

164) SOLFEJO $n^{\circ} 61$ - a capella

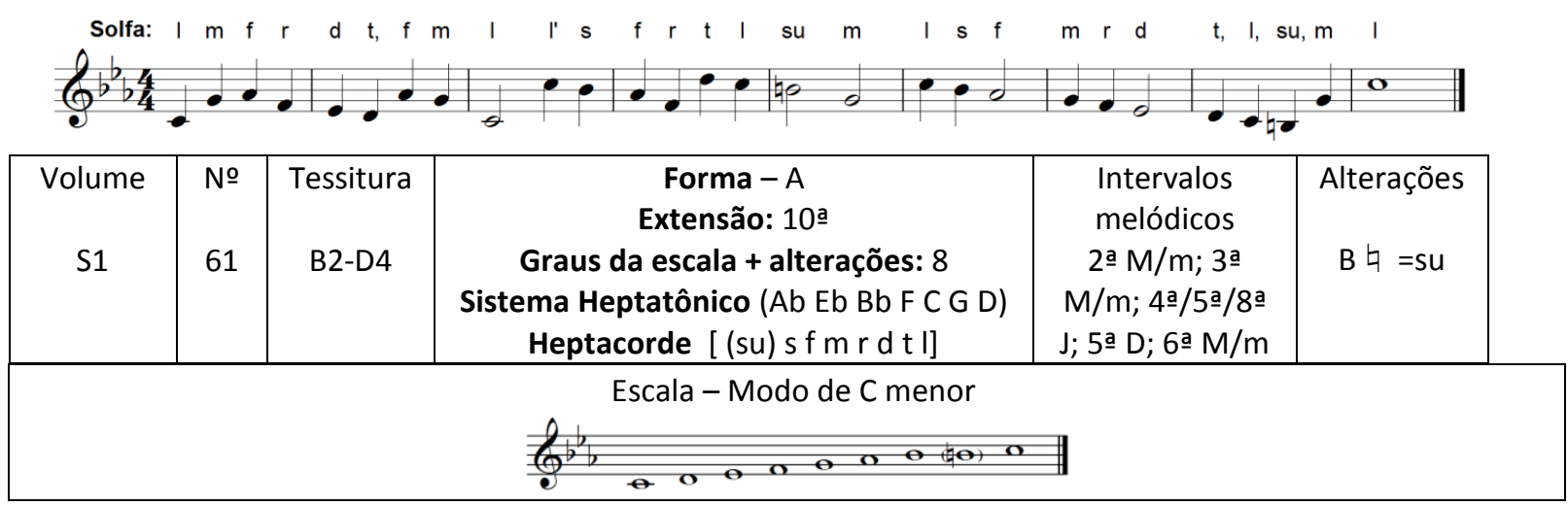

Sugestões de atividades didático-pedagógicas:

Células rítmicas para registro gráfico:

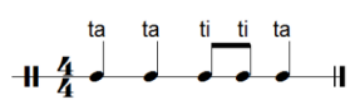

Células melódicas para registro gráfico:

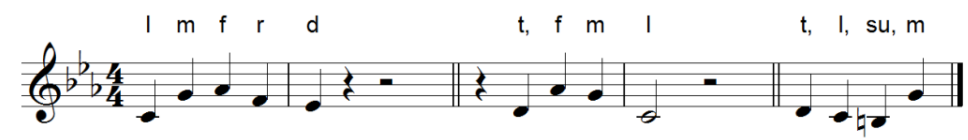

Possível ostinato rítmico:

$$
\mathbf{4} 4: \stackrel{4}{4} \cdot \text { ta ta ta }
$$

Tema de Villa-Lobos com 9 compassos quaternários, com a indicação de andamento: Dolente; sem indicações de dinâmica.

Ritmo - o interesse rítmico está nas figuras de notas longas.

Melodia - desenhos em ondulações em âmbito de $6^{\mathrm{a}} \mathrm{s}$, o segundo alcançado por $8^{\mathrm{a}}$, seguidos de linha escalar até a sensível, com terminação por saltos ascendentes de $6^{\mathrm{a}}$ e $4^{\mathrm{a}}$ para a tônica. 
Ludicidade - apesar de se tratar de um solfejo, a leitura retrogradada pode ser um desafio lúdico.

165) CARANGUEJO (primeira versão) - acompanhamento instrumental (Canto com piano, conjunto instrumental ou Piano solo)

Arr. de H.Villa-Lobos
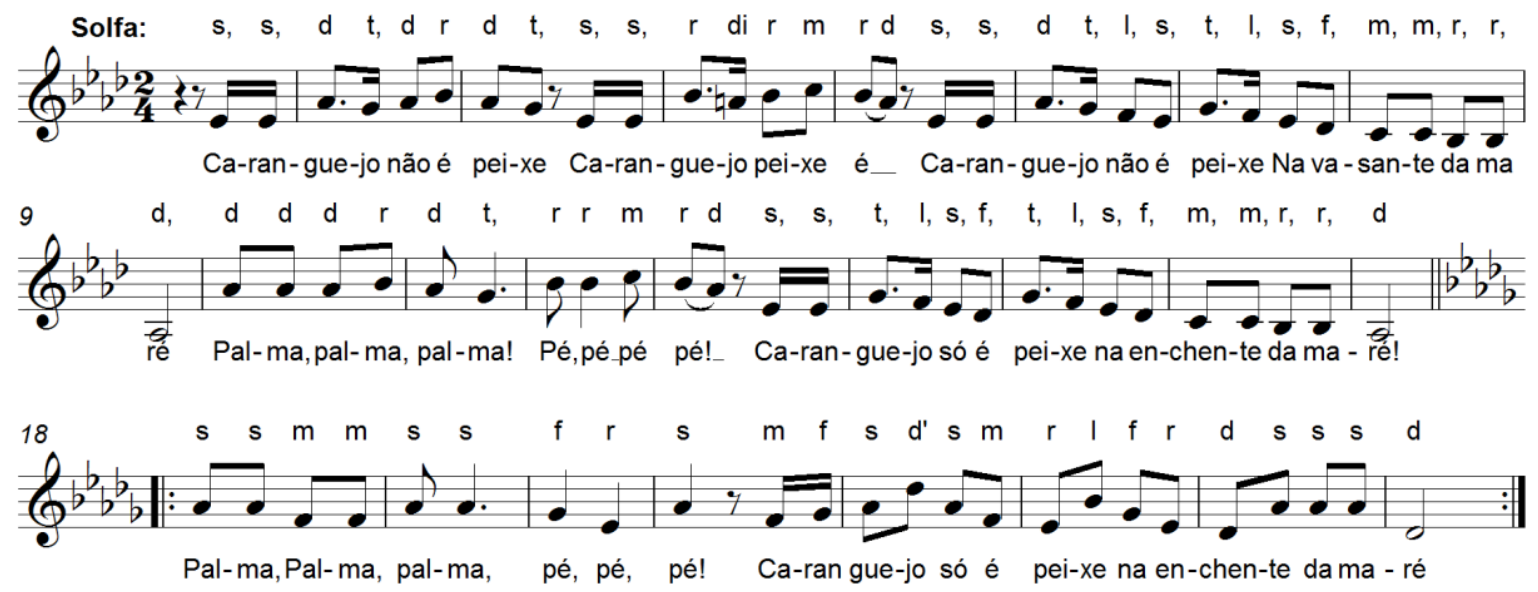

\begin{tabular}{|c|c|c|c|c|c|}
\hline $\begin{array}{l}\text { Volume } \\
\text { GP-VTL } \\
\text { /ABM }\end{array}$ & $\begin{array}{c}\text { № } \\
29 \\
\text { /126 }\end{array}$ & $\begin{array}{c}\text { Tessitura } \\
\text { Ab2-C3 }\end{array}$ & $\begin{array}{c}\text { Forma - AB } \\
\text { Gênero - Cançoneta italiana } \\
\text { Extensão: } 10^{0} \text { a } \\
\text { Graus da escala + alterações: } 8 \\
\text { Sistema Heptatônico }(\mathrm{Db} \text { Ab Eb Bb F C G)/ } \\
\text { Gb Db Ab Eb Bb F C) } \\
\text { Heptacorde [t I s f m r (di) d] }\end{array}$ & 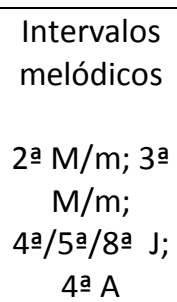 & 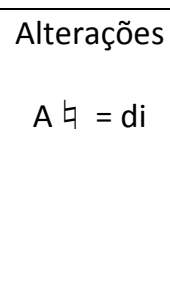 \\
\hline \multicolumn{6}{|c|}{ Escala - Modo de Ab maior / Db maior } \\
\hline
\end{tabular}

Sugestões de atividades didático-pedagógicas:

Células rítmicas para registro gráfico:

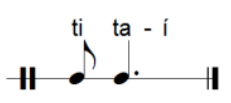

Células melódicas para registro gráfico:

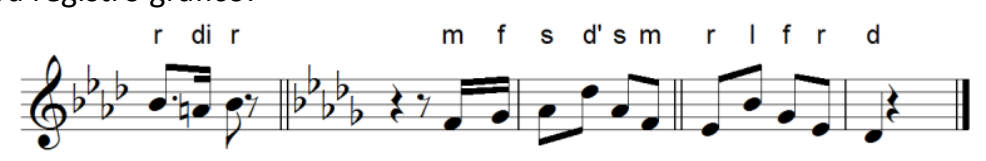

Possivel ostinato rítmico:

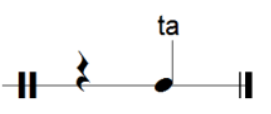

Análise complementar em $2.2-n^{\circ} 62$.

Canção com 25 compassos binários, com a indicação de andamento: Allegro $(144=c)$; indicações de dinâmica: $\boldsymbol{f}$; $\boldsymbol{m f}$; $\boldsymbol{p}$; ff acentos >

Tema popular, folclórico infantil, de brincadeira cantada cujo desenvolvimento baseia-se no texto.

Texto - cantiga de roda sobre o tema do caranguejo. 
Ritmo - o interesse rítmico está na sincopa métrica, na célula correspondente a ela com pausa, nos anacruses e nas diferentes linhas rítmicas das duas canções.

Melodia - são apresentadas duas versões melódicas para o mesmo texto, em tonalidades diferentes. A primeira melodia desenvolve-se, na primeira parte, a partir de saltos iniciais de quarta e quinta, e a finalização na $\mathrm{T}$ por linha escalar; a segunda parte varia a resposta. É possível que o autor tenha se enganado quanto ao compasso 17, que, pela lógica e pela constatação da prática dessa canção seria igual ao compasso 7. A segunda melodia (apenas o refrão) inicia-se com notas rebatidas e a resposta finaliza na $\mathrm{T}$ por salto descendente de quinta (D), após arpejos de S e T. Em GP/ABM, não consta uma fermata no compasso 36, no segundo pulso. Faltam ligaduras no penúltimo compasso.

Acompanhamento instrumental (piano) - introdução em pedal no primeiro grau na mão direita e ostinato rítmico a ser utilizado na primeira melodia na mão esquerda. A melodia é dobrada pela mão direita. A segunda melodia, em nova tonalidade, é dobrada na mão direita, com os acordes distribuídos entre as duas mãos. A codeta repete a introdução com pedal em terça maior harmônica da $\mathrm{T}$ para o ritornello. A coda é a codeta acrescida de um compasso, com o final no primeiro grau.

Ludicidade - brincadeira de roda, com imitação dos movimentos laterais do caranguejo e demais movimentos sugeridos pelo texto.

166) VOCÊ DIZ QUE SABE TUDO - acompanhamento instrumental

(Canto com piano ou conjunto instrumental)

Amb. por H.Villa-Lobos

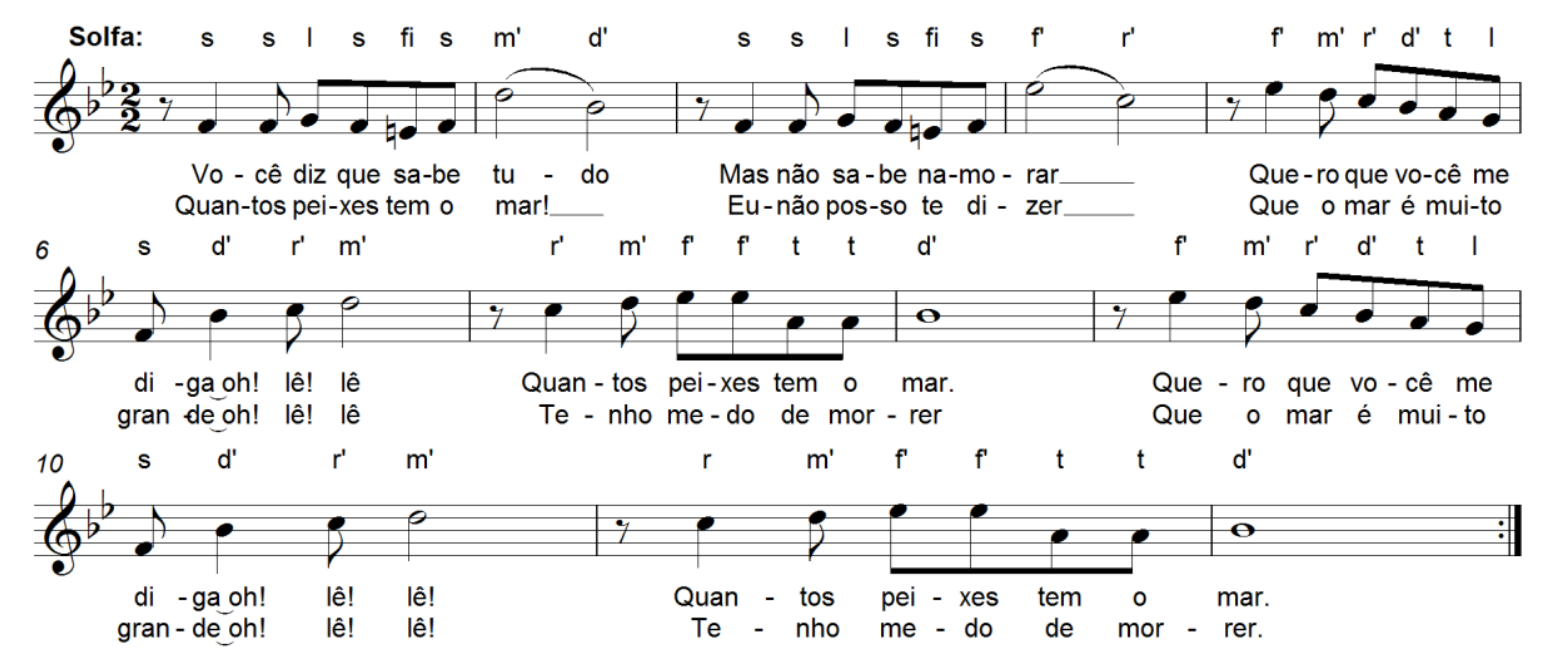

\begin{tabular}{|c|c|c|c|c|c|}
\hline $\begin{array}{l}\text { Volume } \\
\text { GP-VTL } \\
\text { /ABM }\end{array}$ & $\begin{array}{l}\text { № } \\
136 \\
\text { /81 }\end{array}$ & $\begin{array}{l}\text { Tessitura } \\
\text { F3-Eb4 }\end{array}$ & $\begin{array}{c}\text { Forma - A } \\
\text { Gênero - Lundu } \\
\text { Extensão: 7ạ } \\
\text { Graus da escala + alterações: } 9 \\
\text { Sistema Heptatônico (Eb Bb F C G D A) } \\
\text { Heptacorde [t I s (fi) f m r d] }\end{array}$ & 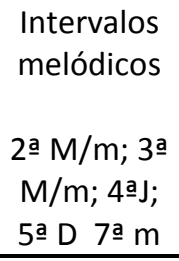 & 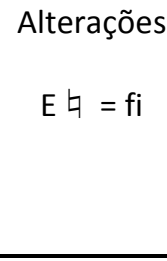 \\
\hline \multicolumn{6}{|c|}{ Escala - Modo de Bb maior } \\
\hline
\end{tabular}

Sugestões de atividades didático-pedagógicas:

Células rítmicas para registro gráfico: 


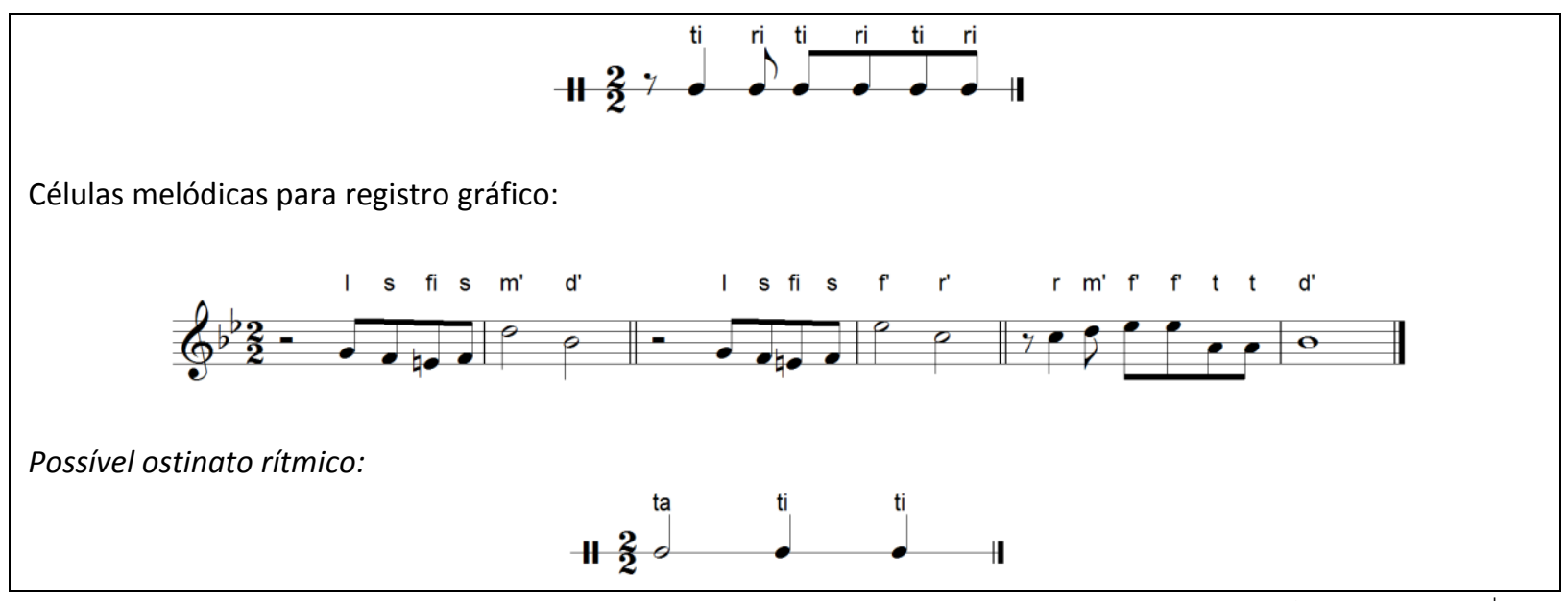

Canção com 12 compassos binários, com a indicação de andamento: Moderato $(\mathbf{8 8}=\mathrm{J})$; Lento; Vagaroso; Fermata ; affret. - - - rall.; indicações de dinâmica: $\boldsymbol{m f}$; $\boldsymbol{p}$; acentos

Tema popular, folclórico infantil, de brincadeira cantada cujo desenvolvimento baseia-se no texto.

Texto - descrição de brincadeira de roda em que há um diálogo com a personagem e os demais participantes. Forma em que o último verso torna-se o primeiro verso da nova estrofe.

Ritmo - o interesse rítmico está nas síncopas e notas longas.

Melodia - desenho em curva com grupetto inicial e salto de sexta ascendente e terça descendente (sétima e terça na repetição), seguido de linha descendente escalar e ascendente sexta acima, com a conclusão por salto descendente para a sensível e resolução na T.

Acompanhamento instrumental (piano) - introdução em linha escalar descendente por duas oitavas em terças, com terminação na $\mathrm{S}, \mathrm{s}^{7-} \mathrm{D}^{6-} \mathrm{D}$. A melodia é dobrada pela mão direita com acompanhamento harmônico nas duas mãos. A coda tem apenas um compasso com terminação em uníssono no primeiro grau. Em GP/ABM, no penúltimo compasso, na mão direita os três acordes deveriam ter as notas: $\boldsymbol{A} \boldsymbol{b}, \boldsymbol{B} \boldsymbol{b}, \boldsymbol{D} / \boldsymbol{G} \boldsymbol{C} \boldsymbol{E} \boldsymbol{b} / \boldsymbol{F} \boldsymbol{B} \boldsymbol{b} \boldsymbol{D} \boldsymbol{F}$.

Ludicidade - brincadeira de roda com diálogo e encenação.

\section{7) SOLFEJO $\mathbf{n}^{\circ} 1$ (Ditado) - a capella}
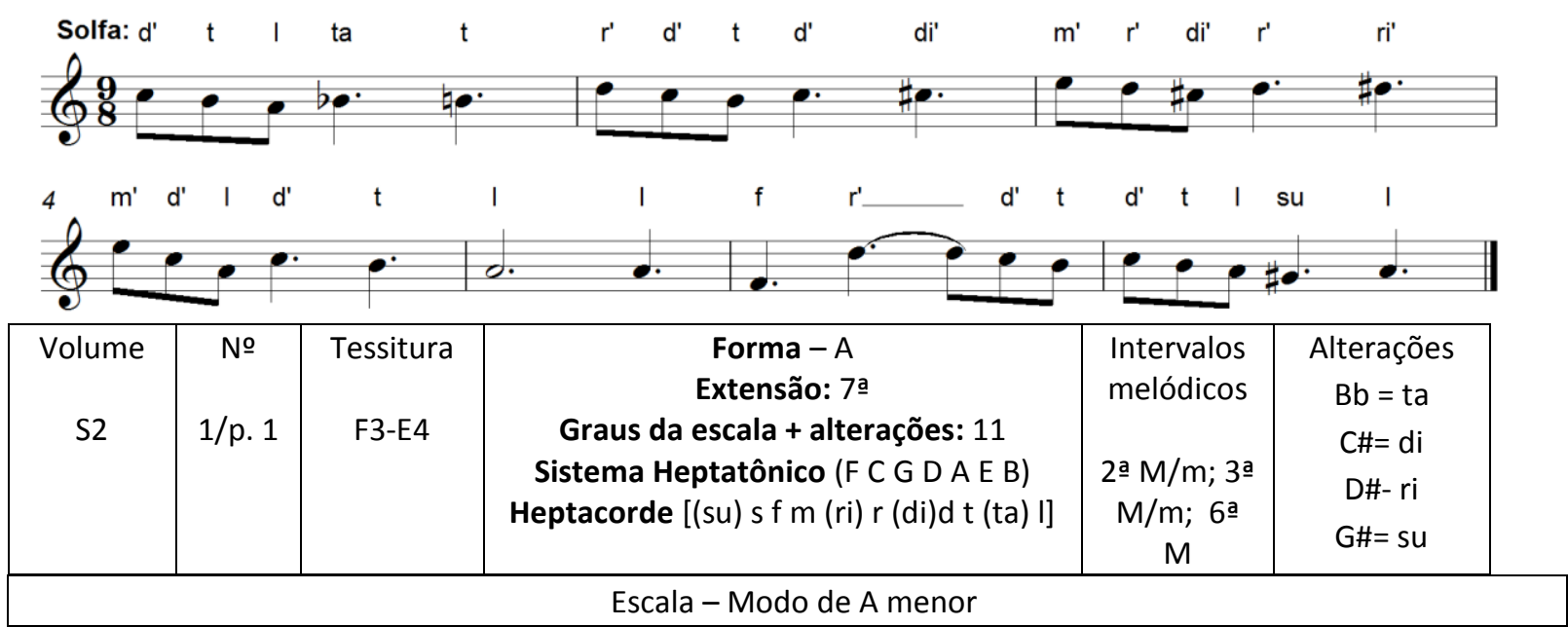


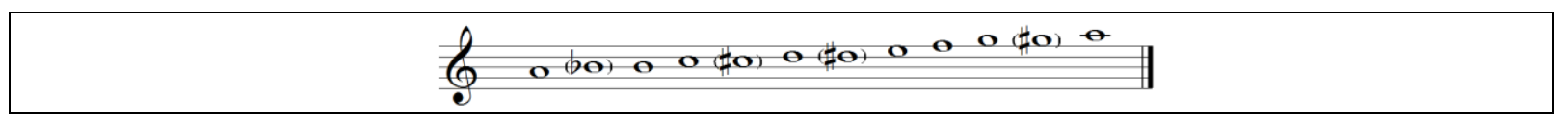

Sugestões de atividades didático-pedagógicas:

Células rítmicas para registro gráfico:

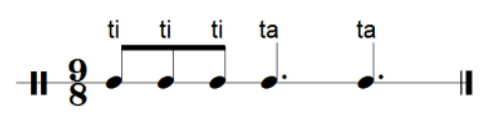

Células melódicas para registro gráfico:

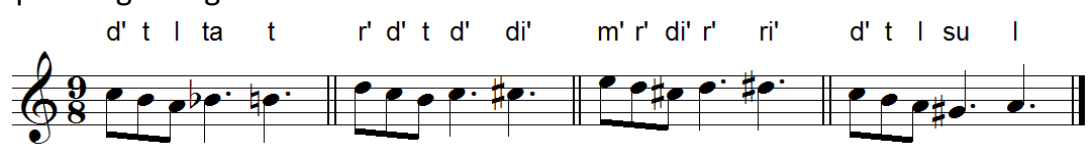

Possivel ostinato rítmico:

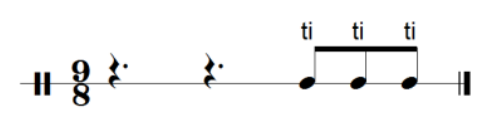

Tema de Villa-Lobos com 7 compassos ternários com subdivisão ternária, com a indicação de andamento: Andantino; sem indicações de dinâmica.

Ritmo - o interesse rítmico está no compasso ternário e subdivisão ternária. Frase assimétrica com 3,2 e 2 compassos.

Melodia - motivo inicial em âmbito de terça com cromatismo ascendente, repetido duas vezes em sequência ascendente por grau conjunto. Novo desenho sobre arpejo descendente da tríade de tônica e terça cheia resolvendo também na tônica. Desenho final na subdominante com finalização $\mathrm{D} / \mathrm{t}$ por linha descendente em terças cheias. As alterações são de cromatismo ornamental na primeira frase e estrutural na segunda (sétimo grau).

Ludicidade - o desafio principal do solfejo é o cromatismo, que pode ser trabalhado com jogos de associação com trechos de outras melodias, por exemplo.

\section{8) CACHORRINHO - acompanhamento instrumental}

(Canto com piano, conjunto instrumental ou Piano solo)

Amb. por H.Villa-Lobos

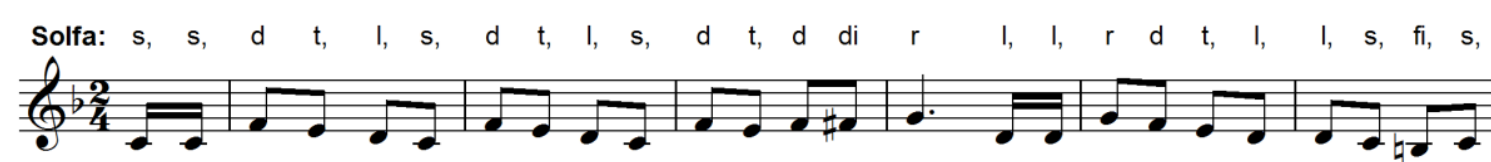

Ca-chor - ri nho es-tá la - tin-do Lá no fun-do do quin - tal, Ca-la a bo-ca ca-chor - ri-nho Dei-xa

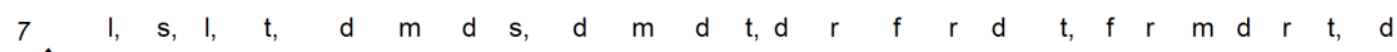

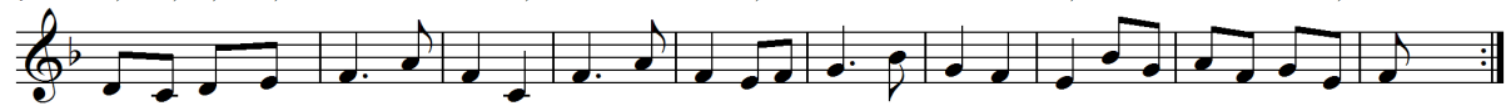

meu ben-zi-nho en-trar Cri - ou-la, lá! Cri - ou-lá lá! lá! Cri - ou-la lá! Não sou eu que cai - o lá

\begin{tabular}{|c|c|c|c|c|c|}
\hline $\begin{array}{l}\text { Volume } \\
\text { GP-VTL } \\
\text { /ABM }\end{array}$ & $\begin{array}{l}\text { № } \\
18 \\
/ 68\end{array}$ & $\begin{array}{l}\text { Tessitura } \\
\text { B2-Bb3 }\end{array}$ & $\begin{array}{c}\text { Forma - AB } \\
\text { Gênero - Polca } \\
\text { Extensão: } \text { 8a }^{\text {Ex }} \\
\text { Graus da escala + alterações: } 9 \\
\text { Sistema Heptatônico (Bb F C G D A E) } \\
\text { Heptacorde [t I s (fi) f m r (di)d] }\end{array}$ & $\begin{array}{l}\text { Intervalos } \\
\text { melódicos } \\
\text { 2a M/m; 3ạ } \\
\mathrm{M} / \mathrm{m} ; 4 \text { a J } \\
\text { / 5ㅁ D }\end{array}$ & $\begin{array}{l}\text { Alterações } \\
\text { F\#=di; B } \emptyset=f i\end{array}$ \\
\hline \multicolumn{6}{|c|}{ Escala - Modo de F maior } \\
\hline
\end{tabular}

Sugestões de atividades didático-pedagógicas: 
Células rítmicas para registro gráfico:

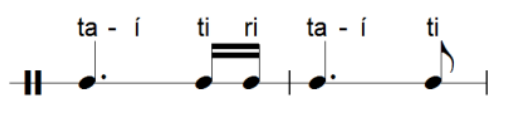

Células melódicas para registro gráfico:

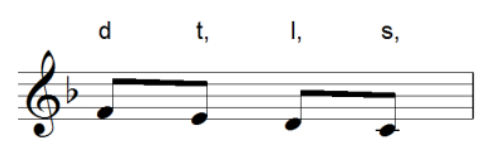

Possivel ostinato rítmico:

$$
\text { H. } \stackrel{\text { ti }}{\text { ti }} \cdot \text { ta }
$$

Canção com 17 compassos binários, com a indicação de andamento: Tempo de marcha (M.M. 138=ل ); indicações de dinâmica: $\boldsymbol{f} ; \boldsymbol{f f} ; \boldsymbol{p p} ; \boldsymbol{m f} ;\langle<>$; Acentos $>$

Tema popular, folclórico infantil, de brincadeira cantada cujo desenvolvimento baseia-se no texto.

Texto - quadrinhas populares com refrão.

Ritmo - o interesse rítmico está nos motivos anacrúsicos e figuras pontuadas.

Melodia - primeira parte: dois tetracordes descendentes alcançados por salto ascendente, seguidos de desenho ascendente com terminação na $S$; sequiência do primeiro motivo, grau conjunto acima, seguida de linha descendente para a Tônica. Segunda parte: arpejo da T, em seguida da $\mathrm{D}^{7}$, com terminação descendente em terças quebradas na $\mathrm{T}$.

Acompanhamento instrumental (piano) - notas graves (quinto grau) rebatidas continuam em pedal na mão direita enquanto a esquerda apresenta um ostinato que se repetirá nos primeiros compassos da melodia. Esta é dobrada na mão direita com acordes, enquanto a esquerda faz contraponto em oitavas. Nos três últimos compassos a mão esquerda dobra a mão direita, com acentos, confere novo timbre para a finalização na T. A introdução propõe uma cadência de engano. A movimentação constante da mão esquerda pode sugerir a algazarra do cachorro. Em GP/ABM, no compasso 7, na mão esquerda, faltam bequadros na última colcheia e, por conseqüência, bemóis na primeira colcheia do compasso 8 . No compasso 12 , deve ser eliminada a nota fundamental do primeiro acorde (que deve ser tocada pela mão esquerda). No compasso 15, o último acorde deve ter as notas $\boldsymbol{F} \boldsymbol{B} \boldsymbol{b} \boldsymbol{D} \boldsymbol{F}$. No compasso 19 falta um bemol na nota $\boldsymbol{G}$ na quarta colcheia.

Ludicidade - brinquedo de roda com dança no refrão.

Complemento do texto ${ }^{63}$ :

Cachorrinho está latindo / no fundo do quintal, / cala a boca cachorrinho, / deixa meu benzinho entrar.

Refrão: Crioula-lá, / Crioula-lá-lá / Crioula-lá-lá / não sou eu que caio lá.

Meu potinho de melado / minha cesta de cará / quem quiser comer mingau / feche a porta e venha cá. Atirei um cravo n'água / de pesado foi ao fundo / os peixinhos responderam / viva D. Pedro II.

169) ACORDEI DE MADRUGADA ( ${ }^{\mathrm{a}}$ versão $)$ - a capella

${ }^{63}$ GP/ABM - $2^{\circ}$ Caderno, p. 108 e 118. 


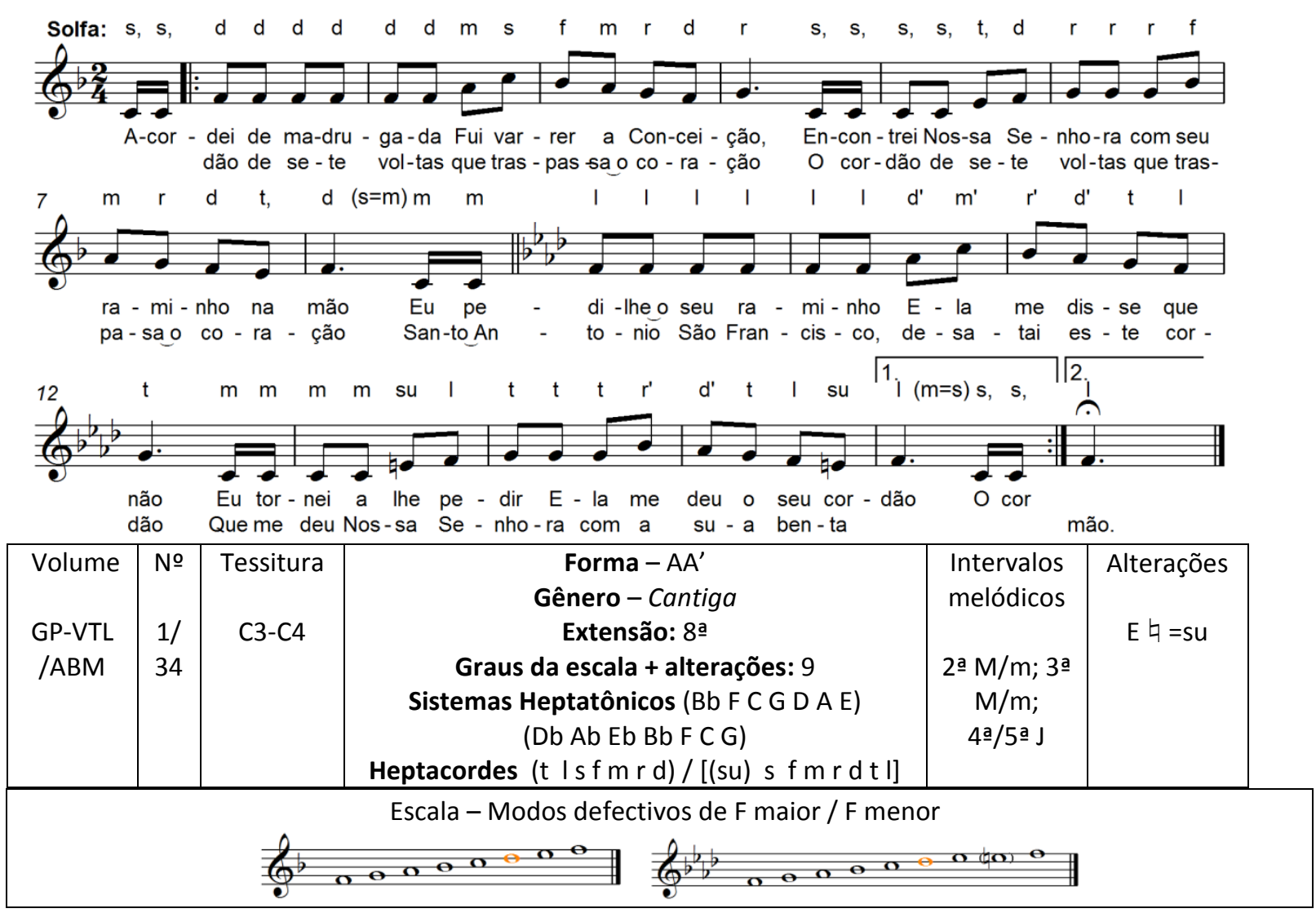

Sugestões de atividades didático-pedagógicas:

Células rítmicas para registro gráfico:

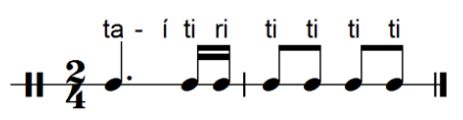

Células melódicas para registro gráfico:

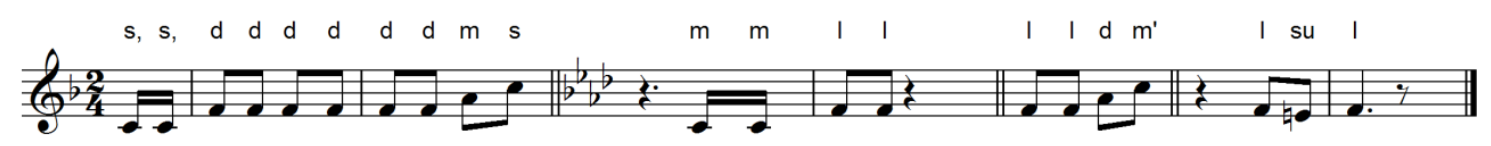

Possivel ostinato rítmico:

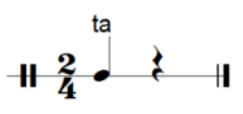

Análise complementar em $2.2-n^{\circ} 6$.

Canção com 18 compassos binários, com a indicação de andamento: Moderato (69= ل ); sem indicações de dinâmica.

Tema popular, folclórico infantil, de brincadeira cantada cujo desenvolvimento baseia-se no texto.

Texto - religioso, católico, o texto trata da lavagem tradicional de igrejas, especialmente na Bahia, e descreve um diálogo com Nossa Senhora, que presenteia o personagem com seu cordão de sete voltas. Santo Antônio e São Francisco são invocados para desatar o cordão. O modo menor da segunda parte está reservado às referências aos santos.

Ritmo - o interesse rítmico está nos motivos anacrúsicos. 
Melodia - a melodia começa com notas rebatidas e arpejo da tríade da $\mathrm{T}$ e pentacorde descendente com final na $\mathrm{D}$; curva em âmbito de sétima, na $\mathrm{D}$, com pentacorde descendente com final na T. Na segunda parte idem, com mudança do modo maior para o modo menor.

Ludicidade - acalanto, a canção pode sugerir várias ações lúdicas com acessórios como bonecas, etc.

\section{0) SOLFEJO $n^{\circ} 51$ - a capella}

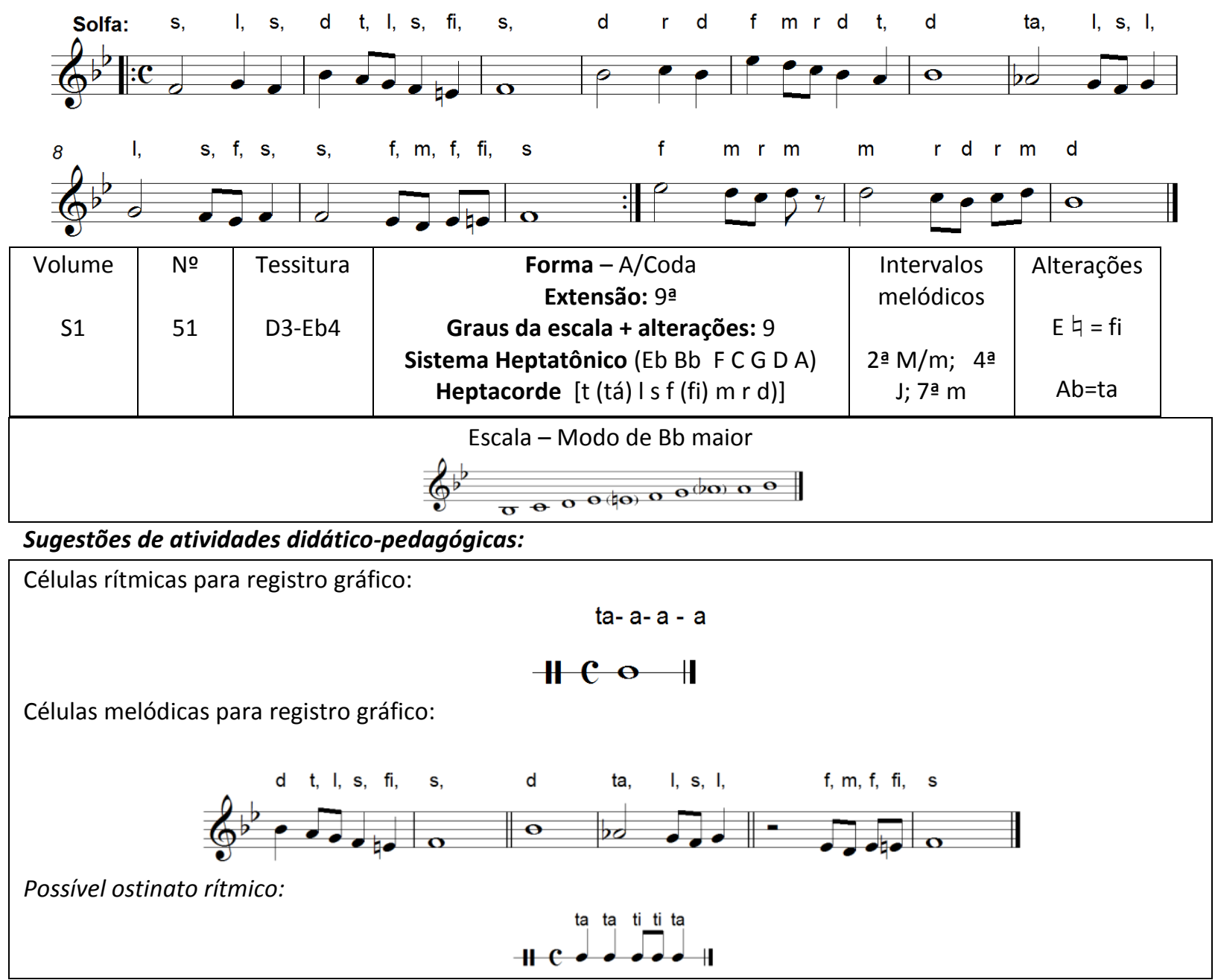

Tema de Villa-Lobos com 13 compassos quaternários, com a indicação de andamento: Poco Allegro; sem indicações de dinâmica.

Ritmo - o interesse rítmico está nas notas longas.

Melodia - pequena curva em torno do $5^{\circ}$ grau, repetida em sequência em torno do $1^{\circ}$ grau $\left(4^{\mathrm{a}}\right.$ acima) seguida de linha descendente ornamentada com bordaduras, alcançada por $4^{\text {a }}$ ascendente com terminação no grau inicial $\left(5^{\circ}\right)$; final em coda com sequência descendente por grau conjunto com dois desenhos com bordaduras chegando à $\mathrm{T}$.

Ludicidade - o solfejo possibilita o treinamento de percepção e entoação de segundas maiores e menores, e para tanto devem ser criadas propostas lúdicas. 
171) A VELHA QUE TINHA NOVE FILHAS - acompanhamento instrumental

(Canto com piano, conjunto instrumental ou Piano solo)

Amb. por H.Villa-Lobos
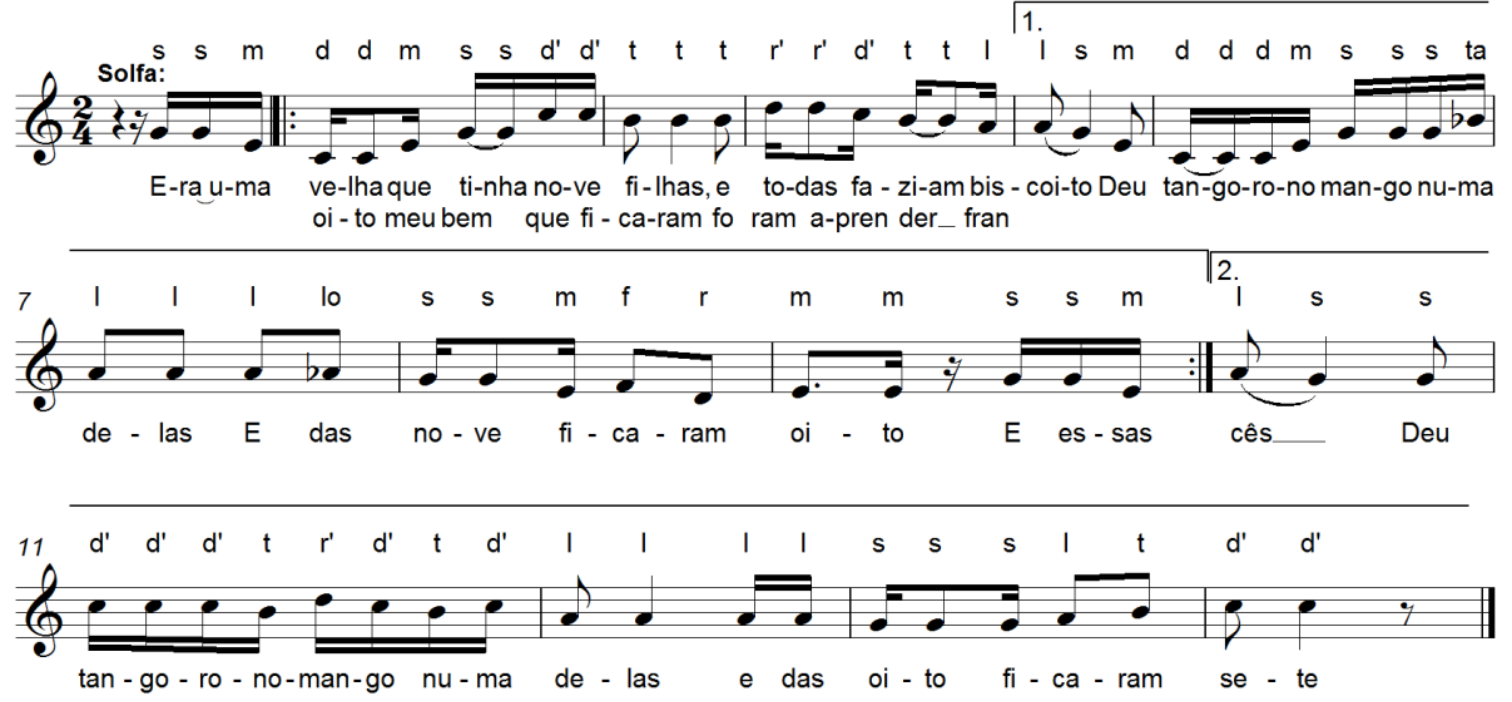

\begin{tabular}{|c|c|c|c|c|c|}
\hline $\begin{array}{c}\text { Volume } \\
\text { GP-VTL } \\
\text { /ABM }\end{array}$ & $\begin{array}{l}\text { № } \\
129 \\
\text { /86 }\end{array}$ & $\begin{array}{c}\text { Tessitura } \\
\text { C3-D4 }\end{array}$ & $\begin{array}{c}\text { Forma - A } \\
\text { Gênero - Samba canção } \\
\text { Extensão: 9ạ } \\
\text { Graus da escala + alterações: } 9 \\
\text { Sistema Heptatônico (F C G D A E B) } \\
\text { Heptacorde }[\mathrm{t}(\mathrm{ta}) \text { I s f m r d] }\end{array}$ & $\begin{array}{l}\text { Intervalos } \\
\text { melódicos } \\
\text { 2a } \mathrm{M} / \mathrm{m} ; 3 \text { ạ } \\
\mathrm{M} / \mathrm{m} ; \\
\text { 4ㅁaㄷa J }\end{array}$ & $\begin{array}{l}\text { Alterações } \\
\qquad \text { Bb=ta }\end{array}$ \\
\hline \multicolumn{6}{|c|}{ Escala - Modo de C maior } \\
\hline & & & 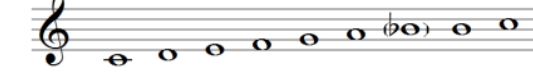 & & \\
\hline
\end{tabular}

Sugestões de atividades didático-pedagógicas:

Células rítmicas para registro gráfico:

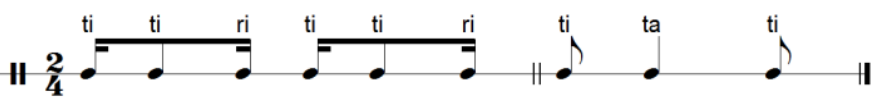

Células melódicas para registro gráfico:

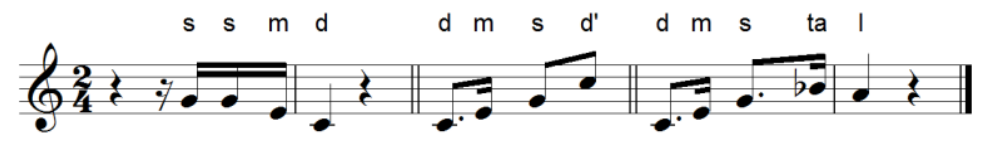

Possivel ostinato rítmico:

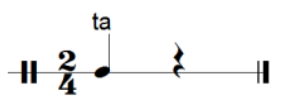

Canção com 30 compassos binários, com a indicação de andamento: Allegro non Troppo $(108=c$ ); Em tempo absoluto; indicações de dinâmica: $\boldsymbol{m f}$; acentos >

Tema popular, folclórico infantil, de brincadeira cantada cujo desenvolvimento baseia-se no texto.

Texto - história acumulativa da velha que tinha nove filhas e, uma a uma, desaparecem na brincadeira. GP/ABM apresenta o texto completo, enquanto que em GP/VTL está incompleto, apresentando, inclusive, na terceira estrofe, a rima para "seis": "batata"!

Ritmo - o interesse rítmico está nas síncopas e semicolcheias.

Melodia - desenhos que se caracterizam pelos inícios em arpejos com conclusões ora ascendentes ora descendentes sobre S, D e T. 
Acompanhamento instrumental (piano) - a introdução apresenta linha descendente com o arpejo da $\mathrm{T}$ em notas rebatidas, terminando na DD e cromatismo na mediante da S. A melodia é dobrada pela mão direita, com uma voz intermediária em contraponto com síncopas e ritmo regular, enquanto a mão esquerda estabelece outra voz com contraponto em ritmo regular com algumas tercinas, em saltos em sua maioria de décimas. A coda tem dois compassos, com terminação em uníssono com quinto e primeiro graus.

Ludicidade - canção acumulativa, que por si só é lúdica, pode ser realizada em roda, ou outras possibilidades, segundo o texto.

Complemento do texto ${ }^{64}$

Era uma velha que tinha nove filhas / e todas faziam biscoito / deu tangoronomango numa delas / e das nove ficaram oito.

E essas oito meu bem que ficaram / foram jogar três-sete / deu tangoronomango numa delas / e das oito ficaram sete.

E essas sete meu bem que ficaram / foram aprender francês / deu tangoronomango numa delas / e das sete ficaram seis.

E essas seis meu bem que ficaram / foram fabricar brinco / deu tangoronomango numa delas / e das seis ficaram cinco.

E essas cinco meu bem que ficaram / foram jogar o taco / deu tangoronomango numa delas / e das cinco ficaram quatro.

E essas quatro meu bem que ficaram / foram para o xadrez / deu tangoronomango numa delas / e das quatro ficaram três.

E essas três meu bem que ficaram / foram correr as ruas / deu tangoronomango numa delas / e das três ficaram duas.

E essas duas meu bem que ficaram / foram pra Inhauma / deu tangoronomango numa delas / e das duas ficou só uma.

E essa uma, meu bem que ficou / foi parar na correção / deu tangoronomango nela / e acabou-se a geração.

172) SOLFEJO $n^{\circ} 136$ - a capella

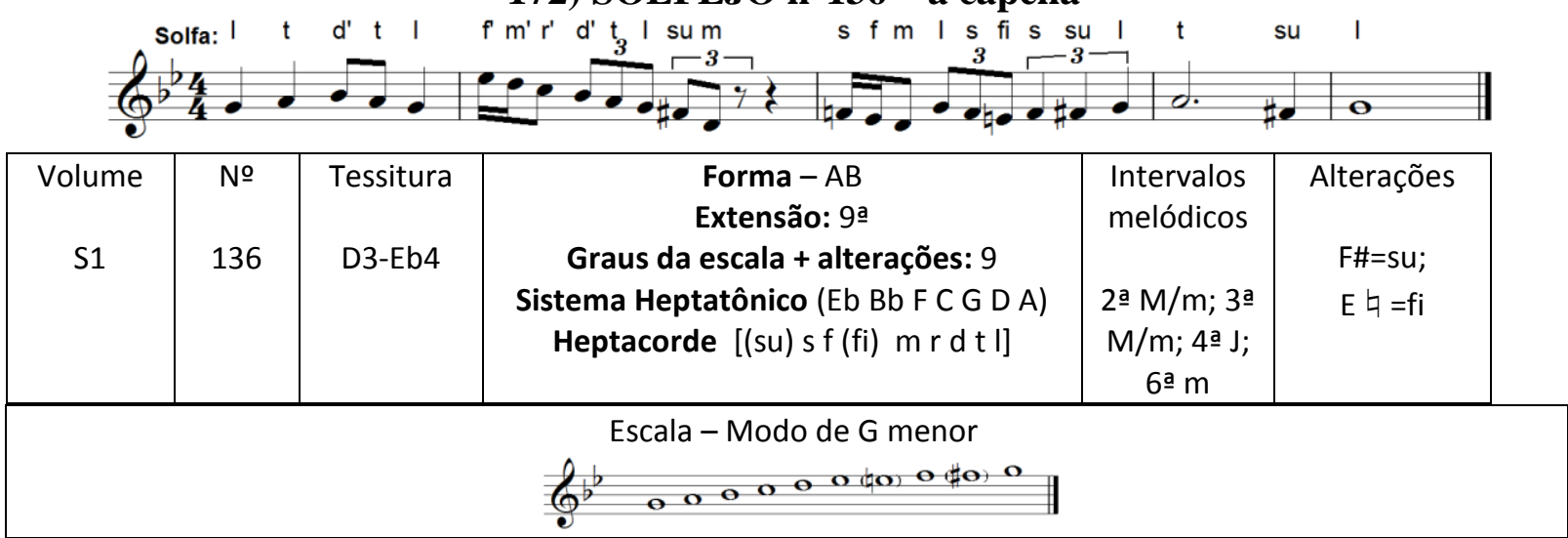

Sugestões de atividades didático-pedagógicas:

Células rítmicas para registro gráfico:

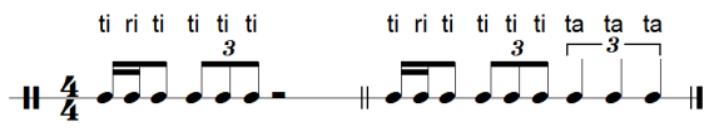

Células melódicas para registro gráfico:

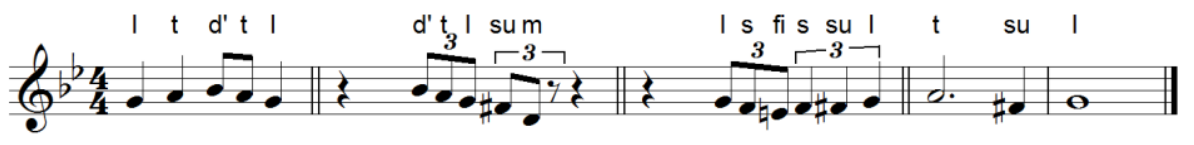

${ }^{64} \mathrm{GP} / \mathrm{ABM}-2^{\circ}$ Caderno, p. 110 e 123/124. 
Possivel ostinato rítmico:

$$
114: \text { : } 4 \text { : I }
$$

Tema de Villa-Lobos com 5 compassos quaternários, sem indicações de andamento ou dinâmica.

Ritmo - o interesse rítmico está nas tercinas (métrica e de pulso) e grupos com semicolcheias.

Melodia - curva inicial partindo da tônica para a S e D em linha escalar descendente, seguida de pequena curva com final na tônica.

Ludicidade - apesar de se tratar de um solfejo, a própria linha rítmica rica em polirritmia é um desafio lúdico.

\section{3) FELIZ ANO NOVO - a capella}
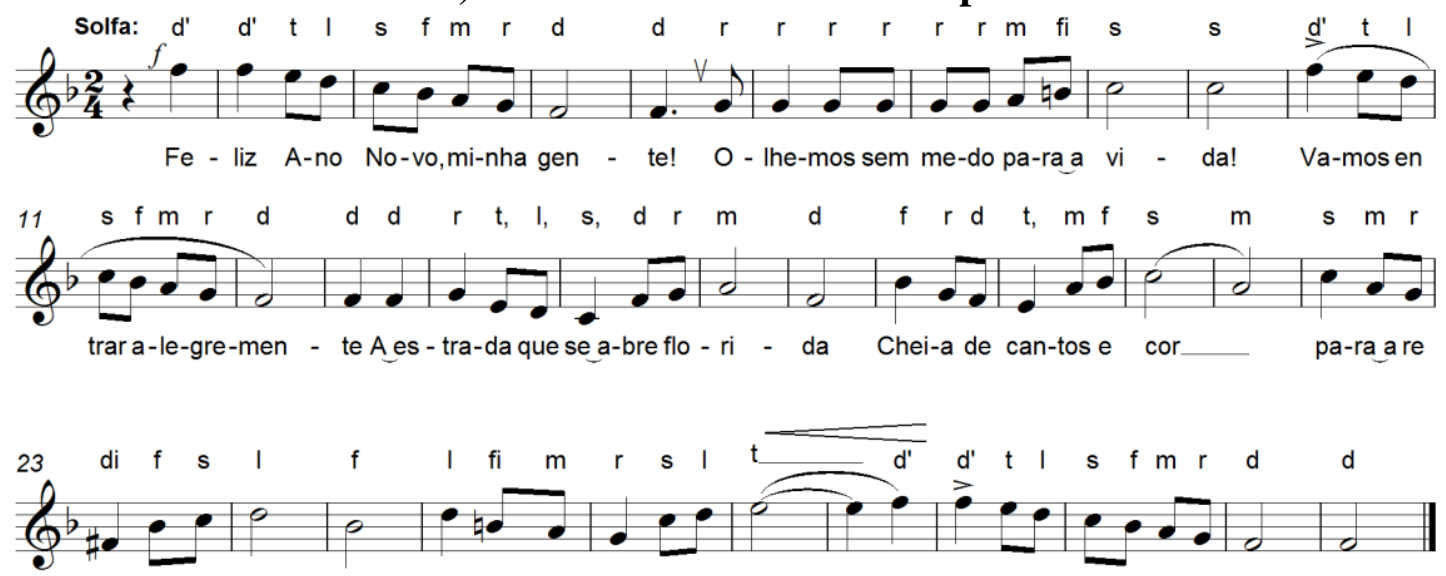

gião pro-me - ti - da, so-nho de ummun-do me- Ihor!___ Fe - liz A-no No-vo to-da gen - te

\begin{tabular}{|c|c|c|c|c|c|}
\hline $\begin{array}{c}\text { Volume } \\
\text { CO2 }\end{array}$ & $\begin{array}{l}\text { № } \\
11\end{array}$ & $\begin{array}{c}\text { Tessitura } \\
\text { C3-F4 }\end{array}$ & $\begin{array}{c}\text { Forma - AB } \\
\text { Extensão: } 11 \underline{\text { a }} \\
\text { Graus da escala + alterações: } 9 \\
\text { Sistema Heptatônico (Bb F C G D A E) } \\
\text { Heptacorde [t I s (fi) f m r (di)d] }\end{array}$ & $\begin{array}{l}\text { Intervalos } \\
\text { melódicos } \\
\text { 2aㅡ M/m; 3ạ } \\
\mathrm{M} / \mathrm{m} ; 4 \text { a j }\end{array}$ & $\begin{array}{l}\text { Alterações } \\
\text { B } 甘=f i ; F \#=d i\end{array}$ \\
\hline \multicolumn{6}{|c|}{ Escala - Modo de F maior } \\
\hline
\end{tabular}

Sugestões de atividades didático-pedagógicas:

Células rítmicas para registro gráfico:

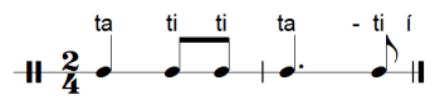

Células melódicas para registro gráfico:

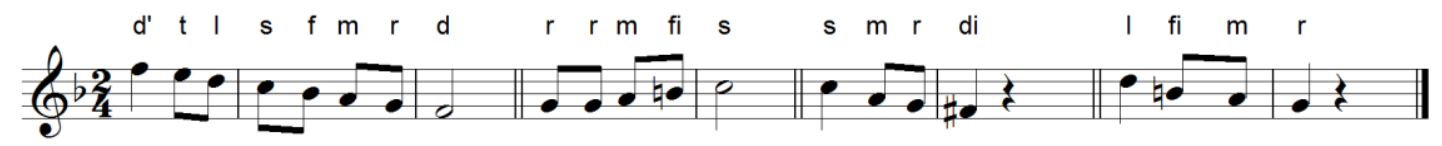

Possivel ostinato rítmico:

$\| \underset{\mathbf{2}}{\mathbf{4}} \cdot \stackrel{\text { ta }}{\boldsymbol{H}} \boldsymbol{H}$

Análise complementar em 2.2 - no 179. 
Canção com 33 compassos binários, com a indicação de andamento: Allegro Vivace; poco allarg.; indicações de dinâmica: $\boldsymbol{f}$; Cresc. anim. ; < ; Acento >

Tema de passagem de ano, com letra de Manuel Bandeira e música e harmonização de H.Villa-Lobos, datada de 1945 - Rio de Janeiro.

Texto - poesia bem construída; consiste em canto de otimismo frente ao novo ano.

Ritmo - o interesse rítmico está no compasso binário e sua subdivisão.

Melodia - a frase inicial, em escala maior descendente, cita o início da melodia Antioch, de G.F. Haendel utilizada para canto natalino. Após a linha escalar descendente, a resposta se dá por notas rebatidas e chega à D passando pela DD por graus conjuntos; após a segunda escala, seguem-se sequências ascendentes para chegar à sensível para retomar a última escala descendente que conclui a peça (essa frase inicia-se com a palavra "Feliz" - com difícil emissão das vogais e/i na altura de $\boldsymbol{F} 4$ ),

Ludicidade - peça para ocasião festiva, portanto lúdica.

174) SOLFEJO $n^{\circ} 43$ - a capella

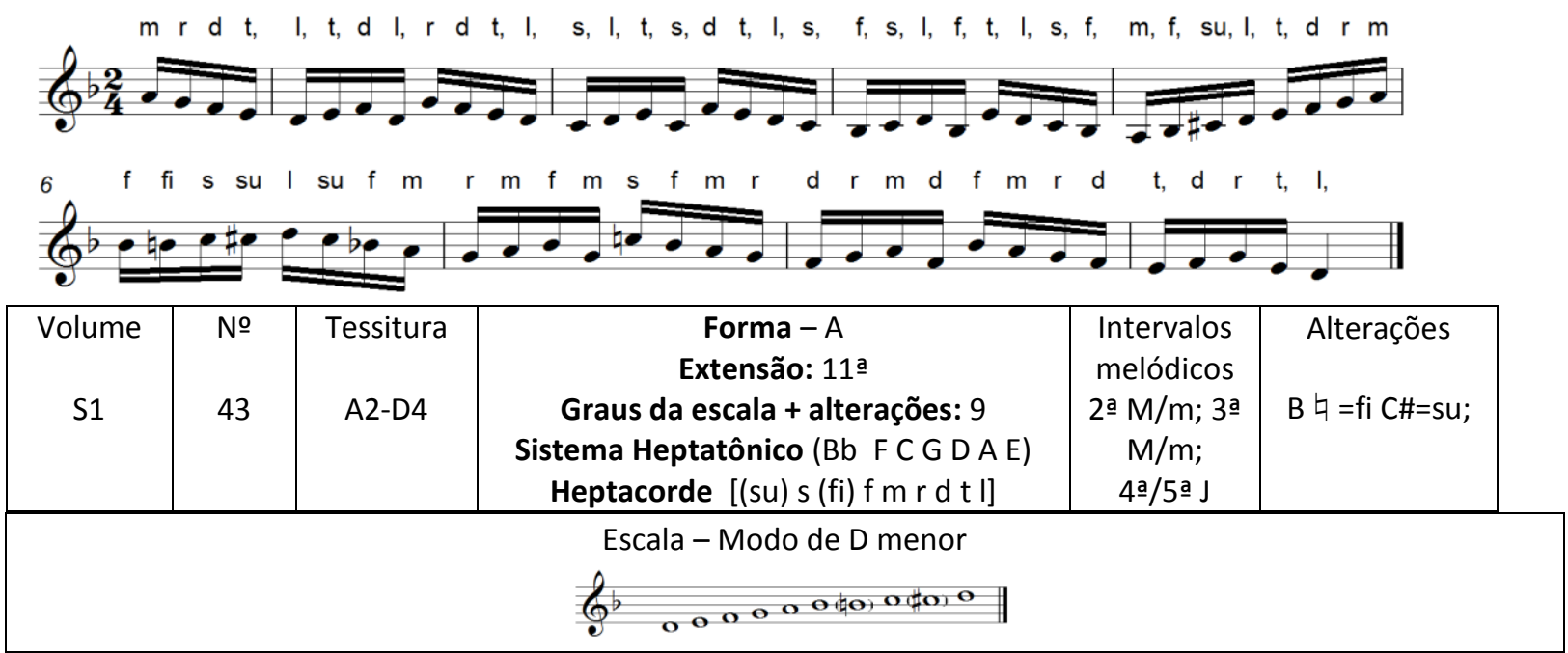

Sugestões de atividades didático-pedagógicas:

Células rítmicas para registro gráfico:

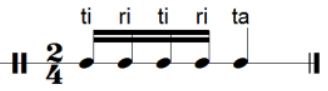

Células melódicas para registro gráfico:

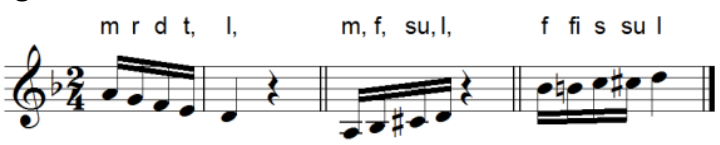

Possivel ostinato rítmico:

$$
\| \underset{\mathbf{2}}{\mathbf{t a}} \cdot \stackrel{\text { ti }}{\text { ti }} \cdot \mathbf{\cdot}
$$

Tema de Villa-Lobos com 9 compassos binários, sem indicações de andamento ou dinâmica.

Ritmo - o interesse rítmico está síncopas seguidas de notas longas. 
Melodia - moto contínuo como o motivo inicial repetido quatro vezes por sequência descendente em graus conjuntos, seguido de linha ascendente escalar - com cromatismo no último pulso, para retomada do mesmo motivo por sequência descendente, por três vezes com terminação na $\mathrm{T}$.

Ludicidade - apesar de se tratar de um solfejo, o moto contínuo é um desafio lúdico, podendo, por exemplo, ser executado com acompanhamento rítmico de chorinho.

\section{5) VIDA FORMOSA - acompanhamento instrumental}

(Canto com piano ou conjunto instrumental)

Amb. por H.Villa-Lobos

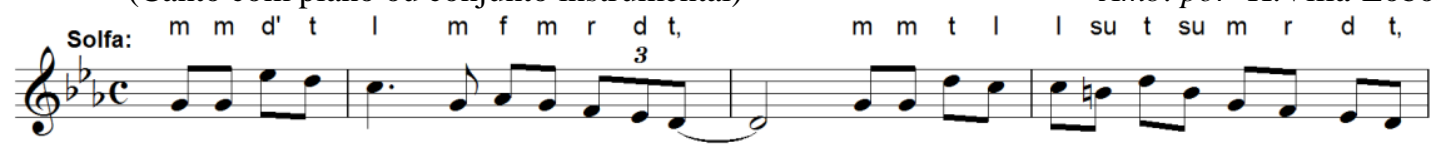

○ mo-re noé meu, não é demaisnin guém Quemti-ver in - ve-ja o-ra fa-ça as-simtam-

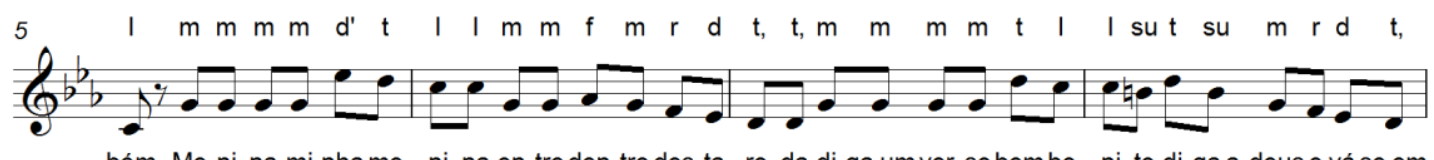

bém Me-ni-na, mi-nha me - ni-na,en-tre den-tro des-ta ro-da,di ga um ver-so bem bo - ni-to,di-ga a-deus e vá se em
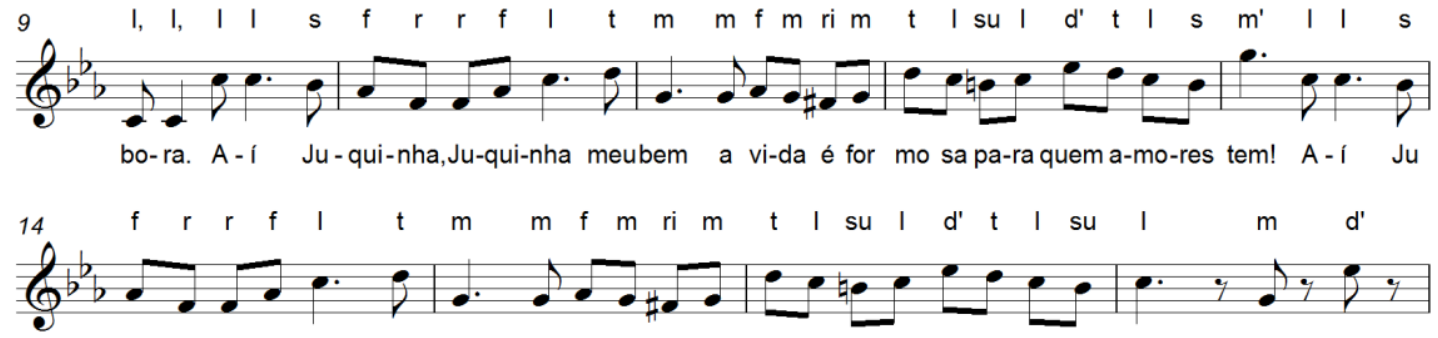

qui-nha,Ju-qui-nha meu bem, a vi-da é for-mo-sa pa-raquema-mo-res tem. Um, dois,

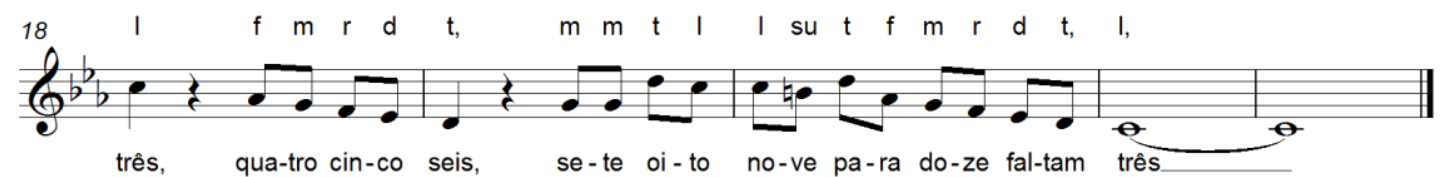

\begin{tabular}{|c|c|c|c|c|c|}
\hline $\begin{array}{l}\text { GP-VTL } \\
\text { /ABM }\end{array}$ & $\begin{array}{l}\text { № } \\
132 \\
/ 80\end{array}$ & $\begin{array}{c}\text { Tessitura } \\
\text { G4-C3 }\end{array}$ & $\begin{array}{c}\text { Forma - } \mathrm{ABA}^{\prime} \\
\text { Gênero - Marcha de rancho } \\
\text { Extensão: } 12^{\underline{a}} \\
\text { Graus da escala + alterações: } 9 \\
\text { Sistema Heptatônico (Ab Eb Bb F C G D) } \\
\text { Heptacorde [(su) s f m r (ri) d t I] }\end{array}$ & 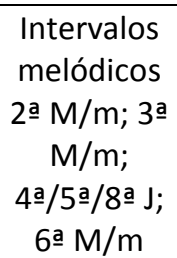 & $\begin{array}{c}\text { Alterações } \\
\text { F\#=ri; } \\
\text { B } \square=s u\end{array}$ \\
\hline \multicolumn{6}{|c|}{ Escala - Modo de C menor } \\
\hline
\end{tabular}

Sugestões de atividades didático-pedagógicas:

Células rítmicas para registro gráfico:

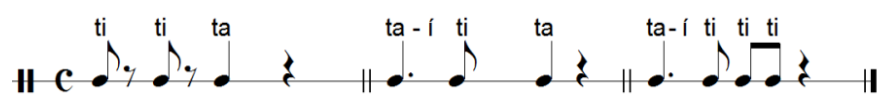

Células melódicas para registro gáfico:

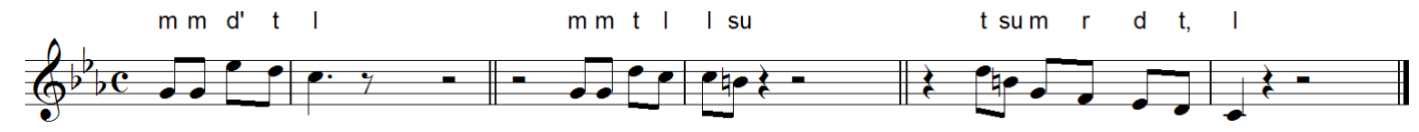


Possivel ostinato rítmico:

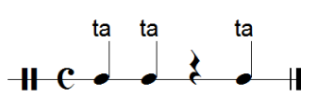

Canção com 21 compassos quaternários, com a indicação de andamento: Movimento de Marcha de Rancho (M.M. 132=c); rall. A tempo; indicações de dinâmica: p ; pp ; cresc. ; < ; > ; acentos > . Em GP/ABM, consta a correspondência com GP/VTL número 134, quando o número correto é 132. Concordamos com GP/ABM sobre a indicação metronômica, muito rápida para o movimento de marcha rancho, como indicado.

Tema popular (1895), recolhido e ambientado por Villa-Lobos. Sob curiosa indicação "inexpressivamente", a melodia em tom menor denota romantismo que não condiz com o teor da segunda estrofe.

Texto - três quadrinhas populares, a segunda e a terceira utilizadas em várias canções de roda.

Ritmo - o interesse rítmico está nos motivos anacrúsicos, pausas e ritmos pontuados.

Melodia - a tônica é alcançada por salto ascendente de sexta menor e graus conjuntos descendentes, finalizando descendentemente para a quinta da $\mathrm{D}$; linha descendente para a tônica iniciada por salto de quinta ascendente. Repetição das frases. O refrão sobre a tríade da subdominante retoma a tônica, vai para a DD por grupetto cromático e salto ascendente, passa pela $\mathrm{D}$ em pequena curva e resolve na dominante da subdominante com nona menor por salto ascendente de sexta, e na repetição da frase, finaliza na tônica. A segunda estrofe varia a linha rítmica. Em GP/ABM, no compasso 15, na mão direita, as notas dos acordes deveriam ser $\boldsymbol{F}$ $\boldsymbol{A} \boldsymbol{b} \boldsymbol{C D}$, e a segunda semicolcheia deveria ser $\boldsymbol{B} \boldsymbol{b}$.

Acompanhamento instrumental (piano) - a introdução, em tercinas na mão direita com arpejo quebrado ascendente da tônica, chega a um acorde de DD e faz a linha descendente por graus conjuntos até finalizar na $\mathrm{D}$ em pequena suspensão, mudando o ritmo de tercina para síncopa, e resolvendo na tônica para iniciar o ostinato rítmico que fará o acompanhamento de toda a melodia. A mão esquerda faz o contraponto em oitavas com movimento contrário. Nas partes A, refrão (B) e A', a melodia não é dobrada pelo piano, que se limita ao ostinato rítmicoharmônico com uma pequena ponte no arpejo da $\mathrm{DD}^{9-}$ para a entrada do refrão. A coda repete o arpejo ascendente de tônica, como na introdução, porém em subdivisão binária, concluindo com pequena curva passando pela $\mathrm{D}$ e tônica.

Ludicidade - desafio para solistas de voz aguda, a canção pode suscitar interpretações românticas, humorísticas, dramáticas, trágicas ou outras, que podem se converter em atividades lúdicas.

\section{6) SOLFEJO $\mathbf{n}^{\circ} 50$ - a capella}

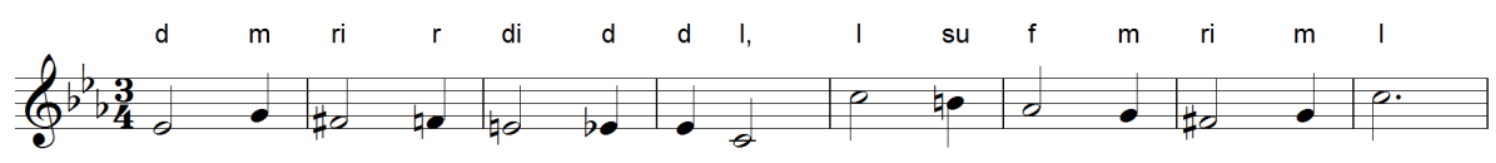

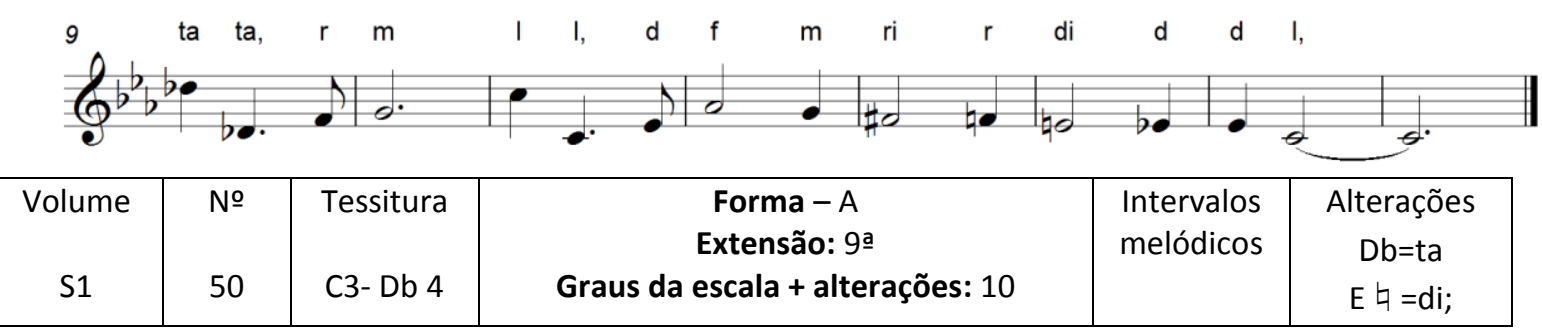




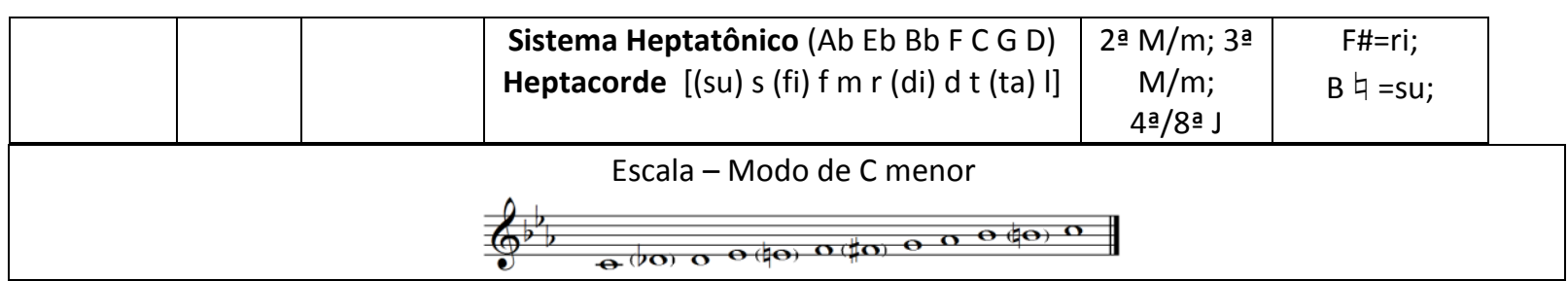

Sugestões de atividades didático-pedagógicas:

Células rítmicas para registro gráfico:

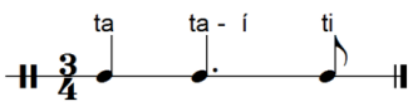

Células melódicas para registro gráfico:

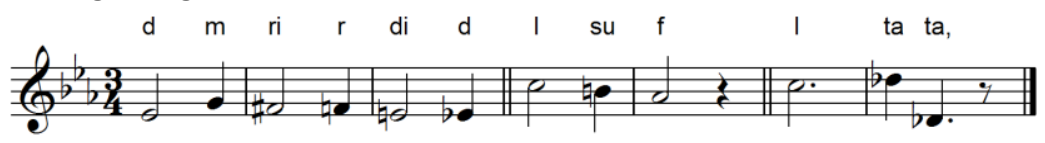

Possível ostinato rítmico:

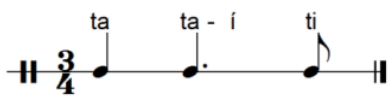

Tema de Villa-Lobos com 16 compassos ternários, com a indicação de andamento: Andante; sem indicações de dinâmica.

Ritmo - o interesse rítmico está no compasso ternário e ritmos pontuados.

Melodia - pentacordes descendentes cromatizados na primeira frase. Na segunda frase, iniciada por saltos de $8^{\mathrm{a}} \mathrm{s}$ descendentes seguidos de $3^{\mathrm{a}} \mathrm{s}$ ascendentes e linha final descendente de hexacorde cromatizado finalizando na tônica.

Ludicidade - apesar de se tratar de um solfejo, o cromatismo é um desafio lúdico.

\section{7) SOLFEJO $n^{\circ} 55$ - a capella}
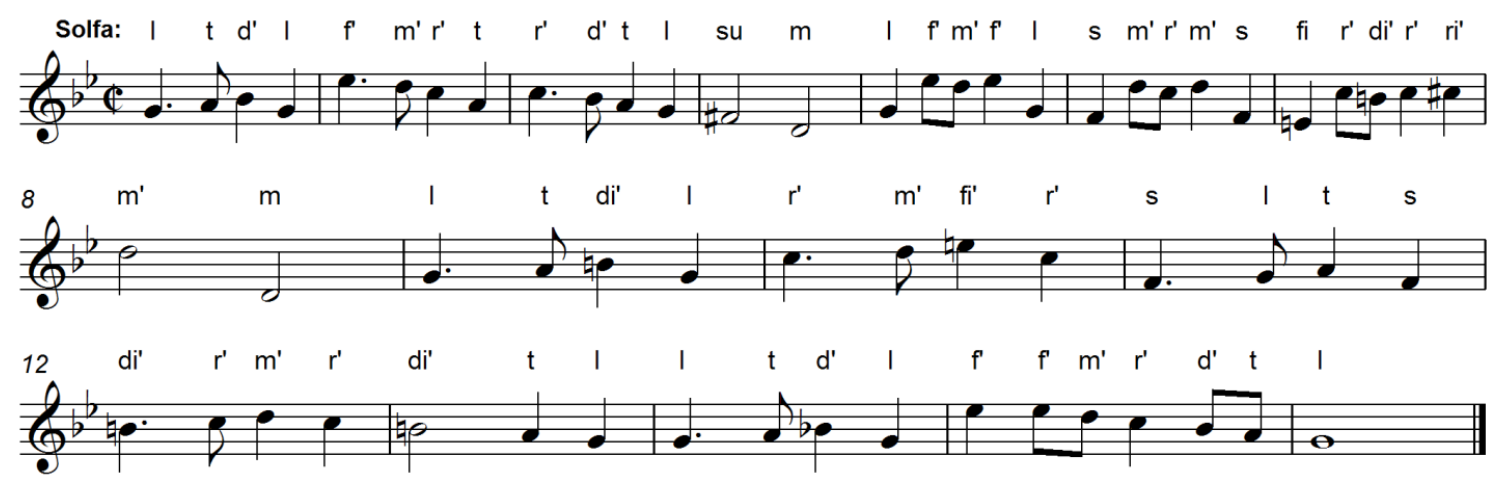

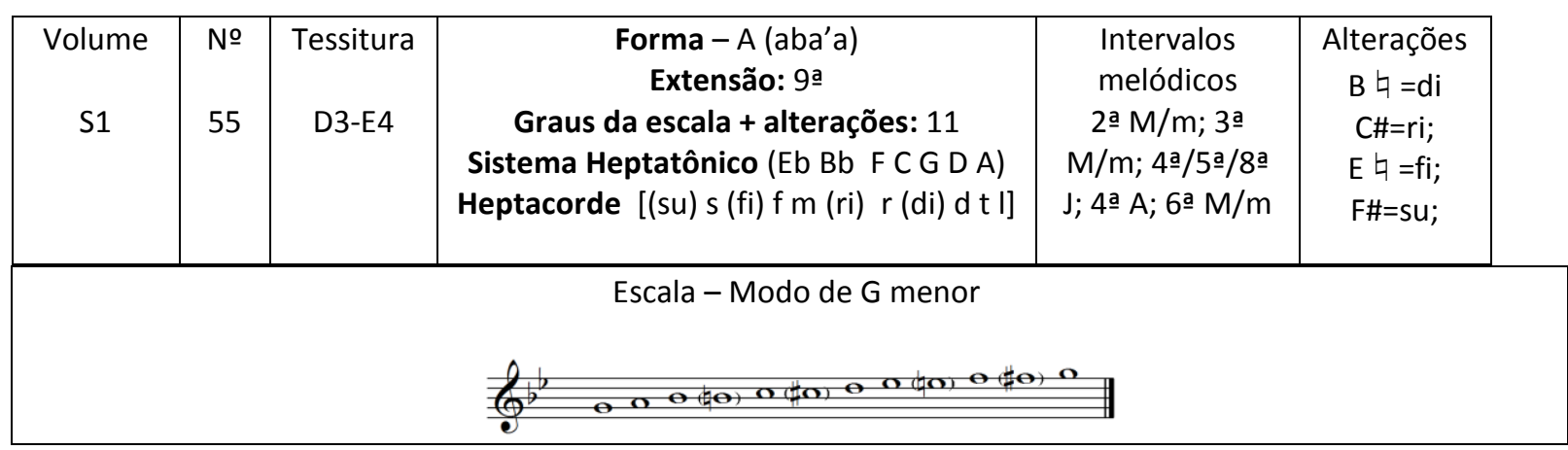


Sugestões de atividades didático-pedagógicas:

Células rítmicas para registro gráfico:

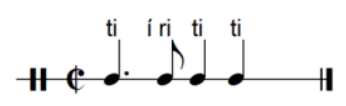

Células melódicas para registro gráfico:

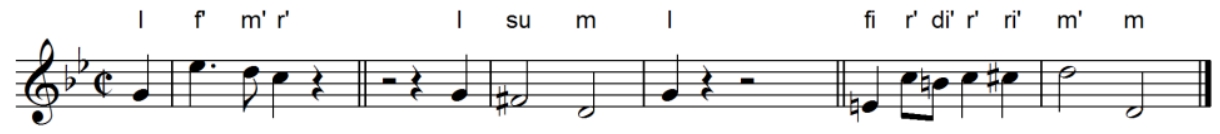

Possivel ostinato rítmico:

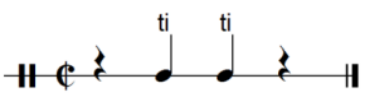

Tema de Villa-Lobos com 16 compassos binários, com a indicação de andamento: Allegretto; sem indicações de dinâmica.

Ritmo - o interesse rítmico está no compasso com a mínima como unidade de pulso e nas notas pontuadas.

Melodia - primeira frase com curva ascendente/descendente partindo do primeiro grau e sequência do segundo desenho por $3^{\mathrm{a}}$ descendente finalizando na $\mathrm{D}$; segue sequência descendente de novo desenho, iniciando na tônica e terminando na $\mathrm{D}$; a segunda frase, em maior (exceto motivo na subdominante), repete o primeiro motivo, sequenciando-o $4^{\mathrm{a}}$ acima, $5^{a}$ abaixo e $4^{a}$ acima, com finalização na tônica com a repetição dos dois motivos iniciais ligeiramente variados. Observe-se a semelhança do tema inicial com o solfejo $\mathrm{n}^{\circ} 136$ :

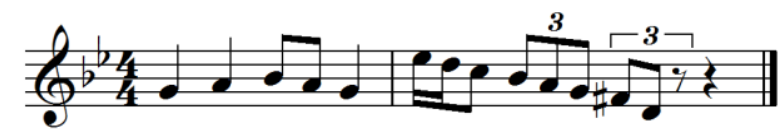

Ludicidade - apesar de se tratar de um solfejo, a variedade de sequências e motivos podem ser encarados como desafios lúdicos.

\section{8) SOLFEJO n ${ }^{\circ} 46$ - a capella}

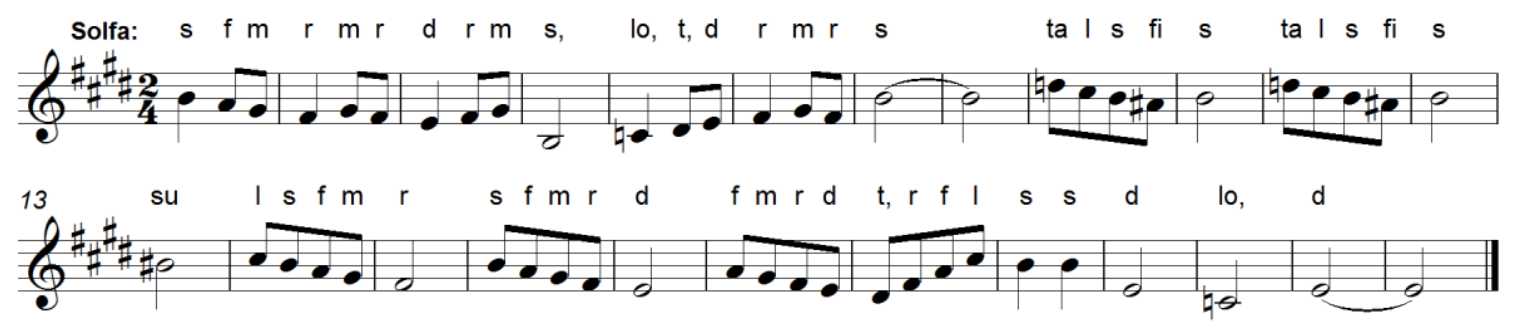

\begin{tabular}{|c|c|c|c|c|c|}
\hline $\begin{array}{c}\text { Volume } \\
\text { S1 }\end{array}$ & $\begin{array}{l}\text { № } \\
46\end{array}$ & $\begin{array}{c}\text { Tessitura } \\
\text { B2-D4 }\end{array}$ & $\begin{array}{c}\text { Forma - A } \\
\text { Gênero - Polca } \\
\text { Extensão: 10a } \\
\text { Graus da escala + alterações: } 11 \\
\text { Sistema Heptatônico (A E B F\# C\# G\# D\#) } \\
\text { Heptacorde [t (ta) I (lo) (su) s (fi) f m r d] }\end{array}$ & 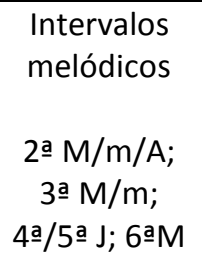 & $\begin{array}{l}\text { Alterações } \\
\qquad \begin{array}{l}\text { A\#=fi; } \\
\text { B\#= su } \\
\text { C } \text { }=l o ; \\
\text { D } \text { =ta; }\end{array}\end{array}$ \\
\hline \multicolumn{6}{|c|}{ Escala - Modo de E maior } \\
\hline
\end{tabular}

Sugestões de atividades didático-pedagógicas: 
Células rítmicas para registro gráfico:

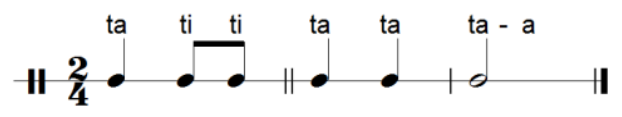

Células melódicas para registro gráfico:

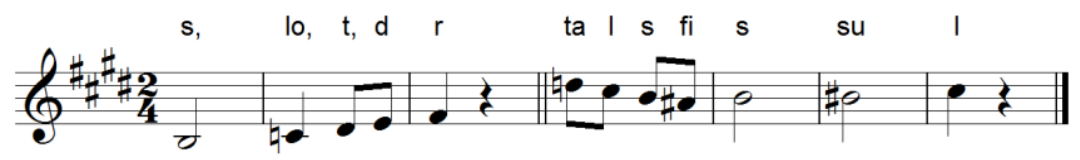

Possivel ostinato rítmico:

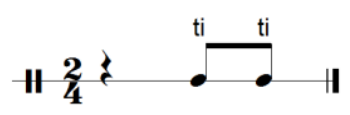

Tema de Villa-Lobos com 23 compassos binários, com a indicação de andamento: Allegretto; sem indicações de dinâmica.

Ritmo - o interesse rítmico está nas assimetrias e notas longas.

Melodia - primeira frase: linha escalar ornamentada descendente e ascendente em âmbito de oitava (D); segunda frase - grupetto sobre a dominante (duas vezes) com terminação cromática ascendente para a última frase em sequência por graus conjuntos de pentacordes descendentes, finalizando com arpejo ascendente de $7^{\mathrm{a}}$ diminuta (D) e saltos descendentes de $5^{\mathrm{a}}$ e $3^{\mathrm{a}}$ e finalização na $\mathrm{T}$ por $3^{\mathrm{a}}$ maior ascendente, na função de mediante inferior.

Ludicidade - apesar de se tratar de um solfejo, as alterações e os saltos configuram desafios lúdicos.

\subsection{Melodias e canções a duas ou mais vozes}

Após a aquisição de habilidades e conteúdos musicais pela prática de canções a uma voz, o canto a duas ou mais vozes deve ser inserido no processo de educação musical pelo seu refinamento artístico e para garantir melhor afinação, segundo Kodály ${ }^{65}$ (KODALY, s.d.)

As canções foram aqui agrupadas pelas categorias: pedais harmônicos; ostinatos; quodlibet; cânones; contraponto imitativo; contraponto livre; harmonizações.

Foram utilizados os seguintes critérios analíticos: número de vozes ou partes; extensão da peça; compassos - fórmulas e quantidades; tessitura de cada voz; tonalidade ou modalidade; intervalos melódicos; intervalos harmônicos; forma; gênero - segundo a classificação de Villa-Lobos; indicações de andamento e de intensidade; créditos referentes à: autoria de letra e música, arranjo e ambientação; indicação do autor das possibilidades de

\footnotetext{
${ }^{65}$ Para Kodály, "O canto a duas vozes ajuda o desenvolvimento auditivo em todos os seus aspectos, inclusive para cantar em uníssono/ de fato, os que cantam sempre em uníssono nunca chegam a cantar corretamente. Por paradoxal que pareça, somente se pode chegar a cantar corretamente em uníssono praticando intensamente o canto a duas partes: com esta prática as vozes se ajustam e balanceiam entre si. (Z. KODÁLY. Cantemos correctamente a dos voces. 2.ed. Buenos Aires: Barry, s.d. - p. 1). Tradução livre da autora.
} 
execução: a capella, canto e piano, conjunto instrumental ou piano solo; eventuais problemas detectados nas versões consultadas; considerações sobre o texto, particularidades técnicas e aspectos lúdico-didáticos; eventuais sugestões de ordem didático-pedagógica.

\subsubsection{Pedais harmônicos}

\section{1) MARGARIDA - Acompanhamento instrumental}

\begin{tabular}{|c|c|c|c|c|c|c|c|}
\hline Volume & № & Vozes & Extensão & Tessitura & Tonalidade & $\begin{array}{l}\text { Intervalos } \\
\text { melódicos }\end{array}$ & $\begin{array}{c}\text { Intervalos } \\
\text { harmônicos }\end{array}$ \\
\hline $\begin{array}{c}\text { GP-VTL / } \\
\text { ABM }\end{array}$ & $\begin{array}{l}77 / \\
123\end{array}$ & 2 & $\begin{array}{c}12^{a} \\
11 \text { compassos } \\
\text { binários }\end{array}$ & $\begin{array}{l}\text { G3-E4 } \\
\text { D3-G3 }\end{array}$ & $\begin{array}{l}\text { Modo defectivo } \\
\text { de C maior - (t I } \\
\text { s m r d) }\end{array}$ & $\begin{array}{c}\text { 2a } \mathrm{M} / \mathrm{m} ; \\
\text { 4a J; }\end{array}$ & 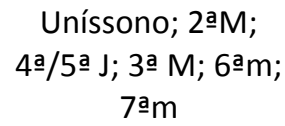 \\
\hline
\end{tabular}

Para canto com piano, conjunto instrumental ou piano solo.

Gênero canção, melodia ambientada por H.Villa-Lobos, com indicação de andamento Allegro $(\mathbf{1 1 6}=\mathrm{J})$. Forma: A. A primeira voz utiliza o hexacorde de $\boldsymbol{G}$ a $\boldsymbol{E}$, enquanto a segunda voz faz um pedal no quinto grau, variando apenas nos finais de frase para uma apojatura $\boldsymbol{A} \boldsymbol{G}$ na primeira vez e para finalizar, salto de quarta descendente $-\boldsymbol{D}$ e segunda ascendente $-\boldsymbol{E}$. A articulação da nota pedal facilita a manutenção da afinação.

Embora em GP/ABM conste um arranjo para a segunda voz com base no acompanhamento do piano (voz superior do contraponto da mão esquerda), preferimos manter a proposta vocal de Villa-Lobos, conforme GP/VTL, justamente por se tratar de um pedal tão interessante quanto facilitador para as primeiras experiências de canto a duas vozes. GP/ABM traz uma complementação do texto, porém invertendo a ordem das quadrinhas: primeira, quarta, segunda, terceira, quinta, sexta e sétima estrofes.

Na brincadeira, a Margarida fica sentada no chão (seu castelo) e é escondida por outras crianças, que representam as pedras do castelo. Para que se encontre a Margarida, vão sendo retiradas as pedras, quantas forem as crianças que escondem a Margarida e quando a última pedra é tirada, todos dançam finalizando a brincadeira. Segue o texto com a sequência correta, completada pela estrofe final ${ }^{66}$ :

1 Que é da Margarida? / O que, o que, o que, ? Que é da Margarida? / O que se vai fazer? 2 Ela está no seu castelo / O que, o que, o que, ? Ela está no seu castelo / O que se vai fazer?

3 O castelo é muito alto / O que, o que, o que, ? O castelo é muito alto / O que se vai fazer?

4 Tirando uma pedra / O que, o que, o que, ? Tirando uma pedra / O que se vai fazer?

5 Uma pedra só não chega / O que, o que, o que, ? Uma pedra só não chega / O que se vai fazer?

6 Tirando duas pedras / O que, o que, o que, ? Tirando duas pedras / O que se vai fazer?

7 Duas pedras só não chegam / O que, o que, o que, ? Duas pedras só não chegam / O que se vai fazer?

Última estrofe - Apareceu a Margarida, o que, o que, o que, apareceu a Margarida, o que se vai fazer.

O acompanhamento instrumental ao piano apresenta as vozes dobradas na mão direita, e na mão esquerda um contraponto em movimento contínuo de sextas, que, por uma questão de lógica e de resolução harmônica, poderia ser corrigido no compasso 4, a primeira colcheia

\footnotetext{
${ }^{66}$ Texto recolhido pela autora.
} 
$(\boldsymbol{B} \boldsymbol{G}$ ao invés de $\boldsymbol{B} \boldsymbol{F})$. GP/ABM faz essa correção no corpo da segunda voz, mas não no acompanhamento.

\section{2) PINTOR DE CANNAHY - A capella}

\begin{tabular}{|c|c|c|c|c|c|c|c|}
\hline Volume & № & Vozes & Extensão & Tessitura & Tonalidade & $\begin{array}{l}\text { Intervalos } \\
\text { melódicos }\end{array}$ & $\begin{array}{c}\text { Intervalos } \\
\text { harmônicos }\end{array}$ \\
\hline $\begin{array}{l}\text { GP-VTL } \\
\text { /ABM }\end{array}$ & $\begin{array}{c}94 / \\
35\end{array}$ & 2 & $\begin{array}{c}12^{\mathrm{a}} \\
26 \text { compassos: } \\
10 \text { ternários e } \\
16 \text { binários }\end{array}$ & Eb3-F4 & $\begin{array}{l}\text { Modo eólio } \\
\text { de F }\end{array}$ & 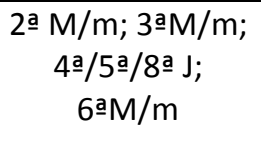 & 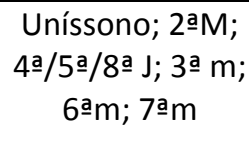 \\
\hline
\end{tabular}

Popular, arranjo de H.Villa-Lobos - Rio, 1935, com indicações de andamento Moderato (M.M. 84= J) Poco Animato; Moderato; de intensidade $\boldsymbol{m f}$; sf ; acento > . Forma: A.

A introdução, em andamento Moderato, apresenta a melodia na segunda voz, iniciada com notas rebatidas em compasso ternário, com pedal no primeiro grau na primeira voz. A melodia, em compasso binário e andamento Poco Animato, está na primeira voz, iniciada pelo arpejo da tríade da tônica e complementada por tetracordes descendentes, sobre pedal também no primeiro grau na segunda voz.

Os pedais sobre notas longas são desafios para a manutenção da afinação, e, por outro lado, são básicos para a justeza na emissão dos intervalos harmônicos.

A peça, sem texto, caracteriza-se pelo vocalismo sobre as sílabas: Nan!; Anêe! E Ah!

\section{3) UM CANTO QUE SAIU DAS SENZALAS - A capella}

\begin{tabular}{|c|c|c|c|c|c|c|c|}
\hline Volume & № & Vozes & Extensão & Tessitura & Tonalidade & $\begin{array}{l}\text { Intervalos } \\
\text { melódicos }\end{array}$ & $\begin{array}{c}\text { Intervalos } \\
\text { harmônicos }\end{array}$ \\
\hline $\mathrm{CO} 2$ & 23 & 2 & $\begin{array}{c}12 \underline{a} \\
24 \text { compassos } \\
\text { binários }\end{array}$ & $\begin{array}{l}\text { F\#3-E4 } \\
\text { B2-F\#3 }\end{array}$ & $\begin{array}{c}\text { Modo eólio } \\
\text { defectivo de B }\end{array}$ & 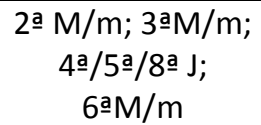 & 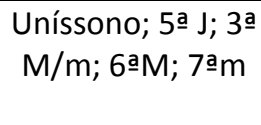 \\
\hline
\end{tabular}

Análise parcial em $2.1-n^{\circ} 6$.

A peça, em seu todo é um acorde menor com sétima - tanto a melodia como o acompanhamento, que oscila entre as terças inferiores e superiores da tríade menor. Com apenas quatro notas da escala do modo eólio defectivo de $\boldsymbol{B}$, a peça apresenta uma sonoridade que sai de um possível lugar comum, pelas limitações quantitativas, para se tornar um momento de placidez harmônica relevante dentro do repertório vocal, principalmente na área da educação musical.

Embora curta, apresenta grande variedade de nuanças interpretativas, como o portamento/glissando, ritmando, fermatas suspensivas e variações de dinâmica. O ritmo, com suas síncopas e polirritmia enriquece em muito a melodia simples.

O texto, em redondilha maior, é de procedência de negros baianos, constando de duas quadras em versos heptassílabos. Fala do apego de seu povo às coisas simples da vida. A "pobreza rica" da construção melódica e harmônica realça a "riqueza pobre" da opção do negro por seu ranchinho e sua plantação. 
4) SODADE - a capella

\begin{tabular}{|c|c|c|c|c|c|c|c|}
\hline Volume & № & Vozes & Extensão & Tessitura & $\begin{array}{c}\text { Tonalidad } \\
\mathrm{e}\end{array}$ & $\begin{array}{l}\text { Intervalos } \\
\text { melódicos }\end{array}$ & $\begin{array}{c}\text { Intervalos } \\
\text { harmônicos }\end{array}$ \\
\hline $\begin{array}{l}\text { GP-VTL } \\
\text { /ABM } \\
\text { /S1 }\end{array}$ & $\begin{array}{l}121 \\
/ 36 \\
/ 29\end{array}$ & 2 & $\begin{array}{c}7 \mathfrak{a} \\
11 \text { compassos } \\
\text { binários }\end{array}$ & $\begin{array}{c}1-\mathrm{a} v .: \mathrm{F} \# 3- \\
\text { D4 } \\
\text { 2a v.: G2-B3 }\end{array}$ & $\begin{array}{l}\text { Modo de } \\
\text { G maior }\end{array}$ & 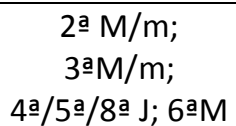 & 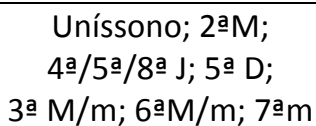 \\
\hline
\end{tabular}

Análise parcial em $2.1-n^{\circ} 94$.

A primeira voz utiliza o hexacorde de $\boldsymbol{G}$ a $\boldsymbol{E}$, enquanto a segunda voz faz um pedal no quinto grau ornamentado por apojatura superior, variando apenas nos compassos 6,7 e 9 . Todas as articulações da nota pedal estão no contratempo.

5) AINDA NÃO COMPREI - a capella

\begin{tabular}{|c|c|c|c|c|c|c|c|}
\hline Volume & № & Vozes & Extensão & Tessitura & Tonalidade & $\begin{array}{l}\text { Intervalos } \\
\text { melódicos }\end{array}$ & $\begin{array}{c}\text { Intervalos } \\
\text { harmônicos }\end{array}$ \\
\hline $\begin{array}{l}\text { GP-VTL } \\
\text { /ABM }\end{array}$ & $\begin{array}{l}4 / \\
51\end{array}$ & 3 & $\begin{array}{c}12^{\mathrm{a}} \\
21 \\
\text { compassos } \\
\text { binários }\end{array}$ & $\begin{array}{c}\text { 1a voz: D3-D4 } \\
\text { 2a voz: C\#3-D4 } \\
\text { 3a voz: A2-A3 }\end{array}$ & D maior & $\begin{array}{c}\text { 2а } \mathrm{M} / \mathrm{m} ; \\
\text { 3а } \mathrm{a} / \mathrm{m} ; \\
\text { 4а/5a/8a J; } \\
\text { 6а } \mathrm{aM} / \mathrm{m}\end{array}$ & 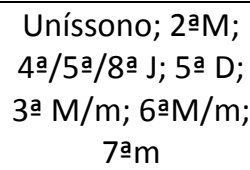 \\
\hline
\end{tabular}

Análise parcial em $2.1-n^{\circ} 19$.

Nesta peça, os pedais são parciais, no quinto grau, exceto no sexto compasso (no terceiro grau). Inicialmente aparece na segunda voz, enquanto a melodia e a harmonização estão respectivamente na primeira e terceira vozes; passa para a primeira voz na repetição da frase, ficando a melodia na segunda e a harmonização em terças e sextas na terceira voz. A Coda está em uníssono no quinto grau, precedido do primeiro. Quanto ao texto, o pedal no quinto grau - sem resolução - pode sugerir conceito de "ainda".

$\mathrm{O}$ arranjo favorece a percepção harmônica das funções $\mathrm{T}$ e $\mathrm{D}$, bem como a busca de uma afinação justa, tendo o quinto grau como referência, embora desafiante pela sua sustentação. O contraste das articulações em Legatto e Stacatto são de grande utilidade para a aquisição dos conceitos teóricos e de efeito musical interessante. Os revezamentos entre as vozes - da melodia e pedal - enriquecem o timbre e são elementos para o desenvolvimento da concentração dos cantores.

É importante a função do silêncio no compasso 21 - após extinção de uníssono em $p p$ - um compasso de espera para retomar o mesmo som no pedal inicial - um teste de memória, além do efeito interpretativo.

Solo instrumental - há indicação para que a mão esquerda toque uma oitava abaixo quando a peça for executada ao piano.

\subsubsection{Ostinatos}


6) ACORDEI DE MADRUGADA ( $1^{\text {a }}$ versão $)$ - a capella

\begin{tabular}{|c|c|c|c|c|c|c|c|}
\hline Volume & № & Vozes & Extensão & Tessitura & Tonalidade & $\begin{array}{l}\text { Intervalos } \\
\text { melódicos }\end{array}$ & $\begin{array}{c}\text { Intervalos } \\
\text { harmônicos }\end{array}$ \\
\hline $\begin{array}{c}\text { GP VTL / } \\
\text { ABM }\end{array}$ & $\begin{array}{c}1 \\
134\end{array}$ & $\begin{array}{c}2 \\
a \\
\text { seco }\end{array}$ & $\begin{array}{c}12^{\mathrm{a}} \\
21 \text { compassos } \\
\text { binários }\end{array}$ & $\begin{array}{c}1 \text { a e } 2^{\text {a }} \\
\text { vozes: C3- } \\
\text { C4 }\end{array}$ & $\begin{array}{l}\text { Modos de } F \\
\text { maior e } F \\
\text { menor }\end{array}$ & $\begin{array}{l}\text { 2a } \mathrm{M} / \mathrm{m} ; \\
\text { 3a } \mathrm{M} / \mathrm{m} ; \\
\text { 4으리 }\end{array}$ & 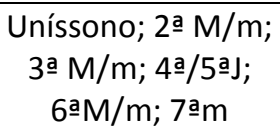 \\
\hline
\end{tabular}

Análise parcial em $2.1-n^{\circ} 169$.

O ostinato baseia-se em quartas e terças (T/D), dando suporte harmônico para a melodia. Para uma fácil assimilação auditiva da segunda voz, a memorização da ordem desses intervalos é relevante: duas quartas e duas terças na introdução; três quartas, quatro terças e uma quarta nas estrofes. A segunda voz, um vocalize sobre a sílaba "Hum!", praticamente em B.C. é um acompanhamento delicado para as melodias, de acordo com o caráter do acalanto e o tema religioso. O arranjo é muito acessível e indicado para a iniciação coral infantil.

Solo instrumental - há indicação para que a mão esquerda toque uma oitava abaixo quando a peça for executada ao piano.

7) A ROSEIRA ( $1^{\mathrm{a}}$ versão $)$ - a capella

\begin{tabular}{|c|c|c|c|c|c|c|c|}
\hline Volume & № & Vozes & Extensão & Tessitura & Tonalidade & $\begin{array}{l}\text { Intervalos } \\
\text { melódicos }\end{array}$ & $\begin{array}{c}\text { Intervalos } \\
\text { harmônicos }\end{array}$ \\
\hline $\begin{array}{l}\text { GP VTL / } \\
\text { ABM }\end{array}$ & $\begin{array}{l}110 \\
/ 52\end{array}$ & $\begin{array}{c}3 \\
\text { a seco }\end{array}$ & $\begin{array}{c}12^{\mathrm{a}} \\
8 \text { compassos } \\
\text { quinários }\end{array}$ & $\begin{array}{l}1 \text { a v.: D3-D4 } \\
\text { 2a v.: A2-A3 } \\
\text { 3a v.: A2-F\#3 }\end{array}$ & $\begin{array}{l}\text { Modo de D } \\
\text { maior }\end{array}$ & 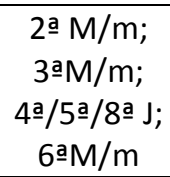 & $\begin{array}{c}\text { Uníssono; 2a } \mathrm{M} / \mathrm{m} ; \\
\text { 3a } \mathrm{M} / \mathrm{m} ; 4 \mathrm{a} / 5 \mathrm{a} / 8^{\mathrm{a}} \mathrm{J} ; \\
\text { 4a } \mathrm{D} ; 6 \mathrm{a} / \mathrm{M} / \mathrm{m} ; 7^{\mathrm{a}} \mathrm{m} ; \\
10^{\mathrm{a}} \mathrm{M}\end{array}$ \\
\hline
\end{tabular}

Análise parcial em $2.1-n^{\circ} 7$.

A melodia é acompanhada por um ostinato rítmico/harmônico sobre acorde de $\mathrm{T}$, com uma variação no compasso final (DT) nas duas últimas notas. Sobre as sílabas: “Ah! Tum! Tam!”, em compasso alternado - ternário/binário, o efeito timbrístico é de imitação de instrumento percussivo. Os saltos de quinta e oitava na segunda voz e de terça e sexta na terceira voz devem ser trabalhados isoladamente para garantir uma boa afinação, tanto quanto resistência vocal, e respiração adequada, pela grande extensão dos mesmos.

Solo instrumental - há indicação para que a mão esquerda toque uma oitava abaixo quando a peça for executada ao piano.

\section{8) CANÁRIO - a capella}

\begin{tabular}{|c|c|c|c|c|c|c|c|}
\hline Volume & № & Vozes & Extensão & Tessitura & Tonalidade & $\begin{array}{l}\text { Intervalos } \\
\text { melódicos }\end{array}$ & Intervalos harmônicos \\
\hline $\begin{array}{l}\text { GP VTL } \\
\text { / ABM } \\
\text { / S1 }\end{array}$ & $\begin{array}{l}21 \\
/ 28 \\
/ 26\end{array}$ & 2 & $\begin{array}{l}9 \underline{a} \\
19 \text { compassos } \\
\text { ternários }\end{array}$ & $\begin{array}{l}1^{\mathrm{a}} \text { v.: D3-D4 } \\
2^{\mathrm{a}} \text { v.: A2-G3 }\end{array}$ & $\begin{array}{l}\text { Modo de D } \\
\text { maior }\end{array}$ & 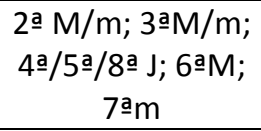 & 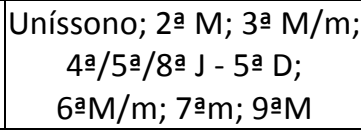 \\
\hline
\end{tabular}

Análise parcial em $2.1-n^{\circ} 27$. 
Melodia com extensão de uma sexta, com as frases terminando na $\mathrm{D}$ e na T. A segunda voz faz um acompanhamento de ostinato rítmico sobre os acordes de $\mathrm{T}$ e $\mathrm{D}^{7}$, dando suporte harmônico para a melodia. Os acentos nos primeiros pulsos caracterizam um acompanhamento instrumental em ritmo de valsa, com utilização da sílaba "Plum!' - possível imitação de pzicatti. O compasso ternário pode levar à sensação do balanço na rede.

9) CANTOS DE ÇAIRÉ № 1 - a capella

\begin{tabular}{|c|c|c|c|c|c|c|c|}
\hline Volume & № & Vozes & Extensão & Tessitura & Tonalidade & $\begin{array}{l}\text { Intervalos } \\
\text { melódicos }\end{array}$ & $\begin{array}{c}\text { Intervalos } \\
\text { harmônicos }\end{array}$ \\
\hline $\mathrm{CO} 2$ & 18 & 2 & $\begin{array}{c}12^{a} \\
11 \\
\text { compassos } \\
\text { binários }\end{array}$ & $\begin{array}{l}\text { 1․ v.: G3-Eb4 } \\
\text { 2ㅁ v.: A2-G3 }\end{array}$ & $\begin{array}{l}\text { Modo mixolídio } \\
\text { defectivo de F }\end{array}$ & $\begin{array}{l}\text { 2a } \mathrm{M} / \mathrm{m} ; \\
\text { 3믈 } \mathrm{m} ; \text { 4a J }\end{array}$ & $\begin{array}{c}\text { Uníssono; 2a } \mathrm{M} ; 3^{\mathrm{a}} \\
\mathrm{M} / \mathrm{m} ; 4 \mathrm{a} / 5^{\mathrm{a}} / 8^{\mathrm{a}} \mathrm{J} ; 4^{\mathrm{a}} \\
\mathrm{A} ; 6 \mathrm{a} \mathrm{M} / \mathrm{m} ; 7^{\mathrm{a}} \mathrm{m} ; 10^{\mathrm{a}} \\
\mathrm{m} ; 12^{\mathrm{a}} \mathrm{D}\end{array}$ \\
\hline
\end{tabular}

Análise parcial em $2.1-n^{\circ} 12$.

A segunda voz apresenta ostinato em linha descendente [ $\boldsymbol{f} \boldsymbol{m} \boldsymbol{d} \boldsymbol{l}$,] interrompido após a segunda repetição e no final por tetracordes descendentes. Há predominância do intervalo de sexta no contraponto. Não há indicação de texto para a segunda voz, o qual pode ser criado, considerando-se o texto da primeira voz e os acentos no contraponto. Essas acentuações devem buscar equilíbrio com o plano de intensidade suave na primeira voz. A execução dos ostinatos, em movimento lento e acentuando as pulsações, interfere no timbre, variando conforme a solução dada para o texto.

10) CARNEIRINHO DE ALGODÃO - a capella

\begin{tabular}{|c|c|c|c|c|c|c|c|}
\hline Volume & № & Vozes & Extensão & Tessitura & Tonalidade & $\begin{array}{l}\text { Intervalos } \\
\text { melódicos }\end{array}$ & $\begin{array}{l}\text { Intervalos } \\
\text { harmônicos }\end{array}$ \\
\hline CO1 & 4 & 2 & $\begin{array}{c}10^{\mathrm{a}} \\
18 \text { compassos } \\
\text { binários }\end{array}$ & $\begin{array}{l}1 \text { a v.:D3-D4 } \\
\text { 2a v.:B2-B3 }\end{array}$ & $\begin{array}{c}\text { Modo de } A \\
\text { maior }\end{array}$ & 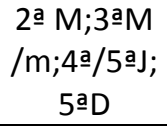 & $\begin{array}{l}\text { Uníssono;3a } \\
\text { M/m;5a/4âj; } \\
\text { 5ㅁ; 6aM/m }\end{array}$ \\
\hline
\end{tabular}

Análise parcial em $2.1-n^{\circ} 124$.

O contraponto, na segunda voz, sobre a sílaba Nan!, é estruturado sobre ostinato rítmico, cuja linha melódica é mudada no final das semifrases e repetida por sequência descendente. A última frase acompanha a melodia em sextas e terças paralelas. Peça de fácil execução para coros principiantes.

11) LÁ NA PONTE DA VINHAÇA (Passa, passa gavião) - a capella

\begin{tabular}{|c|c|c|c|c|c|c|c|}
\hline Volume & № & Vozes & Extensão & Tessitura & Tonalidade & $\begin{array}{l}\text { Intervalos } \\
\text { melódicos }\end{array}$ & $\begin{array}{l}\text { Intervalos } \\
\text { harmônicos }\end{array}$ \\
\hline $\begin{array}{c}\text { GP-VTL } \\
\text { / ABM } \\
/ \mathrm{S} 1\end{array}$ & $\begin{array}{l}104 \\
/ 14 \\
/ 2\end{array}$ & 2 & $\begin{array}{c}12^{\mathrm{a}} \\
6 \text { compassos } \\
\text { binários }\end{array}$ & $\begin{array}{l}\text { 1a v.: C3-C4 } \\
\text { 2a v.: B2-A3 }\end{array}$ & $\begin{array}{c}\text { Modo de C } \\
\text { maior }\end{array}$ & $\begin{array}{c}\text { 2а } \mathrm{M} / \mathrm{m} ; \\
\text { 3ам } / \mathrm{m} ; 8^{\text {a J }} \\
\text { 6ам } / \mathrm{m}\end{array}$ & $\begin{array}{l}\text { Uníssono; 3a } \\
\mathrm{M} / \mathrm{m} ; 5 \mathrm{a} / 8^{\mathrm{a}} \mathrm{J}\end{array}$ \\
\hline
\end{tabular}

Análise parcial em $2.1-n^{\circ} 39$. 
A configuração melódica da peça baseia-se no ostinato em terças descendentes (primeira e segunda voz): $\boldsymbol{d}$ l $\boldsymbol{s} \boldsymbol{m} / \boldsymbol{l} \boldsymbol{f} \boldsymbol{m} \boldsymbol{d}$ - repetido duas vezes em cada frase. A primeira nota do ostinato é alcançada por salto ascendente de sexta menor na primeira voz e sexta maior na segunda voz. Esses intervalos podem ser trabalhados à parte, simultaneamente, com base em recurso mnemônico (associação com intervalo idêntico de início ou parte de outra canção conhecida) ou simplesmente nomeando as notas. Embora o paralelismo em terças não seja, a princípio, de fácil realização, a repetição dos ostinatos é uma estratégia adequada.

A repetição da palavra 'assim' tem efeito timbrístico.

12) OS POMBINHOS - a capella

\begin{tabular}{|c|c|c|c|c|c|c|c|}
\hline Volume & № & Vozes & Extensão & Tessitura & Tonalidade & $\begin{array}{l}\text { Intervalos } \\
\text { melódicos }\end{array}$ & $\begin{array}{c}\text { Intervalos } \\
\text { harmônicos }\end{array}$ \\
\hline $\begin{array}{c}\text { GP-VTL } \\
\text { / ABM } \\
\text { / S1 }\end{array}$ & $\begin{array}{l}101 \\
/ 8 \\
/ 15\end{array}$ & 2 & $\begin{array}{c}11 \text { a } \\
10 \text { compassos } \\
\text { ternários }\end{array}$ & $\begin{array}{c}\text { 19 voz: Eb3-Eb4 } \\
\text { 2a voz: Bb2- } \\
\text { Bb3 }\end{array}$ & $\begin{array}{c}\text { Modo de Eb } \\
\text { maior }\end{array}$ & 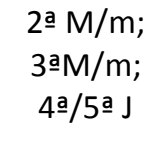 & 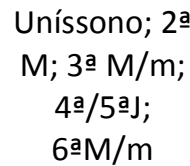 \\
\hline
\end{tabular}

Análise parcial em $2.1-n^{\circ} 37$.

O ostinato rítmico é válido para toda a peça: $\delta \_\Omega$ - enquanto que o melódico é parcial, com duas frases que se repetem. A harmonização recai sobre a D no terceiro pulso e na $\mathrm{T}$ no primeiro e segundo pulsos dos compassos. $\mathrm{O}$ contraponto alterna movimentos contrários e terças paralelas. Com exceção de segundas maiores decorrentes de notas de passagem, os demais intervalos são consonantes. O âmbito de oitava para as duas vozes é confortável, e os planos de alturas são favoráveis para a boa emissão vocal.

Quanto ao significado da palavra "rola", que pode ser substantivo - rola (pomba-rola), como flexão do verbo rolar, preferimos manter como GP/VTL (rola pombinha). Em GP/ABM consta "Rola a pombinha".

Solo instrumental - há indicação para que a mão esquerda toque uma oitava abaixo quando a peça for executada ao piano.

13) MARCHA ESCOLAR (Meu sapinho) - a capella

\begin{tabular}{|c|c|c|c|c|c|c|c|}
\hline Volume & № & Vozes & Extensão & Tessitura & Tonalidade & $\begin{array}{l}\text { Intervalos } \\
\text { melódicos }\end{array}$ & $\begin{array}{l}\text { Intervalos } \\
\text { harmônicos }\end{array}$ \\
\hline $\mathrm{CO} 1$ & 07 & 2 & $\begin{array}{c}10 \text { ạ } \\
39 \text { compassos } \\
\text { binários }\end{array}$ & $\begin{array}{l}1 \text { a v.: C3-E4 } \\
\text { 2a v.: C3-C4 }\end{array}$ & $\begin{array}{l}\text { Modo de } \mathrm{F} \\
\text { maior }\end{array}$ & 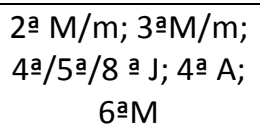 & $\begin{array}{c}\text { Uníssono; 3a } \\
\mathrm{M} / \mathrm{m} ; 4 \underline{a} / 5^{\mathrm{a}} / 8^{\mathrm{a}} \\
\mathrm{J} ; 7^{\mathrm{a}} \mathrm{m}\end{array}$ \\
\hline
\end{tabular}

Cantiga para o jardim de infância, com letra de Sylvio Salema (dedicada "ao meu Carlinhos”) e música de H. Villa-Lobos, 1934 - Rio de Janeiro. Forma: A. Indicação de andamento Allegro Marcial

Texto infantil, de caráter recreativo, incentivando a criança a movimentar-se como um sapinho, e a imitar seu coaxar. A peça inicia-se com um ostinato na segunda voz, compartilhado pontualmente pela primeira. Após a repetição por quatro vezes desse ostinato, o arranjo segue com as vozes em terças paralelas praticamente até o seu final. Nos compassos 23,25 e 27, tanto quanto na repetição da frase, a sequência descendente por grau conjunto é 
ressaltada por acentos, como efeito timbrístico, podendo também sugerir momentos específicos de pulos em uma possível coreografia. O texto do ostinato, sobre as sílabas: "Quá! Quão! Quê!'”, imitações da voz do sapo, são reforçadas em seu objetivo pelos constantes saltos intervalares e pelo ritmo sempre regular em semínimas nas duas vozes. O uníssono final, em som prolongado por fermata, distribui tais sílabas para quatro grupos, como efeito timbrístico.

14) ANQUINHAS - a capella

\begin{tabular}{|c|c|c|c|c|c|c|c|}
\hline Volume & № & Vozes & Extensão & Tessitura & Tonalidade & $\begin{array}{l}\text { Intervalos } \\
\text { melódicos }\end{array}$ & Intervalos harmônicos \\
\hline $\begin{array}{l}\text { GP VTL } \\
\text { / ABM } \\
\text { /S1 }\end{array}$ & $\begin{array}{c}9 \\
130 \\
/ 24\end{array}$ & 2 & $\begin{array}{c}11 \underline{a} \\
10 \\
\text { compassos } \\
\text { binários }\end{array}$ & $\begin{array}{l}1 \text { a v.: E3-C4 } \\
2 \text { a v.: G2-A3 }\end{array}$ & $\begin{array}{c}\text { Modo de C } \\
\text { Maior }\end{array}$ & $\begin{array}{c}2 \text { a } M / m ; \\
\text { 3a } \mathrm{a} / \mathrm{m} ; \\
\text { 4a } / \mathrm{A} / \mathrm{A} \\
\text { 6а } \mathrm{M} / \mathrm{m}\end{array}$ & 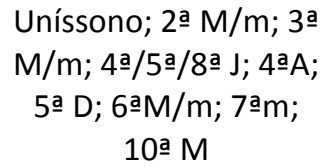 \\
\hline
\end{tabular}

Análise parcial em $2.1-n^{\circ} 66$.

O ostinato rítmico da segunda voz, com uma variação no penúltimo compasso, é uma ambientação no ritmo de habanera, em que a sílaba "Tum!" tem a função de imitar instrumentos percussivos e ao final, a palavra "Olé!" confirma a indicação do ritmo. Trata-se da distribuição de acordes quebrados, a cada compasso, segundo suas funções tonais relacionadas com a melodia.

Para facilitar o aprendizado da segunda voz, podem-se realizar pedais com as primeiras de cada compasso, com a melodia simultânea executada na primeira voz. Outra possibilidade é a de entoar todos os acordes propostos de maneira lúdica, com jogos, explorando as posições fundamentais e as inversões.

Há uma opção de variante na primeira voz nos compassos 6 e 7, que pode também se transformar em divisi, provocando uma distribuição pontual a três vozes.

Solo instrumental - há indicação para que a mão esquerda toque uma oitava abaixo quando a peça for executada ao piano.

15) A GATINHA PARDA ( $2^{\mathrm{a}}$ versão) - a capella

\begin{tabular}{|c|c|c|c|c|c|c|c|}
\hline Volume & № & Vozes & Extensão & Tessitura & Tonalidade & $\begin{array}{l}\text { Intervalos } \\
\text { melódicos }\end{array}$ & $\begin{array}{l}\text { Intervalos } \\
\text { harmônicos }\end{array}$ \\
\hline $\begin{array}{c}\text { GP VTL / } \\
\text { ABM }\end{array}$ & $\begin{array}{l}60 \\
/ 33\end{array}$ & 2 & $\begin{array}{c}12 \text { a } \\
41 \text { compassos } \\
\text { binários }\end{array}$ & $\begin{array}{c}1 \text { a v.: D3-D4 } \\
\text { 2a voz: A2-B3 }\end{array}$ & $\begin{array}{l}\text { Modo de D } \\
\text { maior }\end{array}$ & $\begin{array}{c}\text { 2a } \mathrm{M} / \mathrm{m} ; \\
\text { 3а } \mathrm{M} / \mathrm{m} ; \\
\text { 4a/5a/8a J; } \\
\text { 6ам }\end{array}$ & 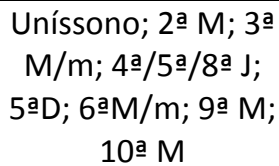 \\
\hline
\end{tabular}

Análise parcial em $2.1-n^{\circ} 103$.

Ostinato rítmico-melódico parcial [compassos 1-10; 33-39] e rítmico em toda a peça. Trata-se de acordes quebrados das funções tonais relacionadas à melodia. Por esse aspecto, seria interessante utilizar a nota $\boldsymbol{G}$ na primeira semínima do compasso 14, para melhor caracterizar a função de subdominante. O texto da segunda voz, sobre as sílabas "Nhau! Raul!' têm efeito timbrístico, imitando o miado do gato, sem se desprezar, ainda, a hipótese de eventual homenagem ou citação do arranjador ao seu pai (Raul Villa-Lobos), considerando-se seu 
senso de humor. As notas longas na primeira voz podem originar jogos para treino da respiração.

Solo instrumental - há indicação para que a mão esquerda toque uma oitava abaixo quando a peça for executada ao piano.

16) A GATINHA PARDA (1 ${ }^{\mathrm{a}}$ versão $)$ - a capella

\begin{tabular}{|c|c|c|c|c|c|c|c|}
\hline Volume & № & Vozes & Extensão & Tessitura & Tonalidade & $\begin{array}{l}\text { Intervalos } \\
\text { melódicos }\end{array}$ & $\begin{array}{l}\text { Intervalos } \\
\text { harmônicos }\end{array}$ \\
\hline $\begin{array}{l}\text { GP VTL } \\
\text { / ABM } \\
\text { /S1 }\end{array}$ & $\begin{array}{l}59 \\
132 \\
/ 30\end{array}$ & 2 & $\begin{array}{c}10^{\mathrm{a}} \\
9 \\
\text { compassos } \\
\text { quaternários }\end{array}$ & $\begin{array}{l}\text { 1'a v.: Eb3-D4 } \\
\text { 2a v.: Bb2-C3 }\end{array}$ & $\begin{array}{l}\text { Modo de } \\
\text { Eb Maior }\end{array}$ & 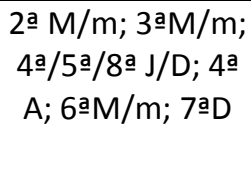 & 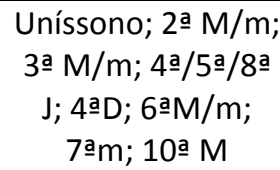 \\
\hline
\end{tabular}

Análise parcial em $2.1-n^{\circ} 51$.

O ostinato rítmico na segunda voz contém acordes quebrados com as funções tonais relacionadas à melodia - em seus três primeiros pulsos de cada compasso, tendo, no quarto pulso, dominantes (primárias e secundárias) resolvendo em suas tônicas no compasso seguinte. As sílabas nasaladas utilizadas na primeira voz "Miau”" (na introdução) e "Nan!" no ostinato da segunda voz são elementos timbrísticos, associados ao som do miado do gato. Podem ser criados jogos com pedais em notas em ambas as vozes, com objetivos de aprimoramento da emissão e da precisão da afinação, explorando também o humorismo contido na peça.

Solo instrumental - há indicação para que a mão esquerda toque uma oitava abaixo quando a peça for executada ao piano.

17) SOLFEJO $\mathrm{N}^{\circ} 109$ - a capella

\begin{tabular}{|c|c|c|c|c|c|c|c|}
\hline Volume & № & Vozes & Extensão & Tessitura & Tonalidade & $\begin{array}{l}\text { Intervalos } \\
\text { melódicos }\end{array}$ & $\begin{array}{c}\text { Intervalos } \\
\text { harmônicos }\end{array}$ \\
\hline S1 & 109 & 2 & $\begin{array}{l}\quad 14^{a} \underline{a} \\
11 \text { compassos } \\
\text { quaternários }\end{array}$ & $\begin{array}{c}1 \stackrel{a}{a} \text { v.:C3-E4 } \\
2^{a} \text { v.:F2-F\#3 }\end{array}$ & $\begin{array}{l}\text { Modo de C } \\
\text { maior }\end{array}$ & 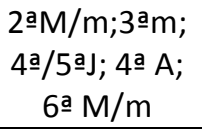 & 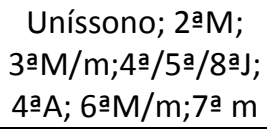 \\
\hline
\end{tabular}

Melodia de Villa-Lobos, com indicação de andamento Tempo de Marcha. Forma: A.

A melodia apresenta saltos de sexta iniciando frases e semifrases. Acompanhamento com ostinato rítmico de marcha popular brasileira, cujas notas explicitam a harmonia em cada compasso. Terças e sextas são recorrentes. Além das funções harmônicas primárias, a partir do compasso 7 há uma passagem para a Tr pela sua dominante, dominante secundária e resolução na $\mathrm{D}$ da $\mathrm{Tr}, \mathrm{S}$ da $\mathrm{Tr}$, para a cadência final D/T. Deve-se aproveitar o caráter lúdico do estilo popular, especialmente o acompanhamento rítmico como ponto de interesse.

\subsubsection{Quodlibet}

Trata-se do canto simultâneo de duas ou mais melodias que seguem a mesma sequência de funções harmônicas e são compatíveis ritmicamente: quod (o quê) libet (agrada). 
É um meio simples de introdução ao canto a duas ou mais vozes, devido à segurança que os grupos apresentam pelo domínio das melodias isoladas.

18)BAM-BA-LA-LÃO (Senhor Capitão) - (Oferta da criança à lua) - a capella

\begin{tabular}{|c|c|c|c|c|c|c|c|}
\hline Volume & № & Vozes & Extensão & Tessitura & Tonalidade & $\begin{array}{l}\text { Intervalos } \\
\text { melódicos }\end{array}$ & $\begin{array}{l}\text { Intervalos } \\
\text { harmônicos }\end{array}$ \\
\hline $\begin{array}{c}\text { GP-VTL / } \\
\text { ABM }\end{array}$ & $\begin{array}{c}13 / \\
45\end{array}$ & 2 & $\begin{array}{c}5 \underline{\text { a }} / 7 \underline{7} \\
9 \text { compassos } \\
\text { binários }\end{array}$ & $\begin{array}{l}\text { C3-G3 } \\
\text { / F3-E4 }\end{array}$ & $\mathrm{F}$ maior & 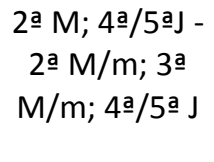 & 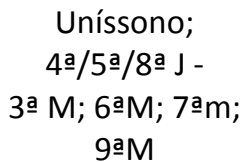 \\
\hline
\end{tabular}

Análise parcial em $2.1-n^{\circ} 1$.

Popular, arranjo de H.Villa-Lobos. Gênero: Berceuse. Melodias: Bam-balalão e Oferta da criança à lua. $\mathrm{O}$ contraste ocorre pelo ostinato rítmico e mínima quantidade de sons na primeira e na linha rítmico/melódica mais fluente na segunda melodia, bem como os diferentes planos de altura.

19) À PRAIA (Chamados para brinquedo de roda) - a capella

\begin{tabular}{|c|c|c|c|c|c|c|c|}
\hline Volume & № & Vozes & Extensão & Tessitura & Tonalidade & $\begin{array}{l}\text { Intervalos } \\
\text { melódicos }\end{array}$ & $\begin{array}{c}\text { Intervalos } \\
\text { harmônicos }\end{array}$ \\
\hline $\begin{array}{c}\text { GP-VTL / } \\
\text { ABM }\end{array}$ & $\begin{array}{l}33 \\
/ 58\end{array}$ & $\begin{array}{c}4 \\
\text { grupos } \\
/ 3 \\
\text { vozes }\end{array}$ & $\begin{array}{c}13^{\mathbf{a}} \\
33 \text { compassos } \\
\text { binários }\end{array}$ & G2-E4 & $\begin{array}{c}\text { Modo de C } \\
\text { maior }\end{array}$ & $\begin{array}{c}\text { 2а } \mathrm{M} / \mathrm{m} ; \\
\text { 3а } \mathrm{a} / \mathrm{m} ; \\
\text { 4а/5а/8а J; } \\
\text { 6а } \mathrm{a} / \mathrm{m}\end{array}$ & $\begin{array}{c}\text { Uníssono; 2aM; } \\
\text { 4a/5a/8a J; 5a } \mathrm{D} ; \\
\text { 3a M/m; 6aM/m; } \\
\text { 7am }\end{array}$ \\
\hline
\end{tabular}

Popular, ambientado no gênero de embolada por H.Villa-Lobos. Forma: ABA.

A primeira melodia dialogada por quatro grupos, sobre a frase "Ajunta o povo pra brincar", tem como título: "Chamados para brinquedos". A segunda melodia, À Praia, ou Vamos Maninha, ou Barca nova, por sua configuração harmônica, impõe modificações à primeira melodia. A coda, em um compasso, repete o texto 'brincar' em sextas paralelas descendentes. Em GP/ABM, os compassos 20 e 28 deveriam apresentar a mesma alteração, sendo que $\boldsymbol{A} \boldsymbol{b}$ é mais correta. No compasso 27, para adequação da prosódia, a última semínima para o texto "os an-" deveria ser dobrada em duas colcheias. Quanto ao título, parece mais adequado em GP/VTL: À praia, do que A praia em GP/ABM.

\subsubsection{Cânones}

Os cânones, em geral, apresentam algumas dificuldades que precisam ser trabalhadas antes da execução: 
- o conceito deve ser adquirido a partir do visual, seja pela exposição da partitura por extenso, a duas ou mais vozes, ou por exercícios de simulação do cânone com os grupos (representando as vozes) em movimentos diferentes e defasados.

- antes do canto, pode-se executar o cânone falado.

- nas primeiras experiências, a melodia deve ser totalmente assimilada e memorizada.

20) NOZANI-NÁ - A capella

\begin{tabular}{|c|c|c|c|c|c|c|c|}
\hline Volume & № & Vozes & Extensão & Tessitura & Tonalidade & $\begin{array}{l}\text { Intervalos } \\
\text { melódicos }\end{array}$ & $\begin{array}{c}\text { Intervalos } \\
\text { harmônicos }\end{array}$ \\
\hline $\mathrm{CO} 1$ & 32 & 2 & $\begin{array}{c}\text { 6a } \\
31 \text { compassos } \\
\text { binários }\end{array}$ & E3-C4 & $\begin{array}{l}\text { Modo mixolídio } \\
\text { defectivo de } \mathrm{G}\end{array}$ & $\begin{array}{l}2 \underline{a} \mathrm{M} / \mathrm{m} ; 3^{\mathrm{a}} \\
\mathrm{M} / \mathrm{m} ; 4 \mathrm{a} \mathrm{J}\end{array}$ & 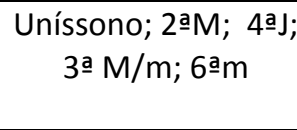 \\
\hline
\end{tabular}

Análise parcial em $2.1-n^{\circ} 78$.

Sobre um tema dos índios Parecis, a construção do cânone fica fora dos padrões estruturais do contraponto que Villa-Lobos emprega nos demais, porém resulta coerente com a origem da melodia.

Para a execução deste cânone, é aconselhável que a melodia seja memorizada com segurança, pela novidade do texto e pelo ritmo recorrente em frases assimétricas. A melodia é simples, em âmbito de sexta menor, mas as vozes simultâneas resultam em intervalos dissonantes de segunda maior, especialmente. Para uma afinação precisa, portanto, um trabalho prévio deve ser feito, a partir da memorização e de ações lúdicas, como, por exemplo, manter uma voz em pedal sobre uma determinada nota ou sílaba, até que a outra voz chegue ao uníssono, invertendo-se então os papéis.

No volume Solfejo 2, constam 20 cânones, entre eles os de números 2, 4, 5, 6, 10, 11, 13, 14 e 15, já foram objeto de análise entre as melodias em uníssono no tópico 2.1 deste capítulo.

Os demais cânones de números $1,3,7,8,9,12,16,17,18,19$ e 20, podem obedecer à seguinte ordem, por grau de complexidade:

21) CÂNONE $\mathbf{N}^{\circ} 12$ - a capella

\begin{tabular}{|c|c|c|c|c|c|c|c|}
\hline Volume & № & Vozes & Extensão & $\begin{array}{c}\text { Tessitur } \\
\text { a }\end{array}$ & Tonalidade & $\begin{array}{l}\text { Intervalos } \\
\text { melódicos } \\
\end{array}$ & Intervalos harmônicos \\
\hline S2 & $\begin{array}{c}12 / p . \\
22\end{array}$ & 2 & $\begin{array}{l}\text { 9ạ } \\
8 \text { compassos } \\
\text { quaternários }\end{array}$ & D3-Eb4 & $\begin{array}{c}\text { Modo de G } \\
\text { menor }\end{array}$ & 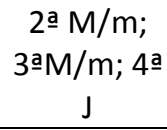 & 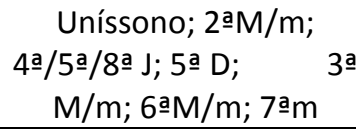 \\
\hline
\end{tabular}


Com o título: Tcheco, de autoria de Miroslav Krejči, sem texto. Forma: A.

Em tonalidade menor, sobre a tríade da tônica, pode ser enriquecido por um ostinato melódico instrumental contendo os dois primeiros compassos, invertendo o D3 para $D 4$.

22) CÂNONE $\mathbf{N}^{\circ} \mathbf{2 0}$ - Brasil - a capella

\begin{tabular}{|c|c|c|c|c|c|c|c|}
\hline Volume & № & Vozes & Extensão & Tessitura & Tonalidade & $\begin{array}{l}\text { Intervalos } \\
\text { melódicos }\end{array}$ & $\begin{array}{c}\text { Intervalos } \\
\text { harmônicos }\end{array}$ \\
\hline S2 & $\begin{array}{c}20 / \\
\text { p. } 26\end{array}$ & 6 & $\begin{array}{c}8 \underline{a} \\
17 \text { compassos } \\
\text { binários }\end{array}$ & C3-C4 & $\begin{array}{l}\text { Modo de } F \\
\text { maior }\end{array}$ & 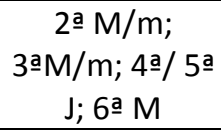 & $\begin{array}{l}\text { Uníssono; 2aM; } \\
\text { 4a/5a/8a J; 3a } \\
\mathrm{M} / \mathrm{m} ; 6^{\mathrm{a}} \mathrm{M} ; 7^{\mathrm{a}} \mathrm{m}\end{array}$ \\
\hline
\end{tabular}

Música de H.Villa-Lobos, sem texto, com indicação de andamento Marcial. Cânone a seis vozes, sendo que em cada entrada aparecem sucessivamente as letras que formam a palavra Brasil. A harmonia foi pensada na cadência $\mathrm{T} \mathrm{D}^{7}(\mathrm{~T})$.

Embora não haja explicação quanto à formação da palavra Brasil, pode-se criar uma série de interpretações com componentes visuais para o cânone, como formação das letras por grupos de cantores ou utilização de outros recursos tecnológicos visuais.

23) CÂNONE $\mathbf{N}^{\circ} 7$ - a capella

\begin{tabular}{|c|c|c|c|c|c|c|c|}
\hline Volume & № & Vozes & Extensão & Tessitura & Tonalidade & $\begin{array}{l}\text { Intervalos } \\
\text { melódicos }\end{array}$ & $\begin{array}{c}\text { Intervalos } \\
\text { harmônicos }\end{array}$ \\
\hline S2 & $\begin{array}{c}7 / \mathrm{p} . \\
21\end{array}$ & 2 & $\begin{array}{c}12 \text { a } \\
11 \\
\text { compassos } \\
\text { ternários }\end{array}$ & B2-F4 & C menor & 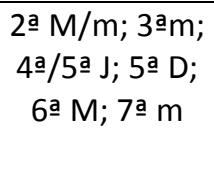 & 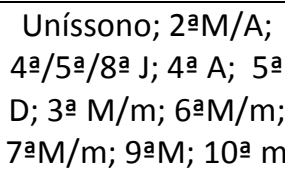 \\
\hline
\end{tabular}

Música de H.Villa-Lobos, sem texto, com indicação de andamento Andante. Forma: A.

Há polirritmia de $3 \times 2$ no compasso 5 . Há nota do autor sugerindo a realização do cânone por quatro vezes em B.C., obedecendo a uma serialização de níveis de dinâmica em $f ; \boldsymbol{m} \boldsymbol{f} ; \boldsymbol{p} ; \boldsymbol{p} \boldsymbol{p}$ em cada execução, reservando-se a realização da Coda após a última repetição.

A linha melódica é uma grande curva que parte da tônica, tem seu ponto culminante no quarto grau, retomando a volta para a tônica com intervalo descendente de quinta diminuta, que, juntamente com o de sétima menor, requerem cuidados especiais para uma afinação precisa. A harmonia baseia-se na cadência $\mathrm{T} \mathrm{D}^{7}(\mathrm{~T})$.

24) CÂNONE $\mathbf{N}^{\circ}$ 9- a capella

\begin{tabular}{|c|c|c|c|c|c|c|c|}
\hline Volume & № & Vozes & Extensão & Tessitura & Tonalidade & $\begin{array}{l}\text { Intervalos } \\
\text { melódicos }\end{array}$ & $\begin{array}{c}\text { Intervalos } \\
\text { harmônicos }\end{array}$ \\
\hline S2 & $\begin{array}{l}\text { 9/ } \\
\text { p. } \\
21\end{array}$ & 3 & $\begin{array}{c}10^{a} \\
12 \text { compassos } \\
\text { binários }\end{array}$ & C3-Eb4 & Eb maior & 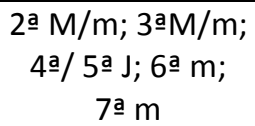 & 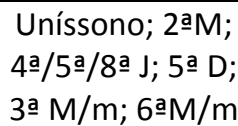 \\
\hline
\end{tabular}

Música de H.Villa-Lobos, sem texto, com indicação de andamento Allegretto Gracioso. Forma: A. 
A primeira e a terceira frases, com ritmo mais atrelado à pulsação, contrastam com a segunda frase, mais movimentada na subdivisão. A harmonia se desenvolve na cadência: T s D T.

25) CÂNONE $\mathbf{N}^{\circ} 18$ - a capella

\begin{tabular}{|c|c|c|c|c|c|c|c|}
\hline Volume & № & Vozes & Extensão & Tessitura & Tonalidade & $\begin{array}{l}\text { Intervalos } \\
\text { melódicos }\end{array}$ & $\begin{array}{c}\text { Intervalos } \\
\text { harmônicos }\end{array}$ \\
\hline S2 & $\begin{array}{l}18 / \\
\text { p. } 24\end{array}$ & $\begin{array}{l}4-\text { iguais } \\
\text { (Circular) }\end{array}$ & $\begin{array}{c}12^{\mathrm{a}} \\
32 \\
\text { compassos } \\
\text { binários }\end{array}$ & A2-E4 & $\begin{array}{l}\text { Modo de D } \\
\text { maior }\end{array}$ & $\begin{array}{c}\text { 2а } \mathrm{M} / \mathrm{m} ; \\
\text { 3а } \mathrm{a} / \mathrm{m} ; \\
\text { 4a/5a/8a J; } \\
\text { 6а } \mathrm{M} / \mathrm{m}\end{array}$ & 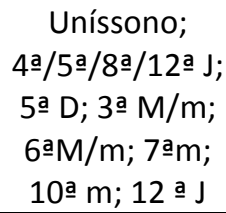 \\
\hline
\end{tabular}

Música de Francisco Braga e versos de Tito d'Alba, com indicação de andamento Allegretto. Forma: A.

O texto humorístico tem intenção correspondente na linha rítmica, onde palavras são entrecortadas por pausas. Harmonia sobre T D (S) D T.

26) CÂNONE $\mathbf{N}^{\circ} 1$ - a capella

\begin{tabular}{|c|c|c|c|c|c|c|c|}
\hline Volume & № & Vozes & Extensão & Tessitura & Tonalidade & $\begin{array}{l}\text { Intervalos } \\
\text { melódicos }\end{array}$ & $\begin{array}{l}\text { Intervalos } \\
\text { harmônicos }\end{array}$ \\
\hline S2 & $\begin{array}{c}1 / p . \\
20\end{array}$ & 4 & $\begin{array}{c}10^{a} \\
8 \text { compassos } \\
\text { binários }\end{array}$ & C3-E4 & F maior & 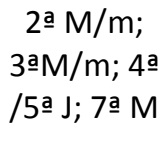 & 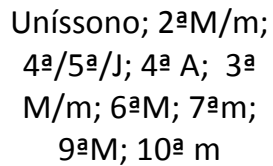 \\
\hline
\end{tabular}

Música de H.Villa-Lobos, com indicação de andamento Movimento Contínuo. Forma: A

Com o título: Alegria de viver, o texto complementa: no trabalho, no dever e no prazer. Há uma nota do autor: "Canção educativa para fazer distinguir a entoação do intervalo melódico de sétima do de oitava." Embora esse intervalo incida na sétima nota $\boldsymbol{E}$, ela não tem função de sensível, mas é a quinta do acorde de Dr. Portanto, a cadência harmônica básica se inicia com cadência de engano no primeiro pulso do compasso: Dr D / T.

27) CÂNONE $\mathbf{N}^{\circ} 3-$ a capella

\begin{tabular}{|c|c|c|c|c|c|c|c|}
\hline Volume & № & Vozes & Extensão & Tessitura & Tonalidade & $\begin{array}{l}\text { Intervalos } \\
\text { melódicos } \\
\end{array}$ & $\begin{array}{c}\text { Intervalos } \\
\text { harmônicos }\end{array}$ \\
\hline S2 & $\begin{array}{c}3 / \\
\text { p. } 20\end{array}$ & 2 & $\begin{array}{l}11 \underline{a} \\
18 \text { compassos } \\
\text { binários }\end{array}$ & C3-F4 & $\mathrm{F}$ maior & 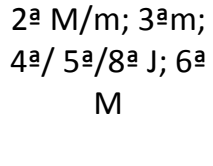 & 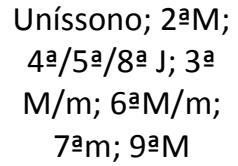 \\
\hline
\end{tabular}

Música de H.Villa-Lobos, sem texto, com indicação de andamento Marcial. Forma: A.

Há polirritmia métrica nos compassos 6 e 7 / 15 e 16, cujas tercinas devem ser confrontadas com o motivo rítmico principal apresentado no primeiro compasso. Harmonia sobre: T D (T). 
28) CÂNONE $\mathbf{N}^{\circ} 17$ - a capella

\begin{tabular}{|c|c|c|c|c|c|c|c|}
\hline Volume & № & Vozes & Extensão & Tessitura & Tonalidade & $\begin{array}{l}\text { Intervalos } \\
\text { melódicos }\end{array}$ & $\begin{array}{c}\text { Intervalos } \\
\text { harmônicos }\end{array}$ \\
\hline S2 & $\begin{array}{l}17 / \\
\text { p. } 23\end{array}$ & 8 & $\begin{array}{c}12 \underline{a} \\
8 \text { compassos } \\
\text { quaternários }\end{array}$ & C3-G4 & $\begin{array}{c}\text { Modo de C } \\
\text { maior }\end{array}$ & 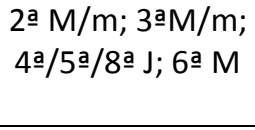 & 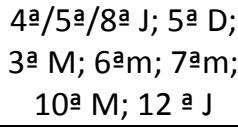 \\
\hline
\end{tabular}

Música de F. Solano (Ad Lectorem Mordacem $^{67}$ ), com indicação de andamento Andantino. Forma: A.

Em GP/VTL, o compasso 5 está incompleto: seriam: mínima pontuada e semínima, ou mínima e duas semínimas, ou mais provavelmente duas mínimas. O Lector mordax talvez devesse perguntar se a primeira voz deve entrar no segundo compasso, como indicado, ou ignorar a indicação inadequada. A maneira correta para indicar as oito vozes seria, a partir do primeiro compasso, constar a letra A para a entrada da primeira voz, B no segundo compasso para a segunda e assim sucessivamente até a oitava letra, F que não consta. A harmonia está sobre $\mathrm{T} \mathrm{D}^{7}(\mathrm{~T})$.

29) CÂNONE $N^{\circ} 19$ - a capella

\begin{tabular}{|c|c|c|c|c|c|c|c|}
\hline Volume & № & Vozes & Extensão & Tessitura & Tonalidade & $\begin{array}{l}\text { Intervalos } \\
\text { melódicos }\end{array}$ & $\begin{array}{l}\text { Intervalos } \\
\text { harmônicos }\end{array}$ \\
\hline \multirow[t]{2}{*}{ S2 } & \multirow[t]{2}{*}{$\begin{array}{l}19 / \\
\text { p. } 25\end{array}$} & \multirow[t]{2}{*}{$\begin{array}{l}\text { 4-iguais } \\
\text { (Circular) }\end{array}$} & \multirow{2}{*}{$\begin{array}{c}10^{\mathrm{a}} \\
32 \text { compassos } \\
\text { ternários }\end{array}$} & \multirow[t]{2}{*}{ B2-D4 } & \multirow[t]{2}{*}{$\mathrm{C}$ maior } & $\begin{array}{l}\text { 2a } \mathrm{M} / \mathrm{m} ; \\
\text { 3a } \mathrm{M} / \mathrm{m} ;\end{array}$ & 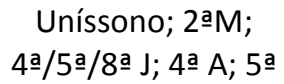 \\
\hline & & & & & & $\begin{array}{c}4 \mathrm{a} / 5 \mathrm{a} \mathrm{J} ; 6^{\mathrm{a}} \mathrm{m} ; \\
7 \mathrm{a}\end{array}$ & 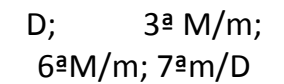 \\
\hline
\end{tabular}

Dedicada "Ao grande Villa-Lobos”, música de Francisco Braga e poesia de Tito d'Alba, com indicação de andamento Tempo de Minuete. Forma: A.

O vocabulário arcaico merece uma eventual análise textual para contextualização histórica. Embora com indicação de Minueto, a peça aproxima-se bastante das características da valsa brasileira.

30) CÂNONES Nº 8 e 16 - a capella

\begin{tabular}{|c|c|c|c|c|c|c|c|}
\hline Volume & № & Vozes & Extensão & Tessitura & Tonalidade & $\begin{array}{l}\text { Intervalos } \\
\text { melódicos }\end{array}$ & $\begin{array}{c}\text { Intervalos } \\
\text { harmônicos }\end{array}$ \\
\hline S2 & $\begin{array}{c}8 \text { p. } 21 \\
/ 16 \text { p. } \\
23\end{array}$ & 2 & $\begin{array}{c}11 \text { a } \\
26 / 34 \\
\text { compassos } \\
\text { binários }\end{array}$ & $\begin{array}{l}\text { C3-F4 / } \\
\text { Bb2-Eb3 }\end{array}$ & $\begin{array}{l}\mathrm{F} \text { maior / } \\
\text { Eb maior }\end{array}$ & 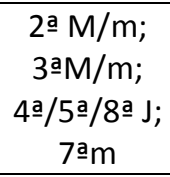 & 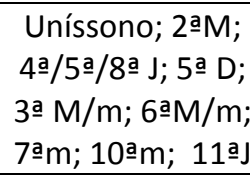 \\
\hline
\end{tabular}

Música de H.Villa-Lobos, sem texto, com indicações : (a oitava) e de andamento Allegro Vivace / Andantino. Forma: A.

Os cânones 8 e 16 são idênticos, com mínimas alterações no final, sendo que o primeiro é para vozes iguais, em compasso 2 por 2, e o segundo para vozes mistas, um tom abaixo, em compasso 2 por 4 . O grande desafio dessas peças são os saltos de oitavas e sétimas, embora o movimento harmônico D (ou S) T em cada compasso facilite o alcance das notas. No compasso 9 (solfejo $\mathrm{n}^{\circ} 16$ ), a última nota $\boldsymbol{D}$, na primeira voz deve ser bemol.

$\overline{{ }^{67} \text { N.A. Tradução: Para o leitor mordaz. }}$ 


\subsubsection{Contraponto imitativo}

31) O ANEL - a capella

\begin{tabular}{|c|c|c|c|c|c|c|c|}
\hline Volume & № & Vozes & Extensão & Tessitura & Tonalidade & $\begin{array}{l}\text { Intervalos } \\
\text { melódicos }\end{array}$ & $\begin{array}{l}\text { Intervalos } \\
\text { harmônicos }\end{array}$ \\
\hline $\begin{array}{c}\text { GP VTL / } \\
\text { ABM }\end{array}$ & $\begin{array}{c}8 \\
/ 42\end{array}$ & 2 & $\begin{array}{c}\text { 9á } \\
10 \text { compassos } \\
\text { binários }\end{array}$ & $\begin{array}{l}\text { 1a v.: Eb3-C4 } \\
\text { 2a v.: Bb2-G3 }\end{array}$ & $\begin{array}{l}\text { Modo } \\
\text { hexatônico } \\
\text { de Eb }\end{array}$ & $\begin{array}{c}\text { 2а } \mathrm{M} / \mathrm{m} ; \\
\text { 3а } \mathrm{M} / \mathrm{m} ; \\
\text { 4 }\end{array}$ & 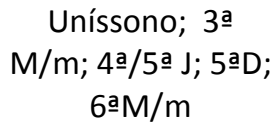 \\
\hline
\end{tabular}

Análise parcial em $2.1-n^{\circ} 29$.

Contraponto imitativo por movimento contrário de terças cheias. Na segunda frase, o texto tem sílabas repetidas sobre notas rebatidas, enriquecendo a linha rítmica e o plano de timbres. $\mathrm{O}$ arranjo, de fácil execução, é adequado para coros infantis.

Solo instrumental - há indicação para que a mão esquerda toque uma oitava abaixo quando a peça for executada ao piano.

32) CANTOS DE ÇAIRÉ (3) - a capella

\begin{tabular}{|c|c|c|c|c|c|c|c|}
\hline Volume & № & Vozes & Extensão & Tessitura & Tonalidade & $\begin{array}{l}\text { Intervalos } \\
\text { melódicos }\end{array}$ & $\begin{array}{c}\text { Intervalos } \\
\text { harmônicos }\end{array}$ \\
\hline $\mathrm{CO} 2$ & 20 & 2 & $\begin{array}{c}10^{\mathrm{a}} \\
12 \text { compassos } \\
\text { binários }\end{array}$ & $\begin{array}{c}\text { 1a v.: Bb3-Eb4 } \\
\text { 2a v.: C3-G3 }\end{array}$ & $\begin{array}{c}\text { Modo Hexatônico } \\
\text { menor defectivo } \\
\text { de } \mathrm{Bb}\end{array}$ & 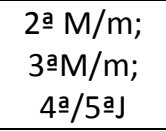 & 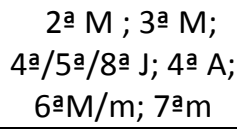 \\
\hline
\end{tabular}

Análise parcial em $2.1-n^{\circ} 62$.

Com imitação à quinta inicialmente, o contraponto privilegia intervalos de sextas no decorrer da peça, terminando em quinta. Apojaturas ascendentes de terças interferem no plano timbrístico e, ligeiramente, no plano harmônico. Peça adequada e motivadora para coro infantil principiante.

33) SOLFEJO $\mathrm{N}^{\circ} \mathbf{s}$ 1, 2, 3 - Imitações - a capella

\begin{tabular}{|c|c|c|c|c|c|c|c|}
\hline Volume & № & Vozes & Extensão & Tessitura & Tonalidade & $\begin{array}{l}\text { Intervalos } \\
\text { melódicos }\end{array}$ & $\begin{array}{l}\text { Intervalos } \\
\text { harmônicos }\end{array}$ \\
\hline S2 & $\begin{array}{l}1-3 / \\
\text { p.18 }\end{array}$ & 2 & $\begin{array}{c}11 \text { a } \\
8 \\
\text { compassos } \\
\text { binários }\end{array}$ & $\begin{array}{l}\text { 1a v.: G3-F4; } \\
\text { 2a v.: C3-D4 } \\
\text { 2a v.: C3-G3 } \\
\text { 2a v.: C3-C4 }\end{array}$ & $\begin{array}{c}\text { Modo de C } \\
\text { maior }\end{array}$ & 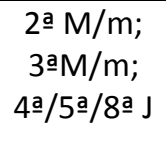 & 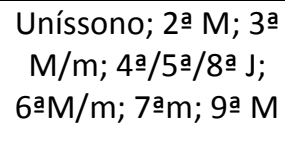 \\
\hline
\end{tabular}

Melodia de Villa-Lobos, formada por três motivos descendentes, com imitação à oitava, à quinta e à sexta na segunda voz respectivamente dos números 1, 2 e 3 . Forma: A.

O contraponto privilegia intervalos de terças e sextas paralelas, é de simples execução, porém sua extensão e plano de alturas são indicações para vozes adultas.

34) SOLFEJO $N^{\circ} \mathbf{4}$ - Imitação - a capella

\begin{tabular}{|c|c|c|c|c|c|c|c|}
\hline Volume & № & Vozes & Extensão & Tessitura & Tonalidade & $\begin{array}{l}\text { Intervalos } \\
\text { melódicos }\end{array}$ & Intervalos harmônicos \\
\hline S2 & $\begin{array}{c}4 / \\
\text { p.18 }\end{array}$ & 2 & $\begin{array}{c}14^{a} \\
8 \\
\text { compassos } \\
\text { binários }\end{array}$ & $\begin{array}{l}\text { 1a v.: F3-G4; } \\
\text { 2a v.: A2-A3 }\end{array}$ & $\begin{array}{c}\text { Modo de A } \\
\text { menor }\end{array}$ & 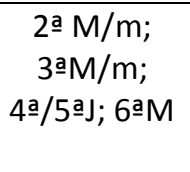 & 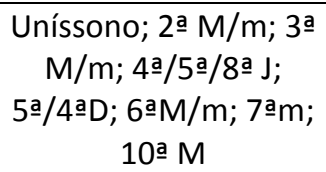 \\
\hline
\end{tabular}


Muito semelhante aos anteriores, o interesse está no modo menor e maior diversidade dos intervalos harmônicos.

35) SAPO JURURU - a capella

\begin{tabular}{|c|c|c|c|c|c|c|c|}
\hline Volum3e & № & Vozes & Extensão & Tessitura & Tonalidade & $\begin{array}{l}\text { Intervalos } \\
\text { melódicos }\end{array}$ & $\begin{array}{l}\text { Intervalos } \\
\text { harmônicos }\end{array}$ \\
\hline $\begin{array}{l}\text { GP-VTL } \\
\text { /ABM }\end{array}$ & $\begin{array}{l}113 \\
/ 41\end{array}$ & 2 & $\begin{array}{c}11 \text { a } \\
10 \text { compassos } \\
\text { binários }\end{array}$ & $\begin{array}{c}\text { 1a v.: C\#3-D4 } \\
\text { 2a v.: A2-A3 }\end{array}$ & $\begin{array}{l}\text { Modo de } A \\
\text { maior }\end{array}$ & 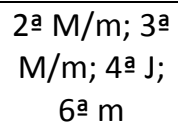 & $\begin{array}{c}\text { 2a } M / m ; 3^{a} \\
M / m ; 4 \text { a } / 5^{a} / 8^{a} \mathrm{~J} ; \\
6 \underline{a} \mathrm{M} / \mathrm{m}\end{array}$ \\
\hline
\end{tabular}

Análise parcial em $2.1-n^{\circ} 76$.

Iniciado com imitação à oitava, o contraponto enfatiza terças e sextas harmônicas, terminando por movimento contrário em oitava. Em GP/ABM, a primeira nota do penúltimo compasso na segunda voz é $\boldsymbol{E}$ e não $\boldsymbol{D}$, como consta.

36) O BALÃO DO BITU (Sobre o tema "Vem cá Bitu") - a capella

\begin{tabular}{|c|c|c|c|c|c|c|c|}
\hline Volume & № & Vozes & Extensão & Tessitura & Tonalidade & $\begin{array}{l}\text { Intervalos } \\
\text { melódicos }\end{array}$ & $\begin{array}{l}\text { Intervalos } \\
\text { harmônicos }\end{array}$ \\
\hline $\mathrm{CO} 2$ & 3 & 2 & $\begin{array}{c}9 \underline{a} \\
14 \text { compassos } \\
\text { binários }\end{array}$ & $\begin{array}{l}\text { 1a e 2a } \\
\text { vozes: } \\
\text { D3-E4 }\end{array}$ & $\begin{array}{l}\text { Modo de D } \\
\text { maior }\end{array}$ & 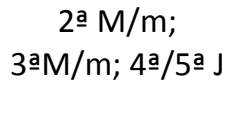 & 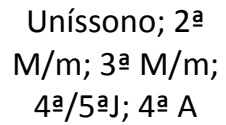 \\
\hline
\end{tabular}

Letra e tema populares, com melodia ambientada por H.Villa-Lobos. Forma: A.

Nesta peça, o autor interfere na configuração melódica tradicional, e emprega o contraponto imitativo utilizando os textos das duas versões mais conhecidas: Cai, cai, balão e Vem cá, Bitu. A melodia passa para a segunda voz nos compassos 8-10, com cruzamento das vozes.

37) SOLFEJO $\mathbf{N}^{\circ} 73$ - a capella

\begin{tabular}{|c|c|c|c|c|c|c|c|}
\hline Volume & № & Vozes & Extensão & Tessitura & Tonalidade & $\begin{array}{l}\text { Intervalos } \\
\text { melódicos }\end{array}$ & $\begin{array}{c}\text { Intervalos } \\
\text { harmônicos }\end{array}$ \\
\hline S1 & 73 & 2 & $\begin{array}{c}10^{a} \\
8 \text { compassos } \\
\text { ternários }\end{array}$ & $\begin{array}{c}1 \text { a v.:D3-C\#4 } \\
\text { 2a v.:A2-A3 }\end{array}$ & $\begin{array}{c}\text { Modo de D } \\
\text { maior }\end{array}$ & $\begin{array}{l}\text { 2a } \mathrm{M} / \mathrm{m} ; \\
\text { 3묵 4의 }\end{array}$ & 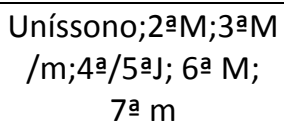 \\
\hline
\end{tabular}

Tema de Villa-Lobos com indicação de andamento Tempo de Mazurka, apresentado nos quatro primeiros compassos na segunda voz e imitado à quarta na primeira voz nos últimos quatro compassos, com graus conjuntos em contraponto na segunda voz com valores longos, com finalização por salto de quarta.

38) VAMOS, COMPANHEIROS - Canção escolar - a capella

\begin{tabular}{|c|c|c|c|c|c|c|c|}
\hline Volume & № & Vozes & Extensão & Tessitura & Tonalidade & $\begin{array}{l}\text { Intervalos } \\
\text { melódicos }\end{array}$ & $\begin{array}{c}\text { Intervalos } \\
\text { harmônicos }\end{array}$ \\
\hline $\mathrm{CO} 1$ & 3 & 2 & $\begin{array}{c}11 \text { a } \\
14 \text { compassos } \\
\text { binários }\end{array}$ & $\begin{array}{l}1 \text { a v.: C3-C4 } \\
2^{\text {a } ~ v .: ~ G 2-A 3 ~}\end{array}$ & Modo de C maior & $\begin{array}{l}\text { 2a } \mathrm{M} / \mathrm{m} ; 3 \text { a } \\
\mathrm{M} / \mathrm{m} ; 4 \text { a } / 5 \text { a J }\end{array}$ & 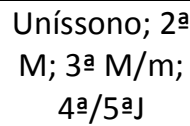 \\
\hline
\end{tabular}

Análise parcial em $2.1-n^{\circ} 36$. 
Arranjo de Villa-Lobos (Rio, 1935), iniciado com imitação à oitava, porém com a sequência em terças paralelas até o final da peça, exceto nas finalizações da segunda frase. Com a indicação Moderato, contam indicações de intensidade $\boldsymbol{f}$ para os inícios da primeira frase, $\boldsymbol{m} \boldsymbol{f}$ e pp para as interferências de eco na primeira frase.

39) MARCHA ESCOLAR (Ida para o recreio) - a capella

\begin{tabular}{|c|c|c|c|c|c|c|c|}
\hline Volume & № & Vozes & Extensão & Tessitura & Tonalidade & $\begin{array}{l}\text { Intervalos } \\
\text { melódicos }\end{array}$ & $\begin{array}{c}\text { Intervalos } \\
\text { harmônicos }\end{array}$ \\
\hline $\mathrm{CO} 1$ & 9 & 2 & $\begin{array}{c}10^{a} \\
15 \text { compassos } \\
\text { binários }\end{array}$ & $\begin{array}{c}1 \text { a v.: C3-D4 } \\
\text { 2a v.: Bb2-A3 }\end{array}$ & $\begin{array}{l}\text { Modo de } \mathrm{F} \\
\text { maior }\end{array}$ & 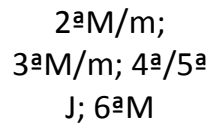 & 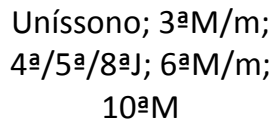 \\
\hline
\end{tabular}

Anônimo, com arranjo de Villa-Lobos. Forma: A.

O contraponto imitativo tem predomínio de intervalos harmônicos de terças e sextas. De fácil execução, a peça é adequada para coros infantis iniciantes.

40) ENTREI NA RODA- a capella

\begin{tabular}{|c|c|c|c|c|c|c|c|}
\hline Volume & № & $\begin{array}{c}\text { Voze } \\
\text { s }\end{array}$ & Extensão & Tessitura & Tonalidade & $\begin{array}{l}\text { Intervalos } \\
\text { melódicos }\end{array}$ & $\begin{array}{c}\text { Intervalos } \\
\text { harmônicos }\end{array}$ \\
\hline $\begin{array}{l}\text { GP VTL } \\
\text { / ABM } \\
\text { /S1 }\end{array}$ & $\begin{array}{l}49 \\
/ 43 \\
/ 18\end{array}$ & 2 & $\begin{array}{c}12^{\mathrm{a}} \\
24 \text { compassos } \\
\text { binários }\end{array}$ & $\begin{array}{l}\text { 1a v.: D3-D4 } \\
\text { 2a v.: G2-B3 }\end{array}$ & $\begin{array}{l}\text { Modo de G } \\
\text { maior }\end{array}$ & 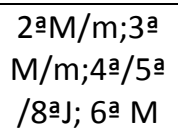 & 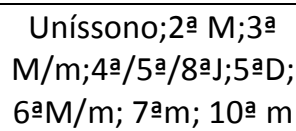 \\
\hline
\end{tabular}

Análise parcial em $2.1-n^{\circ} 20$.

Contraponto imitativo à sexta, com ênfase nos intervalos melódicos de terças e sextas. A harmonia passa pelas funções principais, com apenas uma alteração [G\#] para passagem da dominante secundária para a Sr na segunda voz. A peça termina com um salto ascendente paralelo de oitava, com opção de salto de terça para a primeira voz.

Solo instrumental - há indicação para que a mão esquerda toque uma oitava abaixo quando a peça for executada ao piano.

41) REPIU-PIU-PIU - a capella

\begin{tabular}{|c|c|c|c|c|c|c|c|}
\hline Volume & № & Vozes & Extensão & Tessitura & Tonalidade & $\begin{array}{l}\text { Intervalos } \\
\text { melódicos }\end{array}$ & $\begin{array}{l}\text { Intervalos } \\
\text { harmônicos }\end{array}$ \\
\hline $\mathrm{CO} 2$ & 4 & 2 & $\begin{array}{c}10^{a} \\
9 \text { compassos } \\
\text { quaternários }\end{array}$ & $\begin{array}{l}\text { 1a v.: C3-C4 } \\
\text { 2a v.: A2-G3 }\end{array}$ & $\begin{array}{l}\text { Modo de } F \\
\text { maior }\end{array}$ & $\begin{array}{c}\text { 2а } M / m ; 3 a M / m ; \\
\text { 4а/5a } ; 6 \text {; } \mathrm{a} / \mathrm{m}\end{array}$ & 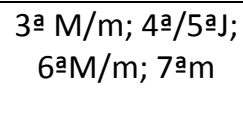 \\
\hline
\end{tabular}

Com letra de Affonso Lopes Vieira e melodia de Tomas Borba, Villa-Lobos faz o arranjo com contraponto imitativo à oitava, com predomínio de intervalos harmônicos de terças e sextas. A indicação de andamento é Allegretto (leve e ligeiro). Forma: A.

O texto, com intenção timbrística, imita o piar do pássaro. A melodia favorece a aquisição dos intervalos melódicos de quarta e quinta justas. As colcheias ligadas a semicolcheias poderiam ser substituídas por colcheias pontuadas para facilitar a leitura.

Complementação do texto:

- Repiu-piu-piu canta o passarinho, canta o passarinho mal o sol subiu. 
Repiu-piu-piu, Repiu-piu-piu, Repiu-piu-piu, piu-piu-piu,

- Repiu-piu-piu, lá vem a voar, e pôs-se a falar quando o outro viu:

Repiu-piu-piu, Repiu-piu-piu, Repiu-piu-piu, piu-piu-piu,

- Repiu-piu-piu, ai! que graça tem! Já outro também canta quando o ouviu:

Repiu-piu-piu, Repiu-piu-piu, Repiu-piu-piu, piu-piu-piu,

- Repiu-piu-piu canta o passarinho, mas devagarinho que o sol se sumiu.

Repiu-piu-piu, Repiu-piu-piu, Repiu-piu-piu, piu-piu-piu,

42) SOLFEJO $N^{\circ} 157$ - a capella

\begin{tabular}{|c|c|c|c|c|c|c|c|}
\hline Volume & № & Vozes & Extensão & Tessitura & Tonalidade & $\begin{array}{l}\text { Intervalos } \\
\text { melódicos }\end{array}$ & $\begin{array}{l}\text { Intervalos } \\
\text { harmônicos }\end{array}$ \\
\hline S1 & 157 & 2 & $\begin{array}{c}11 \text { a } \\
6 \text { compassos } \\
\text { binários (subdivisão } \\
\text { ternária) }\end{array}$ & $\begin{array}{l}\text { 1a v.:G3-Eb4 } \\
\text { 2a v.:G2-Bb3 }\end{array}$ & $\begin{array}{l}\text { Modo de } \mathrm{F} \\
\text { maior }\end{array}$ & 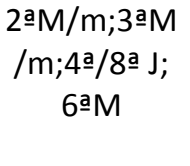 & $\begin{array}{l}\text { Uníssono; 3a } \\
\mathrm{M} / \mathrm{m} ; 5 \underline{a} \mathrm{D} ; \\
\text { 6ㅁM/m; }\end{array}$ \\
\hline
\end{tabular}

Melodia de Villa-Lobos, com indicação de andamento Andantino (Barcarola), em subdivisão ternária, com base no arpejo da T com apojatura 6-5 e da D com sétima alcançada por nota de passagem com resolução na $\mathrm{T}$ por apojatura 4-3 na primeira frase e no primeiro grau ao final. O contraponto imitativo na segunda voz privilegia terças e sextas harmônicas.

43) SOLFEJO $N^{\circ} 6$ - Imitação - a capella

\begin{tabular}{|c|c|c|c|c|c|c|c|}
\hline Volume & № & Vozes & Extensão & Tessitura & Tonalidade & $\begin{array}{l}\text { Intervalos } \\
\text { melódicos }\end{array}$ & $\begin{array}{c}\text { Intervalos } \\
\text { harmônicos }\end{array}$ \\
\hline S2 & $\begin{array}{c}6 / \\
\text { p.19 }\end{array}$ & 2 & $\begin{array}{c}\text { 7ạ } \\
8 \text { compassos } \\
\text { quaternários }\end{array}$ & F3-E4 & $\begin{array}{c}\text { Modo eólio } \\
\text { de A }\end{array}$ & 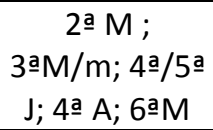 & 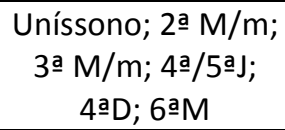 \\
\hline
\end{tabular}

Tema de Villa-Lobos com indicação de andamento Adagio e de intensidades: $\boldsymbol{f}>$ para a primeira voz e $\boldsymbol{p}$ para a segunda voz em toda a peça. Forma: A.

Contraponto imitativo perfeito, com única variação no final, na primeira voz. Privilegia os intervalos de terças e sextas.

44) BRINCADEIRA DE PEGAR (No prado da Madalena) - a capella

\begin{tabular}{|c|c|c|c|c|c|c|c|}
\hline Volume & № & Vozes & Extensão & Tessitura & Tonalidade & $\begin{array}{c}\text { Intervalos } \\
\text { melódicos }\end{array}$ & $\begin{array}{c}\text { Intervalos } \\
\text { harmônicos }\end{array}$ \\
\hline CO2 & 1 & 2 & $\begin{array}{c}10^{\mathrm{a}} \\
\begin{array}{c}18 \text { compassos } \\
\text { binários }\end{array}\end{array}$ & $\begin{array}{c}1^{\mathrm{a}} \mathrm{a} . \mathrm{F} \# 3-\mathrm{F} 4 \\
2^{\mathrm{a}} \mathrm{v} . \mathrm{C} \# 3-\mathrm{C \# 4}\end{array}$ & $\begin{array}{c}\text { Modo de G } \\
\text { maior }\end{array}$ & $\begin{array}{c}2^{\mathrm{a}} \mathrm{M} / \mathrm{m} ; \\
3^{\mathrm{a}} \mathrm{M} / \mathrm{m} ; 5^{\mathrm{a}} \mathrm{J} ; \\
5^{\mathrm{a}} \mathrm{D} ; 6^{\mathrm{a}} \mathrm{m}\end{array}$ & $\begin{array}{c}\text { Uníssono; } \\
\mathrm{M} / \mathrm{m} ; 4^{\mathrm{a}} \\
\mathrm{D} / 5^{\underline{a}} / 8^{\mathrm{a}} \mathrm{J} ; 5^{\mathrm{a}} \\
\mathrm{D} ; 6^{\mathrm{a}} \mathrm{m} ; 7^{\mathrm{a}} \mathrm{m}\end{array}$ \\
\hline
\end{tabular}

Composição de Villa-Lobos dedicada a Ernani Braga e às crianças de Recife (8/07/1934).

Com o contraponto imitativo à quarta, a melodia está na segunda voz, exceto na última frase, quando passa para a primeira. Todas as frases iniciam com arpejos ascendentes de tríades que determinam a sequência das funções harmônicas. As terças harmônicas predominam, inclusive com paralelismos eventuais. A única alteração $[\boldsymbol{A} \#]$ determina a dominante secundária para resolver na Sr. Como indicação de andamento, consta: "Começar em Allegretto, aumentando pouco a pouco até Presto". A peça termina na T com uma oitava em $f f$. 
45) SOLFEJO $N^{\circ} 89$ - a capella

\begin{tabular}{|c|c|c|c|c|c|c|c|}
\hline Volume & № & Vozes & Extensão & Tessitura & Tonalidade & $\begin{array}{l}\text { Intervalos } \\
\text { melódicos }\end{array}$ & $\begin{array}{c}\text { Intervalos } \\
\text { harmônicos }\end{array}$ \\
\hline S1 & 89 & 2 & $\begin{array}{c}18^{a} \\
8 \text { compassos } \\
\text { quaternários }\end{array}$ & $\begin{array}{l}\text { 1a v.:E3-F4 } \\
\text { 2a v.:C3-E4 }\end{array}$ & $\begin{array}{c}\text { Modo de C } \\
\text { maior }\end{array}$ & 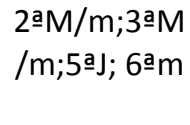 & 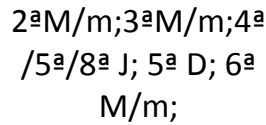 \\
\hline
\end{tabular}

Melodia de Villa-Lobos com indicação de andamento Allegretto, com o contraponto imitativo na segunda voz, à oitava, apresenta polirritmia de $6 \times 4$ na segunda parte. Terças e sextas predominam na primeira parte e quintas e quartas na segunda. As vozes se desenvolvem por graus conjuntos e saltos de terças ou sextas, na primeira parte em linhas ascendentes e na segunda em planos de alturas próximos.

46) SOLFEJO N $\mathrm{N}^{\circ} 84$ / 121 - a capella

\begin{tabular}{|c|c|c|c|c|c|c|c|}
\hline Volume & № & Vozes & Extensão & Tessitura & Tonalidade & $\begin{array}{l}\text { Intervalos } \\
\text { melódicos }\end{array}$ & $\begin{array}{c}\text { Intervalos } \\
\text { harmônicos }\end{array}$ \\
\hline S1 & $\begin{array}{c}84 \\
/ 121\end{array}$ & 2 & $\begin{array}{c}18^{a} \\
8 \text { compassos } \\
\text { binários }\end{array}$ & $\begin{array}{c}\text { 1a v.:E3-E4 } \\
\text { 2a v.:Bb1-Bb2 }\end{array}$ & $\begin{array}{l}\text { Modo de D } \\
\text { menor }\end{array}$ & 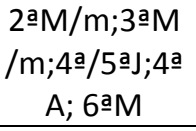 & 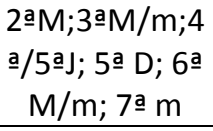 \\
\hline
\end{tabular}

Com indicação de andamento Movimento de Gavotte, a melodia de Villa-Lobos para vozes mistas inicia-se em $\boldsymbol{F}$ maior, passa para sua relativa menor e termina com o acorde final em $\boldsymbol{D}$ maior. Este solfejo aparece também com o número 121, idêntico, apenas com a indicação de andamento Tempo de Gavotte. Contraponto imitativo na segunda voz, à quarta, com predomínio de terças e sextas de forma recorrente. Nos compassos 5 e 6 , primeira voz e compasso 6 (no $\mathrm{n}^{\circ}$ 121) na segunda voz há cromatismos ornamentais em apojaturas descendentes e, no compasso 7, a alteração é de cunho estrutural.

47) SOLFEJO $\mathbf{N}^{\circ} 70$ - a capella

\begin{tabular}{|c|c|c|c|c|c|c|c|}
\hline Volume & № & Vozes & Extensão & Tessitura & Tonalidade & $\begin{array}{l}\text { Intervalos } \\
\text { melódicos }\end{array}$ & $\begin{array}{l}\text { Intervalos } \\
\text { harmônicos }\end{array}$ \\
\hline S1 & 70 & 2 & $\begin{array}{c}10^{\mathrm{a}} \\
16 \\
\text { compassos } \\
\text { binários }\end{array}$ & 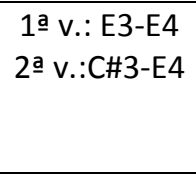 & $\begin{array}{l}\text { Modo de A } \\
\text { maior }\end{array}$ & 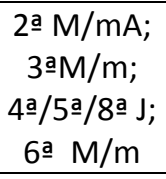 & 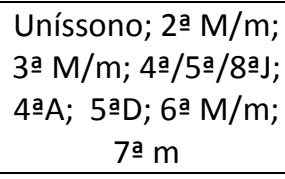 \\
\hline
\end{tabular}

Melodia de Villa-Lobos, com indicação de andamento Allegretto, em forma ABA, no modo maior na primeira parte, em menor, na Tr na segunda parte. A primeira frase emprega células rítmicas que se contrapõem a figuras correspondentes à pulsação. A segunda voz começa imitando as células rítmicas iniciais e continua com síncopas em linha escalar ascendente com finalização na T. A segunda parte, em modo menor, é imitativa, com a primeira frase terminando em terça, na dominante e a segunda terminando em uníssono, na tônica. 
48) SOLFEJO N ${ }^{\circ} 7$ - IMITAÇÃO - a capella

\begin{tabular}{|c|c|c|c|c|c|c|c|}
\hline Volume & № & Vozes & Extensão & Tessitura & Tonalidade & $\begin{array}{l}\text { Intervalos } \\
\text { melódicos }\end{array}$ & Intervalos harmônicos \\
\hline S2 & $\begin{array}{c}7 \\
/ p .19\end{array}$ & 3 & $\begin{array}{l}12^{a} \\
\text { Ritmo } \\
\text { livre }\end{array}$ & $\begin{array}{l}1 \text { a v.: D3-D4 } \\
\text { 2a v.: D3-A3 } \\
\text { 3ㅁ v.: G2-D3 }\end{array}$ & $\begin{array}{c}\text { Modo } \\
\text { dórico de } \mathrm{D}\end{array}$ & 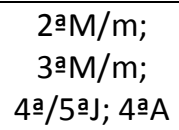 & 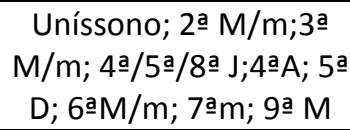 \\
\hline
\end{tabular}

Melodia sobre motivos gregos (Coros femininos do bailado). Forma: A.

O contraponto, em ritmo livre, apresenta imitações à sexta e à sétima na segunda e terceira vozes respectivamente, privilegiando tríades maiores e menores. Terminação em cadência modal com final em uníssono. O efeito timbrístico no vocalize entre as vozes está na variação das sílabas: $1^{\mathrm{a}}$ vez: $A h !\left(1^{\mathrm{a}}\right.$ voz); $2^{\mathrm{a}}$ vez: $U m !\left(2^{\mathrm{a}}\right.$ e $3^{\mathrm{a}}$ voz); $3^{\mathrm{a}}$ vez: $U !$ (todas as vozes), ou seja: na primeira vez, apenas a primeira voz, na segunda vez todas as vozes com suas sílabas prédeterminadas e terceira vez todas as vozes em uma única sílaba.

49) SOLFEJO N $N^{\circ} 153$ / 163 - a capella

\begin{tabular}{|c|c|c|c|c|c|c|c|}
\hline Volume & № & Vozes & Extensão & Tessitura & Tonalidade & $\begin{array}{l}\text { Intervalos } \\
\text { melódicos }\end{array}$ & $\begin{array}{l}\text { Intervalos } \\
\text { harmônicos }\end{array}$ \\
\hline S1 & 153 & 2 & $\begin{array}{c}12^{\mathrm{a}} \\
8 \text { compassos } \\
\text { binários }\end{array}$ & $\begin{array}{l}\text { 1a v.:A3-F4 } \\
\text { 2a v.:A2-A3 }\end{array}$ & $\begin{array}{c}\text { Modo de A } \\
\text { menor }\end{array}$ & $\begin{array}{c}\text { 2aM/m;3aM } \\
\text { /m;4aj; }\end{array}$ & $\begin{array}{l}\text { 3a } \mathrm{M} ; \text { 4a / } \\
\text { 8a; 6ㅁM }\end{array}$ \\
\hline
\end{tabular}

Melodia de Villa-Lobos, com indicação de andamento Andantino, baseada em imitação, em diálogo por bordaduras inferiores. A primeira voz apresenta movimento ascendente de tetracorde a partir do primeiro grau, finalizando em linha escalar de pentacorde para a tônica, com o contraponto em movimento contrário. A segunda frase tem o mesmo procedimento na segunda voz, encaminhando-se do quinto grau ascendentemente para a tônica, com movimento contrário da primeira voz com finalização na tônica. O último compasso apresenta intervalos harmônicos de arpejo descendente do acorde de tônica com sexta. Este solfejo é igual ao $\mathrm{n}^{\circ} 163$.

50) SOLFEJO $\mathbf{N}^{\circ} 99$ - a capella

\begin{tabular}{|c|c|c|c|c|c|c|c|}
\hline Volume & № & Vozes & Extensão & Tessitura & Tonalidade & $\begin{array}{l}\text { Intervalos } \\
\text { melódicos }\end{array}$ & $\begin{array}{l}\text { Intervalos } \\
\text { harmônicos }\end{array}$ \\
\hline S1 & 99 & 2 & $\begin{array}{c}15^{a} \\
10 \text { compassos } \\
\text { ternários }\end{array}$ & $\begin{array}{l}1 \stackrel{a}{a} \text { v.:E3-E4 } \\
\text { 2a v.:E2-D3 }\end{array}$ & $\begin{array}{l}\text { Modo de D } \\
\text { maior }\end{array}$ & $\begin{array}{c}2 \text { a } \mathrm{M} / \mathrm{m} ; 3^{\mathrm{a}} \mathrm{M} / \\
\mathrm{m} ; 4 \mathrm{a} / 5^{\mathrm{a}} \mathrm{J} ; 6^{\mathrm{a}} \\
\mathrm{M} / \mathrm{m}\end{array}$ & 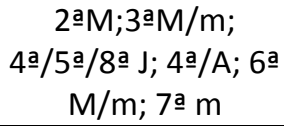 \\
\hline
\end{tabular}

Melodia de Villa-Lobos, com indicação de andamento Andantino, para vozes mistas. O contraponto imitativo na segunda voz, à segunda, apresenta terças e sextas recorrentes. Enquanto a melodia apresenta saltos de sextas e outros, o contraponto trabalha mais com graus conjuntos.

51) SOLFEJO $N^{\circ} 161$ - a capella

\begin{tabular}{|c|c|c|c|c|c|c|c|}
\hline Volume & № & Vozes & Extensão & Tessitura & Tonalidade & $\begin{array}{l}\text { Intervalos } \\
\text { melódicos }\end{array}$ & Intervalos harmônicos \\
\hline S1 & 161 & 2 & $\begin{array}{c}20^{a} \\
8 \text { compassos } \\
\text { binários }\end{array}$ & $\begin{array}{l}1 \text { a v.:C3-Eb4 } \\
\text { 2a v.:G1-Ab2 }\end{array}$ & $\begin{array}{l}\text { Modo de C } \\
\text { menor }\end{array}$ & 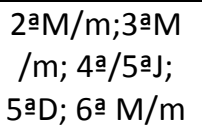 & 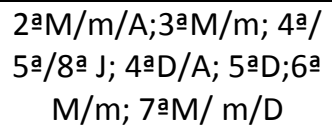 \\
\hline
\end{tabular}


Melodia de Villa-Lobos, com indicação de andamento Allegro Moderato, para vozes mistas. O contraponto imitativo na primeira voz, à oitava, apresenta sextas recorrentes. As alterações são estruturais e ornamentais (cromatismo no compasso 6), e o ritmo caracteriza-se pelas síncopas apresentadas no tema inicial.

\subsubsection{Contraponto livre}

52) VAMOS, CRIANÇAS - a capella

\begin{tabular}{|c|c|c|c|c|c|c|c|}
\hline Volume & № & Vozes & Extensão & Tessitura & Tonalidade & $\begin{array}{l}\text { Intervalos } \\
\text { melódicos }\end{array}$ & $\begin{array}{l}\text { Intervalos } \\
\text { harmônicos }\end{array}$ \\
\hline $\mathrm{CO} 1$ & 2 & 3 & $\begin{array}{c}\text { 9a } \\
\text { 8compassos } \\
\text { binários }\end{array}$ & $\begin{array}{l}\text { 1a v.:Eb3-C4 } \\
\text { 2a v.:Bb2-G3 } \\
\text { 3a v.:Bb2-Eb3 }\end{array}$ & $\begin{array}{l}\text { Modo de Eb } \\
\text { maior }\end{array}$ & $\begin{array}{c}2 \mathrm{a} M / \mathrm{m} ; 3^{\mathrm{a}} \\
\mathrm{M} / \mathrm{m} \\
4 \mathrm{a} / 8^{\mathrm{a}} \mathrm{J}\end{array}$ & 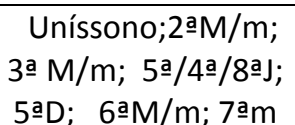 \\
\hline
\end{tabular}

Análise parcial em $2.1-\mathrm{n}^{\circ} 23$.

Tema popular, conhecido como "Marcha Soldado", é adequado para o repertório coral dirigido à Educação Infantil. O autor recomenda a primeira execução em $\boldsymbol{p}$, a segunda em $\boldsymbol{m f}$ e a terceira em $\boldsymbol{p}$ com decrescendo até o pianíssimo, sugerindo um distanciamento cada vez maior, conservando, porém, o mesmo andamento. Essa observação de Villa-Lobos é uma interessante constatação de sua afinidade com a criança e sua capacidade de interpretação da música em todos os seus elementos.

A três vozes, os contrapontos da segunda e terceira vozes têm papel de acompanhamento para a melodia na primeira voz, sobre o texto: Hum!, que resulta em delicada marcação rítmica de marcha. A segunda voz faz um arpejo da $\mathrm{T}$ na primeira frase, e finaliza a segunda frase com sensível/tônica. A terceira voz faz uma progressão de intervalos ascendentes de segunda, terça e quarta, de muito fácil execução.

Trata-se de um ótimo exemplo de peça para corais principiantes, e modelo para arranjos de canções similares.

53) BELA PASTORA - acompanhamento instrumental

\begin{tabular}{|c|c|c|c|c|c|c|c|}
\hline Volume & № & Vozes & Extensão & Tessitura & Tonalidade & $\begin{array}{l}\text { Intervalos } \\
\text { melódicos }\end{array}$ & $\begin{array}{l}\text { Intervalos } \\
\text { harmônicos }\end{array}$ \\
\hline $\begin{array}{l}\text { GP-VTL } \\
\text { / ABM }\end{array}$ & $\begin{array}{l}15 \\
/ 124\end{array}$ & 2 & $\begin{array}{c}10^{\mathrm{a}} \\
22 \text { compassos } \\
\text { binários }\end{array}$ & $\begin{array}{l}\text { 1a v.:D3-D4 } \\
\text { 2a v.:B2-B3 }\end{array}$ & $\begin{array}{c}\text { Modo de } A \\
\text { maior }\end{array}$ & 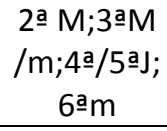 & $\begin{array}{l}\text { Uníssono;3a } \\
\mathrm{M} / \mathrm{m} ; 5^{\mathrm{a}} / 4^{\mathrm{a}} \mathrm{J} ; 6^{\mathrm{a}} \mathrm{m}\end{array}$ \\
\hline
\end{tabular}

Análise parcial em $2.1-n^{\circ} 4$.

O contraponto, na segunda voz, prioriza o movimento direto entre as vozes, em quartas, quintas e sextas, como toques de trompas de caça, com as funções de $\mathrm{T}$ e $\mathrm{D}$ a cada compasso.

Acompanhamento instrumental (piano) - a introdução (dois compassos) é feita pela mão direita com um pedal de $\mathrm{T}$ na segunda inversão, sem terça, o qual se repete até o final, com coda de três compassos. A mão esquerda dobra a melodia, em duas vozes, com intervalos harmônicos de terças, quartas, quintas e sextas. 
54) HIGIENE - a capella

\begin{tabular}{|c|c|c|c|c|c|c|c|}
\hline Volume & № & Vozes & Extensão & Tessitura & Tonalidade & $\begin{array}{l}\text { Intervalos } \\
\text { melódicos }\end{array}$ & $\begin{array}{l}\text { Intervalos } \\
\text { harmônicos }\end{array}$ \\
\hline $\begin{array}{l}\text { GP VTL } \\
\text { / ABM } \\
\text { /S1 }\end{array}$ & $\begin{array}{l}64 \\
/ 19 \\
/ 3\end{array}$ & 2 & $\begin{array}{c}8^{\text {a }} \\
11 \text { compassos } \\
\text { ternários }\end{array}$ & $\begin{array}{l}1 \text { a v.: E3-C4 } \\
2^{\text {a }} \text { v.: C3-A3 }\end{array}$ & $\begin{array}{l}\text { Modo de F } \\
\text { maior }\end{array}$ & $\begin{array}{c}\text { 2aM/m;3aM } \\
/ \mathrm{m} ; \\
\text { 4a/5a } / 8 \text { a J; } \\
\text { 6aM }\end{array}$ & $\begin{array}{c}\text { Uníssono; 2a } \mathrm{M} \text {; } \\
\text { 3a } \mathrm{M} / \mathrm{m} ; 4 \text { a } / 5^{\mathrm{a}} / 8^{\mathrm{a}} \\
\mathrm{J} ; 7^{\mathrm{a}} \mathrm{m}\end{array}$ \\
\hline
\end{tabular}

Análise parcial em $2.1-n^{\circ} 28$.

Contraponto com base no movimento contrário, alterna quintas, terças e sétimas nos primeiros pulsos dos compassos ternários. Peça adequada para o repertório de coral principiante.

55) A CANOA VIROU - a capella

\begin{tabular}{|c|c|c|c|c|c|c|c|}
\hline Volume & № & Vozes & Extensão & Tessitura & Tonalidade & $\begin{array}{l}\text { Intervalos } \\
\text { melódicos }\end{array}$ & $\begin{array}{l}\text { Intervalos } \\
\text { harmônicos }\end{array}$ \\
\hline $\begin{array}{l}\text { GP-VTL } \\
\text { /ABM } \\
\text { /S1 }\end{array}$ & $\begin{array}{l}23 \\
/ 31 \\
/ 5\end{array}$ & 2 & $\begin{array}{c}9 \underline{a} \\
9 \text { compassos } \\
\text { binários }\end{array}$ & $\begin{array}{l}1 \text { a v.: D3-C4 } \\
2 \text { a v.: B2-G3 }\end{array}$ & $\begin{array}{l}\text { Modo de C } \\
\text { maior }\end{array}$ & 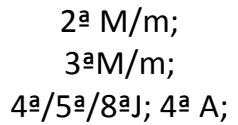 & 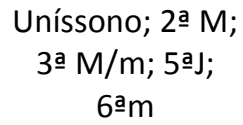 \\
\hline
\end{tabular}

Análise parcial em $2.1-n^{\circ} 96$.

A segunda voz utiliza a sílaba “Schxê!!”, com intenção timbrística de imitação do som da água movimentada pelo remo, complementada por fragmento do texto da canção, em frase repetida duas vezes. O ritmo do contraponto é independente da melodia, marcando as pulsações quando imita as 'remadas'. Os intervalos harmônicos priorizam as terças. O arranjo é de fácil execução, pequena extensão e apropriada para coros principiantes.

Solo instrumental - há indicação para que a mão esquerda toque uma oitava abaixo quando a peça for executada ao piano.

56) CAPELINHA DE MELÃO - a capella

\begin{tabular}{|c|c|c|c|c|c|c|c|}
\hline Volume & № & $\begin{array}{c}\text { Voze } \\
\text { s }\end{array}$ & Extensão & Tessitura & Tonalidade & $\begin{array}{l}\text { Intervalos } \\
\text { melódicos }\end{array}$ & $\begin{array}{l}\text { Intervalos } \\
\text { harmônicos }\end{array}$ \\
\hline $\begin{array}{l}\text { GP VTL } \\
\text { / ABM } \\
\text { /S1 }\end{array}$ & $\begin{array}{l}27 \\
/ 15 \\
/ 7\end{array}$ & 2 & $\begin{array}{c}9 \underline{a} \\
10 \text { compassos } \\
\text { binários }\end{array}$ & $\begin{array}{l}1 \text { a v.: D3-C4 } \\
2^{\mathrm{a}} \text { v.: B2-F3 }\end{array}$ & $\begin{array}{l}\text { Modo de C } \\
\text { maior }\end{array}$ & 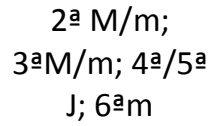 & 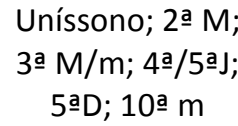 \\
\hline
\end{tabular}

Análise parcial em $2.1-n^{\circ} 25$.

Contraponto com início em movimento contrário, na primeira frase e terças paralelas na segunda frase. Peça de fácil execução, própria para coral iniciante.

Solo instrumental - há indicação para que a mão esquerda toque uma oitava abaixo quando a peça for executada ao piano. Indicado para acompanhamento de piano ou conjunto instrumental. 
57) A CANTIGA DE RODA (As bonecas) - a capella

\begin{tabular}{|c|c|c|c|c|c|c|c|}
\hline Volume & № & Vozes & Extensão & Tessitura & Tonalidade & $\begin{array}{l}\text { Intervalos } \\
\text { melódicos }\end{array}$ & $\begin{array}{l}\text { Intervalos } \\
\text { harmônicos }\end{array}$ \\
\hline $\begin{array}{c}\text { GP-VTL } \\
\text { / ABM } \\
\text { / S1 } \\
\text { /CO2 }\end{array}$ & $\begin{array}{c}26 \\
/ 9 \\
/ 19 \\
\text { /29№4 }\end{array}$ & 2 & $\begin{array}{c}10 \text { ạ } \\
10 \text { compassos } \\
\text { binários } \\
\text { (subdivisão } \\
\text { ternária) }\end{array}$ & $\begin{array}{l}\text { 1a voz: C3-D4 } \\
\text { 2a voz: B2-G3 }\end{array}$ & $\begin{array}{l}\text { Modo de C } \\
\text { maior }\end{array}$ & 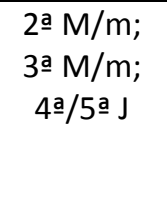 & 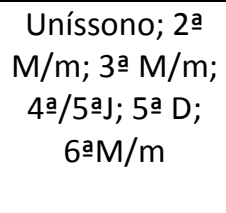 \\
\hline
\end{tabular}

Análise parcial em $2.1-n^{\circ} 131$.

A segunda voz está baseada em intervalos de segundas e terças, com notas rebatidas, sendo de fácil assimilação. A primeira nota e a última, em uníssono, são pontos de apoio, especialmente para a segunda voz. A simplicidade da melodia e do arranjo faz a peça ser muito adequada para compor um primeiro repertório coral.

58) A AGULHA - a capella

\begin{tabular}{|c|c|c|c|c|c|c|c|}
\hline Volume & № & Vozes & Extensão & Tessitura & Tonalidade & $\begin{array}{l}\text { Intervalos } \\
\text { melódicos }\end{array}$ & $\begin{array}{l}\text { Intervalos } \\
\text { harmônicos }\end{array}$ \\
\hline $\begin{array}{c}\text { GP-VTL } \\
\text { / ABM } \\
\text { /S1 }\end{array}$ & $\begin{array}{l}3 \\
/ 7 \\
/ 23\end{array}$ & 2 & $\begin{array}{c}\text { 9a } \\
10 \text { compassos } \\
\text { quaternários }\end{array}$ & $\begin{array}{l}1 \text { a v.:D3-C4 } \\
2 \text { a v.:B2-A3 }\end{array}$ & $\begin{array}{c}\text { Modo de C } \\
\text { maior }\end{array}$ & $\begin{array}{c}\text { 2a } M / M ; \\
\text { 3ㅁ } \\
/ m ; 4 \text { a } / 5 \text { a } J\end{array}$ & $\begin{array}{c}\text { Uníssono;3a } \\
\mathrm{M} / \mathrm{m} ; 5 \underline{a} \text { /4미;6ㅁm }\end{array}$ \\
\hline
\end{tabular}

Análise parcial em $2.1-n^{\circ} 42$.

A segunda voz desenvolve-se terça abaixo de forma paralela em quase toda a peça. A extensão, tessitura e relação intervalar de pequeno âmbito favorece à execução por grupos principiantes.

59) MEUS BRINQUEDOS (Canção escolar) - a capella

\begin{tabular}{|c|c|c|c|c|c|c|c|}
\hline Volume & № & Vozes & Extensão & Tessitura & Tonalidade & $\begin{array}{l}\text { Intervalos } \\
\text { melódicos }\end{array}$ & $\begin{array}{l}\text { Intervalos } \\
\text { harmônicos }\end{array}$ \\
\hline CO1 & 1 & 2 & $\begin{array}{c}11 \underline{a} \\
13 \text { compassos } \\
\text { binários }\end{array}$ & $\begin{array}{l}\text { 1a v.:Eb3-Eb4 } \\
\text { 2a v.:Bb2-G3 }\end{array}$ & $\begin{array}{c}\text { Modo de Eb } \\
\text { maior }\end{array}$ & $\begin{array}{l}\text { 2a } \mathrm{M} / \mathrm{m} ; 3 \mathrm{a} \\
\mathrm{M} / \mathrm{m} ; 4 \mathrm{a} ; \\
\text { 6-m }\end{array}$ & 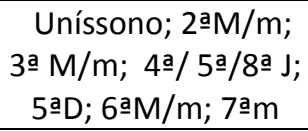 \\
\hline
\end{tabular}

Música de Júlia Dickie com arranjo de H. Villa-Lobos, 1935. Indicação de andamento: Movimento de Marcha. Forma AB. Canção didática cuja primeira parte é adequada ao canto na Educação Infantil, sendo apropriada para a aquisição do conceito de compasso, especialmente com o uso da bola como acessório. Como peça de repertório coral infantil, seria dirigida para o mesmo público.

O contraponto, na segunda voz, privilegia intervalos de terças paralelas. Na segunda parte o texto baseia-se na sílaba: $N a \tilde{\text { I }}$, a qual, além de interferir no plano do timbre, pode ser utilizada como exercício técnico com sons nasais. Merece atenção o cromatismo na segunda voz, compasso 9. Não há indicação de dinâmica, apenas stacatto em toda a peça, sugerindo certa leveza nas articulações sonoras ou o caráter saltitante da bola.

60) O CRAVO BRIGOU COM A ROSA - a capella

\begin{tabular}{|c|c|c|c|c|c|c|c|}
\hline Volume & № & Vozes & Extensão & Tessitura & Tonalidade & $\begin{array}{l}\text { Intervalos } \\
\text { melódicos }\end{array}$ & $\begin{array}{c}\text { Intervalos } \\
\text { harmônicos }\end{array}$ \\
\hline $\begin{array}{l}\text { GP-VTL/ } \\
\text { ABM/ } \\
\text { S1 }\end{array}$ & $\begin{array}{l}46 / \\
12 / \\
21\end{array}$ & 2 & $\begin{array}{c}11 \underline{a} \\
10 \text { compassos } \\
\text { ternários }\end{array}$ & 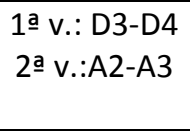 & $\begin{array}{c}\text { Modo de D } \\
\text { maior }\end{array}$ & $\begin{array}{c}2 \text { a } M / m ; 3^{a} \\
M / m ; 4^{a} / 5^{a} \\
J ; 6-m\end{array}$ & 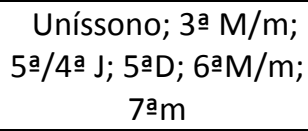 \\
\hline
\end{tabular}


Análise parcial em $2.1-n^{\circ} 125$.

O contraponto prioriza terças e sextas paralelas. No compasso 4, para facilitar a respiração, a prosódia deveria gerar três semínimas. GP/ABM corrige o último compasso substituindo as semínimas ligadas (GP/VTL) por mínima.

Solo instrumental - há indicação para que a mão esquerda toque uma oitava abaixo quando a peça for executada ao piano.

61) TEREZINHA DE JESUS - a capella

\begin{tabular}{|c|c|c|c|c|c|c|c|}
\hline Volume & № & Vozes & Extensão & Tessitura & Tonalidade & $\begin{array}{l}\text { Intervalos } \\
\text { melódicos }\end{array}$ & $\begin{array}{c}\text { Intervalos } \\
\text { harmônicos }\end{array}$ \\
\hline $\begin{array}{c}\text { GP VTL } \\
\text { / ABM } \\
\text { /S1 }\end{array}$ & $\begin{array}{l}123 \\
/ 11 \\
/ 12 \\
\end{array}$ & 2 & $\begin{array}{c}10^{\mathrm{a}} \\
10 \text { compassos } \\
\text { ternários }\end{array}$ & $\begin{array}{l}1 \text { a v.: E3-D4 } \\
2 \text { a v.: B2-A3 }\end{array}$ & $\begin{array}{c}\text { Modo de A } \\
\text { menor }\end{array}$ & 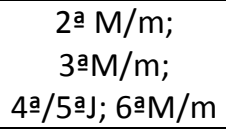 & $\begin{array}{c}\text { Uníssono; 3a } \\
\mathrm{M} / \mathrm{m} ; 4 \text { a } ; \\
\text { 6ㅁM/m }\end{array}$ \\
\hline
\end{tabular}

Análise parcial em $2.1-n^{\circ} 152$.

Uníssonos são pontos de referência entre as vozes no contraponto baseado em intervalos harmônicos de terças e sextas. De fácil execução, a melodia é ternária, em modo menor.

62) CARANGUEJO ( $\left(1^{\text {a }}\right.$ versão $)$ - acompanhamento instrumental

\begin{tabular}{|c|c|c|c|c|c|c|c|}
\hline Volume & № & Vozes & Extensão & Tessitura & Tonalidade & $\begin{array}{l}\text { Intervalos } \\
\text { melódicos }\end{array}$ & $\begin{array}{c}\text { Intervalos } \\
\text { harmônicos }\end{array}$ \\
\hline $\begin{array}{c}\text { GP-VTL/ } \\
\text { ABM }\end{array}$ & $\begin{array}{l}29 / \\
126\end{array}$ & 2 & $\begin{array}{c}14^{a} \\
35 \text { compassos } \\
\text { binários }\end{array}$ & $\begin{array}{l}\text { 1a v.:Ab2-Db4 } \\
\text { 2a v.:Eb2-Bb3 }\end{array}$ & $\begin{array}{l}\text { Modo de Ab } \\
\text { / Db maior }\end{array}$ & 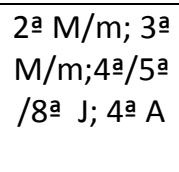 & 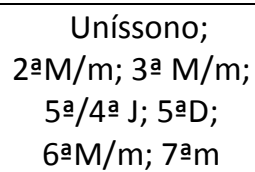 \\
\hline
\end{tabular}

Análise parcial em $2.1-n^{\circ} 165$.

A peça, em duas partes, apresenta uma repetição na segunda parte em tonalidade quarta acima, com modulação instrumental para o tom inicial para codeta e ritornello.

O contraponto, na primeira parte, apresenta pedais na segunda voz, sobre a terça (uma vez a fundamental) da T e sétima da $\mathrm{D}$, sobre a sílaba êh!. Apenas a última semifrase inclui o texto na segunda voz, conduzida em terças paralelas com final em uníssono. O mesmo acontece com a segunda melodia ainda ma primeira parte.

Em GP/ABM, na repetição da segunda parte, a segunda voz repete a melodia oitava abaixo, a primeira voz faz solo de uma frase e a segunda voz idem da frase final. No trecho oitavado a segunda voz é muito grave, em torno das notas $\boldsymbol{F} 1$ e $\boldsymbol{E} \boldsymbol{b} 1$, região proibitiva para a voz infantil. A sugestão mais simples seria a realização em uníssono.

Acompanhamento instrumental (piano) - introdução em pedal no primeiro grau na mão direita e ostinato rítmico a ser utilizado na primeira melodia na mão esquerda. A melodia é dobrada pela mão direita. A repetição da segunda parte, em nova tonalidade, é dobrada na mão direita, com os acordes distribuídos entre as duas mãos. A codeta repete a introdução com pedal em terça maior harmônica da T para o ritornello. A coda é a codeta acrescida de um compasso, com o final uníssono no primeiro grau. Em GP/ABM faltam: uma fermata no 
compasso 36 no último acorde e ligaduras nas notas da mão direita no compasso 41, na segunda casa do ritornello.

63) QUANTOS DIAS TEM O MÊS? - a capella

\begin{tabular}{|c|c|c|c|c|c|c|c|}
\hline Volume & № & Vozes & Extensão & Tessitura & Tonalidade & $\begin{array}{l}\text { Intervalos } \\
\text { melódicos }\end{array}$ & $\begin{array}{c}\text { Intervalos } \\
\text { harmônicos }\end{array}$ \\
\hline $\begin{array}{c}\text { GP VTL } \\
\text { / ABM } \\
\text { /S1 }\end{array}$ & $\begin{array}{l}106 \\
/ 39 \\
/ 11\end{array}$ & 2 & $\begin{array}{c}8^{\underline{a}} \\
9 \text { compassos } \\
\text { binários }\end{array}$ & $\begin{array}{l}1^{\mathrm{a}} \text { v.: E3-C4 } \\
2^{\mathrm{a}} \text { v.: C3-G3 }\end{array}$ & $\begin{array}{l}\text { Modo de F } \\
\text { maior }\end{array}$ & $\begin{array}{c}\text { 2a } \mathrm{M} / \mathrm{m} ; \\
\text { 3a } \mathrm{a} / \mathrm{m} ; \\
\text { 4a/5a/8a J; } \\
\text { 6а } \mathrm{a} / \mathrm{m}\end{array}$ & 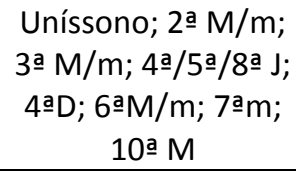 \\
\hline
\end{tabular}

Análise parcial em $2.1-n^{\circ} 79$.

A segunda voz consiste em um vocalize sobre a sílaba $A h$ ! em linha cromática descendente na primeira frase, variada na segunda. O cromatismo descendente facilita a aquisição da sequência de semitons.

64) CAI, CAI BALÃO (Vem cá, Bitu) - a capella

\begin{tabular}{|c|c|c|c|c|c|c|c|}
\hline Volume & № & Vozes & Extensão & Tessitura & Tonalidade & $\begin{array}{l}\text { Intervalos } \\
\text { melódicos }\end{array}$ & $\begin{array}{l}\text { Intervalos } \\
\text { harmônicos }\end{array}$ \\
\hline $\begin{array}{l}\text { GP VTL } \\
\text { / ABM }\end{array}$ & $\begin{array}{c}19 \\
/ 13\end{array}$ & 2 & $\begin{array}{c}9 \underline{9} \\
10 \text { compassos } \\
\text { binários }\end{array}$ & $\begin{array}{l}1 \text { a v.: F3-D4 } \\
\text { 2a v.: C3-A3 }\end{array}$ & $\begin{array}{l}\text { Modo de F } \\
\text { maior }\end{array}$ & $\begin{array}{c}\text { 2a } \mathrm{M} / \mathrm{m} ; \\
\text { 3a } \mathrm{M} / \mathrm{m} ; \\
\text { 4a/5aj; 6â }\end{array}$ & 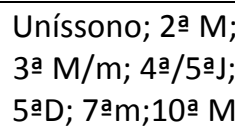 \\
\hline
\end{tabular}

Análise parcial em $2.1-n^{\circ} 31$.

O contraponto privilegia o movimento contrário, com terças paralelas apenas em dois compassos. O salto inicial de sexta na segunda voz merece cuidado para que a afinação da primeira terça harmônica seja precisa.

Solo instrumental - há indicação para que a mão esquerda toque uma oitava abaixo quando a peça for executada ao piano.

65) FELIZ NATAL (Canção de cordialidade) - a capella

\begin{tabular}{|c|c|c|c|c|c|c|c|}
\hline Volume & № & Vozes & Extensão & Tessitura & Tonalidade & $\begin{array}{l}\text { Intervalos } \\
\text { melódicos }\end{array}$ & $\begin{array}{l}\text { Intervalos } \\
\text { harmônicos }\end{array}$ \\
\hline $\mathrm{CO} 2$ & 10 & 2 & $\begin{array}{c}12 \text { a } \\
9 \text { compassos } \\
\text { quaternários }\end{array}$ & $\begin{array}{c}1 \text { a v.:Eb3-F4 } \\
\text { 2a v.:Bb2-Bb3 }\end{array}$ & $\begin{array}{c}\text { Modo de Eb } \\
\text { maior }\end{array}$ & 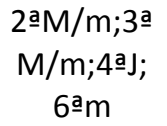 & 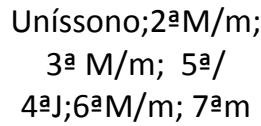 \\
\hline
\end{tabular}

Análise parcial em $2.1-n^{\circ} 129$.

O contraponto, na segunda voz, prioriza terças e sextas paralelas. No compasso 7, terceiro pulso, a segunda voz deveria ter duas colcheias para adequar a prosódia, e no compasso 4 as ligaduras são indevidas.

66) A CANTIGA DE NINAR - a capella

\begin{tabular}{|c|c|c|c|c|c|c|c|}
\hline Volume & № & Vozes & Extensão & Tessitura & Tonalidade & $\begin{array}{l}\text { Intervalos } \\
\text { melódicos }\end{array}$ & $\begin{array}{c}\text { Intervalos } \\
\text { harmônicos }\end{array}$ \\
\hline $\begin{array}{c}\text { GP-VTL/ } \\
\text { ABM }\end{array}$ & $\begin{array}{c}25 / \\
18\end{array}$ & 2 & $\begin{array}{c}14 \underline{a} \\
16 \text { compassos } \\
\text { binários }\end{array}$ & $\begin{array}{l}\text { 1a v.: D3-D4 } \\
\text { 2a v.:B2-A3 }\end{array}$ & $\begin{array}{c}\text { Modo de G } \\
\text { maior }\end{array}$ & $\begin{array}{c}2^{\text {a }} \mathrm{M} / \mathrm{m} ; \\
\text { 3a } \mathrm{M} / \mathrm{m} ; 4 \text { a/5a }\end{array}$ & $\begin{array}{c}\text { Uníssono; 3ạ } \\
\mathrm{M} / \mathrm{m} ; 5 \text { a } / 4 \text { a J; } \\
\text { 6aM/m }\end{array}$ \\
\hline
\end{tabular}


Análise parcial em $2.1-n^{\circ} 114$.

O contraponto, na segunda voz, prioriza movimentos diretos e paralelos e intervalos harmônicos de terças. Repete a configuração rítmica da melodia.

Solo instrumental - há indicação para que a mão esquerda toque uma oitava abaixo quando a peça for executada ao piano.

67) CANDEEIRO - a capella

\begin{tabular}{|c|c|c|c|c|c|c|c|}
\hline Volume & № & Vozes & Extensão & Tessitura & Tonalidade & $\begin{array}{l}\text { Intervalos } \\
\text { melódicos }\end{array}$ & $\begin{array}{c}\text { Intervalos } \\
\text { harmônicos }\end{array}$ \\
\hline $\begin{array}{l}\text { GP-VTL/ } \\
\text { ABM/ } \\
\text { S1 }\end{array}$ & $\begin{array}{l}22 / \\
21 / \\
27\end{array}$ & 2 & $\begin{array}{c}14 \underline{a} \\
21 \text { compassos } \\
\text { binários }\end{array}$ & $\begin{array}{l}\text { 1'a v.:E3-E4 } \\
2^{\text {a }} \text { v.:B2-B3 }\end{array}$ & $\begin{array}{l}\text { Modo de A } \\
\text { maior }\end{array}$ & 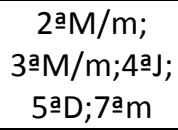 & 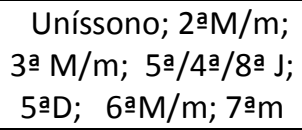 \\
\hline
\end{tabular}

Análise parcial em $2.1-n^{\circ} 113$.

A introdução e a coda apresentam pequeno pedal (2 compassos) sobre o quinto grau, com a segunda voz descendo por cromatismo para a sétima da D. O contraponto baseia-se em terças e sextas na primeira parte da peça, caracterizando as funções harmônicas primárias. Na segunda parte, a segunda voz se mantém na terça da $\mathrm{T}$ e na sétima da $\mathrm{D}$. A coda provoca uma sensação suspensiva.

Solo instrumental - há indicação para que a mão esquerda toque uma oitava abaixo quando a peça for executada ao piano.

68) VIUVINHA DA BANDA D'ALÉM - a capella

\begin{tabular}{|c|c|c|c|c|c|c|c|}
\hline Volume & № & Vozes & Extensão & Tessitura & Tonalidade & $\begin{array}{l}\text { Intervalos } \\
\text { melódicos }\end{array}$ & $\begin{array}{l}\text { Intervalos } \\
\text { harmônicos }\end{array}$ \\
\hline $\begin{array}{c}\text { GP-VTL/ } \\
\text { ABM }\end{array}$ & $\begin{array}{c}134 / \\
22\end{array}$ & 2 & $\begin{array}{c}9 \text { a } \\
12 \text { compassos } \\
\text { binários }\end{array}$ & $\begin{array}{c}1 \text { a v.:Eb3-C4 } \\
\text { 2a v.:Bb2-Ab3 }\end{array}$ & $\begin{array}{l}\text { Modo de F } \\
\text { maior }\end{array}$ & 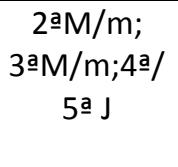 & 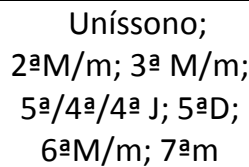 \\
\hline
\end{tabular}

Análise parcial em $2.1-n^{\circ} 33$.

A introdução e a coda apresentam intervalo de terça: quinta e terça da $\mathrm{T}$ com fermata sobre a sílaba: $A h$ !, com finalidade timbrística, além de ser referência para a entrada das vozes na melodia. O contraponto é feito por movimento contrário entre as vozes, iniciando a segunda voz com uma linha cromática, que merece atenção com relação à afinação. Nos compassos $6 \mathrm{a}$ 8 há divisi na primeira voz, podendo resultar em três vozes, assim como se pode optar por uma das duas linhas melódicas.

Solo instrumental - há indicação para que a mão esquerda toque uma oitava abaixo quando a peça for executada ao piano.

69) O CAFÉ - a capella

\begin{tabular}{|c|c|c|c|c|c|c|c|}
\hline Volume & № & Vozes & Extensão & Tessitura & Tonalidade & $\begin{array}{l}\text { Intervalos } \\
\text { melódicos }\end{array}$ & $\begin{array}{c}\text { Intervalos } \\
\text { harmônicos }\end{array}$ \\
\hline $\begin{array}{l}\text { GP-VTL } \\
\text { /ABM } \\
\text { /S1 }\end{array}$ & $\begin{array}{c}20 / \\
10 / \\
8\end{array}$ & 2 & $\begin{array}{c}13 \text { a } \\
19 \text { compassos } \\
\text { binários }\end{array}$ & $\begin{array}{l}1 \text { a v.: D3-E4 } \\
\text { 2a v.:G2-B3 }\end{array}$ & $\begin{array}{l}\text { Modo de G } \\
\text { maior }\end{array}$ & 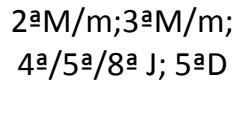 & 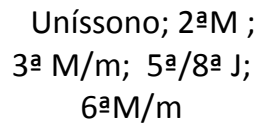 \\
\hline
\end{tabular}

Análise parcial em $2.1-n^{\circ} 61$. 
O arranjo apresenta contraponto na segunda voz iniciado em movimento contrário e apresentando em seguida movimento paralelo de terças, repetindo a linha rítmica da melodia.

70) BESUNTÃO DA LAGOA - a capella

\begin{tabular}{|c|c|c|c|c|c|c|c|}
\hline Volume & № & Vozes & Extensão & Tessitura & Tonalidade & $\begin{array}{l}\text { Intervalos } \\
\text { melódicos }\end{array}$ & $\begin{array}{l}\text { Intervalos } \\
\text { harmônicos }\end{array}$ \\
\hline $\begin{array}{c}\text { GP-VTL } \\
\text { /ABM } \\
/ \mathrm{S} 1\end{array}$ & $\begin{array}{l}16 \\
/ 38 \\
/ 22\end{array}$ & 2 & $\begin{array}{c}12 \mathrm{a} \\
6 \text { compassos } \\
\text { binários }\end{array}$ & $\begin{array}{l}\text { 1a v.: C3-C4 } \\
\text { 2a v.: G2-A3 }\end{array}$ & $\begin{array}{l}\text { Modo de } \mathrm{F} \\
\text { maior }\end{array}$ & $\begin{array}{c}\text { 2а } \mathrm{M} / \mathrm{m} \\
\text { 3а } \mathrm{M} / \mathrm{m} \\
\text { 6ам }\end{array}$ & 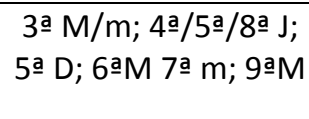 \\
\hline
\end{tabular}

Análise parcial em $2.1-n^{\circ} 34$.

Contraponto para vozes mistas, em que a segunda voz, com melodia independente, utiliza a sílaba "Lá" como texto, marcando a subdivisão binária, em contraposição ao ritmo sincopado da primeira voz. Predominam intervalos melódicos de oitavas, terças e sextas.

Solo instrumental - há indicação para que a mão esquerda toque uma oitava abaixo quando a peça for executada ao piano.

71) CARANGUEJO ( $2^{\mathrm{a}}$ versão $)$ - a capella

\begin{tabular}{|c|c|c|c|c|c|c|c|}
\hline Volume & № & Vozes & Extensão & Tessitura & Tonalidade & $\begin{array}{l}\text { Intervalos } \\
\text { melódicos }\end{array}$ & $\begin{array}{c}\text { Intervalos } \\
\text { harmônicos }\end{array}$ \\
\hline $\begin{array}{l}\text { GP-VTL/ } \\
\text { ABM/ } \\
\text { S1 }\end{array}$ & $\begin{array}{c}30 / \\
16 / \\
10\end{array}$ & 2 & $\begin{array}{c}11 \underline{a} \\
17 \text { compassos } \\
\text { binários }\end{array}$ & $\begin{array}{l}1^{\mathrm{a}} \text { v.: B2-C4 } \\
2^{\mathrm{a}} \text { v.: G2-F3 }\end{array}$ & $\begin{array}{l}\text { Modo de C } \\
\text { maior }\end{array}$ & 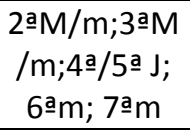 & 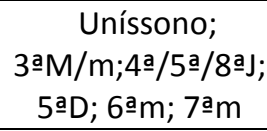 \\
\hline
\end{tabular}

Análise parcial em $2.1-n^{\circ} 60$.

O contraponto alterna movimento contrário entre as vozes e terças paralelas. O início e o final são uníssonos, proporcionando segurança para a execução por coro infantil principiante.

72) FUI PASSAR NA PONTE (Na Bahia tem) - a capella

\begin{tabular}{|c|c|c|c|c|c|c|c|}
\hline Volume & № & Vozes & Extensão & Tessitura & Tonalidade & $\begin{array}{l}\text { Intervalos } \\
\text { melódicos }\end{array}$ & $\begin{array}{c}\text { Intervalos } \\
\text { harmônicos }\end{array}$ \\
\hline $\begin{array}{l}\text { GP-VTL/ } \\
\text { ABM/ } \\
\text { S1 }\end{array}$ & $\begin{array}{l}56 \\
/ 26 \\
/ 16\end{array}$ & 2 & $\begin{array}{c}10^{a} \\
8 \text { compassos } \\
\text { binários }\end{array}$ & $\begin{array}{c}\text { 1a v.: D3-C\#4 } \\
\text { 2a v.:A2-G3 }\end{array}$ & $\begin{array}{c}\text { Modo de D } \\
\text { maior }\end{array}$ & 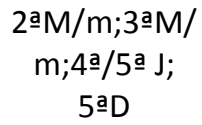 & 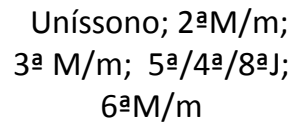 \\
\hline
\end{tabular}

Análise parcial em $2.1-n^{\circ} 49$.

Contraponto com base em terças e sextas paralelas, com início e final em uníssono. Da primeira para a segunda frase há um salto paralelo de quinta, diminuta na segunda voz, o que pode produzir oscilação na afinação, embora o primeiro acorde da segunda frase seja de terça. A peça é de fácil execução, recomendada para corais principiantes.

Solo instrumental - há indicação para que a mão esquerda toque uma oitava abaixo quando a peça for executada ao piano. 
73) VAMOS, MANINHA ( $2^{\mathrm{a}}$ versão) - a capella

\begin{tabular}{|c|c|c|c|c|c|c|c|}
\hline Volume & № & Vozes & Extensão & Tessitura & Tonalidade & $\begin{array}{l}\text { Intervalos } \\
\text { melódicos }\end{array}$ & $\begin{array}{l}\text { Intervalos } \\
\text { harmônicos }\end{array}$ \\
\hline $\begin{array}{l}\text { GP-VTL/ } \\
\text { ABM/ } \\
\text { S1 }\end{array}$ & $\begin{array}{c}127 / \\
23 / \\
13\end{array}$ & 2 & $\begin{array}{c}11^{\mathrm{a}} \\
13 \text { compassos } \\
\text { quaternários }\end{array}$ & $\begin{array}{l}\text { 1 v.: D3-D4 } \\
2^{\text {a }} \text { v.:A2-B3 }\end{array}$ & $\begin{array}{l}\text { Modo de D } \\
\text { maior }\end{array}$ & $\begin{array}{l}2 \mathrm{a} M / \mathrm{m} ; 3^{a} \\
\mathrm{M} / \mathrm{m} ; 4 \underline{a} / 5 \underline{a} \\
\mathrm{~J} ; 6 \underline{\mathrm{a}} \mathrm{m}\end{array}$ & 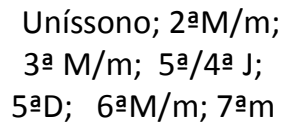 \\
\hline
\end{tabular}

Análise parcial em $2.1-n^{\circ} 148$.

Contraponto com base em terças e sextas paralelas, com início e final em uníssono. Harmonização sobre funções primárias e relativas. Preferimos a melodia segundo GP/VTL, (em detrimento de GP/ABM, que traz as notas $\boldsymbol{E} \boldsymbol{E} \boldsymbol{G B}$, conforme Solfejo $1 \mathrm{n}^{\circ} 13$ ) no compasso 11, com as notas GGGB para a primeira voz, por se tratar de uma repetição da frase anterior (compasso 7) e para evitar uníssono que interrompe a intenção de terças paralelas nesta parte da frase. A peça é de fácil execução, recomendada para corais principiantes.

Solo instrumental - há indicação para que a mão esquerda toque uma oitava abaixo quando a peça for executada ao piano.

74) LINDAS LARANJAS - a capella

\begin{tabular}{|c|c|c|c|c|c|c|c|}
\hline Volume & $\mathrm{N}^{\mathrm{o}}$ & Vozes & Extensão & Tessitura & Tonalidade & $\begin{array}{l}\text { Intervalos } \\
\text { melódicos }\end{array}$ & $\begin{array}{c}\text { Intervalos } \\
\text { harmônicos }\end{array}$ \\
\hline $\begin{array}{l}\text { GP VTL } \\
\text { / ABM } \\
\text { /S1 }\end{array}$ & $\begin{array}{l}70 \\
/ 25 \\
/ 35\end{array}$ & 2 & $\begin{array}{c}12^{a} \\
10 \\
\text { compassos } \\
\text { binários } \\
\end{array}$ & $\begin{array}{l}\text { 1a v.: B2-D4 } \\
\text { 2a v.: G2-F3 }\end{array}$ & $\begin{array}{c}\text { Modo de C } \\
\text { maior }\end{array}$ & 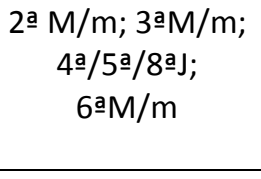 & 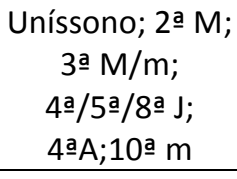 \\
\hline
\end{tabular}

Análise parcial em $2.1-n^{\circ} 160$.

O contraponto prioriza intervalos de terças e sextas harmônicas, sendo de fácil execução, por movimentar as vozes por graus conjuntos e pequenos intervalos melódicos. Uníssonos e oitavas nos inícios e finais de frases são pontos de referências importantes para a manutenção da afinação.

75) NIGUE NINHAS - a capella

\begin{tabular}{|c|c|c|c|c|c|c|c|}
\hline Volume & № & Vozes & Extensão & Tessitura & Tonalidade & $\begin{array}{l}\text { Intervalos } \\
\text { melódicos }\end{array}$ & $\begin{array}{l}\text { Intervalos } \\
\text { harmônicos }\end{array}$ \\
\hline $\begin{array}{c}\text { GP-VTL/ } \\
\text { ABM }\end{array}$ & $\begin{array}{c}83 / \\
20\end{array}$ & 2 & $\begin{array}{c}12^{\mathrm{a}} \\
12 \text { compassos } \\
\text { binários }\end{array}$ & $\begin{array}{l}\text { 1a v.: D3-D4 } \\
\text { 2a v.:G2-B3 }\end{array}$ & $\begin{array}{l}\text { Modo de G } \\
\text { maior }\end{array}$ & $\begin{array}{c}2^{\mathrm{a}} \mathrm{M} / \mathrm{m} ; 3^{\mathrm{a}} \\
\mathrm{M} / \mathrm{m} ; 4^{\mathrm{a}} / 5^{\mathrm{a}} \\
/ 8^{\mathrm{a}} \mathrm{J}\end{array}$ & 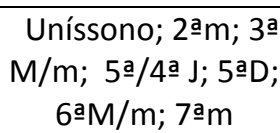 \\
\hline
\end{tabular}

Análise parcial em $2.1-n^{\circ} 70$.

Contraponto com prioridade para intervalos melódicos de terças e sextas. A peça tende para o ritmo livre, com várias indicações de rallentando, com uma suspensão por fermata após a primeira frase. A dinâmica, sempre suave pela característica do acalanto, termina em pianíssimo ao final, com quintas oitavadas sobre a T. Seguimos a correção do texto segundo $\mathrm{GP} \mathrm{ABM}^{68}-$ mussangolá.

Solo instrumental - há indicação para que a mão esquerda toque uma oitava abaixo quando a peça for executada ao piano.

${ }^{68} \mathrm{GP} / \mathrm{ABM}-1{ }^{\circ}$ Caderno, p. 85. 
76) NO JARDIM CELESTIAL - acompanhamento instrumental

\begin{tabular}{|c|c|c|c|c|c|c|c|}
\hline Volume & № & Vozes & Extensão & Tessitura & Tonalidade & $\begin{array}{l}\text { Intervalos } \\
\text { melódicos }\end{array}$ & $\begin{array}{l}\text { Intervalos } \\
\text { harmônicos }\end{array}$ \\
\hline $\begin{array}{l}\text { GP-VTL } \\
\text { / ABM }\end{array}$ & $\begin{array}{c}65 \\
/ 122\end{array}$ & 2 & $\begin{array}{c}11 \text { a } \\
24 \text { compassos } \\
\text { binários }\end{array}$ & $\begin{array}{l}1 \text { a v.:C3-C4 } \\
2 \text { a v.:G2-E3 }\end{array}$ & $\begin{array}{c}\text { Modo de C } \\
\text { maior }\end{array}$ & $\begin{array}{c}\text { 2a M;3a } \\
\text { /m;4ㅇJ }\end{array}$ & $\begin{array}{l}\text { Uníssono;3a } \\
\mathrm{M} / \mathrm{m} ; 4 \stackrel{a}{a} 5^{a} \mathrm{~J} ; 6^{\mathrm{a}} \mathrm{m}\end{array}$ \\
\hline
\end{tabular}

Análise parcial em $2.1-n^{\circ} 3$.

Embora não definido por Villa-Lobos o contraponto da segunda voz, em GP/ABM consta uma solução adequada, privilegiando movimentos oblíquos entre as vozes quando há notas rebatidas.

Acompanhamento instrumental (piano) - a introdução é feita sobre um pedal de T, com oito compassos, em que o primeiro motivo é exposto inicialmente, seguido de resposta que evolui para a $\mathrm{T}$, sempre com a mão direita em oitavas e a esquerda promovendo dissonâncias, privilegiando a nota $\boldsymbol{B}$ b, com a finalização característica do modo mixolído. $\mathrm{O}$ acompanhamento da melodia cantada, dobrada pela mão direita com acordes, apresenta na mão esquerda um contraponto em oitavas com linhas descendentes por graus conjuntos e cromatismos, com terminação em D/T. A coda repete a introdução. Em GP/ABM, no compasso 15, o último acorde, na mão direita, deveria conter as notas: $\boldsymbol{G} 2, \boldsymbol{B} 2$ e $\boldsymbol{G} 3$. No compasso 16 há uma clave indevida ao final do compasso. Em GP/VTL, no compasso 2, a nota mais aguda do último acorde, $\boldsymbol{C}$, deveria ser $\boldsymbol{B}$ b, como consta corrigida na repetição do trecho no compasso 18. GP/ABM conserva o engano em ambos os compassos.

77) MINHA TERRA TEM PALMEIRAS - a capella

\begin{tabular}{|c|c|c|c|c|c|c|c|}
\hline Volume & $\mathrm{N}^{\mathrm{o}}$ & Vozes & Extensão & Tessitura & Tonalidade & $\begin{array}{c}\text { Intervalos } \\
\text { melódicos }\end{array}$ & Intervalos harmônicos \\
\hline $\mathrm{CO} 2$ & 5 & 2 & $\begin{array}{c}12^{\mathrm{a}} \\
13 \text { compassos } \\
\text { binários }\end{array}$ & $\begin{array}{c}1^{\mathrm{a}} \mathrm{v} . \mathrm{C} 3-\mathrm{C} 4 ; \\
2^{\mathrm{a}} \mathrm{v} . \mathrm{Bb} 2-\mathrm{B} 3\end{array}$ & $\begin{array}{c}\text { Modo de } \mathrm{F} \\
\text { maior }\end{array}$ & $\begin{array}{c}2^{\mathrm{a}} \mathrm{M} / \mathrm{m} ; 3^{\mathrm{a}} \\
\mathrm{M} / \mathrm{m} ; 4^{\mathrm{a}} \mathrm{J} ; \\
6^{\mathrm{a}} \mathrm{M}\end{array}$ & $\begin{array}{c}\text { Uníssono; } 2^{\mathrm{a}} \mathrm{M} / \mathrm{m} ; 3^{\mathrm{a}} \\
\mathrm{M} / \mathrm{m} ; 4^{\mathrm{a}} / 5^{\mathrm{a}} / 8^{\mathrm{a} J} \\
4^{\mathrm{a}} \mathrm{D} ; 6^{\mathrm{a}} \mathrm{M} / \mathrm{m} ; 7^{\mathrm{a}} \mathrm{m} ; 10^{\mathrm{a}} \mathrm{M}\end{array}$ \\
\hline
\end{tabular}

Análise parcial em $2.1-n^{\circ} 156$.

Privilegiando terças paralelas e o movimento direto, a peça requer um trabalho prévio com cada parte. $\mathrm{O}$ arpejo descendente do acorde de sétima menor na primeira voz pode ser trabalhado em duas etapas - a tríade maior descendente $\left[\begin{array}{lll}s & \boldsymbol{m}\end{array}\right]$, a tríade menor descendente [ $\boldsymbol{m} \boldsymbol{d} \boldsymbol{l}$, , ] e a junção das duas $[\boldsymbol{s} \boldsymbol{m} \boldsymbol{d} \boldsymbol{l}$,$] . O mesmo com a segunda voz, com o arpejo$ descendente do acorde de sétima maior na segunda voz: tríade menor [ $\boldsymbol{m} \boldsymbol{d} \boldsymbol{l}$, ], tríade maior [ $\boldsymbol{d}$ $\boldsymbol{l}, \boldsymbol{f}$,] e junção das duas [ $\boldsymbol{m} \boldsymbol{d} \boldsymbol{l}, \boldsymbol{f}$,]. O cruzamento de vozes no compasso 5 pode ser utilizado como sugestão para a inversão das vozes em outros trechos, como atividade lúdica. Merece atenção especial a passagem modulatória nos compassos 8 e 9 , tanto no que se refere à entoação correta (trítono na segunda voz e notas alteradas), como na aquisição do conteúdo teórico. O salto de oitava da primeira voz, no último compasso, deve ser trabalhado pela sua extensão e a região aguda. 
78) NESTA RUA (Esta Noite) - a capella

\begin{tabular}{|c|c|c|c|c|c|c|c|}
\hline Volume & № & Vozes & Extensão & Tessitura & Tonalidade & $\begin{array}{l}\text { Intervalos } \\
\text { melódicos }\end{array}$ & $\begin{array}{l}\text { Intervalos } \\
\text { harmônicos }\end{array}$ \\
\hline $\begin{array}{l}\text { GP-VTL/ } \\
\text { ABM / } \\
\text { S1 }\end{array}$ & $\begin{array}{l}82 / \\
24 / \\
14\end{array}$ & 2 & $\begin{array}{c}13^{a} \\
20 \text { compassos } \\
\text { binários }\end{array}$ & $\begin{array}{l}\text { 1a v.:C3-Eb4 } \\
\text { 2a v.:G2-Ab3 }\end{array}$ & $\begin{array}{l}\text { Modo de C } \\
\text { menor }\end{array}$ & 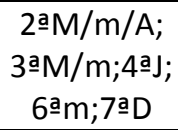 & 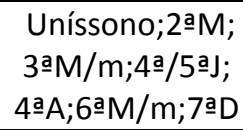 \\
\hline
\end{tabular}

Análise parcial em $2.1-n^{\circ} 161$.

O contraponto, na segunda voz, alterna paralelismos de sextas, quartas e terças com movimento contrário entre as vozes. $\mathrm{O}$ modo menor determina alterações que resultam em intervalos aumentados e diminutos, que devem ser trabalhados com atenção. Em GP/ABM, falta o compasso 40, que deveria repetir o compasso 16.

79) FORMIGUINHAS - a capella

\begin{tabular}{|c|c|c|c|c|c|c|c|}
\hline Volume & № & Vozes & Extensão & Tessitura & Tonalidade & $\begin{array}{l}\text { Intervalos } \\
\text { melódicos }\end{array}$ & $\begin{array}{c}\text { Intervalos } \\
\text { harmônicos }\end{array}$ \\
\hline $\begin{array}{l}\text { GP-VTL/ } \\
\text { ABM/ } \\
\text { S1 }\end{array}$ & $\begin{array}{l}52 / \\
17 / \\
33\end{array}$ & 2 & $\begin{array}{l}11 \underline{a} \\
12 \text { compassos } \\
\text { binários }\end{array}$ & $\begin{array}{c}\text { 1a v.:G3-Eb4 } \\
\text { 2a v.:Bb2-Bb3 }\end{array}$ & $\begin{array}{l}\text { Modo de } \mathrm{F} \\
\text { maior }\end{array}$ & $\begin{array}{l}\text { 2a } \mathrm{a} / \mathrm{m} ; 3^{\mathrm{a}} \mathrm{M} / \\
\mathrm{m} ; 4^{\mathrm{a}} ; 5^{\mathrm{a}} \mathrm{J} ; 4^{\mathrm{a}} \\
\mathrm{A} ; 7^{\mathrm{a}} \mathrm{am}\end{array}$ & $\begin{array}{c}\text { Uníssono; 2a } \mathrm{a} / \mathrm{m} ; 3^{\mathrm{a}} \\
\mathrm{M} / \mathrm{m} ; 4 \text { 4a } / 5 \text { a } / 8 \text { J; } \\
\text { 5a } \mathrm{D} ; 6 \mathrm{a} \mathrm{M} / \mathrm{m} ; 7 \mathrm{a} \mathrm{m}\end{array}$ \\
\hline
\end{tabular}

Análise parcial em $2.1-n^{\circ} 69$.

O contraponto inicia-se com saltos ascendentes de quarta (o primeiro consiste na curta introdução da peça), na segunda voz, apresentando em seguida terças paralelas descendentes. GP/ABM informa que o texto $A h$ ! $A h$ ! é válido apenas para o primeiro compasso, e, sendo assim, falta o texto para a última nota da primeira casa do ritornello. Não resolve também a prosódia no segundo pulso do compasso 7 na segunda voz, que deveria conter quatro semicolcheias para as quatro sílabas do texto. Omite também uma sugestão de divisi no compasso 9, última nota da primeira voz. Em GP/VTL, no compasso 9, a sugestão de divisi na primeira voz tem intenção timbrística, que resultaria em interessante pequeno cluster $(\boldsymbol{F}+\boldsymbol{G}+\boldsymbol{A})$, ou na opção de terminar a melodia de modo diferente para o ritornello.

Solo instrumental - há indicação para que a mão esquerda toque uma oitava abaixo quando a peça for executada ao piano.

80) OS ESCRAVOS DE JÓ - a capella

\begin{tabular}{|c|c|c|c|c|c|c|c|}
\hline Volume & № & Vozes & Extensão & Tessitura & Tonalidade & $\begin{array}{l}\text { Intervalos } \\
\text { melódicos }\end{array}$ & $\begin{array}{l}\text { Intervalos } \\
\text { harmônicos }\end{array}$ \\
\hline $\begin{array}{l}\text { GP-VTL } \\
/ \text { ABM }\end{array}$ & $\begin{array}{l}50 \\
/ 55\end{array}$ & 3 & $\begin{array}{c}13 a \\
19 \text { compassos } \\
\text { binários }\end{array}$ & $\begin{array}{l}\text { 1a v.:E3-E4 } \\
\text { 2a v.:B2-G3 } \\
\text { 3a v.:G2-E3 }\end{array}$ & $\begin{array}{l}\text { Modo de } C \\
\text { maior }\end{array}$ & $\begin{array}{l}\text { 2a } \mathrm{a} ; 3 \text {;aM } \\
\text { /m;4a/5aj; }\end{array}$ & 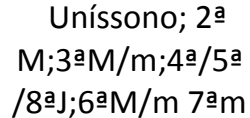 \\
\hline
\end{tabular}

Análise parcial em $2.1-n^{\circ} 112$.

A segunda e a terceira voz contrapõem a primeira, responsável pela melodia, em B.C. A segunda voz em âmbito de sexta, sempre por graus conjuntos, com exceção de um intervalo de sexta, de fácil execução. A terceira voz, em intervalos de quarta e graus conjuntos, também é uma proposta simples. A linha rítmica que acompanha as vozes, provavelmente tem a ver com a percussão de acessórios que seriam utilizados na brincadeira. 
Solo instrumental - há indicação para que a mão esquerda toque uma oitava abaixo quando a peça for executada ao piano. GP/ABM apresenta a grafia com distribuição das vozes separadas em três pentagramas, o que dificulta a leitura para a eventual e sugerida execução ao piano.

81) VIVA O CARNAVAL - a capella

\begin{tabular}{|c|c|c|c|c|c|c|c|}
\hline Volume & № & Vozes & Extensão & Tessitura & Tonalidade & $\begin{array}{l}\text { Intervalos } \\
\text { melódicos }\end{array}$ & $\begin{array}{c}\text { Intervalos } \\
\text { harmônicos }\end{array}$ \\
\hline $\begin{array}{l}\text { GP-VTL } \\
\text { ABM }\end{array}$ & $\begin{array}{l}135 \\
/ 54\end{array}$ & 2 & $\begin{array}{c}10 \text { ạ } \\
19 \text { compassos } \\
\text { binários }\end{array}$ & $\begin{array}{l}\text { 1 v.:D3-D4 } \\
\text { 2a v.:B2-B3 }\end{array}$ & $\begin{array}{c}\text { Modo de G } \\
\text { maior }\end{array}$ & 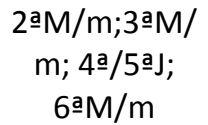 & 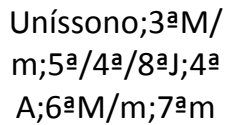 \\
\hline
\end{tabular}

Análise parcial em $2.1-n^{\circ} 85$.

O arranjo de Villa-Lobos, para duas vozes e efeitos rítmicos, sobre tema carnavalesco, apresenta grande variedade de timbres. A introdução em 8 compassos tem as indicações de imitação do bumbo com a sílaba Bum! e do tambor com as sílabas Ran-tam-plam! , para primeira e segunda voz. Com a entrada da melodia, e o contraponto a duas vozes, a terceira voz assume os timbres dos dois instrumentos como anteriormente, em ostinato até o final da peça. O contraponto, na segunda voz, prioriza movimento contrário e oblíquo entre as vozes. Na parte B as duas vozes imitam cornetas próprias de bandas e fanfarras. Em GP/ABM, falta uma pausa de mínima no último compasso do ostinato rítmico e uma letra " $t$ " na última colcheia do compasso 24. Consta, na p. 59, indicação indevida: "Canto a 3 vozes".

82) ANDA A RODA ( $1^{\text {a }}$ versão $)$ - a capella

\begin{tabular}{|c|c|c|c|c|c|c|c|}
\hline Volume & № & Vozes & Extensão & Tessitura & Tonalidade & $\begin{array}{l}\text { Intervalos } \\
\text { melódicos }\end{array}$ & $\begin{array}{l}\text { Intervalos } \\
\text { harmônicos }\end{array}$ \\
\hline $\begin{array}{l}\text { GP-VTL } \\
/ \text { ABM } \\
\text { /S1 } \\
/ \mathrm{CO} 2\end{array}$ & $\begin{array}{c}5 \\
/ 5 \\
/ 31 \\
\text { /29№5 }\end{array}$ & 2 & $\begin{array}{c}10 \text { a } \\
21 \text { compassos } \\
\text { binários }\end{array}$ & $\begin{array}{l}\text { 19 v.:Eb3-Eb4 } \\
\text { 2a v.:C3-Eb4 }\end{array}$ & $\begin{array}{l}\text { Modo de } \\
\text { Ab maior }\end{array}$ & $\begin{array}{c}2 \mathrm{a} M / \mathrm{m} ; 3^{\mathrm{a}} \mathrm{M} \\
/ \mathrm{m} ; 4 \mathrm{a} / \mathrm{g}^{\mathrm{a}} \mathrm{J} ; \\
6 \mathrm{aM} / \mathrm{m}\end{array}$ & $\begin{array}{c}\text { Uníssono;2aM; } \\
\text { 3a M/m; } \\
\text { 5a/4a J; 5a D/A; } \\
\text { 6a } \mathrm{M} / \mathrm{m}\end{array}$ \\
\hline
\end{tabular}

Análise parcial em $2.1-n^{\circ} 155$.

A parte A apresenta a segunda voz acompanhando a primeira com intervalos de sextas paralelas prioritariamente. A segunda parte em uníssono, com a indicação de Villa-Lobos: Unido, indicando a união das duas vozes em uníssono.

\section{3) SENHORA VIÚVA (VIUVINHA) - a capella}

\begin{tabular}{|c|c|c|c|c|c|c|c|}
\hline Volume & № & Vozes & Extensão & Tessitura & Tonalidade & $\begin{array}{l}\text { Intervalos } \\
\text { melódicos }\end{array}$ & $\begin{array}{l}\text { Intervalos } \\
\text { harmônicos }\end{array}$ \\
\hline $\begin{array}{l}\text { GP-VTL } \\
\text { / ABM }\end{array}$ & $\begin{array}{l}118 \\
/ 53\end{array}$ & 3 & $\begin{array}{c}10^{a} \\
16 \text { compassos } \\
\text { binários (subdivisão } \\
\text { ternária) }\end{array}$ & $\begin{array}{l}\text { 1a v.:D3-E4 } \\
\text { 2a v.:D3-D4 } \\
\text { 3a v.:A2-D4 }\end{array}$ & $\begin{array}{l}\text { Modo de } \\
\text { D maior }\end{array}$ & $\begin{array}{l}\text { 2a M;3ㅁM } \\
/ \mathrm{m} ; 4 \text { a } / 5 \text { a J }\end{array}$ & $\begin{array}{l}\text { Uníssono;3a } \\
\mathrm{M} / \mathrm{m} ; 5 \text { a } / 4 \text { a } \mathrm{j} ; 6^{\mathrm{a}} \mathrm{m}\end{array}$ \\
\hline
\end{tabular}

Análise parcial em $2.1-n^{\circ} 130$.

Primeira parte - melodia na primeira voz acompanhada por terças paralelas na segunda e terceira vozes sobre a sílaba Nan!, com a conclusão em uníssono. Timbre e dinâmica são bem explorados nesta parte, salientando-se acentos no segundo pulso nos compassos 5 e 6 . Na 
segunda parte, há redução para duas vozes, que se apresentam em terças paralelas terminando em uníssono.

84) SENHORA DONA VIÚVA - acompanhamento instrumental

\begin{tabular}{|c|c|c|c|c|c|c|c|}
\hline Volume & № & Vozes & Extensão & Tessitura & Tonalidade & $\begin{array}{l}\text { Intervalos } \\
\text { melódicos }\end{array}$ & $\begin{array}{l}\text { Intervalos } \\
\text { harmônicos }\end{array}$ \\
\hline GP-VTL & 117/ & 2 & $11 \underline{a}$ & $1-\mathrm{a} v .: B 2-\mathrm{C} 4$ & Modo de & 2aM;3모 & Uníssono;2a \\
\hline / ABM & 130 & & $\begin{array}{c}45 \text { compassos } \\
\text { binários (subdivisão } \\
\text { ternária) }\end{array}$ & $2^{\mathrm{a}} \mathrm{v} \cdot: \mathrm{G} 2-\mathrm{G} 3$ & C maior & $\begin{array}{c}/ \mathrm{m} ; 4 \mathrm{a} / 5 \mathrm{a} \mathrm{j} ; \\
6 \mathrm{a} \mathrm{M} / \mathrm{m}\end{array}$ & $\begin{array}{c}M ; 3 \text { a } M / m ; 4 \text { a } / ~ \\
5 \text { a J }\end{array}$ \\
\hline
\end{tabular}

Popular, arranjado por Villa-Lobos, com indicação de andamento Vivo - Movimento de Tarantela $(162=$ J); de intensidade: $s f f z ; \boldsymbol{m f} ; \boldsymbol{f p} ; \boldsymbol{p} ;>$; pp ;fff ; acentos >. A indicação 162 para semínima pontuada é rápida demais para a cantiga de roda, não sendo adequada ao texto nem ao desenvolvimento da brincadeira. Provavelmente o correto seria 162 para a colcheia. A subdivisão ternária e o andamento vivo remetem à tarantela. $\mathrm{O}$ plano de intensidades é rico, salientando-se a recorrência dos contrastes $s f f z$ / $p$. GP/VTL apresenta muitos problemas solucionados em GP/ABM, como: definição da segunda voz e acerto da prosódia da segunda parte, declamada. No entanto, os problemas de prosódia nos compassos 21-22/29-30 continuam presentes: separação do ditongo rei (re-i), e as duas sílabas o se(nhor) para uma única nota. Para a palavra rei deveria haver apenas uma ligadura sob as notas, inclusive na segunda voz, e a sequência deveria ser "ou com o se-" para quatro colcheias.

Acompanhamento instrumental (piano) - a introdução prioriza cromatismos e dissonâncias sobre pedal no primeiro grau na mão esquerda e quase sempre na nota mais aguda da mão direita, com os quatro últimos compassos desenvolvendo por movimento contrário linhas escalares finalizando na $\mathrm{T}$ com arpejo descendente $\mathrm{T}^{653}$, repetido por três vezes em planos sequencialmente mais grave. O pedal no primeiro grau continua na apresentação das vozes até a parte b (após aa'), quando a linha do baixo desenvolve uma linha de sétimas quebradas por sequência ascendente. Na segunda parte, declamada, a mão esquerda apresenta polirritmia, por 4 compassos ternários, com a mão direita apresentando arpejos da $\mathrm{T}$ em planos ascendentes. Segue uma linha cromática descendente em quartas com interrupção em acorde de $\mathrm{D}$, com glissando também em quartas nas duas mãos terminando na $\mathrm{D}$ suspensa por fermata, ritornello e para finalizar uníssono na $\mathrm{T}$ em fff. GP/ABM apresenta problemas no compasso 32 - a última nota na mão esquerda é $\boldsymbol{E}$, não $\boldsymbol{F}$; no compasso 41 o último compasso deveria conter os acidentes como prevenção, pela mudança de clave; falta a linha de oitava nos compassos 43-45; no compasso 45, na mão direita, a terceira nota mais aguda é $\boldsymbol{F}$, não $\boldsymbol{E}$; no compasso 49, na mão direita, a nota $\boldsymbol{B}$ é natural, na quarta colcheia - falta um bequadro.

85) O CRAVO ( $\left(1^{\mathrm{a}}\right.$ versão $)$ - acompanhamento instrumental

\begin{tabular}{|c|c|c|c|c|c|c|c|}
\hline Volume & № & Vozes & Extensão & Tessitura & Tonalidade & $\begin{array}{l}\text { Intervalos } \\
\text { melódicos }\end{array}$ & $\begin{array}{l}\text { Intervalos } \\
\text { harmônicos }\end{array}$ \\
\hline $\begin{array}{l}\text { GP-VTL } \\
\text { / ABM }\end{array}$ & $\begin{array}{c}45 \\
/ 118\end{array}$ & 2 & $\begin{array}{c}10^{a} \\
11 \text { compassos } \\
\text { ternários }\end{array}$ & $\begin{array}{l}\text { 1 v.:C3-D4 } \\
\text { 2a v.:B2-A3 }\end{array}$ & $\begin{array}{c}\text { Modo de C } \\
\text { maior }\end{array}$ & $\begin{array}{c}\text { 2a M/M;3a } \\
M / m ; 4 \text { a/5aj; } \\
\text { 6-m }\end{array}$ & 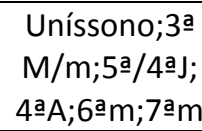 \\
\hline
\end{tabular}

Análise parcial em $2.1-n^{\circ} 126$.

As vozes se desenvolvem por terças ou sextas paralelas. A sugestão em GP/ABM é adequada e resolve a segunda voz quando não é definida em GP/VTL. 
Acompanhamento instrumental (piano) - a mão direita dobra a melodia em acordes, ou intervalos de terças ou sextas, enquanto a mão esquerda faz o baixo das funções básicas, com ostinato de ritmos sincopados, com a linha de baixos lembrando o violão.

86) FUI NO ITORORÓ (1 ${ }^{\mathrm{a}}$ versão) - acompanhamento instrumental

\begin{tabular}{|c|c|c|c|c|c|c|c|}
\hline Volume & № & Vozes & Extensão & Tessitura & Tonalidade & $\begin{array}{l}\text { Intervalos } \\
\text { melódicos }\end{array}$ & $\begin{array}{l}\text { Intervalos } \\
\text { harmônicos }\end{array}$ \\
\hline $\begin{array}{l}\text { GP-VTL } \\
\text { / ABM }\end{array}$ & $\begin{array}{l}54 / \\
129\end{array}$ & 2 & $\begin{array}{c}12^{a} \\
32 \text { compassos: } \\
10 \text { binários e } 22 \\
\text { quaternários }\end{array}$ & $\begin{array}{l}\text { 1a v.:C\#3-D4 } \\
\text { 2a v.:F\#2-C\#4 }\end{array}$ & $\begin{array}{c}\text { Modo de D } \\
\text { maior }\end{array}$ & 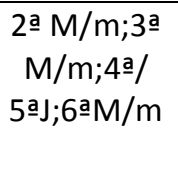 & 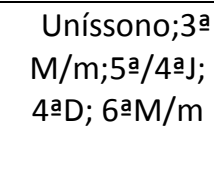 \\
\hline
\end{tabular}

Análise parcial em $2.1-n^{\circ} 122$.

A peça apresenta duas canções diferentes - a primeira mais rápida, a segunda mais lenta com retorno à primeira parte. A segunda voz não está definida no arranjo, o que possibilita várias soluções, entre elas a que consta em GP/ABM. Na parte A, para se evitar as notas muito graves na segunda voz, nessa edição, pode-se trocar sextas por terças paralelas na primeira música. Na parte B, a segunda voz tem notas sustentadas por tempo excessivo, em se tratando de coro infanto-juvenil, o que pode ser resolvido com mais articulações da sílaba $A h$ !

Acompanhamento instrumental (piano) - a parte A e a última, A', apresentam a harmonização distribuída em acordes para ambas as mãos, com a melodia dobrada na mão direita e um pedal de $\mathrm{T}$ (primeiro e quinto graus) no baixo da esquerda. A melodia principal, parte B tem um contraponto na mão esquerda em linhas descendentes em oitavas. A segunda parte de B tem tratamento harmônico, com alguns cromatismos estruturais e ornamentais, e polirritmia nos compassos 29 e 31 . A coda tem um compasso no acorde de $\mathrm{T}$.

\section{7) VITU - acompanhamento instrumental}

\begin{tabular}{|c|c|c|c|c|c|c|c|}
\hline Volume & № & Vozes & Extensão & Tessitura & Tonalidade & $\begin{array}{l}\text { Intervalos } \\
\text { melódicos }\end{array}$ & $\begin{array}{l}\text { Intervalos } \\
\text { harmônicos }\end{array}$ \\
\hline $\begin{array}{l}\text { GP-VTL } \\
\text { / ABM }\end{array}$ & $\begin{array}{l}133 \\
/ 119\end{array}$ & 2 & $\begin{array}{c}\text { 7ạ } \\
19 \text { compassos } \\
\text { binários }\end{array}$ & $\begin{array}{l}1 \text { a v.:C3-A3 } \\
2 \text { a v.:B2-F3 }\end{array}$ & $\begin{array}{c}\text { Modo de C } \\
\text { maior }\end{array}$ & $\begin{array}{l}\text { 2a } \mathrm{M} / \mathrm{m} ; \\
\text { 3ㅁ } / \mathrm{m}\end{array}$ & $\begin{array}{l}\text { Uníssono;3a } \\
\text { M/m; 6am }\end{array}$ \\
\hline
\end{tabular}

Análise parcial em $2.1-n^{\circ} 32$.

A segunda voz acompanha a primeira em terça paralela inferior, com exceção de três sextas paralelas na última frase. Para uma boa afinação dessa modalidade de canto a duas vozes, é preciso haver independência entre os grupos, o que deve ser trabalho com jogos e exercícios, sendo uma sugestão inverter as vozes.

Acompanhamento instrumental (piano) - a introdução (4 compassos) apresenta ostinato em dois compassos, que se repete quatro vezes, mais duas vezes no ritornello e na Coda mais 
duas vezes. A melodia é dobrada pela mão direita em terças e sextas, paralelas, com interferências da mão esquerda com pequenas linhas cromáticas em movimento contrário.

88) QUE LINDOS OLHOS - acompanhamento instrumental

\begin{tabular}{|c|c|c|c|c|c|c|c|}
\hline Volume & № & Vozes & Extensão & Tessitura & Tonalidade & $\begin{array}{l}\text { Intervalos } \\
\text { melódicos }\end{array}$ & $\begin{array}{l}\text { Intervalos } \\
\text { harmônicos }\end{array}$ \\
\hline $\begin{array}{l}\text { GP-VTL } \\
\text { / ABM }\end{array}$ & $\begin{array}{l}107 \\
/ 121\end{array}$ & 2 & $\begin{array}{c}9 \underline{a} \\
23 \text { compassos } \\
\text { binários }\end{array}$ & $\begin{array}{l}1 \mathrm{a} \text { v.:C3-C4 } \\
2^{\mathrm{a}} \mathrm{v} .: B 2-A 3\end{array}$ & $\begin{array}{c}\text { Modo de C } \\
\text { maior }\end{array}$ & $\begin{array}{c}\text { 2a M/m;3aM } \\
\text { /m;4a/5aj; } \\
\text { 6am; 7a } \mathrm{a}\end{array}$ & $\begin{array}{c}\text { Uníssono; 2a } \\
\mathrm{M} ; 3^{\mathrm{a}} \mathrm{M} / \mathrm{m} \\
\text { 4a/5a }{ }^{\mathrm{a}} \mathrm{a} \mathrm{j} ; 6 \mathrm{~m}\end{array}$ \\
\hline
\end{tabular}

Análise parcial em $2.1-n^{\circ} 154$.

Em GP/VTL a segunda voz não é totalmente definida no arranjo, e em GP/ABM as duas primeiras frases são iniciadas por oitavas. Outra solução, seria o início dessas frases em terças, como segue o procedimento em movimento paralelo, com exceção de apenas 3 compassos.

Acompanhamento instrumental (piano) - introdução em linha descendente com tétrades desde a $\mathrm{T}$ até $\mathrm{D}$ com acordes rebatidos. A melodia é dobrada pela mão direita em terças e sextas, com o baixo expresso pela mão esquerda sobre as funções primárias, ornamentado com alguns cromatismos. Coda com um compasso com finalização em uníssono no primeiro grau.

89) ROSA AMARELA ( $2^{\text {a }}$ versão $)$ - acompanhamento instrumental

\begin{tabular}{|c|c|c|c|c|c|c|c|}
\hline Volume & № & Vozes & Extensão & Tessitura & Tonalidade & $\begin{array}{l}\text { Intervalos } \\
\text { melódicos }\end{array}$ & $\begin{array}{l}\text { Intervalos } \\
\text { harmônicos }\end{array}$ \\
\hline $\begin{array}{l}\text { GP-VTL } \\
\text { / ABM }\end{array}$ & $\begin{array}{l}109 \\
/ 120\end{array}$ & 2 & $\begin{array}{c}10^{\mathrm{a}} \\
22 \text { compassos } \\
\text { binários }\end{array}$ & $\begin{array}{l}1 \text { a v.:D3-D4 } \\
\text { 2a v.:B2-B3 }\end{array}$ & $\begin{array}{c}\text { Modo de A } \\
\text { maior }\end{array}$ & $\begin{array}{l}\text { 2a } M ; 3 \text { a } M \\
/ m ; 4 \text { a } / 5 \text { aj; } \\
\text { 6-m }\end{array}$ & $\begin{array}{l}\text { Uníssono;3a } \\
\mathrm{M} / \mathrm{m} ; 5 \underline{a} / 4 \underline{\mathrm{a}} ; 6^{\mathrm{a}} \mathrm{am}\end{array}$ \\
\hline
\end{tabular}

Análise parcial em $2.1-n^{\circ} 139$.

Em GP/VTL a segunda voz não é totalmente definida no arranjo, estando na maior parte das vezes apresentada em terça inferior paralela na segunda voz, havendo liberdade para se buscar muitas soluções. A que propõe GP/ABM é viável, porém apresenta notas muito graves para a segunda voz em alguns momentos e algumas oitavas que esvaziam um pouco o contexto harmônico.

Acompanhamento instrumental (piano) - introdução sobre bordaduras de quinto e sexto graus na mão direita, com a mão esquerda apresentando o ostinato rítmico a ser utilizado durante toda a peça, com cromatismos na voz superior das tríades, com finalização na T. A melodia é dobrada pela mão direita, em terças, e sextas, sobre o ostinato rítmico-melódico na mão esquerda. A coda repete a introdução com finalização por linha descendente sobre $T^{6-5}$. Em GP/ABM, nos compassos 17 e 25 , no segundo acorde, o bequadro deve estar na nota $\boldsymbol{E}$ e não $C \#$ como consta, portanto não deve constar sustenido no $\boldsymbol{C}$ no quarto acorde. 
90) O PASTORZINHO - acompanhamento instrumental

\begin{tabular}{|c|c|c|c|c|c|c|c|}
\hline Volume & № & Vozes & Extensão & Tessitura & Tonalidade & $\begin{array}{l}\text { Intervalos } \\
\text { melódicos }\end{array}$ & $\begin{array}{l}\text { Intervalos } \\
\text { harmônicos }\end{array}$ \\
\hline GP-VTL & 91 & 2 & $10^{\mathrm{a}}$ & 1a v.:F3-C4 & Modo de & 2a $\mathrm{M} / \mathrm{m} ; 3^{\mathrm{a}}$ & Uníssono;3a \\
\hline / ABM & /125 & & $\begin{array}{l}29 \text { compassos } \\
\text { binários }\end{array}$ & 2a v.:A2-G3 & Bb maior & $\mathrm{M} / \mathrm{m} ; 4 \mathrm{a} / 5 \mathrm{a} \mathrm{J}$ & 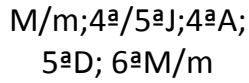 \\
\hline
\end{tabular}

Análise parcial em $2.1-n^{\circ} 63$.

A própria indicação do autor em GP/VTL, a duas vozes Ad Libitum, libera o canto a uma voz, ou a busca de soluções variadas para uma segunda voz. GP/ABM sugere uma segunda voz na parte B, inserindo a sílaba Hum..., já que o texto da primeira voz refere-se aos nomes das notas, que não poderiam ser repetidos em outra altura. Nesta canção fica provado que VillaLobos não adotou o solfejo relativo, mudando o texto popular (que também não adota a nomenclatura relativa) de acordo com a tonalidade adotada.

Acompanhamento instrumental (piano) - introdução com ostinato rítmico na mão esquerda (que segue até o final da parte A) e linha melódica descendente por terças na mão direita. A melodia é dobrada pela mão direita quase totalmente por terças. Na parte B há um contraponto no baixo com linha descendente contendo cromatismo ornamental. A coda, em dois compassos, apresenta uma escala descendente em sextas.

91) CANOINHA NOVA - a capella

\begin{tabular}{|c|c|c|c|c|c|c|c|}
\hline Volume & № & Vozes & Extensão & Tessitura & Tonalidade & $\begin{array}{l}\text { Intervalos } \\
\text { melódicos }\end{array}$ & $\begin{array}{l}\text { Intervalos } \\
\text { harmônicos }\end{array}$ \\
\hline $\begin{array}{l}\text { GP-VTL/ } \\
\text { ABM/ } \\
\text { S1 }\end{array}$ & $\begin{array}{c}24 / \\
40 / \\
20\end{array}$ & 2 & $\begin{array}{c}14^{a} \underline{a} \\
10 \text { compassos } \\
\text { binários }\end{array}$ & $\begin{array}{l}\text { 1'a v.:G3-F4 } \\
\text { 2a v.:G2-G3 }\end{array}$ & $\begin{array}{c}\text { Modo de C } \\
\text { maior }\end{array}$ & $\begin{array}{c}\text { 2a } \mathrm{aM} / \mathrm{m} ; \\
\text { 3a } \mathrm{M} / \mathrm{m} ; 4 \text { aj; } \\
\text { 6a } \mathrm{M} / \mathrm{m}\end{array}$ & 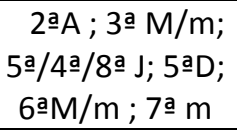 \\
\hline
\end{tabular}

Análise parcial em $2.1-n^{\circ} 150$.

Na segunda voz, o contraponto antecipa a entrada da melodia com sons onomatopaicos imitando o som da água movida pelo remo, em quartas descendentes. Em movimento contrário, prioriza intervalos harmônicos de terças e sextas. Ritmicamente, não repete o ritmo de marcha enfatizado por acentos na melodia.

92) POBRE CEGO ( $2^{\text {a }}$ versão $)$ - a capella

\begin{tabular}{|c|c|c|c|c|c|c|c|}
\hline Volume & № & Vozes & Extensão & Tessitura & Tonalidade & $\begin{array}{l}\text { Intervalos } \\
\text { melódicos }\end{array}$ & $\begin{array}{c}\text { Intervalos } \\
\text { harmônicos }\end{array}$ \\
\hline $\begin{array}{c}\text { GP-VTL/ } \\
\text { ABM }\end{array}$ & $\begin{array}{c}97 / \\
44 / \\
17\end{array}$ & 2 & $\begin{array}{c}12 \underline{a} \\
9 \text { compassos } \\
\text { binários }\end{array}$ & $\begin{array}{c}1 \text { a v.:C3-Eb4 } \\
\text { 2a v.:Ab2-Ab3 }\end{array}$ & F menor & $\begin{array}{l}\text { 2a } \mathrm{M} / \mathrm{m} / \mathrm{A} ; \\
\text { 3a } \mathrm{M} / \mathrm{m} ; \\
\text { 4a } / 5 \text { a J; } \\
\text { 6am }\end{array}$ & 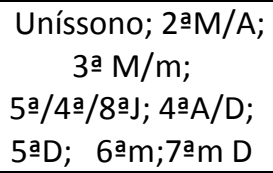 \\
\hline
\end{tabular}

Análise parcial em $2.1-n^{\circ} 162$.

O contraponto tem ritmo independente, na segunda voz, reforça intervalos melódicos de sextas. As alterações, com base na escala menor melódica, tanto quanto o cromatismo estrutural no compasso 5, devem ser trabalhadas cuidadosamente. Os pontos estratégicos em uníssono ajudam no controle da afinação.

Em GP/ABM, compasso 9, na segunda voz consta “cantar”, equivocadamente. A prosódia aparece corrigida nos compassos 13 e 14 ("minha"), mas não no compasso 6, na mesma 
situação. Diferente de GP/VTL, que indica o andamento Moderato, em GP/ABM consta Allegretto.

93) A COBRA E A ROLINHA - a capella

\begin{tabular}{|c|c|c|c|c|c|c|c|}
\hline Volume & № & Vozes & Extensão & Tessitura & Tonalidade & $\begin{array}{l}\text { Intervalos } \\
\text { melódicos }\end{array}$ & $\begin{array}{c}\text { Intervalos } \\
\text { harmônicos }\end{array}$ \\
\hline $\begin{array}{c}\text { GP-VTL/ } \\
\text { ABM }\end{array}$ & $\begin{array}{l}36 / \\
27\end{array}$ & 2 & $\begin{array}{c}14 \text { a } \\
13 \text { compassos } \\
\text { binários }\end{array}$ & $\begin{array}{c}1 \text { a v.:C3-C4 } \\
\text { 2a v.:B2-Bb3 }\end{array}$ & $\begin{array}{c}\text { Modo de F } \\
\text { maior }\end{array}$ & $\begin{array}{l}\text { 2-aM/m;3a } \\
M / m ; 4 \text { a j; } \\
\text { 7am }\end{array}$ & $\begin{array}{l}\text { Uníssono; 2a } \mathrm{a} / \mathrm{m} ; \\
\text { 3a } \mathrm{M} / \mathrm{m} ; 5 \mathrm{a} / 4 \mathrm{a} \mathrm{J} ; \\
\text { 5aD; 6aM } \mathrm{a} / \mathrm{m} \text {; 7am }\end{array}$ \\
\hline
\end{tabular}

Análise parcial em $2.1-n^{\circ} 102$.

A peça é rica em variações de andamento e de intensidade, semelhante a certas modas de viola.

O contraponto, na segunda voz, acompanha a configuração rítmica da melodia enfatizando intervalos de terças paralelas. $\mathrm{Na}$ segunda parte desenvolve motivo de linha escalar pentatônica descendente e ascendente sob as notas rebatidas da primeira voz, com repetição em sequência descendente por grau conjunto.

Solo instrumental - há indicação para que a mão esquerda toque uma oitava abaixo quando a peça for executada ao piano.

94) SOLFEJO N ${ }^{\circ} 131$ - a capella

\begin{tabular}{|c|c|c|c|c|c|c|c|}
\hline Volume & № & Vozes & Extensão & Tessitura & Tonalidade & $\begin{array}{l}\text { Intervalos } \\
\text { melódicos }\end{array}$ & $\begin{array}{l}\text { Intervalos } \\
\text { harmônicos }\end{array}$ \\
\hline S1 & 131 & 2 & $\begin{array}{c}13 \text { a } \\
8 \text { compassos } \\
\text { quaternários }\end{array}$ & $\begin{array}{l}\text { 1a v.:D3-E4 } \\
\text { 2a v.:G2-G3 }\end{array}$ & $\begin{array}{l}\text { Modo de G } \\
\text { maior }\end{array}$ & $\begin{array}{c}2{ }^{\mathrm{a}} \mathrm{M} / \mathrm{m} ; 3^{\mathrm{a}} \\
\mathrm{m} ; 4 \mathrm{4} / 5^{\mathrm{a} J} ; \\
6 \mathrm{am}\end{array}$ & 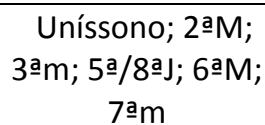 \\
\hline
\end{tabular}

Melodia de Villa-Lobos, com indicação de andamento Andantino, sobre ostinato rítmico válido para as duas vozes. A primeira voz tem o primeiro desenho, em linha ascendente, repetido em sequência grau conjunto acima, o mesmo acontecendo com o segundo desenho, em linha descendente, repetido grau conjunto abaixo, ligeiramente modificado ao final. $\mathrm{O}$ contraponto, na segunda voz, mantém o mesmo critério, por movimento contrário na primeira frase e variando na segunda para a terminação. Pelas características, o solfejo, de fácil execução, é recomendado para os corais principiantes.

95) SOLFEJO $N^{\circ} 8$ (Vocalismo) - a capella

\begin{tabular}{|c|c|c|c|c|c|c|c|}
\hline Volume & № & Vozes & Extensão & Tessitura & Tonalidade & $\begin{array}{l}\text { Intervalos } \\
\text { melódicos }\end{array}$ & $\begin{array}{c}\text { Intervalos } \\
\text { harmônicos }\end{array}$ \\
\hline S2 & $\begin{array}{l}8 / \\
P . \\
5\end{array}$ & 2 & $\begin{array}{c}12^{\mathrm{a}} \\
13 \text { compassos } \\
\text { binários }\end{array}$ & $\begin{array}{c}1 \text { a v.: F3-F4 } \\
\text { 2a v.: Bb2-Bb3 }\end{array}$ & $\begin{array}{l}\text { Modo de F } \\
\text { menor }\end{array}$ & 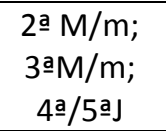 & 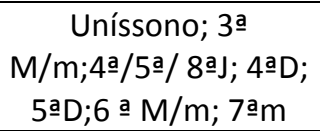 \\
\hline
\end{tabular}

Tema de origem tcheca, do compositor Miroslav Krejči, o contraponto é desenvolvido por movimento contrário na primeira frase, permitindo paralelismos com algumas sextas na segunda frase, com finalização em movimento contrário. Em tonalidade menor, as alterações aparecem no sexto e sétimo graus $(\boldsymbol{D} \boldsymbol{G}$ e $\boldsymbol{E} \boldsymbol{\natural})$. Há indicações de serialização de intensidade, partindo de $\boldsymbol{p}$ para $\boldsymbol{m} \boldsymbol{f}$ e $\boldsymbol{f}$, com decrescendo no final. As frases assimétricas têm acento nas 
primeiras notas das semifrases: A (ab - com três compassos cada) e B (aba' - com dois, dois e três compassos respectivamente).

96) SOLFEJO $\mathrm{N}^{\circ} 128$ - a capella

\begin{tabular}{|c|c|c|c|c|c|c|c|}
\hline Volume & № & Vozes & Extensão & Tessitura & Tonalidade & $\begin{array}{l}\text { Intervalos } \\
\text { melódicos }\end{array}$ & $\begin{array}{l}\text { Intervalos } \\
\text { harmônicos }\end{array}$ \\
\hline S1 & 128 & 2 & $\begin{array}{c}15^{\mathrm{a}} \\
8 \text { compassos }\end{array}$ & $\begin{array}{l}1^{\mathrm{a}} \mathrm{v} .: \mathrm{C3}-\mathrm{G} 3 \\
2^{\mathrm{a}} \mathrm{v} .: \mathrm{B} 2-\mathrm{G} 3\end{array}$ & $\begin{array}{c}\text { Modo de G } \\
\text { menor }\end{array}$ & $\begin{array}{c}2 \mathrm{a} M / \mathrm{m} ; 3^{\mathrm{a}} \\
\mathrm{m} ; 4 \mathrm{a} J\end{array}$ & $\begin{array}{c}\text { Uníssono; } \\
\text { 2ạ/m/A; 3a } \mathrm{a} / \mathrm{m} ; \\
\text { 4a/5a/8aj; 5a } \mathrm{D} ; 7 \text { a } \mathrm{m}\end{array}$ \\
\hline
\end{tabular}

Análise parcial em $2.1-n^{\circ} 64$.

Melodia de Villa-Lobos, com indicação de andamento Grave, tem seu interesse pela configuração rítmica, caracterizada pela alternância de compassos: Binários e Ternário com subdivisão binária; binário com subdivisão ternária, quaternário, binário e quaternário com subdivisão binária. A segunda parte apresenta cruzamento entre as vozes. O solfejo favorece o aprendizado da figura breve, tanto quanto as variadas fórmulas de compassos sobre unidades de pulso variadas.

97) SOLFEJO $\mathbf{N}^{\circ} 144$ - a capella

\begin{tabular}{|c|c|c|c|c|c|c|c|}
\hline Volume & № & Vozes & Extensão & Tessitura & Tonalidade & $\begin{array}{l}\text { Intervalos } \\
\text { melódicos }\end{array}$ & $\begin{array}{l}\text { Intervalos } \\
\text { harmônicos }\end{array}$ \\
\hline S1 & 144 & 2 & $\begin{array}{c}12^{a} \\
8 \text { compassos } \\
\text { ternários }\end{array}$ & $\begin{array}{l}\text { 1a v.:F3-C4 } \\
\text { 2a v.:A2-A3 }\end{array}$ & $\begin{array}{l}\text { Modo de } F \\
\text { maior }\end{array}$ & 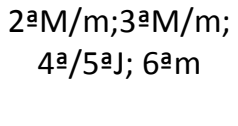 & 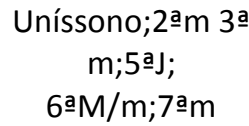 \\
\hline
\end{tabular}

Análise parcial em $2.1-n^{\circ} 14$.

Melodia de Villa-Lobos com indicação de andamento Tempo de Mazurka. Sobre o pentacorde da T, a melodia parte do acorde quebrado da tríade e apresenta novos motivos enfatizando o terceiro grau, presente na totalidade da peça. $\mathrm{O}$ contraponto, na segunda voz, privilegia intervalos harmônicos de terças e sextas, com movimento contrário na primeira frase e algum paralelismo na segunda.

98) SOLFEJO $\mathrm{N}^{\circ} 135$ - a capella

\begin{tabular}{|c|c|c|c|c|c|c|c|}
\hline Volume & № & Vozes & Extensão & Tessitura & Tonalidade & $\begin{array}{l}\text { Intervalos } \\
\text { melódicos }\end{array}$ & $\begin{array}{c}\text { Intervalos } \\
\text { harmônicos }\end{array}$ \\
\hline S1 & 135 & 2 & $\begin{array}{c}10^{\mathrm{a}} \\
14 \text { compassos } \\
\text { binários }\end{array}$ & $\begin{array}{l}1 \text { a v.:E3-C4 } \\
\text { 2a v.:A2-F3 }\end{array}$ & $\begin{array}{c}\text { Modo } \\
\text { hexatônico } \\
\text { menor de A }\end{array}$ & 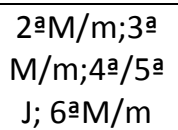 & 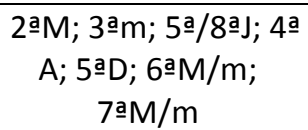 \\
\hline
\end{tabular}

Melodia de Villa-Lobos, com indicação de andamento Allegretto. As frases são assimétricas: a primeira contém duas semifrases com quatro compassos cada, e a segunda, duas semifrases com três compassos cada. O contraponto, na segunda voz, faz uma imitação antecipada do ritmo da segunda semifrase. Solfejo de fácil execução.

99)SOLFEJO N ${ }^{\circ} 149$ - a capella

\begin{tabular}{|c|c|c|c|c|c|c|c|}
\hline Volume & № & Vozes & Extensão & Tessitura & Tonalidade & $\begin{array}{l}\text { Intervalos } \\
\text { melódicos }\end{array}$ & $\begin{array}{c}\text { Intervalos } \\
\text { harmônicos }\end{array}$ \\
\hline S1 & 149 & 2 & $\begin{array}{c}12^{a} \\
8 \text { compassos } \\
\text { quaternários }\end{array}$ & $\begin{array}{l}\text { 1a v.:G3-D4 } \\
\text { 2a v.:C3-B3 }\end{array}$ & $\begin{array}{l}\text { Modo de G } \\
\text { maior }\end{array}$ & $\begin{array}{c}\text { 2aM/m;3aM } \\
\text { /m;4의; }\end{array}$ & 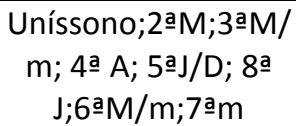 \\
\hline
\end{tabular}


Análise parcial em $2.1-n^{\circ} 146$.

Melodia de Villa-Lobos com indicação de andamento Allegretto. Sobre o pentacorde da T, a melodia apresenta valores mais largos na primeira frase e mais movimentados na segunda, na qual consta uma alteração $(\boldsymbol{G} \#)$ no penúltimo compasso, que caracteriza uma bordadura cromática inferior, tanto quanto a D da Dr. O contraponto na segunda voz inicia-se em movimento contrário e na segunda frase, movimento paralelo de terças, retomando o movimento contrário ao final, sempre recorrendo a terças e sextas harmônicas.

100) SOLFEJO $\mathrm{N}^{\circ} 137$ - a capella

\begin{tabular}{|c|c|c|c|c|c|c|c|}
\hline Volume & № & Vozes & Extensão & Tessitura & Tonalidade & $\begin{array}{l}\text { Intervalos } \\
\text { melódicos }\end{array}$ & $\begin{array}{c}\text { Intervalos } \\
\text { harmônicos }\end{array}$ \\
\hline S1 & 137 & 2 & $\begin{array}{c}9 \underline{a} \\
8 \text { compassos } \\
\text { binários (subdivisão } \\
\text { ternária) }\end{array}$ & $\begin{array}{c}1 \text { a v.:D3-D4 } \\
\text { 2a v.:C\#3-B3 }\end{array}$ & $\begin{array}{c}\text { Modo de D } \\
\text { maior }\end{array}$ & 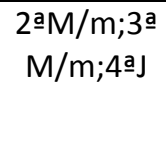 & 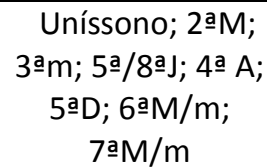 \\
\hline
\end{tabular}

Melodia de Villa-Lobos, com a indicação de andamento Moderato, com subdivisão ternária. A primeira voz apresenta linha escalar ascendente, do primeiro ao oitavo grau, descendo para a terça e novamente segue para a $\mathrm{T}$ ascendentemente. No compasso 6 , falta um ponto de aumento na segunda nota. O contraponto, na segunda voz, inicia com imitação à oitava, segue com valores rítmicos dobrados e termina a frase em terças paralelas descendentes. A segunda frase inicia-se com terças paralelas ascendentes, por sequências em graus conjuntos, terminando em sexta harmônica.

101) SOLFEJO $\mathrm{N}^{\circ} 75$ - a capella

\begin{tabular}{|c|c|c|c|c|c|c|c|}
\hline Volume & № & Vozes & Extensão & Tessitura & Tonalidade & $\begin{array}{l}\text { Intervalos } \\
\text { melódicos }\end{array}$ & $\begin{array}{c}\text { Intervalos } \\
\text { harmônicos }\end{array}$ \\
\hline S1 & 75 & $\begin{array}{c}2 \\
\text { iguais }\end{array}$ & $\begin{array}{c}11 \underline{a} \\
11 \text { compassos } \\
\text { binários }\end{array}$ & $\begin{array}{l}\text { 1a voz: C3-E4; } \\
\text { 2a voz: B2-D4 }\end{array}$ & $\begin{array}{l}\text { Modo de } \\
\text { C maior }\end{array}$ & 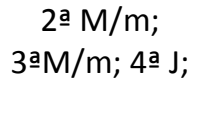 & 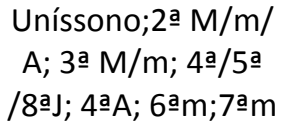 \\
\hline
\end{tabular}

Melodia de H. Villa-Lobos, com indicação de andamento Presto e Deciso / rit.; de intensidade: < ; > acentos >; sfz. Forma: A. O contraponto, na segunda voz, é apresentado em movimento contrário, com cruzamento de vozes nos quatro compassos finais. As melodias das duas vozes caracterizam-se por linhas em pentacordes e escalares completas ascendentes e descendentes. O sexto compasso é polirrítmico, com a tercina reduzindo o movimento do compasso anterior e promovendo repouso em nota longa no seguinte. Os cromatismos são ornamentais.

102) SOLFEJO $N^{\circ} 102$ - a capella

\begin{tabular}{|c|c|c|c|c|c|c|c|}
\hline Volume & № & Vozes & Extensão & Tessitura & $\begin{array}{c}\text { Tonalidad } \\
\mathrm{e}\end{array}$ & $\begin{array}{l}\text { Intervalos } \\
\text { melódicos }\end{array}$ & $\begin{array}{c}\text { Intervalos } \\
\text { harmônicos }\end{array}$ \\
\hline S1 & 102 & 2 & $\begin{array}{c}16^{\mathbf{a}} \\
8 \text { compassos } \\
\text { quaternários }\end{array}$ & $\begin{array}{l}\text { 1a v.:C3-E4 } \\
\text { 2a v.:A2-C4 }\end{array}$ & $\begin{array}{l}\text { Modo de C } \\
\text { maior }\end{array}$ & $\begin{array}{c}2 \text { a } M / m ; 3^{a} m ; \\
4 \text { a } / 5 \text { a J }\end{array}$ & 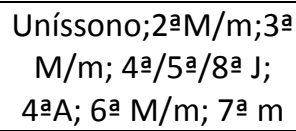 \\
\hline
\end{tabular}

Melodia de Villa-Lobos, com indicação de andamento Allegretto - iniciada por quartas quebradas, apresenta, ainda dois desenhos anacrúsicos em âmbito de quarta, finalizando com tetracorde descendente para a T. O contraponto baseia-se em intervalos harmônicos de terças 
e sextas com alguns retardos provocando intervalos de segundas, especialmente no tetracorde final em terças paralelas, concluindo em uníssono.

103) SOLFEJO $N^{\circ} 130$ - a capella

\begin{tabular}{|c|c|c|c|c|c|c|c|}
\hline Volume & № & Vozes & Extensão & Tessitura & Tonalidade & $\begin{array}{l}\text { Intervalos } \\
\text { melódicos }\end{array}$ & $\begin{array}{l}\text { Intervalos } \\
\text { harmônicos }\end{array}$ \\
\hline S1 & 130 & 2 & $\begin{array}{c}11 \text { a } \\
9 \text { compassos } \\
\text { quaternários }\end{array}$ & $\begin{array}{l}1 \text { a v.:C3-E4 } \\
\text { 2a v.:B2-A3 }\end{array}$ & $\begin{array}{c}\text { Modo de C } \\
\text { maior }\end{array}$ & $\begin{array}{c}\text { 2aM/m;3a } \\
\mathrm{m} ; 6 \underline{\mathrm{a}} \mathrm{M}\end{array}$ & 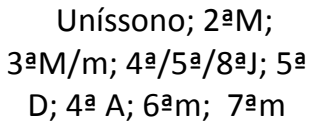 \\
\hline
\end{tabular}

Melodia de Villa-Lobos, com indicação de andamento Andante. Desenvolvida sobre graus conjuntos e eventuais intervalos de terças, a melodia tem a primeira frase em plano agudo, e a segunda segue em linha descendente com finalização na $\mathrm{T}$ oitava abaixo da inicial. $\mathrm{O}$ contraponto se movimenta por movimento contrário, apresentando na segunda frase alteração $(\boldsymbol{F} \#)$ que configura a função de DD. Na primeira voz, no compasso 7, a alteração $(\boldsymbol{G} \#)$ pode ser interpretada como bordadura cromática, ou como $\mathrm{D}$ da Tr. O último tetracorde descendente se dá por retardos entre terças e segundas harmônicas. Sextas e terças harmônicas são recorrentes.

104) SOLFEJO $N^{\circ} 143$ - a capella

\begin{tabular}{|c|c|c|c|c|c|c|c|}
\hline Volume & № & Vozes & Extensão & Tessitura & Tonalidade & $\begin{array}{l}\text { Intervalos } \\
\text { melódicos }\end{array}$ & $\begin{array}{c}\text { Intervalos } \\
\text { harmônicos }\end{array}$ \\
\hline S1 & 143 & 2 & $\begin{array}{c}12^{a} \\
7 \text { compassos } \\
\text { ternários }\end{array}$ & $\begin{array}{c}\text { 1a v.:A3-Eb4 } \\
\text { 2a v.:Bb2-Bb3 }\end{array}$ & $\begin{array}{l}\text { Modo de } \\
\text { Bb maior }\end{array}$ & 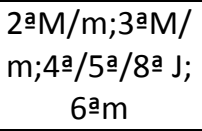 & 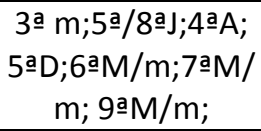 \\
\hline
\end{tabular}

Melodia de Villa-Lobos com indicação de andamento Grave Religioso. Em subdivisão binária, a configuração rítmica do contraponto sugere subdivisão ternária, resultando eventual polirritmia. No compasso 3 da primeira voz há duas colcheias que, em princípio, são semínimas. O contraponto, na segunda voz, inicia-se com os elementos rítmicos e melódicos do quarto compasso da melodia. Apresenta alteração que caracteriza a D da S. Terças e sextas harmônicas são recorrentes.

105) SOLFEJO $\mathrm{N}^{\circ} 69$ - a capella

\begin{tabular}{|c|c|c|c|c|c|c|c|}
\hline Volume & № & Vozes & Extensão & Tessitura & Tonalidade & $\begin{array}{l}\text { Intervalos } \\
\text { melódicos }\end{array}$ & $\begin{array}{c}\text { Intervalos } \\
\text { harmônicos }\end{array}$ \\
\hline S1 & 69 & 2 & $\begin{array}{c}13^{a} \text { a } \\
15 \\
\text { compassos } \\
\text { ternários }\end{array}$ & $\begin{array}{c}\text { 1a v.: C\#2-F\#4 } \\
\text { 2a v.:A2-B3 }\end{array}$ & $\begin{array}{c}\text { Modo de D } \\
\text { maior }\end{array}$ & $\begin{array}{l}\text { 2a } \mathrm{M} / \mathrm{mA} ; \\
\text { 3a } \mathrm{M} / \mathrm{m} ; \\
\text { 4a/5a/8a J; } \\
\text { 6а } \mathrm{M} / \mathrm{m}\end{array}$ & 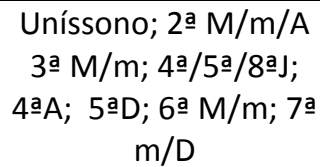 \\
\hline
\end{tabular}

Melodia de Villa-Lobos, com indicação de andamento Moderato, tem alterações cromáticas ornamentais. O contraponto apresenta simples linhas descendentes por graus conjuntos e poucos saltos, contrastando com a maior complexidade melódica. O solfejo não é de fácil execução, no entanto, pelos grandes saltos e pelos grandes intervalos melódicos e harmônicos. 
106) SOLFEJO $\mathrm{N}^{\circ} 111$ - a capella

\begin{tabular}{|c|c|c|c|c|c|c|c|}
\hline Volume & № & Vozes & Extensão & Tessitura & Tonalidade & $\begin{array}{l}\text { Intervalos } \\
\text { melódicos }\end{array}$ & $\begin{array}{c}\text { Intervalos } \\
\text { harmônicos }\end{array}$ \\
\hline S1 & 111 & 2 & $\begin{array}{c}14^{a} \\
8 \text { compassos } \\
\text { binários }\end{array}$ & $\begin{array}{l}1 \text { a v.:C3-F4 } \\
\text { 2a v.:C3-C4 }\end{array}$ & $\begin{array}{l}\text { Modo de F } \\
\text { maior }\end{array}$ & 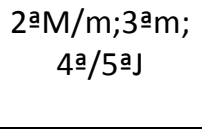 & 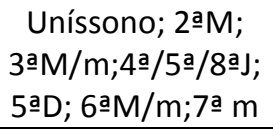 \\
\hline
\end{tabular}

Melodia de Villa-Lobos, com indicação Andantino, iniciada com linha descendente e ascendente do pentacorde da $\mathrm{T}$ e finalizada na $\mathrm{T}$ com hexacorde descendente. $\mathrm{O}$ contraponto trabalha inicialmente o tetracorde do quinto grau, por movimento contrário e na segunda frase os desenhos do primeiro compasso são invertidos nas duas vozes. No sétimo compasso a alteração indica a função de DD, voltando para D no oitavo compasso para resolução na $\mathrm{T}$. Embora com extensão grande, as linhas em graus conjuntos e pequenos saltam tornam o solfejo de fácil execução.

107) SOLFEJO $\mathbf{N}^{\circ} 9$ (Vocalismo) - a capella

\begin{tabular}{|c|c|c|c|c|c|c|c|}
\hline Volume & № & Vozes & Extensão & Tessitura & Tonalidade & $\begin{array}{l}\text { Intervalos } \\
\text { melódicos }\end{array}$ & $\begin{array}{l}\text { Intervalos } \\
\text { harmônicos }\end{array}$ \\
\hline S2 & $\begin{array}{c}\text { 9/ } \\
\text { p. } 6\end{array}$ & 2 & $\begin{array}{c}11 \underline{a} \\
8 \text { compassos } \\
\text { ternários }\end{array}$ & $\begin{array}{c}19 \text { v.: F\#3-F42a } \\
\text { v.: B2-A3 }\end{array}$ & $\begin{array}{l}\text { Modo de D } \\
\text { menor }\end{array}$ & 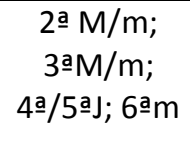 & 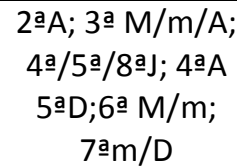 \\
\hline
\end{tabular}

Tema de Villa-Lobos, com indicação de andamento Moderato, em tonalidade menor, as alterações de ordem tonal estão no sexto e sétimo graus $(\boldsymbol{B}$ দ $\boldsymbol{e} \boldsymbol{C \#})$, de ordem modal $(\boldsymbol{F} \#)$ e um cromatismo ornamental $(\boldsymbol{E} \boldsymbol{b})$. O contraponto, com a configuração rítmica caracterizando as vozes independentes, prioriza o movimento paralelo de sextas e terças.

108) SOLFEJO $\mathrm{N}^{\circ} 67$ - a capella

\begin{tabular}{|c|c|c|c|c|c|c|c|}
\hline Volume & № & Vozes & Extensão & Tessitura & Tonalidade & $\begin{array}{l}\text { Intervalos } \\
\text { melódicos }\end{array}$ & $\begin{array}{l}\text { Intervalos } \\
\text { harmônicos }\end{array}$ \\
\hline S1 & 67 & 2 & $\begin{array}{c}11 \text { a } \\
9 \text { compassos } \\
\text { binários }\end{array}$ & $\begin{array}{c}\text { 1a v.: C\#3-D4 } \\
\text { 2a v.:A2-F3 }\end{array}$ & $\begin{array}{l}\text { Modo de C } \\
\text { maior }\end{array}$ & $\begin{array}{c}\text { 2a Mm; } \\
\text { 3am; 4무; }\end{array}$ & 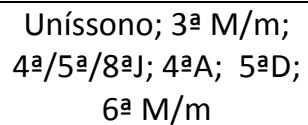 \\
\hline
\end{tabular}

Melodia de Villa-Lobos com indicação de andamento Allegro, baseada em linhas descendentes por graus conjuntos em tetracordes. O contraponto inicia-se com valores largos, priorizando intervalos harmônicos de sextas e terças. Na segunda frase, o ritmo pontuado da melodia contrasta com a subdivisão binária exata na linha descendente de terças paralelas. De fácil execução, o solfejo é adequado para coros principiantes

109) SOLFEJO $\mathbf{N}^{\circ} 3$ (Vocalismo) - a capella

\begin{tabular}{|c|c|c|c|c|c|c|c|}
\hline Volume & № & Vozes & Extensão & Tessitura & Tonalidade & $\begin{array}{l}\text { Intervalos } \\
\text { melódicos }\end{array}$ & Intervalos harmônicos \\
\hline S2 & $\begin{array}{l}3 / \\
\text { p. } \\
3\end{array}$ & 2 & $\begin{array}{c}11^{a} \underline{a} \\
8 \text { compassos } \\
\text { quaternários }\end{array}$ & $\begin{array}{l}1 \text { a v.: F3-E4 } \\
\text { 2a v.: G2-G3 }\end{array}$ & $\begin{array}{l}\text { Modo de C } \\
\text { maior }\end{array}$ & 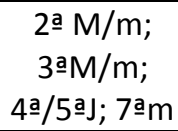 & 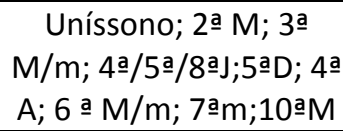 \\
\hline
\end{tabular}

Contraponto iniciado por movimento contrário das vozes, seguindo por sextas paralelas, com finalização em movimento paralelo, privilegiando terças e sextas harmônicas. 
110) SOLFEJO $\mathrm{N}^{\circ} 120$ - a capella

\begin{tabular}{|c|c|c|c|c|c|c|c|}
\hline Volume & № & Vozes & Extensão & Tessitura & Tonalidade & $\begin{array}{l}\text { Intervalos } \\
\text { melódicos }\end{array}$ & $\begin{array}{c}\text { Intervalos } \\
\text { harmônicos }\end{array}$ \\
\hline S1 & 120 & 2 & $\begin{array}{c}11 \text { a } \\
7 \text { compassos } \\
\text { binários }\end{array}$ & $\begin{array}{c}\text { 1a v.:F\#3-D4 } \\
\text { 2a v.:A2-A3 }\end{array}$ & $\begin{array}{c}\text { Modo de D } \\
\text { maior }\end{array}$ & $\begin{array}{l}2^{\mathrm{a}} \mathrm{M} / \mathrm{m} ; 3^{\mathrm{a}} \\
\mathrm{M} ; 4^{\mathrm{a}} / 5^{\mathrm{a}} \mathrm{J}\end{array}$ & 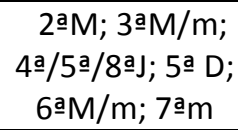 \\
\hline
\end{tabular}

Melodia de Villa-Lobos apresentada na segunda voz, em âmbito de oitava, com movimentação por graus conjuntos e saltos predominantes de quartas. O contraponto inicia-se com a oitava acima do primeiro grau, caminha descendentemente para o quarto grau e faz o caminho inverso por saltos alternados de quartas e terças para finalizar na nota inicial.

111) SOLFEJO $\mathrm{N}^{\circ} 66$ / SOLFEJO $\mathrm{N}^{\circ} 5$ (Vocalismo) - a capella

\begin{tabular}{|c|c|c|c|c|c|c|c|}
\hline Volume & № & Vozes & Extensão & Tessitura & $\begin{array}{c}\text { Tonalida } \\
\text { de }\end{array}$ & $\begin{array}{l}\text { Intervalos } \\
\text { melódicos }\end{array}$ & $\begin{array}{l}\text { Intervalos } \\
\text { harmônicos }\end{array}$ \\
\hline $\begin{array}{l}\text { S1 } \\
\text { S2 }\end{array}$ & $\begin{array}{c}66 \\
5 / \mathrm{p} . \\
4\end{array}$ & 2 & $\begin{array}{c}11 \text { a } \\
18 \text { compassos binários } \\
\text { (subdivisão ternária) }\end{array}$ & $\begin{array}{c}\text { 1'a v.: C\#3-D4 } \\
2^{\text {a }} \text { v.:A2-F3 / } \\
\text { 1a v.: B2-C4 } \\
2^{\text {a }} \text { v.:G2-Bb3 }\end{array}$ & $\begin{array}{l}\text { Modos } \\
\text { de D } \\
\text { menor / } \\
\text { C menor }\end{array}$ & $\begin{array}{c}\text { 2a } \mathrm{Mm} / \mathrm{A} ; \\
\text { 3aM/m; } \\
\text { 4a5aj; 6a m }\end{array}$ & 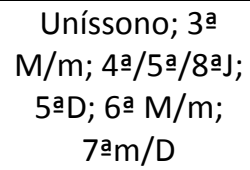 \\
\hline
\end{tabular}

Trata-se do mesmo solfejo: o primeiro encontra-se em S1 - ${ }^{\circ} 66$ em $\boldsymbol{D}$ menor, com indicação de andamento Andante, o segundo em S2 - n 5 (Vocalismo) em $\boldsymbol{C}$ menor, com indicação de andamento Allegretto.

Arranjo de Villa-Lobos sobre tema popular, com alteração no sétimo grau, configurando o tom menor, alternando as funções de tônica e dominante. $\mathrm{O}$ contraponto prioriza sextas e terças diretamente ou por apojaturas. O ritmo é independente entre as vozes, na primeira frase, e na segunda favorece o movimento de terças paralelas.

As pequenas diferenças entre as duas versões deste solfejo (notas pontuadas ou acréscimo de uma nota) estão na segunda voz, nos compassos 2 e 3, na repetição da frase em 6 e 7, em 8, 12 e 16 , e a omissão de uma nota no último compasso. No solfejo $n^{\circ} 66$, falta a barra de repetição no primeiro compasso.

112) SOLFEJO $N^{\circ} 5$ (Imitação) - a capella

\begin{tabular}{|c|c|c|c|c|c|c|c|}
\hline Volume & № & Vozes & Extensão & Tessitura & Tonalidade & $\begin{array}{l}\text { Intervalos } \\
\text { melódicos }\end{array}$ & $\begin{array}{c}\text { Intervalos } \\
\text { harmônicos }\end{array}$ \\
\hline S2 & $\begin{array}{l}5 / \\
\text { p. } \\
19\end{array}$ & $\begin{array}{c}2 \\
\text { iguais }\end{array}$ & $\begin{array}{c}11 \mathfrak{a} \\
8 \text { compassos } \\
\text { ternários (subdivisão } \\
\text { ternária) }\end{array}$ & $\begin{array}{l}\text { 19 voz: B2-C4 } \\
\text { 2a voz: G2-Eb3 }\end{array}$ & $\begin{array}{l}\text { Modo de } \\
\text { C menor }\end{array}$ & 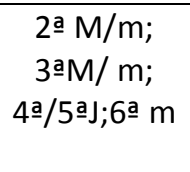 & $\begin{array}{l}\text { Uníssono; 3a } \\
\mathrm{M} / \mathrm{m} ; 4 \text { a/5a } \mathrm{J} ; \\
\text { 5a D; 6a } \mathrm{M} / \mathrm{m} ; \\
\text { 7a } \mathrm{D}\end{array}$ \\
\hline
\end{tabular}

Tema popular, arranjo de Villa-Lobos, com indicação de andamento Allegretto. A primeira frase se repete, com sextas paralelas na primeira semifrase, o mesmo acontecendo com a segunda frase, com terças paralelas. No restante, predomina na segunda voz, uma célula melódica com função harmônica, sobre a tríade da dominante arpejada resolvendo na tônica, alcançada na primeira vez por salto de sexta ascendente após a entrada da primeira voz. 
113) SOLFEJO $N^{\circ} 108$ - a capella

\begin{tabular}{|c|c|c|c|c|c|c|c|}
\hline Volume & № & Vozes & Extensão & Tessitura & Tonalidade & $\begin{array}{l}\text { Intervalos } \\
\text { melódicos }\end{array}$ & $\begin{array}{l}\text { Intervalos } \\
\text { harmônicos }\end{array}$ \\
\hline S1 & 108 & $\begin{array}{c}2 \\
\text { iguais }\end{array}$ & $\begin{array}{c}11 \text { ạ } \\
10 \text { compassos } \\
\text { quaternários }\end{array}$ & $\begin{array}{l}\text { 1a voz: C3-G4 } \\
\text { 2a voz: C3-G4 }\end{array}$ & $\begin{array}{l}\text { Modo de } \\
\text { C maior }\end{array}$ & 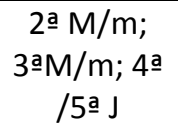 & 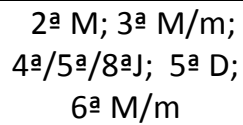 \\
\hline
\end{tabular}

Melodia de H. Villa-Lobos, com indicação de andamento Allegro Deciso ; de intensidade: Acentos >. Forma: A. O contraponto é de imitação perfeita até os três últimos compassos, onde há o encaminhamento para a resolução da peça na região aguda em terça. $\mathrm{O}$ tema apresenta como característica intervalos de quinta e oitava ascendentes com linha escalar descendente, na T e na D.

114) SOLFEJO $N^{\circ} 154$ / 162 - a capella

\begin{tabular}{|c|c|c|c|c|c|c|c|}
\hline Volume & № & Vozes & Extensão & Tessitura & Tonalidade & $\begin{array}{l}\text { Intervalos } \\
\text { melódicos }\end{array}$ & $\begin{array}{c}\text { Intervalos } \\
\text { harmônicos }\end{array}$ \\
\hline S1 & $\begin{array}{l}154 / \\
162\end{array}$ & $\begin{array}{c}2 \\
\text { iguais }\end{array}$ & $\begin{array}{c}13 \text { a } \\
8 \text { compassos } \\
\text { binários }\end{array}$ & $\begin{array}{l}\text { 19 voz: B2-E4 } \\
\text { 2ª voz: G2-A3 }\end{array}$ & $\begin{array}{l}\text { Modo de } \\
\text { D maior }\end{array}$ & $\begin{array}{c}\text { 2a } \mathrm{M} / \mathrm{m} ; \\
\text { 3a } \mathrm{M} / \mathrm{m} ; 4 \mathrm{a} / 5 \mathrm{a} / \\
\text { 8aj; 6a } \mathrm{a} / \mathrm{m}\end{array}$ & $\begin{array}{c}\text { Uníssono; 2a } \mathrm{M} ; 3^{\mathrm{a}} \\
\mathrm{M} / \mathrm{m} / \mathrm{D} ; 4 \text { 4 } / 5 \mathrm{a} a / 8 \mathrm{a} ; 6^{\mathrm{a}} \\
\mathrm{M} / \mathrm{m} ; 7^{\mathrm{a}} \mathrm{M} / \mathrm{m}\end{array}$ \\
\hline
\end{tabular}

Melodia de H. Villa-Lobos, com indicação de andamento Allegretto. Forma: A. Este solfejo é igual ao $\mathrm{n}^{\circ} 162$. A peça caracteriza-se por se iniciar com cromatismos e graus conjuntos e na segunda parte apresentar saltos e arpejos. A primeira voz apresenta o tetracorde superior da T em linha cromática descendente enquanto a segunda voz tem linha com cromatismo ascendente, em movimento contrário. Após linha escalar na primeira voz sobre notas rebatidas da segunda, a conclusão em oitava é alcançada por saltos.

115) SOLFEJO $\mathrm{N}^{\circ} 15$ (Vocalismo) - a capella

\begin{tabular}{|c|c|c|c|c|c|c|c|}
\hline Volume & № & Vozes & Extensão & Tessitura & $\begin{array}{c}\text { Tonalidad } \\
\mathrm{e}\end{array}$ & $\begin{array}{l}\text { Intervalos } \\
\text { melódicos }\end{array}$ & $\begin{array}{c}\text { Intervalos } \\
\text { harmônicos }\end{array}$ \\
\hline S2 & $\begin{array}{l}15 / \\
\text { P. } 7\end{array}$ & 2 & $\begin{array}{c}12^{\mathrm{a}} \\
16 \text { compassos } \\
\text { ternários }\end{array}$ & $\begin{array}{c}\text { 1a v.: D3-F\#4 } \\
\text { 2a v.:B2-B3 }\end{array}$ & $\begin{array}{l}\text { Modo de } \\
\text { A maior }\end{array}$ & 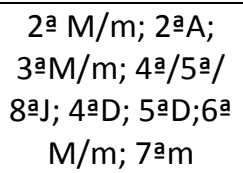 & 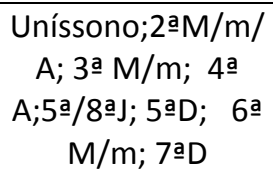 \\
\hline
\end{tabular}

Melodia de Villa-Lobos, com indicação de andamento Movimento de valsa, o contraponto, na segunda voz, apresenta movimento contrário e prioriza o intervalo harmônico de terças. $\mathrm{O}$ primeiro motivo reporta-se à canção "Lampião de gás". Os saltos de sexta e sétima merecem trabalho em separado.

116) SOLFEJO $\mathrm{N}^{\circ} 14$ (Vocalismo) - a capella

\begin{tabular}{|c|c|c|c|c|c|c|c|}
\hline Volume & № & Vozes & Extensão & Tessitura & Tonalidade & $\begin{array}{l}\text { Intervalos } \\
\text { melódicos }\end{array}$ & $\begin{array}{c}\text { Intervalos } \\
\text { harmônicos }\end{array}$ \\
\hline S2 & $\begin{array}{l}\text { 14/ } \\
\text { P. } 7\end{array}$ & 2 & $\begin{array}{c}11 \text { a } \\
16 \text { compassos } \\
\text { binários }\end{array}$ & $\begin{array}{l}1 \text { a v.: D3-E4 } \\
\text { 2a v.:G2-G3 }\end{array}$ & $\begin{array}{c}\text { Modo de G } \\
\text { maior }\end{array}$ & 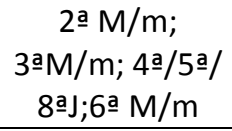 & 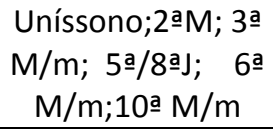 \\
\hline
\end{tabular}

Melodia de Villa-Lobos, caracterizada por terças quebradas, tem o contraponto desenvolvido em movimento contrário, parcialmente paralelo na segunda frase, priorizando terças e sextas harmônicas. A cadência final da primeira frase passa pela dominante da dominante resolvendo na D. A articulação em stacatto tem intenção timbrística. 
117) SOLFEJO $\mathrm{N}^{\circ} 90$ - a capella

\begin{tabular}{|c|c|c|c|c|c|c|c|}
\hline Volume & № & Vozes & Extensão & Tessitura & Tonalidade & $\begin{array}{l}\text { Intervalos } \\
\text { melódicos }\end{array}$ & $\begin{array}{c}\text { Intervalos } \\
\text { harmônicos }\end{array}$ \\
\hline S1 & 90 & 2 & $\begin{array}{c}18^{a} \\
8 \text { compassos } \\
\text { binários }\end{array}$ & $\begin{array}{l}\text { 1a v.:E3-F4 } \\
\text { 2a v.:C3-E4 }\end{array}$ & $\begin{array}{c}\text { Modo de } \mathrm{E} \\
\text { menor }\end{array}$ & $\begin{array}{c}\text { 2a/m;3ㅁ } \\
/ \mathrm{m} ; 4 \text { a } \mathrm{J}\end{array}$ & 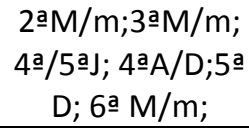 \\
\hline
\end{tabular}

Melodia de Villa-Lobos, com indicação Allegretto, apresentada na segunda voz, com o contraponto em ritmo mais movimentado na primeira voz. As alterações correspondem aos sexto e sétimo graus do modo menor, além de uma bordadura inferior cromática no primeiro compasso com alteração no segundo grau, e, na mesma nota em cromatismo ornamental no terceiro compasso. Terças e sextas harmônicas são recorrentes.

118) SOLFEJO $N^{\circ} 141$ - a capella

\begin{tabular}{|c|c|c|c|c|c|c|c|}
\hline Volume & № & Vozes & Extensão & Tessitura & Tonalidade & $\begin{array}{l}\text { Intervalos } \\
\text { melódicos }\end{array}$ & $\begin{array}{l}\text { Intervalos } \\
\text { harmônicos }\end{array}$ \\
\hline S1 & 141 & 2 & $\begin{array}{c}12^{a} \\
10 \text { compassos } \\
\text { binários }\end{array}$ & $\begin{array}{c}1 \text { a v.:B2-D4 } \\
\text { 2a v.:G\#2-B3 }\end{array}$ & $\begin{array}{l}\text { Modo de G } \\
\text { maior }\end{array}$ & 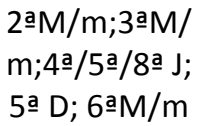 & 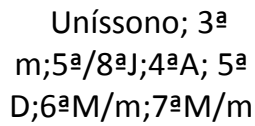 \\
\hline
\end{tabular}

Melodia de Villa-Lobos, com indicação Allegretto, com base no desenho rítmico inicial, no quinto grau por bordadura inferior seguida terças descendentes, o que se repete por sequência descendente por graus conjuntos duas vezes com a terminação com variação rítmica e da configuração melódica. O contraponto, na segunda voz, utiliza elementos rítmicos do motivo inicial da melodia e apresenta movimento contrário no começo e no final do solfejo. Intervalos melódicos de terças e sextas são recorrentes.

119) SOLFEJO $\mathrm{N}^{\circ} 104$ - a capella

\begin{tabular}{|c|c|c|c|c|c|c|c|}
\hline Volume & № & Vozes & Extensão & Tessitura & Tonalidade & $\begin{array}{l}\text { Intervalos } \\
\text { melódicos }\end{array}$ & $\begin{array}{l}\text { Intervalos } \\
\text { harmônicos }\end{array}$ \\
\hline S1 & 104 & $\begin{array}{c}2 \\
\text { iguais }\end{array}$ & $\begin{array}{c}11 \text { a } \\
7 \text { compassos } \\
\text { ternários }\end{array}$ & $\begin{array}{l}\text { 1a voz: E3-D4 } \\
\text { 2a voz: B2-G3 }\end{array}$ & $\begin{array}{l}\text { Modo de } \\
\text { C maior }\end{array}$ & $\begin{array}{c}\text { 2a } \mathrm{M} / \mathrm{m} ; \\
3 \text { a } \mathrm{M} / \mathrm{m} ; 4 \text { 의 }\end{array}$ & 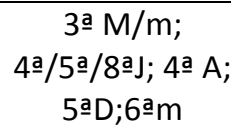 \\
\hline
\end{tabular}

Melodia de H. Villa-Lobos, com indicação de andamento Bem Lento; de intensidade: Acentos >. A primeira voz apresenta dois motivos em sequência por grau conjunto ascendente de terças menores descendentes por cromatismos, com terminação na terça da $\mathrm{T}$ por linha descendente. A segunda voz entra no segundo compasso com imitação à quinta descendente e termina na fundamental da $\mathrm{T}$.

120) SOLFEJO $N^{\circ} 119$ - a capella

\begin{tabular}{|c|c|c|c|c|c|c|c|}
\hline Volume & № & Vozes & Extensão & Tessitura & Tonalidade & $\begin{array}{l}\text { Intervalos } \\
\text { melódicos }\end{array}$ & $\begin{array}{c}\text { Intervalos } \\
\text { harmônicos }\end{array}$ \\
\hline S1 & 119 & $\begin{array}{c}2 \\
\text { iguais }\end{array}$ & $\begin{array}{c}10^{\mathrm{a}} \\
7 \text { compassos } \\
\text { quaternários }\end{array}$ & $\begin{array}{l}\text { 1a voz: C3-F4 } \\
\text { 2a voz: D3-F4 }\end{array}$ & $\begin{array}{l}\text { Modo de } \\
\text { F maior }\end{array}$ & 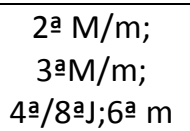 & 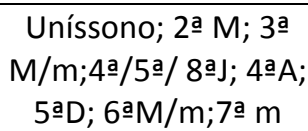 \\
\hline
\end{tabular}

Melodia de H. Villa-Lobos, sem indicação de andamento. Melodia em plano descendente com graus conjuntos na primeira frase e saltos na segunda. $\mathrm{O}$ contraponto, na segunda voz, em 
movimento contrário, apresenta cruzamento de vozes ao final. As alterações são estruturais e os cromatismos e saltos devem ser trabalhados.

121) SOLFEJO $\mathrm{N}^{\circ} 138$ - a capella

\begin{tabular}{|c|c|c|c|c|c|c|c|}
\hline Volume & № & Vozes & Extensão & Tessitura & Tonalidade & $\begin{array}{l}\text { Intervalos } \\
\text { melódicos }\end{array}$ & $\begin{array}{l}\text { Intervalos } \\
\text { harmônicos }\end{array}$ \\
\hline S1 & 138 & 2 & $\begin{array}{c}\text { 9a } \\
5 \text { compassos } \\
\text { quaternários }\end{array}$ & $\begin{array}{c}\text { 1a v.:F3-F4 } \\
\text { 2a v.:C3-Bb3 }\end{array}$ & $\begin{array}{l}\text { Modo de } F \\
\text { maior }\end{array}$ & $\begin{array}{c}\text { 2a } \mathrm{M} / \mathrm{m} ; 3^{\mathrm{a}} \\
\mathrm{M} / \mathrm{m} ; 4^{\mathrm{a}} / 5^{\mathrm{a}} \\
\mathrm{J} ; 6 \mathrm{6} \mathrm{M} / \mathrm{m}\end{array}$ & $\begin{array}{c}3 \mathrm{a} m ; 5^{\mathrm{a}} / 8^{\mathrm{a} J} \\
6 \mathrm{a} M / \mathrm{m} ; 7^{\mathrm{a}} \mathrm{m}\end{array}$ \\
\hline
\end{tabular}

Melodia de Villa-Lobos, com indicação de andamento Lento (Dengoso) e ostinato rítmico. A primeira voz inicia e termina em âmbito do pentacorde da $\mathrm{T}$, pela terça menor ascendente. As síncopas aparecem sempre em contratempo, precedidas de pausas. O contraponto, na segunda voz, propõe um ostinato na primeira frase, por tetracorde descendente com ritmos pontuados, variando na segunda frase com síncopas e tercina em linhas descendentes de hexa e tetracorde. No compasso 3, há polirritmia de $2 \times 3$.

122) SOLFEJO $\mathrm{N}^{\circ} 151$ - a capella

\begin{tabular}{|c|c|c|c|c|c|c|c|}
\hline Volume & № & Vozes & Extensão & Tessitura & Tonalidade & $\begin{array}{l}\text { Intervalos } \\
\text { melódicos }\end{array}$ & $\begin{array}{c}\text { Intervalos } \\
\text { harmônicos }\end{array}$ \\
\hline S1 & 151 & 2 & $\begin{array}{c}\text { 9ạ } \\
4 \text { compassos } \\
\text { quaternários }\end{array}$ & $\begin{array}{l}1^{\mathrm{a}} \text { v.:F\#3-D4 } \\
2^{\mathrm{a}} \text { v.:C\#3-G3 }\end{array}$ & $\begin{array}{l}\text { Modo de D } \\
\text { maior }\end{array}$ & $\begin{array}{l}\text { 2aM/m;3a } \\
\mathrm{M} / \mathrm{m} ; 4^{\mathrm{a}} \mathrm{J}\end{array}$ & 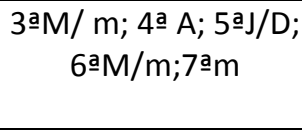 \\
\hline
\end{tabular}

Melodia de Villa-Lobos, com indicação de andamento Andante, iniciada pelo arpejo da tríade invertida, segue em desenhos com finalização em notas longas em linha descendente, por sequência de bordaduras inferiores com resolução por tetracorde no terceiro grau. $\mathrm{O}$ contraponto prioriza intervalos harmônicos de terças e sextas, utilizando elementos rítmicos apresentados na melodia.

123) SOLFEJO $N^{\circ} 155$ - a capella

\begin{tabular}{|c|c|c|c|c|c|c|c|}
\hline Volume & № & Vozes & Extensão & Tessitura & Tonalidade & $\begin{array}{l}\text { Intervalos } \\
\text { melódicos }\end{array}$ & $\begin{array}{c}\text { Intervalos } \\
\text { harmônicos }\end{array}$ \\
\hline S1 & 155 & 2 & $\begin{array}{c}11 \text { a } \\
4 \text { compassos } \\
\text { binários }\end{array}$ & $\begin{array}{l}\text { 1a v.:C3-C4 } \\
\text { 2a v.:G2-A3 }\end{array}$ & $\begin{array}{c}\text { Modo de C } \\
\text { maior }\end{array}$ & 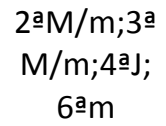 & $\begin{array}{c}\text { Uníssono;3a } \mathrm{M} / \mathrm{m} ; \\
4 \underline{\mathrm{a}} / 5 \mathrm{a} \mathrm{J}\end{array}$ \\
\hline
\end{tabular}

Melodia de Villa-Lobos, com indicação de andamento Allegretto (Gênero Popular), com motivo rítmico inicial prevalecendo em toda a frase. $O$ contraponto define as funções harmônicas e desenvolve o movimento de terças paralelas, exceto as duas últimas notas.

124) SOLFEJO $N^{\circ} 145$ - a capella

\begin{tabular}{|c|c|c|c|c|c|c|c|}
\hline Volume & № & Vozes & Extensão & Tessitura & Tonalidade & $\begin{array}{l}\text { Intervalos } \\
\text { melódicos }\end{array}$ & $\begin{array}{l}\text { Intervalos } \\
\text { harmônicos }\end{array}$ \\
\hline S1 & 145 & 2 & $\begin{array}{c}11 \mathfrak{a} \\
9 \text { compassos } \\
\text { quaternários }\end{array}$ & $\begin{array}{l}1 \text { a v.:F3-F4 } \\
\text { 2a v.:C3-C4 }\end{array}$ & $\begin{array}{l}\text { Modo de } F \\
\text { maior }\end{array}$ & $\begin{array}{c}\text { 2a } \mathrm{M} / \mathrm{m} ; 3 \text { a } \mathrm{M} \\
/ \mathrm{m} ; 4 \text { aj; }\end{array}$ & 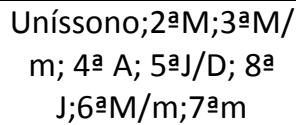 \\
\hline
\end{tabular}

Melodia de Villa-Lobos com indicação Allegretto, iniciada por arpejo da $\mathrm{T}$ com notas de passagem para a oitava superior, seguida de linha escalar descendente. Na segunda frase, 
apresenta alteração $(\boldsymbol{B}$ G) que caracteriza a DD. Na segunda frase, após pentacorde descendente a terminação apresenta linha escalar ascendente do primeiro ao oitavo grau. $\mathrm{O}$ contraponto, na segunda voz, apresenta na primeira frase alteração $(\boldsymbol{G \# )}$ que caracteriza bordadura cromática inferior, ou D da Dr. Há movimento contrário entre as vozes, com a finalização em linha escalar com terças paralelas, terminando em sexta.

125) SOLFEJO $\mathrm{N}^{\circ} 116$ - a capella

\begin{tabular}{|c|c|c|c|c|c|c|c|}
\hline Volume & № & Vozes & Extensão & Tessitura & Tonalidade & $\begin{array}{l}\text { Intervalos } \\
\text { melódicos }\end{array}$ & $\begin{array}{c}\text { Intervalos } \\
\text { harmônicos }\end{array}$ \\
\hline S1 & 116 & 2 & $\begin{array}{c}11^{\text {a }} \\
8 \text { compassos } \\
\text { binários }\end{array}$ & $\begin{array}{l}1 \text { a v.:D3-E4 } \\
\text { 2a v.:B2-G3 }\end{array}$ & $\begin{array}{c}\text { Modo de G } \\
\text { maior }\end{array}$ & $\begin{array}{l}\text { 2aM/m;3a } \\
\text { m; 5aD; } \\
\text { 6M }\end{array}$ & 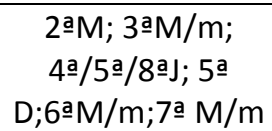 \\
\hline
\end{tabular}

Melodia de Villa-Lobos, com indicação de andamento Allegro, com a segunda frase repetindo a primeira ornamentada com apojaturas. Entre as frases há uma pequena linha em hexacorde ascendente em subdivisão ternária, como elemento de ligação, provocando uma polirritmia de $3 \times 2$ em cada pulso. O contraponto, na segunda voz, desenvolve uma linha escalar descendente, com um cromatismo ornamental ascendente ao final das frases. $\mathrm{Na}$ segunda frase, acompanhando as mudanças rítmicas da melodia, a linha do contraponto apresenta figuras pontuadas. Há recorrência dos intervalos harmônicos de terças e sextas.

126) SOLFEJO $\mathrm{N}^{\circ} 13$ (Vocalismo) - a capella

\begin{tabular}{|c|c|c|c|c|c|c|c|}
\hline Volume & № & Vozes & Extensão & Tessitura & Tonalidade & $\begin{array}{l}\text { Intervalos } \\
\text { melódicos }\end{array}$ & $\begin{array}{l}\text { Intervalos } \\
\text { harmônicos }\end{array}$ \\
\hline S2 & $\begin{array}{l}13 / \\
\text { P. } 7\end{array}$ & 2 & $\begin{array}{c}11 \underline{a} \\
13 \text { compassos } \\
\text { binários }\end{array}$ & $\begin{array}{l}\text { 1a v.: D3-D4 } \\
\text { 2a v.:A2-D3 }\end{array}$ & $\begin{array}{l}\text { Modo de } \mathrm{G} \\
\text { maior }\end{array}$ & $\begin{array}{c}\text { 2a } \mathrm{M} / \mathrm{m} ; \\
\text { 3a } \mathrm{a} / \mathrm{m} ; 4 \text { a } / 8 \text { a }\end{array}$ & $\begin{array}{c}\text { Uníssono;2a } \mathrm{M} ; 3^{\mathrm{a}} \\
\mathrm{M} / \mathrm{m} ; 5^{\mathrm{a}} / 8^{\mathrm{a}} \mathrm{j} ; 6^{\mathrm{a}} \\
\mathrm{M} / \mathrm{m}\end{array}$ \\
\hline
\end{tabular}

Melodia de Villa-Lobos com base em linhas escalares - oitava descendente na primeira frase e na segunda (com ritornello): ascendente, com pentacordes iniciados no quinto e no primeiro graus, e hexatônica descendente ao final. Contraponto em terças paralelas na primeira frase e na segunda, terças e sextas paralelas, com finalizações antecedidas de quintas.

127) SOLFEJO $N^{\circ} 158$ - a capella

\begin{tabular}{|c|c|c|c|c|c|c|c|}
\hline Volume & № & Vozes & Extensão & Tessitura & Tonalidade & $\begin{array}{l}\text { Intervalos } \\
\text { melódicos }\end{array}$ & $\begin{array}{l}\text { Intervalos } \\
\text { harmônicos }\end{array}$ \\
\hline S1 & 158 & 2 & $\begin{array}{c}11 \text { ạ } \\
5 \text { compassos } \\
\text { quaternários }\end{array}$ & $\begin{array}{l}\text { 1a v.:Eb3-Eb4 } \\
\text { 2a v.:G2-Ab3 }\end{array}$ & $\begin{array}{l}\text { Modo de } \\
\text { Eb maior }\end{array}$ & $\begin{array}{l}2 \mathrm{a} M / \mathrm{m} ; 3^{\mathrm{a}} \mathrm{M} / \\
\mathrm{m} ; 4^{\mathrm{a}} / 5^{\mathrm{a}} / 8^{\mathrm{a}} \mathrm{J}\end{array}$ & 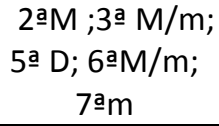 \\
\hline
\end{tabular}

Melodia de Villa-Lobos com indicação de andamento Religioso (Adagio), tendo o início em âmbito de tetracorde da $\mathrm{T}$, com resposta oitava acima em desenho invertido e linha descendente para a T. O contraponto, na segunda voz, enfatiza intervalos harmônicos de terças e sextas. 
128) SOLFEJO $\mathrm{N}^{\circ} 68$ - a capella

\begin{tabular}{|c|c|c|c|c|c|c|c|}
\hline Volume & № & Vozes & Extensão & Tessitura & Tonalidade & $\begin{array}{l}\text { Intervalos } \\
\text { melódicos }\end{array}$ & Intervalos harmônicos \\
\hline S1 & 68 & 2 & $\begin{array}{c}13^{a} \\
8 \text { compassos } \\
\text { binários }\end{array}$ & $\begin{array}{c}\text { 19 v.: Bb2-E4 } \\
\text { 2a v.:G2-A3 }\end{array}$ & $\begin{array}{l}\text { Modo de A } \\
\text { menor }\end{array}$ & 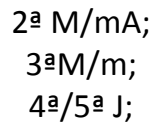 & 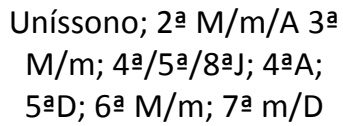 \\
\hline
\end{tabular}

Melodia de Villa-Lobos com indicação de andamento Andantino. O compasso correto deve ser binário de subdivisão ternária e não dois por quatro, como consta. $O$ contraponto na segunda voz é uma linha escalar descendente na primeira frase, com a segunda frase pontuada por salto ascendente e descendente de quinta. Nos compassos 3, 6 e 7 o contraponto apresenta polirritmia de $3 \times 2$.

129) SOLFEJO $\mathrm{N}^{\circ} 83$ - a capella

\begin{tabular}{|c|c|c|c|c|c|c|c|}
\hline Volume & № & Vozes & Extensão & Tessitura & Tonalidade & $\begin{array}{l}\text { Intervalos } \\
\text { melódicos }\end{array}$ & $\begin{array}{c}\text { Intervalos } \\
\text { harmônicos }\end{array}$ \\
\hline S1 & 83 & 2 & $\begin{array}{c}9 \underline{a} \\
8 \text { compassos } \\
\text { binários (subdivisão } \\
\text { ternária) }\end{array}$ & $\begin{array}{l}\text { 1a v.:D3-D4 } \\
\text { 2a v.:G2-G3 }\end{array}$ & $\begin{array}{l}\text { Modo de } \\
\text { F/G maior }\end{array}$ & 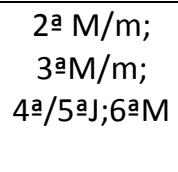 & 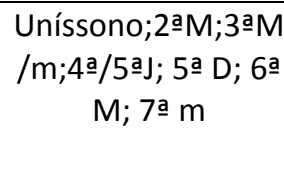 \\
\hline
\end{tabular}

Melodia de Villa-Lobos, com indicação de andamento Tempo de Barcarolla, com a primeira parte em $\boldsymbol{F}$ maior e a segunda em $\boldsymbol{G}$ maior. O contraponto, na segunda voz, enfatiza o quinto grau, recorrente em todos os compassos na primeira parte. Na segunda parte há uma modulação para $\boldsymbol{G}$ maior, com movimento contrário entre as vozes.

130) SOLFEJO $\mathbf{N}^{\circ} 156$ - a capella

\begin{tabular}{|c|c|c|c|c|c|c|c|}
\hline Volume & № & Vozes & Extensão & Tessitura & Tonalidade & $\begin{array}{l}\text { Intervalos } \\
\text { melódicos }\end{array}$ & $\begin{array}{c}\text { Intervalos } \\
\text { harmônicos }\end{array}$ \\
\hline S1 & 156 & 2 & $\begin{array}{c}11 \text { a } \\
10 \text { compassos } \\
\text { ternários }\end{array}$ & $\begin{array}{l}\text { 1ㅁ v.:G3-Eb4 } \\
\text { 2a v.:G2-Bb3 }\end{array}$ & $\begin{array}{l}\text { Modo de G } \\
\text { menor }\end{array}$ & $\begin{array}{c}\text { 2a } \mathrm{M} / \mathrm{m} ; 3 \mathrm{a} \\
\mathrm{M} / \mathrm{m} ; 4 \mathrm{a}) \\
\text { 6а }\end{array}$ & 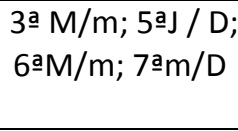 \\
\hline
\end{tabular}

Análise parcial em $2.1-n^{\circ} 65$.

Melodia de Villa-Lobos, com indicação de andamento Valsa Brasileira, caracterizada por linha descendente hexatônica em notas rebatidas e intervalos de terças, com finalização na tônica. O contraponto, na segunda voz, priorizando terças e sextas harmônicas, acompanha a melodia com movimento direto. Apresenta alterações $(\boldsymbol{F \#})$ que caracterizam a dominante do modo menor.

131) SOLFEJO $\mathrm{N}^{\circ} 4$ (Vocalismo) - Natal - a capella

\begin{tabular}{|c|c|c|c|c|c|c|c|}
\hline Volume & № & Vozes & Extensão & Tessitura & Tonalidade & $\begin{array}{l}\text { Intervalos } \\
\text { melódicos }\end{array}$ & $\begin{array}{c}\text { Intervalos } \\
\text { harmônicos }\end{array}$ \\
\hline S2 & 4 & $\begin{array}{c}2 \\
\text { iguais }\end{array}$ & $\begin{array}{c}13^{a} \\
9 \text { compassos binários } \\
\text { (subdivisão ternária) }\end{array}$ & $\begin{array}{l}\text { 1a voz: C3-D4 } \\
\text { 2a voz: F2-A3 }\end{array}$ & $\begin{array}{l}\text { Modo de } \mathrm{F} \\
\text { maior }\end{array}$ & 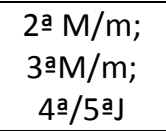 & 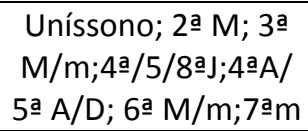 \\
\hline
\end{tabular}

Tema de G. Fernandez com arranjo de H. Villa-Lobos. Indicação de andamento Allegro ma non tropo. Forma: A. O contraponto, na segunda voz, privilegia terças e sextas, bem como caracteriza as dominantes secundárias e a condução para a terminação D/T. 
132) SOLFEJO $\mathrm{N}^{\circ} 71$ - a capella

\begin{tabular}{|c|c|c|c|c|c|c|c|}
\hline Volume & № & Vozes & Extensão & Tessitura & $\begin{array}{c}\text { Tonalidad } \\
\mathrm{e}\end{array}$ & $\begin{array}{l}\text { Intervalos } \\
\text { melódicos }\end{array}$ & $\begin{array}{l}\text { Intervalos } \\
\text { harmônicos }\end{array}$ \\
\hline S1 & 71 & 2 & $\begin{array}{c}10^{a} \\
4 \text { compassos } \\
\text { ternários } \\
\text { (subdivisão ternária) }\end{array}$ & $\begin{array}{l}1 \text { a v.:Db3-Db4 } \\
\text { 2a v.:Ab2-Ab3 }\end{array}$ & $\begin{array}{l}\text { Modo de } \\
\text { Ab maior }\end{array}$ & $\begin{array}{c}\text { 2a M/mA; } \\
\text { 3aM/m; 4a J }\end{array}$ & 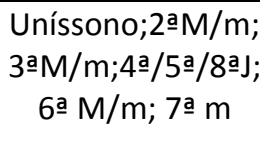 \\
\hline
\end{tabular}

A pequena melodia, em linhas descendentes por graus conjuntos, com indicação de andamento Andante apresenta o terceiro compasso da primeira voz incompleto, faltando uma pulsação. Seguindo-se o raciocínio do contraponto da segunda voz, a primeira nota poderia estar ligada a uma colcheia na mesma altura, sendo que as outras duas colcheias poderiam, entre outras opções, ser $\boldsymbol{E} \boldsymbol{b} 4$ e $\boldsymbol{D} \boldsymbol{b} 4$. O contraponto na segunda voz é estabelecido a partir de notas mais longas, contrastando com as colcheias da primeira voz, procedimento invertido no meio da peça.

133) SOLFEJO No 2 (Vocalismo) - a capella

\begin{tabular}{|c|c|c|c|c|c|c|c|}
\hline Volume & № & Vozes & Extensão & Tessitura & Tonalidade & $\begin{array}{l}\text { Intervalos } \\
\text { melódicos }\end{array}$ & $\begin{array}{l}\text { Intervalos } \\
\text { harmônicos }\end{array}$ \\
\hline S2 & $\begin{array}{l}\text { 2/ } \\
\text { p. } \\
3\end{array}$ & 2 & $\begin{array}{c}11^{\mathrm{a}} \\
12 \text { compassos } \\
\text { binários }\end{array}$ & $\begin{array}{l}\text { 1a v.: E3-C4 } \\
\text { 2a v.: G2-F3 }\end{array}$ & $\begin{array}{l}\text { Modo de C } \\
\text { maior }\end{array}$ & 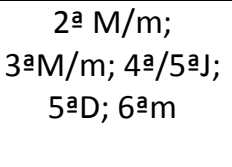 & 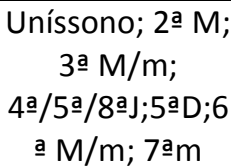 \\
\hline
\end{tabular}

Desafio, gênero popular, andamento Allegro, o contraponto é iniciado com imitação da primeira célula rítmica na primeira frase e desenvolve terças paralelas em seguida, principalmente na segunda frase, procedimento característico dessa forma tradicional brasileira. As notas rebatidas e a pequena extensão são elementos para uma fácil execução do solfejo.

134) SOLFEJO $\mathrm{N}^{\circ} 10$ (Vocalismo) - a capella

\begin{tabular}{|c|c|c|c|c|c|c|c|}
\hline Volume & № & Vozes & Extensão & Tessitura & Tonalidade & $\begin{array}{l}\text { Intervalos } \\
\text { melódicos }\end{array}$ & $\begin{array}{c}\text { Intervalos } \\
\text { harmônicos }\end{array}$ \\
\hline S2 & $\begin{array}{l}10 / \\
\text { P. } 6\end{array}$ & 2 & $\begin{array}{c}11 \text { a } \\
8 \text { compassos } \\
\text { binários (subdivisão } \\
\text { ternária) }\end{array}$ & $\begin{array}{c}\text { 19 v.: D3-F4 } \\
\text { 2a v.: C3- } \\
\text { Bb3 }\end{array}$ & $\begin{array}{l}\text { Modo de } \mathrm{F} \\
\text { maior }\end{array}$ & 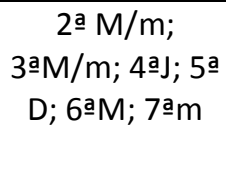 & 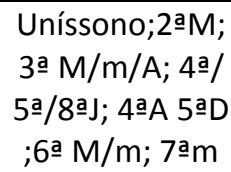 \\
\hline
\end{tabular}

Tema de Villa-Lobos, em compasso binário de subdivisão ternária. O desenho melódico do primeiro compasso é repetido em sequência no quinto compasso, início da segunda frase e imitado na segunda voz no sexto compasso. Predominam intervalos melódicos de sextas e na terminação é empregada a função de T mediante.

135) SOLFEJO $\mathrm{N}^{\circ} 82$ - a capella

\begin{tabular}{|c|c|c|c|c|c|c|c|}
\hline Volume & № & Vozes & Extensão & Tessitura & Tonalidade & $\begin{array}{l}\text { Intervalos } \\
\text { melódicos }\end{array}$ & $\begin{array}{c}\text { Intervalos } \\
\text { harmônicos }\end{array}$ \\
\hline S1 & 82 & 2 & $\begin{array}{c}\text { 9ạ } \\
8 \text { compassos } \\
\text { ternários } \\
\text { (subdivisão ternária) }\end{array}$ & $\begin{array}{l}\text { 1a v.:E3-E4 } \\
\text { 2a v.:D3-E4 }\end{array}$ & $\begin{array}{c}\text { Modo de G } \\
\text { maior }\end{array}$ & 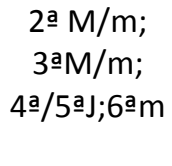 & 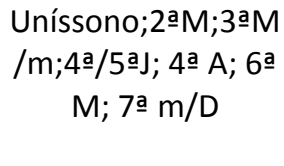 \\
\hline
\end{tabular}

Melodia de Villa-Lobos, com indicação de andamento Allegretto Moderato, com imitação rítmica no contraponto da segunda voz, que apresenta em seu primeiro compasso e 
antepenúltimo, alterações cromáticas ornamentais. As vozes se cruzam a partir da segunda parte da peça, onde aparecem terças e sextas harmônicas de forma recorrente.

136) SOLFEJO $\mathrm{N}^{\circ} 96$ - a capella

\begin{tabular}{|c|c|c|c|c|c|c|c|}
\hline Volume & № & Vozes & Extensão & Tessitura & Tonalidade & $\begin{array}{l}\text { Intervalos } \\
\text { melódicos }\end{array}$ & $\begin{array}{c}\text { Intervalos } \\
\text { harmônicos }\end{array}$ \\
\hline S1 & 96 & $\begin{array}{c}2 \\
\text { iguais }\end{array}$ & $\begin{array}{c}10 \text { a } \\
8 \text { compassos } \\
\text { ternários }\end{array}$ & $\begin{array}{c}\text { 1a voz: E3-E4 } \\
\text { 2a voz: C\#3-E4 }\end{array}$ & $\begin{array}{l}\text { Modo de } \\
\text { E menor }\end{array}$ & $\begin{array}{c}2 \mathrm{a} M / m ; 3^{\mathrm{a}} \mathrm{M} / \mathrm{m} ; \\
4 \mathrm{a} j ; 6 \mathrm{~m}\end{array}$ & $\begin{array}{c}\text { 3a M/m; 4a/5aj; } \\
\text { 4a/5a D ; 6a M/m; } \\
\text { 7am }\end{array}$ \\
\hline
\end{tabular}

Melodia de H. Villa-Lobos, com indicação de andamento Andantino. O contraponto, na segunda voz, prioriza sextas e terças paralelas. Ambas as vozes iniciam em suas notas mais agudas e terminam oitava abaixo.

137) SOLFEJO $\mathbf{N}^{\circ} 159$ - a capella

\begin{tabular}{|c|c|c|c|c|c|c|c|}
\hline Volume & № & Vozes & Extensão & Tessitura & Tonalidade & $\begin{array}{l}\text { Intervalos } \\
\text { melódicos }\end{array}$ & $\begin{array}{c}\text { Intervalos } \\
\text { harmônicos }\end{array}$ \\
\hline S1 & 159 & $\begin{array}{c}2 \\
\text { iguais }\end{array}$ & $\begin{array}{c}13 \text { a } \\
6 \text { compassos } \\
\text { quaternários }\end{array}$ & $\begin{array}{c}\text { 1a voz: Ab3-F4 } \\
\text { 2a voz: Ab2-Ab3 }\end{array}$ & $\begin{array}{l}\text { Modo de } A b \\
\text { maior }\end{array}$ & 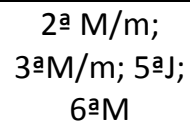 & 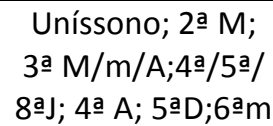 \\
\hline
\end{tabular}

Melodia de H. Villa-Lobos, com recorrência na $\mathrm{T}$ - a cada dois compassos, com indicação de andamento Andante. Forma: A. O contraponto, na segunda voz, é apresentado em movimento contrário, com alterações estruturais, caracterizando dominantes secundárias e, ao final apojatura da $\mathrm{T}$ mediante/D com resolução quinta abaixo na $\mathrm{T}$.

138) SOLFEJO $N^{\circ} 132$ - a capella

\begin{tabular}{|c|c|c|c|c|c|c|c|}
\hline Volume & № & Vozes & Extensão & Tessitura & Tonalidade & $\begin{array}{l}\text { Intervalos } \\
\text { melódicos }\end{array}$ & $\begin{array}{c}\text { Intervalos } \\
\text { harmônicos }\end{array}$ \\
\hline S1 & 132 & 2 & $\begin{array}{c}13^{a} \\
8 \text { compassos } \\
\text { binários }\end{array}$ & $\begin{array}{l}1 \text { a v.:F3-E4 } \\
\text { 2a v.:C2-C3 }\end{array}$ & $\begin{array}{c}\text { Modo de G } \\
\text { maior }\end{array}$ & $\begin{array}{c}2 \mathrm{a} M / \mathrm{m} ; 3^{\mathrm{a}} \\
\mathrm{m} ; 4 \mathrm{a} / 5^{\mathrm{a}} \mathrm{J} \\
6 \mathrm{a} \mathrm{M} / \mathrm{m}\end{array}$ & 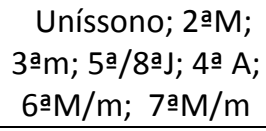 \\
\hline
\end{tabular}

Análise parcial em $2.1-n^{\circ} 73$.

Melodia de Villa-Lobos, com indicação de andamento Andantino, para vozes mistas. A primeira voz explora uma única região de altura em âmbito de sétima, nas duas frases, mantendo simetria na configuração rítmica na primeira. $O$ contraponto, na segunda voz, desenvolve uma linha ascendente do primeiro ao oitavo grau na primeira frase, atendo-se ao pentacorde de T na segunda. Os intervalos de terças e sextas são recorrentes, e a terminação está em intervalo de quinta.

139) SOLFEJO $\mathrm{N}^{\circ} 91$ - a capella

\begin{tabular}{|c|c|c|c|c|c|c|c|}
\hline Volume & № & Vozes & Extensão & Tessitura & Tonalidade & $\begin{array}{l}\text { Intervalos } \\
\text { melódicos }\end{array}$ & $\begin{array}{c}\text { Intervalos } \\
\text { harmônicos }\end{array}$ \\
\hline S1 & 91 & 2 & $\begin{array}{c}19 \underline{a} \\
6 \text { compassos } \\
\text { quaternários }\end{array}$ & $\begin{array}{l}1 \text { a v.:C3-E4 } \\
\text { 2a v.:A1-C3 }\end{array}$ & $\begin{array}{l}\text { Modo de C } \\
\text { maior }\end{array}$ & $\begin{array}{l}\text { 2a } \mathrm{M} / \mathrm{m} ; 4^{\mathrm{a}} / 5^{\mathrm{a}} \mathrm{J} \\
/ 6^{\mathrm{a}} \mathrm{M} / \mathrm{m} / 7^{\mathrm{a}} \mathrm{M}\end{array}$ & $\begin{array}{c}\text { Uníssono;2a } \mathrm{M} / \mathrm{m} ; 3^{a} \\
\mathrm{M} / \mathrm{m} ; 4 \text { a } / 5 \text { a } / 8 \text { a J; } 5 \text { a } \\
\text { D; 6ㅁ } \mathrm{M} / \mathrm{m} ; 7 \underline{\text { a }} \mathrm{m}\end{array}$ \\
\hline
\end{tabular}

Melodia de Villa-Lobos, com indicação de andamento Allegretto, em linha escalar ascendente em âmbito de décima, com resolução descendente por tetracorde permeado de saltos de sétima, sexta, quinta e quarta para a T. Para vozes mistas, o contraponto tem linha escalar em 
movimento contrário, na mesma proporção, com a resolução ascendente por graus conjuntos até a T. Exercício adequado para a aquisição do conceito de escala.

140) SOLFEJO $\mathrm{N}^{\circ} 94$ - a capella

\begin{tabular}{|c|c|c|c|c|c|c|c|}
\hline Volume & № & Vozes & Extensão & Tessitura & Tonalidade & $\begin{array}{l}\text { Intervalos } \\
\text { melódicos }\end{array}$ & $\begin{array}{c}\text { Intervalos } \\
\text { harmônicos }\end{array}$ \\
\hline S1 & 94 & 2 & $\begin{array}{c}15^{a} \\
8 \text { compassos } \\
\text { ternários }\end{array}$ & $\begin{array}{l}\text { 1ㅁ v.:D3-D4 } \\
\text { 2a v.:D2-D3 }\end{array}$ & $\begin{array}{l}\text { Modo de G } \\
\text { maior }\end{array}$ & $\begin{array}{c}2^{\mathrm{a}} \mathrm{M} / \mathrm{m} ; 4^{\mathrm{a}} / 5^{\mathrm{a}} \mathrm{j} \\
5 \text { 5 }^{\mathrm{a}} \mathrm{D}\end{array}$ & 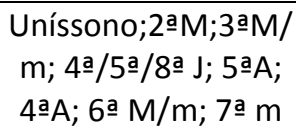 \\
\hline
\end{tabular}

Melodia de Villa-Lobos, em Tempo de Mazurka Moderato, para vozes mistas. O desenho inicial, repetido por sequência descendente por grau conjunto, é repetido na segunda frase de forma invertida, em sequência ascendente. As alterações são cromáticas ornamentais. $\mathrm{O}$ contraponto, em semínimas, tem a função de marcar o ritmo da mazurca.

141) SOLFEJO $\mathbf{N}^{\circ} 125$ - a capella

\begin{tabular}{|c|c|c|c|c|c|c|c|}
\hline Volume & № & Vozes & Extensão & Tessitura & Tonalidade & $\begin{array}{l}\text { Intervalos } \\
\text { melódicos }\end{array}$ & $\begin{array}{c}\text { Intervalos } \\
\text { harmônicos }\end{array}$ \\
\hline S1 & 125 & 2 & $\begin{array}{c}15 \text { a } \\
19 \text { compassos } \\
\text { ternários } \\
\end{array}$ & $\begin{array}{c}\text { 1a v.:G3-Eb4 } \\
\text { 2a v.:E2-D3 }\end{array}$ & $\begin{array}{l}\text { Modo de G } \\
\text { menor }\end{array}$ & 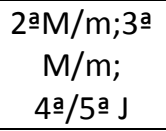 & 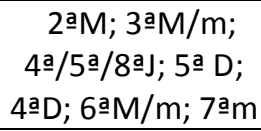 \\
\hline
\end{tabular}

Melodia de Villa-Lobos, com indicação de andamento Andante, com alterações nos sexto e sétimo graus, configurando o modo menor. A peça contém duas frases idênticas, exceto o último compasso - na D na primeira vez e na tônica na segunda vez. O contraponto, na segunda voz, tem ritmo independente e prioriza intervalos melódicos de terças e sextas.

142) SOLFEJO $N^{\circ} 101$ - a capella

\begin{tabular}{|c|c|c|c|c|c|c|c|}
\hline Volume & № & Vozes & Extensão & Tessitura & Tonalidade & $\begin{array}{l}\text { Intervalos } \\
\text { melódicos }\end{array}$ & $\begin{array}{c}\text { Intervalos } \\
\text { harmônicos }\end{array}$ \\
\hline S1 & 101 & 2 & $\begin{array}{c}16 \text { a } \\
8 \text { compassos } \\
\text { binários }\end{array}$ & $\begin{array}{l}1 \text { a v.:D3-E4 } \\
\text { 2a v.:D2-E3 }\end{array}$ & $\begin{array}{l}\text { Modo de G } \\
\text { maior }\end{array}$ & 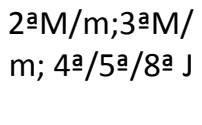 & 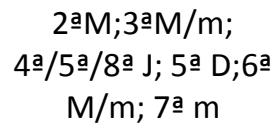 \\
\hline
\end{tabular}

Melodia de Villa-Lobos, com indicação de andamento Vagaroso, para vozes mistas. Sobre notas rebatidas e ritmo contínuo de semicolcheias na primeira frase, a segunda frase responde com um ostinato rítmico em contratempo e síncopa, com o desenho em sequência descendente por grau conjunto. O contraponto marca as pulsações em terças quebradas descendentes na primeira frase e com ritmos pontuados apresenta tríades (D / Dr / D) arpejadas descendentemente, por sequências descendentes por grau conjunto. A finalização, em terças paralelas apresenta apojatura de quarta e sexta/terça e quinta.

143) SOLFEJO N 126 - a capella

\begin{tabular}{|c|c|c|c|c|c|c|c|}
\hline Volume & № & Vozes & Extensão & Tessitura & Tonalidade & $\begin{array}{l}\text { Intervalos } \\
\text { melódicos }\end{array}$ & $\begin{array}{c}\text { Intervalos } \\
\text { harmônicos }\end{array}$ \\
\hline S1 & 126 & 2 & $\begin{array}{c}\text { 9ạ } \\
8 \text { compassos } \\
\text { binários }\end{array}$ & $\begin{array}{c}\text { 1a v.:G3-Eb4 } \\
\text { 2a v.:D2-D3 }\end{array}$ & $\begin{array}{c}\text { Modo de G } \\
\text { menor }\end{array}$ & 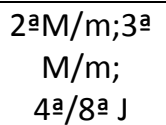 & 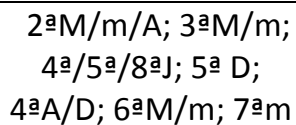 \\
\hline
\end{tabular}

Melodia de Villa-Lobos, com indicação de andamento Moderato, para vozes mistas, baseada em ritmo sincopado. Os dois primeiros compassos da primeira frase são imitados à quinta no contraponto da segunda voz. O contraponto apresenta alterações no sexto e sétimo graus, configurando o modo menor, enquanto a primeira voz utiliza alteração cromática ornamental 
(C\#) nos dois primeiros compassos. As recorrências dos desenhos e a extensão confortável paras ambas as vozes tornam o solfejo acessível.

144) SOLFEJO $\mathrm{N}^{\circ} 97$ - a capella

\begin{tabular}{|c|c|c|c|c|c|c|c|}
\hline Volume & № & Vozes & Extensão & Tessitura & Tonalidade & $\begin{array}{l}\text { Intervalos } \\
\text { melódicos }\end{array}$ & $\begin{array}{c}\text { Intervalos } \\
\text { harmônicos }\end{array}$ \\
\hline S1 & 97 & 2 & $\begin{array}{c}15^{a} \\
8 \text { compassos } \\
\text { binários }\end{array}$ & $\begin{array}{c}1 \text { 1a v.:C3-C4 } \\
2 \text { a v.:B1-Ab2 }\end{array}$ & $\begin{array}{l}\text { Modo de C } \\
\text { maior }\end{array}$ & 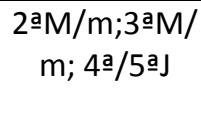 & 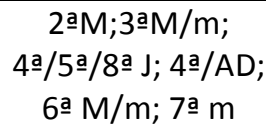 \\
\hline
\end{tabular}

Melodia de Villa-Lobos, com indicação de andamento Allegretto. O contraponto (na segunda voz) e a melodia apresentam terças cheias, bordaduras ou saltos de terças, sucessivamente, nas duas primeiras pulsações dos compassos. As alterações estão no contraponto, a primeira, no compasso 5, caracterizando uma subdominante menor e, no compasso 6, cromatismo ornamental.

145) SOLFEJO $\mathrm{N}^{\circ} 87$ - a capella

\begin{tabular}{|c|c|c|c|c|c|c|c|}
\hline Volume & № & Vozes & Extensão & Tessitura & Tonalidade & $\begin{array}{l}\text { Intervalos } \\
\text { melódicos }\end{array}$ & $\begin{array}{c}\text { Intervalos } \\
\text { harmônicos }\end{array}$ \\
\hline S1 & 87 & 2 & $\begin{array}{c}\text { 9ạ } \\
8 \text { compassos } \\
\text { quaternários }\end{array}$ & $\begin{array}{l}\text { 19 voz: C3-E4 } \\
\text { 2a voz: D2-D3 }\end{array}$ & $\begin{array}{l}\text { Modo de A } \\
\text { menor }\end{array}$ & 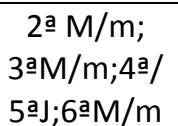 & 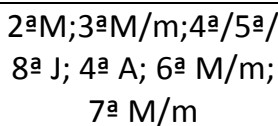 \\
\hline
\end{tabular}

Melodia de Villa-Lobos, com indicação de andamento Moderato, sem indicação de intensidade. O contraponto, na segunda voz, prioriza intervalos melódicos de terças e sextas e notas longas em relação à primeira voz.

146) SOLFEJO $N^{\circ} 114$ - a capella

\begin{tabular}{|c|c|c|c|c|c|c|c|}
\hline Volume & № & Vozes & Extensão & Tessitura & Tonalidade & $\begin{array}{l}\text { Intervalos } \\
\text { melódicos }\end{array}$ & $\begin{array}{c}\text { Intervalos } \\
\text { harmônicos }\end{array}$ \\
\hline S1 & 114 & 2 & $\begin{array}{c}16 \text { a } \\
9 \text { compassos } \\
\text { binários (subdivisão } \\
\text { ternária) }\end{array}$ & $\begin{array}{l}\text { 1ㅁ v.:B2-D4 } \\
\text { 2a v.:C2-C3 }\end{array}$ & $\begin{array}{l}\text { Modo de F } \\
\text { maior }\end{array}$ & $\begin{array}{l}\text { 2aM/m;3a } \\
\mathrm{m} ; 5 \text { aD; } \\
\text { 6모 }\end{array}$ & 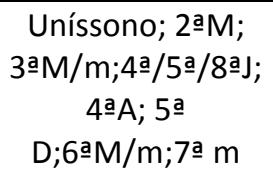 \\
\hline
\end{tabular}

Melodia de Villa-Lobos, com indicação de andamento Andantino, em compasso de subdivisão ternária. Uma abordagem por apojatura de sexta ascendente, seguida de hexacorde descendente inicia a melodia que segue por graus conjuntos e eventuais intervalos de terças. $\mathrm{Na}$ segunda frase a melodia apresenta um pentacorde ascendente e finaliza por hexacorde descendente por terças cheias em sequência por grau conjunto. $\mathrm{O}$ contraponto faz movimento contrário sobre graus conjuntos e intervalos de quarta ou terça.

147) SOLFEJO $\mathrm{N}^{\circ} 81$ - a capella

\begin{tabular}{|c|c|c|c|c|c|c|c|}
\hline Volume & № & Vozes & Extensão & Tessitura & Tonalidade & $\begin{array}{l}\text { Intervalos } \\
\text { melódicos }\end{array}$ & $\begin{array}{l}\text { Intervalos } \\
\text { harmônicos }\end{array}$ \\
\hline S1 & 81 & 2 & $\begin{array}{c}10^{a} \\
6 \text { compassos } \\
\text { binários }\end{array}$ & $\begin{array}{l}1 \text { a v.:C3-E4 } \\
2^{\text {a }} \text { v.:C2-C3 }\end{array}$ & $\begin{array}{c}\text { Modo de D } \\
\text { maior }\end{array}$ & $\begin{array}{l}\text { 2a M/m; } \\
\text { 3무 4의 }\end{array}$ & 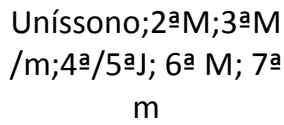 \\
\hline
\end{tabular}

A melodia de Villa-Lobos, com indicação de andamento Allegretto, apresenta um cromatismo ornamental no primeiro compasso e no quarto, na mesma altura, uma alteração que situa a subdominante menor, que com a T, D e T, compõe a cadência final. $\mathrm{O}$ contraponto privilegia terças e sextas paralelas. 
148) SOLFEJO $N^{\circ} 112$ - a capella

\begin{tabular}{|c|c|c|c|c|c|c|c|}
\hline Volume & № & Vozes & Extensão & Tessitura & Tonalidade & $\begin{array}{l}\text { Intervalos } \\
\text { melódicos }\end{array}$ & $\begin{array}{c}\text { Intervalos } \\
\text { harmônicos }\end{array}$ \\
\hline S1 & 112 & $\begin{array}{c}2 \\
\text { mistas }\end{array}$ & $\begin{array}{c}10^{a} \\
8 \text { compassos } \\
\text { binários }\end{array}$ & $\begin{array}{l}\text { 1a voz: D3-E4 } \\
\text { 2a voz: C\#2-E4 }\end{array}$ & $\begin{array}{l}\text { Modo de } \\
\text { A maior }\end{array}$ & 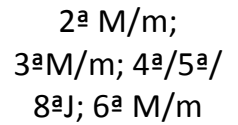 & 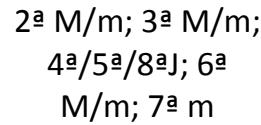 \\
\hline
\end{tabular}

Música de Villa-Lobos, com indicação de andamento Allegretto. Forma: A. A característica da peça, além da articulação em stacatto, são os saltos de terças na primeira voz e as linhas descendentes por graus conjuntos na segunda voz. Intervalos de sextas e terças são priorizados no contraponto, que tem no último compasso fundamental e terça da $\mathrm{T}$ invertidas nas duas vozes.

149) SOLFEJO N ${ }^{\circ} 100$ - a capella

\begin{tabular}{|c|c|c|c|c|c|c|c|}
\hline Volume & № & Vozes & Extensão & Tessitura & Tonalidade & $\begin{array}{l}\text { Intervalos } \\
\text { melódicos }\end{array}$ & Intervalos harmônicos \\
\hline S1 & 100 & $\begin{array}{c}2 \\
\text { mistas }\end{array}$ & $\begin{array}{c}10^{a} \\
6 \text { compassos } \\
\text { quaternários }\end{array}$ & $\begin{array}{l}\text { 19 voz: Eb3-E4 } \\
\text { 2a voz: G1-E3 }\end{array}$ & $\begin{array}{l}\text { Modo de } \\
\text { C maior/ } \\
\text { menor }\end{array}$ & 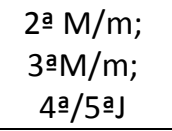 & 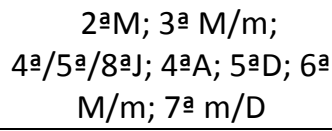 \\
\hline
\end{tabular}

Música de Villa-Lobos, com indicação de andamento Andante. Forma: A. A melodia é apresentada na primeira voz primeiramente em modo maior e na segunda frase em modo menor. O contraponto, na segunda voz confirma os dois modos em movimento rítmico contrastante com a primeira voz.

150) SOLFEJO $\mathrm{N}^{\circ} 92$ - a capella

\begin{tabular}{|c|c|c|c|c|c|c|c|}
\hline Volume & № & Vozes & Extensão & Tessitura & Tonalidade & $\begin{array}{l}\text { Intervalos } \\
\text { melódicos }\end{array}$ & $\begin{array}{c}\text { Intervalos } \\
\text { harmônicos }\end{array}$ \\
\hline S1 & 92 & $\begin{array}{c}2 \\
\text { mistas }\end{array}$ & $\begin{array}{c}10^{\mathrm{a}} \\
8 \text { compassos } \\
\text { quaternários }\end{array}$ & $\begin{array}{c}\text { 19 voz: E3-E4 } \\
\text { 2a voz: C\#3-E4 }\end{array}$ & $\begin{array}{l}\text { Modo de } \\
\text { F maior }\end{array}$ & $\begin{array}{c}\text { 2a } \mathrm{M} / \mathrm{m} ; \\
3 \text { a } \mathrm{M} / \mathrm{m} ; 4 \text { a } / 5 \text { a } / \\
\text { 8a }\end{array}$ & 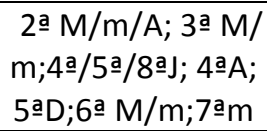 \\
\hline
\end{tabular}

Música de Villa-Lobos, com indicação de andamento Allegro Moderato; de intensidade: $\boldsymbol{f}$; $<$; > ; acento $>$. Forma: A. O tema é apresentado na primeira voz e na segunda frase na voz inferior com variação da parte final. Os ritmos pontuados são recorrentes, aparecendo em polirritmia com tercina no compasso 6 . No compasso 7 o polirritmo é de $3 \times 2$. O contraponto prioriza terças e sextas harmônicas.

151) SOLFEJO $\mathrm{N}^{\circ} 103$ - a capella

\begin{tabular}{|c|c|c|c|c|c|c|c|}
\hline Volume & № & Vozes & Extensão & Tessitura & Tonalidade & $\begin{array}{l}\text { Intervalos } \\
\text { melódicos }\end{array}$ & $\begin{array}{l}\text { Intervalos } \\
\text { harmônicos }\end{array}$ \\
\hline S1 & 103 & $\begin{array}{c}2 \\
\text { mistas }\end{array}$ & $\begin{array}{c}11 \underline{a} \\
5 \text { compassos } \\
\text { quaternários }\end{array}$ & $\begin{array}{l}\text { 19 voz: F3-D4 } \\
\text { 2a voz: C2-C4 }\end{array}$ & $\begin{array}{l}\text { Modo de } \\
\text { F maior }\end{array}$ & $\begin{array}{c}\text { 2a M/m; } \\
\text { 3aM/m; 5a }\end{array}$ & 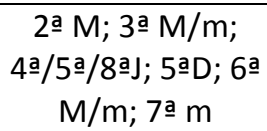 \\
\hline
\end{tabular}

Música de Villa-Lobos, com indicação de andamento Molto Moderato. Forma: A. O tema é a tríade descendente da $\mathrm{T}$ ornamentada por bordaduras na primeira frase e por cromatismo na segunda, seguida de incursão pelo quarto e quinto grau na primeira vez, com resolução no primeiro grau no final. O contraponto trabalha na segunda voz com graus conjuntos e com os mesmos elementos da primeira voz. No compasso 3, o cromatismo em décimas paralelas merece cuidado especial. 
152) SOLFEJO $N^{\circ} 105$ - a capella

\begin{tabular}{|c|c|c|c|c|c|c|c|}
\hline Volume & № & Vozes & Extensão & Tessitura & Tonalidade & $\begin{array}{l}\text { Intervalos } \\
\text { melódicos }\end{array}$ & $\begin{array}{c}\text { Intervalos } \\
\text { harmônicos }\end{array}$ \\
\hline S1 & 105 & $\begin{array}{c}2 \\
\text { mistas }\end{array}$ & $\begin{array}{c}12 \underline{a} \\
8 \text { compassos } \\
\text { quaternários }\end{array}$ & $\begin{array}{l}\text { 19 voz: C3-F4 } \\
\text { 2a voz: B1-D3 }\end{array}$ & $\begin{array}{l}\text { Modo de } \\
\text { C maior }\end{array}$ & 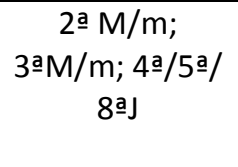 & 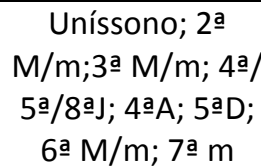 \\
\hline
\end{tabular}

Música de Villa-Lobos, com indicação de andamento Molto Moderato. Forma: A. Há recorrência de tercinas e, no início e final, de notas rebatidas. $\mathrm{O}$ movimento contrário predomina, e as vozes se desenvolvem por graus conjuntos e alguns saltos de quintas e oitavas. O motivo inicial é imitado na segunda voz no segundo compasso.

153) SOLFEJO $\mathrm{N}^{\circ} 106$ - a capella

\begin{tabular}{|c|c|c|c|c|c|c|c|}
\hline Volume & № & Vozes & Extensão & Tessitura & Tonalidade & $\begin{array}{l}\text { Intervalos } \\
\text { melódicos }\end{array}$ & $\begin{array}{c}\text { Intervalos } \\
\text { harmônicos }\end{array}$ \\
\hline S1 & 106 & $\begin{array}{c}2 \\
\text { mistas }\end{array}$ & $\begin{array}{c}10 \underline{a} \\
8 \text { compassos } \\
\text { quaternários }\end{array}$ & $\begin{array}{l}\text { 1a voz: D3-E4 } \\
\text { 2"a voz: C2-C3 }^{2}\end{array}$ & $\begin{array}{l}\text { Modo de } \\
\text { C maior }\end{array}$ & $\begin{array}{c}\text { 2a M/m; 3a } \mathrm{M} \\
/ \mathrm{m} ; 4 \mathrm{a} / 5^{\mathrm{a}} ; 6^{\mathrm{a}} \\
\mathrm{M} / \mathrm{m}\end{array}$ & $\begin{array}{c}\text { 2a M; 3a M/m; } \\
\text { 4a/5a/8aj; 4аa; 6a } \\
M / m ; 7 a m\end{array}$ \\
\hline
\end{tabular}

Música de Villa-Lobos, com indicação de andamento Andantino. Forma: A. A peça desenvolve-se em terças e sextas paralelas com saltos intercalados na primeira voz, com os dois primeiros motivos em sequência ascendente seguidos de encaminhamento para a dominante. $\mathrm{O}$ mesmo acontece na segunda frase, com motivos em sequência descendente, variados, com encaminhamento para a $\mathrm{T}$. Os cromatismos devem ser trabalhados para a garantia de boa afinação, tanto quanto os saltos de sextas.

154) SOLFEJO $N^{\circ} 79$ - a capella

\begin{tabular}{|c|c|c|c|c|c|c|c|}
\hline Volume & № & Vozes & Extensão & Tessitura & Tonalidade & $\begin{array}{l}\text { Intervalos } \\
\text { melódicos }\end{array}$ & $\begin{array}{c}\text { Intervalos } \\
\text { harmônicos }\end{array}$ \\
\hline S1 & 79 & $\begin{array}{c}2 \\
\text { mistas }\end{array}$ & $\begin{array}{c}10^{a} \\
5 \text { compassos } \\
\text { quinários } \\
\end{array}$ & $\begin{array}{c}\text { 1a voz: D3-D4; } \\
\text { 2a voz: B2-E4 }\end{array}$ & $\begin{array}{l}\text { Modo de } \\
\text { A menor }\end{array}$ & $\begin{array}{c}2 \text { a } M / m ; \\
\text { 3aM/m; 4a/5a }\end{array}$ & 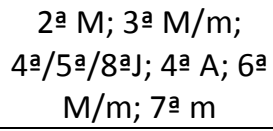 \\
\hline
\end{tabular}

Música de Villa-Lobos, com indicação de andamento Allegro Moderato. Forma: A. O compasso quinário sugere a execução em ternário/binário, nas acentuações e stacatto indicados. Enquanto a primeira voz desenvolve-se em pequenas curvas com graus conjuntos e pequenos intervalos, o contraponto apresenta linhas descendentes por graus conjuntos por movimento contrário.

155) SOLFEJO $\mathrm{N}^{\circ} 80$ - a capella

\begin{tabular}{|c|c|c|c|c|c|c|c|}
\hline Volume & № & Vozes & Extensão & Tessitura & Tonalidade & $\begin{array}{l}\text { Intervalos } \\
\text { melódicos }\end{array}$ & $\begin{array}{c}\text { Intervalos } \\
\text { harmônicos }\end{array}$ \\
\hline S1 & 80 & $\begin{array}{c}2 \\
\text { mistas }\end{array}$ & $\begin{array}{c}12^{\underline{a}} \\
8 \text { compassos } \\
\text { quaternários }\end{array}$ & $\begin{array}{l}\text { 19 voz: G3-G4 } \\
\text { 2a voz: C2-D3 }\end{array}$ & $\begin{array}{l}\text { Modo de } \\
\text { C maior }\end{array}$ & 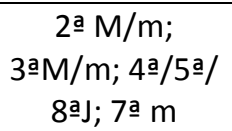 & 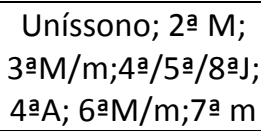 \\
\hline
\end{tabular}

Música de Villa-Lobos, com indicação de andamento Marcha; de intensidade: acento >; Forma: A. A primeira voz apresenta o tema com desenhos sincopados e saltos - na primeira frase, seguidos de bordaduras inferiores - sobre o contraponto na segunda voz priorizando as 
linhas por graus conjuntos. Caberiam ligaduras na última e primeira nota dos compassos 6-7 e 7-8 na primeira voz.

156) SOLFEJO $\mathrm{N}^{\circ} 19$ (Vocalismo) - a capella

\begin{tabular}{|c|c|c|c|c|c|c|c|}
\hline Volume & № & Vozes & Extensão & Tessitura & Tonalidade & $\begin{array}{l}\text { Intervalos } \\
\text { melódicos }\end{array}$ & Intervalos harmônicos \\
\hline S2 & $\begin{array}{l}19 / \\
\text { p. } \\
10\end{array}$ & $\begin{array}{c}3 \\
\text { mistas }\end{array}$ & $\begin{array}{c}11 \text { a } \\
16 \\
\text { compassos } \\
\text { ternários }\end{array}$ & $\begin{array}{l}\text { 1a voz: E3-G4 } \\
\text { 2a voz: B2-E3 } \\
\text { 3a voz: C2-E3 }\end{array}$ & $\begin{array}{l}\text { Modo de G } \\
\text { maior }\end{array}$ & $\begin{array}{c}\text { 2a } \mathrm{M} ; \\
\text { 3a } \mathrm{a} / \mathrm{m} ; \\
\text { 4a/5a/ 8aj; } \\
\text { 6а m }\end{array}$ & 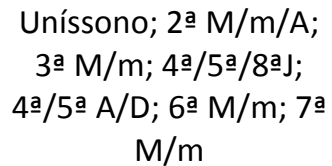 \\
\hline
\end{tabular}

Música de Villa-Lobos, com indicação de andamento Moderato / rall.; de intensidade: $\boldsymbol{p}$. Forma: A. O tema é apresentado na terceira voz, e na sua repetição, apresenta a entrada parcialmente imitativa na primeira voz e a segunda voz iniciando uma sequência descendente de bordaduras, seguida de linha ascendente por terças quebradas. A primeira voz desenvolve saltos ascendentes e descendentes de quartas e quintas, seguidos de linha escalar ascendente por grau conjunto com polirritmo no sétimo e oitavo grau, retomando o segundo grau por salto de sétima descendente, finalizando na terça da tônica. A segunda voz e a terceira finalizam com bordaduras duplas em terças paralelas na $\mathrm{D}$ para resolver na $\mathrm{T}$ com divisi na terceira voz.

157) SOLFEJO $\mathrm{N}^{\circ} 26$ (Vocalismo) - a capella

\begin{tabular}{|c|c|c|c|c|c|c|c|}
\hline Volume & № & Vozes & Extensão & Tessitura & Tonalidade & $\begin{array}{l}\text { Intervalos } \\
\text { melódicos }\end{array}$ & $\begin{array}{c}\text { Intervalos } \\
\text { harmônicos }\end{array}$ \\
\hline S2 & $\begin{array}{c}26 / \\
\text { p. } \\
16\end{array}$ & $\begin{array}{c}6 \\
\text { mistas }\end{array}$ & $\begin{array}{c}\text { 23ạ } \\
10 \text { compassos } \\
\text { quaternários e } \\
1 \text { binário } \\
\text { (subdivisão } \\
\text { ternária) }\end{array}$ & $\begin{array}{c}\text { 1a v.: B3-G4 } \\
\text { 2a v.:G3-D4 } \\
\text { 3a v.:C3-Bb3 } \\
\text { 4a v.:C3-A3 } \\
\text { 5a v.:C2-F3 } \\
\text { 6a v.:F1-D3 }\end{array}$ & Politonal & 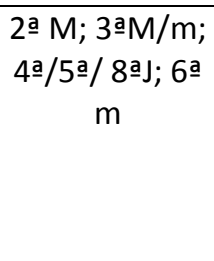 & 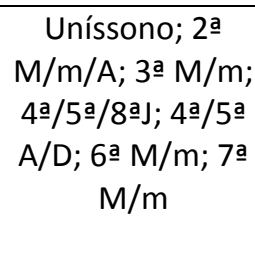 \\
\hline
\end{tabular}

Tema de Villa-Lobos, vocalismo politonal a seis vozes, com indicação de andamento Andante. Após as seis entradas sucessivas, por bordaduras inferiores na primeira, segunda e quarta vozes, e por apojaturas nas terceira, quinta e sexta vozes, o procedimento segue com superposição de tríades segundo a ordem que segue: $\boldsymbol{A m}+\boldsymbol{E m} ; \boldsymbol{A m}+\boldsymbol{F M} ; \boldsymbol{B} \boldsymbol{b} \mathrm{M}+\boldsymbol{G m}$; $\boldsymbol{C M}+\boldsymbol{A m} ; \boldsymbol{D} \mathrm{m}^{6}+\boldsymbol{D} \boldsymbol{b} \mathrm{M} ; \boldsymbol{C M}+\boldsymbol{G} \mathrm{m}-\boldsymbol{D M} / \boldsymbol{F} \mathrm{Mm}+\boldsymbol{G}^{66-5} ;$ uníssono. A harmonização resulta em massa sonora formada por sucessivas tétrades e pêntades em dissonâncias que finalizam em uníssono. O plano de intensidades consta de: entradas em $\boldsymbol{p}$, crescendo para $\boldsymbol{f}$ na sequência de acordes até o ponto culminante, decrescendo para $\boldsymbol{p}$, com indicação de andamento poco rallentando.

\subsubsection{Harmonizações}


158) NA MÃO DIREITA - a capella

\begin{tabular}{|c|c|c|c|c|c|c|c|}
\hline Volume & № & Vozes & Extensão & Tessitura & Tonalidade & $\begin{array}{l}\text { Intervalos } \\
\text { melódicos }\end{array}$ & $\begin{array}{l}\text { Intervalos } \\
\text { harmônicos }\end{array}$ \\
\hline $\begin{array}{l}\text { GP-VTL } \\
\text { / ABM } \\
\text { / S1 }\end{array}$ & $\begin{array}{l}75 \\
/ 48 \\
/ 34\end{array}$ & 3 & $\begin{array}{c}11 \underline{a} \\
10 \text { compassos } \\
\text { binários }\end{array}$ & $\begin{array}{c}\text { 1a v.:D3-D4 } \\
\text { 2a v.:C\#3-A3 } \\
\text { 3a v.:A2-F\#3 }\end{array}$ & $\begin{array}{c}\text { Modo de } D \\
\text { maior }\end{array}$ & $\begin{array}{c}\text { 2a } \mathrm{M} / \mathrm{m} ; 3^{\underline{a}} \\
\mathrm{M} / \mathrm{m} ; 4 \text { a } \mathrm{J}\end{array}$ & 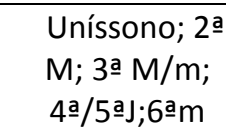 \\
\hline
\end{tabular}

Análise parcial em $2.1-n^{\circ} 21$.

Harmonização sobre T e D, com a segunda e a terceira voz contendo cinco e três notas respectivamente, tornando muito fácil a execução coral. Trata-se de uma versão abrasileirada da canção de origem francesa em compasso quinário. GP/ABM aponta a terceira nota do primeiro motivo como $\boldsymbol{D}$, enquanto GP/VTL trás $\boldsymbol{F} \#$, em uníssono com a primeira voz, o que torna o acesso mais fácil à essa nota.

159) Ó LIMÃO - acompanhamento instrumental

\begin{tabular}{|c|c|c|c|c|c|c|c|}
\hline Volume & № & Vozes & Extensão & Tessitura & Tonalidade & $\begin{array}{l}\text { Intervalos } \\
\text { melódicos }\end{array}$ & $\begin{array}{l}\text { Intervalos } \\
\text { harmônicos }\end{array}$ \\
\hline $\begin{array}{l}\text { GP-VTL } \\
/ \text { ABM }\end{array}$ & $\begin{array}{c}69 \\
/ 49\end{array}$ & 3 & $\begin{array}{c}11 \text { a } \\
13 \text { compassos } \\
\text { binários }\end{array}$ & $\begin{array}{l}1^{\mathrm{a}} \mathrm{v} .: \mathrm{D} 3-\mathrm{D} 4 \\
2^{\mathrm{a}} \mathrm{v} .: \mathrm{D} 3-\mathrm{B} 3 \\
3^{\mathrm{a}} \mathrm{v} .: \mathrm{A} 2-\mathrm{G} 3\end{array}$ & $\begin{array}{l}\text { Modo de } D \\
\text { maior }\end{array}$ & $\begin{array}{c}2 \mathrm{a} M / \mathrm{m} ; 3^{\mathrm{a}} \\
\mathrm{M} / \mathrm{m} ; 4 \mathrm{a} \mathrm{j} \\
\text { 6am }\end{array}$ & 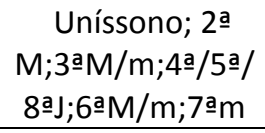 \\
\hline
\end{tabular}

Análise parcial em $2.1-n^{\circ} 83$.

A terceira voz desenvolve pequenos pedais no primeiro grau, ou faz, com as demais vozes, movimentos diretos, exceto no final da frase. A entrada pausada dessa voz anuncia o início da movimentação do 'limão' no segundo compasso. A primeira voz e a segunda caminham em terças paralelas. O contraste rítmico entre as partes é determinado pelas síncopas na primeira parte e a subdivisão da segunda colcheia na segunda. A coda consiste em uma nota em uníssono sobre a sílaba $A h !$.

Em GP/ABM, no compasso 3, terceira voz, não deve constar a ligadura.

Acompanhamento instrumental (piano) - a peça, escrita para três vozes, tem a indicação para ser tocada ao piano optativamente, com a observação do autor: "Quando tocada ao piano, toda a mão esquerda deve ser executada uma oitava abaixo".

160) UMA, DUAS ANGOLINHAS - a capella

\begin{tabular}{|c|c|c|c|c|c|c|c|}
\hline Volume & № & Vozes & Extensão & Tessitura & Tonalidade & $\begin{array}{l}\text { Intervalos } \\
\text { melódicos }\end{array}$ & $\begin{array}{l}\text { Intervalos } \\
\text { harmônicos }\end{array}$ \\
\hline $\begin{array}{l}\text { GP-VTL } \\
\text { / ABM }\end{array}$ & $\begin{array}{l}124 \\
/ 47\end{array}$ & 3 & $\begin{array}{c}13^{a} \\
13 \text { compassos } \\
\text { binários }\end{array}$ & $\begin{array}{c}\text { 1a v.:F3-D4 } \\
\text { 2a v.:C3-Bb3 } \\
\text { 3a v.:F2-F3 }\end{array}$ & $\begin{array}{l}\text { Modo de } \\
\text { F maior }\end{array}$ & 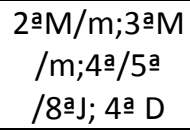 & 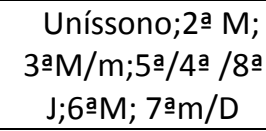 \\
\hline
\end{tabular}

Análise parcial em $2.1-n^{\circ} 24$.

A harmonização desenvolve-se com simplicidade sobre as funções de $\mathrm{T}$ e $\operatorname{Tr}$ e suas dominantes. Os elementos que poderiam dificultar a execução da peça para corais infantis de faixa etária menor seriam as notas: aguda $(\boldsymbol{F} 4)$ e grave $(\boldsymbol{F} 2)$, que podem ser substituídas oitava abaixo e acima respectivamente. Em GP/ABM, nos compassos 10 e 18, na terceira voz, não consta o divisi em oitava, impedindo, assim, a opção pela nota mais aguda. 
Solo instrumental - há indicação em GP/VTL para que a mão esquerda toque uma oitava abaixo quando a peça for executada ao piano. GP/ABM distribui as vozes em sistema de três pautas, o que dificulta a leitura ao piano.

161) Ó SIM! - acompanhamento instrumental

\begin{tabular}{|c|c|c|c|c|c|c|c|}
\hline Volume & № & Vozes & Extensão & Tessitura & Tonalidade & $\begin{array}{l}\text { Intervalos } \\
\text { melódicos }\end{array}$ & $\begin{array}{l}\text { Intervalos } \\
\text { harmônicos }\end{array}$ \\
\hline $\begin{array}{l}\text { GP-VTL } \\
\text { / ABM }\end{array}$ & $\begin{array}{l}119 \\
/ 127\end{array}$ & 2 & $\begin{array}{c}10^{\mathrm{a}} \\
14 \text { compassos } \\
\text { quaternários }\end{array}$ & $\begin{array}{c}1 \mathrm{a} \mathrm{a} \cdot: \mathrm{B3}-\mathrm{B3} \\
\text { 2ㅁv.:G\#2-A3 }\end{array}$ & $\begin{array}{l}\text { Modo de A } \\
\text { maior }\end{array}$ & $\begin{array}{c}\text { 2a } \mathrm{aM} / \mathrm{m} ; \\
\text { 3ạ/m;4a/ } \\
\text { 5aj; 6am }\end{array}$ & $\begin{array}{c}\text { Uníssono; } \\
\text { 2aM;3aM/m; } \\
\text { 4a/5a } / 8 \mathrm{a} ; \\
\text { 5aD; 6a } \mathrm{a} / \mathrm{m}\end{array}$ \\
\hline
\end{tabular}

Popular, o arranjo de Villa-Lobos tem indicação de andamento Allegro (M.M. 144= ل ), e de intensidade apenas acentos: >. Gênero: Cantiga. Em GP/VTL falta a barra de repetição no compasso 9. A melodia caracteriza-se por conter notas rebatidas seguidas de saltos. A harmonização de Villa-Lobos, segundo GP/VTL, priorizando paralelismos de terças e sextas, é uma opção viável, embora em tonalidade um pouco grave, sendo adequada para grupos corais de faixa etária maior. Em GP/ABM a sugestão é interessante, porém a primeira voz é inviável na tessitura $\boldsymbol{B} 3-\boldsymbol{B} 4$ ! No entanto, a segunda voz em plano superior à primeira voz seria própria da prática popular. A segunda parte, com as sílabas Tra-la, pode, como mais uma opção, ser cantada em uníssono.

Acompanhamento instrumental (piano) - a mão direita desenvolve um moto contínuo em semicolcheias, com a melodia dobrada com acentos pela mão esquerda. Em GP/ABM, no compasso 4, parece acertada a substituição da segunda nota $\boldsymbol{A}$ por $\boldsymbol{G}$. No entanto, no compasso 15 não há justificação para a quarta semicolcheia, que deveria ser $\boldsymbol{C}$. No último compasso a semínima na mão direita é $\boldsymbol{G}$.

162) VAMOS ATRÁS DA SERRA, OH CALUNGA - acompanhamento instrumental

\begin{tabular}{|c|c|c|c|c|c|c|c|}
\hline Volume & № & Vozes & Extensão & Tessitura & Tonalidade & $\begin{array}{l}\text { Intervalos } \\
\text { melódicos }\end{array}$ & $\begin{array}{l}\text { Intervalos } \\
\text { harmônicos }\end{array}$ \\
\hline $\begin{array}{l}\text { GP-VTL } \\
\text { / ABM }\end{array}$ & $\begin{array}{l}126 \\
/ 134\end{array}$ & 3 & $\begin{array}{c}10 \text { ạ } \\
35 \text { compassos } \\
\text { binários }\end{array}$ & $\begin{array}{l}\text { 1a v.:G3-D4 } \\
\text { 2a v.:E3-F3 } \\
\text { 3 v.:C3-E3 }\end{array}$ & $\begin{array}{c}\text { Modo de C } \\
\text { maior }\end{array}$ & 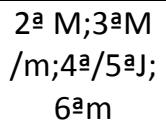 & 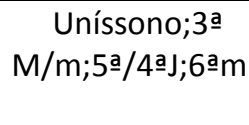 \\
\hline
\end{tabular}

Preferimos a harmonização constante de GP/VTL, por abranger extensão mais adequada para vozes infantis, em detrimento da sugestão de GP/ABM, que, no entanto, é adequada para vozes mistas. Sobre as funções harmônicas de T e D, a peça é de execução simples, apropriada para inserir o coro a três vozes, pois a segunda voz desenvolve-se em apenas duas notas, $\boldsymbol{E}$ e $\boldsymbol{F}$, e a terceira da mesma forma com $\boldsymbol{C}$ e $\boldsymbol{E}$. Em GP/ABM falta um compasso (após o compasso 22) para a execução do ritornello com o texto: "Vamos atrás da", o qual deveria conter a indicação: repetição ad libitum, que ali consta no compasso 22.

Acompanhamento instrumental (piano) - a introdução consiste em notas rebatidas em linha descendente de acordes por saltos de terças na linha superior, até alcançar a oitava do quinto grau em acorde de $\mathrm{D}^{5+}$ - repetido nos dois compassos seguintes. $\mathrm{O}$ acompanhamento segue o ritmo da canção, a mão direita dobra a melodia e a mão esquerda desenvolve uma linha paralela de terças intercalando um pedal de quinto grau. A coda, com a indicação accelerando poco a poco (que não aparece na edição GP/VTL, porém sugerida pela própria configuração rítmica), repete o primeiro motivo três vezes, duas vezes em ritmo de tercinas, variando as 
notas e mais duas vezes também variado em semicolcheias. Terminação na $\mathrm{T}$ com notas longas em décima. Em GP/ABM, no compasso 27, a segunda nota superior da $1^{\text {a }}$ tercina é $\boldsymbol{B} \boldsymbol{b}$ e não $\boldsymbol{C}$, acompanhando a linha do baixo em graus conjuntos descendentes.

163) NA BAHIA TEM - acompanhamento instrumental

\begin{tabular}{|c|c|c|c|c|c|c|c|}
\hline Volume & № & Vozes & Extensão & Tessitura & Tonalidade & $\begin{array}{l}\text { Intervalos } \\
\text { melódicos }\end{array}$ & $\begin{array}{l}\text { Intervalos } \\
\text { harmônicos }\end{array}$ \\
\hline GP-VTL & $12 /$ & $2 / 3$ & $13 \mathrm{a}$ & 1a v.:Eb3-D4 & Modo de & 2a $M / m ; 3$ a $M$ & Uníssono; 2ạ \\
\hline / ABM & 137 & vozes & $\begin{array}{l}34 \text { compassos } \\
\text { binários }\end{array}$ & $\begin{array}{c}\text { 2a v.:C3-G3 } \\
\text { 3a v.:Ab2-G3 }\end{array}$ & Eb maior & /m;4a/5aj & $\begin{array}{c}\mathrm{M} ; 3^{\mathrm{a} M} \mathrm{M} / \mathrm{m} ; 4^{\mathrm{a}} / 5^{\mathrm{a}} / \\
\text { 8 } ; 6^{\mathrm{a}} \mathrm{M} ; 7^{\mathrm{a}} \mathrm{m}\end{array}$ \\
\hline
\end{tabular}

Análise parcial em $2.1-n^{\circ} 50$.

A introdução sobre a sílaba Nan!, por sugestão de GP/ABM, apresenta terças e quartas paralelas a duas vozes. Na primeira nota, a indicação ten. seria mais adequada que rit. A melodia harmonizada a três vozes, com o texto, é de fácil execução. GP/ABM sugere, no compasso 15, a nota $\boldsymbol{G} 2$ para a terceira voz, ao invés da original $\boldsymbol{E} \boldsymbol{b}$.

Acompanhamento instrumental (piano) - a parte A, sem texto, apenas vocalizada com a sílaba Nan!, segundo a edição GP/ABM, que corrige a ausência de texto na edição GP/VTL, funciona como uma introdução de oito compassos. A parte central, que apresenta a melodia, tem a mão direita dobrando as vozes sobre ostinatos rítmicos na mão esquerda. A harmonização é feita nos graus primários da tonalidade. Presença de linhas ornamentais descendentes com intervalos harmônicos de quartas, quintas e eventualmente terças. Repetese A, ou Codeta, com coda instrumental de dois acordes. Na introdução há uma sugestão alternativa para a mão direita em alguns compassos. $\mathrm{O}$ acorde final poderia indicar arpejo, diante da extensão.

164) VAMOS, MARUCA- acompanhamento instrumental

\begin{tabular}{|c|c|c|c|c|c|c|c|}
\hline Volume & № & Vozes & Extensão & Tessitura & Tonalidade & $\begin{array}{l}\text { Intervalos } \\
\text { melódicos }\end{array}$ & $\begin{array}{l}\text { Intervalos } \\
\text { harmônicos }\end{array}$ \\
\hline $\begin{array}{l}\text { GP-VTL } \\
\text { / ABM }\end{array}$ & $\begin{array}{l}128 \\
/ 133\end{array}$ & 3 & $\begin{array}{c}10 \underline{a} \\
16 \text { compassos } \\
\text { binários }\end{array}$ & $\begin{array}{l}\text { 1a v.:A3-E4 } \\
\text { 2a v.:F3-C3 } \\
\text { 3a v.:G2-G3 }\end{array}$ & $\begin{array}{c}\text { Modo de } A \\
\text { maior }\end{array}$ & $\begin{array}{l}\text { 2a M;3aM } \\
/ \mathrm{m} ; 4 \text { a } / 5 \mathrm{a} \mathrm{J} ; \\
6 \mathrm{am}\end{array}$ & $\begin{array}{c}\text { Uníssono;3a } \\
\mathrm{M} / \mathrm{m} ; 5 \mathrm{a} / 4 \mathrm{a} J ; 6 a \mathrm{~m}\end{array}$ \\
\hline
\end{tabular}

Análise parcial em $2.1-n^{\circ} 15$.

Indicado para três vozes, o arranjo não indica a terceira voz na sua totalidade, abrindo para várias soluções. Considerando a sugestão de GP/ABM, a prioridade para terças e sextas paralelas está adequada ao estilo da peça.

Acompanhamento instrumental (piano) - a linha do baixo, após introdução em nota longa na D, caminha por graus conjuntos descendentes completando uma oitava, seguida de cadência DT por quatro vezes. Paralelamente, ambas as mãos dobram o ritmo da melodia, justificando o gênero Catira ali indicado. Segue, após arpejo ascendente ao final da melodia, uma coda que consiste na repetição oitava acima dos primeiros oito compassos da melodia, com arpejos descendentes para voltar à altura inicial, encerrando com os últimos seis compassos em ritmo alargado e com indicação de rallentando.

Em GP/VTL (a), no décimo terceiro compasso, na pauta inferior do acompanhamento, no terceiro tempo, o ritmo indicado para seis quiálteras está equivocado: sendo 6 semicolcheias, 
cada colcheia conteria três delas, e constam quatro semicolcheias para a segunda colcheia. Como a intenção do autor é iniciar o arpejo a partir da segunda colcheia, a grafia correta seria a indicação de três quiálteras para as notas inferiores, transformadas em colcheia e semínima (d). Outra possibilidade seria eliminar a indicação de seis quiálteras e transformar as quatro semicolcheias em fusas (c). Em GP/ABM (b), a proposta também é equivocada, pois aparece a indicação de 3 quiálteras, porém não altera as figuras inferiores.

a) GP/VTL

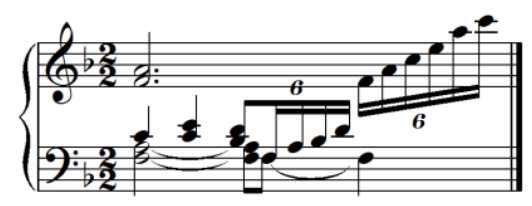

c) possível correção

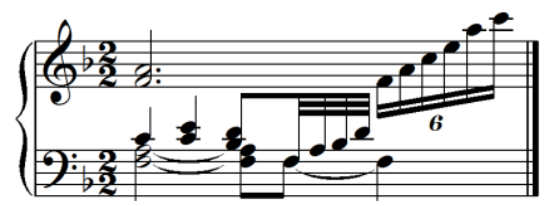

b) $\mathrm{GP} / \mathrm{ABM}$

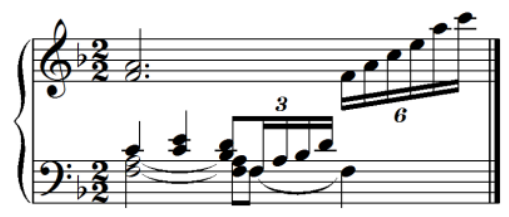

d) correção segundo a concepção original

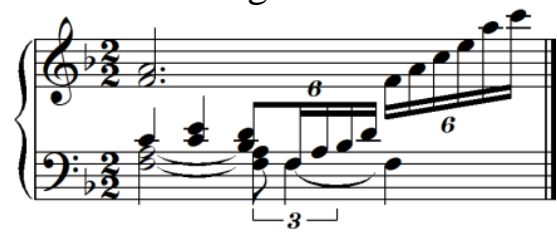

165) CHORA, MENINA, CHORA - acompanhamento instrumental

\begin{tabular}{|c|c|c|c|c|c|c|c|}
\hline Volume & № & Vozes & Extensão & Tessitura & Tonalidade & $\begin{array}{l}\text { Intervalos } \\
\text { melódicos }\end{array}$ & $\begin{array}{l}\text { Intervalos } \\
\text { harmônicos }\end{array}$ \\
\hline $\begin{array}{l}\text { GP-VTL } \\
\text { / ABM }\end{array}$ & $\begin{array}{c}34 \\
/ 136\end{array}$ & 3 & $\begin{array}{c}12 \text { a } \\
22 \text { compassos } \\
\text { binários }\end{array}$ & $\begin{array}{l}\text { 1a } v .: D 3-E 4 \\
\text { 2a } v .: B 2-B 3 \\
\text { 3a } v .: A 2-A 3\end{array}$ & $\begin{array}{c}\text { Modo de C } \\
\text { maior }\end{array}$ & 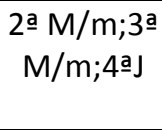 & 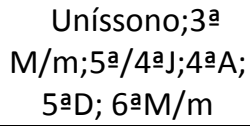 \\
\hline
\end{tabular}

Peça de origem popular, do folclore infantil, para canto com piano, acompanhamento instrumental ou piano solo. Indicação de andamento Poco Animato ( $88=$ d), Più Mosso, poco rall / a tempo. Gênero: Samba do Norte.

A harmonia, a três vozes, tem a melodia na primeira, com as funções harmônicas: T/S/D ${ }^{9} \mathrm{~S}^{6 a}$ /DrDT. A primeira parte termina em uníssono. A segunda parte é declamada. GP/ABM apresenta uma harmonização baseada na harmonização de Villa-Lobos segundo consta em GP/VTL.

Embora rica em elementos timbrísticos, com grande variedade de andamentos e dinâmicas, o texto da peça não é, do ponto de vista educacional, adequada nos dias de hoje, e merece ser substituída.

Acompanhamento instrumental (piano) - a introdução resume-se a um acorde, que é seguido da parte vocal dobrada na mão direita, enquanto a mão esquerda desenvolve uma linha escalar descendente oitavada, com extensão de duas oitavas. Na repetição da frase a linha do baixo é interrompida na $\mathrm{D}$, e o uníssono vocal é acompanhado também em uníssono por oitavas em ambas as mãos. A segunda parte, declamada pelas vozes, a mão direita reforça o ritmo do texto em $\boldsymbol{p}, \boldsymbol{m f}$, cresc., $\boldsymbol{f}, \boldsymbol{f f}$ e, numa pequena codeta (3 compassos) em $\boldsymbol{f f f} \boldsymbol{e} \boldsymbol{f f}$ para o ritornello, 
com tetracorde em uníssono por oitavas em ambas as mãos, finalizando na $\mathrm{D}$ e terça cheia descendente para o terceiro grau. A mão esquerda, sobre um pedal no terceiro grau, e acordes de $\operatorname{Dr}^{11}$ com cromatismos na quarta. A coda repete a codeta, terminando em quinta, a mão direita no quinto grau e a esquerda no primeiro, em oitavas. Em GP/ABM, no compasso 13, o último acorde da mão direita deveria ser colcheia seguida de pausa; no compasso 15 , a nota mais aguda do acorde da mão esquerda deveria ser $\boldsymbol{D}$ e no compasso 18 , na nota aguda da oitava, na mão esquerda não deveria constar a ligadura.

166) DE FLOR EM FLOR-acompanhamento instrumental

\begin{tabular}{|c|c|c|c|c|c|c|c|}
\hline Volume & № & Vozes & Extensão & Tessitura & Tonalidade & $\begin{array}{l}\text { Intervalos } \\
\text { melódicos }\end{array}$ & $\begin{array}{l}\text { Intervalos } \\
\text { harmônicos }\end{array}$ \\
\hline $\begin{array}{l}\text { GP-VTL } \\
\text { / ABM }\end{array}$ & $\begin{array}{l}48 / \\
131\end{array}$ & 3 & $\begin{array}{c}10^{\mathrm{a}} \\
14 \text { compassos } \\
\text { quaternários }\end{array}$ & $\begin{array}{l}1{ }^{\mathrm{a}} \mathrm{v} .: B 2-\mathrm{A} 4 \\
2^{\mathrm{a}} \mathrm{v} .: B 2-\mathrm{F} 3 \\
3^{\mathrm{a}} \mathrm{v} \cdot \mathrm{G} 2-\mathrm{F3}\end{array}$ & $\begin{array}{c}\text { Modo de C } \\
\text { maior }\end{array}$ & $\begin{array}{c}2^{\text {a } M / m ; 3^{a} M} \\
/ m ; 4 a / 5 a j\end{array}$ & $\begin{array}{c}\text { Uníssono; 2a } \\
\text { M;3a M/m;4a/ } \\
\text { 5aj:6am:7am }\end{array}$ \\
\hline
\end{tabular}

Análise parcial em $2.1-n^{\circ} 91$.

A primeira parte caracteriza-se por notas rebatidas, com pequena extensão intervalar para primeiras e segundas vozes, com apenas duas notas em intervalo de quarta para a terceira voz. A segunda parte, em uníssono, é movimentada por tetracordes ascendentes e tríades descendentes. Esta parte seria ritmicamente mais confortável se fosse iniciada por anacruse de um pulso. Por ser de simples execução, é apropriada para corais principiantes. Em GP/ABM, a segunda parte apresenta-se oitavada, com notas agudas para coro infantil de faixa etária menor.

Acompanhamento instrumental (piano) - introdução com 4 compassos com desenho descendente com células rítmicas em ostinato em cada pulso, chegando à $\mathrm{Sr}$ e terminando na $\mathrm{D}^{5+}$ por escala ascendente com cromatismos ornamentais, segue com a melodia dobrada na mão direita (sempre acentuada) e contraponto em oitavas na mão esquerda. As indicações de sforzzatto em cada compasso são de ordem timbrística e podem se relacionar também com a movimentação de uma possível coreografia. Toda a peça encontra-se em intensidade forte. A coda repete a introdução com terminação $\mathrm{D}^{5+} \mathrm{T}$.

167) MEU BENZINHO - a capella

\begin{tabular}{|c|c|c|c|c|c|c|c|}
\hline Volume & № & Vozes & Extensão & Tessitura & Tonalidade & $\begin{array}{l}\text { Intervalos } \\
\text { melódicos }\end{array}$ & $\begin{array}{c}\text { Intervalos } \\
\text { harmônicos }\end{array}$ \\
\hline $\begin{array}{l}\text { GP-VTL } \\
\text { / ABM }\end{array}$ & $\begin{array}{l}80 \\
/ 50\end{array}$ & 3 & $\begin{array}{c}10 \underline{a} \\
26 \\
\text { compassos } \\
\text { binários }\end{array}$ & $\begin{array}{l}1 \mathrm{a} v .: D 3-D 4 \\
2{ }^{a} \mathrm{v} .: B 2-G 3 \\
3{ }^{a} v .: G 2-D 3\end{array}$ & $\begin{array}{l}\text { Modo de } D \\
\text { maior }\end{array}$ & 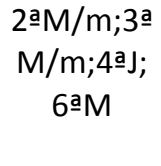 & 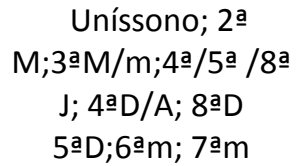 \\
\hline
\end{tabular}

Melodia popular, harmonizada por Villa-Lobos, com indicação de andamento: Allegretto $(M . M .84=ل$ ل ) e de intensidade: $s f z$; acentos > Gênero: Canção.

A harmonização oscila entre $\mathrm{T}$ e $\operatorname{Tr}^{7}$, com terças paralelas entre segunda e terceira vozes, criando uma linha de variação funcional interessante permeada de cromatismos (precedidos de aberturas de acordes), valorizando a melodia. A primeira voz apresenta a melodia sobre a 
tríade da $\mathrm{T}$ e a conclusão por graus conjuntos passando pela $\mathrm{D}$, com resolução na $\mathrm{T}$. A segunda parte tem indicação de B.C., o que traz variação timbrística importante. A peça é de execução mais complexa em virtude dos cromatismos e é apropriada para inseri-los na prática de corais de nível mais adiantado. A introdução e a coda com $\mathrm{D}^{9} / \mathrm{T}$, sobre as sílabas $O h !$ lá?, poderia ter a palavra Olá na grafia atual. GP/ABM poderia ter feito essa atualização.

168) Có, Có, CÓ - acompanhamento instrumental

\begin{tabular}{|c|c|c|c|c|c|c|c|}
\hline Volume & № & Vozes & Extensão & Tessitura & Tonalidade & $\begin{array}{l}\text { Intervalos } \\
\text { melódicos }\end{array}$ & $\begin{array}{l}\text { Intervalos } \\
\text { harmônicos }\end{array}$ \\
\hline $\begin{array}{l}\text { GP-VTL } \\
\text { / ABM }\end{array}$ & $\begin{array}{l}37 / \\
132\end{array}$ & 3 & $\begin{array}{c}12^{\mathrm{a}} \\
18 \\
\text { compassos } \\
\text { quaternários }\end{array}$ & $\begin{array}{l}\text { 1a v.:Eb3-F4 } \\
\text { 2a v.:Bb2-C3 } \\
\text { 3a v.:G2-Ab4 }\end{array}$ & $\begin{array}{c}\text { Modo de Eb } \\
\text { maior }\end{array}$ & $\begin{array}{c}\text { 2a M;3aM/m; } \\
\text { 4a/5a/8a } ; \\
\text { 4aA; 6a m; } \\
\text { 7aM/m }\end{array}$ & 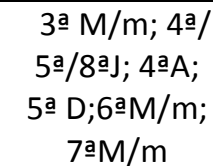 \\
\hline
\end{tabular}

Análise parcial em $2.1-n^{\circ} 127$.

Harmonização vocal mais complexa, com tríades em movimento paralelo, com saltos paralelos de sétimas, inclusive. A sílaba Có! pode ser utilizada ludicamente para exercícios vocais. Pela abundância de saltos de sétima, melódicos e harmônicos, a peça é recomendada para corais infantis de prática mais avançada.

Acompanhamento instrumental (piano) - a introdução é repetida na coda, com exposição do primeiro motivo e bordaduras $\mathrm{D} / \mathrm{T}$ sobre pedal de quinto grau, resolvendo na $\mathrm{T}$ e apresentação do ostinato rítmico (apenas na introdução). A mão direita dobra a melodia em tríades enquanto a mão esquerda dá continuidade ao ostinato no primeiro grau, com o último pulso no quinto, apresentando o ritmo de marcha rancho. Em GP/ABM, no compasso 8 nos dois últimos acordes, a nota correta é $\boldsymbol{D}$ e não $\boldsymbol{E}$ como consta.

169) BOAS FESTAS (Canção de cordialidade) - a capella

\begin{tabular}{|c|c|c|c|c|c|c|c|}
\hline Volume & № & Vozes & Extensão & Tessitura & Tonalidade & $\begin{array}{l}\text { Intervalos } \\
\text { melódicos }\end{array}$ & $\begin{array}{l}\text { Intervalos } \\
\text { harmônicos }\end{array}$ \\
\hline $\mathrm{CO} 2$ & 9 & 3 & $\begin{array}{c}13^{a} \underline{ } \\
14 \text { compassos } \\
\text { ternários }\end{array}$ & $\begin{array}{l}1{ }^{\mathrm{a}} \mathrm{v} .: \mathrm{E} 3-\mathrm{E} 4 \\
\text { 2-av.:B2-D3 } \\
\text { 3av.:G2-G3 }\end{array}$ & $\begin{array}{c}\text { Modo de } \mathrm{G} \\
\text { maior }\end{array}$ & $\begin{array}{c}2^{a} \mathrm{M} / \mathrm{m} ; 3^{a} \\
M / m ; 4^{a} / 5^{a} / 8^{a} \\
J ; 6^{a} \mathrm{~m}\end{array}$ & 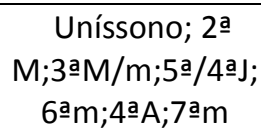 \\
\hline
\end{tabular}

Análise parcial em $2.1-n^{\circ} 41$.

A primeira frase repete-se na segunda frase (com o texto invertido) e na coda, consistindo na mensagem principal do texto. A tríade descendente da $\mathrm{T}$ e a finalização da frase também na $\mathrm{T}$, por apojatura de sexta e quinta estão no início e no final, sendo a resolução da frase na segunda repetição por $\mathrm{D} / \mathrm{T}$. As duas partes da peça são assimétricas, a segunda ampliada em um compasso. As fermatas ao final das saudações são significativas para a interpretação textual, pois precedem e sucedem os votos de 'boas festas'. Os contrastes dos uníssonos com resoluções em cadências harmônicas são elementos timbrísticos que reforçam o texto: saudação e frase imperativa. 
170) FELIZ ANIVERSÁRIO (Canção de cordialidade) - a capella

\begin{tabular}{|c|c|c|c|c|c|c|c|}
\hline Volume & № & Vozes & Extensão & Tessitura & Tonalidade & $\begin{array}{l}\text { Intervalos } \\
\text { melódicos }\end{array}$ & $\begin{array}{l}\text { Intervalos } \\
\text { harmônicos }\end{array}$ \\
\hline $\mathrm{CO} 2$ & 8 & 3 & $\begin{array}{c}12^{\mathrm{a}} \\
13 \text { compassos } \\
\text { ternários }\end{array}$ & $\begin{array}{c}1{ }^{\mathrm{a}} \mathrm{v} .: \mathrm{D} 3-\mathrm{E} 4 \\
2^{\mathrm{a}}{ }^{\mathrm{v}} \mathrm{v} .: \mathrm{D} 3-\mathrm{C \# 3} \\
3^{\mathrm{a}}{ }^{-} \mathrm{v} .: \mathrm{A} 2-\mathrm{A} 3\end{array}$ & $\begin{array}{c}\text { Modo de } A \\
\text { maior }\end{array}$ & 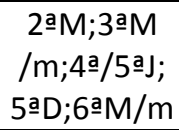 & 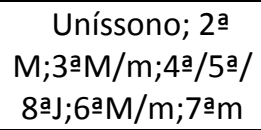 \\
\hline
\end{tabular}

Análise parcial em $2.1-n^{\circ} 133$.

Priorizando o movimento direto entre as vozes, a harmonia apresenta um cromatismo ornamental e as funções primárias e suas relativas. Todos os terceiros pulsos dos compassos, exceto os dois últimos apresentam subdivisão ternária, portanto, caracterizando um ostinato rítmico que facilita a interpretação.

171) CANTOS DE ÇAIRÉ (2) - a capella

\begin{tabular}{|c|c|c|c|c|c|c|c|}
\hline Volume & № & Vozes & Extensão & Tessitura & Tonalidade & $\begin{array}{l}\text { Intervalos } \\
\text { melódicos }\end{array}$ & $\begin{array}{l}\text { Intervalos } \\
\text { harmônicos }\end{array}$ \\
\hline $\mathrm{CO} 2$ & 19 & 3 & $\begin{array}{c}11 \text { a } \\
12 \text { compassos } \\
\text { binários }\end{array}$ & $\begin{array}{c}\text { 1a v.:Ab3-Eb4 } \\
\text { 2a v.:Db3-Bb3 } \\
\text { 3a v.:Bb2-G3 }\end{array}$ & $\begin{array}{c}\text { Modo } \\
\text { dórico de } \mathrm{Bb}\end{array}$ & $\begin{array}{c}\text { 2a } \mathrm{a} ; 3^{\mathrm{a}} \mathrm{M} \\
\text { /m;4a }\end{array}$ & $\begin{array}{c}\text { Uníssono; 2a M } \\
\text { /m;3a M/m; 4a/5a } \\
\text { /8 a } ; 6 \text { a } \mathrm{m} ; 7^{\mathrm{a}} \mathrm{M} / \mathrm{m} / \mathrm{m}\end{array}$ \\
\hline
\end{tabular}

Análise parcial em $2.1-n^{\circ} 5$.

A harmonização desenvolve-se em movimentos paralelos de tríades e movimentos oblíquos nas notas rebatidas. As interrupções por fermatas e as apojaturas dão um caráter livre ao ritmo. A polirritmia se desfaz no penúltimo compasso, sendo um elemento de interesse para a interpretação, que está especificada para vozes femininas em plano de intensidade piano.

172) SOLFEJO $\mathbf{N}^{\circ} 25$ (Vocalismo) - a capella

\begin{tabular}{|c|c|c|c|c|c|c|c|}
\hline Volume & № & Vozes & Extensão & Tessitura & Tonalidade & $\begin{array}{l}\text { Intervalos } \\
\text { melódicos }\end{array}$ & $\begin{array}{l}\text { Intervalos } \\
\text { harmônicos }\end{array}$ \\
\hline S2 & $\begin{array}{l}25 / \\
\text { p. } \\
15\end{array}$ & 3 & $\begin{array}{c}11 \text { a } \\
5 \text { compassos } \\
\text { quaternários }\end{array}$ & $\begin{array}{l}\text { 19 v.: C3-G4 } \\
\text { 2a v.:C3-E3 } \\
\text { 3a v.:C3-E3 }\end{array}$ & $\begin{array}{l}\text { Modo de C } \\
\text { maior }\end{array}$ & $\begin{array}{c}\text { 2a } M ; 3^{a} \mathrm{a} / \mathrm{m} ; \\
\text { 4a/5a/ 8aj;6a } \\
M / m\end{array}$ & $\begin{array}{c}\text { Uníssono; 3a } \\
\mathrm{M} / \mathrm{m} ; 4^{a} \mathrm{a} / 5^{\mathrm{a}} / 8^{\mathrm{a}} \mathrm{J} \\
6 \mathrm{a} \mathrm{M} / \mathrm{m}\end{array}$ \\
\hline
\end{tabular}

A harmonização sobre um Toque de silêncio, adaptação orfeônica, segundo Villa-Lobos, tem a indicação de andamento Adagio e de procedimento de execução: "Repetir três vezes, a primeira em uníssono, a segunda com adaptação orfeônica e a terceira em uníssono". Praticamente sobre a tríade da T, constam duas notas estranhas a ela - nos primeiros pulsos do quarto e quinto compassos. Os dois primeiros compassos têm ao final, fermatas suspensivas e o movimento é direto em toda a peça. O plano de intensidade caracteriza-se por sinais de crescendo e decrescendo atrelados às linhas ascendentes e descendentes respectivamente, exceto no último compasso, que apresenta a mesma proposta em linha descendente.

173) HEI DE NAMORAR - a capella

\begin{tabular}{|c|c|c|c|c|c|c|c|}
\hline Volume & № & Vozes & Extensão & Tessitura & Tonalidade & $\begin{array}{l}\text { Intervalos } \\
\text { melódicos }\end{array}$ & $\begin{array}{l}\text { Intervalos } \\
\text { harmônicos }\end{array}$ \\
\hline $\begin{array}{l}\text { GP-VTL } \\
\text { / ABM }\end{array}$ & $\begin{array}{l}62 \\
/ 56\end{array}$ & 4 & $\begin{array}{c}13^{a} \\
57 \text { compassos } \\
\text { binários }\end{array}$ & $\begin{array}{l}\text { 1a v.:C3-D4 } \\
\text { 2a v.:E3-A3 } \\
\text { 3a v.:C3-F4 } \\
\text { 4a v.:F2-D3 }\end{array}$ & $\begin{array}{c}\text { Modo de C } \\
\text { maior }\end{array}$ & $\begin{array}{c}\text { 2a } \mathrm{M} / \mathrm{m} ; \\
\text { 3aM/m;4의; } \\
\text { 4ㅁA }\end{array}$ & 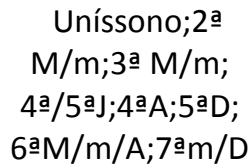 \\
\hline
\end{tabular}

Análise parcial em $2.1-n^{\circ} 120$. 
A melodia está na primeira voz, acompanhada de acordes sobre a sílaba $A n !$ na introdução e B.C. no restante da peça. A introdução ( 8 compassos) apresenta acentos rítmicos defasados entre a $1^{\mathrm{a}}$ e as demais vozes, pedal no quinto grau na $1^{\mathrm{a}}$ voz e a harmonia nas outras três vozes: T Tr T D T D T ${ }^{65} \mathrm{D}$ (duas vezes); $\mathrm{S}^{6 \mathrm{a}} \mathrm{Dr}^{7} \mathrm{~T}$ (duas vezes); T $\mathrm{S}$ mediante com sexta, $\mathrm{DD} \mathrm{D}^{67} \mathrm{~T}$. Individualmente, as vozes são de fácil execução, sendo uma peça indicada para a iniciação a quatro vozes em corais principiantes.

Execução instrumental - nota do autor ${ }^{69}$ : "Quando tocado ao piano, toda a parte da mão esquerda deve ser executada uma oitava abaixo"GP/ABM ${ }^{70}$ apresenta a grafia com distribuição das vozes separadas em quatro pentagramas, o que dificulta a leitura para a eventual e sugerida execução ao piano. Apresenta ainda a indicação indevida: Canto a 3 vozes.

174) PADRE FRANCISCO - a capella

\begin{tabular}{|c|c|c|c|c|c|c|c|}
\hline Volume & № & Vozes & Extensão & Tessitura & Tonalidade & $\begin{array}{l}\text { Intervalos } \\
\text { melódicos }\end{array}$ & $\begin{array}{l}\text { Intervalos } \\
\text { harmônicos }\end{array}$ \\
\hline $\begin{array}{l}\text { GP-VTL } \\
\text { / ABM }\end{array}$ & $\begin{array}{l}86 \\
/ 57\end{array}$ & 4 & $\begin{array}{c}10^{a} \\
20 \text { compassos } \\
\text { binários }\end{array}$ & $\begin{array}{l}1 \text { a v.:C3-F4 } \\
\text { 2a v.:C3-A3 } \\
\text { 3a v.:A2-F3 } \\
4 \text { a v.:F2-F3 }\end{array}$ & $\begin{array}{c}\text { Modo de } F \\
\text { maior }\end{array}$ & $\begin{array}{c}\text { 2aM/m;3aM } \\
/ \mathrm{m} ; 4^{\mathrm{a}} / 5^{\mathrm{a}} / 8^{\mathrm{a}} \\
\mathrm{J} ; 6^{\mathrm{a}} \mathrm{M} / \mathrm{m} ; \\
7 \mathrm{a} \mathrm{m}\end{array}$ & $\begin{array}{c}\text { Uníssono; 2a } \\
\mathrm{M} / \mathrm{m} ; 3^{\mathrm{a}} \mathrm{M} / \mathrm{m} ; \\
\text { 4a/5a/8a } ; \\
\text { 6a } \mathrm{M} / \mathrm{m} ; \text { 7a } \mathrm{a} / \mathrm{m}\end{array}$ \\
\hline
\end{tabular}

De origem popular, ambientada por Villa-Lobos. Gênero: Dança-canção. Andantino quasi allegretto $(\mathbf{8 8}=ل$ ) / $(\mathbf{9 6}=ل$ ) $)$ GP/ABM insere Più mosso (no lugar da segunda indicação metronômica); poco rall. / a tempo na segunda parte e as indicações de dinâmica: $f \boldsymbol{f}, \boldsymbol{f}, \boldsymbol{p}, \boldsymbol{m f}$ cresc. e fff.

A harmonização da melodia (com texto) na primeira voz é completada com as três vozes inferiores, sobre a sílaba Lá!. Trata-se de um acompanhamento rítmico-harmônico. A introdução, em uníssono pelas três vozes inferiores, no quinto grau, precede a entrada da primeira voz. A primeira parte apresenta o mesmo procedimento: no primeiro compasso, entra em solo a primeira voz e no segundo compasso entram as demais vozes. A segunda parte, um pouco mais rápida, uma embolada, tem o acompanhamento harmônico sempre em semínimas com alguma variação. GP/ABM não corrige as ligaduras indevidas nos compassos 21 e 22 na primeira voz.

175) SOLFEJO $\mathrm{N}^{\circ} 12$ (Vocalismo) - a capella

\begin{tabular}{|c|c|c|c|c|c|c|c|}
\hline Volume & № & Vozes & Extensão & Tessitura & Tonalidade & $\begin{array}{l}\text { Intervalos } \\
\text { melódicos }\end{array}$ & $\begin{array}{c}\text { Intervalos } \\
\text { harmônicos }\end{array}$ \\
\hline S2 & $\begin{array}{l}\text { 12/ } \\
\text { P. } 7\end{array}$ & 3 & $\begin{array}{c}15 \text { a } \\
4 \text { compassos } \\
\text { binários / } \\
\text { ternários }\end{array}$ & $\begin{array}{c}\text { 1a v.: G3-G4 } \\
\text { 2a v.:G\#2-C\#3 } \\
\text { 3a v.:B2-A3 }\end{array}$ & $\begin{array}{l}\text { Modo de G } \\
\text { maior }\end{array}$ & 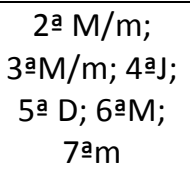 & 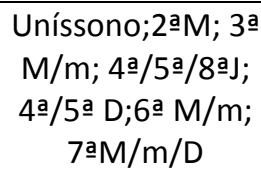 \\
\hline
\end{tabular}

A melodia de Villa-Lobos é construída sobre o pentacorde descendente de $\boldsymbol{G}$ maior, apresentado no início da primeira frase e confirmado por duas vezes na segunda frase. A harmonização a três vozes, passa pelas funções $\mathrm{D}^{7} \mathrm{~T} \mathrm{~S}^{7} \mathrm{D}^{7} \mathrm{~T} \mathrm{D} / \mathrm{T} \mathrm{D} \operatorname{Tr} \mathrm{DD}^{6}{ }^{7} \mathrm{D}$ - na primeira frase; $\mathrm{D}^{43} \mathrm{~T} \mathrm{D}^{7} \mathrm{~T} \mathrm{Sr}\left(\mathrm{D}^{7}\right) \mathrm{S} \mathrm{T} \mathrm{D}^{7} \mathrm{~T}$ na segunda frase. O plano de intensidade iniciase com $\boldsymbol{m f}$, decrescendo, crescendo para $\boldsymbol{f}$ com decrescendo para iniciar a segunda frase em $\boldsymbol{p}$ com crescendo e final decrescendo. Quanto aos compassos alternados 2 e 3 pela mínima, o

\footnotetext{
${ }^{69}$ GP/VTL, p. 85

${ }^{70}$ GP/ABM, Primeiro caderno, p. 61.
} 
segundo compasso, indicado como 3 pela mínima, tem um acento na quarta semínima, que caracterizaria o compasso 2 pela mínima pontuada.

176) CANTIGA DE REDE - a capella

\begin{tabular}{|c|c|c|c|c|c|c|c|}
\hline Volume & № & Vozes & Extensão & Tessitura & Tonalidade & $\begin{array}{l}\text { Intervalos } \\
\text { melódicos }\end{array}$ & $\begin{array}{l}\text { Intervalos } \\
\text { harmônicos }\end{array}$ \\
\hline $\mathrm{CO} 2$ & 7 & 3 & $\begin{array}{c}10^{a} \\
21 \text { compassos } \\
\text { binários }\end{array}$ & 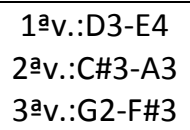 & $\begin{array}{l}\text { Modo de } \\
\text { A maior }\end{array}$ & 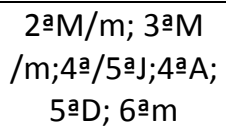 & 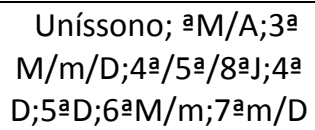 \\
\hline
\end{tabular}

Letra e música de A. Cardoso Machado e arranjo de H. Villa-Lobos. Forma: A / coda. Indicação de andamento Moderato / Poco rall. --- a tempo / Poco rall.; de intensidade: p; pp

O texto é uma quadra de sete sílabas, com exceção do terceiro e quarto versos que têm seis, com problemas de prosódia no segundo verso. Parece um acalanto ao contrário - como se a criança cantasse internamente sobre um canto materno e sua própria potencialidade de futuro cantor. Para as palavras: Range, range, Canta, canta há uma sequência em quartas descendentes.

A melodia não apresenta dificuldades, exceto alguns trítonos. Todas as alterações são ornamentais, presentes em bordaduras cromáticas, ou simples cromatismos de passagem.

A harmonização pode ser o ponto principal de interesse da peça. As cadências terminam em $\mathrm{D}, \mathrm{Dr}, \mathrm{D}$ e T. A coda inicia-se e termina na T. A terceira voz apresenta pequenos pedais no quinto grau.

A variação de timbres se dá pela harmonia fechada contrastando com alguns momentos de distensão, quando a primeira voz alcança as notas mais agudas; quando acontece variação agógica, na B.C. na coda, na ligeira variação de intensidade e nos finais de frase sempre em uníssono.

177) MÊS DE JUNHO - a capella

\begin{tabular}{|c|c|c|c|c|c|c|c|}
\hline Volume & № & Vozes & Extensão & Tessitura & Tonalidade & $\begin{array}{l}\text { Intervalos } \\
\text { melódicos }\end{array}$ & $\begin{array}{l}\text { Intervalos } \\
\text { harmônicos }\end{array}$ \\
\hline $\begin{array}{c}\mathrm{CO} 2 / \\
\text { GP-VTL }\end{array}$ & $\begin{array}{l}15 / \\
96 /\end{array}$ & 3 & $\begin{array}{c}10^{\mathrm{a}} \\
15 \text { compassos }\end{array}$ & $\begin{array}{c}\text { 1a v.:F\#3-Eb4 } \\
\text { 2a v.:D3-C4 }\end{array}$ & $\begin{array}{l}\text { Modo de } G \\
\text { menor }\end{array}$ & $\begin{array}{l}2 \mathrm{a} M / \mathrm{m} ; 3^{\mathrm{a}} \\
\mathrm{M} / \mathrm{m} ; / \mathrm{m} ; 4^{\mathrm{a}} /\end{array}$ & 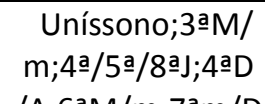 \\
\hline
\end{tabular}

Análise parcial em $2.1-n^{\circ} 149$.

A peça, em GP/ABM/VTL, consta com o título Pobre cega, gênero Cantiga, sem texto, apenas com a sugestão de vocalize na sílaba $A h !$. No volume $\mathrm{CO} 2$, o texto refere-se ao inverno e às festas juninas. A introdução e a coda resumem-se ao uníssono no primeiro grau sobre a sílaba $A h !$. A harmonização fica no centro tonal em modo menor, com as funções tonais básicas e apojaturas nos compassos 7, 9, 13 e no penúltimo compasso. A segunda voz apresenta cromatismo no compasso 2, e a terceira voz na apojatura dos compassos 7 e 9 . Mesmo não sendo de difícil execução, a peça é adequada para corais com mediana experiência. 
178) BOAS VINDAS (Canção de cordialidade) - a capella

\begin{tabular}{|c|c|c|c|c|c|c|c|}
\hline Volume & № & Vozes & Extensão & Tessitura & Tonalidade & $\begin{array}{l}\text { Intervalos } \\
\text { melódicos }\end{array}$ & $\begin{array}{l}\text { Intervalos } \\
\text { harmônicos }\end{array}$ \\
\hline $\mathrm{CO} 2$ & 12 & 4 & $\begin{array}{c}10^{a} \\
24 \text { compassos } \\
\text { binários }\end{array}$ & 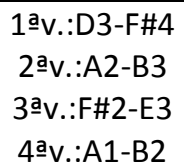 & $\begin{array}{l}\text { Modo de } D \\
\text { maior }\end{array}$ & 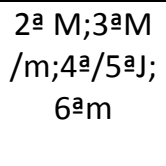 & 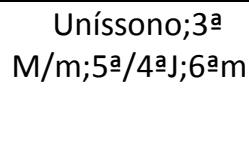 \\
\hline
\end{tabular}

A música de Villa-Lobos tem a letra de Manuel Bandeira, uma canção de cordialidade para quatro vozes mistas. São várias as indicações de andamento: Poco andante; rit. / a tempo ; rit. /Più mosso. Quanto à intensidade, apenas sinais de decrescendo ao final de algumas palavras. A nota $\boldsymbol{E}$ da $2^{\text {a }}$ voz no compasso 10 deve ser $\boldsymbol{D}$ - por analogia com os compassos 2, 12 e 20. No compasso 11 a primeira semínima deve ser uma colcheia. O texto no compasso 17 deveria ser apenas ' $E$ ' e no compasso 17 , 'mais'.

As conclusões das três frases formam a grande cadência T D T. A $1^{\text {a }}$ frase inicia-se com a saudação, assim como a $3^{\mathrm{a}}$ encerra com a saudação. A $2^{\mathrm{a}}$ frase repete o primeiro motivo por sequência ascendente e desenvolve, como as demais, uma linha escalar descendente, terminando em salto de oitava ascendente na primeira voz, para introduzir a linha descendente da terceira frase. O ponto culminante, nos compassos 17-18 apresenta abertura de acordes. As duas alterações têm função estrutural, a primeira em dominante secundária, e a segunda como apojatura da Dr. A linha rítmica alterna a subdivisão ternária com tercinas e a binária com semicolcheias. O caráter conclusivo da primeira frase reforça a saudação inicial e final. Os encadeamentos da segunda parte conferem importância crescente ao texto. A quarta voz deve trabalhar bem o salto de sétima descendente no compasso 17.

O autor sugere em nota: (Para o ensino primário, podendo cantar separadamente a principal melodia no tom de Dó)

179) FELIZ ANO NOVO (Canção de cordialidade) - a capella

\begin{tabular}{|c|c|c|c|c|c|c|c|}
\hline Volume & № & Vozes & Extensão & Tessitura & Tonalidade & $\begin{array}{l}\text { Intervalos } \\
\text { melódicos }\end{array}$ & $\begin{array}{l}\text { Intervalos } \\
\text { harmônicos }\end{array}$ \\
\hline $\mathrm{CO} 2$ & 11 & 3 & $\begin{array}{c}15^{a} \\
33 \text { compassos } \\
\text { binários }\end{array}$ & 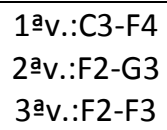 & $\begin{array}{l}\text { Modo de } \mathrm{F} \\
\text { maior }\end{array}$ & 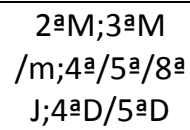 & 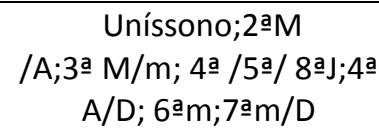 \\
\hline
\end{tabular}

Análise parcial em $2.1-n^{\circ} 173$.

A primeira e a última frase, a duas vozes, apresentam a escala maior descendente, na primeira voz, e por movimento contrário nas demais, com o mesmo texto. Após o segundo verso, repete-se o motivo inicial, com texto do terceiro verso. A partir desse ponto, a primeira voz segue uma linha melódica que vai, pouco a pouco, alcançando por grau conjunto todas as notas da escala, até chegar ao oitavo grau, para a linha descendente final. Há incidência de segundas harmônicas a duas e três vozes, influindo no plano de timbres, tanto quanto passagens cromáticas com resolução estrutural (compasso $16-\mathrm{T}^{5+} / 17-\mathrm{Sr}$; compasso $24-\mathrm{S}^{5+} / 25$ DD; compassos: 21-dominante secundária com 7ª / D; 22 - Sr). A tessitura mais ampla sugere execução para coros de faixa etária mais alta. 


\subsection{Peças para repertório coral}

Além das peças a uma, duas ou mais vozes já analisadas nos capítulos anteriores, pertinentes a repertório coral de várias faixas etárias, outras que apresentam nível de complexidade maior seguem aqui. Muitas delas já fazem parte de programações de corais femininos, infantis ou mistos.

A seleção foi feita segundo os seguintes critérios: apresentação das peças em uma possível ordem de complexidade; seleção de peças para vozes iguais; seleção de peças para vozes mistas; qualidade do arranjo; possibilidade de inserção do texto em objetivos educacionais, ideológicos e artísticos nos contextos atuais; viabilidade de execução para grupos vocais desde principiantes aos avançados.

Os critérios analíticos foram: número de vozes ou partes; extensão da peça; compassos - fórmulas e quantidades; tessitura de cada voz; tonalidade ou modalidade; forma; gênero segundo a classificação de Villa-Lobos; indicações de andamento e de intensidade; créditos referentes a: autoria de letra e música, arranjo e ambientação; indicação do autor das possibilidades de execução: a capella, canto e piano, conjunto instrumental ou piano solo; eventuais problemas detectados nas versões consultadas; eventuais sugestões de ordem didático-pedagógica.

\subsubsection{Vozes iguais}

\section{1) QUADRILHA DAS ESTRELAS NO CÉU DO BRASIL}

Bailado cívico-artístico-folclórico. Compõe-se de: Introdução, Quadrilha Brasileira, Fui no Itororó, Cantiga de Roda e Anda à Roda.

( $\mathbf{N}^{0}$ 1a Introdução) - a capella

\begin{tabular}{|c|c|c|c|c|c|c|}
\hline Volume & № & Vozes & Extensão & Tessitura & Tonalidade & Forma \\
\hline $\mathrm{CO} 2$ & $\begin{array}{l}\text { 29/ } \\
\text { no } 1\end{array}$ & 3 & $\begin{array}{l}25 \text { compassos } \\
\text { quaternários }\end{array}$ & $\begin{array}{c}\text { 1a voz: C3-F4 } \\
\text { 2a voz: C3-F4 } \\
\text { 3a voz: F2-Bb3 }\end{array}$ & $\begin{array}{l}\text { Modo de F } \\
\text { menor }\end{array}$ & $\begin{array}{c}\text { Introdução } \\
\text { A B A }\end{array}$ \\
\hline
\end{tabular}

A introdução tem letra de Manuel Bandeira e música de H. Villa-Lobos. Indicação de andamento Tempo Moderado de Dobrado. O final, não indicado, deve ser no término da primeira parte, pela cadência harmônica. Aparecem apenas acentos > como indicativos de intensidade. Alguns problemas com o texto: compasso 6 - falta a vogal ' $e$ ' na palavra estremecemos; 7, 8 - falta crase em à lenta voz dos sinos. 
Quanto à letra, são duas estrofes com versos hexassilábicos, excetuando o primeiro, que é heptassilábico, após os quais a métrica é variada. O tema é a constelação das Três Marias, patrimônio do céu pátrio, que inspira amores terrenos e divinos. Canção de roda, ciranda, trata-se de uma convocação a meninas e moças para a brincadeira. Imagem poética: associa as integrantes da roda às estrelas (brasileiras).

A primeira parte tem tratamento contrapontístico e a segunda parte tem tratamento harmônico. A primeira voz, na parte A apresenta uma sequência descendente de quatro motivos com arpejo ascendente de tétrades seguidas de linha descendente por grau conjunto e terças ou quartas, repete-se a sequência na frase seguinte, com dois arpejos de tríade e novamente de tétrades por duas vezes. A segunda voz faz imitação rítmica, sobre pequenos intervalos e linhas descendentes por grau conjunto. As duas linhas escalares descendentes lembram o bordão do violão.

$\mathrm{Na}$ segunda parte, encontram-se três frases (em alusão à constelação Três Marias), em sequências descendentes nas duas vozes. O motivo da primeira voz é uma sequência oblíqua, a partir do som agudo em pedal, de intervalos descendentes $\left(8^{\mathrm{a}}, 7^{\mathrm{a}}, 6^{\mathrm{a}}, 5^{\mathrm{a}}, 4^{\mathrm{a}}\right)$, terminando na quinta da nota pedal, exceto na terceira vez, em que é alcançado o ponto culminante em sons longos com resolução na dominante quinta abaixo. A segunda voz também apresenta três motivos desenvolvidos em sequência descendente, sobre a sílaba Nan! em sextas paralelas, sendo que a voz intermediária reforça a melodia em ritmo defasado.

O ritmo de marcha apresenta síncopas dentro de um ostinato rítmico que prevalece nas duas partes.

A peça resume-se no desenvolvimento melódico e harmônico do tetracorde descendente $\boldsymbol{F}$ $\boldsymbol{E}(\boldsymbol{b}) \boldsymbol{D} \boldsymbol{b} \boldsymbol{C}$ distribuído nos inícios das semifrases, a cada dois compassos.

( $\mathbf{N}^{\circ} 1 \mathrm{~b}$ Quadrilha Brasileira) - a capella

\begin{tabular}{|c|c|c|c|c|c|c|}
\hline Volume & № & Vozes & Extensão & Tessitura & Tonalidade & Forma \\
\hline CO2 & $\begin{array}{c}29 / \\
\text { no 2 }\end{array}$ & 2 & $\begin{array}{c}\text { 29 compassos binários } \\
\text { (subdivisão ternária) }\end{array}$ & $\begin{array}{c}\text { 1a voz: B2-F4 } \\
\text { 2a voz: B2-F4 }\end{array}$ & $\begin{array}{c}\text { Modo de } \\
\text { C maior }\end{array}$ & A A' \\
\hline
\end{tabular}

Tema folclórico. Não há referências sobre época e local de recolhimento. Gênero: Quadrilha.

Esta obra está associada ao movimento nacionalista que surgiu dentro do modernismo, como o demonstra o vocabulário que remete às cidades de interior do Brasil, como "serras", ou os "sinos" que anunciam o final da tarde ao anunciar a hora da Ave-Maria. Tirar proveito político dos elementos nacionais fazia parte do governo de Getúlio Vargas, ao fazer exaltação da mulata, do morro, entre outros elementos. Foi também o período do surgimento das obras de interpretação do Brasil, tendo como um dos expoentes Gilberto Freyre.

A primeira parte, em uníssono, apresenta a primeira frase em duas linhas escalares descendentes, a segunda, terminando ascendentemente na dominante. Segue uma sequência de grupetti sobre cada grau da escala, com finalização ascendente na subdominante em plano agudo. Os grumete sugerem o movimento circular

A segunda parte, a duas vozes, tem a melodia na segunda voz, que apresenta a primeira semifrase por duas vezes, com um contraponto na primeira voz em notas mais longas sobre a sílaba $A h !$

O ritmo inicial de todas as semifrases se dá em síncopas ou contratempos. 
( $\mathbf{N}^{\circ}$ 1c Fui no Itororó) - a capella

\begin{tabular}{|c|c|c|c|c|c|c|}
\hline Volume & № & Vozes & Extensão & Tessitura & Tonalidade & Forma \\
\hline CO2 & $29 /$ no 3 & 1 & 34 compassos binários & B2-C4 & Modo de C maior & A B \\
\hline
\end{tabular}

Tema folclórico. Não há referências sobre época e local de recolhimento. Indicação de andamento Allegretto / Vivace; de intensidade apenas acentos >. Primeira parte - ciranda; segunda parte - dança do pezinho (tradicionais do folclore brasileiro infantil).

O texto fala de uma fonte de água e de uma morena encontrada em lugar da água. Pezinho é uma dança folclórica da região sul do Brasil, mas conhecida em todo o país, graças ao seu acoplamento (como é o caso desta obra) a muitas cirandas, pelo seu caráter coreográfico. Apesar da variação métrica após a primeira parte, a redondilha maior se destaca.

O primeiro motivo (Fui no Itororó), descendente, repete-se integralmente ou variado (alturas e ritmo) mais sete vezes; (ó dona Maria) idem mais três vezes . Na segunda parte, nova melodia, o motivo inicial apresenta terças descendentes como desenho principal, terminando a parte com uma escala descendente do sétimo ao primeiro grau. $\mathrm{Na}$ segunda parte, os intervalos de pequena extensão coadunam-se ao texto 'bem juntinho ao pé do meu'. Todas as frases encaminham-se para a tônica.

( $\mathbf{N}^{\circ}$ 1d Cantiga de roda) - a capella

\begin{tabular}{|c|c|c|c|c|c|c|}
\hline Volume & № & Vozes & Extensão & Tessitura & Tonalidade & Forma \\
\hline CO2 & $\begin{array}{c}29 / \\
\text { no } 4\end{array}$ & 1 & $\begin{array}{c}\text { 10 compassos binários } \\
\text { (subdivisão ternária) }\end{array}$ & C3-D4 & $\begin{array}{c}\text { Modo de C } \\
\text { maior }\end{array}$ & A estrófica \\
\hline
\end{tabular}

Tema folclórico. Não há referências sobre época e local de recolhimento. Indicação de andamento Allegretto. Gênero: Ciranda.

A repetição das frases e o canto em uníssono são próprios da cantiga de roda. A primeira frase apresenta quartas e terças quebradas em linha descendente e a segunda frase, quartas e terças cheias.

$\left(\mathrm{N}^{0} 1 \mathrm{e}\right.$ Anda à roda $)$ - a capella

\begin{tabular}{|c|c|c|c|c|c|c|}
\hline Volume & № & Vozes & Extensão & Tessitura & Tonalidade & Forma \\
\hline CO2 & $\begin{array}{c}29 / \\
\text { no 5 }\end{array}$ & 3 & $\begin{array}{c}21 \text { compassos } \\
\text { quaternários }\end{array}$ & $\begin{array}{c}\text { 1a voz: Eb3-Eb4 } \\
\text { 2a voz: C3-Eb4 }\end{array}$ & $\begin{array}{c}\text { Modo de } \\
\text { Ab maior }\end{array}$ & A B \\
\hline
\end{tabular}

Tema folclórico. Não há referências sobre época e local de recolhimento. Indicação de andamento: Andantino, quasi movimento de marcha. Gênero: Ciranda.

A parte A, a duas vozes, é harmonizada com prioridade de intervalos harmônicos de terças e sextas. A parte B, em uníssono, é mais movimentada ritmicamente e apresenta intervalos mais amplos, contrastando com a primeira parte. 
2) CANTAR PARA VIVER - a capella

\begin{tabular}{|c|c|c|c|c|c|c|}
\hline Volume & № & Vozes & Extensão & Tessitura & Tonalidade & Forma \\
\hline CO1 & 20 & 2 & $\begin{array}{c}52 \text { compassos } \\
\text { binários }\end{array}$ & $\begin{array}{c}\text { 1a voz: C3-F4 } \\
\text { 2a voz: A2-C3 }\end{array}$ & $\begin{array}{c}\text { Modo de } \\
\text { F maior / D menor }\end{array}$ & ABA \\
\hline
\end{tabular}

Letra de Sylvio Salema e música de H.Villa-Lobos (Rio de Janeiro, 1933). Indicação de andamento Marcha e de intensidade: acentos.

O texto descreve a força do povo e a grandeza da terra, suas belezas naturais, dignas de serem cantadas por quem ama essa pátria que é sua. Pode ser direcionado para o tema 'ecologia'.

A segunda voz desenvolve o contraponto sobre a sílaba Nan! na primeira parte, passando para o texto, em caráter imitativo na segunda parte.

Os ritmos pontuados promovem o entusiasmo sugerido pelo texto. $\mathrm{O}$ contraste faz-se pelos ritmos não pontuados na segunda parte, pela mudança de modo de maior para menor e pelo caráter imitativo e abandono da sílaba neutra, substituída pelo texto na segunda voz. Esses elementos enriquecem o plano timbrístico também.

3) DIA DE ALEGRIA - a capella

\begin{tabular}{|c|c|c|c|c|c|c|}
\hline Volume & № & Vozes & Extensão & Tessitura & Tonalidade & Forma \\
\hline CO1 & 22 & 2 & $\begin{array}{c}39 \text { compassos } \\
\text { binários }\end{array}$ & $\begin{array}{c}\text { 1'a voz: Bb2-F4 2a } \\
\text { voz:F2-F3 }\end{array}$ & $\begin{array}{c}\text { Modo de } \\
\text { F menor }\end{array}$ & $\begin{array}{c}\text { Introdução A } \\
\text { Coda }\end{array}$ \\
\hline
\end{tabular}

Letra de Catarina Santoro e música de H. Villa-Lobos (Rio de Janeiro, 1933). Indicação de andamento Tempo de Marcha de Rancho (um pouco moderado); de intensidade $f$; acentos $>;<>; s f z$

Canção alusiva às férias escolares, expressando a alegria da convivência escolar. Duas quadras em sextilhas.

A introdução, repetida na coda, em uníssono, apresenta ostinato rítmico e em parte melódico que se repete na segunda voz no início da primeira parte. Faz o papel de codeta na repetição da parte A. O ostinato é um suporte rítmico e harmônico para a melodia da primeira voz.

A segunda voz utiliza sempre a sílaba: Nan! . Nesta voz, nos compassos 35-36 deve ser trabalhado o intervalo ascendente de sexta menor para garantia de boa afinação. No mesmo trecho, tanto esta como a primeira voz apresentam um sinal de portamento ou glissando, característica estética da época, que precisa ser analisado com cuidado e, eventualmente, desprezado. O mesmo acontece no compasso 39.

A harmonia é baseada na escala menor harmônica, apresentando intervalos de segundas aumentadas, as quais merecem ser trabalhadas, para resultarem afinadas. 
4) HERANÇAS DA NOSSA RAÇA - a capella

\begin{tabular}{|c|c|c|c|c|c|c|}
\hline Volume & № & Vozes & Extensão & Tessitura & Tonalidade & Forma \\
\hline CO1 & 23 & 2 & $\begin{array}{c}53 \text { compassos } \\
\text { quaternários }\end{array}$ & $\begin{array}{c}\text { 1avoz: A2-D4 } \\
\text { voz: A2-D4 }\end{array}$ & $\begin{array}{c}\text { Modos de } \\
\text { D menor / } \\
\text { D maior }\end{array}$ & AB \\
\hline
\end{tabular}

Dedicada a Joaquim Francisco d'Almeida, com letra de C.Paula Barros e música de H.VillaLobos. Não consta o número 23 na edição. Indicação de andamento Marcha acelerada (de Rancho); de intensidades: $\boldsymbol{f} ; \boldsymbol{m f} ; \boldsymbol{p} ;<>$

O texto traz figuras típicas das várias regiões do país, relacionando-as às características da natureza e dos costumes dos diferentes lugares. O vocabulário contém expressões em desuso, ou não conhecidas em todas as regiões do país, como "touros feros" e "sopro dos pompeiros" (que deveria ser "pampeiros"- vento minuano). Note-se também a expressão "Brasil bem brasileiro", idéia presente na Aquarela do Brasil de Ary Barroso. A palavra "abaio" deve ser "aboio".

Compasso 27 não deve constar a ligadura para as duas últimas notas. Há problemas com a prosódia no compasso 25, com uma nota para duas sílabas do hiato "ia", e nos compassos 33 e 51, a acentuação da primeira sílaba em "canção" e "Brasil”".

Introdução em uníssono, intensidade forte, apresentando o ostinato de dois compassos, que será utilizado parcialmente na primeira parte da peça pela segunda voz. O contraste de forte para piano prepara a entrada da melodia na primeira voz.

A melodia está na primeira voz na primeira parte, em modo menor, caracterizada por arpejos ascendentes e finalizações de frases em sons longos. Na segunda parte, passa para a terceira voz, em modo maior, com as frases reduzidas em pequenas curvas melódicas e finalizações não tão longas quanto na primeira melodia.

Na primeira parte, a duas vozes, o contraponto está na segunda voz, sobre a sílaba Nan!, com ritmo movimentado, em contraste com notas longas da primeira voz. Após repetições e variações melódicas do ostinato apresentado na introdução, há uma sequência ascendente por grau conjunto de motivos iniciados por arpejo de tríade, nota de passagem e finalizados por pentacordes descendentes e salto de segunda e terça respectivamente. Segue outra sequência descendente por grau conjunto com a segunda parte do motivo descrito repetida por seis vezes, dando vez à codeta, com alteração no sexto e terceiro grau da tônica.

Na segunda parte, a três vozes, o acompanhamento da melodia, sobre a sílaba Plim! marcando o pulso na primeira e segunda voz, está no tratamento harmônico, apresentando as funções harmônicas em duas notas das tríades correspondentes. Por se situar esse acompanhamento na região média, há cruzamento de vozes com a melodia da terceira voz.

A harmonia faz as passagens dos modos maior para menor e vice-versa alterando as terças das tônicas - na codeta ao final da primeira parte e na segunda casa do ritornello para o retorno à primeira parte.

Os saltos de sextas devem ser trabalhados e o portamento indicado no compasso 46 precisa ser ponderado quanto ao seu emprego. 
5) O CANTO DO PAJÉ - a capella

\begin{tabular}{|c|c|c|c|l|c|c|}
\hline Volume & No & Vozes & \multicolumn{1}{|c|}{ Extensão } & \multicolumn{1}{|c|}{ Tessitura } & Tonalidade & Forma \\
\hline CO1 & 19 & 3 & 36 compassos & Soprano: C3-F4 & Modos de & AB \\
& & femininas & quaternários & I meio soprano: F2-A3 & A menor \\
& & & & $\begin{array}{l}\text { Il meio soprano: F2-A3 } \\
\text { Contralto: F2-A3 }\end{array}$ & \\
\end{tabular}

"Baseado na música primitiva do aborígene brasileiro com fragmentos de ritmos da música popular espanhola”, com letra de C. Paula Barros e música de H.Villa-Lobos (Rio de Janeiro, 1933). Indicação de andamento Movimento de Marcha Rancho, de intensidade $\boldsymbol{m f} ; \boldsymbol{p}$; >

Para três vozes e solo, ou para quatro vozes, embora na edição conste "a três vozes a seco".

O texto remete ao ambiente indígena, em que Anhangá (entidade do mal) foge, após ter causado o sonho (saudade da terra). Coaracy, a Lua, é a interlocutora que leva a Tupan (entidade superior do bem) os pedidos para que retire a saudade da terra perdida.

As sílabas: Don! ; Don gon don ; Tum ; Ah! ; Hê! são parte do plano timbrístico, fazendo fundo para a linha melódica principal, com a intenção de imitar instrumentos (neste caso, castanholas).

A introdução apresenta o ostinato rítmico-harmônico que acompanhará a melodia do soprano em toda a primeira parte da peça. A segunda e terceira vozes ocupam-se dos intervalos de terças das funções harmônicas, cuja linha de baixo é desenvolvida pela quarta voz, iniciada por salto e completada por linha descendente, mantendo a primeira nota de cada compasso no quinto grau, com exceção dos dois últimos compassos, em que a alteração promove a modulação para o tom menor da segunda parte. O ritmo do ostinato, segundo o autor, é originado de alguma dança espanhola.

A segunda parte, a duas vozes, tem tratamento polifônico com recorrências de terças e sextas harmônicas. O ritmo é enriquecido por tercinas e polirritmos.

A tessitura da peça é ampla, mais adequada para vozes de adolescentes e adultos.

6) CANTO DO LAVRADOR - a capella

\begin{tabular}{|c|c|c|c|c|c|c|}
\hline Volume & № & Vozes & Extensão & Tessitura & Tonalidade & Forma \\
\hline CO1 & 29 & $\begin{array}{c}4 \text { - Coro misto } \\
\text { duplo }\end{array}$ & $\begin{array}{c}53 \text { compassos } \\
\text { binários }\end{array}$ & $\begin{array}{c}\text { Vozes femininas: F2-F3 } \\
\text { Vozes masculinas: F1-F2 }\end{array}$ & $\begin{array}{c}\text { Modo de C } \\
\text { maior/A menor }\end{array}$ & ABCA \\
\hline
\end{tabular}

Letra de C.Paula Barros e música de H.Villa-Lobos (Rio de Janeiro, 1933). Indicação de andamento Movimento de marcha de rancho; de intensidade: ff ; $f z ; p ; m f ; f$; acento > ; $<$

O texto reporta-se ao ciclo do plantio à colheita. Trata-se de canto de exaltação à profissão do lavrador, das benesses do solo brasileiro, da felicidade de quem nasceu brasileiro e pode semear sementes e amor (coração). Da semente à folha, da flor ao fruto e a glória da colheita, a alegria do lavrador renova-se em sua volta para o replantio da semente e no amor ao solo.

A indicação de coro misto duplo, com coro feminino (soprano, meio soprano e meio soprano grave - sopranino, primeiro e segundo contralto) e coro masculino (tenorino, primeiro e segundo tenor, barítono e baixo), seria o mesmo que indicar para vozes iguais. Na verdade, a peça é para três vozes, e não quatro, como indicado, com exceção da primeira parte que apresenta um pequeno pedal, justificando somente ali uma quarta voz. 
A primeira parte é sustentada por pedal sobre o primeiro grau (em notas longas nas vozes mais aguda e mais grave por quatro compassos) e, articulado na voz mais grave termina no penúltimo compasso. A melodia consta de uma frase repetida quatro vezes em terças paralelas nas vozes superiores. O último compasso apresenta uma ponte de ligação para a segunda parte, que desenvolve o ritmo da marcha rancho nas três vozes.

A segunda parte apresenta sequências descendentes por graus conjuntos de tríades em movimento direto e terminações ascendentes das frases, exceto a última que termina terça abaixo, na tônica relativa, introduzindo o novo tom da terceira parte, a duas vozes.

A melodia, na terceira parte, está na segunda voz em contraponto com a primeira voz, com imitação sexta acima. No quarto compasso desta parte há um divisi para terceira e segunda voz.

A densidade da peça é determinada pela variação no número de vozes em cada parte. A última parte fala do replantio, portanto a volta à primeira parte expressa o renovo da alegria ali representada.

\section{7) MARCHA PARA O OESTE - a capella}

\begin{tabular}{|c|c|c|c|c|c|c|}
\hline Volume & № & Vozes & Extensão & Tessitura & Tonalidade & Forma \\
\hline CO2 & 27 & 3 & $\begin{array}{c}\text { 43 compassos binários } \\
\text { (subdivisão ternária) }\end{array}$ & $\begin{array}{c}\text { 1a voz: G2-E4 } \\
\text { 2a voz: G2-C4 } \\
\text { 3a voz: G2-G3 }\end{array}$ & $\begin{array}{c}\text { Modo C } \\
\text { maior }\end{array}$ & A B A \\
& & & & & \\
\hline
\end{tabular}

Letra de J. Sá Roris e música de Vicente Paiva, com arranjo de H. Villa-Lobos. Embora não haja indicações, a obra é propícia a grandes possibilidades de gradações de intensidade. $\mathrm{Na}$ primeira parte, por exemplo, cabe um início em $\boldsymbol{m} \boldsymbol{f}$, crescendo nas aberturas dos acordes e na frase final. Na segunda parte, pode-se iniciar em $\boldsymbol{p}$ e crescer até o final.

A parte A propõe linhas ascendentes com finais descendentes (com exceção do final da última frase, que termina com salto ascendente). $\mathrm{O}$ critério é o mesmo na parte $\mathrm{B}$, porém o plano de alturas segue em crescendo por saltos de quinta, por cromatismo até retomar a dominante para o ritornello.

Não há pausas em toda a peça. Os cortes acontecem apenas nos finais de frases para respiração.

Nas sequências cromáticas da segunda parte, a linha ascendente reforça e valoriza o texto, provocando entusiasmo e euforia. O movimento paralelo das tríades e os cromatismos interferem no plano timbrístico, tanto quanto as duas vozes graves que se apresentam para dobrar uma das vozes superiores a partir do décimo sétimo compasso.

Alternando harmonia estreita (predominante) e larga em momentos estratégicos, enriquecida com cromatismos e sequências combinadas, a harmonização valoriza a melodia e o tema. 
8) A SANFONA - a capella

\begin{tabular}{|c|c|c|c|c|c|c|}
\hline Volume & № & Vozes & Extensão & Tessitura & Tonalidade & Forma \\
\hline $\mathrm{CO} 2$ & 28 & 4 & $\begin{array}{c}20 \text { compassos } \\
\text { binários }\end{array}$ & $\begin{array}{l}\text { 19 voz: A-C\#4 } \\
\text { 2a voz: E3-D4 } \\
\text { 3a voz: E3-A3 } \\
\text { 4a voz: A2-E3 }\end{array}$ & $\begin{array}{c}\text { Modo de } \mathrm{A} \\
\text { maior }\end{array}$ & $A B$ \\
\hline
\end{tabular}

Cateretê à moda paulista, com letra e melodia de Henriqueta M. d'Abreu, ambientado por H.Villa-Lobos.

A julgar pela letra, pode enquadrar-se como música de trabalho na agricultura. O texto faz menção aos mutirões de trabalho coletivo na colheita do café, quando, depois do trabalho, se realizavam bailes até amanhecer o dia. Versos eneassilábicos até "raiá", seguidos de outro que se repete duas vezes, octossilábico, após o qual seguem versos de métrica variada, de 14 e de 16 sílabas, encerrando com vocalizações cuja função é preencher os espaços melódicos.

Melodia e harmonia giram em torno do movimento harmônico de T/D - em alusão ao movimento do fole ${ }^{71}$ da sanfona. A execução em B.C. nas três vozes inferiores, em harmonia estreita tem objetivo de imitar o timbre dos baixos da sanfona.

Na primeira voz, as pausas são de natureza rítmica, para formação de motivos. Nas vozes graves, as frases se repetem por duas vezes cada. A coda, a três vozes, sobre a palavra $A i$ ! também alterna D T terminando com acorde a quatro vozes.

9) PRA FRENTE, Ó BRASIL (Canção Marcial) - a capella

\begin{tabular}{|c|c|c|c|c|c|c|}
\hline Volume & № & Vozes & Extensão & Tessitura & Tonalidade & Forma \\
\hline $\mathrm{CO} 2$ & 32 & 3 & $\begin{array}{c}128 \text { compassos binários } \\
\text { (subdivisão ternária) }\end{array}$ & $\begin{array}{c}\text { 1a voz: F\#3-G4 } \\
\text { 2a voz: Bb2-G4 } \\
\text { 3a voz: A2-C4 } \\
\text { 4a voz: F2-C3 }\end{array}$ & $\begin{array}{c}\text { Modo de } \\
\text { Bb maior / } \\
\text { G menor }\end{array}$ & $\begin{array}{c}\text { Rondó } \\
\text { ABACADA }\end{array}$ \\
\hline
\end{tabular}

Marcha, para coro feminino, composição de H. Villa-Lobos. Indicação de intensidade: $f \boldsymbol{f}$; $\boldsymbol{s} \boldsymbol{z}$; $f$; acentos >

Letra de exaltação à pátria, em todas as suas belezas e elementos característicos, de métrica variada, escrita de modo a sugerir uma longa caminhada, por meio da apresentação desses elementos de modo sequencial: caminhos inóspitos (pela terra ao sol de rachar); cidades (estrada de concreto), litorais (mares) e assim por diante, além de ser uma exaltação ao serviço militar. Por não ser propriamente adequada para coro feminino, uma opção viável para o aproveitamento da peça seria substituir o texto por sílabas neutras.

Rondó, a parte A é curta e em uníssono em oitavas. Seu texto, "Pra frente, ó Brasil”, varia na terceira vez: "Pra frente, ó brasileiros". A parte B, a três vozes, consiste em movimentos recorrentes a cada pulso de $\mathrm{T} \mathrm{D}$. Na parte $\mathrm{C}$, um contraponto a duas vozes com a melodia na voz inferior por linhas descendentes e cromatismos, seguido de uma codeta, a três vozes, com elementos da parte $\mathrm{A}$, com recorrência das funções $\mathrm{T} / \mathrm{S}$. A parte $\mathrm{D}$, no tom relativo menor, a duas vozes, tem a melodia na primeira voz (com sequências de pentacordes e hexacordes defectivos descendentes, por graus conjuntos), em polirritmia ( $3 \times 2)$ com a segunda voz. Ao

\footnotetext{
${ }^{71}$ N.A. Alguns tipos de fole determinam, pelo direcionamento de abrir ou fechar, a mudança quinta acima dos sons correspondentes às teclas ou botões acionados.
} 
final, após a parte A, uma pequena coda (2 compassos) encerra a peça com uníssono, sobre a sílaba "Si", coincidindo com as notas entoadas $(\boldsymbol{B} \boldsymbol{b})$.

A densidade sonora da peça está atrelada à diminuição e acréscimo das partes.

10) O TRENZINHO - a capella

\begin{tabular}{|c|c|c|c|c|c|c|}
\hline Volume & № & Vozes & Extensão & Tessitura & Tonalidade & Forma \\
\hline $\mathrm{CO} 2$ & 31 & 4 & $\begin{array}{c}66 \text { compassos } \\
\text { binários }\end{array}$ & $\begin{array}{l}\text { 1a voz: C3-E4 } \\
\text { 2a voz: G2-E4 } \\
\text { 3a voz: G2-E4 } \\
\text { 4 voz: G2-A3 }\end{array}$ & Modo de & $\begin{array}{l}\text { Introdução } \\
\text { A A' A Coda }\end{array}$ \\
\hline
\end{tabular}

Letra de Catarina Santoro e música de H.Villa-Lobos. Indicação de andamento Lento (muito piano, seco e pouco a pouco stringendo); allarg. e dim. pouco a pouco; de intensidade Muito piano / diminuindo pouco a pouco; $p p-p-m f-f-m f-p-p p$

O texto, com duas estrofes de seis versos de sete sílabas, com rima nos segundo e quinto versos, fala de uma visita à casa da avó, da viagem de trem a vapor, da subida da serra e da velhinha de saia pintadinha.

A grande importância da peça está no seu plano timbrístico, direcionado à reprodução sonora de trenzinho a vapor, com sua "Maria Fumaça". O texto, descritivo, presta-se a esse objetivo em trechos como "Vamos, vamos bem depressa - em semicolcheias"; "vai o trem subindo a serra" - em colcheias e mínimas, por exemplo. Outros elementos: os apitos - cromatismos; Stringendo na introdução e allargando na coda. Os ostinatos sobre as sílabas: caxacata / Caxaca / ta! xacatac / Tá! Caxata / Ta! / Ca! / Tchxa! / Tchxx! / Um! / Do (uma única vez, surpreendentemente ${ }^{72}$, na última nota $-\boldsymbol{C}$ ).

Em realidade, a peça é para três vozes, havendo divisi na segunda voz em apenas quatro compassos. A densidade sonora varia de acordo com a as entradas e finais das partes.

Todas as vozes participam do ostinato, sendo que a primeira e a segunda expõem a melodia, separadamente e em dueto. Toda a peça baseia-se na tríade de $\boldsymbol{C}$ maior, com pequenas nuanças em $\boldsymbol{A}$ menor.

Os "apitos", terças cheias cromáticas, precisam de um trabalho específico, tanto pelo cromatismo, como pelo trítono causado pela primeira nota.

Trata-se de uma obra especial, que desenvolve a concentração, memória, criatividade (no caso dos ostinatos), em que o regente pode transformar uma peça simples quanto à melodia e harmonia, em música de concerto, com toda a sua riqueza agógica, timbrística e de intensidade.

11) AS COSTUREIRAS - a capella

\begin{tabular}{|c|c|c|c|c|c|c|}
\hline Volume & № & Vozes & Extensão & Tessitura & Tonalidade & Forma \\
\hline $\mathrm{CO} 2$ & 33 & $\begin{array}{c}4 \\
\text { femininas }\end{array}$ & $\begin{array}{c}54 \\
\text { compassos } \\
\text { quaternários }\end{array}$ & $\begin{array}{c}\text { 1a voz: C3-Ab4 } \\
\text { 2a voz: Ab2-D3 } \\
\text { 3a voz: G2-Bb3 } \\
\text { 4a voz: F2-F3 }\end{array}$ & $\begin{array}{l}\text { Modo de } \\
\text { Eb maior / } \\
\text { C menor }\end{array}$ & $\begin{array}{c}\text { Opção 1: } \\
\text { A B AC Codeta A Coda } \\
\text { Opção 2: } \\
\text { Introdução AB Coda }\end{array}$ \\
\hline
\end{tabular}

\footnotetext{
${ }^{72}$ Esses pequenos detalhes sugerem a ludicidade presente na atividade composicional em Villa-Lobos.
} 
As Costureiras tem sido interpretada e gravada ao longo do tempo por vários $\operatorname{coros}^{73}$, femininos e infantis e foi gravada também entre as peças que compõem o Álbum n. 1 - música nas escolas brasileiras, uma série de 10 discos de $78 \mathrm{rpm}$ em $25 \mathrm{~cm}$ (10 polegadas), gravados em 1940 e distribuídos pela $\mathrm{RCA}^{74}$. Villa-Lobos divulgava esses discos em suas viagens, segundo comenta ${ }^{75}$ a professora que regeu a peça na citada gravação, Francisca de Miranda Freitas:

O Maestro, plenamente satisfeito com a gravação de Costureiras, levou o disco em sua viagem pela Europa, dando-me a honra de enviar de lá um postal em que dizia: "Costureiras tem feito sucesso!” (Brasiliana n.23, Rio de Janeiro, 2006. In: Presença de Villa-Lobos, vol. 1)

É, talvez, uma das mais elaboradas peças corais que Villa-Lobos inseriu em sua coleção didática. São quatro minutos que remetem a um ambiente da época, quando, em quase todos os lares, havia uma máquina de costura, cujos sons ficaram na lembrança, assim como os das velhas Marias Fumaças. Trata-se de uma peça para coro feminino a quatro vozes, em meio às canções destinadas a incentivar o trabalho, a enaltecer as profissões, numa época, em que, através do decreto do Estado novo, buscava-se a produtividade operária em alta escala. Segundo Galinari (2007):

Com o decreto do Estado Novo, o processo de industrialização tornar-se-ia mais acentuado, devido à crescente aproximação entre burguesia industrial e governo federal. [...] a arrancada urbano-industrial exigiria uma massa disponível, disciplinada e pré-disposta para o trabalho. Sendo assim, no plano social, foram consideradas algumas antigas reivindicações da classe operária, através de toda uma legislação trabalhista, previdenciária e sindical. Para viabilizálas, a primeira atitude do governo foi criar o Ministério do Trabalho, Indústria e Comércio, já em novembro de 1930.

Assim, a peça As costureiras foi dirigida à classe de profissionais que passariam então a compor os quadros das novas fábricas de confecções. Seu texto visa à assimilação e adesão à mensagem política otimista de melhores condições sociais e econômicas para a profissão, desde que as costureiras deixassem o trabalho individual para se integrar no conjunto das modernas 'peças fabris', com produção em larga escala.

Do gênero popular, baseada no ritmo folclórico nordestino embolada ${ }^{76}$, o elemento que mais se aproxima do mesmo é o ostinato, que mantém em quase toda a obra o ritmo em quatro semicolcheias (fazendo, provavelmente, o papel do acompanhamento do pandeiro, instrumento utilizado pelos cantadores de embolada), ininterruptamente, com ênfase no quinto grau da tônica em modo maior, com característica declamatória.

\footnotetext{
${ }^{73}$ Existem gravações em outros países como, por exemplo: Estados Unidos (Washington University's Chamber Singers ; Eesti Koorijuhtide Naiskoor - Eesti Raadio, Estônia, dirigido por Ants Söt, 1995), Argentina (há uma gravação da peça registrada em fita magnética pelo Prof. Dr. Marcos Júlio Sergl, da década de 80, interpretada pelo Coro de Niños de Córdoba), entre outras.

${ }^{74}$ Brasiliana n. 23, Rio de Janeiro, 2006. In: Presença de Villa-Lobos v.1.

${ }^{75}$ Segundo Flávio Silva, na mesma obra, pode haver um engano em relação à origem da correspondência citada, que possivelmente seria Montevidéu ou Buenos Aires.

${ }^{76}$ Embolada, segundo o Dicionário Cravo Albin da Música Popular Brasileira: Gênero musical que teve origem no Nordeste brasileiro, aparecendo mais freqüentemente na zona litorânea e mais raramente na zona rural, suas características principais incluem uma melodia mais ou menos declamatória, em valores rápidos e intervalos curtos. O gênero é simples e não possuiu qualquer composição preestabelecida, quanto ao número e disposição dos versos. Um estribilho é repetido, num intervalo maior ou menor por um dos cantadores, enquanto o outro improvisa. A letra é geralmente cômica, satírica ou descritiva. O texto, com freqüência, é alterado com aliterações e onomatopéias.
} 
Ainda remetendo à embolada, está presente também um pequeno refrão entre as partes: Com $a$ alma a chorar, alegre a sorrir. Embora não tendo caráter de improvisação nem de sátira, o texto é descritivo, o que consiste em uma das possibilidades na composição da embolada.

Sobre a letra, a métrica é irregular, com predominância de versos decassílabos:

\author{
Com a alma a chorar, cantando a sorrir \\ Cantando seus males, as costureiras somos nesta vida \\ Até amores unimos à linha, nós trabalhamos sempre alegres na lida \\ Como alguém que adivinha o belo futuro que nos vai sorrir \\ Com a alma a chorar, cantando a sorrir \\ Cose, cose, cose costureira, cose a manga, a blusa, a saia, \\ cose co' interesse e mostra-te faceira, bem faceira a quem provares \\ o ponteado, o alinhavado, o costurado, o chuliado (sic), o preguiado (sic), \\ Ah! Larila lálalala lalalala lá! \\ Cose, cose, cose costureira, cose a manga, a blusa, a saia, \\ cose co' interesse e mostra-te faceira, bem faceira a quem provares \\ o ponteado, o alinhavado, o costurado, \\ Ah! Larila lálalala lalalala lá! \\ Com a alma a chorar, cantando a sorrir
}

Sobre um ostinato rítmico-harmônico, que sugere o trabalho incessante da máquina de costura, o texto é objetivo em sua tarefa de convencer. As três primeiras frases dizem respeito à condição emocional das costureiras - Com alma a chorar, alegre a sorrir, cantando seus males. Note-se que a primeira sílaba do texto (Com...) inicia-se na sétima da dominante, acorde muito presente na música nordestina, o que confirma a inspiração do autor no gênero embolada, e que a segunda sílaba da palavra sorrir repousa na terça do acorde de tônica, compondo um salto ascendente de sexta maior, remetendo à amplitude desse ato (um amplo sorriso).

As três frases seguintes são um depoimento do conformismo das personagens com esse estado emocional - As costureiras somos nesta vida, até amores unimos à linha; nós trabalhamos sempre alegres na lida! A linha melódica (que partiu inicialmente de $\boldsymbol{D b}$ 4) alcança seu novo ponto mais agudo na nota $\boldsymbol{E} \boldsymbol{b} 4$, enfatizando a palavra costureiras. Novo ponto culminante em F4 para a palavra amores, realçando um componente emocional muito importante no imaginário feminino.

Uma passagem em linha descendente do ostinato para a dominante relativa (passando da quarta para a terceira voz e novamente para a quarta voz) implica em mudança timbrística e de plano de intensidade como preparação para os dois versos seguintes, que apontam para uma esperança de mudanças - como alguém que adivinha o belo futuro que nos vai sorrir.

Alternando-se as funções de $\boldsymbol{C m}$ e sua subdominante $\boldsymbol{F m}$ com sexta maior, chega-se ao ponto culminante da peça com a nota $\boldsymbol{G} 4$ na estratégica palavra futuro, seguindo-se a repetição nos vai sorrir como reforço da idéia e retorno à dominante da tonalidade principal. Na repetição do refrão Com a alma a chorar, alegre a sorrir, desta vez a segunda sílaba da palavra sorrir permanece na quinta da tríade da tônica (compassos 30-31), antevendo o desfecho final 
quando, na última repetição terminará quarta acima na fundamental da tônica (compassos 52$53)$.

Voltando o comentário para o andamento mais rápido, Muito Animado, os próximos seis versos contêm a mensagem principal, sempre no imperativo e com reforço nas repetições de palavras chave e das frases:

"Cose, cose, cose costureira, cose a manga, a blusa, a saia;

cose com interesse e mostra-te faceira,

bem faceira a quem provares o ponteado,

o alinhavado, o costurado, o chuleado, o pregueado".

Expressões em língua portuguesa começavam a substituir os termos italianos com os compositores chamados nacionalistas, como Villa-Lobos e alguns de seus contemporâneos. A expressão 'Muito Animado' pode ser entendida como um estado de espírito muito próprio do povo brasileiro, podendo associar-se à animação do Carnaval, por exemplo. A esse respeito, Villa-Lobos disse: "Pode parecer ridicula a frase: 'Todo o Brasil deve cantar'. No entanto, o Brasil inteiro canta no Carnaval, essa festa rica de ritmos e alucinante ${ }^{77}$.

A mudança de ânimo aparece no início de uma nova seção da obra, justamente para apresentar a idéia mais relevante do texto, que está relacionada ao pensamento institucional (valorização do trabalho e da profissão). A alteração do andamento neste trecho consiste numa indicação subjetiva do autor, que resulta numa interpretação mais rápida e alegre. Colaboram para tanto o alargamento do ostinato de semicolcheias para semínimas, calando o pandeiro com sua marcação de controle silábico, a intensidade forte, bem como a sequência de tríades em primeira inversão em movimento paralelo, atraindo toda a atenção para o texto (esse recurso já fora usado nos compassos 11 a 20, mas com o pedal de tônica, o ostinato nas terceira e quarta vozes, e o andamento mais lento, o efeito é diferente).

A finalização com cromatismos como elemento novo a valorizar agora a primeira voz, destaca as alegres tarefas da costureira, como principal personagem no contato com seu cliente.

Após uma ponte escalar em terças e ainda como reforço do texto, embora ligeiramente abreviado, repetem-se os imperativos Cose, cose, cose, cujas repetições lembram cantos de trabalho rural, indicando os movimentos corporais cíclicos e recorrentes durante a jornada diária.

O trecho finaliza com os acordes agora em novas posições, mantendo-se as mesmas funções, para chegar à repetição da ponte escalar em terças e retorno ao tempo primo.

A última repetição do refrão, cujas frases já foram analisadas anteriormente, retoma o primeiro tempo - com alma a chorar, alegre a sorrir, ou seja, a idéia inicial da mulher forte diante de dificuldades. Essa recorrência é um reforço, um último argumento apelativo às mulheres para o novo campo profissional nas fábricas, como já citado.

Quanto à prosódia, a adaptação do texto à musica apresenta pequenos problemas, que podem ser contornados pelo realce da articulação em acentos tônicos das palavras: somos

\footnotetext{
77 PRESENÇA DE VILLA-LOBOS. Brasília, MEC, DAC, MVL. 1972. p.89. v.7.
} 
(compasso13) e belo (compasso23); a frase não confortável: o belo futuro que nos vai sorrir (compasso 23-24) - com indicação, inclusive de uma respiração após a palavra futuro

Há problemas também no compasso 44, no encaixe texto / ritmo: provares o / colcheia pontuada e semicolcheia. Deveria estar repetido o compasso 36, onde o ritmo está correto: colcheia e duas semicolcheias, pois é impossível fazer-se elisão de sílaba com terminação em " $s$ " seguida de vogal.

A melodia é caracterizada por linhas descendentes em sua maioria, com exceção do trecho onde se encontra o ponto culminante (21-24), quando há linhas em curvas convexas.

É recorrente o caráter de arpejo na maioria das frases, como afirmação da característica tonal da peça, nas diversas vozes. Apenas nos compassos 18-19, 39-40 e 46-47 aparecem linhas de caráter escalar nas $1^{\mathrm{a}}$ e $2^{\mathrm{a}}$ vozes.

A extensão das vozes agudas é ampla, como no compasso 23 , onde há um arpejo ascendente de décima na primeira voz e de nona na segunda.

O grau de dificuldade da peça e sua ampla tessitura $(\boldsymbol{F} 2-\boldsymbol{A b} 4)$ ratificam a indicação do autor - coro feminino a quatro vozes. Em catálogos de corais americanos que inserem a edição Schirmer da peça em seus repertórios, a classificação varia entre intermediate e difficult. ${ }^{78}$

Quanto à direcionalidade melódica, são descendentes os finais das frases (compassos 4-20); ascendente em curva (compassos 21, 23); graus conjuntos e notas repetidas (compassos 33-45 e todos os ostinati), talvez em associação à sonoridade resultante dos impulsos do mecanismo da máquina de costurar pela ação do pedal.

O refrão apresenta uma sequência melódica entre $1^{\mathrm{a}}$ (com a alma a chorar) e $2^{\mathrm{a}}$ vozes (alegre a sorrir). Essas vozes agudas alternam a predominância na exposição da melodia.

O tratamento rítmico da peça é rico, dentro do estilo, com grande densidade no sentido vertical, apresentando variações por transição nos finais das partes, sendo que essas alterações de densidade rítmica estão associadas às densidades harmônicas nesses compassos e com finalidade expressiva. As polirritmias tão comuns na música popular brasileira estão presentes em toda a peça. São grupos de 4 semicolcheias ou duas colcheias contra 3 colcheias. Essa polirritmia era comum na época, pois estavam presentes nas marchas e em especial nas marchas-rancho. Portanto, os polirritmos eram familiares e não apresentavam dificuldades de percepção e execução, o que, nos dias de hoje são desafios a serem vencidos.

Não somente pela presença de polirritmos, mas também pelo ostinato, a peça é densa ritmicamente, no sentido vertical. Essa densidade rítmica está relacionada com a densidade harmônica nos compassos 33-38 e 41-47, e com finalidade expressiva nos compassos 36-40 e 43-48.

Sobre a estrutura formal, há duas leituras possíveis e não conseguimos optar por apenas uma delas. Em função disso, mostramos ambas a seguir:

1. num primeiro momento pode-se definir a obra como canção estrófica com refrão: Introdução (1-10) / A (aba - 11-32) / B (33-47) / Coda (48-54)

\footnotetext{
${ }^{78}$ G.Schirmer's Secular Choral Music (1945) - www.villalobos.ca; Southern California Vocal Association - Grade: Difficult. www.scvachoral.org.
} 
2. forma rondó - por se tratar de uma embolada - onde versos e refrão se alternam: A (1-20) / B (21-26) / A (27-32) / C (33-40) / Codeta (41-47) / A (48-54) / Coda (54 - acorde final).

As seções apresentam contrastes determinados por modulação, pela distribuição das vozes pelos elementos rítmicos variados, e pela dinâmica. Os ostinati e pontes são elementos unificadores.

$\mathrm{O}$ andamento está atrelado à estrutura formal, iniciando-se em Allegretto, chega ao Muito Animado e retoma o Allegretto inicial. As variações de andamento são constantes, contendo as expressões: Poco rall.; a tempo; rall. - Tempo $1^{o}$; rall.- Muito animado; string.; poco rall.rall.- String., distribuídas por toda a peça, remetendo ao vai e vem na dinâmica do trabalho à máquina de costura.

O tratamento harmônico é básico na obra. Trata-se de um discurso sobre sextas, enquanto o ostinato é realizado sobre o acorde de Tônica. A tonalidade principal é $\boldsymbol{A} \boldsymbol{b}$ Maior na primeira seção; $\boldsymbol{C}$ menor na seção central, com uma cadência modulatória $(19,20)$ e retorno para $\boldsymbol{A} \boldsymbol{b}$ Maior. A idéia do ostinato melódico, em segundas maiores, resulta em pedal harmônico. Há alguma variação na densidade harmônica em trechos que valorizam e contrastam o encadeamento (compassos 11-13 / 33-39 / 36 / 41-47 / 54).

Quanto ao plano de intensidades, em relação com as direções melódicas, as indicações são direcionadas a salientar temas melódicos e frases. Há variações por contrastes nas mudanças de elementos rítmicos, reforço de texto e tratamento timbrístico nos compassos: $10(p p)-11$ (mf) / 20 (pp) - 21 (mf) / 27 (pp) - 28 (mf) / 32 ( $p$ e pp) - 33(f) / 46 (f) - 47 (p, pp) / 54 (ff). As variações de intensidade por passagem estão nas mudanças de tonalidades (modulações), solos melódicos - nos ostinati, nos temas melódicos - $p$ ou $p p$ para $m f$. Essas mudanças são usadas para destacar as mensagens textuais e definir os planos. Embora não haja relação direta com as direções harmônicas, há uma ênfase através de acentuações estratégicas de alguns acordes (compassos 31-42, especialmente na quarta voz com o sinal >).

Sobre o aspecto timbrístico, é interessante notar que há uma estreita relação entre mudanças no texto e no tratamento do ostinato, ocasionando grande variedade de timbres. Contribuem também para essa variação, trechos em uníssono entre as vozes com nuanças de dinâmica; distribuição das melodias em solo, dueto, trio e quarteto; melodias oitavadas; dinâmicas de contraste; aparecem alterações na colocação das vozes, como a B.C., resultando em transformação timbrística; indicações de legatto e stacatto. Tudo isso, conjuntamente, corrobora com a idéia de imitação dos sons de uma máquina de costura ao ser manipulada.

Há também consequências timbrísticas decorrentes do trabalho rítmico nas polirritmias, em novos elementos rítmicos (compassos 33-46) e no próprio ostinato - na emissão do

texto e na regularidade das quatro semicolcheias, remetendo ao movimento regular da agulha no tecido.

O uso das pausas é quase sempre timbrístico, no sentido em que elas se instalam por procedimentos de filtragens e certas tendências dinâmicas, não havendo silêncio total indicado em momento algum, talvez mesmo em alusão à própria dinâmica de trabalho numa fábrica em turno contínuo.

Os elementos unificadores empregados na obra, como grandes alinhavos, são os ostinati, as pontes escalares, a tonalidade mantida em um único centro tonal, as recorrências rítmicas e 
melódicas, e a mensagem textual realçada por todos esses elementos. São desafios importantes a regularidade rítmica nos ostinati, principalmente na sua alternância entre as vozes e nas retomadas após indicações como rallentando e mudanças de andamento; a precisão na execução dos polirritmos e da articulação do texto. Da mesma forma, a manutenção da afinação na linha contínua do ostinato, nos momentos de modulação e retomada do tom inicial; a clara definição de arpejos e escalas, principalmente em regiões muito agudas ou graves, em intensidades que vão do $p p$ ao $f f$.

Enfim, são variações estruturais e ornamentais rítmicas, melódicas, harmônicas, de intensidades e timbrísticas, que consistem em um grande desafio para o intérprete - cantor e regente - em fazer de uma peça de 54 compassos uma pequena obra prima.

12) SERTANEJO DO BRASIL - a capella

\begin{tabular}{|c|c|c|c|c|c|c|}
\hline Volume & № & Vozes & Extensão & Tessitura & Tonalidade & Forma \\
\hline CO1 & 27 & 2 & $\begin{array}{c}71 \text { compassos } \\
\text { binários }\end{array}$ & $\begin{array}{c}\text { A2-Eb4 } \\
\text { Nas duas vozes }\end{array}$ & $\begin{array}{c}\text { Modo de } \\
\text { Ab Maior }\end{array}$ & A A A $^{\prime}$ A \\
\hline
\end{tabular}

Samba-canção com melodia e letra de Clóvis Carneiro e arranjo de H. Villa-Lobos. Indicação de andamento Vagaroso e ligado (Marcha lenta)

O texto menciona o sertanejo que se emociona com as belezas naturais que representam as cores da bandeira brasileira, com o canto dos pássaros e com a terra onde reina a riqueza; tem na alma a audácia do tupi, é consciente da grandeza que o cerca, é cavalheiro e hospitaleiro, não é ambicioso e, como o Cruzeiro do Sul, escolhe ser parte desse sertão. A expressão "arapongas teimosos" deveria ser "arapongas teimosas".

Não consta indicação sobre o tipo de acompanhamento que faria a introdução dos oito compassos vazios iniciais.

Na primeira estrofe a melodia está na primeira voz, com contraponto em B.C. na segunda, invertendo a situação na segunda estrofe. Falta a indicação de Boca Fechada no início, aparecendo apenas na segunda estrofe para a primeira voz. Apenas a segunda nota do contraponto é diferente nas repetições.

A coda apresenta uníssono entre as vozes em âmbito de oitava. A peça é complexa para coros principiantes e adequada para vozes adultas. 
13) VIRA - a capella

\begin{tabular}{|c|c|c|c|c|c|c|}
\hline Volume & № & Vozes & Extensão & Tessitura & Tonalidade & Forma \\
\hline CO2 & 40 & 5 & 51 compassos & 1a voz: Eb3-F4 & Modo de & A B \\
& & & binários & 2a voz: Eb3-Ab3 & Ab maior & \\
& & & (subdivisão & 3a voz: Eb3-Eb3 & & \\
& & & ternária) & 4a voz: Ab2-Db3 & & \\
& & & & 5a voz: Ab2-Bb2 & & \\
\hline
\end{tabular}

Popular português, recolhido e ambientado por H. Villa-Lobos. Sem indicação de andamento, com indicação de intensidade $\boldsymbol{f}$; acentos $>$

As quatro vozes inferiores formam o ostinato rítmico, com a harmonia sobre $\mathrm{T}$ e $\mathrm{D}$, reportando à concertina ${ }^{79}$. A primeira voz apresenta a melodia - na parte $\mathrm{A}$, a primeira frase, pentacordal, é variada na repetição, o mesmo acontecendo na parte B. Os ornamentos em apojaturas duplas resultam em sons longos com função de pedal.

A letra é de inspiração religiosa. O texto do ostinato remete ao sotaque português, com as sílabas e palavras: Lá! ; Larilá! ; Ah! ; A última palavra, da coda, Prrrrlim! é inusitada, parecendo querer imitar uma campainha.

14) PÁTRIA - a capella

\begin{tabular}{|c|c|c|c|c|c|c|}
\hline Volume & № & Vozes & Extensão & Tessitura & Tonalidade & Forma \\
\hline $\mathrm{CO} 2$ & 34 & $\begin{array}{c}4 \\
\text { femininas }\end{array}$ & $\begin{array}{l}38 \text { compassos } \\
\text { quaternários }\end{array}$ & $\begin{array}{c}\text { 1a voz: Bb2-Bb4 } \\
\text { 2a voz: Bb2-F4 } \\
\text { 3a voz: A2-D3 } \\
\text { 4a voz: F2-D3 }\end{array}$ & $\begin{array}{c}\text { Modo de Bb } \\
\text { Maior }\end{array}$ & A B A' Coda \\
\hline
\end{tabular}

Letra de F. Haroldo e música de H. Villa-Lobos (Rio de Janeiro, 1932). Indicações de andamento ao longo da peça: Meno ; Maestoso; rall

O compasso poderia ser 12 por 8 , ou 4 pela semínima pontuada, o que evitaria a grande poluição visual das indicações de tercina. Falta a indicação de andamento na parte A.

Embora haja a indicação 'a quatro vozes', na grande maioria a harmonização é para duas vozes. Nos finais de frase os acordes são a quatro vozes, mas em quase toda a obra as vozes intermediárias dobram a demais.

Há grande uso de cromatismos estruturais, o que indica a exploração de funções secundárias.

A melodia caracteriza-se por arpejos descendentes quebrados seguidos de elementos escalares ascendentes. A tessitura do soprano é muito aguda, o que leva a indicação da peça para vozes adultas.

15) ABOIOS - a capella

\begin{tabular}{|c|c|c|c|c|c|c|}
\hline Volume & № & Vozes & Extensão & Tessitura & Tonalidade & Forma \\
\hline CO2 & 16 & 2 & $\begin{array}{c}36 \text { compassos } \\
\text { ternários }\end{array}$ & $\begin{array}{c}\text { 1' } \text { a voz: F3-Fb4 } \\
\text { 2a voz: F3-Eb4 }\end{array}$ & $\begin{array}{c}\text { Modo misto } \\
\text { de F }\end{array}$ & AB \\
\hline
\end{tabular}

\footnotetext{
${ }^{79}$ Verificar nota anterior correspondente à análise $n^{\circ} 8$ (A sanfona).
} 
Aboios sobre temas ameríndio-mestiços do Rio Amazonas, recolhido e ambientado por H.Villa-Lobos (Rio de Janeiro, 1935). Indicação de andamento Allegretto $(\mathbf{1 6 8}=\mathrm{J}$ ); de intensidade: $\boldsymbol{p}$; Acentos $>$ _ sfz

Sem modo definido, o início sugere $\boldsymbol{F}$ menor, a seguir modo mixolídio defectivo de $\boldsymbol{D} \boldsymbol{b}$, cromatismos, $\boldsymbol{A} \boldsymbol{b}$ maior, cromatismos e finalização em uníssono em $\boldsymbol{F}$. A primeira parte caracteriza-se pelas terças melódicas e harmônicas, graus conjuntos e cromatismos; a segunda parte pelas quintas e quartas, terças, graus conjuntos e cromatismos. A coda apresenta uma complexa linha cromática em glissando.

A melodia baseia-se em intervalos de terças na primeira parte, e na segunda parte em quintas e quartas.

Na segunda parte o ritmo é mais movimentado e o plano timbrístico é enriquecido pelos acentos e as sílabas: Nan; $\hat{E} ; E h !$, tanto quanto pelo glissando final.

16) EVOCAÇÃO - a capella

\begin{tabular}{|c|c|c|c|c|c|c|}
\hline Volume & $\mathrm{N}^{\circ}$ & Vozes & Extensão & Tessitura & Tonalidade & Forma \\
\hline $\begin{array}{c}\mathrm{CO} 2 / \\
\mathrm{S} 2\end{array}$ & $\begin{array}{c}21 / \\
17\end{array}$ & 2 & $\begin{array}{c}42 \text { compassos } \\
\text { binários }\end{array}$ & $\begin{array}{c}\text { 1ㅁ voz: Eb3-F4 } \\
2^{\text {a }} \text { voz: C3-Eb4 }\end{array}$ & $\begin{array}{c}\text { Modo eólio de } \\
\text { Eb }\end{array}$ & $\mathrm{A}$ \\
\hline
\end{tabular}

Sobre temas ameríndios do solo do Amazonas, ambientado por H. Villa-Lobos. Indicação de andamento: Andantino; de intensidade: $\boldsymbol{m f}$; acentos >

Esta peça consta em $\mathrm{S} 1 \mathrm{n}^{\circ} 17$, em que, no compasso 18 falta um bequadro na primeira nota da segunda voz, porém contém a fórmula de compasso ternária para os três últimos compassos, inexistente em $\mathrm{CO} 2 \mathrm{n}^{\circ} 21$.

Dividida em cinco frases que se repetem: a primeira delas é ligeiramente variada na segunda frase, a terceira é se apresenta terça abaixo, a quarta e a quinta são repetições integrais da primeira, a última abreviada na finalização.

Toda a peça está em B.C., o que traz certa complexidade, principalmente nas notas agudas e acentuadas. $\mathrm{O}$ contraponto, na segunda voz, é iniciado com um intervalo de sétima menor, há cromatismos, os compassos são alternados e o ritmo apresenta síncopas e notas pontuadas esses são detalhes que tornam relativamente difícil a execução, mas, ao mesmo tempo, consistem em desafios importantes para o bom desenvolvimento de grupos corais.

17) INVOCAÇÃO EM DEFESA DA PÁTRIA - a capella

\begin{tabular}{|c|c|c|c|c|c|c|}
\hline Volume & № & Vozes & Extensão & Tessitura & Tonalidade & Forma \\
\hline CO2 & 45 & 4 & 40 compassos & Solo: G3-A4 & Modo de & A A' $^{\prime}$ \\
& & & quaternários & 1a voz: E3-A4 & G menor & \\
& & & & 2a voz: D3-D4 & & \\
& & & & 3a voz: Bb2-A3(D4) & & \\
& & & & 4a voz: G2-G3(D4) & & \\
\hline
\end{tabular}

Cívico-religioso, com letra de Manuel Bandeira e música de H. Villa-Lobos (Rio de Janeiro, 1943). Não há indicação de andamento, mas de intensidades: $\boldsymbol{f} ; \boldsymbol{f f}$

Existe um acompanhamento instrumental para a peça, que não consta na edição.

O solo, que entra na repetição da peça, tem características de recitativo, com eventuais saltos de oitava. Note-se os inícios acéfalos de todas as frases. O coro apresenta a melodia no 
soprano, com linhas ondulantes, tendo a frase final em linha ascendente por arpejo. O solo intervém com recitativos, sobre a base harmônica, sempre em regiões muito agudas.

A expressão: "de uma raça livre" apresenta a palavra livre em uníssono oitavado, timbre contrastante de reforço ao texto; "clarins da aurora" - em arpejos maiores ascendentes - em associação aos próprios instrumentos.

\subsubsection{Vozes mistas}

18) XANGÔ - a capella

\begin{tabular}{|c|c|c|c|c|c|c|}
\hline Volume & No & Vozes & Extensão & Tessitura & Tonalidade & Forma \\
\hline CO2 & 24 & 5 & $\begin{array}{c}20 \text { compassos } \\
\text { quaternários }\end{array}$ & $\begin{array}{c}\text { Soprano: A3-G4 } \\
\text { Contralto: E3-F3 } \\
\text { Tenor: A2-G3 } \\
\text { Barítono: E2-A2 } \\
\text { Baixo: A1-D2 }\end{array}$ & $\begin{array}{c}\text { Modo eólio } \\
\text { de A }\end{array}$ & A Coda \\
\hline
\end{tabular}

Gênero de Macumba de época passada, anônimo, recolhido no Rio de Janeiro e ambientado por H. Villa-Lobos. Indicação de andamento: Animado $(\mathbf{1 2 6}=\mathrm{J})$; de intensidade: $\boldsymbol{f}$; $\boldsymbol{f f}$; acentos >

Texto de procedência de povos africanos, contendo uma quadra de versos em heptassílabo.

A polirritmia é linear na primeira voz, que se ocupa da melodia pentacordal sobre pedais em quintas nas demais vozes sobre as sílabas $A h ! / \hat{E}$. A coda apresenta uma apojatura descendente por quinta em região aguda.

A peça tem uma única seção, com harmonias sobre o primeiro e o quarto graus. Os finais das frases são descendentes, terminando na fundamental e na terça do primeiro grau respectivamente.

19) CANIDE IOUNE - (Sabath) - a capella

\begin{tabular}{|c|c|c|c|c|c|c|}
\hline Volume & № & Vozes & Extensão & Tessitura & Tonalidade & Forma \\
\hline CO2 & 22 & 6 & 31 compassos: & Soprano: G3-E4 & Modo eólio de & A B A' \\
& & Para coro & 6 binários, 21 & Segundo soprano: E3-C3 & E \\
& & misto duplo & ternários e 4 & Contralto: G2-C4 & & \\
& & a seco & quaternários & Tenor: G2-E3 & & \\
& & & & Barítono: E2-A2 & & \\
& & & & Baixo: F\#1-E2 & \\
\hline
\end{tabular}

Sobre tema indígena brasileiro (anônimo) recolhido por Jean de Léry em 1530. Harmonização de H.Villa-Lobos (Rio de Janeiro, 1933). Indicação de andamento Andante / Poco Più Mosso / rit. / a tempo / rit. / a tempo primo; de intensidade: $\boldsymbol{m f}$; pp ; ff ; acentos (>) ; morrendo; $m f$

Tradução de Canide Ioune: Ave amarela. Sabath: Canto elegíaco. Texto em língua indígena brasileira recolhido por Jean de Léry no século XVI, logo após o descobrimento.

Na primeira e terceira partes a melodia apresenta-se em uníssono com pedal no baixo e barítono. Na segunda parte, a seis vozes, a melodia está no soprano e no tenor, em oitavas paralelas, com pedais em oitavas nas vozes intermediárias masculinas e femininas. Os movimentos paralelos conferem à peça aspectos primitivos tribais. 
A peça é rica em elementos interpretativos, sendo recomendada para corais mistos principiantes.

20) TERRA NATAL - a capella

\begin{tabular}{|c|c|c|c|c|c|c|}
\hline Volume & № & Vozes & Extensão & Tessitura & Tonalidade & Forma \\
\hline CO2 & 43 & $\begin{array}{c}4 \\
\text { mistas }\end{array}$ & $\begin{array}{c}12 \text { compassos } \\
\text { quaternários }\end{array}$ & $\begin{array}{c}\text { Soprano: C3-D4 } \\
\text { Contralto: G4-A3 Tenor: } \\
\text { C2-C3 Bodo de F } \\
\text { maior }\end{array}$ & $\begin{array}{c}\text { A Coda } \\
\text { Baixo: }\end{array}$ & \\
\hline
\end{tabular}

Clássico, melodia de W. A. Mozart, palavras em português adaptadas por Honorato Faustino e arranjo de H. Villa-Lobos. Indicação de andamento: Moderato; intensidade: $\boldsymbol{m f}$; < ; pp

Harmonia a quatro vozes mistas, a última frase reduz a densidade ao uníssono, e retoma as quatro partes para a conclusão. Segue-se a coda em B.C., causando contraste timbrístico.

$\mathrm{Na}$ coda a melodia, no soprano, é acompanhada pelas vozes intermediárias com valores mais largos, e as vozes graves apresentam o acompanhamento de baixo de Alberti, com movimento de D T.

21) NA RISONHA MADRUGADA - a capella

\begin{tabular}{|c|c|c|c|c|c|c|}
\hline Volume & № & Vozes & Extensão & Tessitura & Tonalidade & Forma \\
\hline $\mathrm{CO} 2$ & 41 & $\begin{array}{c}4 \\
\text { mistas }\end{array}$ & $\begin{array}{c}27 \text { compassos } \\
\text { binários }\end{array}$ & $\begin{array}{c}\text { Soprano: D3-E4 } \\
\text { Contralto: G2-C4 } \\
\text { Tenor: A2-G3 Baixo: } \\
\text { G1-C3 }\end{array}$ & $\begin{array}{c}\text { Modo de G } \\
\text { maior }\end{array}$ & $A A^{\prime} A$ \\
\hline
\end{tabular}

Clássico, melodia de J. Haydn, palavras de F. Haroldo e arranjo de H. Villa-Lobos. Indicação de andamento Moderato; de intensidade: $\boldsymbol{p}$ - não há indicação de intensidade mais forte em A', mas reaparece $\boldsymbol{p}$ na volta a A. No compasso 38 há uma ligadura incorreta.

Apesar de não ter uma escola estética a que se filie, a poesia está mais próxima ao parnasianismo do século XIX, sendo a imagem da "risonha madrugada" típica do movimento, embora o restante afasta-se da referida escola. O texto é adequado para a faixa etária menor.

O texto é apresentado pelas três vozes superiores, cabendo ao divise no baixo um acompanhamento rítmico sobre a sílaba Tum!

O plano timbrístico abrange a articulação stacatto (indicado por pausas): a sílaba Tum, imitando instrumento percussivo ou um pzicatto, a linha do baixo em legato na parte $\mathrm{B}$, tudo contribuindo para uma leveza na interpretação. 
22) O TAMBORZINHO - a capella

\begin{tabular}{|c|c|c|c|c|c|c|}
\hline Volume & № & Vozes & Extensão & Tessitura & Tonalidade & Forma \\
\hline CO2 & 42 & $\begin{array}{c}4 \\
\text { mistas }\end{array}$ & $\begin{array}{c}18 \text { compassos } \\
\text { binários }\end{array}$ & $\begin{array}{c}\text { Soprano: D3-F4 } \\
\text { Contralto: C\#3-Bb3 } \\
\text { Tenor: G2-F4 } \\
\text { Baixo: A1-D3 }\end{array}$ & $\begin{array}{c}\text { Modo de } \\
\text { D menor }\end{array}$ & ABA \\
& & & $\begin{array}{c} \\
\end{array}$ & & &
\end{tabular}

Clássico, melodia de J. Rameau, palavras em português adaptadas por F. Haroldo, e arranjo de H. Villa-Lobos. Indicação de andamento Moderato; rall. ; fermatas ; rall./ A tempo $1^{\text {o }}$; de intensidade $\boldsymbol{m f} ; \boldsymbol{p}$

A melodia, sempre em uníssono (com divisão em duas vozes apenas nos finais de frase), está distribuída entre contralto e soprano na parte A; no soprano, contralto e tenor em $\mathrm{B}$. $\mathrm{O}$ acompanhamento: no baixo, com divisi, idem no tenor e no contralto. Na parte B, o contralto faz ecos nos compassos 18 e 20.

O acompanhamento está baseado em uma linha do baixo seguida de contratempos nas demais vozes, sobre as sílabas Prrram!; Um!, imitando sons da caixa e do surdo.

A variação dos timbres são causados: pelos contratempos; pelas sílabas utilizadas; pelos dobramentos da melodia, como reforço: em A - soprano reforça a melodia do contralto, em B - contralto e tenor reforçam a melodia do soprano - timbres voz feminina / masculina; imitação de tambores e instrumento melódico (notas longas).

23) ESTRELA É LUA NOVA - a capella

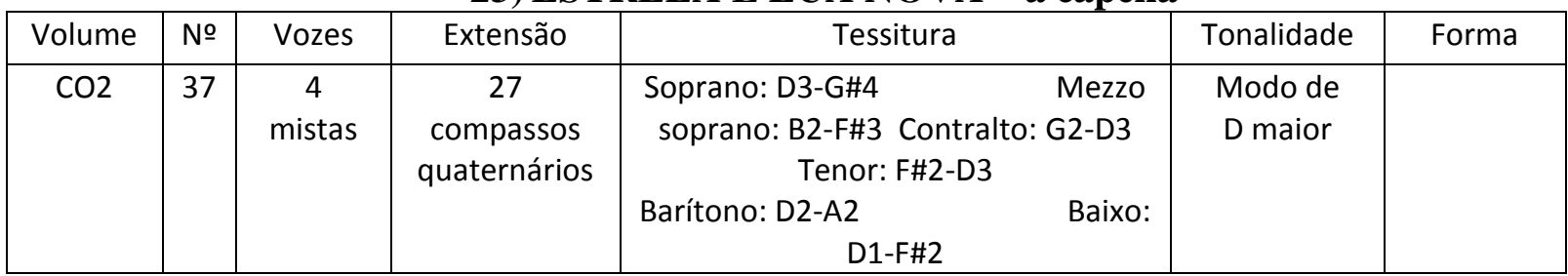

Gênero de macumba de época passada, ambientada por H. Villa-Lobos. Indicação de andamento Poco animato; intensidade $s f z ;$ Acentos $>; f ; p ; p p$. Falta a indicação simile a partir do compasso 4 para o ostinato.

Esta é uma das peças mais conhecidas e executadas por corais dentro e fora do Brasil.

Embora não haja indicação na edição, a melodia é própria para soprano solista, com pequenas intervenções de um contralto solista. O ostinato rítmico está distribuído para três vozes masculinas e duas femininas.

A introdução apresenta o ostinato rítmico, em quatro compassos, com tríades em movimento paralelo por terça descendente, configuração essa que vai se modificar apenas quando há mudanças de funções harmônicas. Os acentos são utilizados para dar ênfase à segunda metade do tempo de cada compasso, caracterizando o ritmo sincopado, que lembra a presença de tambores e dança ritual.

A melodia principal inicia-se no tetracorde superior e termina no tetracorde inferior da escala maior. O soprano utiliza apojaturas de segunda maior e menor, quarta e quinta justas, todas descendentes, interferindo no plano timbrístico. O contralto solista faz o mesmo sobre as sílabas Niá! e Nan!, iniciando o solo com apojatura de segunda descendente. 
A harmonia, expressa no ostinato, oscila entre $\mathrm{T}$ e $\mathrm{Tr}$, até chegar à $\mathrm{D}$ com resolução na $\mathrm{T}$ na primeira parte. A segunda parte é iniciada pela $\mathrm{D}$ da subdominante até resolver na $\mathrm{S}$ e $\mathrm{Sr}$, retornando à $\mathrm{T}$, D e T para finalizar.

Ao final o baixo deve emitir um som $\boldsymbol{f}$, em região muito grave, seguido de $\boldsymbol{p} \boldsymbol{p}$ pelas demais vozes em B.C. e $\boldsymbol{p}$ no solo, com apojatura sobre a palavra Niá!

\section{4) REMEIRO DE SÃO FRANCISCO (Solo e piano ou coro) - a capella}

\begin{tabular}{|c|c|c|c|c|c|c|}
\hline Volume & № & Vozes & Extensão & Tessitura & Tonalidade & Forma \\
\hline CO2 & 44 & 4 & 28 compassos & Solo: F3-F4 & Modo de & A Coda \\
& & Mistas e & quaternários & Soprano: F2-F4 & F maior & \\
& & solo & & Contralto: F2-F3 Tenor: & & \\
& & & & F2-E3 & & \\
& & & & Barítono: C2-C3 Baixo: & & \\
\hline
\end{tabular}

Popular, folclórico, canto dos mestiços do Rio São Francisco da Bahia, recolhido por Sodré Viana e ambientado por H. Villa-Lobos (Rio de Janeiro, 1934). Indicação de andamento Andante (69= J)); de intensidade $\boldsymbol{m f} ; \boldsymbol{p} ;<$; > ; pp ; ppp

O arranjo para solo e coro ou piano, não prevê texto para tenor e baixo. A melodia encaminha-se para a terça da tônica, e é apresentada sobre ostinato sobre a T, com as partes graves evidenciando a tônica maior e as agudas a tônica relativa menor. $\mathrm{O}$ ostinato repousa na $S$ menor ${ }^{7}$ nas vozes graves e maior ${ }^{7}$ nas agudas, para retomar sua configuração inicial para o ritornello. A coda apresenta uma linha cromática na terceira voz, descendente, sobre pedal da T.

A harmonia é recorrente em toda a peça: $\mathrm{D}$ com quinta aumentada e $\mathrm{T}^{6}$. O plano timbrístico inclui especialmente a palavra Shuê! , imitação do som dos remos em movimento na água. Outras sílabas $(O h !)$ e a expressão Lelê Diá!, tanto quanto a B.C. na linha escalar ascendente usada como ponte, são outras determinantes para a variação timbrística.

As modulações abrangem tons afastados. A harmonia desenvolve-se na parte A: na primeira frase, iniciada na tônica em $\boldsymbol{G}$ menor; segue modulação para $\boldsymbol{A}$ menor; na segunda frase, Iniciada na dominante do tom original, chega-se à $\boldsymbol{D}$ menor, imediatamente transformada novamente na dominante original; a terceira frase repete a segunda; $\mathrm{A}^{\prime}$ : a primeira frase repete como em A; a segunda frase parte da tônica para a dominante; a frase final é um grande arpejo em $\boldsymbol{E} \boldsymbol{b}$ maior que termina na dominante original, que resolve na tônica.

Os timbres são ricos, pelos acordes abertos, extensão ampla de tessituras, contrastes rítmicos, apojaturas, modulações, sílaba $A h$ ! e B.C. na segunda execução para suporte ao solo.

25) JAQUIBAU - a capella

\begin{tabular}{|c|c|c|c|c|c|c|}
\hline Volume & № & Vozes & Extensão & Tessitura & Tonalidade & Forma \\
\hline $\mathrm{CO} 2$ & 38 & 6 & $\begin{array}{l}48 \text { compassos: } \\
41 \text { binários, } 4 \\
\text { ternários e } \\
3 \text { quaternários }\end{array}$ & $\begin{array}{l}\text { Solistas - (Contralto: D3-G4; Tenor: B2-A3) } \\
\text { Soprano: D3-E4 } \\
\text { Mezzo soprano: B2-E4 } \\
\text { Contralto: F\#2-A3 } \\
\text { Tenor: D2-E3 } \\
\text { Barítono: D2-G2 } \\
\text { Baixo: G1-E2 }\end{array}$ & $\begin{array}{l}\text { Modo de } \\
\text { G maior }\end{array}$ & $\begin{array}{c}\mathrm{ABA}^{\prime} \mathrm{BA}^{\prime} \\
\text { Coda }\end{array}$ \\
\hline
\end{tabular}

Popular, tema dos negros mina, da época da escravidão no estado de minas Gerais, ambientado por H. Villa-Lobos. Não há indicação de andamento na primeira parte (embora 
haja 'a tempo $1^{o}$ ); Lento (recitativo); A Tempo $1^{o}$; rall. ; um pouco animado; de intensidade: $\boldsymbol{p p} ; \boldsymbol{s f z} ; \boldsymbol{p} ; \boldsymbol{m f} ; \boldsymbol{f}$; $\boldsymbol{c r e s c}$. ;

A letra é um lamento sobre as condições precárias em que viviam os escravos, representados pela figura do Pai João, tanto no que respeita à alimentação quanto à moradia, além de outros padecimentos. Texto misto, em português e idioma africano, com a fonética própria do idioma português mal assimilado pelos escravos, como "pru quê" ou "tá cum fome".

A parte A apresenta dueto de contralto e tenor sobre pedal em oitavas no quinto grau por apojatura superior. O tema é harmonizado em terças com final em sextas, em ritmo sincopado, alternando $\mathrm{D}$ e $\mathrm{T}$. A parte $\mathrm{B}$, em andamento lento, é um recitativo do tenor com acompanhamento harmônico do coro, sobre a sílaba Tum! , sobre as funções de T, S menor, apojaturas, $\mathrm{D}$ secundária em bordadura cromática com término na $\mathrm{D}^{9}$. $\mathrm{O}$ recitativo sobre uma nota e terminação em apojatura superior em segunda menor é repetido três vezes em sequência ascendente terminando com a nona da D.

A' tem a melodia variada, com solo do tenor, em tetracordes descendentes, com acompanhamento harmônico em síncopas sobre as sílabas Dan! ; Um! Uai! . A parte A é retomada com o dueto original, com acompanhamento em ostinato rítmico sobre as sílabas repetidas pelas vozes em dueto em terças, e apojaturas em oitavas sobre o quinto grau no início das duas frases e no final. O ritornello traz novamente a parte B com a segunda estrofe, A' e a Coda, com indicação de andamento mais rápido com dueto entre solistas e vozes femininas sobre pedal em apojatura no quinto grau nas vozes masculinas. O final apresenta nota aguda no primeiro grau pelo tenor seguido de uníssono na mesma nota pelo coro.

O plano timbrístico é determinado pelos solos, duetos, acompanhamento harmônico, pedais, variação de intensidades por contraste: $s f z$ / pp (coro no recitativo) ou passagem (recitativo solo $\boldsymbol{p} \boldsymbol{m f} \boldsymbol{f}$ ). Da mesma forma, as sílabas e palavras: Uai! ; Tum! ; Dan! ; Um! Uh!; Ah! vogais abertas (dan) seguidas de fechadas (Um) e abertas articuladas (uai).

26) BAZZUM - a capella

\begin{tabular}{|c|c|c|c|c|c|c|}
\hline Volume & № & Vozes & Extensão & Tessitura & Tonalidade & Forma \\
\hline CO2 & 39 & $\begin{array}{c}\text { 3 - Coro } \\
\text { masculino } \\
\text { "negreiro" }\end{array}$ & $\begin{array}{c}26 \\
\text { compassos } \\
\text { quaternários }\end{array}$ & $\begin{array}{c}\text { Tenores: I - F2-A3; II - A2-C3 } \\
\text { Barítonos: I - E2-F3; II - C2-D3 Baixo: } \\
\text { F1-Bb2 }\end{array}$ & $\begin{array}{c}\text { Modo de } \\
\text { F maior }\end{array}$ & A B \\
Estrófica \\
\hline
\end{tabular}

Popular, (ensaio para a canção popular), dedicado a Arminda Neves d'Almeida, com letra de Domingos Magarinos e música de H. Villa-Lobos para Coro masculino "Negreiro" (Rio de Janeiro, 1936). Indicação de andamento: Moderato; de intensidade: $\boldsymbol{m f}$; $\langle$; ; pp ; acentos > . A primeira casa para o ritornello é idêntica à segunda casa, sendo esta dispensável. Não há indicação para o ritornello para a terceira estrofe. As ligaduras em notas de alturas diferentes estão inadequadas. O espaçamento demasiado (um compasso por linha) é desnecessário e atrapalha a leitura.

O texto conta a lenda de Bazzum, o feiticeiro, que ateou fogo à fazenda, em oposição à idéia: "negro é sombra, não é gente".

A melodia é apresentada por tenores com acompanhamento a três vozes masculinas, com ostinato rítmico sobre a palavra Bazzum! O ritmo sincopado e pontuado pode ser associado a várias danças de origem africana. 
A parte A inicia-se introdutoriamente com pedal em oitava sobre o quinto grau em apojatura superior pelos tenores, sobre a palavra Auê! Segue a primeira estrofe, em terças sobre o ostinato rítmico, responsável pela apresentação das funções tonais alternando $\mathrm{T}$ e $\mathrm{D}$ na maioria dos compassos, passando pela S, Sr e Dr ao final.

A parte $\mathrm{B}$, iniciada como A com pedal em oitava sobre o quinto grau em apojatura superior sobre as palavras Auê! Hê! , é mais cantada na melodia em oitavas, com sons longos. As frases melódicas consistem em arpejos ascendentes de tríades e tétrade menor, finalizando a frase descendentemente. Uma codeta apresenta novamente a apojatura sobre a palavra Auê! com silêncio no acompanhamento, repetida com o retorno do ostinato para o ritornello. A (segunda estrofe) e B se repetem e a coda, iniciada com pedal, tem o ostinato repetido por três vezes, seguido da mesma apojatura pelos tenores, em pedal para uma linha escalar cromática sobre a sílaba Zum! nas três vozes em âmbito de quinta diminuta, em tríades na segunda inversão, com fermata no terceiro acorde (dominante da Dr), segue crescendo até a nota mais aguda, decrescendo e descendo uma segunda, para a finalização na $\mathrm{T}$ em pianíssimo.

A diversidade de timbres tem como base a palavra Bazzum, presente em toda a peça, criando uma sonoridade específica pelo sibilar da consoante Z. Seguem as alternâncias entre as vozes, no tratamento em terças, oitavas e acordes abertos e fechados, ostinatos e pedais. Destaca-se, pela complexidade, a linha cromática ao final, que exige trabalho a parte para que seja propriamente executada.

Todas as direções melódicas resumem-se em T D T, com exceção de dois momentos em Sr (c.7 e 17).

27) VERDE PÁTRIA - a capella

\begin{tabular}{|c|c|c|c|c|c|c|}
\hline Volume & № & Vozes & Extensão & Tessitura & Tonalidade & Forma \\
\hline CO1 & 26 & $\begin{array}{c}5 \\
\text { mistas }\end{array}$ & $\begin{array}{c}32 \text { compassos } \\
\text { binários }\end{array}$ & $\begin{array}{c}\text { Soprano: Eb3-F4 } \\
\text { Contralto: B2-C4 } \\
\text { Tenor: Eb2-G3 } \\
\text { Barítono: G1-C3 Baixo: } \\
\text { Eb1-C3 }\end{array}$ & $\begin{array}{c}\text { Modo de } \\
\text { Eb M }\end{array}$ & A A' $^{\prime}$ \\
\end{tabular}

Canção cívica, com versos de Humberto de Campos e música e harmonização de Francisco Braga. Indicação de andamento Marcial; de intensidade $\boldsymbol{f} ; \boldsymbol{p}$

O texto é um toque de despertar à nação grandiosa dormente, para que revele ao mundo sua riqueza natural, sua raça (Tupi), pois seus filhos clamam por isso. No compasso 4 há um problema na prosódia: "fun-do" com uma nota para as duas sílabas.

As vozes femininas apresentam um 'toque de clarim' no compasso 15, como pequena ponte para a segunda parte, que se inicia no segundo ponto culminante da peça (o primeiro encontra-se no compasso 7 na mesma altura), com um "grito de despertar" em intensidade forte.

A harmonia apresenta acordes alterados, quintas aumentadas por duas vezes, que constituem dominantes secundárias ou cromatismos que enriquecem o campo harmônico da peça. 
28) PÁTRIA (Hino Orfeônico Brasileiro) - a capella

\begin{tabular}{|c|c|c|c|c|c|c|}
\hline Volume & № & Vozes & Extensão & Tessitura & Tonalidade & Forma \\
\hline $\mathrm{CO} 2$ & 35 & $\begin{array}{c}6 \\
\text { mistas }\end{array}$ & $\begin{array}{c}30 \\
\text { compassos } \\
\text { quaternários }\end{array}$ & $\begin{array}{c}\text { Soprano: Bb2-Bb4 } \\
\text { Mezzo soprano: Bb2-F4 } \\
\text { Contralto: Ab2-Bb3 } \\
\text { Tenor: Bb2-F3 } \\
\text { Barítono: Bb2-D3 } \\
\text { Baixo: E1-D3 }\end{array}$ & Modo de & A B A' Coda \\
\hline
\end{tabular}

Canção cívica, letra de F. Haroldo e música de H. Villa-Lobos (Rio de Janeiro, 1932). Indicação de andamento Magestoso (sic); allarg. ; rall. / a tempo $\mathbf{1}^{\boldsymbol{o}}$; de intensidades: $\boldsymbol{f}$; > ; p cres. pouco a pouco ; ff

O texto enaltece os valores pátrios, como a bandeira, o hino e outros, em que a palavra Brasil é repetida onze vezes, sempre forte e com acorde cheio.

A frase inicial apresenta arpejo descendente e escala ascendente no soprano com movimento contrário no baixo, com interferência responsiva das vozes intermediárias por cinco vezes. A segunda e a terceira frase apresentam-se em terças pelo soprano e baixo, e a última frase é harmonizada a seis vozes. A parte B mantém os responsos sobre a palavra "Brasil". Após o retorno à parte $\mathrm{A}$, ligeiramente variada, uma coda (2 compassos) apresenta um acorde completo com o soprano em região muito aguda seguido de uníssono por oitavas.

O compasso poderia ser 12 por 8 , ou 4 pela semínima pontuada, o que evitaria a grande poluição visual das indicações de tercina. Nos compassos 11,12, aparece uma flecha para indicar o texto do tenor, que deveria ser evitada, com a simples edição do texto no lugar adequado.

O plano timbrístico inclui dois momentos interessantes de imitação do vento (compasso 4) com a sílaba Vuff (com indicação de glissando - partindo de uma pausa), e do mar (compasso $32)$, indicado por notas em losango $(\boldsymbol{G}, \boldsymbol{F}, \boldsymbol{E} \boldsymbol{b})$ com indicação de respiração em $\boldsymbol{f f}$.

A harmonização a seis vozes é mais complexa que as outras peças do volume dois do Canto Orfeônico. Há grande uso de cromatismos estruturais, o que indica a exploração de funções secundárias. A tessitura do soprano é muito aguda, do baixo muito grave, o que implica em que o coro seja experiente e tenha vozes privilegiadas.

29) CÂNTICO DO PARÁ - a capella

\begin{tabular}{|c|c|c|c|c|c|c|}
\hline Volume & № & Vozes & Extensão & Tessitura & Tonalidade & Forma \\
\hline $\mathrm{CO} 2$ & 17 & 3 & $\begin{array}{l}21 \text { compassos: } 6 \\
\text { ternários, } 2 \\
\text { quaternários e } \\
13 \text { binários }\end{array}$ & $\begin{array}{c}\text { 1a voz: F3-Gb4 } \\
\text { 2a voz: C3-Eb4 } \\
\text { 3a voz: B1-C3 }\end{array}$ & Modo de & ABA \\
\hline
\end{tabular}

Tema guerreiro, anônimo, recolhido e ambientado por H. Villa-Lobos (Rio de Janeiro, 1935). Indicação de andamento: Vagaroso $(80=/)$ / Allegro / String.; de intensidade: $\boldsymbol{m f}$; acentos $>/<$.

Sem modo definido, o início sugere modo eólio de $\boldsymbol{C}$ seguido de trecho atonal; a segunda parte as duas vozes inferiores sugerem $\boldsymbol{D}$ menor, enquanto a primeira voz continua sobre o modo inicial, sendo a terminação da parte uma tríade diminuta de $\boldsymbol{C}$ com saltos ascendentes de trítono na primeira e segunda voz para a volta à primeira parte. 
O ritmo é complexo, com polirritmias de 3 e 5x2, com variação de fórmulas de compasso e andamentos diferentes. Há uma seriação no plano de intensidades em combinação com a variação agógica.

Toda a peça é executada em B.C., portanto, recomenda-se um trabalho especial de respiração que possibilite a interpretação de notas repetidas, as variações de intensidade, acentos, notas agudas e outros pequenos detalhes.

A peça é de difícil execução, porém consiste em desafio para coros intermediários.

\subsection{Execução instrumental}

Nos capítulos anteriores foram analisadas as peças vocais que selecionamos para serem executadas a capella ou com acompanhamento instrumental. Além dessas, Villa-Lobos destinou algumas que estão registradas no Guia Prático exclusivamente para piano, e aqui seguem as que sugerimos, além da execução vocal, a instrumental.

A classificação das peças ocorreu segundo os critérios: peças recomendadas pelo autor para piano; peças recomendadas pelo autor para piano ou conjunto instrumental; peças sugeridas para execução instrumental - instrumentos de percussão, cordas ou sopro - para solos ou grupos.

As peças foram selecionadas segundo os seguintes critérios: alto grau de dificuldade técnica - em relação ao público alvo da educação musical; textos de pequeno interesse educacional e musical (outros autores); peças com características instrumentais.

Foram utilizados os seguintes critérios analíticos: número de vozes ou partes; compassos - fórmulas e quantidades; tessitura de cada voz; tonalidade ou modalidade; forma; gênero - segundo a classificação de Villa-Lobos; indicações de andamento; créditos referentes a: autoria de letra e música, arranjo e ambientação; eventuais problemas detectados nas versões consultadas; sugestões de instrumentos para execução

\subsubsection{Para Piano}


1) ACORDEI DE MADRUGADA (II versão - para piano)

\begin{tabular}{|c|c|c|c|c|c|c|}
\hline Volume & № & Instrumento & Extensão & Tessitura & Tonalidade & Forma \\
\hline GP-VTL & 2 & Piano & $\begin{array}{c}26 \text { compassos } \\
\text { binários }\end{array}$ & $\begin{array}{c}\text { m.d.: C3 - F5 } \\
\text { m.e.: F-1 - Ab2 }\end{array}$ & $\begin{array}{c}\text { Modo de } \\
\text { F maior / } \\
\text { F menor }\end{array}$ & A A $^{\prime}$ \\
\hline $\begin{array}{c}\text { Andamento } \\
\text { Gênero }\end{array}$ & $\begin{array}{l}\text { Moderato (60= J) } \\
\text { Peça de salão }\end{array}$ & & \\
\hline
\end{tabular}

Sobre um tema popular infantil, ambientado por H. Villa-Lobos. GP/ABM não apresenta as alterações com bequadro nas duas últimas notas da mão esquerda, como preparação para o retorno em tom maior.

2) ANDA A RODA ( $3^{\text {a }}$ versão - para piano solo)

\begin{tabular}{|c|c|c|c|c|c|c|}
\hline Volume & No & Instrumento & Extensão & Tessitura & Tonalidade & Forma \\
\hline $\begin{array}{c}\text { GP-VTL } \\
\text { /ABM }\end{array}$ & 716 & Piano & $\begin{array}{c}41 \\
\text { compassos } \\
\text { binários }\end{array}$ & $\begin{array}{c}\text { m.d.: Ab2 - Ab5 } \\
\text { m.e.: Db-1 - Db3 }\end{array}$ & $\begin{array}{c}\text { Modo de Ab } \\
\text { maior }\end{array}$ & ABA \\
\hline $\begin{array}{c}\text { Andamento } \\
\text { Gênero }\end{array}$ & \multicolumn{2}{l|}{$\begin{array}{l}\text { Movimento de Marcha (Imponente) - ABM traz Marcha Imponente } \\
\text { Marcha }\end{array}$} \\
\hline
\end{tabular}

Popular, folclore infantil, ambientado por H. Villa-Lobos. Em GP/VTL falta uma clave de $\boldsymbol{F}$ no penúltimo compasso, antes das duas últimas notas da mão esquerda, o que GP/ABM apresenta corrigido.

\subsubsection{Para canto e piano, conjunto instrumental ou piano solo (Peças já analisadas nos capítulos anteriores):}

Guia Prático - VTL: 11, 12, 14, 15, 17, 18, 27, 28, 29, 31, 32, 34, 35, 37, 39, 40, 41, 43, $44,45,48,53,54,55,57,58,61,63,65,66,67,68,69,71,73,74$, $76,77,78,79,84,85,87,88,89,90,91,93,95,98,99,100,102$, $103,107,108,109,111,112,114,117,119,120,125,126,128$, $129,131,132,133,136$.

GP/ABM: 15, 49, 61, 62, 64, 65, 66, 67, 68, 69, 70, 71, 72, 73, 74, 75, 76, $78,79,80,81,82,83,84,85,86,87,88,89,90,91,92,93,94,95,96$, 97, 98, 99, 101, 102, 103, 104, 107, 108, 109, 110, 111, 112, 113, 114, $118,119,120,121,122,123,124,125,126,127,128,129,130,131$, 132, 133, 134, 135, 136, 137.

Canto Orfeônico 2 - 44. Nos volumes de Canto Orfeônico não constam as partes dos acompanhamentos. 
Muitas peças dos cinco volumes aqui pesquisados e não selecionadas para execução vocal poderiam, além se serem executadas por vozes, ser inseridas no repertório instrumental como exercício de leitura, com objetivo de desenvolvimento técnico ou mesmo para execução de cunho artístico.

O próprio Villa-Lobos praticava o exercício que ora propomos, quando utilizava seus temas em várias composições, arranjava peças solísticas para orquestras ou outros tipos de formação instrumental, transformando e recriando sua obra com total liberdade.

Evidentemente, não teríamos autoridade para mudar uma nota sequer do que nos foi legado pelo compositor, mas podemos nos enquadrar dentro de suas sugestões: em muitas de suas peças inseridas nesses volumes pedagógicos constatamos indicações como - solo ou conjunto ou voz, peças a três ou mais vozes com possibilidades de redução das partes, sugestão de criação de texto, omissão de textos em favor de efeitos vocais, enfim, nota-se uma abertura suficiente para ousarmos sugerir usos diferentes para algumas delas.

As peças relacionadas a seguir estão sendo sugeridas para, além de serem aproveitadas para solfejo ou canto, serem executadas por instrumentos. Os motivos de não terem sido selecionadas anteriormente seriam:

- Grau maior de dificuldade - sons muito agudos, intervalos muito amplos, acima de oitavas, ritmos e andamentos muito rápidos, recorrência de dissonâncias, ou outras, considerando o público de capacidade mediana a ser trabalhado no ensino básico e escolas de ensino instrumental.

- Texto ou tema sem interesse pedagógico imediato ou com termos arcaicos.

- Peças que contêm características de música instrumental.

Sendo destinadas somente à interpretação vocal, essas peças seriam utilizadas por um grupo muito reduzido de estudantes. Aproveitadas na leitura instrumental, teria o grande mérito de compor repertórios para alunos principiantes e adiantados com muitas peças de ótima qualidade musical, e seu uso seria bem ampliado. Tornar viável a execução instrumental de peças interessantes musicalmente parece-nos melhor do que a não execução vocal por motivos vários.

Os instrumentos podem ser desde os que comumente estão presentes em salas de aula, como percussão, inclusive metalofones e xilofones, flautas doces, violão e outros, até os das demais famílias de sopro, cordas e teclados.

Os arranjos podem servir a vários objetivos, seja de leitura ou de execução artística. Seguem as sugestões para execução instrumental, independente da participação vocal: 
3) A MAMÃE ESTAVA DOENTE

\begin{tabular}{|c|c|c|c|c|c|c|}
\hline Volume & No & Vozes & Extensão & Tessitura & Tonalidade & Forma \\
\hline GP/VTL & 72 & 1 & 35 compassos binários & D3-D4 & Modo de & Introdução \\
ABM/ & 63 & & & & & ABA \\
& & & & & \\
\hline $\begin{array}{l}\text { Andamento } \\
\text { Gênero }\end{array}$ & \multicolumn{6}{l}{ Poco Moderato (104= J) - (Elegante) / Vivace } \\
\hline
\end{tabular}

Popular, ambientado por H.Villa-Lobos. Indicação: Canto com Piano, conjunto instrumental ou Piano solo.

Sugestão de instrumentos: Piano

\section{4) АTCHÉ}

\begin{tabular}{|c|c|c|c|c|c|c|}
\hline Volume & № & Vozes & Extensão & Tessitura & Tonalidade & Forma \\
\hline $\begin{array}{c}\text { GP/VTL } \\
\text { ABM/ }\end{array}$ & 10 & 2 & 13 compassos binários & $\begin{array}{c}\text { 1a voz: Eb3-Db4 } \\
\text { 2a voz: C3-F3 }\end{array}$ & $\begin{array}{c}\text { Modo de } \\
\text { Ab maior }\end{array}$ & $\begin{array}{c}\text { Introdução } \\
\text { A Coda }\end{array}$ \\
\hline $\begin{array}{c}\text { Andamento } \\
\text { Gênero }\end{array}$ & \multicolumn{2}{l}{$\begin{array}{l}\text { Allegretto }(80=\mathrm{d}) \\
\text { Dança Inglesa }\end{array}$} \\
\hline
\end{tabular}

Popular com arranjo de H.Villa-Lobos, com indicação: Para canto e piano ou conjunto instrumental.

Sugestão de instrumentos: Piano e violinos (transpor para A maior)

5) MAR DO BRASIL

\begin{tabular}{|c|c|c|c|c|c|c|}
\hline Volume & № & Vozes & Extensão & Tessitura & Tonalidade & Forma \\
\hline $\mathrm{CO} 1$ & 38 & $\begin{array}{c}2 \\
\text { (Cânone 4) }\end{array}$ & $\begin{array}{c}133 \\
\text { compassos binários }\end{array}$ & $\begin{array}{c}\text { Uníssono: D3-E4 } \\
\text { 1a voz: D3-G4 } \\
\text { 2a voz: G2-D4 }\end{array}$ & $\begin{array}{l}\text { Modo de G } \\
\text { maior/ E } \\
\text { menor }\end{array}$ & A (cânone) B \\
\hline Gênero & \multicolumn{6}{|c|}{ Marcial } \\
\hline
\end{tabular}

Letra de Sylvio Salema e música de H. Villa-Lobos.

Sugestão de instrumentos: Piano / Banda

6) MEU PAI AMARROU MEUS OLHOS

\begin{tabular}{|c|c|c|c|c|c|c|}
\hline Volume & № & Vozes & Extensão & Tessitura & Tonalidade & Forma \\
\hline $\begin{array}{l}\text { GP/VTL } \\
\text { ABM/ }\end{array}$ & $\begin{array}{c}81 \\
115\end{array}$ & 1 & $\begin{array}{l}26 \text { compassos } \\
\text { quaternários }\end{array}$ & C3-C4 & $\begin{array}{l}\text { Modo de } \\
\text { C maior }\end{array}$ & $A B A$ \\
\hline Andamento & \multirow{2}{*}{\multicolumn{6}{|c|}{$\begin{array}{l}\text { Poco animato }(120=\mathrm{d}) \\
\text { Cancão camponesa }\end{array}$}} \\
\hline Gênero & & & & & & \\
\hline
\end{tabular}

Popular, ambientado por H.Villa-Lobos. Indicação: para Piano. GP/ABM corrige adequadamente as figuras rítmicas nos compassos 24 e 25, tanto quanto elimina a indicação de oitava inapropriada na última nota do glissando no mesmo trecho. 
Sugestão de instrumentos: Piano

7) O CORCUNDA

\begin{tabular}{|c|c|c|c|c|c|c|}
\hline Volume & № & Vozes & Extensão & Tessitura & Tonalidade & Forma \\
\hline $\begin{array}{l}\text { GP/VTL } \\
\text { ABM/ }\end{array}$ & $\begin{array}{c}42 \\
100\end{array}$ & 1 & 21 compassos binários & D3-C\#4 & $\begin{array}{l}\text { Modo de } \\
\text { D maior }\end{array}$ & $A B A$ \\
\hline $\begin{array}{l}\text { Andamento } \\
\text { Gênero }\end{array}$ & \multicolumn{6}{|c|}{$\begin{array}{l}\text { Andantino calmo (M.M. 104= ل ) } \\
\text { Canção }\end{array}$} \\
\hline
\end{tabular}

Popular, ambientado por H.Villa-Lobos. Indicação: Canto com Piano, conjunto instrumental ou Piano solo.

Sugestão de instrumentos: Piano

\section{8) QUANDO EU ERA PEQUENINO}

\begin{tabular}{|c|c|c|c|c|c|c|}
\hline Volume & No & Vozes & Extensão & Tessitura & Tonalidade & Forma \\
\hline GP/VTL & 105 & 1 & 41 compassos binários & C3-C4 & Modo de & Introdução \\
ABM/ & 77 & & & & \\
AB Coda \\
$\begin{array}{c}\text { Andamento } \\
\text { Gênero }\end{array}$
\end{tabular}

Popular, arranjo de H.Villa-Lobos. Indicação: Canto com Piano, conjunto instrumental ou Piano solo.

Sugestão de instrumentos: Piano / Flauta, xilofone e metalofone.

\section{9) SONHO DE UMA CRIANÇA}

\begin{tabular}{|c|c|c|c|c|c|c|}
\hline Volume & № & Vozes & Extensão & Tessitura & Tonalidade & Forma \\
\hline GP-VTL & 122 & 1 & 49 & $\begin{array}{c}\text { Voz: B2-D4 } \\
\text { m.d.: C3-B4 } \\
\text { m.e.: G1-D5 }\end{array}$ & $\begin{array}{c}\text { Modo de G } \\
\text { maior }\end{array}$ & ABA \\
& 60 & & compassos ternários & & & \\
Andamento \\
Gênero
\end{tabular}

Popular, folclore infantil, ambientado por H.Villa-Lobos. Indicação: Canto com Piano, conjunto instrumental ou Piano solo. Em GP/VTL, falta a barra de repetição no compasso 9.

Sugestão de instrumentos: Piano

\section{0) VEM CÁ, SIRIRI}

\begin{tabular}{|c|c|c|c|c|c|c|}
\hline Volume & № & Vozes & Extensão & Tessitura & Tonalidade & Forma \\
\hline $\begin{array}{l}\text { GP-VTL } \\
\text { /ABM }\end{array}$ & $\begin{array}{l}130 \\
106\end{array}$ & $\begin{array}{c}1 \\
\text { (Piano) }\end{array}$ & $\begin{array}{c}45 \text { compassos } \\
\text { binários }\end{array}$ & $\begin{array}{l}\text { Voz: D3-D4 } \\
\text { m.d.: A2-D4 } \\
\text { m.e.: B-1-A2 }\end{array}$ & $\begin{array}{l}\text { Modo de } \\
\text { D maior }\end{array}$ & $A^{\prime}{ }^{\prime} B$ \\
\hline $\begin{array}{l}\text { Andamento } \\
\text { Gênero }\end{array}$ & \multicolumn{6}{|c|}{$\begin{array}{l}\text { Andantino }(104=\text { ل ) / Allegro quasi Vivo } \\
\text { Cantiga }\end{array}$} \\
\hline
\end{tabular}


Popular, folclore infantil, arranjo de H.Villa-Lobos. Indicação: Canto com Piano, conjunto instrumental ou Piano solo.

Sugestão de instrumentos: Piano

11) Xô! PASSARINHO

\begin{tabular}{|c|c|c|c|c|c|c|}
\hline Volume & № & Vozes & Extensão & Tessitura & Tonalidade & Forma \\
\hline $\begin{array}{l}\text { GP-VTL } \\
\text { /ABM }\end{array}$ & $\begin{array}{l}137 \\
105\end{array}$ & $\begin{array}{c}1 \\
\text { (Piano) }\end{array}$ & $\begin{array}{c}16 \text { compassos } \\
\text { binários }\end{array}$ & $\begin{array}{c}\text { Voz: C\#3-B2 } \\
\text { m.d.: C\#3-B3 } \\
\text { m.e.: D2-B2 }\end{array}$ & $\begin{array}{l}\text { Modo de } \\
\text { D maior }\end{array}$ & A \\
\hline $\begin{array}{l}\text { Andamento } \\
\text { Gênero }\end{array}$ & \multicolumn{6}{|c|}{$\begin{array}{l}\text { Andante (M.M. 56= ل ) } \\
\text { Cantiga }\end{array}$} \\
\hline
\end{tabular}

Popular, folclore infantil, arranjo de H.Villa-Lobos. Indicação: Canto com Piano ou conjunto instrumental. O texto recitado (compassos 13 e 14) deve ser efetuado.

Sugestão de instrumentos: Flauta doce, metalofones e xilofones.

\section{2) A CANÇÃO DO MARCENEIRO}

\begin{tabular}{|c|c|c|c|c|c|c|}
\hline Volume & № & Vozes & Extensão & Tessitura & Tonalidade & Forma \\
\hline CO1 & 33 & $\begin{array}{c}2 \\
\text { masculinas }\end{array}$ & $\begin{array}{c}33 \text { compassos } \\
\text { quaternários }\end{array}$ & $\begin{array}{c}\text { 1a voz: E2-F3 } \\
\text { 2a voz:F1-F2 }\end{array}$ & $\begin{array}{c}\text { Modo de } \mathrm{F} \\
\text { maior }\end{array}$ & ABA \\
\hline Gênero & \multicolumn{7}{l}{} \\
\hline
\end{tabular}

Canção de ofício, de caráter didático, com letra de autor desconhecido e música de H.VillaLobos, 1932 - Rio de Janeiro. A introdução cita o Hino Nacional Brasileiro.

Compasso 15 na segunda voz - visualmente trata-se de tercina, e no caso, deveria a terceira nota ser uma mínima, mais o colchete com indicação de tercina. Não sendo esse o caso, as duas últimas colcheias estão fora de lugar.

Sugestão de instrumentos: Sopros - madeiras

13) A JANGADA

\begin{tabular}{|c|c|c|c|c|c|c|}
\hline Volume & № & Vozes & Extensão & Tessitura & Tonalidade & Forma \\
\hline CO1 & 6 & 2 & $\begin{array}{c}41 \text { compassos } \\
\text { binários }\end{array}$ & $\begin{array}{c}\text { 1a voz: B2-B3 } \\
\text { 2a voz: G2-A3 }\end{array}$ & $\begin{array}{c}\text { Modo de } \\
\text { C maior }\end{array}$ & $\mathrm{AA}^{\prime}$ \\
\hline Andamento & \multicolumn{7}{|l}{} \\
\hline
\end{tabular}

Letra e música de Henriqueta M. d'Abreu e arranjo de H. Villa-Lobos.

14) ALERTA (Rataplan)

Sugestão de instrumentos: Flautas

\begin{tabular}{|c|c|c|c|c|c|c|}
\hline Volume & № & Vozes & Extensão & Tessitura & Tonalidade & Forma \\
\hline CO1 & 39 & 2 & $\begin{array}{c}103 \text { compassos } \\
\text { binários }\end{array}$ & $\begin{array}{c}\text { 1a voz: D3-E4 } \\
\text { 2a voz: A2-D3 }\end{array}$ & $\begin{array}{c}\text { Modo de G } \\
\text { maior / C maior }\end{array}$ & AB - estrófica \\
\hline Gênero & \multicolumn{7}{|l}{ Marcial } \\
\hline
\end{tabular}

Letra e melodia de B. Cellini, arranjo de H.Villa-Lobos. 
15) ANDA A RODA (2 ${ }^{\mathrm{a}}$ Versão)

\begin{tabular}{|c|c|c|c|c|c|c|}
\hline Volume & № & Vozes & Extensão & Tessitura & Tonalidade & Forma \\
\hline $\begin{array}{c}\text { GP/VTL } \\
\text { ABM/ } \\
\text { S1 }\end{array}$ & $\begin{array}{r}6 \\
6 \\
32 \\
\end{array}$ & 2 & $\begin{array}{l}24 \text { compassos binários } \\
\text { (subdivisão ternária) }\end{array}$ & $\begin{array}{l}\text { 1a voz: E3-D4 } \\
\text { 2a voz: D3-A3 }\end{array}$ & $\begin{array}{l}\text { Modo de } \\
\text { A maior }\end{array}$ & ABA \\
\hline $\begin{array}{l}\text { Andamento } \\
\text { Gênero }\end{array}$ & $\begin{array}{l}\text { And } \\
\text { Sard }\end{array}$ & tino ( d & & & & \\
\hline
\end{tabular}

Popular, arranjo de H. Villa-Lobos. A peça é recomendada para piano pelo arranjador.

Sugestão de instrumentos: Piano / Flautas doce e ou violinos

16) AS CONCHINHAS

\begin{tabular}{|c|c|c|c|c|c|c|}
\hline Volume & № & Vozes & Extensão & Tessitura & Tonalidade & Forma \\
\hline $\begin{array}{c}\text { GP/VTL } \\
\text { ABM/ } \\
\text { S1 }\end{array}$ & $\begin{array}{l}38 \\
37 \\
25\end{array}$ & 2 & 21compassos binários & $\begin{array}{l}\text { 19 voz: E3-D4 } \\
\text { 2a voz: D3-A3 }\end{array}$ & $\begin{array}{l}\text { Modo de } \\
\text { D maior }\end{array}$ & $A$ \\
\hline $\begin{array}{c}\text { Andamento } \\
\text { Gênero }\end{array}$ & $\begin{array}{l}\text { And } \\
\text { Can }\end{array}$ & $\begin{array}{l}\text { tino }(92 \\
\text { o }\end{array}$ & & & & \\
\hline
\end{tabular}

Popular, arranjo de H. Villa-Lobos.

Sugestão de instrumentos: Flauta / violino e xilofone

17) BRASIL UNIDO

\begin{tabular}{|c|c|c|c|c|c|c|}
\hline Volume & № & Vozes & Extensão & Tessitura & Tonalidade & Forma \\
\hline CO1 & 15 & 2 & $\begin{array}{c}\text { 33 compassos } \\
\text { quaternários }\end{array}$ & $\begin{array}{c}\text { 1a voz: Bb2-Eb4 } \\
\text { 2a voz: Bb2-C3 }\end{array}$ & $\begin{array}{c}\text { Modo de Eb } \\
\text { maior }\end{array}$ & AB \\
\hline Gênero & \multicolumn{7}{|l}{ Marcha } \\
\hline
\end{tabular}

Canção patriótica, com letra de Domingos Magarinos e música de Plínio de Brito. A barra divisória deveria estar no compasso 18 , deveria haver uma segunda casa para ritornello D.C. para a segunda estrofe.

Sugestão de instrumentos: Sopros

\section{8) CANÇÃO DO NORTE}

\begin{tabular}{|c|c|c|c|c|c|c|}
\hline Volume & № & Vozes & Extensão & Tessitura & Tonalidade & Forma \\
\hline CO1 & 17 & 2 & $\begin{array}{c}\text { 34 compassos } \\
\text { quaternários }\end{array}$ & $\begin{array}{c}\text { 1a voz: C3-D3 2 } \\
\text { voz: G2-A3 }\end{array}$ & $\begin{array}{c}\text { Modo de C } \\
\text { maior }\end{array}$ & AA' $^{\prime}$ \\
\hline Gênero & \multicolumn{2}{|l|}{ Marcial }
\end{tabular}

Dedicada ao estado do Ceará, com poesia de Thomas Lopes, música de A. Nepomuceno e arranjo de H. Villa-Lobos, 1932 - Rio de Janeiro.

Sugestão de instrumentos: Flautas doces soprano e contralto

19) CANÇÃO DO PESCADOR BRASILEIRO

\begin{tabular}{|c|c|c|c|c|c|c|}
\hline Volume & № & Vozes & Extensão & Tessitura & Tonalidade & Forma \\
\hline CO2 & 26 & 3 & $\begin{array}{c}54 \\
\text { compassos } \\
\text { quaternários }\end{array}$ & $\begin{array}{c}\text { 1a voz: Bb2-Eb4 } \\
\text { a voz: Bb2-Eb4 } \\
\text { 3a voz: Ab2-Bb3 }\end{array}$ & $\begin{array}{c}\text { Modo de } \\
\text { Eb Maior / } \\
\text { Ab Maior }\end{array}$ & A B \\
\hline Gênero & \multicolumn{6}{|l|}{ Tempo de Marcha de Rancho (Grandioso e solene / Toque de alvorada / Barcarola) } \\
\hline
\end{tabular}


Letra de Bastos Tigre e música de Eduardo Souto, com arranjo de H. Villa-Lobos.

Sugestão de instrumentos: Cordas

20) CANÇÃO DO TRABALHO

\begin{tabular}{|c|c|c|c|c|c|c|}
\hline Volume & № & Vozes & Extensão & Tessitura & Tonalidade & Forma \\
\hline CO1 & 31 & 4 & $\begin{array}{c}33 \\
\text { compassos } \\
\text { binários }\end{array}$ & $\begin{array}{c}\text { Sopranos/Tenorinos: D3-E4; Mezzo } \\
\text { Sopranos e Tenores: C\#3-C\#4; } \\
\text { Sopraninos e Baritonos: A2-G3; } \\
\text { Contraltos e Baixos: G2-E3 }\end{array}$ & $\begin{array}{c}\text { Modo de G } \\
\text { maior }\end{array}$ & A A' Estrófica \\
\hline Gênero & \multicolumn{2}{|l|}{ (Um pouco marcial) } & \multicolumn{3}{l|}{} \\
\hline
\end{tabular}

Poesia de Dr. José Rangel e melodia de Duque Bicalho, e arranjo de H.Villa-Lobos.

Sugestão de instrumentos: Quarteto de flautas / cordas / sopros

\section{1) CANÇÃO ESCOLAR}

\begin{tabular}{|c|c|c|c|c|c|c|}
\hline Volume & № & Vozes & Extensão & Tessitura & Tonalidade & Forma \\
\hline CO1 & 12 & 2 & $\begin{array}{c}\text { 32 compassos } \\
\text { quaternários }\end{array}$ & $\begin{array}{c}\text { 1a voz: F3-F4; 2a voz: } \\
\text { F2-D3 }\end{array}$ & $\begin{array}{c}\text { Modo de F maior / } \\
\text { Bb maior }\end{array}$ & AB Estrófica \\
\hline Gênero & \multicolumn{6}{|l|}{ Solene (Marcial) } \\
\hline
\end{tabular}

Dedicado a Alberto Barth, letra de autor desconhecido e música de Assis Pacheco.

Sugestão de instrumentos: Sopros

22) ESPERANÇA DA MÃE POBRE

\begin{tabular}{|c|c|c|c|c|c|c|}
\hline Volume & № & Vozes & Extensão & Tessitura & Tonalidade & Forma \\
\hline CO2 & 2 & $\begin{array}{c}3 \\
\text { infantis }\end{array}$ & $\begin{array}{c}64 \\
\text { compassos binários }\end{array}$ & $\begin{array}{c}\text { 1a voz: C3-C4 } \\
\text { 2a voz: B2-A3 }\end{array}$ & $\begin{array}{c}\text { Modo de C } \\
\text { maior }\end{array}$ & $\begin{array}{c}\text { Introdução A / } \\
\text { Coda }\end{array}$ \\
\hline Gênero & \multicolumn{1}{|l}{ Marcha } \\
\hline
\end{tabular}

Caráter didático. Rio de Janeiro, 1933. Texto sobre um pensamento de Lygia P. Leite. Música de Heitor Villa-Lobos.

Sugestão de instrumentos: Flautas doce soprano e contralto

23) HINO À VITÓRIA

\begin{tabular}{|c|c|c|c|c|c|c|}
\hline Volume & № & Vozes & Extensão & Tessitura & Tonalidade & Forma \\
\hline $\mathrm{CO} 2$ & 36 & 1 a 4 & $\begin{array}{c}20 \\
\text { compassos } \\
\text { quaternários }\end{array}$ & $\begin{array}{c}\text { 19 voz: C3-G4 } \\
\text { 2a voz: Bb2-D4 } \\
\text { 3a voz: A2-B3 } \\
\text { 4a voz: F2-G3 }\end{array}$ & $\begin{array}{l}\text { Modo de F } \\
\text { maior }\end{array}$ & $A B$ \\
\hline Gênero & \multicolumn{6}{|c|}{ Marcha (Moderado - tempo de marcha) } \\
\hline
\end{tabular}


Canção de caráter didático. Letra de Gustavo Capanema* e música de H.Villa-Lobos. O compasso poderia ser 12 por 8 , ou 4 pela semínima pontuada, para evitar a poluição visual causada pelas indicações de tercinas.

*Ministro da Educação na ocasião.

Sugestão de instrumentos: Flautas doce

24) JURAMENTO

\begin{tabular}{|c|c|c|c|c|c|c|}
\hline Volume & № & Vozes & Extensão & Tessitura & Tonalidade & Forma \\
\hline $\mathrm{CO} 2$ & 30 & $\begin{array}{c}4 \\
\text { (3 solistas) }\end{array}$ & $\begin{array}{c}190 \\
\text { compassos } \\
\text { quaternários }\end{array}$ & $\begin{array}{l}\text { 1a voz: C3-F4 } \\
\text { 2a voz: C3-F4 } \\
\text { 3a voz: F2-D3 } \\
\text { 4a voz: F2-D3 }\end{array}$ & $\begin{array}{l}\text { Modo de } \mathrm{F} \\
\text { maior }\end{array}$ & Introdução A / Coda \\
\hline Gênero & Mar & (Movimer & de marcha mo & & & \\
\hline
\end{tabular}

Canção com características didáticas, letra de Murilo de Araújo e música de H. Villa-Lobos.

Sugestão de instrumentos: Flautas doces, metalofones, xilofones

25) MARCHA ESCOLAR (Passeio)

\begin{tabular}{|c|c|c|c|c|c|c|}
\hline Volume & № & Vozes & Extensão & Tessitura & Tonalidade & Forma \\
\hline CO1 & 10 & 2 & $\begin{array}{c}72 \text { compassos } \\
\text { binários }\end{array}$ & $\begin{array}{c}\text { 1' } \text { a voz: D3-E4; } \\
\text { 2a voz: G2-D3 }\end{array}$ & $\begin{array}{c}\text { Modo de D } \\
\text { maior }\end{array}$ & A / coda \\
\hline Gênero & \multicolumn{7}{|l}{ Marcha } & & & \\
\hline
\end{tabular}

Melodia e letra desconhecidas com arranjo de H.Villa-Lobos.

Sugestão de instrumentos: Flautas doces soprano e contralto

26) MARCHA ESCOLAR (Vocalismo)

\begin{tabular}{|l|l|c|c|c|c|c|}
\hline \multicolumn{1}{|c|}{ Volume } & № & Vozes & Extensão & Tessitura & Tonalidade & Forma \\
\hline CO1 & 11 & 2 & $\begin{array}{c}48 \text { compassos } \\
\text { binários }\end{array}$ & $\begin{array}{l}\text { 1a voz: D3-F4 } \\
\text { 2a voz: G2-C3 }\end{array}$ & $\begin{array}{l}\text { Modo de } \\
\text { G menor }\end{array}$ & B A \\
\hline $\begin{array}{l}\text { Andament } \\
\text { o } \\
\text { Gênero }\end{array}$ & \multicolumn{2}{l}{$\begin{array}{l}\text { Tempo de Marcha } \\
\text { Marcha }\end{array}$} \\
\hline
\end{tabular}

Vocalização para educação do sentido rítmico da marcha, em compassos diversos. H.VillaLobos (Rio de Janeiro, 1940). Há indicações para a execução, na segunda vez, seja em compasso quaternário e na terceira vez em compasso seis por quatro. Outra nota do autor: "Podendo-se adaptar uma letra ao critério do Professor".

Sugestão de instrumentos: Flautas soprano e contralto / metalofones e xilofones

27) MARCHA ESCOLAR (Volta do recreio)

\begin{tabular}{|c|c|c|c|c|c|c|}
\hline Volume & № & Vozes & Extensão & Tessitura & Tonalidade & Forma \\
\hline CO1 & 8 & 2 & $\begin{array}{c}75 \text { compassos } \\
\text { binários }\end{array}$ & $\begin{array}{c}\text { 1a voz: D3-D4 } \\
\text { 2a voz: B2-E4 }\end{array}$ & $\begin{array}{c}\text { Modo de G } \\
\text { maior }\end{array}$ & $\begin{array}{c}\text { Introdução A / } \\
\text { Coda }\end{array}$ \\
\hline $\begin{array}{l}\text { Andament } \\
\text { o Gênero }\end{array}$ & \multicolumn{6}{|l}{ Tempo de Marcha de Rancho de Rancho } \\
\hline
\end{tabular}


Letra de Catarina Santoro e música de E. Villalba Filho*, com arranjo de H. Villa-Lobos. *Pseudônimo de H. Villa-Lobos.

Sugestão de instrumentos: Sopros.

28) O FERREIRO

\begin{tabular}{|c|c|c|c|c|c|c|}
\hline Volume & № & Vozes & Extensão & Tessitura & Tonalidade & Forma \\
\hline CO1 & 28 & 2 & 39 compassos binários & $\begin{array}{r}\text { 1a voz: Eb3-Eb4 } \\
\text { 2a voz: Bb1-C3 }\end{array}$ & $\begin{array}{c}\text { Modo de } \\
\text { Eb maior }\end{array}$ & A A' $^{\prime}$ \\
\hline Gênero & \multicolumn{6}{l}{} \\
\hline
\end{tabular}

D. R. Antolisei, transformada em canção de ofício para vozes masculinas, com letra de S.V. e arranjo de H.Villa-Lobos.

Sugestão de instrumentos: Sopros - madeiras

\section{9) O GATURAMO}

\begin{tabular}{|c|c|c|c|c|c|c|}
\hline Volume & № & Vozes & Extensão & Tessitura & Tonalidade & Forma \\
\hline CO2 & 6 & 3 & $\begin{array}{c}65 \\
\text { compassos ternários }\end{array}$ & $\begin{array}{c}\text { 1a voz: C\#3-D4 } \\
\text { 2a voz: B2-C3 } \\
\text { 3a voz: G2-G3 }\end{array}$ & $\begin{array}{c}\text { Modo de C } \\
\text { maior }\end{array}$ & AA' $^{\prime}$ \\
\hline Gênero & \multicolumn{7}{|l|}{ Valsa } & & \\
\hline
\end{tabular}

Letra de J. Pinto e Silva, melodia de J. Carlos Dias e arranjo de H.Villa-Lobos.

Sugestão de instrumentos: Flauta metalofone, xilofone, cordas, outros.

30) O PESCADOR DA BARQUINHA

\begin{tabular}{|c|c|c|c|c|c|c|}
\hline Volume & No & Vozes & Extensão & Tessitura & Tonalidade & Forma \\
\hline $\begin{array}{c}\text { GP/VTL } \\
\text { ABM/ }\end{array}$ & 92 & 2 & $\begin{array}{c}\text { 51 compassos binários } \\
\text { (subdivisão ternária) }\end{array}$ & $\begin{array}{c}\text { 1a voz: G2-D4 } \\
\text { 2a voz: G2-A3 }\end{array}$ & $\begin{array}{c}\text { Modo de } \\
\text { C maior }\end{array}$ & $\begin{array}{c}\text { Introdução } \\
\text { A Coda }\end{array}$ \\
\hline $\begin{array}{l}\text { Andamento } \\
\text { Gênero }\end{array}$ & \multicolumn{2}{l}{$\begin{array}{l}\text { Movimento de barcarola (76= d.) } \\
\text { Barcarola }\end{array}$} \\
\hline
\end{tabular}

Popular, arranjo de H.Villa-Lobos.

Sugestão de instrumentos: Piano / Flauta doce e metalofone / outros

31) SANTOS DUMONT (A conquista do ar)

\begin{tabular}{|c|c|c|c|c|c|c|}
\hline Volume & № & Vozes & Extensão & Tessitura & Tonalidade & Forma \\
\hline CO2 & 25 & 3 & 64 & $\begin{array}{c}\text { 1a voz: C3-E4 } \\
\text { 2a voz: B2-C4 } \\
\text { 3a voz: F2-C3 }\end{array}$ & $\begin{array}{c}\text { Modo de F } \\
\text { maior }\end{array}$ & $\begin{array}{c}\text { Introdução } \\
\text { A B Coda }\end{array}$ \\
\hline Gênero & & & compassos binários & & & \\
\hline
\end{tabular}

Letra e música de Eduardo das Neves, subtítulo: A conquista do Ar, arranjo de H. VillaLobos. 
32) SOLDADINHOS (Canção escolar)

\begin{tabular}{|c|c|c|c|c|c|c|}
\hline Volume & № & Vozes & Extensão & Tessitura & Tonalidade & Forma \\
\hline CO1 & 5 & 2 & $\begin{array}{c}\text { 16 compassos } \\
\text { binários e 24 quaternários }\end{array}$ & $\begin{array}{c}\text { 1a voz: D3-D4 } \\
\text { 2a voz: A2-B3 }\end{array}$ & $\begin{array}{c}\text { Modo de } \\
\text { G maior }\end{array}$ & $\begin{array}{c}\text { Introdução } \\
\text { AB coda }\end{array}$ \\
\hline Andamento & \multicolumn{6}{|l}{} \\
\hline
\end{tabular}

Letra de Narbal Fontes, música de Sylvio Salema e arranjo de H. Villa-Lobos.

Sugestão de instrumentos: Flauta e xilofone

33) SOLFEJO No 8 (Ditado)

\begin{tabular}{|c|c|c|c|c|c|c|}
\hline Volume & № & Vozes & Extensão & Tessitura & Tonalidade & Forma \\
\hline S2 ditado & 8 & 1 & 8 compassos quaternários & E3 - E4 & Modo de D menor & A \\
\hline Andamento & \multicolumn{3}{|l|}{ (Sem indicação) } \\
\hline
\end{tabular}

Sugestão de instrumentos: Cordas / Sopros

34) SOLFEJO No 3 (Ditado)

\begin{tabular}{|c|c|c|c|c|c|c|}
\hline Volume & № & Vozes & Extensão & Tessitura & Tonalidade & Forma \\
\hline S2 ditado & 3 & 1 & 7 compassos binários & E3-E4 & Modo de A menor & A \\
\hline Andamento & \multicolumn{1}{|l}{ (Sem indicação) } \\
\hline
\end{tabular}

Sugestão de instrumentos: Cordas / Sopros

35) SOLFEJO No 6 (Vocalismo)

\begin{tabular}{|c|c|c|c|c|c|c|}
\hline Volume & № & Vozes & Extensão & Tessitura & Tonalidade & Forma \\
\hline $\begin{array}{c}\text { S2 } \\
\text { Vocalismo }\end{array}$ & 6 & 2 & 6 compassos quaternários & $\begin{array}{c}\text { 1a voz: C3-F4 } \\
\text { 2a voz: G1-Db3 1a }\end{array}$ & $\begin{array}{c}\text { Modo de C } \\
\text { menor }\end{array}$ & A \\
\hline Andamento & \multicolumn{2}{|l|}{ Andante } & \\
\hline
\end{tabular}

Sugestão de instrumentos: Cordas / Sopros

36) SOLFEJO No 21 (Vocalismo)

\begin{tabular}{|c|c|c|c|c|c|c|}
\hline Volume & № & Vozes & Extensão & Tessitura & Tonalidade & Forma \\
\hline $\begin{array}{c}\text { S2 } \\
\text { Vocalismo }\end{array}$ & 21 & 1 & $\begin{array}{c}15 \text { compassos quaternários /4 } \\
\text { ternários }\end{array}$ & $\begin{array}{c}\text { B3-A4 } \\
\text { menor }\end{array}$ & $\mathrm{A}$ \\
\hline Andamento & \multicolumn{2}{|l|}{ Adagio } & \multicolumn{4}{|l|}{} \\
\hline
\end{tabular}

Sugestão de instrumentos: Cordas / Sopros

37) SOLFEJO $\mathbf{N}^{\circ} 48$

\begin{tabular}{|c|c|c|c|c|c|c|}
\hline Volume & № & Vozes & Extensão & Tessitura & Tonalidade & Forma \\
\hline S1 & 48 & 1 & 18 compassos binários & G\#2-D4 & Modo de C\# menor & A \\
\hline Andamento & \multicolumn{1}{|l}{ Moderato } \\
\hline
\end{tabular}

Sugestão de instrumentos: Sopros - madeira 
38) SOLFEJO No 58

\begin{tabular}{|c|c|c|c|c|c|c|}
\hline Volume & No & Vozes & Extensão & Tessitura & Tonalidade & Forma \\
\hline S1 & 58 & 1 & $\begin{array}{c}16 \text { compassos binários } \\
\text { (subdivisão ternária) }\end{array}$ & A2-E4 & $\begin{array}{c}\text { Modo de } \\
\text { D maior }\end{array}$ & A \\
\hline Andamento & \multicolumn{6}{|l}{ Movimento de Quadrilha } \\
\hline
\end{tabular}

Sugestão de instrumentos: Cordas / Sopros

39) SOLFEJO No 54

\begin{tabular}{|c|c|c|c|c|c|c|}
\hline Volume & No & Vozes & Extensão & Tessitura & Tonalidade & Forma \\
\hline S1 & 54 & 1 & $\begin{array}{c}16 \text { compassos binários } \\
\text { (subdivisão ternária) }\end{array}$ & F3-Ab4 & $\begin{array}{c}\text { Modo de } \\
\text { Ab maior }\end{array}$ & A \\
\hline Andamento & \multicolumn{6}{l}{ Movimento de Barcarole } \\
\hline
\end{tabular}

Sugestão de instrumentos: Cordas / Sopros

40) SOLFEJO No 53

\begin{tabular}{|c|c|c|c|c|c|c|}
\hline Volume & No & Vozes & Extensão & Tessitura & Tonalidade & Forma \\
\hline S1 & 53 & 2 & 8 compassos binários & F3-A4 & Modo de F maior & A \\
\hline Andamento
\end{tabular}

Sugestão de instrumentos: Cordas / Sopros

41) SOLFEJO No 59

\begin{tabular}{|c|c|c|c|c|c|c|}
\hline Volume & No & Vozes & Extensão & Tessitura & Tonalidade & Forma \\
\hline S1 & 59 & 1 & 9 compassos binários & D3-G4 & Modo de B menor & A \\
\hline Andamento & \multicolumn{2}{|l|}{ Lento } & & & \\
\hline
\end{tabular}

Sugestão de instrumentos: Cordas / Sopros

\section{2) SOLFEJO No 52}

\begin{tabular}{|c|c|c|c|c|c|c|}
\hline Volume & № & Vozes & Extensão & Tessitura & Tonalidade & Forma \\
\hline S1 & 52 & 1 & $\begin{array}{c}\text { 16 compassos binários } \\
\text { (subdivisão ternária) }\end{array}$ & Eb3-Ab4 & $\begin{array}{c}\text { Modo de } \\
\text { Ab maior }\end{array}$ & A \\
\hline Andamento & \multicolumn{2}{|l|}{ Allegro } \\
\hline
\end{tabular}

Sugestão de instrumentos: Cordas / Sopros

43) SOLFEJO No 47

\begin{tabular}{|c|c|c|c|c|c|c|}
\hline Volume & № & Vozes & Extensão & Tessitura & Tonalidade & Forma \\
\hline S1 & 47 & 1 & 20 compassos ternários & A2-B4 & Modo de C maior & A \\
\hline Andamento & \multicolumn{1}{l}{ Andante } \\
\hline
\end{tabular}

Sugestão de instrumentos: Violino 
44) SOLFEJO No 22 (Vocalismo)

\begin{tabular}{|c|c|c|c|c|c|c|}
\hline Volume & № & Vozes & Extensão & Tessitura & Tonalidade & Forma \\
\hline S2 vocalismo & 22 & 1 & 13 compassos ternários & C\#3-A4 & Modo de D menor & A \\
\hline Andamento & Lento \\
\hline
\end{tabular}

Sugestão de instrumentos: Cordas / Sopros

45) SOLFEJO No 24 (Vocalismo)

\begin{tabular}{|c|c|c|c|c|c|c|}
\hline Volume & No & Vozes & Extensão & Tessitura & Tonalidade & Forma \\
\hline $\begin{array}{c}\text { S2 } \\
\text { Vocalismo }\end{array}$ & 24 & 2 & 32 compassos ternários & $\begin{array}{c}\text { 1a voz: C3-G4 } \\
\text { 2a voz: G2-D4 } \\
\text { 3a voz: B2-Eb4 }\end{array}$ & $\begin{array}{c}\text { Modo de C } \\
\text { menor }\end{array}$ & A \\
\hline Andamento & & & & & & \\
\hline
\end{tabular}

Sugestão de instrumentos: Cordas / Sopros / Piano

46) SOLFEJO No 95

\begin{tabular}{|c|c|c|c|c|c|c|}
\hline Volume & № & Vozes & Extensão & Tessitura & Tonalidade & Forma \\
\hline S1 & 95 & 2 & $\begin{array}{c}\text { 8 compassos } \\
\text { quaternários }\end{array}$ & $\begin{array}{c}\text { 1a voz: E3-E4 } \\
\text { 2a voz: C\#3-E4 }\end{array}$ & $\begin{array}{c}\text { Modo de } \\
\text { D maior }\end{array}$ & A \\
\hline Andamento & \multicolumn{2}{l}{ Andantino } & \\
\hline
\end{tabular}

Sugestão de instrumentos: Cordas / Sopros

47) SOLFEJO No 123

\begin{tabular}{|c|c|c|c|c|c|c|}
\hline Volume & № & Vozes & Extensão & Tessitura & Tonalidade & Forma \\
\hline S1 & 123 & 2 & $\begin{array}{c}\text { 16 compassos } \\
\text { quaternários }\end{array}$ & $\begin{array}{c}\text { 19 voz: F3-Ab4 } \\
\text { 2a voz: Ab2-C3 }\end{array}$ & $\begin{array}{c}\text { Modo de } \\
\text { Ab maior }\end{array}$ & A \\
\hline Andamento & \multicolumn{6}{|l}{} \\
\hline
\end{tabular}

Sugestão de instrumentos: Cordas / Sopros

\section{8) SOLFEJO No 150}

\begin{tabular}{|c|c|c|c|c|c|c|}
\hline Volume & No & Vozes & Extensão & Tessitura & Tonalidade & Forma \\
\hline S1 & 150 & 2 & 10 compassos binários & $\begin{array}{c}\text { 1a voz: C3-D4 } \\
\text { 2a voz: C3-D4 }\end{array}$ & $\begin{array}{c}\text { Modo de } \\
\text { F maior }\end{array}$ & A \\
\hline Andamento & \multicolumn{6}{|l|}{ Andante Calmo } \\
\hline
\end{tabular}

Sugestão de instrumentos: Cordas / Sopros

49) SOLFEJO No 20 (Vocalismo)

\begin{tabular}{|c|c|c|c|c|c|c|}
\hline Volume & No & Vozes & Extensão & Tessitura & Tonalidade & Forma \\
\hline $\begin{array}{c}\text { S2 } \\
\text { Vocalismo }\end{array}$ & 20 & 2 & 17 compassos ternários & $\begin{array}{c}\text { 1a voz: E3-F4 } \\
\text { 2a voz: Bb2-Bb3 }\end{array}$ & $\begin{array}{c}\text { Modo de F } \\
\text { menor }\end{array}$ & $\mathrm{A}$ \\
\hline Andamento & \multicolumn{2}{|l|}{ Allegro } & & & \\
\hline
\end{tabular}

Sugestão de instrumentos: Cordas / Sopros 
50) SOLFEJO No 16 (Vocalismo)

\begin{tabular}{|c|c|c|c|c|c|c|}
\hline Volume & № & Vozes & Extensão & Tessitura & Tonalidade & Forma \\
\hline $\begin{array}{c}\text { S2 } \\
\text { Vocalismo }\end{array}$ & 16 & 2 & 8 compassos ternários & $\begin{array}{l}\text { 1a voz: C3-E4 } \\
\text { 2a voz: A2-E3 }\end{array}$ & $\begin{array}{l}\text { Modo de } \\
\text { G maior }\end{array}$ & A \\
\hline Andamento & \multicolumn{2}{|l|}{ Allegretto } & & & \\
\hline
\end{tabular}

Sugestão de instrumentos: Cordas / Sopros

51) SOLFEJO No 140

\begin{tabular}{|c|c|c|c|c|c|c|}
\hline Volume & № & Vozes & Extensão & Tessitura & Tonalidade & Forma \\
\hline S1 & 140 & 2 & 16 compassos ternários & $\begin{array}{l}\text { 1a voz: B2-E4 } \\
\text { 2a voz: G2-C3 }\end{array}$ & $\begin{array}{c}\text { Modo de } \\
\text { E menor }\end{array}$ & A \\
\hline Andamento & \multicolumn{2}{l}{ Tempo de Valsa } \\
\hline
\end{tabular}

Sugestão de instrumentos: Cordas / Sopros

\section{2) SOLFEJO No 148}

\begin{tabular}{|c|c|c|c|c|c|c|}
\hline Volume & № & Vozes & Extensão & Tessitura & Tonalidade & Forma \\
\hline S1 & 148 & 2 & $\begin{array}{l}5 \text { compassos } \\
\text { quaternários }\end{array}$ & $\begin{array}{c}\text { 1avoz: D3-F\#4 } \\
\text { 2a voz: A2-D4 }\end{array}$ & $\begin{array}{l}\text { Modo de } \\
\text { G maior }\end{array}$ & A \\
\hline Andamento & \multicolumn{7}{|l|}{ Allegretto } \\
\hline
\end{tabular}

Sugestão de instrumentos: Cordas / Sopros

\section{3) SOLFEJO No 115}

\begin{tabular}{|c|c|c|c|c|c|c|}
\hline Volume & № & Vozes & Extensão & Tessitura & Tonalidade & Forma \\
\hline S1 & 115 & 2 & $\begin{array}{l}\text { 7 compassos binários } \\
\text { (subdivisão ternária) }\end{array}$ & $\begin{array}{l}\text { 1a voz: C3-G4 } \\
\text { 2a voz: G2-C4 }\end{array}$ & $\begin{array}{c}\text { Modo de } \\
\text { G menor }\end{array}$ & A \\
\hline $\begin{array}{l}\text { Andament } \\
\text { o }\end{array}$ & \multicolumn{7}{|l|}{ Moderato } & & \\
\hline
\end{tabular}

No compasso 5, segunda voz, as figuras deveriam ser 4 semifusas e duas semicolcheias.

Sugestão de instrumentos: Cordas / Sopros

\section{4) SOLFEJO No 18 (Vocalismo)}

\begin{tabular}{|c|c|c|c|c|c|c|}
\hline Volume & № & Vozes & Extensão & Tessitura & Tonalidade & Forma \\
\hline $\begin{array}{c}\text { S2 } \\
\text { vocalismo }\end{array}$ & 18 & 2 & 8 compassos quaternários & $\begin{array}{c}\text { 1a voz: D3-G4 } \\
\text { 2a voz: F2-Bb3 }\end{array}$ & $\begin{array}{c}\text { Modo de F } \\
\text { maior }\end{array}$ & A \\
\hline Andamento & \multicolumn{2}{|l|}{ Adagio } & & & \\
\hline
\end{tabular}

Sugestão de instrumentos: Cordas / Sopros

\section{5) SOLFEJO No 1 (Vocalismo)}

\begin{tabular}{|c|c|c|c|c|c|c|}
\hline Volume & No & Vozes & Extensão & Tessitura & Tonalidade & Forma \\
\hline $\begin{array}{c}\text { S2 } \\
\text { vocalismo }\end{array}$ & 1 & 2 & 8 compassos quaternários & $\begin{array}{c}\text { 1a Voz: F3 - D3 } \\
\text { 2a Voz: Bb2 - Bb3 }\end{array}$ & $\begin{array}{l}\text { Modo de } \\
\text { C maior }\end{array}$ & A \\
\hline Andamento & \multicolumn{6}{|c|}{ Andante Religioso } \\
\hline
\end{tabular}

Sugestão de instrumentos: Cordas / Sopros 
56) SOLFEJO No 7 (Vocalismo)

\begin{tabular}{|c|c|c|c|c|c|c|}
\hline Volume & № & Vozes & Extensão & Tessitura & Tonalidade & Forma \\
\hline $\begin{array}{c}\text { S2 } \\
\text { vocalismo }\end{array}$ & 7 & 2 & 8 compassos binários & $\begin{array}{c}\text { 1a voz: Bb2-Ab4 2a } \\
\text { voz: Ab2-C4 }\end{array}$ & $\begin{array}{c}\text { Modo de } \\
\text { Ab maior }\end{array}$ & A \\
\hline Andamento & \multicolumn{2}{|l|}{ Allegretto } & & &
\end{tabular}

Sugestão de instrumentos: Cordas / Sopros

57) SOLFEJO No 23 (Vocalismo)

\begin{tabular}{|c|c|c|c|c|c|c|}
\hline Volume & № & Vozes & Extensão & Tessitura & Tonalidade & Forma \\
\hline $\begin{array}{c}\text { S2 } \\
\text { Vocalismo }\end{array}$ & 23 & 2 & $\begin{array}{c}\text { 9 compassos binários } \\
\text { (subdivisão ternária)/1 } \\
\text { quaternário }\end{array}$ & $\begin{array}{c}\text { 1a voz: C3-G4 } \\
\text { 2a voz: G2-Bb3 }\end{array}$ & $\begin{array}{c}\text { Modo de C } \\
\text { menor }\end{array}$ & A \\
\hline Andamento & \multicolumn{2}{|l|}{ Moderato } & \multicolumn{3}{|l}{} \\
\hline
\end{tabular}

Sugestão de instrumentos: Cordas / Sopros

58) SOLFEJO No 17 (Vocalismo)

\begin{tabular}{|c|c|c|c|c|c|c|}
\hline Volume & № & Vozes & Extensão & Tessitura & Tonalidade & Forma \\
\hline $\begin{array}{c}\text { S2 } \\
\text { Vocalismo }\end{array}$ & 17 & 2 & $\begin{array}{c}29 \text { compassos ternários/4 } \\
\text { quaternários / 4 binários }\end{array}$ & $\begin{array}{c}\text { 1a voz: E3-F4 } \\
\text { 2a voz: C3-Eb4 }\end{array}$ & $\begin{array}{c}\text { Modo jônio } \\
\text { de Eb }\end{array}$ & A \\
\hline Andamento & \multicolumn{2}{|l}{ Andantino } \\
\hline
\end{tabular}

Sobre temas ameríndios do vale do Amazonas. Recolhido e ambientado por H. Villa-Lobos.

Sugestão de instrumentos: Cordas / Sopros

59) SOLFEJO No 86

\begin{tabular}{|c|c|c|c|c|c|c|}
\hline Volume & № & Vozes & Extensão & Tessitura & Tonalidade & Forma \\
\hline S1 & 86 & 2 & $\begin{array}{c}8 \\
\text { compassos binários }\end{array}$ & $\begin{array}{c}\text { 1a voz: C3-E4 } \\
\text { 2a voz: C3-G3 }\end{array}$ & $\begin{array}{c}\text { Modo de } \\
\text { C maior }\end{array}$ & A \\
\hline Andamento & \multicolumn{2}{l}{ Andantino } & & \\
\hline
\end{tabular}

Sugestão de instrumentos: Cordas / Sopros

60) SOLFEJO No 11 (Vocalismo)

\begin{tabular}{|c|c|c|c|c|c|c|}
\hline Volume & No & Vozes & Extensão & Tessitura & Tonalidade & Forma \\
\hline $\begin{array}{c}\text { S2 } \\
\text { Vocalismo }\end{array}$ & 11 & 2 & $\begin{array}{c}\text { 8 compassos alternados } \\
\text { quaternário/ternários } \\
\text { (subdivisão ternária) }\end{array}$ & $\begin{array}{c}\text { 1a voz: D3-G4 } \\
2^{\text {a }} \text { voz: G\#2-D3 }\end{array}$ & $\begin{array}{c}\text { Modo de A } \\
\text { menor }\end{array}$ & A \\
\hline Andamento & \multicolumn{7}{|l|}{ Andantino (tipo sarda nas) } \\
\hline
\end{tabular}

Sugestão de instrumentos: Cordas / Sopros

61) SOLFEJO No 152 / 160

\begin{tabular}{|c|c|c|c|c|c|c|}
\hline Volume & No & Vozes & Extensão & Tessitura & Tonalidade & Forma \\
\hline S1 & 152 & 2 & 16 compassos ternários & $\begin{array}{c}\text { 1avoz: F3-F4; 2a voz: } \\
\text { C2-C3 }\end{array}$ & $\begin{array}{c}\text { Modo de } \\
\text { G menor }\end{array}$ & A \\
& & & & & \\
\hline Andamento
\end{tabular}


A primeira nota da primeira voz deve ser F sustenido. Este solfejo é igual ao no 160 .

Sugestão de instrumentos: Cordas / Sopros / Piano

62) SOLFEJO No 122

\begin{tabular}{|c|c|c|c|c|c|c|}
\hline Volume & No & Vozes & Extensão & Tessitura & Tonalidade & Forma \\
\hline S1 & 122 & 2 & $\begin{array}{c}\text { 8 compassos } \\
\text { quaternários }\end{array}$ & $\begin{array}{c}\text { 1a voz: B2-F4 } \\
\text { 2a voz: G\#1-E3 }\end{array}$ & $\begin{array}{c}\text { Modo de } \\
\text { C maior }\end{array}$ & A \\
\hline Andamento & \multicolumn{1}{l|}{ Moderato } \\
\hline
\end{tabular}

Sugestão de instrumentos: Cordas / Sopros

63) SOLFEJO No 117

\begin{tabular}{|c|c|c|c|c|c|c|}
\hline Volume & № & Vozes & Extensão & Tessitura & Tonalidade & Forma \\
\hline S1 & 117 & 2 & 8 compassos binários & $\begin{array}{l}\text { 1a voz: B2-E4 } \\
\text { 2a voz: E1-E3 }\end{array}$ & $\begin{array}{c}\text { Modo de } \\
\text { E menor }\end{array}$ & A \\
\hline Andamento & \multicolumn{2}{|l}{ Vagaroso } & & & \\
\hline
\end{tabular}

Sugestão de instrumentos: Cordas / Sopros / Piano

64) SOLFEJO No 127

\begin{tabular}{|c|c|c|c|c|c|c|}
\hline Volume & № & Vozes & Extensão & Tessitura & Tonalidade & Forma \\
\hline S1 & 127 & 2 & $\begin{array}{c}\text { 8 compassos } \\
\text { quaternários }\end{array}$ & $\begin{array}{c}\text { 1a voz: C3-F4 } \\
\text { 2a voz: C2-Eb3 }\end{array}$ & $\begin{array}{c}\text { Modo de } \\
\text { Bb maior }\end{array}$ & A \\
\hline Andamento & \multicolumn{7}{l|}{ Moderato } \\
\hline
\end{tabular}

Sugestão de instrumentos: Cordas / Sopros

65) SOLFEJO $\mathrm{N}^{\circ} 76$

\begin{tabular}{|c|c|c|c|c|c|c|}
\hline Volume & № & Vozes & Extensão & Tessitura & Tonalidade & Forma \\
\hline S1 & 76 & 2 & $\begin{array}{c}\text { 8 compassos binários } \\
\text { (subdivisão ternária) }\end{array}$ & $\begin{array}{c}\text { 1a voz: E3-G4 } \\
\text { 2a voz: Bb1-C3 }\end{array}$ & $\begin{array}{c}\text { Modo de } \\
\text { Bb maior }\end{array}$ & A \\
\hline Andamento & \multicolumn{6}{|l}{ Andantino } \\
\hline
\end{tabular}

Sugestão de instrumentos: Cordas / Sopros

66) SOLFEJO No 124

\begin{tabular}{|c|c|c|c|c|c|c|}
\hline Volume & № & Vozes & Extensão & Tessitura & Tonalidade & Forma \\
\hline S1 & 124 & 2 & $\begin{array}{c}\text { 4 compassos quaternários } \\
\text { (subdivisão ternária) }\end{array}$ & $\begin{array}{c}\text { 1avoz: D3-D4 } \\
\text { 2a voz: C\#2-B2 }\end{array}$ & $\begin{array}{c}\text { Modo de } \\
\text { A maior }\end{array}$ & A \\
\hline Andamento & \multicolumn{2}{|l|}{ Moderato } \\
\hline
\end{tabular}

Sugestão de instrumentos: Cordas / Sopros

67) SOLFEJO No 118

\begin{tabular}{|c|c|c|c|c|c|c|}
\hline Volume & № & Vozes & Extensão & Tessitura & Tonalidade & Forma \\
\hline S1 & 118 & 2 & 8 compassos ternários & $\begin{array}{c}\text { 1a voz: G3-Eb4 } \\
\text { 2a voz: G1-G2 }\end{array}$ & $\begin{array}{c}\text { Modo de } \\
\text { C menor }\end{array}$ & A \\
\hline Andamento & \multicolumn{3}{l}{ Andante } \\
\hline
\end{tabular}


Sugestão de instrumentos: Cordas / Sopros

\section{8) SOLFEJO No 133}

\begin{tabular}{|c|c|c|c|c|c|c|}
\hline Volume & No & Vozes & Extensão & Tessitura & Tonalidade & Forma \\
\hline S1 & 133 & 2 & $\begin{array}{c}\text { 11 compassos } \\
\text { quaternários }\end{array}$ & $\begin{array}{c}\text { 1a voz: D3-E4 } \\
\text { a voz: C2-C3 }\end{array}$ & $\begin{array}{c}\text { Modo de } \\
\text { G maior }\end{array}$ & A \\
\hline Andamento & \multicolumn{7}{|l|}{ Moderato }
\end{tabular}

Sugestão de instrumentos: Cordas / Sopros / Piano

69) SOLFEJO No 85

\begin{tabular}{|c|c|c|c|c|c|c|}
\hline Volume & № & Vozes & Extensão & Tessitura & Tonalidade & Forma \\
\hline S1 & 85 & 2 & $\begin{array}{c}8 \\
\text { compassos binários }\end{array}$ & $\begin{array}{c}\text { 1a voz: F3-F4 } \\
\text { 2a voz: E3-D3 }\end{array}$ & $\begin{array}{c}\text { Modo de } \\
\text { F maior }\end{array}$ & A \\
\hline Andamento & \multicolumn{7}{|l}{ Allegretto } & & & \\
\hline
\end{tabular}

Sugestão de instrumentos: Cordas / Sopros

70) SOLFEJO No 88

\begin{tabular}{|c|c|c|c|c|c|c|}
\hline Volume & № & Vozes & Extensão & Tessitura & Tonalidade & Forma \\
\hline S1 & 88 & 2 & 8 compassos quaternários & $\begin{array}{c}\text { 1a voz: C\#3-E4 2a } \\
\text { voz: B1-E3 }\end{array}$ & $\begin{array}{c}\text { Modo de } \\
\text { B menor }\end{array}$ & A \\
\hline Andamento & \multicolumn{2}{|l}{ Andante } \\
\hline
\end{tabular}

Sugestão de instrumentos: Cordas / Sopros

\section{1) SOLFEJO No 107}

\begin{tabular}{|c|c|c|c|c|c|c|}
\hline Volume & № & Vozes & Extensão & Tessitura & Tonalidade & Forma \\
\hline S1 & 107 & 2 & 7 compassos ternários & $\begin{array}{c}\text { 1ạ voz: Eb3-Eb4 2a } \\
\text { voz: C2-Eb3 }\end{array}$ & $\begin{array}{c}\text { Modo de } \\
\text { Ab maior }\end{array}$ & A \\
\hline Andamento & \multicolumn{2}{|l}{} & & & & \\
\hline
\end{tabular}

Sugestão de instrumentos: Cordas / Sopros

72) SOLFEJO No 72

\begin{tabular}{|c|c|c|c|c|c|c|}
\hline Volume & No & Vozes & Extensão & Tessitura & Tonalidade & Forma \\
\hline S1 & 72 & 2 & 40 compassos ternários & $\begin{array}{c}\text { 1a voz: C3-F4; } \\
\text { 2a voz: G1-Eb3 }\end{array}$ & $\begin{array}{c}\text { Modo de } \\
\text { F menor }\end{array}$ & A \\
\hline Andamento & \multicolumn{6}{|l}{ Movimento de Valsa Lenta } \\
\hline
\end{tabular}

Sugestão de instrumentos: Cordas / Sopros / Piano

73) SOLFEJO No 129

\begin{tabular}{|c|c|c|c|c|c|c|}
\hline Volume & № & Vozes & Extensão & Tessitura & Tonalidade & Forma \\
\hline S1 & 129 & 2 & 14 compassos ternários & $\begin{array}{l}\text { 1a voz: E3-E4 } \\
\text { 2a voz: E2-E3 }\end{array}$ & $\begin{array}{c}\text { Modo de } \\
\text { E menor }\end{array}$ & A \\
\hline Andamento & \multicolumn{3}{l}{} & \\
\hline
\end{tabular}


Sugestão de instrumentos: Cordas / Sopros

\section{4) SOLFEJO No 113}

\begin{tabular}{|c|c|c|c|c|c|c|}
\hline Volume & № & Vozes & Extensão & Tessitura & Tonalidade & Forma \\
\hline S1 & 113 & 2 & 6 compassos binários & $\begin{array}{c}\text { 1a voz: D3-D4 } \\
\text { 2a voz: C\#2-D3 }\end{array}$ & $\begin{array}{c}\text { Modo de } \\
\text { D maior }\end{array}$ & A \\
& & & & & \\
\hline Andamento & \multicolumn{2}{|l}{ Andante }
\end{tabular}

Sugestão de instrumentos: Cordas / Sopros / Piano

75) SOLFEJO No 147

\begin{tabular}{|c|c|c|c|c|c|c|}
\hline Volume & № & Vozes & Extensão & Tessitura & Tonalidade & Forma \\
\hline S1 & 147 & 2 & $\begin{array}{c}5 \text { compassos } \\
\text { quaternários }\end{array}$ & $\begin{array}{c}\text { 1a voz: Bb2-Gb4 } \\
\text { 2a voz: C2-Db3 }\end{array}$ & $\begin{array}{c}\text { Modo de } \\
\text { F menor }\end{array}$ & A \\
\hline Andamento & \multicolumn{2}{l|}{ Moderato } \\
\hline
\end{tabular}

Sugestão de instrumentos: Cordas / Sopros

76) SOLFEJO No 74

\begin{tabular}{|c|c|c|c|c|c|c|}
\hline Volume & № & Vozes & Extensão & Tessitura & Tonalidade & Forma \\
\hline S1 & 74 & 2 & 9 compassos binários & $\begin{array}{l}\text { 1a voz: C3-F4; } \\
\text { 2a voz: C2-F3 }\end{array}$ & $\begin{array}{l}\text { Modo de } \\
\text { C maior }\end{array}$ & A \\
\hline Andamento & \multicolumn{2}{|l}{ Allegretto } \\
\hline
\end{tabular}

Sugestão de instrumentos: Cordas / Sopros

\section{7) SOLFEJO No 6 (Ditado)}

\begin{tabular}{|c|c|c|c|c|c|c|}
\hline Volume & No & Vozes & Extensão & Tessitura & Tonalidade & Forma \\
\hline $\begin{array}{c}\text { S2 } \\
\text { ditado }\end{array}$ & 6 & 1 & $\begin{array}{c}5 \text { compassos quaternários } \\
\text { (subdivisão ternária) }\end{array}$ & G2-G3 & $\begin{array}{c}\text { Modo de } \\
\text { Bb maior }\end{array}$ & $\mathrm{A}$ \\
\hline Andamento & \multicolumn{2}{|l|}{ (Sem indicação) } & \\
\hline
\end{tabular}

Sugestão de instrumentos: Cordas / Sopros

\section{8) SOLFEJO No 146}

\begin{tabular}{|c|c|c|c|c|c|c|}
\hline Volume & № & Vozes & Extensão & Tessitura & Tonalidade & Forma \\
\hline S1 & 146 & 2 & 12 compassos ternários & $\begin{array}{c}\text { 1a voz: B2-F4 } \\
\text { 2a voz: C\#2-D3 }\end{array}$ & $\begin{array}{c}\text { Modo de } \\
\text { G maior }\end{array}$ & A \\
\hline Andamento & \multicolumn{2}{|l}{ Andante } & & \\
\hline
\end{tabular}

Sugestão de instrumentos: Cordas / Sopros / Piano

79) SOLFEJO No 134

\begin{tabular}{|c|c|c|c|c|c|c|}
\hline Volume & No & Vozes & Extensão & Tessitura & Tonalidade & Forma \\
\hline S1 & 134 & 2 & $\begin{array}{c}\text { 12 compassos } \\
\text { quaternários }\end{array}$ & $\begin{array}{l}\text { 1a voz: C3-F4 } \\
\text { 2a voz: E2-C3 }\end{array}$ & $\begin{array}{c}\text { Modo de } \\
\text { F maior }\end{array}$ & A \\
\hline Andamento & \multicolumn{2}{|l|}{ Marcial } & \\
\hline
\end{tabular}

Sugestão de instrumentos: Cordas / Sopros / Piano 
80) SOLFEJO No 110

\begin{tabular}{|c|c|c|c|c|c|c|}
\hline Volume & № & Vozes & Extensão & Tessitura & Tonalidade & Forma \\
\hline S1 & 110 & 2 & $\begin{array}{c}\text { 8 compassos ternários } \\
\text { (subdivisão ternária) }\end{array}$ & $\begin{array}{c}\text { 1avoz: Bb2-Eb4 2a } \\
\text { voz: Bb1-D3 }\end{array}$ & $\begin{array}{c}\text { Modo de } \\
\text { Eb maior }\end{array}$ & A \\
\hline Andamento & \multicolumn{6}{|l}{ Animado (bem ritmado) Em forma de Sardanas } \\
\hline
\end{tabular}

Sugestão de instrumentos: Cordas / Sopros

81) SOLFEJO No 98

\begin{tabular}{|c|l|c|c|c|c|c|}
\hline Volume & № & Vozes & Extensão & Tessitura & Tonalidade & Forma \\
\hline S1 & 98 & 2 & $\begin{array}{c}\text { 8 compassos binários } \\
\text { (subdivisão ternária) }\end{array}$ & $\begin{array}{c}\text { 1a voz: E3-E4 2a } \\
\text { voz: C\#3-E4 }\end{array}$ & Modo de A menor & A \\
\hline Andamento & \multicolumn{6}{|l}{ Andantino } \\
\hline
\end{tabular}

Sugestão de instrumentos: Cordas / Sopros

82) SOLFEJO No 93

\begin{tabular}{|c|c|c|c|c|c|c|}
\hline Volume & № & Vozes & Extensão & Tessitura & Tonalidade & Forma \\
\hline S1 & 93 & 2 & $\begin{array}{c}8 \\
\text { compassos binários }\end{array}$ & $\begin{array}{c}\text { 1a voz: E3-E4 } \\
\text { 2a voz: C\#3-E4 }\end{array}$ & $\begin{array}{c}\text { Modo de } \\
\text { C menor }\end{array}$ & A \\
\hline Andamento & \multicolumn{2}{l|}{ (sem indicação) } \\
\hline
\end{tabular}

Sugestão de instrumentos: Cordas / Sopros / Piano

83) SOLFEJO No 77

\begin{tabular}{|c|c|c|c|c|c|c|}
\hline Volume & No & Vozes & Extensão & Tessitura & Tonalidade & Forma \\
\hline S1 & 77 & 2 & 8 compassos ternários & $\begin{array}{l}\text { 1a voz: F3-F4 } \\
\text { 2a voz: A1-C3 }\end{array}$ & $\begin{array}{c}\text { Modo de } \\
\text { A menor }\end{array}$ & A \\
\hline Andamento & \multicolumn{6}{l}{ Andantino } \\
\hline
\end{tabular}

Sugestão de instrumentos: Cordas / Sopros

84) SOLFEJO No 78

\begin{tabular}{|c|c|c|c|c|c|c|}
\hline Volume & № & Vozes & Extensão & Tessitura & Tonalidade & Forma \\
\hline S1 & 78 & 2 & $\begin{array}{c}\text { 3 compassos quaternários } \\
\text { (subdivisão ternária) }\end{array}$ & $\begin{array}{c}\text { 1a voz: C\#3-D4 } \\
\text { 2a voz: G1-A2 }\end{array}$ & $\begin{array}{c}\text { Modo de } \\
\text { A maior }\end{array}$ & A \\
\hline Andamento & \multicolumn{2}{|l}{ Pastoril e Agreste } \\
\hline
\end{tabular}

Sugestão de instrumentos: Cordas / Sopros

\section{5) SOLFEJO No 1 (Fuga)}

\begin{tabular}{|c|c|c|c|c|c|c|}
\hline Volume & № & Vozes & Extensão & Tessitura & Tonalidade & Forma \\
\hline $\begin{array}{l}\text { S2 } \\
\text { fuga }\end{array}$ & 1 & $\begin{array}{c}4 \\
\text { mistas }\end{array}$ & $\begin{array}{l}63 \text { compassos } \\
\text { quaternários }\end{array}$ & $\begin{array}{c}\text { soprano: C3-Ab4; } \\
\text { contralto: G2-E4 } \\
\text { tenor: B1-G4 } \\
\text { baixo: E1-C3 }\end{array}$ & $\begin{array}{l}\text { Modo de C } \\
\text { menor }\end{array}$ & $A B A$ \\
\hline Andamento & \multicolumn{6}{|c|}{ Assai moderato $(\mathrm{M} .76=\mathrm{J})$} \\
\hline
\end{tabular}


Dedicada à Mindinha. Fuga IV sobre um tema de caráter popular brasileiro.

Sugestão de instrumentos: Cordas / Sopros

86) SOLFEJO No 2 (Fuga)

\begin{tabular}{|c|c|c|c|c|c|c|}
\hline Volume & № & Vozes & Extensão & Tessitura & Tonalidade & Forma \\
\hline $\begin{array}{c}\text { S2 } \\
\text { fuga }\end{array}$ & 2 & 3 & 45 compassos binários & $\begin{array}{c}\text { 1a voz: F3-G4 } \\
\text { 2a voz: C\#3-Eb4 } \\
\text { 3a voz: G2-G\#3 }\end{array}$ & $\begin{array}{c}\text { Série } \\
\text { sobre C }\end{array}$ & ABA \\
\hline Andamento & \multicolumn{6}{|c|}{$d=60$} \\
\hline
\end{tabular}

Dedicada a H.Villa-Lobos. Pequeno estudo (técnica de 12 sons) de Max Brand.

Sugestão de instrumentos: Cordas / Sopros

\section{7) SOLFEJO No 3 (Fuga)}

\begin{tabular}{|c|c|c|c|c|c|c|}
\hline Volume & № & Vozes & Extensão & Tessitura & Tonalidade & Forma \\
\hline $\begin{array}{c}\text { S2 } \\
\text { fuga }\end{array}$ & 3 & 2 & $\begin{array}{l}64 \text { compassos } \\
\text { quaternários }\end{array}$ & $\begin{array}{c}\text { soprano: } \mathrm{C} 3-\mathrm{Bb} 4 ; \\
\text { contralto: } \mathrm{G} 2-\mathrm{Eb} 4 \\
\text { tenor: } \mathrm{C2}-\mathrm{G} 3 \\
\text { baixo: Eb1-C3 }\end{array}$ & $\begin{array}{l}\text { Modo de } \\
\mathrm{Cm}\end{array}$ & ABA \\
\hline Andamento & \multicolumn{6}{|c|}{ Moderato expressivo / final: Adagio } \\
\hline
\end{tabular}

Fuga IV de G.F. Haendel - arranjo de H. Villa-Lobos.

Sugestão de instrumentos: Cordas / Sopros

\section{8) SOLFEJO No 4 (Fuga)}

\begin{tabular}{|c|c|c|c|c|c|c|}
\hline Volume & № & Vozes & Extensão & Tessitura & Tonalidade & Forma \\
\hline $\begin{array}{l}\text { S2 } \\
\text { fuga }\end{array}$ & 4 & 2 & $\begin{array}{c}87 \text { compassos } \\
\text { quaternários }\end{array}$ & $\begin{array}{c}\text { soprano: C\#3-A4; } \\
\text { contralto: G32-E4 } \\
\text { tenor: B1-G\#3 } \\
\text { baixo: C\#1-E3 }\end{array}$ & $\begin{array}{l}\text { Modo de } \\
\text { A\# menor }\end{array}$ & ABA \\
\hline Andamento & \multicolumn{6}{|c|}{ Andante Sostenuto $(d=72$ ) } \\
\hline
\end{tabular}

Fuga ${ }^{\mathbf{0}} 8$ de J.S. Bach - arranjo de H. Villa-Lobos.

Sugestão de instrumentos: Cordas / Sopros

89) SAUDAÇÃO A GETÚLIO VARGAS

\begin{tabular}{|c|c|c|c|c|c|c|}
\hline Volume & № & Vozes & Extensão & Tessitura & Tonalidade & Forma \\
\hline CO1 & 40 & 4 & $\begin{array}{c}\text { 8 compassos quaternários } \\
\text { (subdivisão ternária); } 2 \text { binários }\end{array}$ & D3 - B4 & $\begin{array}{l}\text { Modo de } \\
\text { D maior }\end{array}$ & ABA \\
\hline Andamento & \multicolumn{7}{|l}{ Moderato } \\
\hline
\end{tabular}

Autoria de H. Villa-Lobos.

Sugestão de instrumentos: Metais 
90) BRASIL

\begin{tabular}{|c|c|c|c|c|c|c|}
\hline Volume & № & Vozes & Extensão & Tessitura & Tonalidade & Forma \\
\hline CO2 & 13 & 2 & $\begin{array}{c}132 \\
\text { compassos binários }\end{array}$ & $\begin{array}{c}\text { 1a voz: C3-F4 } \\
\text { 2a voz: Bb2-A3 }\end{array}$ & $\begin{array}{c}\text { Modo de C menor } \\
\text { / Eb maior }\end{array}$ & AB \\
\hline Gênero & \multicolumn{2}{l|}{ Marcha } & \\
\hline
\end{tabular}

Marcha instrumental de Thiers Cardoso com arranjo vocal de H.Villa-Lobos.

Sugestão de instrumentos: Banda / Fanfarra

91) BRASIL NOVO

\begin{tabular}{|c|c|c|c|c|c|c|}
\hline Volume & № & Vozes & Extensão & Tessitura & Tonalidade & Forma \\
\hline CO1 & 18 & $\begin{array}{c}4 \\
\text { Coro misto } \\
\text { acompanhado }\end{array}$ & $\begin{array}{c}110 \\
\text { compassos } \\
\text { quaternários }\end{array}$ & $\begin{array}{c}\text { Soprano: E3-G4; Contralto: } \\
\text { C\#3-C\#4; Tenor: B2-A3; } \\
\text { Baixo: E2-E3 }\end{array}$ & $\begin{array}{c}\text { Modo de A } \\
\text { maior / B menor } \\
\text { / A maior }\end{array}$ & $\begin{array}{c}\text { A B - } \\
\text { estrófica }\end{array}$ \\
\hline Gênero & \multicolumn{2}{|l|}{ Movimento de Marcha Moderado (de Rancho) } \\
\hline
\end{tabular}

Popular, com poesia de Zé Povo* e música de H.Villa-Lobos, 1922 - Rio de Janeiro.

*Pseudônimo de H. Villa-Lobos

Sugestão de instrumentos: Banda

\section{2) CANÇÃO CÍVICA RIO DE JANEIRO}

\begin{tabular}{|c|c|c|c|c|c|c|}
\hline Volume & № & Vozes & Extensão & Tessitura & Tonalidade & Forma \\
\hline CO1 & 13 & 3 & $\begin{array}{c}40 \text { compassos } \\
\text { binários }\end{array}$ & $\begin{array}{c}\text { 1a voz: E3-G4; } \\
\text { 2a voz: D\#3-C3; } \\
\text { 3a voz: G2-A3 }\end{array}$ & $\begin{array}{c}\text { Modos de C } \\
\text { maior }\end{array}$ & AB \\
\hline Gênero & \multicolumn{7}{|l}{ Marcial } & & \\
\hline
\end{tabular}

Canção cívica com letra de Leôncio Corrêa e música de Ernesto Nazareth.

Sugestão de instrumentos: Metais

93) CANÇÃO DA IMPRENSA

\begin{tabular}{|c|c|c|c|c|c|c|}
\hline Volume & No & Vozes & Extensão & Tessitura & Tonalidade & Forma \\
\hline CO1 & 34 & 2 & $\begin{array}{c}\text { 50 compassos } \\
\text { quaternários }\end{array}$ & C3 - Eb4 & $\begin{array}{c}\text { Modo de } \\
\text { Ab maior }\end{array}$ & ABA \\
\hline Andamento & \multicolumn{6}{|l}{ Andante Sostenuto - J $=72$} \\
\hline
\end{tabular}

Esta peça tem arranjo instrumental que não consta na edição.

Sugestão de instrumentos: Fanfarra / metais

\section{4) CANÇÃO DO ARTILHEIRO DA COSTA}

\begin{tabular}{|c|c|c|c|c|c|c|}
\hline Volume & № & Vozes & Extensão & Tessitura & Tonalidade & Forma \\
\hline CO1 & 37 & 2 & 62 compassos binários & $\begin{array}{l}\text { 1a voz: A2-G3 } \\
\text { 2a voz: G2-C3 }\end{array}$ & $\begin{array}{c}\text { Modo de } \\
\text { C maior }\end{array}$ & $\begin{array}{c}\text { Introdução } \\
\text { AB coda }\end{array}$ \\
\hline Andamento & & \multicolumn{7}{|l}{ Marcial } & \\
\hline
\end{tabular}

Letra do Coronel Luiz Lobo, melodia do Tenente Hermínio P. Souza e arranjo de H. VillaLobos. Na edição consta erradamente $n^{\circ} 57$. Esta peça tem arranjo instrumental que não consta na edição. 
95) CANÇÃO DOS ARTISTAS

\begin{tabular}{|c|c|c|c|c|c|c|}
\hline Volume & № & Vozes & Extensão & Tessitura & Tonalidade & Forma \\
\hline CO1 & 41 & 4 & $\begin{array}{c}60 \text { compassos } \\
\text { quaternários }\end{array}$ & D1-G4 & $\begin{array}{c}\text { Modo de } \\
\text { G maior }\end{array}$ & $\begin{array}{c}\text { Introdução } \\
\text { ABABA }\end{array}$ \\
\hline Andamento & \multicolumn{7}{|l|}{ Marcial } \\
\hline
\end{tabular}

Hino da Casa dos Artistas com letra de Raul Pederneiras e música de H. Villa-Lobos (Rio de Janeiro, 1919). Esta peça tem acompanhamento para piano.

Sugestão de instrumentos: Piano e cordas

96) CANÇÃO DO MARINHEIRO

\begin{tabular}{|c|c|c|c|c|c|c|}
\hline Volume & No & Vozes & Extensão & Tessitura & Tonalidade & Forma \\
\hline CO2 & 14 & 4 & 184 compassos binários & $\begin{array}{l}\text { 1a voz: D3-G4 } \\
\text { 2a voz: B2-E4 } \\
\text { 3a voz: A2-C3 } \\
\text { 4a voz: G2-C3 }\end{array}$ & $\begin{array}{c}\text { Modo de } \\
\text { A menor }\end{array}$ & $\begin{array}{c}\text { Introdução A } \\
\text { codeta B A }\end{array}$ \\
& & & & & \\
& & & & \\
\hline Andamento & \multicolumn{2}{|l|}{ Dobrado } & & \\
\hline
\end{tabular}

Letra de Benedito Xavier de Macedo, música de Antônio M. do Espírito Santo e arranjo de H. Villa-Lobos (Rio de Janeiro, 1937).

Sugestão de instrumentos: Banda / Fanfarra

97) CANÇÃO DO OPERÁRIO BRASILEIRO

\begin{tabular}{|c|c|c|c|c|c|c|}
\hline Volume & № & Vozes & Extensão & Tessitura & Tonalidade & Forma \\
\hline CO1 & 30 & 2 & $\begin{array}{c}\text { 51 compassos } \\
\text { binários }\end{array}$ & $\begin{array}{c}\text { 1a voz: Bb2-Eb4 } \\
\text { 2a voz: Bb2-Bb3 }\end{array}$ & $\begin{array}{c}\text { Modo de } \\
\text { Eb maior }\end{array}$ & AB \\
\hline Gênero & \multicolumn{2}{|l}{ Marcial } & & & \\
\hline
\end{tabular}

Letra de Paulino Santos e melodia de E.Villalba Filho*, 1939 - Rio de Janeiro *Pseudônimo de H. Villa-Lobos.

Sugestão de instrumentos: Banda / Fanfarra

98) DEODORO (Canção marcial)

\begin{tabular}{|c|c|c|c|c|c|c|}
\hline Volume & № & Vozes & Extensão & Tessitura & Tonalidade & Forma \\
\hline CO1 & 36 & 1 & $\begin{array}{c}18 \text { compassos } \\
\text { quaternários }\end{array}$ & C3 - F4 & $\begin{array}{c}\text { Modo de } \\
\text { F maior }\end{array}$ & AB \\
\hline Andamento & \multicolumn{2}{|l}{ Marcial } \\
\hline
\end{tabular}

Letra de Leôncio Corrêa e música de Francisco Braga. Esta peça tem arranjo instrumental que não consta na edição.

Sugestão de instrumentos: Fanfarra / metais

\section{9) DESFILE AOS HERÓIS DO BRASIL - a capella}

\begin{tabular}{|c|c|c|c|c|c|c|}
\hline Volume & № & Vozes & Extensão & Tessitura & Tonalidade & Forma \\
\hline CO1 & 21 & 3 & $\begin{array}{c}128 \text { compassos } \\
\text { binários }\end{array}$ & $\begin{array}{c}\text { 19- voz: C3-G4 2a } \\
\text { voz: A2-G4 3a } \\
\text { voz: F2-G3 }\end{array}$ & $\begin{array}{c}\text { Modos de } \\
\text { Bb maior / Gm }\end{array}$ & $A B$ \\
\hline Andamento & Movi & de Mar & e Rancho & & & \\
\hline
\end{tabular}


Letra de C. Paula Barros e música de H. Villa-Lobos (Rio de Janeiro, 1936). Indicação de andamento: Movimento de marcha rancho.

Sugestão de instrumentos: Banda

100) DUQUE DE CAXIAS (Canção Patriótica)

\begin{tabular}{|c|c|c|c|c|c|c|}
\hline Volume & № & Vozes & Extensão & Tessitura & Tonalidade & Forma \\
\hline CO1 & 35 & 1 & $\begin{array}{c}37 \text { compassos } \\
\text { quaternários }\end{array}$ & D3 - D4 & $\begin{array}{c}\text { Modo de } \\
\text { Bb maior }\end{array}$ & AB estrófico \\
\hline Andamento & \multicolumn{7}{|l}{ Marcial } \\
\hline
\end{tabular}

Letra de D. Aquino Corrêa e música de Francisco de Paula Gomes. Esta peça tem arranjo instrumental que não consta na edição.

Sugestão de instrumentos: Fanfarra / metais

101) MEU BRASIL (Samba)

\begin{tabular}{|c|c|c|c|c|c|c|}
\hline Volume & № & Vozes & Extensão & Tessitura & Tonalidade & Forma \\
\hline CO1 & 14 & 1 & $\begin{array}{c}55 \text { compassos } \\
\text { quaternários }\end{array}$ & $\begin{array}{c}\text { 19 voz: D3-D4 } \\
\text { 2a voz: B2-E4 }\end{array}$ & $\begin{array}{c}\text { Modo de D } \\
\text { maior }\end{array}$ & $\begin{array}{c}\text { Introdução } \\
\text { A B A }\end{array}$ \\
\hline Gênero & \multicolumn{6}{|c|}{ Tempo de marcha de rancho (embora no título a indicação seja: Samba) } \\
\hline
\end{tabular}

"Análises, estudos e adaptações da música popular - Tema e o 'ambiente' recolhidos pelo SEMA e adaptados para a educação folclórica nas escolas municipais. Melodia de Ernane da Silva, vendedor de jornais e compositor popular de 'escolas de samba' do R.J. Arranjado pelo SEMA para coro uníssono com acompanhamento de bateria (ritmo original) e Banda de Música. Letra de Alberto Ribeiro, ambientado por H.Villa-Lobos, 1935 - RJ”.

Sugestão de instrumentos: Percussão, piano e metais

102) MEU PAÍS

\begin{tabular}{|c|c|c|c|c|c|c|}
\hline Volume & № & Vozes & Extensão & Tessitura & Tonalidade & Forma \\
\hline CO1 & 24 & $\begin{array}{c}4 \\
\text { mistas }\end{array}$ & $\begin{array}{c}60 \\
\text { compassos } \\
\text { quaternários }\end{array}$ & $\begin{array}{c}\text { Soprano: B2-A4; Contralto: } \\
\text { A2-E4; Tenor: B1-F\#3; } \\
\text { Barítono: B1-E3; Baixo: F\#1-E3 }\end{array}$ & $\begin{array}{c}\text { Modo de } \\
\text { A maior }\end{array}$ & AB Estrófica \\
\hline Gênero & \multicolumn{7}{|l}{ Marcial } \\
\hline
\end{tabular}

Popular, canção patriótica brasileira (exortação), com texto anônimo e música de H.VillaLobos, 1919 - Rio de Janeiro.

Sugestão de instrumentos: Banda / Fanfarra

103) TIRADENTES

\begin{tabular}{|c|c|c|c|c|c|c|}
\hline Volume & № & Vozes & Extensão & Tessitura & Tonalidade & Forma \\
\hline CO1 & 25 & $\begin{array}{c}4 \\
\text { mistas }\end{array}$ & $\begin{array}{c}56 \\
\text { compassos } \\
\text { quaternários }\end{array}$ & $\begin{array}{c}\text { Soprano: B2-C\#3; } \\
\text { Contralto: C\#3-D4; } \\
\text { Tenor: D2-E3; } \\
\text { Barítono: G2-D3; } \\
\text { Baixo: G2-D3 }\end{array}$ & $\begin{array}{l}\text { Modo de } \\
\text { G maior }\end{array}$ & $\begin{array}{l}\text { Rondó } \\
\text { ABABA }\end{array}$ \\
\hline Gênero & \multicolumn{6}{|c|}{ Marcial } \\
\hline
\end{tabular}

Popular, canto patriótico, com letra de Viriato Correa e música de E.Villalba Filho* (Rio de Janeiro, 1938).

*Pseudônimo de H. Villa-Lobos 


\section{CONCLUSÃO}

Após análise cuidadosa das peças que compõem os cinco volumes aqui focalizados, foi possível confirmar a hipótese inicial de que se trata de um material importante para ser utilizado em qualquer programa de ensino musical pelos seguintes motivos:

O repertório é abrangente com relação a níveis de complexidade, desde o canto uníssono a capella ou acompanhado, a duas ou mais vozes, até aos aspectos de ordem composicional - arranjos com emprego de polifonia e harmonizações. Partindo do simples e do conhecido, como as canções infantis folclóricas e similares, os aspectos pedagógicos contemplam a voz infantil e adulta de maneira adequada em relação à extensão vocal, apresentando predominância de ritmos binários, de modos maiores, e da utilização de pedais harmônicos e ostinatos.

As sugestões pedagógicas que acompanham as análises apresentam-se como alternativas para o ensino da leitura e da escrita musical a partir das peças analisadas.

A ordenação das peças, partindo das melodias e canções em uníssono, forma uma sequência adequada para uso didático - tanto para o desenvolvimento do canto, quanto da leitura. $\mathrm{O}$ fato de as melodias a duas ou mais vozes estarem registradas no capítulo posterior não significa que os arranjos mais simples (polifônicos, especialmente) não devam ou possam ser utilizados concomitantemente com as melodias ou canções a uma voz.

Sobre os arranjos com emprego de contraponto, pode-se observar um grande predomínio de intervalos de terças e sextas, estratégia que se aproxima da realidade tonal harmônica da música popular. Os contrapontos imitativos e os livres precedem pela ordem as harmonizações, por apresentarem menor dificuldade para o aprendizado. Os arranjos de maior complexidade foram aqui sugeridos para execução instrumental no caso de não serem viáveis para a execução vocal do grupo de destino.

As harmonizações para vozes iguais são mais indicadas para aproveitamento didático, e as dirigidas para vozes mistas são mais adequadas à prática coral de nível médio.

Os textos nem sempre são próprios para uso educacional, seja pela inadequação do ponto de vista pedagógico, como, por exemplo, o uso do termo "bobalhão",80 e outros, de fundo preconceituoso como "O corcunda",

\footnotetext{
${ }^{80}$ Em GP-VTL número 34.

${ }^{81}$ Em GP-VTL número 42.
} 
político do período em que foram compostas, como a "Saudação a Getúlio Vargas",82, e outras. Há que se considerar que todos esses termos e expressões tinham outra conotação naquela época, mas por não serem hoje pertinentes ao contexto educacional, são válidas as sugestões de aproveitamento dessas músicas para execução instrumental ou vocal com outros textos, ou outras soluções de cunho timbrístico.

As peças com acompanhamento instrumental apresentam uma abertura rica e oportuna para o exercício da criatividade por parte de docentes e discentes.

As indicações do autor para a execução ao piano - “com a mão esquerda oitava abaixo” - merecem dos professores desse instrumento uma atenção especial, como opção para que sejam incorporadas ao repertório técnico e artístico da fase inicial de estudo, podendo a parte da mão esquerda ser transcrita para a clave de $\boldsymbol{F}$.

As melodias e canções propostas por Villa-Lobos tinham outro significado estético em sua época, quando se praticava mais o canto e as brincadeiras infantis. Admitindo-se que hoje a criança canta menos e não cultiva na mesma proporção tais brincadeiras, o aproveitamento desse conteúdo passa a ser uma possibilidade para a prática escolar, dado o seu rico teor musical e aspectos lúdicos que cumprem papel importante na formação da criança.

A eventual utilidade deste trabalho está ligada aos objetivos do educador musical em várias instâncias - poderá utilizar-se das sugestões pedagógicas, dos dados analíticos, da ordenação das peças, da seleção de solfejos para incorporação em repertório instrumental, tanto com objetivo artístico como didático, sendo que este aspecto merece um trabalho criterioso de conhecimento técnico de cada instrumento. Por outro lado, pode simplesmente trazer à memória esse conteúdo específico da obra de Villa-Lobos como sugestão para novos estudos.

\footnotetext{
${ }^{82}$ Em CO1 número 40
} 


\section{REFERÊNCIAS BIBLIOGRÁFICAS}

ALMEIDA, Judith Morrisson. Aulas de Canto Orfeônico - para as quatro séries do curso ginasial. São Paulo: Cia. Ed. Nacional, 1952.

ALVARENGA, Oneyda. Música popular brasileira. 2.ed. São Paulo: Duas Cidades, 1982.

AMATO, Rita de Cássia Fucci. Momento Brasileiro: Reflexões sobre o Nacionalismo, a Educação Musical e o Canto Orfeônico em Villa-Lobos. Revista Electrónica Complutense de Investigación em Educación Musical, v. 5 nº. 2, 2008.

ANDRADE, M. de. Aspectos da Música Brasileira. São Paulo: Martins,1965.

. Música do Brasil. São Paulo: Guaíra, 1941.

. Dicionário Musical Brasileiro. Coord. de Oneyda Alvarenga e Flávia Camargo

Toni. Belo Horizonte: Itatiaia; Ministério da Cultura; São Paulo: Instituto de Estudos Brasileiros, EDUSP, 1989.

Ensaio sobre música brasileira. São Paulo: Martins, 1962.

. O Turista Aprendiz. Estabelecimento. São Paulo: Duas Cidades, 1976.

ANDREOZZI DA COSTA, M. L. Piaget e a intervenção psicopedagógica. São Paulo: Olho D’água, 1997.

ANTUNES, C. Como identificar em você e em seus alunos as inteligências múltiplas. Petrópolis: Vozes, 2001.

AZEVEDO, Luiz Heitor Correia de. Escala, ritmo e melodia na música dos índios brasileiros. Rio de Janeiro: Jornal do Commercio, 1938.

150 anos de Música no Brasil (1800-1950). In: Coleção Documentos Brasileiros, dirigida por Octavio Tarquínio de Souza No 87. Rio de Janeiro: José Olympio, 1956.

BARRETO, Ceição de Barros. Côro Orfeão. Rio de Janeiro: Melhoramentos, 1938.

BAS, Júlio. Tratado de la Forma Musical. 6. ed. Buenos Aires: Ricordi Americana, 1972.

BEHAGE, Gerard. Heitor Villa-Lobos: the search for Brazil's musical soul. Austin, Texas: ILAS, 1994.

BEUTTENMÜLLER, M. G.; LAPORT, N. Expressão vocal e expressão corporal. Rio de Janeiro: Forense-Universitária, 1974.

BISPO, Antônio Alexandre. Brasil 2000. Colóquio - Heitor Villa-Lobos. Revista da organização de estudos culturais em contextos internacionais Brasil-Europa. www.brasileuropa.eu 
Fundamentos da cultura musical no Brasil. Revista da organização de estudos culturais em contextos internacionais Brasil-Europa. www.brasil-europa.eu

BRASILIANA. Revista quadrimestral da Academia Brasileira de Música. No. 3, setembro de 1999; No. 06, maio de 2000; No. 11, maio de 2002; No. 23, Maio de 2006.

BRAUNWIESER, M. Vinte e cinco rodas cantadas. São Paulo: Vitale, s.d.

BRITO, T. A. de. Música na Educação Infantil. Ed. Fundação Peirópolis, São Paulo: 2003.

. Koellreutter educador - o humano como objetivo da educação musical. São Paulo: Peirópolis, 2001.

BRISOLLA, Cyro. Princípios de Harmonia Funcional. São Paulo: Novas Metas, 1979.

BROUGÈRE, G. Brinquedo e cultura. 2.ed. São Paulo: Cortez, 1997.

BRUNET-LECOMTE, H. Jaques-Dalcroze: sa vie, son oeuvre. Genebra: Jeheber, 1950.

CACCIATORE, Olga G. Dicionário Biográfico de Música Erudita Brasileira. Rio de Janeiro: Forense, 2005.

CAETANO, Pedro. 54 Anos de Música Popular Brasileira - O que fiz, o que vi. 2. Ed. Rio de Janeiro: Pallas, 1988.

CAMBI, Franco. História da Pedagogia. Trad. Álvaro Lorencini. São Paulo: UNESP, 1999.

CAMPOS, M. C. A Educação Musical e o novo paradigma. Rio de Janeiro: Enelivros, 2000.

CARVALHO, A.; D. de. Como brincar à moda antiga. Belo Horizonte: Ed. Lê, 1995.

CAUDURO, V. R. Iniciação Musical na idade Pré-Escolar. Porto Alegre: Sagra, 1996.

CERNICCHIARO, Vincenzo. Storia della Musica nel Brasile - dai tempi coloniali fino ai nostri giorni (1549-1925). Milano: Fratelli Riccioni. 1926.

CHAilley, J.; CHAllan, H. Theorie Complète de la Musique. Paris: Alphonse Leduc, 1944.

CHATEAU, Jean. O jogo e a criança. Trad. Guido de Almeida. São Paulo: Summus, 1987.

CHOKSY, L. The Kodály Method - comprehensive music education from infant to adult. New Jersey: Prentice-Hall, 1981.

Prentice-Hall, 1981.

. The Kodály context - creating an environment for musical learning. New Jersey:

COELHO, H. W. Técnica vocal para coros. São Leopoldo (RS): Sinodal, 1994.

CONTIER, Arnaldo Daraya. Música e Ideologia no Brasil. 2.ed. São Paulo: Novas Metas, 1985.

COSTA, M. L. A. da. Piaget e a intervenção psicopedagógica. São Paulo: Olho d'água, 1997. 
COSTA, N. M. da; VALLE, E. AL. DEL. Música na escola primária. Rio de Janeiro: José Olympio, 1969.

COUTINHO, M.L. A dança da Carochinha - Folclore Infantil. Belo Horizonte: O Lutador, 1989.

DAHLHAUS, Carl. Estética Musical. Lisboa: 70, 1991.

DEPARTAMENTO DE CULTURA DA CIDADE DE SÃO PAULO. Melodias coletadas por meios não mecânicos. São Paulo, 1938.

DICIONÁRIO CRAVO ALBIN DA MÚSICA POPULAR BRASILEIRA. http://www. dicionariompb.com.br

DOMONKOS, P. L. Método Kodály - enseñanza musical en las escuelas primarias. Buenos Aires: Aedes Beethoven Al Pin's, 1969.

Enciclopédia da Música Brasileira: popular, erudita e folclórica. 2. ed. São Paulo: Art/Publifolha, 1998.

FERREIRA, Aurélio Buarque de Holanda. Novo dicionário Aurélio da língua portuguesa. 3.ed. Curitiba: Positivo, 2004.

FERRERO, M. I.; FURNÓ, S. C.; LANFRANCHI, A. V. L. e QUADRANTEI, R. A. Planeamento de la enseñanza musical. Buenos Aires: Ricordi, 1979.

. Musijugando. Actividades de Educación Musical. Buenos Aires: EME, 1977.

FONTERRADA, Marisa Trench de Oliveira. De tramas e fios - Um ensaio sobre Música e Educação. São Paulo: UNESP, 2005.

Música e meio ambiente - Ecologia Sonora. São Paulo: Vitale, 2004.

FRIDMAN, R. Los comienzos de la conducta musical - del primer vagido al lenguaje entonado y articulado. Buenos Aires: Paidós, 1974

GAGNARD, M. Iniciação musical dos jovens. Trad. José Luís Tinoco. Lisboa: Estampa, 1974.

GAINZA, V. H. de. (Ed.). La transformación de la educación Musical a las puertas del siglo XXI. Buenos Aires: Guadalupe, 1997.

. Pedagogía Musical - Dos décadas de pensamiento y acción educativa. Buenos Aires: Lumen, 2003.

. Estudos de Psicopedagogía Musical. São Paulo: Summus, 1988.

. (Ed.) La Educación Musical frente al futuro. Buenos Aires: Guadalupe, 1993.

. Problemática actual y perspectivas de la Educación Musical para el siglo XXI. Lima: Pontificia Universidad Catolica del Peru, 2000.

. La improvisación musical. Buenos Aires: Ricordi Americana, 1983. 
GALINARI, Meliandro Mendes. A era Vargas no pentagrama: dimensões políticodiscursivas do Canto Orfeônico de Villa-Lobos. Tese de Doutorado. Belo Horizonte: UFMG, Faculdade de Letras, 2007.

GARCIA, R. M. R.; MARQUES, L. A. Brincadeiras cantadas. Porto Alegre: Kuarup, 1989. Jogos e Passeios Infantis. Porto Alegre: Kuarup, 1991.

GARDNER, H. A criança Pré-Escolar: como pensa e como a escola pode ensiná-la. Porto Alegre: Artes Médicas, 1994.

GIFFORD, E. F. Road and Play, the Singing Way (Kodály based). Victoria: National Library of Australia, 1981.

GILIOLI, R. de S. P. “Civilizando” pela música: a pedagogia do Canto Orfeônico na Escola Paulista da Primeira República (1910-1930). Dissertação de Mestrado. São Paulo: FE-USP, 2003.

GORDON, E. Teoria de aprendizagem musical para recém-nascidos e crianças em idade pré-escolar. Lisboa: Calouste Gulbenkian, 2000.

HALASZ, L.; FRISS, G. Kodály Method. USA: Hill\&Range Songs, 1971.

HALL, D. Orff-Schulwerk, Music for Children - Teacher's Manual. Mainz: B. Schott's Söhne, 1960.

HEGYI, E. Stylistic knowledge on the basis of the Kodály Concept. Budapeste: Editio Musica, 1984.

Solfege according to the Kodály-concept. Vol. I e II. Kecskemét: Z. Kodály Pedagogical Institute of Music, 1975

HEIN, M. A. The Legacy of Zoltán Kodály: an oral history perspective. Budapeste: IKS,1992.

HEYLEN, J. Parlenda, riqueza folclórica - Base para a Educação e Iniciação à Música. São Paulo: Hucitec, 1991.

HOWARD, W. A música e a criança. São Paulo: Summus, 1984.

HUNDOEGGER, A. Lehrweise nach Tonika Do. Köln: Kistner\&Siegel\&Co., s.d.

IVANCKO, Lucy. Nova Orientação Pedagógica do Solfejo. 3.ed. São Paulo: Vitale, 1968

JANNIBELLI, E. D’A. Seleção Didática de Músicas escolares. Cadernos 1, 2, 3 e 4. São Paulo: Ed. do autor, 1974.

JAQUES-DALCROZE, Émile. La musique et nous. Genebra: P.F. Perret-Gentil, 1945. . Le rythme, la musique et l'éducation. Lausanne: Foetisch Frères, 1965. . Notes Bariolées. Genebra: Jeheber, 1948.

JARDIM, Gil. O estilo antropofágico de Heitor Villa-Lobos. São Paulo: Philarmonia Brasileira, 2005. 
JARDIM, Vera Gomes. Os Sons da República - O ensino da Música nas escolas públicas de São Paulo na Primeira República (1889-1930). Tese de mestrado. São Paulo: PUC-SP, 2003.

JOPPERT, M. A.; SILVA, O. F. L. V. da. Canções folclóricas brasileiras. Rio de Janeiro: Eulenstein, 1969.

KAMII, C.; DeVRIES, R. Jogos em grupo na Educação Infantil - implicações da teoria de Piaget. Trad. Marina Célia Dias Carrasqueira. São Paulo: Trajetória Cultural, 1991.

KASZÁS, J. Aprender cantando. São Paulo: SKB, 1997. Aprender ouvindo. São Paulo: SKB, 1999.

KELLER, W. Orff-Schulwerk - Introduction to music for children. New York: Schott, 1970.

KEMP, A. E. Introdução à investigação em Educação Musical. Lisboa: Calouste Gulbenian, 1995.

KEETMAN, Gunild. Elementaria - First acquaintance with Orff-Schulwerk. Londres: Schott, 1974.

Söhne, S.d.

Orff-Schulwerk - Jugenmusick - Spielstücke für Blockflöten. Mainz: Schott's

KERMAN, Joseph. Musicologia. Coleção Opus 86. Trad. de Álvaro Cabral. São Paulo: Martins Fontes, 1987.

KIEFER, Bruno. Villa-Lobos e o modernismo na música brasileira. 2.ed. Porto Alegre: Movimento; Brasília: Fundação Nacional Pró-Memória, 1986.

. Elementos da linguagem musical. Porto Alegre: Movimento, 1982.

KISHIMOTO, T. M. (Org.). Jogo, Brinquedo, Brincadeira e a Educação. 5. ed. São Paulo: Cortez, 2001.

KODÁLY, Zoltán. Cantemos correctamente a dos voces. 2.ed. Buenos Aires: Barry, s.d.

KOELLREUTTER, H. J. Contraponto Modal do Século XVI (Palestrina). Brasília:

Musimed, 1996.

. Estética. Trad. e Coord. Saloméa Gandelman. São Paulo: Novas Metas, 1984.

. Harmonia Funcional. São Paulo: Novas Metas 1980.

KREHL, S. Contrapunto. Buenos Aires: Labor, 1930.

LEMOS JR, Wilson. Canto Orfeônico: Uma investigação acerca do ensino de música na escola secundária pública de Curitiba (1931-1956). Dissertação de Mestrado. Curitiba: UFP, 2005.

LIMA, F. de A. O Canto Orfeônico no Curso Secundário - $3^{\mathrm{a}}$ e $4^{\mathrm{a}}$ séries. 3.ed. Rio de Janeiro: Baptista de Souza, 1957.

LISBOA, Alessandra Coutinho. Villa-Lobos e o Canto Orfeônico: Música, Nacionalismo e Ideal Civilizador. Dissertação de mestrado. São Paulo: UNESP, 2005. 
LISBOA, Alessandra C.; KERR, Dorotéa M. Villa-Lobos e o Canto Orfeônico: análise de discurso nas canções e cantos cívicos. São Paulo: ANPPOM - Décimo Quinto Congresso, 2005.

LOZANO,F.; GAMA, Y. Cantos e Recreações Infantis. São Paulo: Melhoramentos. S.d.

LOZANO, Fabiano. Meu livro de solfejo. São Paulo: Vitale, 1954.

. Minhas cantigas. São Paulo: Ricordi, 1933.

MACHADO, Maria Celia. Heitor Villa-Lobos: Tradição e renovação na música brasileira. Rio de Janeiro: Francisco Alves, 1987.

MAFFIOLETTI, L. Cantigas de roda. Porto Alegre: Magister, 1995.

MAIA, Maria. Villa-Lobos: Alma Brasileira. Rio de Janeiro: Contraponto/ PETROBRÁS, 2000.

MARCONI, M. A. Brinquedos cantados e danças do Brasil. São Paulo: Ricordi, 1978.

MÁRIO, F. Cantar e brincar. Rio de Janeiro: R. B. E., 2000.

MARIZ, VASCO. História da Música no Brasil - 5.ed. Rio de Janeiro: Nova Fronteira, 2000. . Villa-Lobos - o homem e a obra. Rio de Janeiro: Francisco Alves, 2005.

Cultural, 1947.

Heitor Villa-Lobos. Rio de Janeiro: Ministério das Relações Exteriores - Divisão

MÁRSICO, L. A voz infantil e o desenvolvimento músico-vocal. Porto Alegre: Escola Superior de Teologia, 1979. . A criança e a música. Porto Alegre: Globo, 1982.

MARTENOT, M. Método Martenot - Solfeo - Guía Didáctica del Maestro. Buenos Aires: Ricordi, 1976.

La carrera de las notas. Buenos Aires: Ricordi, 1976.

. Formacion y Desarrollo Musical $-1^{\circ}$ e $2^{\circ}$ Cuadernos. Buenos Aires: Ricordi, 1976.

Ricordi, 1976.

Entonacion - Transporte - Ritmo - Fraseo - $3^{\circ}$. Cuaderno. Buenos Aires:

MARTINS, J. B. Antropologia da Música Brasileira. Natureza, ritmo, texto, cultura. São Paulo: Obelisco, 1978.

MARTINS, M. de L. A criança e a música - a cartilha do aluno. Lisboa: Horizonte, 1987. . Orff-schullwerk - Música para Crianças. Vol. I, II. Mainz: Schott, 1969.

MAYOR, Jean-Claude. Rythme et Joie avec Émile Jaques-Dalcroze. Genève: Ketty\&Alexandre, 1996.

MED, Bohumil. Ritmo. 4.ed. Brasília: Musimed, 1986. 
Teoria da Música. 2. ed. Brasília: Musimed, 1985.

. Solfejo. 2.d. Brasília: Musimed, 1986.

MELO, Veríssimo de. Folclore Infantil. Belo Horizonte: Itatiaia, 1980.

MIGNONE, L. CH. Guia para o professor de Recreação Musical. São Paulo: Ricordi, 1967.

MINISTÉRIO DA EDUCAÇÃO E CULTURA. Música na Escola Primária. MEC, 1962.

MINISTÉRIO DA EDUCAÇÃO E DO DESPORTO - Secretaria de Educação Fundamental, Departamento de Política da Educação Fundamental, Coordenação Geral de Educação Infantil - Referencial Curricular Nacional para a Educação Infantil - Brasília, 1998.

. Parâmetros curriculares nacionais. Adaptações curriculares e estratégias para a educação de alunos com necessidades educacionais especiais. Brasília: MEC/SEF/SEESP, 1999.

MOURA, I. C. de; BOSCARDIN, M. T. T.; ZAGONEL, B. Musicalizando crianças - Teoria e Prática da Educação Musical. São Paulo: Ática, 1996.

NAPOLITANO, Marcos. História \& Música - História Cultural da Música Popular. Belo Horizonte: Autêntica, 2002.

NOVAES, I. C. Brincando de roda. Rio de Janeiro: Agir, 1983.

PIRET, S.; BÉZIERS, M. M. A coordenação motora - aspecto mecânico da organização psicomotora do homem. São Paulo: Summus, 1992.

OLIVEIRA, J. Z.; Marilena de. Prática de estruturas musicais I e II. São Paulo: Ed. do autor, 1976.

Harmonia Funcional I e II. São Paulo: Cultura Musical, 1978.

OLIVEIRA, V. B. de. (Org.) O brincar e a criança do nascimento aos seis anos. Petrópolis, RJ: Vozes, 2000.

ÖRDÖG, L. La educación musical según el sistema Kodály. Valencia: Rivera, 2000.

ORFF, C.; KEETMAN, G. Musik für kinder. Liederbuch A, B, C. Mainz: Schott's Söhne, 1964.

. Orff-Schulwerk - Music for Children - Sayings-Riddles- Auguries- Charms studies for speech. Mainz: Schott's Söhne, 1969.

Grundbungen. Mainz: Schott, s.d.

. Musik für kinder. Vol. I, II, III, IV, V. Mainz: Schott, 1964.

OSTROWER, Fayga. Criatividade e Processos de Criação. Petrópolis: Vozes, 1987.

PAHLEN, K. A criança e a música. São Paulo: Melhoramentos. S.d.

PAZ, E. A. Quinhentas canções brasileiras. Rio de Janeiro: Luiz Gogo, 1989. 
Musimed, 2000.

Pedagogia Musical Brasileira no Século XX - Metodologias e tendências. Brasília: . O Modalismo na Música Brasileira. Brasília: Musimed, 2002.

. Sôdade do Cordão. Rio de Janeiro: Fundação Universitária José Bonifácio, 1994.

. Heitor Villa-Lobos - O Educador. Brasília: Instituto Nacional de Estudos e Pesquisas, 1988.

As estruturas modais na música folclórica brasileira. Rio de Janeiro: UFRJ, 1993.

PENNA, Maura (coord.). O Dito e o Feito - Política Educacional e Arte no ensino Médio. João Pessoa: Manufatura, 2003.

PEPPERCORN, Lisa. Villa-Lobos - Biografia ilustrada do mais importante compositor brasileiro. Ed. Audrey Sampson. Trad. Talita M. Rodrigues. Rio de Janeiro: Ediouro, 2000.

PEREIRA, Marco. Heitor Villa-Lobos - sua obra para violão. Brasília: Musimed, 1984.

PIAGET, Jean. Fazer e Compreender. São Paulo: Melhoramentos/Edusp, 1978.

PIRES, Filipe. Elementos teóricos do contraponto e cânon. Lisboa: Fundação Calouste Gulbenkian, 1981.

RAMOS, Marco Antonio da Silva Ramos. O Uso Musical do Silêncio. In: Revista música. São Paulo, Vol. No. 8, maio/novembro -1997, p. 129 -168.

. O ensino da regência coral. Tese apresentada como requisito parcial para Livredocência. Escola de Comunicações e Artes da Universidade de São Paulo. São Paulo: ECA/USP, 2003.

RAMSIER, P. Games children sing around the world. USA: Warner Bros Music. S.d.

REAM, A. Um estudo sobre a voz infantil. São Paulo: Metodista, 1973.

RIBEIRO, João Carlos. (Org.) O pensamento vivo de Heitor Villa-Lobos. São Paulo: Martin Claret, 1987.

RIBEIRO, Wagner. História da Música na América. São Paulo: F.T.D., 1965.

Antologia de Cantos Orfeônicos e Folclóricos. Parte I e II. São Paulo: F.T.D., 1965.

RIBIÈRE-RAVERLAT, J. Un chemin pedagogique en passant par les chansons - adaptation française de la Méthode Kodály. Vol. I a IV. Paris: Alphonse Leduc, 1974.

. Chant-Musique - adaptation française de la Méthode Kodály. Livre de l'élève I, II. Paris: Alphonse Leduc, 1976.

. Chant-Musique - adaptation française de la Méthode Kodály. Classes élémentaires - 1er. Année. Livre du Maitre I, II . Paris: Alphonse Leduc, 1975.

RICHARDS, M. H. Hand singing and other techniques. Belmont, California: Fearon-Pitman, 1966. 
RIEMANN, H. Fraseo Musical. Buenos Aires: Labor, 1928.

ROCHA, C. M. M. Educação Musical - Método Willems. Salvador: FE-Bahia, 1990

RODRIGUES, I. E. La Rítmica de: Emile Jaques Dalcroze - una educación por la musica y para la musica. Genebra: Instituto Dalcroze, 2003.

ROUSSEL-POUILLES, M. Iniciation musicale par le chant. Paris: Armand Colin, 1970.

RUSSEL-SMITH, G. Be a better musician. A book for Young classes based on the Kodály method. Londres: Boosey\&Hawkes, 1977.

Be a better musician. The second book for Young classes based on the Kodály method. Londres: Boosey\&Hawkes, 1978.

SADIE, Stanley (editor). Dicionário Grove de música, edição concisa. (Tradução de

The Grove Concise Dictionary of Music) Rio de Janeiro: Jorge Zahar, 1994.

SALlES, Pedro Paulo. Gênese da Notação Musical na Criança. Dissertação de Mestrado. São Paulo: FEUSP, 1996.

A Reinvenção da Música pela Criança: implicações pedagógicas da criação musical. Tese de Doutorado. São Paulo: FEUSP, 2002.

SÁNDOR, F. (org.) Educación Musical en Hungria. Budapeste: Corvina Kiadó,1981.

SECRETARIA DE ESTADO DA EDUCAÇÃO - São Paulo - Coordenadoria de Estudos e Normas Pedagógicas. Proposta Curricular para o Ensino de Educação Artística - $1^{\circ}$ Grau. São Paulo, 1991.

SCHAFER, Murray. O Ouvido Pensante. Trad. Marisa Trench de O. Fonterrada, Magda R. Gomes da Silva, Maria Lúcia Pascoal. São Paulo: UNESP, 1991.

SCHOLZ, H. Compendio de Armonia. Buenos Aires: Labor, 1946.

SCHWARTZMAN, Simon; BOMENY, Helena M. Bousquet; COSTA, Vanda M. Ribeiro. Tempos de Capanema. São Paulo: Paz e Terra - FGV, 2000.

SCLIAR, E. Fraseologia Musical. Porto Alegre: Movimento, 1982.

SEVERIANO, Jairo. Uma história da música popular brasileira - Das origens à modernidade. São Paulo: 34, 2008.

SIMÕES, R. M. Canções para a Educação Musical. Lisboa: Valentim de Carvalho. S.d.

SIQUEIRA, Baptista. Pentamodalismo Nordestino - baseado em dados folclóricos. I e II Volumes. Rio de Janeiro: Escola Nacional de Música da Universidade do Brasil, 1956.

SLOBODA, John A. A mente musical - A psicologia cognitiva da música. Trad. Beatriz Ilari e Rodolfo Ilari. Londrina: EDUEL, 2008.

SÖNYI, E. Musical reading writing. Vol. I . Budapest: Editio Musica, 1974. 
Musical reading writing. Vol. II . Budapest: Editio Musica, 1978.

Ávila. São Paulo: SKB, 1996.

. A Educação Musical na Hungria através do Método Kodály. Trad. Marli Batista . Leitura e Escrita Musical. Trad. Marli Batista Ávila. São Paulo: SKB, 1999.

SOUZA, Loly Amaro de. Heitor Villa-Lobos. São Paulo: Moderna, 2001.

STOKES ENCYCLOPEDIA OF MUSIC AND MUSICIANS, vol. 2 - in http://books.google.com . Acesso em 14/10/2009.

STOKOE, P.; HARF. R. Expressão corporal na pré-escola. São Paulo: Summus, 1987.

STOKOE, P. Expresión corporal - Arte, Salud y Educación. Buenos Aires: Humanitas, 1990.

. Expresión corporal - guia didáctica para el docente. Buenos Aires: Ricordi Americana, 1978.

STRAVINSKY, Igor; CRAFT, Robert. Conversas com Igor Stravinski. Trad. Stella Rodrigo Octavio Moutinho. São Paulo: Perspectiva, 2004.

STRAVINSKY, Igor. Poética Musical em Seis Lições. Trad. Luiz Paulo Horta. Rio de Janeiro: Jorge Zahar, 1996.

SWANWICK, K. Permanecendo fiel à música na educação musical. Porto Alegre: ABEM, 1993. . Ensinando música musicalmente. São Paulo: Moderna: 2003.

TINHORÃO, José Ramos. História Social da Música Popular Brasileira. São Paulo: 34, 2005.

- Cultura Popular - Questões e Temas. São Paulo: Editora 34, 2001.

2008. . Os sons dos negros no Brasil - Cantos, danças, folguedos: origens. São Paulo: 34,

TOCH, E. La melodía. Buenos Aires: Labor, 1931.

TONI, Flávia Camargo. Mário de Andrade e Villa-Lobos. São Paulo: Centro Cultural, 1987.

TORRES, Rosa Maria. As Canções Tradicionais Portuguesas no ensino da Música Contribuição da Metodologia de Zoltán Kodály. Lisboa: Caminho, 1998.

UNGLAUB, Tânia Regina da Rocha. Processo de homogeneização cultural em Santa Catarina via Canto Orfeônico durante a ditadura de Vargas. Florianópolis: UFSC, 2006.

VASCONCELOS, Ary. A nova música da república velha. Rio de Janeiro: Elizart, 1985.

VIGOTSKY, L. S. A formação social da mente. São Paulo: Martins Fontes,1991.

Pensamento e linguagem. São Paulo: Martins Fontes, 1991.

VILLA-LOBOS, H. Guia prático - estudo folclórico musical. São Paulo: Irmãos Vitale, 1941. 
. Canto Orfeônico. $1^{\circ}$ volume. São Paulo: Vitale, 1976.

. Canto Orfeônico. $2^{\circ}$ volume. São Paulo: Vitale, 1951.

. Solfejos. $1^{\text {o }}$ volume. São Paulo: Vitale, 1976.

. Solfejos. $2^{\circ}$ volume. São Paulo: Vitale, 1946.

Lobos, 1991.

Educação Musical. Presença de Villa-Lobos, volume 13. Rio de Janeiro: Mus Villa-

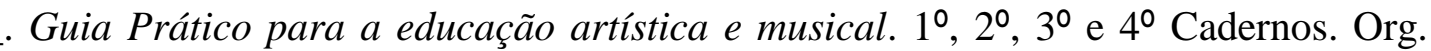
editorial: Valéria Peixoto; textos e pesquisa: Manoel Aranha Correa do Lago, Sérgio Barboza, Maria Clara Barbosa. Rio de Janeiro: ABM-FUNARTE, 2009.

WEIGEL, AM.G. Brincando de música: experiência com sons, ritmos, músicas e movimentos na pré-escola. Porto Alegre: Kuarup, 1988.

WHEELER, L.; RAEBECK, L. Orff and Kodály adapted for the elementary school. Dubuque, Iowa: Brown Company, 1974.

WILLEMS, E. As bases psicológicas da Educação Musical. Fribourg: Pro-Música, 1970.

. L'Oreille musicale - la préparation auditive de l'enfant. Bienne: Edições

Pro-Musica, 1970.

. Le rythme musical. Paris: Presses Universitaires de France, 1954.

. La preparación musical de los más pequeños. Buenos Aires: Eudeba, 1976.

. Educación musical - Canciones de intervalos. Buenos Aires: Eudeba, S.D.

. Iniciação musical das crianças - princípios e plano de trabalho. Bienne: ProMusica, 1968. Caderno 0

Chansons de deux a cinq notes; Chansons d'intervalles; Chansons d'intervalles avec accompagnement de piano; Les exercices d'audition; Les frappés et l'instinct rythmique; Le rythme musical et le mouvement naturel dans les cours d'éducation musicale; Introduction a l'écriture et a la lecture. Genève: Pro Musica. Carnets 1, 2, 2b, 3, 4b,4c et 5, S.D.

WISNIK, José Miguel. O Coro dos Contrários - música em torno da semana de 22. São Paulo: Duas cidades, 1977.

O Som e o Sentido, Companhia das Letras, 1999.

WOOD, D. Move, sing, listen, play - Preparing the Young child for music. Ontario: Warner/Chappel Music Canada, 1995.

YELIN, J. Movement that fits - Dalcroze Eurhythmics and the Suzuki Method. New Jersey: Summy-Birchard, 1990. 
YEPES, A.; GRAETZER, G. Introducción a la práctica del Orff-Schulwerk. Buenos Aires: Barry, 1961.

YEPES, A. Enseñanza elemental de la musica mediante la práctica instrumental y vocal. Buenos Aires: Barry, 1966.

ZAGONEL, B.; CHIAMULERA, S. M. La. (Orgs.) H.J. Koellreutter - introdução à estética e à composição musical contemporânea. Porto Alegre: Movimento, 1987.

ZEMKE, L. The Kodály concept - its history, philosophy and development. USA: Mark Foster Music Company, 1977.

http://www.soleis.adv.br/cantoorfeonicoleiorganica.htm . Acesso em 09/07/08

http://www.villalobos.ca;

http://www.scvachoral.org.

http://www.leokestenberg.com

http://www.nla.gov.au

http://gallica.bnf.fr 


\section{ANEXOS}

\section{A - Índices das peças analisadas}

\begin{tabular}{|c|c|c|c|c|c|c|c|c|c|}
\hline $\mathrm{N}^{\circ}$ & CAPÍTULO 2.1 - UMA VOZ & GP & $\mathrm{ABM}$ & S1 & $\mathrm{S} 2$ & $\begin{array}{c}\mathrm{CO} \\
1\end{array}$ & $\begin{array}{c}\mathrm{CO} \\
2 \\
\end{array}$ & $\begin{array}{c}\text { Capítulo } \\
2.2 \\
\end{array}$ & Página \\
\hline 1 & BAM-BA-LA-LÃO (Senhor Capitão) - a capella & 13 & 45 & & & & & 18 & 37 \\
\hline 2 & REGOZIJO DE UMA RAÇA (Canto Mestiço - II) - a capella & & & & & 16 & & & 38 \\
\hline 3 & NO JARDIM CELESTIAL - acompanhamento instrumental & 65 & 122 & & & & & 76 & 39 \\
\hline 4 & BELA PASTORA - acompanhamento instrumental & 15 & 124 & & & & & 53 & 41 \\
\hline 5 & CANTOS DE ÇAIRÉ (2) - a capella & & & & & & 19 & 171 & 42 \\
\hline 6 & UM CANTO QUE SAIU DA SENZALA - a capella & & & & & & 23 & 3 & 43 \\
\hline 7 & A ROSEIRA ( $1^{\mathrm{a}}$ versão $)$ - a capella & 110 & 52 & & & & & 7 & 44 \\
\hline 8 & A ROSEIRA ( $2^{\mathrm{a}}$ versão) - acompanhamento instrumental & 111 & 73 & & & & & & 45 \\
\hline 9 & JOÃO CAMBUETE - acompanhamento instrumental & 66 & 110 & & & & & & 46 \\
\hline 10 & CONSTÂNCIA - acompanhamento instrumental & 41 & 95 & & & & & & 48 \\
\hline 11 & REGOZIJO DE UMA RAÇA (Canto Africano - I ) - a capella & & & & & 16 & & & 49 \\
\hline 12 & CANTOS DE ÇAIRÉ № 1 - a capella & & & & & & 18 & 9 & 50 \\
\hline 13 & O RICO E O POBRE- acompanhamento instrumental & 98 & 104 & & & & & & 52 \\
\hline 14 & SOLFEJO $n^{\circ} 144$ - a capella & & & 144 & & & & 97 & 53 \\
\hline 15 & VAMOS, MARUCA- acompanhamento instrumental & 128 & 133 & & & & & 164 & 54 \\
\hline 16 & MANDA TIRO, TIRO, LÁ- acompanhamento instrumental & 73 & 64 & & & & & & 55 \\
\hline 17 & $\begin{array}{l}\text { VAMOS ATRÁS DA SERRA, OH CALUNGA - } \\
\text { acompanhamento instrumental }\end{array}$ & 126 & 134 & & & & & 162 & 57 \\
\hline 18 & $\begin{array}{l}\text { PASSE, PASSE, GAVIÃO (Lá na ponte de Vinhaça) - } \\
\text { acompanhamento instrumental }\end{array}$ & 89 & 97 & & & & & & 58 \\
\hline 19 & AINDA NÃO COMPREI- a capella & 4 & 51 & & & & & 5 & 59 \\
\hline 20 & ENTREI NA RODA- a capella & 49 & 43 & 18 & & & & 40 & 60 \\
\hline 21 & NA MÃO DIREITA - a capella & 75 & 48 & 34 & & & & 158 & 61 \\
\hline 22 & NA CORDA DA VIOLA - acompanhamento instrumental & 43 & 87 & & & & & & 62 \\
\hline 23 & VAMOS, CRIANÇAS - a capella & & & & & & 2 & 52 & 64 \\
\hline 24 & UMA, DUAS ANGOLINHAS - a capella & 124 & 47 & & & & & 160 & 65 \\
\hline 25 & CAPELINHA DE MELÃO - a capella & 27 & 15 & 7 & & & & 56 & 66 \\
\hline 26 & CÂNONE 13 - a capella & & & & p. 22 & & & & 67 \\
\hline 27 & CANÁRIO - a capella & 21 & 28 & 26 & & & & 8 & 68 \\
\hline 28 & HIGIENE - a capella & 64 & 19 & 3 & & & & 54 & 70 \\
\hline 29 & O ANEL - a capella & 8 & 42 & & & & & 31 & 70 \\
\hline 30 & $\begin{array}{l}\text { BRINQUEDO (Olhe aquela menina) - acompanhamento } \\
\text { instrumental }\end{array}$ & 17 & 89 & & & & & & 71 \\
\hline 31 & CAI, CAI BALÃO (Vem cá, Bitu) - a capella & 19 & 13 & 9 & & & & 64 & 72 \\
\hline 32 & VITU - acompanhamento instrumental & 133 & 119 & & & & & 87 & 74 \\
\hline 33 & VIUVINHA DA BANDA D'ALÉM - a capella & 134 & 22 & & & & & 68 & 75 \\
\hline 34 & BESUNTÃO DA LAGOA - a capella & 16 & 38 & 22 & & & & 70 & 76 \\
\hline 35 & SENHORA DONA SANCHA ( $2^{\mathrm{a}}$ versão $)$ - a capella & 115 & 1 & 1 & & & & & 77 \\
\hline 36 & VAMOS , COMPANHEIROS - a capella & & & & & 3 & & 38 & 78 \\
\hline 37 & OS POMBINHOS - a capella & 101 & 8 & 15 & & & & 12 & 79 \\
\hline
\end{tabular}




\begin{tabular}{|c|c|c|c|c|c|c|c|c|c|}
\hline 38 & OS POMBINHOS ( $\left(2^{\mathrm{a}}\right.$ versão) - acompanhamento instrumental & 102 & 72 & & & & & & 80 \\
\hline 39 & $\begin{array}{l}\text { LÁ NA PONTE DA VINHAÇA (Passa, passa gavião) - a } \\
\text { capella }\end{array}$ & 104 & 14 & 2 & & & & 11 & 81 \\
\hline 40 & $\begin{array}{l}\text { NO FUNDO DO MEU QUINTAL - acompanhamento } \\
\text { instrumental }\end{array}$ & 57 & 85 & & & & & & 82 \\
\hline 41 & BOAS FESTAS (Canção de cordialidade) - a capella & & & & & & 9 & 169 & 84 \\
\hline 42 & A AGULHA - a capella & 3 & 7 & 23 & & & & 58 & 85 \\
\hline 43 & SOLFEJO ${ }^{\circ} 5$ (Cânone) - a capella & & & & p. 20 & & & & 86 \\
\hline 44 & COMPANHEIROS, COMPANHEIROS (Cânone 2) - a capella & & & & p. 20 & & & & 87 \\
\hline 45 & ESPANHA - acompanhamento instrumental & 63 & 62 & & & & & & 88 \\
\hline 46 & $\begin{array}{l}\text { PASSARÁS, NÃO PASSARÁS - acompanhamento } \\
\text { instrumental }\end{array}$ & 90 & 98 & & & & & & 89 \\
\hline 47 & ROSA AMARELA ( $1^{\text {a }}$ versão) - acompanhamento instrumental & 108 & 92 & & & & & & 90 \\
\hline 48 & CONSTANTE - acompanhamento instrumental & 40 & 69 & 10 & & & & & 91 \\
\hline 49 & FUI PASSAR NA PONTE (NA BAHIA TEM) - a capella & 56 & 26 & 16 & & & & 72 & 92 \\
\hline 50 & NA BAHIA TEM - acompanhamento instrumental & 12 & 137 & & & & & 163 & 93 \\
\hline 51 & A GATINHA PARDA - a capella & 59 & 32 & 30 & & & & 16 & 94 \\
\hline 52 & MENINAS, Ó MENINAS - acompanhamento instrumental & 79 & 93 & & & & & & 95 \\
\hline 53 & GARIBALDI FOI À MISSA - acompanhamento instrumental & 58 & 102 & & & & & & 96 \\
\hline 54 & SOLFEJO $\mathrm{n}^{\circ} 49$ - a capella & & & 49 & & & & & 98 \\
\hline 55 & SOLFEJO $\mathrm{n}^{\circ} 41$ - a capella & & & 41 & & & & & 99 \\
\hline 56 & PAI FRANCISCO ( $1^{\text {a }}$ versão $)$ - acompanhamento instrumental & 87 & 78 & & & & & & 100 \\
\hline 57 & PAI FRANCISCO $\left(2^{a}\right.$ versão $)$ - acompanhamento instrumental & 88 & 79 & & & & & & 101 \\
\hline 58 & A MARÉ ENCHEU - acompanhamento instrumental & $\begin{array}{l}76, \\
76 a \\
\end{array}$ & 83 & 36 & & & & & 102 \\
\hline 59 & A CUTIA - acompanhamento instrumental & 44 & 70 & & & & & & 104 \\
\hline 60 & CARANGUEJO - a capella & 30 & 16 & 10 & & & & 71 & 105 \\
\hline 61 & O CAFÉ - a capella & 20 & 10 & 8 & & & & 69 & 106 \\
\hline 62 & CANTOS DE ÇAIRÉ (3) - a capella & & & & & & 20 & 32 & 108 \\
\hline 63 & O PASTORZINHO - acompanhamento instrumental & 91 & 125 & & & & & 90 & 109 \\
\hline 64 & SOLFEJO ${ }^{\circ} 128$ - a capella & & & 128 & & & & 96 & 110 \\
\hline 65 & SOLFEJO ${ }^{\circ} 156$ - a capella & & & 156 & & & & 130 & 111 \\
\hline 66 & ANQUINHAS - a capella & 9 & 30 & 24 & & & & 14 & 112 \\
\hline 67 & O GATO - acompanhamento instrumental & 61 & 109 & & & & & & 113 \\
\hline 68 & SAMBA LELÊ - acompanhamento instrumental & 112 & 82 & & & & & & 114 \\
\hline 69 & FORMIGUINHAS - a capella & 52 & 17 & 33 & & & & 79 & 115 \\
\hline 70 & NIGUE NINHAS - a capella & 83 & 20 & & & & & 75 & 116 \\
\hline 71 & POBRE PEREGRINO - acompanhamento instrumental & 99 & 99 & & & & & & 117 \\
\hline 72 & A DANÇA DA CARRANQUINHA - a capella & 47 & 4 & 6 & & & & & 118 \\
\hline 73 & SOLFEJO $^{\circ} 132-$ a capella & & & 132 & & & & 138 & 120 \\
\hline 74 & SOLFEJO $^{\circ} 38$ - a capella & & & 38 & & & & & 120 \\
\hline 75 & O CASTELO - acompanhamento instrumental & 32 & 76 & & & & & & 121 \\
\hline 76 & SAPO JURURU - a capella & 113 & 41 & & & & & 35 & 122 \\
\hline 77 & SOLFEJO ${ }^{\circ} 37$ - a capella & & & 37 & & & & & 123 \\
\hline 78 & NOZANI-NÁ - A capella & & & & & 32 & & 20 & 124 \\
\hline
\end{tabular}




\begin{tabular}{|c|c|c|c|c|c|c|c|}
\hline 79 & QUANTOS DIAS TEM O MÊS? - a capella & 106 & 39 & 11 & & 63 & 125 \\
\hline 80 & OLHA O BICHO & 84 & 135 & & & & 127 \\
\hline 81 & POMBINHA, ROLINHA - acompanhamento instrumental & 100 & 108 & & & & 128 \\
\hline 82 & MARIQUITA MUCHACHA - acompanhamento instrumental & 78 & 91 & & & & 129 \\
\hline 83 & Ó LIMÃO - acompanhamento instrumental & 69 & 49 & & & 159 & 130 \\
\hline 84 & SENHORA DONA SANCHA ( $3^{a}$ versão) - a capella & 116 & 2 & 28 & & & 131 \\
\hline 85 & VIVA O CARNAVAL - a capella & 135 & 54 & & & 81 & 133 \\
\hline 86 & $\begin{array}{l}\text { Ó CIRANDA, Ó CIRANDINHA - acompanhamento } \\
\text { instrumental }\end{array}$ & 35 & 61 & & & & 134 \\
\hline 87 & MACHADINHA - acompanhamento instrumental & 71 & 74 & & & & 135 \\
\hline 88 & VAI ABÓBORA - acompanhamento instrumental & 125 & 113 & & & & 136 \\
\hline 89 & MANQUINHA - acompanhamento instrumental & 74 & 111 & & & & 137 \\
\hline 90 & SENHORA DONA SANCHA - acompanhamento instrumental & 114 & 75 & & & & 139 \\
\hline 91 & DE FLOR EM FLOR-acompanhamento instrumental & 48 & 131 & & & 166 & 140 \\
\hline 92 & SOLFEJO $\mathrm{n}^{\circ} 57$ - a capella & & & 57 & & & 141 \\
\hline 93 & OFERTA DA CRIANÇA À LUA - a capella & 13 & 45 & & & 13 & 142 \\
\hline 94 & SODADE - a capella & 121 & 36 & 29 & & 4 & 143 \\
\hline 95 & Ó LIMÃO (primeira versão) & 68 & 88 & & & & 144 \\
\hline 96 & A CANOA VIROU - a capella & 23 & 31 & 5 & & 55 & 145 \\
\hline 97 & Ó PIÃO - acompanhamento instrumental & 93 & 67 & & & & 146 \\
\hline 98 & O BASTÃO (MIA GATO) - acompanhamento instrumental & 14 & 103 & & & & 148 \\
\hline 99 & SOLFEJO $\mathrm{n}^{\circ} 142-$ a capella & & & 142 & & & 149 \\
\hline 100 & $\begin{array}{l}\begin{array}{l}\text { SOLFEJO N }{ }^{\circ} 27 \text { - Introitos da missa de São Sebastião } \\
\text { (Vocalismo ) - a capella }\end{array} \\
\end{array}$ & & & & p. 17 & & 150 \\
\hline 101 & FICARÁS SOZINHA (FUI NO ITORORÓ) - a capella & 51 & 3 & 4 & & & 151 \\
\hline 102 & A COBRA E A ROLINHA & 36 & & & & 93 & 152 \\
\hline 103 & A GATINHA PARDA (segunda versão) - a capella & 60 & 33 & & & 15 & 153 \\
\hline 104 & SOLFEJO $^{\circ} 6$ (Cânone) - a capella & & & & p. 20 & & 154 \\
\hline 105 & SOLFEJO $n^{\circ} 62-$ a capella & & & 62 & & & 155 \\
\hline 106 & SOLFEJO $^{\circ} 5$ (Ditado) - a capella & & & & p. 2 & & 156 \\
\hline 107 & A FREIRA & 53 & 71 & & & & 156 \\
\hline 108 & SOLFEJO ${ }^{\circ} 60-$ a capella & & & 60 & & & 158 \\
\hline 109 & SOLFEJO ${ }^{\circ} 15$ (Cânone) - a capella & & & & p. 22 & & 158 \\
\hline 110 & LARANJEIRA PEQUENINA - acompanhamento instrumental & 67 & 114 & & & & 159 \\
\hline 111 & SINH' ANINHA - acompanhamento instrumental & 120 & 107 & & & & 160 \\
\hline 112 & OS ESCRAVOS DE JÓ - a capella & 50 & 55 & & & 80 & 162 \\
\hline 113 & CANDEEIRO - a capella & 22 & 21 & 27 & & 67 & 163 \\
\hline 114 & A CANTIGA DE NINAR - a capella & 25 & 18 & & & 66 & 164 \\
\hline 115 & PIROLITO (FIORITO) - acompanhamento instrumental & 95 & 84 & & & & 165 \\
\hline 116 & VESTIDINHO BRANCO - acompanhamento instrumental & 131 & 112 & & & & 166 \\
\hline 117 & CARNEIRINHO, CARNEIRÃO - a capella & 31 & 96 & & & & 167 \\
\hline 118 & SOLFEJO $^{\circ} 11$ (Cânone circular) - a capella & & & & p. 22 & & 169 \\
\hline 119 & SOLFEJO $\mathrm{n}^{\circ} 39-$ a capella & & & 39 & & & 169 \\
\hline 120 & HEI DE NAMORAR - a capella & 62 & 56 & & & 173 & 170 \\
\hline 121 & CARAMBOLA - acompanhamento instrumental & 28 & 65 & & & & 171 \\
\hline
\end{tabular}




\begin{tabular}{|c|c|c|c|c|c|c|c|c|c|}
\hline 122 & $\begin{array}{l}\text { FUI NO ITORORÓ (1 }{ }^{\mathrm{a}} \text { versão) - acompanhamento } \\
\text { instrumental }\end{array}$ & 54 & 129 & & & & & 86 & 172 \\
\hline 123 & $\begin{array}{l}\text { FUI NO ITORORÓ ( } 2^{\mathrm{a}} \text { versão) - acompanhamento } \\
\text { instrumental }\end{array}$ & 55 & 90 & & & & & & 173 \\
\hline 124 & CARNEIRINHO DE ALGODÃO - a capella & & & & & 4 & & 10 & 174 \\
\hline 125 & O CRAVO BRIGOU COM A ROSA - a capella & 46 & 12 & 21 & & & & 60 & 175 \\
\hline 126 & O CRAVO (primeira versão) - acompanhamento instrumental & 45 & 118 & & & & & 85 & 176 \\
\hline 127 & CÓ, CÓ, CÓ - acompanhamento instrumental & 37 & 132 & & & & & 168 & 177 \\
\hline 128 & $\mathrm{BA}, \mathrm{BE}, \mathrm{BI}, \mathrm{BO}, \mathrm{BU}$ - acompanhamento instrumental & 11 & 66 & & & & & & 178 \\
\hline 129 & FELIZ NATAL - a capella & & & & & & 10 & 65 & 180 \\
\hline 130 & SENHORA VIÚVA (VIUVINHA) - a capella & 118 & 53 & & & & & 83 & 181 \\
\hline 131 & CANTIGA DE RODA - a capella & 26 & 9 & 19 & & & $29 \mathrm{~d}$ & & 182 \\
\hline 132 & SOLFEJO $\mathrm{n}^{\circ} 45$ - a capella & & & 45 & & & & & 183 \\
\hline 133 & FELIZ ANIVERSÁRIO - a capella & & & & & & 8 & 130 & 184 \\
\hline 134 & SOLFEJO $\mathrm{n}^{\circ} 65$ - a capella & & & 65 & & & & & 185 \\
\hline 135 & SOLFEJO ${ }^{\circ} 4$ (Ditado) - a capella & & & & p.1 & & & & 186 \\
\hline 136 & SOLFEJO n ${ }^{\circ} 14-$ Mar do Brasil (Cânone) - a capella & & & & p. 22 & & & & 186 \\
\hline 137 & SOLFEJO ${ }^{\circ} 63-$ a capella & & & 63 & & & & & 187 \\
\hline 138 & SOLFEJO ${ }^{\circ} 64$ - a capella & & & 64 & & & & & 188 \\
\hline 139 & ROSA AMARELA ( $2^{\mathrm{a}}$ versão $)$ - acompanhamento instrumental & 109 & 120 & & & & & 89 & 189 \\
\hline 140 & SOLFEJO n ${ }^{\circ} 56$ - a capella & & & 56 & & & & & 190 \\
\hline 141 & SOLFEJO ${ }^{\circ} 42-$ a capella & & & 42 & & & & & 190 \\
\hline 142 & A POMBINHA VOOU - acompanhamento instrumental & 103 & 101 & & & & & & 191 \\
\hline 143 & SOLFEJO n ${ }^{\circ} 10$ - A Caxias (Cânone) - a capella & & & & p. 22 & & & & 193 \\
\hline 144 & SOLFEJO $n^{\circ} 139$ - a capella & & & 139 & & & & & 193 \\
\hline 145 & SOLFEJO n ${ }^{\circ} 4$ (Cânone) - a capella & & & & p. 20 & & & & 194 \\
\hline 146 & SOLFEJO $\mathrm{n}^{\circ} 149$ - a capella & & & 149 & & & & 99 & 195 \\
\hline 147 & SOLFEJO n ${ }^{\circ} 7$ (Ditado) - a capella & & & & p.2 & & & & 196 \\
\hline 148 & VAMOS, MANINHA ( $2^{\mathrm{a}}$ versão) - a capella & 127 & 23 & 13 & & & & 73 & 197 \\
\hline 149 & MÊS DE JUNHO - a capella & 96 & 46 & & & & 15 & 177 & 198 \\
\hline 150 & CANOINHA NOVA - a capella & 24 & 40 & 20 & & & & 91 & 199 \\
\hline 151 & OLHA O PASSARINHO - acompanhamento instrumental & 85 & 94 & & & & & & 200 \\
\hline 152 & TEREZINHA DE JESUS - a capella & 123 & 11 & 12 & & & & 61 & 201 \\
\hline 153 & CONDESSA - acompanhamento instrumental & 39 & 128 & & & & & & 203 \\
\hline 154 & QUE LINDOS OLHOS - acompanhamento instrumental & 107 & 121 & & & & & 88 & 204 \\
\hline 155 & ANDA A RODA ( $\left(1^{\mathrm{a}}\right.$ versão $)$ - a capella & 5 & 5 & 31 & & & $29 \mathrm{e}$ & 82 & 205 \\
\hline 156 & SOLFEJO ${ }^{\circ} 40-$ a capella & & & 40 & & & & & 206 \\
\hline 157 & MINHA TERRA TEM PALMEIRAS - a capella & & & & & & 5 & 77 & 207 \\
\hline 158 & SOLFEJO n ${ }^{\circ} 2($ Ditado $)$ - a capella & & & & p.1 & & & & 209 \\
\hline 159 & SOLFEJO n ${ }^{\circ} 15$ (Vocalismo) - a capella & & & & p. 8 & & & 115 & 209 \\
\hline 160 & LINDAS LARANJAS - a capella & 70 & 25 & 35 & & & & 74 & 210 \\
\hline 161 & NESTA RUA (ESTA NOITE) - a capella & 82 & 24 & & & & & 78 & 212 \\
\hline 162 & POBRE CEGO ( $2^{\mathrm{a}}$ versão $)$ - a capella & 97 & 44 & 17 & & & & 92 & 212 \\
\hline 163 & SOLFEJO ${ }^{\circ} 44-$ a capella & & & 44 & & & & & 213 \\
\hline 164 & SOLFEJO $n^{\circ} 61-$ a capella & & & 61 & & & & & 214 \\
\hline 165 & CARANGUEJO ( $1^{\mathrm{a}}$ versão $)$ - acompanhamento instrumental & 29 & 126 & & & & & 62 & 215 \\
\hline
\end{tabular}




\begin{tabular}{|c|c|c|c|c|c|c|c|c|}
\hline 166 & $\begin{array}{l}\text { VOCÊ DIZ QUE SABE TUDO - acompanhamento } \\
\text { instrumental }\end{array}$ & 136 & 81 & & & & & 216 \\
\hline 167 & SOLFEJO n ${ }^{\circ} 1$ (Ditado) - a capella & & & & p.1 & & & 217 \\
\hline 168 & CACHORRINHO - acompanhamento instrumental & 18 & 68 & & & & & 218 \\
\hline 169 & ACORDEI DE MADRUGADA ( $\left(1^{a}\right.$ versão $)$ - a capella & 1 & 34 & & & & 6 & 220 \\
\hline 170 & SOLFEJO ${ }^{\circ} 51-$ a capella & & & 51 & & & & 221 \\
\hline 171 & $\begin{array}{l}\text { A VELHA QUE TINHA NOVE FILHAS - acompanhamento } \\
\text { instrumental }\end{array}$ & 129 & 86 & & & & & 222 \\
\hline 172 & SOLFEJO n $^{\circ} 136$ - a capella & & & 136 & & & & 223 \\
\hline 173 & FELIZ ANO NOVO - a capella & & & & & 11 & 179 & 224 \\
\hline 174 & SOLFEJO $n^{\circ} 43$ - a capella & & & 43 & & & & 225 \\
\hline 175 & VIDA FORMOSA - acompanhamento instrumental & 132 & 80 & & & & & 226 \\
\hline 176 & SOLFEJO $n^{\circ} 50-$ a capella & & & 50 & & & & 227 \\
\hline 177 & SOLFEJO n ${ }^{\circ} 55$ - a capella & & & 55 & & & & 228 \\
\hline 178 & SOLFEJO $\mathrm{n}^{\circ} 46-$ a capella & & & 46 & & & & 229 \\
\hline
\end{tabular}

\begin{tabular}{|c|c|c|c|c|c|c|c|c|c|}
\hline $\mathrm{N}^{\circ}$ & $\begin{array}{c}\text { CAPÍTULO } 2.1 \text { - UMA VOZ - ordem } \\
\text { alfabética }\end{array}$ & GP & $\mathrm{ABM}$ & S1 & S2 & $\begin{array}{c}\mathrm{CO} \\
1\end{array}$ & $\mathrm{CO} 2$ & $\begin{array}{c}\text { Capítulo } \\
2.2\end{array}$ & Página \\
\hline 42 & A AGULHA - a capella & 3 & 7 & 23 & & & & 58 & 85 \\
\hline 96 & A CANOA VIROU - a capella & 23 & 31 & 5 & & & & 55 & 145 \\
\hline 114 & A CANTIGA DE NINAR - a capella & 25 & 18 & & & & & 66 & 164 \\
\hline 102 & A COBRA E A ROLINHA & 36 & & & & & & 93 & 152 \\
\hline 59 & A CUTIA - acompanhamento instrumental & 44 & 70 & & & & & & 104 \\
\hline 72 & A DANÇA DA CARRANQUINHA - a capella & 47 & 4 & 6 & & & & & 118 \\
\hline 107 & ( & 53 & 71 & & & & & & 156 \\
\hline 51 & A GATINHA PARDA - a capella & 59 & 32 & 30 & & & & 16 & 94 \\
\hline 103 & A GATINHA PARDA (segunda versão) - a capella & 60 & 33 & & & & & 15 & 153 \\
\hline 58 & A MARÉ ENCHEU - acompanhamento instrumental & $\begin{array}{l}76, \\
76 a \\
\end{array}$ & 83 & 36 & & & & & 102 \\
\hline 142 & A POMBINHA VOOU - acompanhamento instrumental & 103 & 101 & & & & & & 191 \\
\hline 7 & A ROSEIRA ( $\left({ }^{\text {a }}\right.$ versão $)$ - a capella & 110 & 52 & & & & & 7 & 44 \\
\hline 8 & A ROSEIRA ( $2^{\mathrm{a}}$ versão) - acompanhamento instrumental & 111 & 73 & & & & & & 45 \\
\hline 171 & $\begin{array}{l}\text { A VELHA QUE TINHA NOVE FILHAS - acompanhamento } \\
\text { instrumental }\end{array}$ & 129 & 86 & & & & & & 222 \\
\hline 169 & ACORDEI DE MADRUGADA ( $\left(1^{\mathrm{a}}\right.$ versão $)$ - a capella & 1 & 34 & & & & & 6 & 220 \\
\hline 19 & AINDA NÃO COMPREI- a capella & 4 & 51 & & & & & 5 & 59 \\
\hline 155 & ANDA A RODA ( $1^{\text {a }}$ versão $)$ - a capella & 5 & 5 & 31 & & & $29 \mathrm{~d}$ & 82 & 205 \\
\hline
\end{tabular}




\begin{tabular}{|c|c|c|c|c|c|c|c|c|c|}
\hline 66 & ANQUINHAS - a capella & 9 & 30 & 24 & & & & 14 & 112 \\
\hline 128 & BA, BE, BI, BO, BU - acompanhamento instrumental & 11 & 66 & & & & & & 178 \\
\hline 1 & BAM-BA-LA-LÃO (Senhor Capitão) - a capella & 13 & 45 & & & & & 18 & 37 \\
\hline 4 & BELA PASTORA - acompanhamento instrumental & 15 & 124 & & & & & 53 & 41 \\
\hline 34 & BESUNTÃO DA LAGOA - a capella & 16 & 38 & 22 & & & & 70 & 76 \\
\hline 41 & BOAS FESTAS (Canção de cordialidade) - a capella & & & & & & 9 & 169 & 84 \\
\hline 30 & $\begin{array}{l}\text { BRINQUEDO (Olhe aquela menina) - acompanhamento } \\
\text { instrumental }\end{array}$ & 17 & 89 & & & & & & 71 \\
\hline 168 & CACHORRINHO - acompanhamento instrumental & 18 & 68 & & & & & & 218 \\
\hline 31 & CAI, CAI BALÃO (Vem cá, Bitu) - a capella & 19 & 13 & 9 & & & & 64 & 72 \\
\hline 27 & CANÁRIO - a capella & 21 & 28 & 26 & & & & 8 & 68 \\
\hline 113 & CANDEEIRO - a capella & 22 & 21 & 27 & & & & 67 & 163 \\
\hline 150 & CANOINHA NOVA - a capella & 24 & 40 & 20 & & & & 91 & 199 \\
\hline 26 & CÂNONE 13 - a capella & & & & p. 22 & & & & 67 \\
\hline 131 & CANTIGA DE RODA - a capella & 26 & 9 & 19 & & & $29 \mathrm{~d}$ & & 182 \\
\hline 5 & CANTOS DE ÇAIRÉ (2) - a capella & & & & & & 19 & 171 & 42 \\
\hline 62 & CANTOS DE ÇAIRÉ (3) - a capella & & & & & & 20 & 32 & 108 \\
\hline 12 & CANTOS DE ÇAIRÉ № 1 - a capella & & & & & & 18 & 9 & 50 \\
\hline 25 & CAPELINHA DE MELÃO - a capella & 27 & 15 & 7 & & & & 56 & 66 \\
\hline 121 & CARAMBOLA - acompanhamento instrumental & 28 & 65 & & & & & & 171 \\
\hline 60 & CARANGUEJO - a capella & 30 & 16 & 10 & & & & 71 & 105 \\
\hline 165 & CARANGUEJO $\left(1^{\text {a }}\right.$ versão $)$ - acompanhamento instrumental & 29 & 126 & & & & & 62 & 215 \\
\hline 124 & CARNEIRINHO DE ALGODÃO - a capella & & & & & 4 & & 10 & 174 \\
\hline 117 & CARNEIRINHO, CARNEIRÃO - a capella & 31 & 96 & & & & & & 167 \\
\hline 127 & CÓ, CÓ, CÓ - acompanhamento instrumental & 37 & 132 & & & & & 168 & 177 \\
\hline 44 & COMPANHEIROS, COMPANHEIROS (Cânone 2 ) - a capella & & & & p. 20 & & & & 87 \\
\hline 153 & CONDESSA - acompanhamento instrumental & 39 & 128 & & & & & & 203 \\
\hline 10 & CONSTÂNCIA - acompanhamento instrumental & 41 & 95 & & & & & & 48 \\
\hline 48 & CONSTANTE - acompanhamento instrumental & 40 & 69 & 10 & & & & & 91 \\
\hline 91 & DE FLOR EM FLOR-acompanhamento instrumental & 48 & 131 & & & & & 166 & 140 \\
\hline 20 & ENTREI NA RODA- a capella & 49 & 43 & 18 & & & & 40 & 60 \\
\hline 45 & ESPANHA - acompanhamento instrumental & 63 & 62 & & & & & & 88 \\
\hline 133 & FELIZ ANIVERSÁRIO - a capella & & & & & & 8 & 130 & 184 \\
\hline
\end{tabular}




\begin{tabular}{|c|c|c|c|c|c|c|c|c|}
\hline 173 & FELIZ ANO NOVO - a capella & & & & & 11 & 179 & 224 \\
\hline 129 & FELIZ NATAL - a capella & & & & & 10 & 65 & 180 \\
\hline 101 & FICARÁS SOZINHA (FUI NO ITORORÓ) - a capella & 51 & 3 & 4 & & & & 151 \\
\hline 69 & FORMIGUINHAS - a capella & 52 & 17 & 33 & & & 79 & 115 \\
\hline 122 & $\begin{array}{l}\text { FUI NO ITORORÓ ( } 1^{\text {a }} \text { versão) - acompanhamento } \\
\text { instrumental }\end{array}$ & 54 & 129 & & & & 86 & 172 \\
\hline 123 & $\begin{array}{l}\text { FUI NO ITORORÓ ( } 2^{\mathrm{a}} \text { versão) - acompanhamento } \\
\text { instrumental }\end{array}$ & 55 & 90 & & & & & 173 \\
\hline 49 & FUI PASSAR NA PONTE (NA BAHIA TEM) - a capella & 56 & 26 & 16 & & & 72 & 92 \\
\hline 53 & GARIBALDI FOI À MISSA - acompanhamento instrumental & 58 & 102 & & & & & 96 \\
\hline 120 & HEI DE NAMORAR - a capella & 62 & 56 & & & & 173 & 170 \\
\hline 28 & HIGIENE - a capella & 64 & 19 & 3 & & & 54 & 70 \\
\hline 9 & JOÃO CAMBUETE - acompanhamento instrumental & 66 & 110 & & & & & 46 \\
\hline 39 & $\begin{array}{l}\text { LÁ NA PONTE DA VINHAÇA (Passa, passa gavião) - a } \\
\text { capella }\end{array}$ & 104 & 14 & 2 & & & 11 & 81 \\
\hline 110 & LARANJEIRA PEQUENINA - acompanhamento instrumental & 67 & 114 & & & & & 159 \\
\hline 160 & LINDAS LARANJAS - a capella & 70 & 25 & 35 & & & 74 & 210 \\
\hline 87 & MACHADINHA - acompanhamento instrumental & 71 & 74 & & & & & 135 \\
\hline 16 & MANDA TIRO, TIRO, LÁ- acompanhamento instrumental & 73 & 64 & & & & & 55 \\
\hline 89 & MANQUINHA - acompanhamento instrumental & 74 & 111 & & & & & 137 \\
\hline 82 & MARIQUITA MUCHACHA - acompanhamento instrumental & 78 & 91 & & & & & 129 \\
\hline 52 & MENINAS, Ó MENINAS - acompanhamento instrumental & 79 & 93 & & & & & 95 \\
\hline 149 & MÊS DE JUNHO - a capella & 96 & 46 & & & 15 & 177 & 198 \\
\hline 157 & MINHA TERRA TEM PALMEIRAS - a capella & & & & & 5 & 77 & 207 \\
\hline 50 & NA BAHIA TEM - acompanhamento instrumental & 12 & 137 & & & & 163 & 93 \\
\hline 22 & NA CORDA DA VIOLA - acompanhamento instrumental & 43 & 87 & & & & & 62 \\
\hline 21 & NA MÃO DIREITA - a capella & 75 & 48 & 34 & & & 158 & 61 \\
\hline 161 & NESTA RUA (ESTA NOITE) - a capella & 82 & 24 & & & & 78 & 212 \\
\hline 70 & NIGUE NINHAS - a capella & 83 & 20 & & & & 75 & 116 \\
\hline 40 & $\begin{array}{l}\text { NO FUNDO DO MEU QUINTAL - acompanhamento } \\
\text { instrumental }\end{array}$ & 57 & 85 & & & & & 82 \\
\hline 3 & NO JARDIM CELESTIAL - acompanhamento instrumental & 65 & 122 & & & & 76 & 39 \\
\hline 78 & NOZANI-NÁ - A capella & & & & 32 & & 20 & 124 \\
\hline 29 & O ANEL - a capella & 8 & 42 & & & & 31 & 70 \\
\hline 98 & O BASTÃO (MIA GATO) - acompanhamento instrumental & 14 & 103 & & & & & 148 \\
\hline
\end{tabular}




\begin{tabular}{|c|c|c|c|c|c|c|c|}
\hline 61 & O CAFÉ - a capella & 20 & 10 & 8 & & 69 & 106 \\
\hline 75 & O CASTELO - acompanhamento instrumental & 32 & 76 & & & & 121 \\
\hline 86 & $\begin{array}{l}\text { Ó CIRANDA, Ó CIRANDINHA - acompanhamento } \\
\text { instrumental }\end{array}$ & 35 & 61 & & & & 134 \\
\hline 126 & O CRAVO (primeira versão) - acompanhamento instrumental & 45 & 118 & & & 85 & 176 \\
\hline 125 & O CRAVO BRIGOU COM A ROSA - a capella & 46 & 12 & 21 & & 60 & 175 \\
\hline 67 & O GATO - acompanhamento instrumental & 61 & 109 & & & & 113 \\
\hline 83 & Ó LIMÃO - acompanhamento instrumental & 69 & 49 & & & 159 & 130 \\
\hline 95 & Ó LIMÃO (primeira versão) & 68 & 88 & & & & 144 \\
\hline 63 & O PASTORZINHO - acompanhamento instrumental & 91 & 125 & & & 90 & 109 \\
\hline 97 & Ó PIÃO - acompanhamento instrumental & 93 & 67 & & & & 146 \\
\hline 13 & O RICO E O POBRE-acompanhamento instrumental & 98 & 104 & & & & 52 \\
\hline 93 & OFERTA DA CRIANÇA À LUA - a capella & 13 & 45 & & & 13 & 142 \\
\hline 80 & OLHA O BICHO & 84 & 135 & & & & 127 \\
\hline 151 & OLHA O PASSARINHO - acompanhamento instrumental & 85 & 94 & & & & 200 \\
\hline 112 & OS ESCRAVOS DE JÓ - a capella & 50 & 55 & & & 80 & 162 \\
\hline 37 & OS POMBINHOS - a capella & 101 & 8 & 15 & & 12 & 79 \\
\hline 38 & OS POMBINHOS ( $2^{\mathrm{a}}$ versão) - acompanhamento instrumental & 102 & 72 & & & & 80 \\
\hline 56 & PAI FRANCISCO ( $1^{\mathrm{a}}$ versão $)$ - acompanhamento instrumental & 87 & 78 & & & & 100 \\
\hline 57 & PAI FRANCISCO ( $2^{\mathrm{a}}$ versão $)$ - acompanhamento instrumental & 88 & 79 & & & & 101 \\
\hline 46 & $\begin{array}{l}\text { PASSARÁS, NÃO PASSARÁS - acompanhamento } \\
\text { instrumental }\end{array}$ & 90 & 98 & & & & 89 \\
\hline 18 & $\begin{array}{l}\text { PASSE, PASSE, GAVIÃO (Lá na ponte de Vinhaça)- } \\
\text { acompanhamento instrumental }\end{array}$ & 89 & 97 & & & & 58 \\
\hline 115 & PIROLITO (FIORITO) - acompanhamento instrumental & 95 & 84 & & & & 165 \\
\hline 162 & POBRE CEGO ( $2^{\mathrm{a}}$ versão $)$ - a capella & 97 & 44 & 17 & & 92 & 212 \\
\hline 71 & POBRE PEREGRINO - acompanhamento instrumental & 99 & 99 & & & & 117 \\
\hline 81 & POMBINHA, ROLINHA - acompanhamento instrumental & 100 & 108 & & & & 128 \\
\hline 79 & QUANTOS DIAS TEM O MÊS? - a capella & 106 & 39 & 11 & & 63 & 125 \\
\hline 154 & QUE LINDOS OLHOS - acompanhamento instrumental & 107 & 121 & & & 88 & 204 \\
\hline 11 & REGOZIJO DE UMA RAÇA (Canto Africano - I) - a capella & & & & 16 & & 49 \\
\hline 2 & REGOZIJO DE UMA RAÇA (Canto Mestiço - II) - a capella & & & & 16 & & 38 \\
\hline 47 & ROSA AMARELA ( $1^{\text {a }}$ versão $)$ - acompanhamento instrumental & 108 & 92 & & & & 90 \\
\hline 139 & ROSA AMARELA ( $2^{\mathrm{a}}$ versão $)$ - acompanhamento instrumental & 109 & 120 & & & 89 & 189 \\
\hline
\end{tabular}




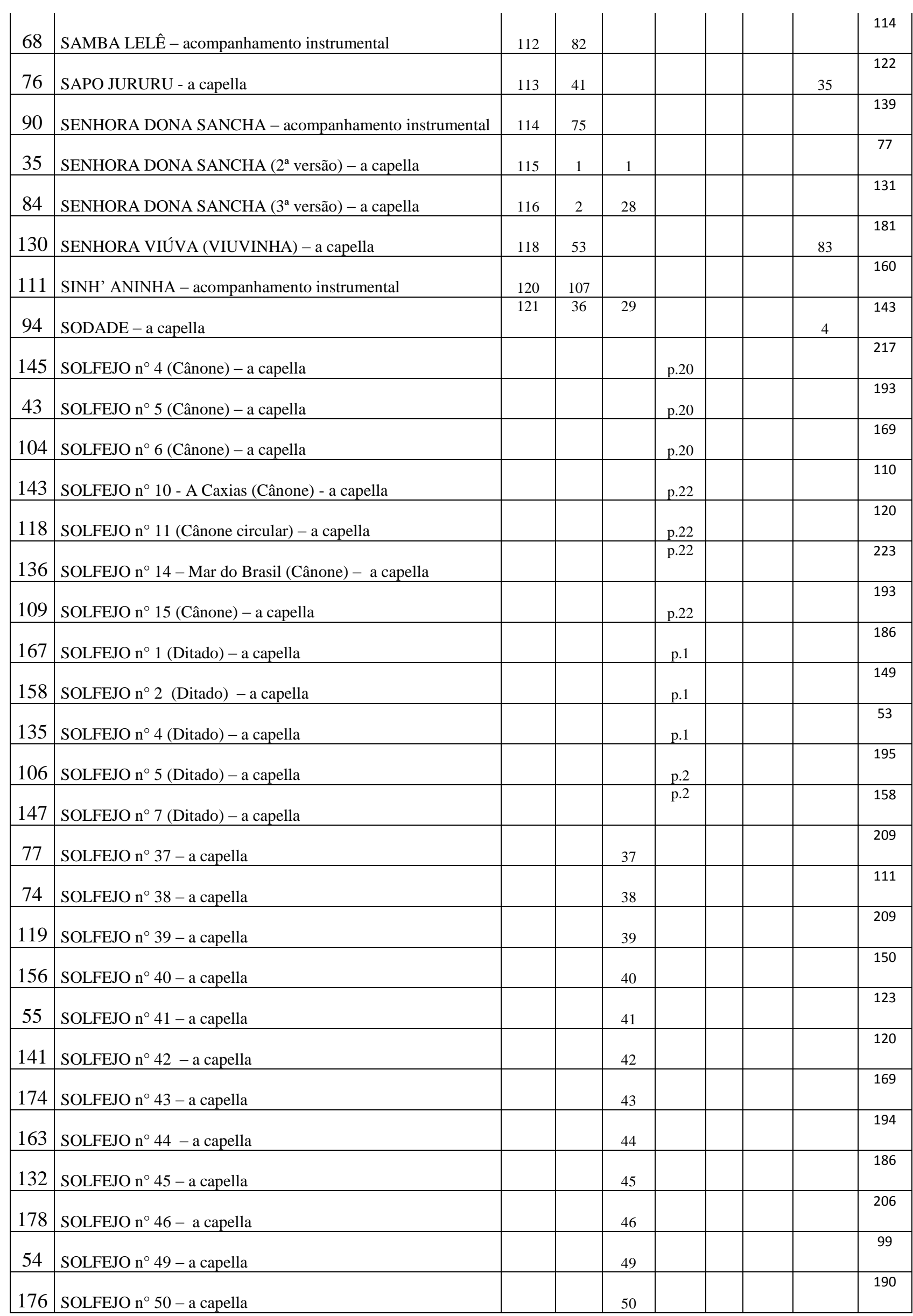




\begin{tabular}{|c|c|c|c|c|c|c|c|c|c|}
\hline 170 & SOLFEJO ${ }^{\circ} 51-$ a capella & & & 51 & & & & & 225 \\
\hline 177 & SOLFEJO n $^{\circ} 55-$ a capella & & & 55 & & & & & 213 \\
\hline 140 & SOLFEJO $\mathrm{n}^{\circ} 56$ - a capella & & & 56 & & & & & 183 \\
\hline 92 & SOLFEJO n ${ }^{\circ} 57$ - a capella & & & 57 & & & & & 229 \\
\hline 108 & SOLFEJO ${ }^{\circ} 60$ - a capella & & & 60 & & & & & 98 \\
\hline 164 & SOLFEJO $n^{\circ} 61-$ a capella & & & 61 & & & & & 86 \\
\hline 105 & SOLFEJO ${ }^{\circ} 62-$ a capella & & & 62 & & & & & 156 \\
\hline 137 & SOLFEJO n ${ }^{\circ} 63-$ a capella & & & 63 & & & & & 227 \\
\hline 138 & SOLFEJO n ${ }^{\circ} 64$ - a capella & & & 64 & & & & & 221 \\
\hline 134 & SOLFEJO ${ }^{\circ} 65-$ a capella & & & 65 & & & & & 228 \\
\hline 64 & SOLFEJO n ${ }^{\circ} 128$ - a capella & & & 128 & & & & 96 & 190 \\
\hline 73 & SOLFEJO $\mathrm{n}^{\circ} 132-$ a capella & & & 132 & & & & 138 & 141 \\
\hline 172 & SOLFEJO n $^{\circ} 136$ - a capella & & & 136 & & & & & 154 \\
\hline 144 & SOLFEJO $n^{\circ} 139$ - a capella & & & 139 & & & & & 158 \\
\hline 99 & SOLFEJO ${ }^{\circ} 142$ - a capella & & & 142 & & & & & 214 \\
\hline 14 & SOLFEJO ${ }^{\circ} 144-$ a capella & & & 144 & & & & 97 & 155 \\
\hline 146 & SOLFEJO ${ }^{\circ} 149$ - a capella & & & 149 & & & & 99 & 187 \\
\hline 65 & SOLFEJO ${ }^{\circ} 156-$ a capella & & & 156 & & & & 130 & 188 \\
\hline 159 & SOLFEJO $\mathrm{n}^{\circ} 15$ (Vocalismo) - a capella & & & & p. 8 & & & 115 & 185 \\
\hline 100 & $\begin{array}{l}\text { SOLFEJO No } 27 \text { - Introitos da missa de São Sebastião } \\
\text { (Vocalismo ) - a capella }\end{array}$ & & & & p. 17 & & & & 196 \\
\hline 152 & TEREZINHA DE JESUS - a capella & 123 & 11 & 12 & & & & 61 & 201 \\
\hline 6 & UM CANTO QUE SAIU DA SENZALA - a capella & & & & & & 23 & 3 & 43 \\
\hline 24 & UMA, DUAS ANGOLINHAS - a capella & 124 & 47 & & & & & 160 & 65 \\
\hline 88 & VAI ABÓBORA - acompanhamento instrumental & 125 & 113 & & & & & & 136 \\
\hline 36 & VAMOS , COMPANHEIROS - a capella & & & & & 3 & & 38 & 78 \\
\hline 17 & $\begin{array}{l}\text { VAMOS ATRÁS DA SERRA, OH CALUNGA - } \\
\text { acompanhamento instrumental }\end{array}$ & 126 & 134 & & & & & 162 & 57 \\
\hline 23 & VAMOS, CRIANÇAS - a capella & & & & & & 2 & 52 & 64 \\
\hline 148 & VAMOS, MANINHA ( $2^{\mathrm{a}}$ versão $)$ - a capella & 127 & 23 & 13 & & & & 73 & 197 \\
\hline 15 & VAMOS, MARUCA- acompanhamento instrumental & 128 & 133 & & & & & 164 & 54 \\
\hline 116 & VESTIDINHO BRANCO - acompanhamento instrumental & 131 & 112 & & & & & & 166 \\
\hline 175 & VIDA FORMOSA - acompanhamento instrumental & 132 & 80 & & & & & & 226 \\
\hline
\end{tabular}




\begin{tabular}{|c|l|c|c|c|c|c|c|c|c|}
\hline 32 & VITU - acompanhamento instrumental & 133 & 119 & & & & & 74 \\
\hline 33 & VIUVINHA DA BANDA D'ALÉM - a capella & 134 & 22 & & & & & 68 & 75 \\
\hline 85 & VIVA O CARNAVAL - a capella & 135 & 54 & & & & & 81 & 133 \\
\hline $\begin{array}{l}\text { VOCÊ DIZ QUE SABE TUDO - acompanhamento } \\
\text { instrumental }\end{array}$ & 136 & 81 & & & & & & 216 \\
\hline
\end{tabular}

\begin{tabular}{|c|l|c|c|c|c|c|c|c|c|c|}
\hline \multicolumn{7}{|c|}{ CAPÍTULO 2.2 - DUAS OU MAIS VOZES } & Capítulo & \multicolumn{1}{|c|}{} \\
\cline { 1 - 6 } $\mathrm{N}^{\circ}$ & I. PEDAIS HARMÔNICOS & & ABM & S1 & S2 & CO1 & CO2 & 2.1 & Página \\
\hline 1 & MARGARIDA - Acompanhamento instrumental & 77 & 123 & & & & & & 231 \\
\hline 2 & PINTOR DE CANNAHY - A capella & 94 & 35 & & & & & & 232 \\
\hline 3 & UM CANTO QUE SAIU DAS SENZALAS - A capella & & & & & & 23 & 6 & 232 \\
\hline 4 & SODADE - a capella & 121 & 36 & 29 & & & & 93 & 233 \\
\hline 5 & AINDA NÃO COMPREI - a capella & 4 & 51 & & & & & 19 & 233 \\
\hline
\end{tabular}
II - OSTINATOS

\begin{tabular}{|c|c|c|c|c|c|c|c|c|}
\hline 6 & ACORDEI DE MADRUGADA ( $1^{\mathrm{a}}$ versão $)$ - a capella & 1 & 34 & & & & 168 & 234 \\
\hline 7 & A ROSEIRA ( $1^{\mathrm{a}}$ versão $)$ - a capella & 110 & 52 & & & & 7 & 234 \\
\hline 8 & CANÁRIO - a capella & 21 & 28 & & & & 27 & 234 \\
\hline 9 & CANTOS DE ÇAIRÉ (1) - a capella & & & & & 18 & 12 & 235 \\
\hline 10 & CARNEIRINHO DE ALGODÃO - a capella & & & & 4 & & 124 & 235 \\
\hline 11 & $\begin{array}{l}\begin{array}{l}\text { LÁ NA PONTE DA VINHAÇA (Passa, passa gavião) - a } \\
\text { capella }\end{array} \\
\end{array}$ & 104 & 14 & 2 & & & 39 & 235 \\
\hline 12 & OS POMBINHOS - a capella & 101 & 8 & 15 & & & 37 & 236 \\
\hline 13 & MARCHA ESCOLAR (Meu sapinho) - A capella & & & & 7 & & & 236 \\
\hline 14 & ANQUINHAS - a capella & 9 & 30 & 24 & & & 67 & 237 \\
\hline 15 & A GATINHA PARDA ( $2^{\mathrm{a}}$ versão $)$ - a capella & 60 & 33 & & & & 102 & 237 \\
\hline 16 & A GATINHA PARDA ( $1^{\mathrm{a}}$ versão $)$ - a capella & 59 & 32 & 30 & & & 51 & 238 \\
\hline 17 & SOLFEJO N ${ }^{\circ} 109$ - a capella & & & 109 & & & & 238 \\
\hline
\end{tabular}

III - QUODLIBET

\begin{tabular}{|l|l|c|c|c|c|c|c|c|c|}
\hline 18 & $\begin{array}{l}\text { BAM-BA-LA-LÃO (Senhor Capitão) - (Oferta da criança } \\
\text { à lua) - capella }\end{array}$ & 13 & 45 & & & & & 1 & 239 \\
\hline 19 & À PRAIA (Chamados para brinquedo de roda) - a capella & 33 & 58 & & & & & & 239 \\
\hline
\end{tabular} IV. CÂNONES

\begin{tabular}{|l|l|l|l|l|l|l|l|l|l|}
\hline 20 & NOZANI-NÁ - A capella & & & & & 32 & & & 240 \\
\hline 21 & CÂNONE N $^{\circ} 2-$ a capella & & & & p.22 & & & & 240 \\
\hline 22 & CÂNONE N $^{\circ} 0-$ a capella & & & & p.26 & & & & 241 \\
\hline 23 & CÂNONE N $^{\circ}-$ a capella & & & & p. 21 & & & & 241 \\
\hline 24 & CÂNONE N $^{\circ}-$ a capella & & & & p.21 & & & & 241 \\
\hline
\end{tabular}




\begin{tabular}{|c|c|c|c|c|c|c|c|c|c|}
\hline 25 & CÂNONE $N^{\circ} 18-$ a capella & & & & p. 24 & & & & 242 \\
\hline 26 & CÂNONE $N^{\circ} 1-$ a capella & & & & p. 20 & & & & 242 \\
\hline 27 & CÂNONE No 3 - a capella & & & & p. 20 & & & & 242 \\
\hline 28 & CÂNONE $N^{\circ} 17-$ a capella & & & & p. 23 & & & & 243 \\
\hline 29 & CÂNONE N ${ }^{\circ} 19-$ a capella & & & & p. 25 & & & & 243 \\
\hline \multirow[t]{2}{*}{30} & CÂNONE $N^{\circ} 8$ e $N^{\circ} 16$ - a capella & & & & pp. $21 / 23$ & & & & 243 \\
\hline & V. CONTRAPONTO IMITATIVO & & & & & & & & \\
\hline 31 & O ANEL - a capella & 8 & 42 & & & & & 29 & 244 \\
\hline 32 & CANTOS DE ÇAIRÉ (3) - a capella & & & & & & 20 & 62 & 244 \\
\hline 33 & SOLFEJO N$^{\circ} \mathrm{s} 1,2$ e 3 - Imitações - a capella & & & & p.18 & & & & 244 \\
\hline 34 & SOLFEJO N ${ }^{\circ} 4-$ Imitação - a capella & & & & p.18 & & & & 244 \\
\hline 35 & SAPO JURURU - a capella & 113 & 41 & & & & & & 245 \\
\hline 36 & $\begin{array}{l}\text { O BALÃO DO BITU (Sobre o tema "Vem cá Bitu") - a } \\
\text { capella }\end{array}$ & & & & & & 3 & & 245 \\
\hline 37 & SOLFEJO N ${ }^{\circ} 73$ - a capella & & & 73 & & & & & 245 \\
\hline 38 & $\begin{array}{l}\text { VAMOS, COMPANHEIROS - Canção escolar - a } \\
\text { capella }\end{array}$ & & & & & 3 & & 36 & 245 \\
\hline 39 & MARCHA ESCOLAR (Ida para o recreio) - a capella & & & & & 9 & & & 246 \\
\hline 40 & ENTREI NA RODA- a capella & 49 & 43 & 18 & & & & 20 & 246 \\
\hline 41 & REPIU-PIU-PIU - a capella & & & & & & 4 & & 246 \\
\hline 42 & SOLFEJO N ${ }^{\circ} 157$ - a capella & & & 157 & & & & & 247 \\
\hline 43 & SOLFEJO Nº $6-$ Imitação - a capella & & & & p.19 & & & & 247 \\
\hline 44 & $\begin{array}{l}\text { BRINCADEIRA DE PEGAR (No prado da Madalena) - } \\
\text { a capella }\end{array}$ & & & & & & 1 & & 247 \\
\hline 45 & SOLFEJO No $89-$ a capella & & & 89 & & & & & 248 \\
\hline 46 & SOLFEJO Nº 84 / 121 - a capella & & & $84 / 121$ & & & & & 248 \\
\hline 47 & SOLFEJO $\mathrm{N}^{\circ} 70-$ a capella & & & 70 & & & & & 248 \\
\hline 48 & SOLFEJO N ${ }^{\circ}-$ Imitação - a capella & & & & p.19 & & & & 249 \\
\hline 49 & SOLFEJO N ${ }^{\circ}$ s $153 / 163$ - a capella & & & $153 / 163$ & & & & & 249 \\
\hline 50 & SOLFEJO N ${ }^{\circ} 99-$ a capella & & & 99 & & & & & 249 \\
\hline 51 & SOLFEJO N ${ }^{\circ} 161$ - a capella & & & 161 & & & & & 249 \\
\hline
\end{tabular}

VI. CONTRAPONTO LIVRE

\begin{tabular}{|l|l|c|c|c|c|c|c|c|c|}
\hline 52 & VAMOS, CRIANÇAS - a capella & & & & & 2 & & 23 & 250 \\
\hline 53 & BELA PASTORA - acompanhamento instrumental & 15 & 124 & & & & & 4 & 250 \\
\hline 54 & HIGIENE - a capella & 64 & 19 & 3 & & & & 28 & 251 \\
\hline 55 & A CANOA VIROU - a capella & 23 & 31 & 5 & & & & 95 & 251 \\
\hline 56 & CAPELINHA DE MELÃO - a capella & 27 & 15 & 7 & & & & 25 & 251 \\
\hline 57 & A CANTIGA DE RODA (As bonecas) - a capella & 26 & 9 & 19 & & & $29 \mathrm{~d}$ & 131 & 252 \\
\hline 58 & A AGULHA - a capella & 3 & 7 & 23 & & & & 42 & 252 \\
\hline 59 & MEUS BRINQUEDOS (Canção escolar) - a capella & & & & & 1 & & & 252 \\
\hline 60 & O CRAVO BRIGOU COM A ROSA - a capella & 46 & 12 & 21 & & & & 125 & 252 \\
\hline 61 & TEREZINHA DE JESUS - a capella & 123 & 11 & 12 & & & & 151 & 253 \\
\hline & $\begin{array}{l}\text { CARANGUEJO (1a versão) - acompanhamento } \\
\text { instrumental }\end{array}$ & & & & & & & \\
\hline 63 & QUANTOS DIAS TEM O MÊS? - a capella & 106 & 39 & 11 & & & & 78 & 254 \\
\hline
\end{tabular}




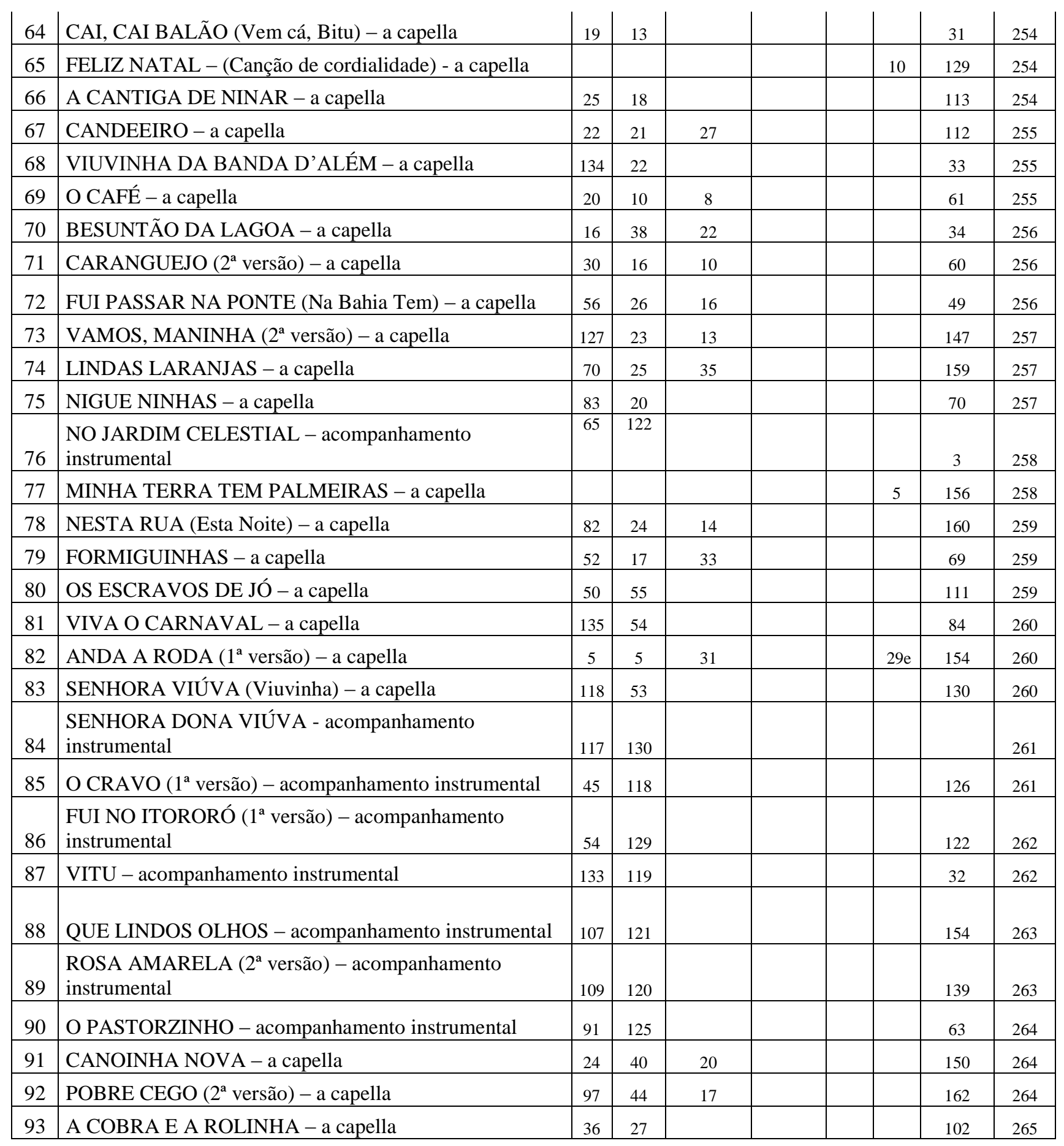

SOLFEJOS - Vozes iguais:

\begin{tabular}{|c|c|c|c|c|c|}
\hline 94 & SOLFEJO N $^{\circ} 131$ - a capella & 131 & & & 265 \\
\hline 95 & SOLFEJO N ${ }^{\circ} 8$ (Vocalismo) - a capella & & p. 5 & & 265 \\
\hline 96 & SOLFEJO N ${ }^{\circ} 128$ - a capella & 128 & & 64 & 266 \\
\hline 97 & SOLFEJO N$^{\circ} 144$ - a capella & 144 & & 14 & 266 \\
\hline 98 & SOLFEJO N ${ }^{\circ} 135$ - a capella & 135 & & & 266 \\
\hline 99 & SOLFEJO N ${ }^{\circ} 149$ - a capella & 149 & & 146 & 266 \\
\hline 100 & SOLFEJO N ${ }^{\circ} 137$ - a capella & 137 & & & 267 \\
\hline 101 & SOLFEJO $N^{\circ} 75$ - a capella & 75 & & & 267 \\
\hline 102 & SOLFEJO N ${ }^{\circ} 102$ - a capella & 102 & & & 267 \\
\hline
\end{tabular}




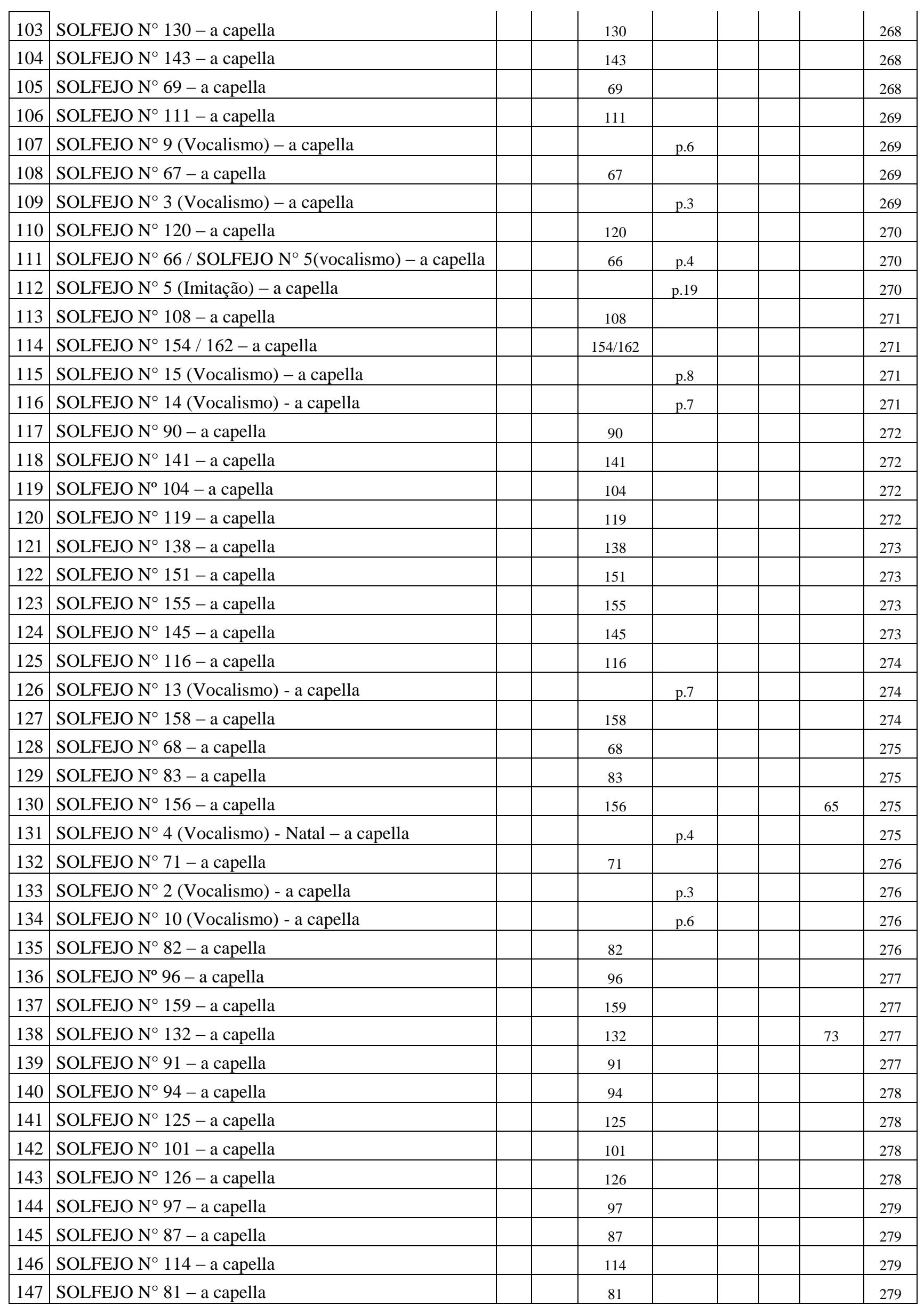




\begin{tabular}{|c|c|c|c|c|}
\hline 148 & SOLFEJO N ${ }^{\circ} 112$ - a capella & 112 & & 280 \\
\hline 149 & SOLFEJO N ${ }^{\circ} 100$ - a capella & 100 & & 280 \\
\hline 150 & SOLFEJO $N^{\circ} 92-$ a capella & 92 & & 280 \\
\hline 151 & SOLFEJO No 103 - a capella & 103 & & 280 \\
\hline 152 & SOLFEJO N ${ }^{\circ} 105$ - a capella & 105 & & 281 \\
\hline 153 & SOLFEJO N ${ }^{\circ} 106$ - a capella & 106 & & 281 \\
\hline 154 & SOLFEJO No 79 - a capella & 79 & & 281 \\
\hline 155 & SOLFEJO No 80 - a capella & 80 & & 281 \\
\hline 156 & SOLFEJO N ${ }^{\circ} 19$ (Vocalismo) - a capella & & p.10 & 282 \\
\hline 157 & SOLFEJO N ${ }^{\circ} 26$ (Vocalismo) - a capella & & p.16 & 282 \\
\hline
\end{tabular}

VII - Harmonizações

\begin{tabular}{|c|c|c|c|c|c|c|c|c|}
\hline 158 & NA MÃO DIREITA - a capella & 75 & 48 & 34 & & & 21 & 283 \\
\hline 159 & Ó LIMÃO - acompanhamento instrumental & 69 & 49 & & & & 83 & 283 \\
\hline 160 & UMA, DUAS ANGOLINHAS - a capella & 124 & 47 & & & & 24 & 283 \\
\hline 161 & Ó SIM! - acompanhamento instrumental & 119 & 127 & & & & & 284 \\
\hline 162 & $\begin{array}{l}\text { VAMOS ATRÁS DA SERRA, OH CALUNGA - } \\
\text { acompanhamento instrumental }\end{array}$ & 126 & 134 & & & & 17 & 284 \\
\hline 163 & NA BAHIA TEM - acompanhamento instrumental & 12 & 137 & & & & 50 & 285 \\
\hline 164 & VAMOS, MARUCA - acompanhamento instrumental & 128 & 133 & & & & 15 & 285 \\
\hline 165 & $\begin{array}{l}\text { CHORA, MENINA, CHORA - acompanhamento } \\
\text { instrumental }\end{array}$ & 34 & 136 & & & & & 286 \\
\hline 166 & DE FLOR EM FLOR-acompanhamento instrumental & 48 & 131 & & & & 91 & 287 \\
\hline 167 & MEU BENZINHO - a capella & 80 & 50 & & & & & 287 \\
\hline 168 & CÓ, CÓ, CÓ - acompanhamento instrumental & 37 & 132 & & & & 127 & 288 \\
\hline 169 & BOAS FESTAS (Canção de cordialidade) - a capella & & & & & 9 & 41 & 288 \\
\hline 170 & $\begin{array}{l}\text { FELIZ ANIVERSÁRIO - (canção de cordialidade) - a } \\
\text { capella }\end{array}$ & & & & & 8 & 133 & 289 \\
\hline 171 & CANTOS DE ÇAIRÉ (2) - a capella & & & & & 19 & 5 & 289 \\
\hline 172 & SOLFEJO $N^{\circ} 25$ (Vocalismo) - a capella & & & & p. 15 & & & 289 \\
\hline 173 & HEI DE NAMORAR - a capella & 62 & 56 & & & & 120 & 289 \\
\hline 174 & PADRE FRANCISCO - a capella & 86 & 57 & & & & & 290 \\
\hline 175 & SOLFEJO N ${ }^{\circ} 12$ (Vocalismo) - a capella & & & & p. 7 & & & 290 \\
\hline 176 & CANTIGA DE REDE - a capella & & & & & 7 & & 291 \\
\hline 177 & MÊS DE JUNHO - a capella & 96 & 46 & & & 15 & 149 & 291 \\
\hline 178 & BOAS VINDAS (Canção de cordialidade) - a capella & & & & & 12 & & 292 \\
\hline 179 & FELIZ ANO NOVO - (canção de cordialidade) -a capella & & & & & 11 & 173 & 292 \\
\hline
\end{tabular}

\begin{tabular}{|c|c|c|c|c|c|c|c|c|c|}
\hline & CAPÍTULO 2.2 - DUAS OU MAIS VOZES & & & & & & & Capítulo & \\
\hline $\mathrm{N}^{\circ}$ & Ordem alfabética & GP & $\mathrm{ABM}$ & S1 & $\mathrm{S} 2$ & $\mathrm{CO1}$ & $\mathrm{CO} 2$ & 2.1 & Página \\
\hline 58 & A AGULHA - a capella & 3 & 7 & 23 & & & & 42 & 252 \\
\hline
\end{tabular}




\begin{tabular}{|c|c|c|c|c|c|c|c|c|c|}
\hline 55 & A CANOA VIROU - a capella & 23 & 31 & 5 & & & & 95 & 251 \\
\hline 66 & A CANTIGA DE NINAR - a capella & 25 & 18 & & & & & 113 & 254 \\
\hline 57 & A CANTIGA DE RODA (As bonecas) - a capella & 26 & 9 & 19 & & & $29 \mathrm{~d}$ & 131 & 250 \\
\hline 93 & A COBRA E A ROLINHA & 36 & 27 & & & & & 102 & 262 \\
\hline 16 & A GATINHA PARDA ( $1^{\text {a }}$ versão $)$ - a capella & 59 & 32 & 30 & & & & 51 & 238 \\
\hline 15 & A GATINHA PARDA ( $2^{\mathrm{a}}$ versão $)$ - a capella & 60 & 33 & & & & & 102 & 237 \\
\hline 19 & À PRAIA (Chamados para brinquedo de roda) & 33 & 58 & & & & & & 239 \\
\hline 7 & A ROSEIRA $\left(1^{\mathrm{a}}\right.$ versão $)$ - a capella & 110 & 52 & & & & & 7 & 234 \\
\hline 6 & ACORDEI DE MADRUGADA ( $\left(1^{\mathrm{a}}\right.$ versão $)$ - a capella & 1 & 34 & & & & & 168 & 234 \\
\hline 5 & AINDA NÃO COMPREI - a capella & 4 & 51 & & & & & 19 & 233 \\
\hline 82 & ANDA A RODA ( $\left({ }^{\text {a }}\right.$ versão $)$ - a capella & 5 & 5 & 31 & & & $29 \mathrm{e}$ & 154 & 260 \\
\hline 14 & ANQUINHAS - a capella & 9 & 30 & 24 & & & & 67 & 237 \\
\hline 18 & BAM-BA-LA-LÃO (Senhor Capitão) - a capella & 13 & 45 & & & & & 1 & 239 \\
\hline 53 & BELA PASTORA - acompanhamento instrumental & 15 & 124 & & & & & 4 & 250 \\
\hline 70 & BESUNTÃO DA LAGOA - a capella & 16 & 38 & 22 & & & & 34 & 256 \\
\hline 169 & BOAS FESTAS (Canção de cordialidade) - a capella & & & & & & 9 & 41 & 288 \\
\hline 178 & BOAS VINDAS (Canção de cordialidade) - a capella & & & & & & 12 & & 292 \\
\hline 44 & $\begin{array}{l}\text { BRINCADEIRA DE PEGAR (No prado da Madalena) - } \\
\text { a capella }\end{array}$ & & & & & & 1 & & 247 \\
\hline 64 & CAI, CAI BALÃO (Vem cá, Bitu) - a capella & 19 & 13 & & & & & 31 & 254 \\
\hline 8 & CANÁRIO - a capella & 21 & 28 & & & & & 27 & 234 \\
\hline 67 & CANDEEIRO - a capella & 22 & 21 & 27 & & & & 112 & 255 \\
\hline 91 & CANOINHA NOVA - a capella & 24 & 40 & 20 & & & & 150 & 264 \\
\hline 26 & CÂNONE N ${ }^{\circ} 1-$ a capella & & & & p. 20 & & & & 242 \\
\hline 27 & CÂNONE $N^{\circ} 3-$ a capella & & & & p. 20 & & & & 242 \\
\hline 23 & CÂNONE $\mathrm{N}^{\circ} 7-$ a capella & & & & p. 21 & & & & 241 \\
\hline 30 & CÂNONE $\mathrm{N}^{\circ} 8$ e $\mathrm{N}^{\circ} 16$ - a capella & & & & pp.21/23 & & & & 243 \\
\hline 24 & CÂNONE $N^{\circ} 9-$ a capella & & & & p.21 & & & & 241 \\
\hline 21 & CÂNONE $N^{\circ} 12-$ a capella & & & & p. 22 & & & & 240 \\
\hline 28 & CÂNONE $N^{\circ} 17-$ a capella & & & & p. 23 & & & & 243 \\
\hline 25 & CÂNONE $N^{\circ} 18-$ a capella & & & & p. 24 & & & & 242 \\
\hline 29 & CÂNONE N ${ }^{\circ} 19-$ a capella & & & & p. 25 & & & & 243 \\
\hline 22 & CÂNONE $N^{\circ} 20-$ a capella & & & & p. 26 & & & & 241 \\
\hline 176 & CANTIGA DE REDE - a capella & & & & & & 7 & & 291 \\
\hline 9 & CANTOS DE ÇAIRÉ (1) - a capella & & & & & & 18 & 12 & 235 \\
\hline 171 & CANTOS DE ÇAIRÉ (2) - a capella & & & & & & 19 & 5 & 289 \\
\hline 32 & CANTOS DE ÇAIRÉ (3) - a capella & & & & & & 20 & 62 & 244 \\
\hline 56 & CAPELINHA DE MELÃO - a capella & 27 & 15 & 7 & & & & 25 & 251 \\
\hline 62 & $\begin{array}{l}\left.\text { CARANGUEJO ( } 1^{\text {a }} \text { versão }\right) \text { - acompanhamento } \\
\text { instrumental }\end{array}$ & 29 & 126 & & & & & 164 & 253 \\
\hline 71 & CARANGUEJO ( $2^{\mathrm{a}}$ versão $)$ - a capella & 30 & 16 & 10 & & & & 60 & 256 \\
\hline 10 & CARNEIRINHO DE ALGODÃO - a capella & & & & & 4 & & 124 & 235 \\
\hline 165 & CHORA, MENINA, CHORA & 34 & 136 & & & & & & 286 \\
\hline 168 & CÓ, CÓ, CÓ - acompanhamento instrumental & 37 & 132 & & & & & 127 & 288 \\
\hline 166 & DE FLOR EM FLOR-acompanhamento instrumental & 48 & 131 & & & & & 91 & 287 \\
\hline 40 & ENTREI NA RODA- a capella & 49 & 43 & 18 & & & & 20 & 246 \\
\hline 170 & FELIZ ANIVERSÁRIO - a capella & & & & & & 8 & 133 & 289 \\
\hline 179 & FELIZ ANO NOVO - a capella & & & & & & 11 & 173 & 292 \\
\hline 65 & FELIZ NATAL - a capella & & & & & & 10 & 129 & 254 \\
\hline 79 & FORMIGUINHAS - a capella & 52 & 17 & 33 & & & & 69 & 259 \\
\hline 86 & $\begin{array}{l}\text { FUI NO ITORORÓ ( } 1^{\text {a }} \text { versão) - acompanhamento } \\
\text { instrumental }\end{array}$ & 54 & 129 & & & & & 122 & 262 \\
\hline
\end{tabular}




\begin{tabular}{|c|c|c|c|c|c|c|c|c|c|}
\hline 72 & FUI PASSAR NA PONTE (Na Bahia Tem) - a capella & 56 & 26 & 16 & & & & 49 & 256 \\
\hline 173 & HEI DE NAMORAR - a capella & 62 & 56 & & & & & 120 & 289 \\
\hline 54 & HIGIENE - a capella & 64 & 19 & 3 & & & & 28 & 251 \\
\hline 11 & $\begin{array}{l}\text { LÁ NA PONTE DA VINHAÇA (Passa, passa gavião) - a } \\
\text { capella }\end{array}$ & 104 & 14 & 2 & & & & 39 & 235 \\
\hline 74 & LINDAS LARANJAS - a capella & 70 & 25 & 35 & & & & 159 & 257 \\
\hline 39 & MARCHA ESCOLAR (Ida para o recreio) & & & & & 9 & & & 246 \\
\hline 13 & MARCHA ESCOLAR (Meu sapinho) - A capella & & & & & 7 & & & 236 \\
\hline 1 & MARGARIDA - Acompanhamento instrumental & 77 & 123 & & & & & & 231 \\
\hline 177 & MÊS DE JUNHO - a capella & 96 & 46 & & & & 15 & 149 & 291 \\
\hline 167 & MEU BENZINHO - a capella & 80 & 50 & & & & & & 287 \\
\hline 59 & MEUS BRINQUEDOS (Canção escolar) - a capella & & & & & 1 & & & 252 \\
\hline 77 & MINHA TERRA TEM PALMEIRAS - a capella & & & & & & 5 & 156 & 258 \\
\hline 163 & NA BAHIA TEM - acompanhamento instrumental & 12 & 137 & & & & & 50 & 285 \\
\hline 158 & NA MÃO DIREITA - a capella & 75 & 48 & 34 & & & & 21 & 283 \\
\hline 78 & NESTA RUA (Esta Noite) - a capella & 82 & 24 & 14 & & & & 160 & 259 \\
\hline 75 & NIGUE NINHAS - a capella & 83 & 20 & & & & & 70 & 257 \\
\hline 76 & $\begin{array}{l}\text { NO JARDIM CELESTIAL - acompanhamento } \\
\text { instrumental }\end{array}$ & 65 & 122 & & & & & 3 & 258 \\
\hline 20 & NOZANI-NÁ - A capella & & & & & 32 & & & 240 \\
\hline 31 & O ANEL - a capella & 8 & 42 & & & & & 29 & 244 \\
\hline 36 & O BALÃO DO BITU (Sobre o tema "Vem cá Bitu") & & & & & & 3 & & 245 \\
\hline 69 & O CAFÉ - a capella & 20 & 10 & 8 & & & & 61 & 255 \\
\hline 85 & O CRAVO (1 ${ }^{\text {a }}$ versão $)$ - acompanhamento instrumental & 45 & 118 & & & & & 126 & 261 \\
\hline 60 & O CRAVO BRIGOU COM A ROSA - a capella & 46 & 12 & 21 & & & & 125 & 252 \\
\hline 159 & Ó LIMÃO - acompanhamento instrumental & 69 & 49 & & & & & 83 & 283 \\
\hline 90 & O PASTORZINHO - acompanhamento instrumental & 91 & 125 & & & & & 63 & 264 \\
\hline 161 & Ó SIM! - acompanhamento instrumental & 119 & 127 & & & & & & 284 \\
\hline 80 & OS ESCRAVOS DE JÓ - a capella & 50 & 55 & & & & & 111 & 259 \\
\hline 12 & OS POMBINHOS - a capella & 101 & 8 & 15 & & & & 37 & 236 \\
\hline 174 & PADRE FRANCISCO - a capella & 86 & 57 & & & & & & 290 \\
\hline 2 & PINTOR DE CANNAHY - A capella & 94 & 35 & & & & & & 232 \\
\hline 92 & POBRE CEGO ( $2^{\mathrm{a}}$ versão $)$ - a capella & 97 & 44 & 17 & & & & 162 & 264 \\
\hline 63 & QUANTOS DIAS TEM O MÊS? - a capella & 106 & 39 & 11 & & & & 78 & 254 \\
\hline 88 & QUE LINDOS OLHOS - acompanhamento instrumental & 107 & 121 & & & & & 154 & 263 \\
\hline 41 & REPIU-PIU-PIU & & & & & & 4 & & 246 \\
\hline 89 & $\begin{array}{l}\text { ROSA AMARELA ( } 2^{\mathrm{a}} \text { versão) - acompanhamento } \\
\text { instrumental }\end{array}$ & 109 & 120 & & & & & 139 & 263 \\
\hline 35 & SAPO JURURU & 113 & 41 & & & & & & 245 \\
\hline 84 & $\begin{array}{l}\text { SENHORA DONA VIÚVA - acompanhamento } \\
\text { instrumental }\end{array}$ & 117 & 130 & & & & & & 261 \\
\hline 83 & SENHORA VIÚVA (Viuvinha) - a capella & 118 & 53 & & & & & 130 & 260 \\
\hline 4 & SODADE - a capella & 121 & 36 & 29 & & & & 93 & 233 \\
\hline 33 & SOLFEJO N ${ }^{\circ}$ s 1,2 e 3 - Imitações - a capella & & & $1,2,3$ & p.18 & & & & 244 \\
\hline 34 & SOLFEJO N ${ }^{\circ} 4-$ Imitação - a capella & & & & p.18 & & & & 244 \\
\hline 112 & SOLFEJO N ${ }^{\circ} 5$ (Imitação) - a capella & & & & p.19 & & & & 270 \\
\hline 43 & SOLFEJO N ${ }^{\circ} 6-$ Imitação - a capella & & & & p.19 & & & & 247 \\
\hline 48 & SOLFEJO N ${ }^{\circ} 7-$ Imitação - a capella & & & & p.19 & & & & 249 \\
\hline 133 & SOLFEJO N $^{\circ} 2$ (Vocalismo) - a capella & & & & p.3 & & & & 276 \\
\hline 109 & SOLFEJO N ${ }^{\circ} 3$ (Vocalismo) - a capella & & & & p.3 & & & & 269 \\
\hline 131 & SOLFEJO N ${ }^{\circ} 4$ (Vocalismo) - Natal - a capella & & & & p. 4 & & & & 275 \\
\hline
\end{tabular}




\begin{tabular}{|c|c|c|c|c|c|}
\hline 95 & SOLFEJO N ${ }^{\circ} 8$ (Vocalismo) - a capella & & p.5 & & 265 \\
\hline 107 & SOLFEJO N ${ }^{\circ} 9$ (Vocalismo) - a capella & & p. .5 & & 269 \\
\hline 134 & SOLFEJO N ${ }^{\circ} 10$ (Vocalismo) - a capella & & p.6 & & 276 \\
\hline 175 & SOLFEJO N ${ }^{\circ} 12$ (Vocalismo) - a capella & & p.7 & & 290 \\
\hline 126 & SOLFEJO N ${ }^{\circ} 13$ (Vocalismo) - a capella & & p.7 & & 274 \\
\hline 116 & SOLFEJO N 14 (Vocalismo) - a capella & & p.7 & & 271 \\
\hline 115 & SOLFEJO N $^{\circ} 15$ (Vocalismo) - a capella & & p. 8 & & 271 \\
\hline 156 & SOLFEJO No 19 (Vocalismo) - a capella & & p.10 & & 282 \\
\hline 172 & SOLFEJO N 25 (Vocalismo) - a capella & & p. 15 & & 289 \\
\hline 157 & SOLFEJO N ${ }^{\circ} 26$ (Vocalismo) - a capella & & p.16 & & 282 \\
\hline 111 & SOLFEJO N $^{\circ} 66$ / VOCALISMO No 5 - a capella & 66 & p.4 & & 270 \\
\hline 108 & SOLFEJO N 67 - a capella & 67 & & & 269 \\
\hline 128 & SOLFEJO N $^{\circ} 68$ - a capella & 68 & & & 275 \\
\hline 105 & SOLFEJO N $^{\circ} 69$ - a capella & 69 & & & 268 \\
\hline 47 & SOLFEJO N $^{\circ} 70$ - a capella & 70 & & & 248 \\
\hline 132 & SOLFEJO N $^{\circ} 71$ - a capella & 71 & & & 276 \\
\hline 37 & SOLFEJO $N^{\circ} 73$ - a capella & 73 & & & 245 \\
\hline 101 & SOLFEJO N $^{\circ} 75$ - a capella & 75 & & & 267 \\
\hline 154 & SOLFEJO No 79 - a capella & 79 & & & 281 \\
\hline 155 & SOLFEJO No $^{\circ} 80$ - a capella & 80 & & & 281 \\
\hline 147 & SOLFEJO N $^{\circ} 81$ - a capella & 81 & & & 279 \\
\hline 135 & SOLFEJO N $^{\circ} 82$ - a capella & 82 & & & 276 \\
\hline 129 & SOLFEJO N ${ }^{\circ} 83-$ a capella & 83 & & & 275 \\
\hline 46 & SOLFEJO N$^{\circ} \mathrm{s} 84 / 121-$ a capella & $84 / 121$ & & & 248 \\
\hline 145 & SOLFEJO N ${ }^{\circ} 87-$ a capella & 87 & & & 279 \\
\hline 45 & SOLFEJO No 89 - a capella & 89 & & & 248 \\
\hline 117 & SOLFEJO N ${ }^{\circ} 90-$ a capella & 90 & & & 272 \\
\hline 139 & SOLFEJO N $^{\circ} 91$ - a capella & 91 & & & 277 \\
\hline 150 & SOLFEJO No 92 - a capella & 92 & & & 280 \\
\hline 140 & SOLFEJO N ${ }^{\circ} 94$ - a capella & 94 & & & 278 \\
\hline 136 & SOLFEJO No 96 - a capella & 96 & & & 277 \\
\hline 144 & SOLFEJO N ${ }^{\circ} 97$ - a capella & 97 & & & 279 \\
\hline 50 & SOLFEJO N ${ }^{\circ} 99$ - a capella & 99 & & & 249 \\
\hline 149 & SOLFEJO N $^{\circ} 100-$ a capella & 100 & & & 280 \\
\hline 142 & SOLFEJO N $^{\circ} 101$ - a capella & 101 & & & 278 \\
\hline 102 & SOLFEJO N $^{\circ} 102-$ a capella & 102 & & & 267 \\
\hline 151 & SOLFEJO No $^{\circ} 103$ - a capella & 103 & & & 280 \\
\hline 119 & SOLFEJO No $104-$ a capella & 104 & & & 272 \\
\hline 152 & SOLFEJO No 105 - a capella & 105 & & & 281 \\
\hline 153 & SOLFEJO No 106 - a capella & 106 & & & 281 \\
\hline 113 & SOLFEJO N ${ }^{\circ} 108$ - a capella & 108 & & & 271 \\
\hline 17 & SOLFEJO N $^{\circ} 109$ - a capella & 109 & & & 238 \\
\hline 106 & SOLFEJO N $^{\circ} 111$ - a capella & 111 & & & 269 \\
\hline 148 & SOLFEJO No 112 - a capella & 112 & & & 280 \\
\hline 146 & SOLFEJO N $^{\circ} 114$ - a capella & 114 & & & 279 \\
\hline 125 & SOLFEJO N $^{\circ} 116$ - a capella & 116 & & & 274 \\
\hline 120 & SOLFEJO N $^{\circ} 119$ - a capella & 119 & & & 272 \\
\hline 110 & SOLFEJO N $^{\circ} 120$ - a capella & 120 & & & 270 \\
\hline 141 & SOLFEJO N $^{\circ} 125$ - a capella & 125 & & & 278 \\
\hline 143 & SOLFEJO N $^{\circ} 126$ - a capella & 126 & & & 278 \\
\hline 96 & SOLFEJO N $^{\circ} 128$ - a capella & 128 & & 64 & 266 \\
\hline 103 & SOLFEJO N $^{\circ} 130$ - a capella & 130 & & & 268 \\
\hline 94 & SOLFEJO N $^{\circ} 131$ - a capella & 131 & & & 265 \\
\hline
\end{tabular}




\begin{tabular}{|c|c|c|c|c|c|c|c|c|}
\hline 138 & SOLFEJO N ${ }^{\circ} 132$ - a capella & & & 132 & & & 73 & 277 \\
\hline 98 & SOLFEJO N $^{\circ} 135$ - a capella & & & 135 & & & & 266 \\
\hline 100 & SOLFEJO N ${ }^{\circ} 137$ - a capella & & & 137 & & & & 267 \\
\hline 121 & SOLFEJO N $^{\circ} 138$ - a capella & & & 138 & & & & 273 \\
\hline 118 & SOLFEJO N $^{\circ} 141-$ a capella & & & 141 & & & & 272 \\
\hline 104 & SOLFEJO N $^{\circ} 143$ - a capella & & & 143 & & & & 268 \\
\hline 97 & SOLFEJO N $^{\circ} 144-$ a capella & & & 144 & & & 14 & 266 \\
\hline 124 & SOLFEJO N $^{\circ} 145$ - a capella & & & 145 & & & & 273 \\
\hline 99 & SOLFEJO N ${ }^{\circ} 149$ - a capella & & & 149 & & & 146 & 266 \\
\hline 122 & SOLFEJO N ${ }^{\circ} 151$ - a capella & & & 151 & & & & 273 \\
\hline 49 & SOLFEJO N ${ }^{\circ}$ s $153 / 163$ - a capella & & & $153 / 163$ & & & & 249 \\
\hline 114 & SOLFEJO N $^{\circ} 154$ / 162 - a capella & & & $154 / 162$ & & & & 271 \\
\hline 123 & SOLFEJO N $^{\circ} 155-$ a capella & & & 155 & & & & 273 \\
\hline 130 & SOLFEJO N $^{\circ} 156$ - a capella & & & 156 & & & 65 & 275 \\
\hline 42 & SOLFEJO N $^{\circ} 157$ - a capella & & & 157 & & & & 247 \\
\hline 127 & SOLFEJO N ${ }^{\circ} 158-$ a capella & & & 158 & & & & 274 \\
\hline 137 & SOLFEJO N $^{\circ} 159$ - a capella & & & 159 & & & & 277 \\
\hline 51 & SOLFEJO N ${ }^{\circ} 161$ - a capella & & & 161 & & & & 249 \\
\hline 61 & TEREZINHA DE JESUS - a capella & 123 & 11 & 12 & & & 151 & 253 \\
\hline 3 & UM CANTO QUE SAIU DAS SENZALAS - A capella & & & & & 23 & 6 & 232 \\
\hline 160 & UMA, DUAS ANGOLINHAS - a capella & 124 & 47 & & & & 24 & 283 \\
\hline 162 & $\begin{array}{l}\text { VAMOS ATRÁS DA SERRA, OH CALUNGA - } \\
\text { acompanhamento instrumental }\end{array}$ & 126 & 134 & & & & 17 & 284 \\
\hline 38 & $\begin{array}{l}\text { VAMOS, COMPANHEIROS - Canção escolar - a } \\
\text { capella }\end{array}$ & & & & 3 & & 36 & 245 \\
\hline 52 & VAMOS, CRIANÇAS - a capella & & & & 2 & & 23 & 250 \\
\hline 73 & VAMOS, MANINHA ( $2^{\text {a }}$ versão $)$ - a capella & 127 & 23 & 13 & & & 147 & 257 \\
\hline 164 & VAMOS, MARUCA- acompanhamento instrumental & 128 & 133 & & & & 15 & 285 \\
\hline 87 & VITU - acompanhamento instrumental & 133 & 119 & & & & 32 & 262 \\
\hline 68 & VIUVINHA DA BANDA D'ALÉM - a capella & 134 & 22 & & & & 33 & 255 \\
\hline 81 & VIVA O CARNAVAL - a capella & 135 & 54 & & & & 84 & 260 \\
\hline
\end{tabular}

\begin{tabular}{|c|c|c|c|c|}
\hline \multirow{2}{*}{$\mathrm{N}^{\circ}$} & \multicolumn{4}{|c|}{ CAPÍTULO 2.3 - REPERTÓRIO CORAL } \\
\hline & Vozes iguais & $\mathrm{CO} 1$ & $\mathrm{CO} 2$ & Página \\
\hline 1 & QUADRILHA DAS ESTRELAS NO CÉU DO BRASIL & & 29 & 293 \\
\hline $1 \mathrm{a}$ & ( $\mathrm{N}^{\circ} 1$ Introdução) - a capella & & $29 \mathrm{a}$ & 293 \\
\hline $1 \mathrm{~b}$ & (No 2 Quadrilha Brasileira) - a capella & & $29 \mathrm{~b}$ & 294 \\
\hline $1 \mathrm{c}$ & (No 3 Fui no Itororó) - a capella & & $29 \mathrm{c}$ & 295 \\
\hline $1 \mathrm{~d}$ & (No 4 Cantiga de roda) - a capella & & $29 \mathrm{~d}$ & 295 \\
\hline $1 \mathrm{e}$ & $\left(\mathrm{N}^{\circ} 5\right.$ Anda à roda $)-$ a capella & & $29 \mathrm{e}$ & 295 \\
\hline 2 & CANTAR PARA VIVER - a capella & 20 & & 296 \\
\hline 3 & DIA DE ALEGRIA - a capella & 22 & & 296 \\
\hline 4 & HERANÇAS DA NOSSA RAÇA - a capella & 23 & & 297 \\
\hline 5 & O CANTO DO PAJÉ - a capella & 19 & & 298 \\
\hline 6 & CANTO DO LAVRADOR - a capella & 29 & & 298 \\
\hline 7 & MARCHA PARA O OESTE - a capella & & 27 & 299 \\
\hline 8 & A SANFONA - a capella & & 28 & 300 \\
\hline 9 & PRA FRENTE, Ó BRASIL (Canção Marcial) - a capella & & 32 & 300 \\
\hline
\end{tabular}




\begin{tabular}{|l|l|c|c|c|}
10 & O TRENZINHO - a capella & 31 & 301 \\
\hline 11 & AS COSTUREIRAS - a capella & 33 & 301 \\
\hline 12 & SERTANEJO DO BRASIL - a capella & 27 & & 307 \\
\hline 13 & VIRA - a capella & & 40 & 308 \\
\hline 14 & PÁTRIA - a capella & 34 & 308 \\
\hline 15 & ABOIOS - a capella & 16 & 308 \\
\hline 16 & EVOCAÇÃO - a capella & 21 & 309 \\
\hline 17 & INVOCAÇÃO EM DEFESA DA PÁTRIA - a capella & 45 & 309 \\
\hline & Vozes mistas & \multicolumn{3}{|l|}{} \\
\hline 18 & XANGÔ - a capella & 24 & 310 \\
\hline 19 & CANIDE IOUNE - (Sabath) - a capella & 22 & 310 \\
\hline 20 & TERRA NATAL - a capella & 43 & 311 \\
\hline 21 & NA RISONHA MADRUGADA - a capella & 41 & 311 \\
\hline 22 & O TAMBORZINHO - a capella & 42 & 312 \\
\hline 23 & ESTRELA É LUA NOVA - a capella & 37 & 312 \\
\hline 24 & REMEIRO DE SÃO FRANCISCO (Solo e piano ou coro) & 44 & 313 \\
\hline 25 & JAQUIBAU - a capella & 38 & 313 \\
\hline 26 & BAZZUM - a capella & 26 & 39 & 314 \\
\hline 27 & VERDE PÁTRIA - a capella & & 35 & 315 \\
\hline 28 & PÁTRIA (Hino Orfeônico Brasileiro) - a capella & 17 & 316 \\
\hline 29 & CÂNTICO DO PARÁ - a capella & & 17 \\
\hline
\end{tabular}

\begin{tabular}{|c|l|c|c|c|}
\hline $\mathrm{N}^{\circ}$ & $\begin{array}{l}\text { CAPÍTULO 2.3 - REPERTÓRIO CORAL - Ordem } \\
\text { alfabética }\end{array}$ & $\mathrm{CO} 1$ & $\mathrm{CO} 2$ & Página \\
\hline 8 & A SANFONA - a capella & 28 & 300 \\
\hline 15 & ABOIOS - a capella & 16 & 308 \\
\hline 11 & AS COSTUREIRAS - a capella & 33 & 301 \\
\hline 26 & BAZZUM - a capella & 39 & 314 \\
\hline 19 & CANIDE IOUNE - (Sabath) - a capella & 22 & 310 \\
\hline 2 & CANTAR PARA VIVER - a capella & 20 & & 296 \\
\hline 29 & CÂNTICO DO PARÁ - a capella & 29 & 17 & 316 \\
\hline 6 & CANTO DO LAVRADOR - a capella & 22 & & 298 \\
\hline 3 & DIA DE ALEGRIA - a capella & & 37 & 312 \\
\hline 23 & ESTRELA É LUA NOVA - a capella & 21 & 309 \\
\hline 16 & EVOCAÇÃO - a capella & 23 & & 297 \\
\hline 4 & HERANÇAS DA NOSSA RAÇA - a capella & 45 & 309 \\
\hline 17 & INVOCAÇÃO EM DEFESA DA PÁTRIA - a capella & 38 & 313 \\
\hline 25 & JAQUIBAU - a capella & 27 & 299 \\
\hline 7 & MARCHA PARA O OESTE - a capella & & 41 & 311 \\
\hline 21 & NA RISONHA MADRUGADA - a capella & 19 & & 298 \\
\hline 5 & O CANTO DO PAJÉ - a capella & & 42 & 312 \\
\hline 22 & O TAMBORZINHO - a capella & 31 & 301 \\
\hline 10 & O TRENZINHO - a capella & 35 & 316 \\
\hline 28 & PÁTRIA (Hino Orfeônico Brasileiro) - a capella & 34 & 308 \\
\hline 14 & PÁTRIA - a capella & 32 & 300 \\
\hline 9 & PRA FRENTE, Ó BRASIL (Canção Marcial) - a capella & & \\
\hline
\end{tabular}




\begin{tabular}{|c|c|c|c|c|}
\hline 1 & QUADRILHA DAS ESTRELAS NO CÉU DO BRASIL & & 29 & 293 \\
\hline $1 \mathrm{a}$ & ( $\mathrm{N}^{\circ} 1$ Introdução) - a capella & & $29 \mathrm{a}$ & 293 \\
\hline $1 \mathrm{~b}$ & ( $\mathrm{N}^{\circ} 2$ Quadrilha Brasileira) - a capella & & $29 \mathrm{~b}$ & 294 \\
\hline $1 \mathrm{c}$ & (No 3 Fui no Itororó) - a capella & & $29 \mathrm{c}$ & 295 \\
\hline $1 \mathrm{~d}$ & $\left(\mathrm{~N}^{\circ} 4\right.$ Cantiga de roda) - a capella & & $29 \mathrm{~d}$ & 295 \\
\hline $1 \mathrm{e}$ & ( $\mathrm{N}^{\circ} 5$ Anda à roda $)-\mathrm{a}$ capella & & $29 \mathrm{e}$ & 295 \\
\hline 24 & REMEIRO DE SÃO FRANCISCO (Solo e piano ou coro) & & 44 & 313 \\
\hline 12 & SERTANEJO DO BRASIL - a capella & 27 & & 307 \\
\hline 20 & TERRA NATAL - a capella & & 43 & 311 \\
\hline 27 & VERDE PÁTRIA - a capella & 26 & & 315 \\
\hline 13 & VIRA - a capella & & 40 & 308 \\
\hline 18 & XANGÔ - a capella & & 24 & 310 \\
\hline
\end{tabular}

\begin{tabular}{|c|c|c|c|c|c|c|c|c|c|}
\hline $\mathrm{N}^{\circ}$ & INSTRUMENTAL 2.4 & $\begin{array}{c}\text { GP/ } \\
\text { VTL }\end{array}$ & $\begin{array}{c}\text { GP/ } \\
\text { ABM }\end{array}$ & S1 & $\mathrm{S} 2$ & $\mathrm{CO} 1$ & $\mathrm{CO} 2$ & Instrumento & Página \\
\hline 1 & $\begin{array}{l}\text { ACORDEI DE MADRUGADA (II versão - } \\
\text { para piano) }\end{array}$ & 2 & 59 & & & & & piano & 318 \\
\hline 2 & $\begin{array}{l}\text { ANDA A RODA ( } 3^{\text {a }} \text { versão - para piano } \\
\text { solo) }\end{array}$ & 7 & 116 & & & & & piano & 318 \\
\hline 3 & A MAMÃE ESTAVA DOENTE & 72 & 63 & & & & & piano & 320 \\
\hline 4 & ATCHÉ & 10 & 117 & & & & & piano & 320 \\
\hline 5 & MAR DO BRASIL & & & & & 38 & & piano & 320 \\
\hline 6 & MEU PAI AMARROU MEUS OLHOS & 81 & 115 & & & & & piano & 320 \\
\hline 7 & O CORCUNDA & 42 & 100 & & & & & piano & 321 \\
\hline 8 & QUANDO EU ERA PEQUENINO & 105 & 77 & & & & & piano & 321 \\
\hline 9 & SONHO DE UMA CRIANÇA & 122 & 60 & & & & & piano & 321 \\
\hline 10 & VEM CÁ, SIRIRI & 130 & 106 & & & & & piano & 321 \\
\hline 11 & XÔ! PASSARINHO & 137 & 105 & & & & & piano & 322 \\
\hline 12 & A CANÇÃO DO MARCENEIRO & & & & & 33 & & sopro/cordas & 322 \\
\hline 13 & A JANGADA & & & & & 6 & & sopro/cordas & 322 \\
\hline 14 & ALERTA (Rataplan) & & & & & 39 & & sopro/cordas & 322 \\
\hline 15 & ANDA A RODA ( (2 ${ }^{\mathrm{a}}$ Versão) & 6 & 6 & 32 & & & & sopro/cordas & 323 \\
\hline 16 & AS CONCHINHAS & 38 & 37 & 25 & & & & sopro/cordas & 323 \\
\hline 17 & BRASIL UNIDO & & & & & 15 & & sopro/cordas & 323 \\
\hline 18 & CANÇÃO DO NORTE & & & & & 17 & & sopro/cordas & 323 \\
\hline 19 & CANÇÃO DO PESCADOR BRASILEIRO & & & & & & 26 & sopro/cordas & 323 \\
\hline 20 & CANÇÃO DO TRABALHO & & & & & 31 & & sopro/cordas & 324 \\
\hline 21 & CANÇÃO ESCOLAR & & & & & 12 & & sopro/cordas & 324 \\
\hline 22 & ESPERANÇA DA MÃE POBRE & & & & & & 2 & sopro/cordas & 324 \\
\hline 23 & HINO À VITÓRIA & & & & & & 36 & sopro/cordas & 324 \\
\hline 24 & JURAMENTO & & & & & & 30 & sopro/cordas & 325 \\
\hline 25 & MARCHA ESCOLAR (Passeio) & & & & & 10 & & sopro/cordas & 325 \\
\hline 26 & MARCHA ESCOLAR (Vocalismo) & & & & & 11 & & sopro/cordas & 325 \\
\hline 27 & MARCHA ESCOLAR (Volta do recreio) & & & & & 8 & & sopro/cordas & 325 \\
\hline 28 & O FERREIRO & & & & & 28 & & sopro/cordas & 326 \\
\hline 29 & O GATURAMO & & & & & & 6 & sopro/cordas & 326 \\
\hline 30 & O PESCADOR DA BARQUINHA & 92 & 29 & & & & & sopro/cordas & 326 \\
\hline
\end{tabular}


\begin{tabular}{|l|l|l|l|l|l|l|l|l|l|}
31 & SANTOS DUMONT (A conquista do ar) & & & & & & 25 & sopro/cordas & 326 \\
\hline 32 & SOLDADINHOS (Canção escolar) & & & & & 5 & & sopro/cordas & 327 \\
\hline
\end{tabular}

\begin{tabular}{|c|c|c|c|c|c|}
\hline & $1 \mathrm{voz}$ & & & & \\
\hline 33 & SOLFEJO Nº 8 (Ditado) & & p. 2 & sopro/cordas & 327 \\
\hline 34 & SOLFEJO No 3 (Ditado) & & p. 1 & sopro/cordas & 327 \\
\hline 35 & SOLFEJO N 6 (Vocalismo) & & p.5 & sopro/cordas & 327 \\
\hline 36 & SOLFEJO N ${ }^{\circ} 21$ (Vocalismo) & & p.11 & sopro/cordas & 327 \\
\hline 37 & SOLFEJO No 48 & 48 & & sopro/cordas & 327 \\
\hline 38 & SOLFEJO N ${ }^{\circ} 58$ & 58 & & sopro/cordas & 328 \\
\hline 39 & SOLFEJO N ${ }^{\circ} 54$ & 54 & & sopro/cordas & 328 \\
\hline 40 & SOLFEJO N ${ }^{\circ} 53$ & 53 & & sopro/cordas & 328 \\
\hline 41 & SOLFEJO N ${ }^{\circ} 59$ & 59 & & sopro/cordas & 328 \\
\hline 42 & SOLFEJO N ${ }^{\circ} 52$ & 52 & & sopro/cordas & 328 \\
\hline 43 & SOLFEJO No 47 & 47 & & sopro/cordas & 328 \\
\hline 44 & SOLFEJO N ${ }^{\circ} 22$ (Vocalismo) & & p. 12 & sopro/cordas & 329 \\
\hline
\end{tabular}

Vozes iguais

\begin{tabular}{|c|c|c|c|c|c|}
\hline \\
\hline 45 & SOLFEJO No 24 (Vocalismo) & & p.14 & sopros & 329 \\
\hline 46 & SOLFEJO No 95 & 95 & & sopro/cordas & 329 \\
\hline 47 & SOLFEJO No 123 & 123 & & sopro/cordas & 329 \\
\hline 48 & SOLFEJO No 150 & 150 & & sopro/cordas & 329 \\
\hline 49 & SOLFEJO N 20 (Vocalismo) & & p.11 & sopro/cordas & 329 \\
\hline 50 & SOLFEJO N ${ }^{\circ} 16$ (Vocalismo) & & p. 8 & sopro/cordas & 330 \\
\hline 51 & SOLFEJO No 140 & 140 & & sopro/cordas & 330 \\
\hline 52 & SOLFEJO No 148 & 148 & & sopro/cordas & 330 \\
\hline 53 & SOLFEJO N 115 & 115 & & sopro/cordas & 330 \\
\hline 54 & SOLFEJO No 18 (Vocalismo) & & p. 10 & sopro/cordas & 330 \\
\hline 55 & SOLFEJO No 1 (Vocalismo) & & p. 3 & sopro/cordas & 330 \\
\hline 56 & SOLFEJO Nº 7 (Vocalismo) & & p. 5 & sopro/cordas & 331 \\
\hline 57 & SOLFEJO N ${ }^{\circ} 23$ (Vocalismo) & & p.13 & sopro/cordas & 331 \\
\hline 58 & SOLFEJO No 17 (Vocalismo) & & p.9 & sopro/cordas & 331 \\
\hline 59 & SOLFEJO N ${ }^{\circ} 86$ - a capella & 86 & & sopro/cordas & 331 \\
\hline \multicolumn{6}{|c|}{ Vozes mistas } \\
\hline 60 & SOLFEJO Nº 11 (Vocalismo) & & p.6 & sopro/cordas & 331 \\
\hline 61 & SOLFEJO N ${ }^{\circ} 152 / 160$ & $152 / 160$ & & sopro/cordas & 331 \\
\hline 62 & SOLFEJO N ${ }^{\circ} 122$ & 122 & & sopro/cordas & 332 \\
\hline 63 & SOLFEJO N $^{\circ} 117$ & 117 & & sopro/cordas & 332 \\
\hline 64 & SOLFEJO N ${ }^{\circ} 127$ & 127 & & sopro/cordas & 332 \\
\hline 65 & SOLFEJO N 76 & 76 & & sopro/cordas & 332 \\
\hline 66 & SOLFEJO No 124 & 124 & & sopro/cordas & 332 \\
\hline 67 & SOLFEJO No 118 & 118 & & sopro/cordas & 332 \\
\hline 68 & SOLFEJO N 133 & 133 & & sopro/cordas & 333 \\
\hline 69 & SOLFEJO No 85 & 85 & & sopro/cordas & 333 \\
\hline 70 & SOLFEJO N ${ }^{\circ} 88$ & 88 & & sopro/cordas & 333 \\
\hline 71 & SOLFEJO No 107 & 107 & & sopro/cordas & 333 \\
\hline 72 & SOLFEJO No 72 & 72 & & sopro/cordas & 333 \\
\hline
\end{tabular}




\begin{tabular}{|c|c|c|c|c|c|c|c|}
\hline 73 & SOLFEJO N ${ }^{\circ} 129$ & 129 & & & & sopro/cordas & 333 \\
\hline 74 & SOLFEJO No 113 & 113 & & & & sopro/cordas & 334 \\
\hline 75 & SOLFEJO No 147 & 147 & & & & sopro/cordas & 334 \\
\hline 76 & SOLFEJO N ${ }^{\circ} 74$ & 74 & & & & sopro/cordas & 334 \\
\hline 77 & SOLFEJO No 6 (Ditado) & & p. 2 & & & sopro/cordas & 334 \\
\hline 78 & SOLFEJO No 146 & 146 & & & & sopro/cordas & 334 \\
\hline 79 & SOLFEJO N 134 & 134 & & & & sopro/cordas & 334 \\
\hline 80 & SOLFEJO N ${ }^{\circ} 110$ & 110 & & & & sopro/cordas & 335 \\
\hline 81 & SOLFEJO No 98 & 98 & & & & sopro/cordas & 335 \\
\hline 82 & SOLFEJO N ${ }^{\circ} 93$ & 93 & & & & sopro/cordas & 335 \\
\hline 83 & SOLFEJO N ${ }^{\circ} 77$ & 77 & & & & sopro/cordas & 335 \\
\hline 84 & SOLFEJO N ${ }^{\circ} 78$ & 78 & & & & sopro/cordas & 335 \\
\hline 85 & SOLFEJO No 1 (Fuga) & & p. 27 & & & sopro/cordas & 335 \\
\hline 86 & SOLFEJO No 2 (Fuga) & & p. 34 & & & sopro/cordas & 336 \\
\hline 87 & SOLFEJO No 3 (Fuga) & & p. 36 & & & sopro/cordas & 336 \\
\hline 88 & SOLFEJO Nº 4 (Fuga) & & p.42 & & & sopro/cordas & 336 \\
\hline 89 & SAUDAÇÃO A GETÚLIO VARGAS & & & 40 & & fanfarra & 336 \\
\hline 90 & BRASIL & & & & 13 & Banda/Fanfarra & 337 \\
\hline 91 & BRASIL NOVO & & & 18 & & Banda/Fanfarra & 337 \\
\hline 92 & CANÇÃO CÍVICA RIO DE JANEIRO & & & 13 & & Banda/Fanfarra & 337 \\
\hline 93 & CANÇÃO DA IMPRENSA & & & 34 & & Banda/Fanfarra & 337 \\
\hline 94 & CANÇÃO DO ARTILHEIRO DA COSTA & & & 37 & & Banda/Fanfarra & 337 \\
\hline 95 & CANÇÃO DOS ARTISTAS & & & 41 & & Banda/Fanfarra & 338 \\
\hline 96 & CANÇÃO DO MARINHEIRO & & & & 14 & Banda/Fanfarra & 338 \\
\hline 97 & CANÇÃO DO OPERÁRIO BRASILEIRO & & & 30 & & Banda/Fanfarra & 338 \\
\hline 98 & DEODORO (Canção marcial) & & & 36 & & Banda/Fanfarra & 338 \\
\hline 99 & $\begin{array}{l}\text { DESFILE AOS HERÓIS DO BRASIL - a } \\
\text { capella }\end{array}$ & & & 21 & & Banda/Fanfarra & 338 \\
\hline 100 & DUQUE DE CAXIAS (Canção Patriótica) & & & 35 & & Banda/Fanfarra & 339 \\
\hline 101 & MEU BRASIL (Samba) & & & 14 & & Banda/Fanfarra & 339 \\
\hline 102 & MEU PAÍS & & & 24 & & Banda/Fanfarra & 339 \\
\hline 103 & TIRADENTES & & & 25 & & Banda/Fanfarra & 339 \\
\hline
\end{tabular}




\begin{tabular}{|c|c|c|c|c|c|c|c|c|c|}
\hline $\mathrm{N}^{\circ}$ & INSTRUMENTAL 2.4 - Ordem alfabética & $\begin{array}{l}\text { GP/ } \\
\text { VTL }\end{array}$ & $\begin{array}{c}\mathrm{GP} / \\
\mathrm{ABM}\end{array}$ & S1 & S2 & $\mathrm{CO} 1$ & $\mathrm{CO} 2$ & Instrumento & Página \\
\hline 12 & A CANÇÃO DO MARCENEIRO & & & & & 33 & & sopro/cordas & 322 \\
\hline 13 & A JANGADA & & & & & 6 & & sopro/cordas & 322 \\
\hline 3 & A MAMÃE ESTAVA DOENTE & 72 & 63 & & & & & piano & 320 \\
\hline 1 & $\begin{array}{l}\text { ACORDEI DE MADRUGADA (II versão - } \\
\text { para piano) }\end{array}$ & 2 & 59 & & & & & piano & 318 \\
\hline 14 & ALERTA (Rataplan) & & & & & 39 & & sopro/cordas & 322 \\
\hline 15 & ANDA A RODA ( $2^{a}$ Versão $)$ & 6 & 6 & 32 & & & & sopro/cordas & 323 \\
\hline 2 & $\begin{array}{l}\text { ANDA A RODA ( } 3^{\text {a }} \text { versão - para piano } \\
\text { solo) }\end{array}$ & 7 & 116 & & & & & piano & 318 \\
\hline 16 & AS CONCHINHAS & 38 & 37 & 25 & & & & sopro/cordas & 323 \\
\hline 4 & ATCHÉ & 10 & 117 & & & & & piano & 320 \\
\hline 90 & BRASIL & & & & & & 13 & Banda/Fanfarra & 337 \\
\hline 91 & BRASIL NOVO & & & & & 18 & & Banda/Fanfarra & 337 \\
\hline 17 & BRASIL UNIDO & & & & & 15 & & sopro/cordas & 323 \\
\hline 92 & CANÇÃO CÍVICA RIO DE JANEIRO & & & & & 13 & & Banda/Fanfarra & 337 \\
\hline 93 & CANÇÃO DA IMPRENSA & & & & & 34 & & Banda/Fanfarra & 337 \\
\hline 94 & CANÇÃO DO ARTILHEIRO DA COSTA & & & & & 37 & & Banda/Fanfarra & 337 \\
\hline 95 & CANÇÃO DOS ARTISTAS & & & & & 41 & & Banda/Fanfarra & 338 \\
\hline 96 & CANÇÃO DO MARINHEIRO & & & & & & 14 & Banda/Fanfarra & 338 \\
\hline 18 & CANÇÃO DO NORTE & & & & & 17 & & sopro/cordas & 323 \\
\hline 97 & CANÇÃO DO OPERÁRIO BRASILEIRO & & & & & 30 & & Banda/Fanfarra & 338 \\
\hline 19 & CANÇÃO DO PESCADOR BRASILEIRO & & & & & & 26 & sopro/cordas & 323 \\
\hline 20 & CANÇÃO DO TRABALHO & & & & & 31 & & sopro/cordas & 324 \\
\hline 21 & CANÇÃO ESCOLAR & & & & & 12 & & sopro/cordas & 324 \\
\hline 98 & DEODORO (Canção marcial) & & & & & 36 & & Banda/Fanfarra & 338 \\
\hline 99 & $\begin{array}{l}\text { DESFILE AOS HERÓIS DO BRASIL - a } \\
\text { capella }\end{array}$ & & & & & 21 & & Banda/Fanfarra & 338 \\
\hline 100 & DUQUE DE CAXIAS (Canção Patriótica) & & & & & 35 & & Banda/Fanfarra & 339 \\
\hline 22 & ESPERANÇA DA MÃE POBRE & & & & & & 2 & sopro/cordas & 324 \\
\hline 23 & HINO À VITÓRIA & & & & & & 36 & sopro/cordas & 325 \\
\hline 24 & JURAMENTO & & & & & & 30 & sopro/cordas & 325 \\
\hline 5 & MAR DO BRASIL & & & & & 38 & & piano & 320 \\
\hline 25 & MARCHA ESCOLAR (Passeio) & & & & & 10 & & sopro/cordas & 325 \\
\hline 26 & MARCHA ESCOLAR (Vocalismo) & & & & & 11 & & sopro/cordas & 325 \\
\hline 27 & MARCHA ESCOLAR (Volta do recreio) & & & & & 8 & & sopro/cordas & 325 \\
\hline 101 & MEU BRASIL (Samba) & & & & & 14 & & Banda/Fanfarra & 339 \\
\hline 6 & MEU PAI AMARROU MEUS OLHOS & 81 & 115 & & & & & piano & 320 \\
\hline 102 & MEU PAÍS & & & & & 24 & & Banda/Fanfarra & 339 \\
\hline 7 & O CORCUNDA & 42 & 100 & & & & & piano & 321 \\
\hline 28 & O FERREIRO & & & & & 28 & & sopro/cordas & 326 \\
\hline 29 & O GATURAMO & & & & & & 6 & sopro/cordas & 326 \\
\hline 30 & O PESCADOR DA BARQUINHA & 92 & 29 & & & & & sopro/cordas & 326 \\
\hline 8 & QUANDO EU ERA PEQUENINO & 105 & 77 & & & & & piano & 322 \\
\hline 31 & SANTOS DUMONT (A conquista do ar) & & & & & & 25 & sopro/cordas & 326 \\
\hline
\end{tabular}




\begin{tabular}{|c|c|c|c|c|c|c|}
\hline 89 & SAUDAÇÃO A GETÚLIO VARGAS & & & 40 & fanfarra & 336 \\
\hline 32 & SOLDADINHOS (Canção escolar) & & & 5 & sopro/cordas & 326 \\
\hline 34 & SOLFEJO No 3 (Ditado) & & p.1 & & sopro/cordas & 327 \\
\hline 77 & SOLFEJO Nº 6 (Ditado) & & p.2 & & sopro/cordas & 334 \\
\hline 33 & SOLFEJO No 8 (Ditado) & & p.2 & & sopro/cordas & 327 \\
\hline 85 & SOLFEJO N $^{\circ} 1$ (Fuga) & & p.27 & & sopro/cordas & 335 \\
\hline 86 & SOLFEJO No 2 (Fuga) & & p.34 & & sopro/cordas & 336 \\
\hline 87 & SOLFEJO No 3 (Fuga) & & p.36 & & sopro/cordas & 336 \\
\hline 88 & SOLFEJO No 4 (Fuga) & & p.42 & & sopro/cordas & 336 \\
\hline 55 & SOLFEJO No 1 (Vocalismo) & & p. 3 & & sopro/cordas & 330 \\
\hline 35 & SOLFEJO N ${ }^{\circ} 6$ (Vocalismo) & & p.5 & & sopro/cordas & 327 \\
\hline 56 & SOLFEJO No 7 (Vocalismo) & & p.5 & & sopro/cordas & 330 \\
\hline 60 & SOLFEJO No 11 (Vocalismo) & & p.6 & & sopro/cordas & 334 \\
\hline 50 & SOLFEJO No 16 (Vocalismo) & & p. 8 & & sopro/cordas & 329 \\
\hline 58 & SOLFEJO No 17 (Vocalismo) & & p.9 & & sopro/cordas & 331 \\
\hline 54 & SOLFEJO No 18 (Vocalismo) & & p.10 & & sopro/cordas & 330 \\
\hline 49 & SOLFEJO No 20 (Vocalismo) & & p.11 & & sopro/cordas & 329 \\
\hline 36 & SOLFEJO No 21 (Vocalismo) & & p.11 & & sopro/cordas & 327 \\
\hline 44 & SOLFEJO No 22 (Vocalismo) & & p.12 & & sopro/cordas & 328 \\
\hline 57 & SOLFEJO No 23 (Vocalismo) & & p.13 & & sopro/cordas & 331 \\
\hline 45 & SOLFEJO No 24 (Vocalismo) & & p.14 & & sopros & 329 \\
\hline 43 & SOLFEJO No 47 - a capella & 47 & & & sopro/cordas & 328 \\
\hline 37 & SOLFEJO No 48 - a capella & 48 & & & sopro/cordas & 327 \\
\hline 42 & SOLFEJO N ${ }^{\circ} 52$ - a capella & 52 & & & sopro/cordas & 328 \\
\hline 40 & SOLFEJO No 53 - a capella & 53 & & & sopro/cordas & 328 \\
\hline 39 & SOLFEJO No 54 - a capella & 54 & & & sopro/cordas & 328 \\
\hline 38 & SOLFEJO No 58 - a capella & 58 & & & sopro/cordas & 327 \\
\hline 41 & SOLFEJO No 59 - a capella & 59 & & & sopro/cordas & 328 \\
\hline 72 & SOLFEJO No 72 - a capella & 72 & & & sopro/cordas & 333 \\
\hline 76 & SOLFEJO N $^{\circ} 74$ - a capella & 74 & & & sopro/cordas & 331 \\
\hline 65 & SOLFEJO N ${ }^{\circ} 76$ - a capella & 76 & & & sopro/cordas & 332 \\
\hline 83 & SOLFEJO N $^{\circ} 77$ - a capella & 77 & & & sopro/cordas & 335 \\
\hline 84 & SOLFEJO No 78 - a capella & 78 & & & sopro/cordas & 335 \\
\hline 69 & SOLFEJO No 85 - a capella & 85 & & & sopro/cordas & 333 \\
\hline 59 & SOLFEJO $N^{\circ} 86$ - a capella & 86 & & & sopro/cordas & 331 \\
\hline 70 & SOLFEJO N ${ }^{\circ} 88-$ a capella & 88 & & & sopro/cordas & 333 \\
\hline 82 & SOLFEJO No 93 - a capella & 93 & & & sopro/cordas & 335 \\
\hline 46 & SOLFEJO No 95 - a capella & 95 & & & sopro/cordas & 329 \\
\hline 81 & SOLFEJO N ${ }^{\circ} 98-$ a capella & 98 & & & sopro/cordas & 335 \\
\hline 71 & SOLFEJO N $^{\circ} 107$ - a capella & 107 & & & sopro/cordas & 333 \\
\hline 80 & SOLFEJO No $110-$ a capella & 110 & & & sopro/cordas & 335 \\
\hline 74 & SOLFEJO N $^{\circ} 113$ - a capella & 113 & & & sopro/cordas & 334 \\
\hline 53 & SOLFEJO No $^{\circ} 115-$ a capella & 115 & & & sopro/cordas & 330 \\
\hline 63 & SOLFEJO N $^{\circ} 117$ - a capella & 117 & & & sopro/cordas & 332 \\
\hline 67 & SOLFEJO N $^{\circ} 118$ - a capella & 118 & & & sopro/cordas & 332 \\
\hline 62 & SOLFEJO N $^{\circ} 122-$ a capella & 122 & & & sopro/cordas & 332 \\
\hline 47 & SOLFEJO N $^{\circ} 123$ - a capella & 123 & & & sopro/cordas & 329 \\
\hline 66 & SOLFEJO N $^{\circ} 124-$ a capella & 124 & & & sopro/cordas & 332 \\
\hline 64 & SOLFEJO N $^{\circ} 127$ - a capella & 127 & & & sopro/cordas & 332 \\
\hline 73 & SOLFEJO N $^{\circ} 129$ - a capella & 129 & & & sopro/cordas & 333 \\
\hline 68 & SOLFEJO N $^{\circ} 133-$ a capella & 133 & & & sopro/cordas & 333 \\
\hline 79 & SOLFEJO N $^{\circ} 134-$ a capella & 134 & & & sopro/cordas & 334 \\
\hline
\end{tabular}




\begin{tabular}{|c|c|c|c|c|c|c|c|}
\hline 51 & SOLFEJO N ${ }^{\circ} 140$ - a capella & & & 140 & & sopro/cordas & 330 \\
\hline 78 & SOLFEJO No 146 - a capella & & & 146 & & sopro/cordas & 334 \\
\hline 75 & SOLFEJO No 147 - a capella & & & 147 & & sopro/cordas & 334 \\
\hline 52 & SOLFEJO No 148 - a capella & & & 148 & & sopro/cordas & 330 \\
\hline 48 & SOLFEJO N $^{\circ} 150$ - a capella & & & 150 & & sopro/cordas & 329 \\
\hline 61 & SOLFEJO No 152 / 160 - a capella & & & $152 / 160$ & & sopro/cordas & 331 \\
\hline 9 & SONHO DE UMA CRIANÇA & 122 & 60 & & & piano & 322 \\
\hline 103 & TIRADENTES & & & & 25 & Banda/Fanfarra & 339 \\
\hline 10 & VEM CÁ, SIRIRI & 130 & 106 & & & piano & 322 \\
\hline 11 & XÔ! PASSARINHO & 137 & 105 & & & piano & 322 \\
\hline
\end{tabular}


B - CD contendo o texto integral da tese 
C - CD contendo arquivos com os volumes da edição Vitale dos cinco volumes analisados; arquivos de peças por ordem de apresentação em cada capítulo 